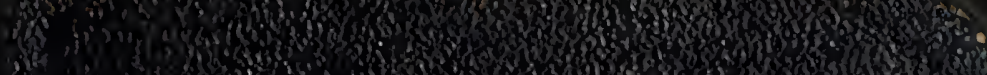

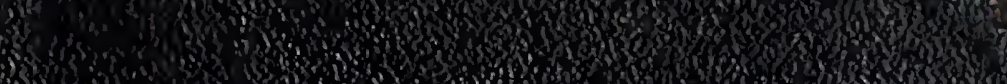

320 n.

3.

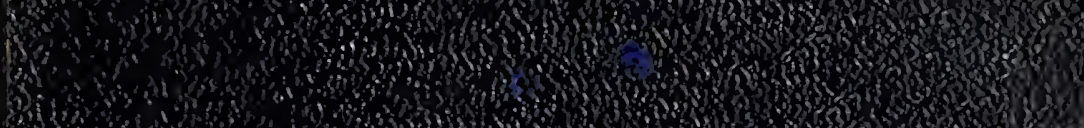

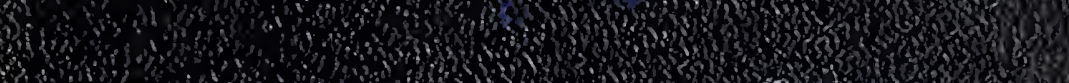

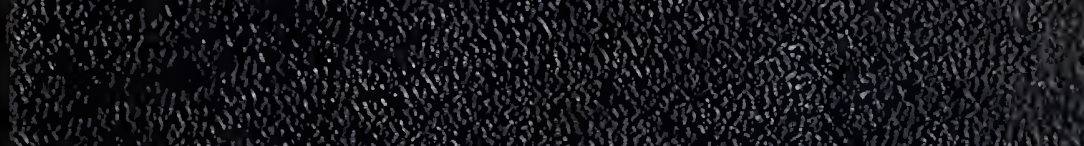

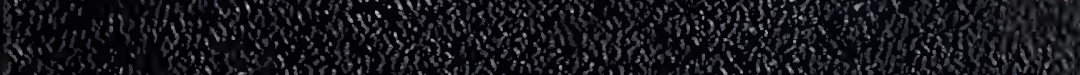

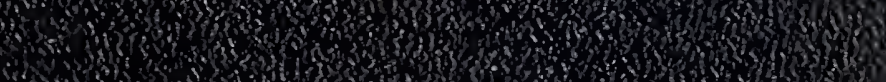

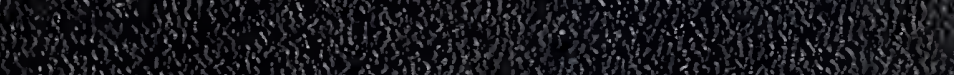

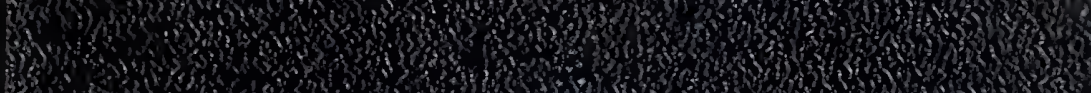

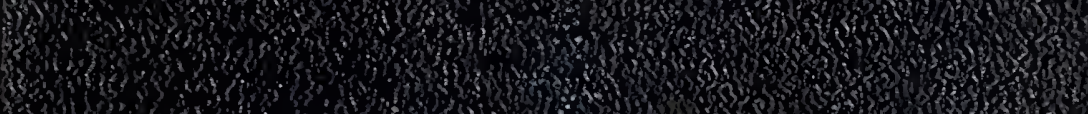
3. S. (1)

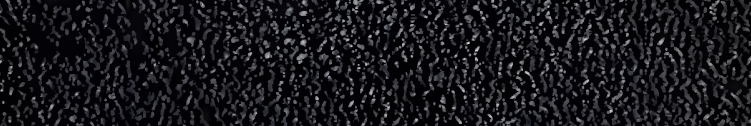

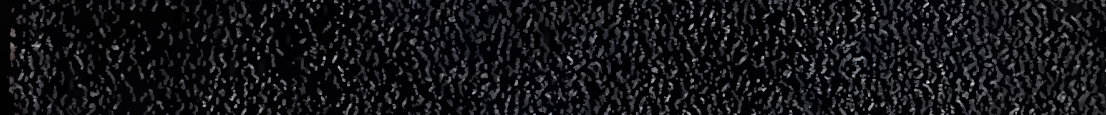

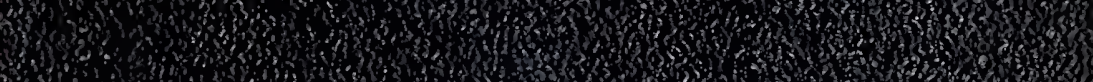

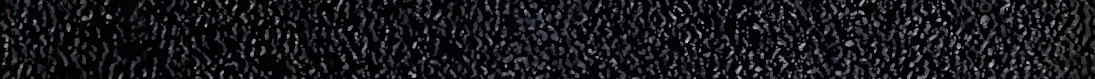

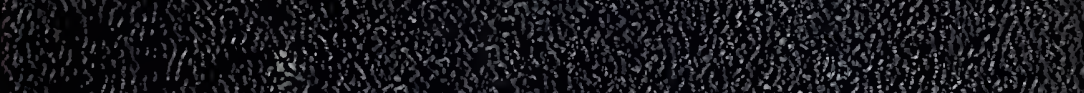
(3)

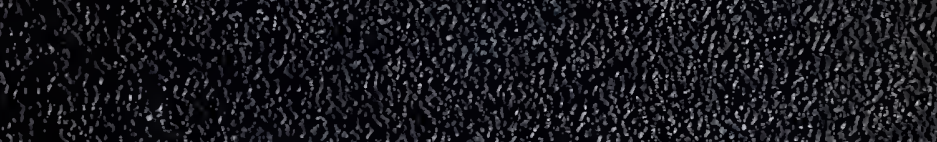
aring

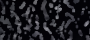

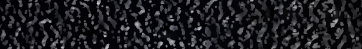

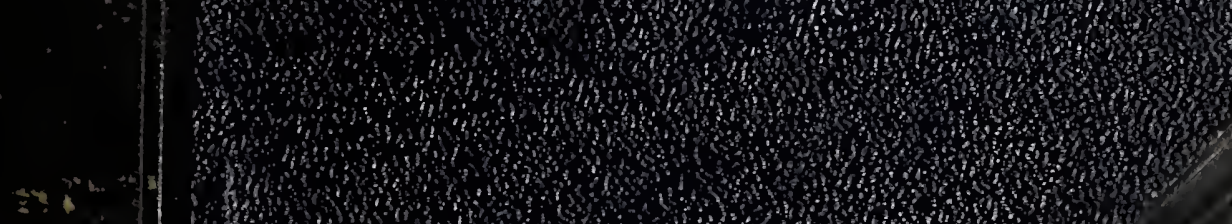

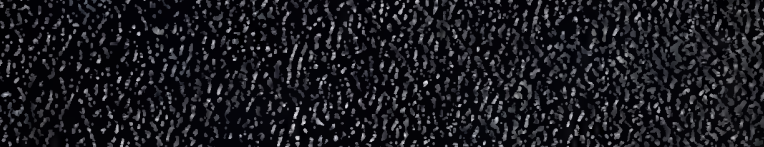





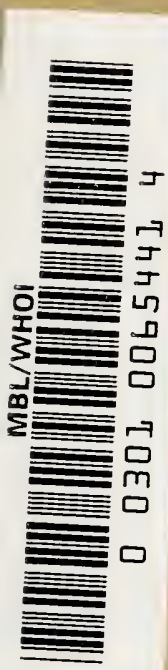






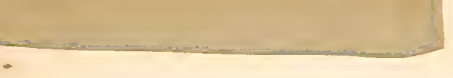




\section{Bovlogifade Briefre}

\section{Matmegeduid)te}

Der

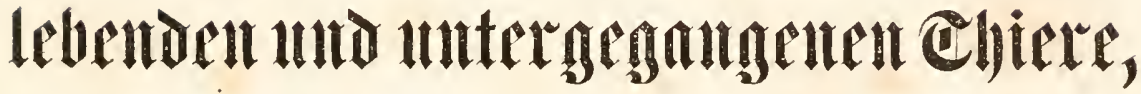

fïl

Regrer, böhere Gchulen und (bicbildocte nller Gtämbe,

von

\section{Cand $30 g^{t}$}

Mit vicle $\mathfrak{A} b$ birsungen.

Eifiter Bumi。

Irmofifurt $\mathfrak{a}$. $\mathfrak{A}$.

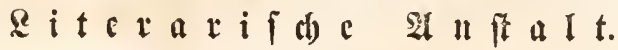

(J. Siitteu.)

1851. 
Drud son (5. Sirebs:@d)mitt. in Eranffut a. Mi. 


\section{$\mathbb{E} \mathfrak{i} \mathfrak{H} \mathfrak{l} \mathfrak{i} \mathfrak{t} \mathfrak{l} \mathfrak{i}$.}

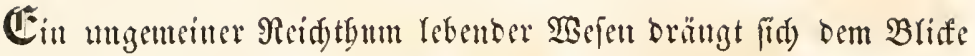
eines Jeben entgegen, Der bie SHngen anf bie ín ungetende Ratur renft. Sn allen Elementen, in Der Ruft, auf mo in Der Eroe, in allen

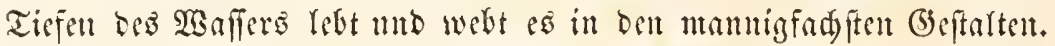

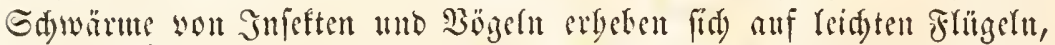
wäbrend andere Thiere, omd ibre Drgantiation an ben Boben ge= feffelt, anf biefem nad) Rabrmug umberfdweifen, ober felbit unter ber

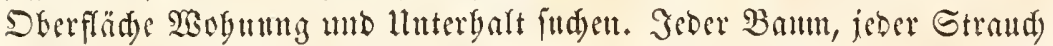

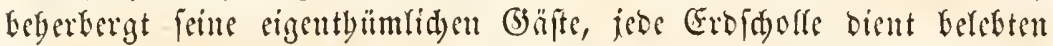

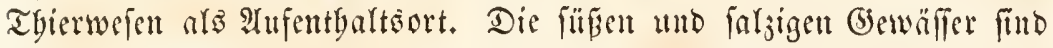
erfüllt mit fdwimmenton Igieren, mit Fifd)en, Sirmfern, SBeidhtbieren, Sufuprien, ibr Boben überjogen von Yolypen, Gtrabltbieren unb

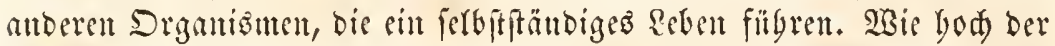
Menid) fid) auth erbeben utag an ben Gerängen ber (bebirge, wie tief er aud) fein forfdendes Gentblei itl ben Deent verienfen mag, hiberall

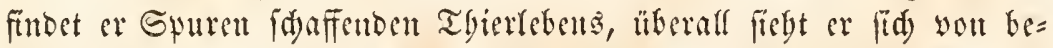
lebten Formen untgeten, beren Mamnigfaltigfeit feine Bewunderung

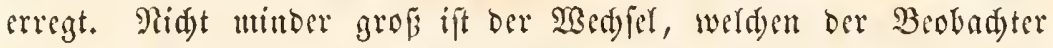
beim Durdumeflen gröferer Entermungen anf Der Erooberfläd) wabr:

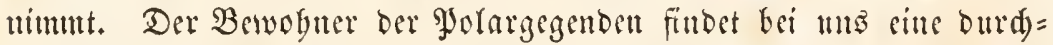

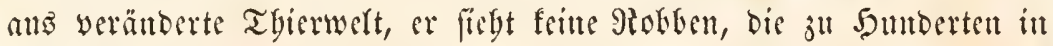
bem Gtrable siner färgliden Gome fdhlafen, feime arte mo Fett= gäıle, bie in unzäbligen Gdwwärmen an ben Felfemnfern feiner Fib= meere niften. Der weipie Bär, der blane Fudba, bie ungefdladjten

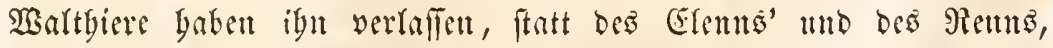
frebt er Sjirfde thb Rebe ill unfern Sálbern, Gifwärme von Ging= vögelu und Tauben anf tufern Feldern, andere Fifd)e, anbere Dlufdeln it unjern Fliffen unb Meeren. Ridst minder erftaunt ber Betwobner unferer 3one bei iem Sinblife jener tropifden Gegenben, die wieber 
ganz anbere Thiere in nod) weit grëferer Mannigfaltigfeit ibm ent=

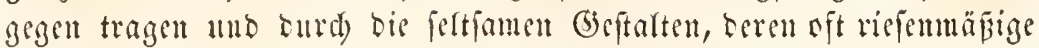
Gröbe uns fdimmernte Farbenpradt bie Sindrüfe wieberbolen, welde

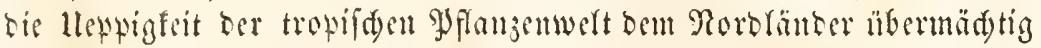
auforïngt.

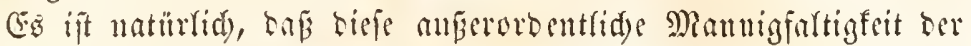

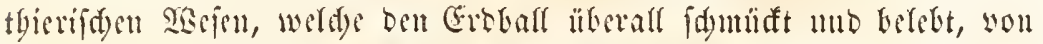

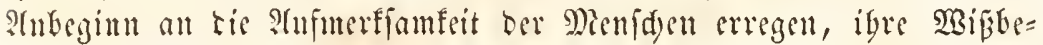
gierbe ftadedu muste. 3uerft feffelte ons llugebenerlidye, ons Bizarte,

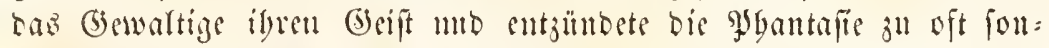
cerbaren llebertreifungen. Die Reid)tglänbigfeit ber Menidgen war

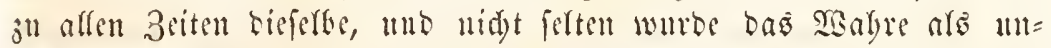

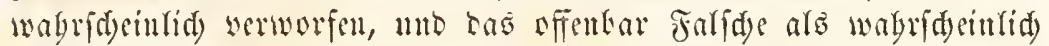
angenommen. Se mefre fid aber bie Beziebungen jwifden ben cinget=

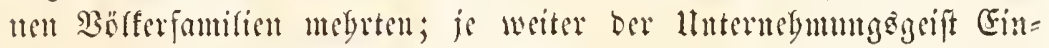
jelner ober ganjer Rationen nad) entfernten (jegenben bin fid) anb=

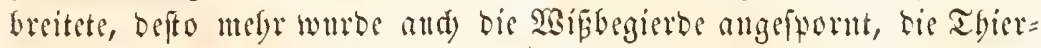
welt jener (Eiegenden fenten zll rernen mto mit berjenigen bes Bater: ranbes ju vergleiden. Da es sitte tiefbegrïnbete Gigenldaft der

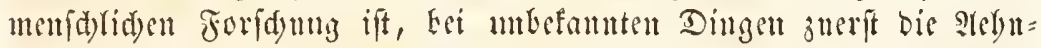

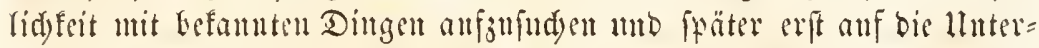

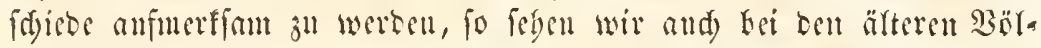

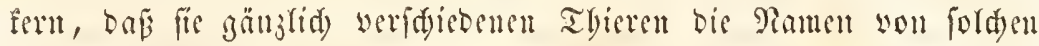
befdoupfen geten, sie igmen näber befant waren, mo bas tie bie Huterfdiede berferten oft nur in unbebentenden Merfmalen fuden.

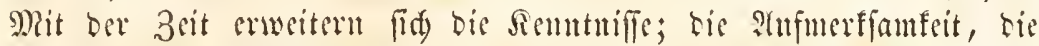

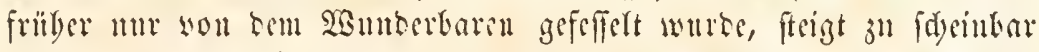
unbebentenberen Gegenftünden Gerab, bie Ssipbegierbe kegü̈t fid

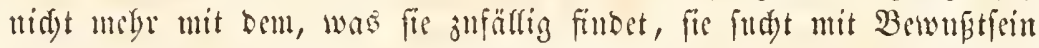
nuf mb gibt firt) gan; ifrem 3werfe bin. Mithlerige gerifen werten muternommen, Befduerten alfer alt ertragen, mu nid)t mu bie Git= ten mo Gebrändfe frember Menfden, fonbern and sie frember Thiere femten ju rermen. In bem untyemein reidyen Minterial, weldyes man amb allen Gefen ber Erbe zHammenidseppt, werliert fid ber

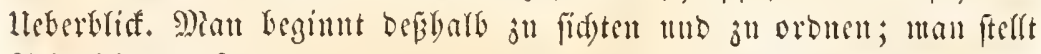

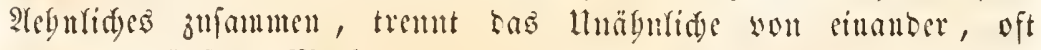

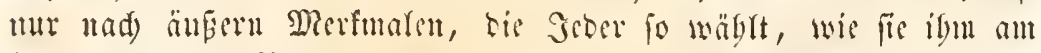

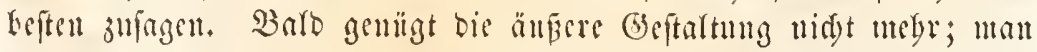
will tiefer in bas Intere bringen; man wifl wiffen auf weld)e atrt cin abueidyento beftaltetes Thier frite Rabrung fid) werfidaffen, frin 
Ecben friften fömne. Nian unterfudgt sic Structur ber Drgane, welde

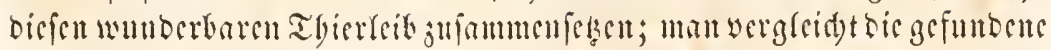
Drganifation mit berienigen ber befanteren Thiere, man entoeft innere Micrfuale, weld)e gecignet erfideduen, bie mantidy fartigen formen unter

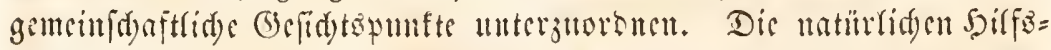

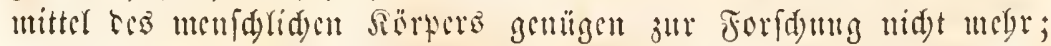
man fdärft bic Gelyeraft ber s(ngen burd) Supen unb Miffrosfope unb

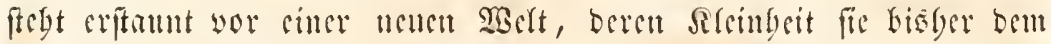
21uge cutjeg. Hucrmilolid) unb raftlog bringt man weiter anf ben ge=

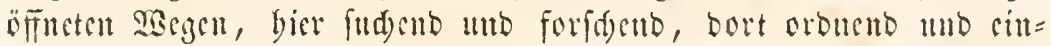

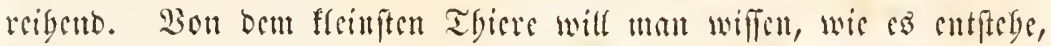
lebe, fid) fortpflamze unb ju (5rumbe gebe; jebes befamte (bejd)öpf will

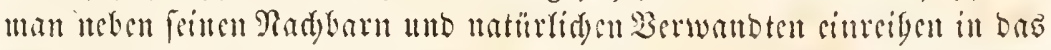
Viegifter, weldes nad) ftreng gefectmäfigen Pormen bie Ramen unb beren

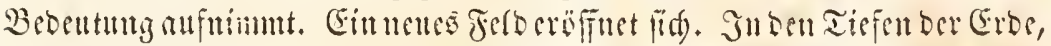
in ben Edjidste ber Jerfirn lyat man sine Dienge won werfenterten

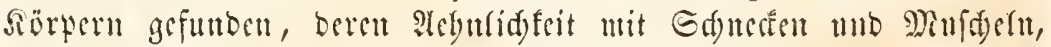

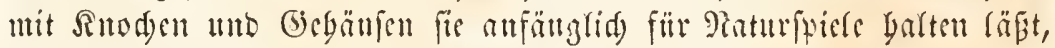

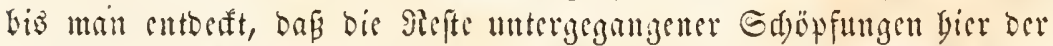

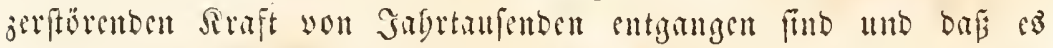

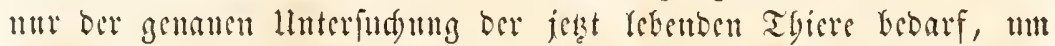

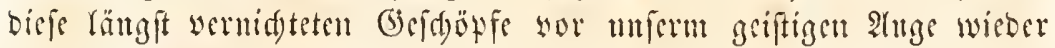

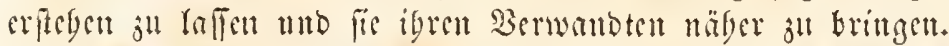

23ir find an bet 2lufgabe ber beutigen zoolsgifacn wiffenfdaft angelangt. Sie foll uns bie mendide Mamnidyfaltigfiet oer thieri=

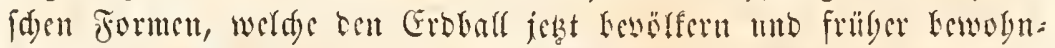
ten, yor bie Itugen führen; nid)t in eiment ungeorbneten Sanfen, ans bem nur bie und on cine anffalfente beftalt bervorficht, foubern wie citt woblgeorbuetes 5 cer, beffen cinzelne Saffengattuttgen in be=

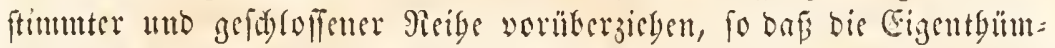

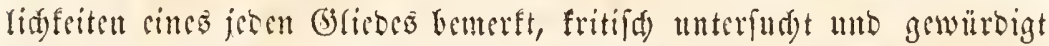
werben fömen; fie folf mus zeigen, wic bicie veridsebenen Grmpten in igrem Sumern geftaltet, wie dicfe Drganiōmen bejdaffen fint und in wel=

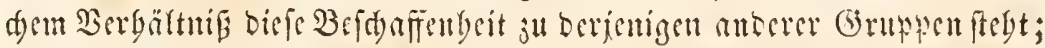
fie foll uns bie (bejdid)te sines jeben flar madyen, wou feiner erifen

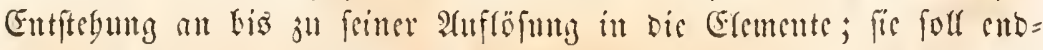

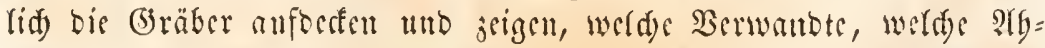
nen it unenoliden Generationsfolgen in ben Sdjiden ber Erbe begra= ben liegen. (E⿱宀 ift wabrlid) nidgt bie trodene Âfzäglung ber Thiere unb

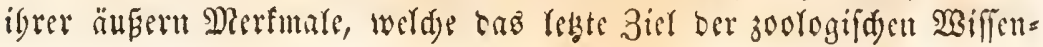




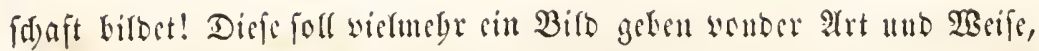
wie bas Seben in ben serfdiebenen Drganisumen fid geftaltet und

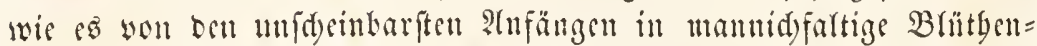

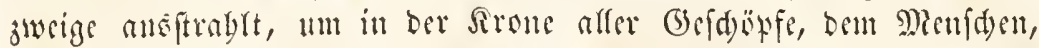

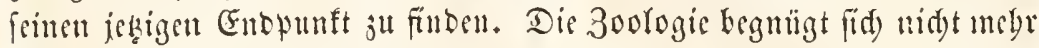
mit jenen Renntuifen, welde bie fy ftematifde 3oologie birben,

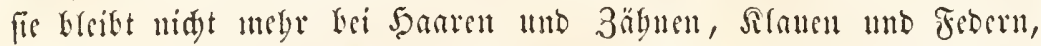
Beinen unb Rismen fteben, jufriebent Renujeidsen entbert ju baben, weldye bie Crimrifung in tas Gyften möglid maden; fie vertangt

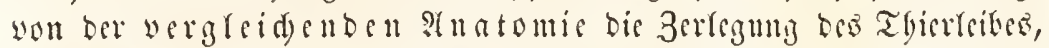
dic Remntnif Der eingelnen Drgane und ifrer frinern Etructur; won ber wergleidenten gygyiorogie die Ergrimbung oer func=

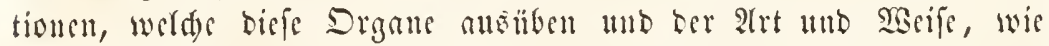
biefe verfdricbenen Fumctionen ju eincm Ganjen ju ber Erbaftung

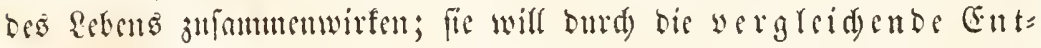

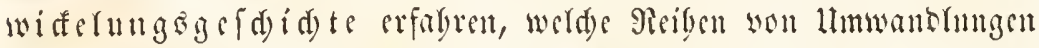

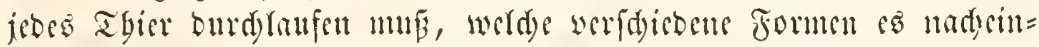
ander annimmt, bis es bas Ziel frines Rebens erreidt bat; bie gy a

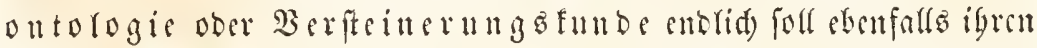
Tribut britgen, inbem fie ans osn verftencrten Gieften anşgeftorbener

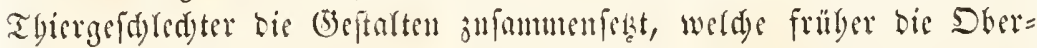

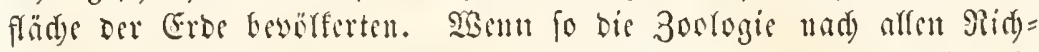
tungen bin bie sinjefuen Theife igres Gedetes fenuen gelernt bat, fo fragt fie nad) bent Gefetsen, welde bie Bertlyeitung ber thierifden

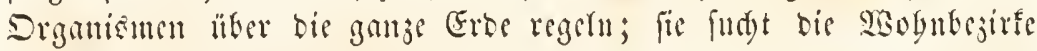

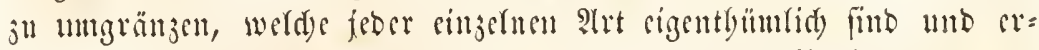
fägrt burd) bie joologifde (5) e graplie, welde Bebingungen des

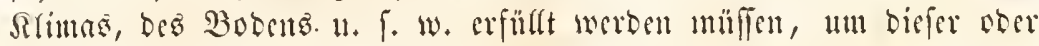
jener art dos Reben möglid ju maden.

gd) Imadye in ben nadjforgenden Bättern ben Berfudy, diefes

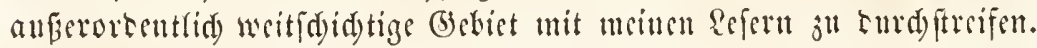

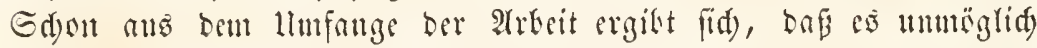

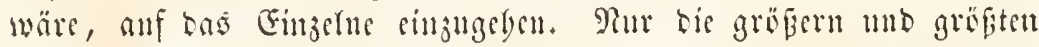

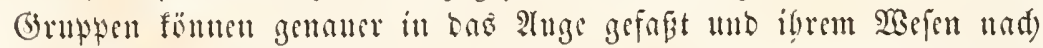
verftänblidy gemadyt werben. Der Sefer wito mit biefem $\mathfrak{B} u d$ e in Der 5ando nidgt bicfen ober jenen Säfer teftimmen mo ben ifm won Den 3oologen gegebenen Ramen anffïnosn fünnen; - fann wird ez ifm möglid) feith, feine Ed)utetterlings - ober Minfderfammlung ciniger= mapen barmad) ju oronen und in bie fyftematifden (brupten ju ver= theilen. Das Biel, bas id) mir gefteft Gabe, if cin anderess; id 
boffe ber sefer foll, nadjoem er biefes 3 ud) aufuerffam gelefen unb fid) mitferincm Jubarte sertrant gemadyt gat, wiffen, was sin Juleft, sine Enalle, ein Fif ber Tbiere 3 Etande fommen, allf weldye Sasife fie fid yon alloern Thieren mnterfdeiben und weldye Etelle fie in bem Bitbe cinnebmen,

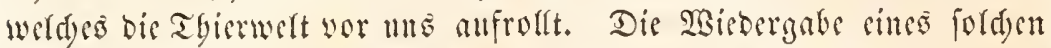

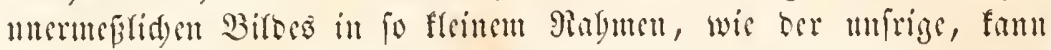

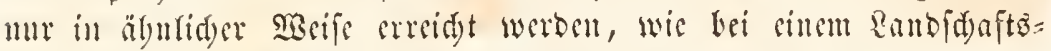

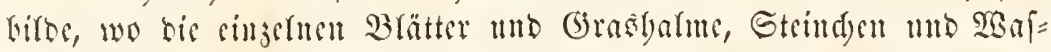

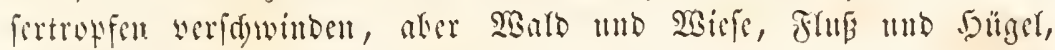

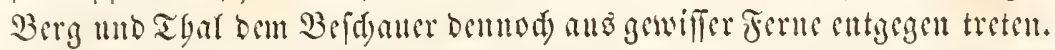

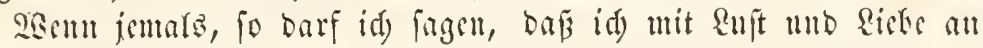
siefem Bitse gemalt yabe, bas mir in feinen eritest llmriflen fdon

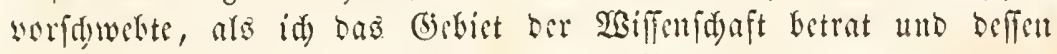

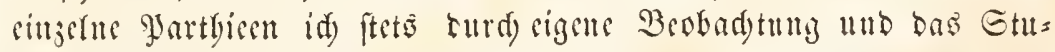

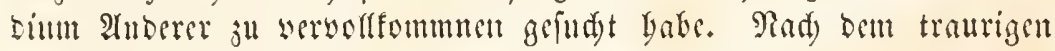

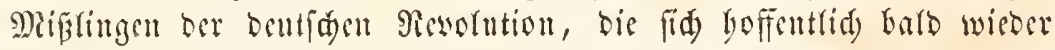

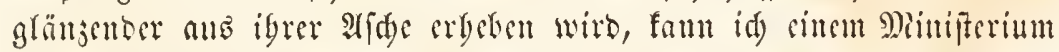
bes liberalften Gimes nur banfbar fein, wenn es mid) für mmwätbig erflärt, Der jum Dienfte cintes d) rifttidy=germanifden Duobej=Staates be= ftimmten ftubirelloen Sngend Raturgefdidte vorjutragen, unb ber fort=

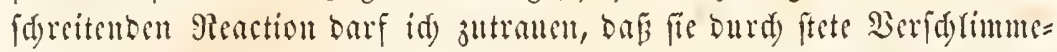

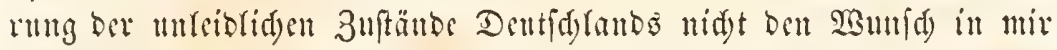

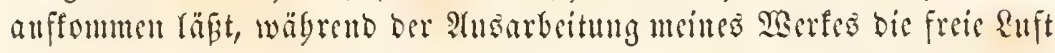

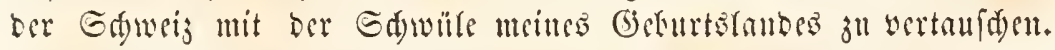

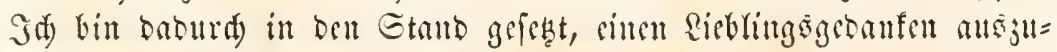
fitgren, ben idy feit langer 3eit legte.

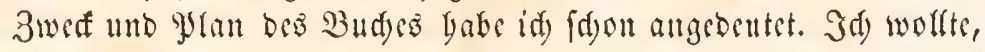

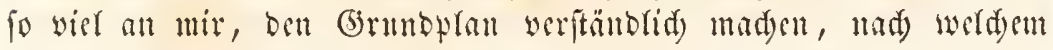

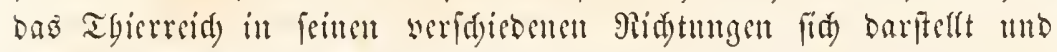

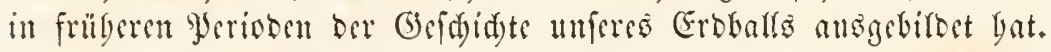

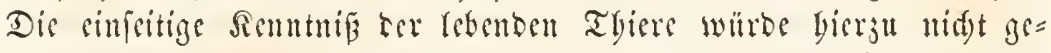
nï̈t laben - oer innere 3ufammenlyang ber einjelnen Brupten, bie

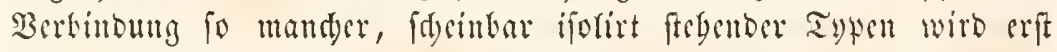

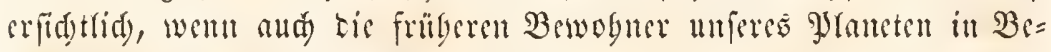

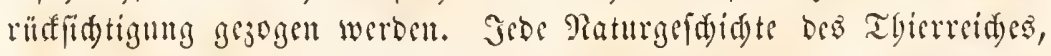

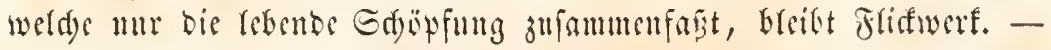
34) Gabe bemmad bie foiffilen Thierrefte, bie Berfteinerungen in bem=

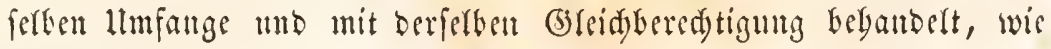
bie lebenben Thiere. 
Die Entwiatung ber cinjefucn Typen beอ TEierreides fann nidt aแs ben äแ

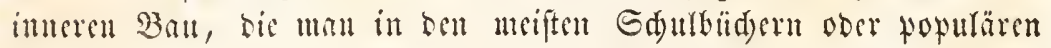

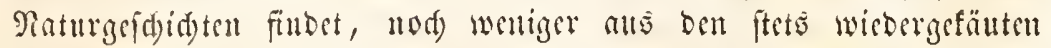

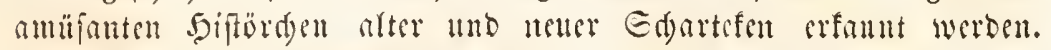

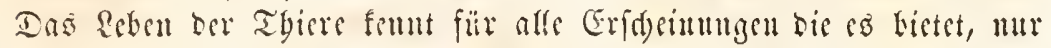

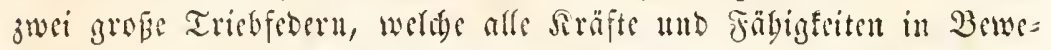

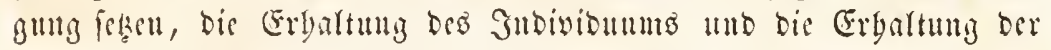
Prt - Ermägrung แnd Jortpflanjung. Beibe Sciten \&es Thiertebens forserten gleide Eorgfalt der Belymbrung. Ero war unvermeiblid, bei

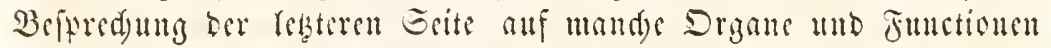

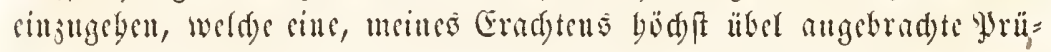

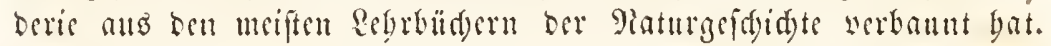

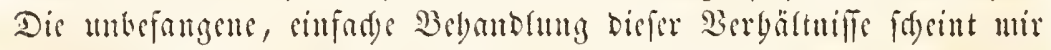

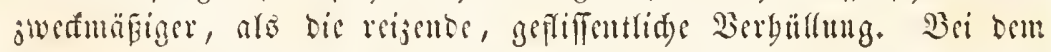
Gentigen Etante der Sisifenidjaft, welde ben Ban ibres Gyftemes,

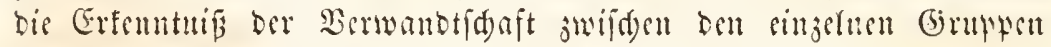

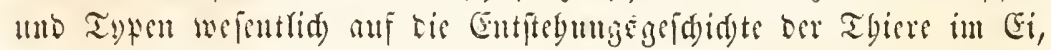

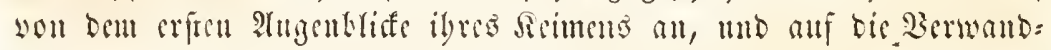

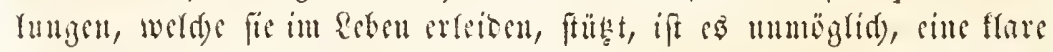

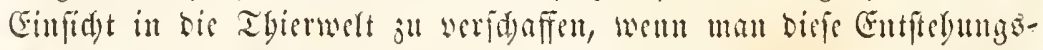

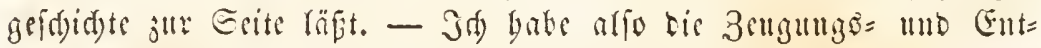
wirfungşgerdeidte ber Thiere, bie vergleidgenbe Embryologie, über

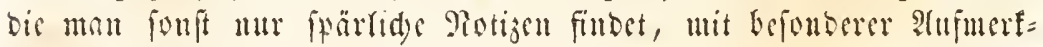
jamfeit rebanoert.

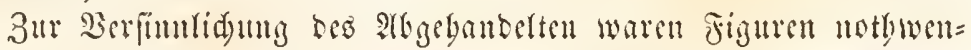
rig. Der Refer wirb ber Berlagghandlung Eanflar fein fönten für

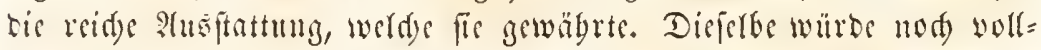
ftüniger in Bejichung auf bie Berfteiturungen geworden fein, wenn cin anberer Budgüutrer, in beffen frembidaftlide Besjegungen zu

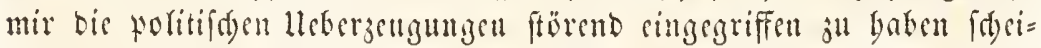

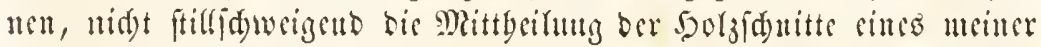

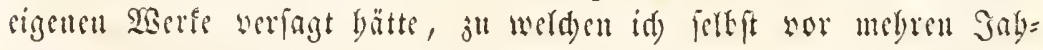
ren bie 3eidunutgen gefortigt hyatts.

Berm an 1. Eeptemrer 1850. 


\section{(Crifter 3rief.}

\section{Striilgere uni jetsitge Beftrelungen.}

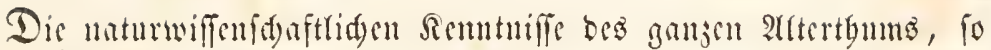

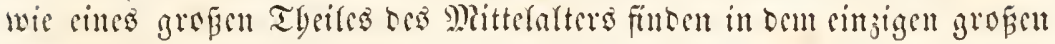

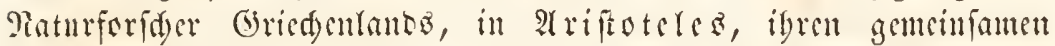

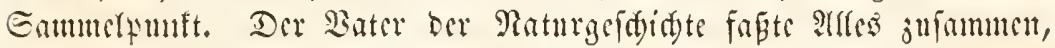

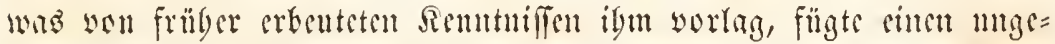

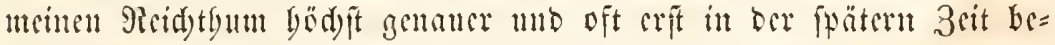
ftätigter Beofadytmugen lyinjll unb wurbe für bic Edjolaftifer bes

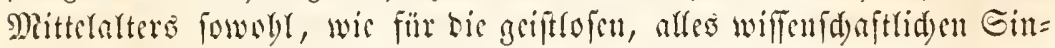

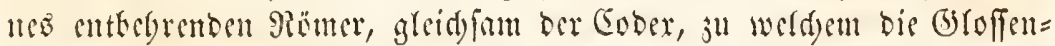
fabrifantent jener treftrofen Berivoen Ertänterungen uto ?tumerfungen fertigten. Ariftoteles trug zuerft save Gealpell in ben siörper ber

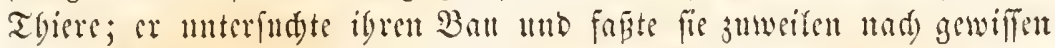
Acthntidfeiten jufammen, bie meifens won ber innern Drganifation

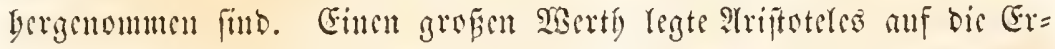

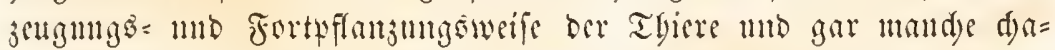

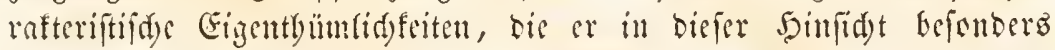
son Esetbieren anfübrt, ergicten crift in ber neucfen 3cit igre solf = fommene Beftätigung Die Bejdereitung Der änseren SGaraftere breibt

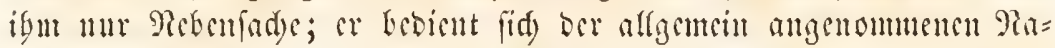

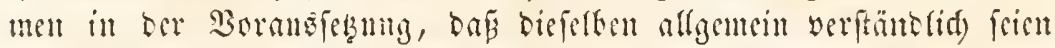

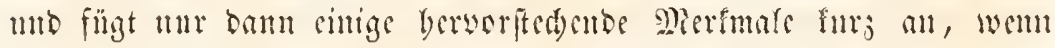

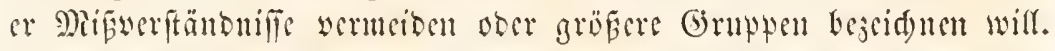
Die grope mo cinfade Raturanfdanung ber Grirdan webt burd)

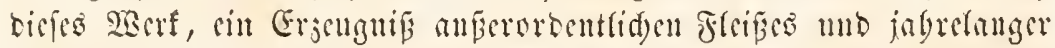

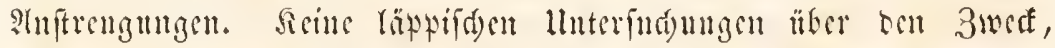
wedden ein fingirter Edjüpfer mit bicfen oder jenem Thierc ober gar Thier=

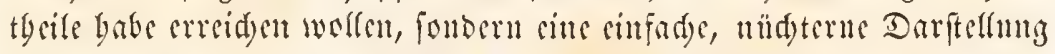

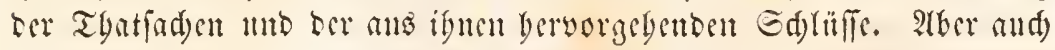

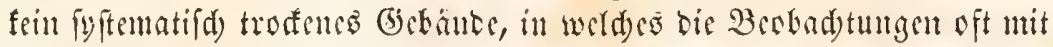
3wang und itbem man ibnen Gowalt antgut, cingerribt werben; fon= 


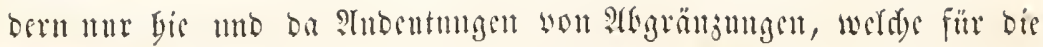

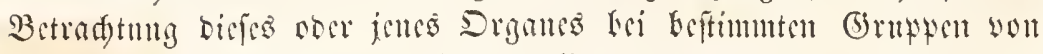

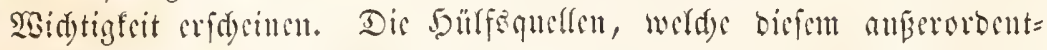

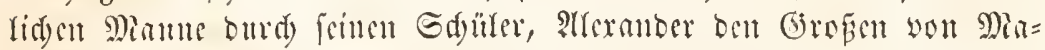
cctonien, zu Gebote geftelt wurben, folfen ungemein gewefen fein; inbé

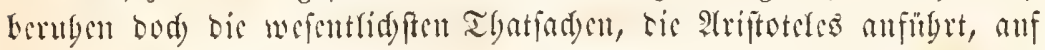

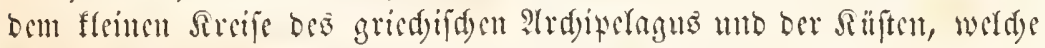

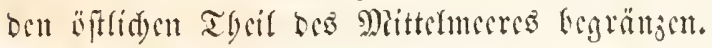

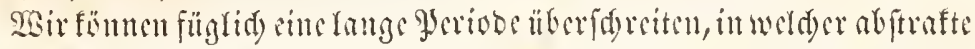

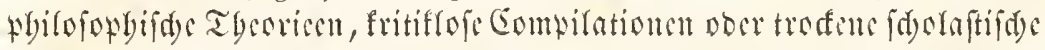

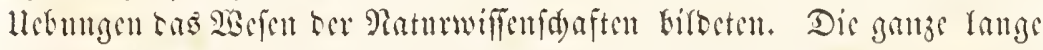

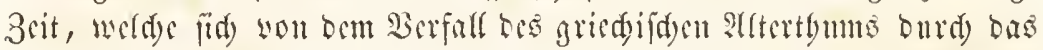
Dittefalter binjicht, jeigt feimen Mamu unt feit Sact auf, bas nut bes

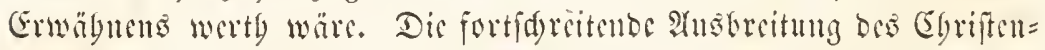

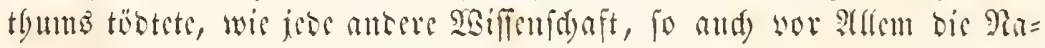

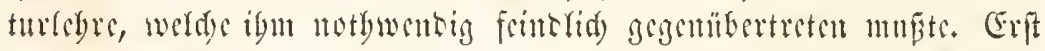
in ber juciten 5älfte bes 16 ten Sabrlumberts, wo ber freic Gedante

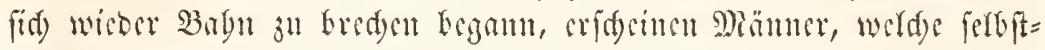

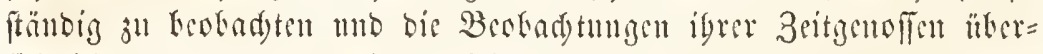

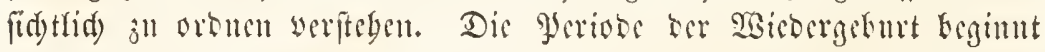

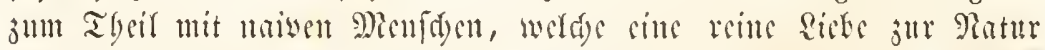

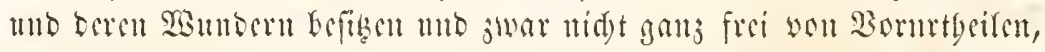

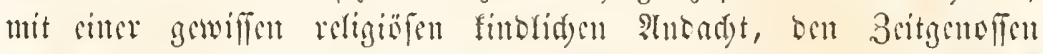
bic Mifultate igrer Etubien mittgeiften. Die menfd)lide Stuatomic

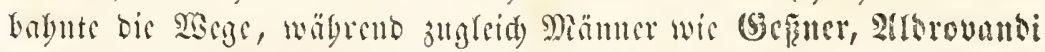
Das gange Gebiet ter Thierwert ju unfaffen ftrebten. Die wiffenfdaft= (id) frenge Metgore, weld)e juerit in ber arftronomie angewant wutse,

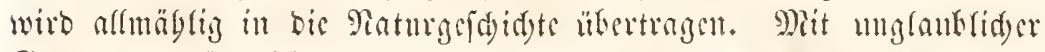

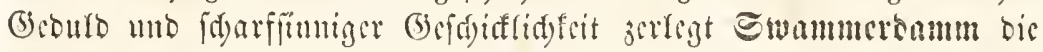
fleinften Suffeften und weift igre Berwandmugen mo Netamorplofen

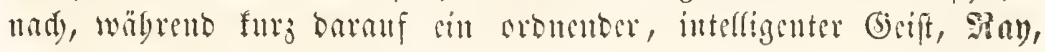
bem Bater fer beutigen 3oologic, Einné, sie Sage Kabut. Go man=

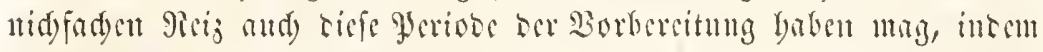

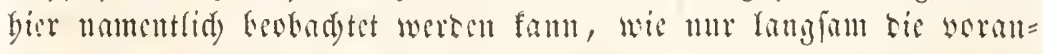

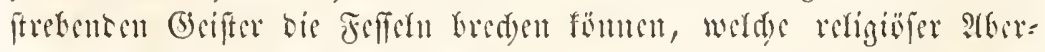

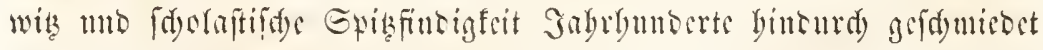

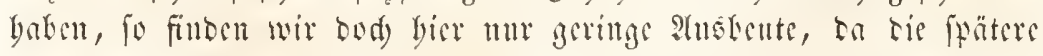

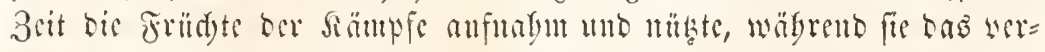
aftete Sriegsmaterial als unbraudbar berwar.

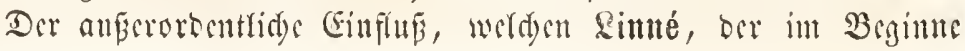




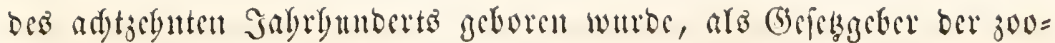

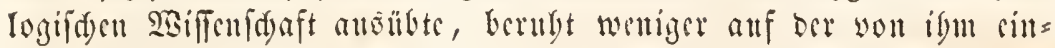

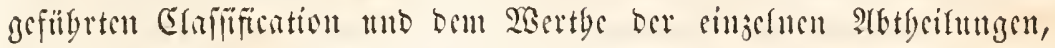

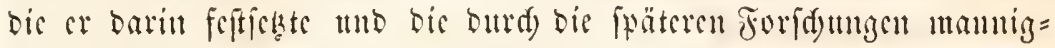
fad) abgränbert watrocu, ars siefmegr auf bem ftreng logifd) burdige=

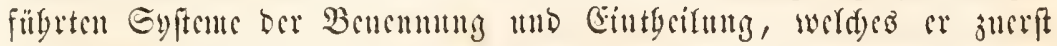

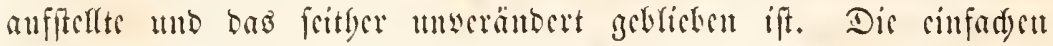

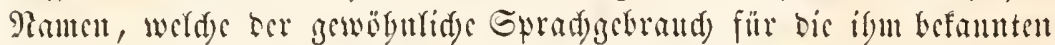

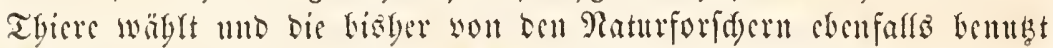
worben waren, geniigten für sine fyftematifde 3 manmenteffenng nidgt,

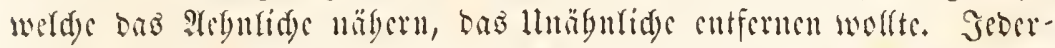

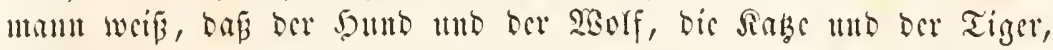

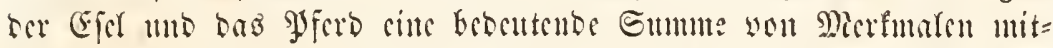

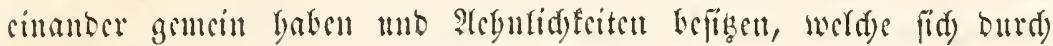

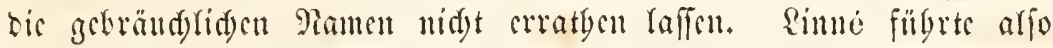
bic bopperte Miantengebung, bas Eyftent ber binären Momenchatnx,

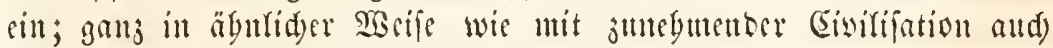

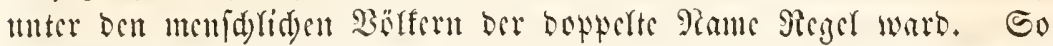

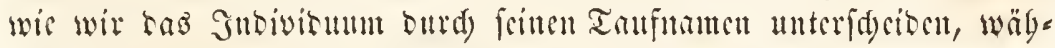

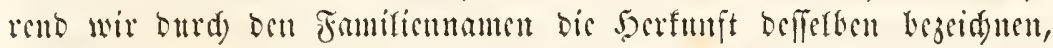

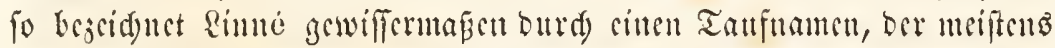

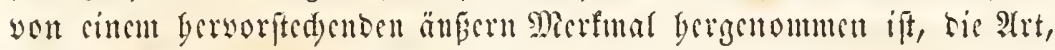
mo burd) cincen worgefegten Ramen bie Bejichungen biefer Art jut ver= wanbren Thicren, weldye mit ibm cine Gattung (Genus) birben.

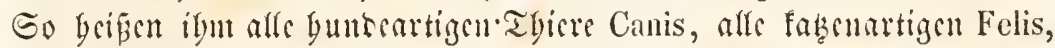

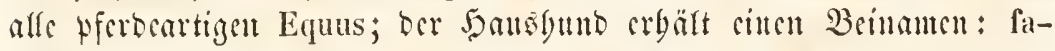

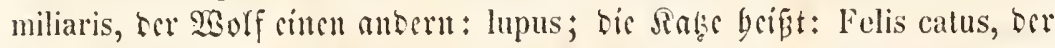
Tiger: Felis tigris; bas \$forb: Equus caballus, ber Ejer: Equus asinus.

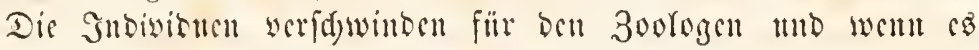

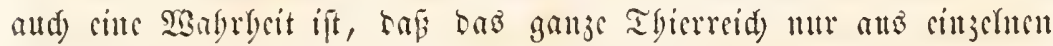

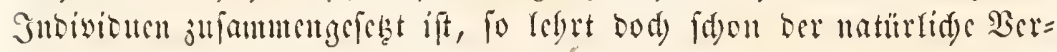

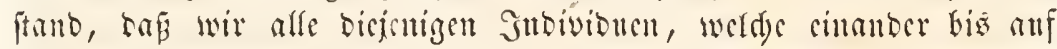

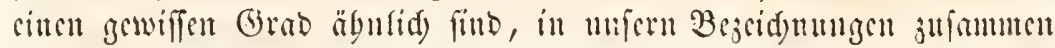

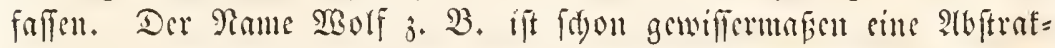
tion, unter weldjer wir alle bicjenigen abiere wercinigen, weldye bie

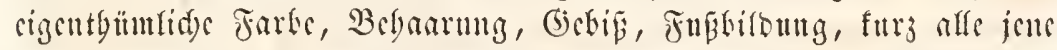

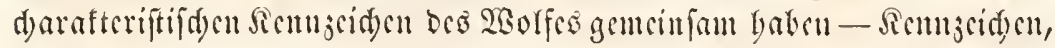

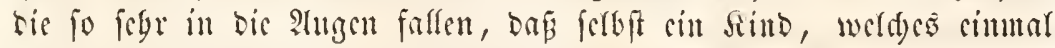

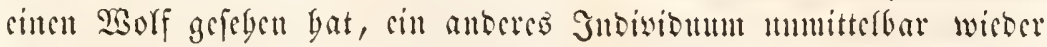

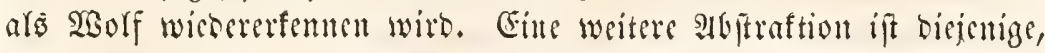


welde auf ben finne’fden Genus- ober Gattmgšnamen fübrt. Dic

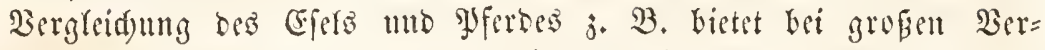
fdiebenbeiten in ber Bebaarung, in ber Geftalt bez Jörpers, ber Shren, bes Gdmanjes, eine anperorbentlide Gumme serfdsebener Dirfmale bar, weldse anf bas Engite mit einanber libereinftimmen,

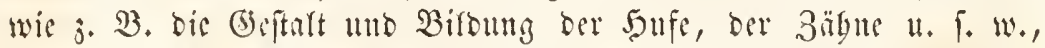

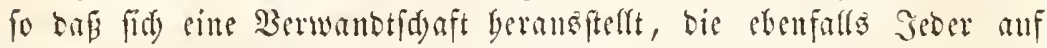
ben erften Bfict füglt, eine $\mathfrak{B}$ erwantidjaft, welde won Simne in bem erifgenauten Gattungsuamen ibren stmsorute erbielt.

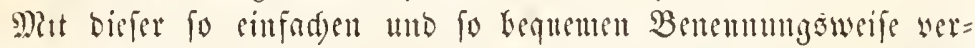

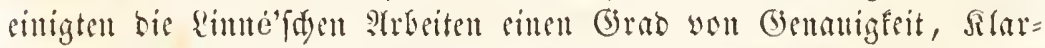

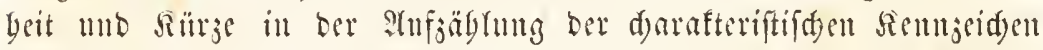

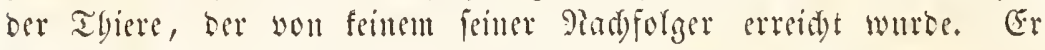
vergrid) bie Beobadytmigen feiner Borgämger, ftellte größjere Gruppen auf, bic er fdarf nad) äubern unb innern Rerfualen fdjeb unb ent= wiffelte eine ungemeine Thätigfeit, fowobl felbft als aud) แamentlid)

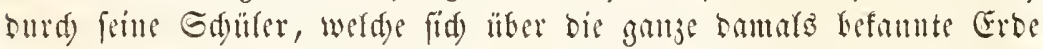
jerftrenten und ifrent Deifter Diaterialin jur Bervorfiandignng leites Syftems fammetten. Trob bes Eimpruders, ben namentfid) Buffon won Shrang an gegen bie chafificirente Metrobe Rinne's erbob, war=

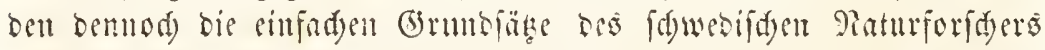

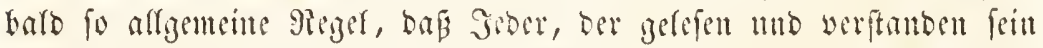

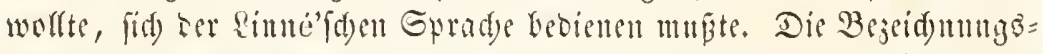

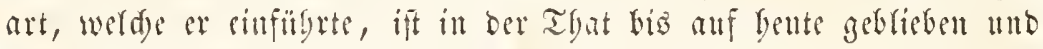
fanı lim to weniger geändert werten, als fie bas affeinige Mittel bleift, bie forfdger verfdjebener eänder in llevereinftimmung ju uringen.

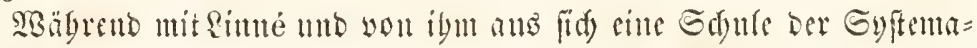
tifer entwidelte, welde bft in bitren Formelfrem werfant uno ifre

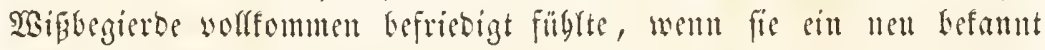
gemorbenes Thier in ben Ratafog regiftrirt batte, bibeten fid auf ber anbern Geite sinige Dänner bervor, weld)e befonters anf bas Reben uno Berbaften ber ffenern Thiere ibre ?Hufmerffanteit ridyteten

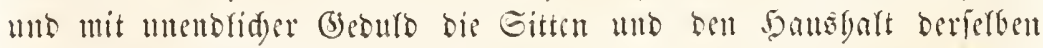

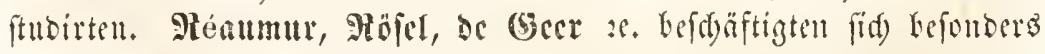
mit biefen zeitraubenben Beobad)tungen mito rieferten baburd) ben Gy= ftematifern vorteffidye Grunblagen ju fräterer Serbeffermus ibrer (5ebäube แno Fad)uerte.

Auch eine ariftofratifde Ridutung ber SBiffenidaft forte in oer

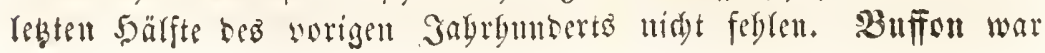




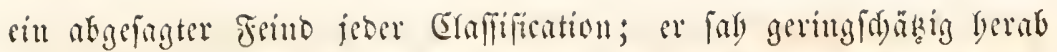

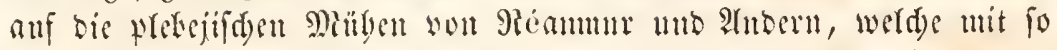

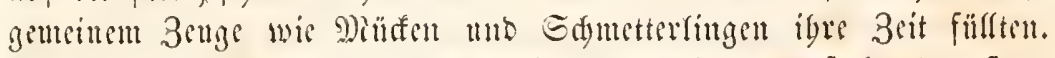
Durd) fein geglattete mo pomplafte Befdreibungen fuddete ber faerr

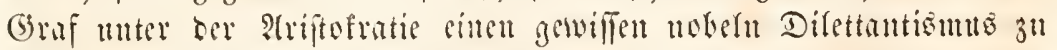

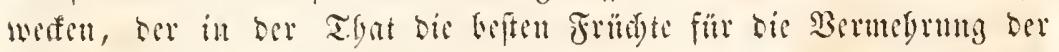

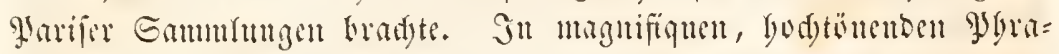

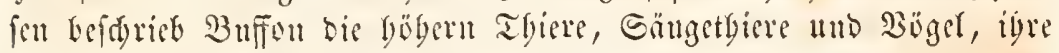

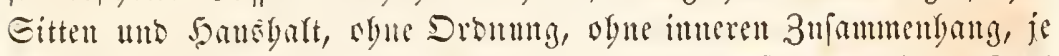
nadjem igm biefer vour jener Etuff gerigneter idjen, feinen Etyl

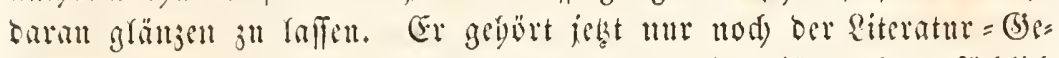

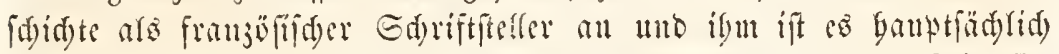

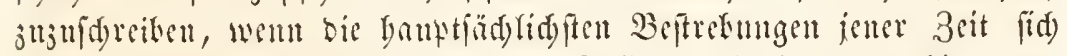

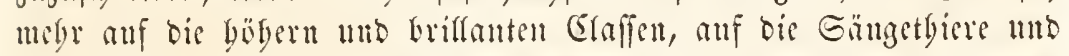

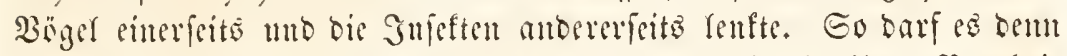
and) tiidgt wutbern, ment biefe (Elaffen sorjüglid) in ifrer Bearbeis tung vorfdritten unto bie Domalo angenommenen Gyfeme fid) ben

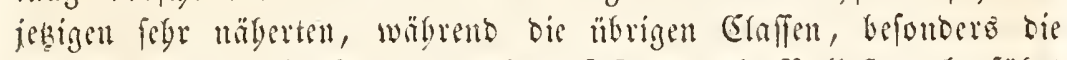

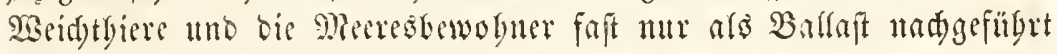
murbell.

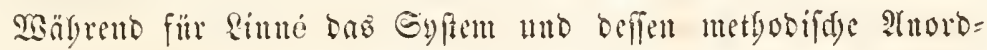

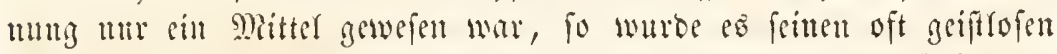

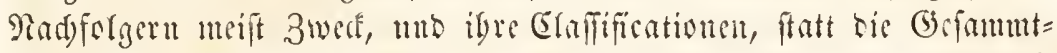
organifation ber Thiere int Stuge ju befarten, ffammerten fid oft ängfitlid) an untergeoronete än

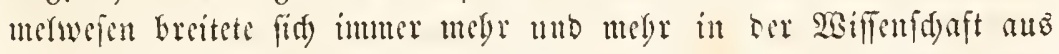

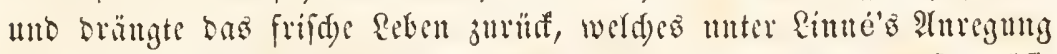

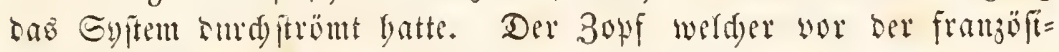

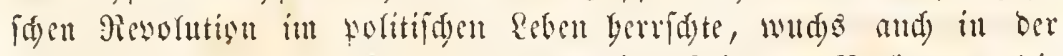

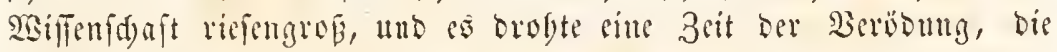

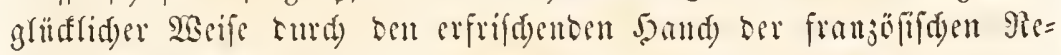
solution überwutuen wurbe.

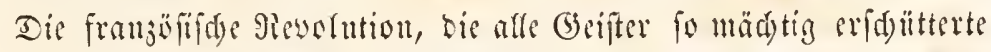

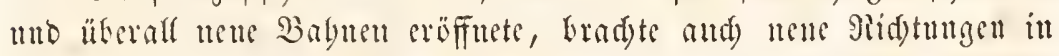
Der zodrgifden raiffenfdaft bervor. Envier batte bie Rüfen ent=

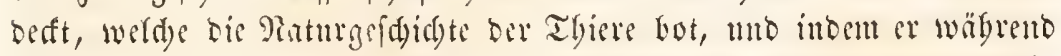

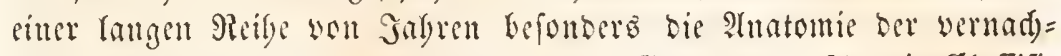

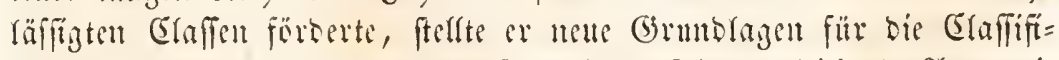
cation ber gefaumten Thierfdöpfung Ger. Die vergleidende 2natomie

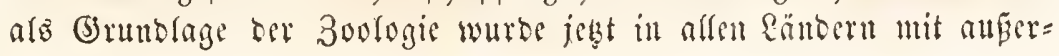


orbentlidyem Gifer betrieben. Man befudyte bie Sefuiften, um ben Ban bet Drganisutu bes Meeres in frifdem 3uftanbe zu unterfuden, unt je tiefer mat in die Drganifation biefer nicberen Thiere einbrang,

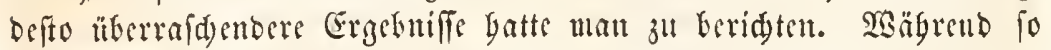
bie Renntuifs Der nicbern Thiere raid geförbert wurbe, babnte Guvier

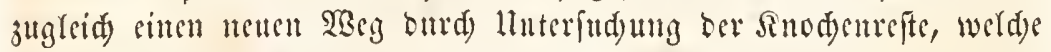
bie Sdjidten ber (Erbe cimfd)ließsen. Durd) bie gentaueften Bergleidun= gen ber cillgetnen Jragmente mit Den Gfeletten jekt Yebenter Thiere, gelang es ibm bie yorweltliden Sängetbiere und Reptifien meift in igren wabren formen wieber Gerzufeflen, igre Bejiebungen zu ber

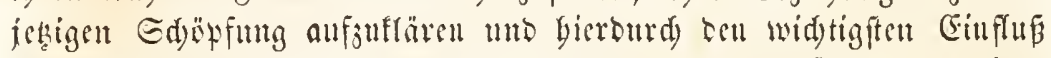
anf ein ftrenges und madbartiges Stubium Der Thatiadyen ju liben.

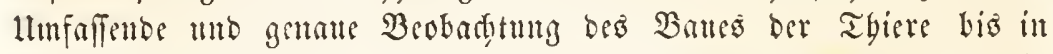

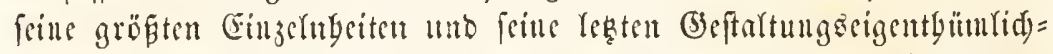
feiten, fritifde Rid)tung unb Bergleidutug ber Itbeiten ber Borgänger mo numittelbares Fefthalten an Den beobadjteten Thatfadjen, waren

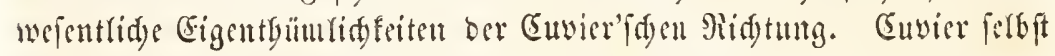
war eilt ftreng metgobijder, aber fuapper Bsifi, ber niemalo ben Boben ber Thatjaden verlié, surdy feine Spefulation bie Rüfen ber Beobadytmig on erfescen fudste, wobl aber sitt reides Daterial mit vieler STarbeit ju orbuen unb zu begerriden wnete.

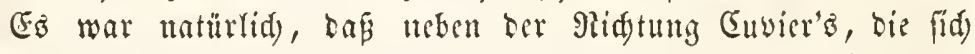
burd) לas ftrenge Feftgalten an ben Thatiad)en auszeidyete, sille megr

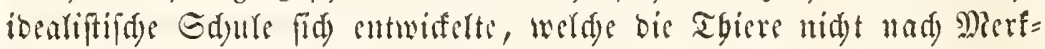
malen, fonbern nad) ben Jringipien orbnen wollte, in beren Befol= gung Die Ratur bie thierifden Drganismen ḧbergaupt Gervorgebrad)t

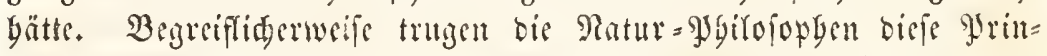

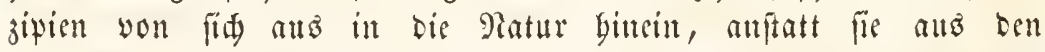
Tyatfadyen berworgegen zu raffen, weldje nur Rebenfadje, gleidjpan nur Berbrämung Des̄ phifolopbifden Fadwertes waren, nad) weldent

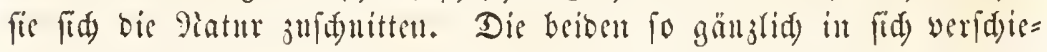
benen Tenbenjen fitefen Galb mit äuperiter Seftigfeit aufeinander, unb

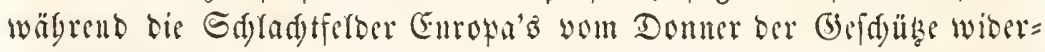
Gafften, war sill nidjt minber beftiger Streit zwifden ben beiben

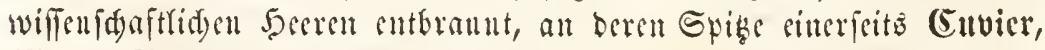
Micefer, Mubolpfi und Ticbcunann, anbererjeito (Sicoffron St. Silaire,

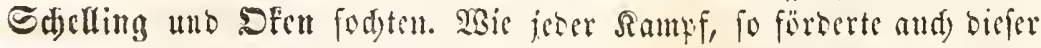
ungemein baburd), bap bie Geguter won beiben Seiten fosiel Material als möglidy Gerbeifdafften, un ibre wiberfader z" wermidaten, unto 
Daß die gegenfeitige Sirtif bie Beobadtungen fidstete unb igren that= fäd)lidyen 2 Berth feftifellte.

2̧ir find mit bicjen Sampfe in dic Hewere 3eit binthergetreten.

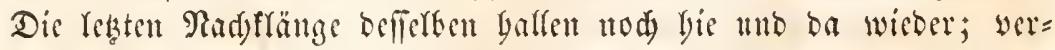
cinjelt trifft man nody jumeifen Ruinen ans ber naturpbilojopbijdyen

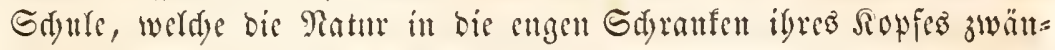
gen midyten. Die thatfüblide Ridytmig bat offenbar Den Sieg Dayon=

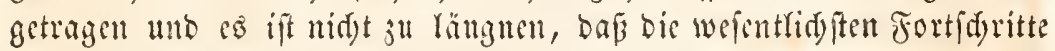

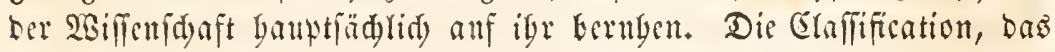
Syftemmadyen, obgleidy nod) bie unb ba eifrig gepflegt, ftelyt int b̧in= tergrunbe; - Man bat cingefeben, bar jebe Ceraffification theirs nur

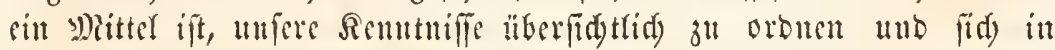

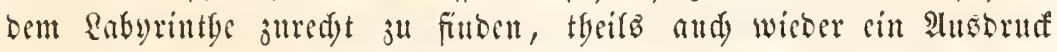
biefer Senntniffe, in weldem bie vergleidgente Beokadytung ibre Re= furtate funb gibt. Der Forfdyer, ber Heue Seiten cinem beobadfeten

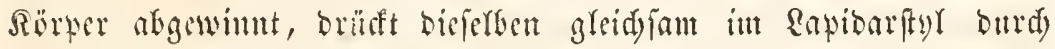
Berälloerung bes Syltems an ber betreffenten Steffe aus, und wäb=

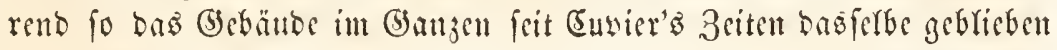
ift, fo bitrfte fanm cine Etelle ju finben feril, bie nidat mebr ober millber burdgreifend weränbert worben wirle.

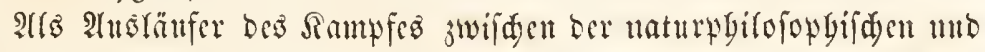
realiftifden Ridytung ferft fid in Der fy fematifden 3oologie wejentlids bie serịdebenartige Tenbens ber Gruppirung bar. Die Einen bebantp=

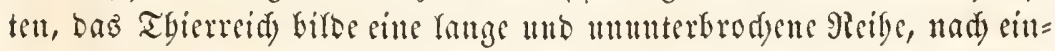
beitlidem \$fane gebaut, wo immer cin $2 B e j e n$ volffoumener fei als bas

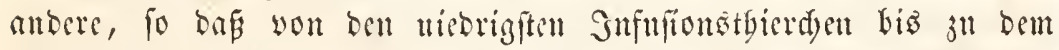

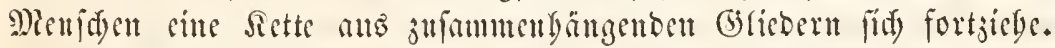
Derfelbe gemeinfame Jुan ber Drganifation rege bem Barue affer

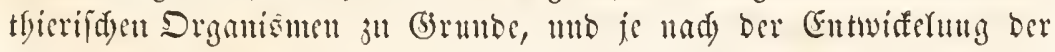

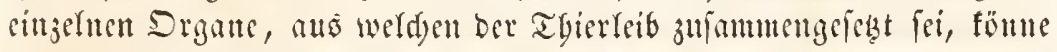
man bie Rangfttfe beftimuen, auf weldye jeber Drganismus geftellt werben mülाi.

Fttbere beganten, bem Bante ber Thiere liegen im Begentlgeil

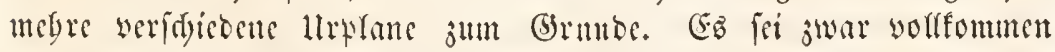

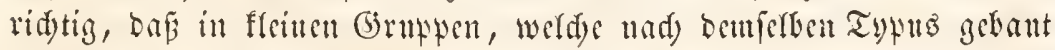

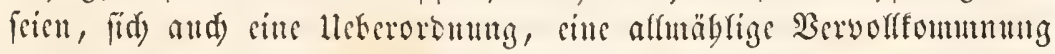
erfenten laffe, für bas banze fei bies aber nidyt ridjtig, inbent jeber

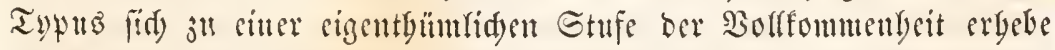

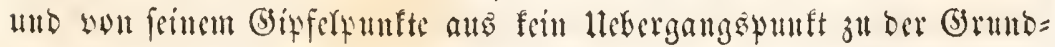




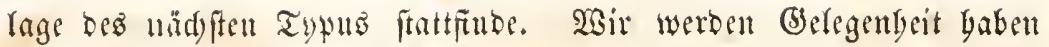

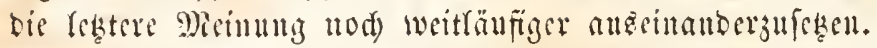

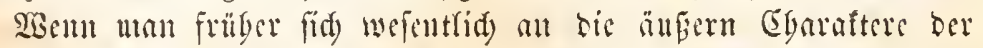
Thiere gebalten Gatte, ferbit fo febr, baj Rime vielen Epott erburben

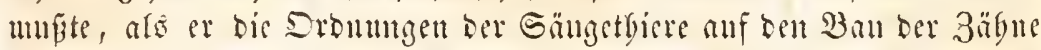

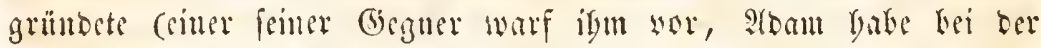
Mamengebung im Yarabiefe den Tbieren bas Maul midt anfigeriffen,

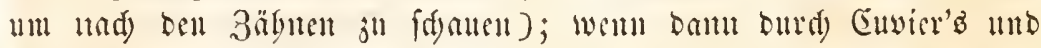

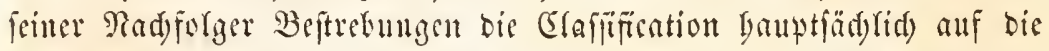
imnere Drganifation, anf beu Ban ber Drgate im erwadjenen Thiere

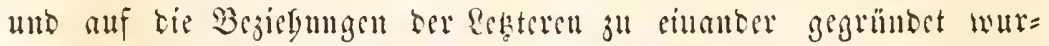
Den, fo fridgt fid jest eine nene Rigtming Babn, anf beren Ent= wiferung Dis Bicwolution son 1848 vielfeidst $\mathfrak{b}$ eftimut ift einen älu=

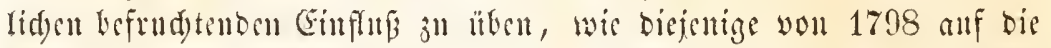

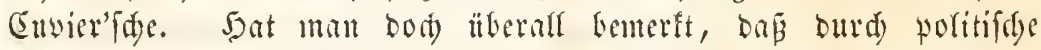

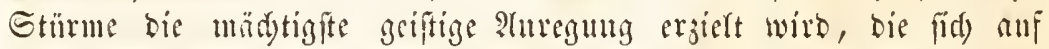

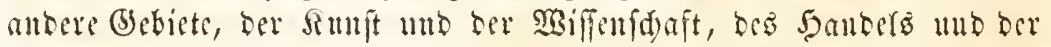

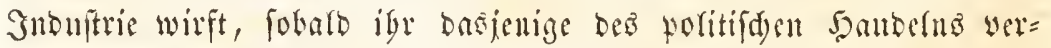
(d) Loffen wirb.

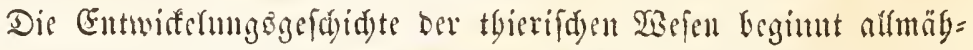
lig ben झlats singmiletmen, welden erit bie äufern Gbaraftere, fräter die innere Drganifation ore erwadjenen There begantete. Wem

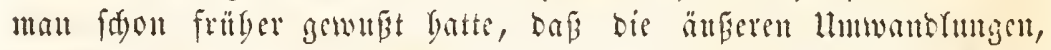

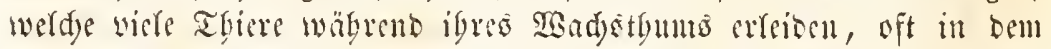

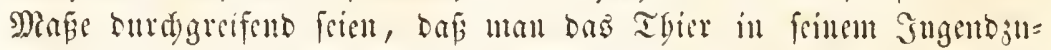

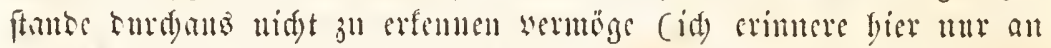

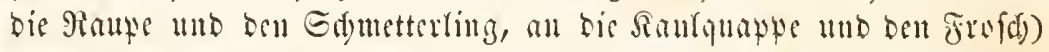

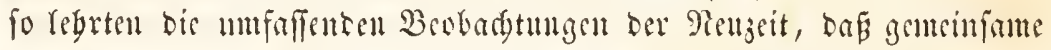
Typen vorbanden feicn, nad) weldyen fid bie Embryonen aub Eem

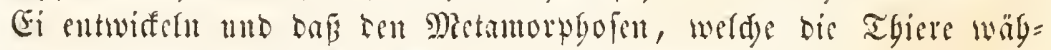

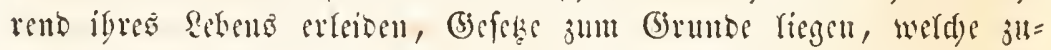
gleid) für bic ?fuskitomng Der gefanmten Gdjöpfung, wie aud) für

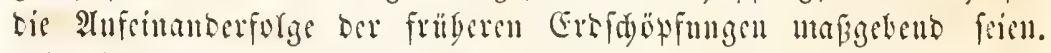

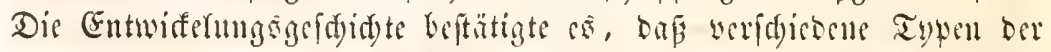
alfgentuen Drganifation sobbansen feicu, werdae in anfiteigender

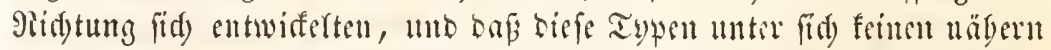

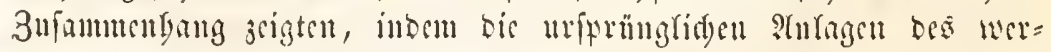

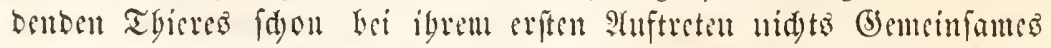

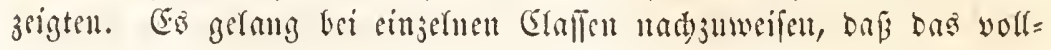

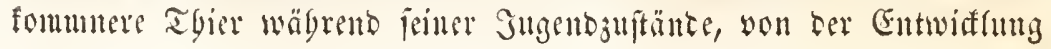


aus Dem Eic an, gewiffe Stufu Der Drganifation ourd)laufe, welde

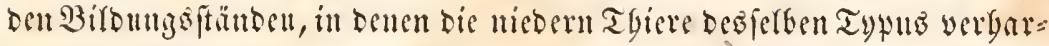

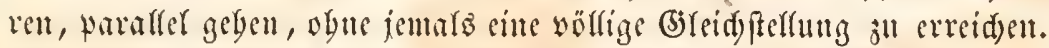

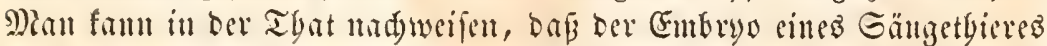

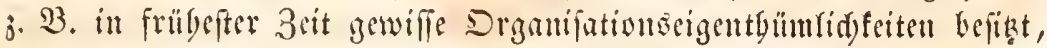
weldye un belt Fifden unt and) biefen nur auf Der niebrigiten Stufe

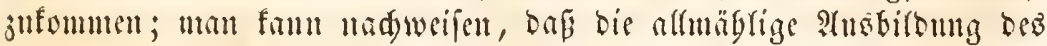
jungen Gängetbietes Stabien Durd)länft, welde der Alusbiloung bet

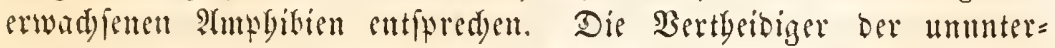
brod)enen Reibe in ber Thierwelt Gaben fogar bebantet, Defe Aebu= liaffeit gebe bis jur volfiämbigen Joentität und das werdende Säuge=

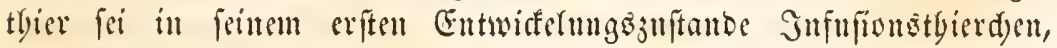
Wurm, SBeidtbier, Fifd) u. f. w. Dieje Begantungen riberid)reiten

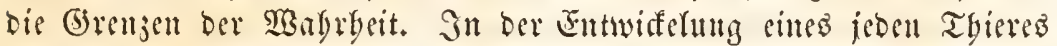

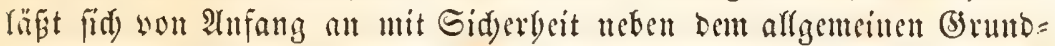

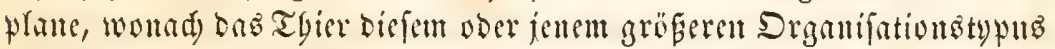

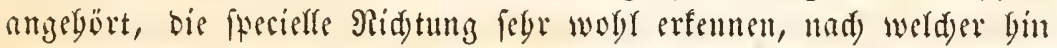

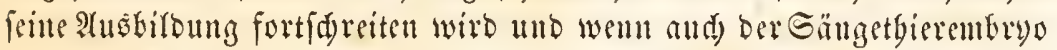

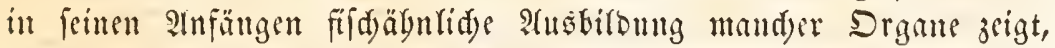
fo ift bod) niemals feime Giefammtorganifation berjenigen sines fifdes gleid) oder ein ferbitfändiges Reben fär ign in diefen 3uftande der

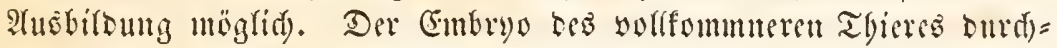

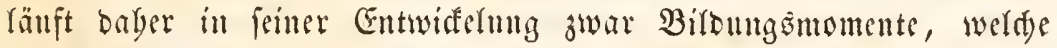

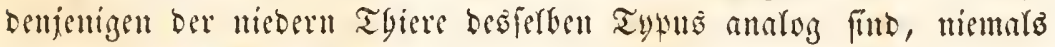
aber ift feine worübergebende Drganifation worftommen gleid) serjenigen

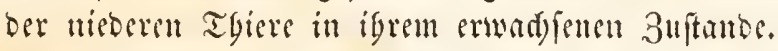

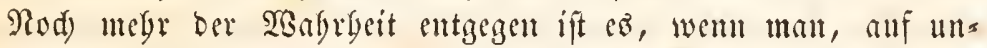
genaue Beokadtungen geitülst, bebauptet, de volffommetten Thiete

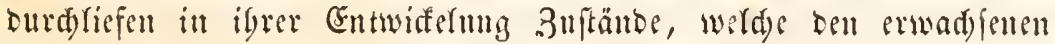

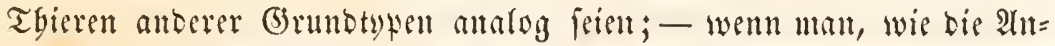
bänger ber unmerbrodyenen Stufenleiter in Der Sryöpfung es oft tyaten, 3. 3. bebautet, oer Boger fei wäbrent feiner Contwifelung

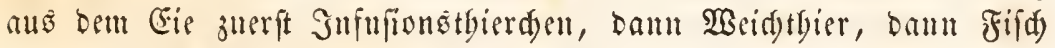
u. \{. w. 3u feiner 3eit feiner Exiftenz gleidnt ber Bogerembryo cinem Juleft ober einem Weidtbier, jul feimer 3eit gleidst bas werdente Jnfeft

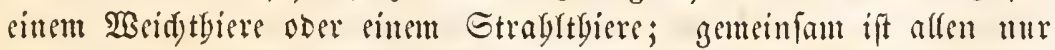

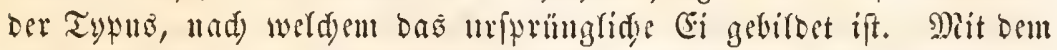

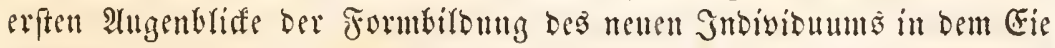
tritt aber aud) Der (5tundtysus berwor, werdyer in bell cinjelnen atb= theilungen bes Thierteides ausgebilbet ift. 


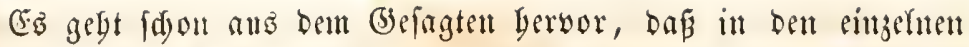
Familien und Gattungen, welde die (5rmbtypen ober gröferen Iftheifungen bes Thierreides zufammenfetsen, cine allmägrige Evo= fution zar bögeren Bolffommenbeit erfanut werben fann, beren ein= jerne Gtabien aud) in ben veridjebenen voriubergelyenden Birbungs: mementen ber böber feelyenden Gimbryonen erfannt werben fömuent. Das Tlyerreid) in feiner befammetbeit betradstet wiebergolt bemada in feinen singernen Formen mo beftaltungen Gleibent gewiffe Bif= sungsonomente, weld)e in ben Gimbryonen im zufammenbängenden

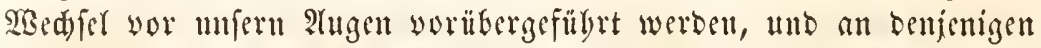
Srganen, an welden bie Entwiffelungs̈gefdidgte biefe vorübergegenden Sglafen ber Bifoung nadyweift, läpt fid bie gröfere ober geringere

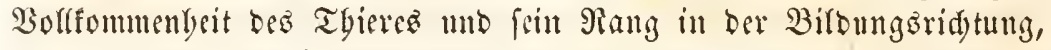

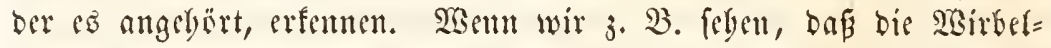
fäufe des Sängetbieres bei igrem erften ?tuftreten ans sinem cinfaden Sinorperifabe beftely, ber nod) frine atbetbeirungen zeigt, fo werben wir benjenigen Fifden, werde im erwadjenen 3 uftande nur einen folden

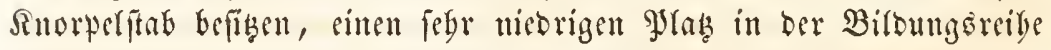
Der Sirbertgiere übergaupt anweifen müiffen.

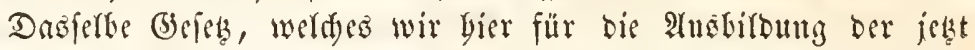
letenten Sdjüpfung aufgerferft lyaben, finbet aud) auf biejenigen Tgiere frine Snmendung, Deren Nefte in Dem Sdjoofe Der Erbe begraben

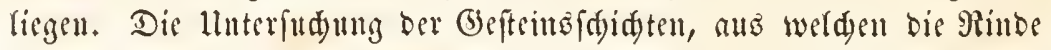

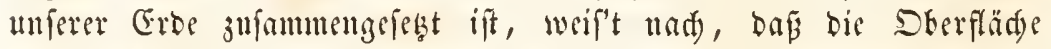

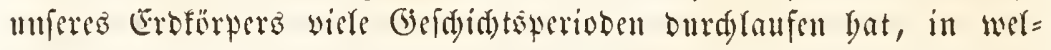
d)en unter fidd veridjiebene Sdjöpfungen bie (Erbe bevälferten; - eine

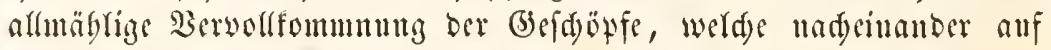

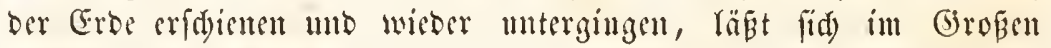

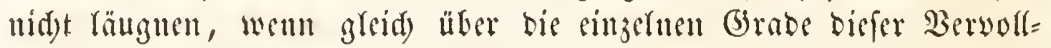

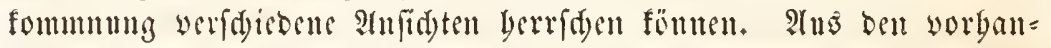

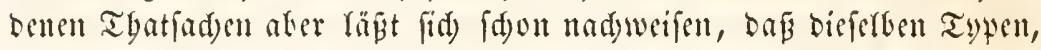
weldye in unferer jestigen Edöpfung vorbanten find, in ibren $\mathfrak{A}_{n=}$ fängen fojon in ber erften 3eit ber organifden Entwiefelung auf ber (Erbe wertreten waren unb baj fie Durd) analoge Stufen ber $\mathfrak{A}$ (usibil= bung binturd) gingen, wie biejenigen fund, welde wir in ber jeksigen Sdÿ̈fung und in ben Dietamorygofen ber werbenden There erfennen.

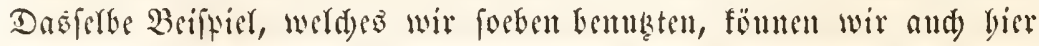
anwenben. Die älefiten Fifde, welde in ben unterften Gdyidsten ge=

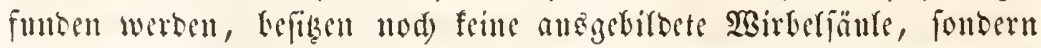

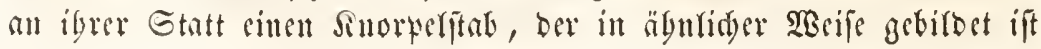




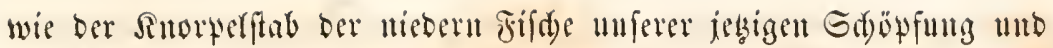
ber Sinoryelfab ber Sirbeltbierembryonen tiberbant in ber erften 3eit igrer Bitoung.

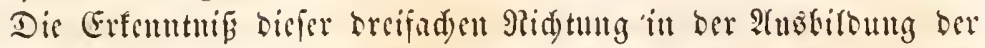
Thierorgantsuen, nümlid) Der biftorifden Entfartung Durd) bie wer=

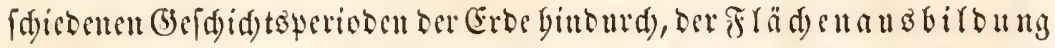

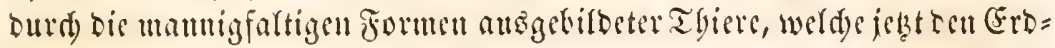

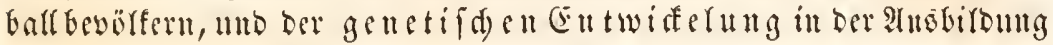

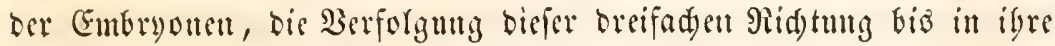

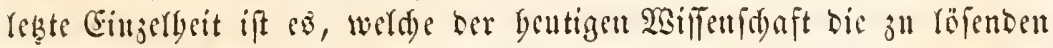
Iuffigaben ftelft. Rad) alfen Geiten bin beftrebt man fid) Die Rürfen

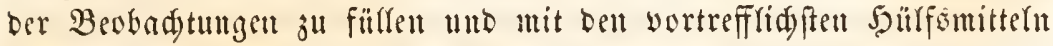
ansgerüftet in bie Cingelubeiten ber Drganifation sinjubringen. Die Ginen werfolgen die singefuen Thiere wou bem erften Alugenblife ibrer

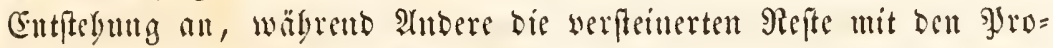

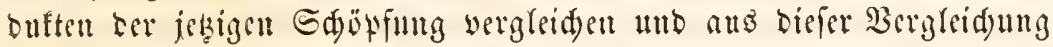

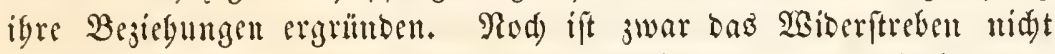
gant überwumben, weld)es gegen bie Berffumeljung Der Thiere ber iesct Kebenden Sdjöpfung mit Der früberen Croperiobe berridte, in= beffen lidsten fid) bod) bie Reigen Der (Begner won Tage ju Tage utto

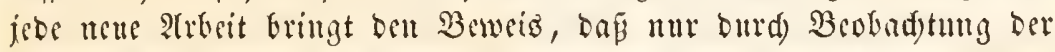

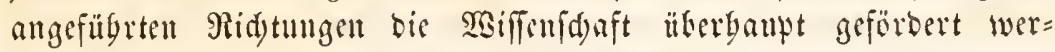
ben faun.

\section{$\longrightarrow 6000-$ \\ Bweiter 23rief.}

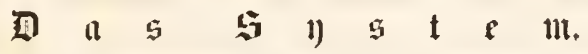

Gobalo man eimmal begonnen Gatte, die befannten Thierwefen ju

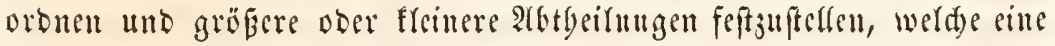
Heberfidst gewäbrten, fo wurbe notbwendiger Sacife Das Gyftem Der

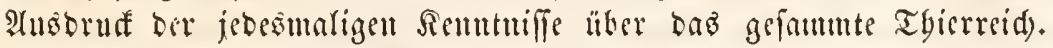
WBir baben fdon oben gefegen, wie Rinte zuerft burd) feinc bopper=

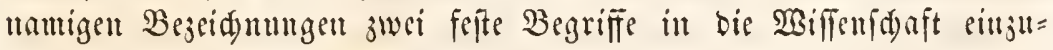
fübren fudte, benjenigen ber 2rrt (Species) und ben weiteren ber (5)attung (Genus), Şierbei befdrünften fid) inber weber Rimne nod 
bie fpäteren Graffiffatoren. Man fteffe unter ftets gröber werbenden

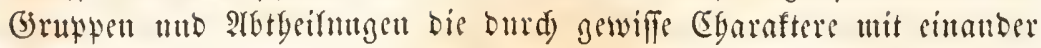

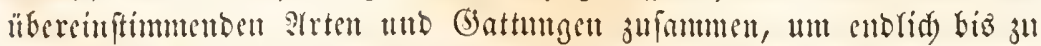

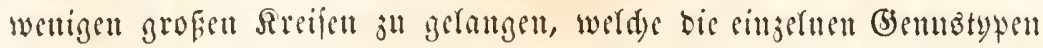

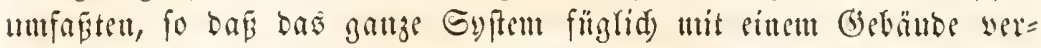

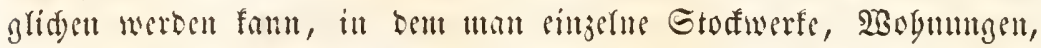

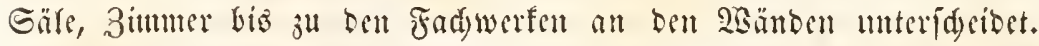

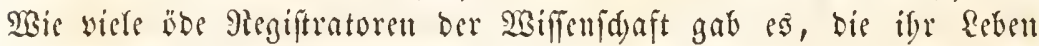

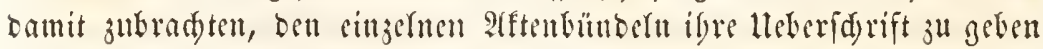
unb fie aus biefem ober jenem Befade in cin anberes binüber z"l tragen!

Die Grunblane anf melder bas ganje Gebälbe ber Gyftematif

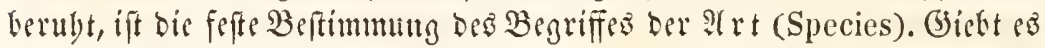

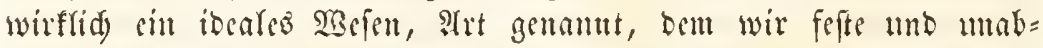
änbertidye Cgaraftere juidretifen fömnen, ober baben wir es nur mit

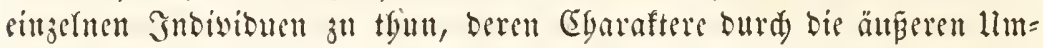
ftitube bebingt und fo weit mobificirt werben fönnen, bas pas jweifel= baft wirb, ob fie nod) Derjelben art angebören?

So weit wir jekst blifen fönnen, fo mitffen wir ben Begriff ber Irt Dabin beftimmen, oaf zu berfelben art alle Snbiviouen gebören, welde wou gleiden Eitern abftammen mto im Berlaufe ibeer Eut= wiffelung, entweber ferbft ober Durd) ifle Desecndenten Den Stamm= ärtern äbulid) werden. 3nr Feftitelfung ber Ggaraftere, welde einer

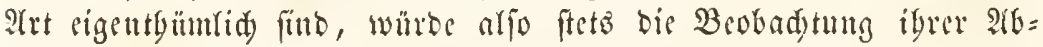
ftamum! gebören und man witrbe bei einem sinjelnen Thier, beffen Seide ober weriteinerte Refte man mur in bie Sand befïme, niemars entfaciben fömen, ob sis ciner andern Art angebört. Sn ter That Gat and) bie 2Biffenidaft idon eitle unjäblige Mienge won Grrtbümern

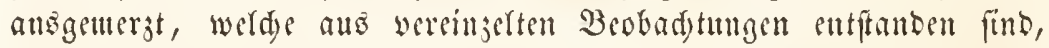
unto täglid) Dienen weiter greifende Beotadutungen baju, Thiere, die man weit weridjeben glanbte, als ju berjelfen ât gebörig anjuer= fennen, ober anbere ju trennen, bie man frïber sereinigt batte. Pies= mand wobr wïbe bie Ranpe ober bell Edmetterting, bie beibe jo untentid) in igrer änferen beftalt wie in igrer interen Srganifation

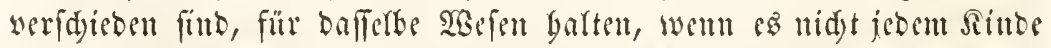

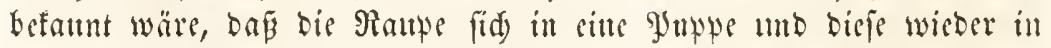
einen Edmetterfing werwandelt. Die Beokadtmug ift aber nidat ilberall fo reidgt, wie in bem angefübrten Falle. SBit fönnten Gunberte won Beifpielen anfübren, wo es jabrelanger, mit ber grö̈ten Itnsoner fortgefingrter Beobadytungen beburfte, um barautbun, das bicfes ober 


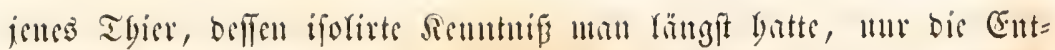

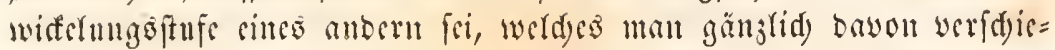
ben glanbete. Bejonders bei fen medern Thieren, betten man erft it

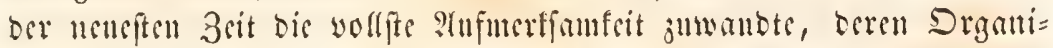
fation ifres abweid)enten Tysus wegen fo räthfergaft war unb beren

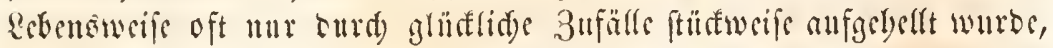
befonders bei bicfen waren nub fund Berfegen biefer Art nod) icket angerorbentlid) bänfig. Şat man aber sin giedt, ans fordden Grr.

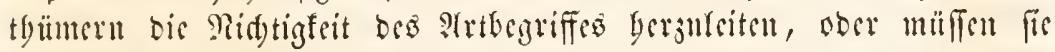

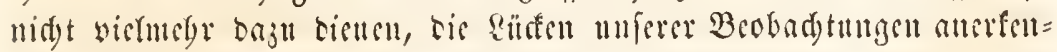

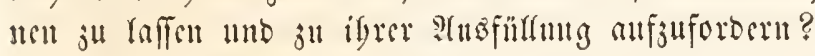

Man bat anf bet anderen Geite singemorfen, baß bie täglide

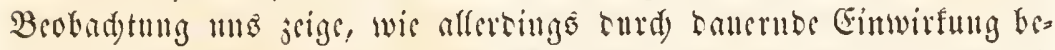

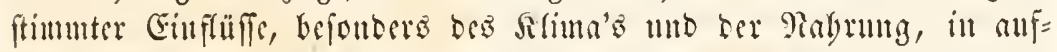
einander folgenden (5) enerationen Beränberungen erjengt werben fïn= uen, bie bebentender feisu, alö biejenigen Merfmale julnfien, weldye utan fïr bis Sart angiebt; - afleill and bier bat bis Beobadtung,

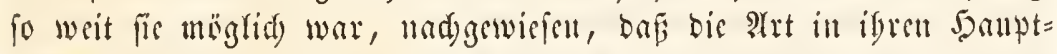

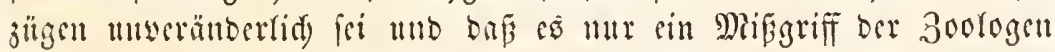
war, went man bie Charaftere ber ate wirflid) wou ford)en Dierf=

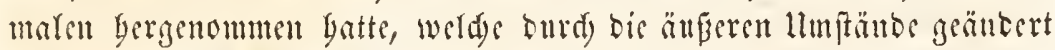

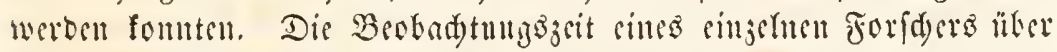

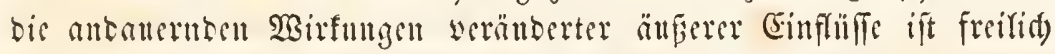

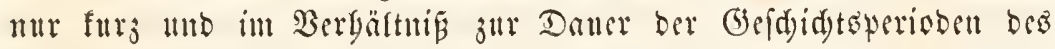

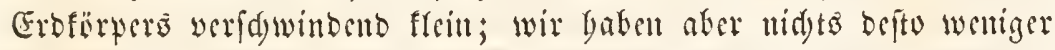
Mitter jur Santo, woourdy wir nad)weifen fönnen, bafis wenigitens feit Der 3eit, ans welder wir gefdrdytlide Denfmale befitsen, bie

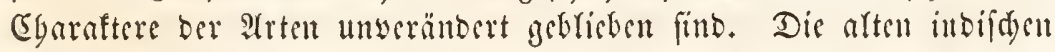
Denfunäler raffen ben afiatifden Gerepbanten uno ben beiligen Buffel= od) fen mit vorfemmener Giderbeit muterfdeiben, und bie Mumien ber

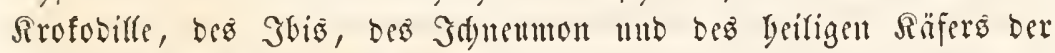
Prgypter, you benen einige mad ben neneren Forfentugen jlum we=

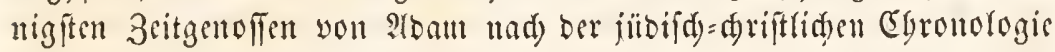
waren, funb bis auf bis fleinften Eingelngeiten in igrer Struftur iben= tiid) mit ben Thicren, weld)e bente nod) an ben llfern bes Thifs Yeben; wir fönuen arjo mit volfsummener Gidertgeit belanpten, baß bei ben in wirben 3ujtand rebenten Thieren bie Charaftere ber alt unver=

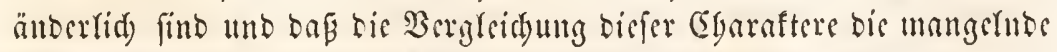
Beobad)tung Der bireften Abftammung erfezen faun.

Minn yat bie Erfenntuif biefer Wabrbeit zum Theil audy in ber 
Albfidst, gewiffen religiöfen Gagen gefällig ju ferin, fogar fo weit anb= gebebnt, baf man bie Art babin befinirte, fie fei ber Snbegriff aller Snowionen, welde von citcm Eeltern. Yaare abitammen. Man that

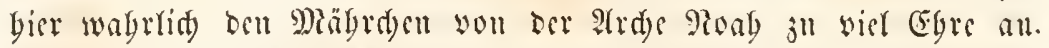
Sätte man gefagt, Dic Fit fei Ler Jubegriff aller berjenigen Snsivi= Duen, Deren Ggaraftere fo hltereinftimment feirn, oas fie möglidyer

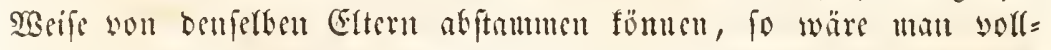

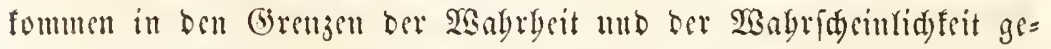

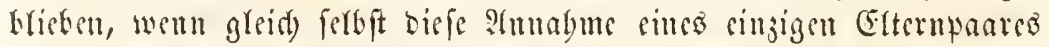

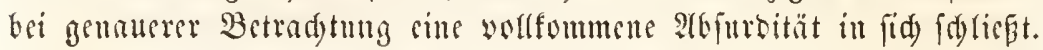
Dis grif̧ere 3abl ber Thicre, wentigftens weit über die 5älfte, rebt won anderen : Frten und ift in ifrer Exiften; auf bie Bergebrung ber= felben angewicien. Dic Entfelyung ber jebigen Sdyüfung in je nur

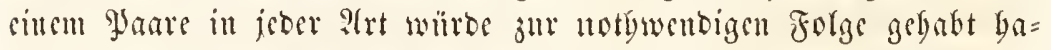

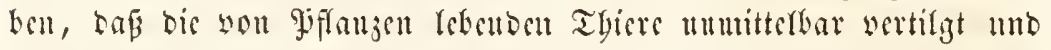
Dic lleberbleibenton bem 5utngertobe in wenig Tagen Jreio gegeben gewejen wären. Sair geben bier uidyt weiter anf bas theoretifdye

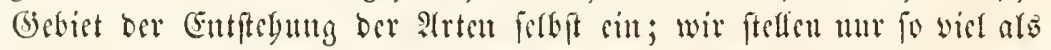

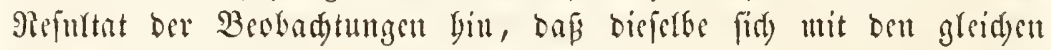
Egarafteren fortpflangt unb sab biefe Egarattere in Saufe ber 3riten unveräubert gevtieben find.

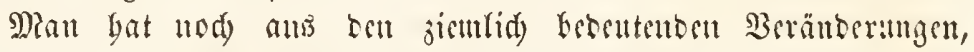

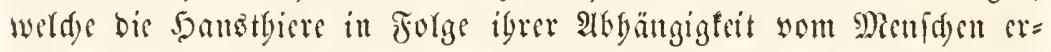
Yriben, Ed)(ülle auf bie Seränocrlid)teit ber Itt jieben wollen. Sn ber That bot es bis Simlt foweit gebrad)t, ourd) Srenjung bejonbers gebirbeter Etterm, Durd) Kepontere Rabrung unb Sartung, Afarten unb Paçen ju erjengen, bie fid) conftant fortpflanjen unb surd) Farbe,

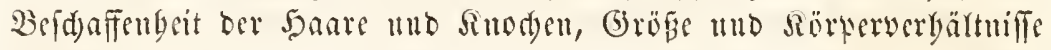
oft bie Gebentenfen Differenjen barbieten. Ridsts befto weniger geben

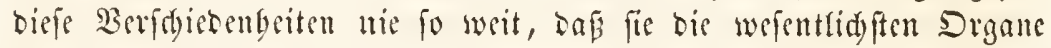
betreffen. Die Theire tes Sterettes breiten bieferben unb es ift nod) Riemanden singefallen bebaupten zu wollen, baí man burd) Serenzmg

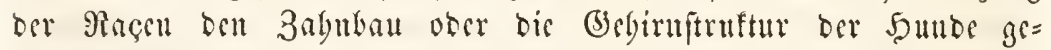
andert babe.

গ่̧ weldas fid) bei ocr Fortpflangung ftets wicoer fortzengen, fo ift freilid)

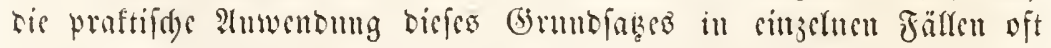

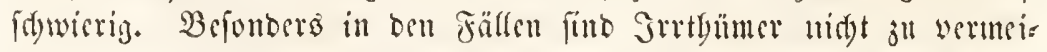
Den, wo burd birette Bevbad)tutg ber Fortpflanjung biejenigen Ega= raftere nid)t ermittelt wurben, weldye burd) bie äufern Giuflüffe mobi= 


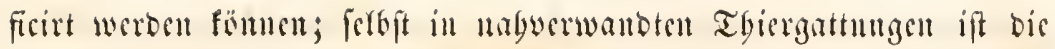

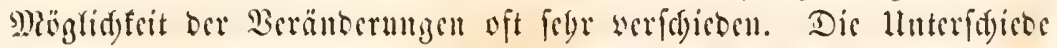

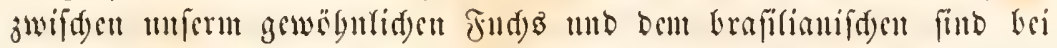

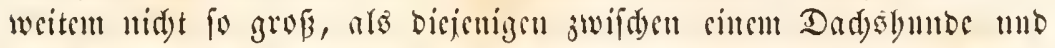

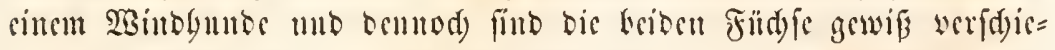
bene 2rten, wäbrend bie beiben Sounte berfelben 2ht angebören mo

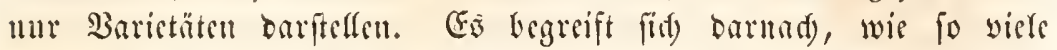

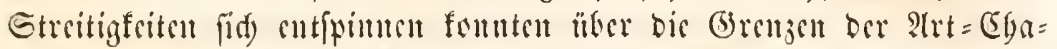
raftere mo wis es möglich war, Dafi ber sime Raturforfder jwei

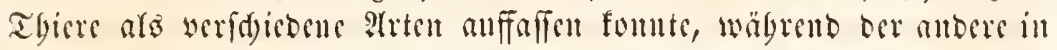
ibuen แur Barietäten berfelben Art erblifte.

Bon ungemeiner SBidytigfeit ift bic Sdylidtung bicfer Streitig= feiten, Kefoubers fïr bic Beftimunutg oerjenigen Sicfe, weld)e wir unr

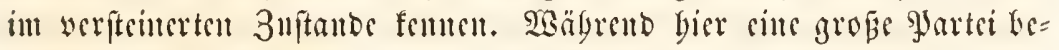
Gantet, bie gyerioben ber (Erogeididyte feien burd) gewaltige 9ievoln=

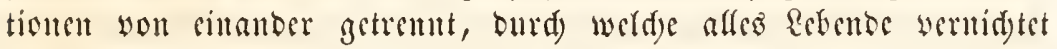
wurbe mid uad) benen urue Arten entitanden feien, weldye you ben

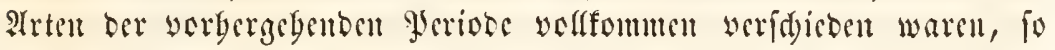

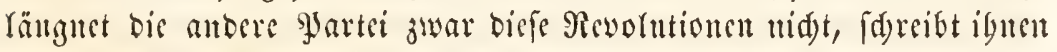
aber unr fartielle $23 i r f u n g e n$ ju und fud)t bie Beränbermug ber cin=

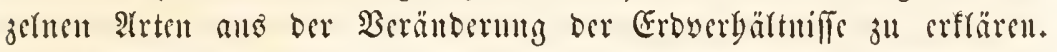
Die Eitten bebaupten, es finte fein llebergang ftatt, dic Antorn wol=

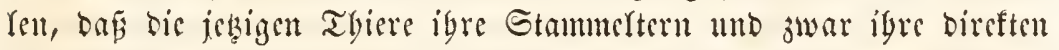
Stanmeltern in ben untergegangenen Gdjöpfungen befißsen. Diefelben

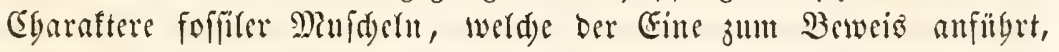
Daß̉ sine Species untergegangen und sine neue entitanden fri, Diefrlben

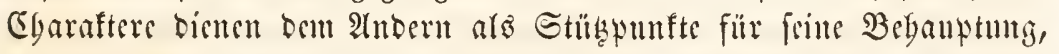

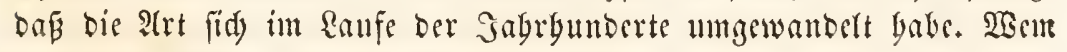
nun bier Redyt gebell, wo bie Entfdecibung Durd) birefte Beobadjtung

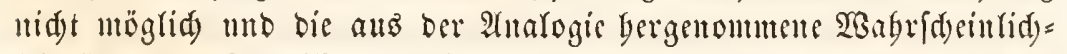

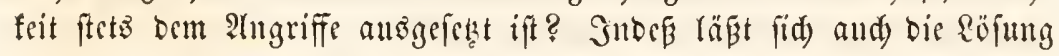
it ber Forge boffen. Da wo bie übergebliebenen Refte widtigen mo d)arafteriftifden Theifen angebüren, fint diefe Disfuffionen über bic arbgrenjung oer âten alfuñblig wou felgit erlofdent. lleber foffilte Säıgetbiere 3. B., Deren volfftündige 3aluneigen und darafteriftifd)e Glicberfuod) man fennt, tand)t mur frtten ein Strcit alt; aber

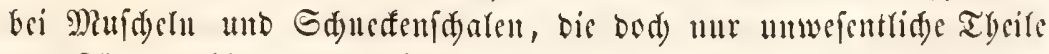
bes Rörpers bilben unb ḧber beren Beränberlidfeit wir nod bei fei=

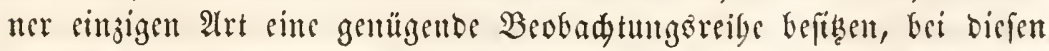
brennt ber Etreit jest nod) bäufig fort; cr wirb audj bier feine cre 


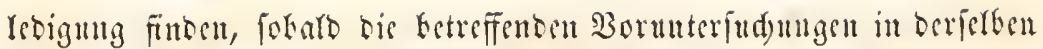
Art erlebigt fint, wis bies bei anbern Tlyieren ber Fall ift.

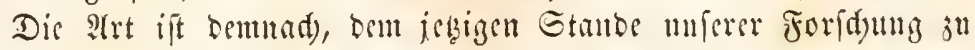
Folge, ein muvcrüncrlider Drganifations = Typus, ber entfeben mo vernid)tet werben foun, aber friner ivejentfid)en A(enberung frinter Egarafters fäbig ift. Dis 2art entfprid)t beftinuten Refensbebingungen,

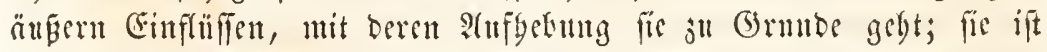

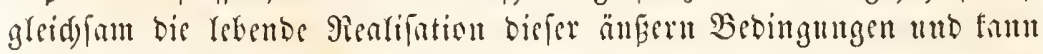
mit uno burd) biefe nur in fo weit verändert werbsu, afs unwefent=

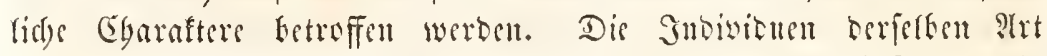

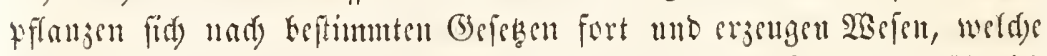

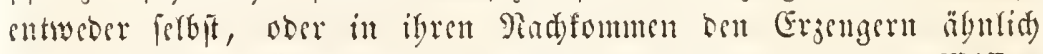
werben. Jrüber founte man nad) bem bamaligen Gtande ber \$ififn=

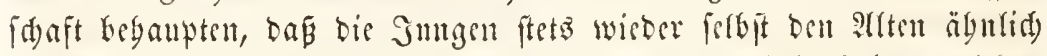
werben mtïsten. Die Mnterjudjungen ber netern 3eit baben getebrt,

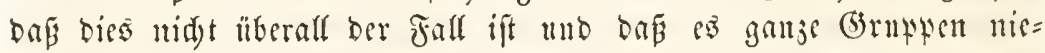
berer Thiete gibt, bei weldyen ber Eychts ber Fortpflanjung erft burd) bas britte ober vierte Snbivibutm gefd)loflen wirs. Sair werben Decresbewobner, fogenanute Dnaflenpolypen fenten fernen, bei wel=

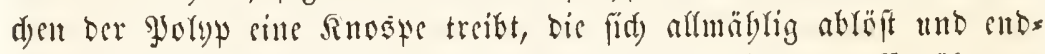
lid) alo wolffänbig ausgebiftete Snalle, mit allen jur Ermäbrung, Bewegung, Empfintung mo Fortpflanjung nöthigen Drganen aubs= geriiftet, frei im Meers umberfdewimutt. Disfe Dualfe wiro niemals

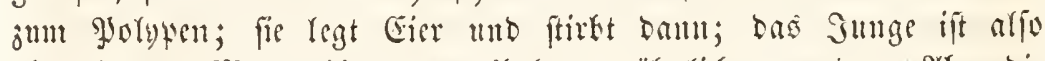

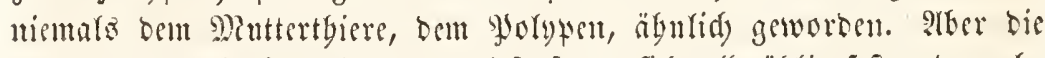
Gier, weldye bie Sualle legte, biefe fezen fid) alfmählig feft uno wad)=

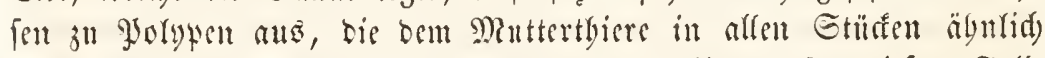

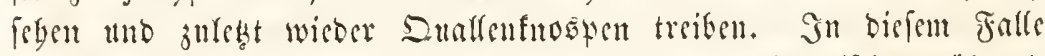
find arfo nur Grofeltern und Enfel mit eimander iosutifa, wägrento Ertern uno Sinoer einanber fo solffommen unäbulich fino, baв man

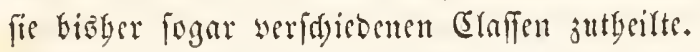

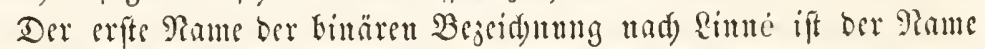
fer (b) attug (Genus). Man umid)reibe baburd) cine Summe von wefentrid)en Ggarafteren, welde melyeren 2trten genteinfan fint. Ra=

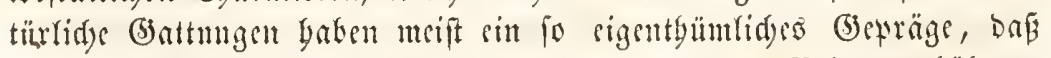
man unwillfürlidi anf bisferben bingeleitst wirt. Bai bon büberen

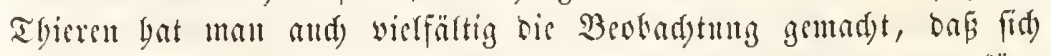
Dis singeluen arten mit cinanter Eegatten mb Baftarte ergengen fön=

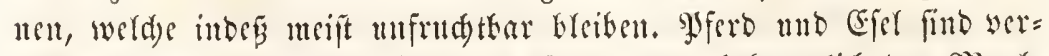
fdricbene S(rten berferten (5attung, fie erjeugen befanntid) oen Dianl= 
ejer unb bas Maultbicr; fo bat man and Baftarte gefeben won 5 mub

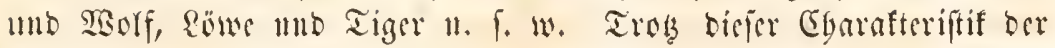

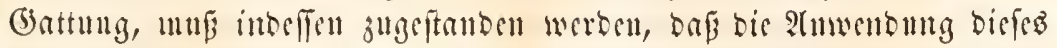
Begriffes sine uners ober minber willfürfide ift, intom bie 2 Berty=

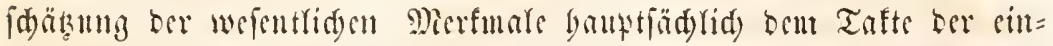

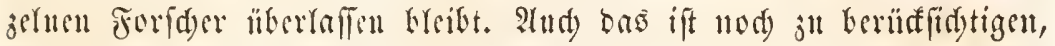

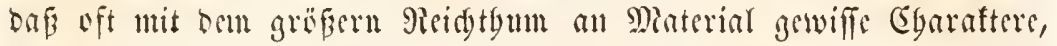

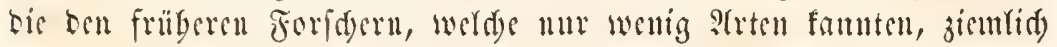

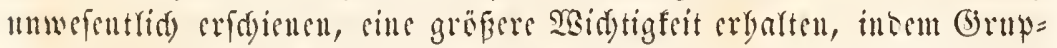

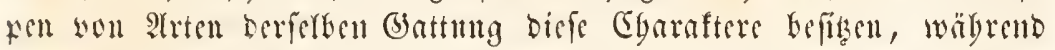
fie anbern afgeben. STus biefem Grunbe ift es erflertidy, warum faft

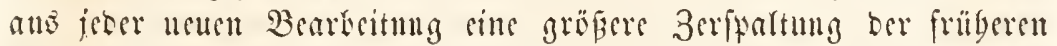

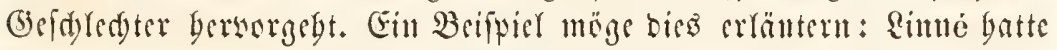

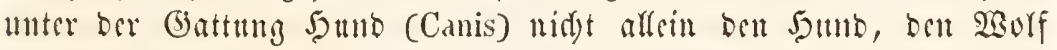

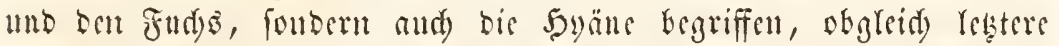

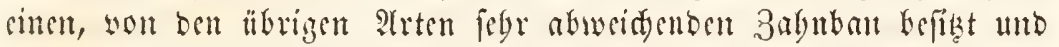
ifr namentlid) bie Soüferjäbne, weld) jene gaben, gänjlid mangern. cin 3citgenoffe Sime's fdyon, Gtorr, tremnte dic beiben Syyänen mit

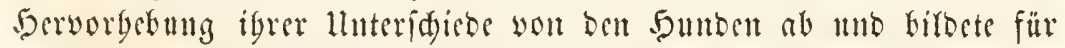
fie bic befonbere Gattung Hyaena, weldye jekt fogar, kefonbers burd) foffite (jattungen, ber Tyyns einer Jamilie geworben ift. Rimne fannte

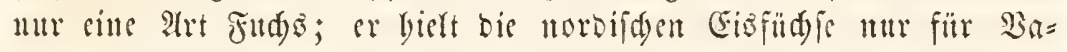

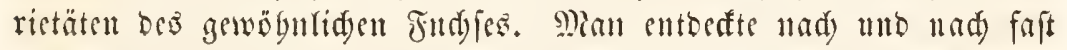
ein Dusend verfdiebener Arten, wetdye alfe mit mererm gemëbnfiden

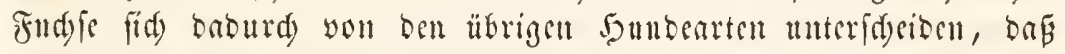
fie simen bidtbebarten, rangen Gdywan, sime fpibe Edyanje unb

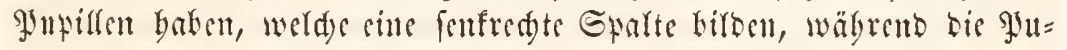
fille ber lukrigen Sombe rumb ift; nuw bie obern Gduncibezäbne

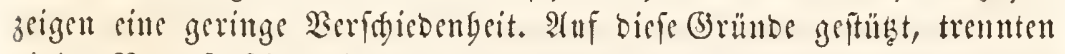

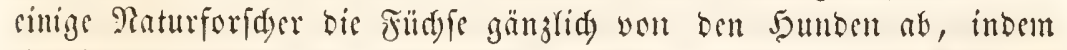
fie bie Gattming Vulpes erridsteten; - anbere, inbem fie bie alte Gat= tung Canis beiberbielten, bilbeten barin mebrere Grupten ober lluter=

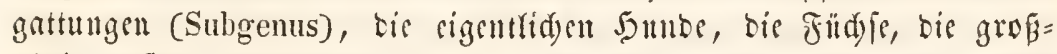
sligen Sumbe von afrifa u. F. M. begreifend. Man fiegt ans biefem

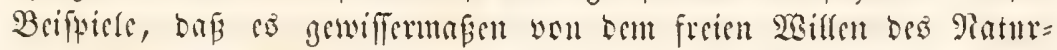

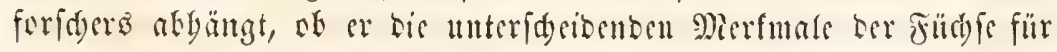

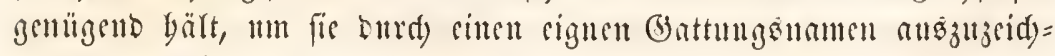
nen, aber ob er biefe Dierfmale nur zur engeren Grmppirumb ber Arten innerbarb cimer gröberen Gattung bemulat.

Durd) bie veridjebenen Begrenjungen, weldye bie Battungen feit 


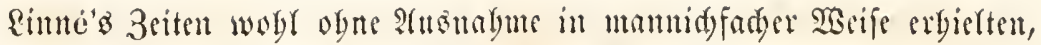

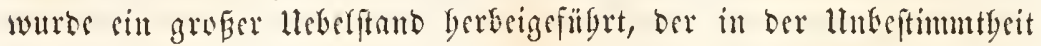

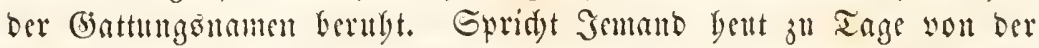

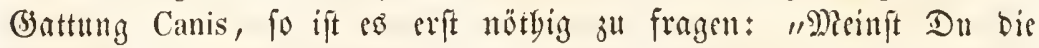

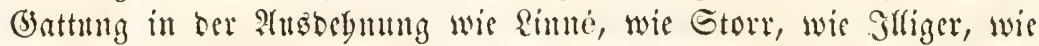

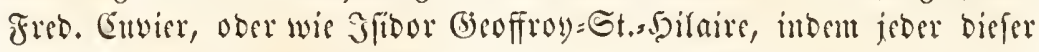
Forfder bic Gattung in anberer 2 seife umfdreibt?" Maan bat biefem

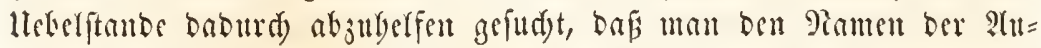
torität, weld)e bie Ganttung in ber siscife umgrengt batte, wie man

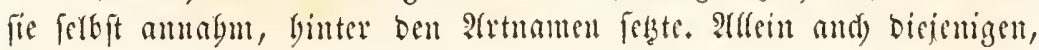
weldye nette Arten befdrieben batten, wodten burd) Brifïgung ibres

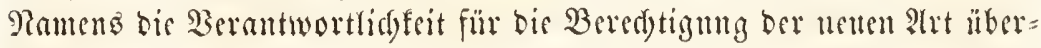
urgmen. So entitand aufá Reue Berwirrung; - man mujte nidyt,

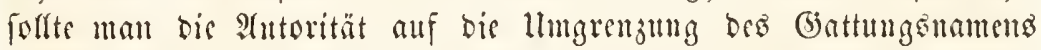

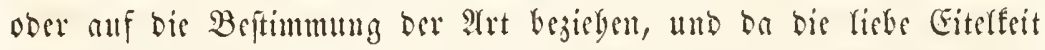
gar Mandlyen verteitets, mur unt bebwillent eine nette Gattung ober cine nene ?at anfjufteffen, tum feinen Pamen in ben Megiftern ber

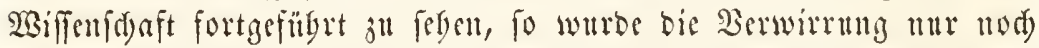

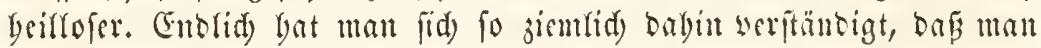

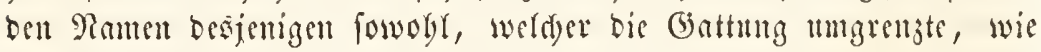

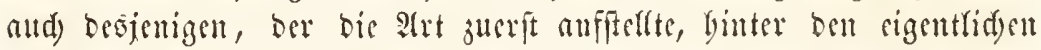
Irtmament feģt und baß man als Synonyme biejernigen Ramen an= fülyrt, weld)e sou früleren sfutoren gegeben wurben. Selne oft foumt

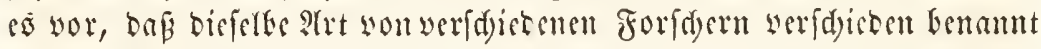

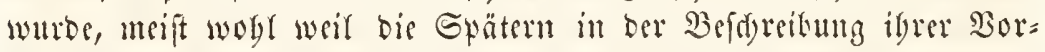
gänger bas ibnen sortiegende Shjest nidft wieber erfarinten. Dian

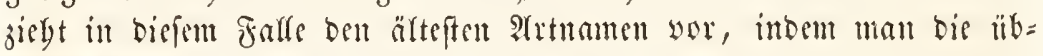
rigen als Synoume citirt.

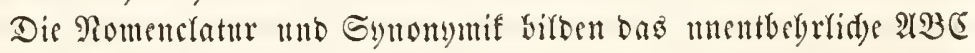

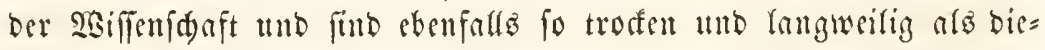

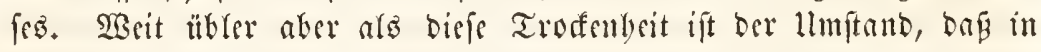
ignen ein grautenerregenter gifterifder Baffaft mitgefübrt wird, ber

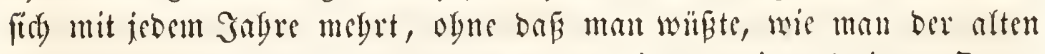
Steine log werden fömute. Sลenn fopfe cingefallent ift, in sintem verbreiteten Joumale einer längit be=

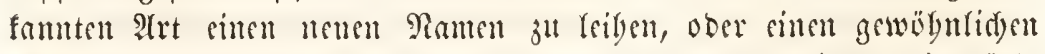

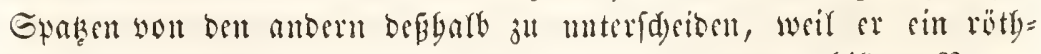
lides Jeberden anf bem Sopfe lyat, fo wirb ber neugrbiftete Ramen

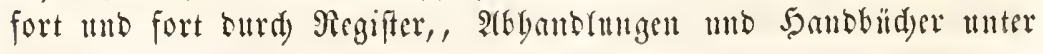


ben Synonymen mitgefïbrt, obne baf man fidy feiner wieber entlebigen föunte.

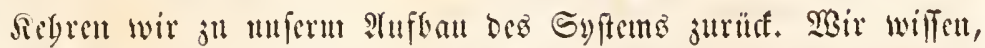
wie bie Atren beftumt, wie bie Gattmigen mugrengt werben, wir fenten die Bebentung ber Doppefnamen, welda bie Arten tragen mub

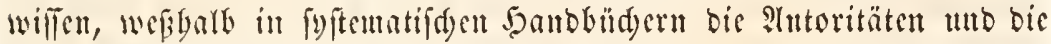

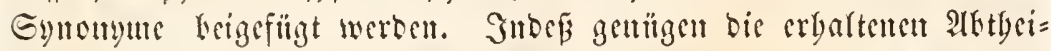

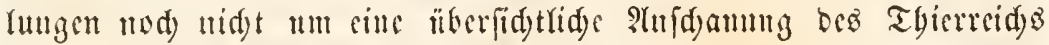

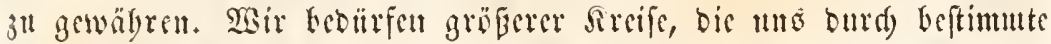
cegaraftere bezeidyet werben. Sier tritt ma zuerft bie Familie (Familia) entigegen, alò jubegriff berjenigen Tbiere, welde eitten ge= meinfauten Habitus zeigen unt in ägulidyer 2 seije bnrd) weiter gebenoe Merfuale un cinen Mittelpunft fids gruppiren, wie bie Gattungen

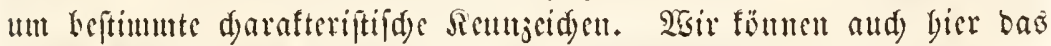

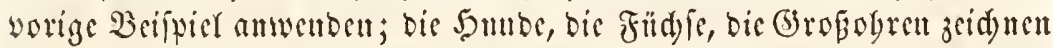

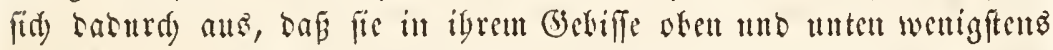

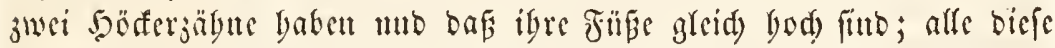

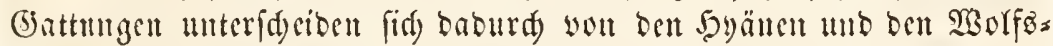

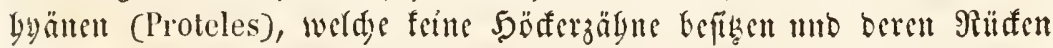
uad) binten abfällt. Die lunbeartigen Thicre begreift man unter ber gemeinfdaftridyen Fannilie Der Caniden, bie Şyämen unter ber Fantile ber Hyaeniden, inbem man ben Raurn berienigen (Jatung, weldye

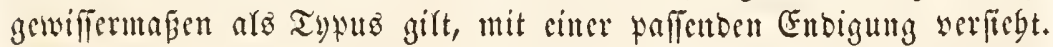
2utd) bei biefen uatür(idsen Fautilien bat man befonbers baun, wemt bie Gattungen febr jablreid) waren, oft ltnterfamilien (Subfamilia), 3üufte (Tribus) ober Sippen unterfdicben, bie man meiftenz wieber Iurd) Gefonbere Sienjeidsen djarafterifirte.

Go gelangt una kei ftets weiterem 2(ufwärtofteigen und freierem

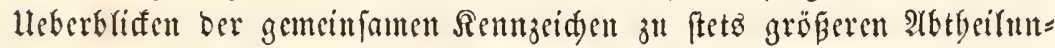

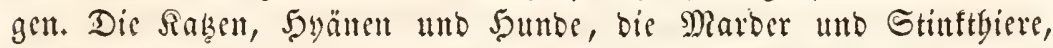
fowie bie $\mathfrak{B a ̈ r e n}$ fint alle reipente Thiere, bie fid son Fleifd) und

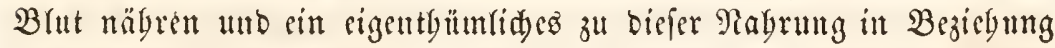
ferbendes Gebif beftzen, bas fo d)arafteriftifd ift, bas felbft ber we=

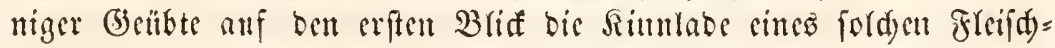
freffero erfenten mag. Dan begreift beśbalb alle biefe Thiere jujam= men in ber Dro $\| u n g$ (Ordo) ber Jleifd)freffer (Carnivora). A(ber biefe unterfdyeiben fid and) wieber burd darafteriftifde Merfmale. Die Familie ber Bären feust bie Füne mit ber ganzen Goble auf ben Boben auf, bie Marber und Stinftyiere berülyren nur mit ber balben 
Solgle ben Bobeu, dic butube, byäncu und Sakzen gelyen auf ber

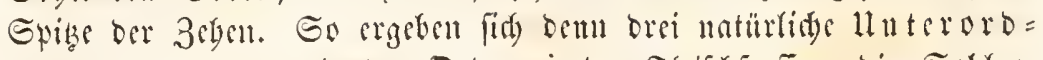
nungen (Subordo) in ber Dronumg ber freifdfrefler, bie Eoblen= gänger, bie 5albroblengänger und bie 3eyengänger, beren jebe einte

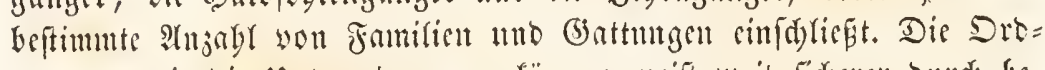
unngen, wie bie lluterorbunngen fönnen meift weit fidserer burd be: ftimunte Merfmale d)arafterifint werben alş bie Familien; und wenn

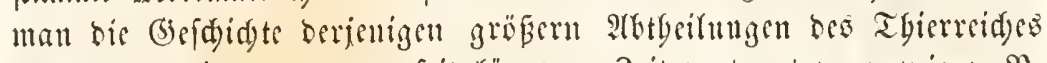
betrad)et, mit benell man foit längerer 3cit vertraut war, wis $j$. $\mathfrak{B}$.

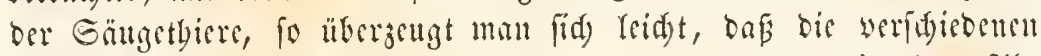

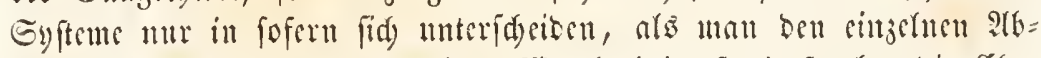

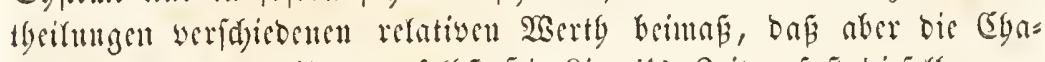

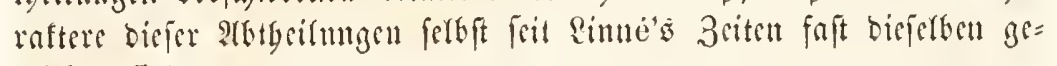
blicben finto.

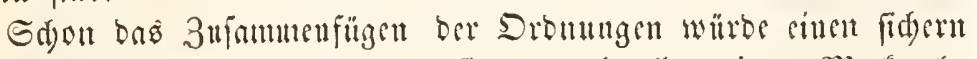
Heberblia gewäbren; alfein man finbet wody allgemeinere Merfunate,

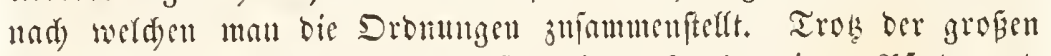

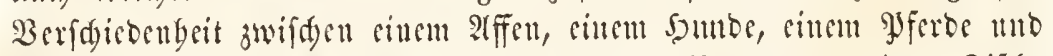

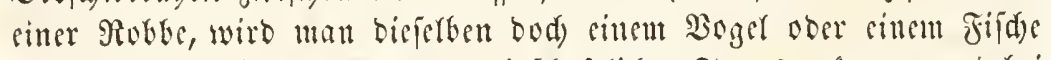

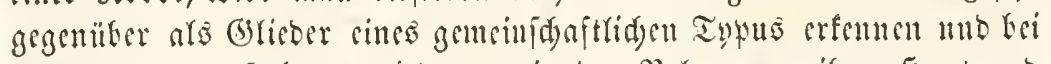

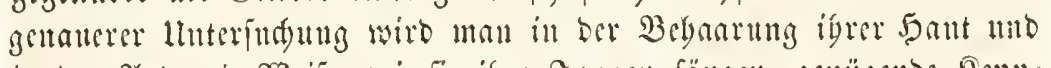

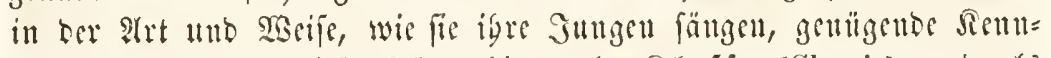

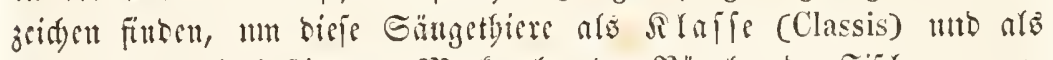
cin (Janjes mit keftimmten Mirfmalen beu Bägetu ober Jifden gegen= liber jul frellew.

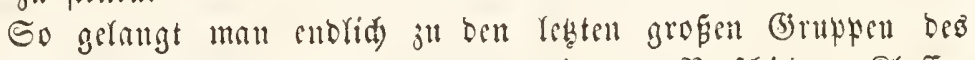

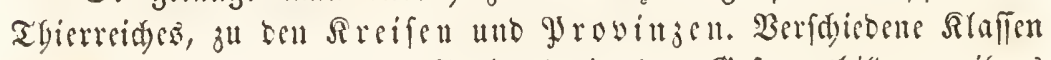
yaben wieber gemeinfame Merfmate in ber Gefammtfiroung igres Sürpers, in ber Sagenuty igrer Drgane, in igrer Entwiffetung wäg=

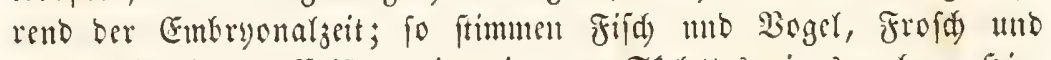

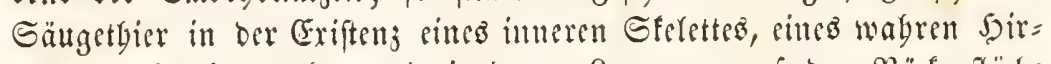

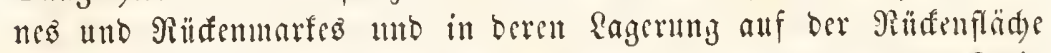

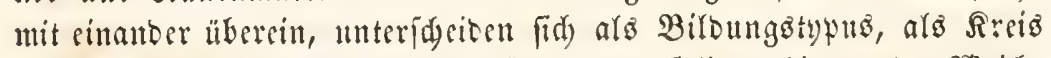

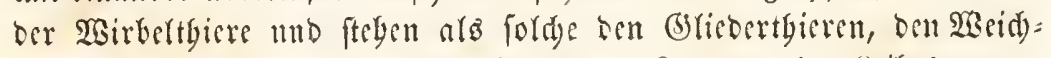

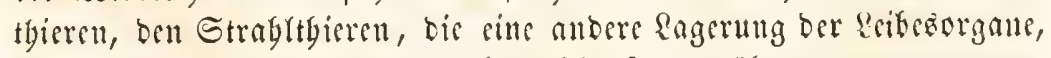
cinte anbere Eintwiaffungäart baben, fd)arf gegenüter.

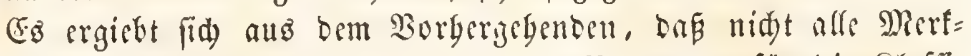

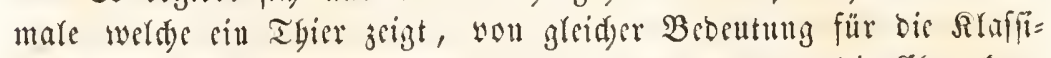
ficationen find, oấ man, wie fdjon oft gefant wurbe, bie Clyaraftere

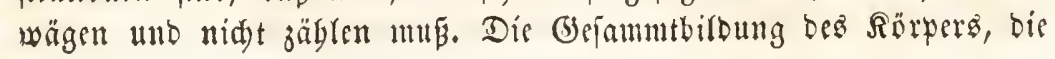




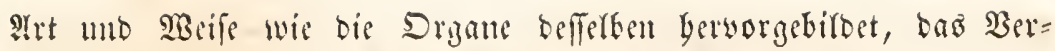

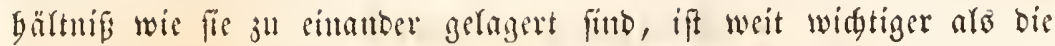

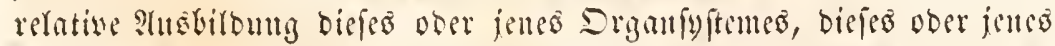

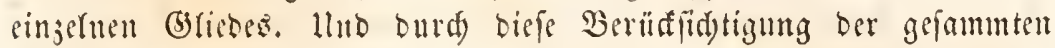
Drganifation unteridseibet fid bent aud bas Streben ber nentu

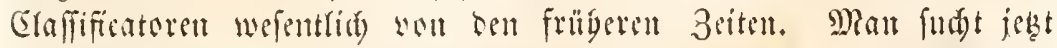

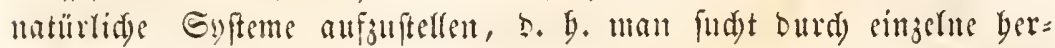
vorftebende Merfmale ans ber gefanmten Drganifation eines̃ Thieres feime Bejiefungen ju ben librigen ju ermitteln und biejenigen Rebenb= bebingungen bervorgubeben, weldye einen wefentliden Ginflug auf bie

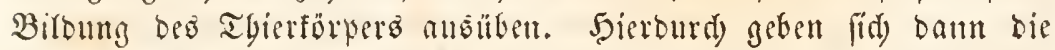
Berwandifdaften, die näbern mo enternteren $\mathfrak{B} e$ ziebungen zwifhen

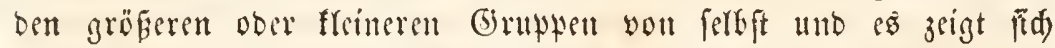
sann bei ber lleberfidt eine überrafdende Sammonie, die freilids an

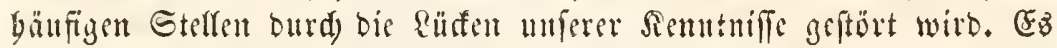
wïrbe liferflüfïz fein bier weiter auf biefe Berbältniffe sinjugeben,

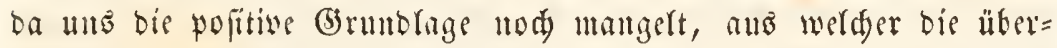
fidetfiden Betrad)tungen Vervorgeben mäfen; jebenfallo werten wit aud) in ber forge samit mur febr fparjam fein, unb inbem wir unb

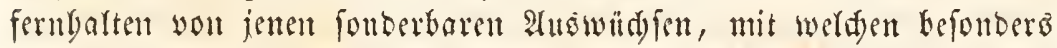
bie Raturphilofopben igre Syfteme ausujd,un̈fen pflegten, werben wir es megr bem benfenten Refer überlaffen, auf ben won uns mit= getbeiten Thatjadyen fein eigeneg Gebäube ju erridgten. 


\section{Dritter Brief.}

\section{Der Cljirteib; Der Aufbun friner Drgane.}

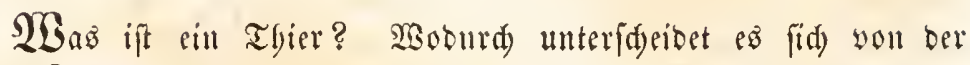
Wflanje?

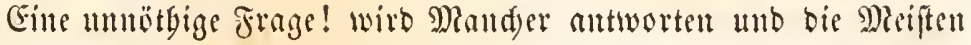

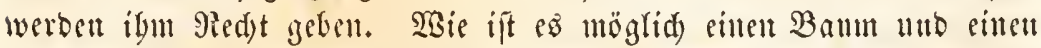

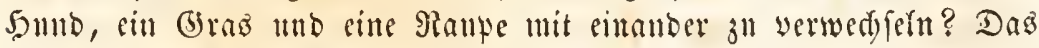
(Eine bewegt fid) wilffielyrlid) uto frei ans innerem Intriebe, nimutt Rabrung ju fid), bie es anffudyt unto burdi eine offene Mänbung cin=

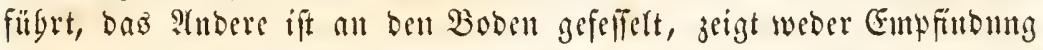

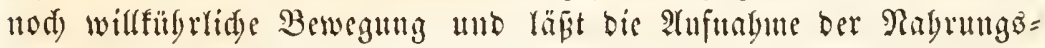

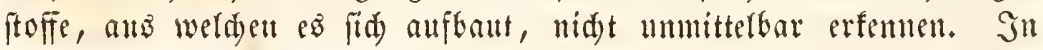

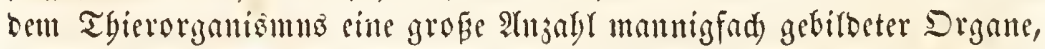
bie ben einzernen Funftionen yorftelgen; in ber Iyflanje bie complicir=

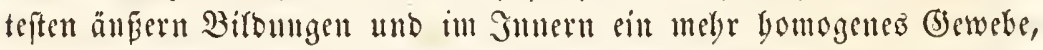

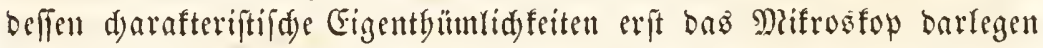

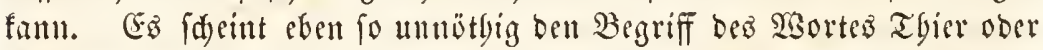

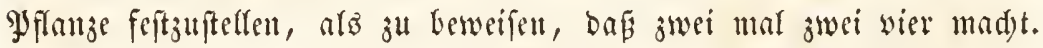

Steflt man aber biefelbe Frage an ben forfder, welder tiefer

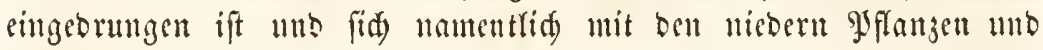

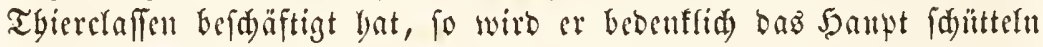

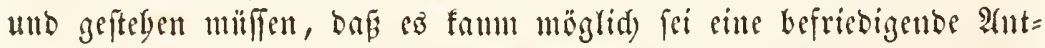

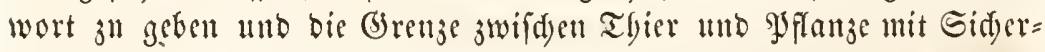
beit jul legen. (Fin Merfmal nad) bem anbern veriduwindet, je tiefer man in bie einfadjten formen bes a ftrigt; - was mแs famm nod cinen fidern balt gewälgrte, mus itm

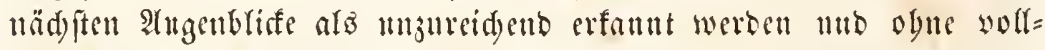

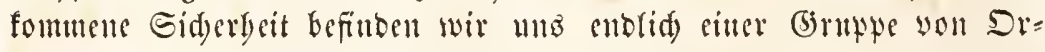

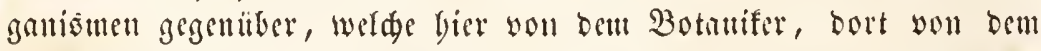

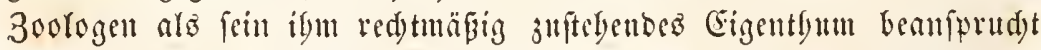
wirb. Der Streit ift nid)t nen uno beginnt fitets yon Renem wieber,

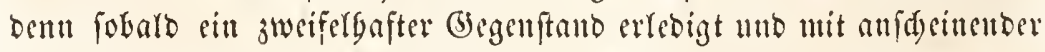
(beswifgeit an feinen ylats in bem einen ober anbern Meidye geftefft ift, trud)en wieber über ein nenes Dbject ernente 3weifsl auf. Biz in bie Mitte bez yorigen Galgrgundert's bieft man bie Soralfen igrer

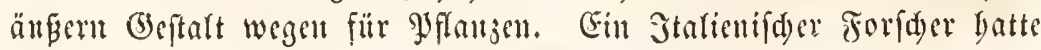




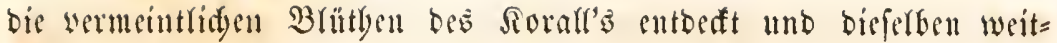

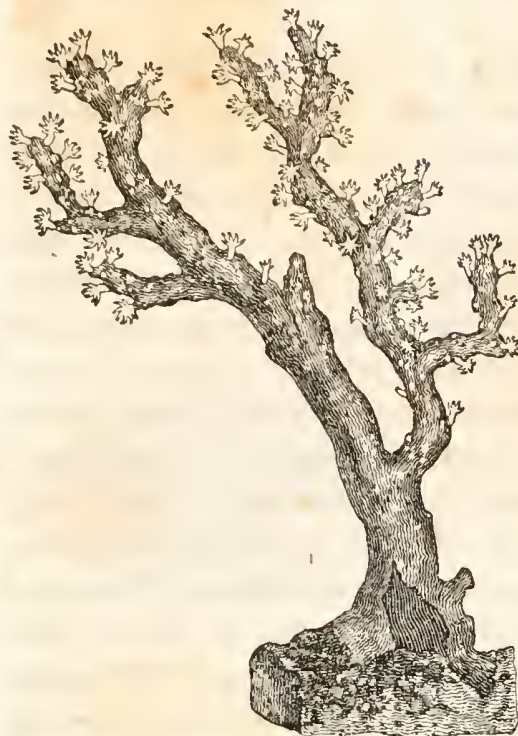

ränfig befdrieben. Fin argt in Mar= feille unterfindte bie Gadye genaner und fint zu feinem Erftamuen, Daß Diefe wermeintlidfen $\mathfrak{B}$ lütben wirf = lide Thiere feien, bie fidf nad) SBillfïly bewegten. Der $\mathfrak{A r}_{j}$ tbeilte feime Entbefung Der Jarifer Iffa= Demie mit; biefe fand aber bie Gadje fo gänjlidy muwabrfdeintid),

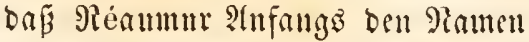
Des Entbeders nidst an mennen wagte, แm ben Mann nid)t ben öffentlid)en Spotte angurezen. Spent zu Tage febst fid) berjenige bem Spotte ans, welder ans llnfenntniés Эolypen alo Jyflangen befdreitet oder Soral=

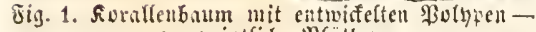
Ien fïr pflanjlidse Ergengniffe bält. sermeintlide $\mathfrak{B}$ (utben.

Die 3weifel baben fidt) in umfern Tagen auf andere Sörper haber= tragen. Rody wor wenigen Gabren bebantete man, jebes Thier babe einen $\mathfrak{M}$ un ferben mebrere freie Deffmungen; aber ễ girbt eine Menge von Thier= wefen, bie gans gewíz und unjweiferbaft Thiere find und bennod fei= nen MRnub befizen, feine äufiere Deffnung irgend einer Art baben,

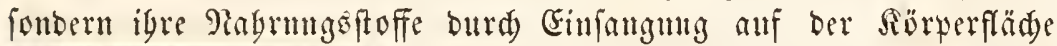

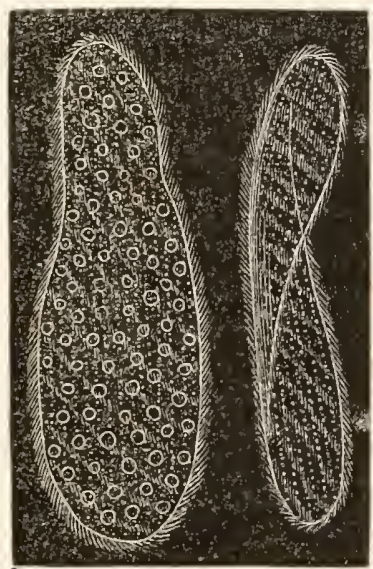

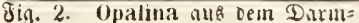
(4) 3" fid) nebmen. So lebt in ben Darmfinale ber Jröfde ein jiemlid grofes Jnfulions = tbierd)en, woffommen burd)fidstig, bas mit= telft Simpern, bie anf feimer Dberflädse an= gebrad)t fint, fid frewillig in oen Flüfigfeiten bes Darmes nmberbewegt und bas ganj be= fitumt weber cinen Minno, nod zerftreute Sangöfrnmgen befist. Biele Snfufiongatbier= d)en, ja felbit bod organifirte cingeweide= whitmer find burd)ans in bemfelben salle, fie friften ibr Reben nur baburd), baf fie burde Gin= fangung ifrer Sörperflät)e Stoffe ans ben Fliiffigteiten anfuebmen, in weldyen fie leben. Die Aufnabme Der Crnäbrnngsiftoffe gebt bier 
gauz auf bielelbe SBeife vor fid wie bei wielen nebern yflanjen, weld)e fid) im $\mathfrak{s a f f e r}$ bifben.

Man glanbte bie freie $\mathfrak{B} e \mathfrak{w} e g l i d$ feit ber Thiere fei ein dan lafteriftifdes semnjeicten. Biele won ínen find juar gänjlid ober wäbrend ber grübten 3eit ibres \&ebens in äbulidjer sacife wie viele Syflanzen an ben Boben feftgebeftet, aber felbft biefe feftitzenden Thiere, bie bejonders im Meere bäufig vorfommen, zffnen und (d) liefien fids, breiten ibre Fangorgane aus uno erbaidsen bie Beute, weldje in ibre Räbe fommt. Man glaubte aljo in ber freivilfigen $\mathfrak{B e w e g u n g}$ ein firderes Merfmal gefuttoen ju baben uno biz sor wenigen Jagren batte man madi bem Damaligen Stande ber Renntniffe volfommen Redt, wenn man fagte, ein Thier fei ein abgefdloffener Drganišnt werder fid willëtyrlid) bewege. Bald aber mufte man erfennen, Daf ez cime anjabl nieberer yflanjen gebe, befonders 2 aflerfäben (Conferven) beren Simfïrner ober Sporen fid solfommen ebenfo bes wegten, wie fleine Gnfufionstbierden. Man foly, wie im Smmern bie:

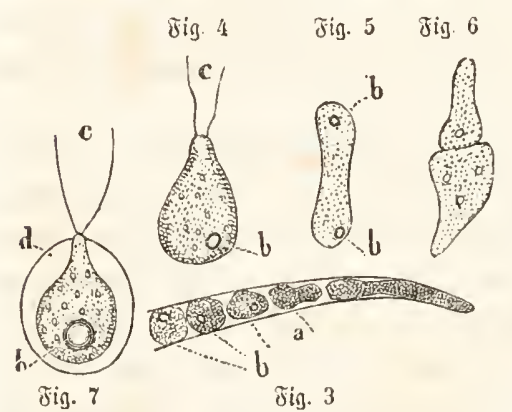

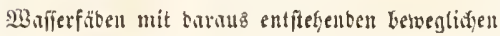
Sieimfirnern (Sporen).

In Dem mnteren Foten Fig. 3 fieht man bei a die Eperen mit ifren rutfen Rernen bie fid ifoliren, bei Tig. 4 cine freigetuor: Dene Epore mit ifyem Sern b mo ifren Betwegungääben $c$; kei 5 eine Erore bie zu feimen begimnt, fei 6 eine, bie for an sine gweite Belle getrieben hat. Fig. 7 ift einc ge fanzerte Epore von einer anoern (b)attmig, die ebenfalls fruber fitr ein Thier gefulten und Disceraea gentanut wutbe. fer Wafferfäoen (Fig. 3.) fị) grüne Seimförner bifbeten, bie nad) einter gewiffen Bait berworbraden mol fid in foldjer şeife in bem $23 a f f e r$ untbertummelten, baji jeber unbe= fangene Beobadyter igre Bewegun= gen unbeoingt für wiflfübrlide gal=

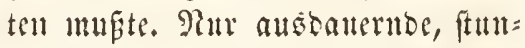
benlange Beobadtung founte über= zengen, dafi diefe Reintörmer nad einiger 3eit fid feffestent unt nad) แno แad) zn wirfliden 2 afferfäben aกริพแน rer Beweglids feit werbalten fid dieje Seimförner volffemmen wie Yebente Snftrionstbierd)en; 一 fie wälgen (it) mad) allen gidd)tungen $r a j$ ids im Taffer berum, bewegen fid) yor=

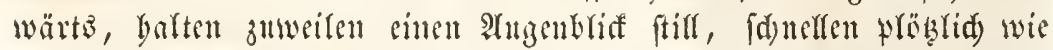

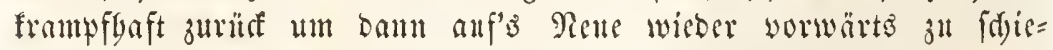

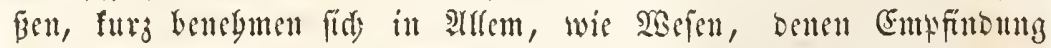
und willfübrlide $\mathfrak{B e w e g u n g}$ jufrumt; aud) ftanden mand)e $\mathfrak{B} e=$ obadter burdans nid) an in Folge biefer Thatjadyen ju bebanten,

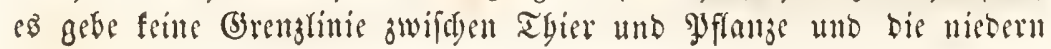




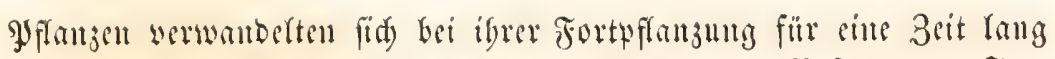

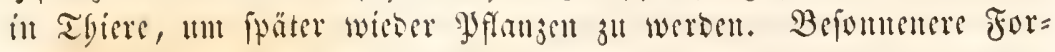

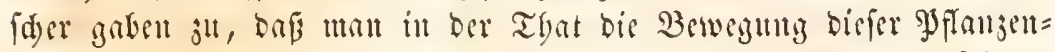

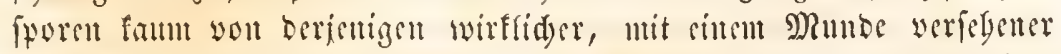

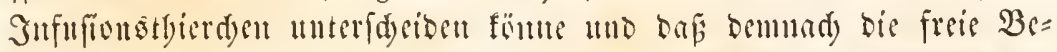

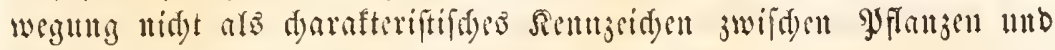
Thiere angefegen werben bürfe.

Diefer freien Beweglidfeit ber Secimfïrner wegent werben nod

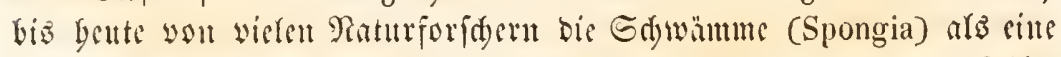

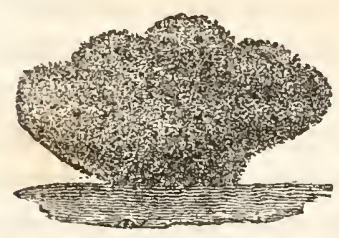

oig. 8. Reballoer Miecrfín,umm.

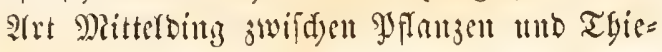
ren betradytet. Co find meift fuolfige ober ut= regermägige, an betl Boben ber (jewäffer gebef= tete poröfe Mañen, die cin bormiges, farfiges ober ferbit ferefiges Sterett in Smmern be= fiฺ่ singeluen Stad)eln und fpiefartigen Rabeln be=

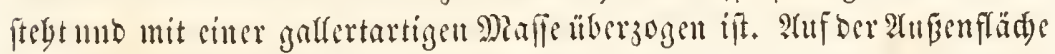

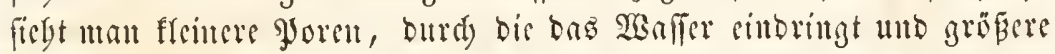
Deffum Babeiduwaum, ber zu biejen Drganismen gebört, riefert bas befte Beifpiel ber Grutur ber Gdyuämme. Man bemerft feitte Gpur von

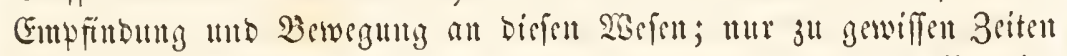
werben mit bem ausfließemben șnffer fleme rtutbe ober ciförmige

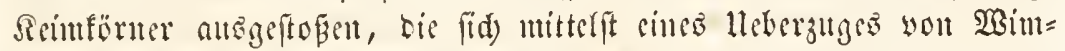
Herbaren foldr lebbaft im 2 onfler bewegen, umberfdwimmen, fidg bant

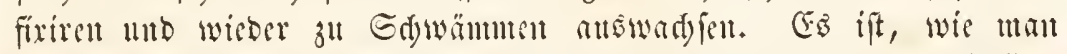

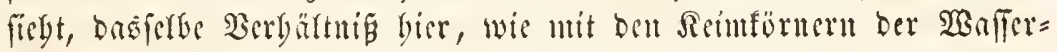

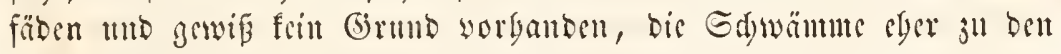

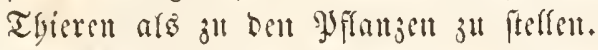

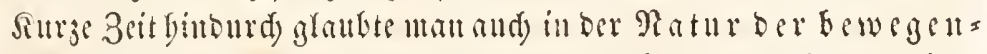
Den Drgate ferbit sin d)arafterififdes Merfutal entoeft zu baben. Bei ben uneiften böbern Thieren fomute anf ben intern 5ä̆tten, bei

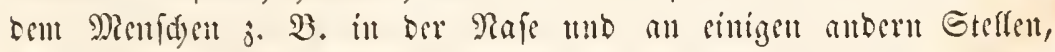
lleberjüge you mifrosfopifden 3elfen wor, anf benen böbit feitte Ffimmerbare ober SBimpern ferben, bie fid in beftïndiger fdwingent=

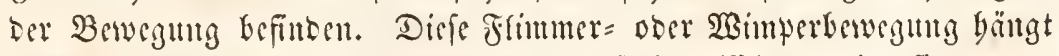
bei ben meiften Therent nidyt wou bem freich SBiflen ab; fie bauert oft nod) lange nad) bem Tobe fort; eingelne loşgeriffene Beflen biefer Art fdwimmen felbft mittelft igrer frimmerbance in ber Flüfigfrit untber. Biele Sufufiongefbierdyen baben entweber anf ber ganjent

\$ogt, 3oologijote sriefe r. 
Sberfläd) igres̃ Sionters ober an befinmenten Stelfen foldye SBimpern,

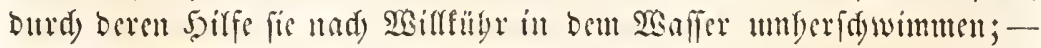

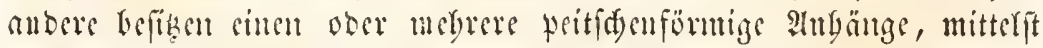
Deren fie im Saffer milyertubern. Man glanbte, baf biefe Bewe= gungsorgane ban Remuförnern ber Săferfäben afgingen mb bielt

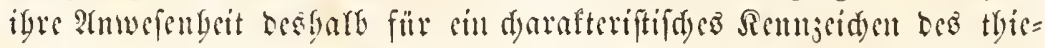
rifden Drganismus. Mian Gatte fid) aud) in bicfen lounte getäufdt. Dan entoefte Reimfirner, weldye auf igrer ganzen Dberfläd) cinen

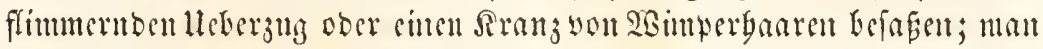

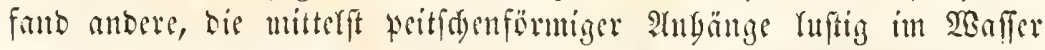

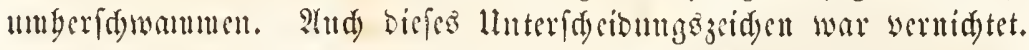

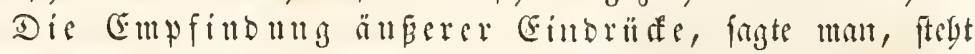

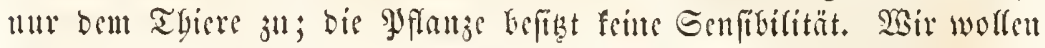
jugeben, dafi bie feltfamen Bewegungen ter Gimnflanjen feinen Beweis

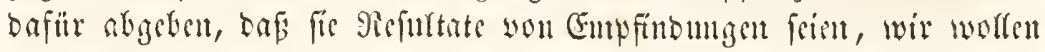

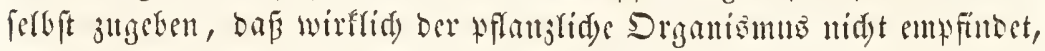
wobl aber ber thierifde; wir wollen anerfenten, bag biefer llnterided theoretifd feftgebalten werben binrfe, aber man wirb uns bafïr jugeben miiffen, baj er burd) bie Beobad)tung nidgt nadggemiefen werben fönue.

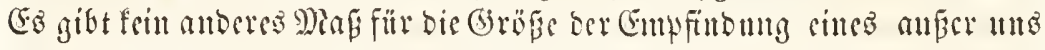

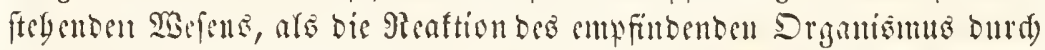
Bewegung. Ginen Rerper, ber fids anf Reize nidst kewegt, feinen Sduter's nidid ju erfennen gitut, Galten wir fïr empfintungôlos. 280

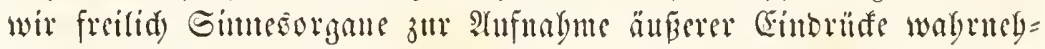
men, ba fdliesen wir notgwenbig and anf empfinbente Fäbigfeit. Itber bie rotben Fleffdyen, weldye man bei vielen Snfufionstbierden volfommen itubegrinbeterweife fitr 2hugen bielt, bat matt aud an vielen Simföntern mit Gid)erbeit nadggemiefen. Biele Snfuftonstbier= dent aber, fogat foldse, weldy: Durdy bie Cxiftenj cinco Mlunbes igre

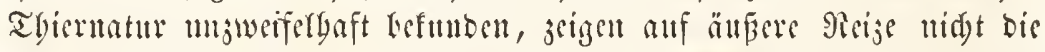
minbefte Epur wou Peaction, fo baß uns wolffommen ber thatfäd)lide

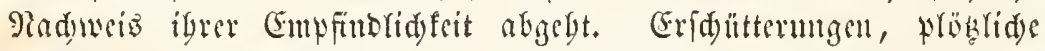

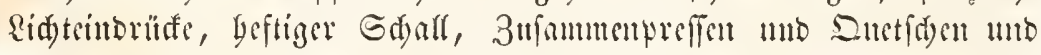

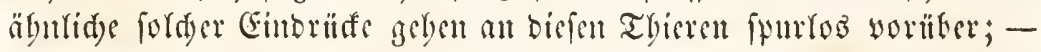
wie foll man mun bei bicfer Stmmpfbeit ber Empfindung mo Bewe= gung bie (5) rälze zichen, wo keibe aufgören?

So wäre es benn wölig numbiglid) in ben nicbrigften Gtufen ber Drganifation sine Sderibelinie jwifden tíserifden mo pflanglidgen

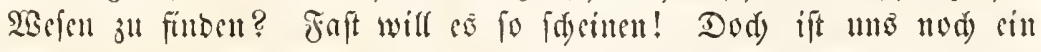

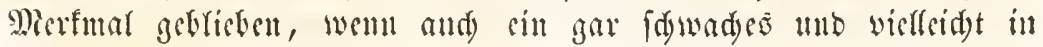




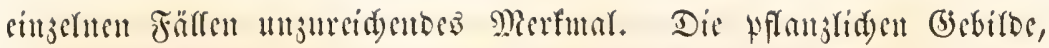

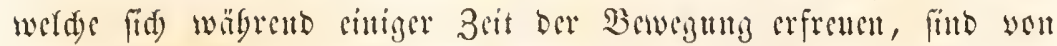
sitter forren bitfle umfleibet, werdye ibere beftalt cine feite, faft un=

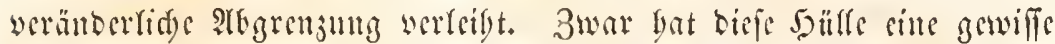

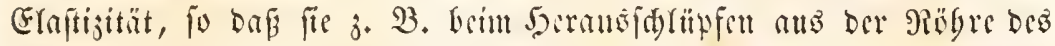

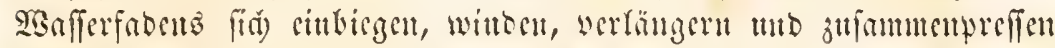

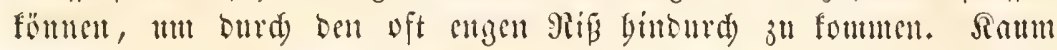
aber bürt bie änfere (jewalt anf, fo nimmt aud) ber gsflanzenförper

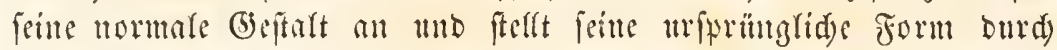

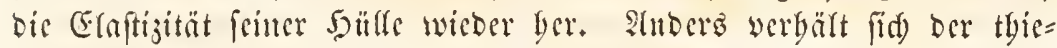
rifde Sï̌per auf jenen nicberen Stufen ber Drgantifation. Scin Gis=

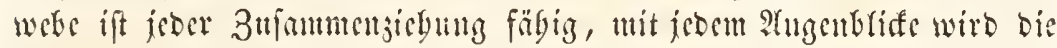

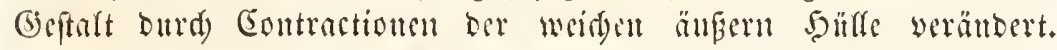

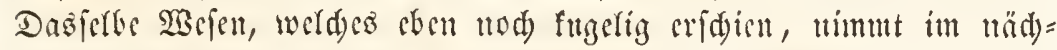

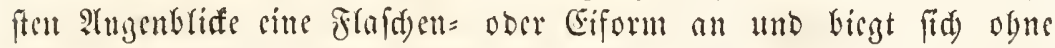
Cinwirfung ättferer bewalt nur unter ben Einfluffe feintes freien SBillens nad) allan Geiten bill zufammen. Dis Contractilität

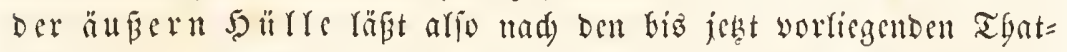

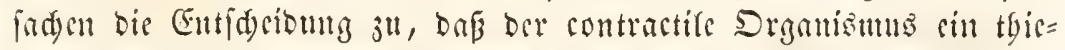
rifdyer Sörper fé, wälrend auf ber anbern Geite Der Manget dicjer

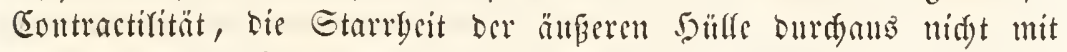

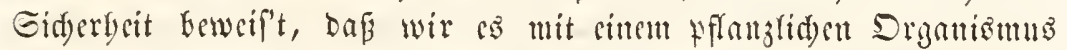
zu thun baben. Cis gibt vicle nicorig frebente Drganismen, bie cinen

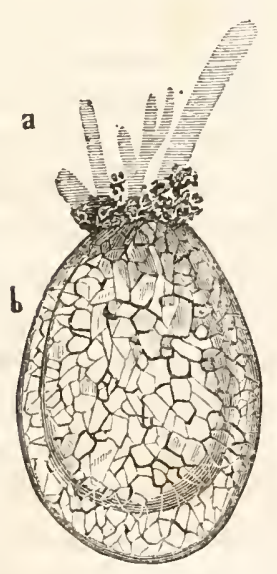

8ig. 9. Fuglypha.

a, bie fingeriórnigett, зur Bewegurg vienemben Fort: fispe; - b, Der int Farmzer

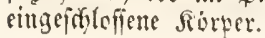
barten, unbiegiamen, ntso Sicjel, Eifen ober Ralf gebauten gyanjer Fefitzen, in weldem ber Siorper fo singeddloffen ift, Dafi unt bie feinen jur $\mathfrak{B}_{c}=$ wegm dienenden Sritfotangänge bervorragen. Mandue Snfufionstgierdyen topielu fid wägreno cinter gewiffen 3cit igres Rebens in barte, fugel= förmige Edonten cin, it weldsen fie wolffommen mubeweglidy ruben, wie gupwen in ibrer Sdyate. In foldyen gällen feblt aud) Das Yeşte Criterimm jur lluterfdreibung jwifden gyflanje und Thier,

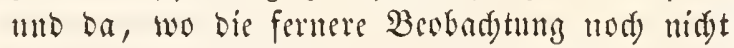
bargetlyan bat, bafi in ber ftarren bitle ben= nod) cin alts contractilem (Scwebe gebifdeter $D r=$

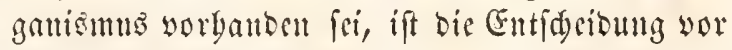
Der 5anto anmö̈glida.

SSent wir fo auf ben nicorigften Etufen ocr Drganifation oft Iange fduanfento fteben 3* 
milfen, bevor wir entidyciben fönnen, ob wir es mit einem Thier ober mit einer Syflatije ju thun baben, fo wirb uns bies, fobalo wir

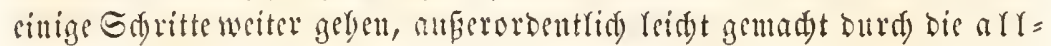
mägrige Entwiffelug Der Drgane in dem thierifden Rörter.

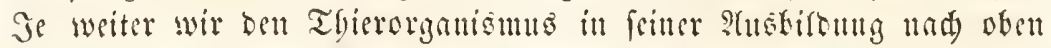
werfolgen, Defto grïber wirb die Complifation feimer Bilbung, befto mannigfaltiger bie 3abl unb Das Spiel friter Drgane, befto genauer und fäarfer umfdrieten die Function jebes einzeluen biejer Drgane. Der Therorganismus beft fich in ber That aแb Dem llubeitimmten

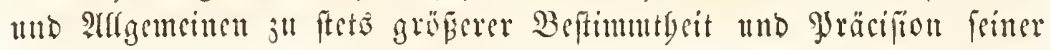
einjeften Theife empor und es wirb nötbig fein wenigftens in

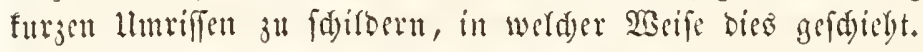

Die nieberften Thiere weldy wir fenten, beftelen aus siner sigentbiumliden, weidsen, gallertartigen, mit fei=

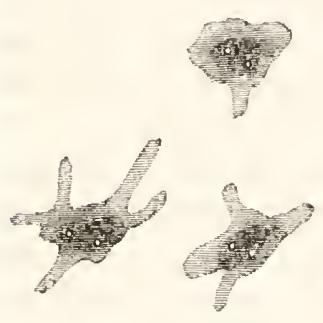

Fig. 10. Amiba nen Rörnd) Durd) fitrenten Grundjubitanj, wer= d) in igrer ganjen Maffe ber 3ufammenjiegung

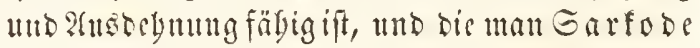
genaunt bat. Bei vielen biefer niebern Thiere wirb bie Bewegung un Dadurd) Gervorgebrad),

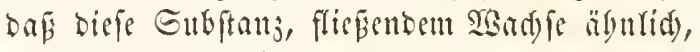
fici) La und bortbin aubbegnt, bei anderen gibt ç eigentbümlide Bewegungsorgane it Form von Simpern ober Fäben. Sm Jnmern diefer Subftanj laflen fid meift nur feime Sïrndyen ober blafige Räume unterfdeiben, bie von

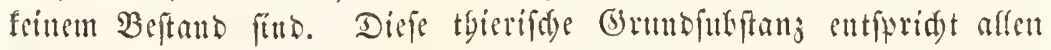

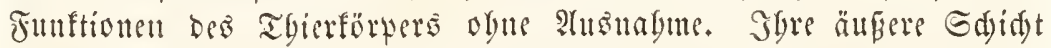
cridseint etwas fefter, als bis Diaffe im Sunern unb filoet fo sine

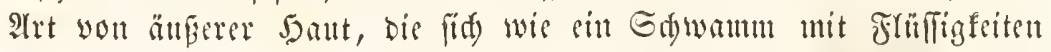
wolfangt und fo ben Rörper eruägrt; ifre 3ufammengiefungen ver= mitteln bie Bewegung, igre ätşere Dberfärde bie Cmpfindung; -

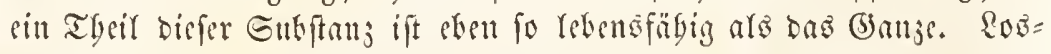
geriffene Stilde biefer Subftanj zieben fid jufammen, befnen fidt) ats,

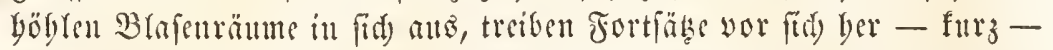

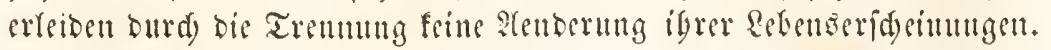

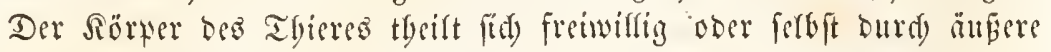

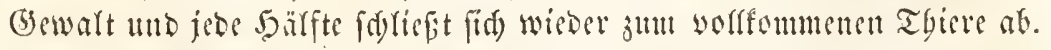

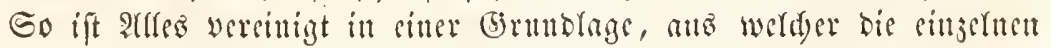

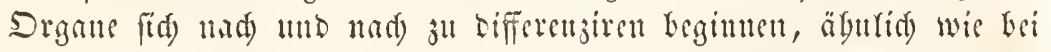

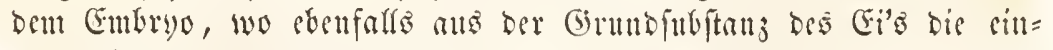
jeluen Drgane und Formelemente burd) fortbanernbe Differenjirung fird 


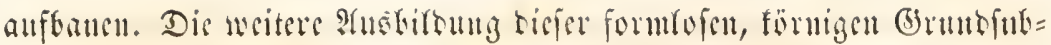
ftanj gebt fowobl bei ben Gutbryonen, wie be ocn Thieren im ermady=

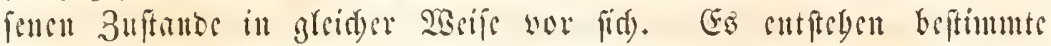

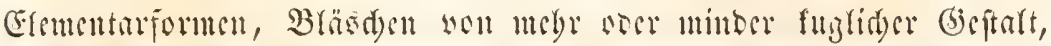

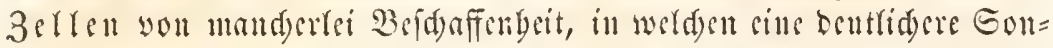

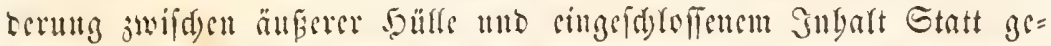

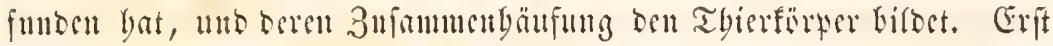

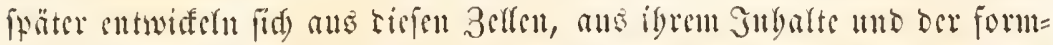

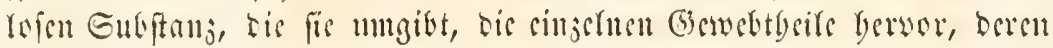
Shannigfartigfeit oen Thierleib mo feine vielfad)en Drgane anf ibrer

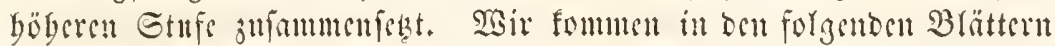

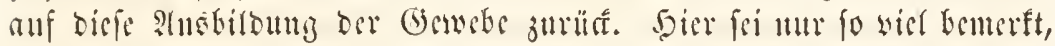

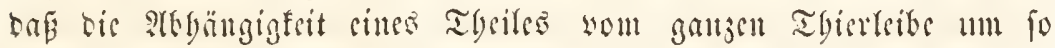

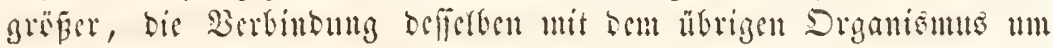

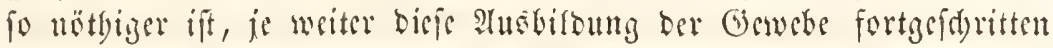

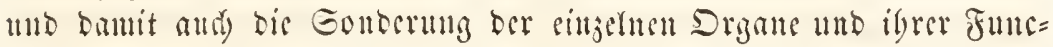
tisnen gebiegnt ift. Bebenft man, oafi bie Garfobe alle Junctionen

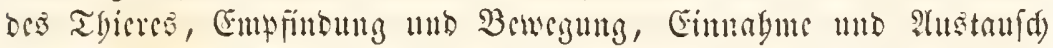
wou Stoffen in Sisme in fid) werentigt, fo wirb es begreiflich, daf aud jeder Tgeil Derferben mit bicjen Junctionen ausgerïitet alb felbit= ftündger Drgantōmus auftreten faut. Se mebr aber de Trennung oct functionen cintritt, befto wentiger ift biez ferner müglid).

Daber benn aud bic erfaunlide Sisicosterjeugu

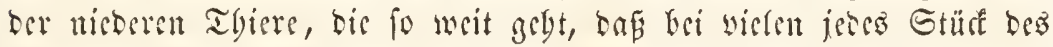

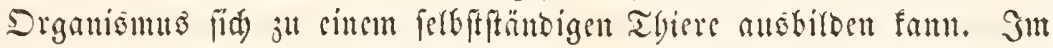
normalen Reben bes Thieres tritt biefe Gigenfd)aft als gefd)lechtolofe 3eugutg ourd) Thcilung, Sindspung, Sproffung auf; oer Tbierlete, werder entweder nur ans Garfode ober ats 3ellen mit fegr wenig bifferenzirten Drganen beftegt, theilt fid freiwillig in mebre ferbit=

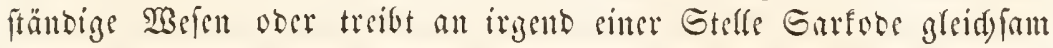
ars lleberwuderung bervor, weld)e fid) thad) und uad) ju sincm ferbit =

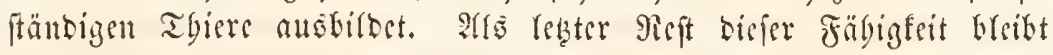

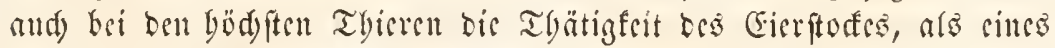

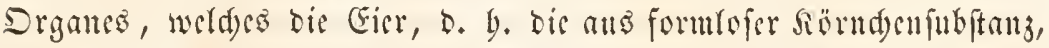

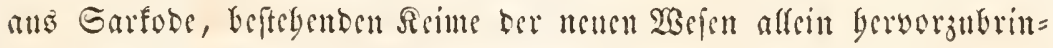
gen iut Stande ift.

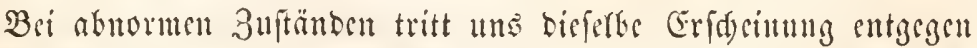
uno in unt fo ausgebifocterem Mafie, je tisfer bas Thier it Shinfid)t

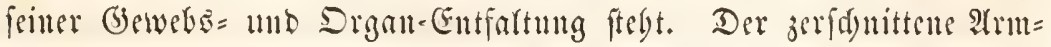

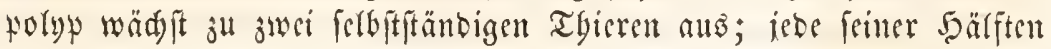




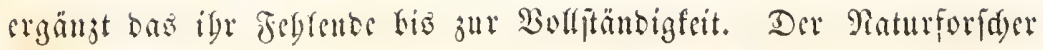
mit feinem Eeafyeff befintoet fid) biefen Thieren gegentiber vollfomuten

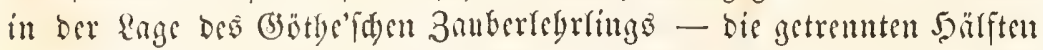
werben ganze Sndistouen. Barb aber, mit ber Diferenjirung be= ftitututer Drgane unto wejentlider Drganfyfteme, befidräntt fid biefe

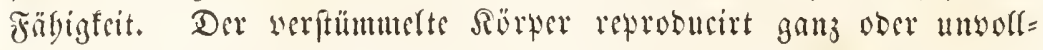
ftänbig sic ageile, bie ifm verloren gingen - ber Srebs bildet fith nene Edjerren, tene frinke, bis Gibedje sinen neusu Edjwans, ber

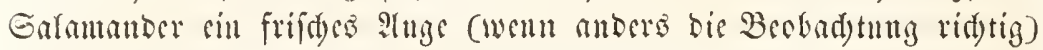

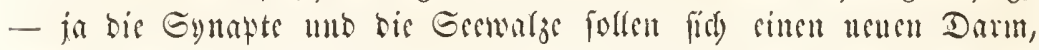
teue Itthemwerf

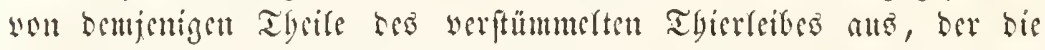

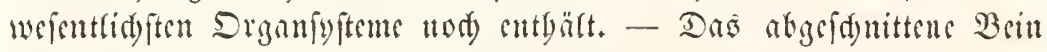

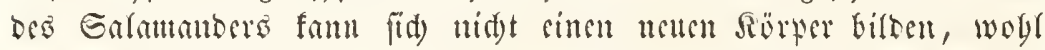

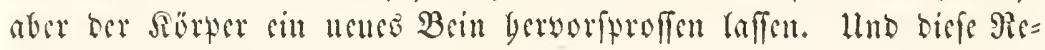

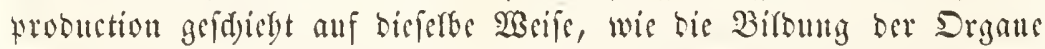
itt. (Ei beim 2 serben bes Embryo's, Durd) Ergus formlojer Bil=

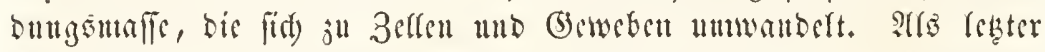

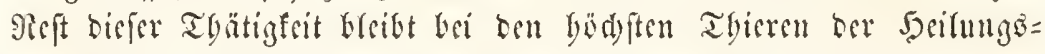

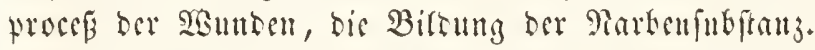

Dod) felyen wir zur Entfaltung Des Tgherteibes unb zur Diffes rensirutng friner Drgane zuritu.

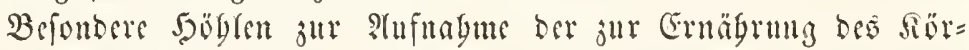

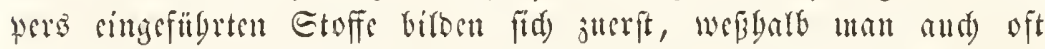

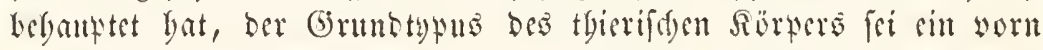

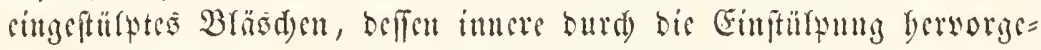

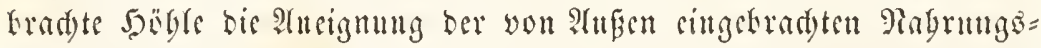

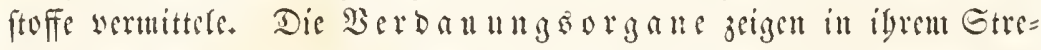

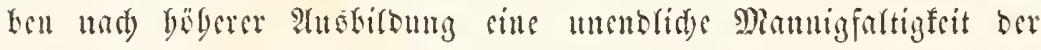

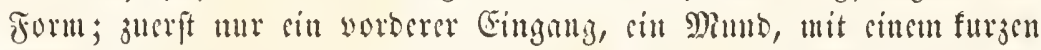

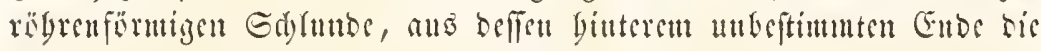

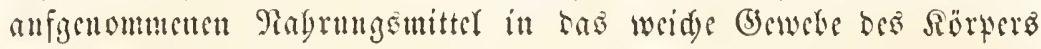

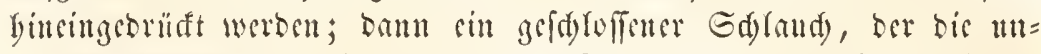

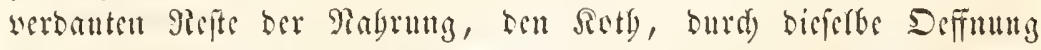

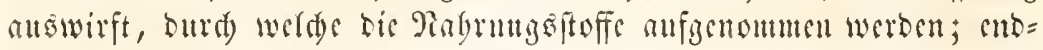

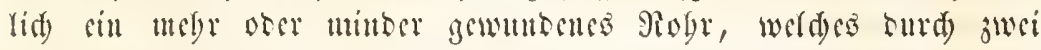

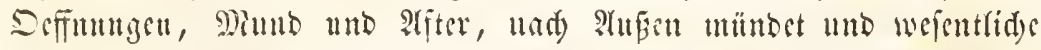

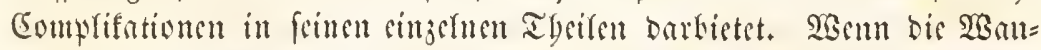

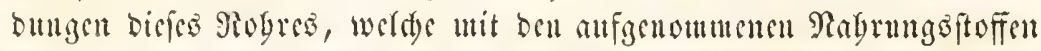

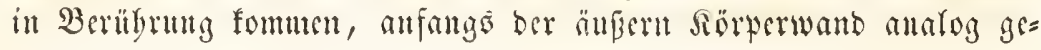


baut und mux als cine Eimftülpung Derfefen mad) Sunen ju betrad)ten

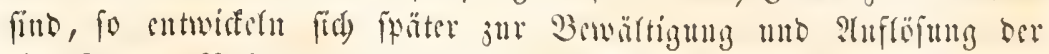

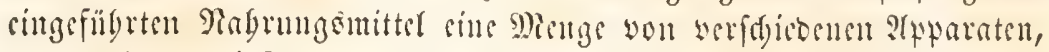

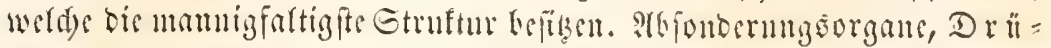

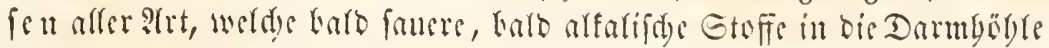

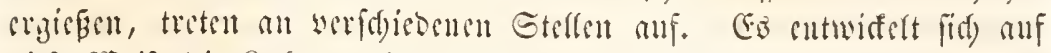

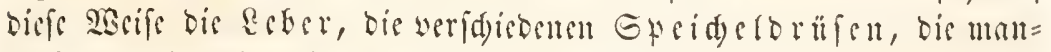

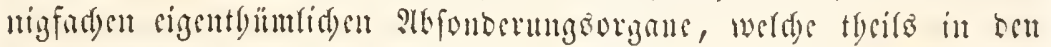

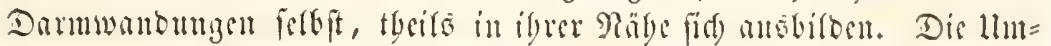
fercung ber fo verfadebenartig geftalteten mo demifa) fo mamigfattig

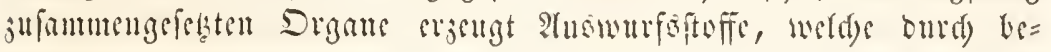

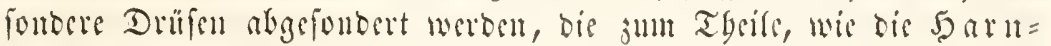

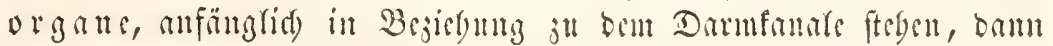
aber fid son ifut trenen unb felbititänoig werben.

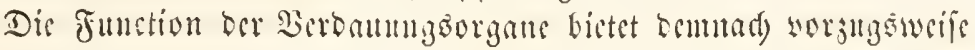

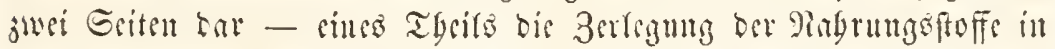
fold)e Enbfanjen, weldye son bem Drganisums anfignommen werben

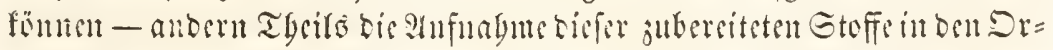

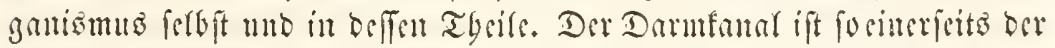

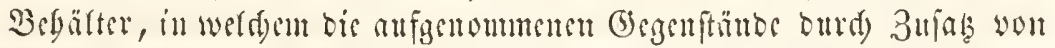

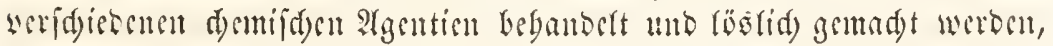
anderfeits ber sitter, burd) ben bis aufgerioften Stoffe abgelsigt, in

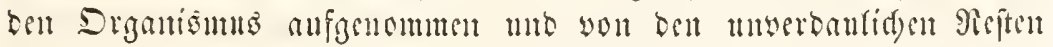
getrentt werben. So mannigfaltig befunt indef bic formen bes Darmebres nub Der Drifien, weld)e die auflöfenten algentien liefern,

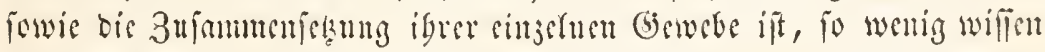
wir son ser sigentlid)en Natur tiefer Borgänge, Gefonders bei ben

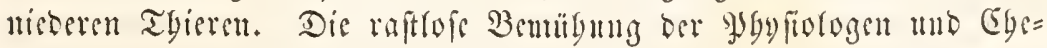
mifer bat uns nadgendefen, baß bei ben böberen Theren bie cingehnen P(ktbeilungeu bes Darmtanals werfdictene Junttionen baben, fo wis aud) Die Rabrungsiftoffe, wenn fie ibren 3wed solffommen erreidsent folfen, mebrere Gtoffe entbalten n!üffu; baf bsim Sienfdaen 3. $\mathfrak{3}$.

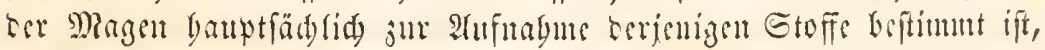
welde sem (Eiweife ober bem Fleifde in igrer demijhen 3ulummen=

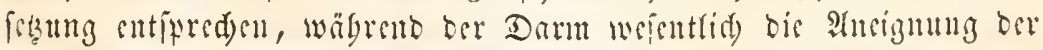

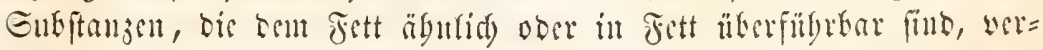
mittelt unb oaf bemmad) bie in ben Darm= uno ben Ningengäuten

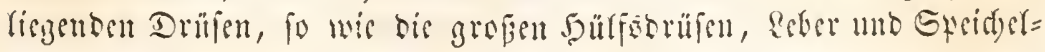
briffer, welde igre Abjonderung in bie Dambögle ergiegen, fegr

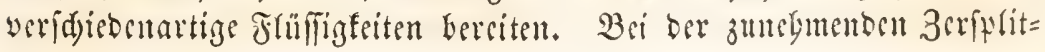


terung ber Functionen an Fefonbere Drgane, bic man bei ber Ent=

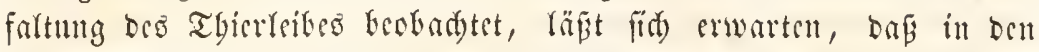
nicberen Igieren, wo nur geringe Diverfitüt ber Derbanungeorgante berrfde, and bic Junction berfelen utbr vereinigt fei. Sier feblen แกร aber bic แäheren Grunblagen sinbringenberen SBiffeng. Unjäly= rige Thiere leben sinjig unt alfein won Gtoffen, bie ben büberen Thieren, berenserbauende Thätigfeit vor̈ugsiweife unterfud)t ift, feine Sub= frats zur Ergartung igres Eebeno bicten fönten; idf nente nur alo

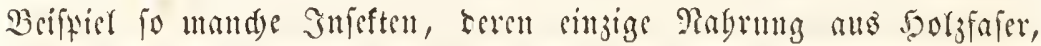
5orufubitanj (5aaren und Febern), fauligen Shaterion mo anderen, fïr nno mo bie büberen Thiere ganj nnverbanliden Stoffen beftebt. Dis anfridtige Raturforfdung fam bier mur fagen, sou welden Etoffen bieje Thiere leben, und wis bie Form ber Drgate Ecjuaffen ift, womit fie bic Ragrungsiftoffe crfaffen, med)anif jerteinern, anf=

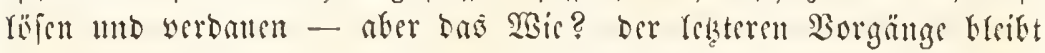
nod) cin reidges felo für finftige Forffenung.

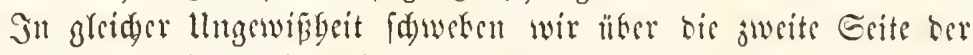

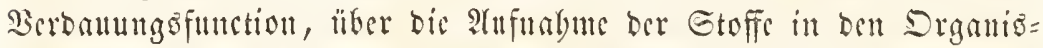

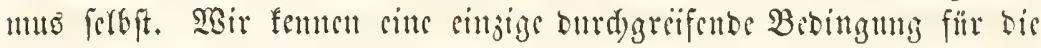
Ancigunng fremser Etoffe, welde für bie ganje Thierwelt gilt -

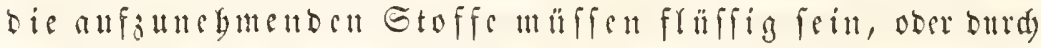
die Berbantuggorgane verfliffigt weren fïntu, unt bur(t) Cinfangung Der Darmwantungen anfgenommen mb mittelft Anstand gegen bic alfgemeine Ermäbrungsfluffigfeit bem Rörter angerignet ju werben. Die Beringungen bicfes Anstanflycs, bes llebertrittes gewiffer Etoffe, wälrenb anbere zuriffbleiben, fennen wir faum bei ben Gängetbieren, gefdeweige bonn in ber hibrigen Thierwelt.

Gobes Thicr if anf

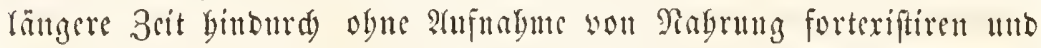
bies unt fo efor, je micbern Stufen fir angebören; aber bennod) breibt

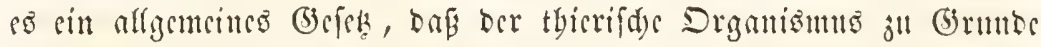

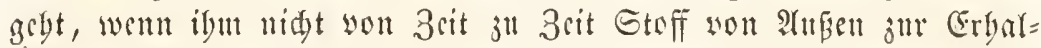
tung zugefïbrt wirb; bas materielle Thicrleben Eeftegt wefentlict) in

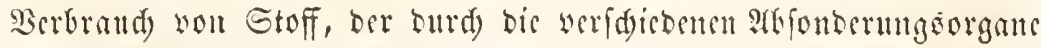

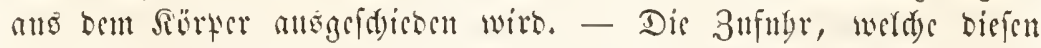
verbrandent Stoff erfeksen foll, mnß̧ bemnad) alfe Enbitanjen entbal= ten, welde Den Rörper ferbft jufammenfęen. Dis Ermäbrung Des therifden Sïtwero, ber Erfats ber mbrand) ger gewordenen Theile Durdy Den werarbeiteten Pägrifofi ift mithin mur bann möglid), wenn Derfelbe in bem ganjen Rärter ülerall bin bringen, uad allen Drga= 


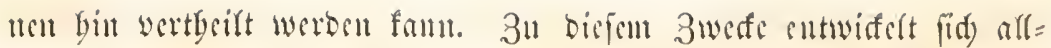

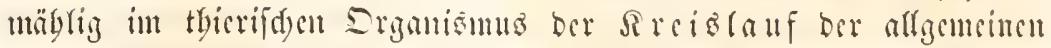

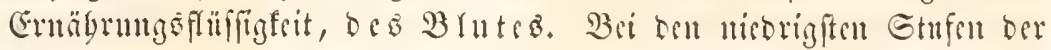

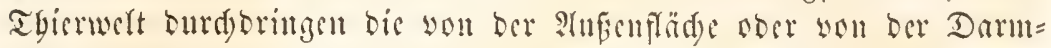

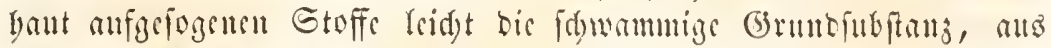

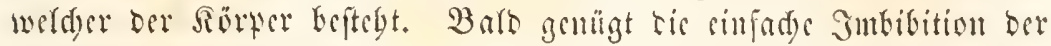

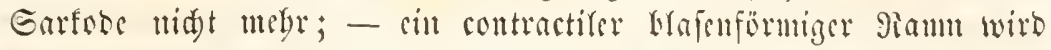

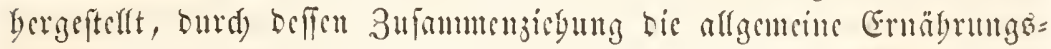

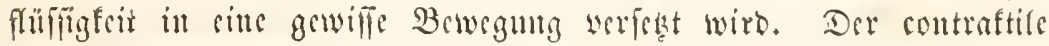

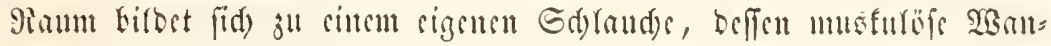

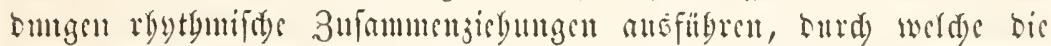

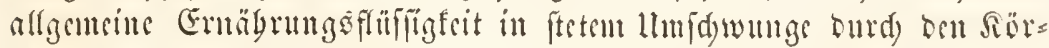

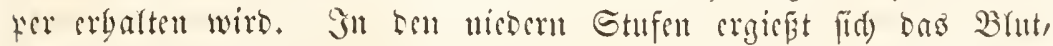

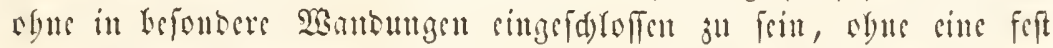

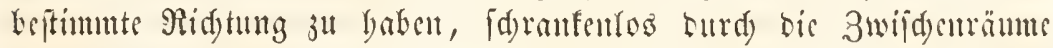
ber Giswebe unb Drgane, unfpült biefserben überall und burdsoringt

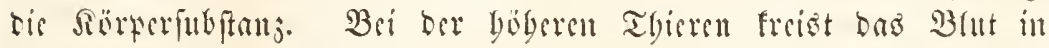

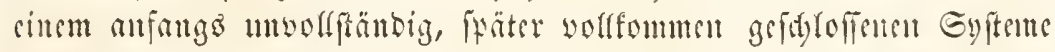

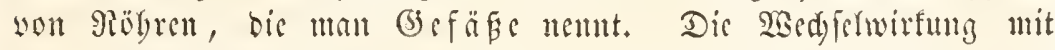

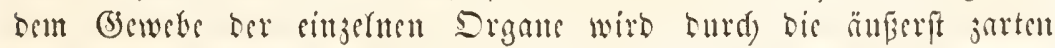

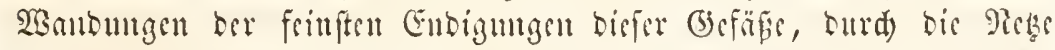

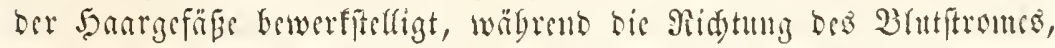

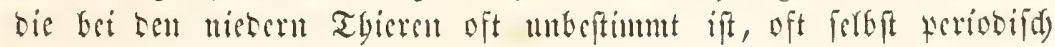

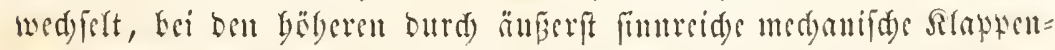

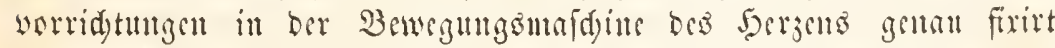

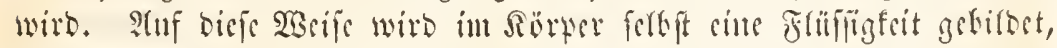

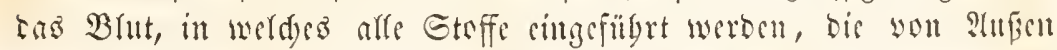

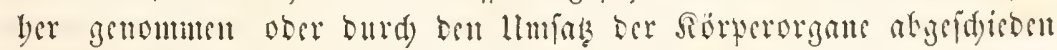

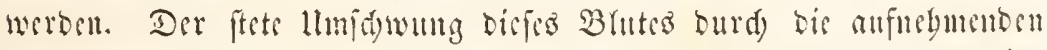

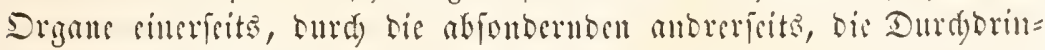

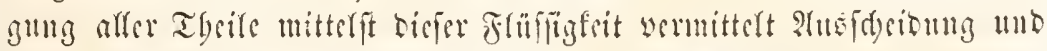

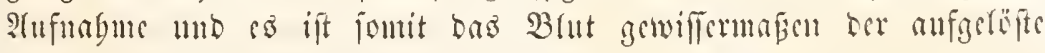

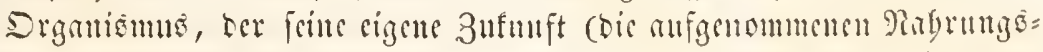
fieffe) mto feine Sergangentgeit (bis wertrandsten Etsffe Der Drgane) in fid) suttyölt.

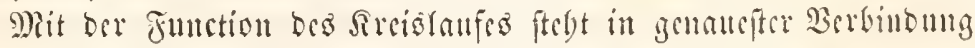

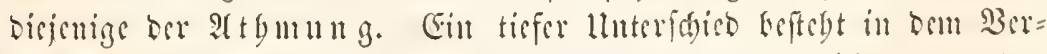

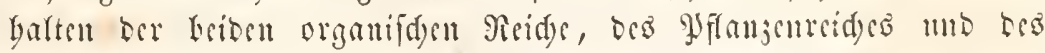

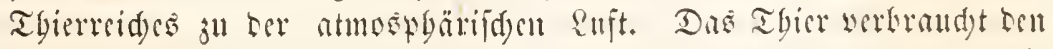

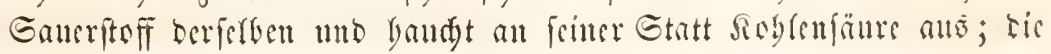




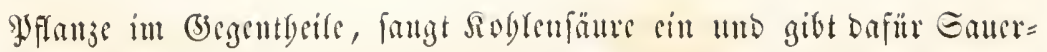

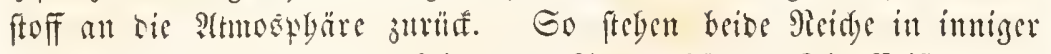

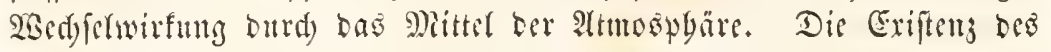

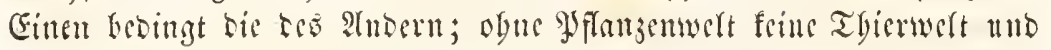

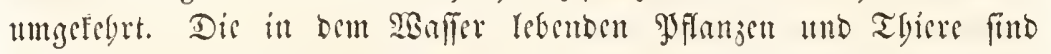

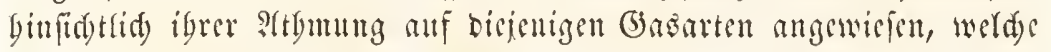

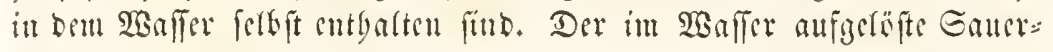

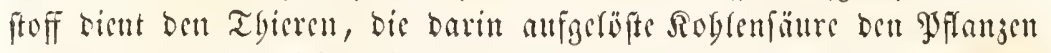

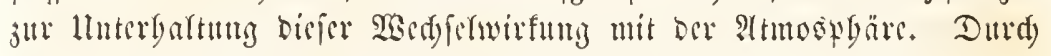

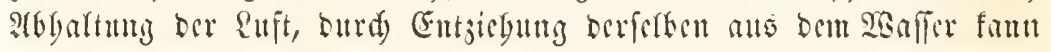

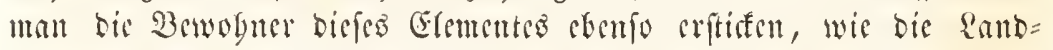

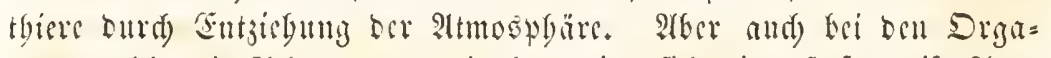

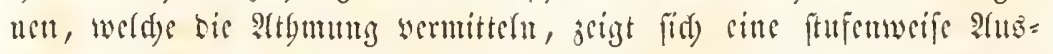
biloung und genauere Specialifung ifrer Function. Sinfünglide ift

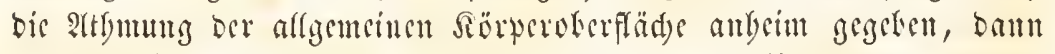
entfeben befondere Drgane, welde oft mit ben Bewegungsorganch

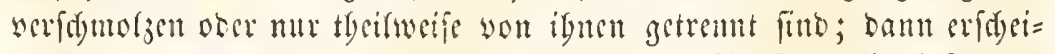

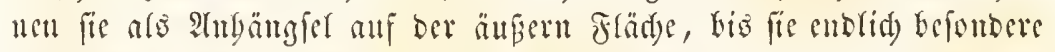
böglen im Smuern bilden, die cimen complecirten röbrenförmigen Bau amuefmen. Mian unterfacibet bier in ber Tbierwelt wefentfid) jwei

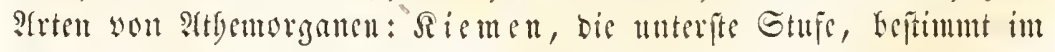

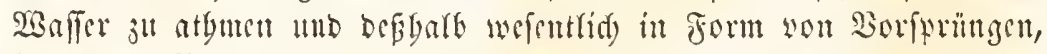

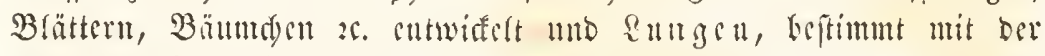

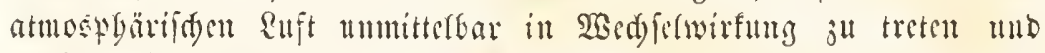

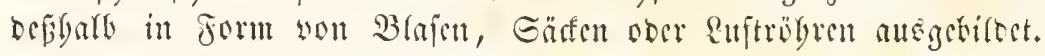

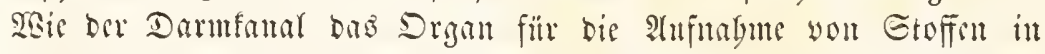
flitfitger Form it, fo baben bie Atbemorgane rie fiecielle Function bes

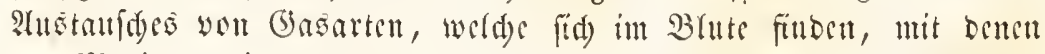

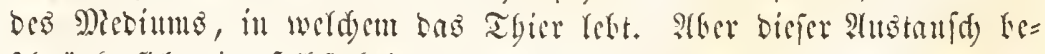

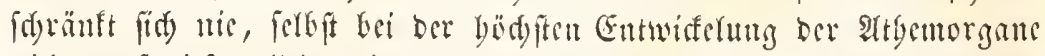
uidyt, auf biefe alfein, inbem ftets aud) bie äubere Saut an bicfer Function, bie fie ânfangs allein batte, Antleil nimmt. Eime wejent=

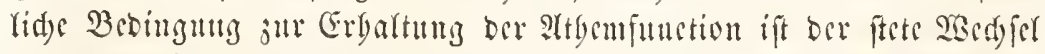

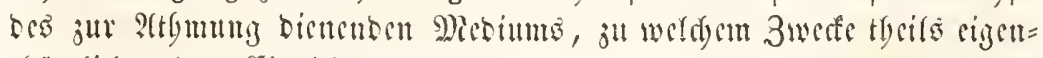

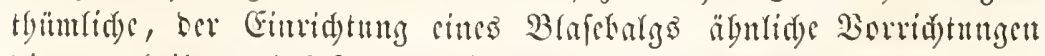

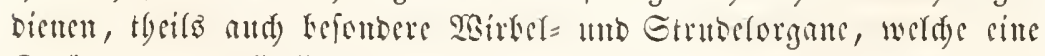

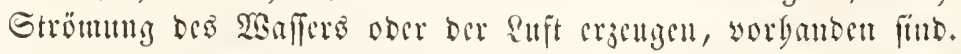

Dic fogenamten wegetativen Functionen, welde bie Erbal=

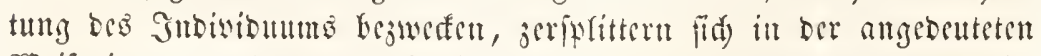

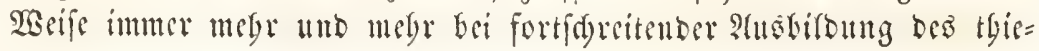


rifden Dryanišmus. Ridjt minber finbet bieferbe Erifderinumg fratt in bem Berside bericnigen Drgane, werd) bie Empfind ung mo Bewegung wermitteln, affo ben sigentlidsen thierifden, ober nui=

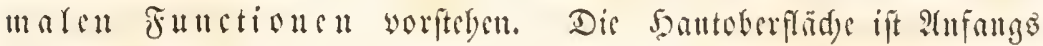
bas gemcinfdaftlidge Drgan für Empfintung mo Bewegung jugleid). Die nicocrn Thiere taften mit jebem gsmtte igrer Deerflüdye uno jebe

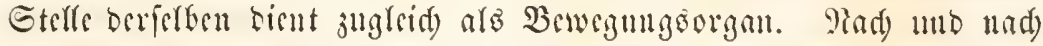
aber treten befondere Taforgane berwor, bis an sinjeftuen Stellen un

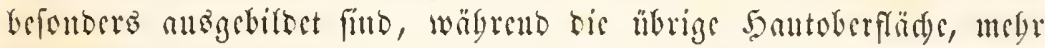

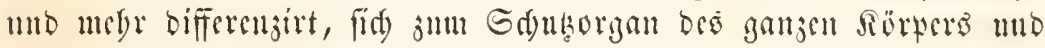

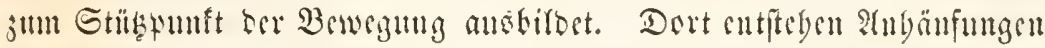

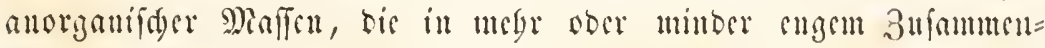

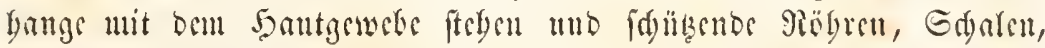

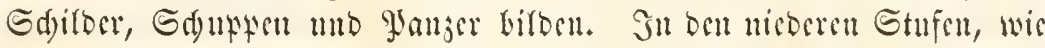

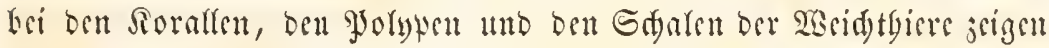
bicfe anorganifden Edutbirbungen im Gmern igrer Maffen megr

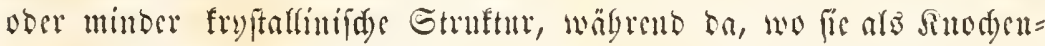

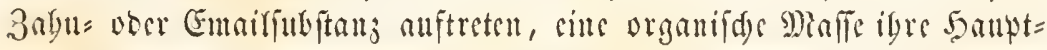

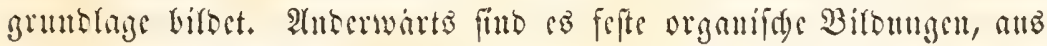

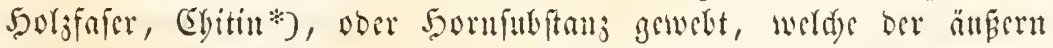

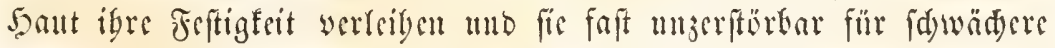

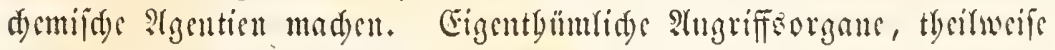

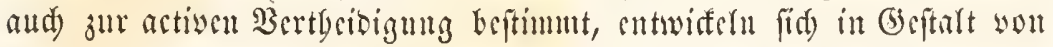

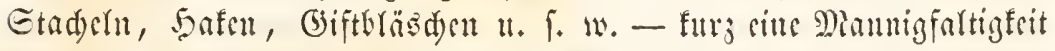

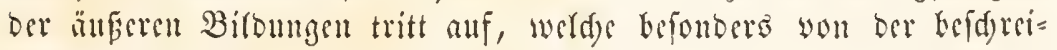

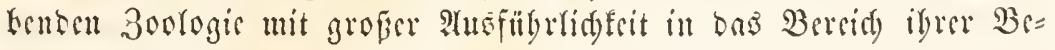
trad) tungen gejogen werben mus. Die greffere ober geringers Särte,

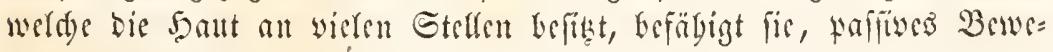
gungsourgan ju werben, indem dic activ bewegenden Theile, bie Ming =

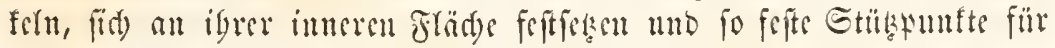

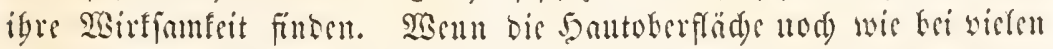

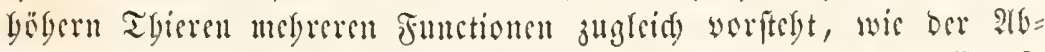

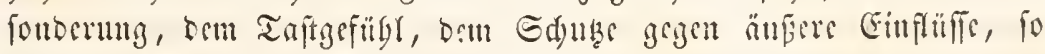

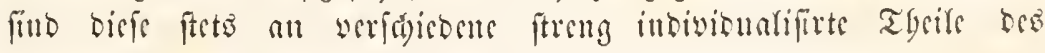
Santgrwebes getumben.

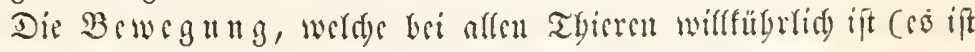

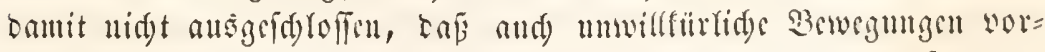
fommen,) und bei ben nicberin Stufen als̄-frmetion fer gefammten

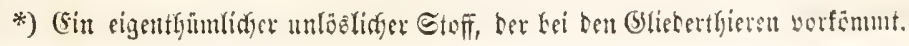




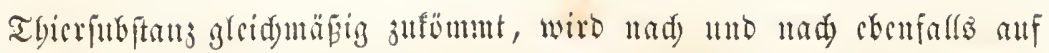
bejonbere Gewete und Digane bejdränft. M)an findet Fäben, die

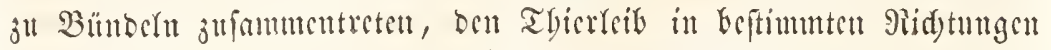

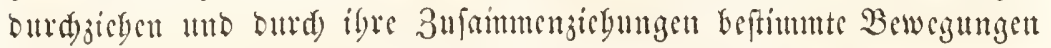

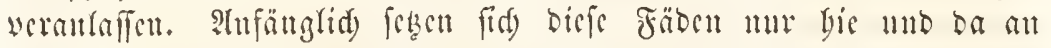
ber Sïrperwantung ofer an Drganen feit, weld)e buth igre Elafti=

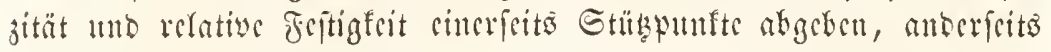
aber aud Beugutigen geftatten. Barb aber entwideln fid) feitere Stüce, bebel, welden jugleid) befoubere wogl daracterifirte, ein cigente bs=

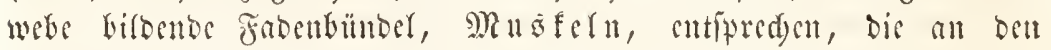
befelartig bewegliden feften Theilen gleid) 3ugfeilen angebrad)t find unto bicje mittelft oft febr fünftlicher Gelenfe auf cinator bewegen. Jn ben nicbern Formen ber Geftaltungen bilben bicfe beter bogle

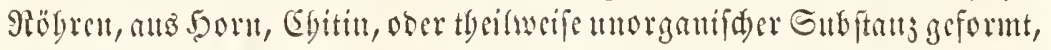
auf beren innerer fläd) bie jest bëbit d)arafteriftifd gebauten utto mit feittem antern Gewebe werwed)ferbaren Mușelfäben angebeftet

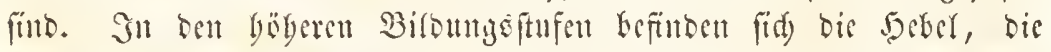

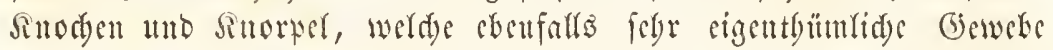

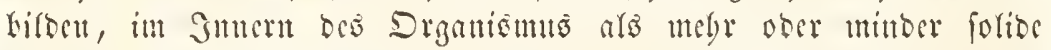
Sörper uแb bie \$)?

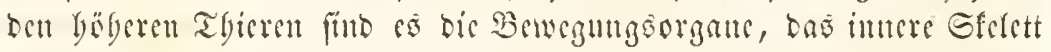
tho bie Musfelt, son welden bie äufere Jormgeftaltung bes Sintwers ablängt, bet ben niebern Thieren futb es oft ganj antere Drganc, befoutcrs afer dic Berbaung

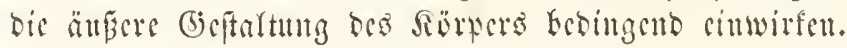

P(td) Dic Giแncs organe bifferenjiren fid) erft alluäblig in bem

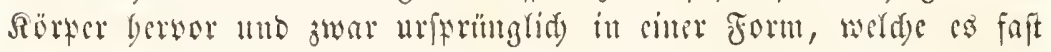

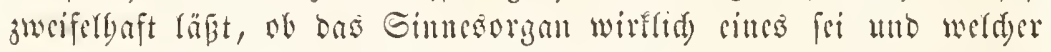
fpeciclleren Function, bem büren ober Gefen, es cigentlid) vorftebe.

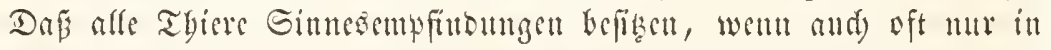
febr ftumpfer sasefe, if unjweifelbaft - ob aber bic 3abl ber Ginne

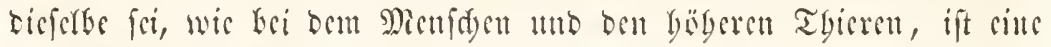

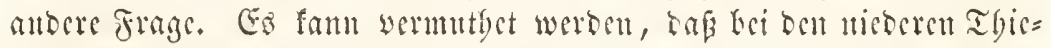

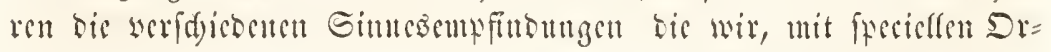
ganten bafür begaft, als Geben, Sören, Ried)en, Sdymeffen unter=

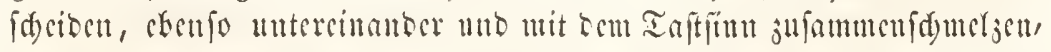

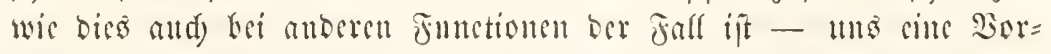

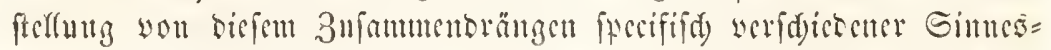
cutpfinbungen in citte ju mad)en, erfdscint mir aber mumiglid). Eben fo fönnen wir bie Gränjen ber eingelnen Sinnesempfintungen nid) ttad) 


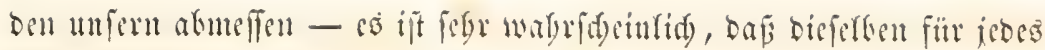

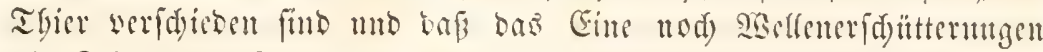

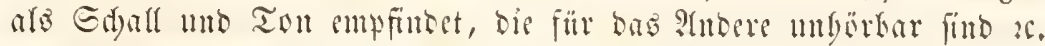

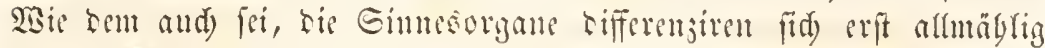

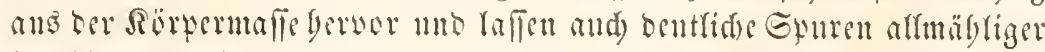

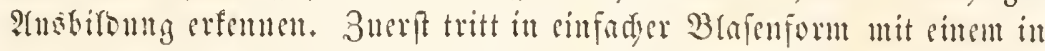

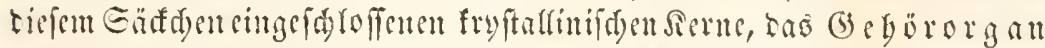

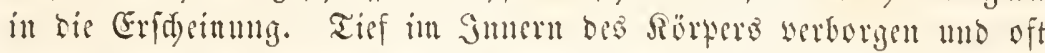
ummitterbar bem Centrafmersenyigtente anfgefelst, murbe biefe primitive

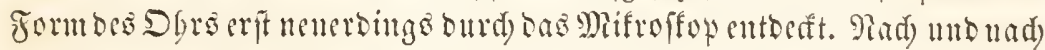
bert es fid) an bie DSerflidge cmpor, um bie Gdyallwellen bireft zu empfangen, bie es yorber nur surd Sermitternt ter Rörtergewebe erbielt. Die binjutretenten Theife erfyalten ons llebergendidgt hetber baz

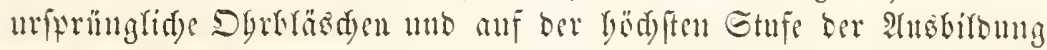
zeigt fid sin eigentlides äuseres 5 br, weldes mit einem munoerkar

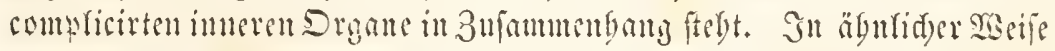

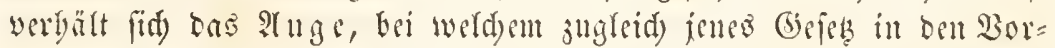
sergrumb tritt, nady weldem sie vieffad)en SBicberformugen eitnes unt befferben Drganes mit Semperten Functionen cine Gtufe mieberer Ans= bifoung verratyen, wägrent bie compricirti Bitoung eines zur fpes cieflen Function beftimmten Drganes, bas in einfarter 3abr worbanten

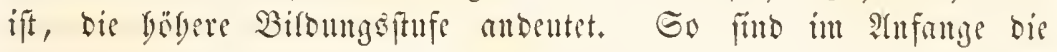

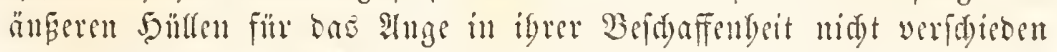

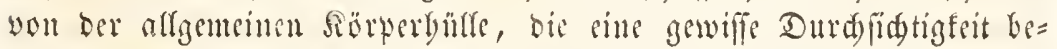

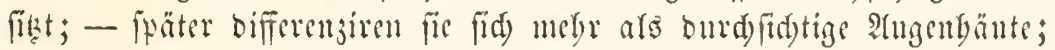
aber nur anf böberen Stufen werben eigentbümlide Sdjugorgane, Siber, fïr oas Gelorgan nad) uno nad) ausgebiloet. Sn ben eriten

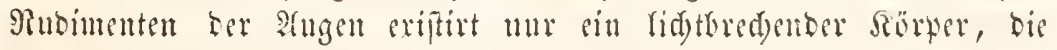

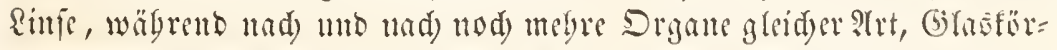

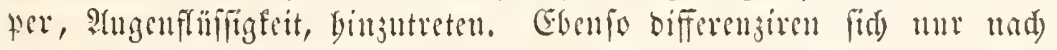

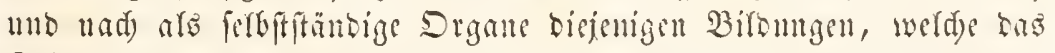
Eeitentidyt arjubalten, die Sagurfe mo Genanigfeit bes Bildes ju $\mathrm{er}=$ böben baben, unb wojn namentfid) bie farrigen stugengänte mo bie in sat won Gdiment bewegliden Migenbogentänte gebören. Sinfangz

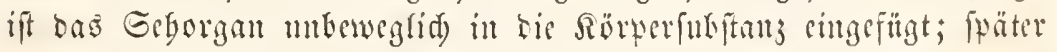
wiro es, ferbit unbeweglid), won bewegliden Rörpertbeifen getragen; auf ber bödyfen Gtufe enolid) wirb bas Drgan wilftityrlid beweslid) uno fann nad) Befieben felbititänig anf fen zu betrad)tenten Gegen= ftand gefenft werten. - Rur frre fät treten Kejondere Drgane

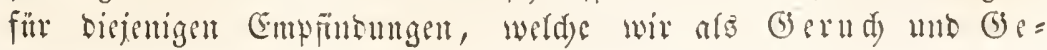




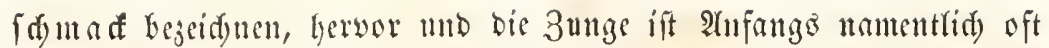
Taforgan, Ergreifungergan mo Gefdutatiogrgan jugleid, wäbrent

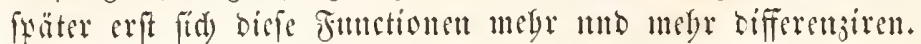

Die Emyfinoungen mo wiffübrlichen Bewegungen Gängen bei ben

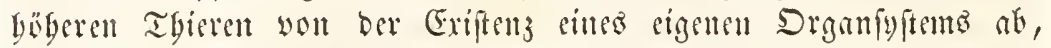

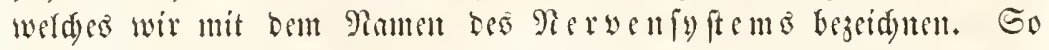
wie bas Blut ber Mittelpunft afler segetativen Functionen ift, Durd) weldyen affer 2(nstanfd ber Rörtertbeile bebingt wirb, fo ftelft baz Rervenisfen bas Gentrum der animalen Functionen bar, weldes die Empfindungen jum Bewnftein bringt und bie Bewegungen regelt.

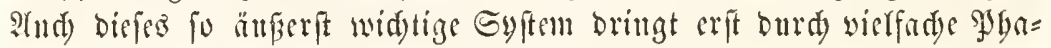

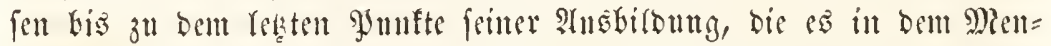
(d) en erreidt, wor. Bei ben nicbern Theren bat and) bie genamefte Interfudung fritte Sondering, weber sin Centralorgan, nod peripherifde Rerwen entberfen laffen; - weiter Ginanf begeguet man eint= jelnen Rerventurnten, won welden feine Fäben an bie widitigften Drgane ansftrablen. Durd) Diefe Fäben verbinden fid bie verfdie= benen Sincten zu sinem genteinfdaftliden Syfteme, bas meift bei ben nicbern Thieren nod) ans unregelmäsig burd) ben Rörer zerjtrenten Snoten jufammengefelat ift. Später birbet fids eitle Pleibe won Snoten,

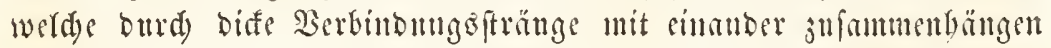

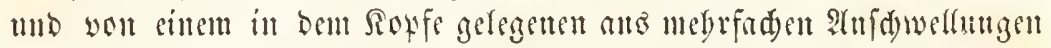

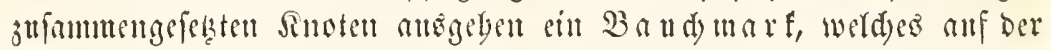
Bandfeite Des Rörterö nuter Den Gingeweiben liegt; - enblid) in ben

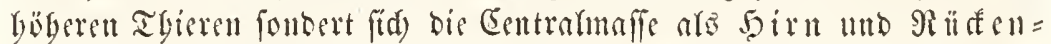
mat fdarf won ben angftrablenten Rervenfäben ab nub wirb in bem

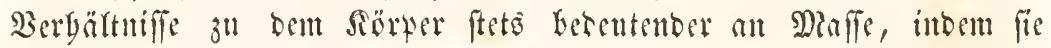
ongletd) bie Rithenlage eimnimmt.

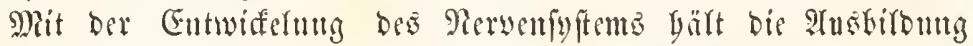
ber geiftigen fäbigfeiten wolfoumen gleidyen Sdritt unt erbebt fid) in jeben eingelnen Typus der Srganifation tis anf rine gewiffe Sä̈be, welde ftets bebentender ift als biejenige, womit ber nädyfte Typus anfängt. Die geiftigen Fübigfeiten ber Thiere finb anf baz Engfte an bas matericle Gubfrat gebunden; - es giebt fein felbft= ftänbiges, unabbängiges, geiftiges gringit, weldes bent thierifden

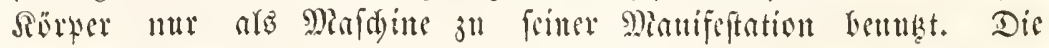

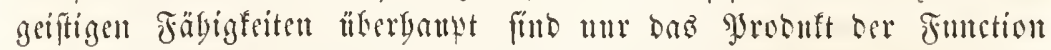
Der Rervenmaffe und bängen von ber Jntegrität biefes Drganigftems ab, wie alfe hibrigen Functionen won igren fpecifiden Drganen.

Die Drgane, Deren Entfartung wir bisker mit furgen 3ügen an= 


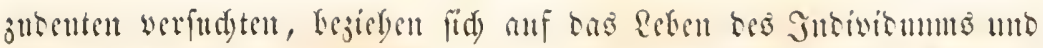

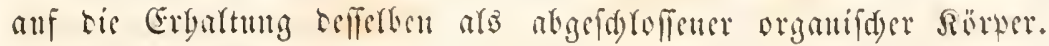

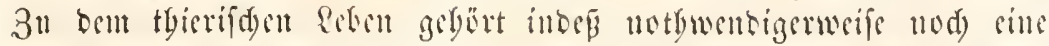
jweite bebingung, bic Erbartung oer Sit

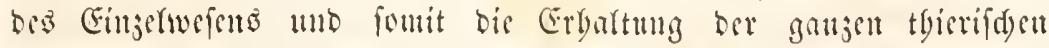

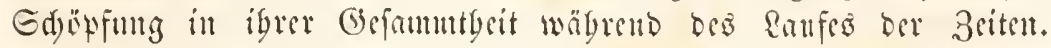
Gedem thierifden Drganismus ift nur sine gewifle Brit ber Exiften; angewiefar; ber Tob ift sin affgementes Gefes für alfe, wälrent bie Fortbaner in ber atrt turd) Erjengung won Padjemuterfdaft sbenfo

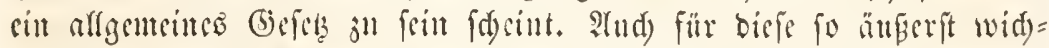
tine Function begegnten wir bem alfgemeinen Gefese ber Differenjirmus.

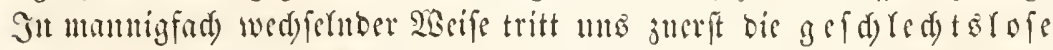

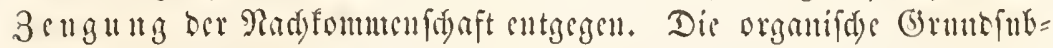

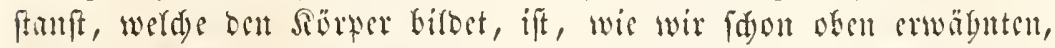

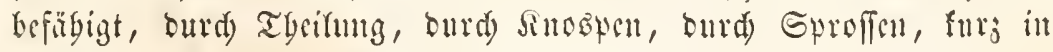

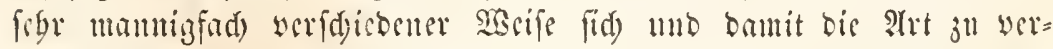

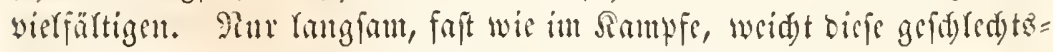

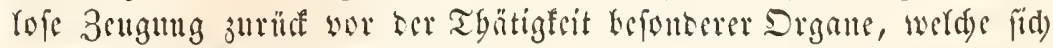

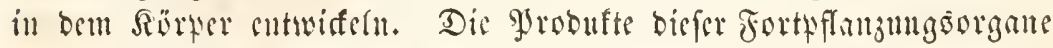

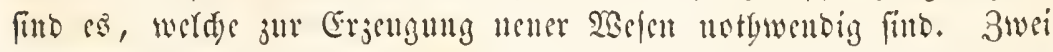

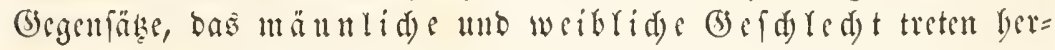

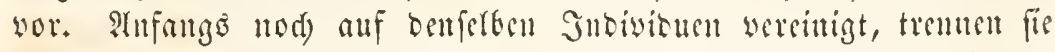

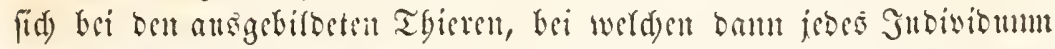

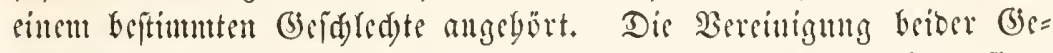

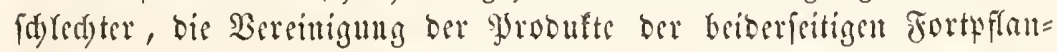

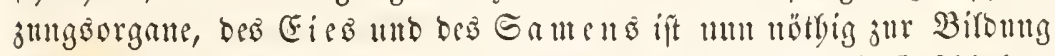

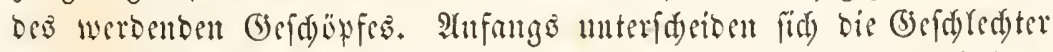
nur burd bent Sulgart ber Sogane, nidjt burd) bis Form berferten;

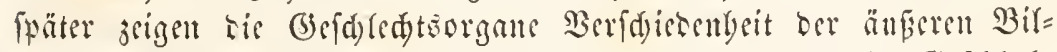

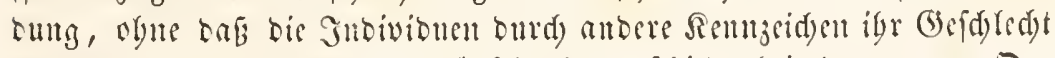

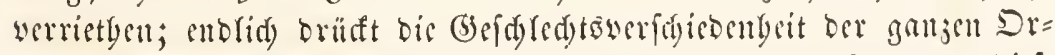

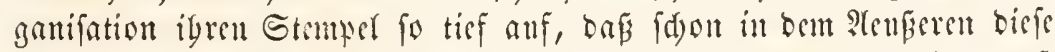

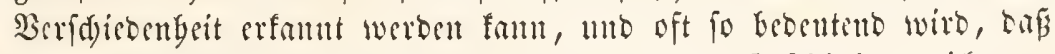

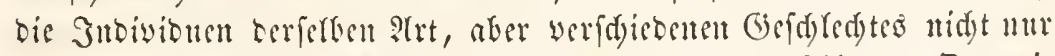
in ganj werfdiebene Sraffen, fonbern fogar in werfdiebene Drgani= fationstypen singersigt wurbent.

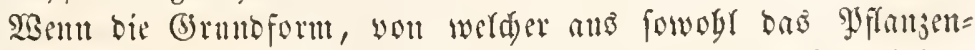

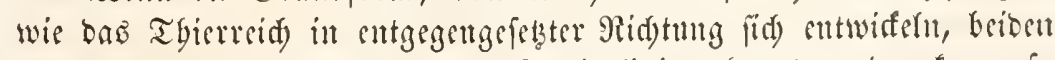

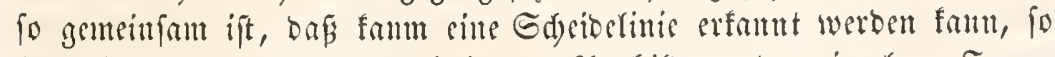
räpt fid) erwarten, onß aud) in ber shäbildung tor sinjernen form= 
elemente, aus welden die Srgane bes pflanzliden und thierifden

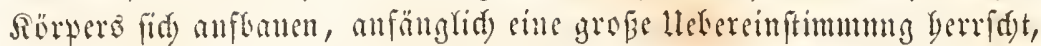
bie erft bei nadjträglider Differengirung mebr mib megr aufgeboben wird. Dies ift in ber That ber farf. Wir Gaken oben gefeben, da

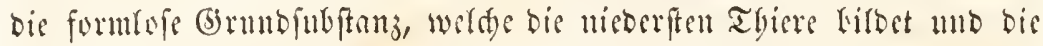
bald mebr bald minber flüfing ift, ben Grunbitod bes thierifaen Ban's barfellt und baj bie erife Formgeftaltung, welde fid Gervorbebt, bis

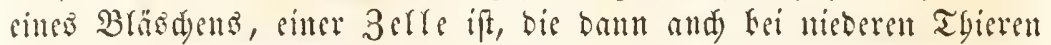

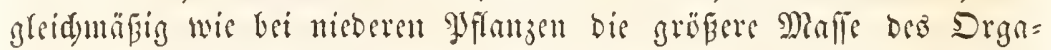

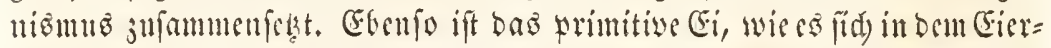

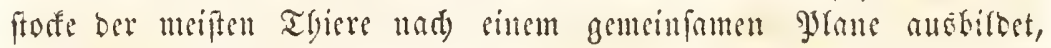
una) biefer Grmblage afler Gewebe uno Drganišmen alo Zelle gebaut.

Diefe Eeftegt wejentfid) ans mebren Theilen. Der 3elleniu=

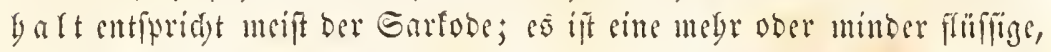

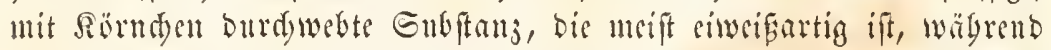
bie Rörnden fettiger Patur fint. Der 3elfeningalt wirb meiftens

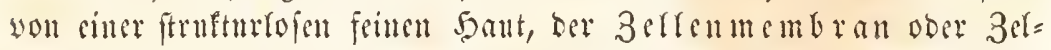

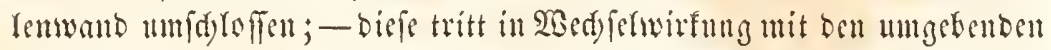
Gubfanjen. Sie bat bie (Figenidaft, biefe ober icne Stoffe, ie nad) ber Natmi ber Zelle anjüundumen ober abzugeben. Die Zelle bes

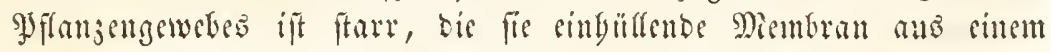
rigentbümliden Gtoffe, Der Fogenamten Geflutofe ober ser boljfafor gemebt, welder als folde volfommen untöglid ift, feinen Etiefitoff entbält unb and bei einer ganzen Sifafe yon Thiern, ben Mantels tyieren, als eigentbüntidyes jormelement vorfommt. Die thierifde 3ellenmembran bagegen beftelyt ans siweifartiger Enbftanj ober ans Mobificationen berfelben nub befït meiftens einen bebentenben Grab

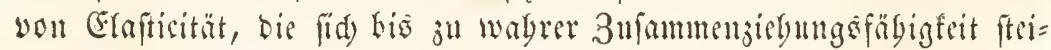
gert. Bei Den einjelfigen Tlieren bifbet diefe 3ellemmembrane tis änfere Sant unt ift banu jeglidjer Bewegnng fäbig.

Sm Smmern ber Beffen bemerft man meift anfer bou befdriebenen

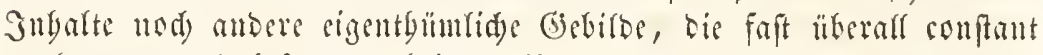
vorfommen nub befontere bei ber Bermegrung ber Beffen cine keben=

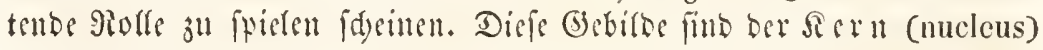

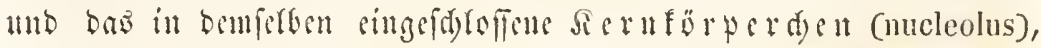
weldye lebtere and in melorfadjer 3 abl worfommen fümnen. Der Siern bitbet bald ein Bläsden, falb cinen fdeinbar foliben, megr ober min= ber fejten Sörndyenganfen, in beffen Miafle Das ober die Sernförper= d) en cingebettet liegen. 2ud bei cinjelligen Thieren ift Der Rern wobl uberalf vorbanben unb bietet befonbers bei ber Jortpflanjung unb 


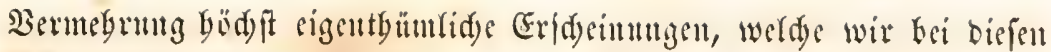

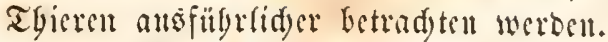

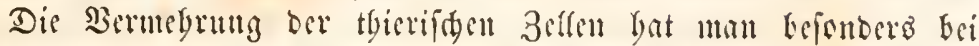

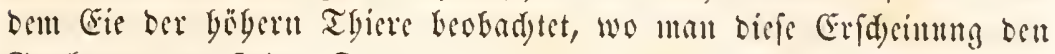

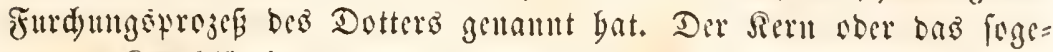

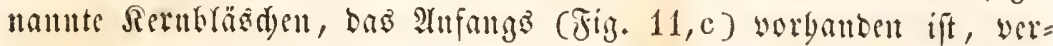

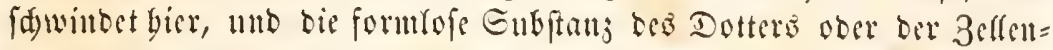
intyalt (b) beginnt fid) in einjeluen Maffen ju kalfen, berent jebe als 2Rit=

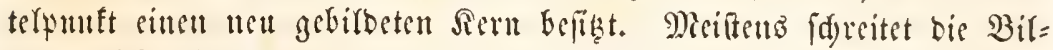
buttg biefer ferntyaltigen $\mathfrak{B a l l e n}$ in ber șsife vor, Dá jeber berferben

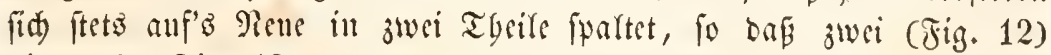

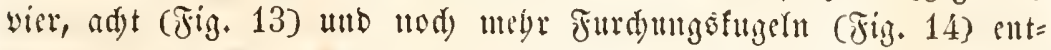

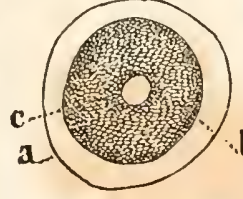

รig. 11.

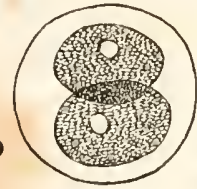

Fig. 12.

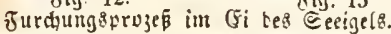

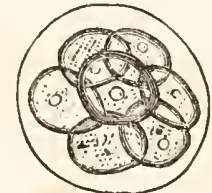

สị. 13

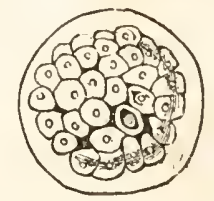

Fiij, 14.

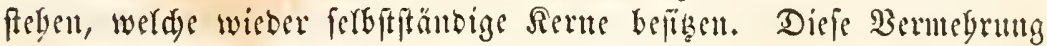
nad) Der 3 weijugl fetst fid) fo lange fort, bis bas ganje Ei, ober silt

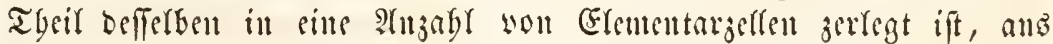
weldyen bie (Sswebe bes (subryo fin) aufbanen. Pad) mo nad) erft

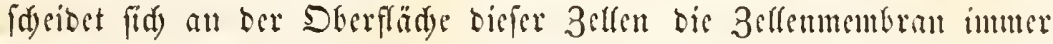

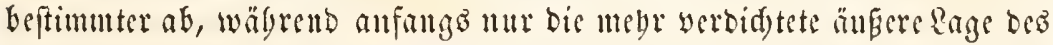

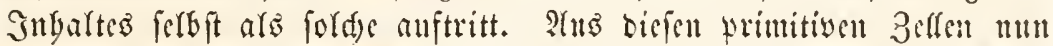

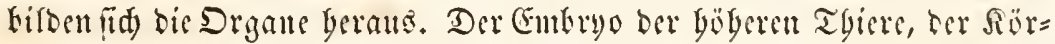

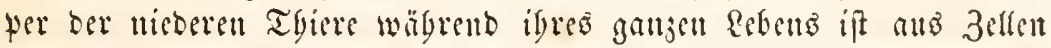
zufaumengebäuft, weld)e jwar in jebem Dryane sine sigentlyümlidse

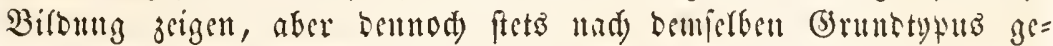
bant fint.

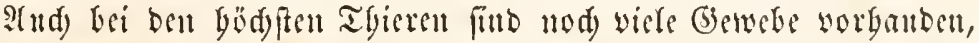
bei weldent fid and) in ansigebifbeten 3 uftanbe bie Belfenftructur ers

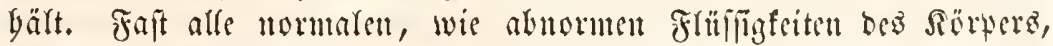
namentfid) aber bas Blut, entgalten megr ober minber yänfig cintge= ftreute Belfen ober Sörperden, Die ans Bellen lyerftammen. Die zarten

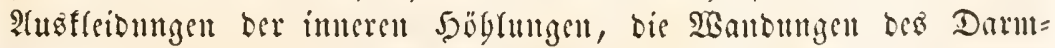

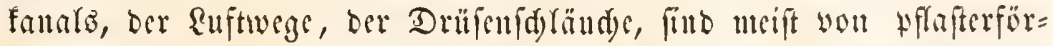
migen, bautartigen 2 tušbreitmugen yon Beflen gebilbet, bie man mít Dene gemeinfamen Samen Der inmeren Dberbänte ober Der Epitbe= lien belegt bat. Alfe jene Gubjtanjen, welde yon ber Gonfitents 
eincr sveid)en (Sallett bis z"l Der elaftifden 5 ärte Des Sinorpels und

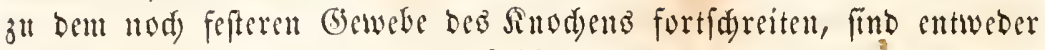
ans nod) erfembaren ober aแt fold)en 3eflen zufammengefent, bie in mannigfad)er siseife burd) imtere P(blagerungen, Berbifungen, Ber= fduelaungen verändert uno mefentlid) geworden find. Fo witrbe zu weit fübren, wolften wir bier auf biefe mantigfaden Mobificntionen cingeben, welde alfe jene Bebitbe berwortreten laffen, bie wefentlid

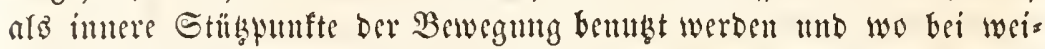
terem Fortforitte burd) ablagemng unorganifaer Subftanj (meift Sart) in bent werfdumoljenen 3elfengewebe jene feften (extemente

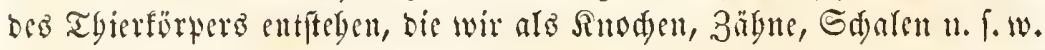
bezeidnen. - Die veridjebenen Fette, bie Farbfoffe unb Sigmente, twelde wir in bem thierifden Rörter abgelagert finden, fund meift ebenfalfo Gubalt von Bellen wto in Zellen urfprünglid abgelagert,

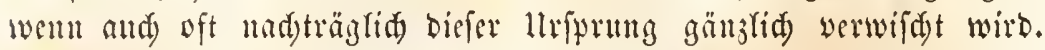
Meift läßjt fid) bei biefen veridfiedenen Modifffationen ber 3elle die

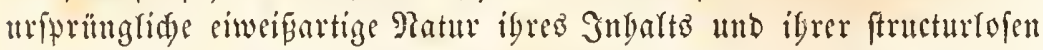
SBandung naddweifen; zuweilen aber treten bejoubere Stoffe anf, wie

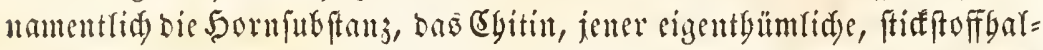

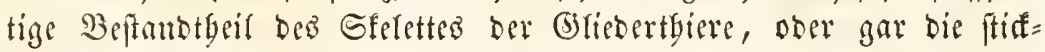

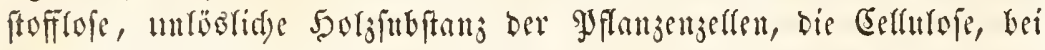
Den Diantertbieren.

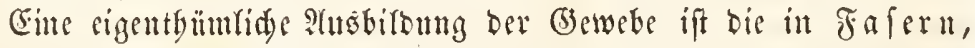
bie fowobl im Sumern Det 3elle, als in igrer SEmbung, ale and in igrer llugetung fïd entwidén fömen. Buerfit fiegt man in ber form= rofen Subftan gleidyfam nttr 3üge, unbeftimmte, verfatwimmente Eängstinien, bie namentlia bei Bewegungen burd) 3ufammengiebung Gervortreten. Diefe 3̈hge werben fefter, beftimmter; genau abgegräujte Fafern won beftimmbarer Diffe muto mannigfartiger 3ufammenfezung treten berwor. Die verfdjebene Feftigfeit, 3ufammenfetung und Diffe Iaffen weidye Binbefafern, feftere Gelnenfafern, eraftifde Fafern u. f. w.

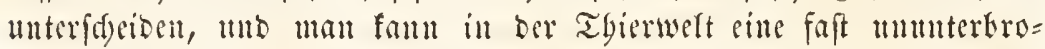
d)ene Sfala von ben unbeftum abgegrängten Fafern Der meberifen

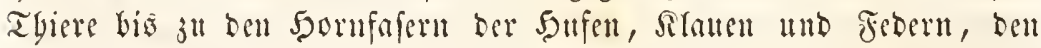
3abufafern tho äbulidgen Gebitben verfolgen. THe biefen Fafern weben fids bann befonbers bie Gantartigen Gebirbe, welde in ben

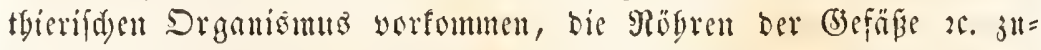
fammen, benen burd cinte fold)e Bifoung meift eite grofie Debubarfeit und Clafticität gefid)ert ift. Sad) eilter anbern Ridutung bin entwiafelt

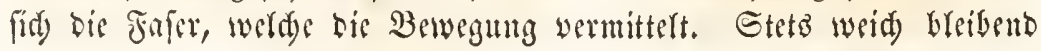


nimmt fie immer beftummtere GGaraftere an unb ftebt entolid bei bent böberen Thieten als Metsefelfafer in zwei Typen Da, je nad)bem fie Der willfürlid)en ober ber unwillerirliden Bewegung bient. In ebento

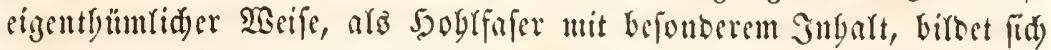
bie Nervenfajer affmäglig mit unterfdsibenben Ggarafteren berwor.

Ga wäre unmöglid), bie Egaraftere ber verfdedenen Formele=

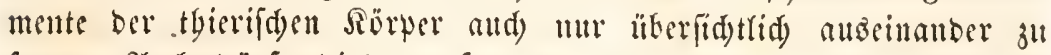

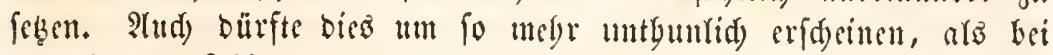
ben nieberen Thieren namentlid) bas meifte nod) ber ffäteren Forfdung iiberlaffen bleibt.

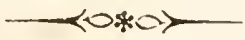

\section{Bierter Brief.}

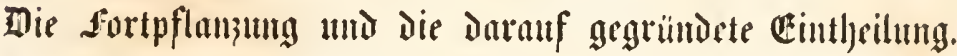

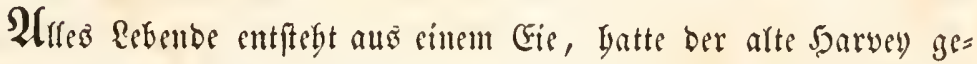

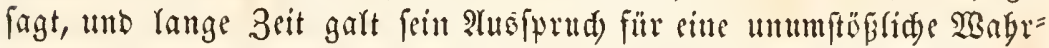
Jeit. Man frritt fid nur barüber, of bie Cier ober Reime ber Tyiere

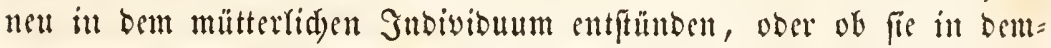

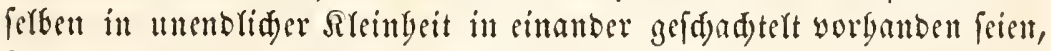

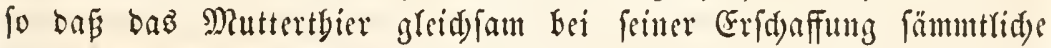
Sieime bis zum Untergange friner Radfoumenfdyaft vorgebilbet im

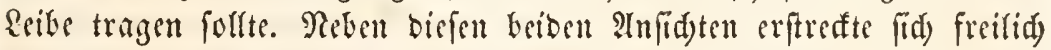

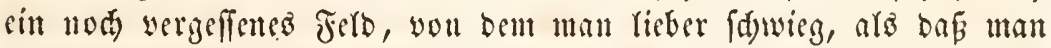
bie fdjwad)en Seiten Gätte aufderfen follen. Die Fortpflanjumb ber Eingeweibewürmer nub mand)er anderen $S_{d}$ marokger, fowie berienigen

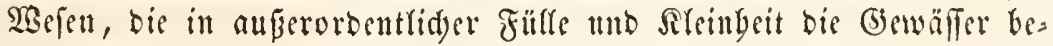
wölfern, war für beibe ftreitende Yarteien in sit unburdjoringlidsez Dunfer gebülft. Snbeffen fülyrte bod) bie Rotlywentigfeit unb ber zut=

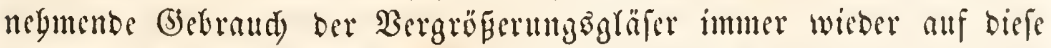

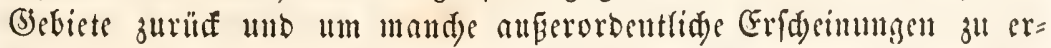

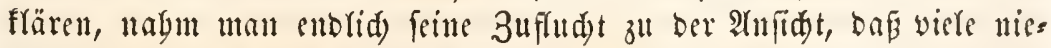
bere Thierwefen nidjt von Eftern igrer Sirt abjtammten, foubern un=

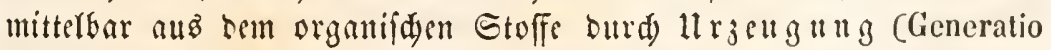

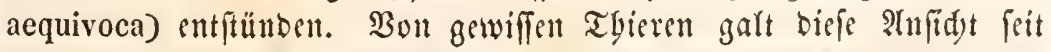

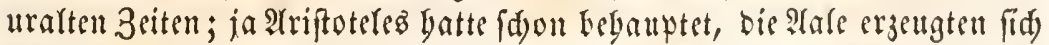

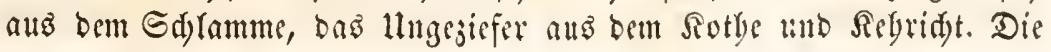




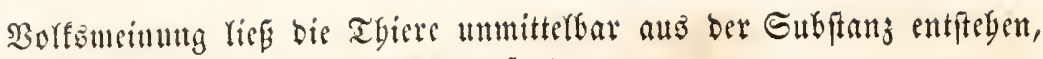
in bet ntan fie juerit als Sunge frotb.

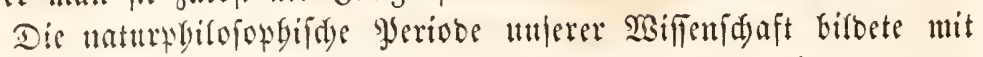
Gefonberer Borlebe tie Theorie won ber Erjenguth ber niebern orga=

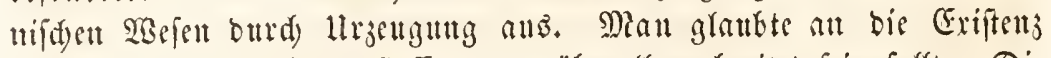
cincs organidaen Grunbftoffes, oer niberall werbreitet fein folfte. Die Srgane ber Goberen Thiere tulo Jyflanjen, tabm man an, biloeten fid) aus biefem Gruttoftoffe bervor utto wärben wieber in ign surüt:

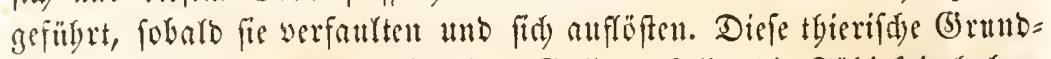

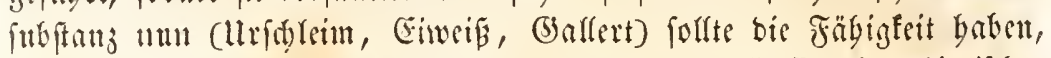

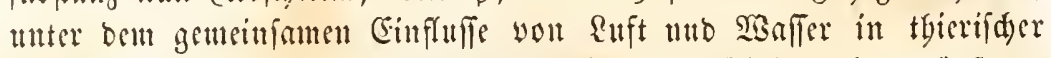

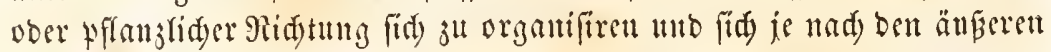
llmftänbell zu beftimment Formgeftaltumgen, zu beftimmten gyfanjen tmo Thieren, Gefonbers Gdjimmelfäben uno Snfuforien, zu entwiffeln. Shute fid wicl näber un bie Drganifation ber entfegenden Mflanjent =

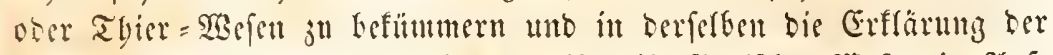

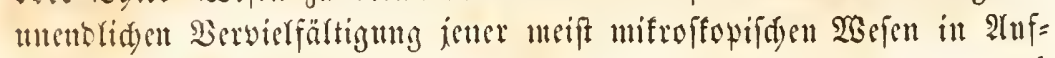

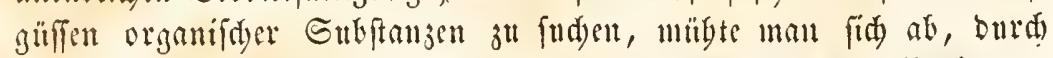
vielfadye uno in ifrem 2 sefen ftets ungenaue Berjudye bic Bebingum= gen ju finden, unter welden aus benferben Stoffen bald \$flamjen, balo Thiere erjetht witroen. SRan feffte all mübevollen llmwegen entid fo wiel feft, baß̧ zut llizengung organifder :

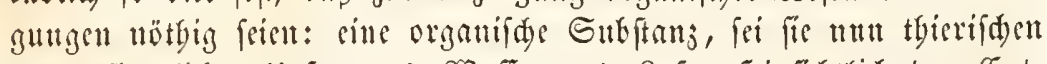

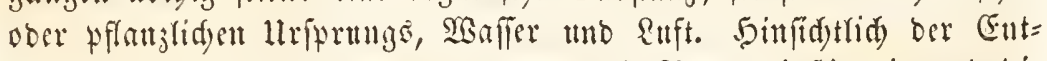

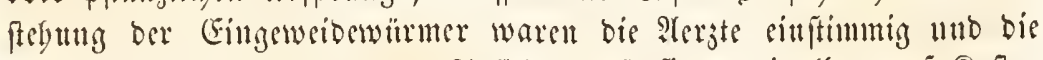

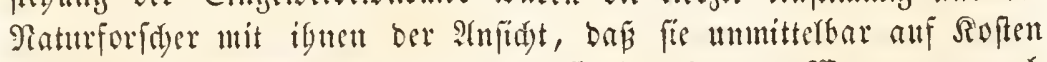

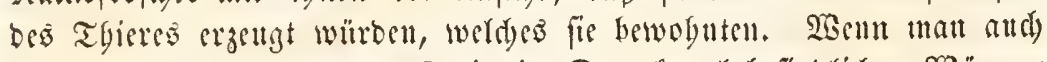

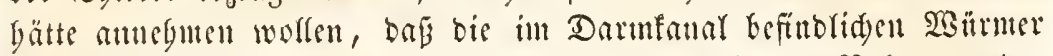
als junge Thiere, ober it Geftalt won Eiern mit ber शabrung ober

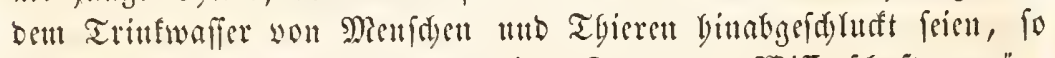
founte man bod nady bem bamaligen Stanbe ber SBiffenfdaft numb̈g=

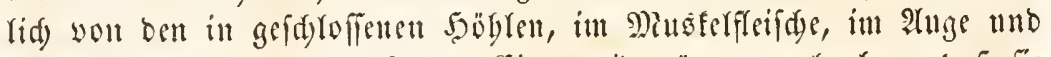
an äbnliden Srten anwejenten Gingeweibewünmern glanben, Daß̧ fie

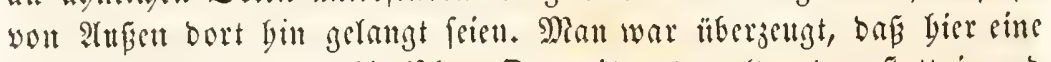

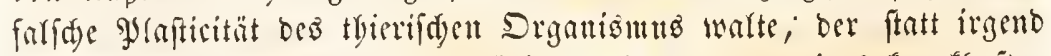
ritter normalen, jum Rörper gebörigen Bilbung ober eittes frantgaften aftergebiloes cin thierifdes $\mathfrak{B}$ ejen neberer art berworbringe.

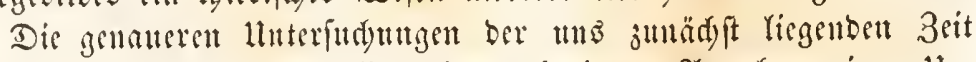

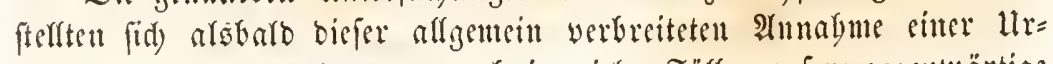
zengแng entgegen, unb wenn aud) in vielent fälfen unjere gegentwärtige 


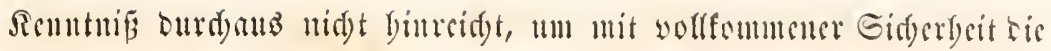

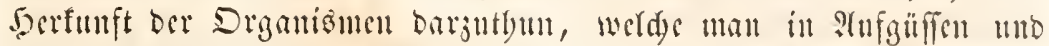
in anderen thicrifden Sïrpern findet, fo war bod) eitl sinjiger, ans

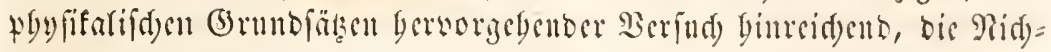
tigleit bes ganjen naturphilofoplifacn Geränbes oajutbun. Fin

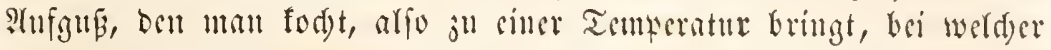

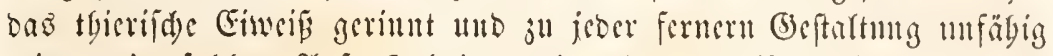

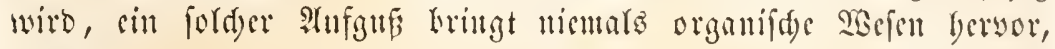

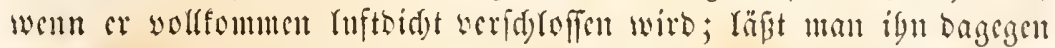

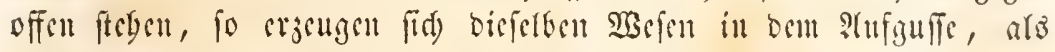

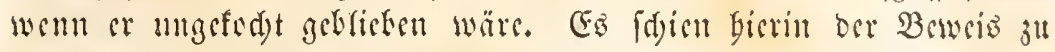

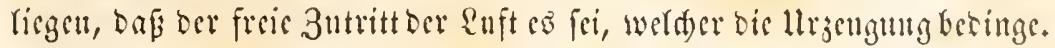

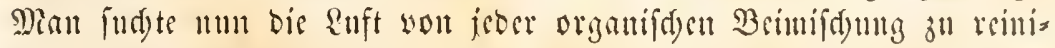

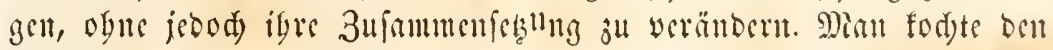
Iufguf ill cillem Solben, burd) werd)en man sincu Euffitroul reiten founte, ber vorber surd) Edumeferfämre ober irgend cine andere Gub=

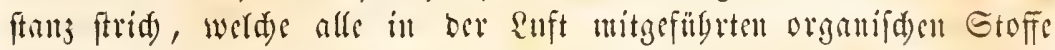

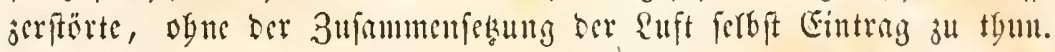
Man riç biefen Apparat wodenlang, monatelang in Funftion unb rrmencrte tägridy bie \&nft, inbem man fie burd) Gdiweferfümre ftrcidyen

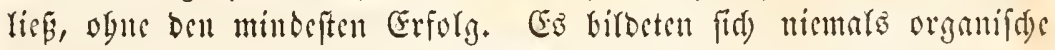

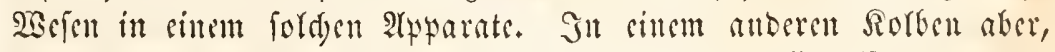
beffen Subart wolffommen gleid) bebandelt war, beffer Ermenerungs

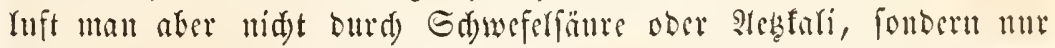

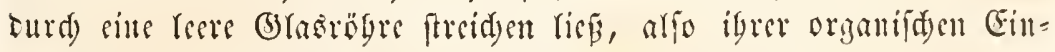

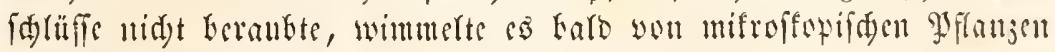

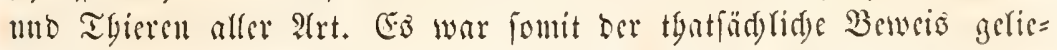

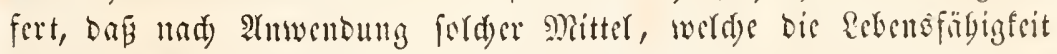
organifder Sïbper zerftëren, and bei Anmefenbeit won organifder

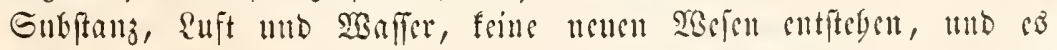
wat Der mittelfare Rad)weiz gelicfert, buf in ber \&uft, in ben foge=

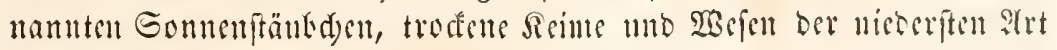
ben 2ufgüffen zugefïbrt wurocu, in werd)en fie cincu gecigneten Boben fil igrer Entwifelung mo Fortpflangung batten. Sn ber I gat ift die

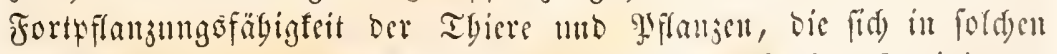

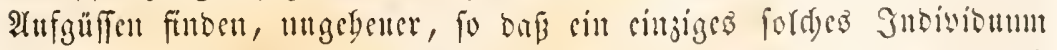

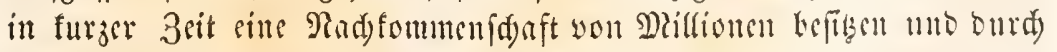
biejerbe sine bebentente Menge von friefigfeit bevilfern fann. 


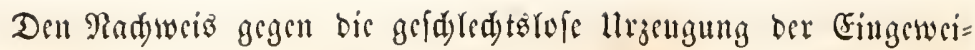
bewürmer auf Joften ber Thicre, welde fie berwobnen, Gat man auf

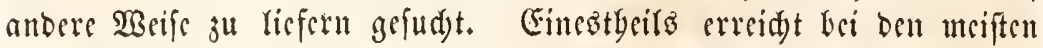
Grattungen Derfeften bic gुrobuftion von Eiern unb Seimen wabrhaft faberlyafte groportionen, fo Daß Millionen biefer Eicr und Reime

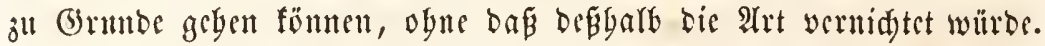
Dann bat man bic meift mifroftopifden Eier und Sungen auf igren

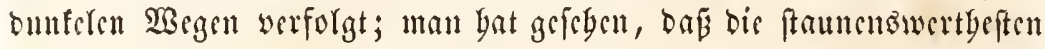
Berwanblungen burd)lanfon werben; Dap oft berferbe Sdmarolacrwurm

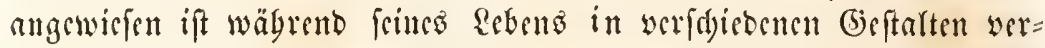

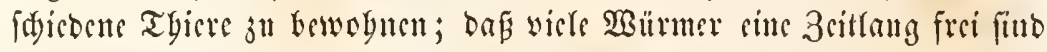

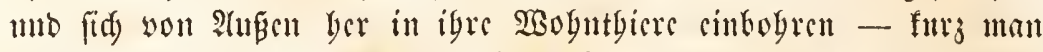
Gat cine Menge won 2 Segen entbeft, auf welden biefe Eingeweibcwitr=

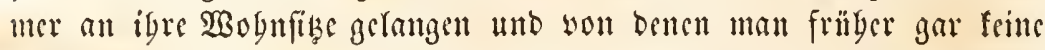

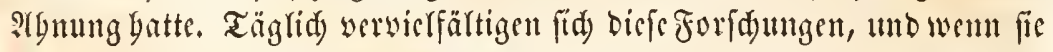

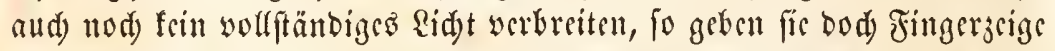
unt Analogieen genug, burd weld)e man affe paraboxen Erifdeinungen

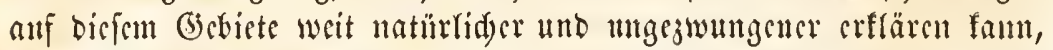
als burd bie STmagme siner Urjengung Der Eingeweibewürmer auf Soften igrer 280 gntgicre.

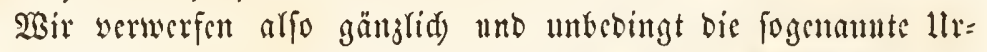

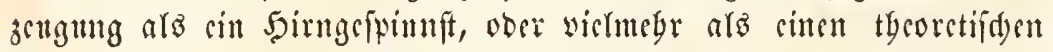

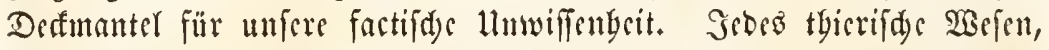
weldes criftirt, ift für uns bas grobuft ber Fortaflanjung yon ans

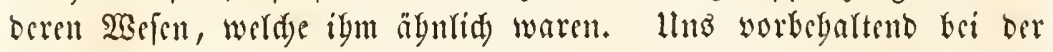
Betrad)tung Der cinzelnen Tyicrffaffen mäger auf bie Cingernbeiten

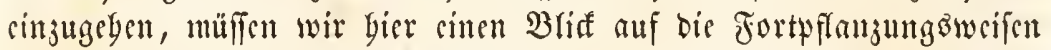

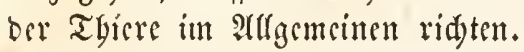

Die gefd)ledstalofe 3 cugung fonmm, wis wir fdon in bom vorigen Bricfe bemerften, Gauptfäd)lidy nur in Den nicbrigften Stufen ber cinzernen Drganifationstypen yor me and bier wicber in fergr

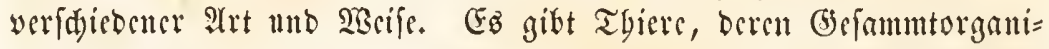
fation inbor nod) nidyt fo woit crforfdet ift, un cin gentigendes $\mathfrak{l l}=$

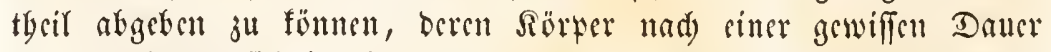

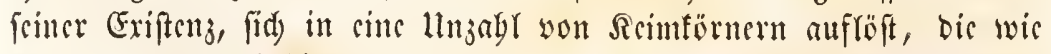

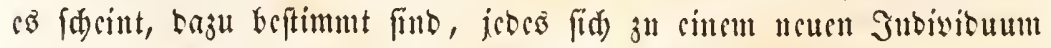
3u geffalten. Das Miuttertbier gebt Gier bei ber Ergcugung feincr Sisime zu Brounde, und bie Seime ferbft ftrenen fid), wie ca fdscint, nad)

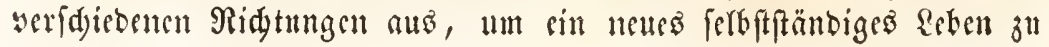
beginnen. 
Cime anbere Bermebrungemeife ift bic burd Theilnng, welde befonbers bei ben Jufufionstbierd)en Gänfig worfommt. Fin Thier,

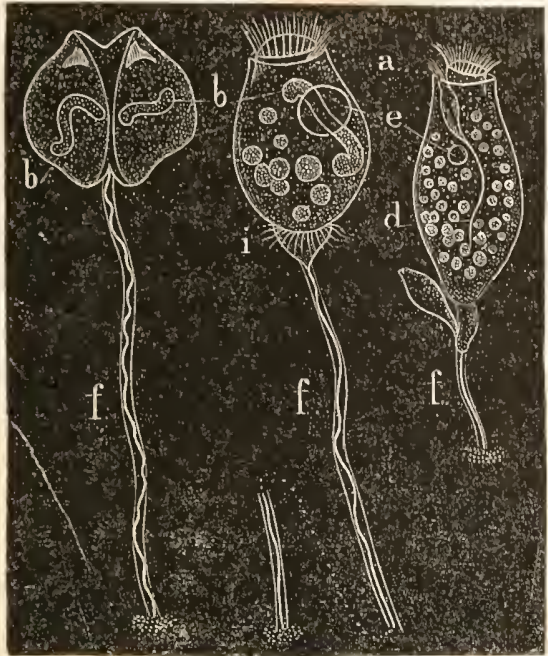

Jig. 15.

รig. 16.

sig. 17.

Blorfentfierden (Vorticella), bie fin burd) Theifung unb Sinosing fortaflanzen.

Das Thierdfen Fig. 15 ift ebent in ber Theilung begriffett, ber Retn b ifi fidyon voll= fummen Doppelt ; Fig. 16 inill fïd you fritem Etiele lozlôfen; Fig. 17 billot an Der Bbaliz Des Etidlez cinte feitlidge Sinosec, die nod) un= wellfonmen ift. Bei aflen breien ift a ber Mutto mit ber 2iimperfone, b Der Rern, d die gefüllten Magentlafen, e bie contractile Blaje, f Der Sticl, i Der accefforifore Ditumper=

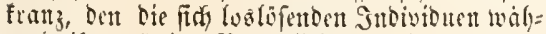
rent ifyer freien Beweglidgfeit Gatent. weld)es bis babin sin forbftitin= bigeg Rereu fübrte und frinc Spur eittes fummetrifden $\mathfrak{B}_{\text {mues jeigte, }}$

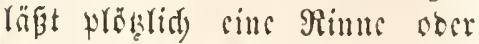
Furde ober eine fonftige Serän= berming in feincut Suneten getuab= ren, welda fid) bis ju einer Tyei= lung in juvei, meiftentbeils gleidse Ђälften ansbiltet-cinc Dis juweilen nad) cinigen Gtmben fid bei ben faum getremuten 50 älf= ten กuf'B Relte wicberbolen famn. So fdreitet bie Fortfflanjung ourd) inmer fortgefescte Theilung Der nenentfandenen gnbivionen in geometrifder SBeifesor, mot man weif a

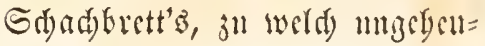
ien Zablen man anf bieje 2 scife gelangen fann nub notbwendig gelangen mur, wemn nid)t ander= weite Soindernifle yemment da= jwifden treten.

Bei ber Tgeilung find bis beiben 5ärften, in weldye bas Thier jerfälft, meift einander yollfommen gleidy. Fs fittoet fein lln=

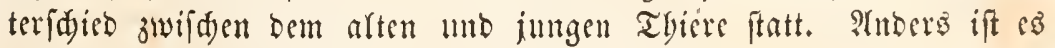

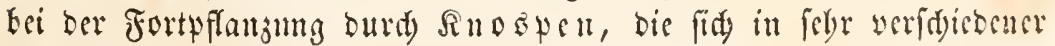

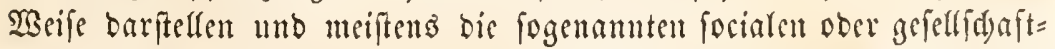
riden Formen ber Thiere jul Folge baten. FH irgent sinem Tyeile Des Särpers, bald an bem yorberen Fubc, bald an ber Seite, Ealb an

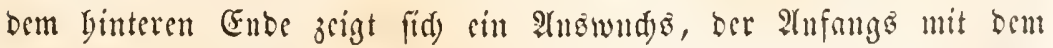
Rörper bes Duttertbieres in bem innigiten 3ufammenbange ftebt. Die

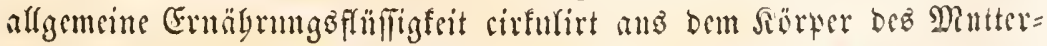
tyierco in bic Söblung ber Rnospe. Diefe fdeint anfanga nux cin jufäl= liger, yon frübern Forfdern oft für frantgaft gebaltener Anstwud)s.

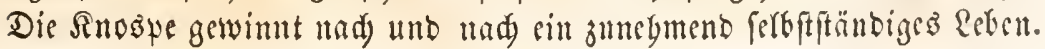




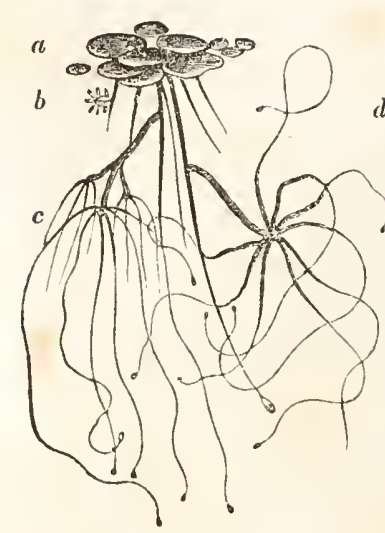

ซig. 18.

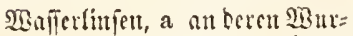

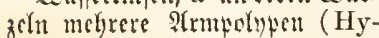

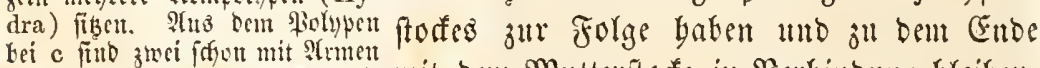
verjefiette Ritrozpen enturiffelt, Die Der siblofutty untye fint.

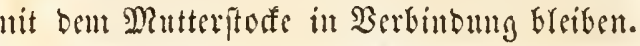
3nweilen bitren fid bie Sinospen aud in

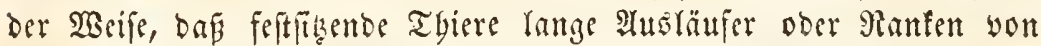

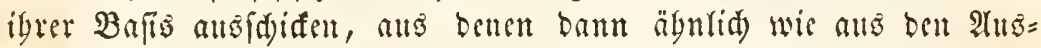
lälfern ber Erbberpflanje von 3eit ju 3eit burd) Rnosipungen neue

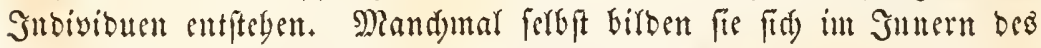
Sörpers und twerben nad) ifrer ablöfung ausgeftofien.

Die büberen Thiere in allen Typen fflanjen fid burd bie $g e=$ (d) $(e d) t$ lidge 3 eugung fort, unb biefe if aud bei vielen nicbern Thieren vorbanben, bei welden auberbem nod) bie Bermebrung ourd Sinospentilbung ftattfinbet. Die gefdeledtlide Jengung bebingt, wie fdon in bem worigen Briefe Dargetban watroe, bie Exiftents sweier ver=

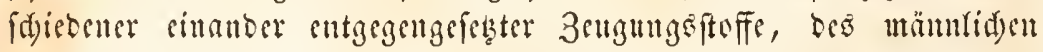
ober bes Gamens uno bes weiblidyen ober bes çes, bie meiftens in

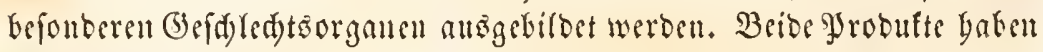
ourd) bie ganje Thierwelt io eigentgümlide Cbaraftere, baß fie nur ferten verfamnt werben fömmen. Das e $i$ aller Thiere ift nad) cincm beftimmten Ylane getant; sine mebr ober minoer förnige weide ober

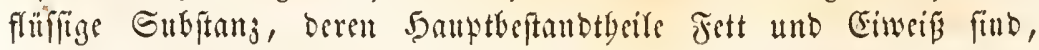
ber Dotter, bilbet Den Saltptingalt bes Ci's und wirb voll einer auberorbentlid) zarten, nur in feltenen Fülfen fefter werbenoen, ftrufturlofen Sant, Der Dotterbaut, muldylofen. Sn biefem Dotter

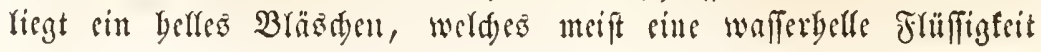




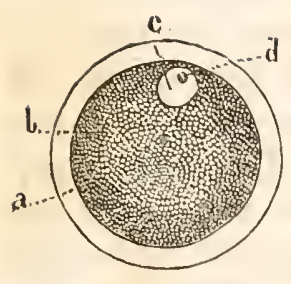

Jig 19. Gierfutsei bes Raututbeแs.

in fid) folicht mo meldyes man bas ficimblä

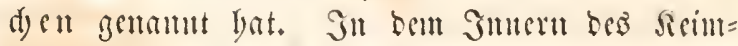

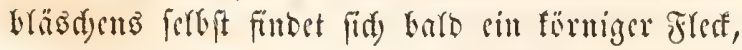
bald an beflet Gtatt, cinb ober melyere anferor=

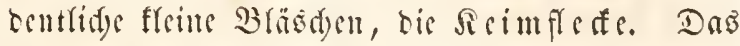
primitive Gi affer Thiere ift all biefen werdje= benen incinanber gefdedstelten Geciloen, Dem

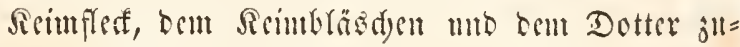
fammengefelst tutb bat ftets cine nur mifroffopifale Sröbe. Die fies merben in befonberen, mand)= a Dotterfiant (Foi ben

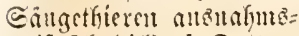
meife Fefrebiat); b Dorter; c Reimblazs)en; d Reim= fiect.

mal fids periobifd entwiafelnben Drgmen, in ben

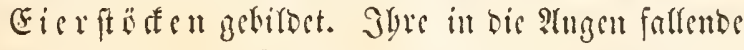
(3röpe erlyalten fie meiftens burd) Bemerbrung bes

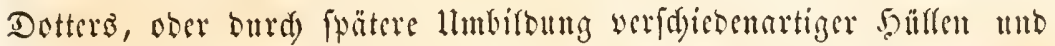

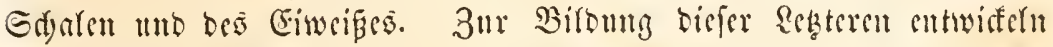

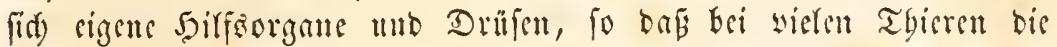
weiblid)en Gefd)led)tätbeile cinen äuferft complicirten $B a u$ befitzen.

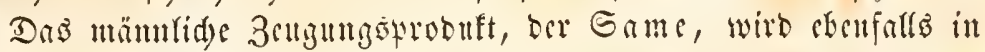
eigenen briafenattigen Drganen ausgebiloet nnb zeigt citte nidt minter

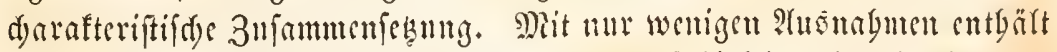

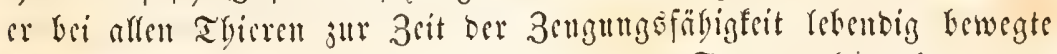

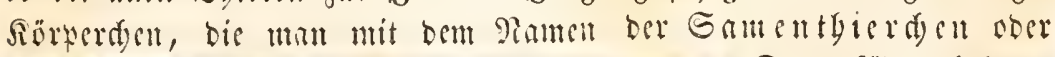

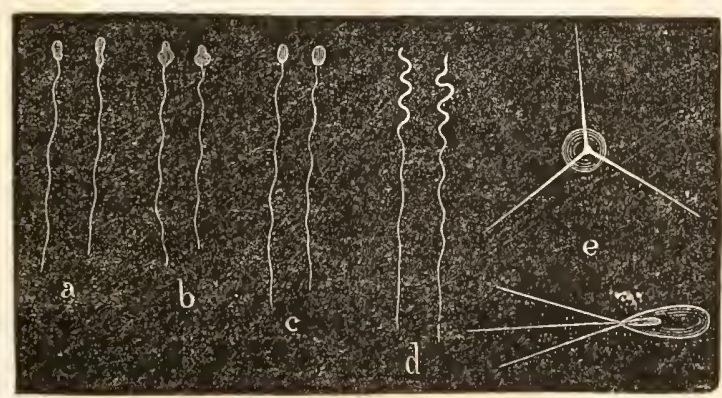

8ig. 20. Saanentficlifen rerifjièener Thitre.

Gmmenfäben Felegte. Jriiger bielt mon fie, ibrer retbaften $\mathfrak{B}=$ wegungen wegen, all= gentein fiir Thicre, Die man balo ben In= fufionstbictryen, barb Den Cingetweitocmür= merus ajöblte. 2rrecin alfe Berfudbe eille itt= nere Driganifation an

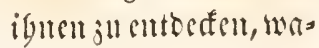

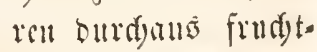
(nถ. Durd) genanere unterjud)ung igrer Eutitegnngstweife an ifrer Bifonngsitätte, bem

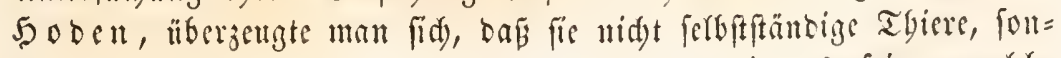
bern nut Formelemente Des mäunliden Srganismus feicu, weld)e

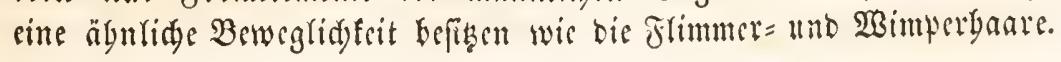


Diefe Gamenfäben baben meif einen megr ober minter siförmigen,

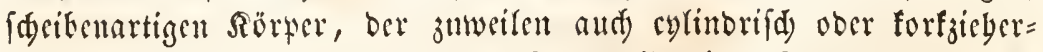
artig gebregt ift und einten langen fdwansförunigen 2ingang, ber fird) peitfdenartig gin me ber bewegt. Das Gervimmel won Taufenben biefer bewegliden Formetemente in cincm einzigen Tropfen zeugungs =

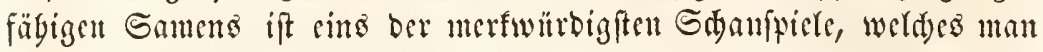
unter bem Miffrosfope crblifen fann. Rur bei wenigen TGieren funt

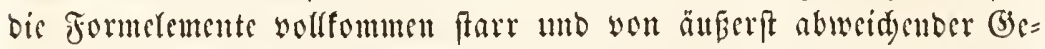
fralt, bei manden aber werben fie nod in sigentguntiden Samen=

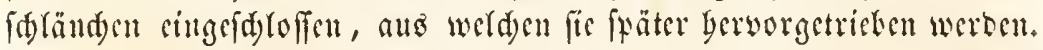

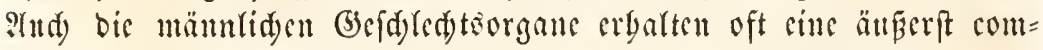

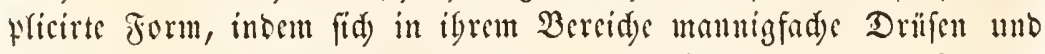

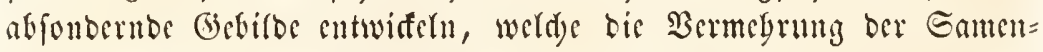
maffe bezweffen. Sattrerbem foumen bei ben Güberen Thieren, fowobl bei bem männlident wie weiblidgen (befd)ledde, änßere Drgane vor,

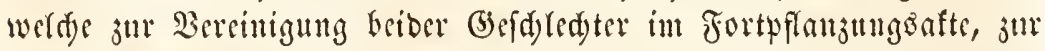

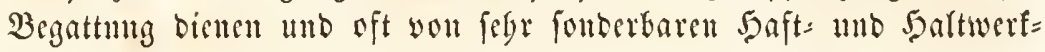
jengen begleitet fint.

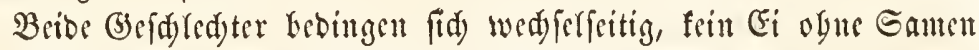

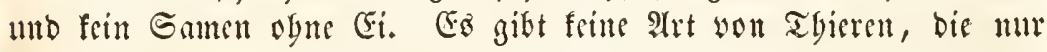
männlid) ober mur weiblid) wären. Mannigfaltige $\mathfrak{B e r g a ̈ l t n i f f e ~ w e d ) = ~}$

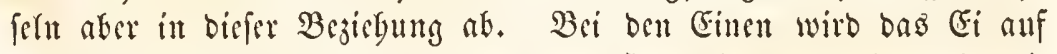

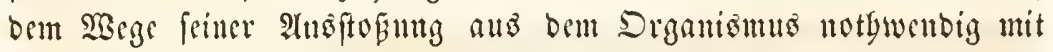
ben mäunliden 3eugumgsftoffen in 3erügrung gebradjt, bic von bem= ferten Snbivibutm in mäutuliden Drganen ergengt werben; - bas

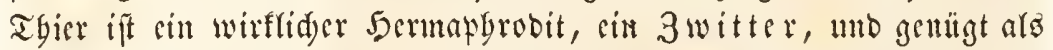

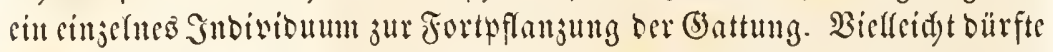

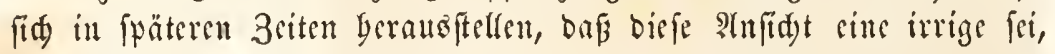

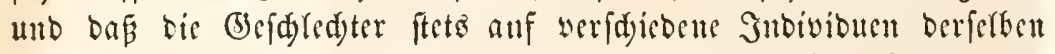
Art vertbeift feien; - bis jesta aber ift der fidjere Beweis biefes Berbal=

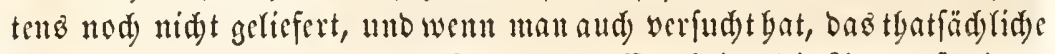

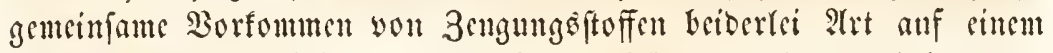
und bemfelben Snbivibumm baburd) 3n erflären, da自 mant bechatptete, bis männliden Bengungêftoffe feicn erit burd Begattming cingefülyrt, fo ift biefe Begauptung bentod) weit entfernt, genitgend unterfituzgt ju fein. Die meiften bermapgrobitifden abiere inbeffen pflanzen fid

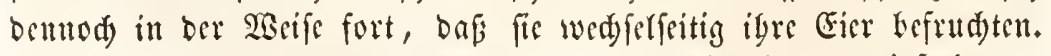

Die Befruditug fereft gefdjegt indeffen in mannigfad ver=

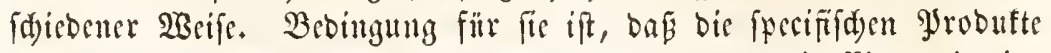
ber Fortpflanjungsorgane, bie Samentbirrden unt bie Eier, mit ein= 
anber in birfte, unmittelfare Beriibrmug fommen. Bei ben sincu

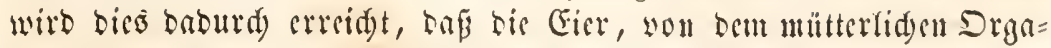

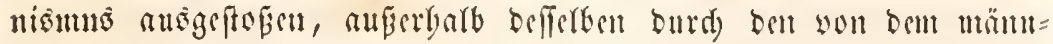
ridgen Indivibumm ansigeftofenten Gamen befrudgtet werben, mitb zwar gefdicht biefes sbenfowobl bei folden Trten, welde an fem Boben

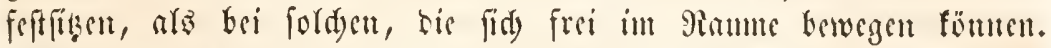
Selbft unter ben Thieren, welde gemeinfdaftlidge Golonisen ober Gtöde

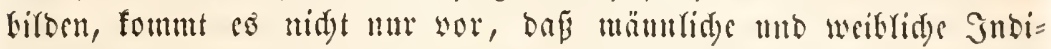

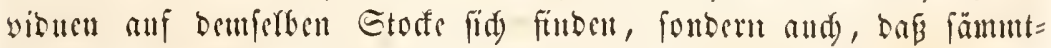

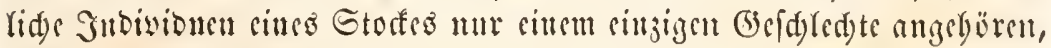

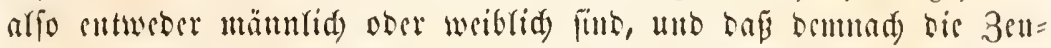

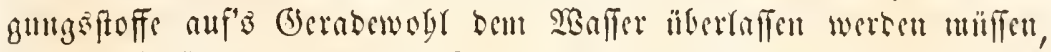
in ber Joffnung, baf ber Etrom bes flüfigen Eelementes fie ben

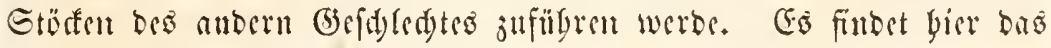

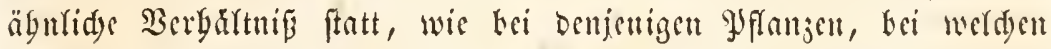

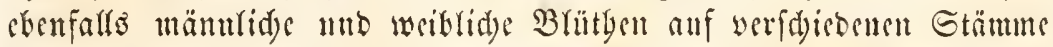
vertbeift find, utto wo Der ŞBitto ben B(ïtbenftanb ben weibliden Bfumen zufïgren muß.

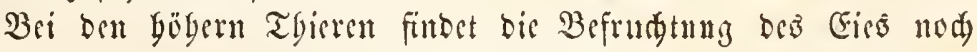
innerbalb bes mütterliden Drganismus ftatt, it weld)en bic mätน=

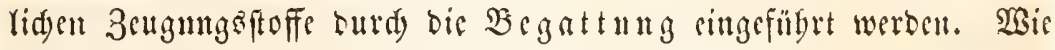
bei Denjenigen Thieren, Deren Eier anferbalb Der Menter befrudetet werben, fo löft fid aud) bier ju gewiffen, periobifis weberfebrenden

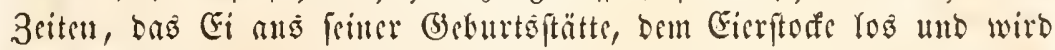

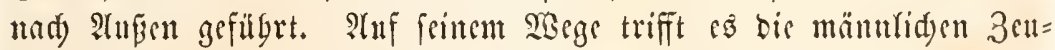
gungsffuffe, bie entweber burd unmittellare Begattung bem weiblidgen Drganismus einverleibt wnrben, ober aber fdyon feit längerer Zeit bort werweilten. Bei vielen TGieren nämlid) unb bejonbers bei ben Snfeften exifftit alo befonberet anbang ber innern weibliden Ge=

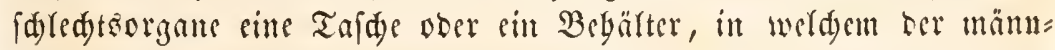
lidye Eamte ferbft Gabrelang unveräubert fid crbät, fo bas cine sinjige

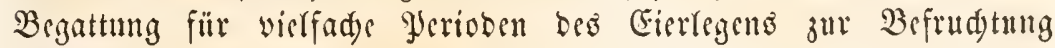
genügent ift. Meift wirb bas Cit nad erfolgter Befrudutumg von bem mütterliden Drganișmus ansgeftoben, juweilen aber and entwidelt

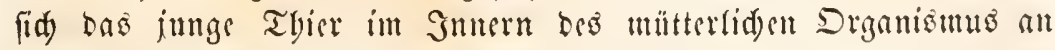
einer bejonberen zu ben Gefdledteorganen gebörigen Brutftätte, bem Ulterns coer Der Gebärumtter, und verlällt bant erft benfelfen als mebr ober mittoer ausgebilbeter fötns. Bei ben böd fét Typen bes Thierreides tritt logar bas Sunge in sincn engen 3ufammentang 


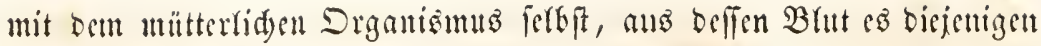
Stoffe entnimnt, welde zu bem Sufbaue feines Siörpers nötbig fint. Jebez Thier Durdhlänft von bem Angenblife feitter erften $\mathfrak{B i}=$

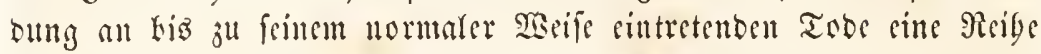
won Bildungsfufen, Deren genauere Betrad)tung für bie Raturgefdydy te

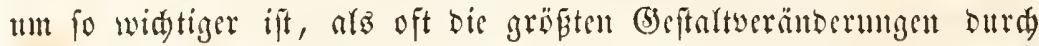
bieferben erzengt werben. Sair werben in Bertaufe biefes Briefes

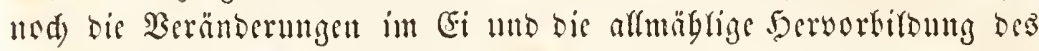
Embryo's aus bou miprünglid) formlofen Stoffe fđon mu befwiflen genaner in's ?luge faffen, weil wir auf bieferben bantfäd)lid die Ent=

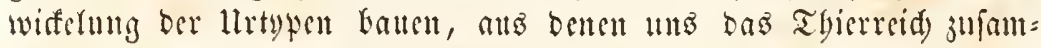
mengejest erid)eint. Ridjt mintor wid)tig finto aber bie Beräntormut= gen, welde bie Thiere aud) baun und erleiben, uadyem fie Duth

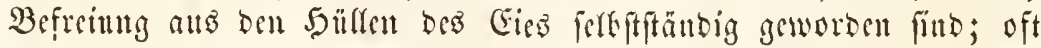
betreffen diefe Beränderungen unto llumgeftaltungen nme bas Subisi= butm, it cinzelnen gällen greifen fie aber fo tief, baßj bas gndivi= buum oarilber ju Grunde gegt uno erft burd) erneute forteflanjung Der Typus Des Muttertbieres bergefteft wirb.

Der Gang Der ftufenweifen Entwidefung Der Thiere gefdsebt meift it ber Weife, baf bie (Befd)led)toreife und biejenige Yyeriobe, in weld)er fie zur fortwflanzung fäbig find, ben Gipfelfunft igrer Atus= riloung bejeidnet. Bei benjenigen Thieren, in wefden periobifd weit

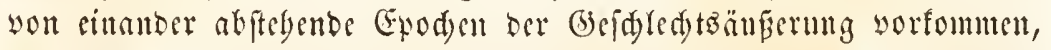
überrafdy fogar bie böbere uno fräftigere Entfaltung alfer Rebenser=

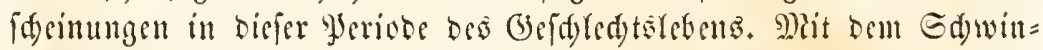
Den oer Fortpflaujungstgätigfeit tritt meift aud) eine alfmälige 3 urït:

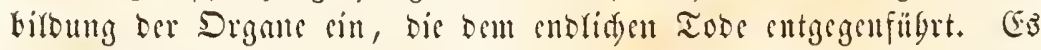

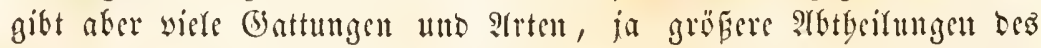

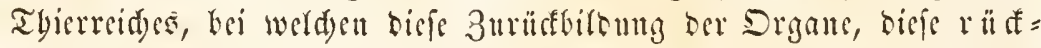
(d) reitenoe Metamorybofe, wie man fie genant bat, fdon frü=

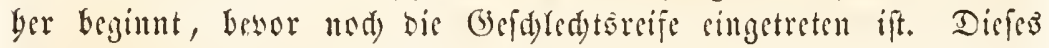
fintet naunentlid) ftatt bei jolden Thieren, welde in ber Sugend frei unberfdweifen, wäbrent fie im silter fid feftelsen oocr enblid als Gd)marozer in antern Thieren reben. Die Bewegungsongane, mit welden fie aแtgerüftet waren, verfümutern, bie Sinnesorgane fdwin=

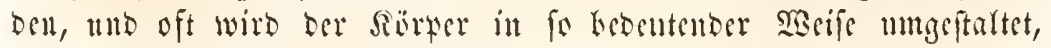
Dafi man bie erwadjenen Thiere in andere Drganifationstypen แnto in neberftegende Claffen vertbeilte, wälreno man bie jüngern Thiere böberen Elaffen zuwiez. Wir werben die auffallendften Beifpiele dies 
fer Art, mamentlid) unter ben Sirufentbieren und ben Eingewsibe= whintern finten.

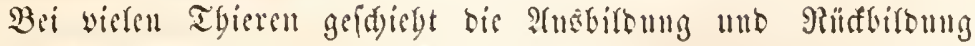

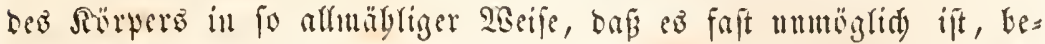
frimmte Stabien berfithen uad)jmveifen. Daz Gunge vertägr bas Ei

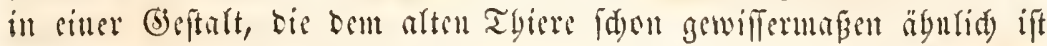

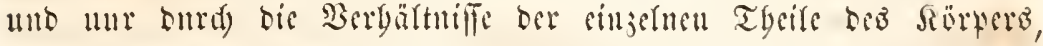

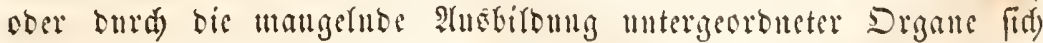

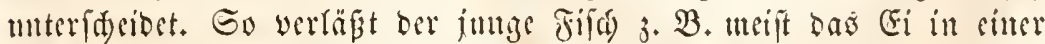

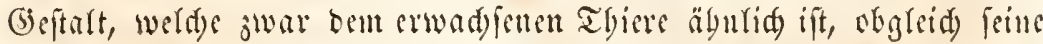

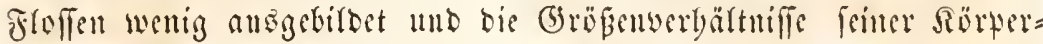

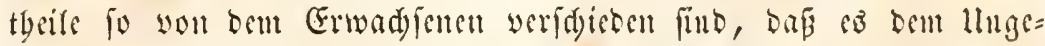
übten umuäglid ift, Gattmig nut strt jul erfentuet. Demnod) aber

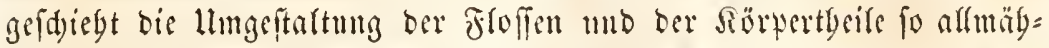

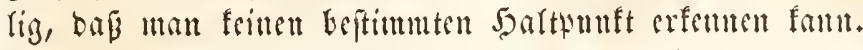

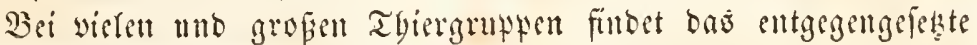
Berbältnif ftatt, fie gelyen Berwanblungen ein, werdye burd beftimutte

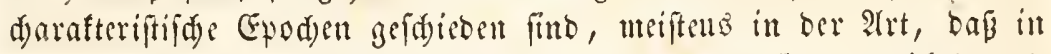

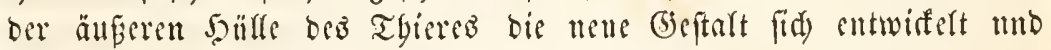
anz ber gefprengten Soülle in vorlenteter form bervorgeyt. Dian bat

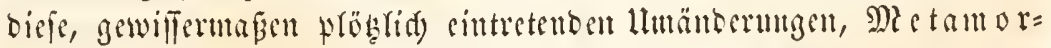
phofen ober $\mathfrak{B}$ erwand angen genanut und fie bejonders in ben Pleiben ber (S) fiedertbiere, faft in alfyemeiner Berberitunty angetroffer.

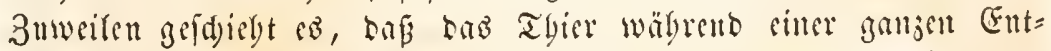

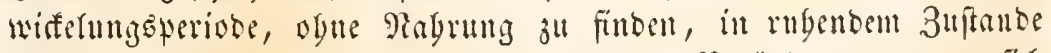
verbart, wäbrent welder Beit bie intuen Berändernngen vor fith

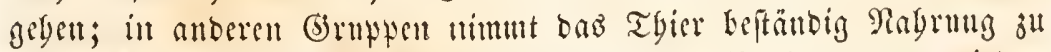

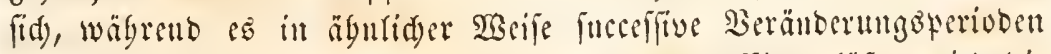
cingegt. Dis form, in werder bas Thier bas Gi vertäpt, wirb bic

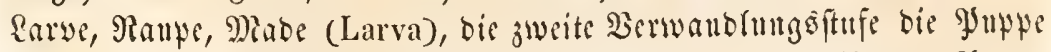
(Pupa, Nympha), sic Dritte baß Bitb (Imago) genamut. Ranpe, Yupte und Edymetterting find bis befaunteften Beifpiete folder $\mathfrak{B} e r w a n t=$

ชิiง. 21.

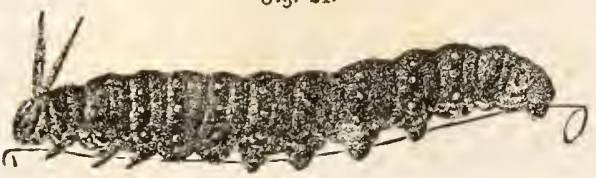

rungêftufen eines und befferten Subivibumus.

Eille abweidente $\mathfrak{A}$ rt ber Distamortyoje foumut bei tric= orig feryenden Gruppen ein= 


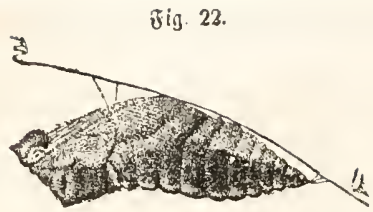

ชig. 23.

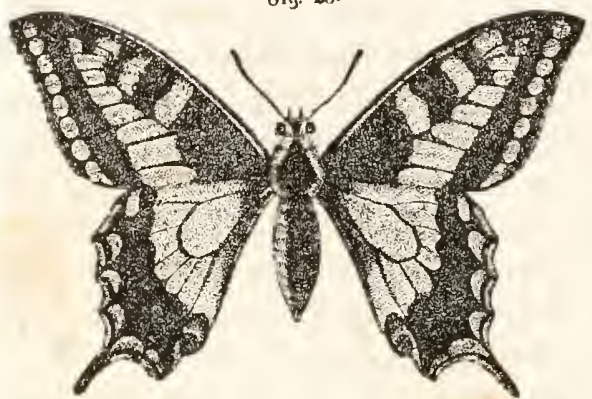

Jig. 21, 22, 23 Sarre, Fupke und Bitb bes Sdiwalkell= fđ̆nanjez (Papilio Hachaon Limne.)

zefuer Drganifationstypen vor. Dกต aแล betn Ei Gervorgebil= bete Snbivibutum wit' 3 thei= ner 3cit Dem Muttertbiere

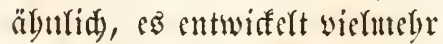
itt Feittett Gttheren, entweber gleidjseitig ober nad) cintan= Der eitte Reibe soll Reimen, bie fid) zll netten $\mathfrak{B e j e n}$ ge= ftalten und babei oftmals wäb $=$

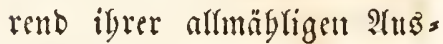

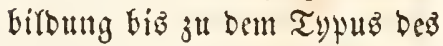
Mittertbicreş ägullide $\mathfrak{B e r}=$ wanblungett eingelyen, wie bie, weldye wir joeben tetradjtetert. 3uweilen ferbft fdeint biefer

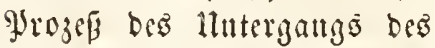
Sttbivibutms und ber Erjengung neuer Reime atts bemferben

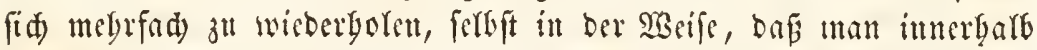
Des entftelyentoen Todjerthieres bas nod) int Reibe ber Dittter einge=

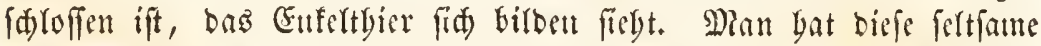

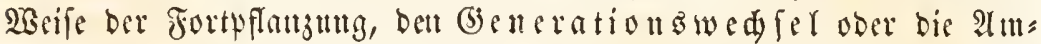

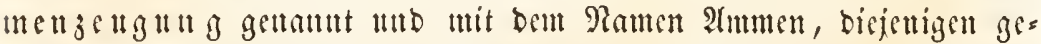
(d) led)tlofen 3mifdenftufen bezeidyet, aus welden burd intere ober

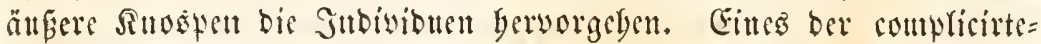

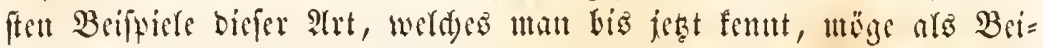

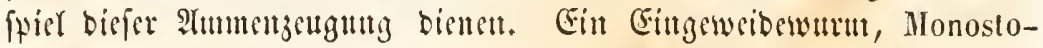
mum mutabile ergetgt Gier, in beren Snttern sin mit frimmern

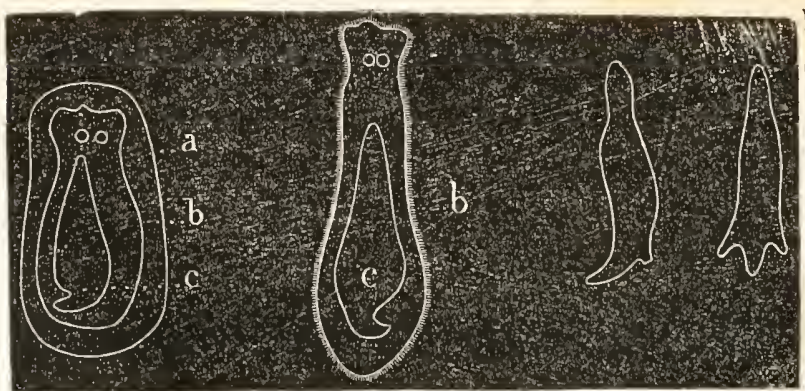
Eefester Eimlryo entiftegt. Diefer Embryo, betl man bic (5) amme nenten föutute, Imb Der nicmals bem Mis= แoftoum äbu= (id) with, gelyt gut 8i.]. 21. ชig. 25. Jig. 326 .

(Sirumbe. Dis (5ivofamme be= 21murezengung bes Monostomnm mutabile.

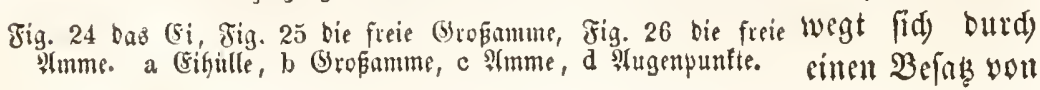

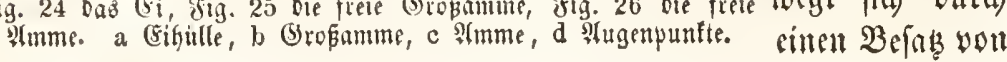




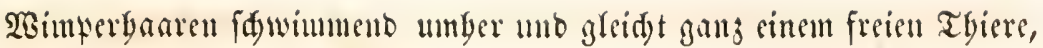

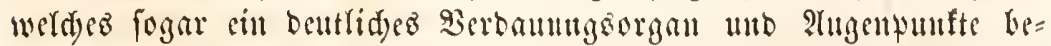

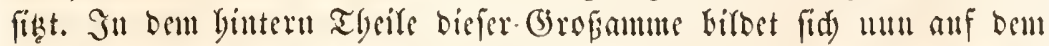

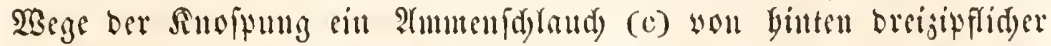

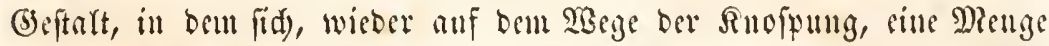
eigentbünlidger Thiere, fogenaunte Eerearien, erjengen, weldye, fobald fii igre volfftänbige 2uล์

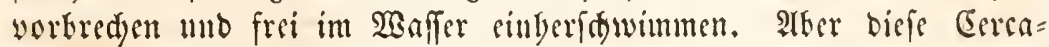
rien find nur Rarven, welde bazu beftimunt find, find in Snfeften ein=

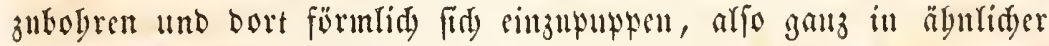

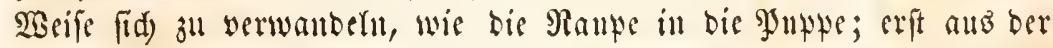
Suppe ber Cercarie gelot wieber cin Monoftomm bervor. Man fiegt, Dás Gier zwei Gemerationen, biejenige ber Grofiamme und Der 2tmme, zu Grunte geben, Gis enblid biefenigen Gnbivibuen ergengt werben,

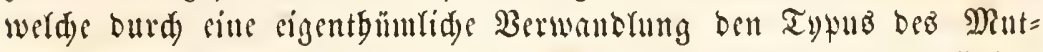

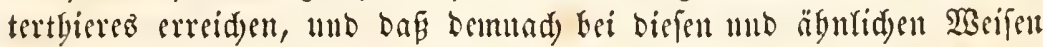
ber Fortpflanzung nidat bie unmitterbaren Nad)fommen, fonbern erft

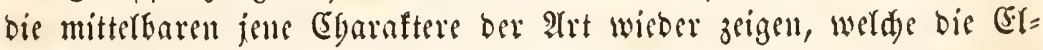
tern bejá̧en.

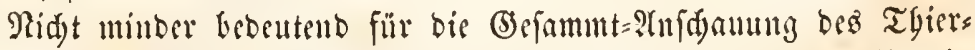
reidg) und namentlid) für Die Begrn̆ndung Der grögeren Sireife, it welde fid) Dafferte cintyeilt, ift bie genauere Betradtung ber 2trt unb

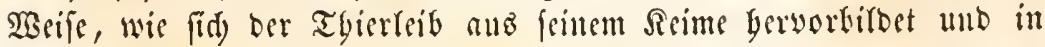
feinen erften Formgeitartungen fid verbält. WBie bei bem Bilbbaner Der formlofe Stein nur nad) unb nad) ber sollenbeten Statue fids entgegentirbet, anfangs mur bie gröberen llmriffe ber Gruppen wno

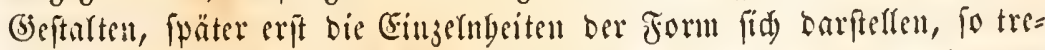
ten aud bei ber Entwifflnng ber Tgiere juerft bic allgemeinen Groutb= linten dez granes bervor, nad) weldjen es getbant ift, mub erft bei

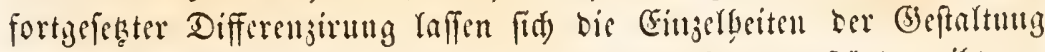

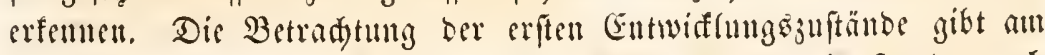

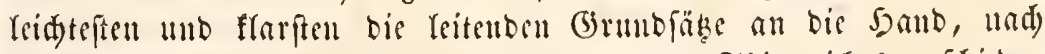

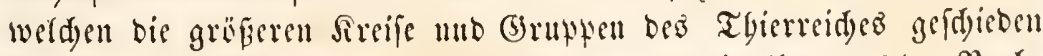

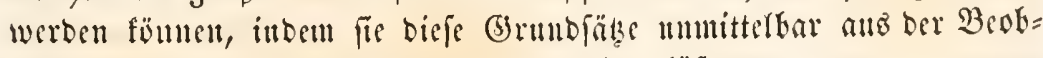
ad)tung obue weiteren 3wang bervorgeben läpt.

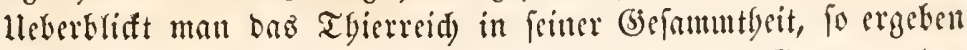
fide, je nad) Der Birbung ber jungen Tflere, brei grofie (Sruppen ober Srovinzen, bie fid) wieber in mannigfade lluteraftyeilungen zerlegen. 


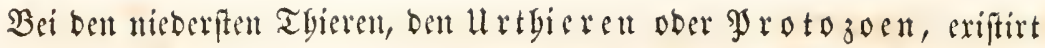

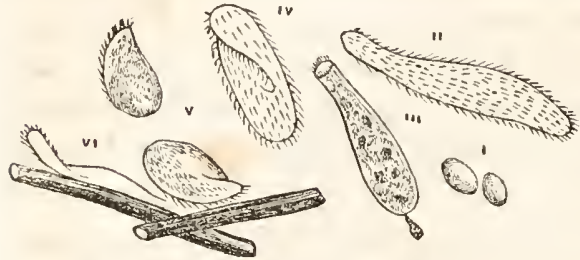

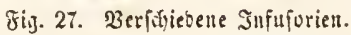
burd)ans feine gefdledytlidye 3eugung, feine Biloung eines wabren (Fies, weldes ourd) Befrudytung erit bie Föbigfeit crbält, fid ju cinem felbjtftün= bigen rbiere zu entwiffelt. Der Cografter ibres gefamm= ten Rörperbaues entipridyt bem ber Belle, ibre Rörperfuttanj ift we= fentlid bie oben erwäbnte Garfobe; Der Sörper ferbit bat eine mebr ober minber runblide Geftalt, in welder feine beftimnte regelmägige (3) ruppirnt son Srganen wabrgenommen werbent fann. Die jungen Thiere entwiffern fid) in ägnlider :

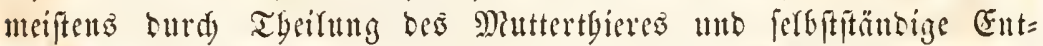
wifferung eites jeben einjelnen Theiles, ober burd) Snofpung ober

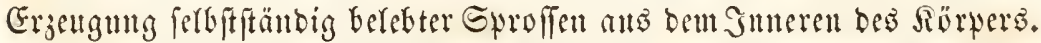
Llebereinjtimmeno mit biefer Entwiferung ift and) bei bem einfad)en Ban ber uieberften Tbiere igre llnterfdeibung von ben Yyflanjen um fo fatwieriger, ie mebr fie ben Bgarafter einer einfadyen 3elle bei= befartent.

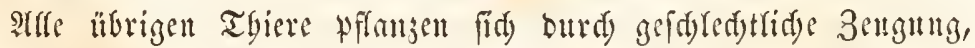
burd) wirflide Eier, wirflide Embryonen fort, obgleid) antere Irten ber Fortpflangung wie Sinoffung, Eproffung :c. Surd) biefe geidjled)t=

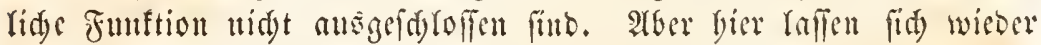
stwei grofe Gruppen ober Jrowingen unterfyeiben. In ber einen grovinz verwanbelt fid bas ganje (5i, ber gefammte Dotter burd) allmäbrige llmbitbung in bas junge Thier; nirgendo jeigt fid sin Gegenfaz jwifden bem werbenten হhiere unb einem Theile bes Dot=

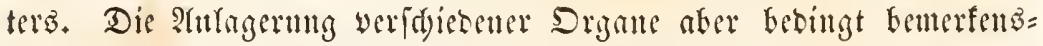
wertbe lluterfdede in biefer glowing unt baomed cine weitere Ein= tyeilung in befdräntere Sreife. Bei Dem Sereije ber Etrabltyiere (Radiata) rogern fid) bie Drgane in gleidnamiger sisieberbolung

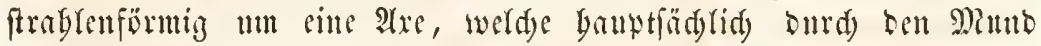

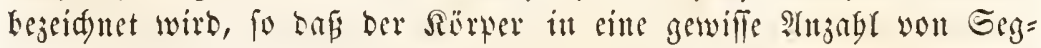
menten zerfält, weldye bieferbe 3njanmenfeşung baben, unb bie ein=

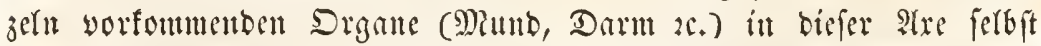
liegen. Die Entwiffelmy um biefe Ate gebt gleidymäbig in alfen Drganen yor fid) und wieberbolt fid) nad) ben einzeluen Strablen= rid)tungen bin in gleidmäpiger Saseife. Die Sorallen, bie Sdeiben= quallen, die Geefterne fömnen als Typen biejer Bilbungsweije bienen. 


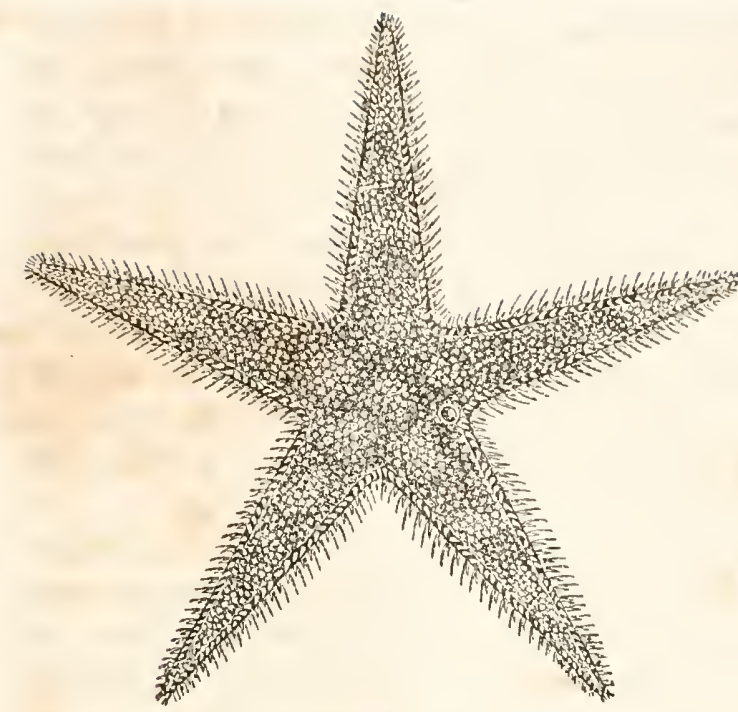

Jii, 28. Eeeftern. (Asterias.)

Sic entfteben alle aแt Embryonen, welde itt ilgren exften $\mathfrak{B i l}=$

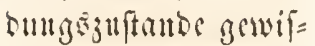
fun Sufmprien ät birft äbulid) feben, lei bencu aber als= balo, in Jolge ber Pusbiloming ibret be $=$ fintisen Drgane, ber frrablige charafter tho sic 3mantuen=

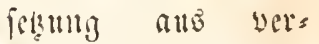
fificoencu gleichles = bententon Segmenten nuf bas biutridjte berwortritt.

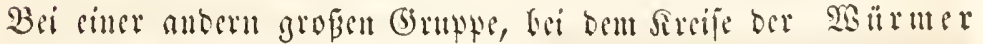

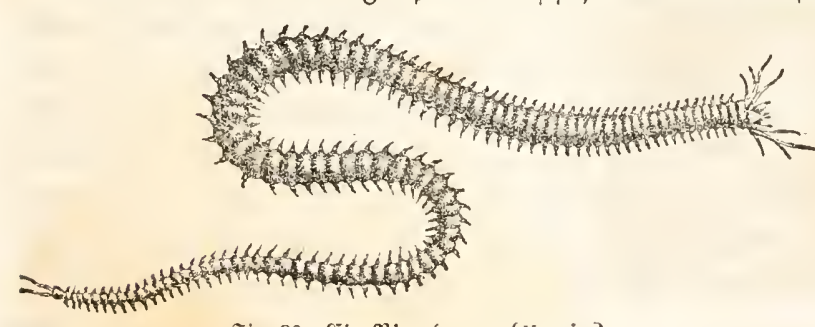

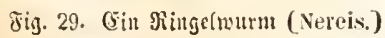

(Vernes), wandelt (iid) chenfallo bas ganje $\mathrm{Ci}_{\text {i }}$ un cinem iifuforienartigen Embryo um. ?tr= reinfegrbalo tritt bict ftatt citter ftrablenförmigen Gegmentation che Ienten; jur bifateralen Ragerung ber Drgane her=

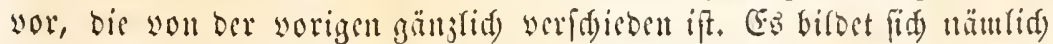

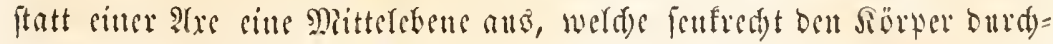

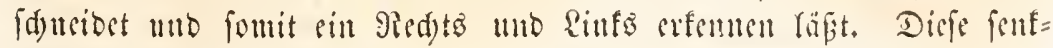

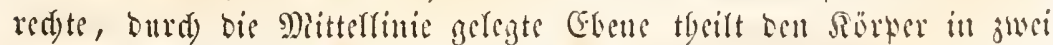

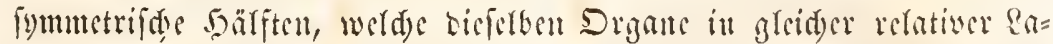

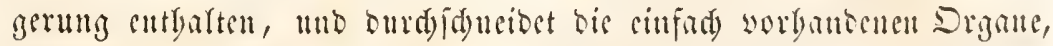
Die ftets in Der Mitte liegen, in zwei gleidfnamige Särften. Die Cents

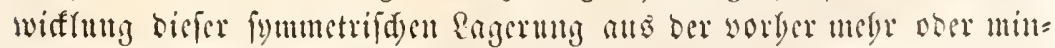

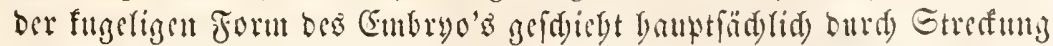

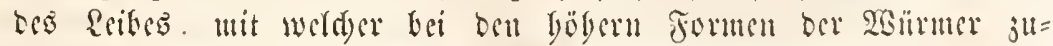

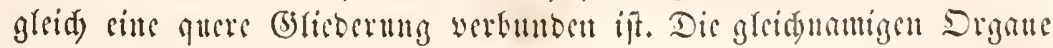
wicberlyolen fid) bann, entipredyent ricfen queren Gricbern, dis

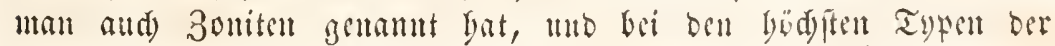


Eraffe tritt sine migr oder minber bentride Sonderung bes Borber:

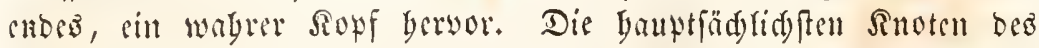
Rerweniffemes, bie wefontfithiten Sinnesorgane, die am Infange des

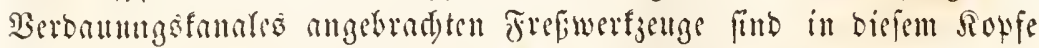
verenigt, wägrend in ben nadjofgenben Ringen bie einjernen Drgane

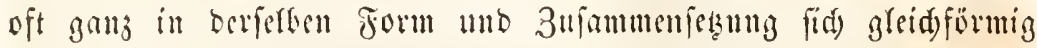

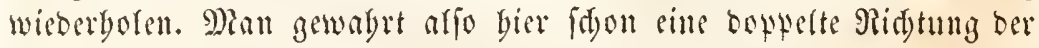
Entfaltung, cinestheils in ber Sagerung ber fymmetrifd) angegebilbeten Drgane ju beiben Esiten ber Mitterfinie mo anbererfeito in ber gleid)=

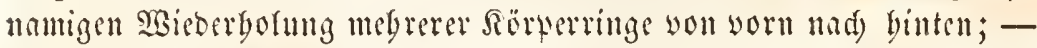

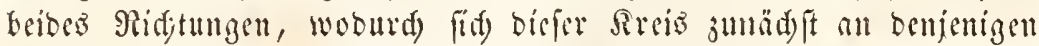
Der (3) liebertbiere anfd)liegt.

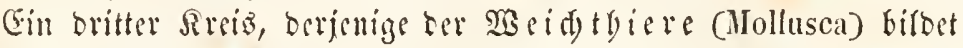
fich) ebonfalla altz (5mbryonen bervor, bie burd) llmbiloung bes gan= zen (rieg entifelgen. Der Typus inbeffen, nad) wetdem biefe Thiere fids

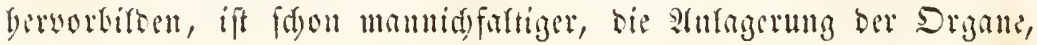
weber bem ftrabligen nody and ganj bem bifaterafen Tytus entflee=

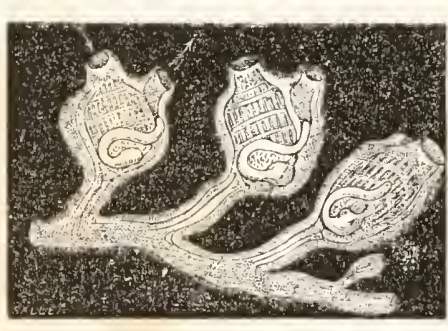
d)ent. In ben untern Formen ber SBeids)= thiere, Keiden Mroffusfoiben, Yäpt fĭd) jwar bei ben büber ftebuben Familien sime Ste mit radiärer Anortumng ber Drgane, voct cime Pittelebene mit fommetrifater Anfagertung ber sinjefnen Sïrtertbeife erfemen, nidyt aber bei ben meiften Gie= fdecisen, tie wolfommen regerfor fint.

Jig. 30. Eceidycion.

Bei ton eigentlid)en Dioflusten fommt

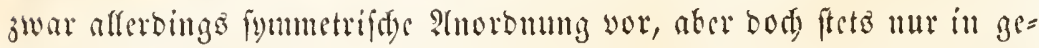

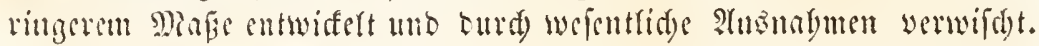

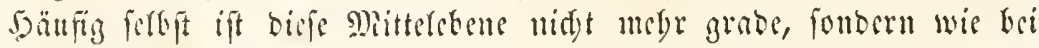
Den Sd)

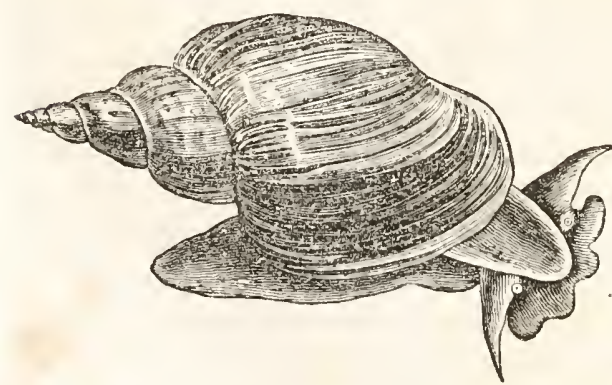

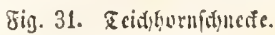
Den Eriten biefr Epiralebent angebradt. Die innern $5 \mathrm{r}=$ gane unb bejonbers biejeni= gen, wedtye der jortpflan= jung angebüten, jeigen biefe (i) unuctrifde stuorboung fajt niemars und laffen fo and in Den böd) Ten Typen ber Elaffe jonen Dangel an Symmetrie, ber in ben unteren fo fdarf 


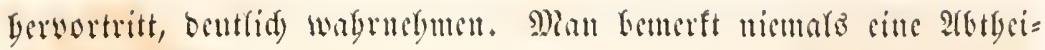

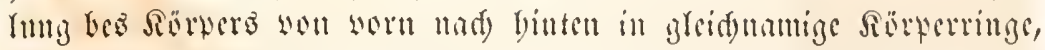

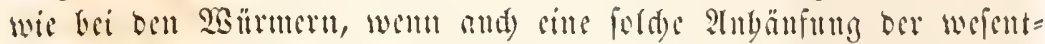

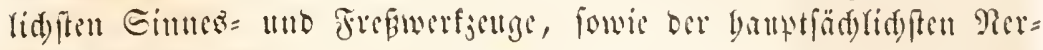
venfuoten in cinem mefr ober minter absetremten Theile, sinem Sopfe, bei ben bëbern formen fid worfittert.

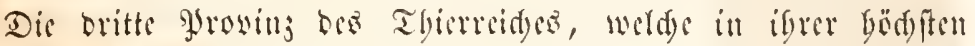

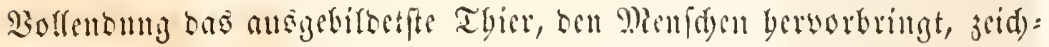

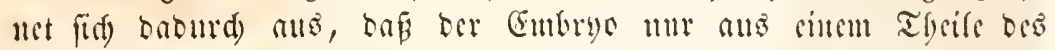

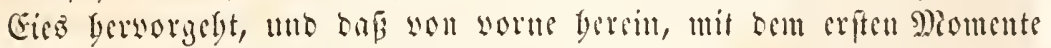

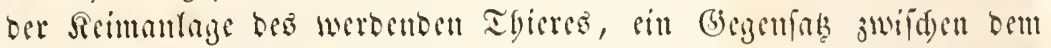

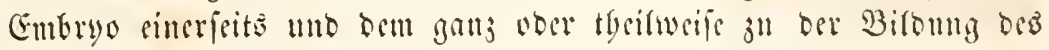

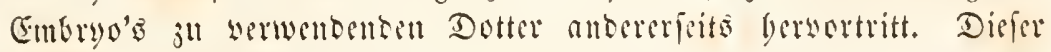

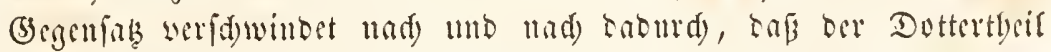

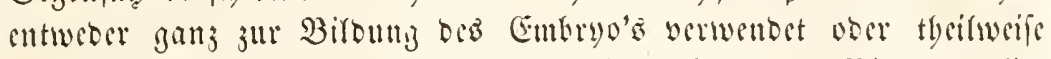

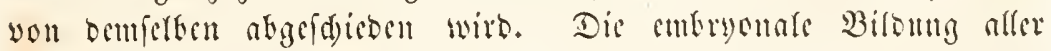

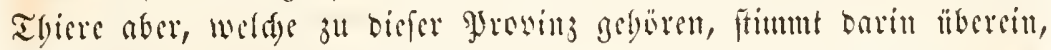

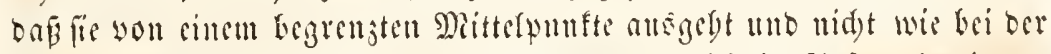

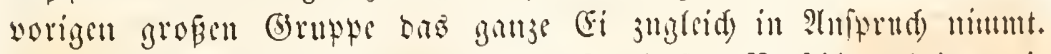

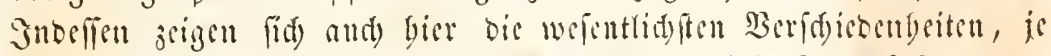

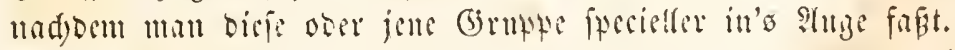

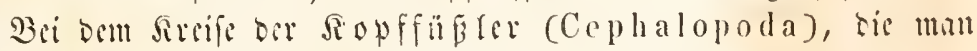

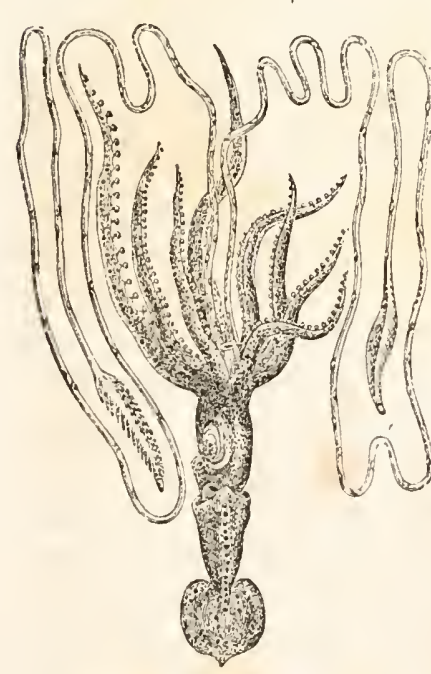

ช:g. 32. Lotigopsis Veranyi.

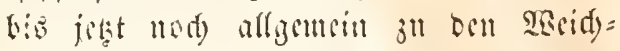

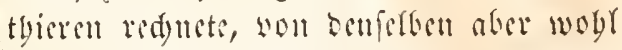
unterfascisen mur, gegt bic Entwiffelung

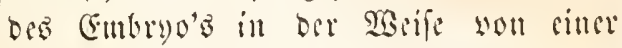
Eeftimuten Stefle bes exics ans, ba ber ab=

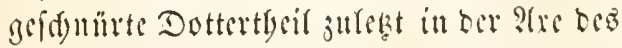
Sï̈rers Eem vorbern Énde Eerferten, Dem

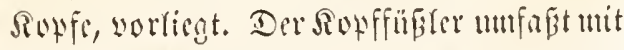

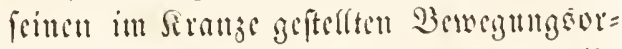
ganten ben Dotter, ber Feitem Sinterleite

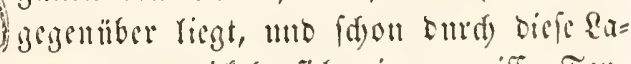

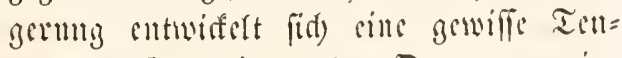

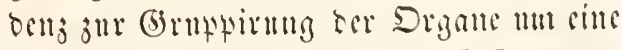
Stre, weldye ittoes, trob ser än

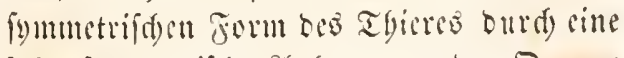

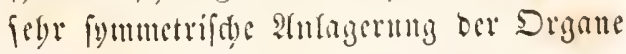




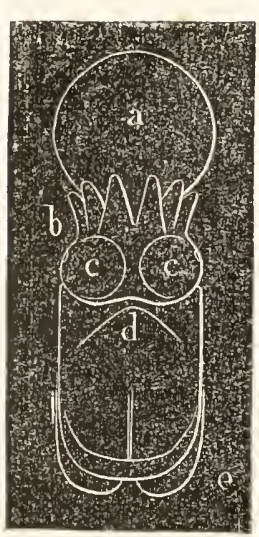

Jìg. 3.3. (smbrobo sines

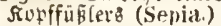
a Der Dotter, b bie Fangarme, c bic $914=$ geu, d ler siblter, e bie Es)winm fluffen.

im Sumern bebentento n̈berwogen wirt. Sn ber Tgat

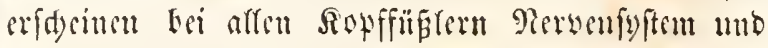

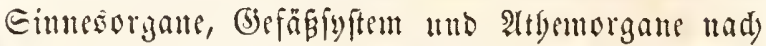

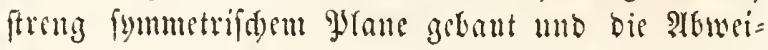

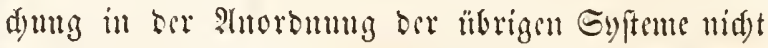
Gebententer, afo fie and) bei anbern bifaterafen Thie=

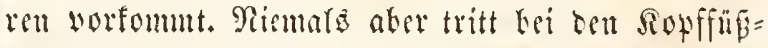
reru sime quere Thestung bes siörpers in Ringe auf, mo aud) bie Tibgrenjung cines Sioffes yon bem

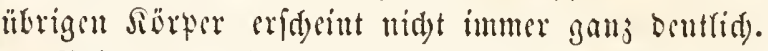

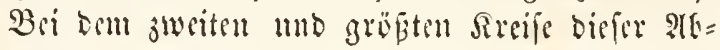

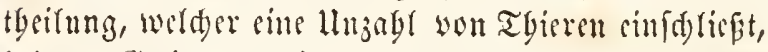

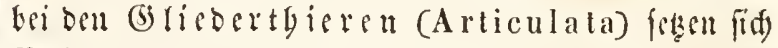

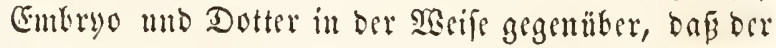
Simbryo frime Riüfenfrite bem Dotter zumendet mo

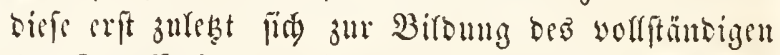

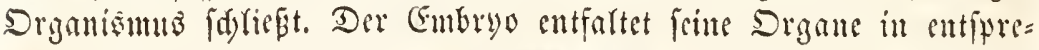

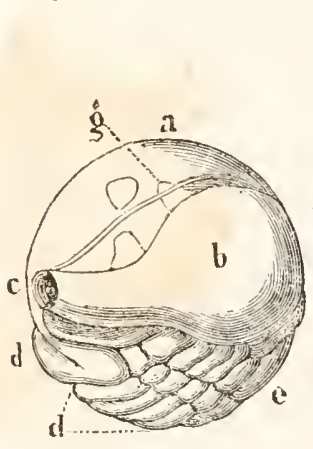

Jig 31. Entbrto bes olup-erebies.

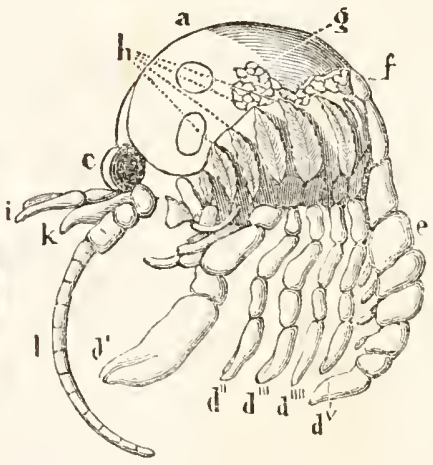

sig. 35 .

dender Sasife, wie tie $\mathfrak{S}_{\mathfrak{B}}$ Den Seiten ciner Mit= terlinie, fobab bribem woffentertu Tbiere sin ftreng fymmetri= fder Bau feider Särs. perbälften worbanten ift, wägrend ougleid sine Grieserung bis Sörpers yon Ginten nad) vorn cintritt.

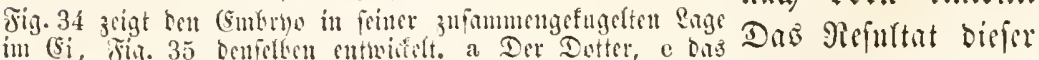

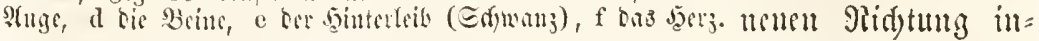
beffen ift nidyt bis Bervorbringung glsidsartiger Ringe, in wetden

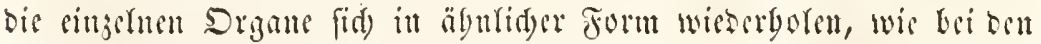

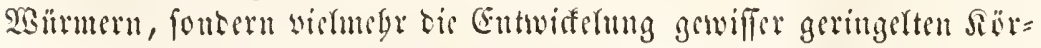
fergruppen, bie wir mit bem Ramen Sopf, Bruft unb Band) unter=

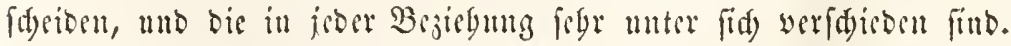

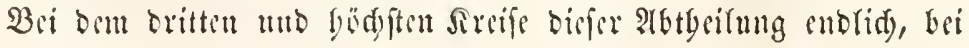

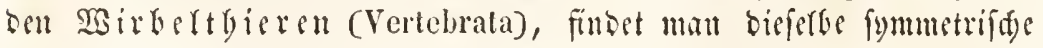

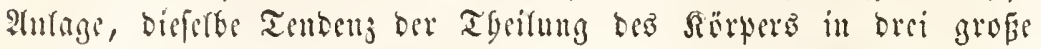
abtheifungen, Ropf, Bruft und Baud), aber sine gänzfid) verfdicbene 


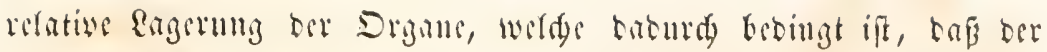

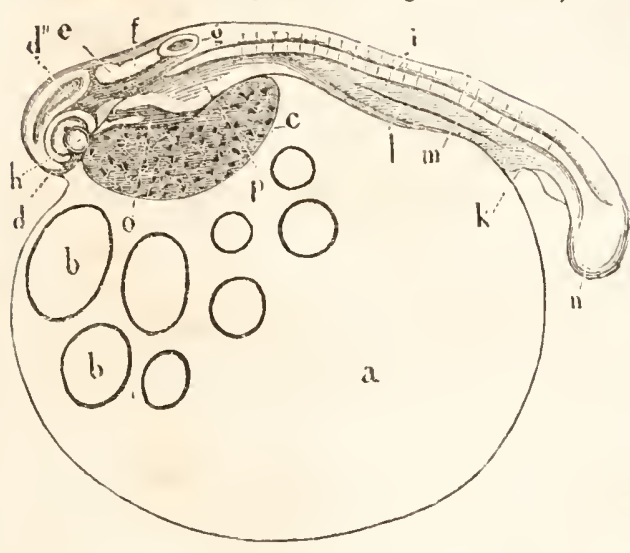
(embryo mit frimet $\mathfrak{B} a n d)=$ fläd) Dem Dotter gegeniliter lingt mo fid) wou ber Mit=

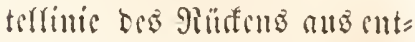

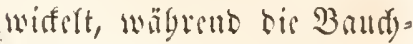
rinie fid in rester Snitanj

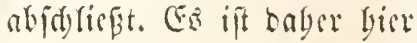
volffommen ber Gegentang ju

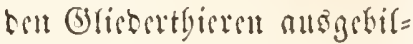
bet, ullo ba bie relative $5 \mathrm{er}^{2}=$

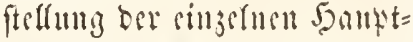
fufteme bes sörters von ber Syripherie bes (Embryos bic= 8ig. 36. (Embrbo cines Jifines (Coregonus).

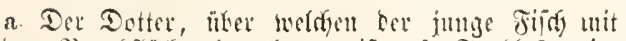
bet Bandiflade hergebogent itt; b Fetthajen im

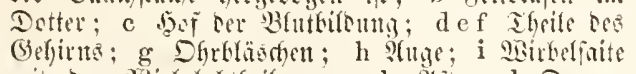

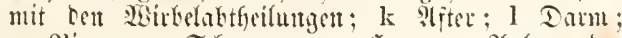

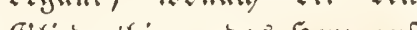

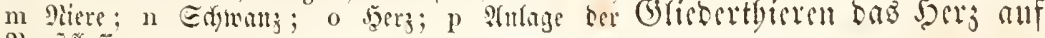
Brmitfunis.

bom 9iuifen, bic Bertanung

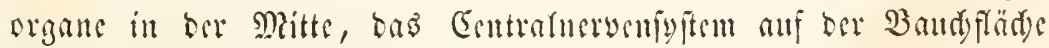

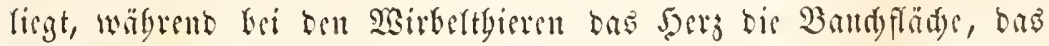

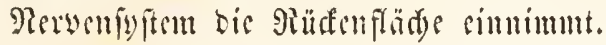

Salten wir bie sben angefïgrten lluterfdedes, bis wir fpäter anb= fübrfidser barfellen werden, feft, fo biloet fid forgendes Gyjtem ber

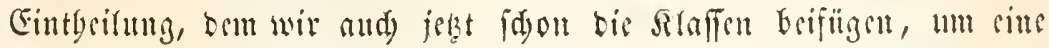
vorläufige llskerfidat gat gewäbren. 

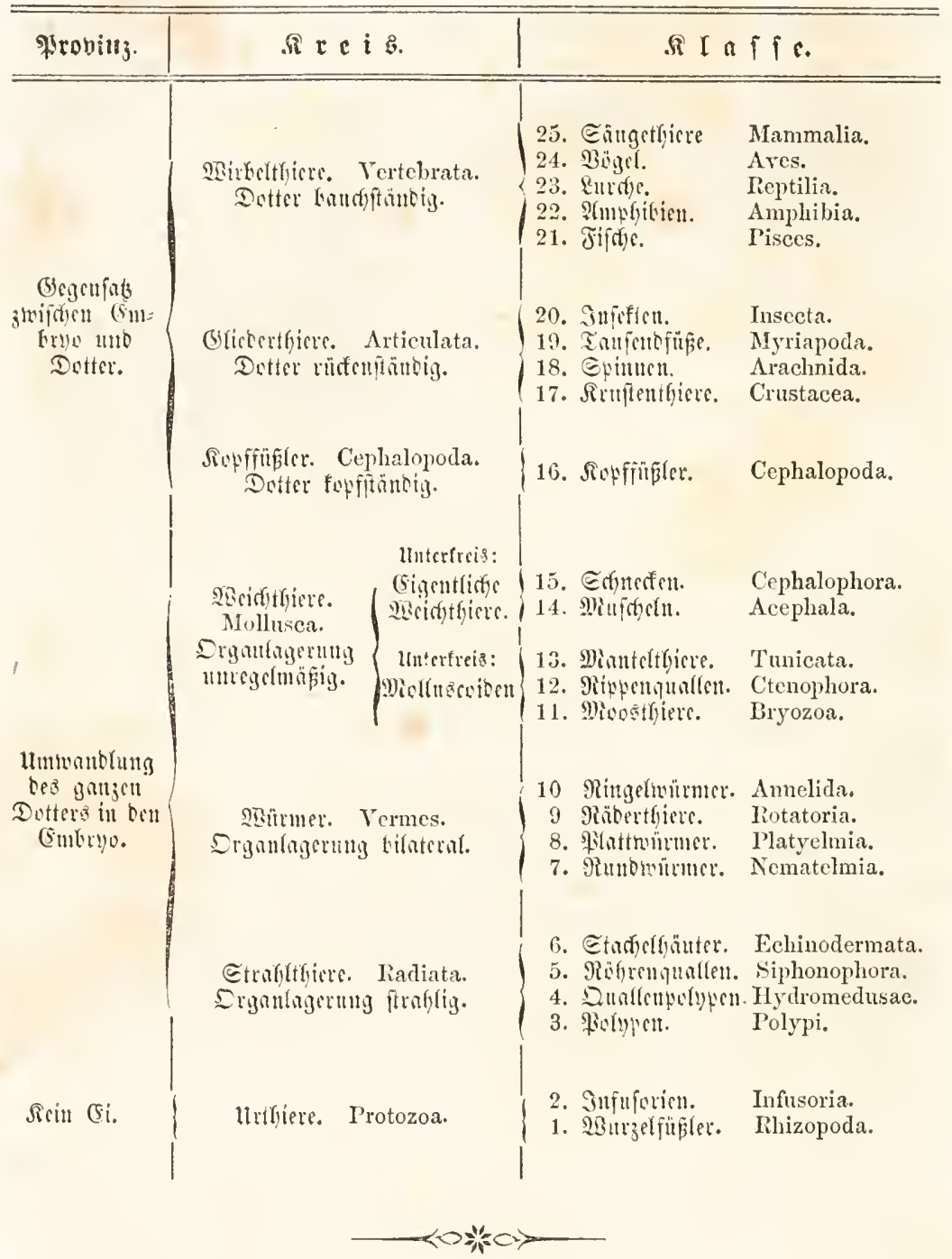


\section{Fîn}

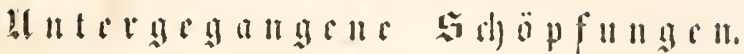

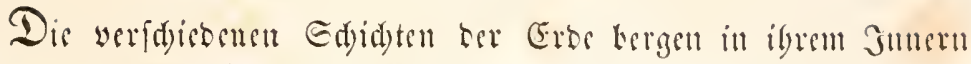

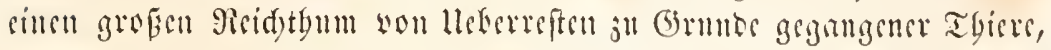

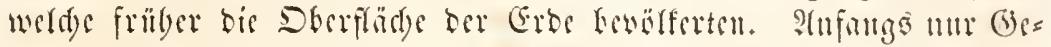

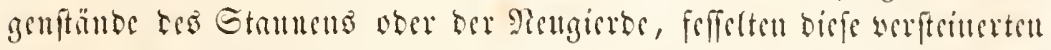

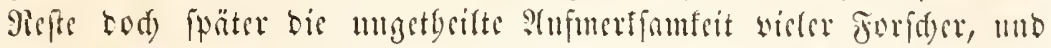

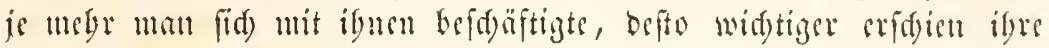

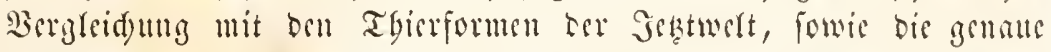

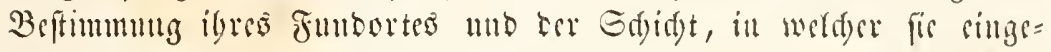

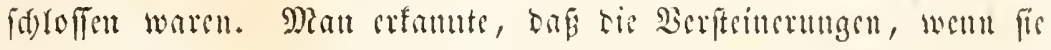

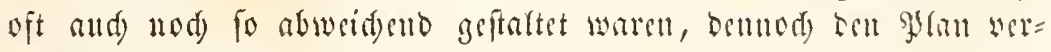

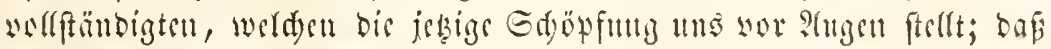

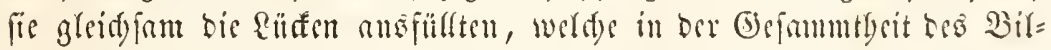

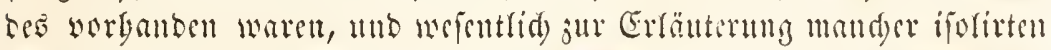
Errdeinungen bienten, beren ?tufnüpfungshunfte man vergetens in

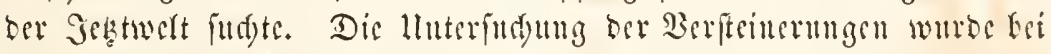

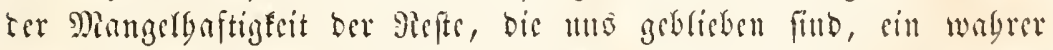

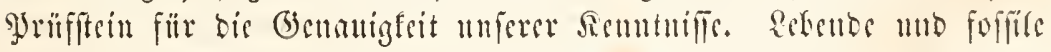

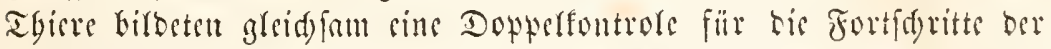

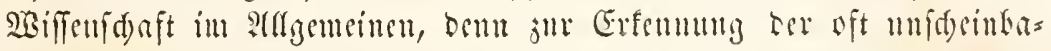

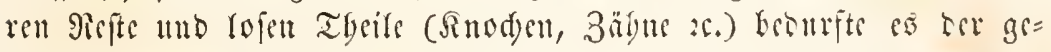

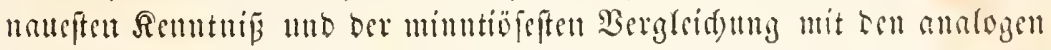

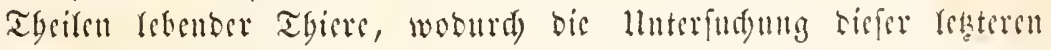
wejentlid) gefürdert wutbe.

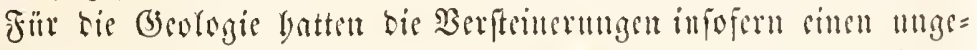

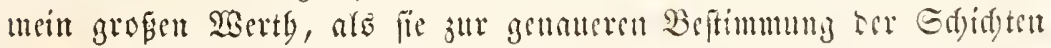

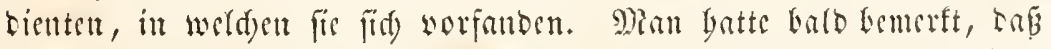

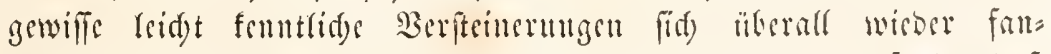

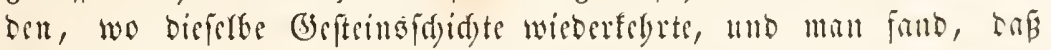

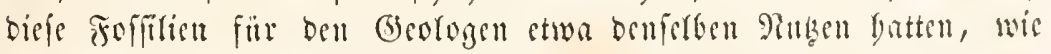

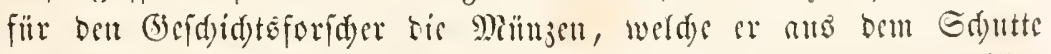

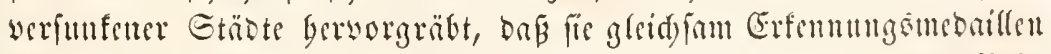

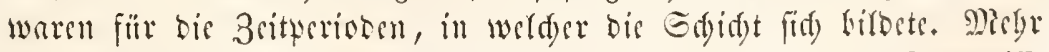

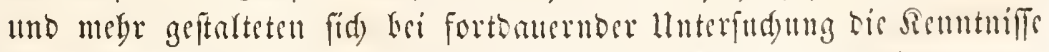

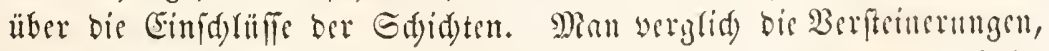

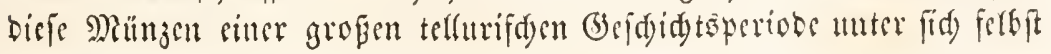




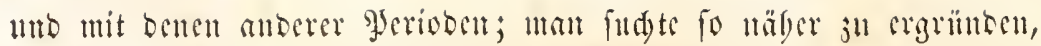

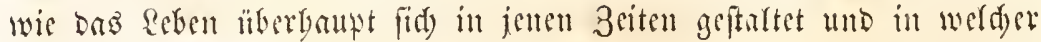

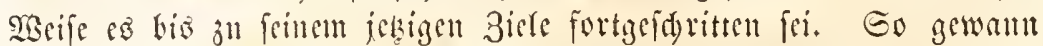
mat แnd) แno und eine Pleife cingelner Birber, beftimute abgegränjte

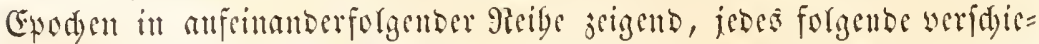
ben won bem vorbergebenten, wolfftänsiger in feiner 2tnsfübrung, reidfer in feinen Eingelngeiten; - Bilcer, bie fid) enblid) in barmo= nifder llebereinftimmung mit ber jeşigen Edyöfung ju cinem gemein= famen (Sanjen grmpiren. Es ergab fid) aber barans and) dic Notb=

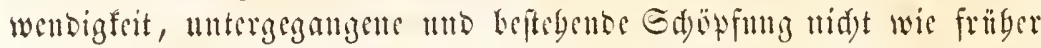

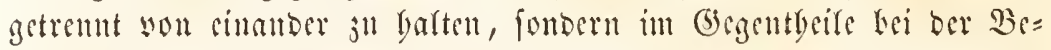
trad)tnng ber Rebensformen mit cinnober ju verid)meljen mb alo mus jertrembares (5)anje ju betradsten. Lufere Semntnif ber Serfteine= rungen ift jekt wenigitens fo weit fortgefdritten, bafs wir ju ben

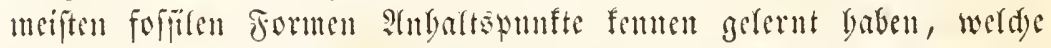

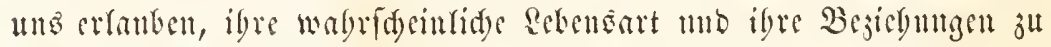

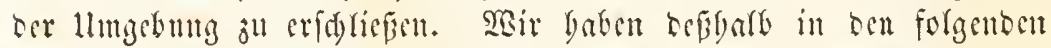
Darferlungen rie Tobten Den Refenden gats gleidy geferlt mib beiben

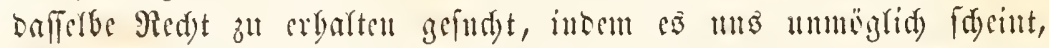

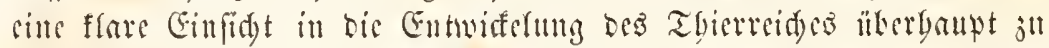
gewinnen, wenn man thidst bie sergangenen Generationen ju bitfe

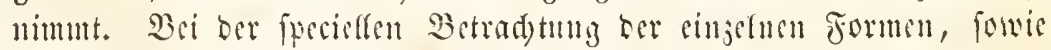

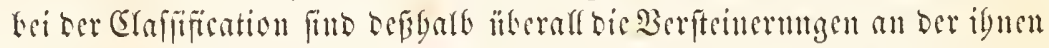
jufommentent Gtelle Des Evftemes cingereigt mo wou aflen Alaffen, DrD=

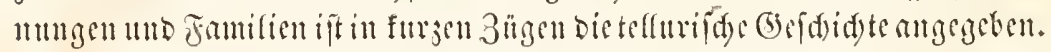

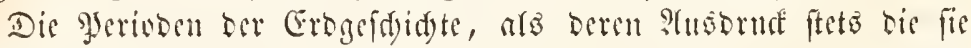

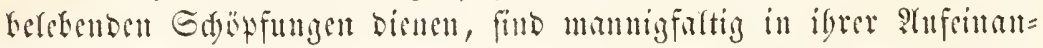
serfolge. Eas exiftiren indeffen cinjelne gröfere (stuppen, welde man be=

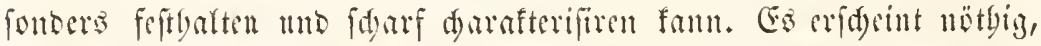
bieferben furj ju erwäbnen, on wir bei jeder cinjeluen Fantic anf

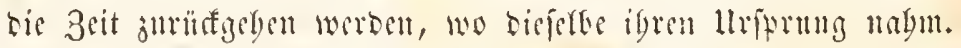

Ste ältefte Belebmizaperive der Erbe fennen wir bie lleber=

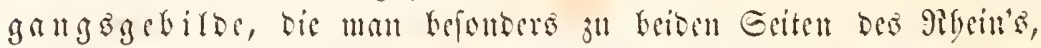
in Puprant, Ghmeden, Englant, in Der Bretague uts in Morbamerifi

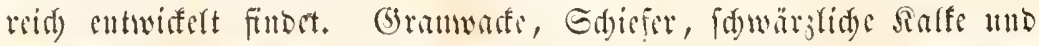

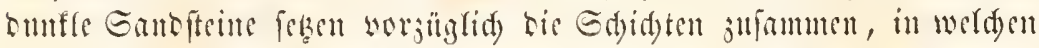

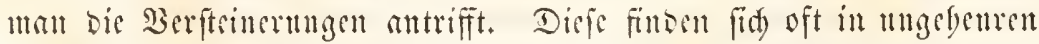

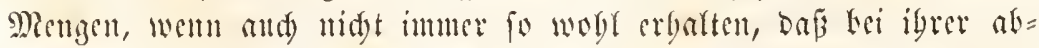

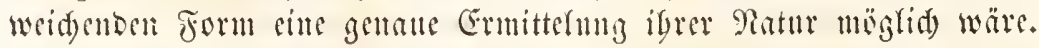

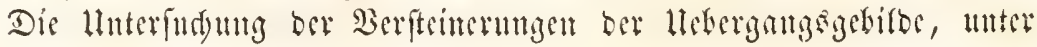


merden mat nod) bejonters juci (brupten, bas filurifde alo

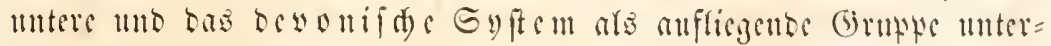

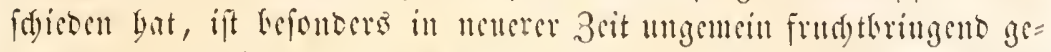

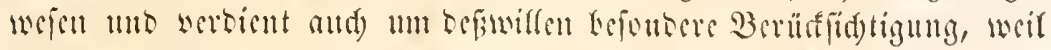
bier bie ? (ufangsty

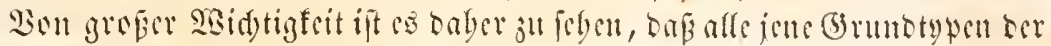
Sireife, weldse wit in tem Thierreidye unteridyciben, fdon im Beginn res

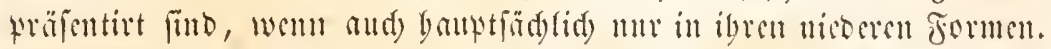

lleber oen llebrgangagebiloen, wobl won ignen unterid)icben unb sine burdans anbere Gdjüpfung bictent, feben mit bis Stcinfoblen=

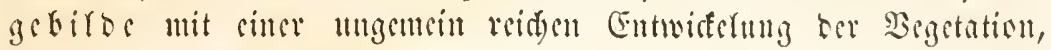

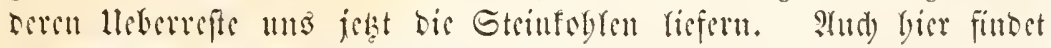

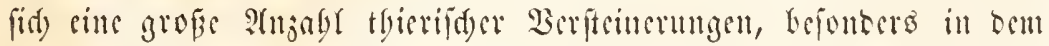
bie Stcinfoglen begleitenton Sivblenfalfe; wie es bemn hberbant alf=

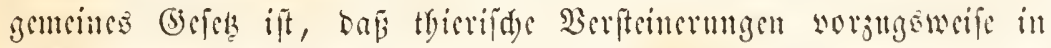

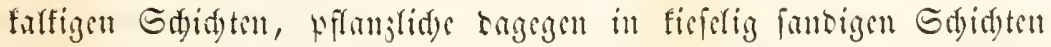
fid) verfinben. Die Soblenformation fommt bantfäd)lid) in eingeluen Besten wor, weldye bato Mectesufer, balo aber atth weit ausge= bebnte Bimnenfümpfe gewejen frin mïgen, an melden bis tiptigen

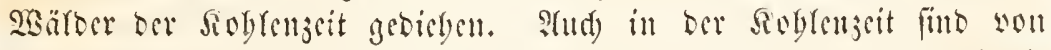

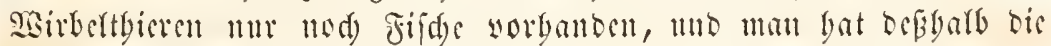
llebergangagebito mo tas fobrengebirge jufammen webr and) at:

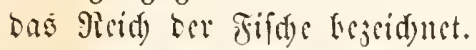

Tuf bem Sioblengebirige hagern sielfadye Gdjidyten, weldye man,

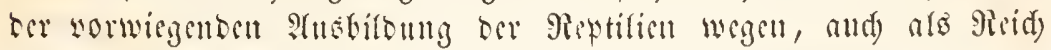

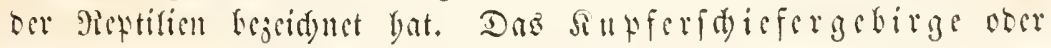

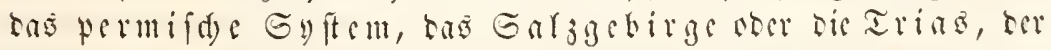

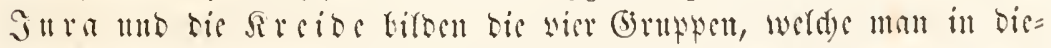
far Periode unteridesen bat. Sn bem triafifden Gy fem, wet= d)e Eamentlid) jull beiben Geiten Des Dberbermes unt in Mittel=

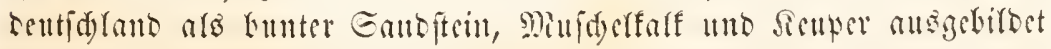

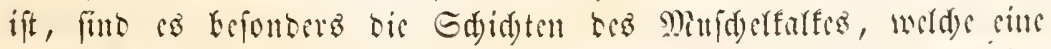

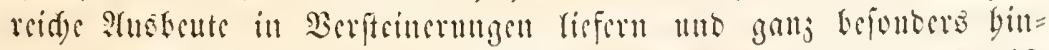

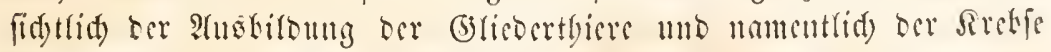

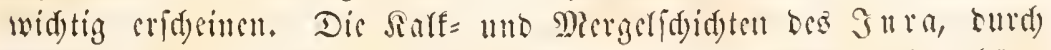

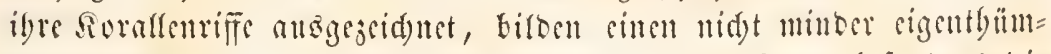

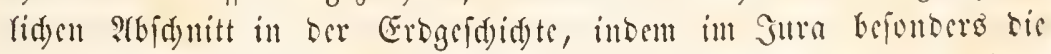

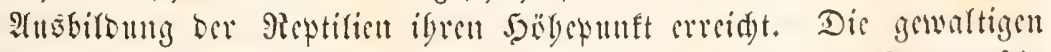

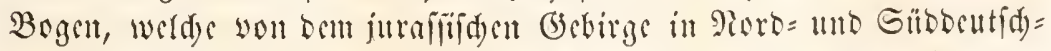
lant, in ber Sdumcis, Franfreid) unb England angefagert find unb 
Die meift trefflide Erbaltung Der Beriteinermugent in Den merigeliden Sagen berfelben madten ben Sura non jeber ju cinem vortreffliden

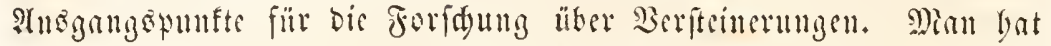

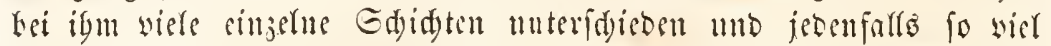
feftgefteft, onfi in ifm wenigftens brei weridgiebente solffommen felbits

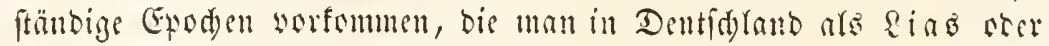

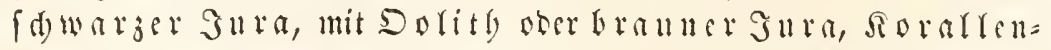

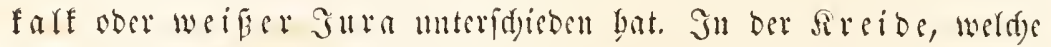

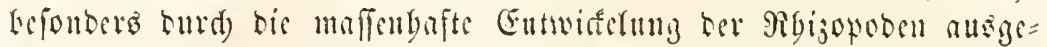

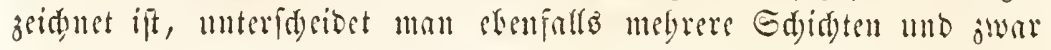
namentlid): bas Néocomien, ben (bränfan b, sie untere d) lori =

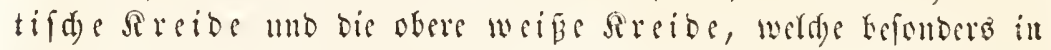

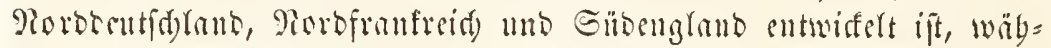

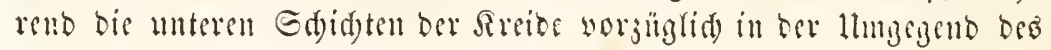

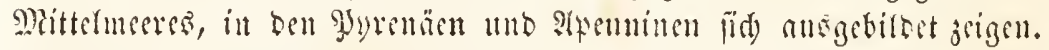

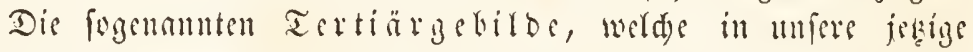

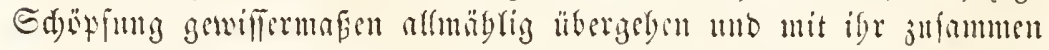

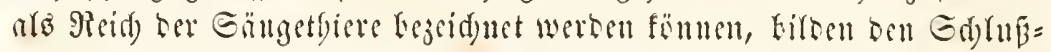

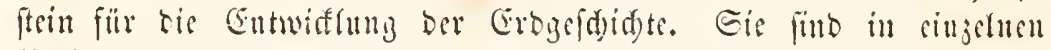
Becten abgetagert, tie jerftrent anf ber ganjen Erte borfommen mb

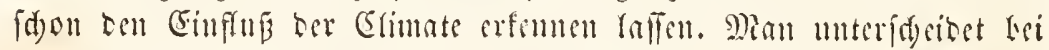
ignen mene, mittlere mo obere Tertiärigerifbe (Eocen, Hiocen, Pliocen) to wie bie Dirmuialgebirbe. Da in ber Tertiäreit tie

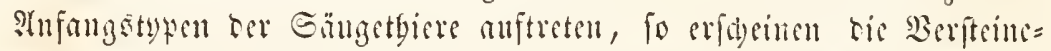

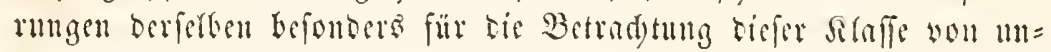
gemeiner $\mathfrak{B}$ id)tigfeit.

Die einjelnen Serivoen, weldse wir in anfiteigenter Aerifenfolye

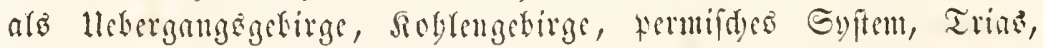

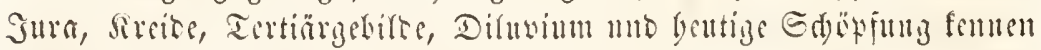

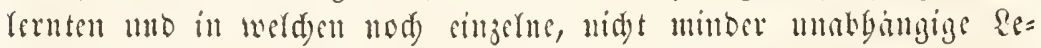
benserodyen unterfdeben werben fümen, riefe Ylerioben, fage iff, wurben won einzelnen mädtigen Revolutionen unterferoden, weldye bie beftebenten Rebensformen burdan wernideten nub mad beren Borübergeben nene Battungen mo 2trten an bie Stelle ber frü=

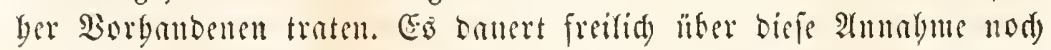
sin mit Seftigfeit gefïlyrter Etreit unter ben Gestogen fort, intem bie (begner feine firungweife Entwiffelungen Durd) Peyolutionen, fon=

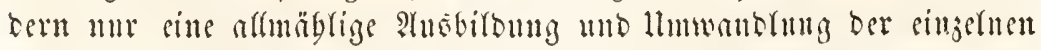
Prten anerfennen wollen. CE wäre unmöglidy, bier auf bie Entwict= rung biefer Streitigfeiten singugeben, weldye sinem nnoern 3weige ber 
TBiffenfdaft angebiren; - bod) fönnen wir nidgt mubin, ben Grund ber werfdebenen ?nfidsen anjugeben, ba refer in bas

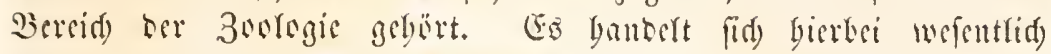

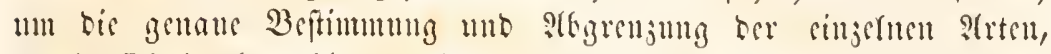

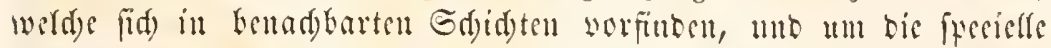

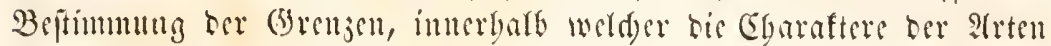
wariiren fönnen. Sisir fübrten fdon früber an, baß bier sin 3wift

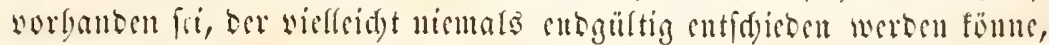

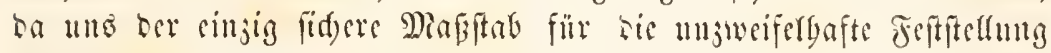

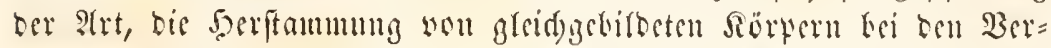
feinerungen butd)as abgegt. Fü แแs ift ber Streit entfdieben, ocun

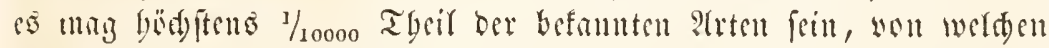
man bebantet, bafif fe mebr ober weniger mobificirt sine Sievolution itberfanoen mo son siner formation it bie antere iffergegangen

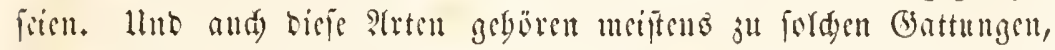

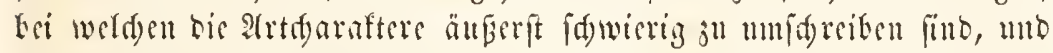

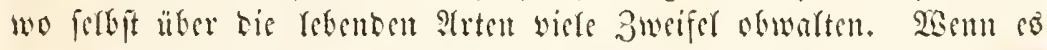
ario and sou ben wenigen Arten, bie jekst thod) jweifelbaft fint, nad)= gentefen weroen follte, bab fie wirflid) ans simer Gdoppung in bie

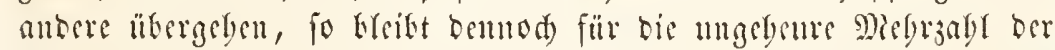

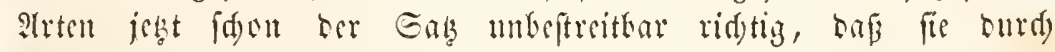
Bevolutionen vernidet wurben, um einer anderen Sdyopfungsperiobe

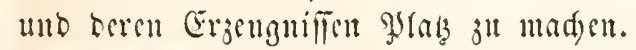

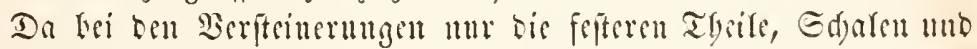
Snod)en, uns erbalten fint, biefe afer bei vielen Thieren nut febr

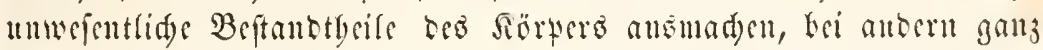

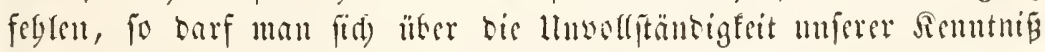

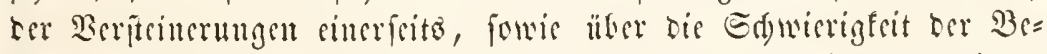
ftimumung andererfeitzo nid)t wumbern. Son ganzen Glaffen weidser,

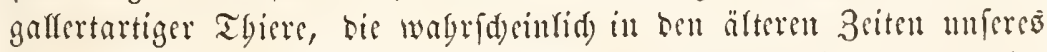
Erbballes mimmerten, ift uns frine Spur übrig geblicben; mur unte= ftimnte sage Eindrinfe beutent anf ibre Exiftenj bin. Bei ben Jrag: menten anberer beburfte eo oft jagrlanger, mübrliger lluterfudgumgen, nur un bie Silaffe ober Drounng zu bezeidyen, zu weldyer bas Thier gebört baben modjte, won bem uns ber rätblelbafte Rejt bliet. Nur bie genaucfen Bergleidungen und bie ftrengfte Aufmerffamfeit

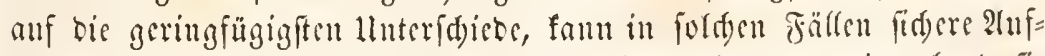

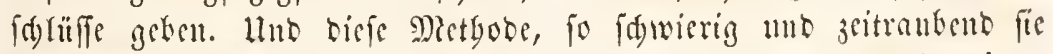
and) ift, breibt bennod die cinzige, welde zmun Birle fübren fann!

Betradenten bie Entwiffung fer cinzefuen Typen bro Thier: 


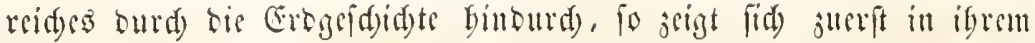
allgemsinen Serbalten sine merfwërbige Berfdebentseit. WBir föm

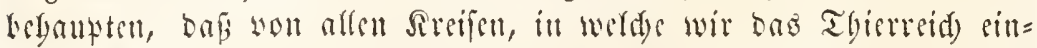

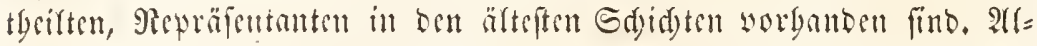

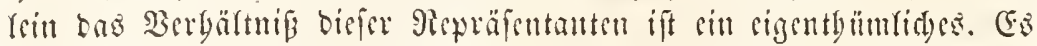
gibt ganje Dromungen, wielfeid) ferbft Slaffen Kei näberer Semutnib, weldye maffentyaft mit wirlen Fantilien, Battungen, Frten unb Snbivi=

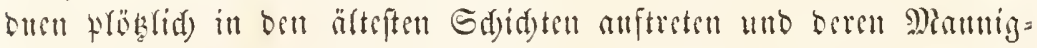

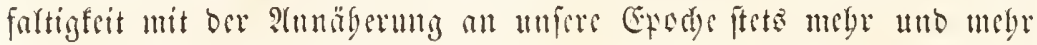

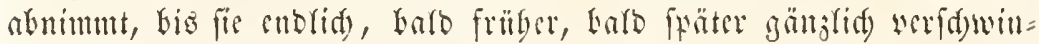

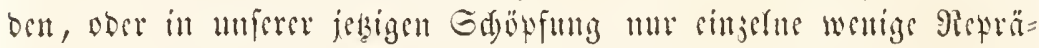

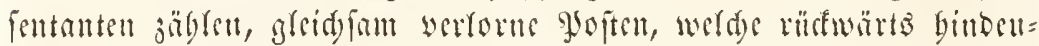
ten, auf bas becr, weldes ifnen worangegangen ift. So ift jencr

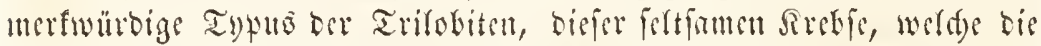

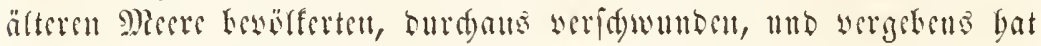
man in ber jebigen Edgryfung igre näberen Berwanden gejudt. Eo

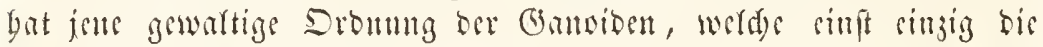

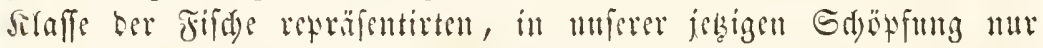

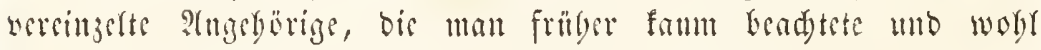

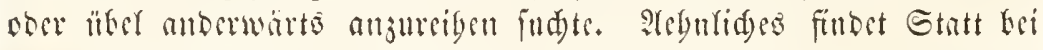

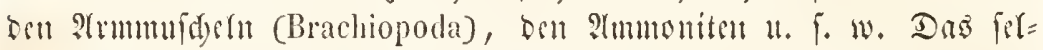
tene Borfommen singefter fonberbarer Typen in unferer Sdüpfung,

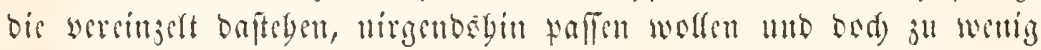

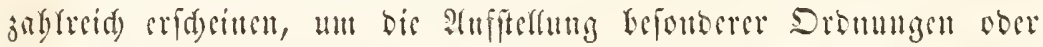

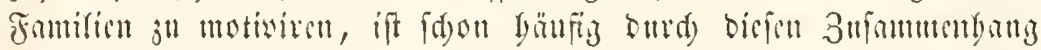

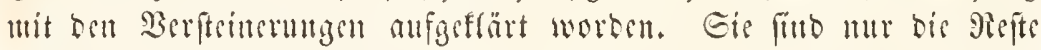

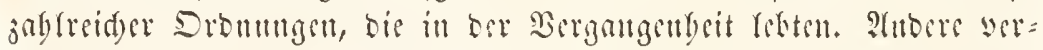

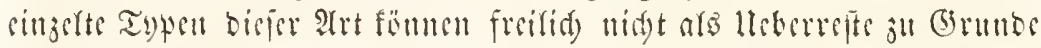
gegangener Refensformen angefben werten, fontern migen siefleidst

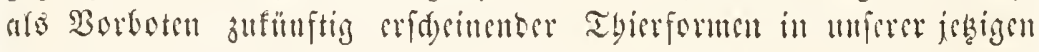
Sdäpfung vorbanben frin.

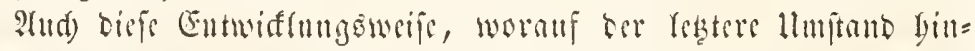
Dentet, fömmt vor. 3nusifen erfdesinen gestille Typen in äteren

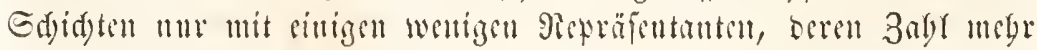

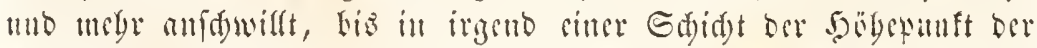

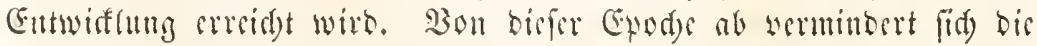
Mamnigfartigfsit, und oft Kreibt nur cin wercingerter Pepräjentant in Der beutigen Sdyüfung zurü. Die Gruppe ber Rautilen unter ben

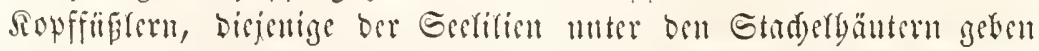

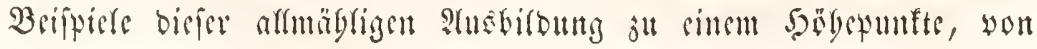




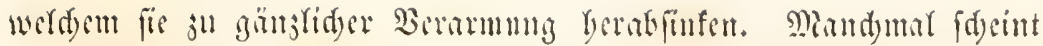

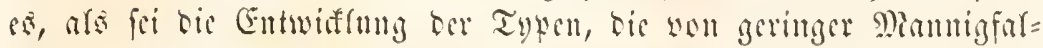
tigfeit ansigeben, ned jegt in ifrem fortidertite begreffen mo als bate

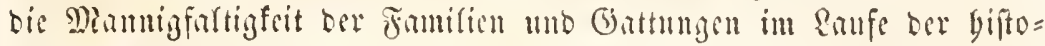

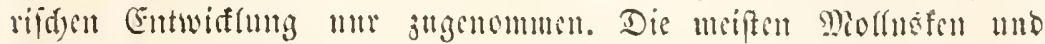

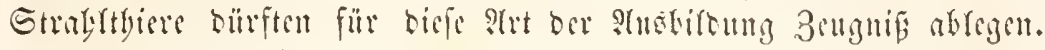

Mian erfirgt for ans bicfer Mannigfartigfeit in ber Entwidfung

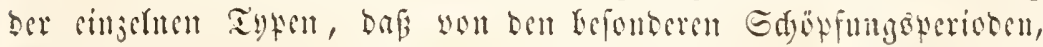

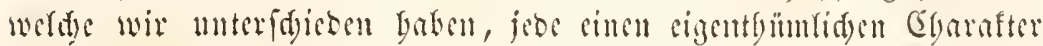

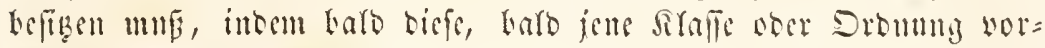

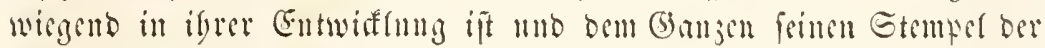
Yुräponberanj anforinft. SBie rotbe Fäben jieben fid aber burd alle biefe

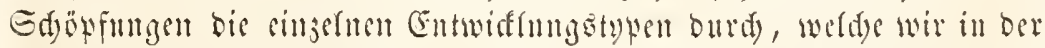

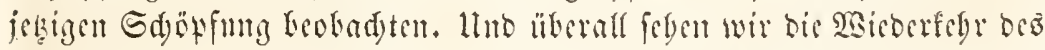

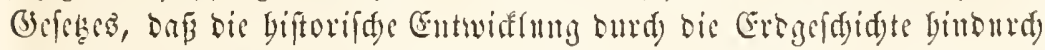

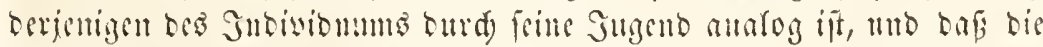

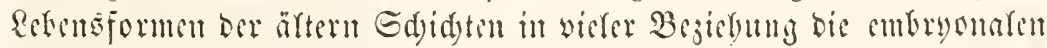

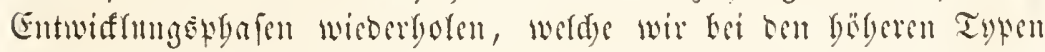

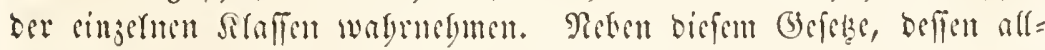

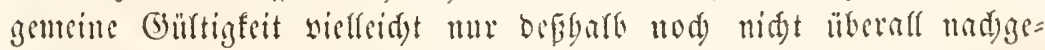

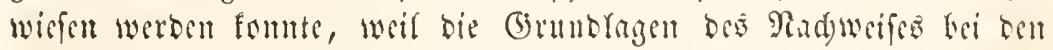
rebenben Tlgieren nod) nid)t binlänglid) bergeftelt fimb, begegnen wir nod) einer anbern d)arafteriftifden (Evfdeimmig, nämfid) siner eigen=

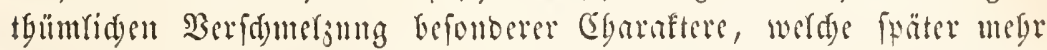
uno mebr bei ben cingernen (5ruppen fid) fdeiben. Mlandymal will co (d) einen, ars träten erfit nad) mo mad) bie Sdetorimien bervor, welde

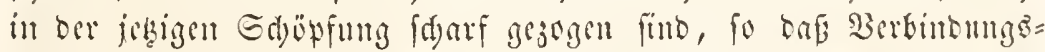
glicber int foffilen 3uftande zwifden Sifaffen unb Stommgen gefun= ben werben, weldye berienige, ber unt bie jesige Edöpfung betradtet, für mrsereinta: erfeärt baben witrbe. So findet man bei ben ätreften Jifden im Berein mit embryonalen Gharafteren anbers, werdse auf

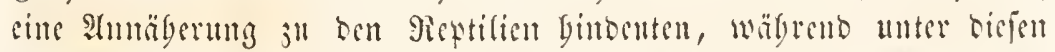
ferbit wieber llebergangeformen jwifden (Eibedjen mo sirofubilen,

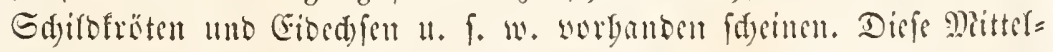

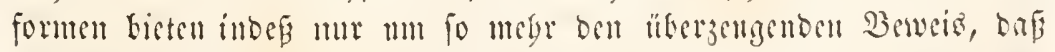

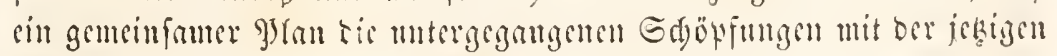
werbinbet, uno baj beioe eimanor gegenfeitig erfäntern mo werftïno= (id) $m a \mathfrak{d})$ en. 


\title{
Senter Brief.
}

\author{
fireis ide llthice. (Protozoa.)
}

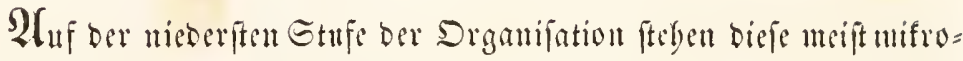

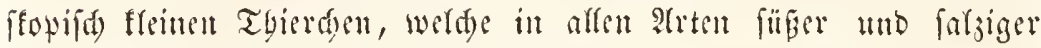
Gewäfler oft in jabfrofen Mengen gefunden werben. Ggr gejammer

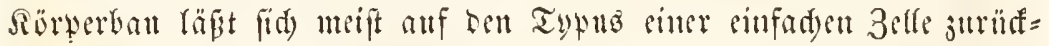
fübren voer anf eine Berbintong megrerer einfadjen Belfen jul ge=

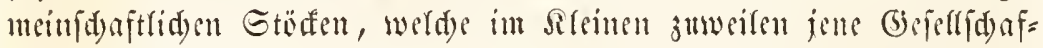

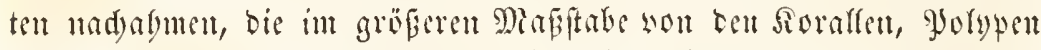

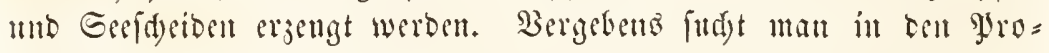
tojoent altögebildete intere Drgane. Der Berbantuggapparat int

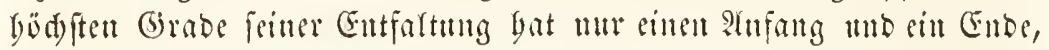

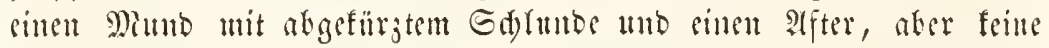

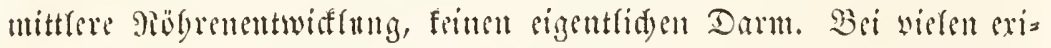

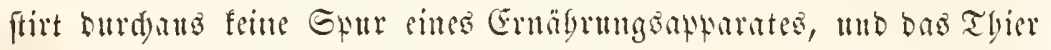

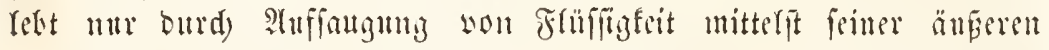

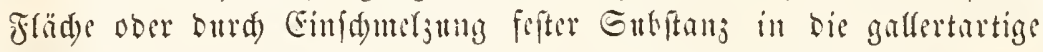

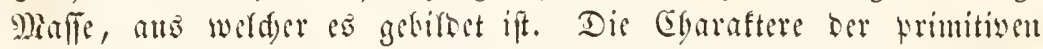

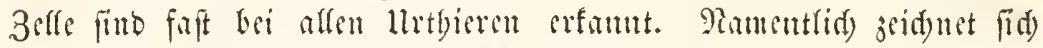

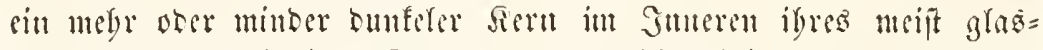

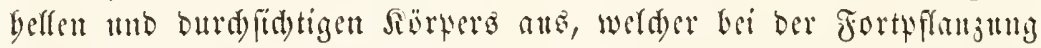

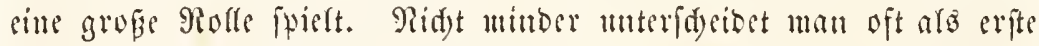

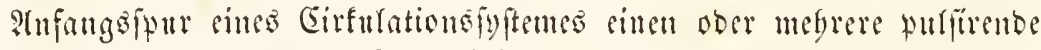

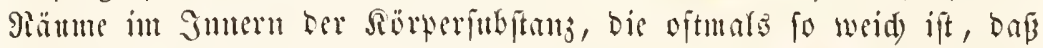

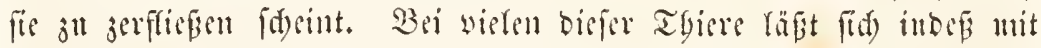
Dentlidfeit sine feftere Sulditanjlage erfenten, weidye die äthere Daut

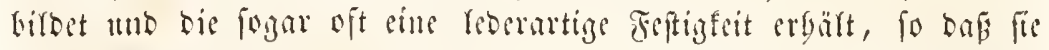

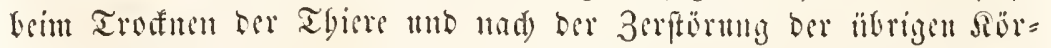

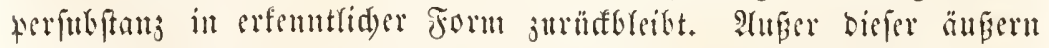

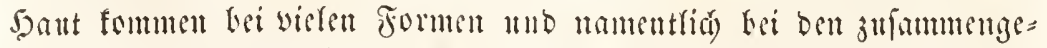

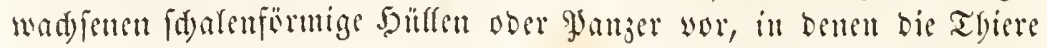

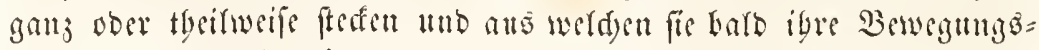

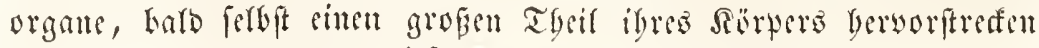

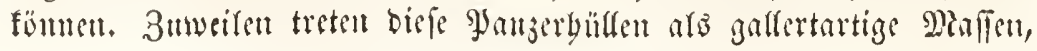


in ambern Fällen als bormartige Bäd) șen auf; - oft fogar furb fie surd) ?ufuntume wou Siefelerbe ober Salf unjerfterbar gemadyt, fo

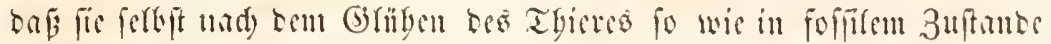

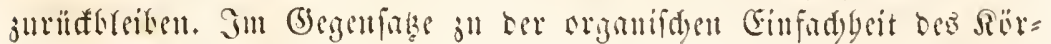

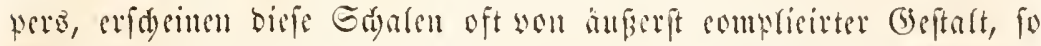

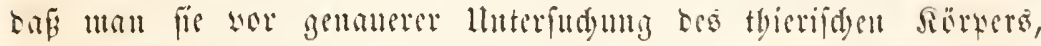
welder fie erjengt mo bewognt, für grobutte weit gëberer Thiere

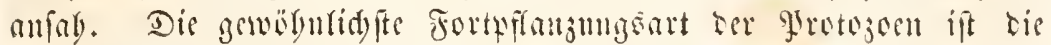

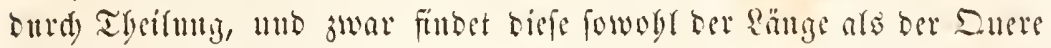
nad) fratt. Der Siem, welder im Smurn bes Thieres liegt mo fid) ourd) feime fejte Befidaffenbeit son ber jerfliefonden Gubfanj bes übri= gen Sïrpers wobl mnterfideibet, reitet bicje Theilming cin; - Man fiebt ibn imterbarb bes nod) cinfaden Sörpers in (septalt ciner Gdubs= foble ober eilles Bisquits, bas fid) immer medr in ber Mitte burd)=

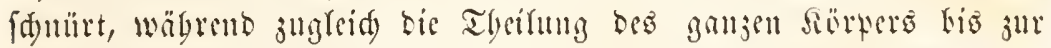
yolffänbigen Trenumij ber beiben bäffen fid) volfjebt. Geltener nur mo jwar namentlid) bei benjenigen lletbieten, weldse gemein=

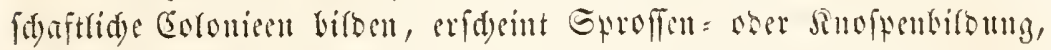

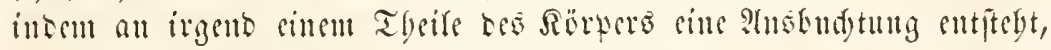

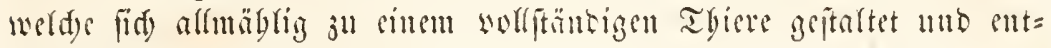

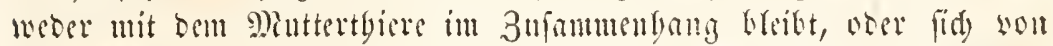

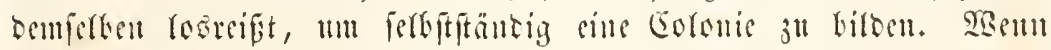
biefe $\mathfrak{R}$ ofpen, wie es bänfig ber Fall ift, nad) beftimmten matbema= tifden Gefeten an bereduneten Stellen fids entwiffern, fo entiteben

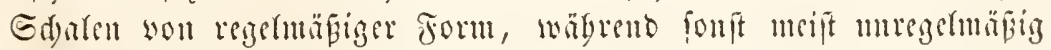
verätelie bammartige Roloniesn fid biloen. Enolid) fommt Hei sinigen

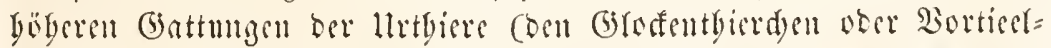

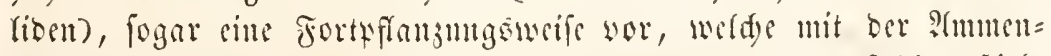

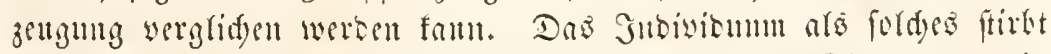
ab uno verwandelt fid in einen mejit mbewegliden fiörter, or in

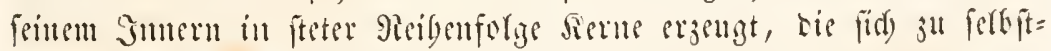

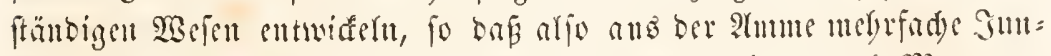
gen bervorgeben, bie, wie es fdecint, fid) unmittelbar surd) Rectamor=

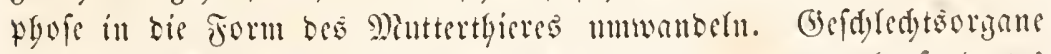
mito beren Shrobnte, wie befonbers Gier, Simnesorgane, algefonbertes

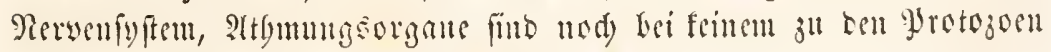
gebörigen Thiere entbeft worben.

Die Bewegungergane geben ourd) igre werjdebene Befdaffen=

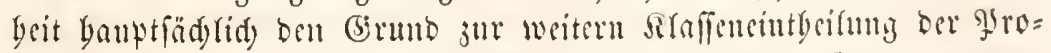

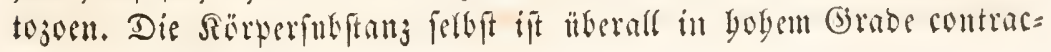


til, fo baß bei benjenigen (battuntgen, weldye an bem Boben befeftigt

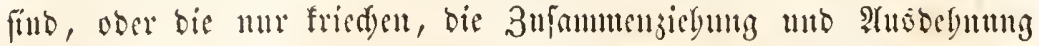

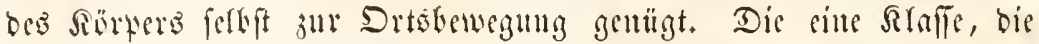

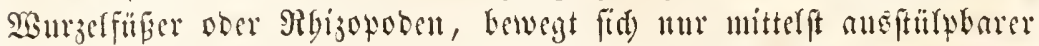

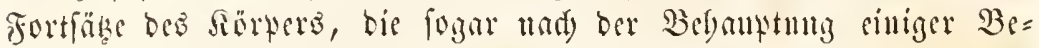

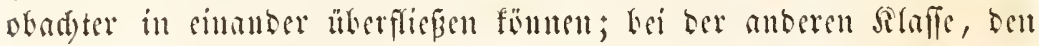

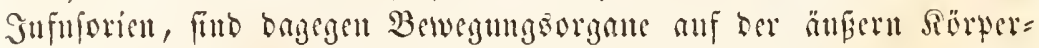

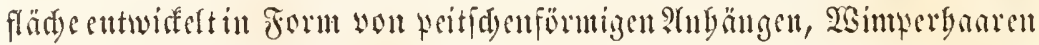
ober Boriten, werde meift aud jugleid) zunt (Ergreifen ber Nabrung Dientel.

Die Srotojoen finden fid) nur im 2 safler, aber meift in jubl= rofen Singen, fo baß ibre mit barten Gdalen verfebenen Gattungen

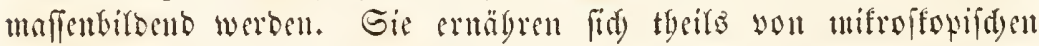

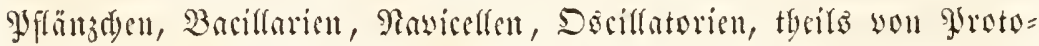
zoen feleft ober and won faulenton Thier = mub glfangenftoffen, in

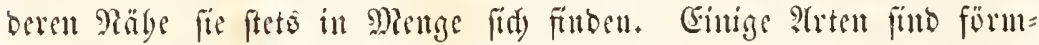

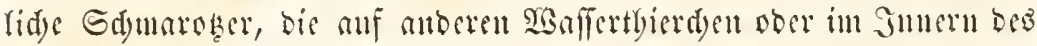
Darmfanales wou böberen Thieren fid anfyaltall. Biefe ber in

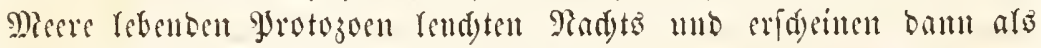

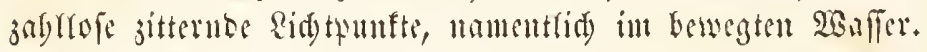

\section{filaffe sar Mlu;iffilfer. (Rhizopoda.)}

Der Sörker biefer Thiere heftebt gänjlid) nus jener gallertartigen

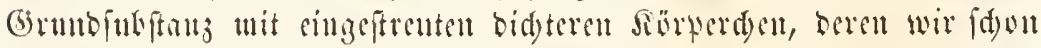

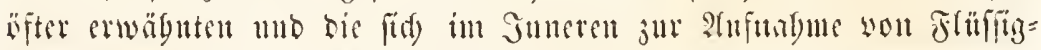

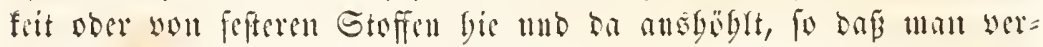

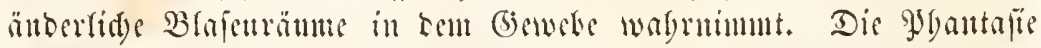

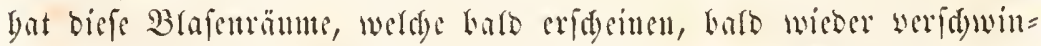

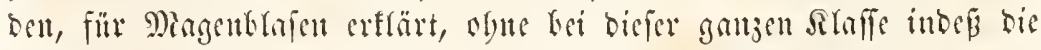

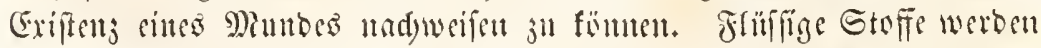
won ber Sïrteroberfläd) eingefangt, feftere baburd) aufgenommen, dab ber gaflertartige Sïrter fid gleidy fam unt ben aufautelmenoen Stoff bermmfdutlst, bet mun an irgend eiller beliebigen Stefle it bas Ge=

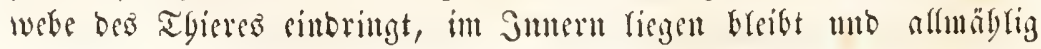




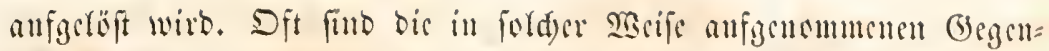

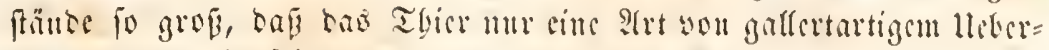

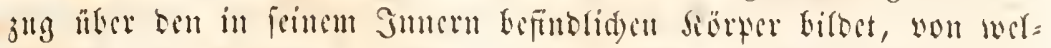

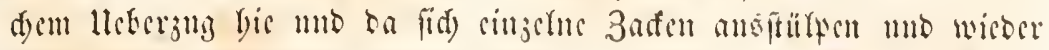

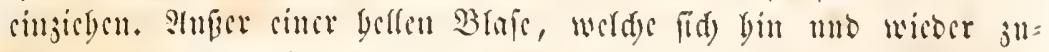

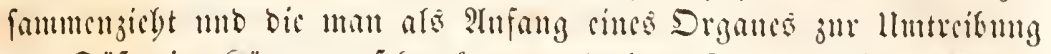

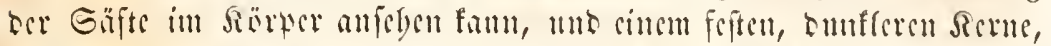

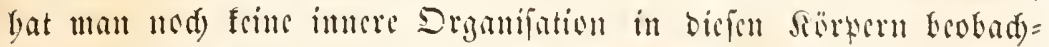

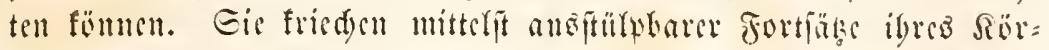
fers, bie katb bicter nno fingerfïrmig, hato feit mo mamnigfad) ver= affert erid)cincu, anf bem Boben ber (sowäffer sinber mo finten fid bejonbers im Meere in zablefen Dengen.

Dis änbere Rörperform Der Rgijopoben bictet febr mannigfade

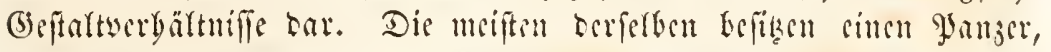

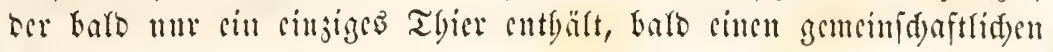

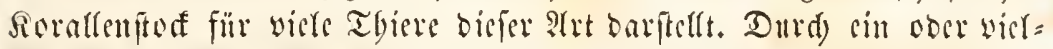
fadje Röder bicfes bornigen ober falfigen ganjers werben die ber

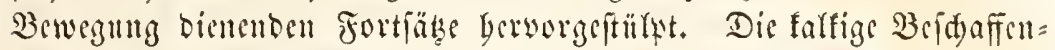

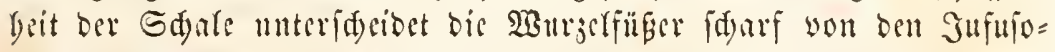
rien, bei wetden um bornige ober fiefergaltige Sdjalen vorfummen.

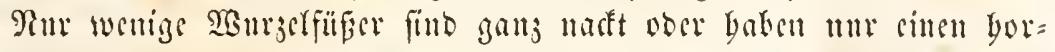
nigen ober leberartigen Janger you ber form ciner 3 äd je.

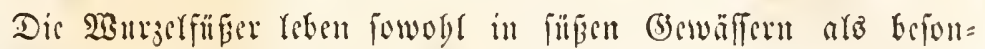

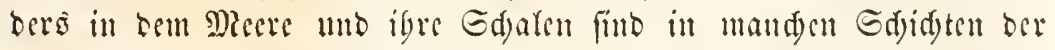

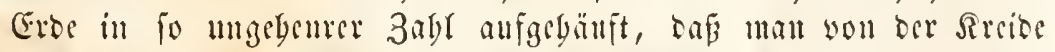

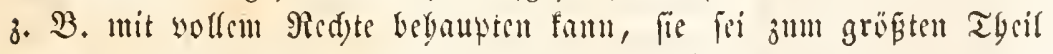

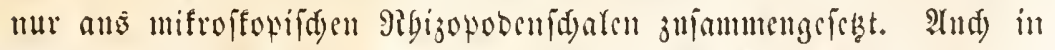
unjerer jebigen Zeit bejtebt namentlid) ber frime Salfiant, welder an fo viefen Drten ben Mectesftrand bilbet, feinct Samptmaffe nad) ans foldacn Rbijopoben mo in bem Rieseridglage und bem Bobenlaze flarer $\mathfrak{B a ̈ d}$ e, fo wie an ben safferwflanzen futben fic fids oft in

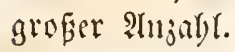

Man theitt die Slaffe ber Rgizopoden in zwei Drommngen ein.

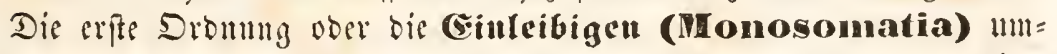
fapt alle biejenigen Săberfüfjer, weldye nut anb cincm sinjigen Thicre befteben mito entweber naft fint, ober in sincr bornigen Saplel ftefen, dic mur eine cinjige Defrum befizt.

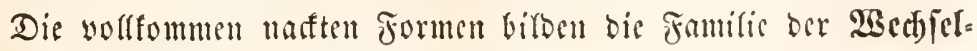
thierchen (Proleida), Thiere Inbeftimmbare Form mo Gröbe, 


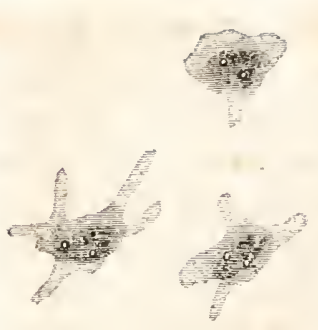

Jig. 37. Amiha.

bie faft iiberall auf ber beswoguten Eroe, wou Sibition bis nad) Rorbitalien Yin, im Boben= fage finßer berwäfer gefunten worben finto.

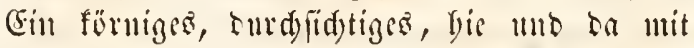

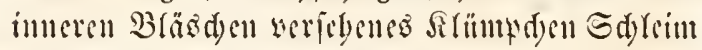

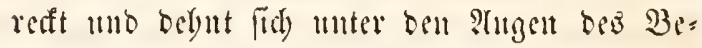
sbad)ters nad) allen Seitin bin ans und wed)= fort beftüntig tis Geptalt feines sörpers, in werdyem man als conftante Beftandtyeife nur

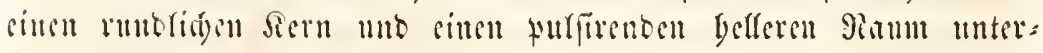
fdgeisen fann, ber sine runblide form gat. Feftere Stoffe, wie

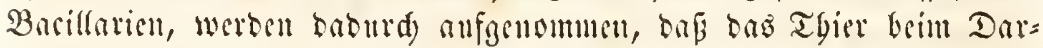

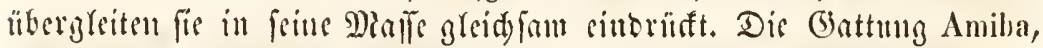

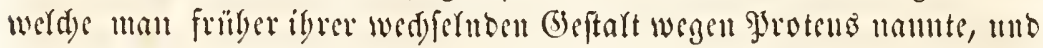
bie Sonnentyierden (Aclinophrys) Gifben biefe fonberbaren sönter.

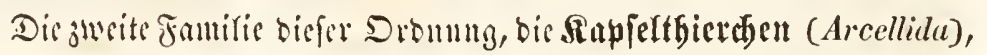

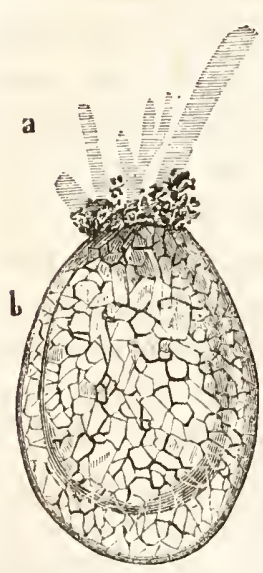

Jig. 33. Euglypha. Gefizzt cinen bornigen ooer farfigen Yallzer, oer

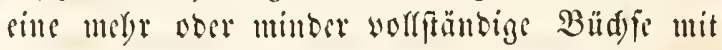
ciner sinjigen Definnung barfefllt, ans weld)er bis

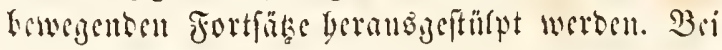
sinigen Battungen find bicforten fingerformig,

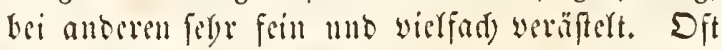

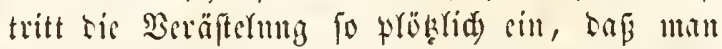
unter bem Mifroffope sinen Yangiam rinnenden

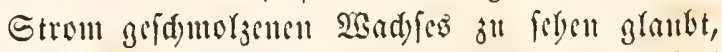
welder nady atten Geiten lyin fid vertysift. Brei ber Gattung Areella if ber youzer unchr ober mintoer groffenfürumig mit grofer runtor Def= unnty, Kei Difflugia unto Euglypha si= oocr flafden=

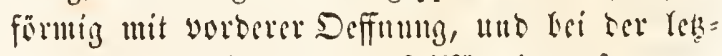

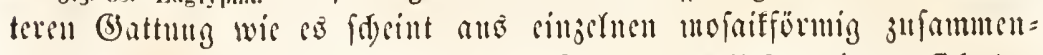

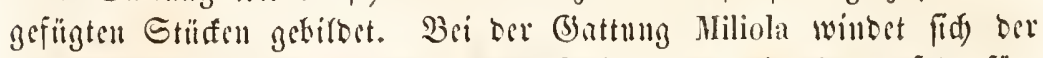

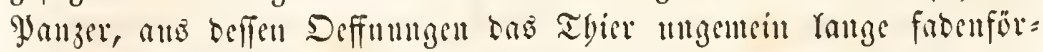

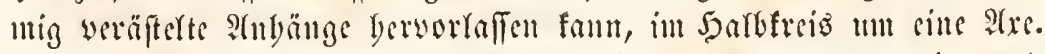

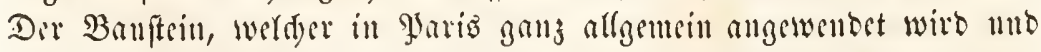

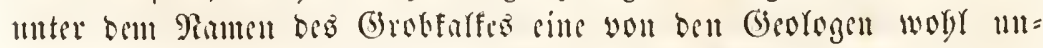

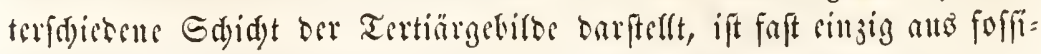




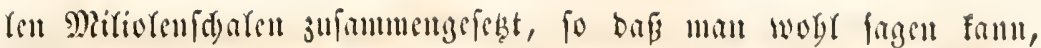

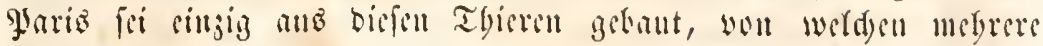
Mitfionen anf rine lluje gebent.

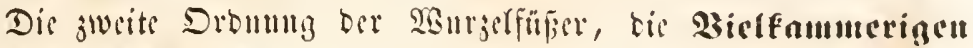
(Polythalamia) beftght ans fociaten Thimen, beren Drganifa=

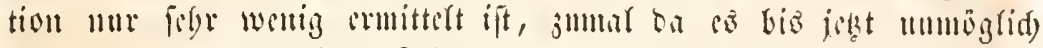

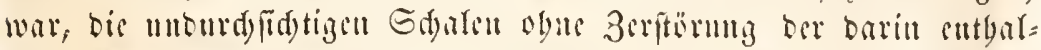

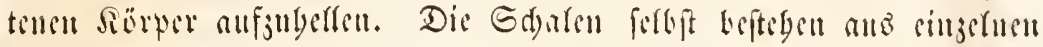
Sinumeru, rie burb burd Deffinungen mit sinnder in Berbintoung

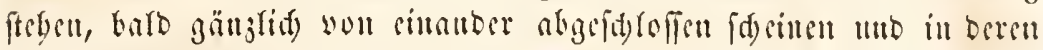

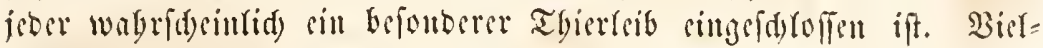

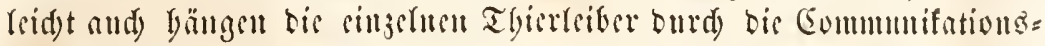

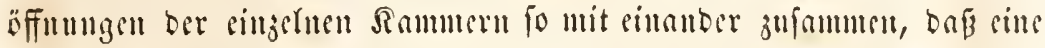

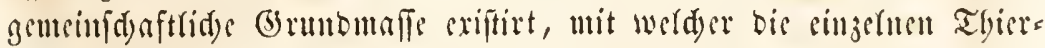

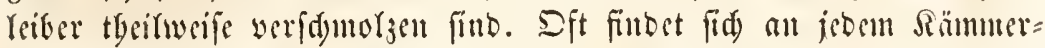

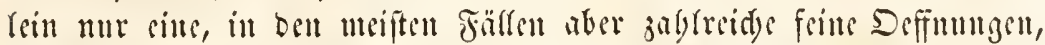

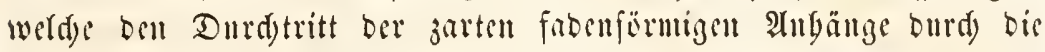

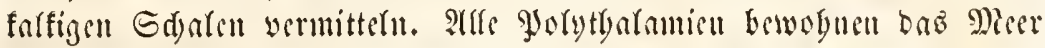
und iger Sdjaten finden fid bejunders in ben mergeligen, fanbigen

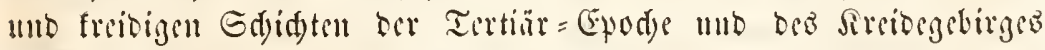

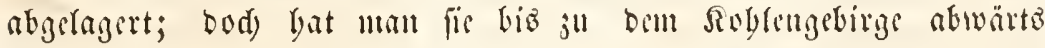

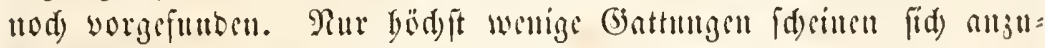

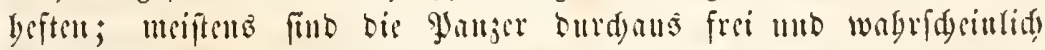

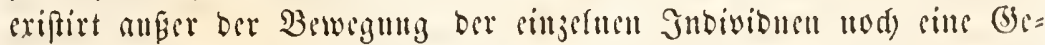

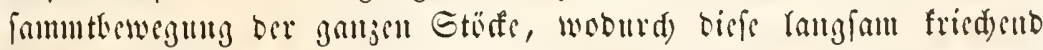
fortbervegt werbon. Dis änferft jierlifife form biefer sielfaumerigen

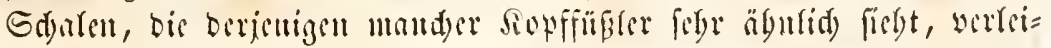
tete frïger bis Beobadter, biefe forfiten Sdyalen für Aefte von mifro.

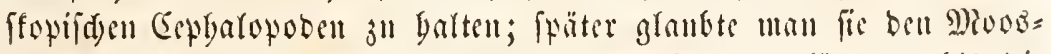

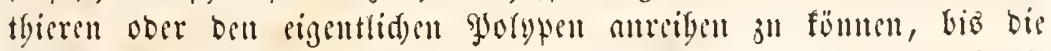

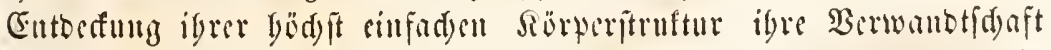

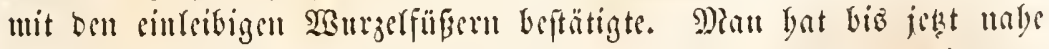

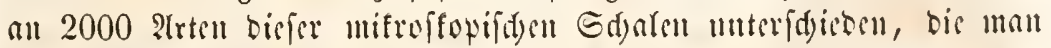

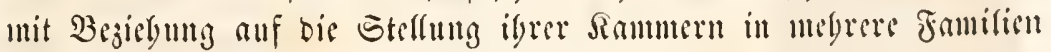
gettyeilt bat. 


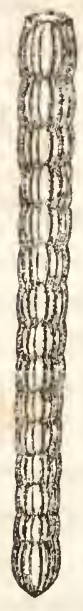
Fig. 39.

In ber Familie ber (Einzeiler (Stichostegida) riegen bie eingelnen Rammern in einer geraben ober wenig getwo genen Sinic mit igren Enoen aneinanber gereigt, wäbrent in ber Familic ber Doppelzeiler (Enallostegida) bie Sam= mern auf jwei ober brei frarlfelen Meiben ueten einander oter abwedyelno geftellt erfdyeimb. Da bie Gattung biefer Familie meift "mit einer citjigen Sammer anfangen uno tie Sammern in briben Reigen fteto größer werben, fo bilden rie Gdjalen gewögntid pyramiona Formen. Die Familie ber Srbmedenjeiler (Ilelicostegida) be=

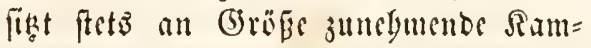
mern, weldye wis bie Gdyeffengäufer ipiralförmig anfgerollt fint uno fo

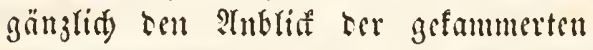
Edalen micberbolen, welde ber glapiev=

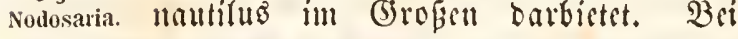
vielen (5attmingen biejer Familie ijt die Goljale in

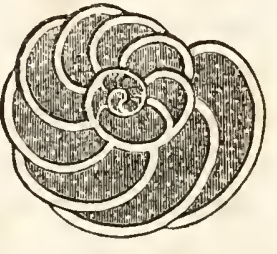

\&ig 40. Planulina. eitner Eibene, bei andern megr ober minder ffilloefförmig wie eime Gartenfdueft: ober sin Tritonğborn aufgerollt. Eine vierte Familie, Die Epiralzeilet (Entomostegida), zeigt stenfalto fpiralförmig in ciner Qbene aufgerofle Rammern, bis aber in boppelten Pleigen georonet

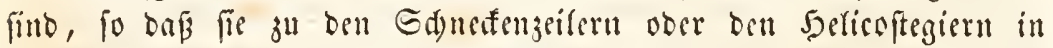
Demielben Berbältniffe fteben, wie die bopperzeiligen Enalfoftegier zn

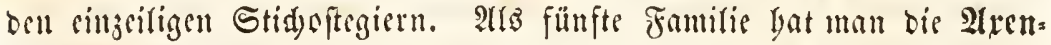
jeiler (Agathistegida) unterfdicben, bei weldsen bie Rammern fo um eime fenfredyte Are geftellt finb, baj fie bie gange Ränge ber Sdjale einnebmen und simanber umfaffel.

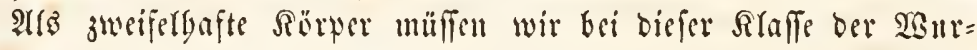
gelfüfler nod) ber fogenanuten $R$ ummuliten oder Q infenfteine crwäbnen. Gi fint meift limpenfürmige verftei=

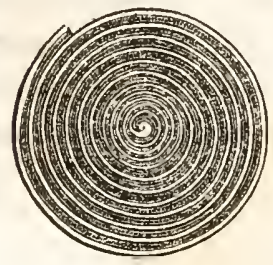

Fij. 11. Nummulites. nerte Rörper, won weldyen man nod) feine lebende Art gefunben bat, bie aber namentlid in ber Llmigegend bes Mittelmeeres ganje Gebirge bif= ben 11 th befonters in tem Sercibegebirge und ben unteren Tertiärfdidsten werbreitet fint. Die Jyramion fint grofentbeils aนs Pummuliten= falf gebaut, ber faft mur aus biefan limfenförmi= gen Rörpern zujammengerszt ift. Edbleift man sinen forden Rummuliten, ber äuberlid) volfommen feft erfdeint, an, fo fiebt man, baß frin Sumeres cine llnjabl von Rammern entbält, bie 


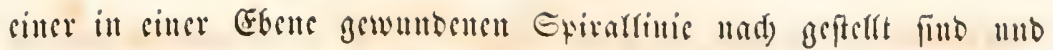
butd) fdjefe Sdjetoenänbe getrennt werben. Die biffe Sdjate, welde

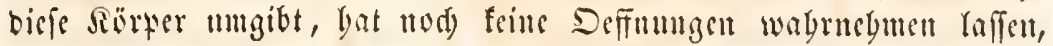

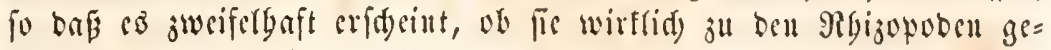
Gören, ober nidyt intere Gdaten wou Thieren waren, welde ben

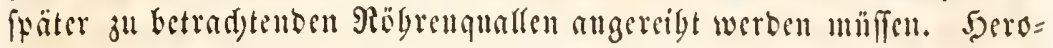

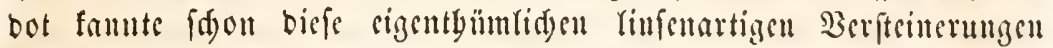
unt gibt für igre Entifelung bie Sage an, baß cin Theil ber für bie ?rbeiter an ben Jyrantiben Eeftimmten Rimfenvorrätbe übergeblie= ben unb werfteinert fei.

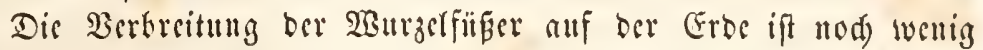
unterfudyt, ba man bic genaueren Padjforfdungen auf wenige Sïften= funtte im Decan, im rotben unb Mittelmeere cingefdräntt lyat. (5)egen ben Plequator Gin nimmt bie 3abl Ler Battungen unb 21rten bebcutent 3t. In ber Roblenperiobe bat man mur wenige Trten gefunben; mebr fdon im Smra; maffenbilbenb treten aber bicfe fleimen Sdjalcn erft in ber Sercide unb Dem Tertiärgebirge auf, wo aud tis $3 a b l$ ifrer $\mathfrak{A}$ rten ftets im 3unebuen begriffen ift.

\section{filuffe ior Infuforien. (Infusoria.)}

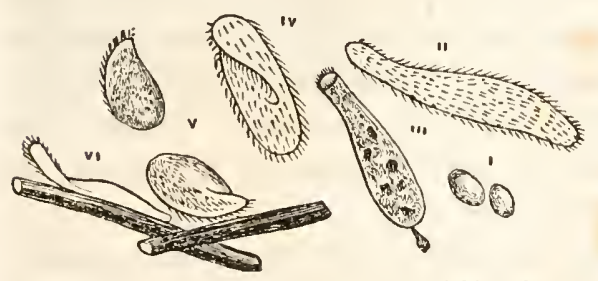

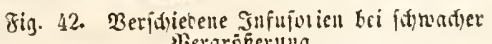
Bergrêperung.

I Monas, II Trachelius anas, III Enchelis, im Stugenblife, wo fie Roth) Durdy ben After

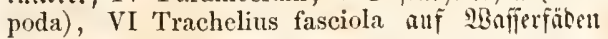
friedrent.

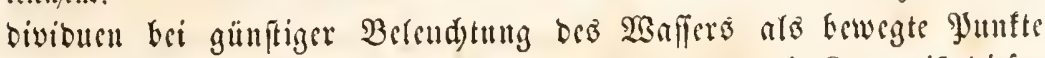
unterfdeden werben. Das Mifroffop nur fenute bie Renntuif bicfer Tgierflaffe vermitteln แnb segleid) bie Ergetnifle utbefangener fors

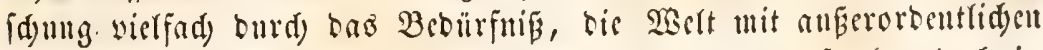
Sounbern in Erftannen ju feben, getrïbt mutben, fo gat bod in

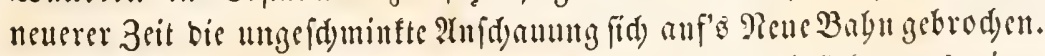

Dis Rörperoberfläde ber meiften Sufnjorien beftebt ans cinct fefteren Sdjidt ber weiden, gelatinöfen mit Rörndyen burd)webten 
Subjtanz, ans werder ige ganjer Drganismus aufgrbaut ift, unt bie wir unter bem Ramen Earfobe fennen gerernt Gaben. Mandymar ift

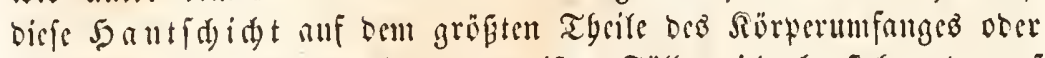

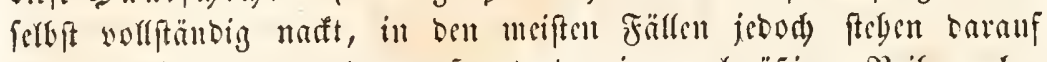

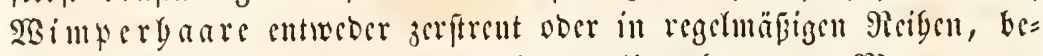

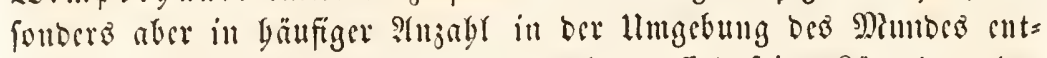

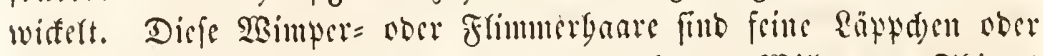

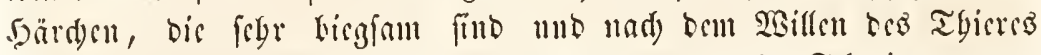

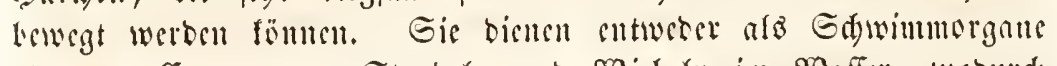

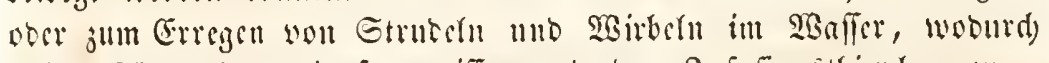

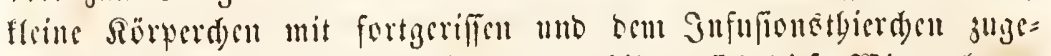

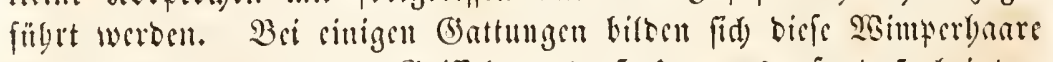

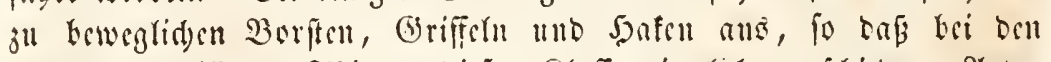

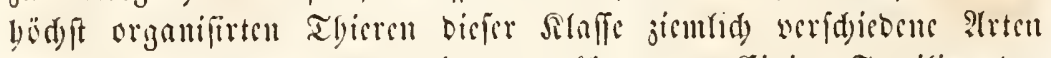

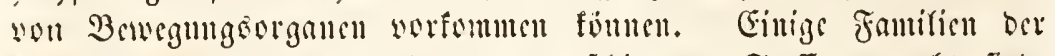

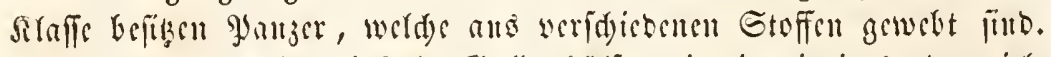

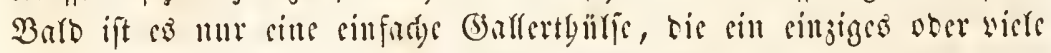

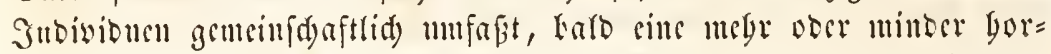

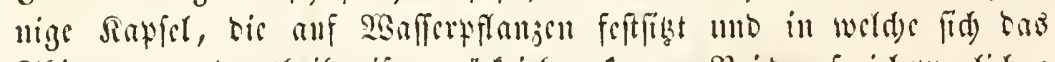

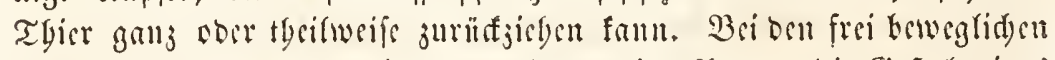
Snfuforien bat ber garnige vocr lederartige g'anjer bie Geffalt cincs Gdjirbden है, werd)

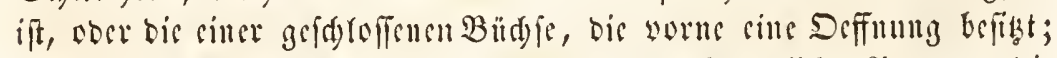

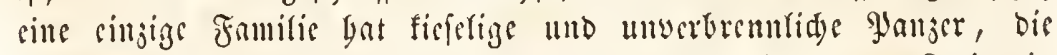
befonder in jablreiden Maffen in sen Jenerfteinen Der Srcibe in foffitem 3uftande gefuntern werten.

Dic Bewegungagrgane ber Sufuforicn fint in mamigfad)er

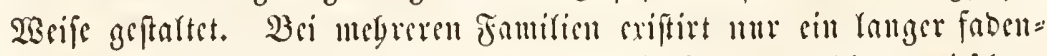

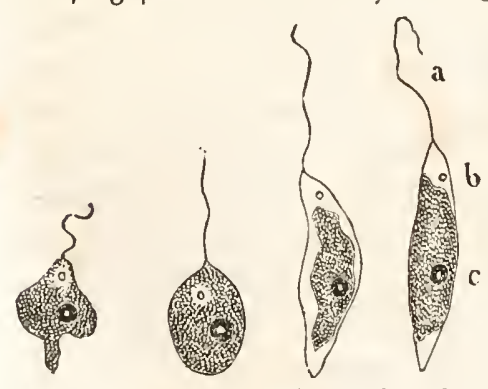

Jig. 43. Jig. 4h. Jig. 4 . Jig. 16. Euglena viridis.

Berfdriebene (Sontrations fer Euglena viridis. a ter গitiffel. b ber IUgenflet. c ber Reru.

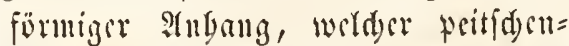
förmig in 'Eaffer bin mol ber bewegt wirs. 3uweilen servielfältigt fid) bie 3abl biefer Geifelt, welde man böd) umfaffentor 2 secife aud) mit beut $9 a=$ men 9iuffer belegt bat, obgleidy fie nidst

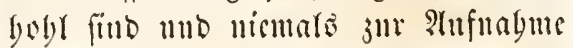
won Pafrung Dicnit. Dic Fnwifen= beit sincs forden 9heffrets fommte bis wor wenigen gabren fiir cinen 2 cweis ber thierifden Patur eitre Drganis= mus getten. Seitorm man aber ent= 


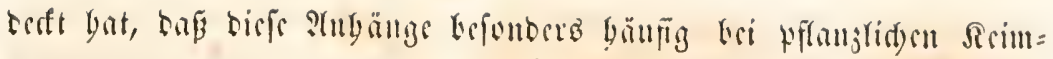

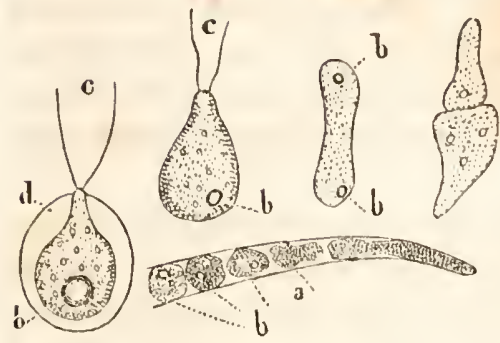

Fig. $47-51$ fimförner

förnern borfommen, weldye bomit ill $\mathfrak{B a f f e r}$ bermmwitbeln, fo faridgt

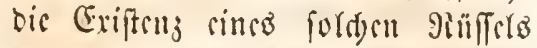
slyer fïr bis fflanjlidas Matur bro

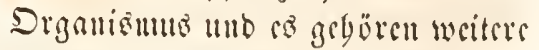
Bewerife baju, wemn man bic this= rifdse Ratur fefteflen will. Eine Menige jencr grüncn Drganisัmen,

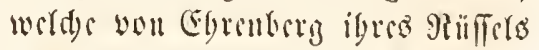

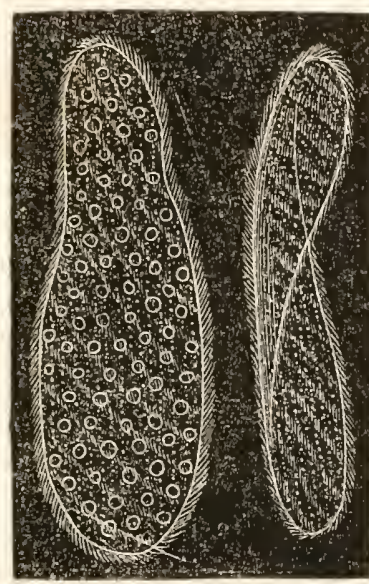

oin 52. Opalina.

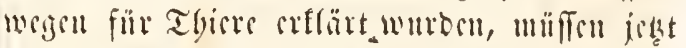

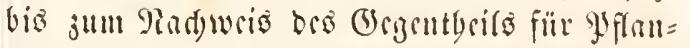

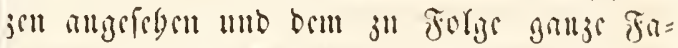
milien, wis bis Singertbierd)on (Botwocitorn), Janjermonaben (Cryptemunainen), aแò ben

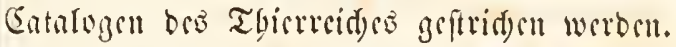

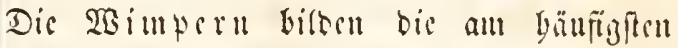
verfreitets Bewegungsart bri bon Snfuforien

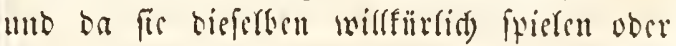

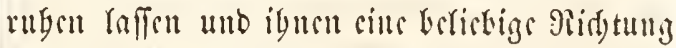

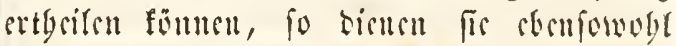
jum Gdwimmen, wie jum borbsifgaffen ber

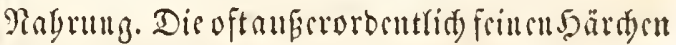

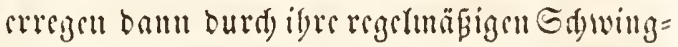
ungen cinen Strubel, weld)er oft bie Erfd) cinmug sincs umrollenton

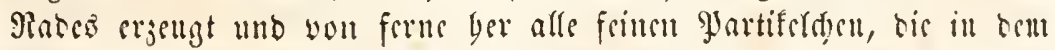

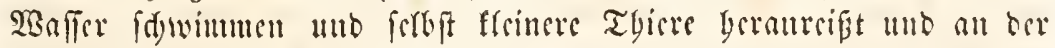

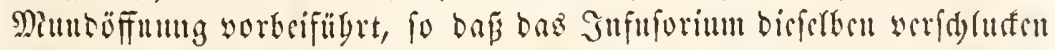

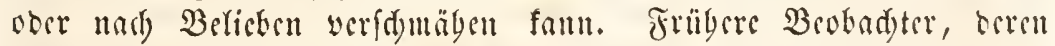

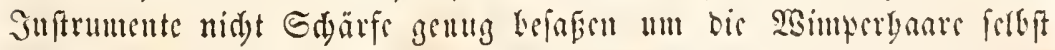

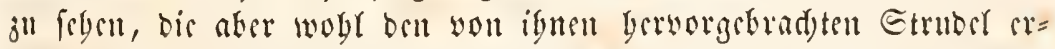

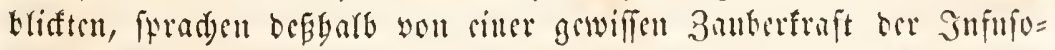

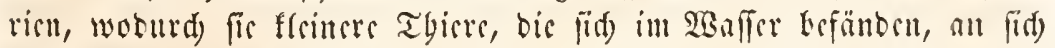

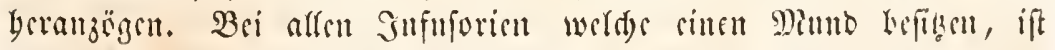

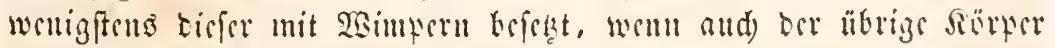

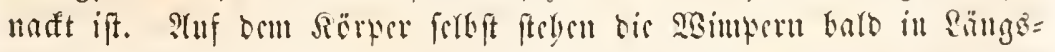

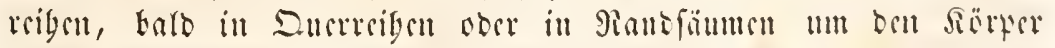

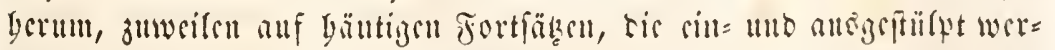

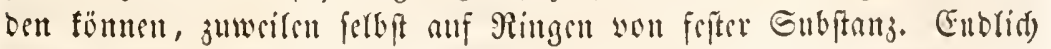
gillt co nod) zwei Fanilien, bei welden ftrifs Borften, Griffer unb 
gebogene ftarfe bafen worbanden fïb, weldye fith mur auf ber Band)=

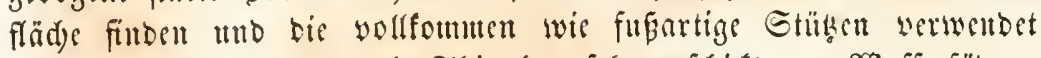

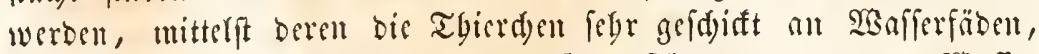

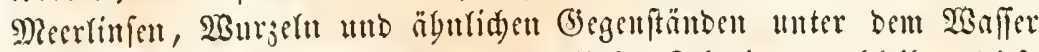
umberlaufen ober fpringen fömten. Beim Sdywimmen blciben biefe Boriten uno Safen unbewegt.

Man bat nod bei feinem Jnfuforium eine abgefonberte Reryen= maffe ober Ginmesorgame walumebmen fömen. 3war entbert man bei viefen berfelben mitb an bäufigften bei ben nicbrigiten for = men cincen meift bodfroth gefärbten Jler, ter mit groper Sidyerbeit

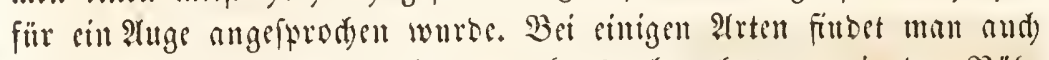
zwei ober brei forder Flede; vergebens aber bat mant in ber Näbe

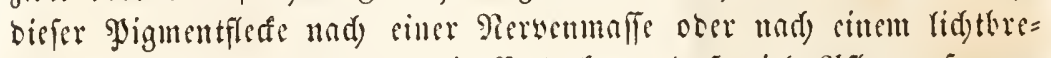
denben Rörper gefudt mib bie Entbefung, onß siele glfanjenfporen,

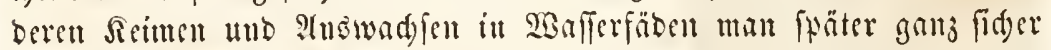
beobadtete, ebenfalla fordse augenartige rotbe Flefen batten, bewiez jur

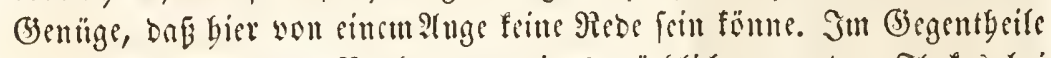

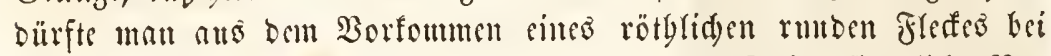
bewegten Drganisumen von grẗner Farbe eler anf bie fflanjlidse Ra=

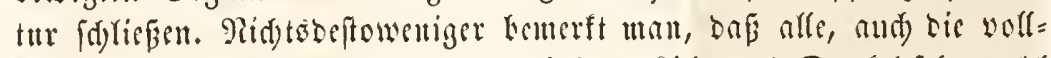
foumen angenlofen Sufulorict, wenigitems Rid)t uno Dutfel febr wobl

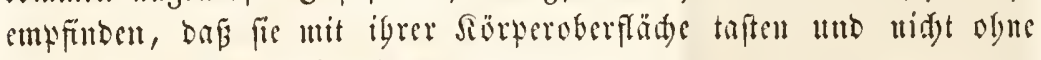

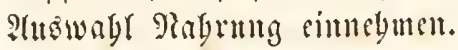

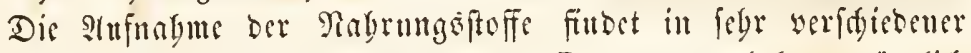
SBeife ftatt. Die Gufuprien Ler simen Sromung enthegren gänjlid citter jeben Deffung att Dem Sïrper, wodurd fefte Stoffe singefilbrt werben fönttill. Die Sörperfubitanj ift inteffen nidgt mebr fo wrids, wie bei Den Rgijofoben, fo sas, wie bei biefen, surd) Gittoriafen in

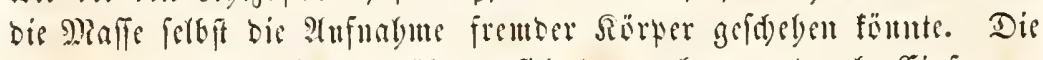

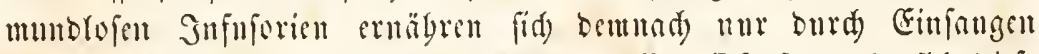
flüfïger Stoffe in bie gelatincife sörpermaffe. Dit fammelt fids bicfe

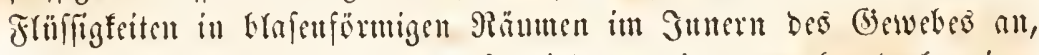
werd)e zwar ffäter ffurfos verfdyinden, bie man aber bod, eimer verfebrten sufidgt juforge, alo eben fo siele Mlagenterafen betradtet

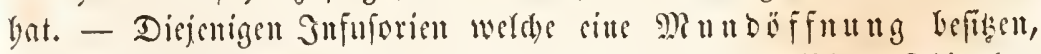
näbren fids befontero wan feften Gtoffen, mifroffopifden Igierdyen

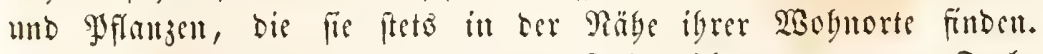

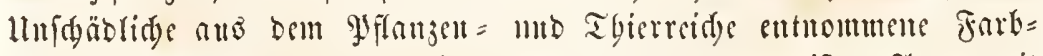
ftoffe wie Carmin ober Surigo werbeli wou bell meiften Arten mit

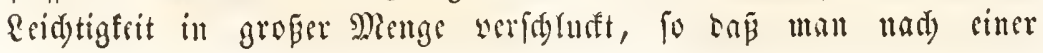




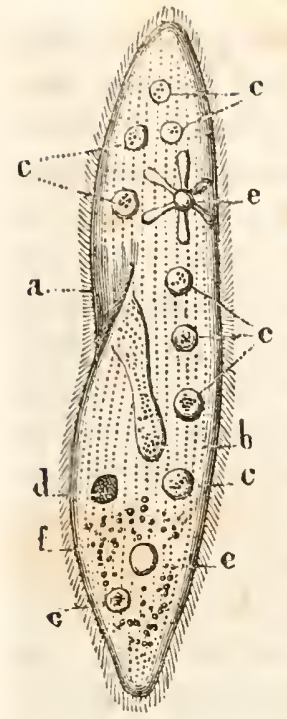
8i, 53. Paramecium
candatum.

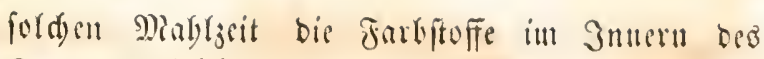
Rörters erbriffen fant. Seit bem vorigen Gabr= bunbert fdon bat man biefe funtreide Jütterunge = metbode ber Jufuforien kennlst, un biber igre in= nere Drganifation ?Inffidülife ju erbaften. Der Mnno ber Snfuforien befiudet fid entweber an vorbern scibesente, wo er ureit citte rumbe Deff: nung bariferft, ober auf ber Baudbfläd) mebr ober minber meit mad) binten gerinte in Gefralt einer owalen ober ferkit fpiralig gewundenen Gpalte. Er ift son wimpernoen siften begrengt, die in cingel= nen Fäflen ferfeft faptenartig werlängert fint mo meift ein = nto ansigeftilft werben fönten, fo

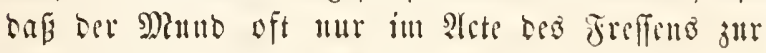
Infdanung fommt. Die Mnubbögle feizt fid tridy= terförmig nad) Junen fort und if thei singen we=

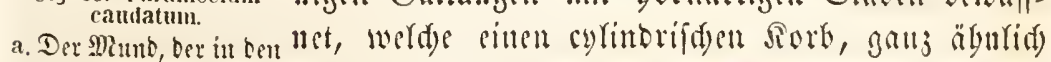

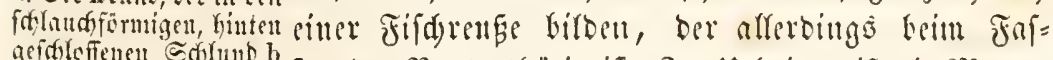

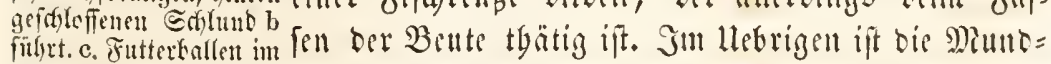

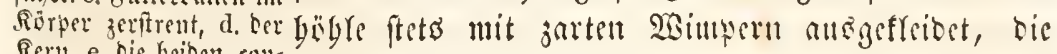

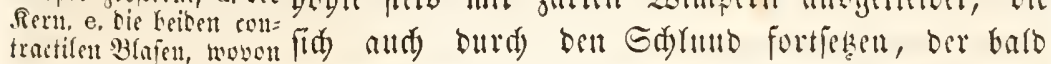
tie vortere fternfämig grabe, bato mebr ober milloer gemunben in oas

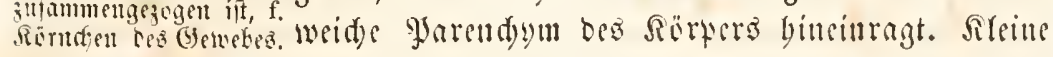

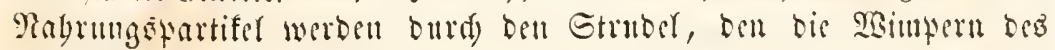
Gd)lunbes erregen, in sine runblide fingel jufammengeballt nub biefe Singel julegt burd, ben Edylun in bas nadgierige siörpergewete biurengeprept. Starre Sörper, wie namentlidg Stüfe mifroftopifder Ifflangen werben febr bänfig in das siöpergemebe bincingetrieben mo fteffen Dann an irgent ciner Etelfe in ber gaflettartigen Enb= fanj. Merift zeigt fid ein beller Erafenartiger bof un biefe in bas

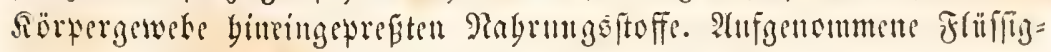
feiten bifoen eiuen belfen Grafenartigen Troffen unb bänfig gewabrt man, baß nabe ftebende Tropfen biefer Strt in einanber flefen, sin

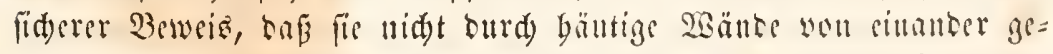
trenut find. Beim rebgaften freffen vou Snfujorien, weldse range ge= bungert baben, erfdesint ber Rörwer oft ganj angefillt mit fordent Rabrungefugetn nno went man Gorige trägt, verfdicbene Farben nadeinauber zu fïttern, fo fiebt man leidyt, sab bie betreffenben Farb:

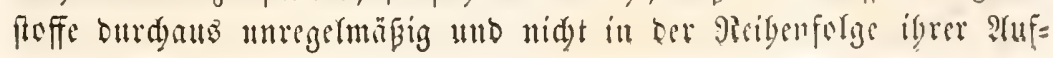


Mabue burd) ben Rörper vertbeift fiub. Man batte geglaubt, ricfe

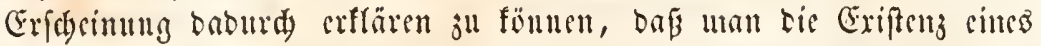
Darmfanales annalym, von weldem geftielte Magenblafen berabbin= gett und man batte fogar uad gewiffen angenommenen Formen ciuco nid)t worbandenen Darmfanales bie Snfüionstbierden in Drounngen zerfällt. Dian bat fid) jekgt liberzengt, baßi man bierin wiel jul weit

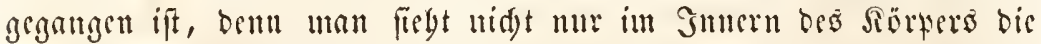
Pabrumgstaflen bin unb ber fid, werfdyeben, fontern aud) bei man=

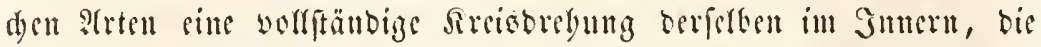

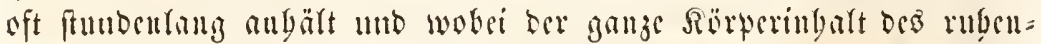
ben Thieres fid) ftets in berferten Rid)tung langfan mu bie Sïrteraxe

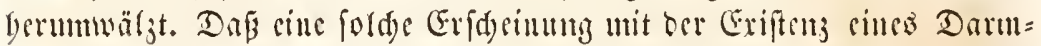

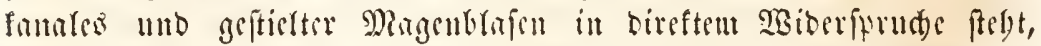

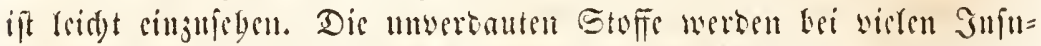
forien Durd) ben Plut wicter nusgeworfen, bei antern butd) citte

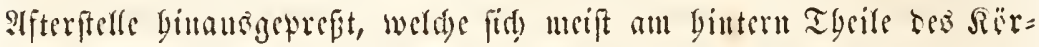
peris fefinbet.

In bem Sïrper affer Snfuforian fubbt man bei gennuerex lluter=

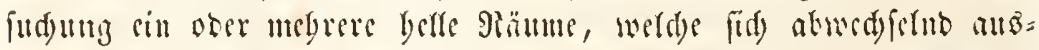
bebuen und jufammenjieben, ater feille eigene 2 Bantungen ju bejitzen

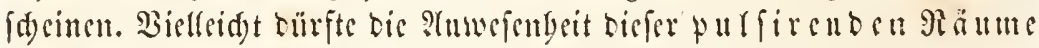

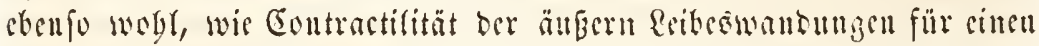

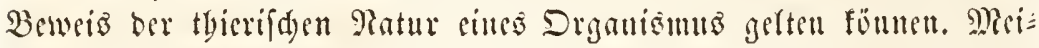
ftens fund bicfe Räume rumb unb juweilen in folder 3agl vorban=

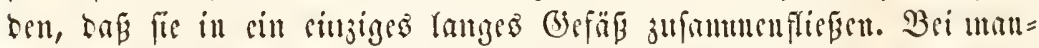
d)en Battungen erfdyeinen fie in Geftalt vielftrabliger Sterne mobei

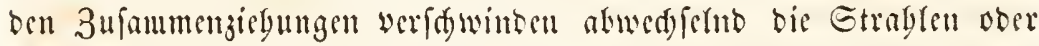

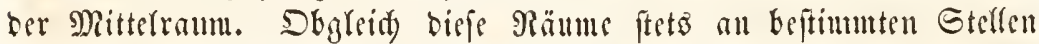
wiebererfdeiten, fo fint fie tod) fider wanbungstos, ba man bei bef=

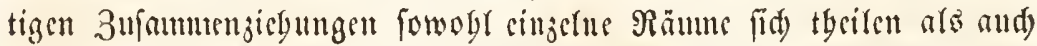

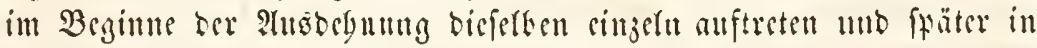

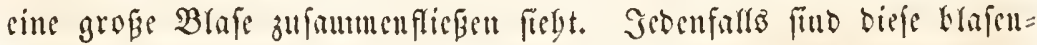

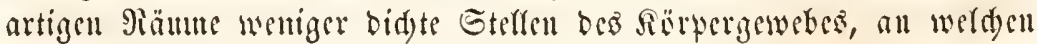

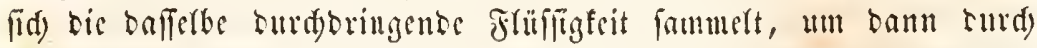

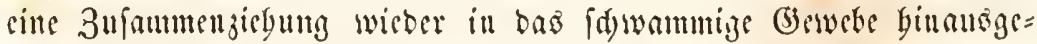
trieben zu werben, fo bab arfo biersurd sine erite, wenn and) göd)ft

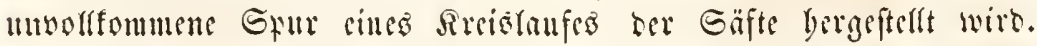
Bielleidyt aud baben biefe contractifen $\mathfrak{B}$ lafenräume sine frine Deff=

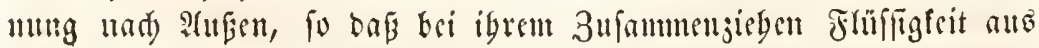

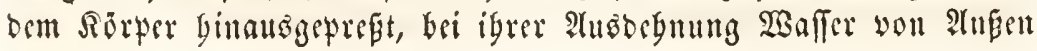




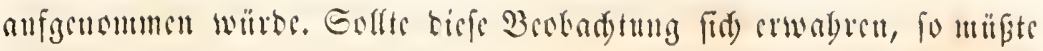

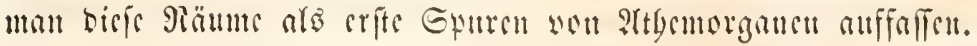

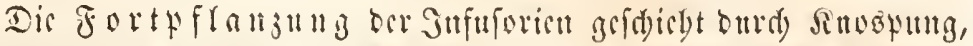

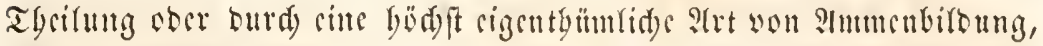
welde inber mut bei wenigen Gattungen mo and bied nidet ganj

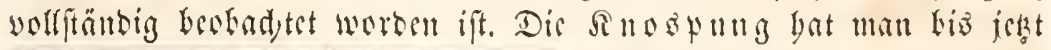

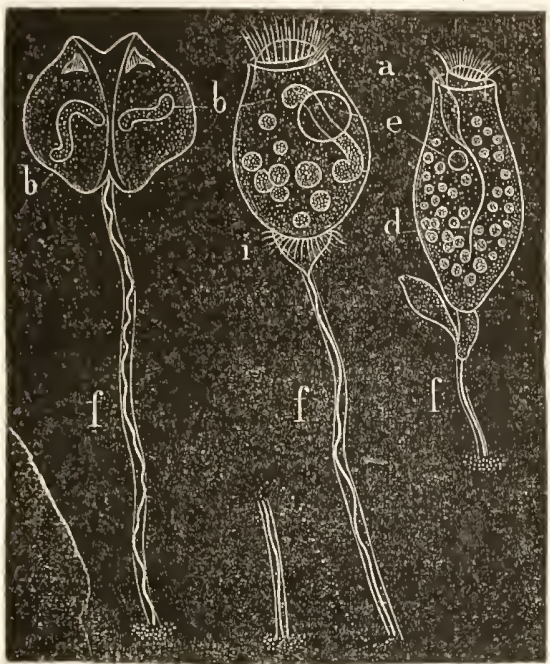

Jig. $51 . \quad$ Jig $55 . \quad$ 5ig. 56.

(B) vofentficterten (Vorticella), bie fith burdi Theidung uno Sito fiturg furtpflatijell.

Das Thierthen Fig. 54 ift chen in ber

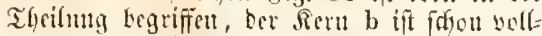
fomment bopteft; Fig. 55 mill fid bon feintm Sticle loshrien; Fig. 56 fildet an Der Bafïs Dez Etieles cine feitlidye Rnusue, bie nod) unt= wolfomment if. $B \mathrm{Bei}$ allen breien ift a ber Muto mit ber Dimperfrone, b ber Sern, d bie gefülten magenhlarm, e bie contractile Blafe, f ber Stiel, i bor accefijurifoce DSimber=

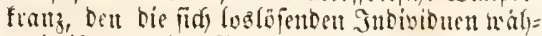
rent ifrer freien Bemegliofeit Gaken.

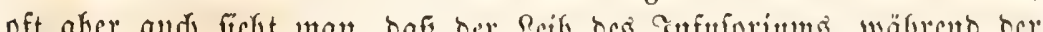

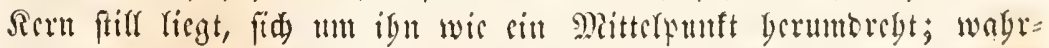

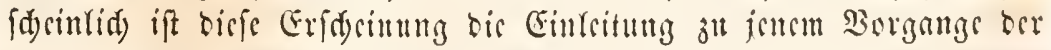

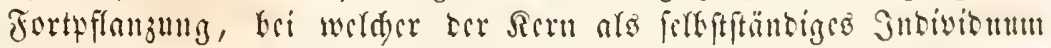

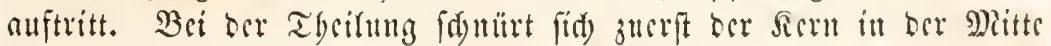

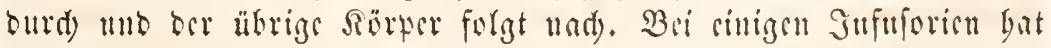
man Kio jelzt un Rängstycifung, bri anbern Encrtbcifung, bri an= bern beibe 2lrten ber Jortpflanjung jugleidy Feokadtet. 


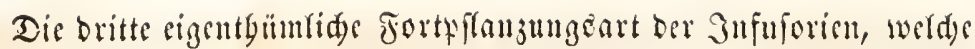

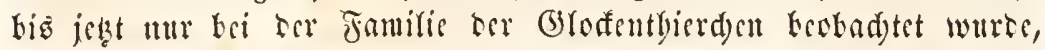
werten wir bei bicfer näger betradten.

Dis Sufuforion finten fid jumeilen in gröferen Maffen zufants

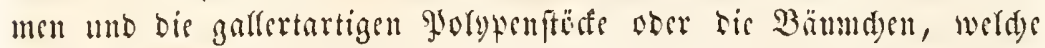
sinige Gattungen bitbon, fint fo gró, ba

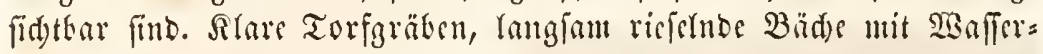

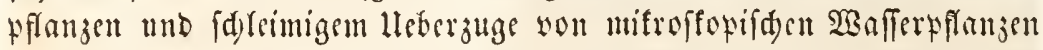
auf Dem Grunde und an Den Esiten, Sagferfüben und Mecrlinfen,

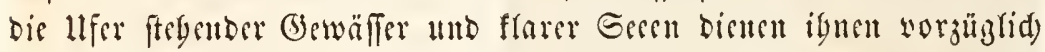

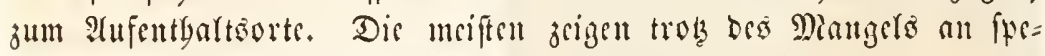

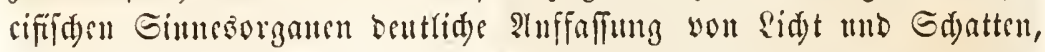

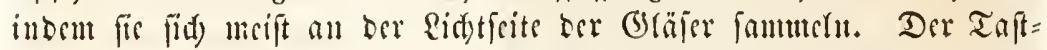

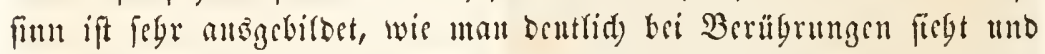
ebenjo erfadenten bie meifen bicfer Tgacre fegr wäglerifd in igrer Magrung, bie fie çำ

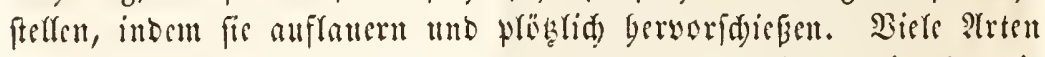
rebon gefslig in groben Sd)wärment andere megr versingert; bic Sd)maroker wiffen fobr gut, Gefonders wemn fie fid an ber stufen= flädye nuberer Tgicre feitferęen, bie Gtellen zu wäglen, wo diefe fie

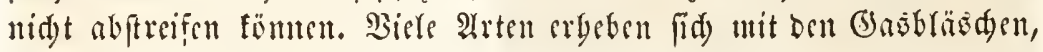

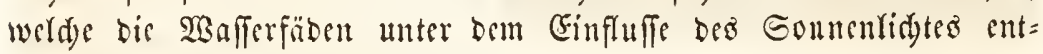

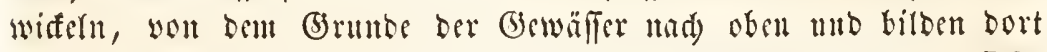

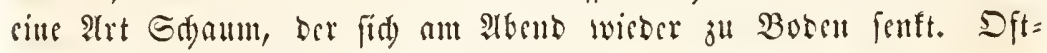

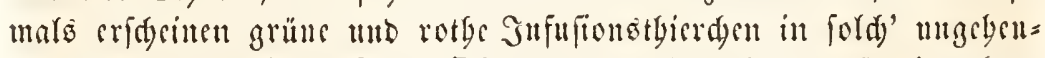

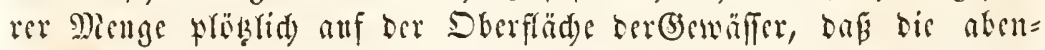

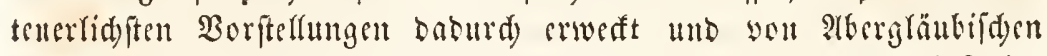
mud gy faffen nad) ifrem Ginne ausgebentet wurben. Biele Snfuforien

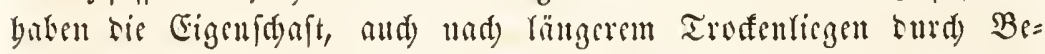

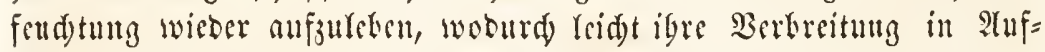

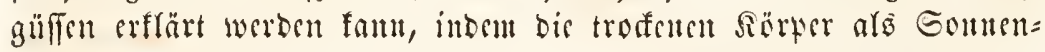

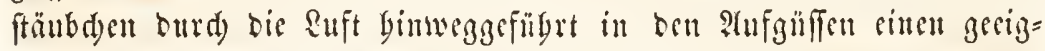

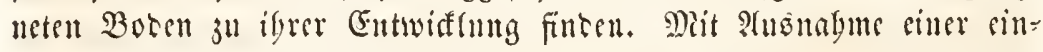

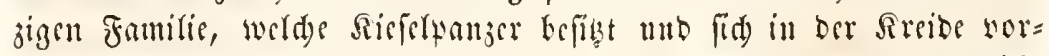

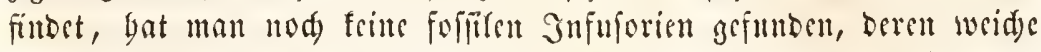

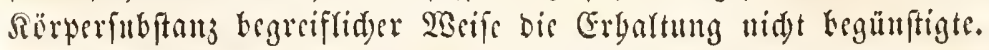

Die Eintbeilung ber Siraffe Eer Gnfuforien erfdseint ans jweierlei

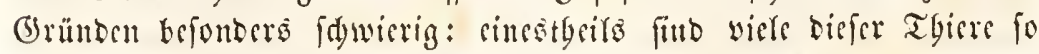

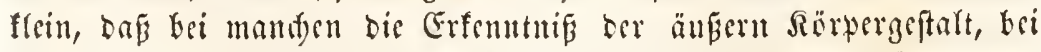
alfen Diejenge ber feineren Struftur igrer Drgane an ber Grenje ber Bergröß̨rungstraft unferer beften Mifroffope ftrgt, unt baun bält 


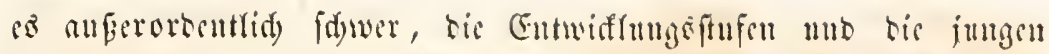

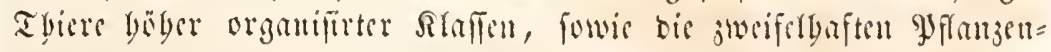

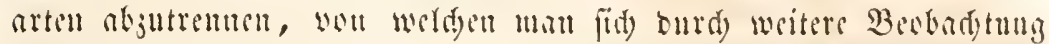

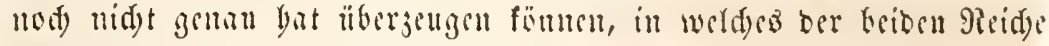
fii gryören. Radbem man ans ber Silafie ber Gufuforien, wie fie ber

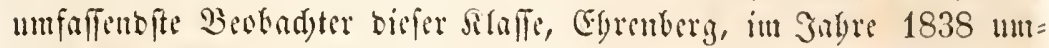

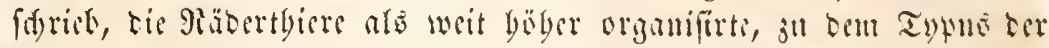

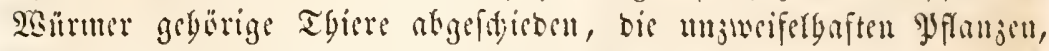
wie bie Closterinen, Bacillarien, Volvocinen abgstremut bat, fo blsi=

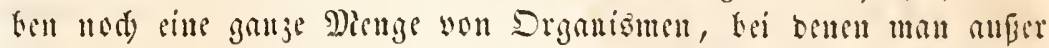

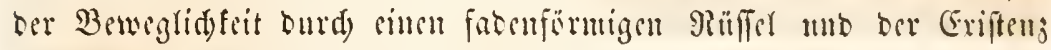

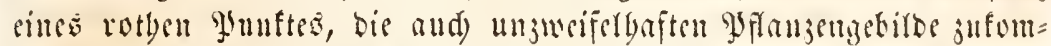

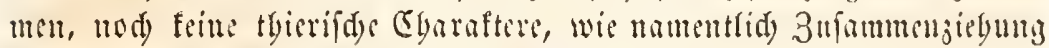

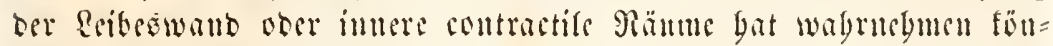

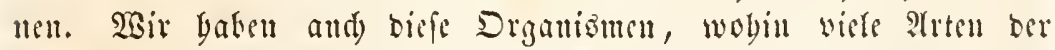

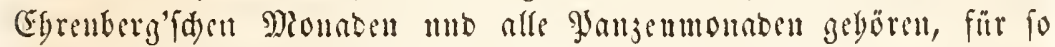

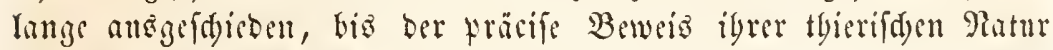

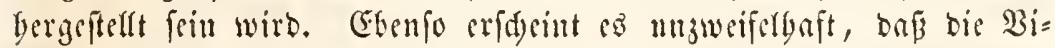
brionen ober Bitterthierden theilweife beweglide Sdjimmerfäben, theil=

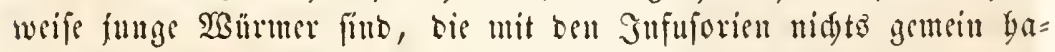

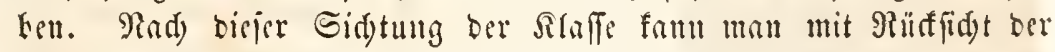
Berbaung

Die erfite Drommg, bie nundolen Infujorien (Astoma) um=

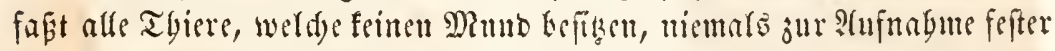
Rabrungènittel gebrad) werben fünen und fidd entweber burd) eincu peitfdenförmigen PRüffer ober Durd) Sisimperorgane fort bewegen. Dic

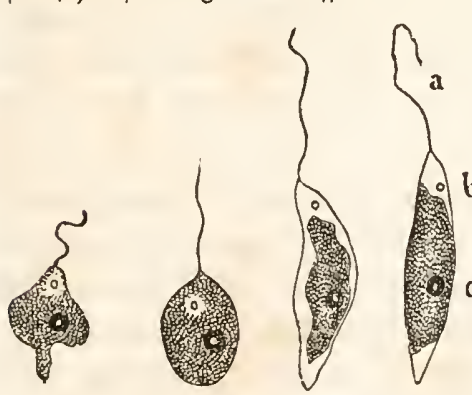

Fig. 57-60. Euglena viridis. Familie ber 2 (enocrlinge (Astasida) geidenet fid) burd) sinen äuferft contrac= tilen Sïrther, meift you grüter ober ros tyer Jarbe unt ränglidjer fpinderfërntu= ger Beffalt aus, werder bei ben eigont= liden Aenderlingen frei ijt, wäbrent bei c ber llnterfamilie ber gepautzerten $\mathscr{A} e$ t $=$ berlinge (Dinobryida) sin bornigrş

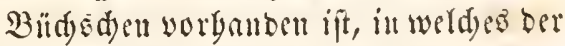

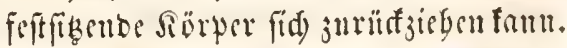

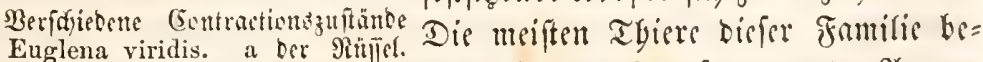

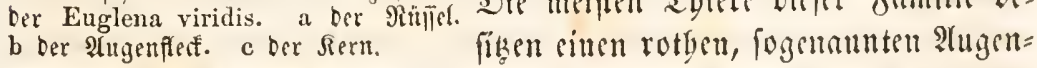
punft, nur ben 2 entoerfingen und ben 5ermentbierd)en (Epipyxis) gebt berferbe ab. Gine Gattnng die 2ingentbjerden (Euglena) mit fpinder=

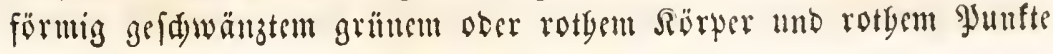




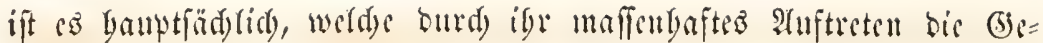
wäfer grüt ober roth färbt.

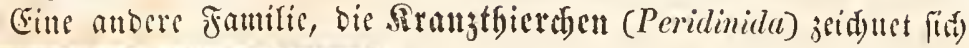

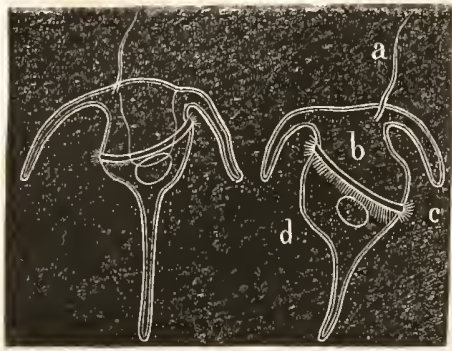

Jig. 61. Peridinium

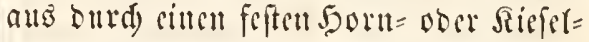
franger, der juweilen in fonberbare bormartige Gpiken ausgejugen ift. Die= fer Mranger bat sillen querell ober (d)ie= fen Sfalt, ber won sincm Simperfranze ansigefüllt ift unb anzerbem nod in friter kewegenton Thätigfeit won rillem fabcuartigen Riulfer unterftübt wirb, ber an siner bejtimmten Etelle bes Janjers

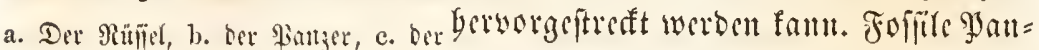
2Rimperfrant, d. Sor תernt. jer biefer jamitie find zwar in oen Fenerfecinen entoeft morben, illocflen butfte bie therifde Ratur bicfer Rörper "̈berbanpt nod) ftarfin 3weifern unterlegen, zแmar ba jwei wou Egrenberg an biefer Familie geftelfte Gattungen, CChaetolyphla un Chaeto -

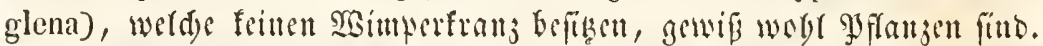

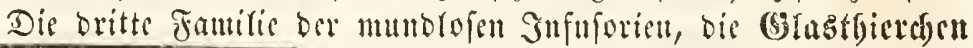

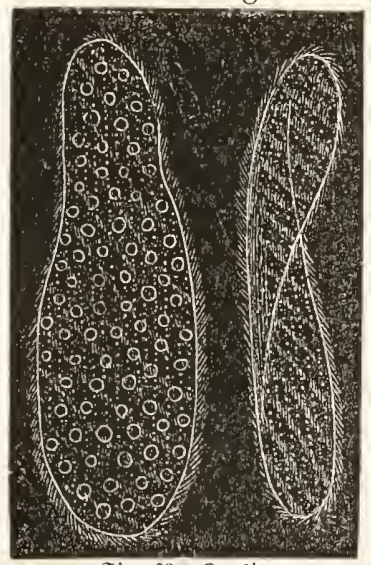

8ig. 62. Opalina.

(Opalinida) fint bis jelst nur ourd) arten befantht, weldse alo Ed)mareker im Darme won Jröfden unt Shattwitumern leben. Gis be= fizen nut $\mathfrak{x i m p e r o r g a n e , ~ b i s ~ i n ~ g e r a b e n ~ 9 i c i = ~}$ ben anf bem ciförmigen platten Sïrper ftelen and mittelft beren fie fid) Yangfam in bent Darmidrume mmberwälzett. Da bas Thier= d)en volffoumen bureflidsting nut farblos ift, fo bat man fid mit Giderbrit von bem Feblen cincr Mlunböffumig Z̈bergengen fönกาก.

Bei weitem zablreicher an werfdedede artigen formen ift bie Sorbmug ber munt =

fübrenoen guruorien (Stomatoda). Bei allen formen ift cine wabre, wou Soimpern umfefte Munbeffung vorbanden, welde bie Alufunbme fefter Rabrungsefteffe geftattet. Die erfe Fa milie, bie ber Mlonaben (IIonadida), beftelt aus Eleinen runbliden

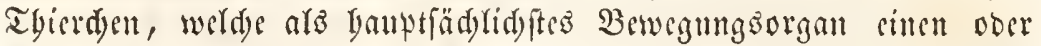
mebreve ritferförmige 2Antyänge befitzen unt anberbent cine beutlidye, fegr feill bewimperte Munböffum!g zcigen, ourd) werde fefte Rabrungs: ftoffe alfgenommen werben, bie man im Gnuen als rumbe Futter=

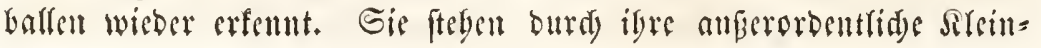




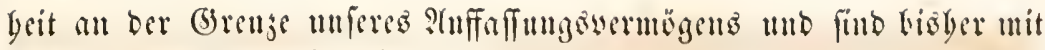
einer Mienge won flanjliden Gefirben jufammen gemorfen worden.

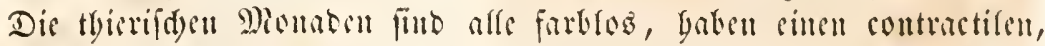

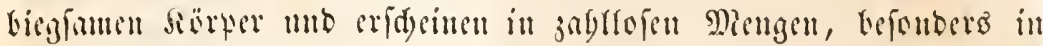

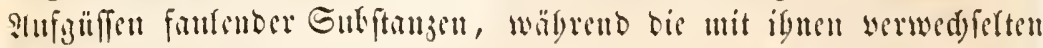

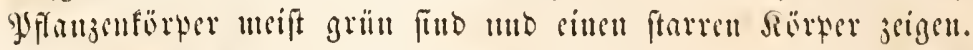

Eime göt)ft merfwübige Fumilie ift Diejenige ber (Gloctenthierdsen (Vorlicellida), bic man wieber, je nad) bem fie frei fund ober in

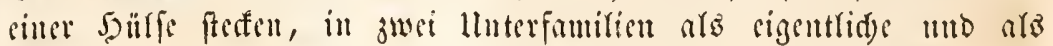
gepanjerte (S)lodenthicrefen (Ophrydina) eintbeilen fant. Stle biefe Thierden baben eillen mebr ober minber gloffenförmigen Sörper, ber meiftens anf einem längern ober fïrjern Stiele feftifizt. Nur bie Trompeteutbierden (Stentor) und die ll rentbierden (Trichodina) mad)en biewon sinc Stmšnabme, intom fie nuf feinem sigent=

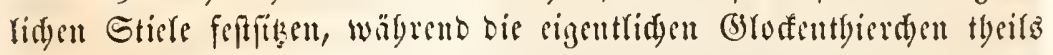
ciufam, theits in Jorm veräfterter Bänmd)en anf Stielen fteben, tie bafo ftart find, balo and) burd) sinen im Innern angebrad)ten Mlns: fel, seffen Faferftuctur beutlid) ift, fduellend jurihfigengen werben

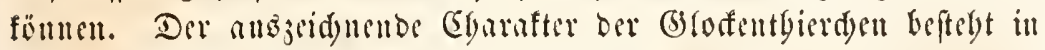
cincm an Dem sorbern Raube Des Sïrpers angebradten frimmer= frume mit verbäftnifmägig langen SBimperbanen, ber nad) SEilfiilyr

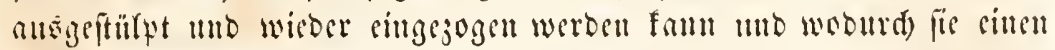

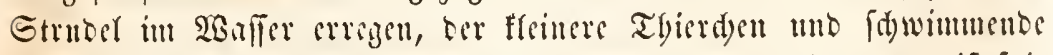

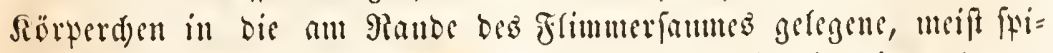

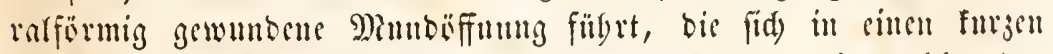

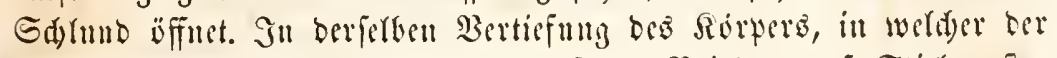

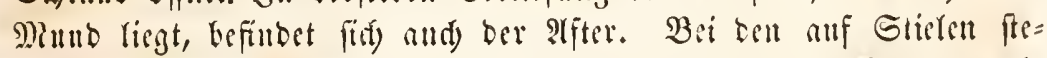

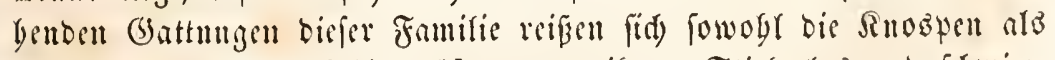

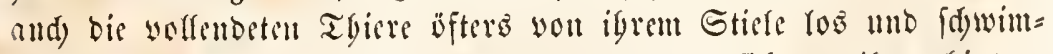
men mittelft cimes jweiten Scimperfranzes, oer fid an igrer bintern

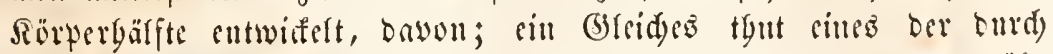
Tgeilung entfintoenen Jnbivionen bei ben eitfamen Gattmigen, wäb= rent bei ben bammartigen Gloffentbierden die lieblidyen Formen baburd) entfelyeu, baf bis getbeiften Jubivionen mit mebr ober minber langen Sticlden auf bem gemeinfament Stanme fteben bleiben

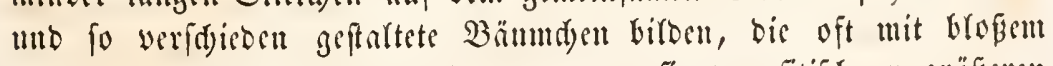
Inge fidsthar find, befonbers bann, went fie parafitifs an grëgeren Salferinfeften angebeftet fub. Rad) ben verfdjebenten gefelfigen Jor men mob ber Patur bes Stieles bat man befonders bic einjelnen (B)attungen unterfdieden. So baben bie sigentliden (3) fofentbier= d) en (Vorticella) einen langen biegfamen Stiel, anf beren jebem mut sin 


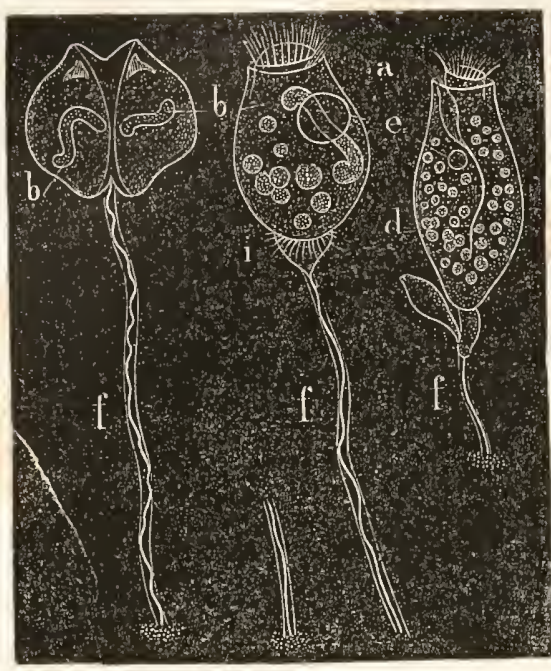

vig. $63-6 j$ vorticella.

cingelnes Tbierdyen fitนt, während Dic (G) chesium) gemeinfam anf seräftel= ten, biegianten mith fidnellenden Etielen firsen. Bei ber grringiten Erid) ütterung zielon fidy bis Eticle mit Blizesfduelle fribalfürmig (d) neflend jufammen, was ber in ifrer 5öblumb befindride faren= artige Mitste tewirt, wäbrento 3ugleid) ber Saimpertranj silige= jogen wirb. Bei eillet alloern

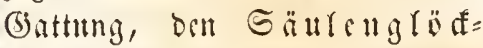
d) en (Epistylis), ift ser Etier ftark Into bas (bröadden wirft (iid) bei ber 3 manmenjiebung mit cincm pröklidyen Ruffe binten

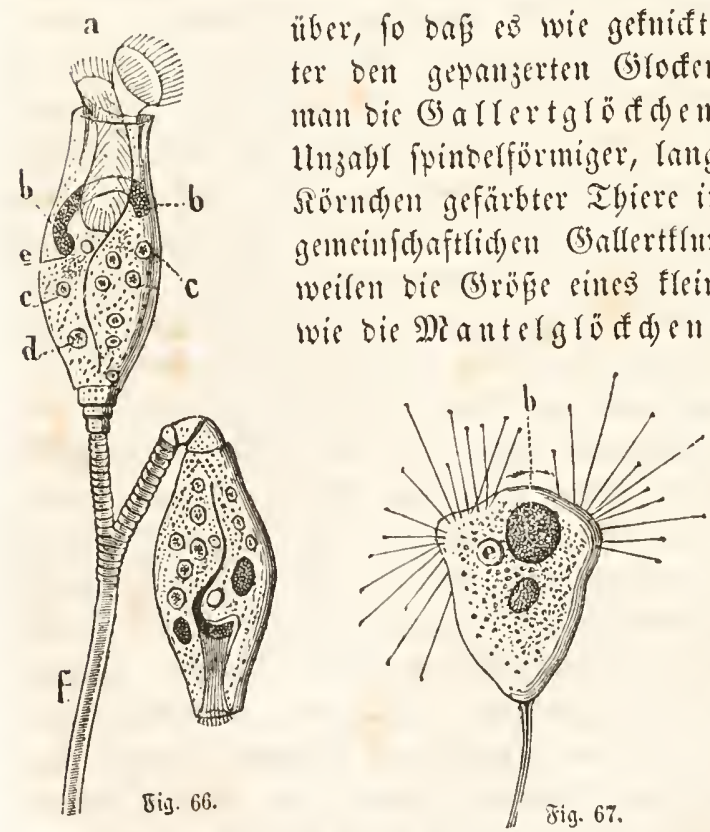

Epistylis nutans.

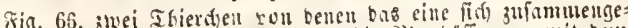
anen gosent, antanenblaien. Il her Edalumb. Wimperframe. her Ror Etiel. Jig. 67. Die Acinetenfurm e bie eontratife B!aie. f ber Eliel, Jig.

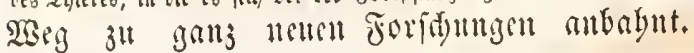

garb borniges, meijt flafd)enförmiger $B$ Bid () en eilljerln anf ysflanzen und Thieren anffiken. Die Beofadintungen Ier neneiten Zeit baben bri ben (Broffentbierden (Vorticella), ธen Gäแ= lenglöfd)en (Epistylis) und ben Miantelglö:= den (Vaginicola) eine ïbereillitimmento att het Forttfonjung $\mathrm{er}=$ fennen laffen, weldye ben Det Rouper differ 


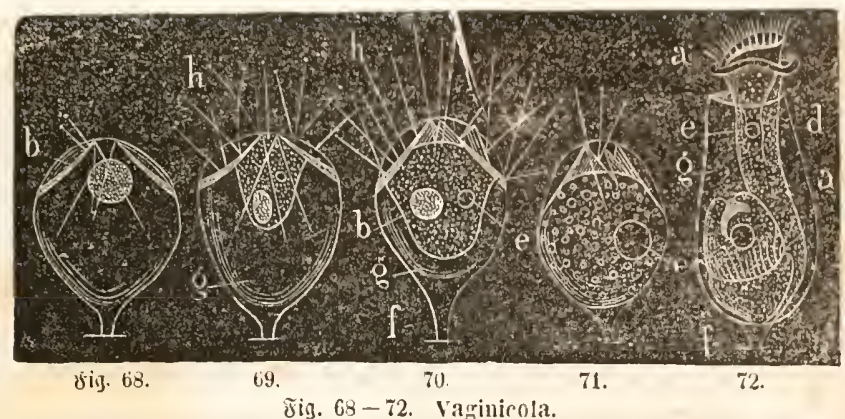

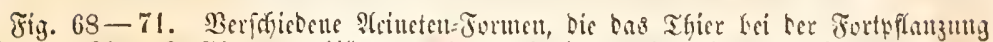

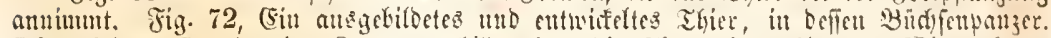

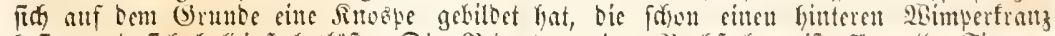

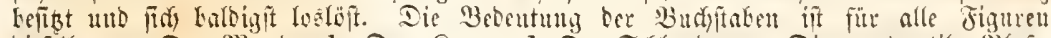
biejelte, a. Der sllumb. b. Der Sert. d. Der Edflumb. e. Dis contractile S3laje.

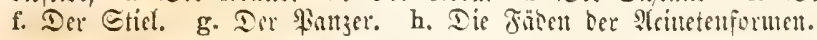

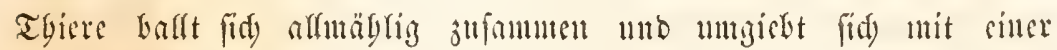

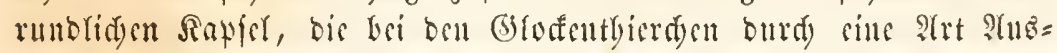

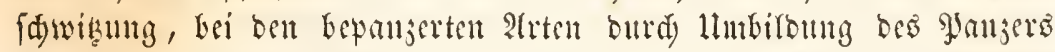

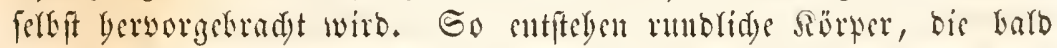
ftiellos, balo gefticlt finto thto int Junern siner glosartig burd)fictiti= gen beülle ben jufammengefugelten Reib tes Thieres entbalten,

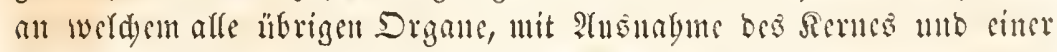

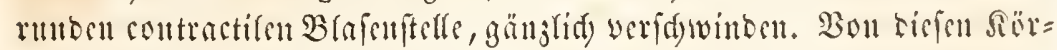
pern frablen rabienartig Fortfäbe ans, welde fid äbulich serbarten, wie bie Fortfäbe, mittelft beren fid bie gibizopooen bewergen, in Sin̈pf=

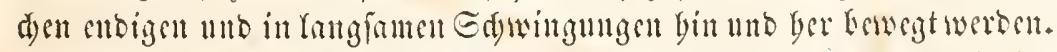
Sn bicfer Form, welde wir bie 2 c in et en= Form nemen, bat man bis cin=

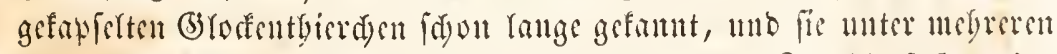
(5attungônamen, alş Sounentbicrt)en (Actinoplrys), Strablenfuß (Podo-

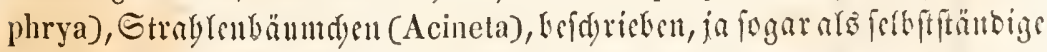

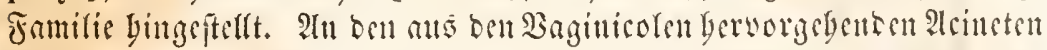
bat man mun fermer beobadytet, onf ber Sern alfmäblig foürfer ber= vortritt, wäbrent bie Fäben jul f)winton anfongen. Der Sern cut=

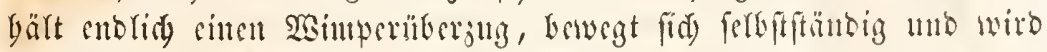

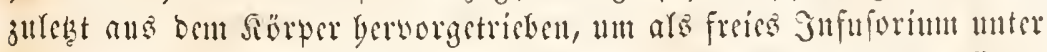

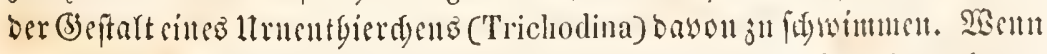
aud) bicfe Beobad)tungen nod) ber Beftätigutg bebinfen, fo gebt bod) we=

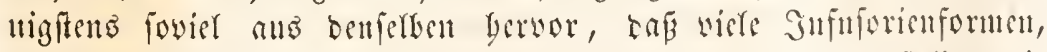

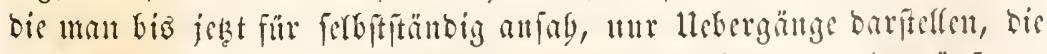
bei genauerer Berfolgung igrer Entwiffelung mit antern ber äuberen

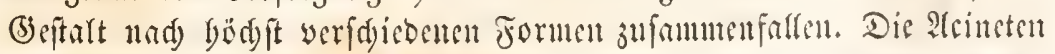




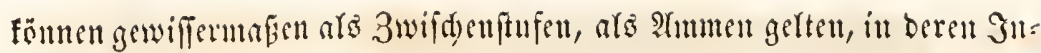

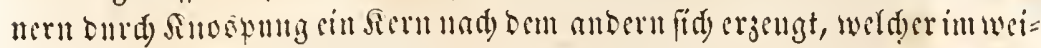

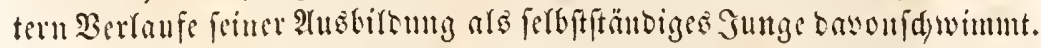

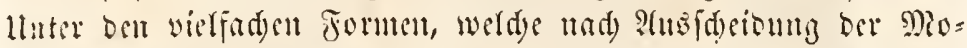

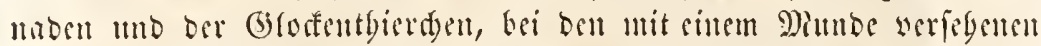

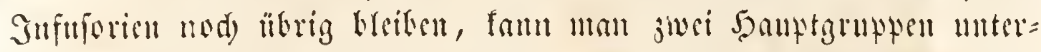
fdsciben. Dis cine, bie grofie jamilie ber Satartbierchen (Trichodida)

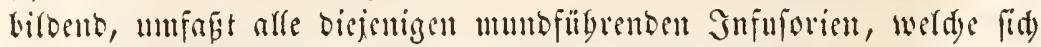

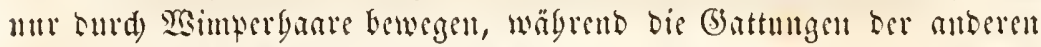
Familie, bis Borftenträger (Selifera), auß̧erben nod) Boritten, Safent

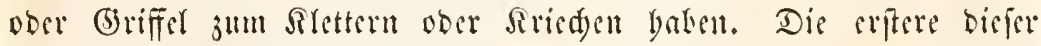
grofen Fanirie faun wieber in folgento llnterfantifen jertegt werben:

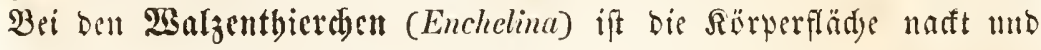

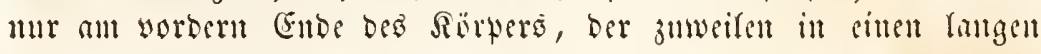

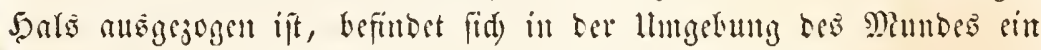

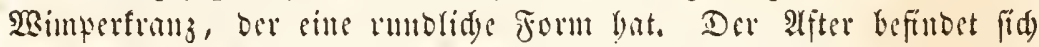

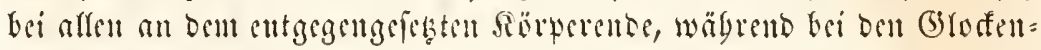

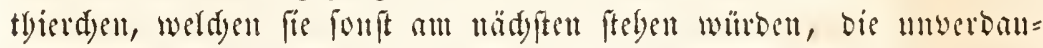

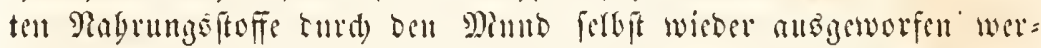

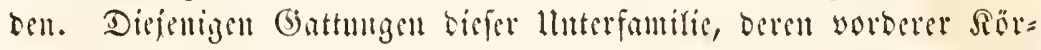

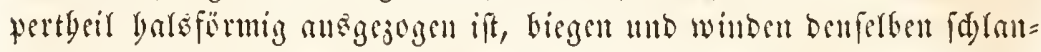

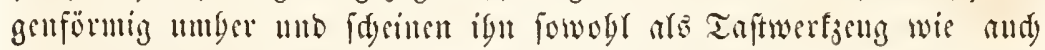
jut Bewegnnty 3u kemusent. Lacrymaria; Trichoda; Enchelys.

Bei einte jwriten lluterfamifie, ben $\mathfrak{g a t s t h i e r c h e n ~ ( T r a c h e l i n a ) , ~}$

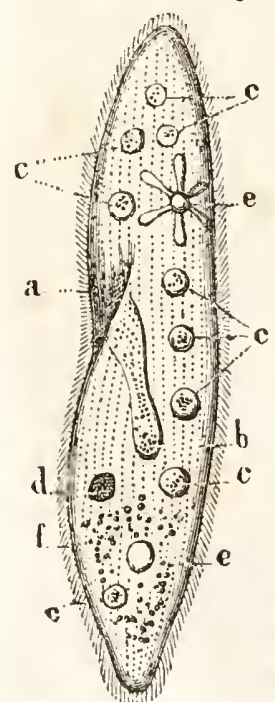

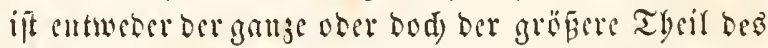

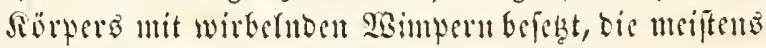

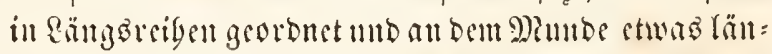

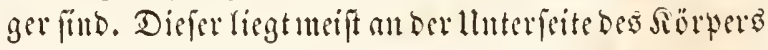
in sinem längliden Spafte unter einer megr oder minder ausgebirbeten Doertippe, weldye juweilen baräntig ober zungenförmiz geftaltet ift. Der 21fter befindet ciit) bato an bem einen (sube, batb etwas feitlid) ant Dem Särwer. Trachelues; Loxodes; Bursaria; Pard= meciun, Kolpoda. Sime britte llnterfannifie, bie ber

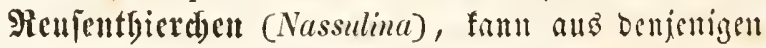
wimpertragentoen formen gebifbet werben, weldye cinen renfenartigen 3aynapparat befizgen, ber ben Gint= gang LeB Edflundes ungibt; aud bier bat man nady ber Steflnng biefer 3alymenfe, bie Gald ant vorbern Erttoe, balo in ber untern Flädye ferbt, mels= 8is. 73. Paramecium. rere Oanttungent unteridjieben. Nassula; Prorodon, 


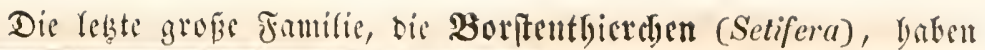

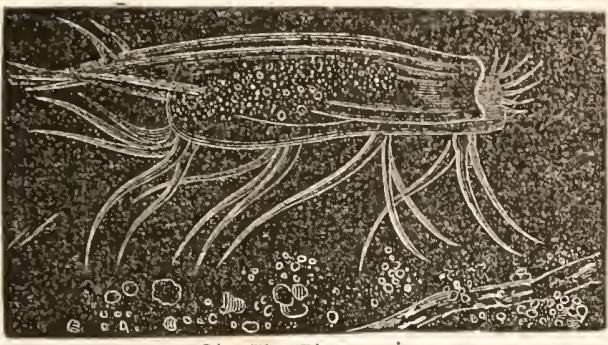

Jig. 74. Ploesconia

wou fer Eeite gejefret, wie fie ant fen 2 and $=$

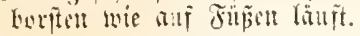

silte megr ober minber afge= glattete bieftalt und auf ber unteru gräd)e bes Rörters, anfer ofu sismpern, welde in ber Nimbrime entwifelt fuib, Boritul ober Saafell zum Sirieden und Epringen anf feiten Gegenftänden iut 2 Bajper. Miunb unb 2lfter befituben fids ftetó auf Der Banduftäd)e bes Sïrwers, juweiten nage Lei einaner in eitter frattörmigen Rimte. Dan fan unter ínen bie cigentrid)en Sed)etthierd)en (Oxytrichina) (Kerona; Urostyla Stylonychia) mit meid)em biegfamen Sïrwer, bie

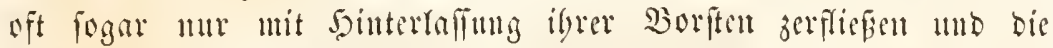

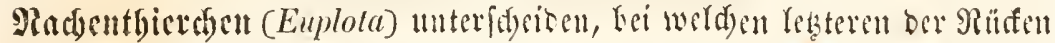

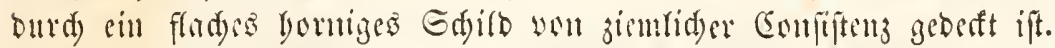
Chlamidodon; Euplotes.

Die Berbreitung ber Gufufunstbierthen anf ber gefammten Eroe

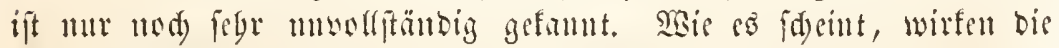

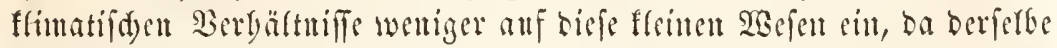

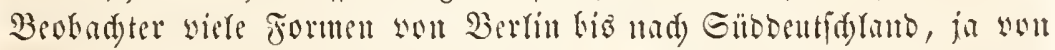

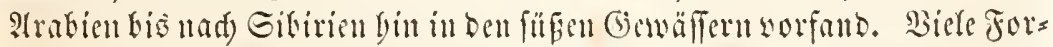

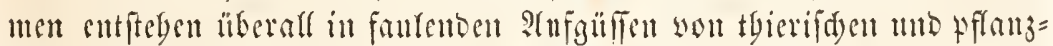
riden Stoffen, nad) ber irrigen Bebautung Einiger burd) llizengutg, nad)

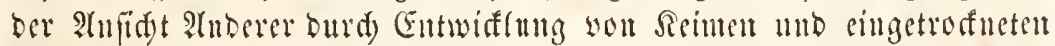
Sïrpern, dic im $\mathfrak{B}$ affer wieber aufleben. Die Bermebrum vieler

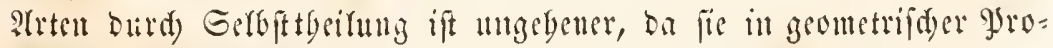
frotion juniumt und jebes burd) Theilung entfanbene Gubivibum

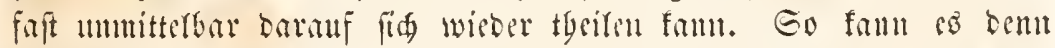

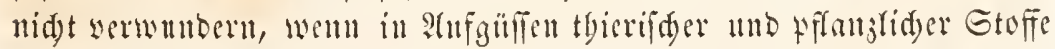

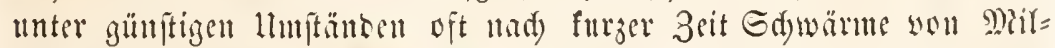

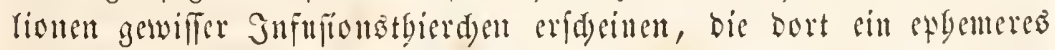
Dripein fübret.

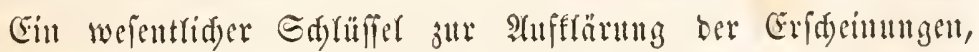

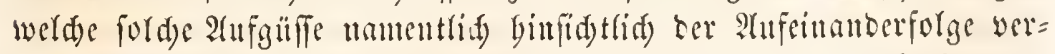
faiebenet 2 rten geben, bürfte in ber Berforgung ber Beobadtungen liber bie Entwidelung berferben liegen, indem frerburd) fitherlidy it:

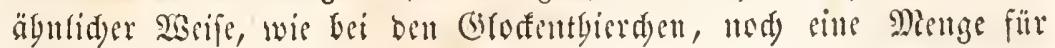




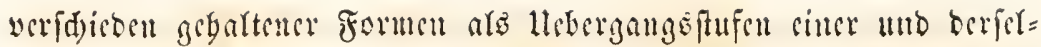

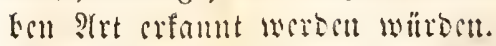

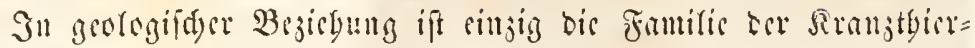

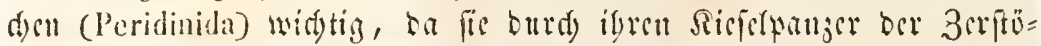

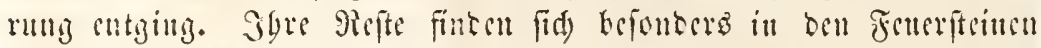

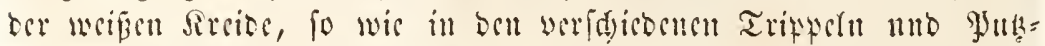

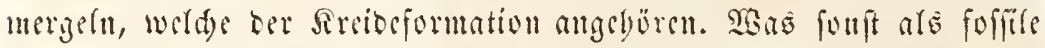

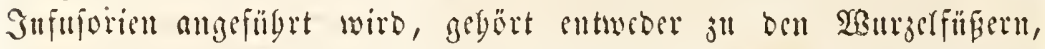

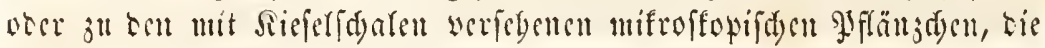

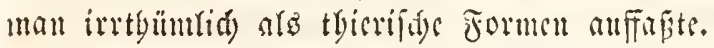

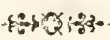 \\ Ciebenter Buref.}

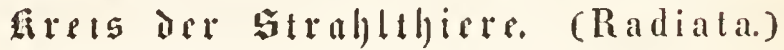

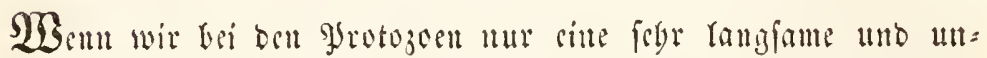

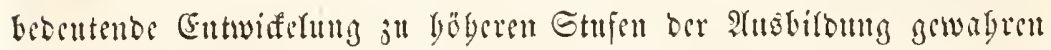
founten, fo gibt fid im Gegentysile unter ben weit juffreidgeren

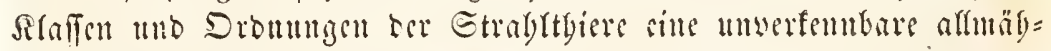

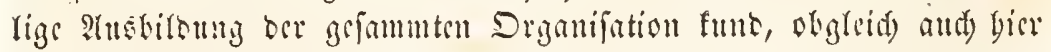

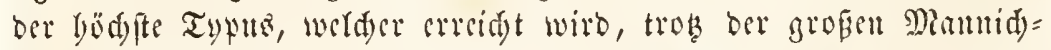

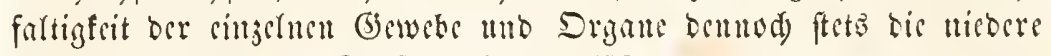

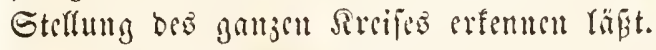

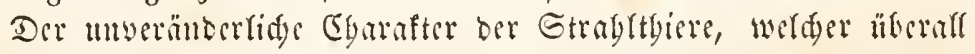

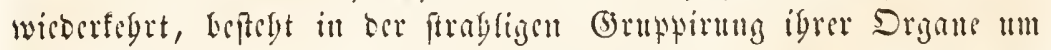

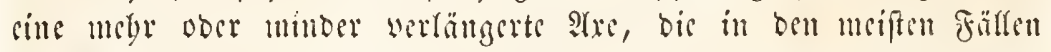

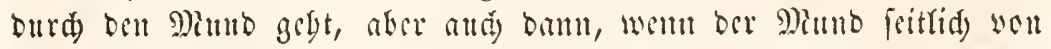

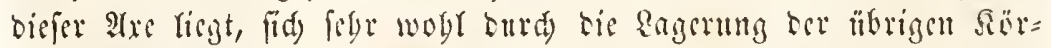

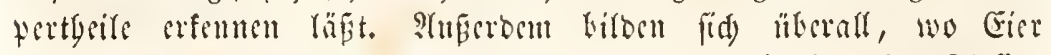

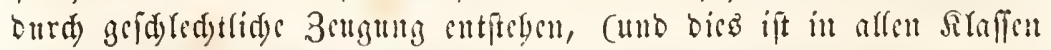

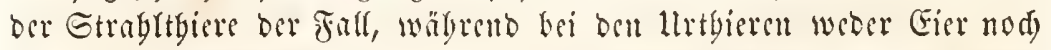

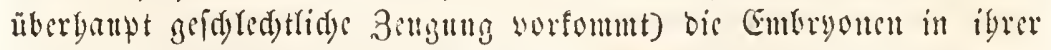

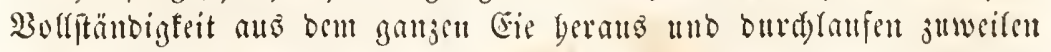

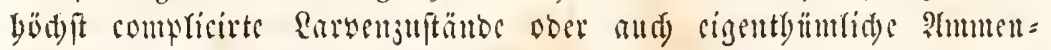
generationen. 
Die Sïrperfurtifanj ber Gtrabgthiere tritt bei ben nicberen Typen

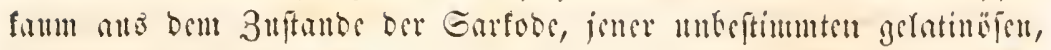

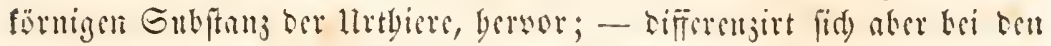

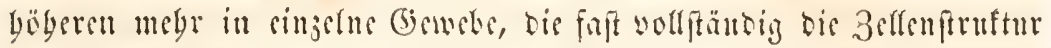

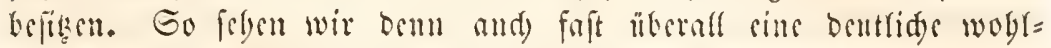
d)aratterifirte äแ fdectbar ift uno bei ben Gtaderlyäutern sine wabrgaft reberartige Conliftenj geminnt, wäbrend fir bri ben übrigen Sifaffen birfes

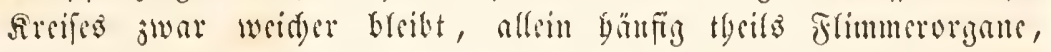

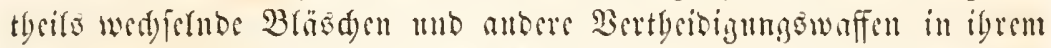

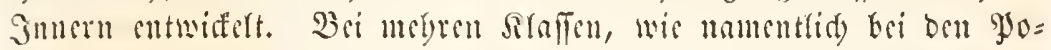

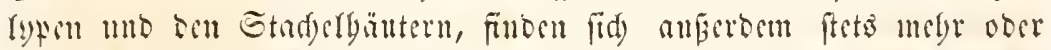

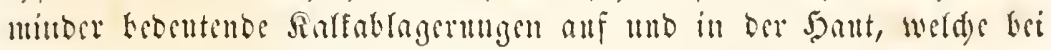

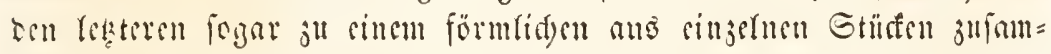

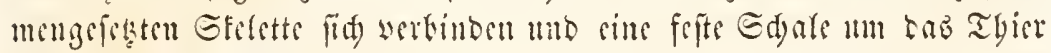
bitrell.

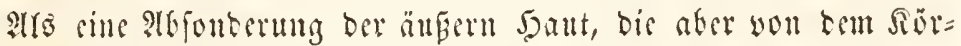
per megr getrentt ift, foum befonbers bei ben glorysen unt Suaflen=

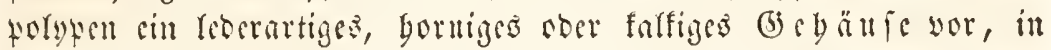

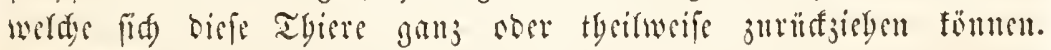

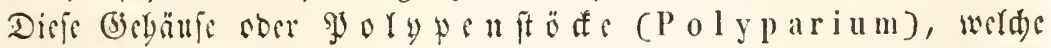

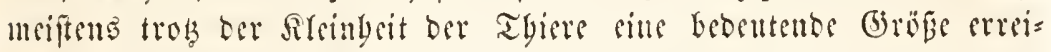
d)en, ba Milfionen Gnoivibuen anf bemferben Stoff organifa mit

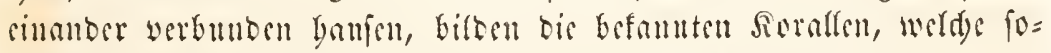
wobl in jesigen als in frillyeren geologifden (Epod)en sinen werent=

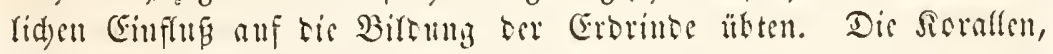
fowie bie Gdyaren Der Gradergänter find in Gejonbers bebententer

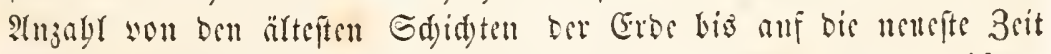

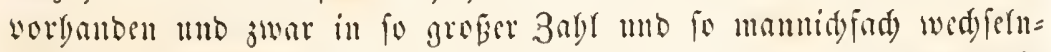

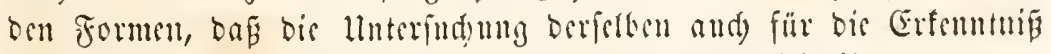

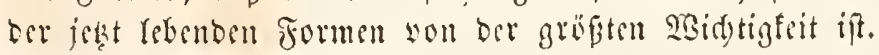

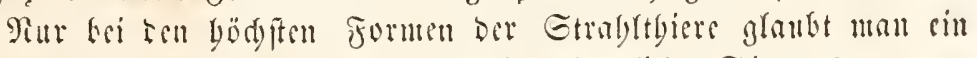

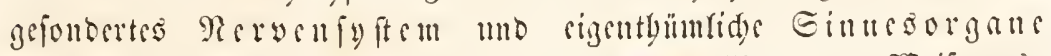

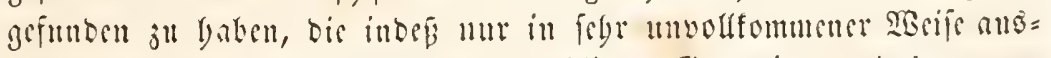
gebifbet erfdeinen und an oer ftrafligen biruppirmug dos ganjen

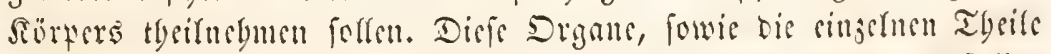

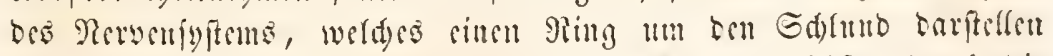

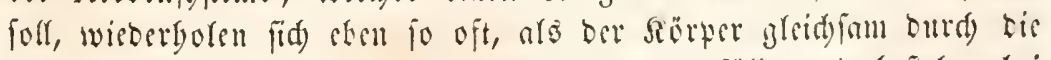
frrablige Antorbumng in eingefne Gegmente zerfällt, unb beftelyen bei

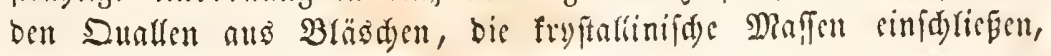


bei ben Stad)erbäutern aus cinem fnotentofen Sdylubringe unb gefürbten Jigmentbafen an beftimmen Sörperftelfen. Die Bewe= gu

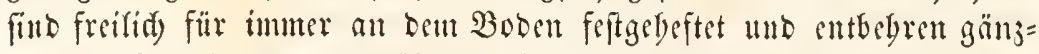
(id) Der Drtóbervegung, wägrend fie fid) mit gröpter sebgaftigfeit ju= fammenjeben und aubbegnen föunen; andete aber fried)en mto flet= tern, theile mit bewegliden Stad)ert, befonders aber mit sigentbüm= liden Gaugröhren, die fie gleid, 3ngleilen jur Fortidyleptung bes Sïrpers antwenten. Biele entid) fdwimmen frit untyer, entweder

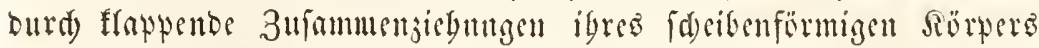

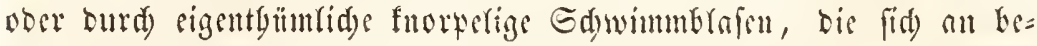

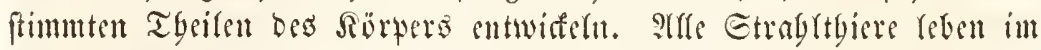

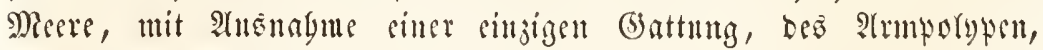

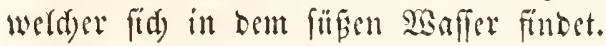

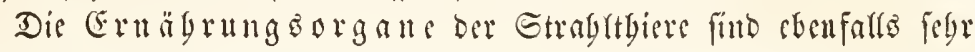

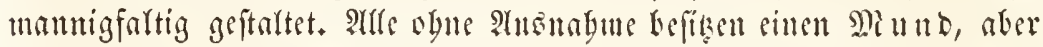
unt bie wenigften einen After, ber bam meiftens in oer Ale bes Sörpers, bem Miunde gegenitber liegt. Bei benjenigen, welde feinen Sfter befizen, werben bie unverbauten Epeiferefte Durd) Den Minto wieber anseworfen, wäbrent bie aแs ber Speife gewonnene Rab=

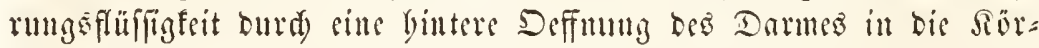
werböble libergegt und fo bei jufammentgefesten Stöfen alfen Gubi= vibuen, Die an Der Rolonie tetbeiligt find, ju Gute fömmt. Bat cint= gen Sattungen Der Strabltbiere findet man fratt cincs einjigen Munoes viele fleime Definungen, welde Durd Röbren mit einer meift fely ge= rämmigen Serbaungggöble in Sertintung fteben, won welder ans bann wieber Röbren nad) allen Geiten bin ausfrablen. Mrcift find in oer llngebung bes Mundes eingieblare Fortiäbe, fïbler ober Tentafeln, in sincm tridyterförmigen Sranje anfgefteflt, bie zum Einfangen Der Rabrung Dienten. Bei cinigen Gtad)ebäntern bemerft man jogar einen äแ ferft eompleirten 3 a buapparat, ber jum Ranen Der uneift vegetabilifden Rabrung bient.

Rut bei ben böbern Typen Der Etrabltbiere fommt ein foldaud)= förmiges 5er jor, weldes burd) feite 3ufammenjiebungen ben Rabrmugsfaft in bem Sïrper umbertreibt. Bei ben nieberen Typen

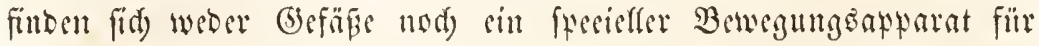
Den Rabrungefaft vor, welder indeffen entweber burd SEimperorgane ober Durd) Die Contractionen oer Reibesmant in Sörper unt in Den Zwifkemräumen ber Drgate bin und ber getrieben wirb. Soierju foumt bann nod) in einigen Rlaffen sin Syftem won giöbren, welde 


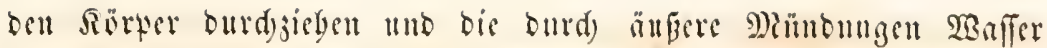

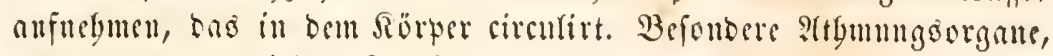

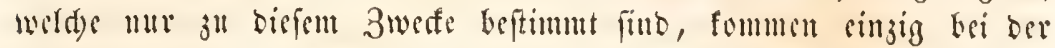

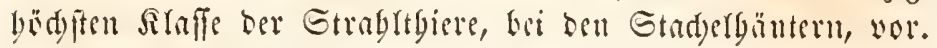

Dic Foltpfranjung mo Entwi felung oer Etrabltbiere ift theifweife erft in ben neneften 3eiten mo and) bier in wieler $B$ ezis=

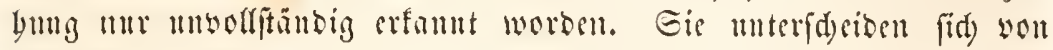

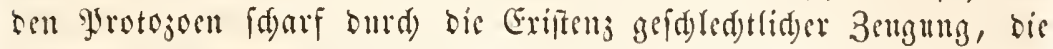

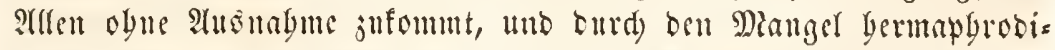
tifder Birtung, befonbers in ben bïgeren Sitaflen. Faft alle Gtrabls

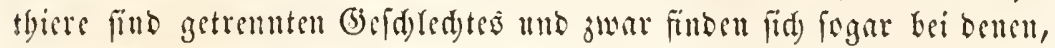

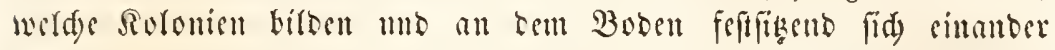
mid)t mäbern fümmen, bie (befd)led)ter meijt allf verfdiebene Gtöde sertbeilt, fo Inß Gier bie Befrndstung ber Bermittlung ber Baffer=

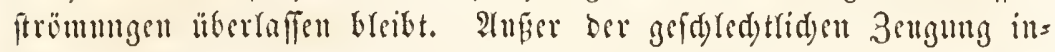
beflen foumt and bei allen gefellidsaftid) lebenden formen, wie fids

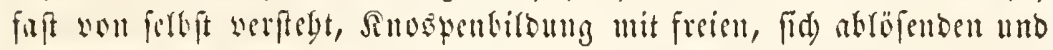
mit feftifienoen Sinosten vor. Eime ganje Silaffe, die tor Duallen= folyten, jeidnet firt) Iurd) sine bödjt merfwärbige 2tmmenzengung

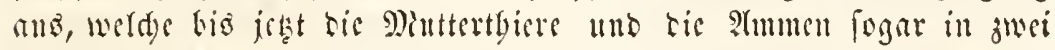

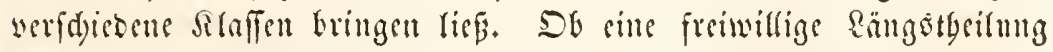
irgeno wo sorfomme, bürte nod) jweifelbaft frim, bas aber ift fider,

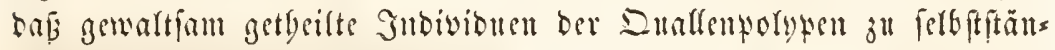

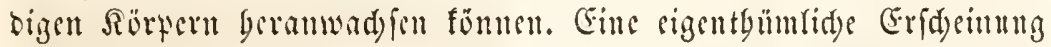
ift tie Tentenj jur Firirung an bem Boben, werde Fei ben mudl= fomment formen fowie im erwadjenen atter sintritt, wägrento bie Snwen mo Jungen ber Strabltbiere mriftens frei beweglid) funb. Die

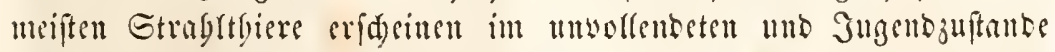

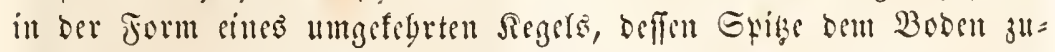
gewant, unb beffen nad) oten geridetete Bafig von ber Munböf=

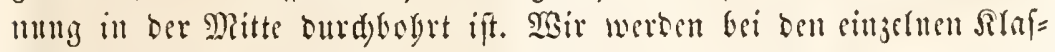

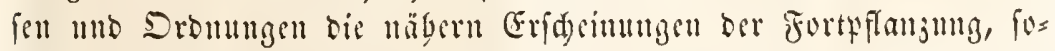
wis bie Sarbenentwifelung Dicfer Thiere genauer betrad)ten.

Die genauere Begrenzmng ber singernen Sirffen, welde ben Freis Der Gtrabltbiere bilben, fonnte bis jest banptfäd)lid) ans bem (jounde

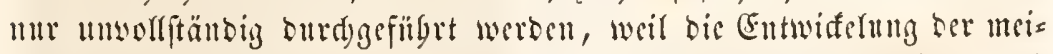

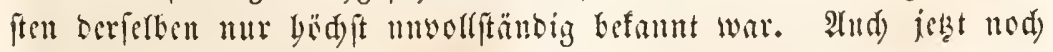
wiffen wir von einer ganjen Silaffe, ben Röbrenquallen, Durdang gar nichts über bie embryonale Entwiffelmng, fo bafi tis Etellung uno llingrengung biefer Slaffe fo lange eine rein bypotyetifde ift, bis er= 
nente Beobad)tungen baz über igr berridente Dunfel aufberlen. Sair unterd)eiben uad) ber äuferen fïrperform, nad ber 9Horbnung Der Bertannแg weife forgende vier Silaffen unter ben Etrabltyieren.

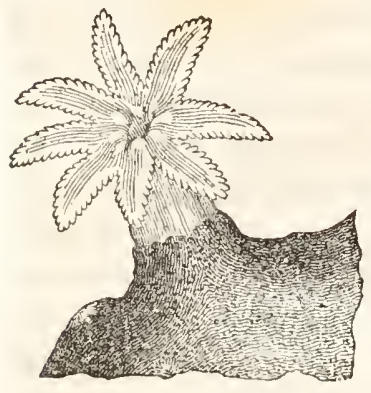

Fig. 75 Einzetner Bothp beß Sicralls rergrépert.

1. 3ुory yen. Sesed e, mebr ober min= Der geratinöle, fegr contractile sörper you

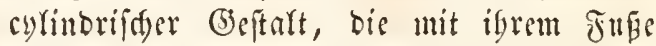
meift unseweglidy fefigewadjen an bent $\mathfrak{B} \mathfrak{o}=$ ben baften. Der Serbaunngstanal beginnt mit einem freişförmigen $\mathfrak{D}$ Runte in ber Mritte eines trid)terförmigen Tentafeftranjes uno fügrt in eille von befondern Sänben mu= gebene Magengoble, rie fid nady unten in bie alfgemeine Reitesgable iffutet, in weld)er

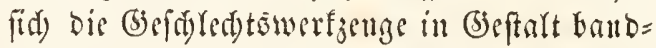
artiger Gtreifen befinden. Gie bilben meiftens bornige ober farfige Sorallentïte, auf weld)en bie Tbiere in grofien Maflen zujammen= reben. Sisir tremten yon ínen bie Armpolysen, weld) zu ber näd)=

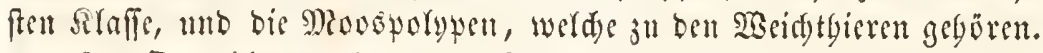

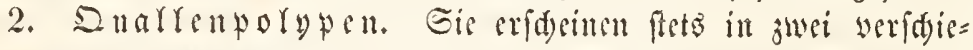

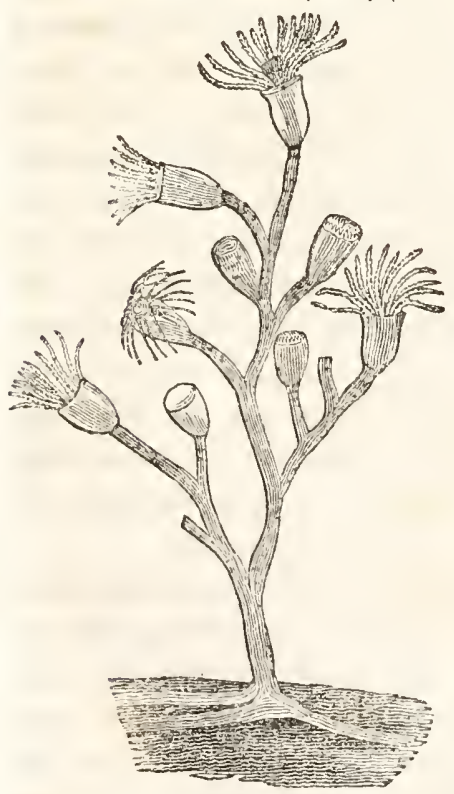

Æig. 76. Sertularia. benen Formen. Die unyollenbete Form gleidet ber vorigen Silaffe fo feldr, baß

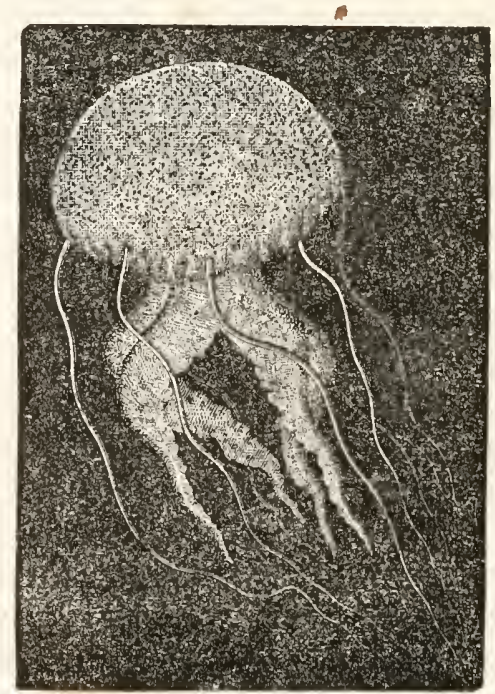

5ig. 77. Pelagia. 


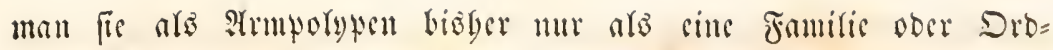

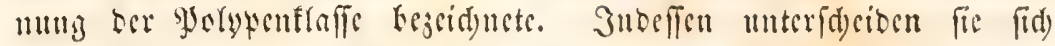
wejentlid) burd) ben Miangel alfer inneren (bejd)led)totbeile unb ciner

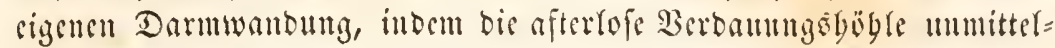

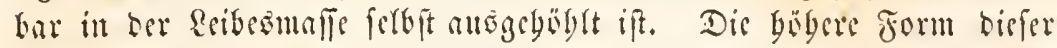
Thiere, welde nus ber Yolypenform burd) Rnospung berworgebt, แm= fä́t bie fogenannten Edsirmquallen, Thicre mit fdesiben= ober gloden= förmigem Sïrper und meif centralem, alf ber lluterflädse ange=

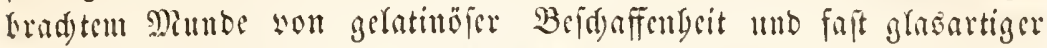

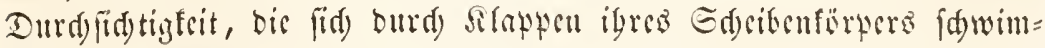
ment im 2anfer bewegen unb Deren Drgane affe nad) Iem ftrengften rabiären Tyłus angeorbnet fint.

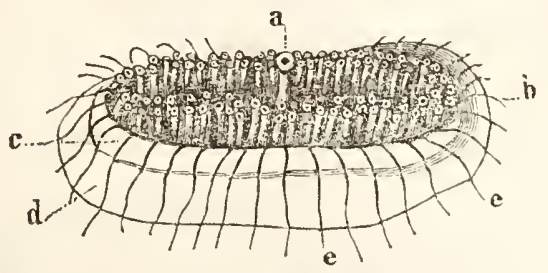

Jig. 78. Velella.

3. Dic Bögrenqual= len baben sine ämberft mube= frimmte (5eftalt, an welder ber

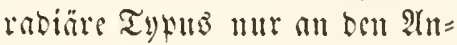
bängen fid erfenten läbt. Gis (d) wimmen mitterfi sigentbüm= lidjer Sinoryelftüfe, dic bei ben meiften surd) gefd)loffene mit

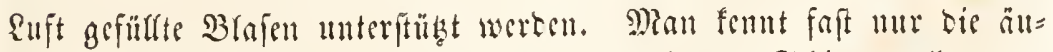
Eere Form biefer Thiere, weldye bisger mit ben Edjimmuallen und

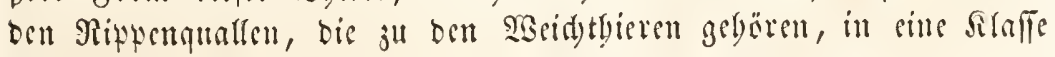
jufaumengefteflt wurben.

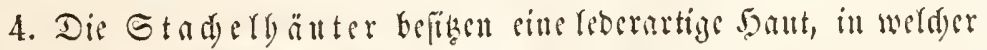

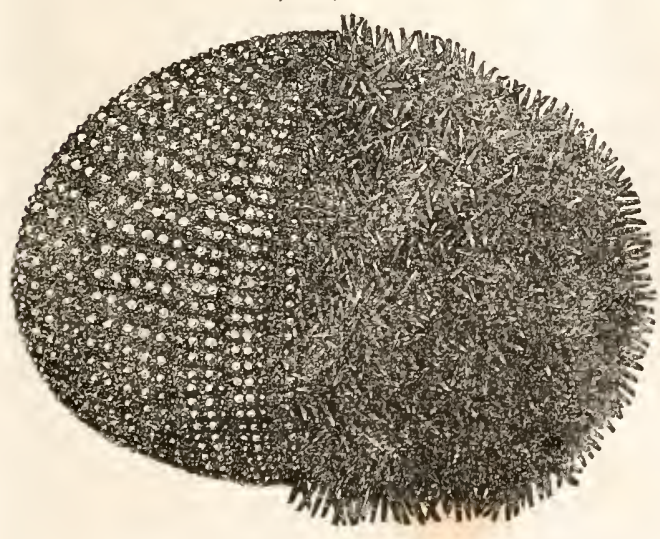

ซig. 79. Echinus.
Ralfablagerungen wor=

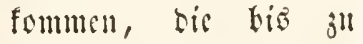
getäfelten unb ganj ge= (d) Loffenen Edyalen ju= fammenifyiefren. Cro fino runblidse, fernförmige, algeplattete ober cy)lind = rifde Ibiere, weld) fid) mrift mittelft Embfüb= rern fried)ento anf bent Boben benegen. Dic frublige ?tureremug oer Drgane ift mur bei ben 


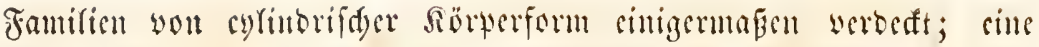

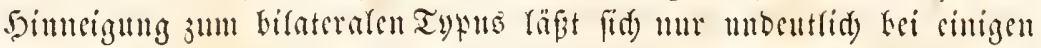
bögern Formen erfennen. Das Rervenfyftem, weldes cinjig bei biefer Rlaffe und aud bier nur fobr suesferbaft erfant worben ipt, foll ans cincm feinen Sdylunbringe beftelyen. Die Befdylerter fint Heberall ges

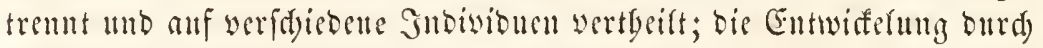

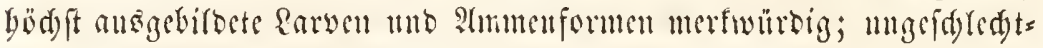
ridge 3eugung fegrt gäujlid).

\section{filaffe Dar polupern. (Polypi.)}

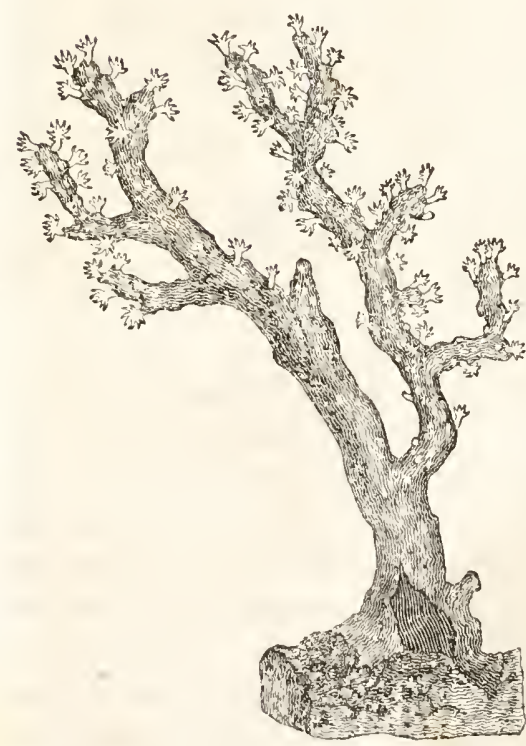

8ig. 80. Foraflenbum mit entwifelten fivityen.

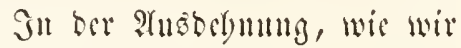
biefe Silnffe begreffen, ittoen wir bie Irmpolypen eiterfeits unb bie Monspolyten als 2arid)tbiere an= berfecto bavon attrement, bifoen bie borysen eine nad) bëd) cinfa=

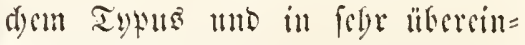
ftimmenten Formen entwidelte Silafie, bie fid burd ben cylintrifdensirs= fer, ben til ber 9yitte cinces meift flimmerlofar Fiilylerfranjes ftelyaton Mind und bie nit cigenen Sänden

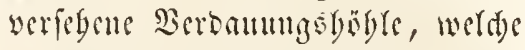
und) binten firl in bie Rectergable

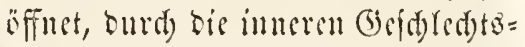
thate, bis in Fanbartigen Etreifen angelagert fint, mob ourd) bie meijt anferorbentlid) entwistelten yormi= 


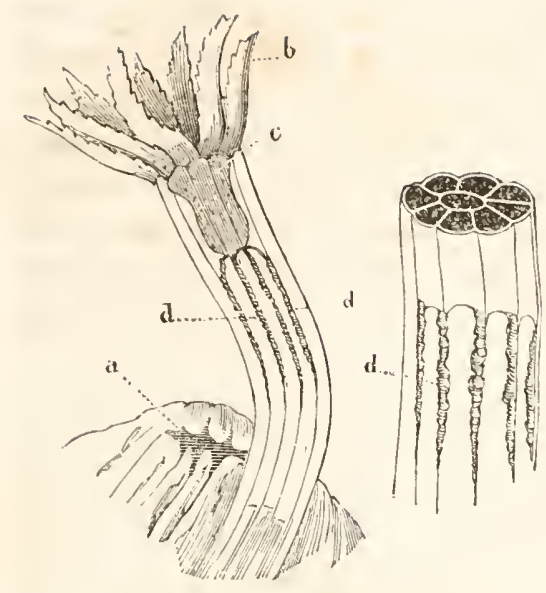

Jig. 81.

8i.g. 82.

Gingefne Botyfen sun Veretillum cynomorimn. ¿tarf rergrisert.

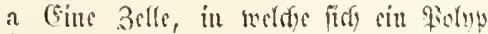

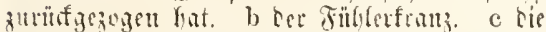

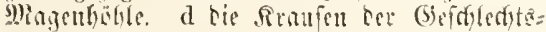
theile. 3ut Ecite ijt Fig. 82. cin Solmo nuev

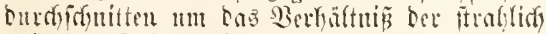

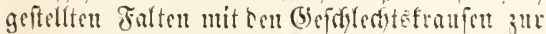

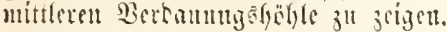

gen ober falfigen Sorallemfïre, weldye igren zemerinfarefidjen Rolonicen ats 3oben mil llm= güllumb bicucu, yor allen b̈bri=

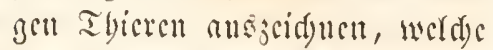

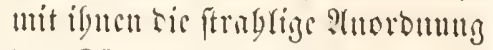
ber Sïrpertyeile um sine centrale

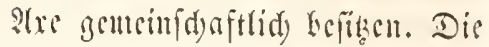
cinjeluten Ificte, weldac in bett Johyenftiden baufa, fund unr fe(ten mifrofforifd), okgicid) zu ibrex gentacru llnterjudung

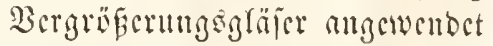
werben mitflen. Dicjenigen Gat=

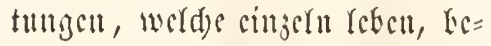
firisen oft cine weit beocntentocie

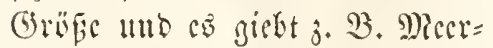
neffelu, weddye weble sen llurfang rimer Fanit erreidyen mögen.

Dic äแ gुalypen ift bei senjanigen Tbic= ten, weldye in Polytenftiden

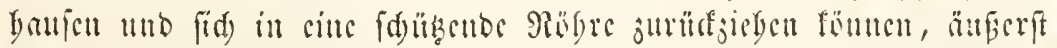

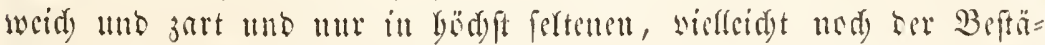

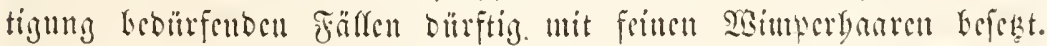

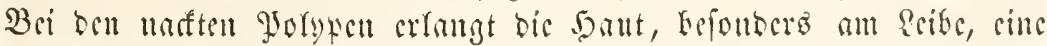
reberartige Jeftigfeit unb bilbet cincu unten gerdyluffencu Saf, in weldyen sie Fübler ober Tentafeln jurhefizejogen werben fömen. In

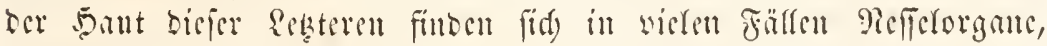

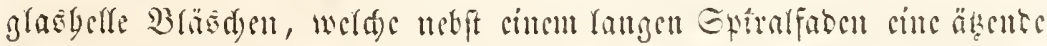

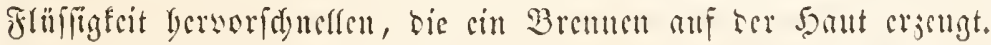

Bon befonderes Saidtigfeit erfdeint bie Birsung ber faffigen

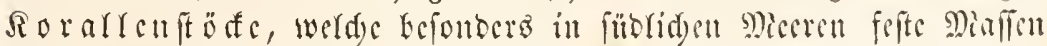

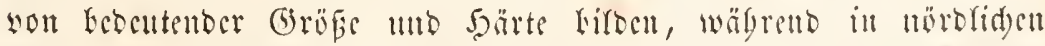

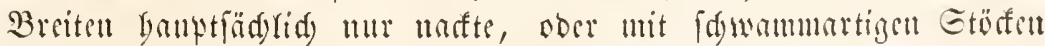
wericbene Jolypen worfommen. Iluterfudyt man bic d)emijde 3ufam=

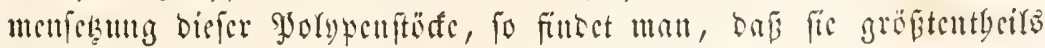
aแs reinem foblenfaurem Sarfe befteben, sem oft ctwas foblemfante

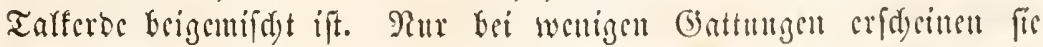

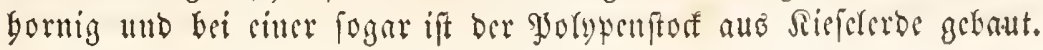


Diefe mineralifanen (Encretionen, bie meift nod) einen fryftafluifenen

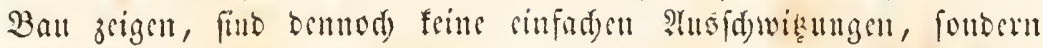

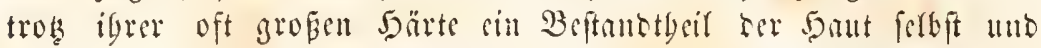
zwar besienigen Tgeifes, welder ben bintern Theif Des Reibez um=

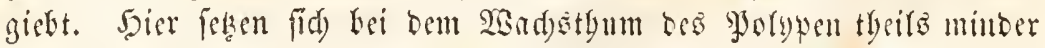

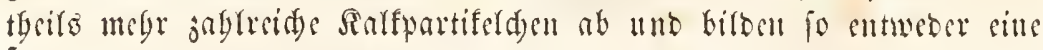
(d)wanmige, yon Satfuetzen ourd)zogene Maffe, ober enblid) sine fteinartige Gubftanj, in weldaer ber organifde Stoff fajt gäujlith verfdumben iff.

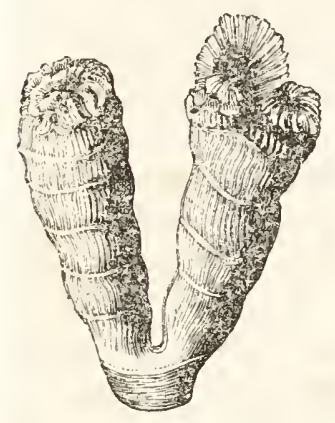

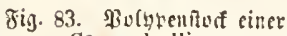
Caryophyllia.

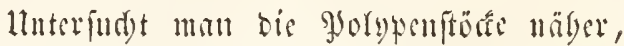

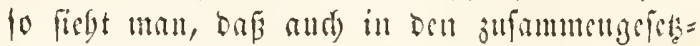
teften Sioronien jeoes Tbier eine eigene 3elle bat, werdye fid) nad) unten jur Rägre vertän=

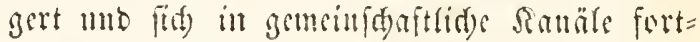
fert, bie ein Mïbrenfyfem biloen, bas mit ber

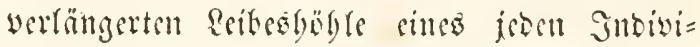
buแns zแnmmentängt. Bei ben tosten mo

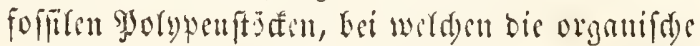
Subftanj weridumuben ift, fam man trefe Dis: fofition ber gemeinidaftliden Sanale nod) frbr wort werforgen. 23ei vielen Yyofyen fliefen

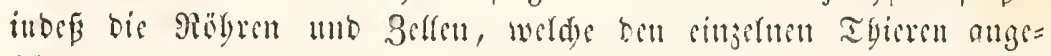

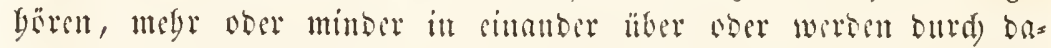

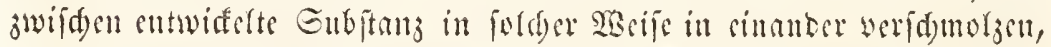

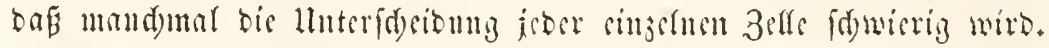

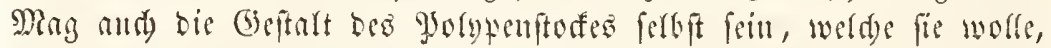
to jeigen bod bie 3ellen fiets sime sillfad)e, rumber ober ftrablige Geftalt

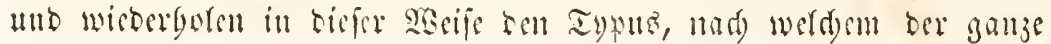
Reib bes Thicres grbaut ift.

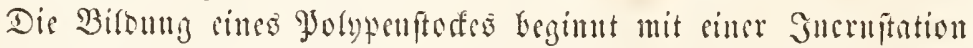

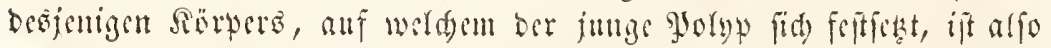

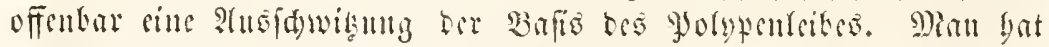

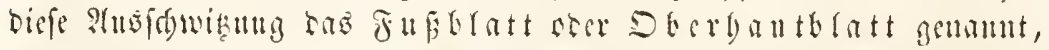

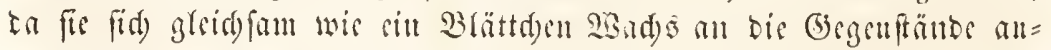

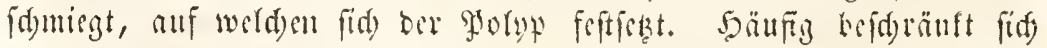

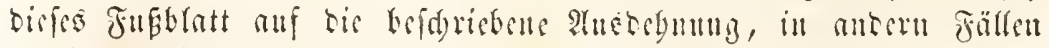

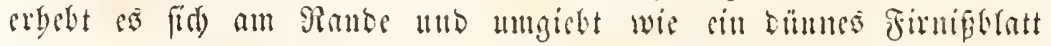

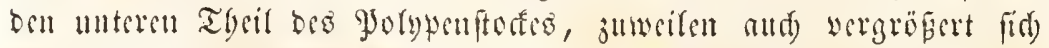

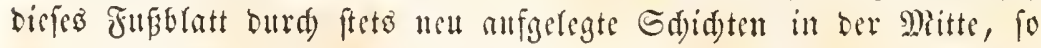

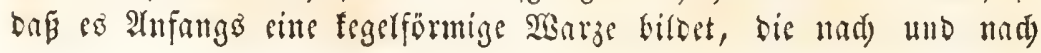




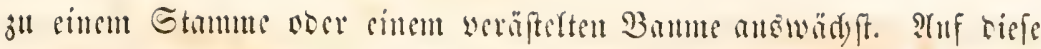

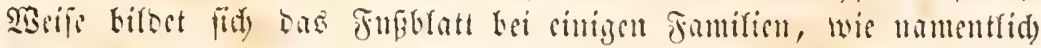

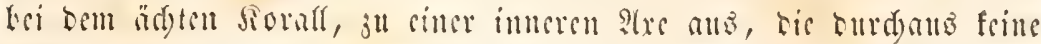

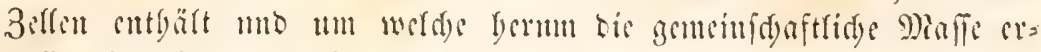

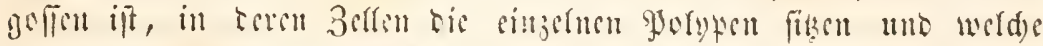

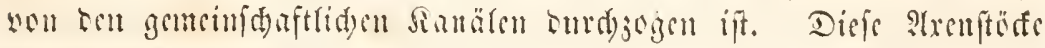

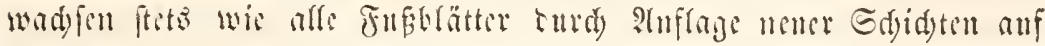
erer ben Woryten jugewation Grite.

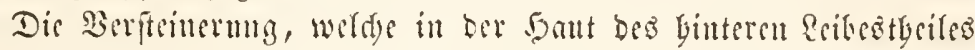

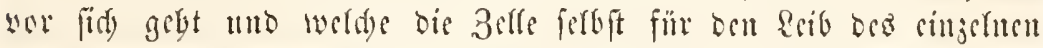

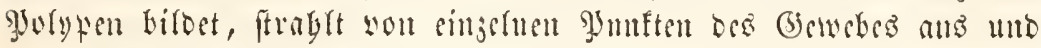

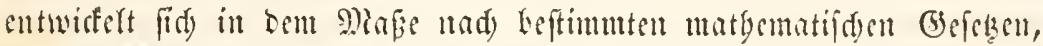

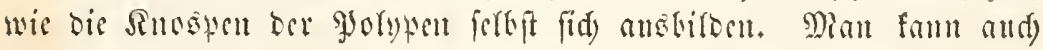
bier wicber verfojictene Therfe unterfdetsen, bie für bis genanere

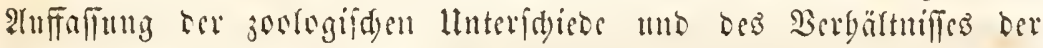

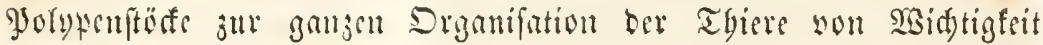
eriderinen.

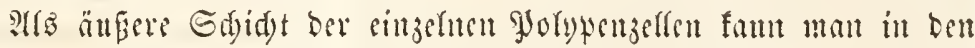

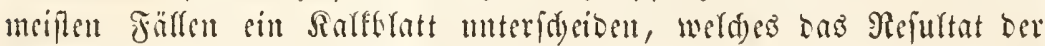
Berftrinerung ber äuferften Santidjidyte bes Thieres ift. Meift bifoct bic=

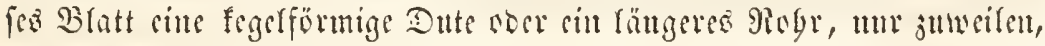
wis fai ben Drgefforaflem, conftituret es für fid) affein bie röbrenförmige

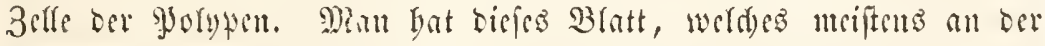

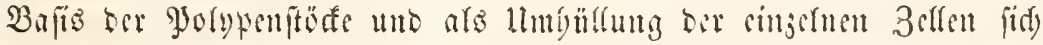

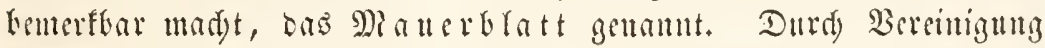

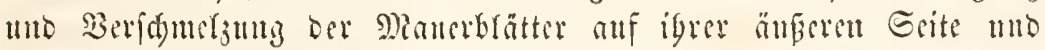

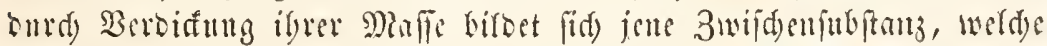

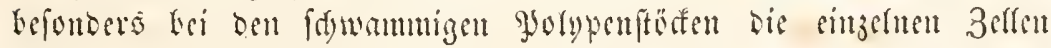
mit einalloer verbintet.

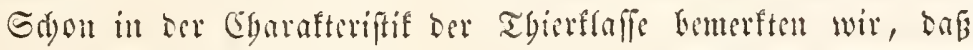

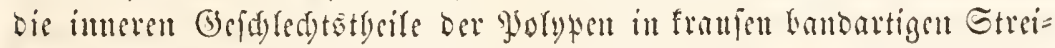

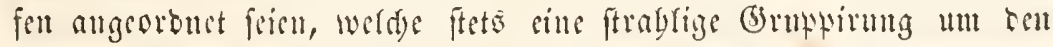
Magenfar und ticfer binab barbiten. Die Berferinerung bicfer baut=

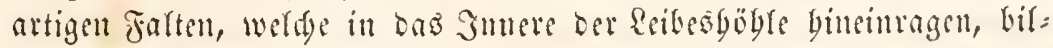

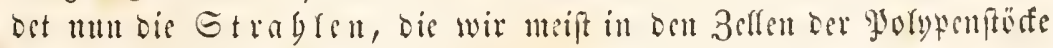

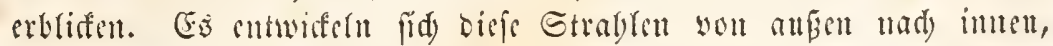

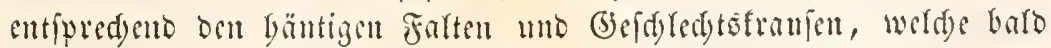
weniger, bato megr sorffringen. So fiegt man tem in bent 3effent

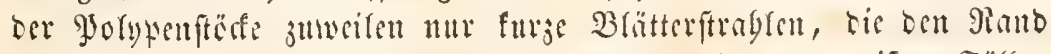

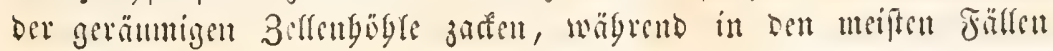


wenigfteng bie 5auptfrablen in Der MRitte fid treffen unb ơlt siute

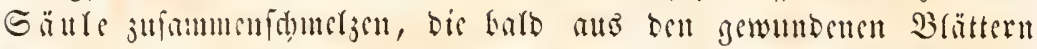

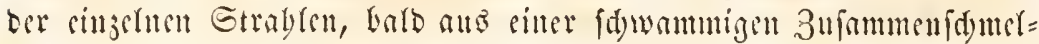

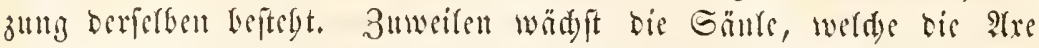
Der Zelfe simmimmt, fid serlängerno fort, wälyremb bic Sd)eibewänte oder Strablen in ifrem : bann cin mittleres mabbängiges Etäbden im Eettrmm oer frrabligen

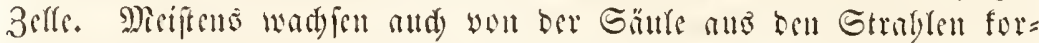

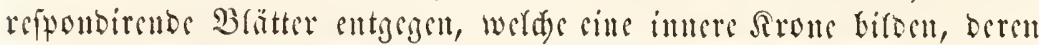

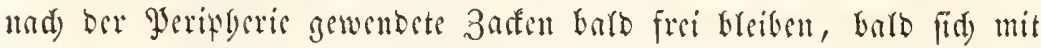
ben won ber Sianer aus bereimwadjenden Grablen werbinben. An Den Stelfet wo dis Gtrablen ober biefe Srournbläter bas äufere Manerblatt erreiden, wirb dicfis oft burd)broden, fo bafis die Srrab=

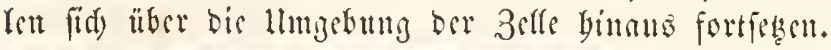

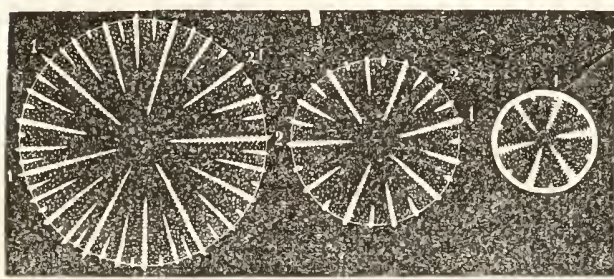

8ig. 86 .

ชi.g. 85 .

Jig. 81.

Sig. $84-86$. Suttge Sovlypentiofe eitter Edymumforalle (Fungia). Jig. 84 bie Ramuter

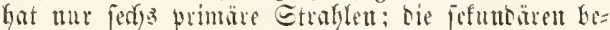
gimen am Maucthatte sorzuprontem. Fig. 85. Die

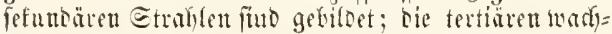
Fett. Fig. 86. Dic quaternätent mib quintärent Etrah=

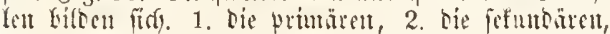
3. Die tertiären Errablett.

Beim erften Begintue Der Birtung émer menen gorypenjelfe jeigen fid) ntm

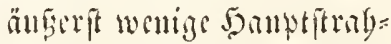
len, weld)e bie 3effe in feds wrimitive sammern abthei= Ien; - wenigitens ift die Sed)sangl, fo biel man bis jebet bat beobadyten föment, die Rormaljabl, mad) wel= d)er fid bie vielfingligen Yolypen Der eigentlidsen

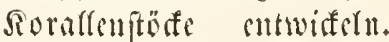

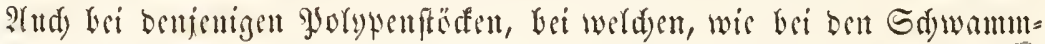
forallen, sint ungebsute stuzabl singeluer Grablen criftirt, aud bei

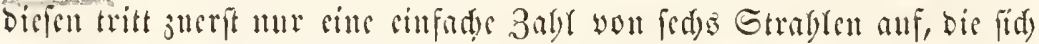

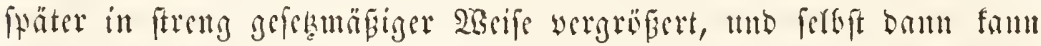
man nod) dis frimären Etrablen meift an igrer gröferen Diffe uno

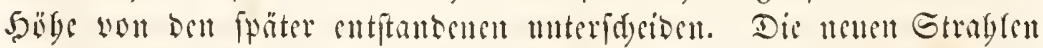

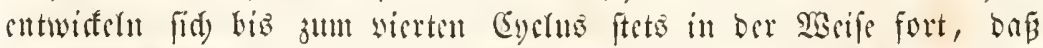

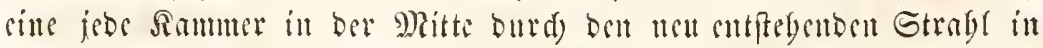

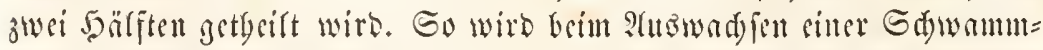

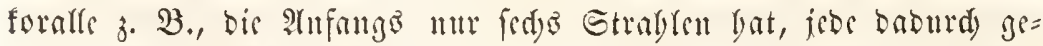

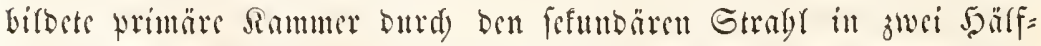

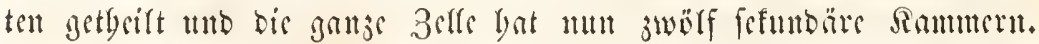
Durdy Dic Entfelung Der tertiören Strablen crbät fie sier und jwan= 
jig tertiäre Sammern, bam aber nidyt adjt unb vicribs, fontern mur

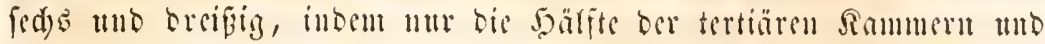
jwat bicjenigen, wedde an bem frimären Etrabl anfi:gen, ourd) qua=

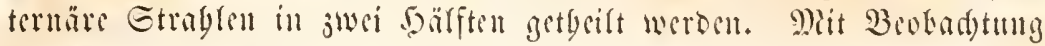

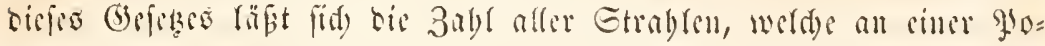

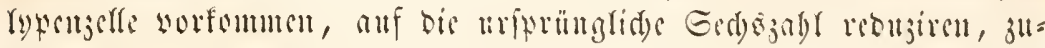

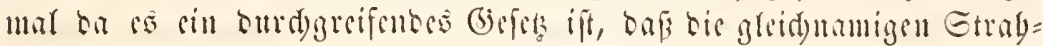
ren fid and fets ju gleider Zeit in ganjen llmfange ber 3elle entwisteln.

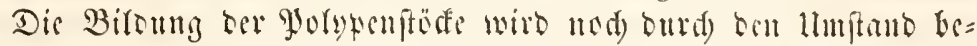

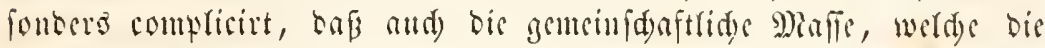
einjelnen Jolypen mit cinanter werbinbet, fids in balo megr, bald minber jufanturnbängender SBeife weriteinert mo nun mit ben Strab:

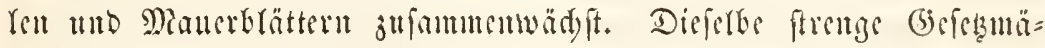

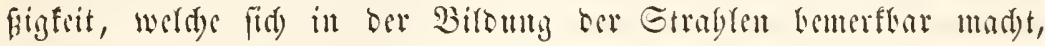

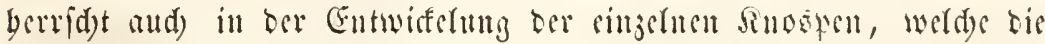
gyolypen treifen. Bai ben sinen werben baburd megr ober minter

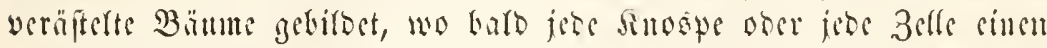

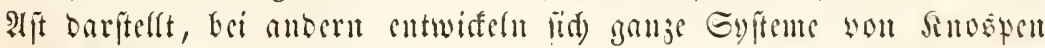

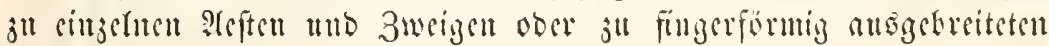
Miafle, bei wieber anberen werben alfe 3ellen in sine sinjige, mebr

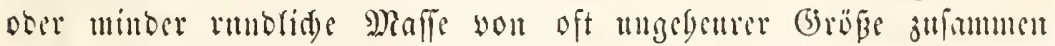

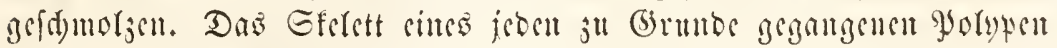

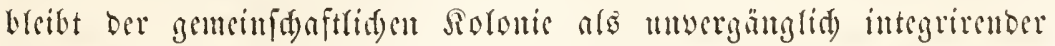

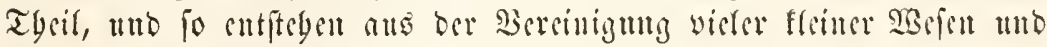

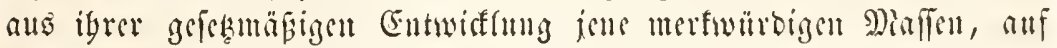
beren Bilbung in (bropen wir nod) cinen weiteren Bliff werfen werben.

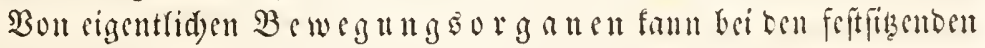

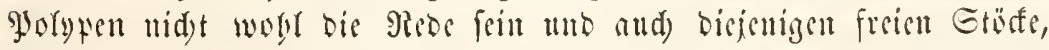
weldye in Ganbe ofer in Gdylamme fteden tmb von weldyen man

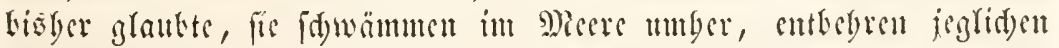

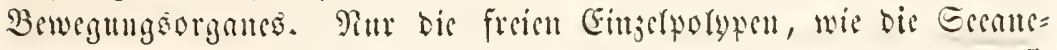
monen, befitzen cincu breiten, fdecibenförmigen Jus, mit weldsen fie

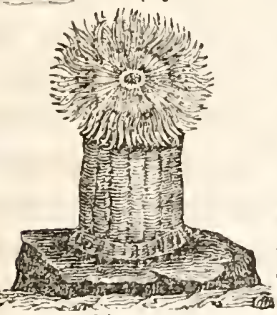

ช่. 87. Eermemune (Actinia.) fiti) anpangen mo bin und bet gleiten fümuen.

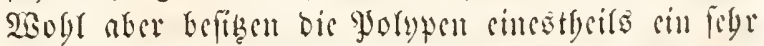

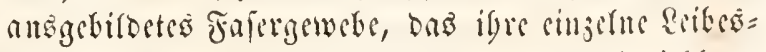
tyeife zmfammenjiebt nub anderfeits cinjeblere

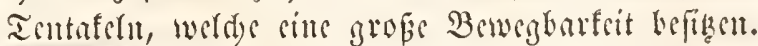
Bei benfenigen Jolypen, weld)e ad)t Tentafert um oen Mand befizen, fund biefelben meift blateformig und ant ben アänbern megr ober minber geferbt, 


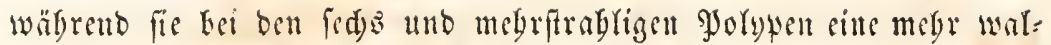

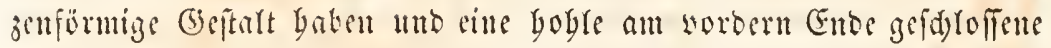

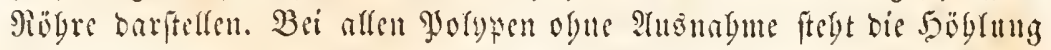
Der Tentafel in Berbinoung mit ber Reibesgäle und tie Eutfaltung

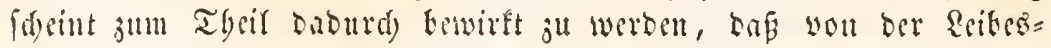
böble ans fruffigfeit in igre boblung ringepregt wirb.

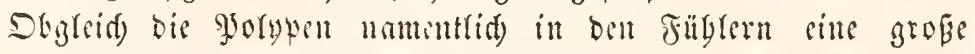

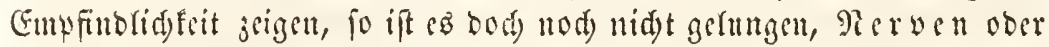
Sinneso rgane bei iguen wabrumebmen. Atd bie Berban organe fteben anf eitter felyr uieberen Stufe ber Entwidfelutg. Der runbe, juweilen auf einem গinopfe in ber Mitte ber Fübler anges bradte Mutub fübrt in eille weite Mangentafde, werdye fid uad) binten frei ourd) offene Sparten in bie Reibesgugle sifnet, fo ba ranfer und Rayrungeftoffe ge= meinfagatlidy burdis biefe bintes ren Deffinttgen it bie Reibes= Göble ïfergeben. Dieje if burd) bäutige Blätter, weldye in bem untert Theile ber Reibesgöble nad) immitl ou frei fint, oben fid) an bie Ragentwanbung an= frbsen mot anf ilyeut freien ge= fransten Planbe bis männlidyen

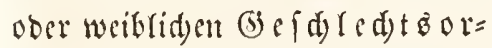
gane tragen, in cine grofie ath zabl you Iafden ober Rammern serfällt. Bei ben gemeinidaftlid) rebenten Polypen geft bie Rei= besgable, in werdyer ber Rab=

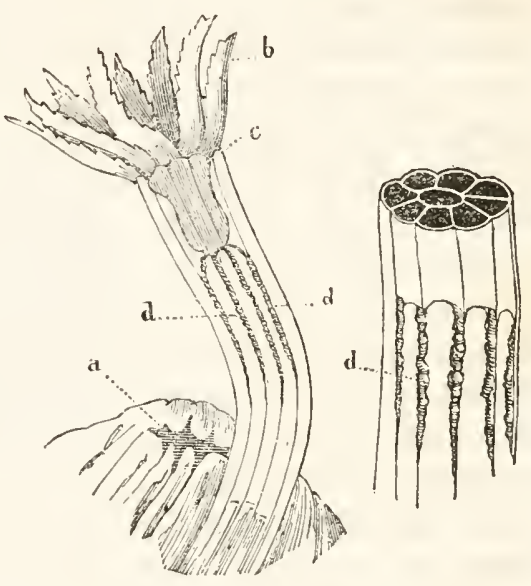

Fig 83.

8ig. 89.

Einjelme Folpten non Veretillum cynomorium. Etarf rergrīerert.

a Cine Belle, in weldae firty ein Fulyp zแrüfoezogen hat. b ber Fülerfianz. c bie songentuble. d bie Rranfen Det Bifdyledyts= theile. 3ur Seite int Fig. 89. ciut Pulup quer

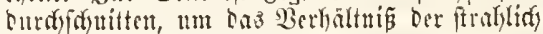
geftellten Falteu mit Den (Sefdyled)taframien zur mittleren Berbanutigetyoghle ju jeigett.

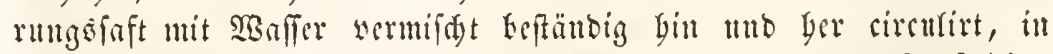

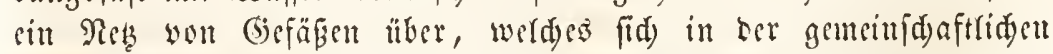

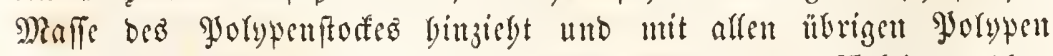
in birefter Communication ftelt. Der Strom ber frïifigfeit, weld)er

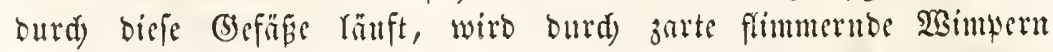
rebingt, thlo gelyt an ber einen Srite ber Fithler biş an beren Spibe, um anf Der alloern Seite wieber binab ju gleiten. Da bie

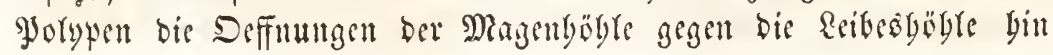




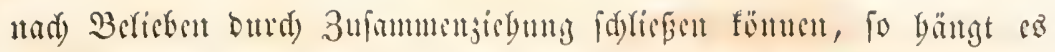

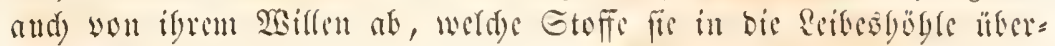

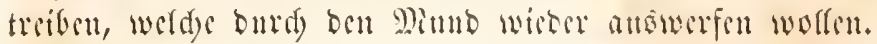

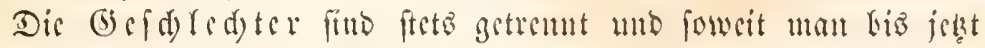

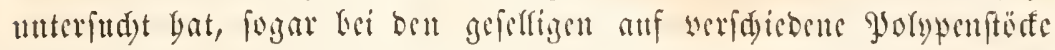

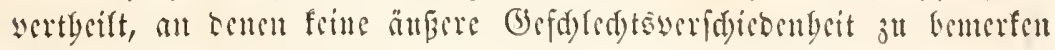

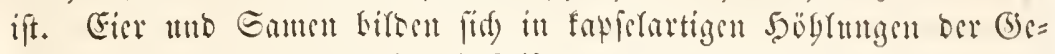

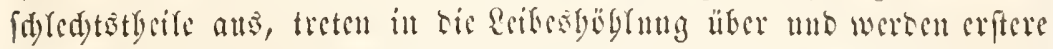

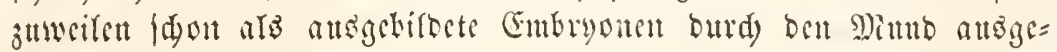
worfen, woratif fie fid entwiteln tho feftiesen. Bei ben vielfterbli=

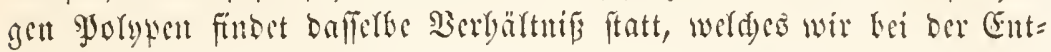
wifelung ber Etrablen igrer 3eflen beobad)teten. Sie baben zutrit un

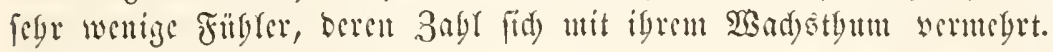

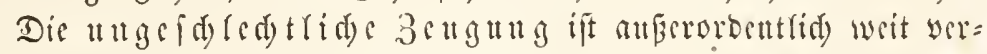

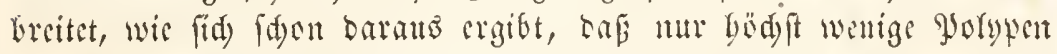
als cinjerne Jubivibuen reben. Smbeffen gat man bie Erfd cintung ber

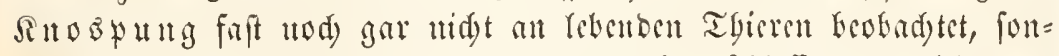

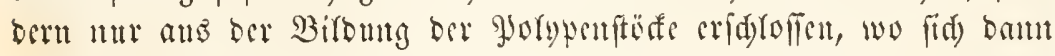

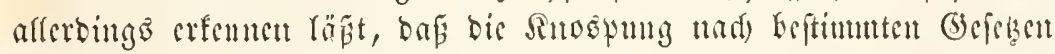

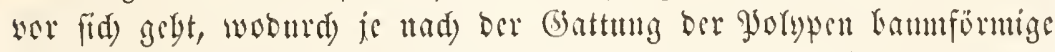
ober idjwanmige formen erjetigt werben. Atto sen jufammenfliefien=

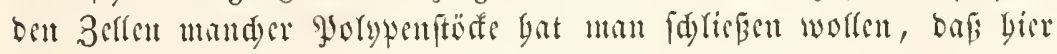

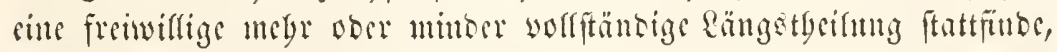

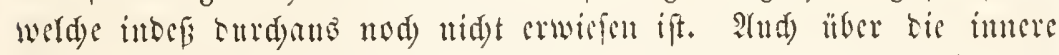

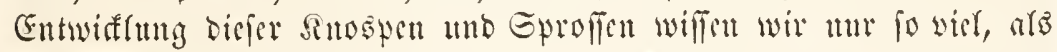
fid) anf bie änfern Drgane unb anf bie Bermelyrung ber in ber \&ei= bes̆bule angebradten Sd)eidewänce bejicht, was ans ber Berviclfälti= gung ser Etrablen in ben 3effen erfdloffen werben fant.

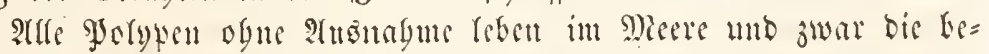

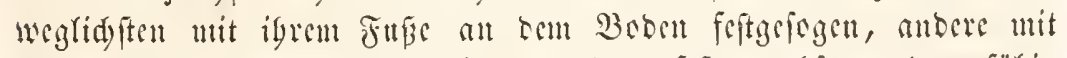
ifyer Bapis in Gdylanme ftefent, antere feitgewadjen unb unfälyig

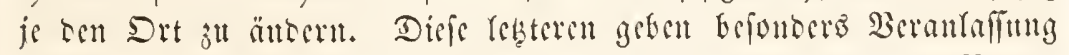

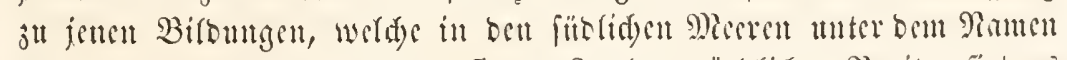
Eer Rorallentiffe befantt fitu. Sit ben mörbliden Breten finto es

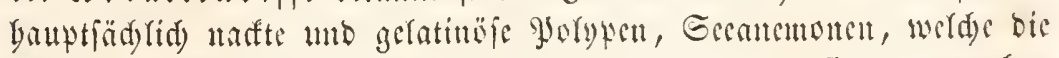
Silaffe repräfentiren. In ben Mecren ber gemäBigten 30 ne fintet man ueben

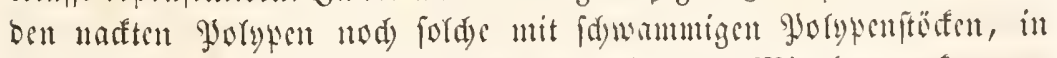
weldyen Sialfubolt jerftrent ftut. Erit in bem Mittelmere foumen

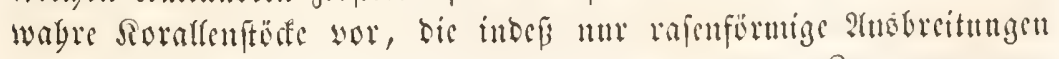

2ogt, 3oologijhe sriefe I. 
bilben. Die cigentfid) 3one ber Sorallenriffe beginnt aln 30ten Grabe

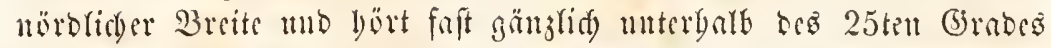

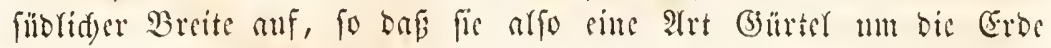

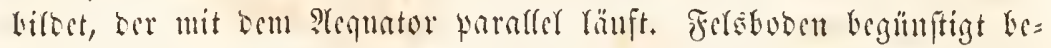

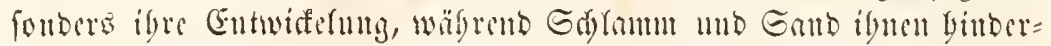

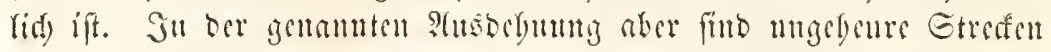

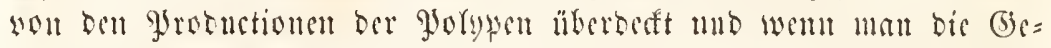

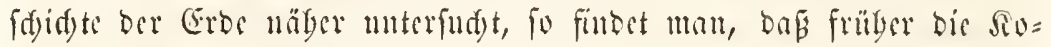

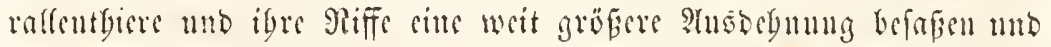
baf mäd)tige Gefirgs

?In Ion feidsten Etellen ber füblidyen Meere rubert ber Eecfalgrer oft üfer weite Gtreffen bin, beren Farbentredyt mit ben fdünften Iin= tou unferer (Segentoen im Sorbfte wetteifert. Durd bas ontd fidgtige

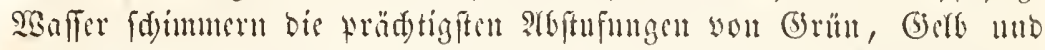

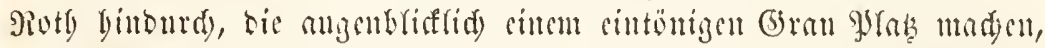

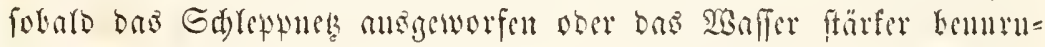

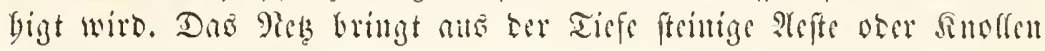
berwor, weldse einen grancu foletemigen llebergug zeigen. Die glolysen,

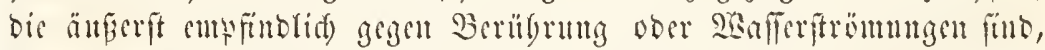

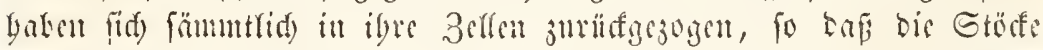
umr bie falfige Maffe zeigen. Eegt man aber bie Gtüre iu's : 2 affer

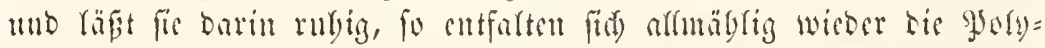
ten, tie bejonbers an igren Fifbern jene rebbaften Fatben jeigen.

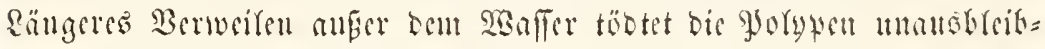

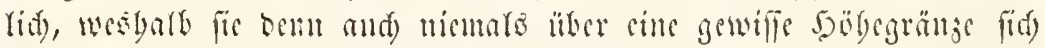

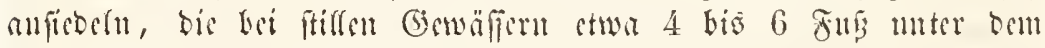
Stande ber Gube fid bät. Gebenfo bebmuten bicicnigen Gattungen,

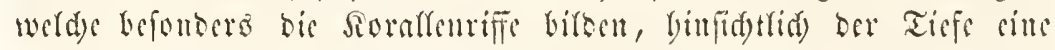
gewiffe Gränjlinic unter weldyer fie fidi) nidid aufiebelu. Go bat man

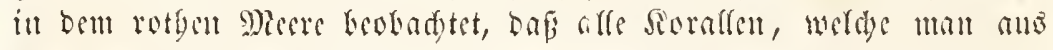

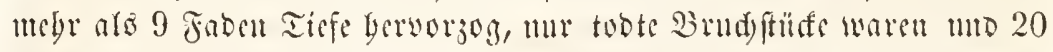
Faben bürfte hiferall als bie grefite Tiefe angefeben werben, ill weldiger

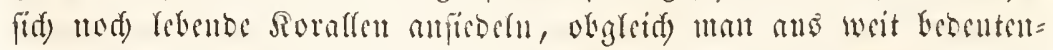
berer Tiefe Yebenbe Solypen berworizegogen bat, bie aber un freite

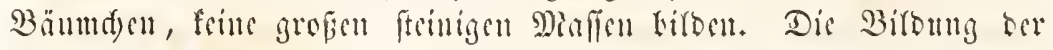

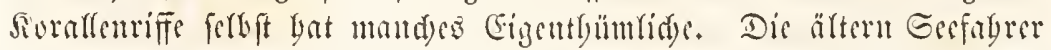

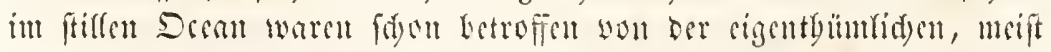
freisförmigen Gefitalt ber cingehen Suferu, welde oft in ibrem Smern

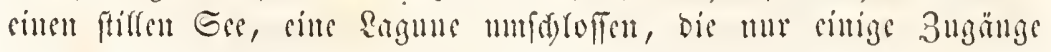

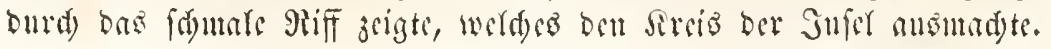




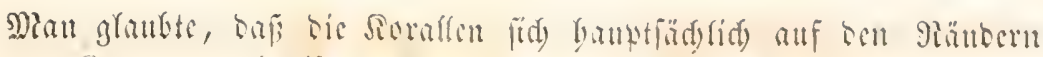

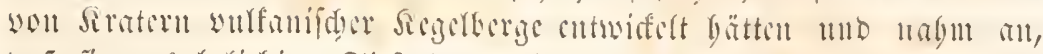

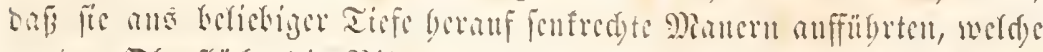

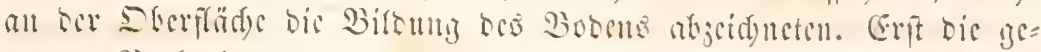

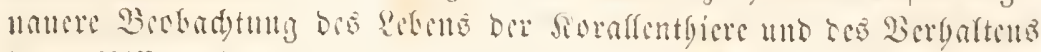

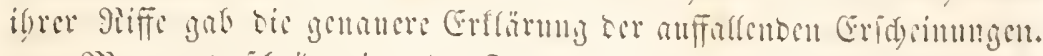

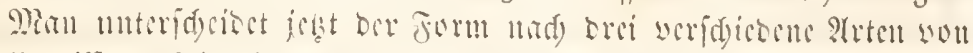

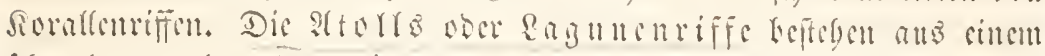

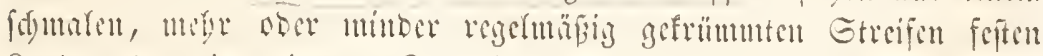

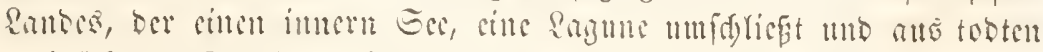

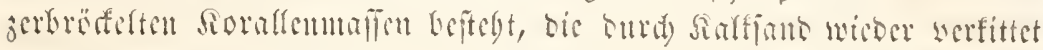

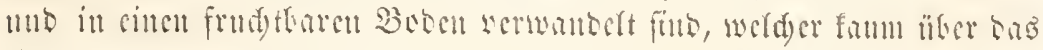

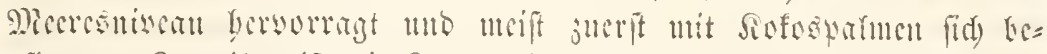

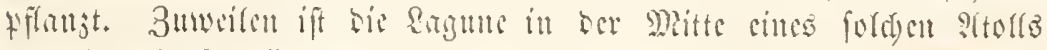

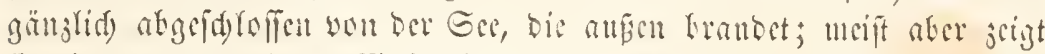

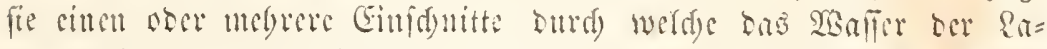

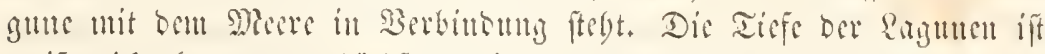

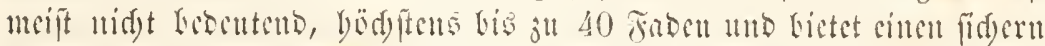

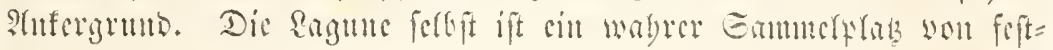

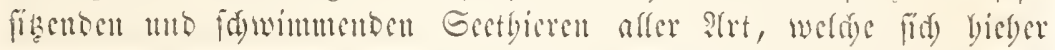

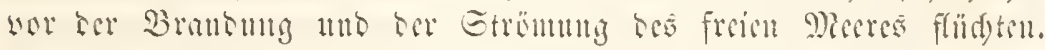

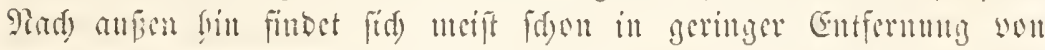

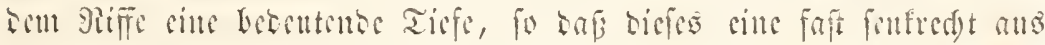
Der Tiffe anfifeigende Minuer bifbet. Die Dammriffe unterídscion

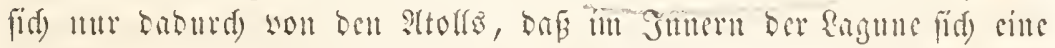

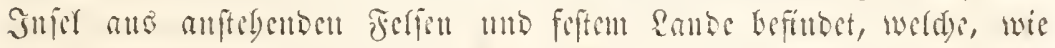

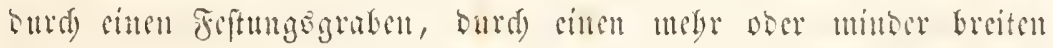

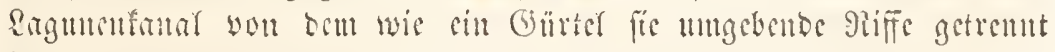
ift. Disfer Ranunenfant if meift nur wou geringer Tiefe, juweilen aber wout fegr Letententor 3reite mub die Dammurffe, weldye gürtel=

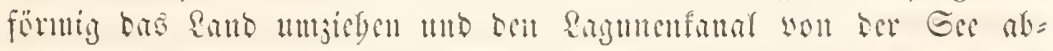

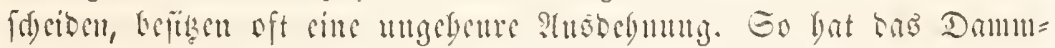

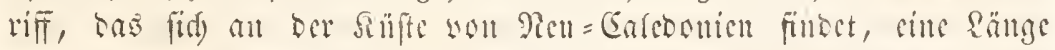

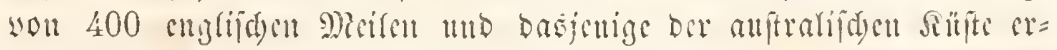
fitreft fied) mit geringen Lluter(wed)ungen Durd) etwa 15 Breitengrabe. Enofid) bic britte int won giffen wirb surd) bie fogenamten

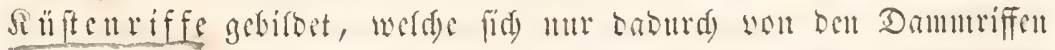

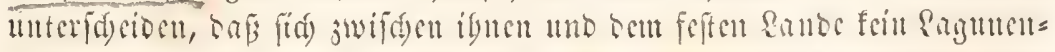

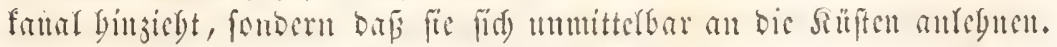

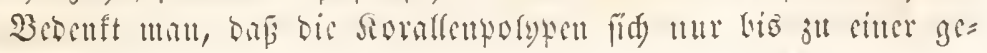




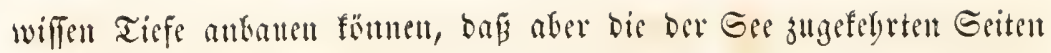

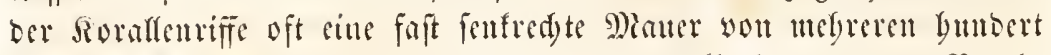

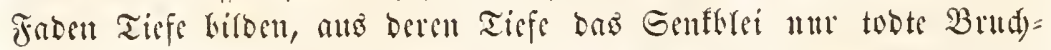
ftüfe berworbringt, wergleidst man mit biefer (Figentlünlidsfeit ber

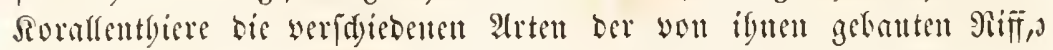

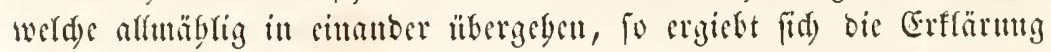

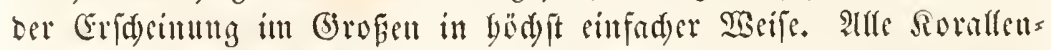
tbiere baben fid fider in ber Näbe der Rüjten in folder Tiffe ange= fest, wie bies igre Rebensbedingungen ignen voridgrieben ntto baben fo uriprüuglids Rüptemiffe gebildet. Run fenfte fid) Der Boden alfmäblig ranglam im Satte von Jabrbutorten tho bis ju siuer

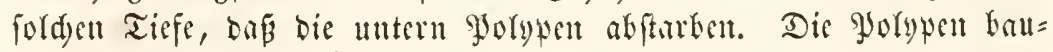
ten nad) oben fort, um bie iguen jufoumente söge unter bem Mles=

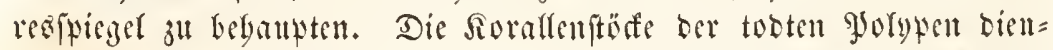
ten als fefter Felsboben für die jüngeren Generationen. Sndem ber Boben fid immer mebr fenfte, bildeten fids bie Dammriffe und als er gäıjlid) verfd)wand, Die 29tolls aแb, bic alfo uแr ringfürutige llmfrei=

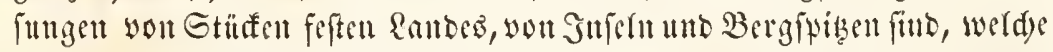

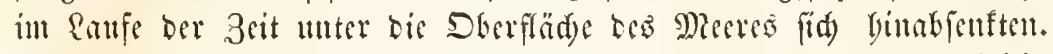

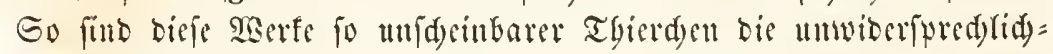
ften 3enguiffe für jene laugfamen und alluäbligen Serä̈berungen ber Crovberfläd), ju Deren Erfenntuif bie Mitter unferer Foridjung fouft nidst Ginreidyen wïrben, und ans bem Borbandenfein ber jable

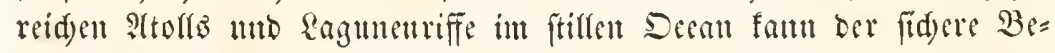

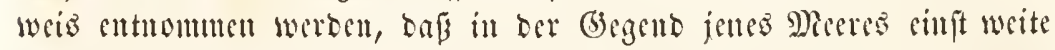

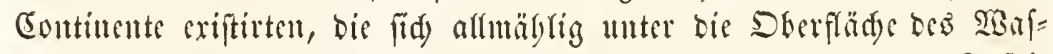

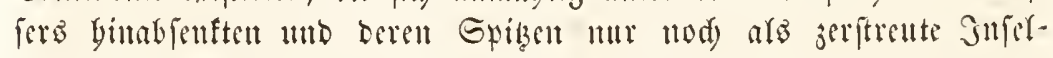
grutpen bie und ba aus ber Tiefe berwortagen.

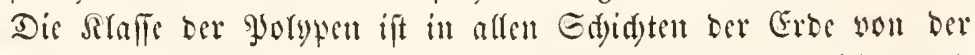
frïlyeften 3eit ber bis auf bie Gegentwart in äuberft jublreiden und mantigfattigen formen vertreten. Dod) waren ill ben 3riten ber

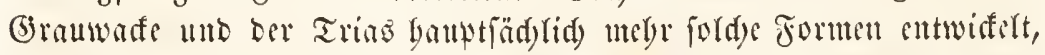

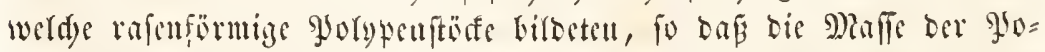

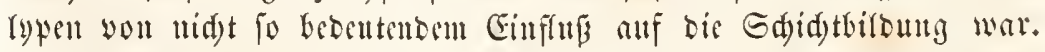

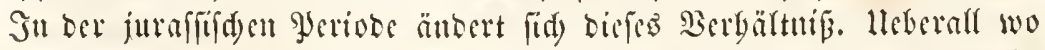
man mod) Den Sura angetroffet bat, in Franfreid, ocr Sdjweis, Dentfdyland uno Englano, arfo in Breiten, weldse jest Dutdaus feitte Riffe mebr jeigen, exiftirten bautals auberorbentlid) autsgebebute Sorallen=

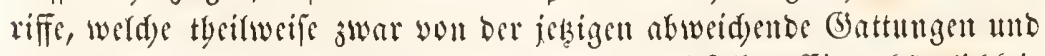

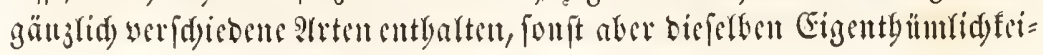


ten zeigen, welde wir and in ben fiorallemiffen ber (begenwart berbad)ten,

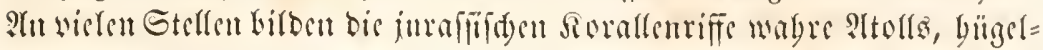

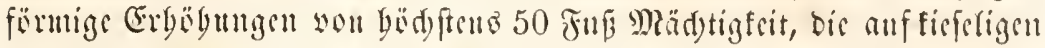

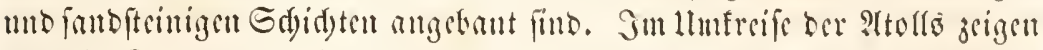

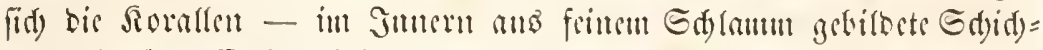

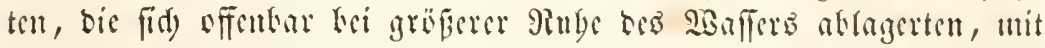

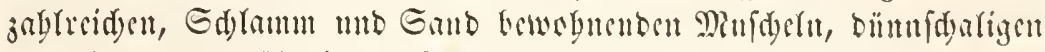
Getbieren tho äbulidan Miertemognern, weldye rubige Drte wer=

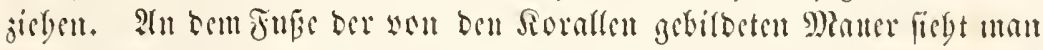

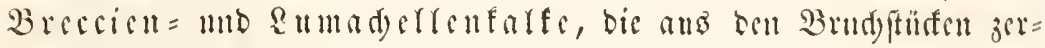
rictener mo jerfindyener Edyalen jufammen gebaften fint unb offen= bar als gifultate ser ben Ptoll mmwogenben Branbung fid Darfeflen. Dic Siorallenitiofe fellit no bis igre 3wifdenränme bewobnenden

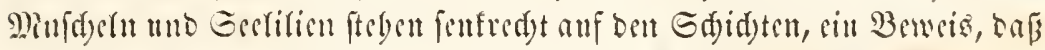

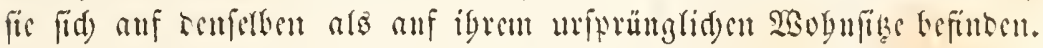

Die Tabrung ber lefenten gorynentbiere beftebt offenbar ans

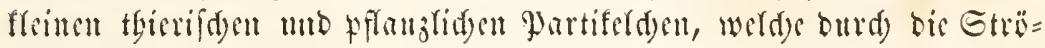

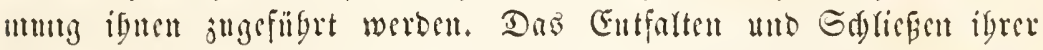
Strme, wis überbant igre ganjen Sebenserfdecimungen, futo meift äuserft träge; bod) bemerft mat bentlid) Empfindlidfait gegen bas

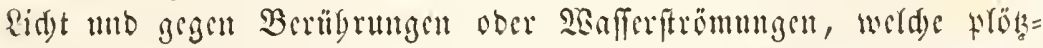

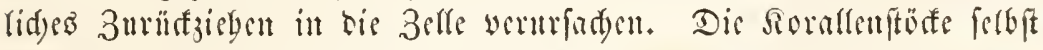

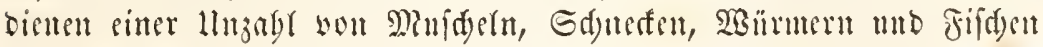

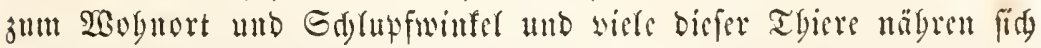

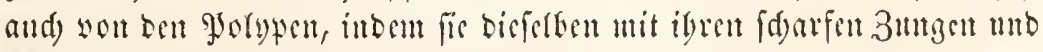
Siefern abtraksen ober and die 3ellen ferbit zwifdyen ten 3äbnen jermatmen.

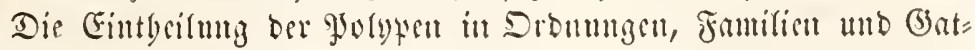
tungen bat befonders befigatb vicle Edywerigfeiten, weil man

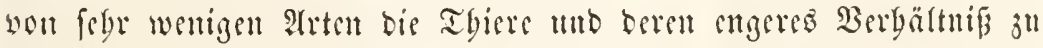

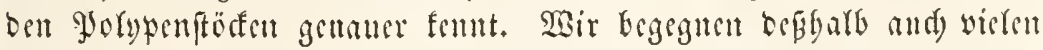

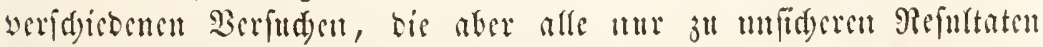

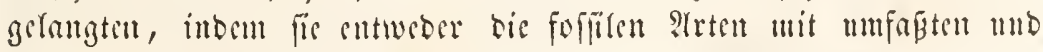

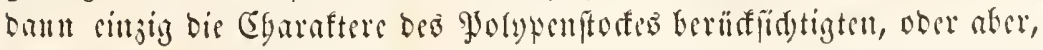
inben fie bis Foffilen fern bielten, sine wefentridge süfe obus alle

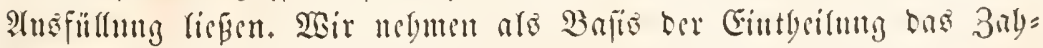

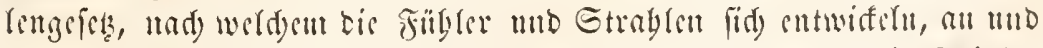
inbem wir jugleid) nad) sintem allgemsinen Raturgefsesc tis focialen Formen für bis nicbriger ftebenben, bis freicn fïr gäber entwiftelt an= feben, erbalten wit folgende brei Dronungen, bie alle febr julflecids in allen Edjidten ber Eroe wertreten fint. 


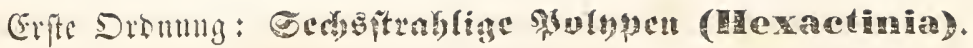

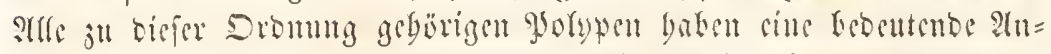

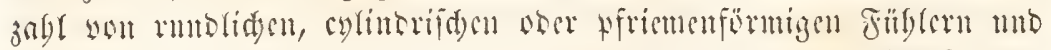

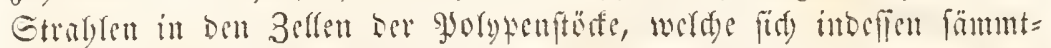

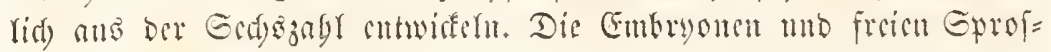

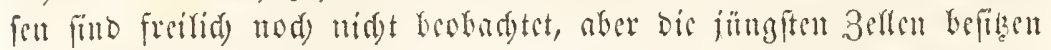

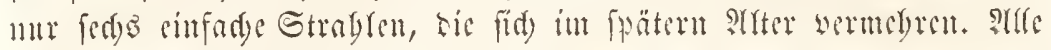

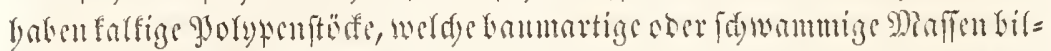

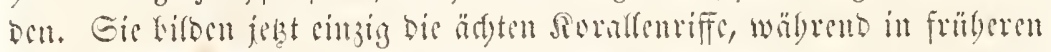

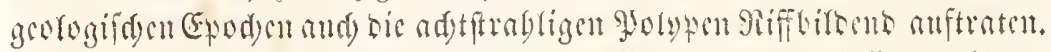

Dis Jamilic Sor Bammforallen (Hadreporida) fofitst meiffens

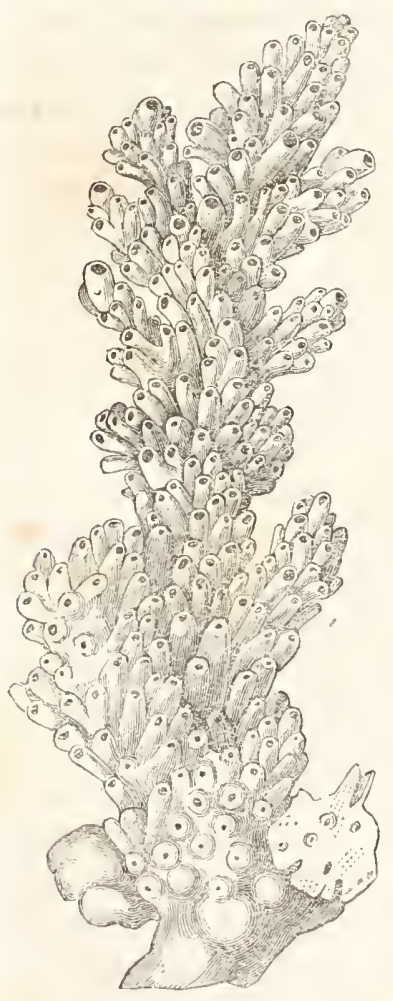

Jig. 90. Madrepora.

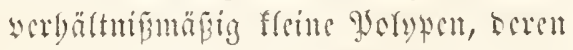
jublf Iontafel in einet sinjigen Beibe ftelen, ferte furj finto und wic serfium=

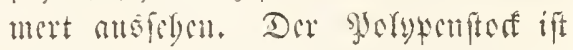
febr porö, meif fingerföming wer= äfert, sic cinjeluen 3elfen rumb ofet

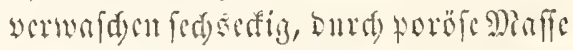
wrrumben ober räbremartig an for Sberflätye berworftebent. Die Grab= ren finto nut in geringer $30 \mathrm{nb}$ wor $=$ banben, reiden nur ferten bis in bic

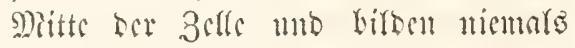
cine rigentfidge Gäule in berferfen. Ge mad) fer Iiefe ser 3eflen mo bet im

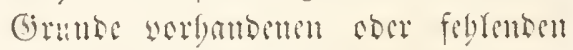
Ebchemän ben bat man in bicler äแ=

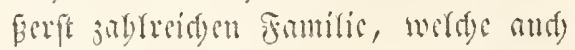

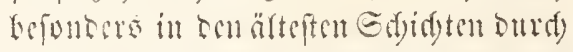
cigentbïm(ide Gattmigen wertreten ift, unandarlei lluteraftycifungen nuter= fdrect, beren serth neth näber er= ötert werten mis. Go baten tie ci= gentficyan mirdererent febr ticfe, hio

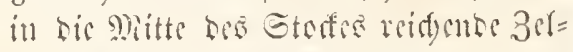
ren; Die Sicibenteralen (Scratopora) die Settenforalen (Catenipora) bic fid) im llebergnngsgetirge finten, ganj tiefe, smed)

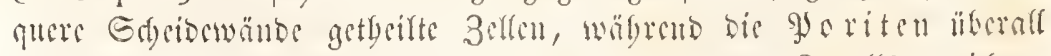

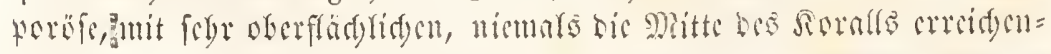

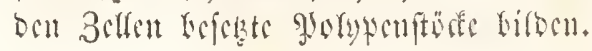




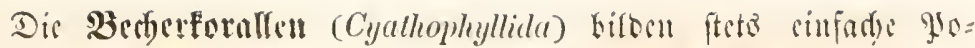

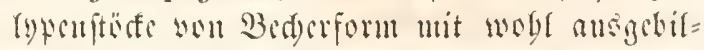

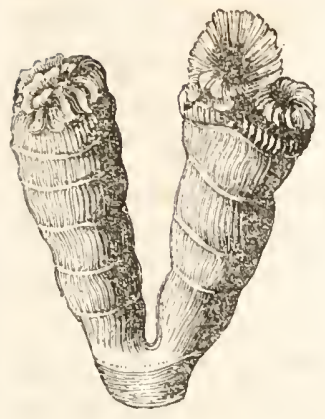

Jig. 91. Caryoplyylia. Ieten Gtrablen, weldse afer lïd)erig mo oben

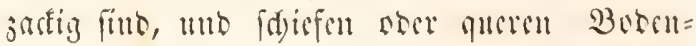
wältoen. Ggre gुolypen fint grob, mit vielen,

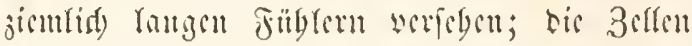
chemfatte gerämmig. Dic Exroffen nemer gyo= (n) ridt), junstu ofen aus oct 3elle, fo sab oer yolypenftut aus mebren in simanter gefdad $=$ teften glorypen ju befteben fdecint. Cyathophyllia; Dendrophyllia; Stephanophyllia; Caryophyllia.

Die Drebforallen (Tubinolida) baben mit Int worigen Fantilic sic Grifalt fo wis tis grofien, mit langen Tentafern verfebenen Thicre gemein; aber ibre

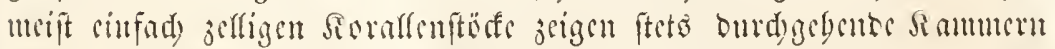

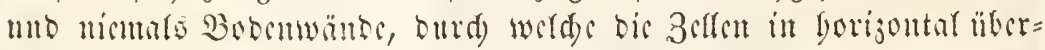

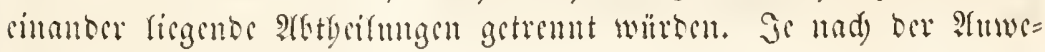
fenbeit cincr Gänle ober wou Gäntenthättern fo mis mad) ber Ganj:

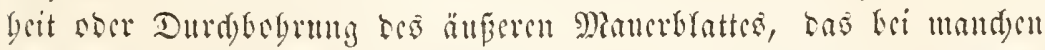

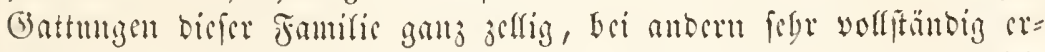

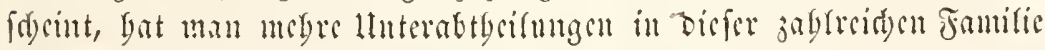
gerirtoct. Turbinolia; Desmophyllum; Cyathina; Desmia.

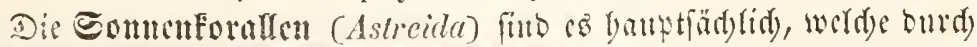

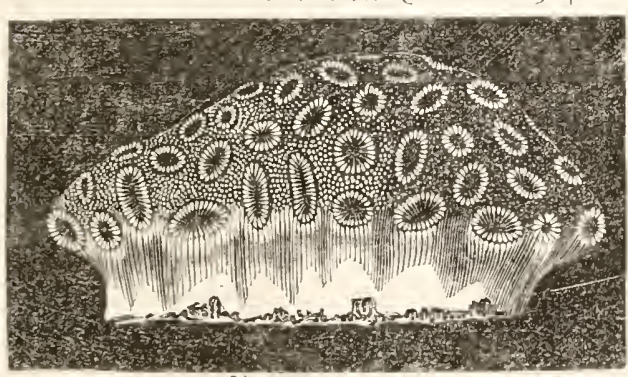

Jig. 92. Astrea.

ifere finweren, fteinigat Diafra bic Sorallemifi bitorn. Gie fint ungrutein jablreidin in (battungen won bem Minfidelfalfe an bio in

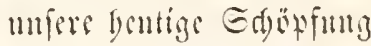
sertreten mo bebgalb in siele lluterfamilien mo (5rupten jerlegt morten.

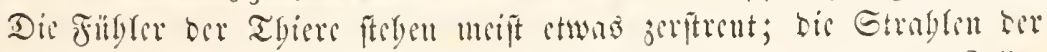

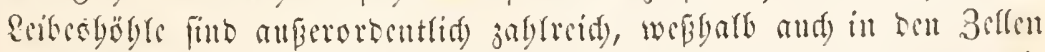
Eer Soraffen ein febr entwiffelter Etrablentranj fid fittoet. Dic

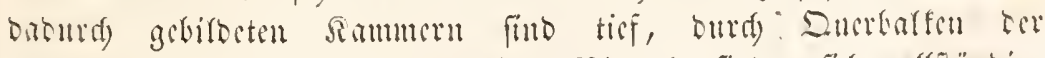

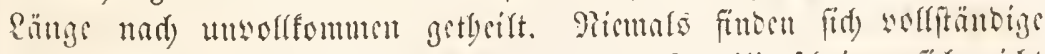

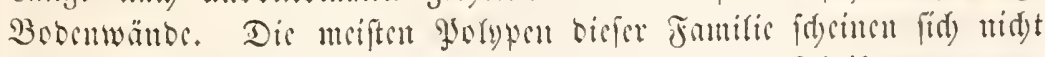

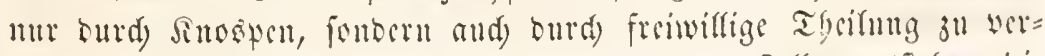

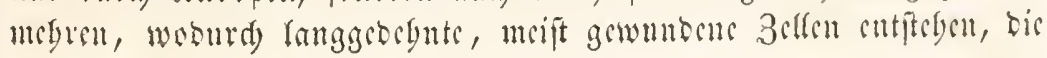




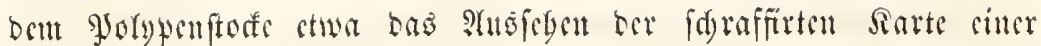
Berggegend geben. Die Roralfen bilben meift runblidse, biffe ftrinige Maffett. Radi Dem oberen Rande Der Gtrablen, Dic Dort ansigejart, bier ganj rumblid find, gat man zwei llnterfamilien unb in biefen sin=

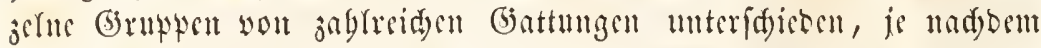
bis 3elfen ganj ifolirt breiben, fo tẩ tic Soralle sin äfiges anfeben crbält, ober Durd) poröfs 3wifd)enmaffe zufammengelcimt, surd) igre

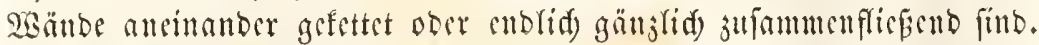
Eusnilia; Diploctenium; Ctenophyllia; Dendrogyra; Stylina; Sarcinula; Astraea; Angia; Echinopora; Macandrina

Die Sdywammforalfen (Fungida) bitoen obronge ober runtidye

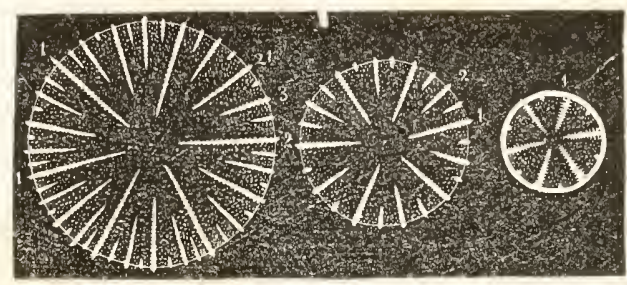

รig. 95.

Sumge Exymanmfurallen (Fungia.)

Maffen bon bebententem llmfange, bie meifîtus frei fitto oder fid) Der lluterfläd)e, anf ber fie riegen, wis ein biffer Heberjtig altwaffen. Dic Strablen Der Zellen find anserorbentlid) zablreid),

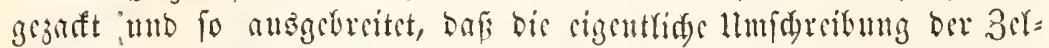
len feleft werloren gelyt. Bai Den cigentlid)en Edjwammforallen, bie sinfant find unb bentwod) oft melor als ben llmfang eines Telfers erreiden, if bas Thier grop, mit cincm ribrenförmigen Munoe und runben,

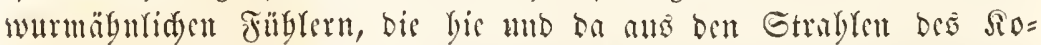
ralle berworftefen. Bei anteren Gattmugen find mur nod) werfümmerte, wulftartige Fübler worbanden. Die zablreiden Irten und Battungen find

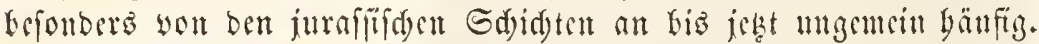

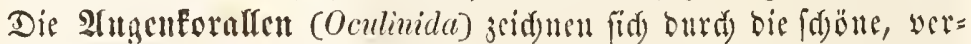

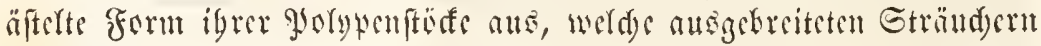
gleiden. Die Zellen find from, runblid), Die Etrablen mm wenis ent=

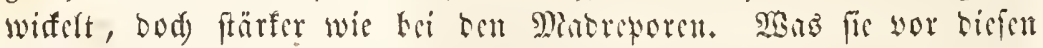
anszeidnet, ift bis ungemcine Särte und Jeftigfcit ber 3mifdenfub=

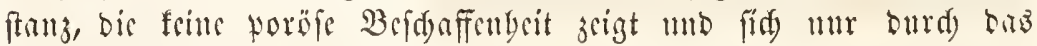

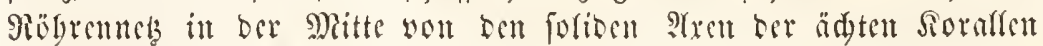
unterfacibet. Mand) Battungen biefer Familis werben befbalb oft

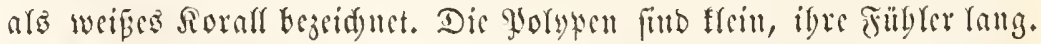

Eine bidglt merfwüroige Fanilie biefer Drbmung fund bie Stait= senforallen (Antipatleida). Der gुolypenforf wirb you sinct bornigen 2lie getirbet, bie cinte leberartige bülle gat, ill welder jufammenjiel =

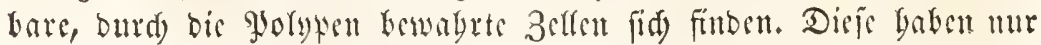
fed) cyrtubrifde Fübler im Sireje un ben Muto, wägrent bie lib= 
rigen Pinben= unb Sornforaflen, welde fouft in ber Etructur ber Sre mit ben Etrubenforalfen volfommen ubleremftimuen, adjt geferbte Fübler fefizzen uno befbark cincr folgenton Drontung angebören.

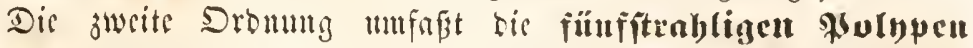

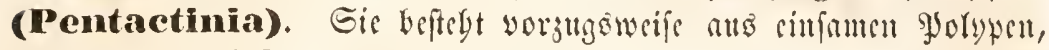
weldye einen cinfadyen ober boppelten Tentafelfranj un ben Mimo

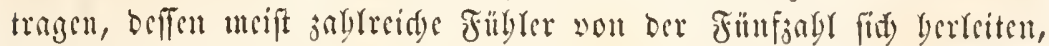
siu Berbăltuí, ons namentlid) im Sugentojufande, wo ber Fübler utr nod) wenige fint, beutlid Gervortritt. Sis baben niemals cinen

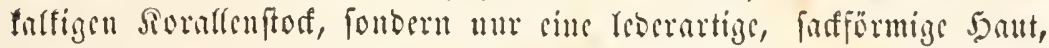
in welde rie füblerftone jurüfgejogen werben fant. Der bintere Tyeil igres Rörkers fibt bei ben gefeffigen arten anf siner leberar=

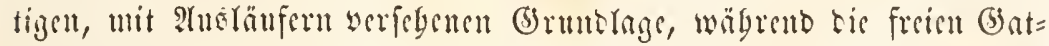
tungen entweber sine Sangid)site bejizen dober mit bem jugefpizten weid)eren Sointertlgeile im Ed)lamme fteffen.

Die Familie ber Secblïtben (Zoanthida) beftegt ats fenlenfür=

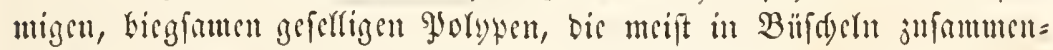

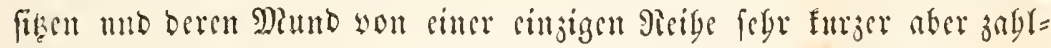
reidser Fübler ungeben wirb. Dis meiften bicfer glolypen tünnen fids theilweife in bie leberartige Sant, bie ben mittleren Sïrper umgiclot,

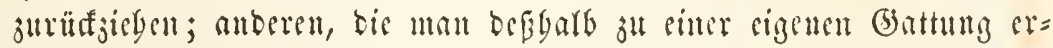
boben bat, gebt bies Sermögen ab.

Die Samilie ber Secancmonen obct Mecrmelleln (Actinida) fommt bejonbers in ben warmen unb gemïpigten

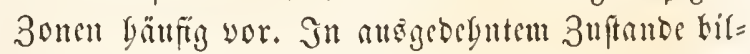
bet ber Sibrper bicfer Jorywen fete einen auf bei= ben Griten abgefutsten Eylintor yon grëperer ofer geringerer bäbe. Die untere Frähe bes Gy= linbers wirt von einer Gangideibe gebiloet, wo=

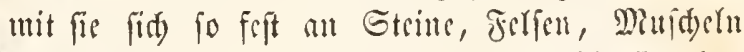
icitfangen, sab es oft faum möglidy ift, fie obute

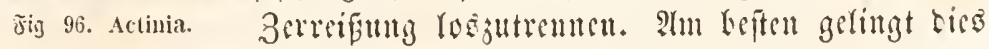

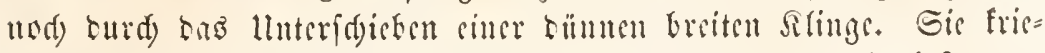

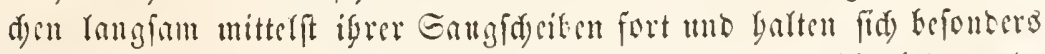
gerne in geringer Tiefe auf. Jn folden Decren, weldye bebentente

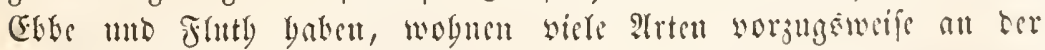
Grönje ber Yebteren in TBaffertümpeln, dis anf ten felfen jurüdblei=

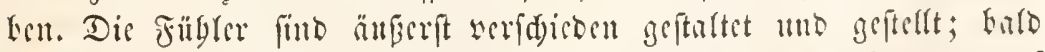

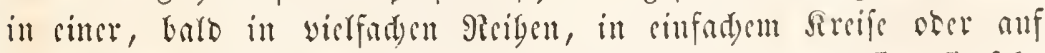
cinem fünflappigen atรftuiflpbaren Gterne. Bai ben sinen finb fie febr 


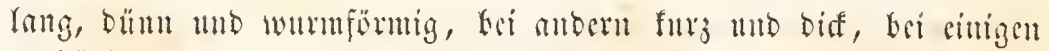

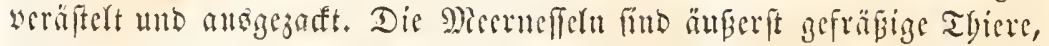

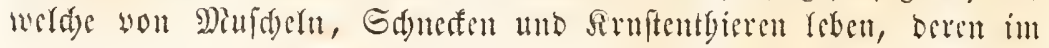
Magen anbgejogene Edaren Durd) Den Muno wieber ansigeworfan werben, was oft mit fo vieler Energie gefdiebt, bafiz ber ganje, weite,

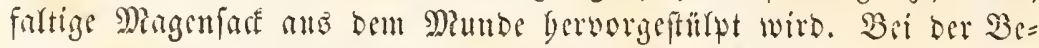
viibrung jieben fie fid mit grofer ecthaftigteit jufammen und ficien

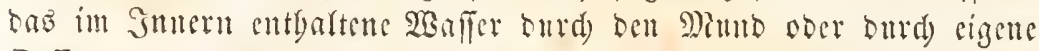
Deffumingen an bem (Stunde ber Tentafel nus. Sie prangen meift in ben rebbafteften farben unb hefonbers jeidnen fid bic sübler surd bremente Tinten aus. Gie baben ein än perft jäbes Seben unb laffen

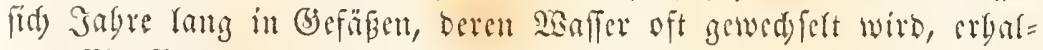
ten. Cin Beobader an ort Rüfte won Gdjottland batte ein fordbes

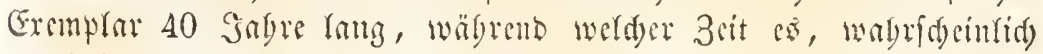
ourd) itnere Sinosentbitoung,

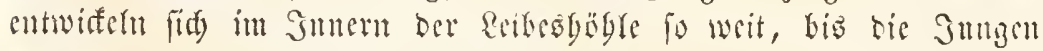
undte gyofypen mit fünf runbliden margenartigen Strablen barferlen. Sn Dicfer beftalt werten fie burd ben Mund ausiofpicen. Die Zabl

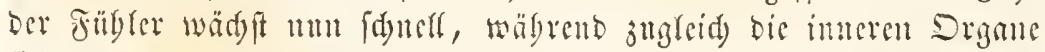
fids antriben. Einige ?trten werben in ben itnlienifden sinfenorten son Dom gemeinen Bolfe gegeffen. Actinia; Cribrina; Minyas.

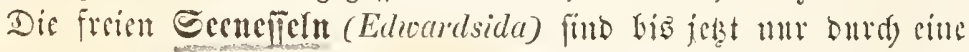

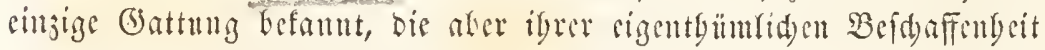

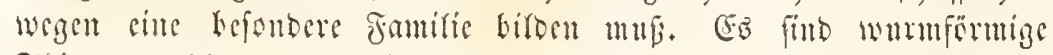
There, werde werfteft im Gande reben und biô jeşt num an ber

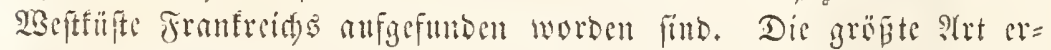

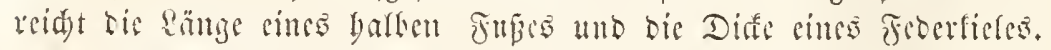

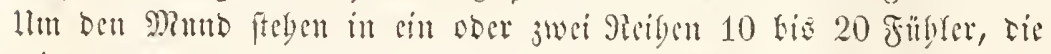

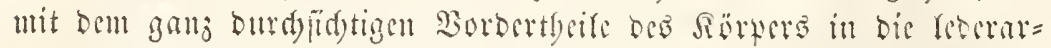

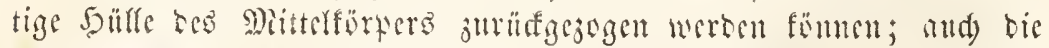

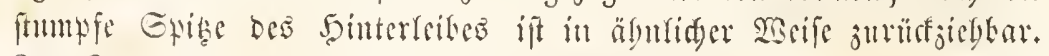

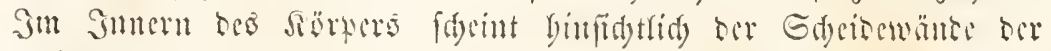

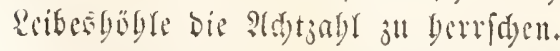

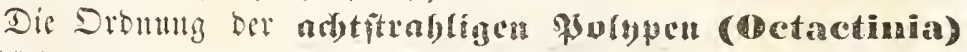

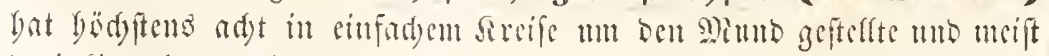
Ereieffige, hrattartige föbler, weldye an ben Geiten gefurt, jumeifen

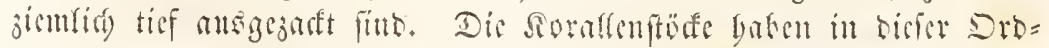

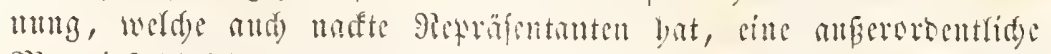

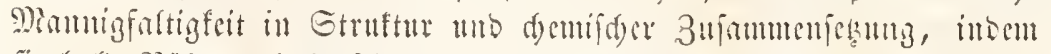
fie baro giobren, bato fowammige Etöfe, hato immere then hitoen.

Dic Familic ser Drgelforalfat (Tubiporida) bat meift falfige 


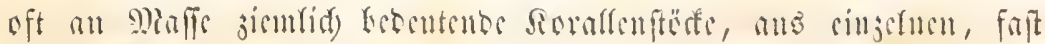

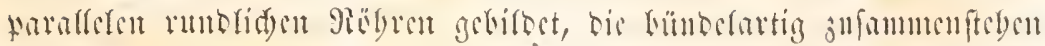

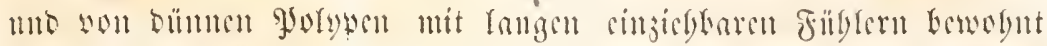

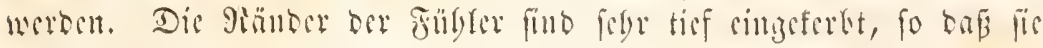

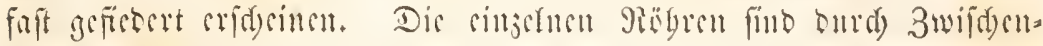

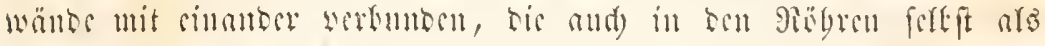

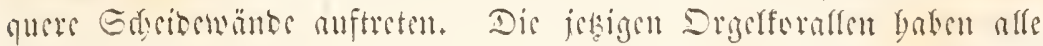

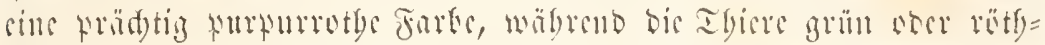

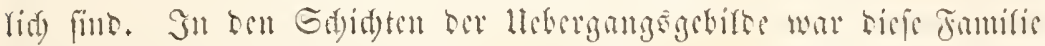

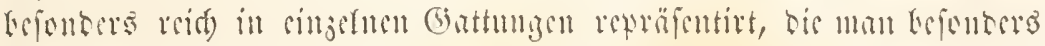
mai) ber Etellumg ber Päbren muteridjicosu bat.

Die Fumilic ser Piljerallen obcr Eecforfe (Alcyonida) bat

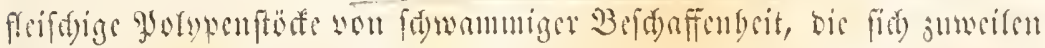

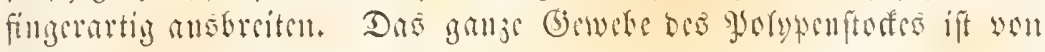

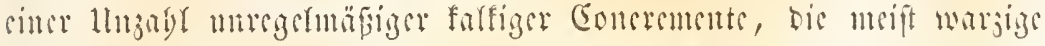

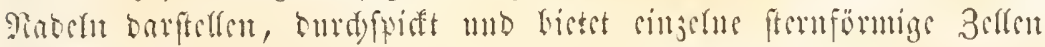

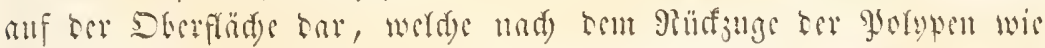

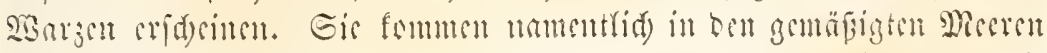

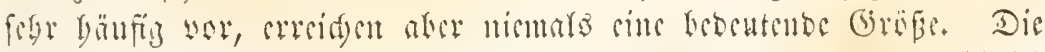

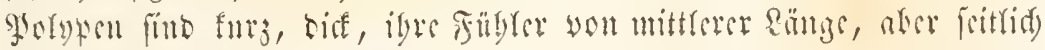
fert tirf singsferbt.

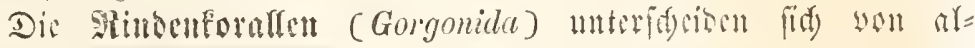

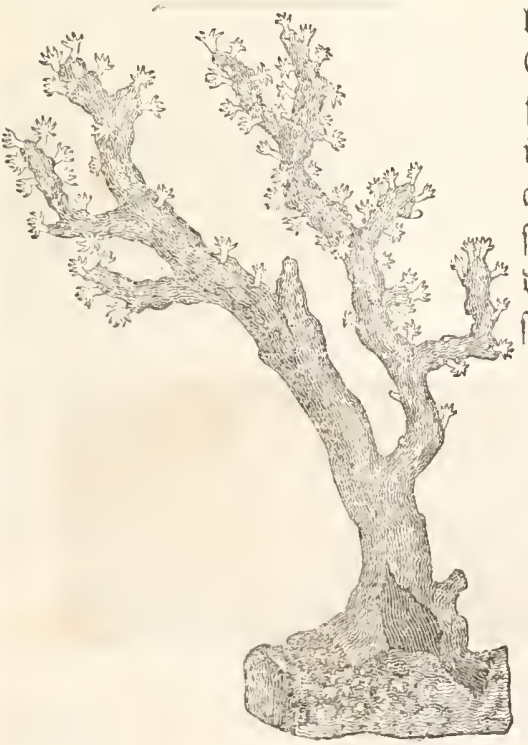

Sii. 97.

Isis nobilis. Då Grbefforaff.

ren Entwidelmug rimel folfigen, fic= frligen ofer bornigen stre, dic in Bammform borätint mo mit cincu reseratigen lleterjuge ser feben ift, in offfen cinjeluen 3 elfen bie gुolyten fteften. 3mweilen wer fteinctu dicfe 3eflen ctenfalts mo

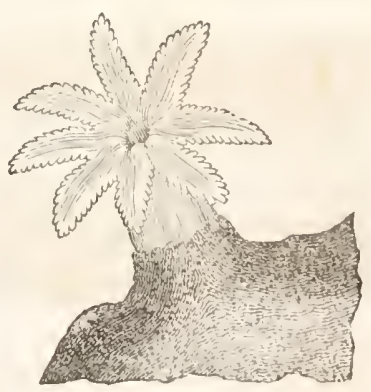

oiis. 93.

(Ein cimje!ner Futur. 
ftellen find bann als furge Bedberdsen bar, welde ber sate auffïben. Sn ber weiden Rinbenfubftanj, welde bie STe mugiebt, fmb meift in

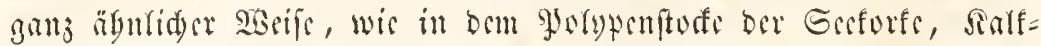

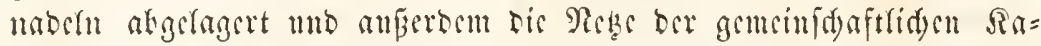
näle, werdes dic golypen verbinden, fidtbar. Die gorypen find ocnen

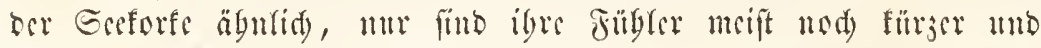
weniger tief singeferbt. Man bat bie singelnen battungen Fefonters

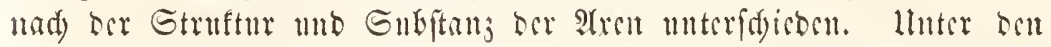

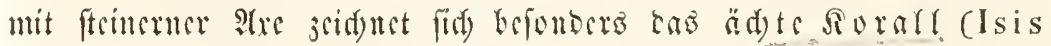

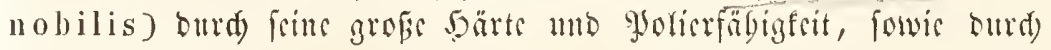

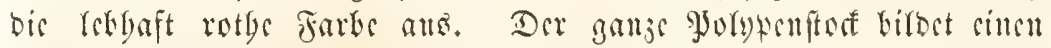

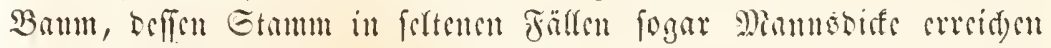
foll. Die ganje atre ift wolfommen ungeglictert, jufammentyängento

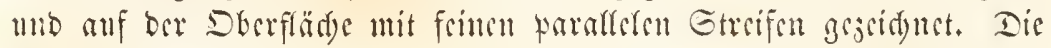

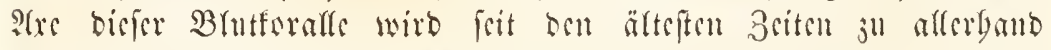

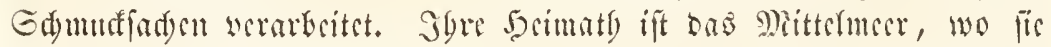

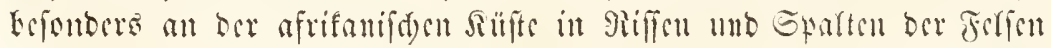

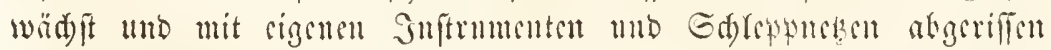
wirb, was fets cinc langwerige Dperation ift, on fie fid) bis in sine Tiefs won 700 Fufen anbant unb bie gröbten Gtöfs meift nur in

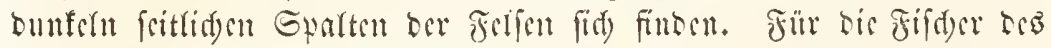

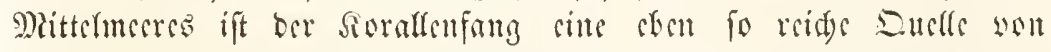

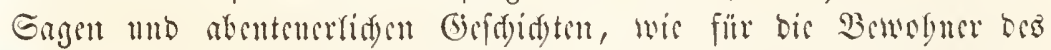

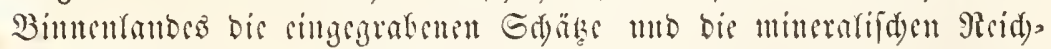

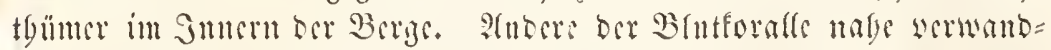
ten Gattungen baten sine geglicoerte Fre mit bornigen ober fteinigen

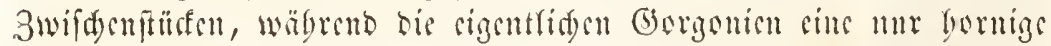

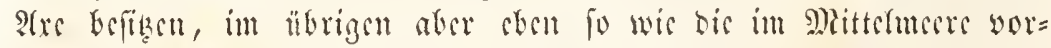
fommente Sicferforalle in igrer Etruftur ganz mit ben Batferaffen ïfercinfommen. Isis; Gorgonia; Hopsea; Prymmoa.

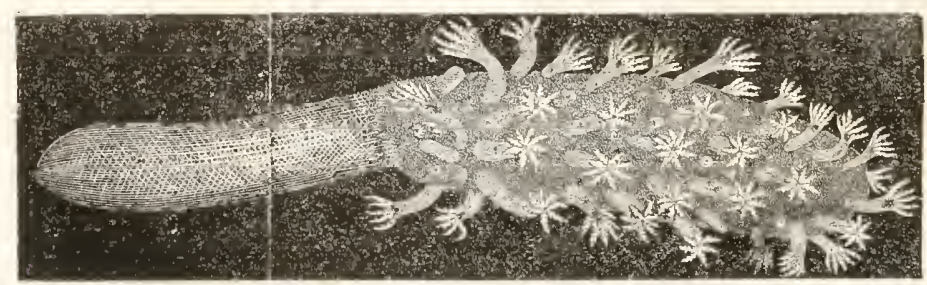

öig. 99. Veretillum cynomorimm.

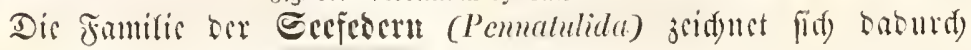

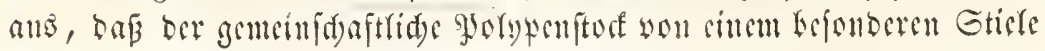




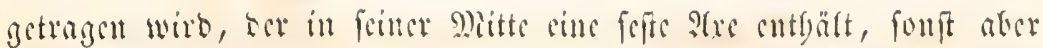

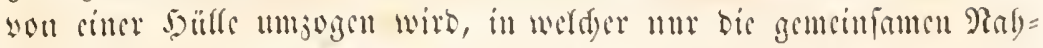

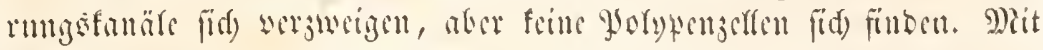

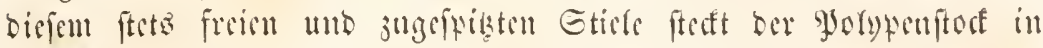

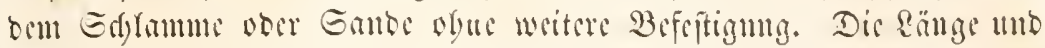

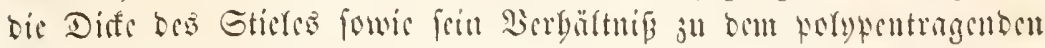
Thalle werblelt ungencin. Bai bou Gregurfen (Verelillum) unb cigentliden Gefeocru (Pennatula) bat or bie eänge mo Diffe

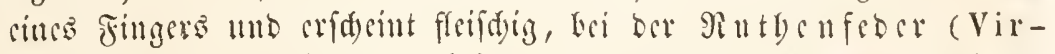

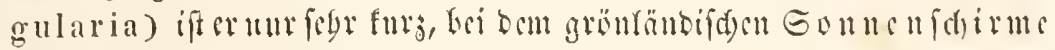

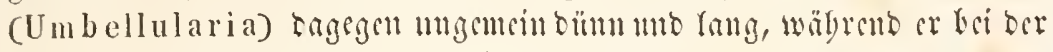

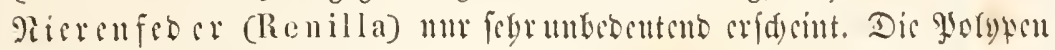

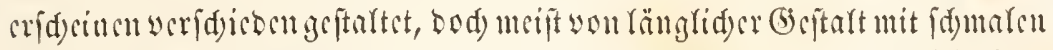

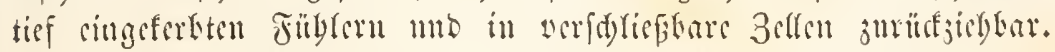

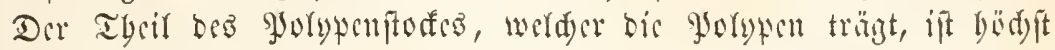

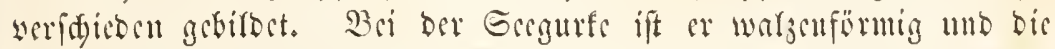

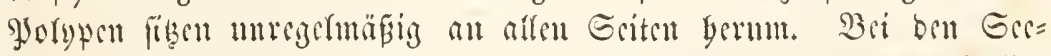
febcrn fteben auf briben Griten cinco mittleren Gticles breite fattige

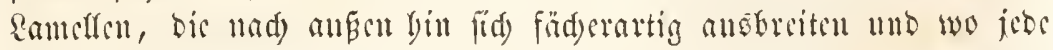

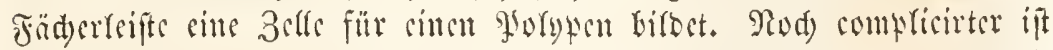
biefr Bifbung bei ben Pintbenferern, wo ju briben Griten sinco Erbaf=

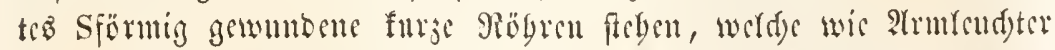

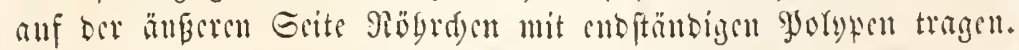

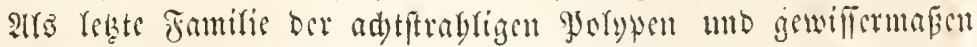
als annloge ber Micenefleln, Getradten wit bie Famitic ber Mices=

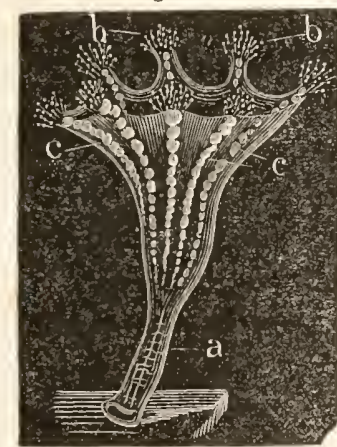

ซig. 100. Lucernaria.

a ber Erid, b tic Füllet:

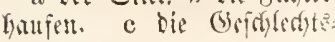
fratiett.

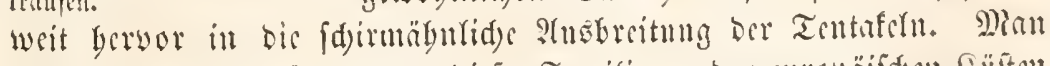
fibirne (Lucernarida) gaflertartige, ourd)fid)= tige, mit rinem lunber Sticle fid) anbeftente

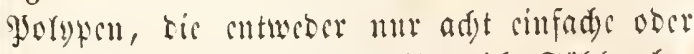
ferfit mat bict feater getlocilte bide Fiibler be=

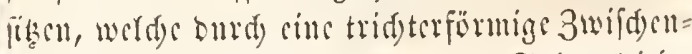

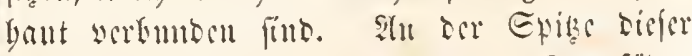
Fïbrer temertt man rigentyümfids Eangfäsen

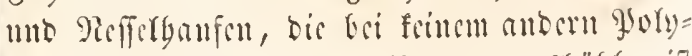
yen worfommen. Dis Berbammugboble ift

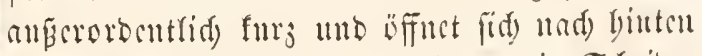

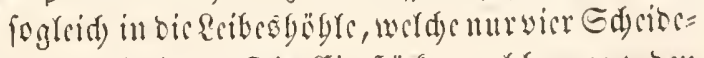

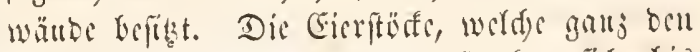

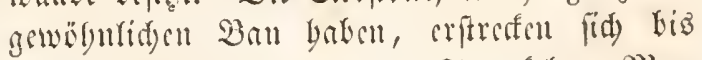

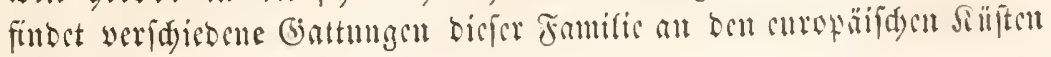
DeB̃ Dceaneg̉. 


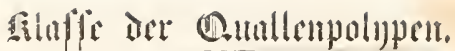

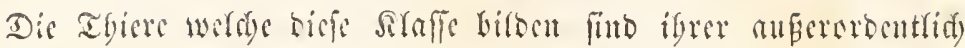

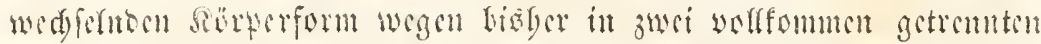

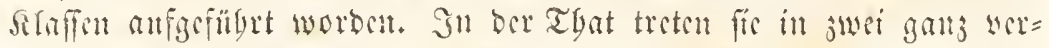

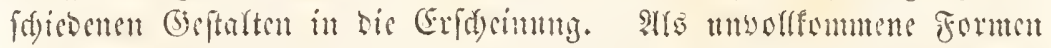

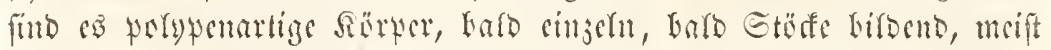

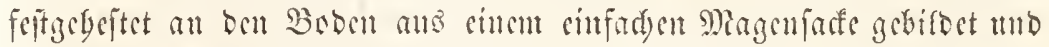

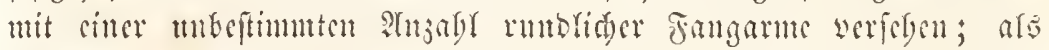
volffommere Form fintet man fie fref fow whment in Necte in runb= lidaer Sdecten= ober Gifofengeftalt, won beftimmt ftrabligent Ban, ber genane 3ablenwergältniffe erfenten läpt. WSth wiffen jest, baf

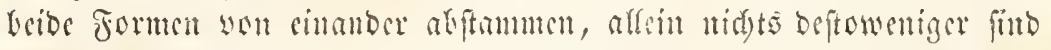

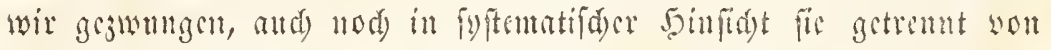

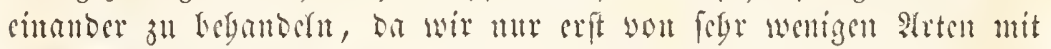

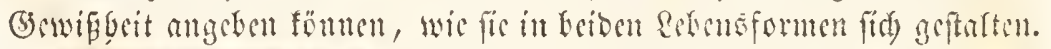

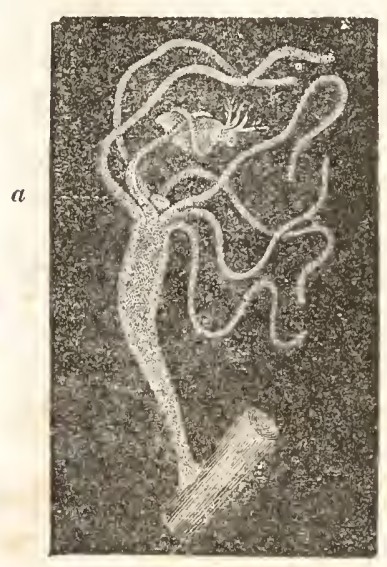

ซii]. 9\%. शrmto glinilere, (Hydra) ter cben eiten 2sofferfol (1)aphuna) gefongen bat unb in begrific fteft, dic

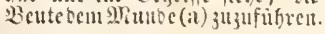

Die mmolffommente Form weldy wir mit bem Ramen bet strmpolguea $\mathfrak{b}=$

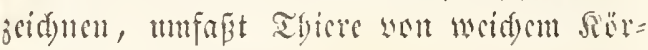
perbat, bie meffens in Sulonten juf reben und beren s]into won ciner ber= änberliden 3abl mimperfofer, rmbliduer,

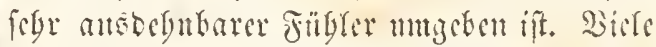
Gattmingen Gaben cinen Grolypento of, Der

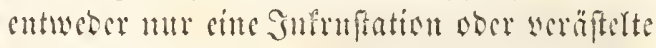
Bämmdjen bifort, die gloffenfürutige 3atfen trigen, in weldas fid meift bie cimjelnent

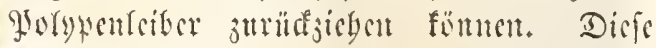

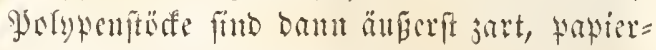
artig oes bormig mo bieglam; fie birben nicmalo grubere Miaffen ober Soralfen, wie bis cigentfidsen gofypen.

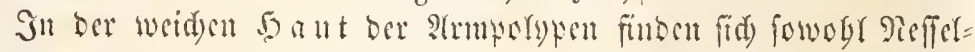

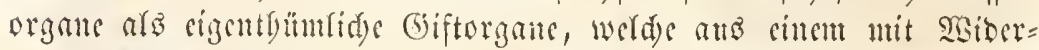

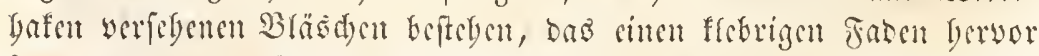

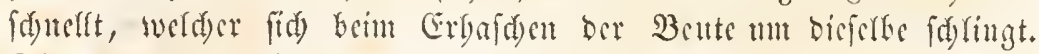

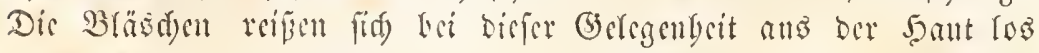

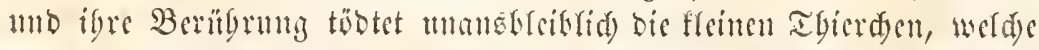
won ben simen erfagt waren. Dic Jangame fereft find ftets rumblich 


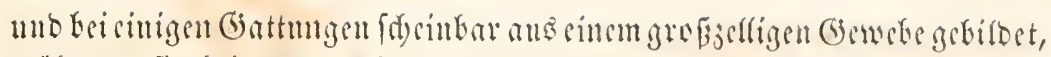

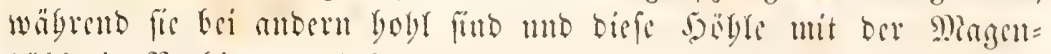

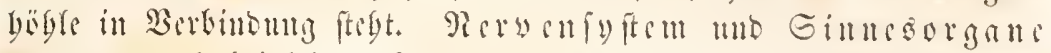

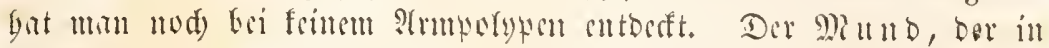

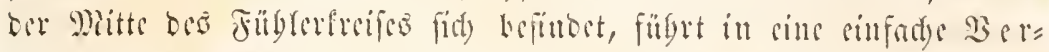

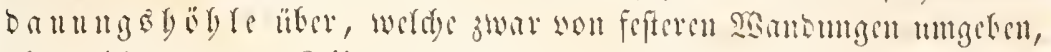

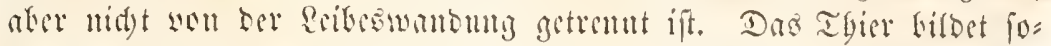

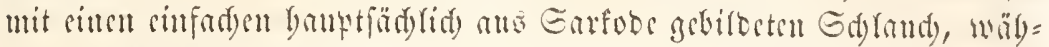

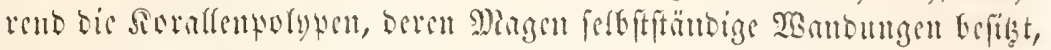

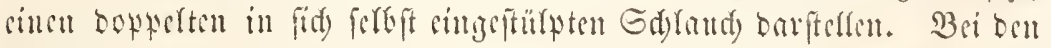

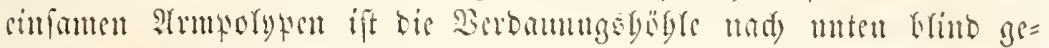
fdeleffen, wälyent bei ben gefelfd aftlicten Gattungen fie nad) unten in

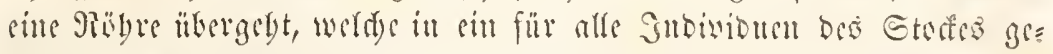

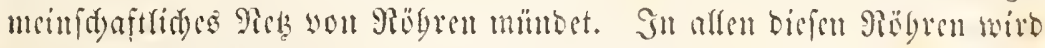

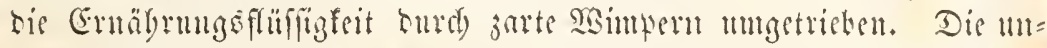

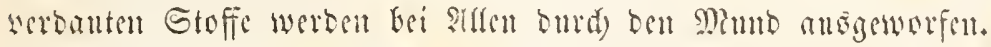

Die Fortpfranz

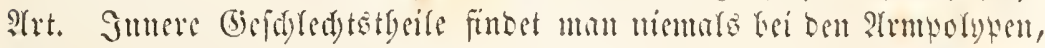
wäbrend Sำ

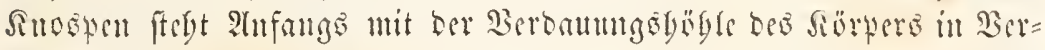

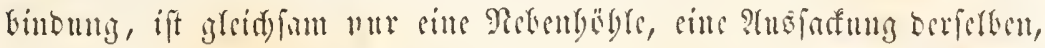

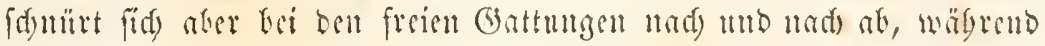

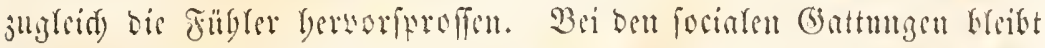

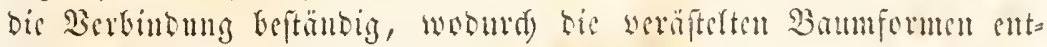

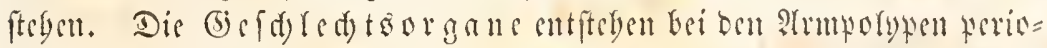

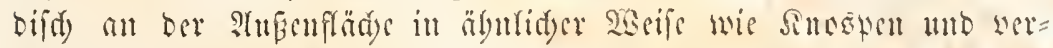

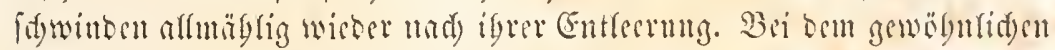

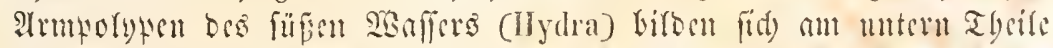

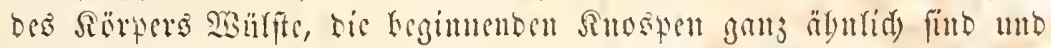

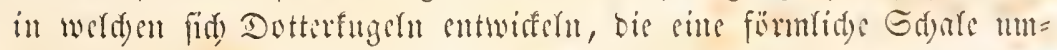

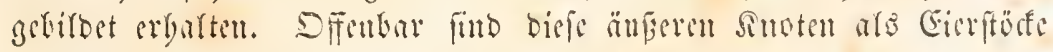

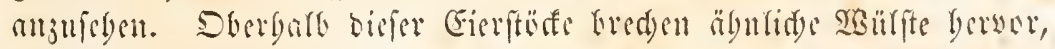

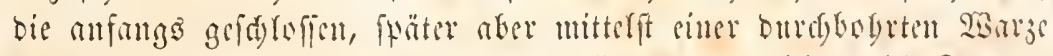

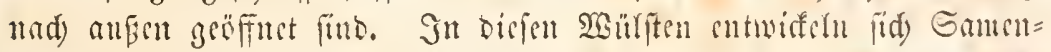

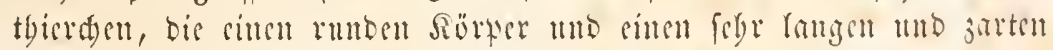

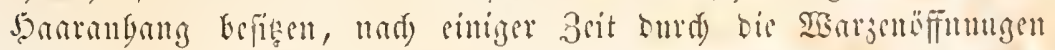

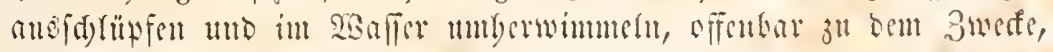

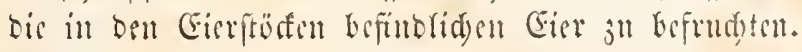

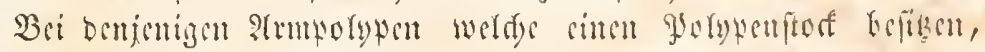
mie manentlid) fei ben Grofenpolypen. (Campanularia) bilocn 


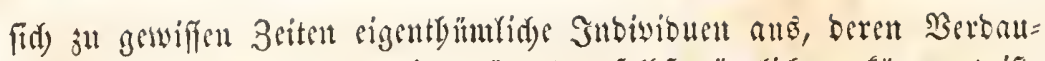
ung

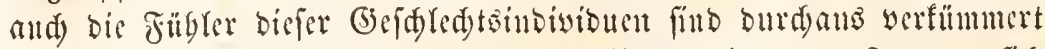
und meiftens bilben fie mur gejd)loffene Bed)er, in beren Juterem fids

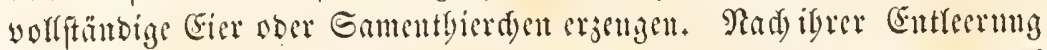

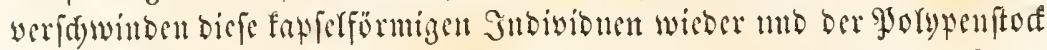

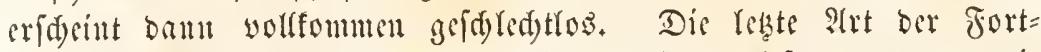
wflanjung, werde die volfommuere Dnaffenform liefert, werben wit erfit fpäter betraduten.

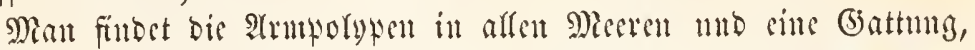

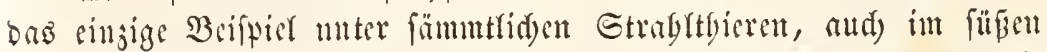
Waffer. Gie bilden ftets unr febr ffeite, bünte Johydentöte, die entweder fruftenartig fint ober fleme Fäbdyen und Bämuden bas= fteffen, bie fid) überafl, befonters aber and auf ben Blättern ber Tange und ansern Geepflanjen anfiebeln. Diejenigen ber fitblidsent Meere fint nod) faft gat nidjt befannt mito and bie ber ä̈rblidaen Gee unt unjurcidyend unterjudst.

Die 3ngl ber befonnten STrmporyen ift nut gering und ftebt burd)ans in feinem Berbältuís mit berjenigen ber vollentoeteren for =

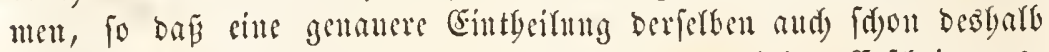

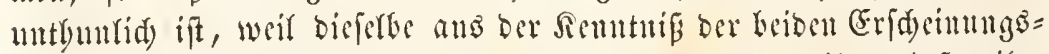
formen gemeinfdaftlid) bervorgeben mabte. Sisir theifen einftweilen die armporyen in forgende Familien eint:

Die Familie ber Sübwaferpolypen (IIydrida) beftebt bautsäd).

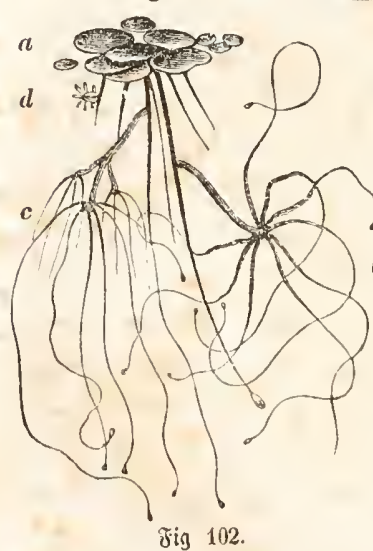

a 9Banertinen, an Deren 9Burzen Die \$olypen fiben, b ein entwistelter folyy. e ein

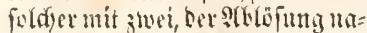

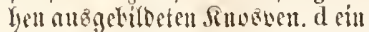
anberer, gaแว zแfammengezogen. lid) ans ber (battming Sybra, beren Arten man worjüglid) bänfig an Sanferfinfenwur= geln angebeftet findet. Das Therer ift ganj uarft, mit langen Fangarmen verfelen, die es and) jum limberflettern brandt, obgheid)

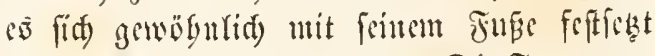
und rubig auf $\mathfrak{B}_{\text {cute }}$ lancrt. Die Fangarme ferbft find gobl und ibre bougle ftebt mit Der, ben ganjen Reib bes Thieres Gilbenden Serbaumgoguble in Serbinbung. Sie fün= แen ungemein verlängert werben unb bienen Durda ibre Reffel = und Jaftorgane zum Fangen Der Bente, die bejoubers in Taffer: flügen (Cyclops), fleiten Miülfenlarven แnto Derlei Thierden beftebt. Die Thiere finto ungebener gefräbig uno yflanjen fid) bei gu= tem Futter Ieblant burd) Sinospen fort, bie 
an ber unteren Reiteşälfte Gerworfproffen. Syr Reben ift fegr jăbe,

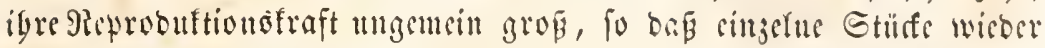

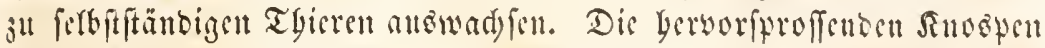

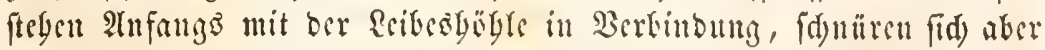

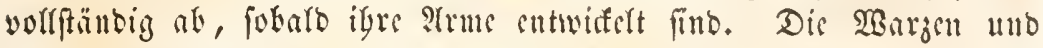
MBallite, weldye won ben bejonters im Gommer berworfproffenben bese

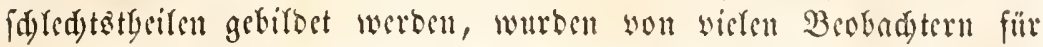

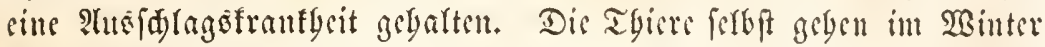

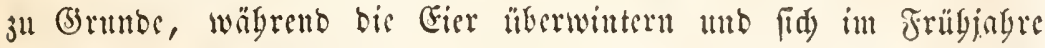
entwiafeln.

Dis Fomilie oer Röbrenplypen (Tubularida) begreift meiftens

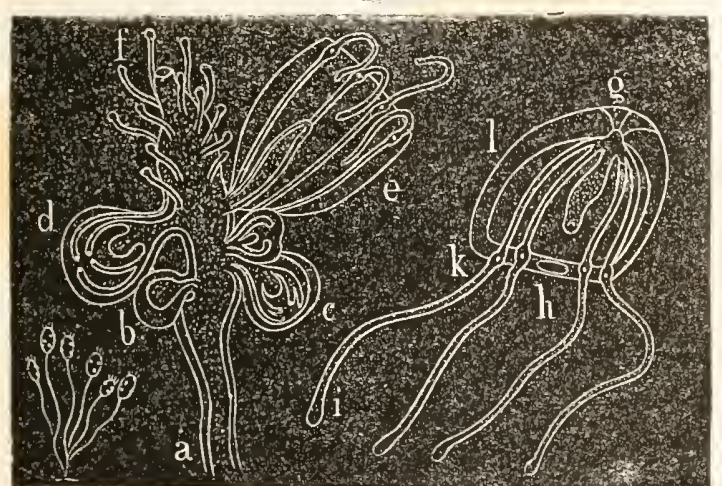

รig. 103.

ชin. $10 \%$

ชิ่ง. 105.

Syncoryne.

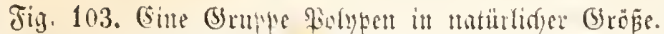
Jig. 104. (Sit Piblyp mit Duallenfustent. Fig. 105. Cine losgelöste Dualle a ber @ticl; b, c, d, e Duallenfutogen in

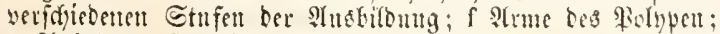

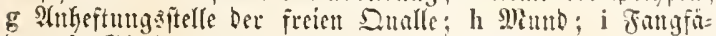
Den; ; Glocfettrant ; I Rorper. fümmerten Füblern. Faft ber affen gat man bie Bifbung ber böberen Euallenform beobadtet. Ge uad) ber Stellung ber Fügler in ciner

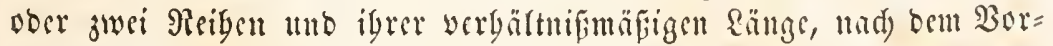
Ganbenfein siner bünnlyätigen göbre ober beren Feblen, Gat man verfdiebene (Sattungen unterid)ieben, bie faft alle an ber Siljte ber Rorbfee und bes Decans yorfommen. Coryne; Syncoryne; Tubularia; Eudendrium; Synhydra.

Cine britte Familic ift bicjenige ber (Glocfenpolypen (Campanularida), bei welden bie Polypen fämmtlid) in flafdyenfürmigen Bed)ern auf wet.

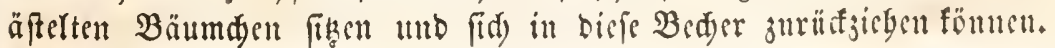

Bogt, Boologilde Brite I,

gerellige Thiere, bie oft sine jarte Pöbre n!s llmfteibung ibres Sörwers befizen, in merdefie fid) aber nies=

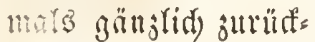
Sitfentümen. Diefrei merbenden Duallen= Enospen entwideln fiid) an ber $\mathfrak{B} a$ fiz ber Jülyler, weld)e nidyt bobl fint. Dis (bis= (d) $(e d)$ to = Gubivionen bilben ba wo fie be= obadjet find feulen= förmige full gefticlte Formen mit ganz yer=

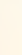




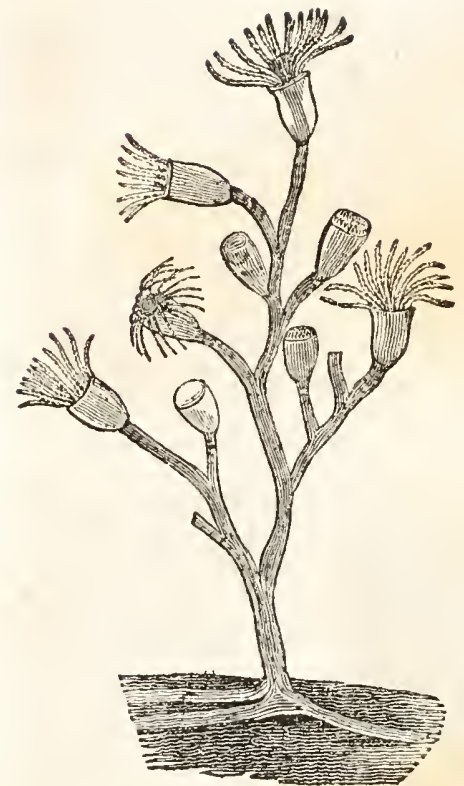

Se nadjbem bie singeluen Bedjer Yang gefielt ober fitellos fillo, bat man verifiedene Gonttungen aus dicjen Brofenporypen grbirdet. Die Bedyer in welden fid Fier und Samen sut= widelu, zeigen weder Fribler nod Berbaungôfanäle, wäbrend bie ge= (d) Ied)tôtofer Gubividuen biejelben be= Figen. Die ganzen gyorypentitäe bit= Den feberartige $\mathfrak{B a ̈ u m d j e n ~ o b e r ~ s i n g e l n e ~}$ Giröadden, bie mit langen Stislen auf

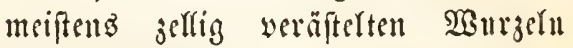
anfïhen. Die grö̈eren Formen fin= ben fid bejonders in füblidjen 2 Res= ren, wäbrend in ben Märblidyen melyr bie jarteren flesineren bonttungen vor= Ganben fint. Campanularia; Sertularia; Plumularia; Dyomea.

รis. 106. Sertularia.

3ei betl mriftell Strmpolypen bes Merres fannte man fajon

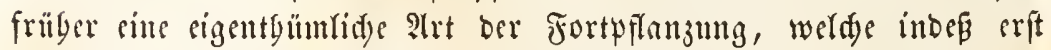
in ber neuren 3 sit in igren anderweitigen $B_{e}$ jiefungen genauer ers faunt utto gewürbigt wurbe. Diefe Jortpflanjungšweife beftegt barin, Dá̧ an irgend ciner Strlle bes Reibes, bard in ben Irenitellen ber

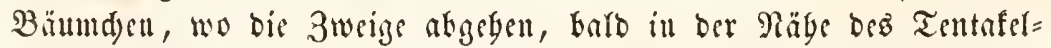
franzes, barb fereft inmerbarb sefferben sigentgümlide Sproffen ent=

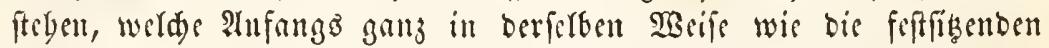

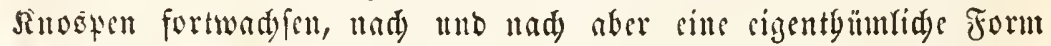
antrgmen, bie von berienigen ber urfprüngliden gyolypen auseror=

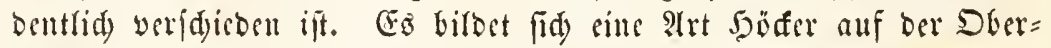

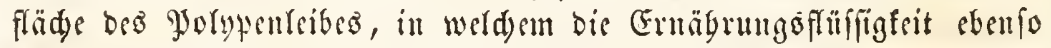

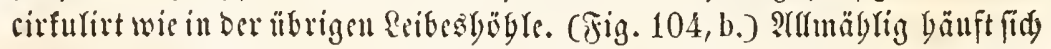

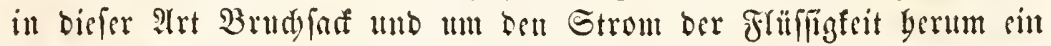
Serun won feftrer feinfürniger Subftanj an, ber fid nad und nad

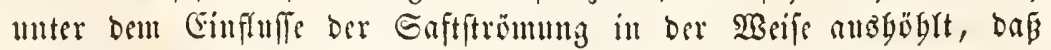
man nad) siniger 3eit cinen mittleren Etrom unt 4 ober 6 Seitenfitröme

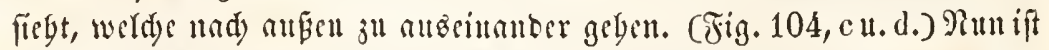

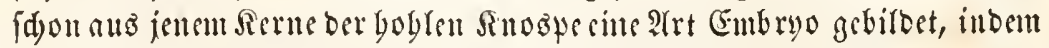

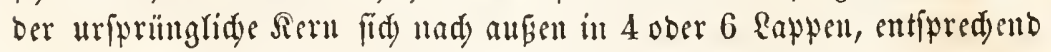

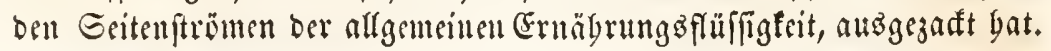


Der fproffende Embryo fiellit mun cine Brode bar, bie mit bem Gipfer

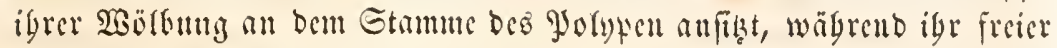
Simb nad) aufen fdjaut. (Fig. 104, e.) 3e nad) ben (Jattungen wadjen

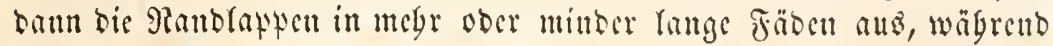

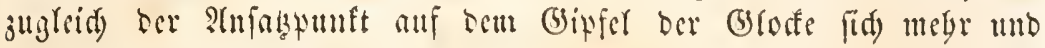
melgr abjdnuirt und ber mittlere 3arfen, in weldest ber Strom ber

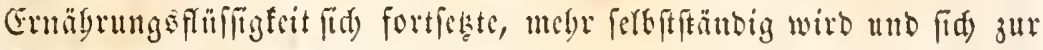

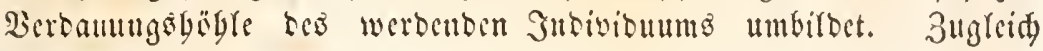

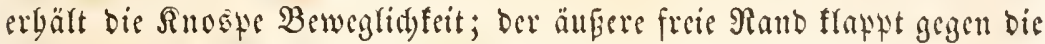

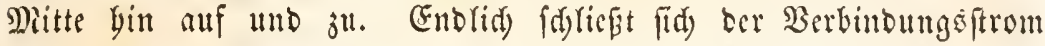

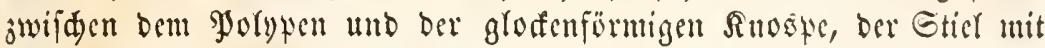
bem bieje anging iduturt fid an igrem Gipfer ab unb sin tryftall=

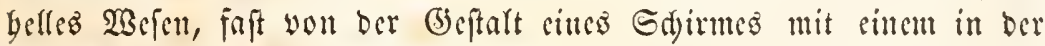
Mitte angebradten Fortiage, auf bem ber Diund firt, cine wabre

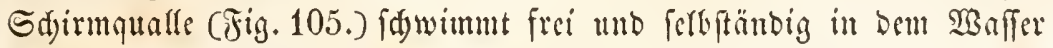
unmber. Mrandamal befitzen bice jungen Sdjirmquallen fdon bei ber

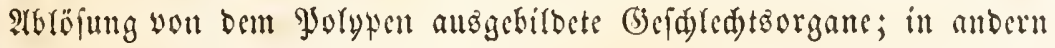

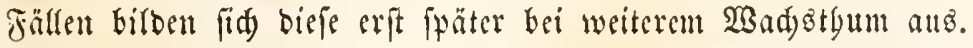

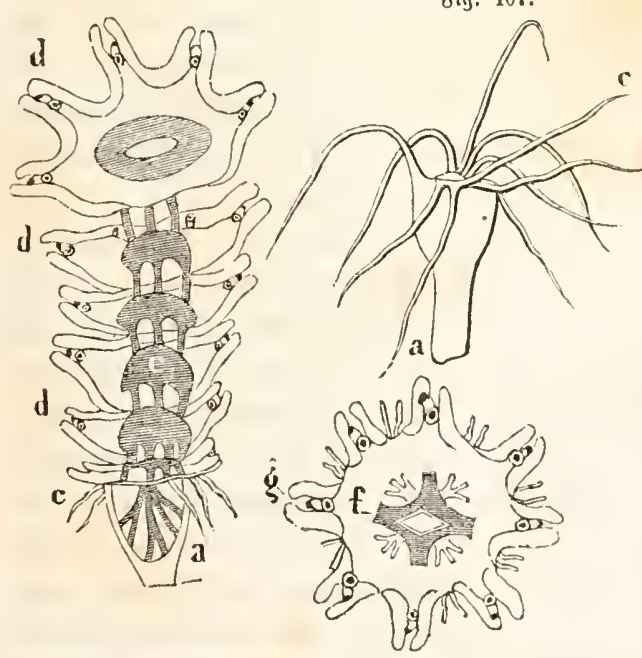

8ig. 108.

Fig 109

Hydra tuba uno bie aus ige herrorfuospenben Duallen.

a ber Fun ber Hydra, c ifye Fangarme, d tie eitzelnen, taflenförmig aufeitumberïbentoen Duallen:

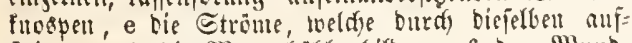
peigen unb bis Mlagentibgle tilben, f ber Miun,

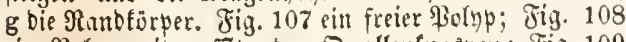
ein \$olyp mit aufîbenden Duallenfnospen; Jig. 109 eine losgelöfte junge Dualle.
In ber einfaden $\mathfrak{2}$ siff wis wir es foeben beidries ben, findet tie Duallenjen= gung nidft bei allen $\mathfrak{A}$ trm= porypen ftatt. Man bat fowogl an ber englifalen, wie an ber norwegijden und norbamerifanifalsen Rilfte Irmpolypen gefuns Den, weldye bem gewöln=

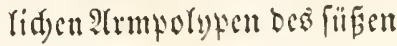
Salfers fo älutlid) falyen, Dá̉ man fie fogar mit bemiflber in cinc Battung bradte unb nur ale 2 trt unteridjicb. Bsi bicjen

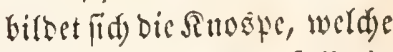
zur Duafle werben foll, in Der Mitte Des grïglerfran.

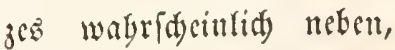
viclleidst feleft auf bem

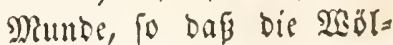


bung bes glodenfirmigen Subivioummt auf bem Munbe bes glolypen aufriegt und ber freie Rand nad) oben ftebt. (Ege fid nod) biefe Rnozpe abgelist bat, bildet fids jwifden ifr unb bem glolypen unb jwar won

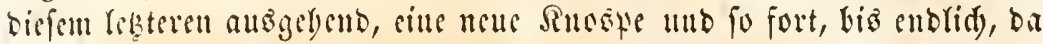

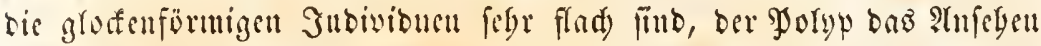
sinco Tuffakes you llutertaffen bat, weldse auf einem furzen, ourdy= fid)tigen Stiele ruben; bie oberfte flad)e GSloffe ift Der ältefte Serim, bie unterfte ber jüngfte. Dic fämuntfiden Snoŝpen fulb mitcinander

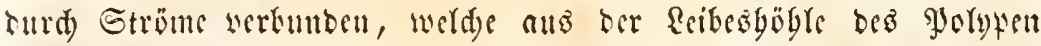
nadb oben anfiteigen. Dieje aufittigenden Ströme, werdae aud bier jur Biroung oer centralen Berbaumbsgägle und ibrer Eci= tenfanäle beitragen, werjëed)en alfmäblig, inben fid bie Rnosten ablöfen แnb alö freic Dualleแ bavoufdwimmen. Sm Plugenblife ibres Befreinng baben biefe Suallen bic Breite eincs viertel 3ollez; fie wad) fen bis zul cincm Durd)uneffer von mebr als eincm balben Fupe unb fint in ber Torb = unb Dftee eine ber bänfigften ?trten, bis it Gd)wärmen von Millionen ju gemiffen 3eiten erfdermen. (5) ift bie

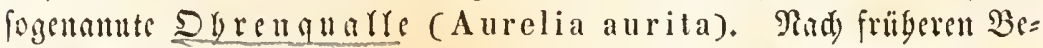
obadytungen glabte man, die fdiffelförmigen Snbiviouen, welde auf

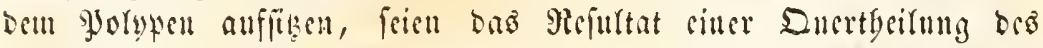

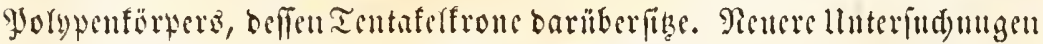
baben gejeigt, Daß bies ein Jrrtlum fei, unb onß ber Fublertranj

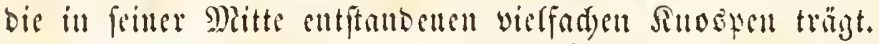

Bir fenuen Durd) bie genaueften Beobadtungen ben gangen Sreio ber Entwiffelung, weld) dic Dorcuqualle burd)lämft. Die
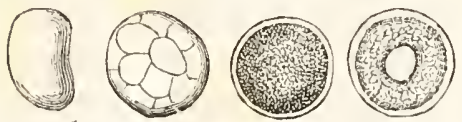

112.

113.

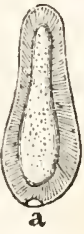

Jis. 110.

111.

Gier ber Dlyrenqualle.

Fig. 110 bas reife 5i; Fig. 111 bafielhe in Der Dottertheilung; Fig. 112 und Der Dotter= Theilung; Fig. 113 ctite Sitoung bez (5mbryo; Fig. 114 ber frei benegte Gulurtor. a Eaugnapf

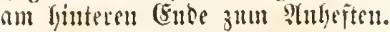

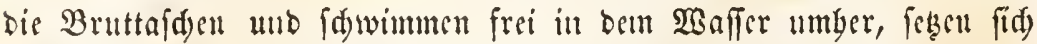
aber nad) einiger 3cit mit ber bemerften (jrube feft unb gebell mun weitere Beränderungen ein. Sie werben cylindrifd, bas freie Enbe

Duallen fint getrenuten (B) $=$ (d) led)tes, ifgre Eier entwiffeln fid in befonberen Bruttafden. Rad)bem fie ben Furd)ungs= projeb burdalanfen baben, lit= ben fie fids ju sincm owalen infuforienartigen $\mathfrak{B}$ cjen un, Das an bem vorbern biftern Finbe sine feidete (b) rube befilst unb cinen lleberzug won grims merbaaren bat. Jn biefem 3ujtanbe werlafien bie Jungen 


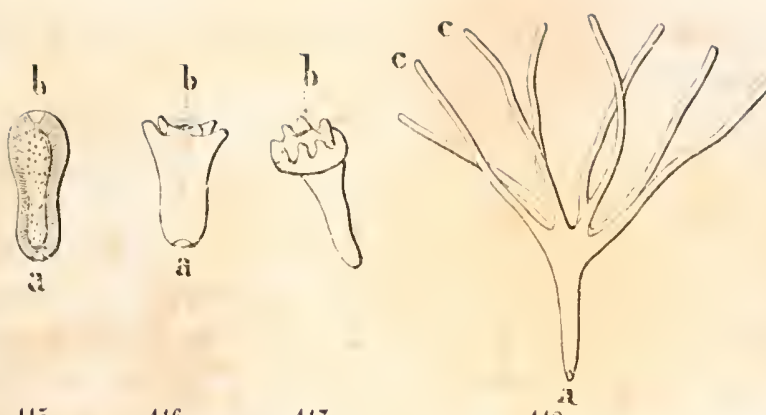

Jin 115.

116.

sunge ber Sfyenqualle.

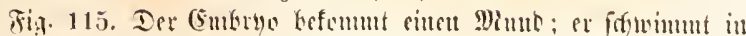

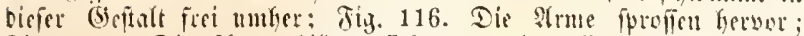

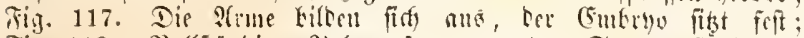

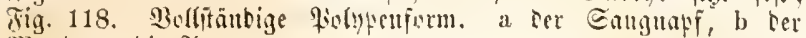
munt, c tic ?lmus.

Surbel gat, tie mit iblem freisu gejabnten Enbe sin Simmmab bewegt.

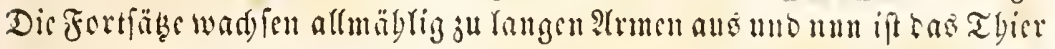
sin wodfommener atmpolyp won grofer Gefräßigfeit, ber mit frinem

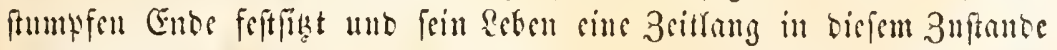
fortielst, um fiäter burdy Sinosisung wicber Dgrenguallen ju erjengen.

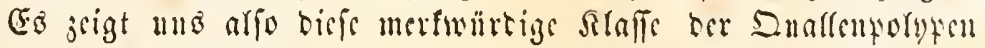

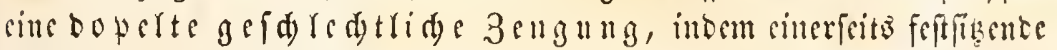

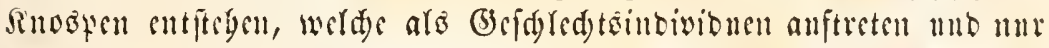
Gier ober Samen erjengen, beren Ernägrmitg aber burd) bie Circmln=

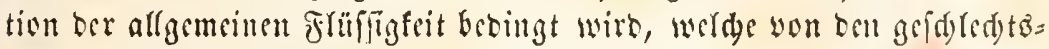

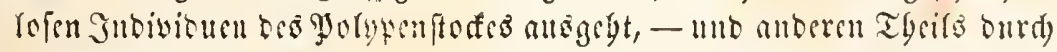

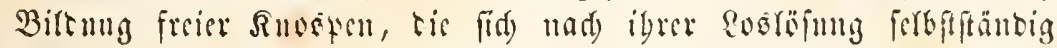
crmälen mb ju werbältnigmägig bebententer Gröge anmadyjen. Diefe Suosten fint bic Edjirminnalfen, beren Etruftur writ vollfommencr ift, arz bickenige ber boryten.

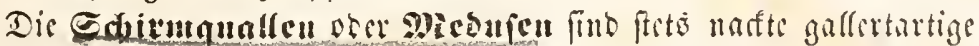

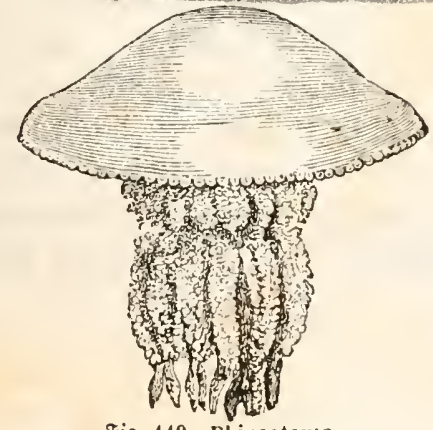

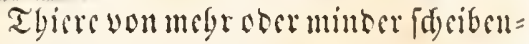
förmigem, juwsilen gledfenförmigem

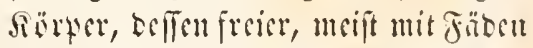
fejegter Rant rutd) wedjeflue flap=

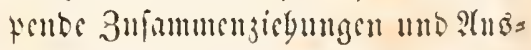

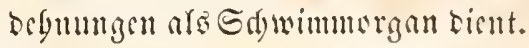
2tu fer untern Flälfe biefer meift glasartig surd)fidgtigen Rërpers bes finbet fid) ber Muno ober bie frime Stelle sertretenben Sanzorgane, oft 
von ftelartigen Berlăngerungen umgeben, fo baß ber ganze Rörper cinigermaken sincm Şutpilze äbulid) fiebt.

Affe Duaffen fint maft unb ibr ans einet oft fnorpelbarten $3 \mathrm{el}=$

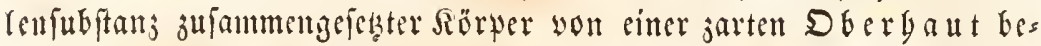
berft, in welder fid meift älnlide Reffelorgane finben, wie wir fie fdjon bei ben Solypen fenten lernten. Die Gäfte ber Seebäber fen. nen bieje ueffectibe Eigenja)aft oft aus eigener fdmerjlider Frfabrumg.

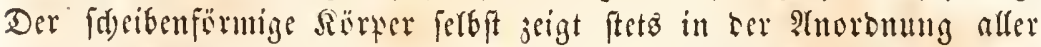

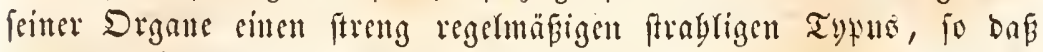
man jebe Duafle in je vier ober fedds volltommen gleidje Gegmente zeripalten faun. Tad biefen 3ablen georbnet jeigen fid benn aud) bei ben meiften biefer Thiere an bem Fantbe angebrad)te, oft auber= orbentliđ lange contractile Fäben, welde offenbar als Füblfäben be= mult werbelt.

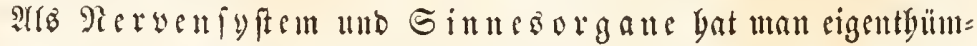

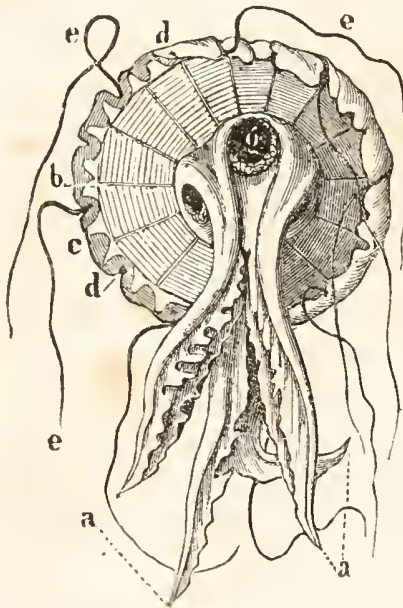

Fig. 120. Pelagia nortiluca

sun unten geichen. a. Die sier Alme, zwifdent welden fict ber Mutio befintet. b. Die (s)lurfe. c. Det Rand berfelten. d. Die Rantofutper. e. Die Fanafübent. g. Die boglen neben bem Magen,

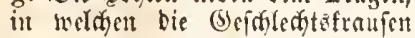
fitsen. lide söper gerentet, welde alt bem

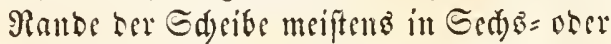
Ad d tzabl eingebettet liegen. (5: bejteben biefe Pantbërper aus sinem fapfefartigen Bläș () en, in weldem ein rullber ober ectiget fryftaltinifder Reru entyalten ift.

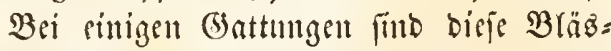
d)en won cinem reblaft gefärbten gyig= mente umgeten, was fic füt ?Ingen all= fipreden lié, wägrento igre 3ujammente

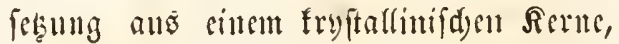
ber in sinem $B$ fäs d)en cingeid)loffen liegt,

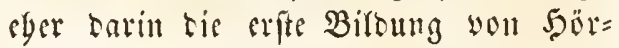
organen erfemen raffen burfte.

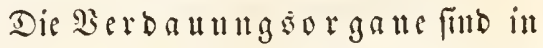
eigentbümlid)er Sacife geftaltet. Meift ift cin cinfadyer Minto verbanden, ber znweifen nux sou einem Panbjatume untgeben, in ben gewögntiden föllen aber won Fangarmen ber weridjebenjten Seftalt umferlt iff. Dft befizen biefe 
Jangarme Ranbfäunc, bie wie cine Sraule gefartet find. Bei viefen

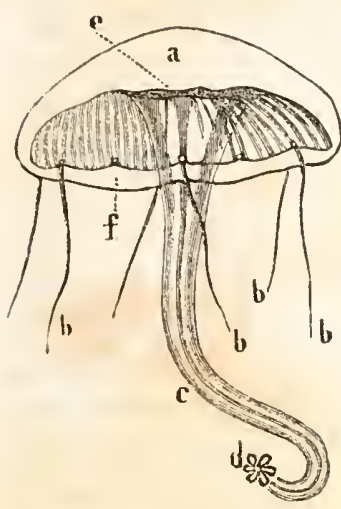

Jig. 121. Geryonia

a. Die Blacte, b. Die 6 Fuffifiten, an unb zwifden welden bie Rantörper fiten. c Det Etirl. d. Die (șt)= lappen befifelfen, wou welden bie 6 Sinate in ben Magen e. nufitrigen. f. Dor @drtiben= ranto.

(3)attungen inbeffen finbet fids feine cinjelne Munbëffun! fondern feine Gaugmuntunngen, bie entweber anf sinem einfad)en Mittelítiele ober auf vielfaden gublern, bie oft nod vers äfelt find, fid mad) anfen iffnen. Die fei= nen Rëbren, weld)e won biefen Gaugmün= Dullgen anfiterigen, fübren ebenlo wie der ein= fadte Nitnd in eille grisere ober fleinere Magenböble, weldye meift eine gewiffe stngabl

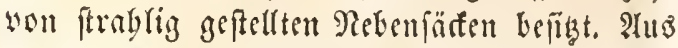
biefen Rebenfäten entpringen (bicfäß̨e in be: ftimunter Znbl, weldye frrablig nad) Dem Raute zulanfen und bort entweber in ein Ranbgefä

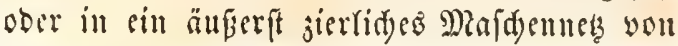
fermeren (b)fäßen libergeben. Der ganje Rör. per wirb nuf biefe art you Der Ernäbrungg: fliffingteit burdsogen uno nidyt fertent firbt man fogar nod) unwerbante Reple fleiner Thierdyen in biejen Sinälen.

Die (befd) led)tsorgane zeigent fid in ber Form baubförmiger Driifen, welde bald als Streifen an bem untern Ranbe ber Sdeibe oft in bebeutenb groper $3 a b l$, barb in eigenen nad aupen geöffneten 5ु̈̈blen jur Seite ber Magenbögle in Form geframfer Franjen ange= brad)t find und cinjelme Särfden entbalten, in weld)en bei bem sinen

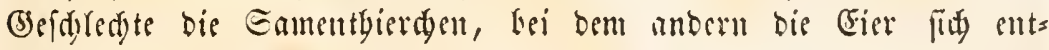
wideln.

Bevor ber Zufammenbang ber eingelten Formen ber Sdjumquallen

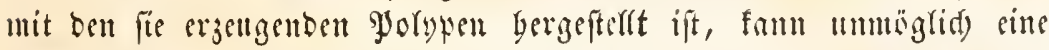

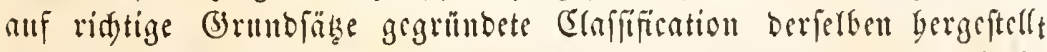
werben. Man fann unr bie mannigfartigen Formen berferten, bie in allen Meeren แnb zwat meift gefllig in Edwärmen angetroffen wer= ben, nad) ber Normaljabl igrer Drgnue unb ber Anorbunng berfelten in einjelne Fnmilien jerlegen.

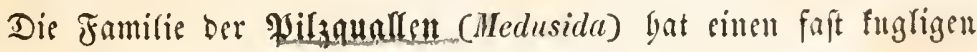
farirmförnigen 5ut uno einen vierjeitigen mittleren Muno, ber wou vier Fangarmen. umitelft ift. Alle Drgane find nad) ber Biergabl 


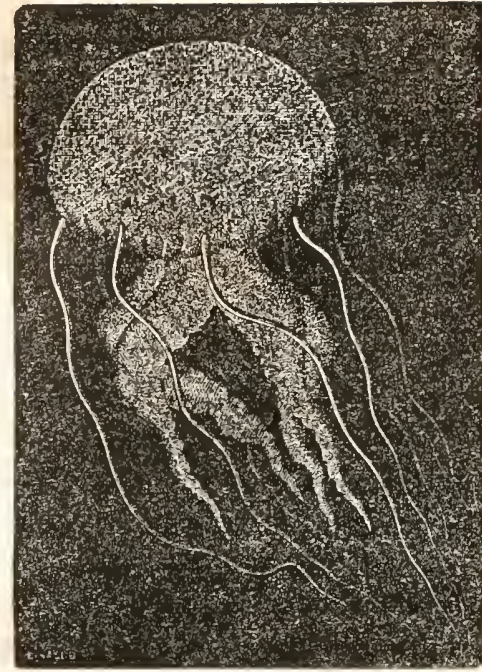

òg. 1'2, Pelagla.

georbnet; dic Mandförter, beren 3abl wenigftens ad)t teträgt, bod)= roth gefärbt unb Kei ganz jungen Sndivibuen an bem Ranbe fo be= Deuteno ausgeferbt, bas bie Rand = förper auf zapfenartigen Berläuge= ruttgen zu liegen fdeinen. Die $\mathfrak{B} a ̈ n=$ Der ber (5e) d)led)tatbeile baben meift cime bodigelbe, rotbe ober braune Jarbe, bie burd) ben glastyellen, siemlid) weiden Rörper burdfidim= mert. 3u biefer Fantilie gebört bie erwägnte Dy tenguarle (Aurelia) bie Eee leud te (Pelagia) und meb= vereandere weit verbveitete(5) attungen. Medusa; Cyanea; Ephyra; Chrysaora. SGnen nab werwandt ift bie Jamilie ber S:equalfen (Oceanida),

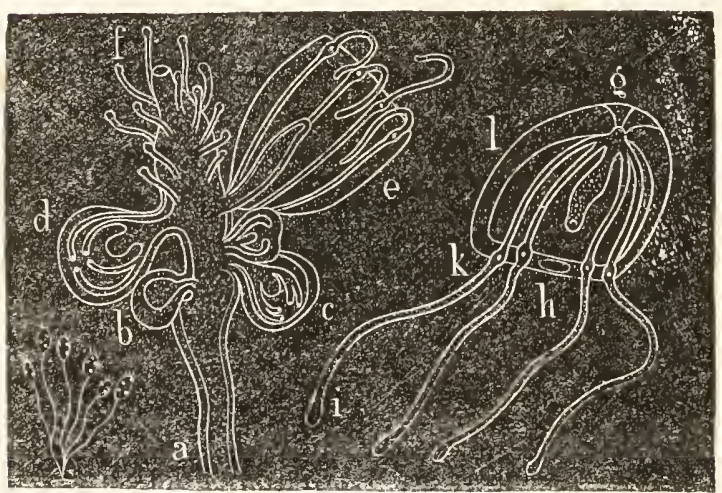

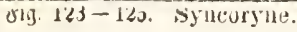

Deren Drgane eben= fall' nad ber Bier= zabl georonet fino. Der Edjirm biefer Duallen ift mebr glofen = roer butför $=$ mig, ber Muno cin= fad) IIno an ter Exizge

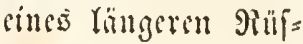
felo angebrad)t. Die (5)efd) Yed)töorgane lie = gea frei auf ber 1 tt =

tern Seite ber Sdatbe, wäbrent fie bei ber vorigen Familie im Grunbe yon Söblungen verfteclt finb, bie fid) an Der $\mathfrak{B a f i s}$ ber Fangarme be= funben. Dic an ber Sdjeibe angebradten Rambfäben erfderinen bei manden (Sattungen veräftelt, bei anbern einfad). Die Ranbförper fint ungefärbt, bie Magenböble flein unb die von igr auşzebenben Gefä̧е mur wenig veräftelt. 3t biefer Familie gebören faft alle bie=

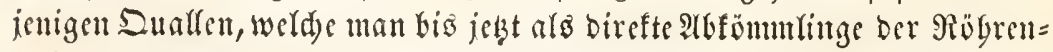
polypen (Tubularida) beobady tet und unter bem Pamen Cladonema, Sthenyo, Callichora ze. bejeidnet Gat. Occania; Thaumantias; Cytacis; Callirhoe.

Die Familie ber Edacibcunuaffen (Aequorida) bat eine meiftens febr flad) limfenförmige Sdube mit farblofen Ranbförpern uno ge=

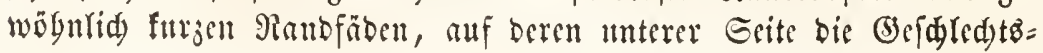




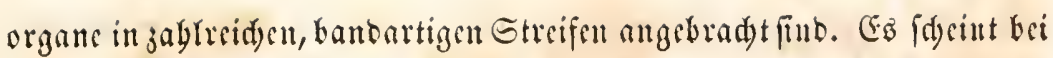

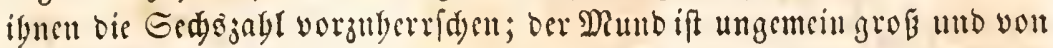

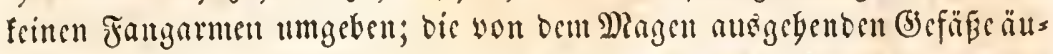
Berft zablreid), aber wenig veräjtelt. Aequorea; Cunina; Eurybia; Aegina.

Die Saarquaflen (Berenicida) baben sime flade (5loffe mit un=

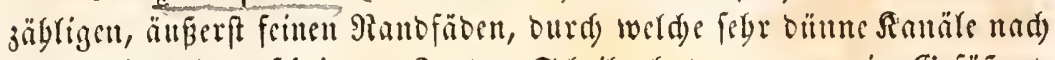

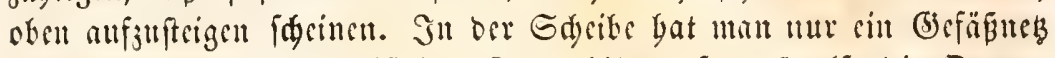

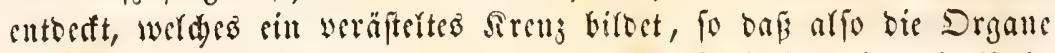

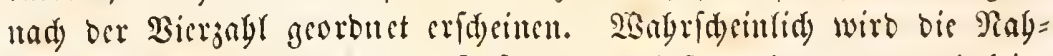
rung burd) bic Ranbfäben anfgefangt, wenigftens bat man nod) feine

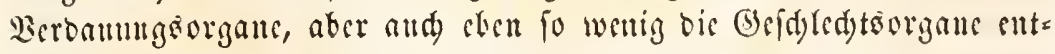
reft. Berenice; Eudora.

llum fo befinnter ift bic Familic ber gourzelquallen (Rhizoslomida). Lluter sinem glofenförmigen 5̧ute fteben nad) ber Sierzabl

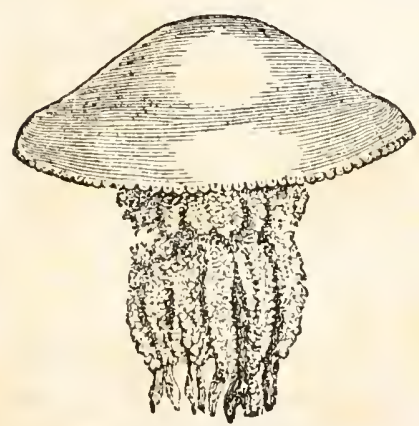

ธิiฺ. 126. Rhizostoma. georoncte Fangarme, bis zuweilen bautl= artig weräftelt futto uno an beren Spitsen (id) Sangunünugan zeigen, tic in sillen geräuntigen Margen fïbren. CFin Miund

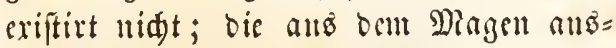
gebenoen Gefäpe bitocn aut Ranbe ber Glocte cin jerlides Mafdenucts. Dic Ranbförer fitto lebbaft rotb gefärbt, bie

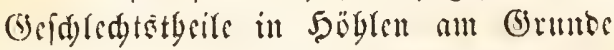
ter Fangatme verborget. Eingefte Gat= tungen biefer Fnmilie erreiden cinen Durds = unffer son urbreren Fub̈en. Rhizostoma; Cephea; Cassiopea.

Die Ritifelquaflen (Geryonida) baben ebenfalta teinen Mimn, fonbern unter ber gloffenförnigen Gdeibe einen fegr bewegli=

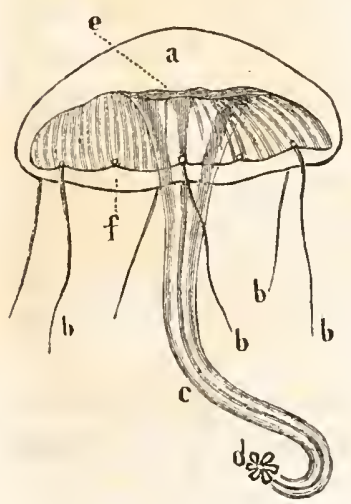

Fig 127. Geryonia. d) un unfïyen Etiel, an werdyen fed) glatte Santale nad) oben fteigen, umt fidg in

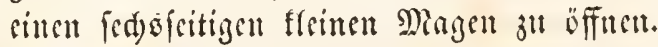
Die Ranoförper fino cbenfallo nadj oct Ged)sabl vertbeilt und ungefärbt. Dic

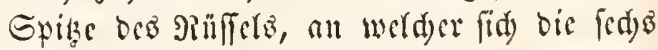
Saugöfunngen befinden, erfd)ciut gefältelt ober zuweilen aud) mit Fäben befect. Geryonia; Favonia; Saphenia; Lymnorea.

Da faft bie ganje Rlaffe oer Zuallen= polypen aus weidyen, gallertartigen Thieren beftel, fo faun yon cincr ahfbewabrung in ben Sdidyten oer Erbe frime Pebe fein, 
obgleid) unbeftinmts abbribe in ben Sdjefern won Solenbofen allerbing Darnuf Gindeuten, baí bie älteren Direre ebenfallo von Duallen bewobnt waren. Itud) bie Bämmd)en, weld)e bie (Gloren= folypen bitben, fint zu weid, 1 m fid erbalten ju finben. Sn Det jekigen Sdippfung find beibe Formen ber Sinfie in allen Meeren verbreitet; Die Duallen namentlid, meift in ungemein jublreiden Sd)wärmen, bie it bejtimmter Ridtung idwimmen mo won Rippenqualfen und fdwimmenten Eduefen verfolgt werben, welde ibre Gauptfädlide Rabrung an ignen finben. PHnägerung Der

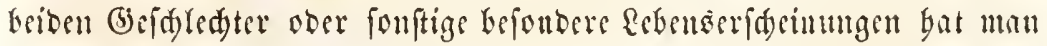
bei ben Duaflen nod) nidyt berbad)tet. Die meiften Yeudyten bes Raáts mit zitterndem, gelbem Ridjte, bas befonbers bei Bewegungen ftär= fer wirt.

filnffe ore höbremqunller. (Siphonophora.)

Gin fonberbares (B)mija) fonberbarer Thiere, beren 3ufammen=

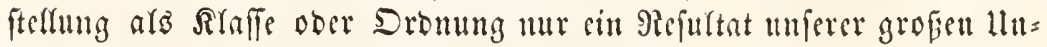
fentutif igrer Diganifation ift. Sn ber That wiffen wir von ben meiften biefer foltfamen Thiere nod nid)t chmal, ob wir fie als cinfad) Thiere mit

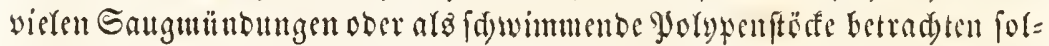
Ien, wo an einem gemeinfduftliden Etamme, ber jum Edwimmen cinge=

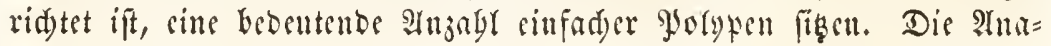
tomie bicfer Thiers ift nur fegr wenig gefamnt, igre Fortpflanjung yolffommen bunfel, fo baß man ftets nur mit llnfid)erbeit bie cinjel= "ten Thieve jufammenftellen fant, welde ju biefer Sifnffe gebören follen.

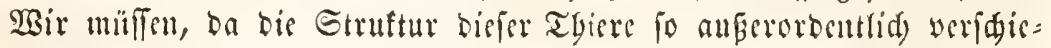
ben ift, auf bis sinzelnen Familien fogleid) eingeben, intem wir mur

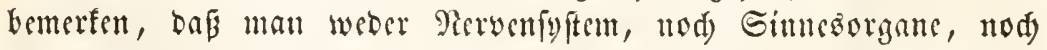

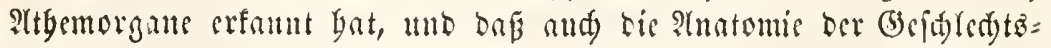
tyeife nod) fait unbefaunt crid) cint.

Die Familie ber Seeblajen (Physalida) beftebt ano grofen blafens

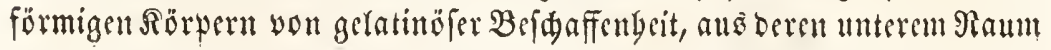




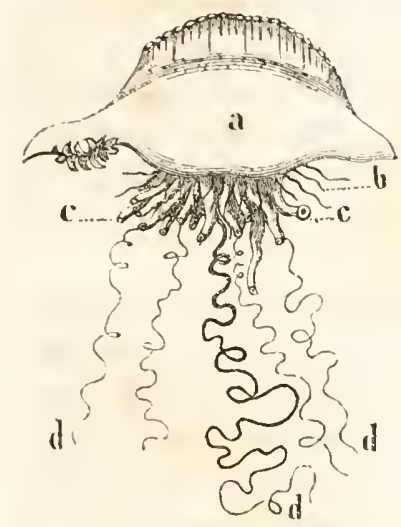

ơiij. 129. Physalia.

a. Der Hafentiomige Rörver. b. Finfläten. c. Eamgumnou= gen. d. Fangrïten.

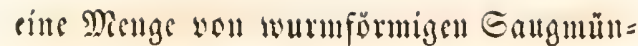
bungen, Füblern und ttngemtein verlängers baren Jangfäben bervorbängen. Der blafenfërmige Rörter befebt cigentlid) ans jwei in cinanber gefdadstelten $\mathfrak{B l a}\{\mathfrak{c}$, woul welden bis innere bollfommen gefdilofien mit mit suft gefilllt ift, wägrent Die äuners einen obern Samm bat, welden bas Thier beim Edwimmen wic sin Gegel bemntht. Diefe äufere Snor= felblare bient anfertem als Deffe für bie Fangfäben แnb bis Gangmündungen,

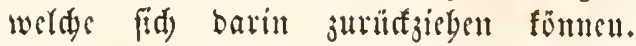
Träubden rotber Sörter am (3runbe ber Gaugröbren wurben als Eiertrauben an= gefeben. Die wumberjdön blau unt rotb gefärbten Thiete fdwimmen in Samfen anf ber Dberflädye ber fïb: liden Deeane unb bringen bei ber Berübrung sille fo bebeutente Nefferfudyt bervor, baj̧ fie von älteren Beobadtern für giftig erflärt murten. Physalia; Discobale.

Die Famílie ber Sinorpelquallen (Velellida) befibt ftatt ciner furor=

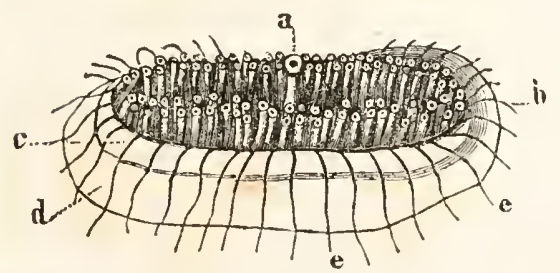

8iig. 129. Velella. pelblape cine zellige Gdysibe ans Rnortelfubftinns, bic $50=$ gar mandamal Ralfablagerun: gen entbält, unb auf beren unterer Fläd)e fịd bie Siör= perorgane befinden. Die 3ellen or Sdeibe find mit suft ge= füllt unb bienen fo, bem Riör= per eine bebentente fpecififde

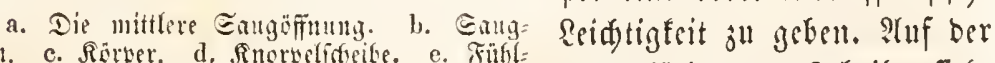

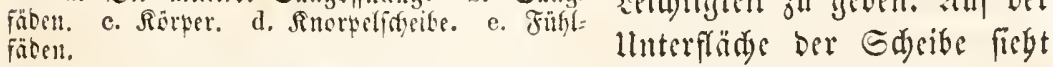
man in oer Mitte sine grö̈pere Definung, you cincu wurmartigen Fortfake getragen, weld)e bie Einen für ben Munb, bie 2 thoern fïr

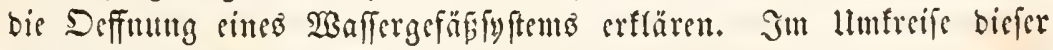

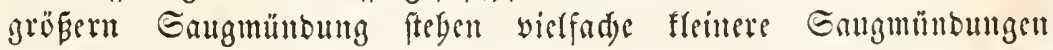
yon ebenfalls wurmförmiger Geftalt, welde von ben Einen für Filly= ler unb Deffnungen von SGafferrögren, von ben 2Atbern für eben to viele faugende Munböfnungen gebalten werben. Itm Grumbe diefer Eauger fiebt man fleine Träubden, welde für bie befduled)tiongane 


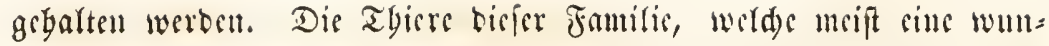

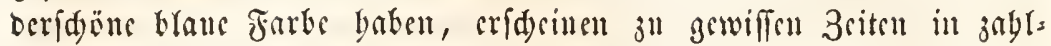

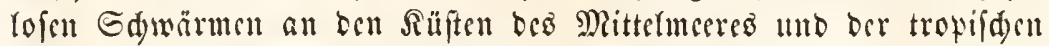
Decane. Die cinc Battung Velella, welde im Mittelmerre vorfoumt,

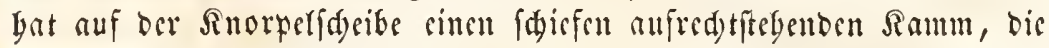
andere, in ben füblidsen Mrecren bäufigere Porpita, sine sinfady runbe ftrablig jellige Sdeibe.

Die Familic ber Doppelquallen (Diplyida) beftelt aus mebr

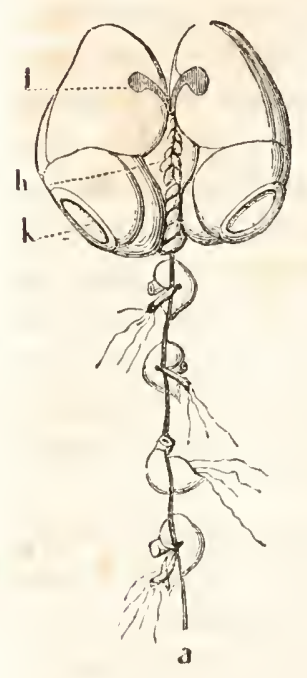

gig. 130

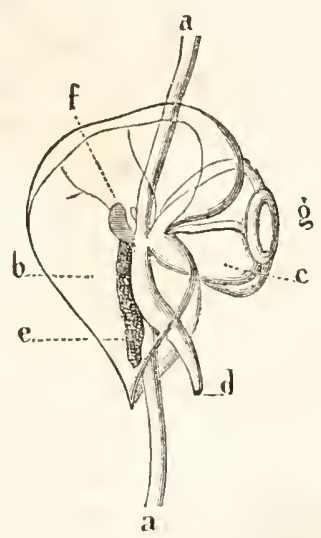

wis 131.
Diphyes Brajae.

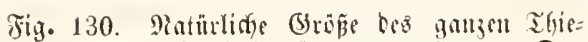

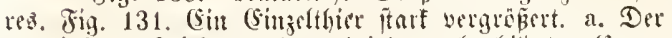
gemeinfante Etirl, an bem bit bent afgibiloten (Sxsul=

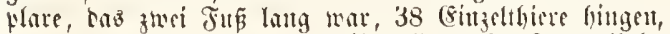

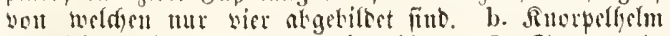

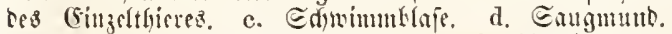

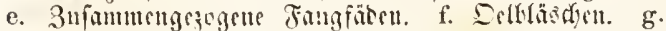

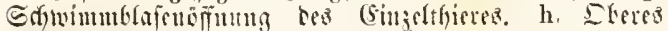
(sttoe brs Eticls mit mentwifeltrn Rutospen nener Gin=

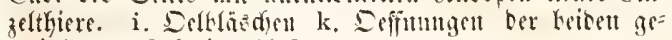

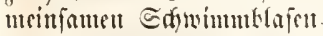

ober minber jufammen= gefesten Tefen, Deren Struftur weit compri= cirter ift, alo bei ben sorlyergelyenton Thieren. Man filloct in bcut Mcere febr bänfig cin= sefle Rörter woll glab = artiger நelle umber. (d) wimmern, weldas bont=

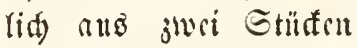
befteben, cillem Dectitillte und siner flappenden Stamimmbible, welde meipt bis form sincr bobra broffi bat milo mit eince runtidan Deffinung wericben ift, bic lebbaft auf mito ju= flapt. Dab aแb frr Gdwimmglefe aแeftro" mende $2 a f f e r$ treitt Durd) frinen Rillffitof bå Thier wormärts, beffa 5amptorgane un= ter bem Derfitiofs ans

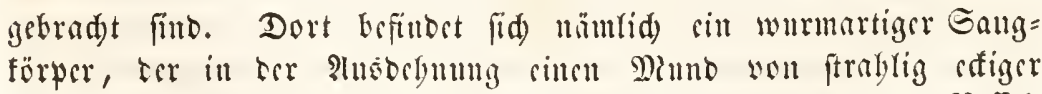
Form zeigt, uno an beffen Grmos ungemein lange Fang= mub Refiel

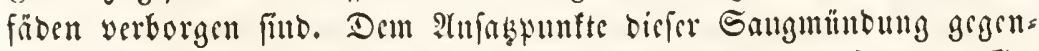
iiber fiegt man im Deffitüfe sine zellige bogle, welde für baz (5e= (đ)led)töorgan gebalten wirb. 


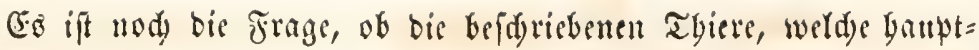
fäd)lid) bie Gattung Diphyes Girben, nidgt abgeröpte Sthide zufammen=

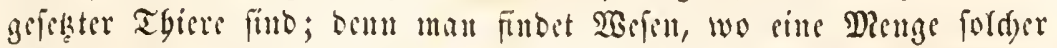
Thire, bis zu vierjig unb meld, jebes ans sinem belmantigen Deft=

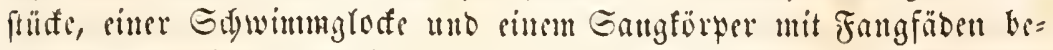
ftelyent, an sinem gemeinfdaftliden Etiele befoftigt fint, an beffen

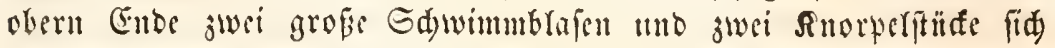
finben, bie jebes sin Derbläsd)en ju entyalten fdeinen. Bwifden bie=

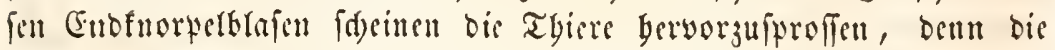

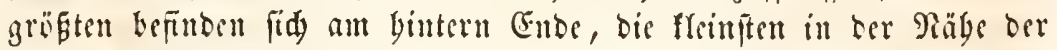

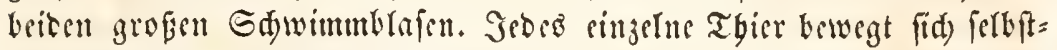
ftänsig fïr fids, aber ber äußereft contractile Etiel bat ebenfallo feine

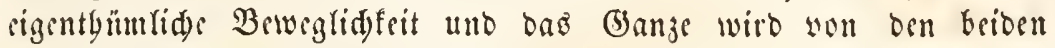

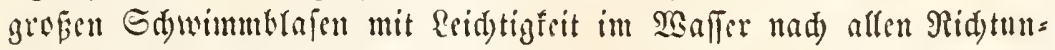
gent bin uno ber gejogen. Der bie Theile vercinigente contractile

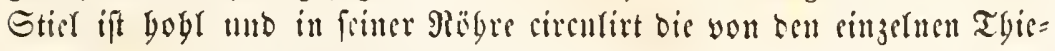
ren Gerfommente Ernägrungefluiffigfsit.

Bei anternt Battungen, wie 3 . B. Stephanomia, wirt Die Berrini=

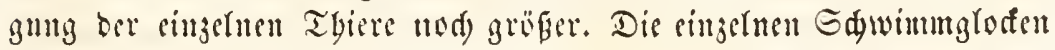
feben iforirt, balo in Petben, bato mebr untegetmäpig am worbern

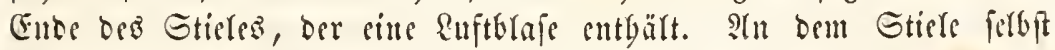
firgen unjäblige wurmartige Gangmündungen, jese son sincm Yafet

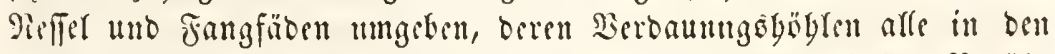

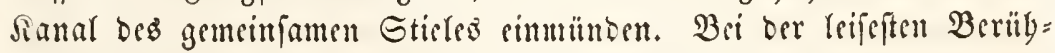
rung fdnelft ber Sticl jufammen und alles birgt fid) Jwifden ben

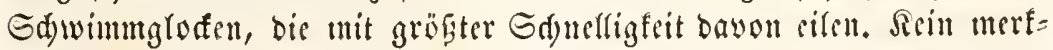

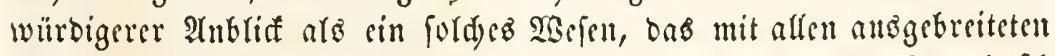
Srganen wie sin surdjiddelider, rïtlylider, fpannentanger Feberbufds im Meere fdrwimmt und aufgefangen, jufammengejogen im Bjlafe sin

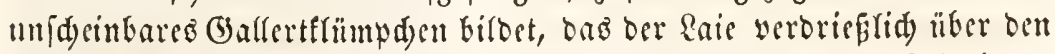

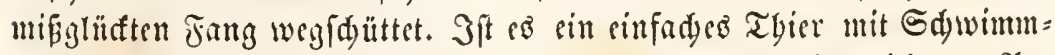
glofen uno Sangröbren ober sin zum Edwwimmen eingerideter $Y_{0}=$

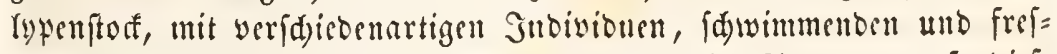
fenden? Epätere ltnterjudungen werben bie 2 antwort auf biefe Frage bringen. Plyssophora; Diphyes; Ersaea; Rhizophysa; Agalma; Hippopodius. 


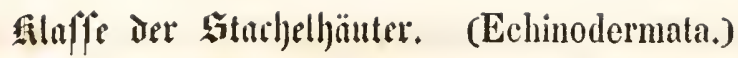

Dic Yeşte am büdjten organifirte Rlaffe Der Strabltbiere, bei

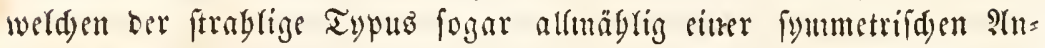
orbnumg fid aumägert. Sie unterideiben fid won bon Rlaffen, werdse wir bisber betradsteten, wejentlid) burd) bie (xijtenz siner melye ober

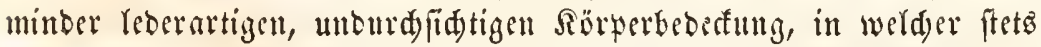
Salf in verfdjiebenen formen abgelagert ift uno bald mur eine unter ben Meffer fniridende 5aut mit singefprengten Contretionen bilbet, balo sin förutrides Efefett julammenfest, bas bie inuern Drgane von

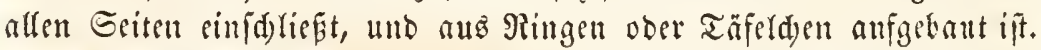

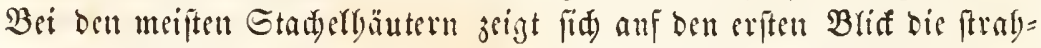
lige Aturbanng ber Drgane bie oft fo amesefproden ift, baf ber Särper ferbjt eine Eternform aumimmt. Sisie bsi ben Duallen und

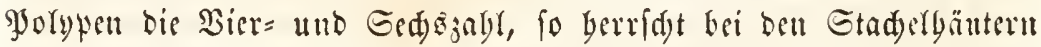

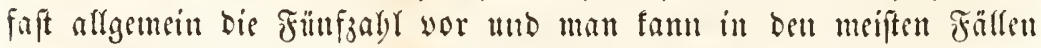
bei biefer 2fnorbonung sinen unfymmetrifden Mittelftragl and auf jeber Seite zwei fymmetrifase Strablen unterideriben, wo fid benu meiftens

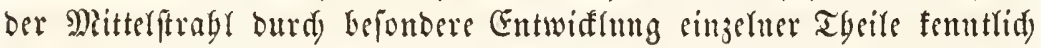

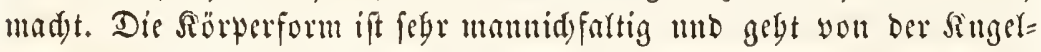
geftalt bis za ber einer platten Sdycibe oder cines Sternes, ober bis jur $\mathfrak{B a l}$ aenform in alten nur erbenffaren 3wifdengeftalten vor. Bei beul angegefteten (battungen wiro bie Sörperform ked)erartig und bann befinden fid Mand uno affer auf ber oberen vou Sticle abgefebrten Siörperfläd)e. Bei ben Ruget= unt Sdycikenformen wirb ber Miuno fetês auf ber unteren, ber Baudffäde, angetroffer, wälgrend bei ber

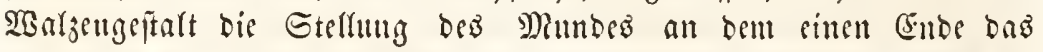
Sorn und binten beutlid bejeidnet. Die Bewegung if́t nidjt fo

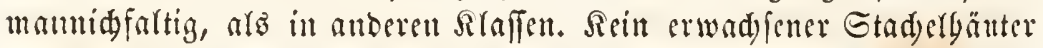
faun fürntid) idjwimunen, obgleid) alfe nur in bem Mecre Teben. Sie

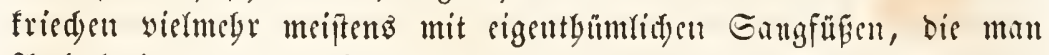
Imbulacien nemt, auf bem Boben beż $\mathfrak{B a f f e r s ~ u m b e r . ~ R u r ~ s i n i g e n ~}$ wenigen geben biefs Gaugfüfe ab ull fie begerfen fid bafür burd

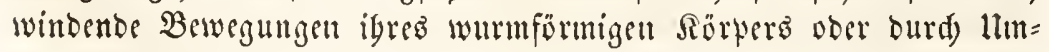
flammerung mittelft beweglider Strablen und $\Re a n f e n$. Gine ganze Familie ber Stadergäuter bleibt zeitlebenz burd sinen mebr ober mill= ber langen Stiel an ben Boben gebeftet unb bietet Durd ibren gloden=

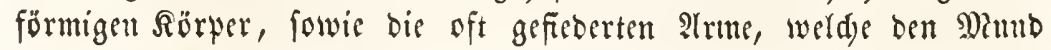

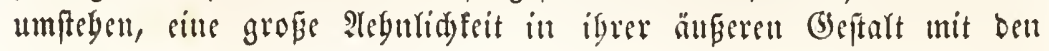


Yुolypen bar. Lebrigens gibt es in ber gangen Rlaffe ber Cajtuder= men fritte focialen Thicrfornten; alfe leben ifolint als Snbiviouen und Hflanzen fid mur ourda gefdyledytlide 3eugung fort.

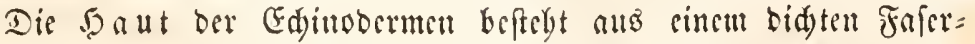
gewebe, weldes meift eitte leberartige Jeftigfeit bat. Dic Ralfablage= rungen, welde onrin yorfommen unb bie mandutal bis auf fleine lleberrejte bie Reberbaut gänjlid verbrängen, fitto in cinfadyter form bei ben pogentanten Seewaljen (Holohuria) voryanden. Sier bil=

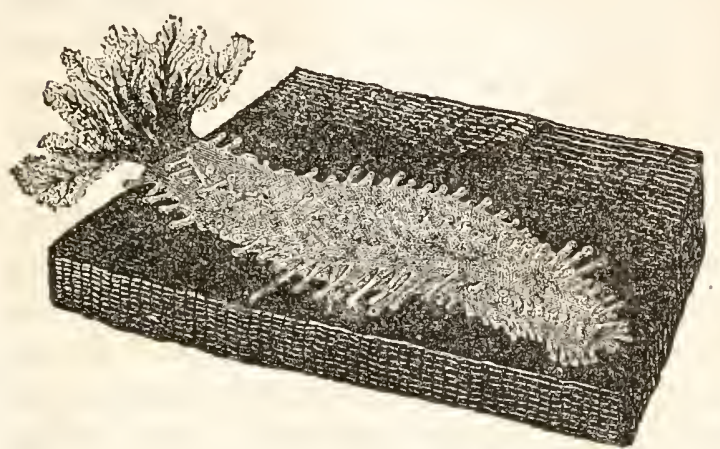

8ig. 132 Holothuria.

belt fie meift unregel= mäpige, netzartige Sötyer, die indef bei eitter anderen Fanti= lie einen förmliden Ingelyaten oder $\mathfrak{A} 11=$ fer tragert, welder aแв Der Jaut bers worftelt titlo beitt Thiere beitn Angreifen eille gewifferaubigfcit gibt. एฐ fdritten dicfe

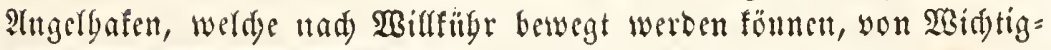

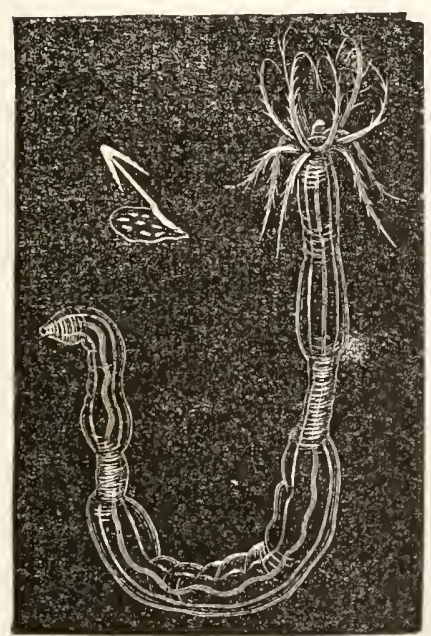

fig. 133. Synajta Duvernoy.

Dian Fieht ben äfigen 8ühlerfranz, ber ben M/unb unngielt, roa welden ans fits ber Darm burd ben glasbeflen, lie unb ba zu= îmmengejogeuen ?eib bis zun? Inter binzieht. Die fieine Jigur nehentei iteflt einen 2lufer: haten mit feimer in bet sout figenben Platte ftarf rergrosert nor. feit fïr bas Sried)en bes Thictes im Sanbe zu feith. Sie fithbelt fid) hibrigetto แแu bei ben Bsattungen wurmförmiger Stad)elgäıter, weld)en altorte Bewe= gungsorgane tut jwar namentlid) bie Gaugfüße abgeben. Bei ber Familic ber Secfterne rühet die unregelmäßigen neşartigen Ralftörwerden it ber Jant fo nabe jufammen, baf fdou cin fürm=

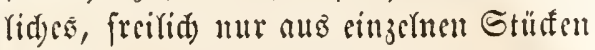
Jufammengeletstes, nad) aflen Rid)tungen bin betweglider Efelett entftebt, bas in gewiffer Beziclung einem Rettenpanzer nid)t unäbulid fiebt. Bon ben äufieren Jangerringen, welde ben Sïrper utto bejonders bie Grablen beflerbert jus faumenfesen, geben nad) innen bin Duerbalfen, bie gelenfartig mit sin= 


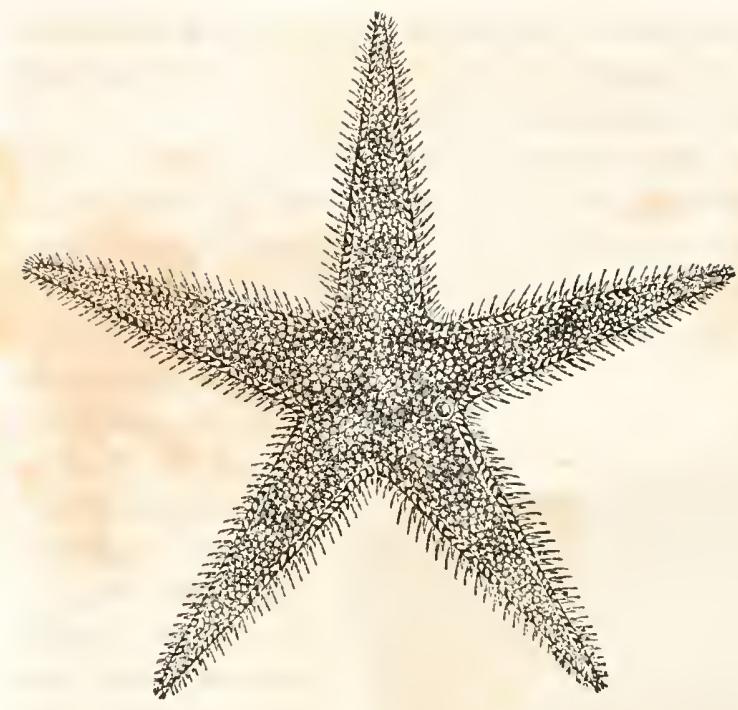

Jig. 134. Asterias.

anber verbunden find und in ber Mritte un=

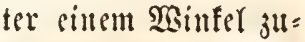
fammenfofien, fo dais an ber Baudjfläde oer arme eine tiefe Rinne, Die fogenamnte Bandrinne, gebildet wirb. 3wifd)en bie= fen Stilfen befitiben fid) cittzelne Deffrum = gen, Durd) avelde bie fun Sireden bienen= Delt und in Der Baud)= rituegelegenenSaug= fübe nad) auben ber: sortreten föntuen. Man faun fid) auf biefe 2 Beife bas Sfelett ber Sefterme als anz cin= zernen gefdloffencu gyanzerringen beftebent vorftellen, weldye Ringe uid)t solffommen rumb, fonbern auf ber Baudfläd)e nad) iumen sill=

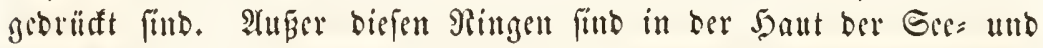
Ed)langenfterne cime Mange von Stadeln singetflangt, beren $\mathfrak{B a f i B}$ it bie Reberbaut eingejenft unb beweglid) ift, fo bas biefe Salfifadertu

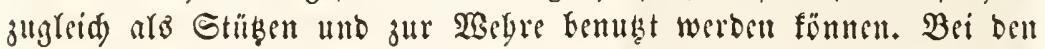
Sdlangenfernen nebmen bie Sanjerringe an ben Armen bie Geftalt yon Tafern an mb laffen fo bie Reberbaut his allf bie Fugen ber Tafeln werfdwinden. Rod) weiter gebt biefe Tafelung bei ben

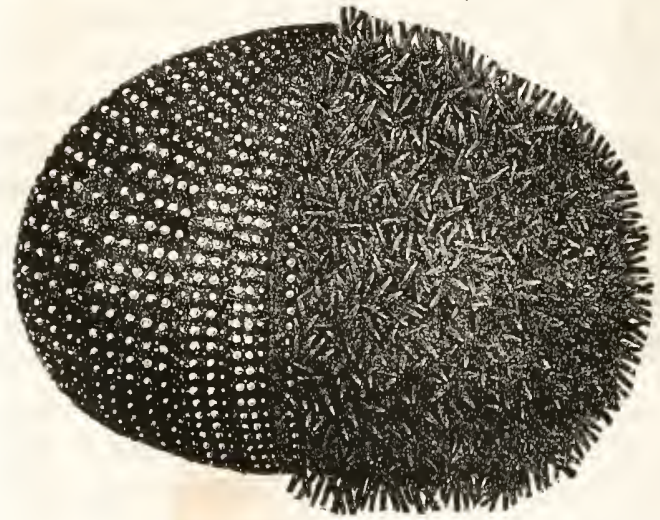

ঠig. 135. Echinus. Serigeln; bier ift ber ganze Rörter von siner Sd)ale umbüllt, meld)e aแb eingelnen meift fünf= ober fed)вedigen Täfel= d)en zufammengefekt ift uno uur sine Deffmung für ben Munt und cine

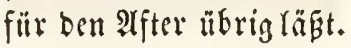
Ea fitto biefe Täfeld)en aus Salfnezen gefilbet, welde nod mittelft orga. nifd)er Fafermaffe ourd)= 


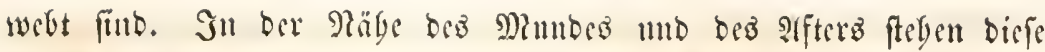
Tafeldyen oft mur in mittelbarem beweglidyem 3ufanmenbange, inbem fie in bic leberartige 5ant gleid) fam siugelegt fint. Bei ben verifeinerten Eecigelu fallen befbalb biefe bewegliden Iafiln Teid)t berans, wäb=

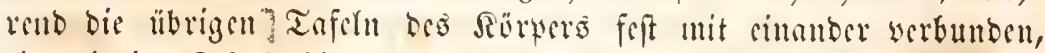

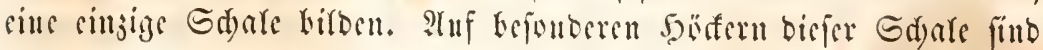
meiftens utbr wber minter grofe beweglidge Gtadjeln cingepflanjt,

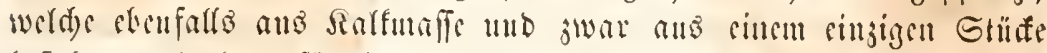

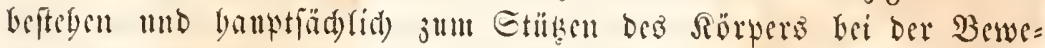
guny bienen. Anper ben Gtad)eln finbet man nod) eigentyümridye (boreif=

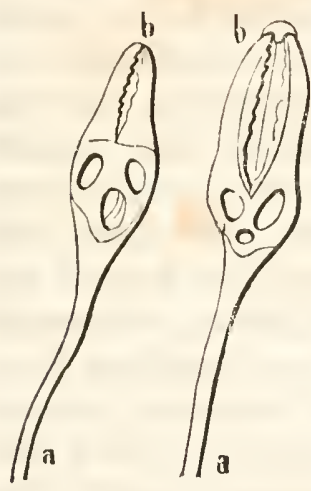

Jig 136. Disticllarien. organe, Yebicellarien genamt, bis anb einem langen Sarffitiele unb cincr orei= ober vierflap= pigen 3ange beftelen, weld e beftünbig geöffuet mub wieder gejdyloffen wirb. Diefe Jebicelfarien, Die man fribler für Sdymaroker bielt, fteben nuf bejonderen fleinen Sö̈ferden, befonbers bäufig in ber Räbe bes Mlundes bei Gecigeln umb Seefternen uno fderinen zum Eruzeifen vou Rabrungsiftoffen beftimmt. Sie erfdeinen fdon frïb bei Den Embryonen nno jeidenen fid bann Durd) igre plumpe beftalt aus. Später wirb ber Stiel ränger und unn fdwanfen biefe Zan= a Der Etiel, b bie 3ange. gen anf Dem Eticle beftändig bin unb ber, wäly= rent íne oberen Bafell allf und zuflappen. Gelght nad) Dem Tobe Des Thieres banern bicfe Benegungen ber Syedicelfarien nod eine ge= ramme 3eit fort.

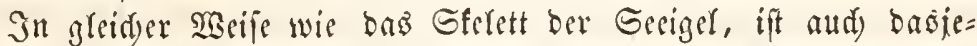
nige ber Geplitien (Crinoidea) zunammengefebt, weldye bejonbers in ben älteren Gididten ber Groe bäufig vorfommen. Der Gtiel biefer Tbiere, womit fie mbeweglid) feftitisen, wirb ans fdesbenförmigen Stüfen anfgebant, die wie Mëngen anfeinander Yiegen, wäbrno der beder= förmige Sörper aus cinzeluen Tafeln gebilbet ift. Die obere gläd) bie fes Sörpers ift mit weider leberartiget 5ant thberzogen, wägrend die Arme mit igren Rebenarmen unb Zweigen, bie an ben Rande Des

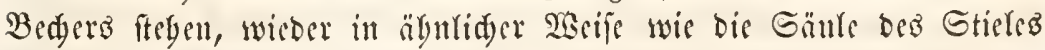
ans cingelnen Taferftüffen aufgetent fint. Bei ber Betradutung Der (5attungen, Familien und Dronungen werben wir auf biefe Berbält= niffe uäber cingebon mitffen.

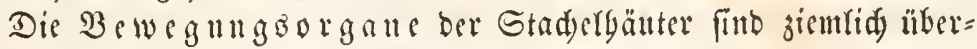
sinftimment bei allen gebilbet. Bei ben wurmförmigen find beutlide 
Muófelmaffen entwide

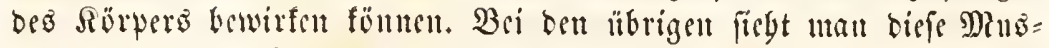

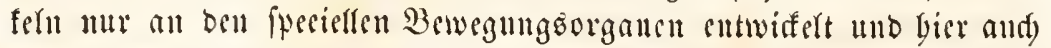
oft ill anggezciduteter Beife. Die Gaugfübden (Ambulacra),

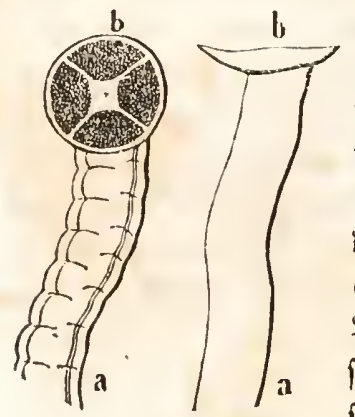
weldye mit $\mathfrak{A}$ (us่nalume simer singigen familie aflen Gtad)erbäıtern jutommen, find bie we= fentlidgften Bewegungs = mild Jaftorgane ber= felben. Era füb Loble, warmförunige Drgane, werdye ourd) Deffuningen des Sferettes oder ber 5ant Gervorgeftedt werben föntuen unt

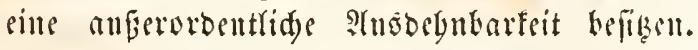
Bei einigen Fanilien fint bie Gaugfitidgen unr fegr flein und furj, frismenförmig, obue end: ftänbigen Gaugnayf, juweilen felbit seräftelt In10 (d) cimen Gauptfäd)lid) nur als Taftorgane

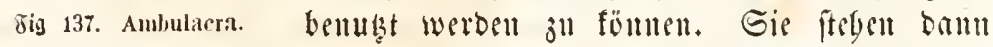

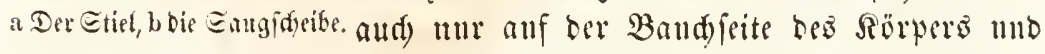
fönnen nidyt ourd) eigene Deffrungen in Das Snnere zurüfgezogen werben. Bei ben Geciternen, oen Gerigeln nub ben cigentliden Mler= wargen bagegen bitoen biefe Eangfügd)en Kange berbläntige Eylinter, tie an ibrer Gpitge mit cintu förmliden Ganguapfe verfeben find, welder nod) obencin Durd sinen yorëfon Raffring in feiner form

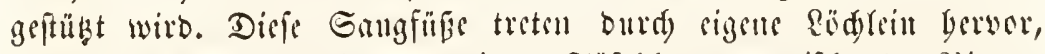

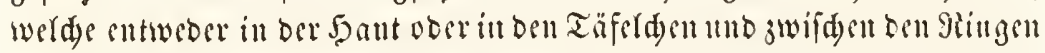

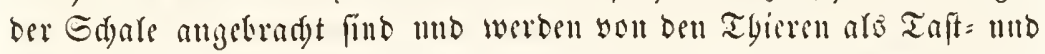

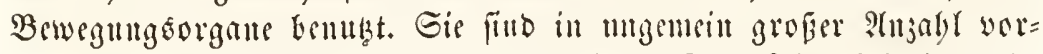

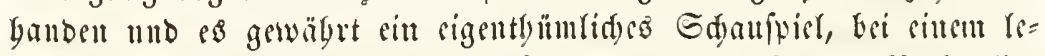

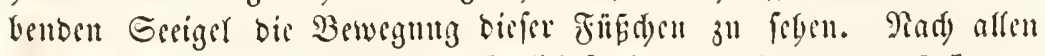
Geiten taften fie berum, ilbocut fie fid fo febr verlängern, bab fie nur

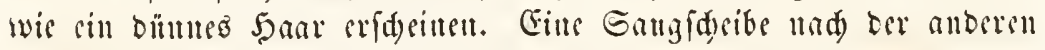

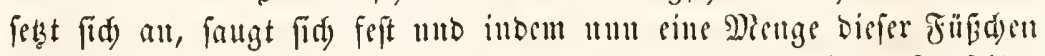
fid) verfïrzen, jieben fie ben Rörper wis an eten fo vielen 3ngleilen

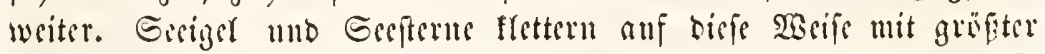

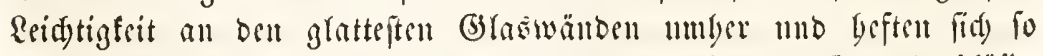

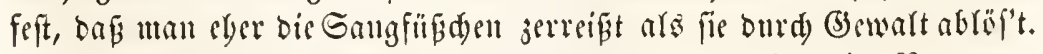

Faft bei affen Gtadyelbäutern bat man geglanbt, ein Rersen= fy ftent nad)weifen zu fönucu. Daffelbe forl anz eincut febr feincu Rervenringe befteben, welder ben Sdylund ungibt und meiftent sin

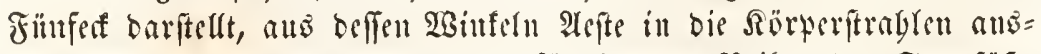
laufen. Die Rervenäfte geben bauptfäd)lid) den Reiben ber Gangfïfi= 
d)en entlang unb geben, we es fdecint, Aefte an bieferben ab. Bejon= bere Snoten bat man bis jebt an biefem Rervenjyfteme nirgends wabr= uebmen fömen, ferbit ba nidst, wo Rerven bavon afgeben follen. Dies räpt bie ganje Ratur biefes fogenannten Rervenfyftemes febr problematifd erfdeinen mo in ber That bebanten aud nemere, aub=

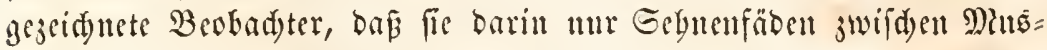
feln, fogenaunte Dinsfelnätbe, aber fein Rervenfyftem erfenten fönnten. Sinnešogane find äuferft jtweifelgaft. Mran finbet jwar an ben Griben ber ?rme ber Geefterne, fowie oben auf bem Räten ber Gee= igel rotbe Fledfen, weldye fogar bei ben Serigeln in feinen söd)lein befonberer Slatten eingelagert fint unt bie man fïr 2 fugen gebalten Gat. Gnbeffen fudste man vergebens in tiejen Sgigmentflecten, ju wel= den man jogar bei ben Seefternen bie änferften Spizen ber 5aupt= nerven veriolgt baben will, nad) einem lidutbed)enden fïrper, fo baj bie Bebeutung biefer Drgane jumal bei ber llnfideryeit bes Rerwen= (y) fems nod) fegr jweifergaft bleibt. Sebenfalls aud) wenn es Stugen

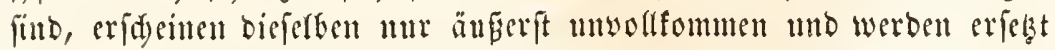
rurd) ben bödft feinen Taftimn, weldem bie Saugfüpe ober bei ben wurmförmigen Stad)elgäutern bie ben Minnd umgebenten Jüblet als Drgane dienen.

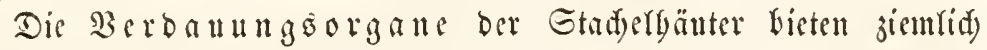
mannidfartige (beftalten Dar. Fait bei allen vefindet fid ber M) un

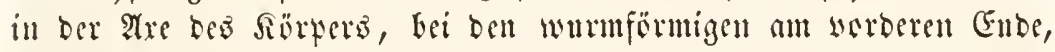
Lei ben übrigen in ber Mritte ober vornen an ber Bandjfläd) als runblidje ober fünjeftige Defrnung. Rur bei einigen Secigeln erideint ber Mind ans biefer centralen Stelfung gewiden unb mebr nad)

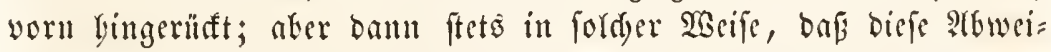
d)ung in ber Fortfezung bes unpanen Strables riegt und baburd) fie Mlittellinie angebentet wirb, welde ben Rörper in jwei 5älften trennt. Bei Den wurmërmigen Staderbäntern ift ber Mlun son cinem Füblerfranje umgeben, welder meift verätelt erfdecint und in

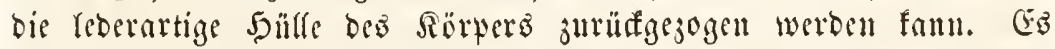

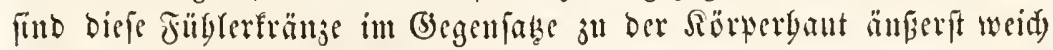
แnlo jart unb ein ansgezeidunetes Tajtorgan, wie man fid leidst bei Beobad)tung Yebender Thiere überzengen faun. Bei ben ẗbrigen be= finbet jid Der Mlund in Der Mitte ciner megr ober minter bebenten=

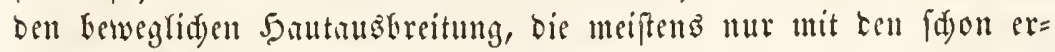
wäbnten Syedicellarien bejest ift. Bei ben Eeefternen find in biejer 5aut woripringenbe mit Garten Sarfftïfen befeşte Warjen angebradt,

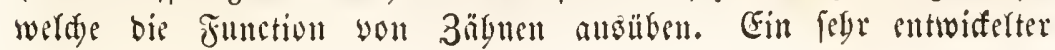




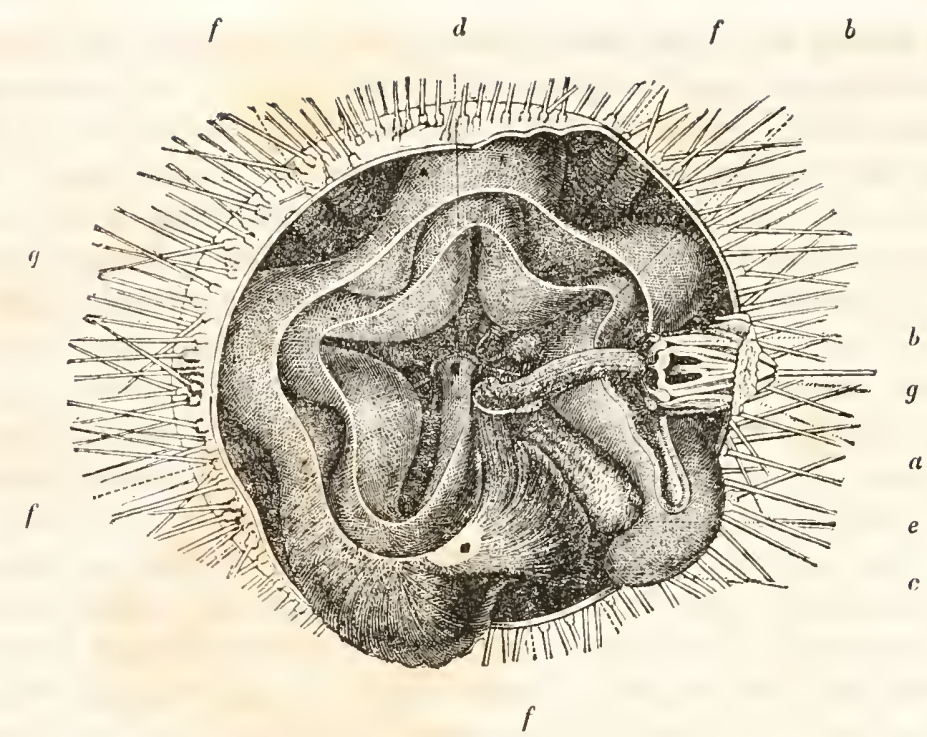

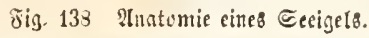

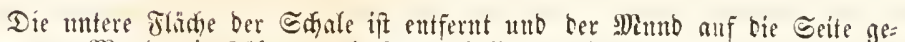

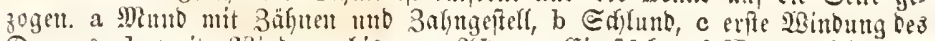

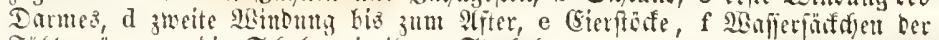
Sublergänge, g tie Edfale mit ilyen Etaffeln.

Sa llapparat jeigt fed bei jwei ltuterfantlien ber Gerigel, nämlid

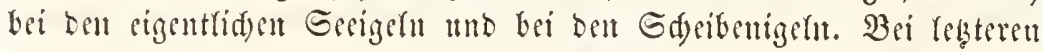

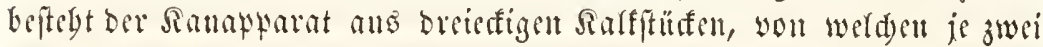
ju cinem V förmigen Etüfe jufummentofien, beffen Eprize gegen ben Dittelfunft bes Mlunbes gerid)tet ift. An biefer vorberen Gpize find

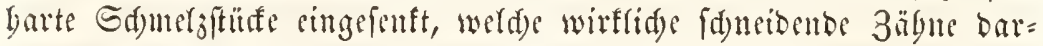

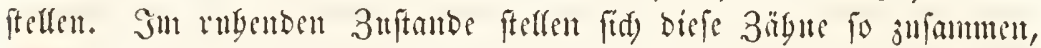

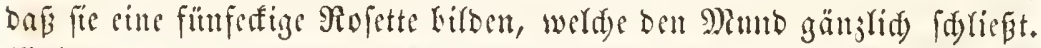
Sacit ausgebiloeter ift ber Ramaptarat ber eigentridyen Gecigel. Eit

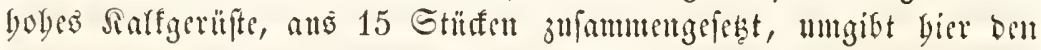

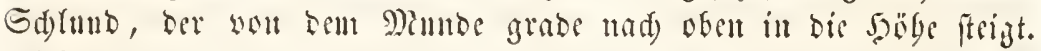

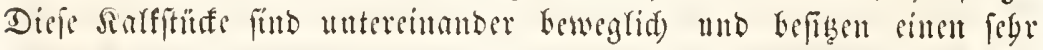
atsgebiloten Sinefelapparat, Der igre Bewegungen wermittelt. ats Sanptitiufe eriderinen barin fïnf breifeitige fdmale givramiben, welde gegent bie Mitte zit eitte Rinte tragen, in weld)er cin (anger Sd)metz=

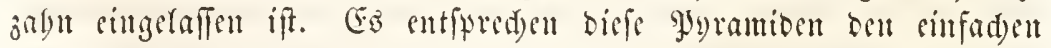
Jyramiden, welde bei ben Edeibenigefu vorfommen. Die meifelartigen Gdmelzjäbue ragen in ber Mantbäble nad) unten berwor und ritfen

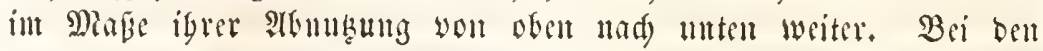




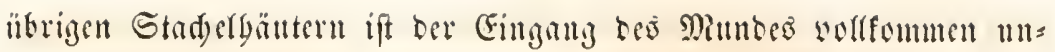
bewafinct.

Der Darmfanar ferbft, welder won bem Minte angogebt, if

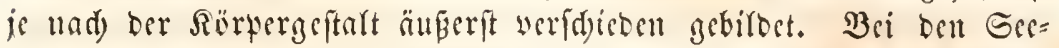

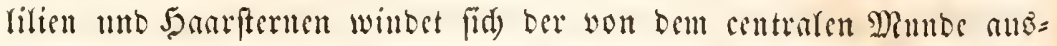

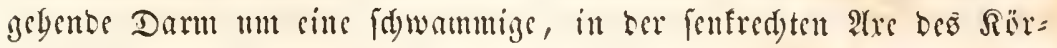
pere Belegene Mittelfpindel und siffuet fid bem unpaaren Strable

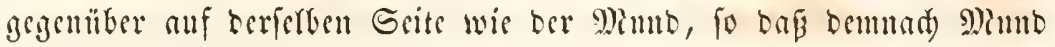

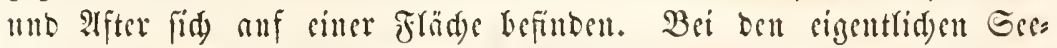
fermen fügrt bie Manböfinm ung untterbar in cincen weiten Magens

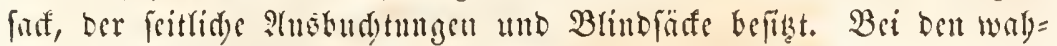
ren Gerfernen erftreffen fid biefe Geitenäpte, Die oft nod anf beiben Seiten tranbenfürmige $\mathfrak{A}$ ngänge Gaben, in sic Strablen bes Sternez binsin. Bei sen Edjlangenfernen bilden fie une melyr ader minber

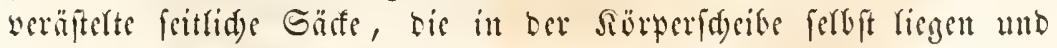
nidst in bie Strablenarme singelgen. Den Sdylangenternen fowolys,

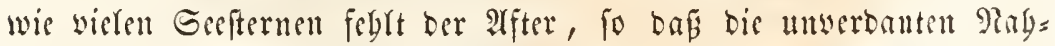

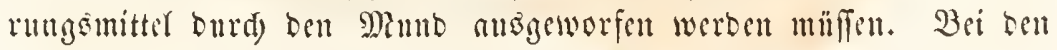

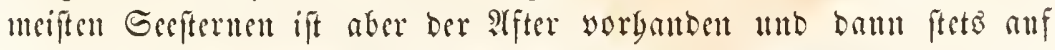
Ler PRinfenflädje Dem Munde gegenüber angebradjt. Bei bent $G_{e c}=$ igstn fintet fid sint Yanger gewnubener Darmfand, welder yon bem

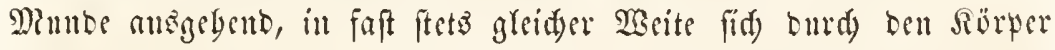
wintet unb entweber auf ber Spise ber Rälfenflädje soer in ber Mitterlinie bem unparan mittlern Strable gegenüber snoct. Mian finter bei ben werfáficbenen Sesigeln jebe abweidente Steflumg in

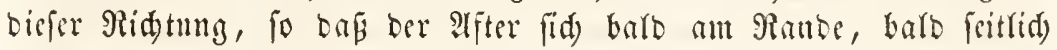
anf ber Doberflüd)e, baro anf ber lluterflüd), aber feets bem mittleren Strable gegenüber fintst. Bei Den wutrmfürmigen Stadyelyäutern liegt ber Mrunb an bem einen, ber Iffer an bem entgegengeresten Enbr; meift indoes iff ber gleidjweite Darm mebrfady in bem Sïrner mo jwar in zwei S fürmige Sdylingen gebogen. Bei alfen Stadjefbän=

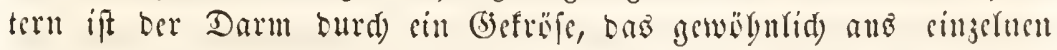
brüfenartigen Selnenfäben beftegt, an Der Reibeswand angelyeftet. Die mit Bägnen bewaffucten Stad)elgänter nägren fïd meitens won Yrlanjenfteffen, befonbers won Tangbrättern, wägrento dis zaburofen

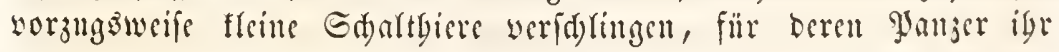

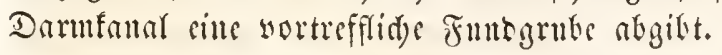

Man barf erwarten, Láp bei fo bed urganifurten Thieren wie

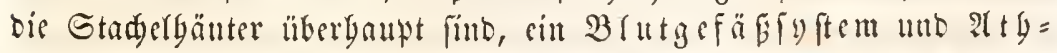

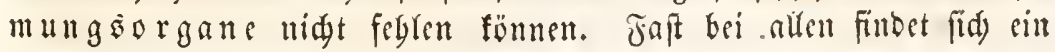


Gerzartiges Eentralorgan, weldeb balt, wie bei Ien Gecualzen,

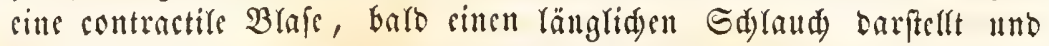
ftets in ber Räbe bes Dumbes an bem Gdjlunbe gelegen ift. Bon bicfem Serzen aus entfpringen bei ben ftrabligen Staderbäutern melyr

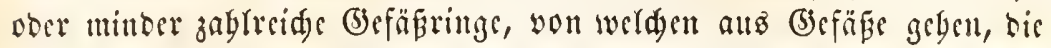

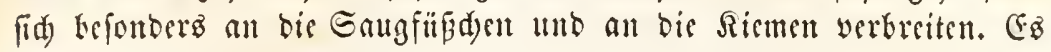
balen bicje (sefäpe beutlidye Sandungen, allein igr Berlauf ift ben= nod) bei ben cinzelnen Gattungen mur febr unvolftänotg getannt, was

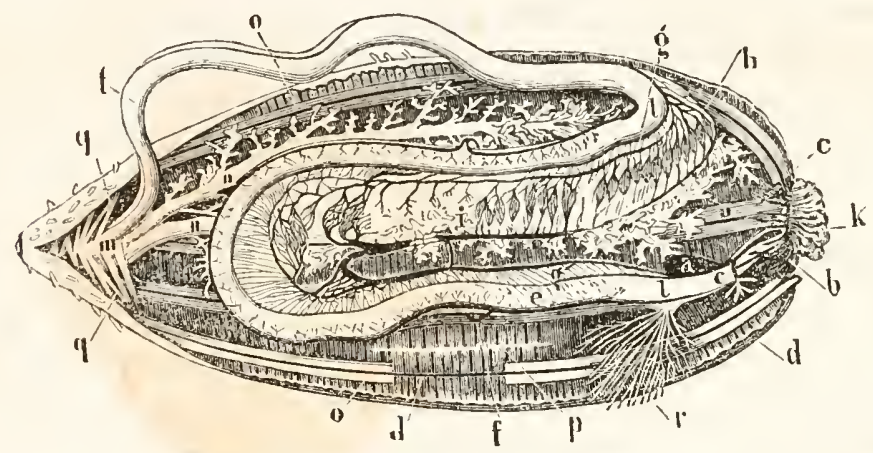

ซึig. 139. Inatomie tet Rêfrenfo otgurie (Holothuria tubulosa).

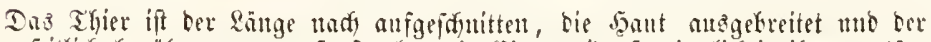

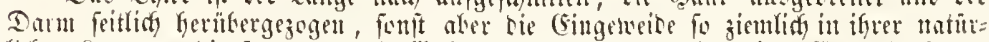

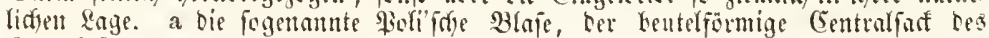

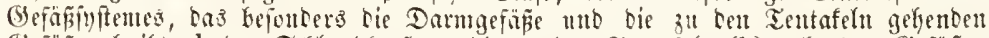

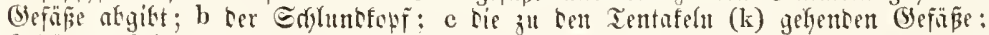

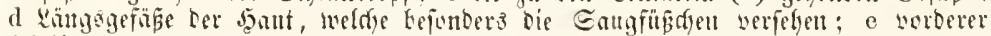

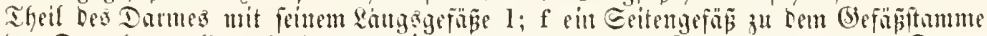

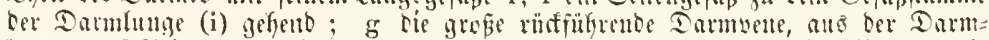

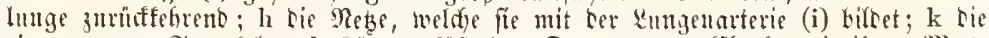

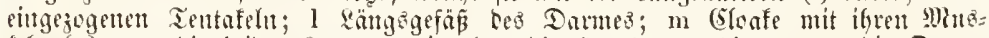

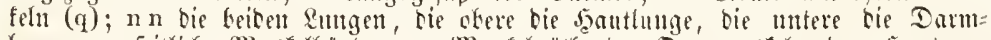

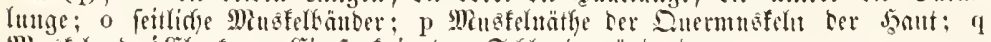

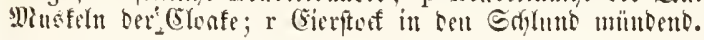

jum Theil in ber Sdwierigfeit ber Beobadtung frinen Grunb baben mag.

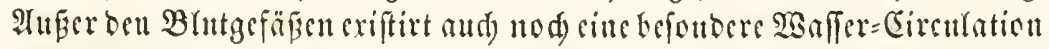

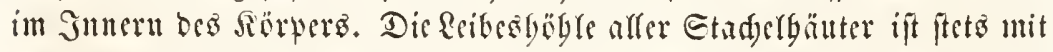
Geevaffer erfülft, bas furd) হBimperbante, weldye fümmtlid) (Fingeweite

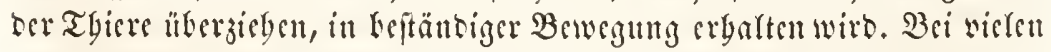
Gradgelbäutern bat man entweder Spalten ober cinfade Sïder ober Rögr: d)en gefunben, burd) welde bas 2 affer it bic Reibesbible sintringt,

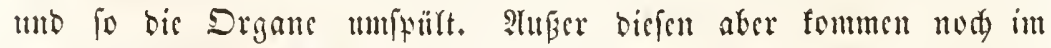

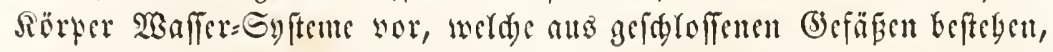
bie befonbers mit ben Sangfüfdyen in Berbinbung fteben unb in wer=

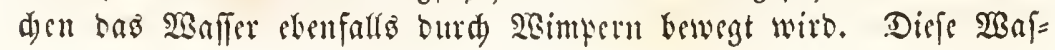




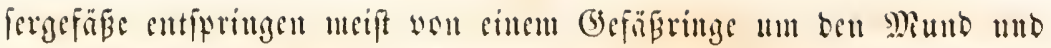

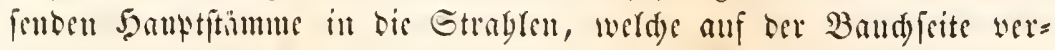
raufen. S)it jebcut fribd)en mo mit jebem Miunbfübrer ftebt ein be=

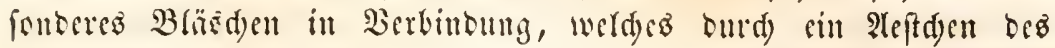

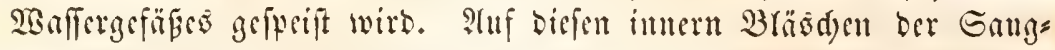

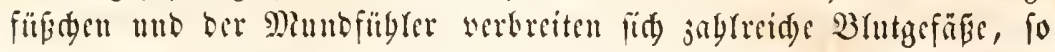
bas mamentrid) bei fordyen Tbieren, weldse feime eigentliage fiemen

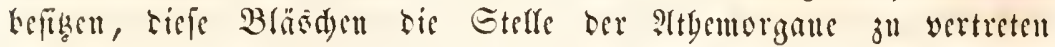

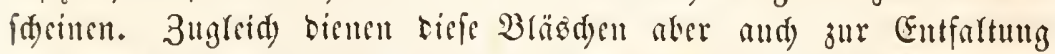

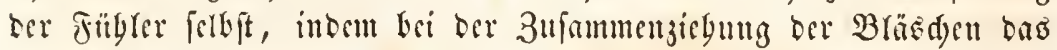
20n

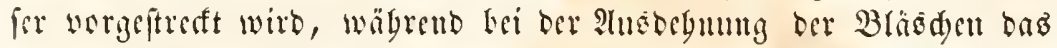

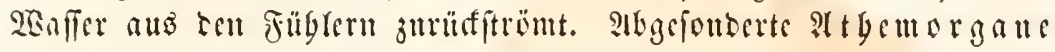
fonmen nur bei ben eigentliden Geewaljen unb bei ben Gerigeln wor. Bei ben reketern finten fid) auf bor äußern Baud)fläd)e in bem llm=

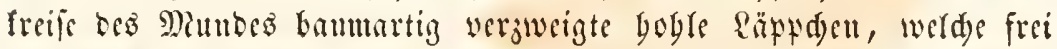

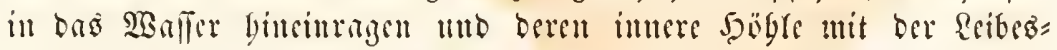

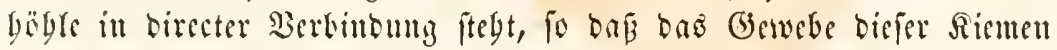

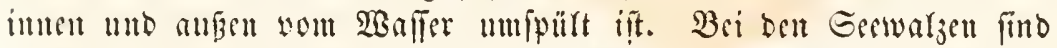
bie Riemen ober \&ungen in Smuern bes Sërpers angebrad)t unb befteben

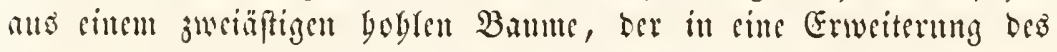

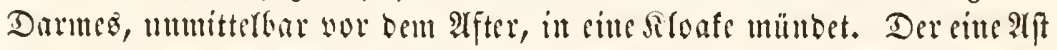
biefer baumartigen Si ieme liegt an bem Darme, ber anbere, bie şantlunge,

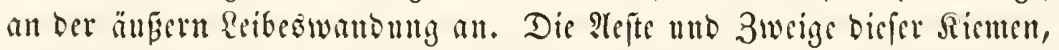
werdye innen mit bem rebgaftefen frimmerïberjuge verieben find, be= finden fid in fteter Mnrmförmiger Bewegung, bie ferbft tingelang uad)

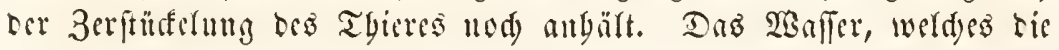
siemen anfü!t, witb burd) ben affer eingefogen unb wieber auşge= fpritzt, oft mit forder Gsowalt, baf ein grofier Their ber Eingeweibe mit berwor getreft wirb.

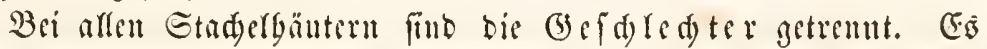

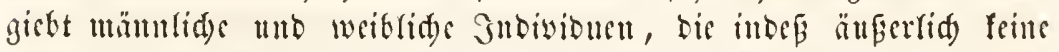
fenntlidgen Merfmale bathicten; and in ibrer Struftur gleiden fids

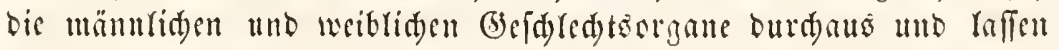

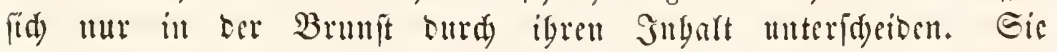

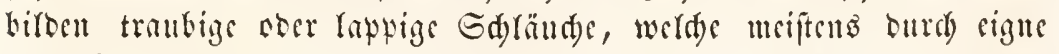

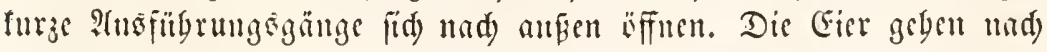

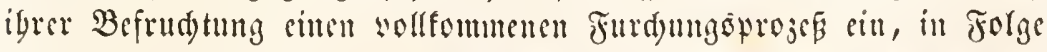
beffen aแz Dem ganzen Detter fid) eitt mit wimperbaaren bejetzer Embryo bilbet, welder sic Eifdale burdbridyt mb frei bewergt im 


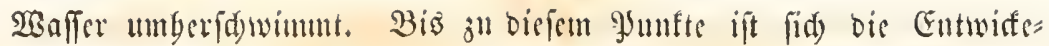
rung aller Stad)elgäuter glcid); yon bieran aber Taufen dic Embryo:

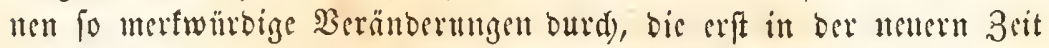
aufgegellt wurben, baf mir bieferben bei ben singernen Dromungen und Familien näber betradyten müfien.

Die Stadyelbäuter leben in allen Meeren oft in grof́cn Mengen

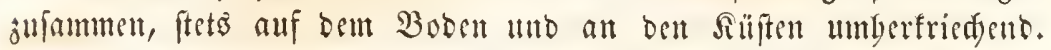

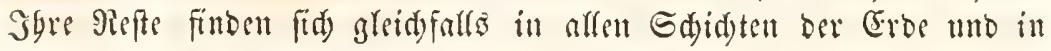
merfwitroiger Itufeinantorfurge igrer sinjernen formen. Durd bic änßerft mannigfaltigen Gefftaltungen ber cinjernen Tyeile igres Rayt

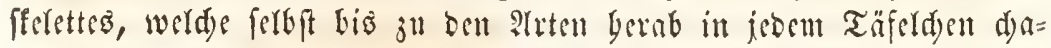
racterifitif find, eignen fid bie Stadjelgänter sor

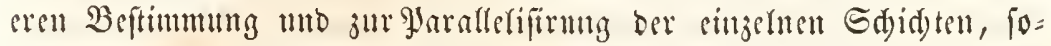
wie jur ?tridjautug ber Fortfdritte, welde ber MIan ber Strabl= tgiere im \&anfe ber (Erogefdjidte madt.

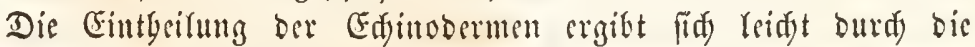

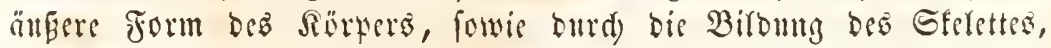

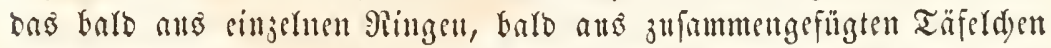
beftegt. Bei zwei Dromungen ber Stadjelyanter ift ber Rërter melyr ober minter Flatt, facibenfïrmig mo in singelne Strablen getbeilt, bei ciner britten megr fugetig, bei ber vierten walgenfürmig. Sti ber Dronung ber Seelifien (Crinoidea) beftegt Drô Salfgerïfte ans cin=

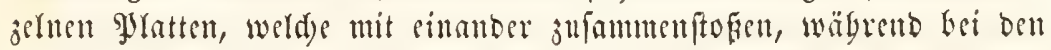
Seejternen (Stellerida) unr sinjefte gsanjerringe exiftiren. Bei der britten Dronung, ben Sesigelı (Echinida) findet man wieber cine fürm=

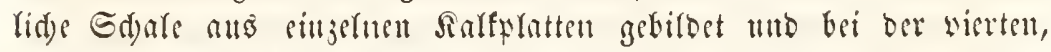

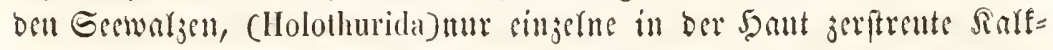
anjammlungen.

Die Dromm ber Eeclilicn (Crinoidea) ift faft ganj ans ber bentigen Sdjöpfung verfdymusen, wägreno fie in ben frübern cinen aแติgez̧eid) allein bie Silaffe ber Etad)elgänter ïberbant repräfentitte. Die mei= ften biefer Thiere fapen anf langen bewegliden Stielen feft mo Latten in igrer än fie in ber That woun älteren Forfidern unter biefe geffelft watrben. Der 


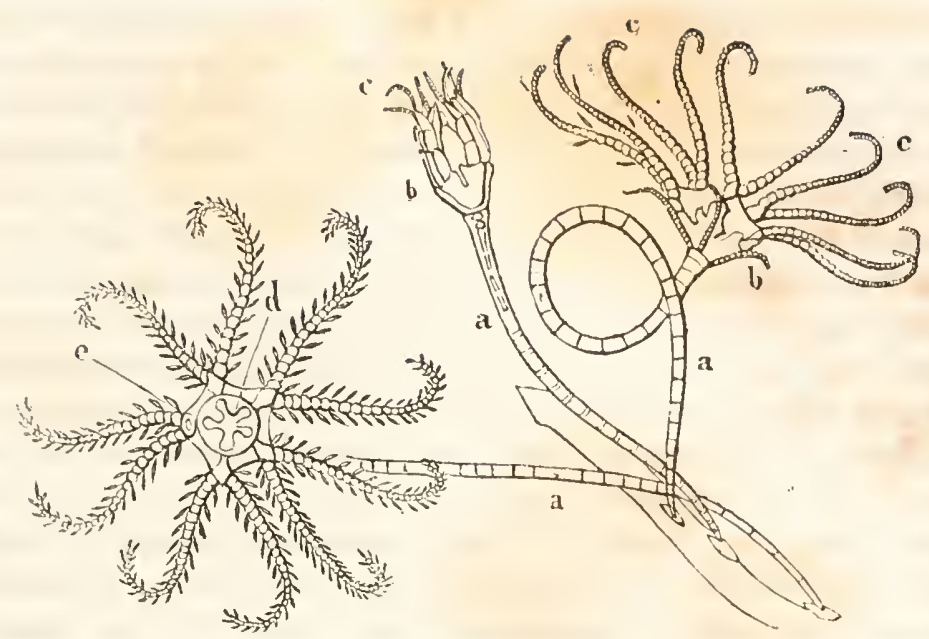

8ig. 110. Pentacrinus enropaeus.

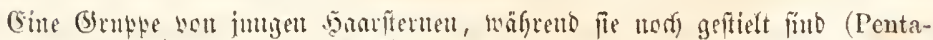
crinus emopaeus) anf cinte Eectifanze fibmo. Daz Thierden linfz Gat frine

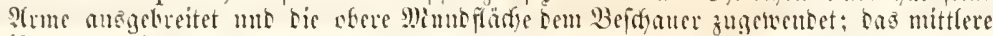

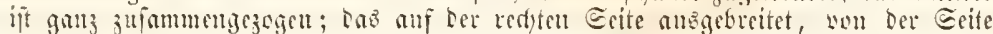

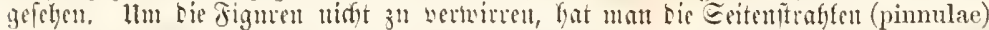

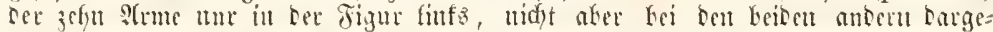

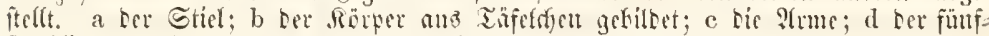

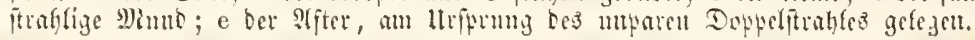

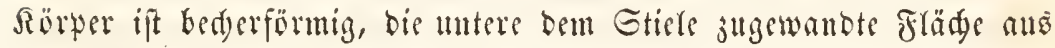

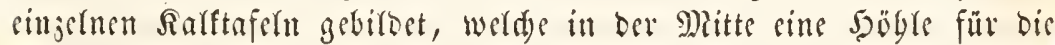
Gingeweide laffen. Die ohere Jläd)e oes Berders ift yon einer leber= artigen Saaut überwölbt, in werdyer fid mitten ber Miund und jur

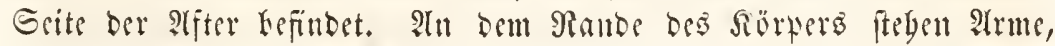
melde son ben Tafeln, bie ben Bed)er bifoen, anşgeben, meift febs leweglid finb, entfaltet uno znfammengelegt werben fönnen แnd zum Ergreifen ber Bente bienen. Dicfe Atrme find anb vielen singelnen Stḧffen jufammengefest, unb tragen oft wisber befonbere Aefte, 3weige unb Ranfen, bie anf Den einjelnen Gbliebern ber Trme cinge= lenft find. Der siörer mit feinen jufammengelegten Armen bat be fonoers bei cinigen furjarmigen Arten ganj bie form cincr Rilien= tnos̄pe auf langem Stengel.

Cime normale Seelitie fann man als jufammengefent ans vier einjelnen Theilen anfeben: bie $\mathfrak{B}_{\mathfrak{H}} \mathrm{g} e \mathrm{l}$, womit bas Thier an ben Boben befejtigt ift, wirb won einer falfigen Mafle gebildet, äburidy Der Girunbmaffe, an Der bie golypen anffiken. Gie eridjeint meift alö

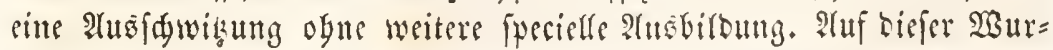




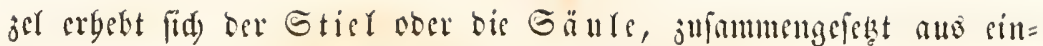
jelnen, meift runben ober fünfectigen (stiebern, welde gewöbnlid) eine mittlere centrale Deffung befizen, burd) bie cin Sintal nad) unten fid erftreft, ber bauptfäd)lid) nur für bie bewegenbe Fafermaffe bes Gticles beftimm id)eint. Die Täferden ber Gänle Gaben meijt nuf beiben Geiten Rerben unb Borfprünge, bie in eitanter greifen mo oft bie Jigur cines fünfitrabligen Sternes bitben. Diefe ifolirten Täfelden, bie man aud Trodjite nober Entroditen genannt bat, fütoen fiá) bälfig in ben Gdjidten ber Erbe vor, wäbrent woblerbaltene Gerlifien in ganjer Geftalt feltenter füt. Bei vielen Gattungen trägt ber Etiel feitfide Ranfen, bie anbern feblen; Lei anbern werfümunert er ober jeigt

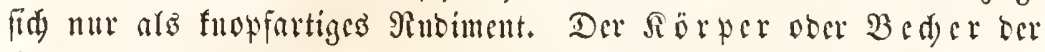
Geclifie beftegt aus cinjelnen Stüten, welde man je nad) ber (Entfer=

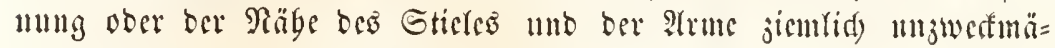
Bigerweife Beftenglieber, Şüftglieber, Edjuterglieber n. f. w. genanut bat. Diefe Täfelden firben mebrere iiber cinanoser liegonte, fids $\mathrm{er}=$ weiternbe Sireife, auf beren äuberftem bie Trme cingelentt funb. Diefer finto fünf ober jebue, bie fiá) aber oft nod) wieffältig in incite ffalten.

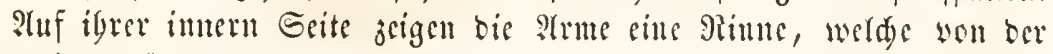
weiden Sautbereffung libergogen ift unt anf ber bie fleinen Eang:

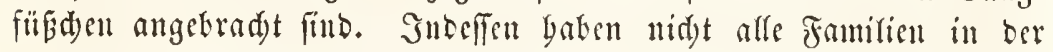
Dronung ber Seetitien bie bezsiduneten Tyeile bes Sörpers. Der fas= milie ber Geeäpfel, bie fid) nur in ben äteften Sdjidjten ecr (Frbe fintet, feblen bic arme burd)ans and nur cin furzer geringfïgiget Etiel ift ausgefildet. Der Familie ber baariterne, welde in mufern Meeren bänfig vorfonmt, gebt in erwad)fench Zuftanbe ber Stiel ab "ull es exiftirt une cin fdecibenförmiger sörper mit febr langen bewerg= lidyen Armen verfeben.

Die Familie ber ammlojen Erindion ober die Seräpfel (Cysto-

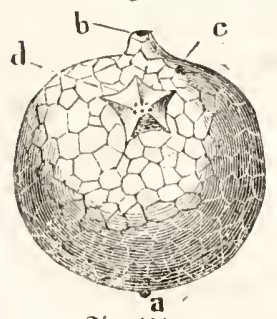

Jig 111 .

Sphaeronites.

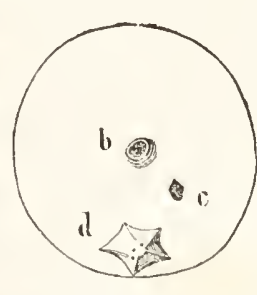

Jig. 142.

2us bem fodwehifden lletergangegefirge (Eiluri=

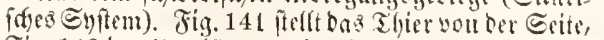
Fig. 142 ben lumriés vou whet bar. a ber fehr furge Stiel. b 2 amb. c 2 fiter. d fümpitraflige Uenital=

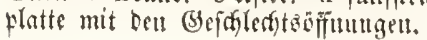

crinida) baben cint siförmi= gen noer rumben Sintret, oer aแถ Garten meift fed) Täfeld)en 3nfanmengeis ift milo burd) cillen furjen bieg= famen Stiel auf tem Boben augebeftet ift. Der fugerför mige תörper jeigt orei Deff= unngen; sinc obere cen= trale, ocr Dauto, neben wer= d)ent fid) eine jweite Deff= 


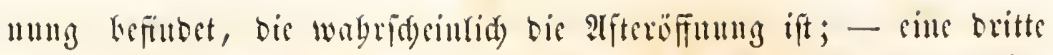

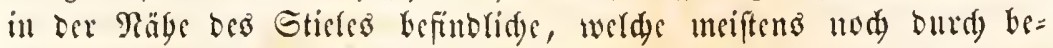

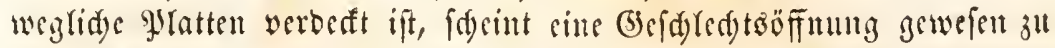

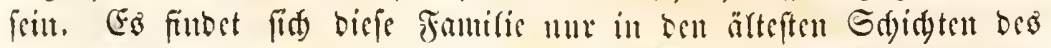
llebergangggebirges, in bem llnterfiturifden Jialfe, unb fie ferlen gleid)=

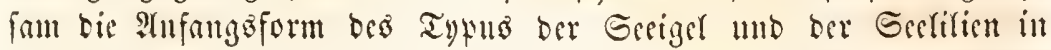
chander vereingt wor. In ber That jeigt fid ald cine (Brupte, welde infofern ben llebergang sermittelt, alo fid anf ibrer Spike

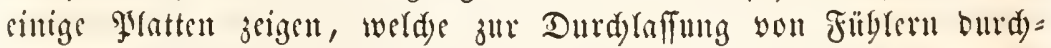

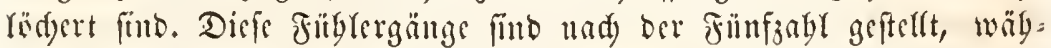

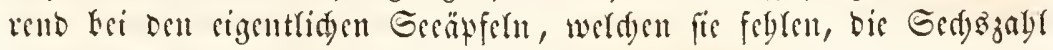
vorberridento ift. Cystocrinus; Sphaeronites.

Dis cigentlidgen Ecelilien (Encrinida) befrzen affe cincu Stiel, cincu ked)erartigen Rörper, beffen obere Fläde Manb unb after ueben= cinatoer zeigt, unb Arme, bie auf igrer Snnenfläd)e site Rinne jux SHFuabue ber süfden zeigen. Sie fommen won ben älteften Sdjidten

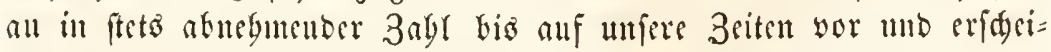
uen ill unerm jesigen Mecren mur nod in jwei bödft fertenen (bat= tungen, währent fie in beul llebergangs= unb Roblengebirge bie grofe

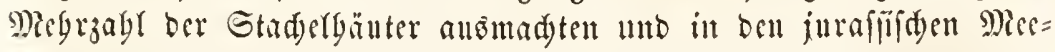
ren bejoubers an ben Soralfenriffen blïgten, welde fid bafelbit vor= fanben. Bon ber cinten rebenben (5)attung Diefer Serlilien (Holopus)

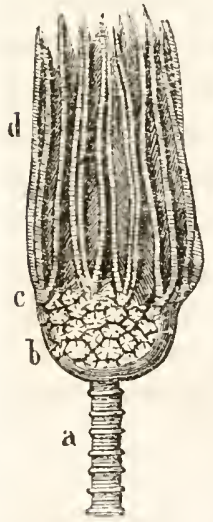

Jig. 113. Actinocrinus.

a Der Etirl, b ber Reldt, c bie Arme, d rie 3 meige mit ben Ranten Saran. ift bis ję̧t unr ein cinziges (5remplar, wou siner an= Dern (Pentacrinus) mur 4 ober 5 mad) Emropa gebrad) worben. Beibe wurben aus grofer Tiefe in bem Meere ber Antillen berworgezogen. Die folfitlen Serlilien bat mant in megrere (5ruppen (Lluterfantifien) jerlegt, weld)e inber nod) nidyt fo solfftändig unterfud)t fint,

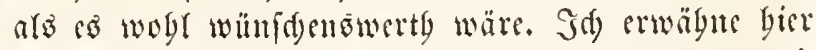
ats bejonbere Typen ber Gattung Caryocrinus, bis auf cincu furjen rumben Gtirle ciment cidgefför=

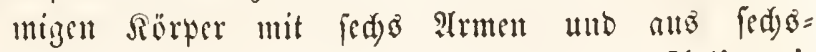
fritigen Täfeld)en getrildet trägt, bie Altinocri= niben unit langer runber Gäule, bederförmigem Sïrper, offfen einjelne Täfelden ulr wenig zu= fammenbalten, unb langen mebrfad) getbeilten Irmen, welde allf ibrer inturn Seite sitte grofe Dienge ar: tifurirter aub cinjelnen Salfftüfen jufammengefebter 2nbänge tragen, fo baß̧ ber Arm sinigermaß̧en bom 
Barte siner geost äbnlid) fiebt. (Fo fömunt biefe Fantlie unt in ben äleren Edjidten, aber bier aud) äuferit zabltrid) sor; fie wirb $\mathfrak{c r}=$ Fegt in Den jurafifigen Meeren Durd) Dic Sruppe Der Pentacriniton, welde fids burd) bie fefte Berbindung ibrer Reldylatten und burd) bic Einlenfung iber Arme auşzidnet, die auf bejonberen, bem Eticle aufirzenden Gtüfen angebeftet find. Der Sticl ifít fünferfig, zeigt

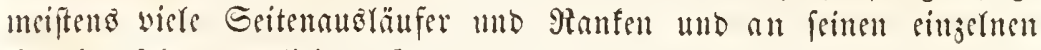
Gtüfen fegr complicirte Gelenffläden, die fünfGlättrige Figuren bar=

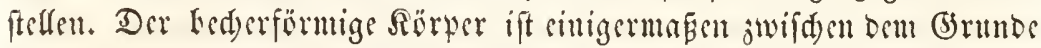

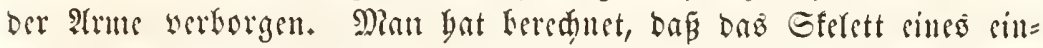
jigen Thierse, bei ser ungemeinen Berjweigung Der Arme unb

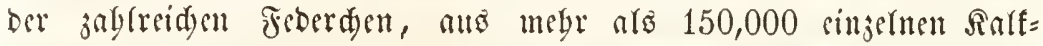
ftüfen jufammengefegrt ift. $3 \mathfrak{u}$ ber Gattung Pentacrinus geböt bie jekgt lebende art. Gine andere fegr anşgescidnute Grupte, bie cbenfalts crit nad ben llebergangegebirgen altfritt unb in Dem Miufderfarfe burdy einte Gattung repräjentirt ijt, änferit zabl= reid) bie juraffifas Soraffentänfe bewohnt und in ber Sireice mur nod) fourweife eridseint, ift bie ber 2(piocrintoen, mit langem, meift runbem Stiel, beflen Täfelden ftrablig gerippt find, obne Geitenrans

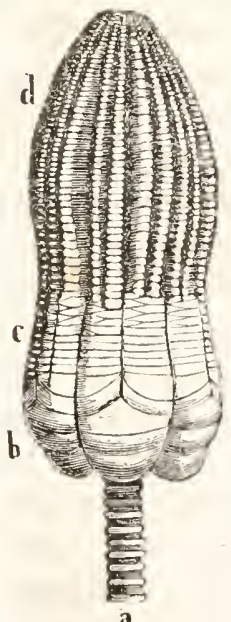

8is. 141.

Encrinus liliiformis

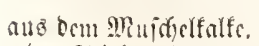
a Der ङtid; b ber att gitatten zufummenge= fiigte Rörper; c bic Slrme; doie getfociltent fit aแs atmzäbligen Gtüif:

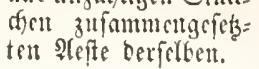

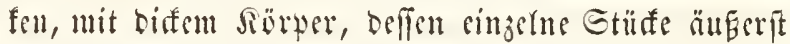
folib fint unb une sinen geringen Panm juifden fid laffen, unb böd)fens cillfad getbeilten Frmen, weldye

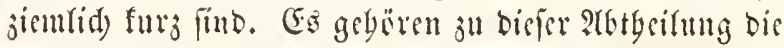
im Mufdueffalfe fo auperorbentlid) bäufigen Gertilien (Eucrinus) unb bie (5attung Apiocrinus, welde be= fonbers an ben Soralfentänfen Des Sura vorfommt.

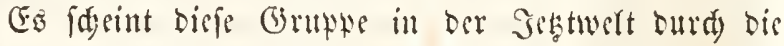
gëd)ft eigentbümtidye binttung Holopus eriegt, beren

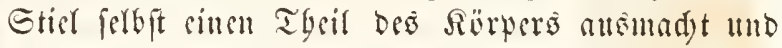
jum Theil die Rörperorgane beberbergt. Das Thier foll mur vier 2trme baben, ift übrigens bis jek̨t nur Durd) sill sinjiges bei Martinique aufgefid)tes Exem= flar befanut.

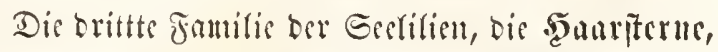
(Comalulida) ift aแอ Thieren gebilost, weld)e im $\mathrm{er}=$

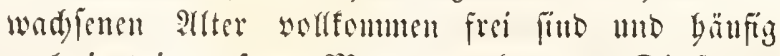
nod) jest in unferen Meren vorfommen. Die Saar= fterne baben cinten abgetratteten $\Re$ örper, Deffen $\Re$ üf=

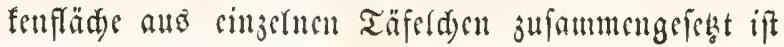


unt auf beffen Baudflinde fid jwei Deffunngen zeigen, eine mittlere, ber Mlund, eille feitfiche warjig berworftebende, ber alfter. Die zebu

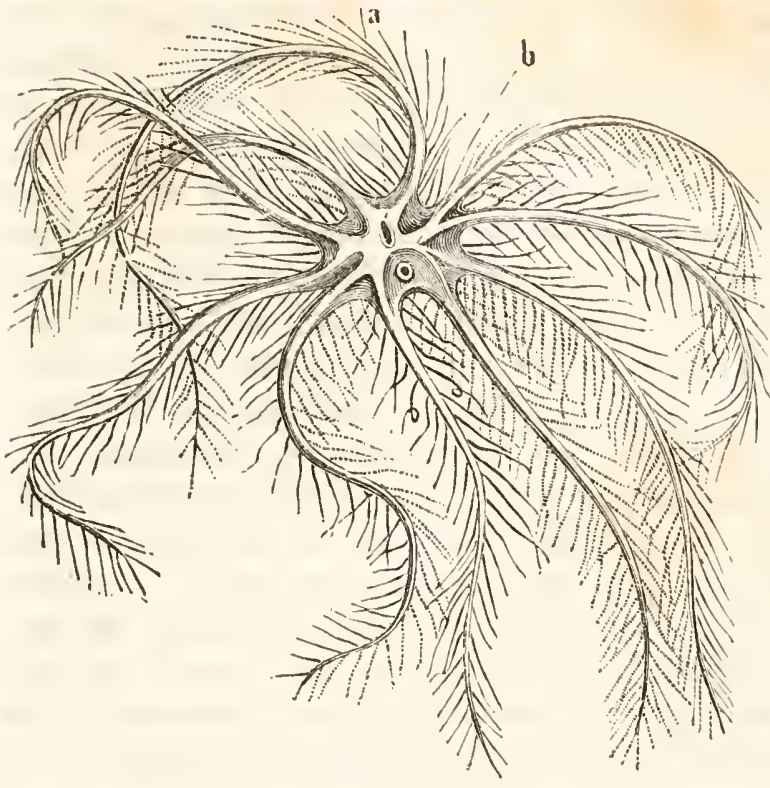

Sin. 145 5aarieru. Comatula mediterranea.

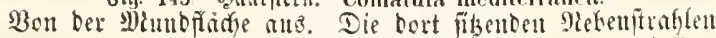

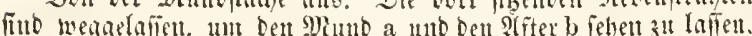

Arme, weldse biefe Tbiere beftisen, fint an bem $\Re$ ande bes nogerlatteten $\mathfrak{B} e=$ d) eris cingelenftund

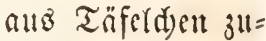
fommengefekt, auf weld)en jweijeilige beweglide feber = nubänge fteben. Mittelft Diefer $\mathfrak{A} r=$ me und ?tubn̈nge flettert ber 5aar= ftern febr gefdjidt aut Meerpflanjen umber, bie er mit feinen Armen ums faşt, loobri ilum die furjen fribler be= Gitlflid) finto, iweldac auf einer Siune an ber Baud)fläd) Der Atrme fteben. Es gleid)en

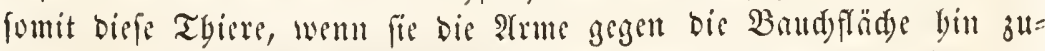
fmumenfd)lagen, volffommen einer Geelilie, beren auf ber Rürfenfläd befinblid)er Sticl weriduwunben ift. Comatula; Alecto; Comaster.

Jn ber That entoefte man, baß̈ die Saarfterne in ber Sugeno

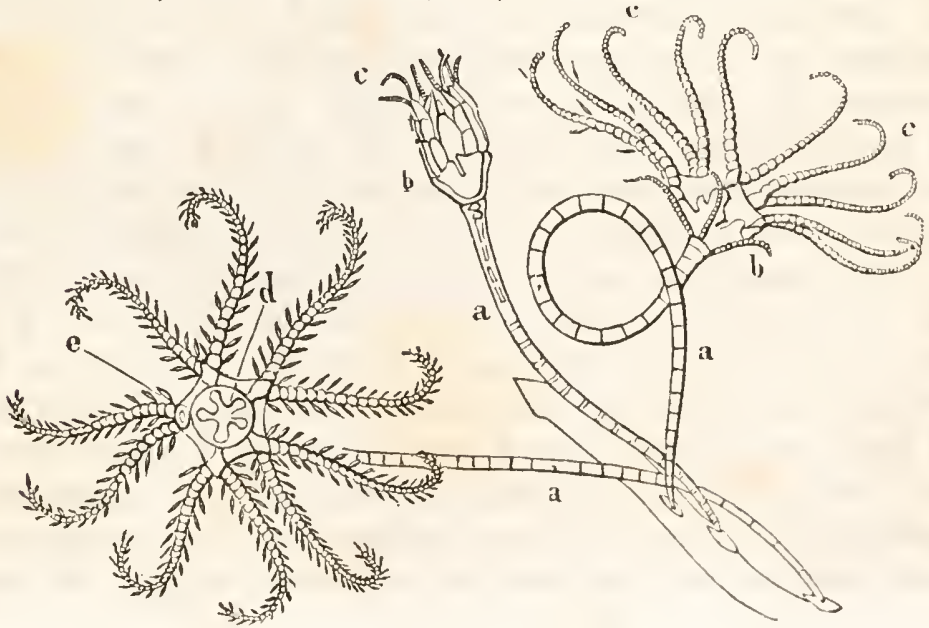

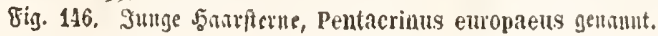


einen biegfamen Stiel befigen, burd) welden fie an ben Botent fept= gebeftet fint unt baj fie in bieferm 3uftande volffomment ciner See=

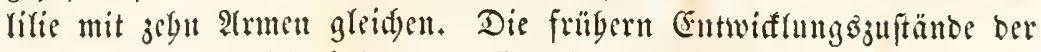

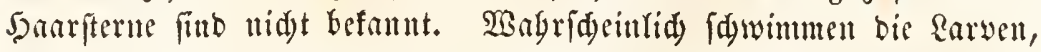
wie biejentigen ber ïbrigen Gtadgelgäuter, wägrent einiger 3cit im

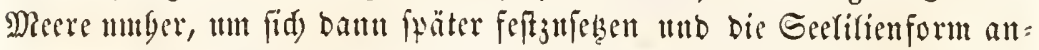

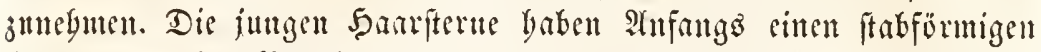
Rörper, ber furpffürmig enbet unb bier mit einigen furgen Fortfähen (Fribler) verfelen ift. Sinn beginnt in bem Stiele bie Ralfablagermug oer eingeluen (5)tieber, wäbrent jugleid) ber Bedger fid bentlider auts= fifbet und bie ?trme bervorfproffen. Barb fielyt man anf ber Sber=

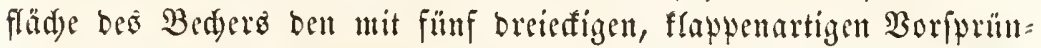
gen bejeşten centralen Minto und aun Ranbe ben wargenartig yor= fpringenben 2 ffter. Das ansigebilbete Gunge bat fünf boppelt getbeifte

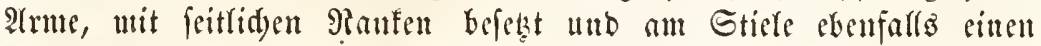
STrans von Pianfen, ber and im fpäteren Reben hleibt. Der Stiel

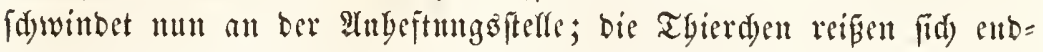

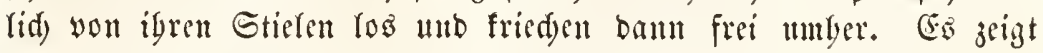
fid) burd biefe Entwiff(nth eine merfwürbige Mebereinftimmung in ber

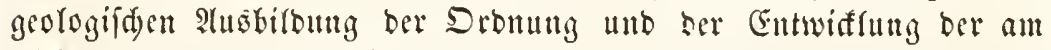
Güdjfen ftegenben Familie, inbem bie in ben äteren Sdidjten wor= fommenten Geelifien alle geftielt fint unt bie ungeffielten 5aarifterne

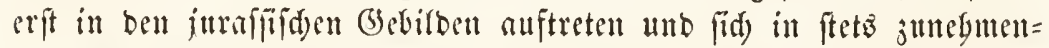
ber 3abl bis in mulere Jestzsit entrwiferen.

Die Dronnug der Eecpterne (Stellerida) begreift mur platt=

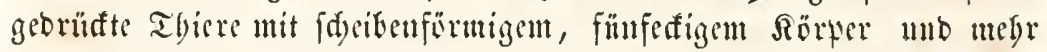

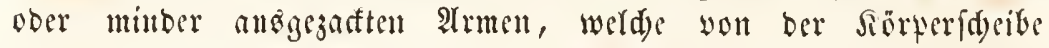

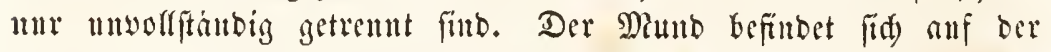
lluterfläde ber Gd)eite itn Mittelpunfte, ber 2/fter, (ween cin ford)er

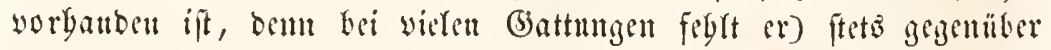

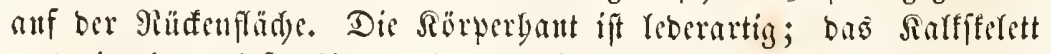
ans cinzefnen, Yofen Yranjerringen jufammengefełt, bie einte grofie $\mathfrak{B} e=$

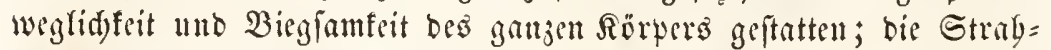

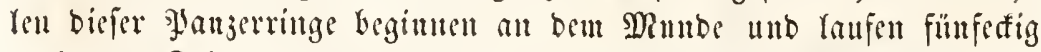
nad) ben Seiten aus. Y(uf ber llnterfläde ber Sdjeibe und, je nard ben Familien, and) ber Irme find in ben Strablen entfpred)ente Nin= nen angebradjt, welde bie Santgfübden beberbergen, bie fait gans in

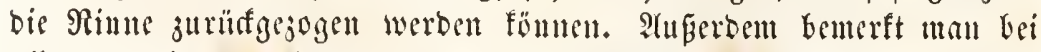
allen an irgent ciner Stefle ber Rörweridseibe cine eigentlyümlide fdyammige Sinlfplatte, bie fogenam

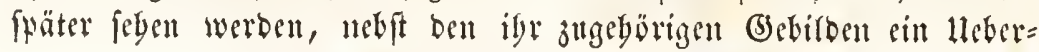




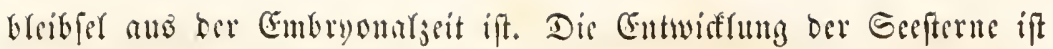
in sinigen igrer Etarien jimlifif genan gefamnt, on aber vier lleber= sinfimmung in biefer sinfidst mit ben Serigetu berridst, fo werben wir fie erft bei biefen im 3ufammenbange abbandern.

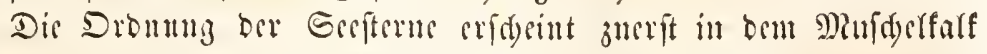
mub räß im Jurn, in ber Sireses, wis in ben Tertiärgebilben einige,

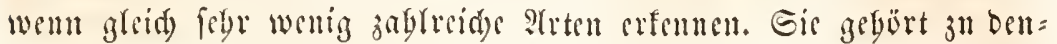
jenigen Dromungen, weld)e in fetz junclymenter 5 änfigteit fid it Der

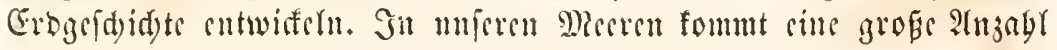
Diefer Thiere mo oft mengemein jablreidy vor, fo bafi z. B. an ber Räfte

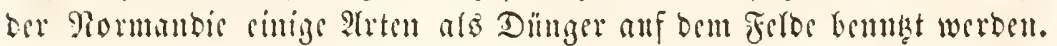

Man theift bie Sromm in Drei, fegr reidst fenntlide Familien. In ber Familie ber Gonnenfterne ober Medufentänpter (Euryalida)


anf ber Bandffädye. Die Rörterorgane befinden fids mur in ber

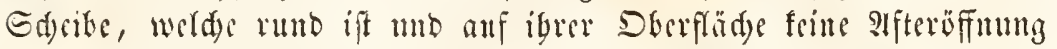
jeigt. Der Mimb befindet fids anf ser Mitte ber llnterfläd) ; anf ber= ferten Srite gegen ben Mand lin bie Mabreporentatte. Die Arme find ftets verätelt, änferfit bieglam mo mriftens mit Sianten verfeben, weld)e fitd fpiralig anfroflen. Eas finden fid bicfe Medufenbäupter be= fonders in ben fïblidsen Dieeren, aber fteto $\mathfrak{n m}$ ferten. Euryale; Trichaster; Asteronyx.

Eine jusite Familis ift bie ber

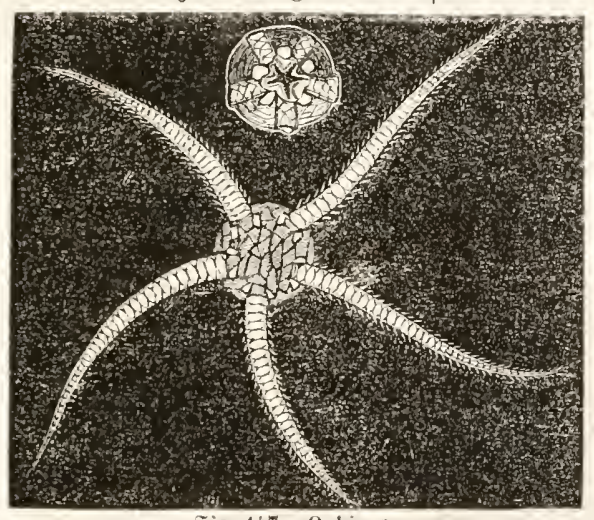

Tiis. 147. Ophiura.

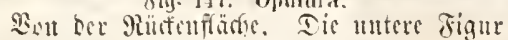

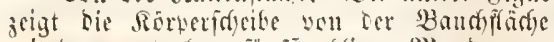
mit bem centralen, fümititafligen wiunbe. mit bem coutralen, fünjtraffligen Miunte.

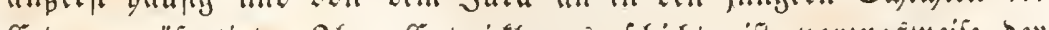

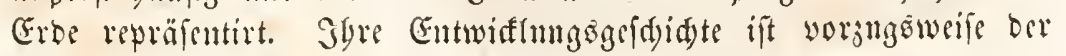
Esegenfand mentre llnterfudungen gewefen. Ophisa; Ophiocoma; Ophiolepis. Der Sïnter ftert cine rmblide obre fünferfige Sdycibe bar, mit fïnf langen, ftets numeräftelten Strmen, woom (b) fie fid we went= (id) you ber worigen familis muterfacisur aud ignen feblt ftets cin sifter mo bis Mabre = forenylatte wer fdwintet bei ben (5rwad) fenen fapt gänjlid). Die langen 2 trme, weld)e frine $B$ and $)=$ furd)e baken, find meift mit Stadyeln ober SBarzen in Dur:= reigen berekt unb folangenartig birgfam. Eis find in alfen Meeren

Edbfangenfterne (Ophiurida). 
Sn ber Famifie ber sigentliden Eeefterme (Asterida) ift Der

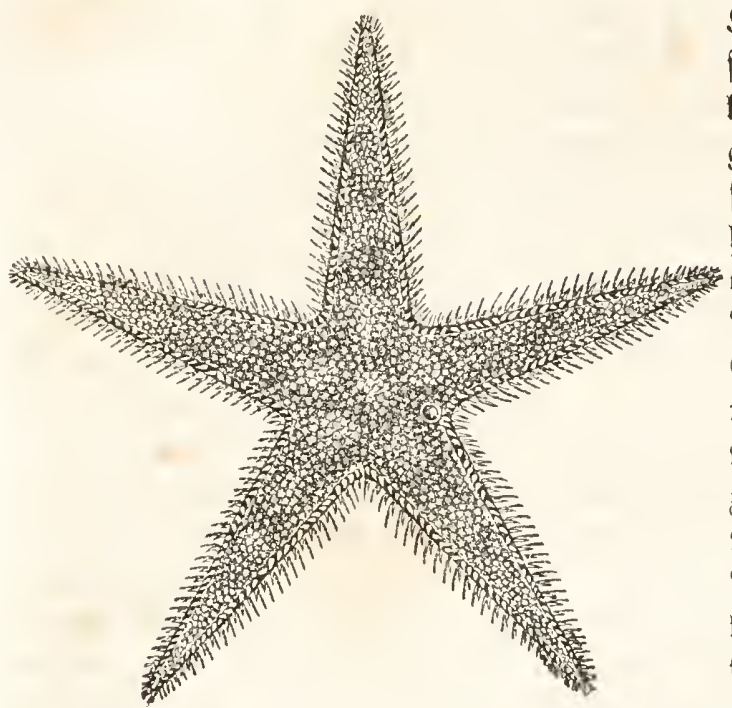

Rörper zแtweilen mur fïnfertig oder in fünf furge Arme ausgejo= gett, in weldye Brind = fäne bes Mingents bineturagen, bie fids oft nod) weräftedt. Pur felten fint Diefe Strablen jablreider unb in diefem falle wedjelt oft igre $\mathfrak{A}=$ zabl ober räbt $916=$ weid) nutgen won beut

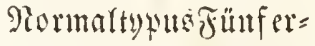
femtuen. Dis (bse $=$ (d) led)tätbeile riegen ebenfallo tyeilweife in Eig. 148. Asterias.

Den Armen, die fteto anf Der Baudfläd)e einte Alinte baben, in wel=

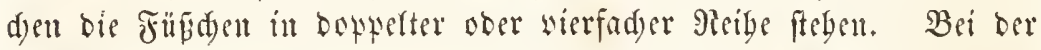
untgemein grofent 2 htzabl ber Arten nub (3attungen bat man befonbers

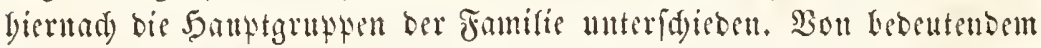
Ginflus anf die Elafifieation ift ferner bie Sörterfurm, Das Borbanbenfein

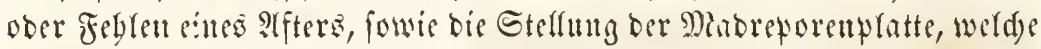
in biefer Fantife mit einem eigentyüntidsen Sanale in Berbindong ftét,

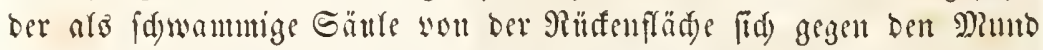
bin erfitreft. Asterias; Astropecten; Stellaster; Solaster; Echinaster.

Die Drommig ber Eecigel (Echinida) ift wobl bie zabls

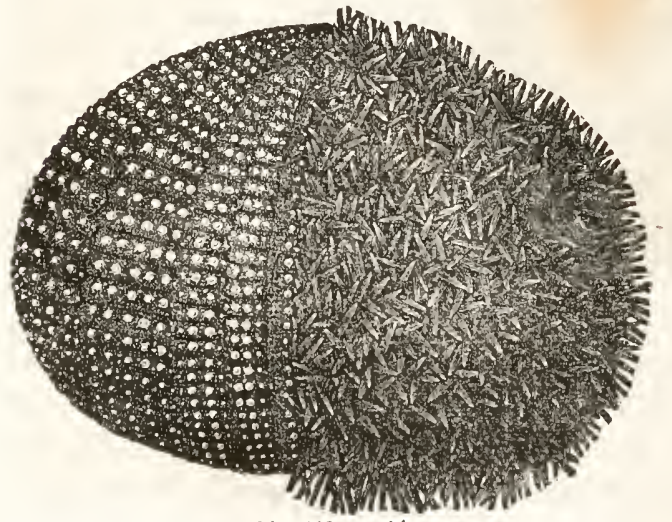

ซig. 119. Echinus. reidjite unter ben Stader= Gäutern, ba fie nidgt mur in mugebeuren Diengen in unfern Dieeren, fon= Dern aud in allen Sdjid = teil Der Erbe in fteto zuntehmenter 3abl ver= treten ift. Die Serigel baben einen rmublicyen ober abgeplatteten siör = fer, weld)er gäıjlid) aแb eingelenftent Täfelden jufammengefest ifi, bie 


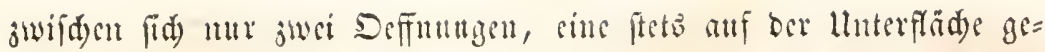

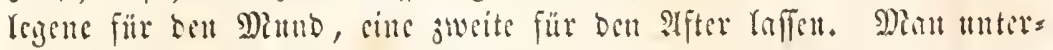

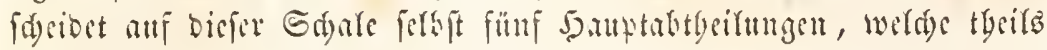

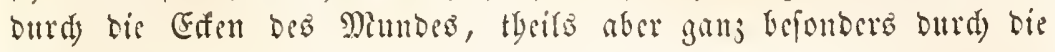

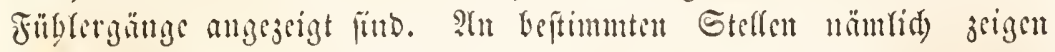

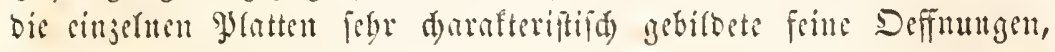

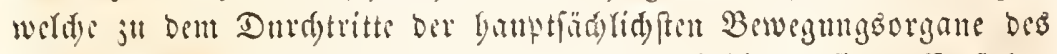

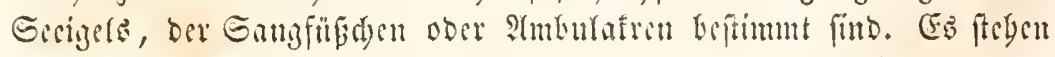

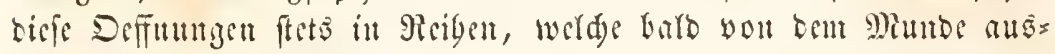

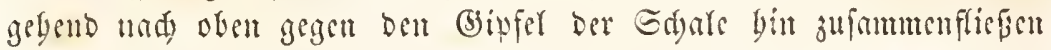
unt bort cinen fünffitrabrigen Stern birben, barb atd nut fid anf

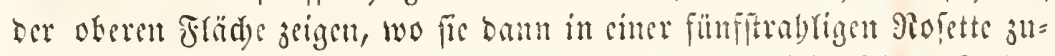

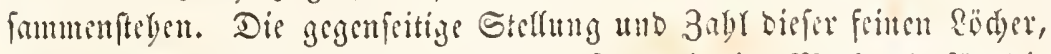

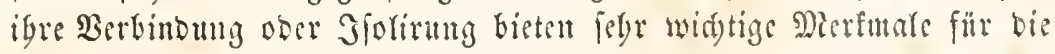

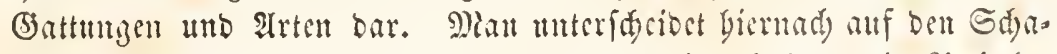

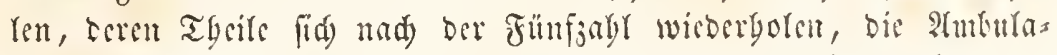

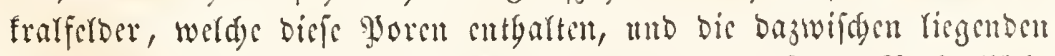
Snteramburafrafferber. Dem Dumbe gegenüber anf ber Päitenfläde

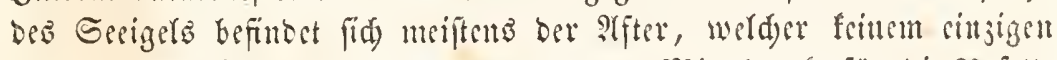
biefer Thiere feblt, und welder bann bent Mitterpunft für bic giofette

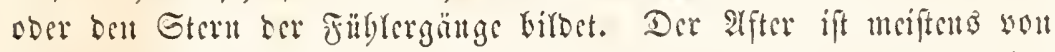

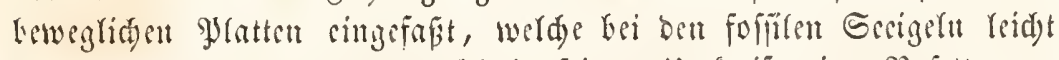

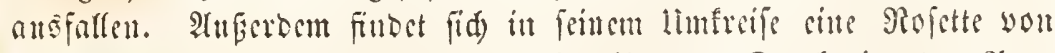

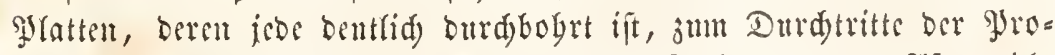
bufte ber Zettgungsorgante. Gerbft in ben Fällen, wo ber affer nidgt

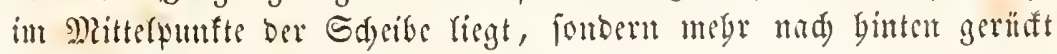

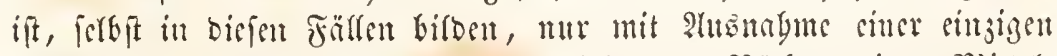

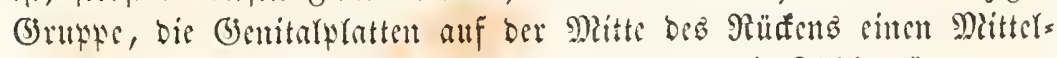
punft mit 5 ober 4 Seffinugen, yon weldem bic Fühlergänge atts=

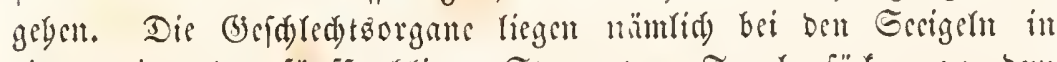
cintem vier ober fünffitrabligen Eterne won Tratbenfäten an bent

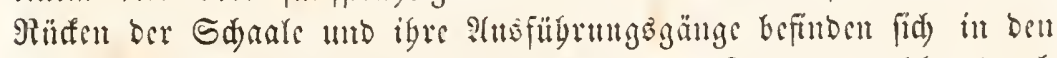

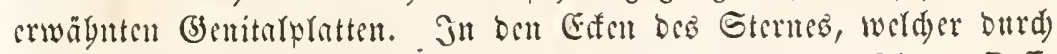
bicfe glatten gebirbet wiro, ficht mant meif nod andere feimere Deffs

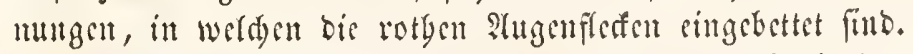

Auf ben Täfelden, weldye bic Sdyaten ber Sccigehn zufaumens

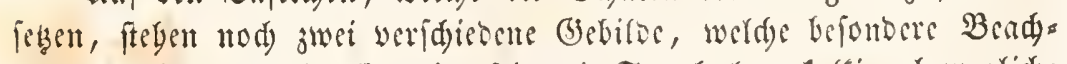
tung verbienen. Dies fint cincrfeits die Stadern, falfige, beweglide Säuren, welde von der Dife eintes baares bis ju ber sincr Ruß

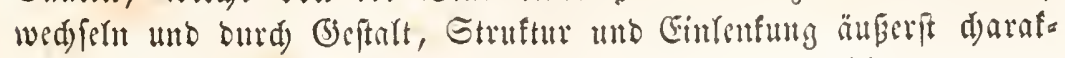




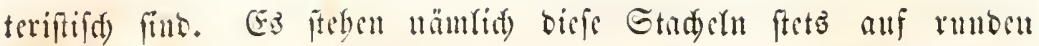

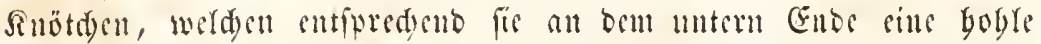

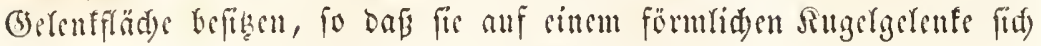

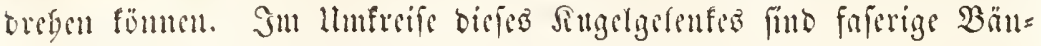

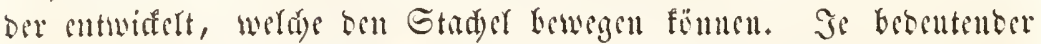

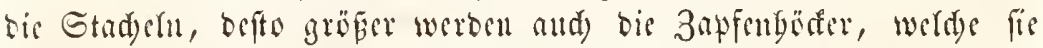
tragen, fo Dap bei benjenigen Gerigeru, wo febr bebeutent grofe Eta=

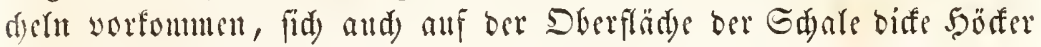

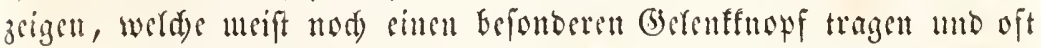

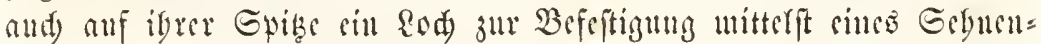

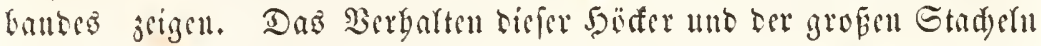

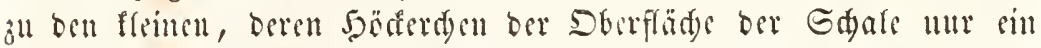

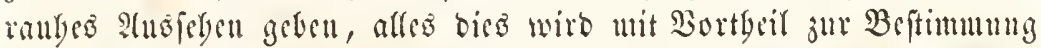
Der (3)attungen uno Frten benust. Die jweite 9 trt yon eigentbüm=

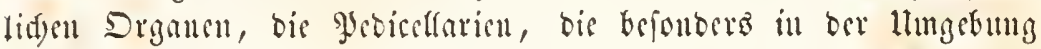

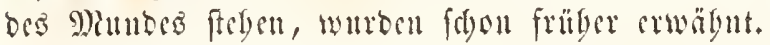

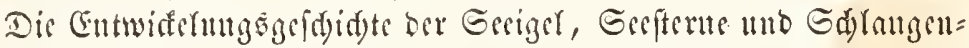
ferue ift befonbers in ber ueneften 3eit fo umfaffent beobadytet wor=

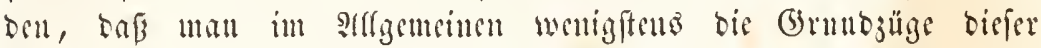
Entwistelung angeben fom. Go beftelgen refe aber im Folgenten:

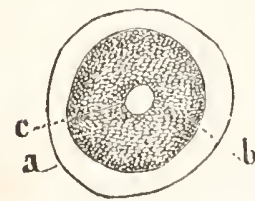

Jig 150 .

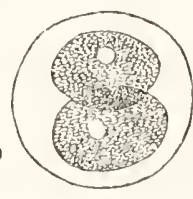

Jig. 151.

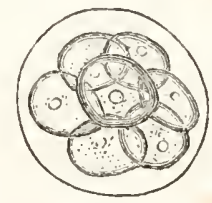

Jig. 152.

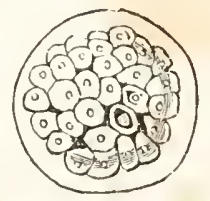

รig. 153.

Seeiged-(Sier im Furdungaptojeffe. Fig. 150. Das reife (Si, a Dotterhaut; b Dotter;

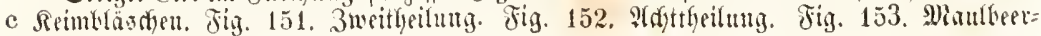
furm bes Dotter.

Die Gier Der Gerigel und Geefterne zeigen sine beutlid) 5 ülle, sincu

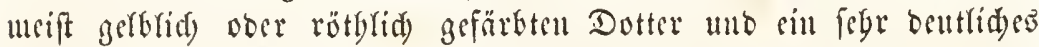

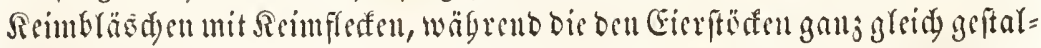
teten männlidyen Drgane Samentbierden mit runblidem Siörper unb cincm Gdwanzanbange erjengen. Rad) oer Befrudtung unt bem reget=

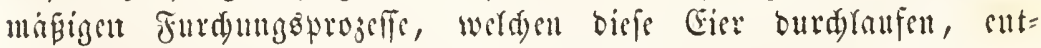

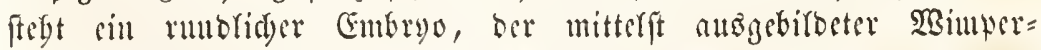

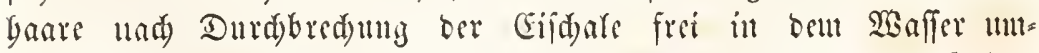
berfdwimmt. Pad und und) erbält biefer Embryo die Geftalt

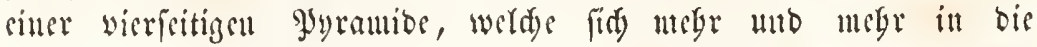




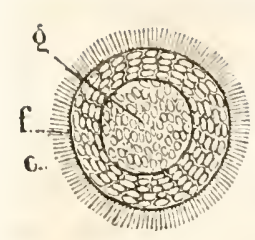

Fig. 154.

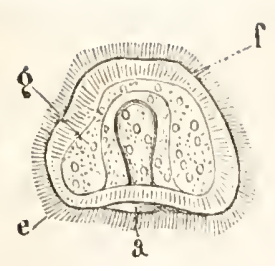

8iig. 155.

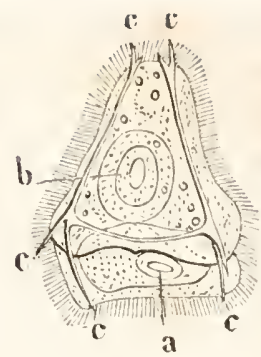

\&iig 156.

Rarventitbung deв Eeciget?.

Ränge ziebt min anf Der, Der Sritge gegen= itrer febenten Bafir cine Deff= แmung zeigt, $\mathfrak{w e l}=$

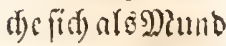
juctemuengift, ber inteinen wei= ten 6 d) luno mito

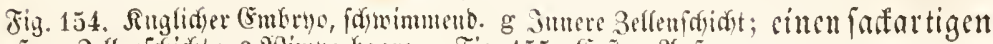

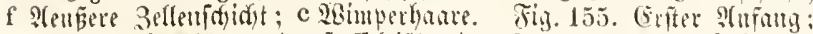

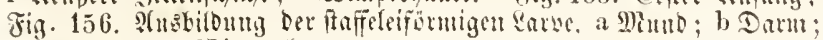
c Salfịăbe ; e simperigare.

Magen fübrt. 3ugleid) zeigen

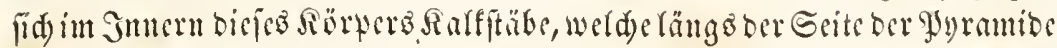
binlaufen und an ber Epize berferben mitcinander yerbunden find. Da wo

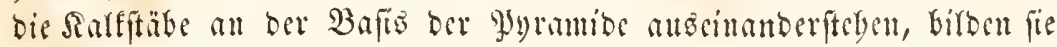

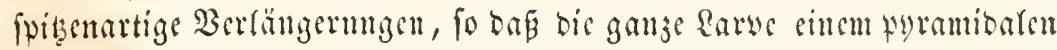

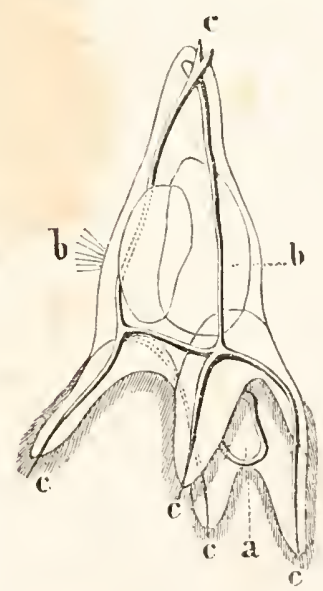

ซig. 157. Muถ̊gefitbete ๔ecigeflarre.

a ber Mutro, b ber Darm mit hem linfz gelegenen sifter. c Raffitäbe.

(5) bilben ans. Ankerordentlid) merfwüroig ift inder bic weitere Ent= wiaflung biefer feltfamen Sarven, weldye burdans frimen ftrabligen Typns jeigen. Das eigentlide Strablthier fprofit nämlid ans biejer

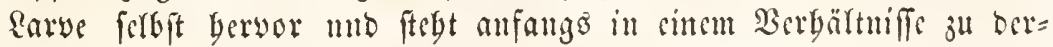
ferben, wis sime Snoope zu igrem Muttertbier, wäbrend fpäter im 


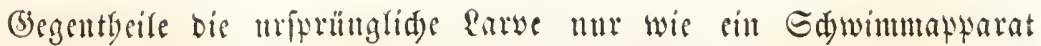
erfdeint, ber alt bem Thiere jelbit befeftigt ift. Die Sarwen, welde fid) aนs bem mprüngliden (Ei ber Geefterne unb Geeigel entwidelu, fteben arjo ju bem jutünftigen Strabltbiere etwa in bem Berbältniffe ciner anme ju ber fid entwidernben Sinosep, Dod) mit bem lluter= fdiebe, baf fogat ein Theil ibrer Digane in bie Drgane ber fid ent=

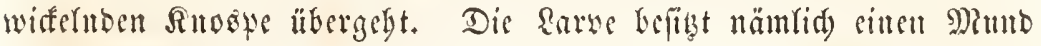
und eitten Sdylunb, welder in ben Magen Des jungen Strabltbieres überfitgrt unb, wie co fdecitt, ift and bei benjenigen Strabtbieren, welde einen Ifter befitzen, bie Rarve mit einem folden verfegen, wäbrenb ber 2ifter bei ben Rarwen feblt, welde afterlojen Gattmugen jugebören.

Die ftaffeleiartigen Sarven ber Edjinobermen finben fid ba, no bie Miuttertbiere bäufig vorfonmen, ebenfalts in grofien Mengen frei um= berfdwimment in Reere. Man bat igre weitere Entwifelung banpt= (äd)lid) bei ben Gdyrangenfermen beobadtet. Sier fproffen int Imtern bes Thieres jur Geite des Mnndes blimblatartige Figuren bevor,

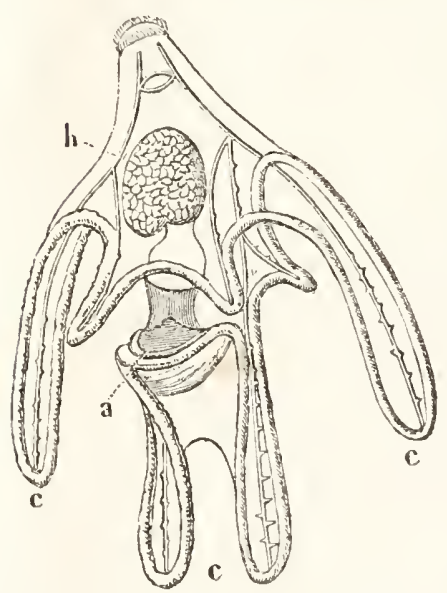

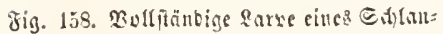

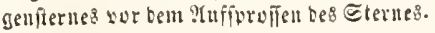

Die Bezridinnmy ift fiit: alle brei Figuren bie felte, a ber Miuno, c bie Salfiääe, h ber afterloje Magen ber Rarwe, i ber aufiptofiende Galangen= Ptern. welde anfange ganz in ber Gubitanj ber Rarve cingefdroffen find, fpäter

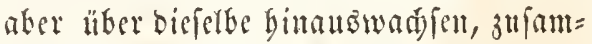
menfinefien mo bii Sderibe bes Ed) Ian= genfternes baritelfen. EB bängt biefe Ed)eite fduief an ber geftellartigen Rave, fo tap bie Joltfebung ber

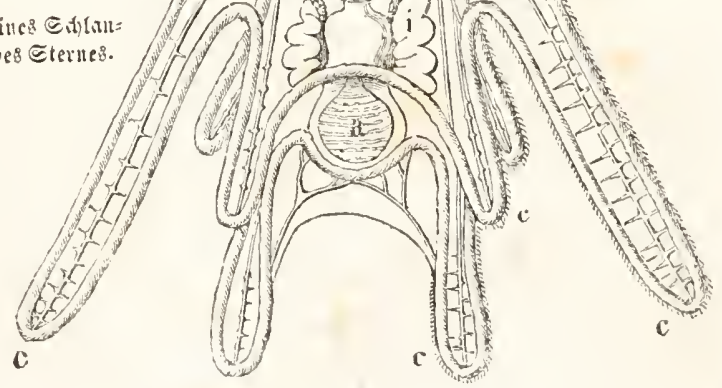




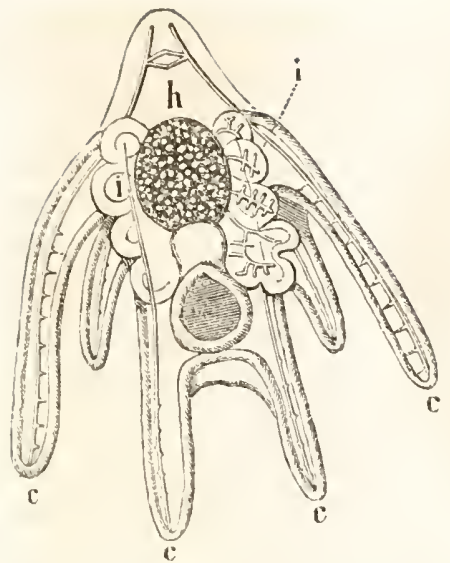

Rmenare nid)t in bie axe bes neuen Ibiereg fältt. Erft nad) einiger 3eit birset fich fint bas eigentfide Thier aud) ein Manb, wägrend es früber ourd) ten 9lunb ber Rarve ernägrt whrbe. Epäter wem die Rarve fid won

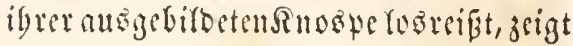
biele an ber Cintrittsîftelle sine Parbe, welde curda tie Mnoreporentlatte ge= (a) loflen wirb. Diefe Mlatte sient mit= bin bei ben erwad) fenen Gtad)erbäntern jur Bejeidumng ber Etelle, an wel= (5)e teibe embrysuate Gebilbe ju= 3ij. 160. (Gine britte sarve, bot wether in fammentingen. Snbem mun jugleid)

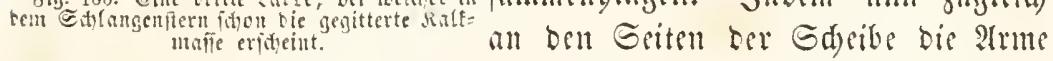
bersoriproffen, jeigen fid in bem Jmmern Des jungen Thieres bie

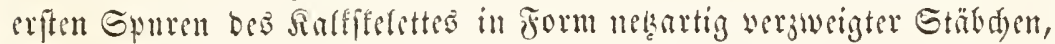
bie barb Drabtförmig gegitterte Gtäbe Eirben. Rad) Der Bildmng Der Etadjetn fproffen and bie Jübden berwor, anfangs mur in febr ge= ringer $3 a b l$ mo äuberft frumper form, wemn man igr ffäteres Bers bältuig ju ben erwad) fenen Thieren berürfigtigt. Se mebr nun ber junge Geejtern wädit, befto geringfügiger wirb bie Rarve in bem Derbältuif ju bemferben, bis fie enbrid) ganj atreift unb ber junge

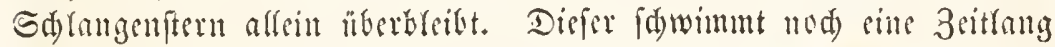
ourd) Simperbare, welde fläter verfaninben, wo fid bant bas Thier fried)eno bewegt.

Die Emben ber werfdebenen Drtumngen mo familien ber

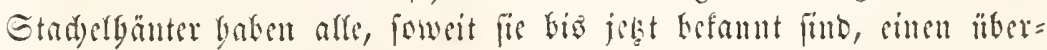

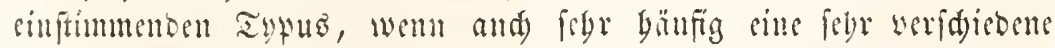
Form. So befdrieb man mter bem Ramen Bipinnaria asterigera sine Rarwe mit anferortentlid langem Stiel mo fibr tmigen fort=

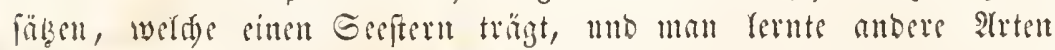
fennen, ans weldaen fids Geciger gerworbiloen, bie mebr but= oder

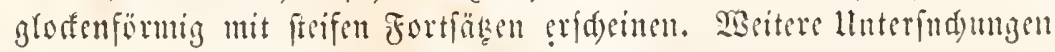
werben ogue 3weifel bie nod) itbrigen Dunteln grunte fduell auffëren.

Man theilt bie Geciget in vier grobe Famitien ein, weldye fids

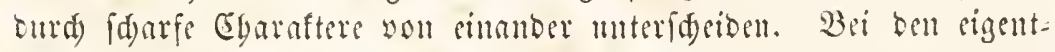
liden Serigeln (Cidarida) ift ber fiörer fugetig, ber Munb in ber 


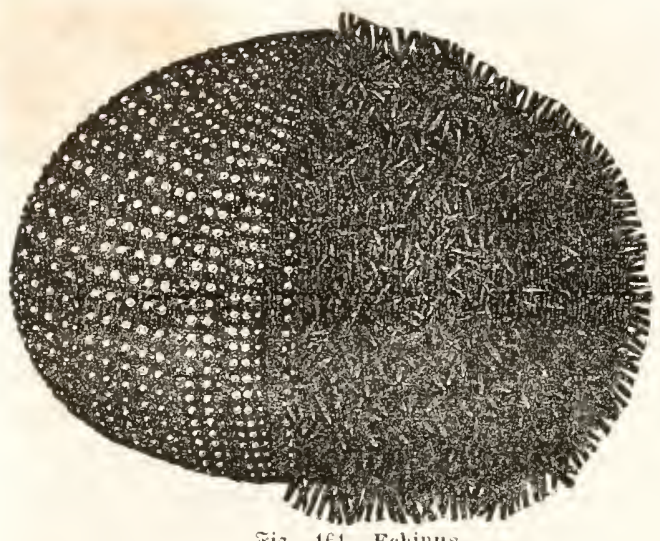

ซiig. 161. Echinus.

Mitte ber llnterfläde in citter bald ganz nadten, bald mit $\mathfrak{s a n}$ rad)en be= fezten 5ant gelegen. Der Affer liegt dem Mlunbe gegenliber anf Der Mitte Des Rïlfens in cincr Rofette, welde alto fünf Bsenitalplatten gebilbet ift, bis mit fïnf Angenplatten $a \mathfrak{b}=$ wed) felt. Die Mabre porenplatte if mit ber unpaaren Genitalplatte werfdumblgen. Der 3abmaptarat ift änerift compricirt und wirb burd) innere Borfpringe ber Sdale an feinemt Whaze gebalten. Die Fïblergänge find fdual unb gebent won bem Munde bis ju beut Ifter, meift in etwas geforängelter Sinie fort.

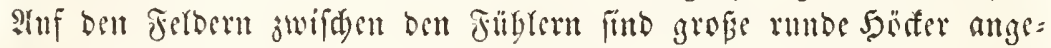
brad)t, welde in Reiben iteben mo bie Gtad)eln tragen. Bei ben zablecidyen (battungen, welde fith in biefer Familie finten, bat man

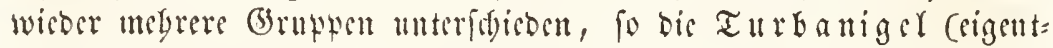
(id)e (Cibariben), (Cidaris; Salenia; Hemicidaris) bei benen auf einer

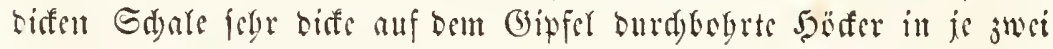
Reifen georbuct fteben, bie ungensin grofe mul lange, oft feulenfürmige Gtad)lutragen, mb tie sigentliden Serigel (Ed)iniben), (Dia(lema, Echinus, Echinometra) bis cine writ bïmete Ed)ale befizesn, mit

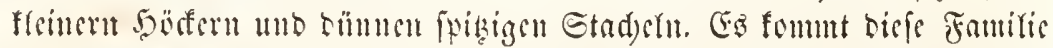
won Dem Roblenfulfe an in alfen Edjidten ber Erbe wor unb idscint

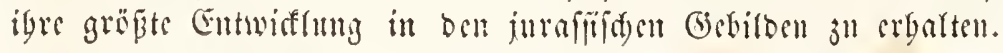
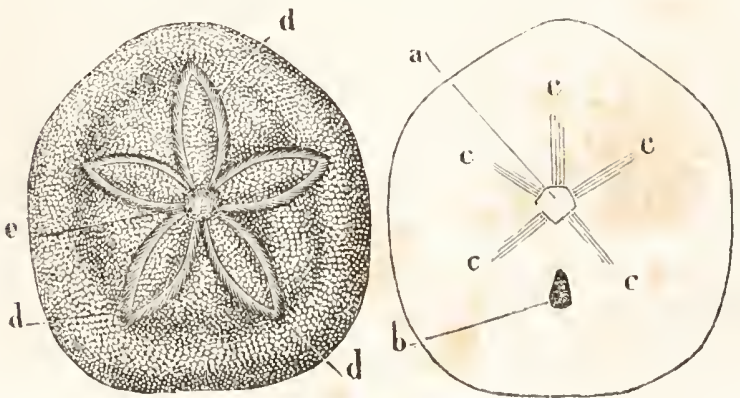

Jig. 162. Laganum.

Bon chen. Dantben ber llmrí̄ ber unteren Fläde, um bie

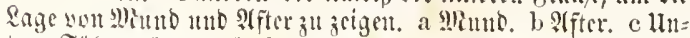
tere Füblergänge. d Etern bet sbern Finhletgänge. e Mitt=

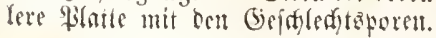

Dis jucite Fantilie, bicicnige ber Sdjitbigel (Clypeastroida) Eegreift Thiere woumeift fociterts fïrmiger Geftalt, Ieren Sdyale felr biff mild mit fei= nen Sö̈ferden befebt iff, welde febroünne, furje, 
baarartige Etadyelu tragen. Diefe bëferdyen fint üteraff gleids. Der

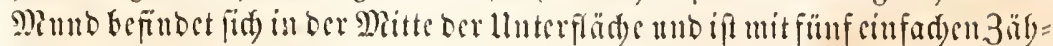

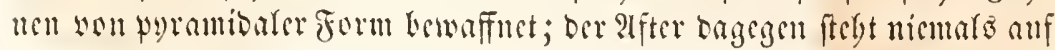

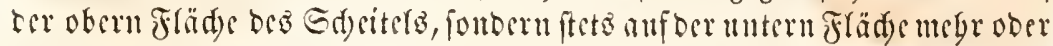
minter nälyer bem 9lande unb bem mittleren Grable entgegengeferat.

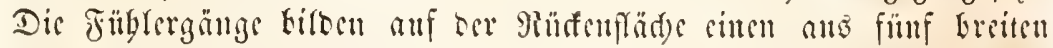
Bfättern jufanmengefshten Stern, bem die Mabreporenplatte mit fünf (befd)lid tö

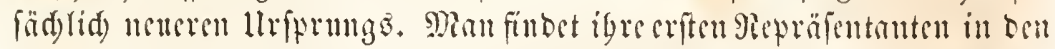
Iertiärgebitoen unb bie meiften leben jest in oen fïblidgen Meeren.

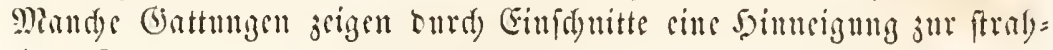
rigen Form. Clypeaster; Laganum; Sculella; Echinocyamus.

Cine oritte Fantife, bie Paningel (Cassidulida), bat cinen runb=

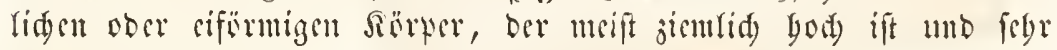

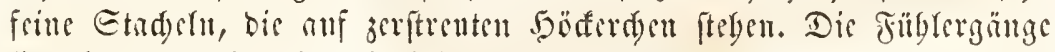
find barb blattfürmig wis bei ben Gdjibigeln, kald reibenfömig wie bei ben Gerigeln. Der Minno ftebt in ber Mitte ber llnterfläde ober ctwas melgr mady vorn, ber steter am Pande ober an ber lluterfläd)e, fo baf rei ber fonft eifürmigen Geftalt bes Thieres bie Dittelne oft

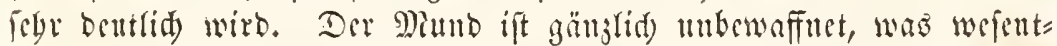

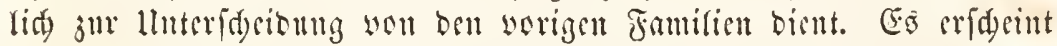

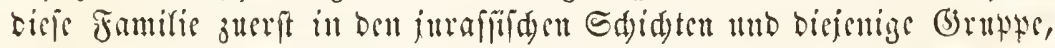
welde brattförmige Füblergänge bat, wermebrt fid) bis ju muferer 3rit,

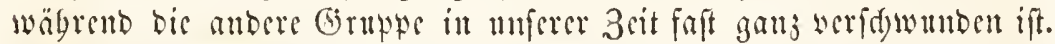
Echinoneus; Discoidea; Galerites; Nucleolites; Cassidulus; Echinolampas.

Die vicrte Jamilie, die Serzigel (Spatangida), bat eine berjför=

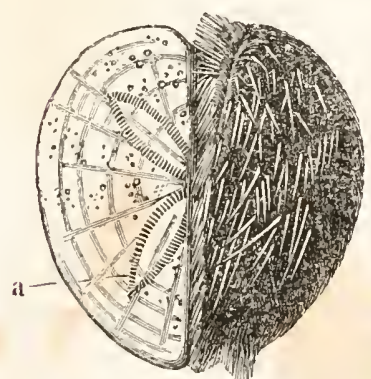

Jiq. 163. Spatangus.

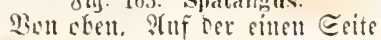
jinb Die saate und Etadjeln gelaf= fou, any ber antern meggenommen, uni bie filatten des firmzers uno bie Fülflergänge a ju sergen.

mige Gejtalt, an welder man bejonters bentlid) sine mittlere Ale unterldseibet, bie

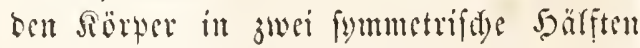
theilt; and bicfer Familis feblt wis ber worigen jebe Sful vou Bejalyung. Der Miund riegt felten in ber Ditte, meift an Dem vorbern Findos, Der after nu bem bintern Ranos ber lluterfläd)e igm gezen= ïber, fo sab aud bierourd bis sorittrl=

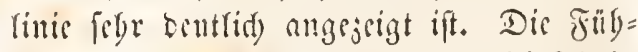
lergänge funt meiftens auf Dem bififfel in

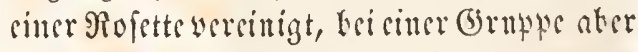
wolfommen getrent. Ser bintere murare Fübrergang riegt meiftens in einer ticfen Rimne, woburd bic berjförmige (Seffalt erjeugt wirb und unterid)eibet fird in friner Ratur von ben

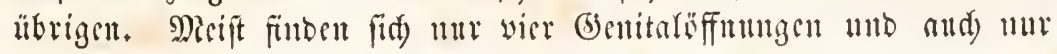




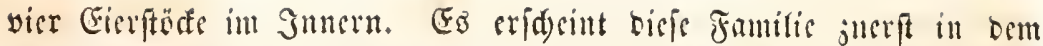
Jura mit Formen, weldye Den Rusigelu äbntid felyen unb ibre 3abl wäh ft ftets bis auf bie beutige 3eit. Spatangus; Brissus; Hemiaster; Schizaster; Holaster; Ananchytes; Dysaster.

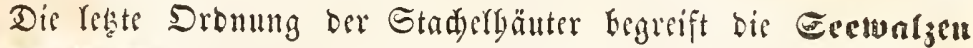
(Holothurida), weldye sine leberartige 5ant mit fparfam einges

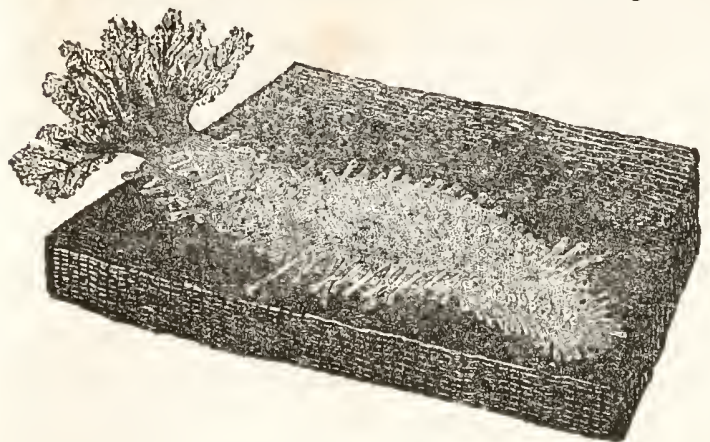

8ig. 161 Holothuria.

ftreuten Salftöndien Into sitte wargen= ober wurmförmige Bejtult befisen, tis mit nodi) Durd) einen Fübler= frans im llmfreife bes Diundes ben frabli= zen Typus erfenten läßt. Der affer liegt an bem bintern I beife Des Thieres und rient,

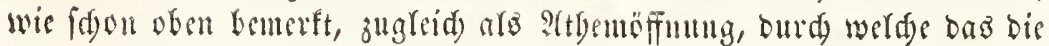

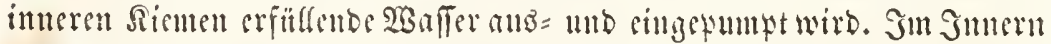

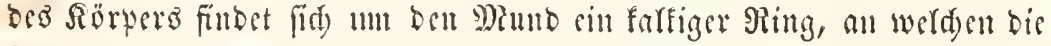

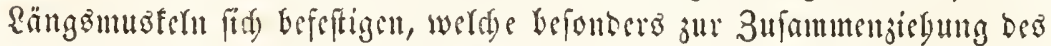
Rörpers bienen. Man unterfdeibet in biefer Dromung zwei Fami=

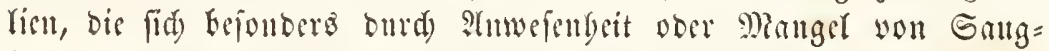

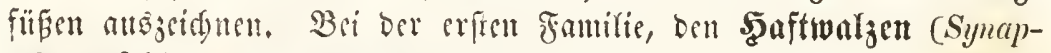

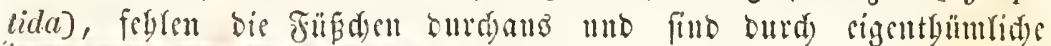

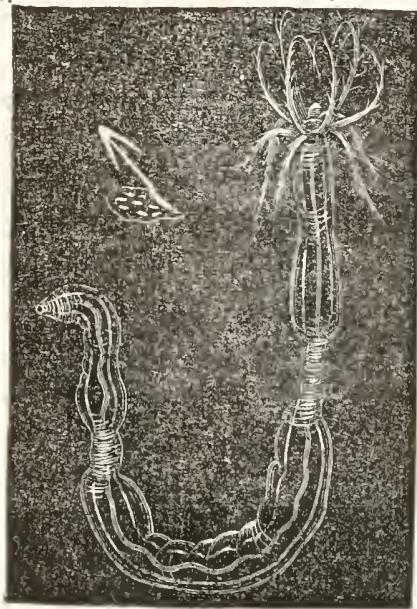

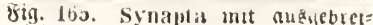
teten oublern. Dantien ein Raltanter, aแB ber Saut, farf rergicisert.
Sialfanfer erjezt, welde die bant raub mad)en. Eebenio feblen imere Riement ober sigene Befpirationsorgane, inbem bas Sanfer burd) Spalten in bie Reiges= Göble tritt. Der Darmtanal ift grabe, ber Sifter an entgegengeferten Reitegentse. Ginte an ben Sinften Des Decrung rebente art, bie ungemein gencu unterfudst ift, bient als Typus ber Fantilie, dis fomit meiftens in fïblidsen Mierren verbreitet ift. Chirodola; Synapta.

Dir jweite Jamilie, bis ber Eer= walgen (Holothurida), bat furje Gang= filischen, gall; bencul ber Seriger äbn= lid), weldye meift in Reiben fteben uno surct) Spalten ber 5out bervorgeftrertt 
werben fönnen. Der Damtanal im Sumern ift Sförmig gewunben uno an feinem bintern Enoe mit siner baumartig vergweigten Sicme in Serbindung. Sn Der Gefangenfdaft jieben fid biefe Thiere oft mit fordyer Energie zufammen, baß fie cinen grofen Theil bes Darm=

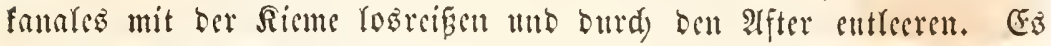
follen fid) indé biefe Theile fpäter wieber erjengen. In ben füblidyen Meeren fommt sine Battung yor, ber Trepang, welder in grofien

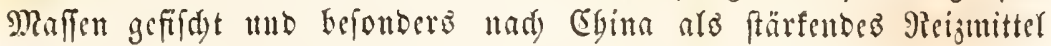
werfanft wirb. Die Gecwaljen finten fid in allen Meeren ungemein bäufig an bem Boben friedend, wo fie fid befonbers yon Sd)aal= tbicren mäbren. Pentacta; Psolus; Holothuria; Bohadschia; Cladolabes.

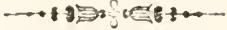

\section{S(d) Sterief.}

\section{fircis ine Würmer. (Vermes.)}

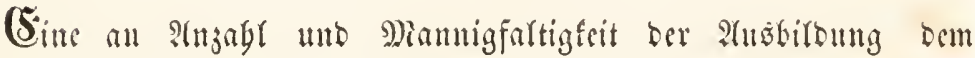

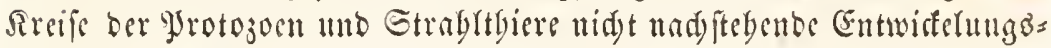

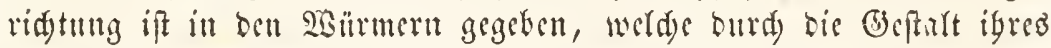

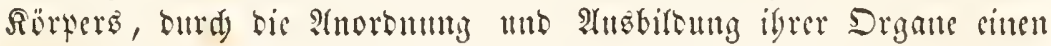
wefentliden Unteridjieb won allen üfrigen Tusen ber miseren Thiere Darbieten uno namentfia in igren büberen gormen fid bis in bie

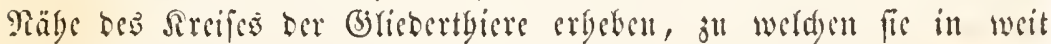

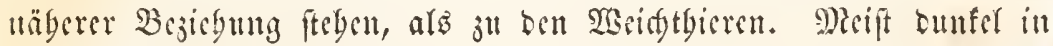

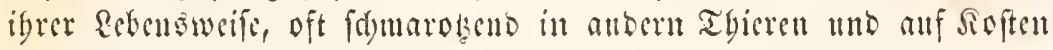

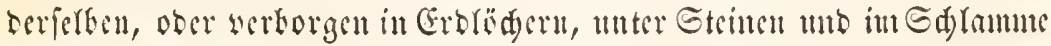
tor Gewaffer rebent, wenig aujielyent burd form ober Jarbe, wurbe bicfer Rreis anfangs son ben Raturforjacrn nur fegr weniz in Betradtum gejogen, bis ticfere B̧lafe in igre Drganifation mo

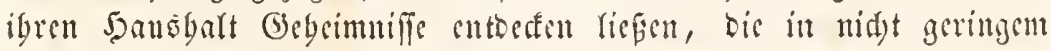
Grabe de 2 Bifbegierbe anfwannen musten. Go fint benu in unferer 3eit gerabe bie siürmer cin wejentrider (begenftanto ber Forfdung

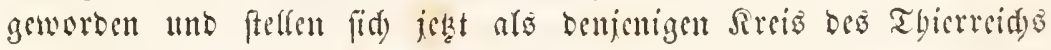
sar, in werdem die miften Pefultate erjiclt werben unb wo aud bie

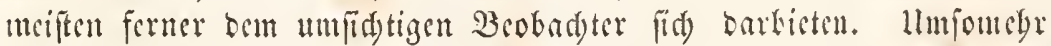

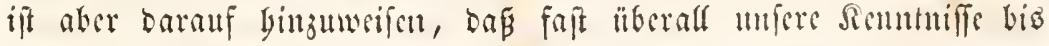

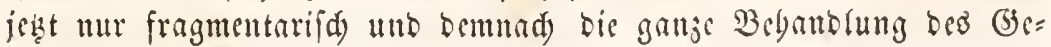




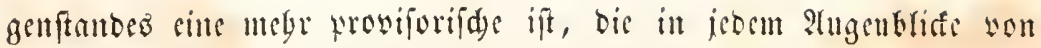

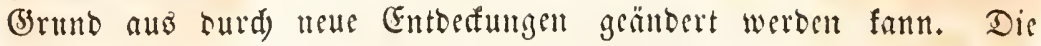

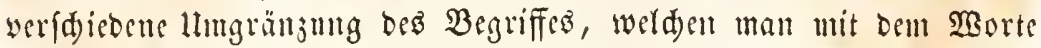

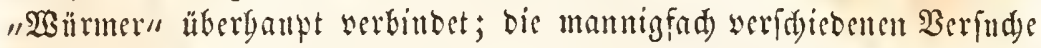
Der Elafification, welde won 3eit ju 3eit mieberbolt werten, find fpredyente Beweife für ben Manget an anserdenter Renntuif in biefen Felde. STir maden likeralf bie Erfabrung, tafi bei mangel= baftem Material bie periönlid)en P(nfdanungen mo P(nfid)ten in's Ilnentide wedjeln, wäbrento bei geböriger Semtnif oer Thatfad)en bie Dišcuffionen won felbft anfgören unt ibre fattifte Crebigung filloen.

Die Wärmer zeiduen fid bem Sereife Der Etrabltbiete gegenüber

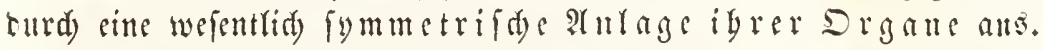

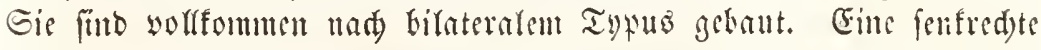
Iurd) bie Mittellinic gelegte Egene theilt bas Thier it jwei volltom= men gleid) bärften. Die einfaden Drgane liegen in ber Mitterfinie, die mebrfad vorbandenen ju beiben Eeiten meift it fmmmetrifder Folge. Zwar finden 2tbweidungen won biejer Symmetrie ftatt, ond fint Diefelben unr felten uno betreffen meift nur Den Darmfanal uno

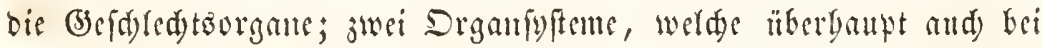
fonft (ymmetrifd) gebanten Thieren leid)t sine Ansuabme zu madyen Yflegen. Der Rörter ber SBurmer if bei biefer Eymmetrie ber Dr= gane meiftens lang geftreft und won oben abgexlattet, oft fo muzemein

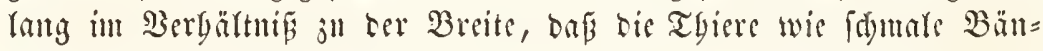

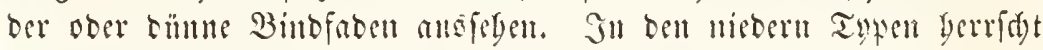

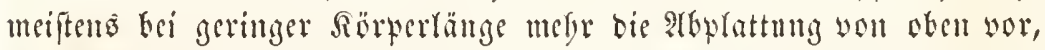

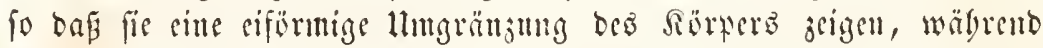

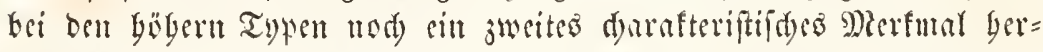

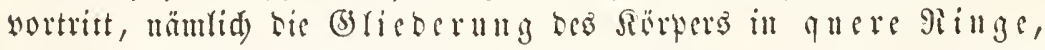

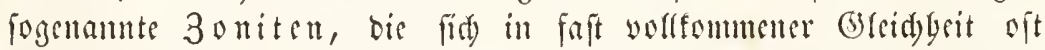
Gunbertfad wieterbolen. Diefe quere blieberung, welde wir nod) bei eitrem anbern Sereife bes Thierreid)es, bei ten Blichertbieren, eben= falf mit ftrenger Symmetrie gepant wabruebmen, ift entweber 9efultat

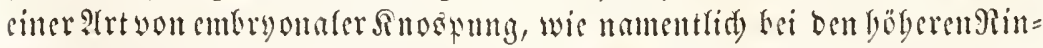
gelwitumern, ober bic Folge cimer muofleäntigen Susspmng, welde mäbrent tes ganjen Rebens fortbanert, wie ties namentlid) bei ben

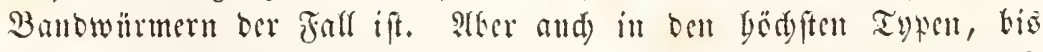

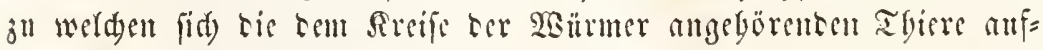
fdumingen, trägt die (blicberung bes Reibes infoferme ben Etemper

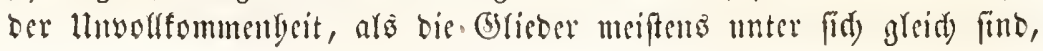


biefereen Drgane entharten, bie mitgin fid wielfad wicberbolen, wäb=

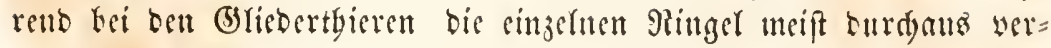
fdicbenen (jebalt unb Bebentung jeigen. Die Alnatomic eines sinjigen Banbwumglicbes genügt beinabe, tmu bie 3nfanmenfeseung eines jeben ber taujent mb aber taujent blicber ju fenturn, ans welden cin fordecs Thier zufammengefest ift; cin Sieferwmrm (Eunice) bat bun=

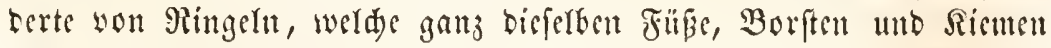
tragen. Dieje bftere ssiebatbolung gleidger Drgane, bie zu serferben Function beftimut finb, ift fets ein 3eidsen neberer Drganifation, wäbreno bie Sonbernng beftimmter. Theile in vielfader 3abl mit ver= falebener Function gögeren Bitoungagrab anzeigt. So feben wir aud) nur bei ben büdften Typen ber $\mathfrak{B}$ bümer cinen wirffid) abge= fonberten Sopf fid) alsbirben, wägrent bei ben übrigen, and bei Durd)greifender Ringelung des Rörpers, ber Ropf, ars Träger ber Ginnesorgane und bes Centralnerwenfyfems, oft nidet von bem ubri= gen Sörper abgetrent ift.

SBie in ben übrigen Sireifen, fo fegen wir aud it bem Sreife

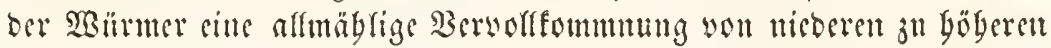
Rekeneformen. Diejelbe fpridt fid nid)t nur in ber änfern Sörper= form, fonbern aud in ber ftufenweijen ?usbiloung ber einjelnen Dr=

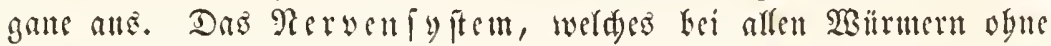
?Hơnabue worbanben, aber in ben nicberen Etufen unr rubimentär ift, mb bann ans jwei unbebententen 3 Keiben Geiten bes Edalmbes

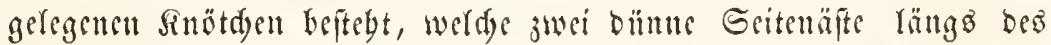

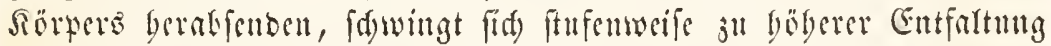

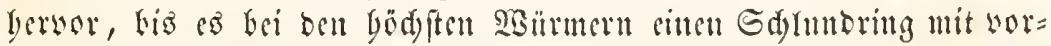

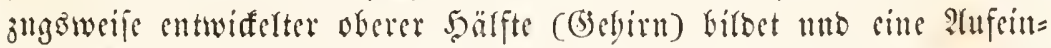
anderfolge won Sinoten zeigt, werde längs ber Mitterfinic bes Bandes

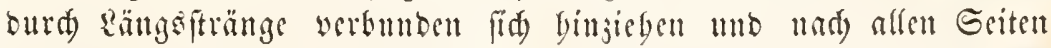

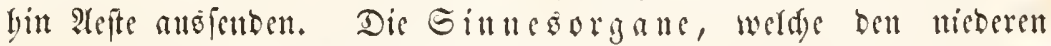
Typen feblen, entwideln fid) anfangs in grofer 3abl, wemt and mit geringer intterer Afubitonng mo geben meift benjenigen Gattmugen

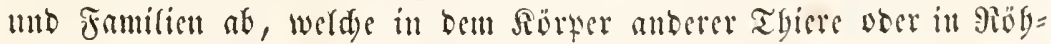

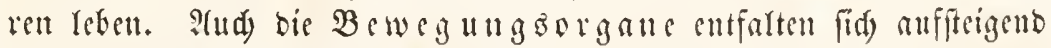
in mannigfader siseife, ocnn wägrent bei ben neberen Tyen entwe=

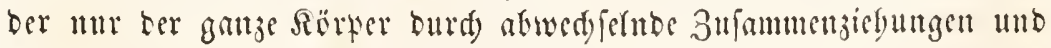

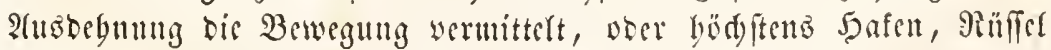
unt Gauguäpfe fich ausbilben, jum Feftbarten an beftimuten Diten,

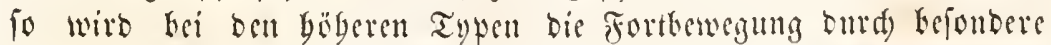
Borfen, Fugftummel mo Edywimmplatten bewirit, welds jub beiben 
Seiten Der Ringel mto an ganjen Sïrper oft in ungebeurer 3abl angebradyt fitto. Sndefi zeigen bicfe Bewegungsorgane nicmals uno unter frimen ltuftünden bie bei ben Gricocrtbieren vorfommende Bric=

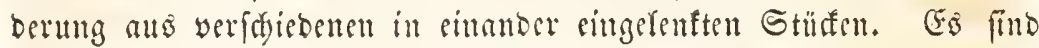

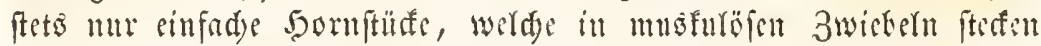
und Durd biefe bewegt werben fülnen.

Nidyt minter in bie Angen fallento ift ber gortfdritt ber Ent=

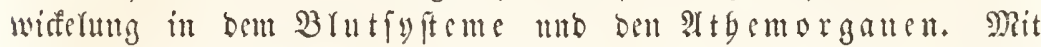

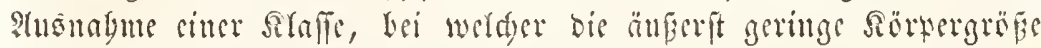

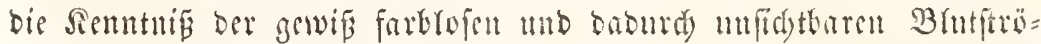
mungen verbittoert baben mag, fent man jist lei aflen SB̈̈rmern sin Blutgefäpiyftem, bas aus gefd)

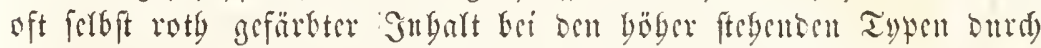

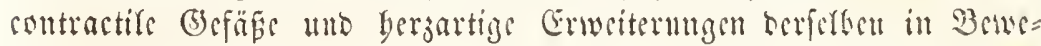

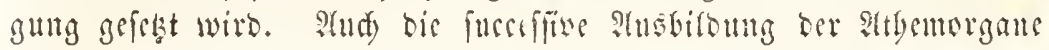
läpt fid) beutlidy nadweifen, bem wägrello biefelben in ben nicberen

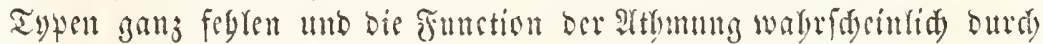

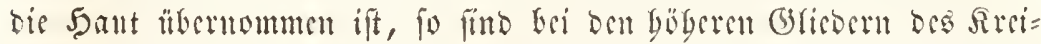

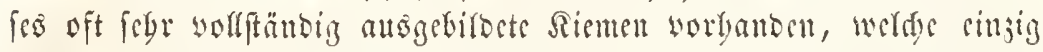

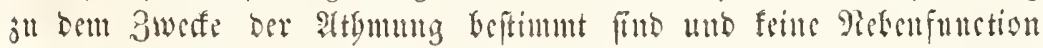
befitsen.

Die Berban แก gอง

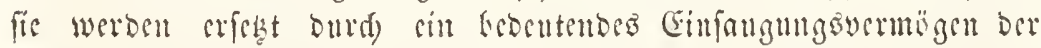

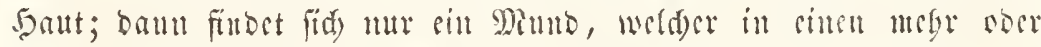
minder verjweigten brimbgenbeten Darmfand fügrt, bis entich bei Den bëleren Typen ch an beiben Enoen geöfineter Darmfanal criftirt, ber oft mit 3äbuen, Sicfern und anbern Borridtungen jun Fangen unt Zerffeinern bet Bente bewafinet ift.

(i) worballoen, oft in auperortentlid vervielfärtigter 3agr, fo oafi bie Frobution ber Gier cille wabrgaft ungebeure ift. Befonders bei benjenigen Gattmigen, oeren Erbaltung anf fdecintar anferge=

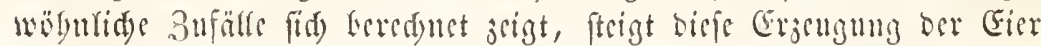

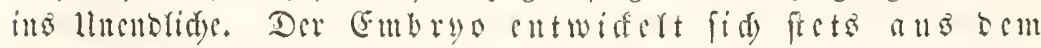

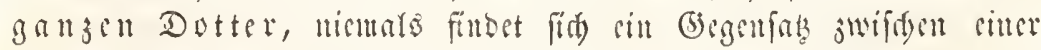

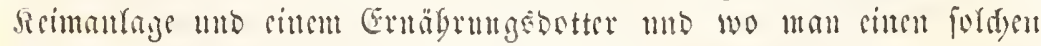
ju finton glantete, irte man fid infofern, als man bie fïr ben Plufban ber innern Drgane beftimmten 3eflen fïr ocn Dotter, sic äneren 3elfen füt dic Sechlage anfar). Die meiften Embryonen wer=

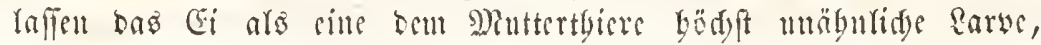


weldye erft furd) fuecefiuc Metamorpbofe ber Drganifation bes er:

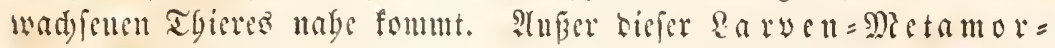
phofe, welde oft nur ourd) tie uberrafdentfen 2tentorungen bes

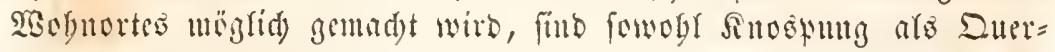

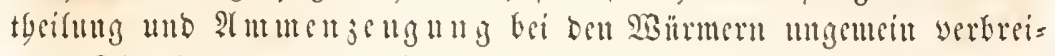
tet. Die leştere namentfid) fommt bejonders bei benjenigen Sro= nutgen vor, weldi in ben Eingeweiben anberer Thiere reben, unb

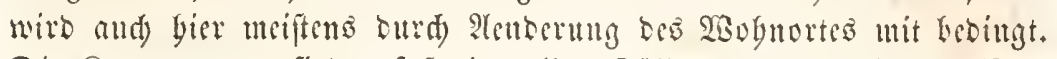

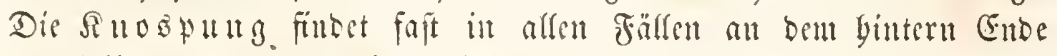

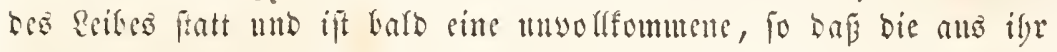

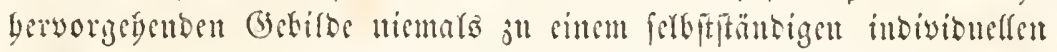
Eeben gelangen, theifs sitte vollftändige, wo dann die Jungen cine

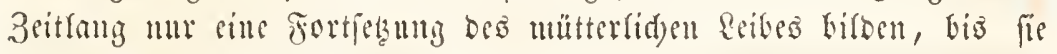

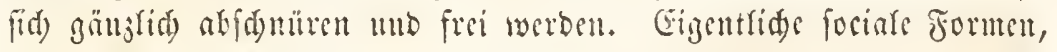

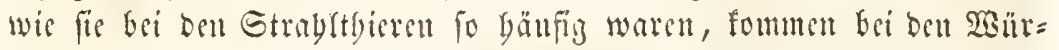

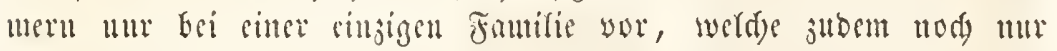

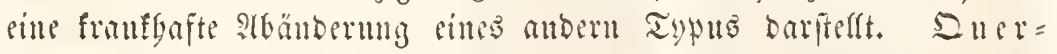

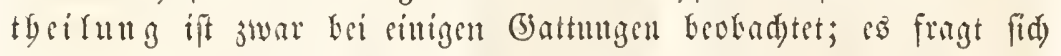
indeffen, wb fie nidjt ftets Jolge medanifder Berlesung unb Repro= Euetion ber eingeluen I beife ju ferkifftübigen Jusivibuen wat, ober

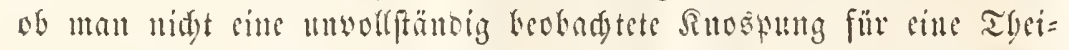
[แแ! aแก

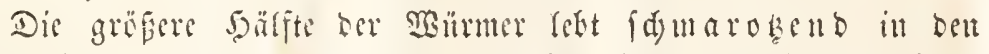
Fingeweiten anberer Thieve, in weldye fie tbetro surd bie natürlidyen Deffunngen, kejonters ber Berbaunng = unb Ruftwege gelaugt, theilö aud)

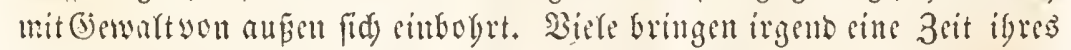

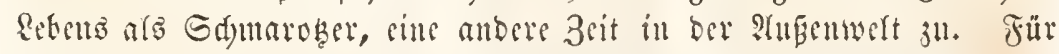
bie meiften biefer Edymarotaer ift bie SBandermb yon sincm Thiere ju tem anbern sine Beringum ber Entwiffelung. Bon bent frei reben=

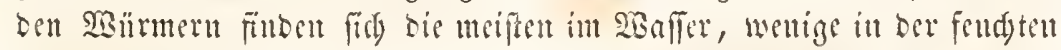
Erte, einige in Rofren, welde fie butb aus fremten Materiafien zn=

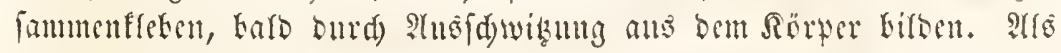

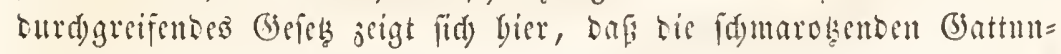
gen ftets bie nieberen Gtufen ber Drganifation sinuelymen, die fret lebenten bagegen bie bëgeren. Biele Eingeweibemürmex folieben fid

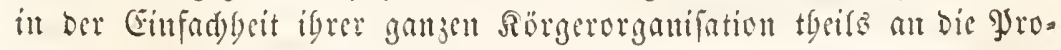
tojoen, theifs an bis unterften Gtrabltbiere an, wägrento bie bigheren

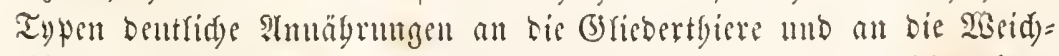
thiere gewabren laffen. Gelbit bei benienigen Igieren, weldye cinten Theil ifres setens in ber Freigeit, eimen anbern ats Sdumarober 
ober an ben Srt gebunben als̀ Rügrenbewogner zubringen, jeigt fid

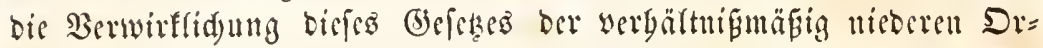

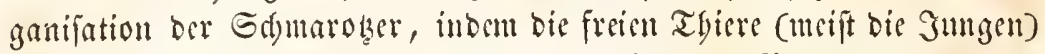
mit bentliden Simnesorganen unb anģgebildeten Bewegungsorganen

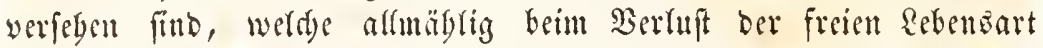

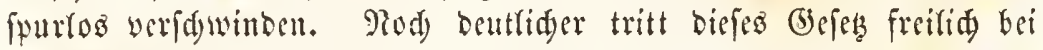
Den Briedertbieren lyervor, wo bie Degrabation ber Srgane oft fo bebeutend ift, dak bie Thicre verfdicbenen ?tlters in ganz verfdjebene sitaffen eingereigt wurben.

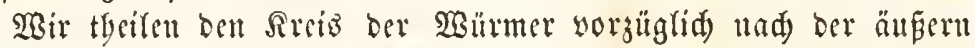

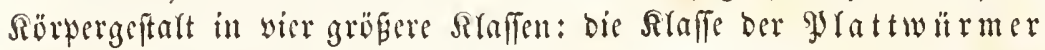
(Platyelmia) mit frattem meift wenig vertängertem Rörper; Der

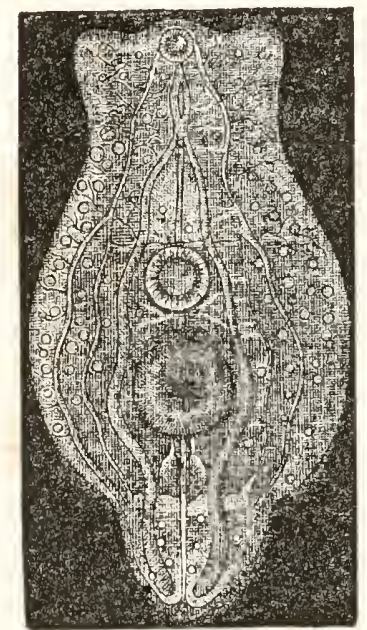

Fig. 166.

Diplostomum.

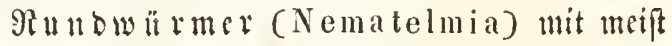
brebrumbem, rangem, fabenartigem siörder;

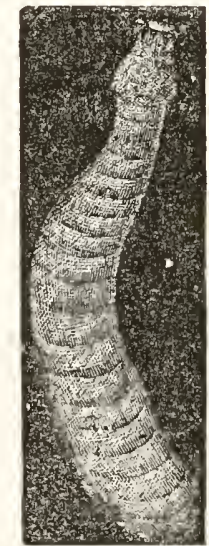

उig 167.

Echimorhỵnchus.

ber Räbertbiere (Ro-

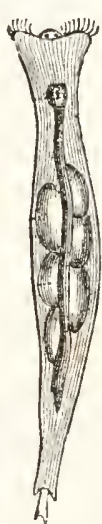

รin. 168.

Rotifer. tatoria) mit will = permben Growimm= räbern nin worberen Rörperente; tho ber Piugelw $\mathfrak{i} \mathfrak{i} \mathfrak{m} \mathfrak{r}$ (Annelida), mit beutlid) geringe(tem, meift wargigem $\Omega a ̈ r=$ fer unt ausgebitbe= tem Rerwen = Syftem. So unbedenteno aud bic ätúere Särpers form im Allfyemeinen fein mag, fo frebt fie Dod mit tieferen Drganifationsverbältniffen im 3ujammentrang, Deren Einjerlacio ten wir bei ben Sitaffen fietbit begrituben wer= Fig. 169. Nereis. Den. Llnverträglidy aber mit alfen joologifden Grunbbegriffen bat ez

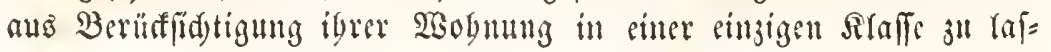


fen, wäbrent bod jeber Bearbeiter biefer merfwätroigen Thire offen

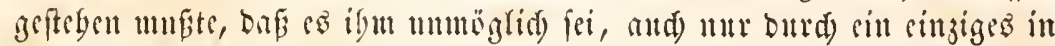
oer Drganifation Legränbetes Merfmal diefe Slaffe ber Gingeweibe= wirtmer ju darafterifiten. Man batte bier Tffes zufammengeworfen,

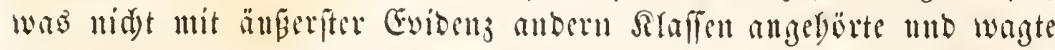
mid,t, mit Tremungen worjuddreiten, welde alte (5swobnbeiten be= reibigen founten, obgleid) man anz anbern Sraffen viele reine Yara= fiten fantte, bie man trok igres 2 Bobnfizes nid)t zn Den Eingendeibe=

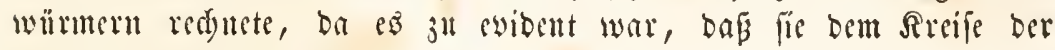
Sลำmer nid)t angebörten.

\section{filaffe der limitü̈rmer. (Nematelmia.)}

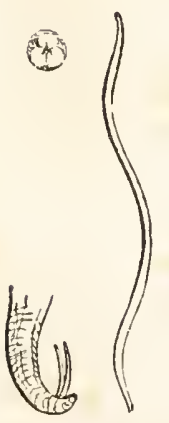

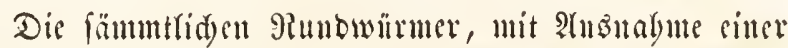

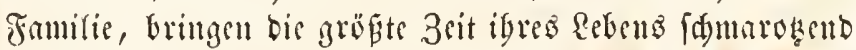

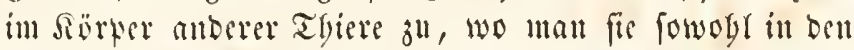
Eingeweiben als aud) innerlyalg gants gefdloffenet Drgane Findet, jut welden fie fid meiftens in Der Sugend sinen

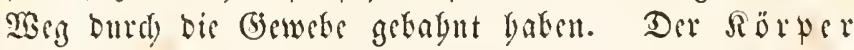
tor Runtwürmer if meifit cylinbrifí), juweilen gleidy= fürmig an beiben Geiten zungefpibat, ferten abgeklattet ober

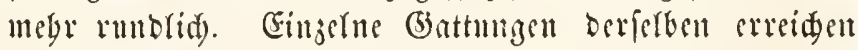

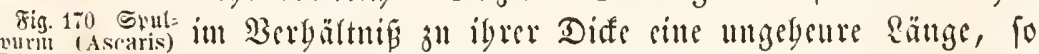

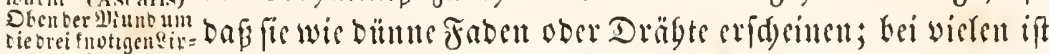

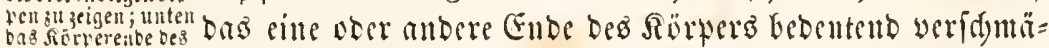

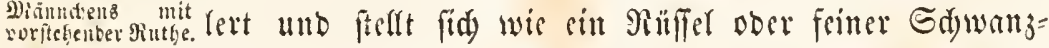

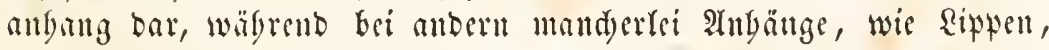
Sdjwanjblajen ze. Das sine ober andere Siörerende breiter oder yer=

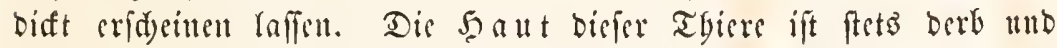

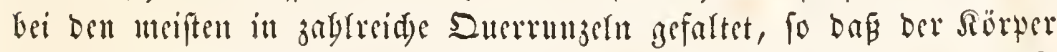

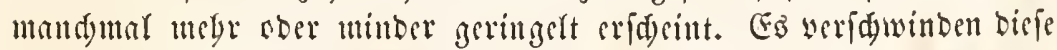

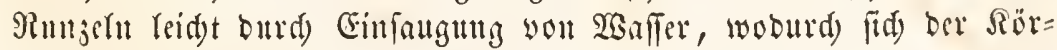

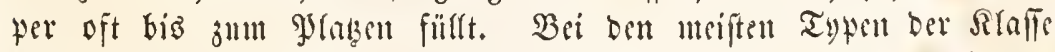

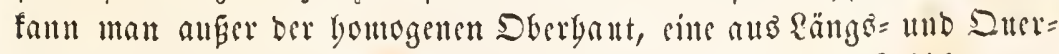
fajern geswebte Scberlyat und auferbem nod) sime Sdjidjt vout Musferfafern unterfdectoen, burd) welde bie 3ufammenjiefungen

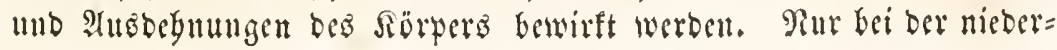


fen Dromung, beren Etellung an biefem Drte man wobl bejweifeln birrite, bie id) aber nirgent beffer unterjubringen wubte, bei ben Oregarinen, finbet fid sine einfadse berbe Santididgt, weldac jugleid) als 3ellenwant gebeutet werben fömnte und an ber man nod feine weitere $\mathfrak{T}$ beilung hat wabruebmen fömuen.

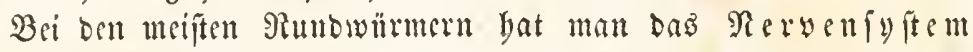
anfgefunben unb jwar will man es bei ben Sirakern in (B)efalt eines centralen Saufens am Begime des Sălunbes gefelen baben, yon

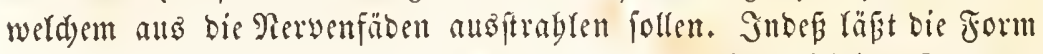
biefes Rervenfyftems nod) grofe 3weifel liter feime ridtige Dentung 31. 3weifellos ift aber bas Rerwenfyitem bei ben Spulmulumern in Form zueier feitlider (5)anglien bargeftellt worben, weldse burd sinen febr feinen Gdylunbring miteinander verbunben fint und you benen aแs jwei feitlide Rervenftämme ausgeben, bie man bis an bas Sin= terende bes Rörters bin verforgen fam. Bei ber nicbrigften Dronung ift feine Spur cines Rervenfyitems vorbanden, unb eben fo sergebens bat man es bei oen Gaitemwirmern gefudt. Sinnesorgane find bei feinem bicfer Thiere entwidelt und unr jum Bebufe bes Taftens erfdeinen bei einzelnen (battungen Snötden ober Räpldyen in bem Llmfreife ocs Menters. Son mandyen Gattungen werben biefe Sinötden aud) zum Durdbogren ber (bewebe Eemulg und fo

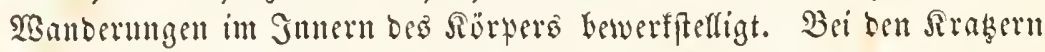
finbet fid biergll ein sigener einfad)er watgenförmiger Rülfel, ber in eine entipled)ente, ringshum abgefdloffene, ourd eigene Mnsfeln be= wegte Sdeibe jurinfigejogen und ans biefem Safe wieber bervorge= ftiilpt werben fant. (Es ift biefer Rüffel in feinem ganjen llmfants mit in Rängereiben georoneten, rĭfwärts gebogenen fdarfen Safen befetit uto er bient bem Thiere bejonbers zut Durdjobrung ter Darmbänte und zแr Fixirung an einem beftimmten Dite.

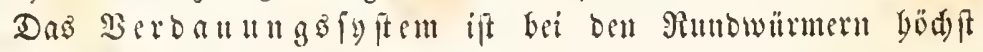
einfad). Bei zwei Dronungen, ben Giegarinen mo ben Sirngern, feglt jebe Sfur sines Darmfanats. Die Thiere ermägren fid mur burd) Crinfangung ber fie mugebenten Früfigfeiten mittelft ber baut. Bei ben Gaitemultmern findet fid wohl cin Darmfanal, ber in bem

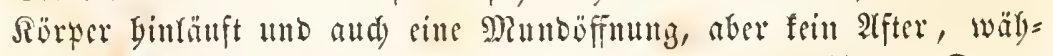
rent bei ben Exufwürmen ftets ein volletänbig auşgebitoeter Darm= fanal mit entofändiger Mund = unb afferëffunng vorbanden ift. Bei biejen laffen fid) aud öfter in bem Sdylunbe unb bem 2 nnfange bes Darmfanales Gornige 3äbndyen ober Bälfte unterid)eiben, bie oft 


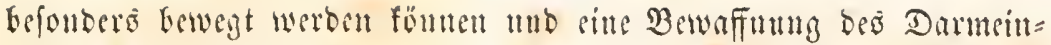
ganiges ondeften.

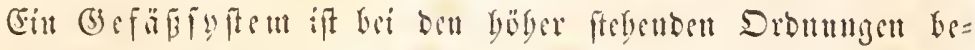

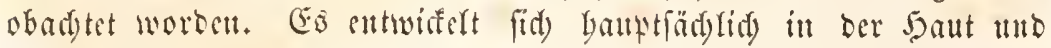

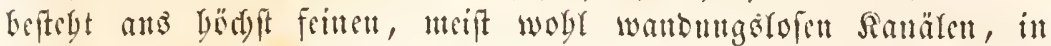

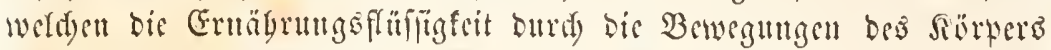

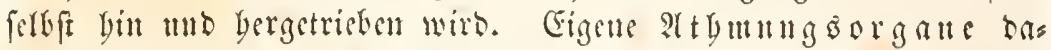
gegen fint nod) bei frinem Hintmuste anfgefunden worben, wäbrent

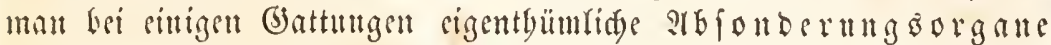
gefeben bat, Deren Beftimmung in ber thirrifden Defonomic nidyt ge= nau befannt ift.

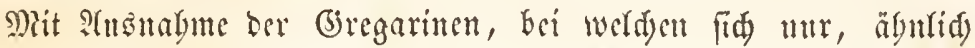

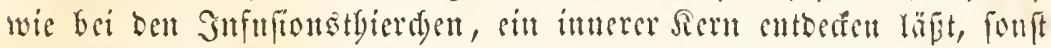
aber feine weiteren \&sibsorgane vorbanten finb, befisen bie thbrigen Ruttowntumer wobl anggebiloete (b)

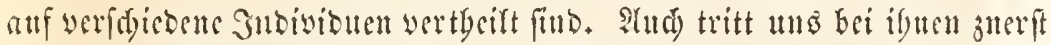

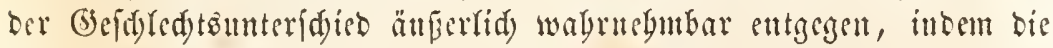

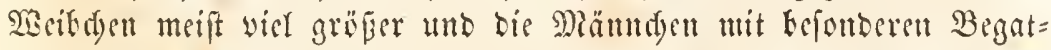
tumgsơ

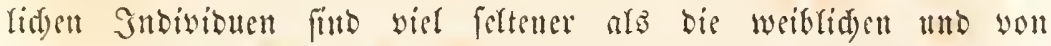

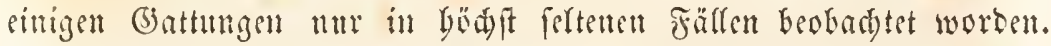
Citte wirflidye Begattung (d)sint bei affen mit Fortpflanjungoorganen

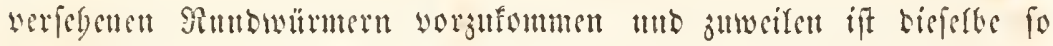
imnig, unb bie beiben Jubivibuen in bem fegr lange anbanernben Begat=

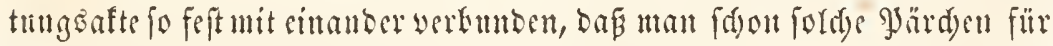

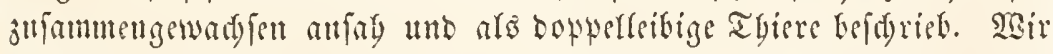

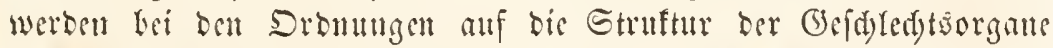
näber singeben, sbenjo alt bie Birblung unb Entwitefung Der Eier.

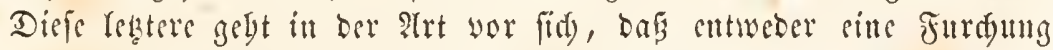
bes̃ Dotters alftritt, weldye ben ganjett Dotter tad mid nadj itt 3ellen umwanbelt, ober aber, bais fid in bem Dotter erit cintige 3ets

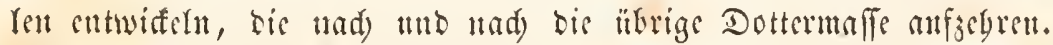
Sobald dis ganje Dottermaffe in Embryonaljellen mmgetwandelt ift, fo bilbet fids ber (Embryo, welder bem Mintertbiere febr äbulid ift unt feine weitere Metamorkhofe burd)lälft. Die jungen Thierden

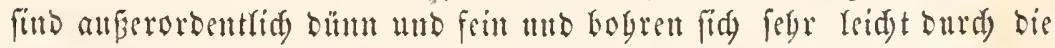
Biewebe der Thiere, in welden fie fdmaroben. Sis geben, wie es

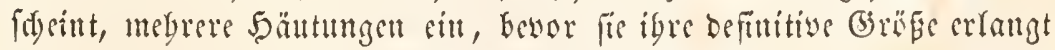

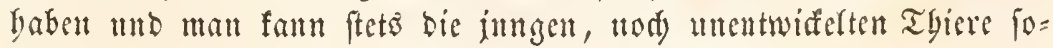




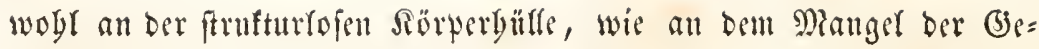
(d) Yed) tåtbeife muterfdeiten.

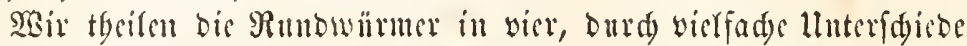
rer Drganifation leidyt ju beftimmende Drbmungen. Bei Der uederfen Drbmung, die man ber Finfadbeit ifrer Bitoung wegen and on ben Jrotojoen ftellen fünnte, bei ben beregarimen, feblt jebe Spur innerer Drgane; bei ben Srabern findet fid ein Safemrüfer obne Darmfanal; bet ben Saitenwärmern ein untorffändiger Darm obue After; bei den Fabenwürmern ellolid solftändige Berban=

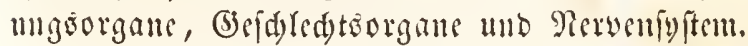

Dis Dronm Def Gregarinen (Gregarimea) beftebt anb fleinen mifroffopifsen Iflerdaen, weldye nur bis jeşt bauptfäd)lid)

8ig. $181 . \quad 179 . \quad 177$.

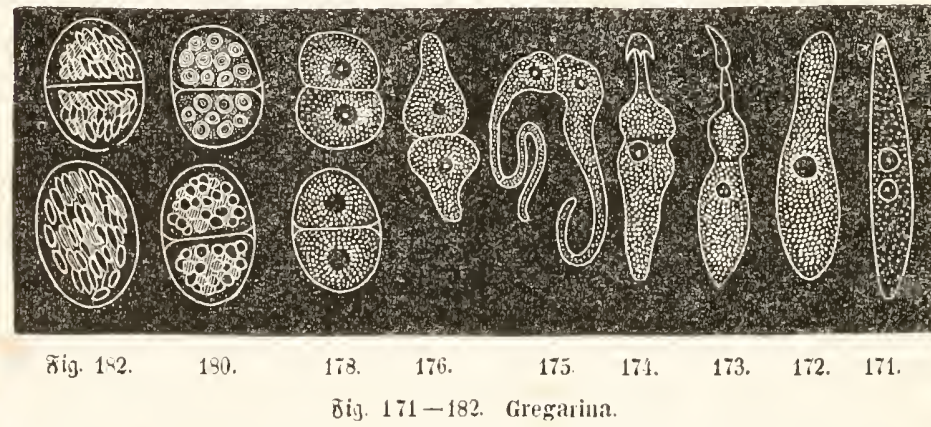

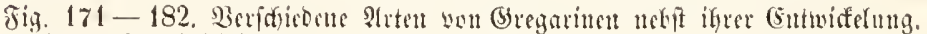

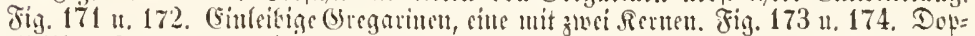

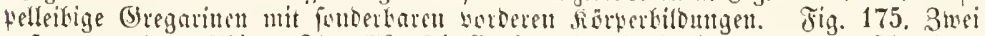
3ufammengelegte Thfiere. Fig. 176. Dis Ennjugation if imniger gemoroen. Fig. 177.

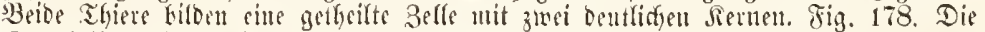

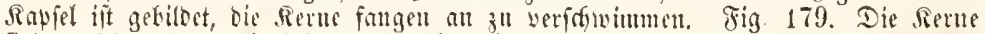

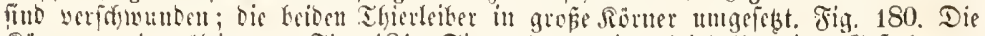
Röner wetben flemer. Fig. 181. Sie melmen eine fpindelformige beftalt an.

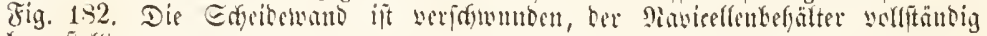
leergeftelit.

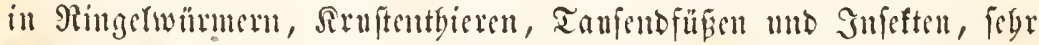

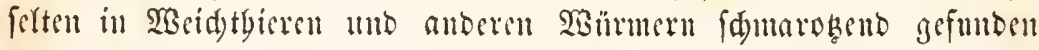
wurben. Die ganje Dronung ift trog vieler genaner llnterfudungen

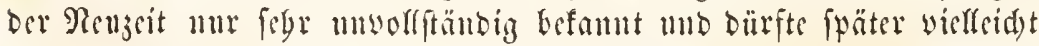

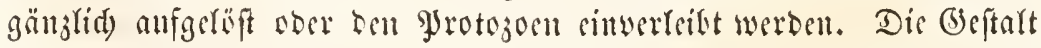
biefer Thiere ift eylindrifa) ober efförmig, zuweifen mit abgefduärtem

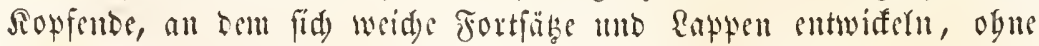
Dafi sin wabrer Sopf worbanden wäre. Das ganje Thier feftit be= febt ans ciner glagbellen, bourgenen Rörperbülle, muf welder nur 


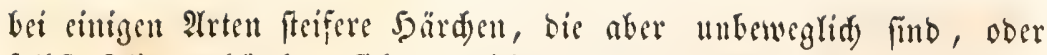

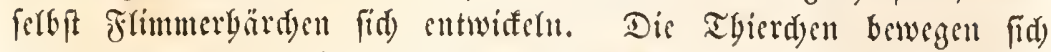

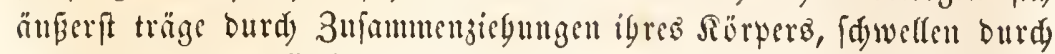
Einfaugung yon $\mathfrak{B a f f e r} a n, \mathfrak{b a b e n ~ f i d j t l i d ) ~ s i n ~ g e w i f f e s ~ T a f t g e f u ̈ b r , ~}$ weld)ę fie Soinderniffe vermeiben läß̨, jeigen aber int igrem Snnern

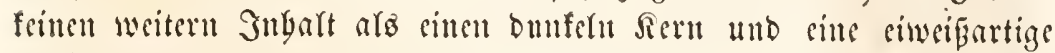

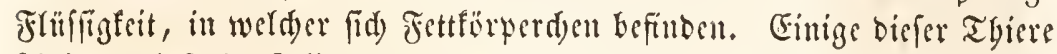
fdscinen einfad)e 3etfen; anbere finto offenbar anz zuei Beflent zufam= mengefest, beren jebe sinen Sern bat. Rady biefen Unterfdicben, fo wie nadj ber äuferen Form, Gat man melyrere Gattungen, ferbft foras =

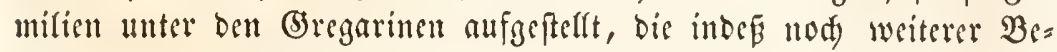

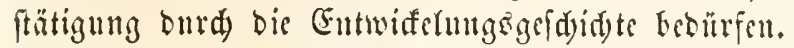

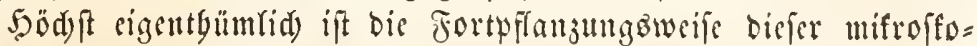

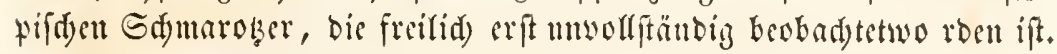
Se zwei Gregarinen legen fing mit gleidnnanigen Gtellen ibres Reibes zufammen uno fleben anfänglid fo feft ancinanber, bafi igre Tren=

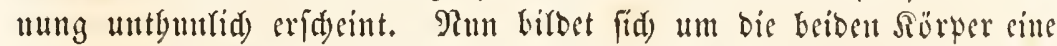

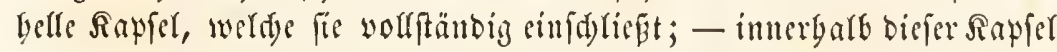
verfd)merjen bie beiben Rürper yollftändig in cine cinjige Maffe, weld)e

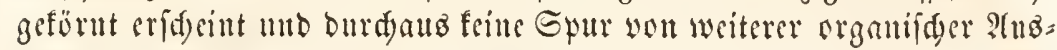

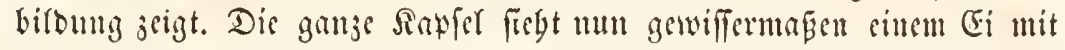
Dottermaffe ägulfids. Jndem Jnbalte biefer Siapfer bifbet fid aber allmäly=

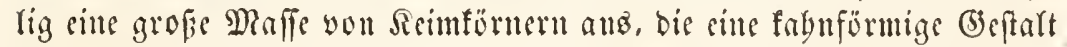
Gaben und in vielen Begicbungen Den Pavicelfen greid)en, fleinen mi= froffopifden Syfäutıd)en anz ber Familie ber Bacillarion, weldye man Gäufig ju ben Gufuforien geredynet gat. Man fannte biefe foge= uanuten Ravicelfenbebälter fidon feit langer 3eit Krefonderz nuz ben Jortwflanjungzorganen bes Miegenwurms und gatte fie fogar theilweife

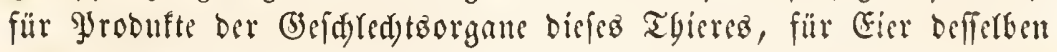

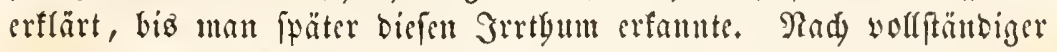

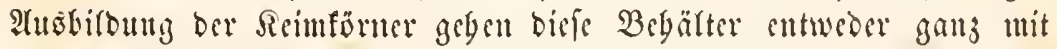

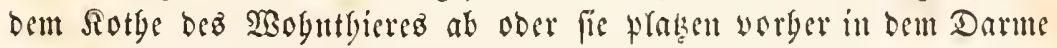
befferben, fo das nur bie Seimfürner entfert werben. Dab weitere

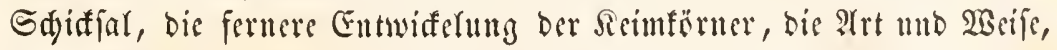
wie bie Bregarinen wieber in bie Thiere getangen, beren Darmfanal

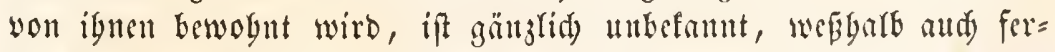
nere Beobadjtungen gewiés nod bedentenden Mosificationen bes jesgt tiber bie Gregarinen Befantent Eringen werben. 


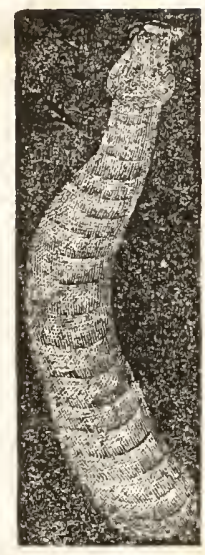

sig. 183.

Erhinonyuchus.

Die Dromung ber Srater (Acanthocephala) entbält unr eine cintige (5)attung, Echinorhynchus, Deren Prten aber febr jablreid) fint uno yon welden Dis größte 2 rt, sin $\mathfrak{3}$ แrm, Der zuweilen sine Ränge yon $1 \%$ Funen erreidyt, in beut Darme Der bei unt ein= brimifden Gdweine, oer wilden wie oer zabmen, ziemlid) Gäufig sorfommt. Die Sirater babon sincu (d) laud) fürmigen quergeringsten fiörper, welder worne einen 5jafentitfer zeigt, ber wie fdon angegeben in

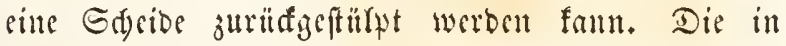
Rriben gefteflten 5 äfdyen finto rïctwärts gewentoet uno

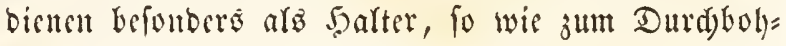
ren der Darmwände und Bewebe dez Sïrters. Der

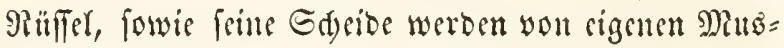
felt bewegt. 3wifden ber Dberbaut ant oer feder= Gant liegt ein Rets weitmajdiger, wantung utcift rötblid gefärbten weid)en Maffe ausgeböblt futb unb bauptfäd)s

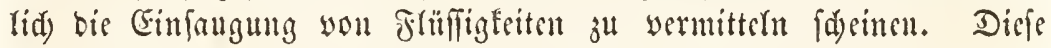

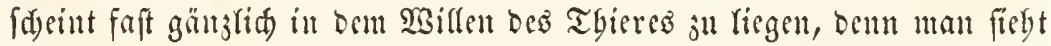

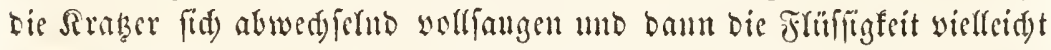

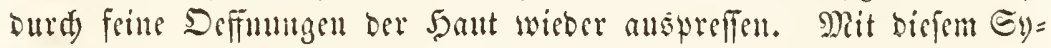
fteme einfangentor Ranale fteben jwor banbförmige Drgane, bie fo=

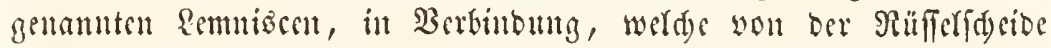

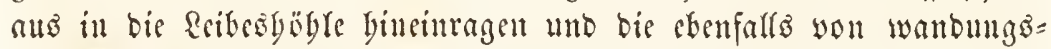
rofen Sanälen burd)zogen finto. Berbanungorgane unb fonftige inmere Drgane feblen burdants. Die (bejd)ledter fint getrennt. Die flei=

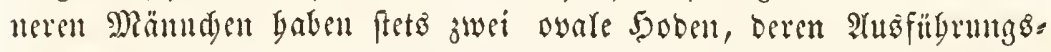
gänge burd) sigentbümlid) Dritifn binburd) in sime fdicfe nayfförmige

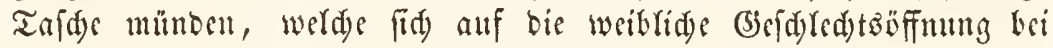
Der Begattung allfittet. Die grofien 2 seibden zeigen an orr griffer

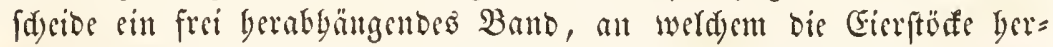

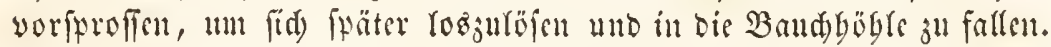
In biefen rofen Gierftöaen entwiffern fid) Die Yangen (Fier, bie meiftens

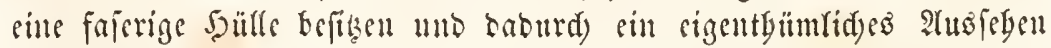

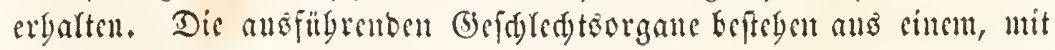
trid)terförmiger Mïnoung in bis Rcibeşgöbre münbenton Sd) laude, weldyer äuberff beweglid) if̈, bie reifen (Fier förmlid sinfdylut mo

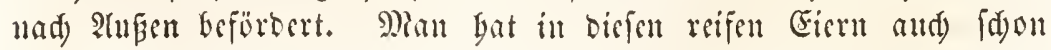
bis uno ba Gmbryonen wabrienommen, bie ferbit in cingernen Fällen

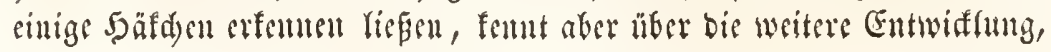




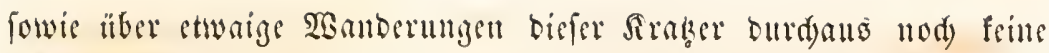

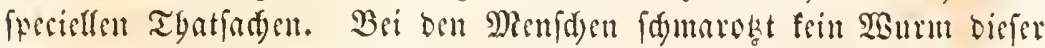
Drbuun, Dagegen find fie tei ben Säugetbieren nid)t fetten uno am bänfigfern bei Fifiden, wo fie befonders mit igren giuffern in ber Darmwato feftigelaft fitien.

Die Dronung der Enitenuïrmer (Gordiacei) beftegt mut aus einigen wenigen auberorbentlid) büntuen, fegr lang gejngenen,

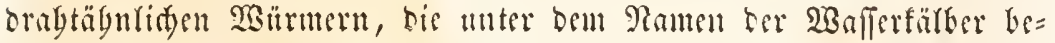
fannt fint. Die Sant biefer SBärmer ift leberartig, fagwärjlid und

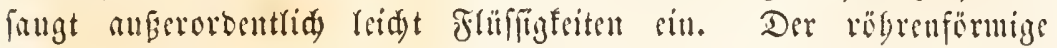
Darmfanal bat niemalè einen after uno bei bem eigentlidsen 2 saffer=

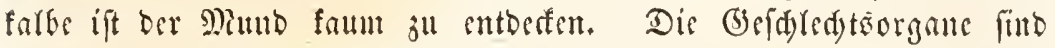

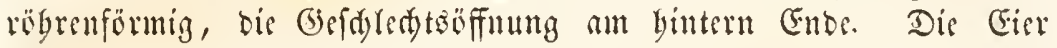

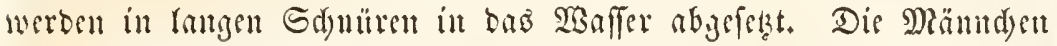

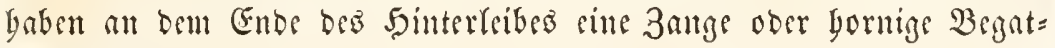
tungaggtieber.

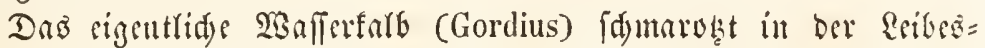

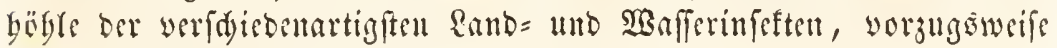

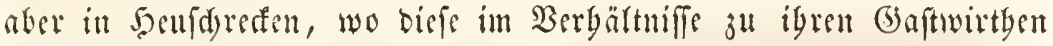

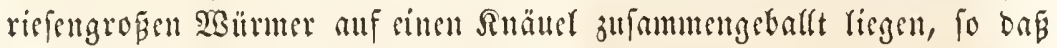
oft bie in Bandje gelegenen Drgane biefer Thiere gans wou ignen

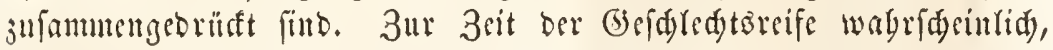

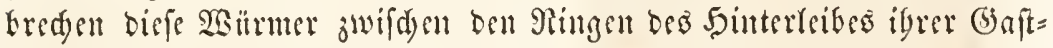

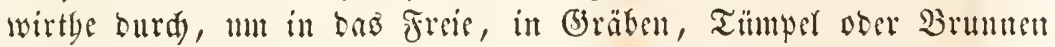
ju gelangen. Suf bem Troftenen fönnen fie nidgt leben, fie verfdrum=

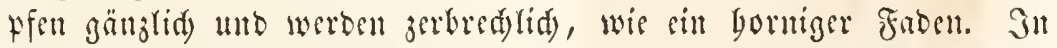

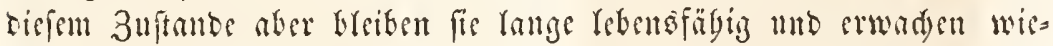

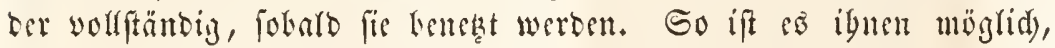

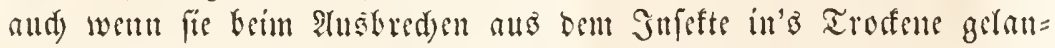

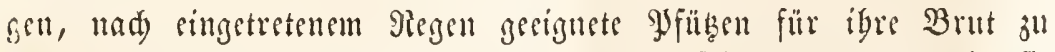
fud)en. Sisie biefe fpäter wieber in bie Jnfeften gelangt, wie fie

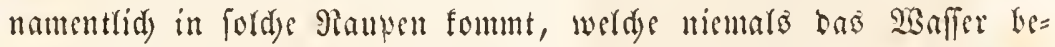

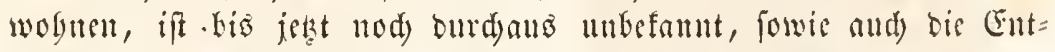

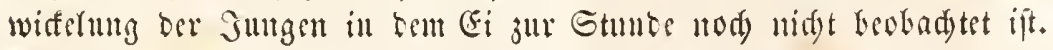
Nermis; Gordius.

Dis Drbnung ter Frobenwiltuter (Nematoidei) ift bic 


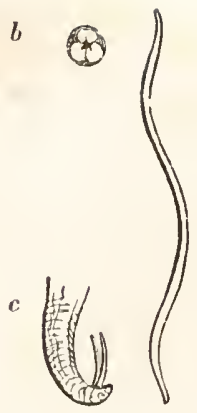

rig. 181.

Ter gewöbulitge Exulmurm

Ascaris lumbricoides.

Bei b fieft man ben Minno you sken, mit ben biei Garten, vorfpringenten \$Bulfiten, bie ifu bei biciser Shet ungeben; Gei c ons sinter= cube bes Mitinndjents mit ben keiben vorftefoncen bortigen Begattungswerfiellgen (Spicula.)

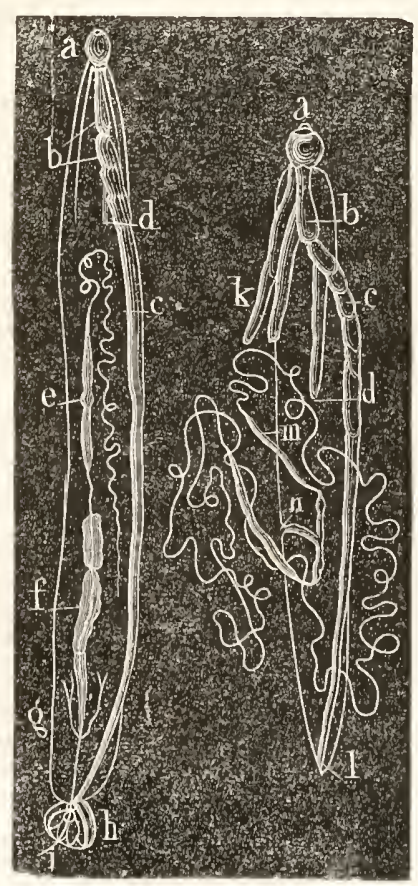

Fig. $1+5$. Scterostoma equinum aus bem Dirme bes giferbes.

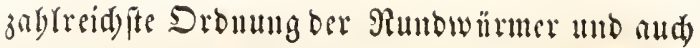
bicicrige, welde burd cinige in Meniden ferbit vorfommente Sdamaroger am beften befannt ift. Die Fabenwürmer erreiden feine fo unge= meffere Eänge, wie bie Saitenwürmer, erfdsci= nell aber bafür in igren alsgewadj/enen Indi= sibuen meift bifer watb ber lluterfutdung ju= gänglider. Syre 5 a ut if reidyt in bie Duere germizelt, reocrartig, ftraff, mit bebeutender

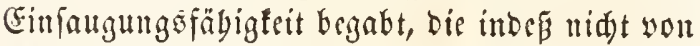
bem sillen bes Thicres beyerrfdyt wird, fo das bicjerben fogar, woun man fir aแs bcm bid)tern Darmidalcime in trines 2 affer bringt, oft bis zun Beriten fid) vollfaugen. Shere $\mathfrak{B} c=$ wegmigen, welde ourd) eine gegitterte Mins= ferfdjidt unter ber Sant bewirft werben, find

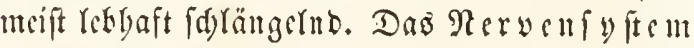
ift bentlid aus sinem febr bünnen Sd)lunb= ringe und jwei feitfiden Merven= ftämmen gebildet. Der $\mathfrak{M}$ u n b befinbet fid) am surbern Ende bes Sörpers unto Der bavan ansigelettoe $\mathfrak{B} \mathfrak{c r}=$

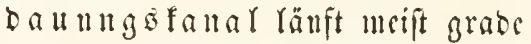
burd) Den siörter Gindurd, um fid

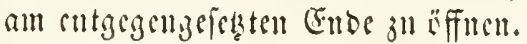
Der Munto felbit if meift mit Sinc=

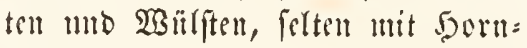
zäbnen untheben, Der Edylund oft fegr lang mo mit sinem runds liden Edylundoffe verielsen. 3n= weilen ift ber ganze Sdylunb und ber Gdiundfopf mit cittem feften bormigen lleterguge ober mit berwerg= liden, bornigen, sorfpringenden

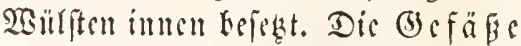

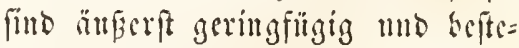

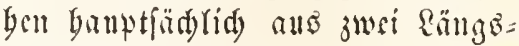
fortälen, weld)e unumitterbar unter ber Görperbant vertanfen. Die beis ben (befdeled)ter, welde ïberall wor=

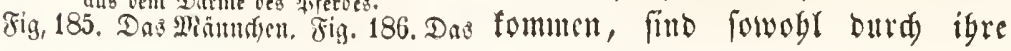




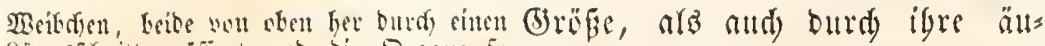

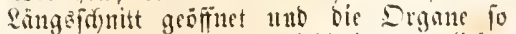

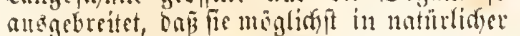
Eage fleiten. a Der slumb, won einem idnuleligen 2isulfe ungeten. b Estund= fopf. (3mifosen beioen fieft man beim Mämn= d)en Fig. 185 tie zlwei feitten, feitlidyen Merven=

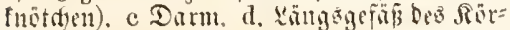
hers. e joben, f Eamenblafe. g sllusfulofe Anteftung fäben dez Fienis. $h$ Edtwanz=

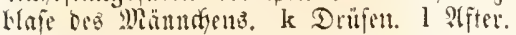

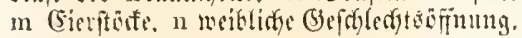

freve Geftalt meift feldr reidst ont unterfaciben. Desi oen $\mathfrak{B s c i b}$. d)en befindet fid nämlid bie woul

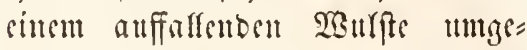
bene (befd) $(e d)+a j$ frutng entweder in oer Ditte oes siörers oder ferbft weiter nad vornen gegen ben Mumb bin, mäbrent bei ben Mäund)en Dieferbe ftets in ber Mlitte bes Sdwanjentes autgerradyt mo oft mit bornigen Begattungewerf

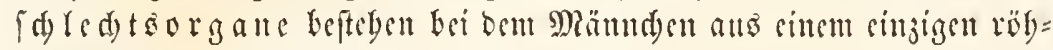
renfürmigen 5oben, ber burd) stute längere Räbre in bas balo sin=

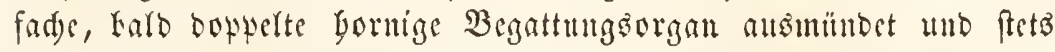

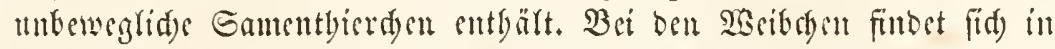
orr Familie ber Sputwürmer cin bopperter Girrftof, bei ben Syfabl= whrmern bagegen cin sinfadyer. In biefen Eierftöten, weldae meift un ben Darm lermmgewumben fint, erblift man bie Eier fets a a f

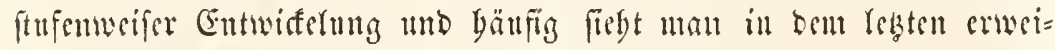
terten Theile des Ceifeiters, welder uad) anjen müntet, แnb ben man oft auty llterts genannt bat, fdon ausgefd)lïpfte Junge, bis ganj bie

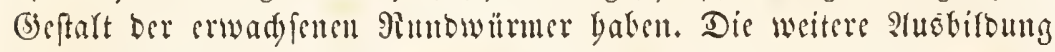

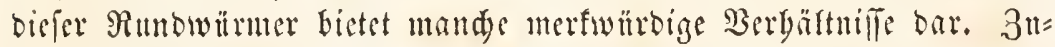
weilen ideint fid) eine befondere Sanberlujt ber erwad) fenen Jnbivi=

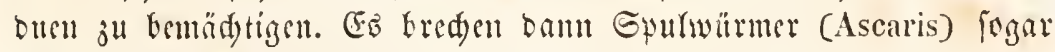
burd) Sie Darmwandungen binturd, wäbrent bie bei Sinbern fo

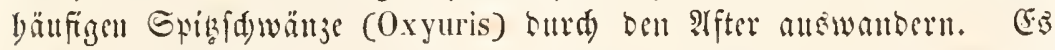
(d) sinen bisfe Saanbernngen mit ber Reife ber Gier und Jungen ju= fammenjubängen, bie smtweber nad) anzen gefdafft, vber aber, wie

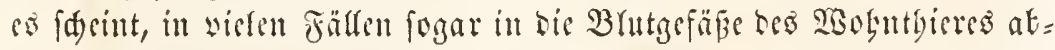
gefelst werben. Die meiften Jabenwämer, weldse man femut, hat man bis jebt mur in ermadjenem 3uftande gefelyen. Die Jumgen bes fo

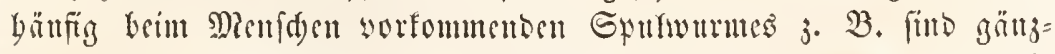

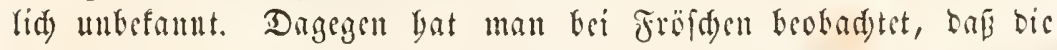

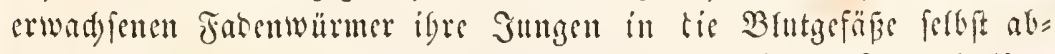

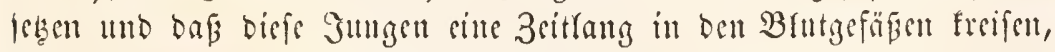
bis fie an irgento sinem gerigneten Drte bie frinften Saargefäpe burd)= bred)en und fid) nun für sinig: 3eit verwuppen. Sis lifoen fid) näm= lid) sine $\mathfrak{A}$ fangs ganj belle, fpätet meift braun weroende Sapfer um, in welder fie fpiralfömig gerold liegen mo die fie fiäter ver: 
laffen, un igren im erwadjenen 3uftanbe ifnen angewiefenen :4ufent= baltoort aufjufuden. Dian findet biefe singefapferten jungen Faben= whiturer fegr bätfig in ben weridiedenen Drganen bes lluterfeibes ber Frojfde, im (sicfröfe, in ber Refer, in ben Darmbäuten mo fann fid

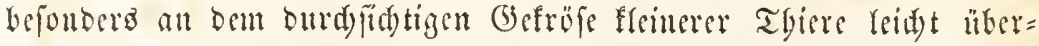
jengen, baß fie fteto ben Battgefäben entlang gereibt fint. Diefe fo

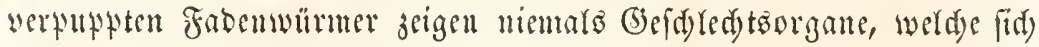
erft aubirben, fobalo ber sism bic Juppenbüle burdbroden gat;

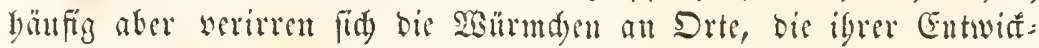
Yung midyt ghinjtig fint. In fold)en Jäflen fterben fie meift in

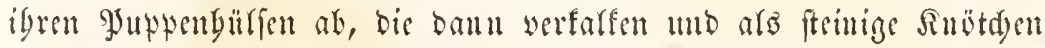
iim Sewebe jurticf bleiben. Dies ift namentlid ber fall bei

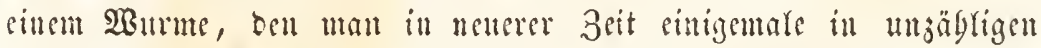
Exemplaren in bem Musferfleifde des Menfden felbft gefunden und mit bem Ramen Trichina spiralis bejeidynet bat.

Wir theilen die Fabenwhinmer in brei Fantien. Bei ben sincn, ben Epulwärmern (Ascarida), finoet man boppette Gierfibute bei ben an bäufigften vorfoumenten şeifden. Sieber gebürt ber Spul= wurm (Ascaris) felfft, wether in bem Darmfintale bes Menjden

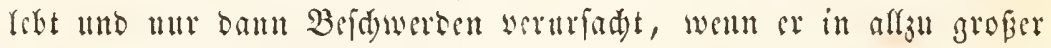
3abl angelsälft ift; ber Fabenwurm ber Tropengegenden (Filaria

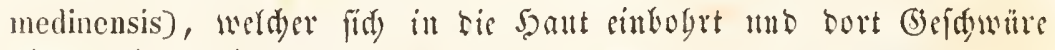

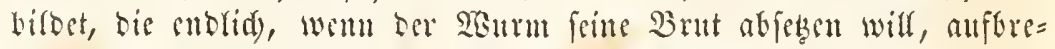

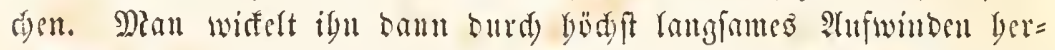

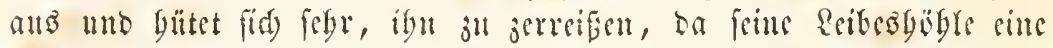

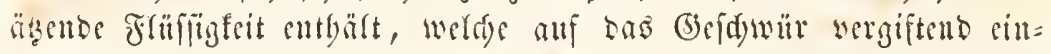
wirft. 3u biefer Gruple gegören fermer bie in bem Maftorme ber

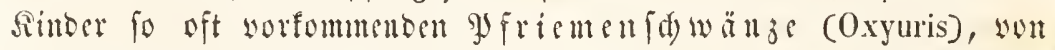

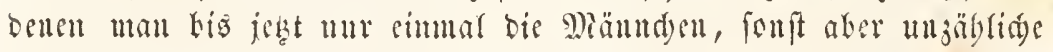
Meibden vorgefunoen bat.

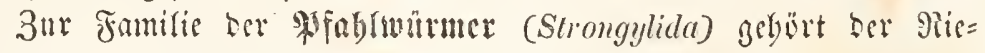
fertwurm (Strongylus gigas), welder in ben Rieren bes Edyweites unt aud, in büd)it feftenen Fälfen, bes Dienfden vorfümut, cine

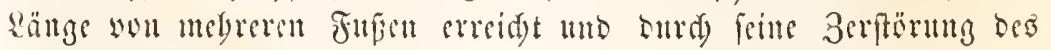

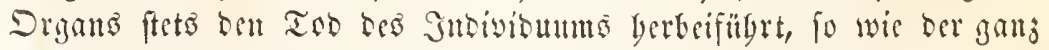
unidäbritye beitfde $n$ wum bes Menfden (Tríchocephalus dispar), beffen vorberes Eube allererbentlich lang uno biun, bas bintere bagegen, in weldyem bie Gefdyledgtsorgane liegen, etwas biffer ift.

Die Frmilie ber Ralwürmeben (Anguillulida) befteyt ans fleinen rumbridgen Fabenwänuden mit fpizen, bei cimer Gattung wargigem 
Gdywangente, bis in grofien Mengen in gäbrenten unb faulenten Gtoffen worfonment. Dis weiblide (3efdyled)töbfintng liegt in ber

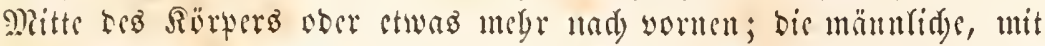
rinem cinfad)en, bornigen Begattungsorgane weriegene, weit mad) bin= ten aแn Begimn bes Gdwwangendes. Der rundidye, enbftäldige Mand ift unbewaffnet, ber Darm gerabe, meift mit einem jwistelar=

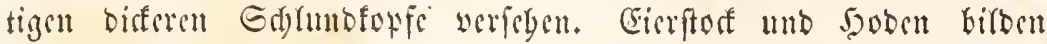
sinen sinfaden Gdjlatd). Die befannten! Effigälden unb Silcifteräld)en, fo wis bis im Nitterforn thl im roftigen Getreibe vorfommenten

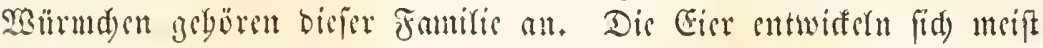
in Seibe ber Mluter, fo baß fie letentige Jutnge gebören.

\section{falafic ide plattmiimer. (Platyelmia.)}

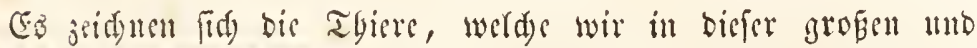

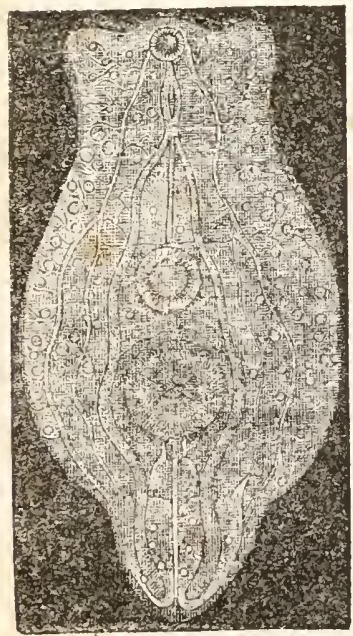

öig. 157, Diplostomum.

Bon ben worberen fleinen Sang=

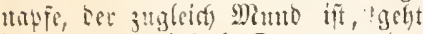
ter anfany ${ }^{3}$ cinforde Darm aus, ter fid) Dann theilt, bie beiten gresen hinteren @augnäpfe nmfag̈t no guterförmig flino binten entet. altoern leben frei in bem $\mathfrak{B} a f f e r$, find inciftens gefärbt unb geigen zablreiden Silaffe zufammenftellen, auf sen erften Brict wor ben übrigen 2 Bür= mern Durd) sine besentende AGplattung igres ä́rers ans, die ferbft bann nod, bemerffer ift, wenn ber Sïrper, wis bei ben $\Xi_{\text {d) }}$ atr $=$ แmb Banbwärmern, sine

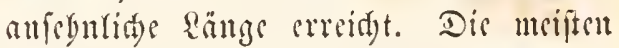
(3)attungen freition baben cine mebr ellit: tifde pratte beftalt, tie jumeilen faft fdeibenförmig wirb. Sisir erfentuen anter ben Jylattwärmern jwei grofe 2tretbei= lungen, welde stenfowobl burd igren äubern CGarafter, wic burd igre Retenb=

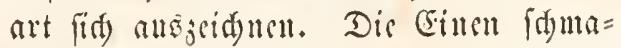
roken in andern Thieren mob befthen sine nafte, fits farblofs baut, in wel= cher meift weife unburdyfidtige Salfgärner in Minfe abgelagert fint; fie entbegren bibers Ginncsorgane mo reben mur von Gaften ibrer Sobntbiere; - dic 


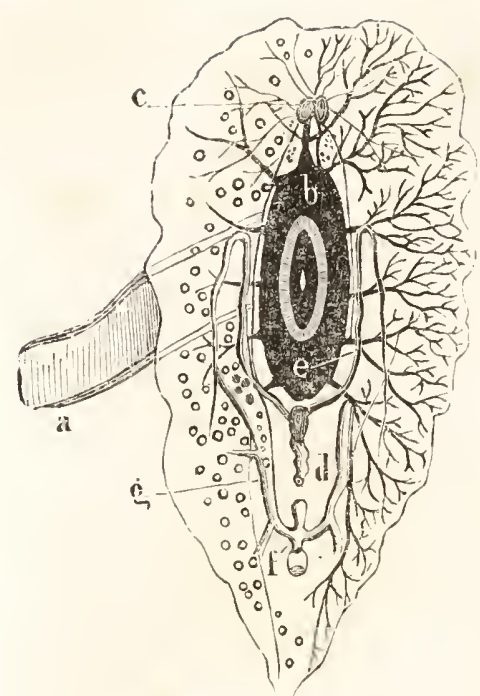

Jig. 188 Planaria.

Anntomic einer Blanarie.

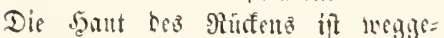
nommen. a Ed)hnoronge. b Majen= Gohle, you weldyer vicle vergmeigte Blint= bäme angeben, bie mur anf ber restent

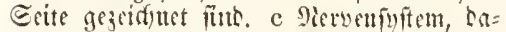

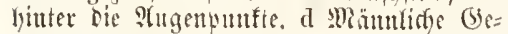

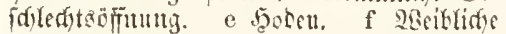

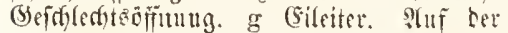
linfen Eeite jieft man Den Gileiter mit Ciern angefüllt, Die an Berbem in berrete ierfitent into. auf ber Dberfläde entweber über= afl ober mur an cinzeluen Gtellen beutlid) aแริ่านrägte Wimperorganc, bie ignen fefonders brim Gdwim= men förocrlid finto, uno wefentlid alz $\mathfrak{B}$ ewegungsorgane dienen. Die Sant ber \$lattwultumer bat nicmalo jene berbe Befdaffenbeit wie bie ber Giunowïnter, unb bei sinigen frei letenben battungen gebt fogar

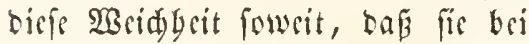

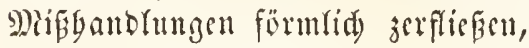
in äbnlider פasife wis bie Snfu= porien.

Dic neneren llnterjudungen ba= ben bei allen Sylattwürmern obne Aแsิnalyme cin Rervenfy ftem er= fennen laffen. Cas heftebt saffelbe ftets aus jower feitlidach sinoten, welde in ben nebern Drounngen

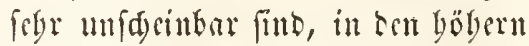
aber juweilen cine jiomlide bröfife erreid)en unb baun aud) sffer aus mebreren Sinoten jufammengefset erfderinen. E⿺辶 liegen diçe Sinoten ftets in obr worbern Jälfte bes Söpers, meift fogar ganj nabe an bem Sopfente, uno fite fint onrd) sin fomales Bändden von Rerwenfubftanj, werbes bei ben Gattun= gen mit enoftänigem Munbe unter bem Ed)lund liegt, mit sinantor verbunden. Dit rüfen biefe feitliden Rervenfuoten and) fo nabe gu=

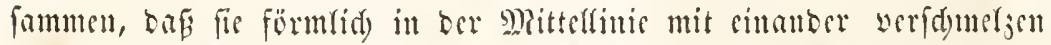
unt nur einen einjigen zweifdenfliden suoten barftellen. Bon bies fem Sinoten aus laufen jwei, meift jiemlid bünne Rervenftämme ju keiben Geiten bes Rörpers binab, um fid in bie Rörperfubfanj 3 u

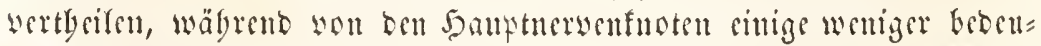
tenbe Fiben nad) vorn ftrablen, bie fids an bie Drgane bes Ropf= endes veräftert. Ginneargane fommen nur ben freilebenoen Wrattwünmen ju; fie befteben in siner gemiffen 3abl won 2lugen, bie

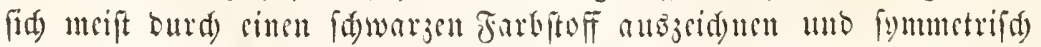
zu beiben Geiten an Dem Sepfende wertgeift find. Man bat in biefen 


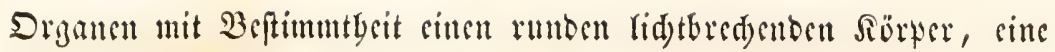
wabre Rinje mabrebegen fönnen und an vielen and die Rerven=

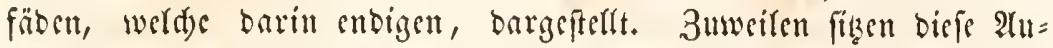
gen numittelbar auf ben Gentraluerwenftuten auf und werben von Der Rörłerbant gänjlid überzogen und verbeft. Die gefärbten freften,

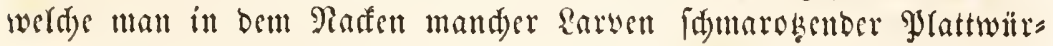

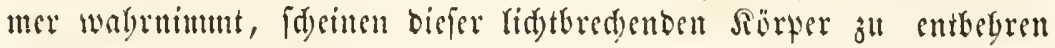

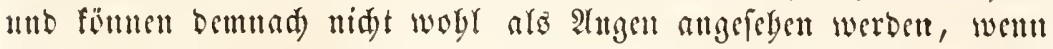

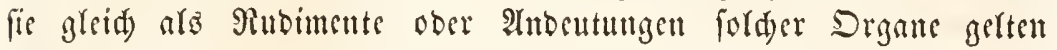

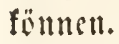

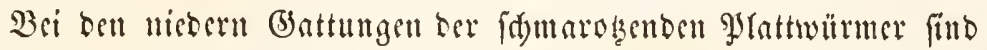

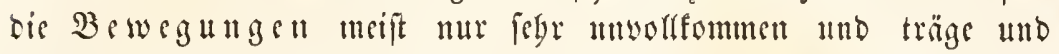

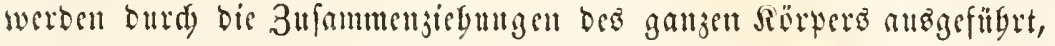
3" weldem 3welfe unter ber Saut cin mafdenfürmiges, febr fein

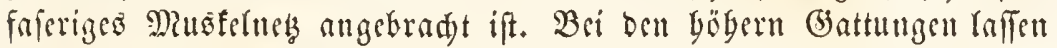

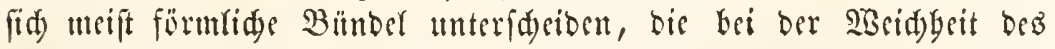
ganjen Rörfergewebes juweilen cine fo außerorbentlide Eontractilität bebingen, bak biefe Thiere auf sin Bebutel ibrer urfprüngliden \&änge (ind) jufanmenzichen föntuen. Diefer beosutenden 3ufammenziegung wegen werben aud bie gylattwïrmer meift beim atufbewabren, fei ries nut in trof́cenem Zuftande ober in glüfïgteiten, febr uns

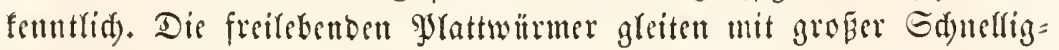

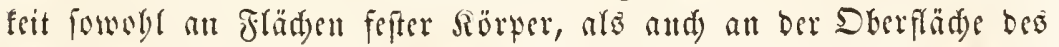

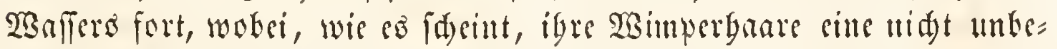

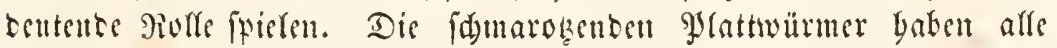
utshr ofer minber bedeutend ausgebitbete Drgane zum Fefthalten,

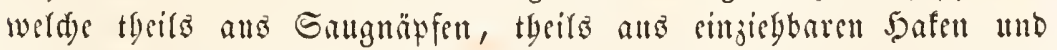

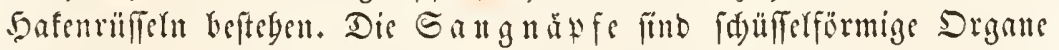

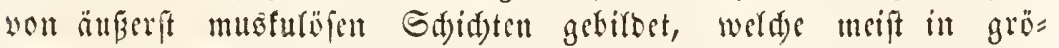
forer $3 a g r$ vorbanben fint ; nur bei sintigen Gattungent ift cin mitt= Terer vorberer Saugnapf zugleid ber Mund, wäbrent fonft biefe Dos=

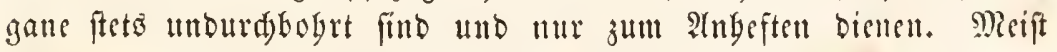
fitto bie Saugnapfe cinfad) rund und obne weitere complication sft aber finten fid gefranjte Ränder, bornlsiften und fereft fegr ent=

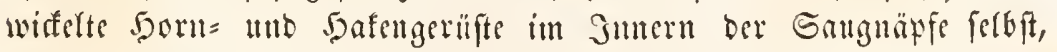

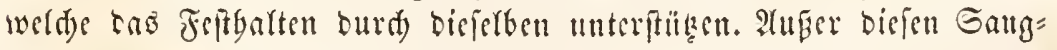
näpfen foumen and) sinzelne Bertiefungen in Der Ecibešlgat yor,

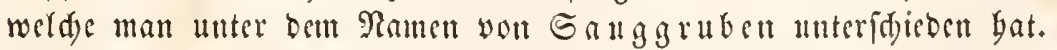
3uweilen find bisfe Sanggruben nod aufserbem burd) oft legr com=

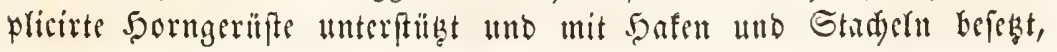


wodurd) fid bie Thiere mit äuperfter Sartmärigfeit an ben Drganen ibrer Gaftwirtbe feffflammern fömuen. Bei ben Banbwürmern findet man cinfade ober bopyelte bafenfränje, bie auf eillem mebr ober minter bemerfbaren, oer Einftülpung fäbigen Fortfake feitfizen unb an bem yorbern Enbe des Ropfes jwifden ben Sanguäpfen ange= Fradgt finto. Seber ber nad) rüfwärto gefrümmten Safen ift eilizeln fiil fing beweglid und bei mandent (battungen geben bieje Safen leidgt werloven, fo baj fribere Beobadyter fie fint unbewafinet bielten. Cin

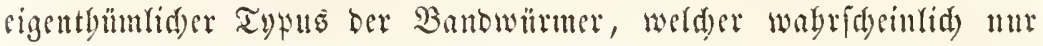
sin Rarwenjuftand ift, Bier=9übiler, Tetrarhynchus, befibt vier, oft febr lange, in eigene Edgeiben zurüdgieblare Rüffer, bie in igrer ganjen Sänge mit anperorbentlid) vielen fdarfen Sornbäfden befest

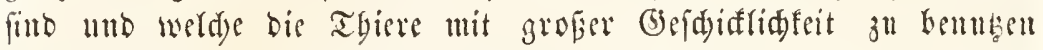

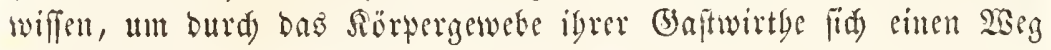
3" babuen.

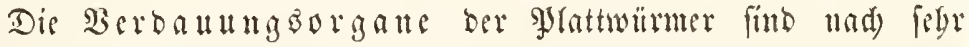
weridebenen Typen angeoronet. Bei ben Banbwïrmern fiebt man

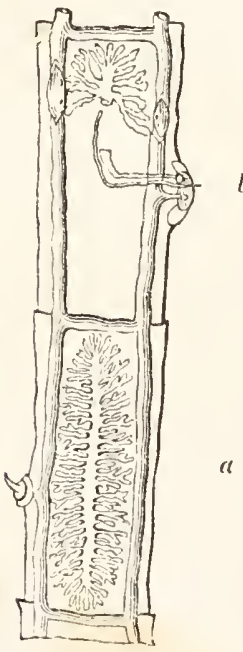

Fi.]. 199.

3wei (Stieber eilles 2 anbuurmes (Taenia solium) retgriésert.

Man fieht rie feitlidju Darmrögren, burd Duerafte werbunben mo bie afuedsferte an ben Eeiten herworitefanbent mäแnlid)eน Begattmug gatte. Sm Estiebe a ift bie bon bem vollen Eieritede ge=

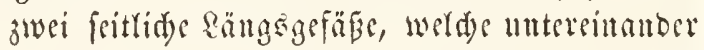
burd) Sueräte in Berbinbung fteben, aber liberall gefdyoffen find, fo bab weber ein Munb nod) ein P(fter worbanben ift. Bei ben Gang=

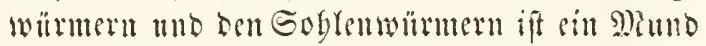
worbanben, aber feill stfter und bei ben erferen fiifyt siefer Diunb meift in jwei feitliabe brind elloende Darmfdrändge, bie oft änferft serjueigt fill, wägrenb bei ben Soblemwinmern jumeilen sie Serjweigung unmittelbar am Mumbe be= gimnt, ber mit simer langen, febr betwegliden Edylmbrigre werfeben ift, weld) jum Einfd) fuden ber Ragrung Gerworgeftreft wirb. Bei ben Sdnurwhtmern enblids findst fid sill meift graber Darmtanal, welder bei bell büber ent= wifferten Gattungen and cinen 9ifter jerigt nul trod) auberbem oft mit cinem mubbängigen Taft = unb Greiforgan, cinem bewaffueten Rilly= fel, in indirecter Berbindung frebt.

Das (S)

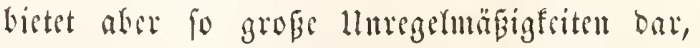
baf wir eà bei ben einjeluen Drbmungen näber Getradyten müffen. Rirgendo fann man cin 
biltete Sigur entraften; im cigentlides 5erz unterfdeiben, mur bei ben

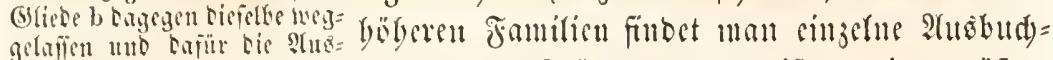

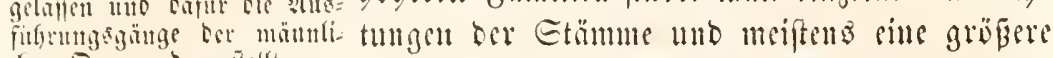
dert Ergaue bargettellt.

Blafe in ser llungrbung ors Centrat= Rerven=

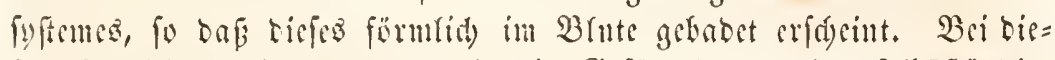

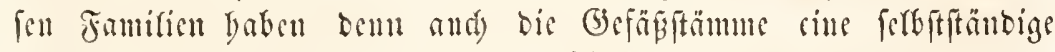

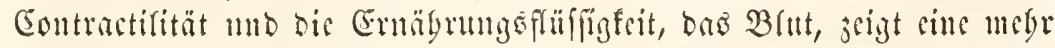
ober minber gerättigte rotge färbung, wägrend bei ben nicbern fami=

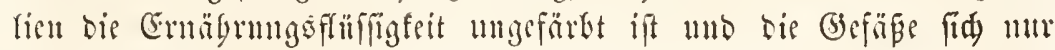

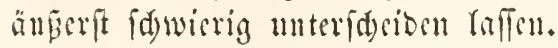

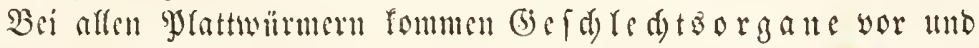

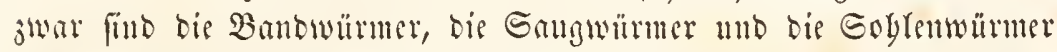

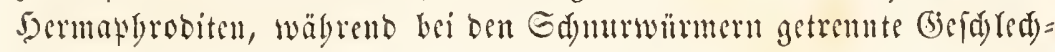
ter worbanden find. And) lier find bic Typen äuferfit verfde ieben, fo

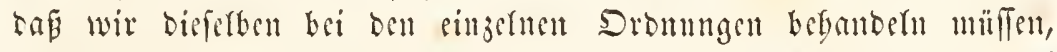
ebento wie die Entwidinng ber Cier unb ber Jungen, weldye oft anf

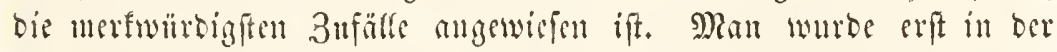

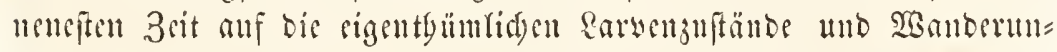
gen, welde mit birfen Earvenzufänden verbunben fint, fo wie auf

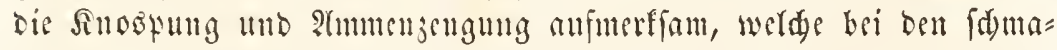

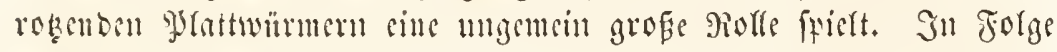

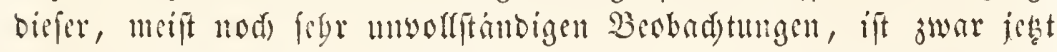

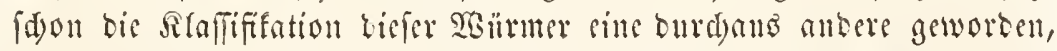

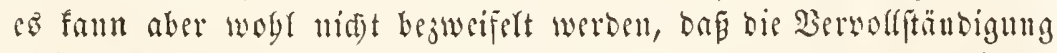
biefer Entbeftungen now mantd)e grofie Fenberung berworbringen

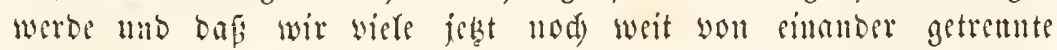

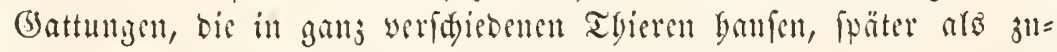

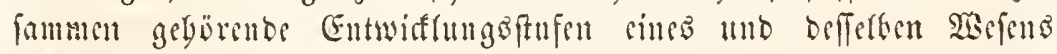
erfenten werben.

SBir theifen bie Ylattwürmer juerft in jwei groge llnterflaflen, bie fid) Surai) ibre Rebensat unb bie Befdaffmbeit ber Jaut wefents

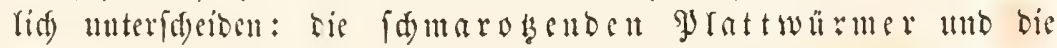
freien gy fattwïrmer, mo jebe biefer lluterffeffen wicber in zwei Stomungen, dic Banbwirmer und bie Saugutimer simerfeits und rie Goblenwïmer un Gdumrwinmer anbererfeits. 
Die Bandwinkmer (Cestoidea) Gaben meift einen fegr Yangen

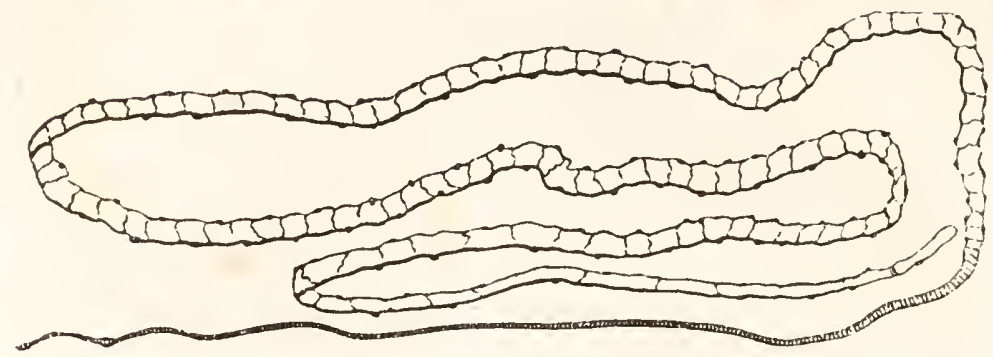

รig. 190.

Der menfalidie Banbwurm (Taenia solium).

Man fielyt bas worbere (Enbe mit beut feinen Ropie, Den unentwitelten Sauls=

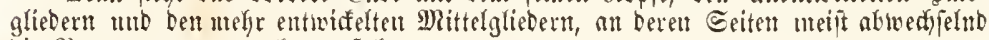
bie Pegattung:ongante herworftefyem.

und aus cittjeluen (bliebern jufanmengefetzten Reib, werdye Durd) un=

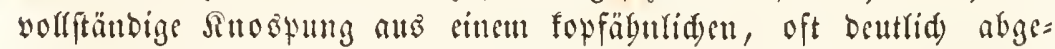
trentent yordern Enogliebe berworipresent. Die $5 a$ at Der Band=

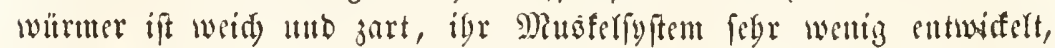

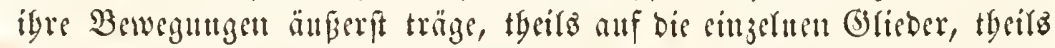

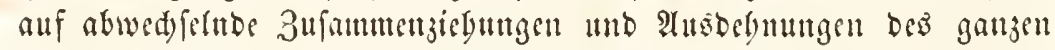
Rörpers befdräntt. Das äuperit uttbebeutende, aus zwei zarten, Durd) citten febr bitnten Berbindungsfaben vereingten Sütdyen beftebende Rervelly fitem liegt it bem Dïnnen Ropfende nub fentet juef fegr feitte feitlidge Rervenftämme nad) binten, bie fids mus it beul vorberm Enbgliede verfolgen laffen. Die weitern (Blieber, weldye bei ben ty= pifden Banbwürmern vorfommen, fitlo um fo vollfommenter ausgebilbet, je weiter fie vou Dem Ropfe abfeben; aber aud bis ju bem Dlo= mente ibrer Sicife, wo fie fidi lositrenten, fiebt mant niemals cine Spur von Rerwenfyptem in ignet entwiffert. Bei ben jungen Sndi=

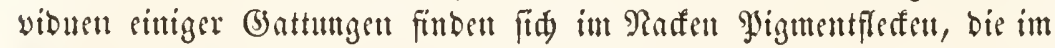
T(ter verfd)willden.

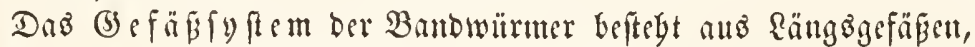

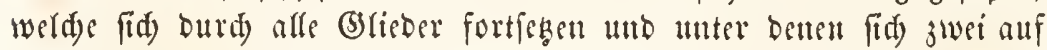
Den Seiten meben Den rubimentären Darmeöbren befonders aแşzeid = nen, wäbrend zugleid) zwei anbere ber Mittelfitie fid uäber befinden. Diefe Gefä̈e fitto Durdy zablreidye Dueräte mit cinanber verbunden, welde fid fanm veräfteln. Dis Bewegung bes farblofen Błutes in iGnet wird Durd) bie 3ufammenjieluttget bes Rürpergewebes bervor= gebradt. Lnabbängig von diefen Gefägen find diejenigen Ränģ = fanäle, welde man fïr verfämmerte Darmröbret anfifl uno 
Die in jebem (3)tiebe burd) ein Duergefäß mit siunduer verbunben fint. Dian glaubte frütger, bá biefe feitliden Darmurgeren mit ben

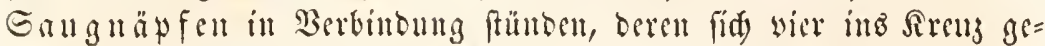
ferlt an bem äußerft bünnen Sepfente ber sigentliden Bantwürmer worfinten. Diefs Gaugnäpfe fint inteffen nur fdüfferförmige Derties

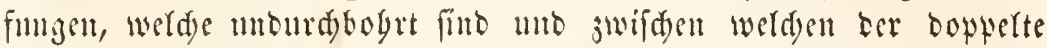
ober sinfadse $\mathfrak{b a f e n f i a n s}$ find befurbet, ber meift auj cinem fleinen

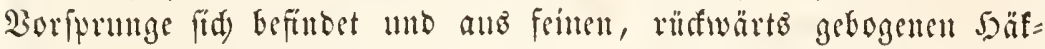
d)en zufammengefest ift. Bei ben fogenaunten (brubenföpfen fino biefe Gangnäpfe burd cine Yänglidje Gauggrube erfeģt unto bei cint=

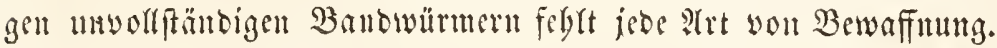

Die Fortpfranjungaorgane finto bei ben eigentriden Band =

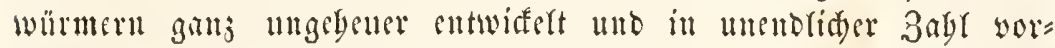

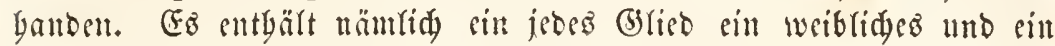

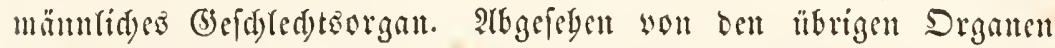

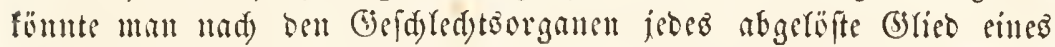

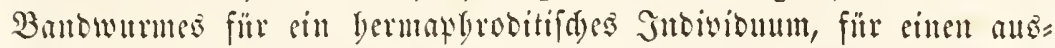

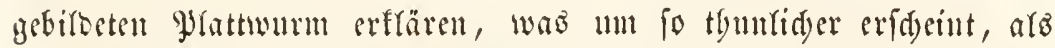

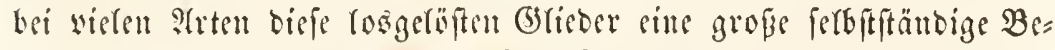

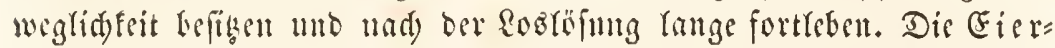

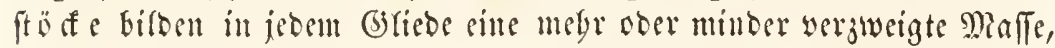

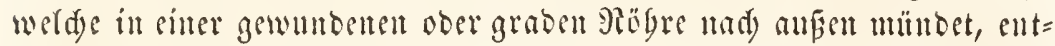

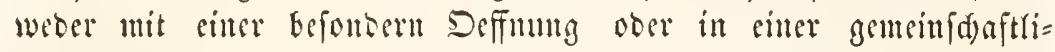
d)en Miüntung mit ben männliden (befdjled)tęorganen. Dirfe be=

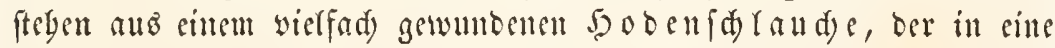

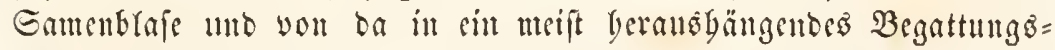

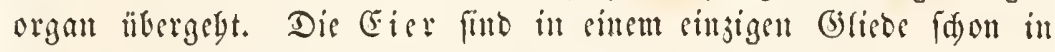
auberorbentlider satjagl aufgebäuft, mifrofforifd flein uno ent= weber you siner sinfad) braumen Cightllte ungeben, ober burd viel=

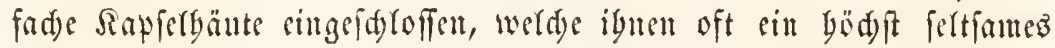

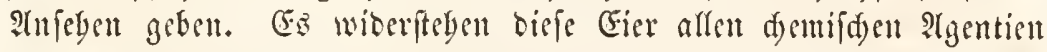

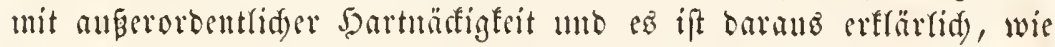
fie in fautenten Gtoffert, in Dintger mo Soth jabrelang igre Rebents= fäbigfeit begauptent.

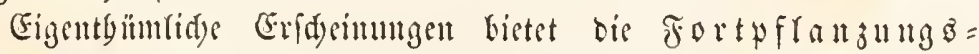

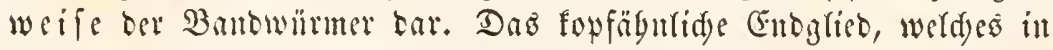

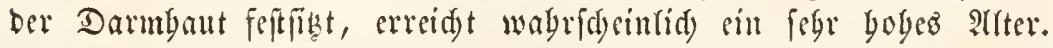

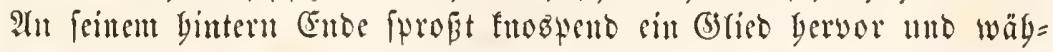

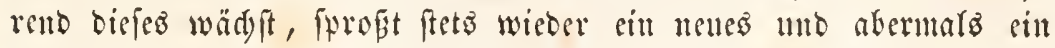

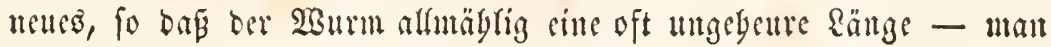


fagt bis ju fünfaig Eellen und merar bei bent bell Menfdyen be= wobnenben 2luten - erreid)t. Das jüngfte Gricb ift ftets bas un=

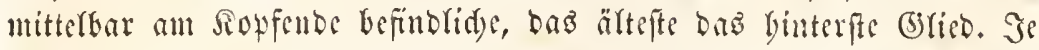

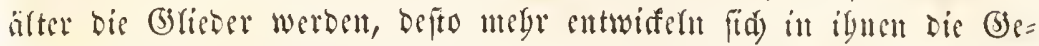

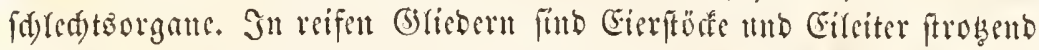
mit Giern angefinlt, in benen fids jubeifen fdon bie Cmbryone er= fenten laffen. In biefent 3uftande löfent fid) die Gilieber ab, bei

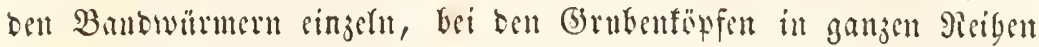

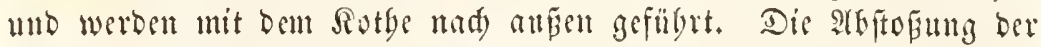
(bileber, weld)e jur regefmäfigen 3eit wieberfebrt, ift alfo cint wabres

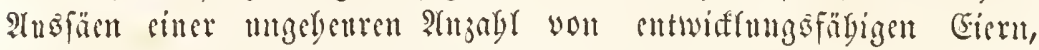

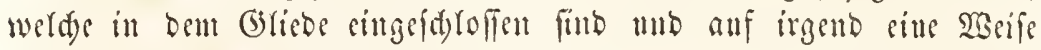
wieber in sin zbier bincintommen mulfen, it beffen Smtern fie

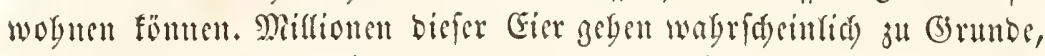

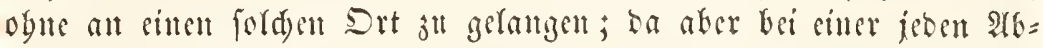
ftofung won (Blicbern and) Mitfionen von Gien angefäet werben, fo

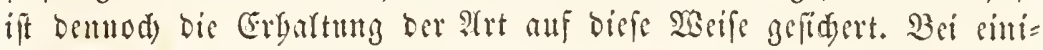

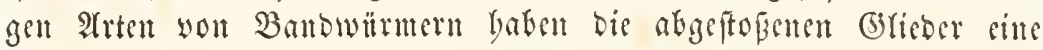

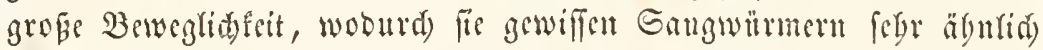
werben. In ber That glanben aud cintige Raturforfder biefe losgeftofie= nen $\mathfrak{B a n b w u r m g l i e b e r ~ a r s ~ e i g e n e ~ S n b i v i b u e n ~ a n j e l e n ~ n u t ~ b e n ~ B a n t ~ = ~}$

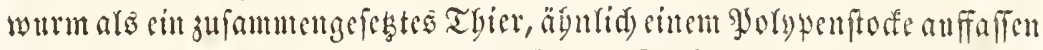

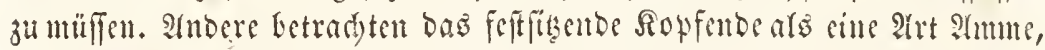

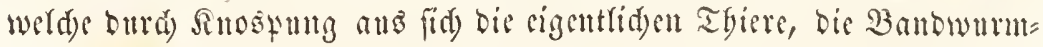

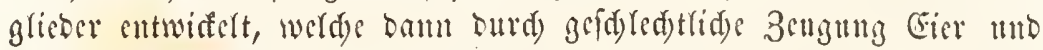

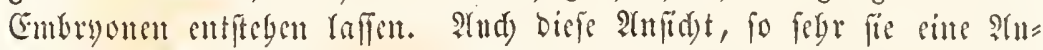
näberming an bie Sangwḧmer gewäbrt, bat beit llmftand gegen fich,

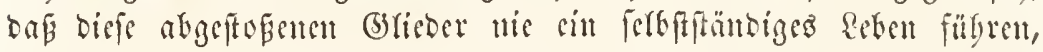

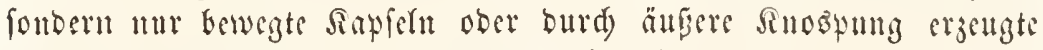
untwolleändige Stumen Der Banbwumeier fint.

Dan weip nod) nidyt, anf weldye IIrt bie mit ben afgeftefienen Gilicbern jerftenten Banbwärmer wieber an bie Srte gefangen, wo

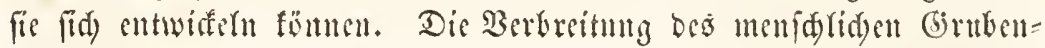
fopfes (Bothriocephalus latus) giebt bier freifid) einen fingergrig.

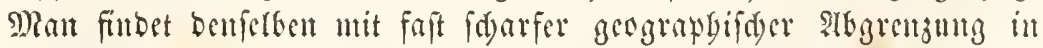

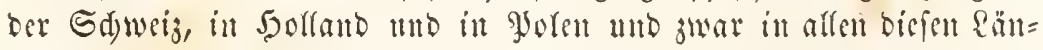
bern an einzeluen Drten fo bänfig, oaf faft jeber Menfd) cinen forl d) Sdumarokser beberbergt, wäbrent in Dentfdrand unt Franfreid nid)t ber Grubenfopf, fonbern bet eigentfid) Banbwurm (Taenia 


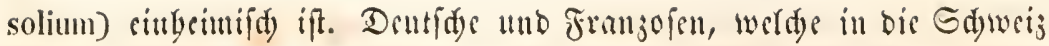
foumen, golen firf bort ben brubenforf, nidat aber ben in ibrem

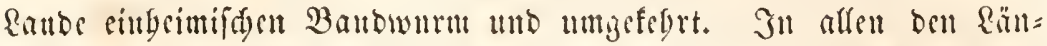
Dern aber, wo ber Grubenfopf fo Gänfig ift, berridgt dis Sitte,

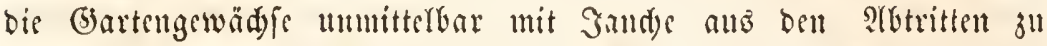

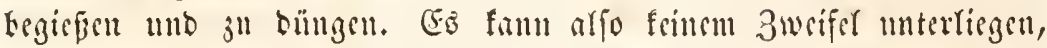
daf son ben Mitlionen mifroffopifden Eidsen, welde burd) bie abge=

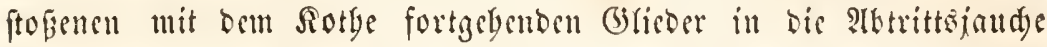
gelangen, cintige mit Sulat ober antern ungefodsten Siräutern, bie man gentest, Ginabgefdluft werben und wicber in Den Darmfanal getan: gen, wo fie fít) entwidéch fömnen.

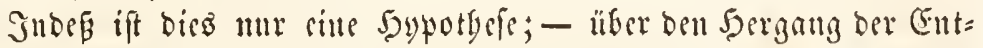
wifertung ferbft fennen wir aber forgende Thatfaden. Dis Cmbryo= nen, welde fid in ben (Ficrn befinden, find äunerit contractile Thier: d)en, welde firl mit vieler Eebgaftigfeit fireden und zufammenjichen

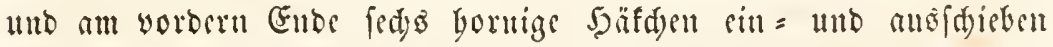

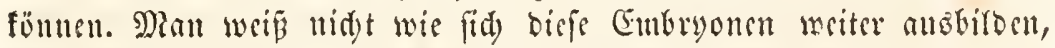
lat aber einige gingerzeige bafür anfgefundert.

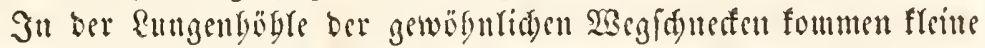

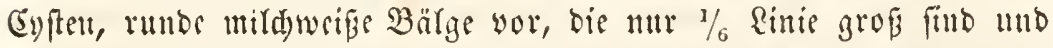
in igrem Guncrn cincu jungen Banbwurm entlyatten, beffen Siopf und

ซig. 19?.

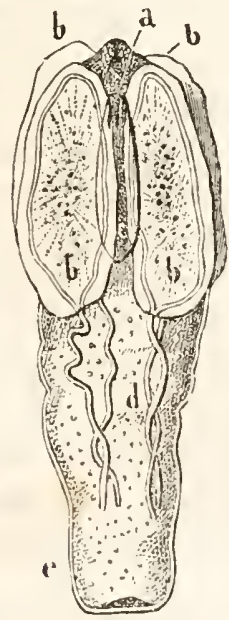

Fin 191.

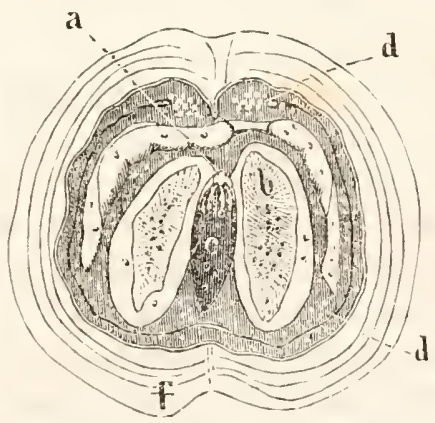

T̃ig. 193.

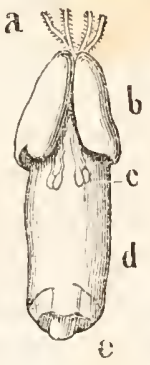

Fig. 191. Die Sapiel mit bem zufammengefugetten Bantwum Darin. Jig. 192. Detfelle anęgettreft. Sig. 193. Reifer Tetrarhynchus, iut 2Eanben begrifien. Bei

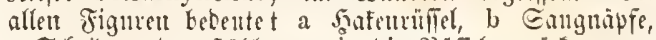

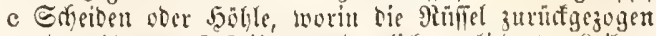
werben fönnell, d Eeib, ellnbeutlid geylieberter Leibesanthang, f Sapjeflyulle.

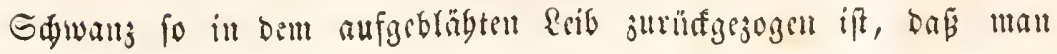


cinen Ropf cines Banbwurms in einem: Gaugwurmleife ju feben

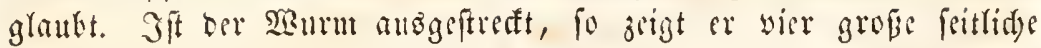

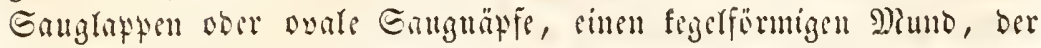

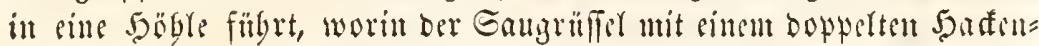
franje liegt mo sincu unbentlidy geglieberten \&eib, in bem man jarte,

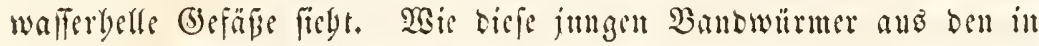
Den Eiern befindiden Embryonen entitegen, ob bireft Durdy Meta=

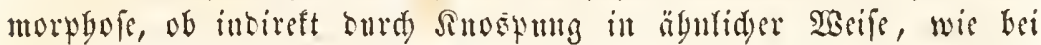

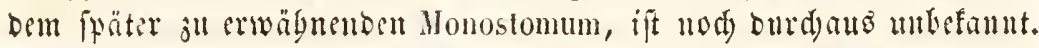

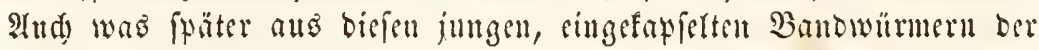
Ednesfen wirb, weí man nidgt - wabrideinlid birben fie fid, nabbem bie Edneffen von allorn Theren gefreffen wurben, in ber

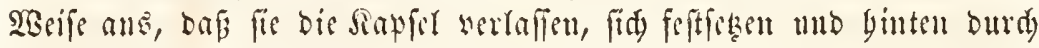

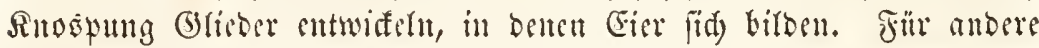
Bandwümer bat man gefmoen, ba befonders bie Gattungen Scolex unt Tetrarhynchus, die man bäufig in ben Eingeweiben ber Eecfilde trifft, folde junge Sopfglieder fint, bie fid fräter anfesen und (s)lis=

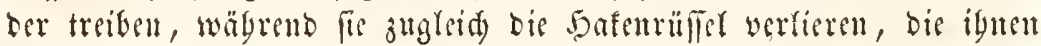

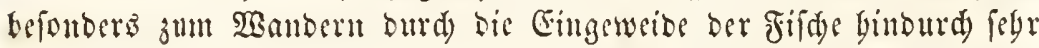
ühtich) fint. Dian glaubte bigber, Daß̧ Diefe Bierrübler (Tetrarhyn-

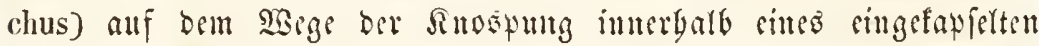
Eaugwurmes entitänden, ittben man ibren anfgebläbten seib, in wel=

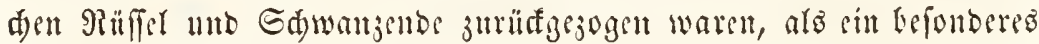

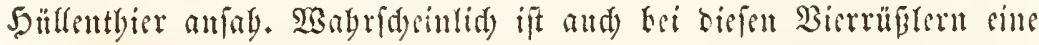
weitere lleberffanjung in anbere Thiere nitbig, um vollfänbige

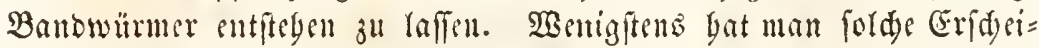
nungen anberwäts heobadtet. So findet fid 3. B. in ben Etichlingen

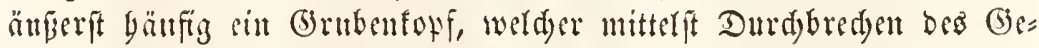

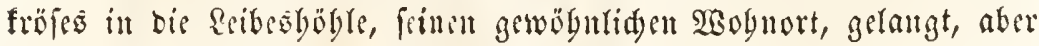

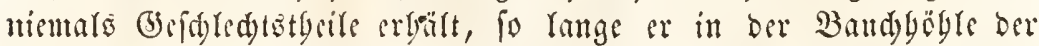

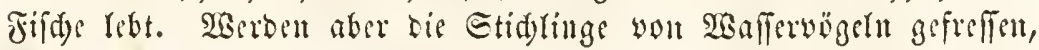
fo entmifteft fidy Der $\mathfrak{B}$ mm im Darmfanale biefer warmblätigen Thiere

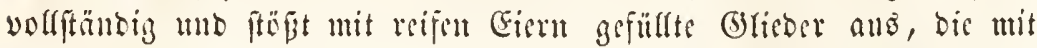
dent Siotle der 2 anfferwöget wieber an ben 2 sobnort ber Etidylinge

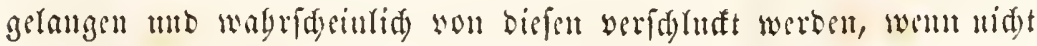
bie ansgejdlüften Embryonen wou auben ber in bie Etidlinge fid sinbobret.

SBir feben alfo, baj bei ber ungemeinen Bermebrung ber Reime, wie fir in ben Banbwitmern vorfommen, wejentlid bie Berednung Der Зufäle mit als Faftor eintritt, welde bas Thier bei feiner Ent= 


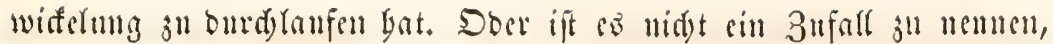

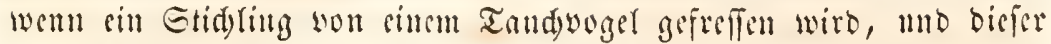

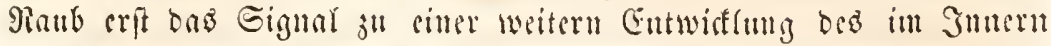

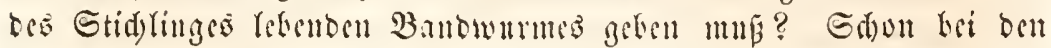

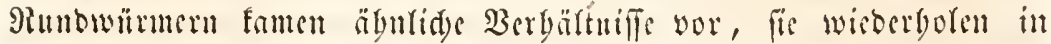
nod) ansgetefnterem Mage fid) bei cigentbümlidyen franfgaften $\mathfrak{B e r}$ Gälniffen ber Banbmämer, fowie bei ben Sangürmern. Säbrento man früber glanbte, bic Gingeweibewärmer mügten notbwendigerweife

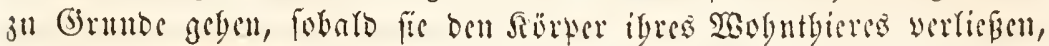

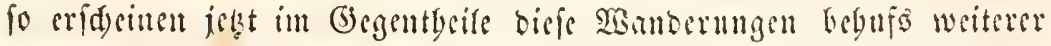

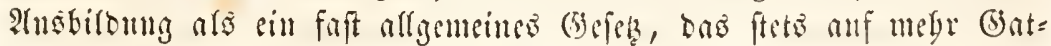

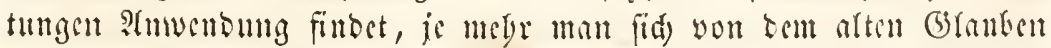

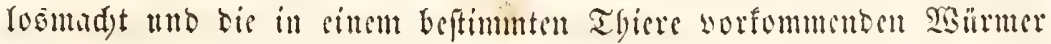
mit ben Eimwobnern berjenigen Thiere bergleidgt, won welden ể fid näbrt unb benen es wicber zar Ragrmng bient.

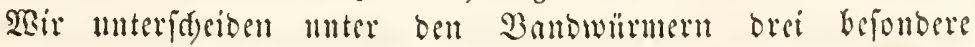
Familien: Die Relfenwïrmer (Caryophyllida) Gaben cincn läng=

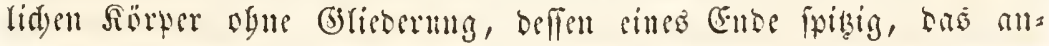

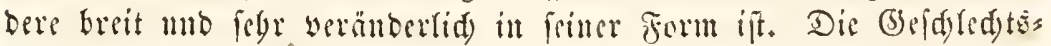
tyeile funb unr sinfad) unb minton in eimer gemeinfdjaftlidjen, an Dem fwiberen Cutte angebradten Deffumn. Das ganje Thier ift

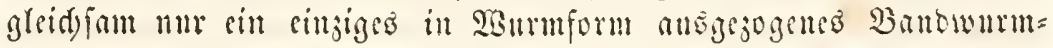

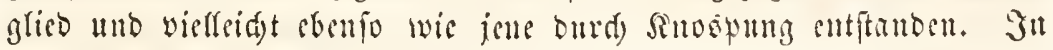

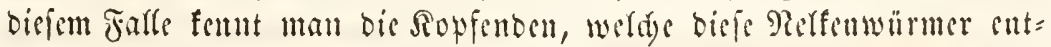

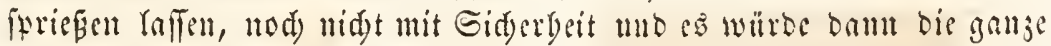
Familie eingeben, wäbrend zugleid) bic Betradstungseneife ter Bands

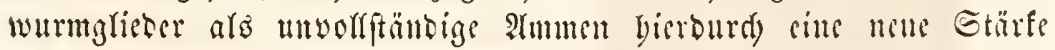
erbielte.

Finte jwoite jamilie birben bie Mitementwümer (Ligulida), lange, fuammengebridte, riemenartige sibumer, an welden fid fein

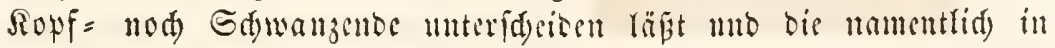
Fifden vorfommen. Dan fiebt feine Duerticilmug an biefen Bsefdöpfen, weldye, fo range fie in ben Fifd)en bleiben, feine (bejd)led)tsentwiflung

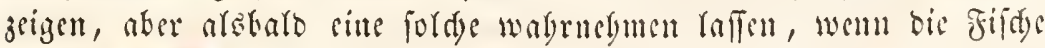
von B̈̈geln gefreflen fino.

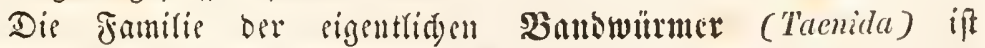
reidt an ber Duerringlung bes Rörtere zu unterfdeiben. Rad oer Bewaffinutg bes Ropfes Iaffen fie fid ittoelfen wieber itt jwei

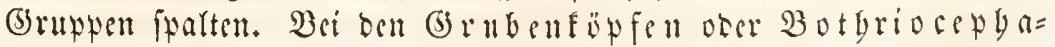
len fiegt man an ben Griten bes Dümmen fopfes mur flad) Gang= 


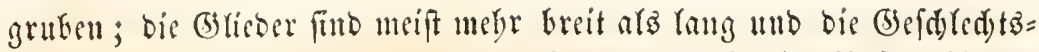
theile in Der Mritte Der (bslicber angebrad)t, wo fie sine Pofette biloen.

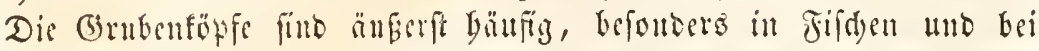

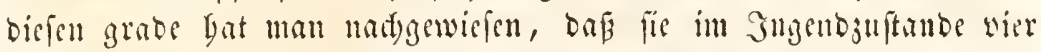
eitzichare bafemriffer baben mb baf bie beiben battmigen Scolex

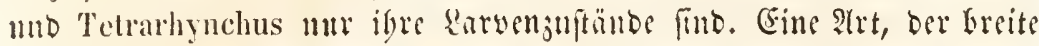
Grubenfopf, bemolnt ben Dünnoam bes Denfden, mb ift in bol=

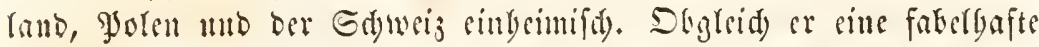

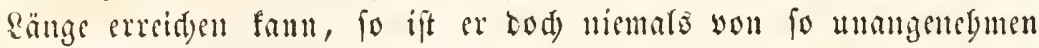

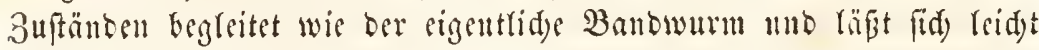
burd) Sammmittel abtriben. Die eigentliden $B$ and (Taenia) baben melyr fïrbisternfürmige, in bie \&änge gejogene (s)lie=

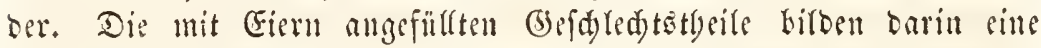
baunartige $\mathfrak{B}_{\mathrm{er}}$ weigumg mb bie (b) Der Geite ber Gslicber, nidyt aber in ber Mitte. Man unterfdeibet

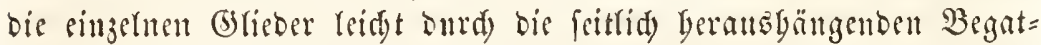
tunggorgane, wäbrend kei bem Grubenfoxfe die Begattungsorgane mitten ans bem Grlicbe bervortretin. Der Ropf ber Banbwintmer trägt ftetz einen boxtelten ober siufaden Jafentranj unb vier Ganguänfe unb ift ängerft fdomicrig ju entfernen.

Fine eigentlümliche Entartung ber Banowürmer if biejenige, welti) die fogenannten $\mathfrak{B}$ (afe $n$ wärmer (Cystica) berworbingt.

$$
a b
$$

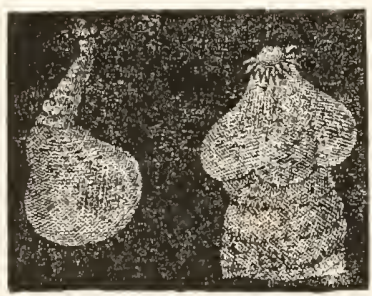

Jig. $19 !$

Ter serwitgutitye finnenwurm (Cysticercus cellulosate) rom $\Xi$ dymecine.

Bei a fitht man bas gange Thier in natürlidfer Grape mit bem vierfetigen

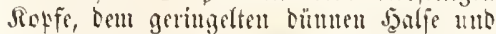
Der Enoflate. Soi b bou Rewf vergreäert,

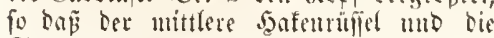
๔augarnken bentlidy funb.
Man finbet nämlid) in vielen Tlyie= rell, bejonbers aber in fouft unju= gänglicyen Theilen und ftets in Eyften eingefdolfen, SBürmer noer Bammfolonisen, weldse Röpfe mit Gaugnäpfa uno şafemrifleln be= fiben, bie volftommen ben fïtrfen der Banbwümer entfpred)en. Fg fizen biefe Sopfenben auf einem mely oder minter langen geglieberten Saalfe, ber in eine mit bidflidjer, ci= weiflyaltiger slüfigfeit gefüllte Blaje endigt. Ric mo unter feinen Ilmftänden findet man bei biefen Bhafenwürmern, beren Sïpfe meift in bie Blafe zurüafgezogen werben

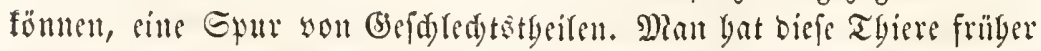
als cine eigene Drbunng betrad)tet, Gat aber jez̧t eingefeben, bas es 


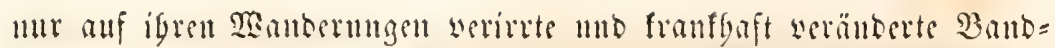

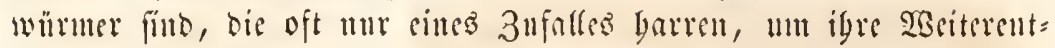
wistelung ju beginnen. Go befindet fid) in ber Reber ber Diämpe nno

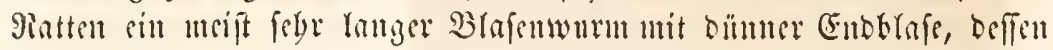

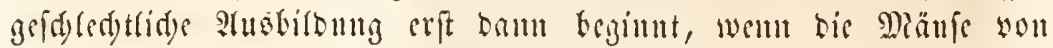
Siaken gefreflen werben. Sn ben Darme biefer Panbetbere angelangt,

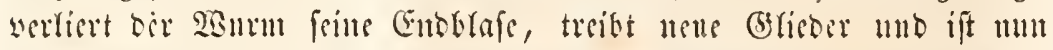
sin vollftünbiger Banbmum, ben man feit Yanger 3eit als bejondere

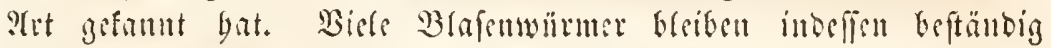

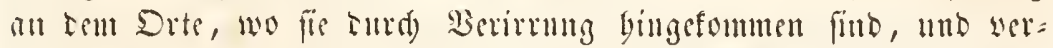

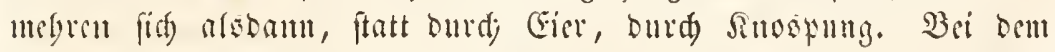
Fin th แ

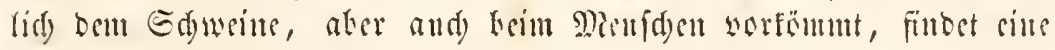

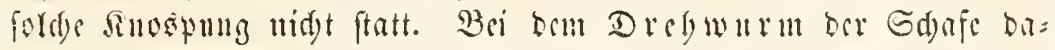

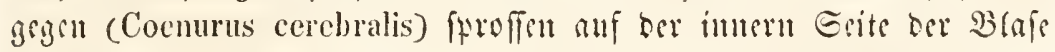
citte Menge wou Söffen berwor, wägrend die Blafe ftets junimut mo anfangs Ind Druf anf bas birn bie Drebfranfyeit, enblid aber

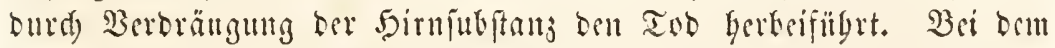
Echinococcus, ber juweilen keim Denfiden vorfonmt, Gifen fid bie

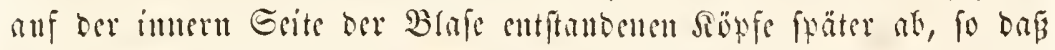
bie simjelnen Generationen in simmoer gefdadytelt fteden. Eine foldse

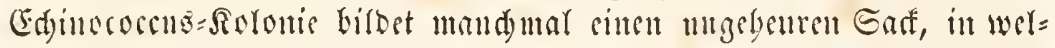

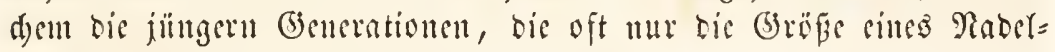
fopfes erreidsen, fid singefbloflen befinben.

Die Dromming fir Eangwiirnter (Trematoda) beftebt anz abgeplatteten, meift elliftifden ober fdyeibenförmigen, im Serbältuifs j"l ben llebrigen febr furgen 2 sinmern, bie alle, wenigftens wäbrend

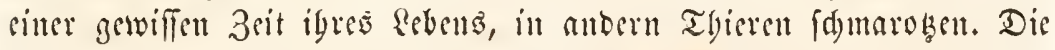

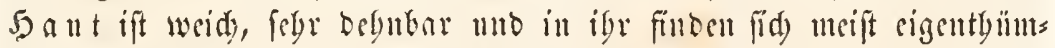

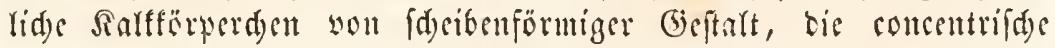

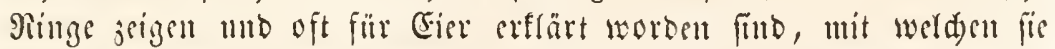
burd)ans nidyts gemein baben. Die bant unt oer ganje siörper find änjer contractil und won eincm majdenförmigen Minfelgewebe

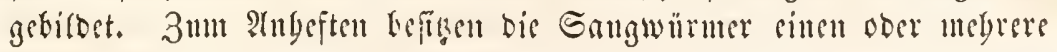




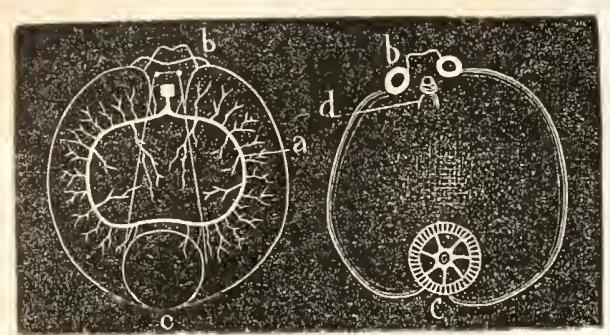

Ti.j. 195 นnо 196. Tristoma cuccinem

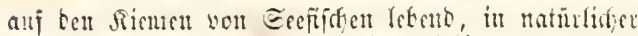
Bröße. Fig. 195 Das unverlebte Thier wou nutent,

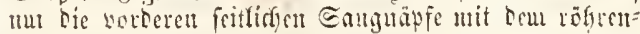

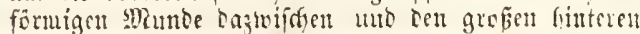

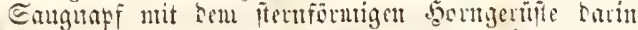

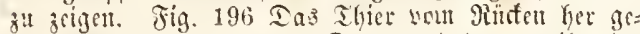

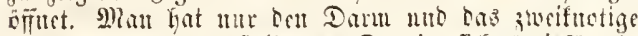

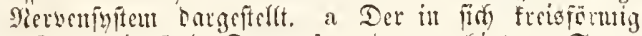

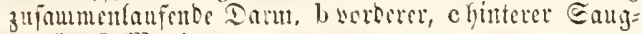

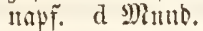

 oft nod wen bornigen (5) riiften und innern Sation unterfitint wers ten, niemars aber foldae bafenriilles, wie bic Bantwitumer baben. Bei eimigen Gattungen entryät Der am yordern Ende deà Reifes gele= gente, meift ftrinere Eangs napf jugreid) ben Diunb. Dic librigen Sangnäpe find unourdbobrt, auf ber Baud)fäd) ober an derm Sinterende des \&eis bes angebrad)t unt mandjmat ferbit in grofer atuzugl vorbanten. Dicie bintern Eangnäfe find Damn zumeilen mit eigentyümliden \$orn= geriffen und Dafen verfeben, bie interlyab der Sauguäpfe ferbit an= gebradst füt. Bei vielen Sangwïmern fommen aud) nur Gang= gruten vor, Dic zuweilcn z" cincm förmlidy gegitterten Rebe an ber

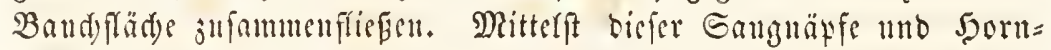
geriffte beften fid) bic Sangwürmer fowobl an ben intern alö an ben "upern Drganen nuberer Thiere febr feft unb entgeben baburd and zicmlicy reidyt fer Radofordung. Das Rerwenfy ftem beftebt aus

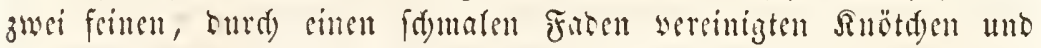
liegt bei ben Gattungen, die einen worbern Mund balen, auf ber Bandjeite bes Sd)luntes, bei ben ührigen an ter entiptedendon Stelle. Die beisen Gritenfäben, welde mad) binten geben, find nur Dünn unb jart, laffen fid) aler meift ourd) ben ganjen Rörter yer=

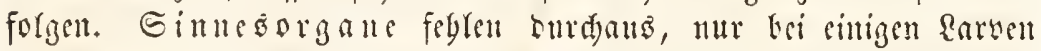
ober ammenartigen $\mathfrak{x e f e n}$ Gat man Sigmentflede gefcben, beren $\mathfrak{B} e=$

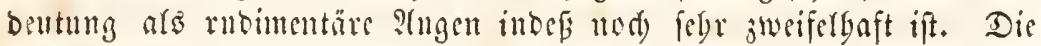

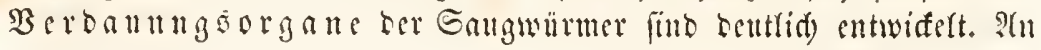
bem Borterente bes Reifes in ber Mittellinic, meift etras anf ber

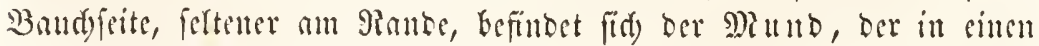
bald rängeren, Gald fürzeren meif graben, zuweilen gefd)längelten

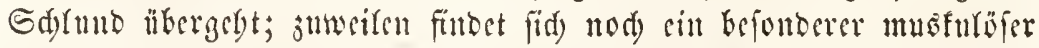
Sdylundforf, niemars aber ein eigentriber Magen. TAm Ende bes Sdylunbes theilt fid nämtid) ber Darm in zwei gaterförmige 2lefte, 


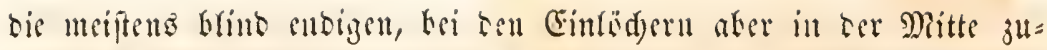
fammenlanfen, fo baß ber Darmfanal sinen fïrmliden Sierio bilbet. Rur bei einigen wenigen mob in igrem ganjen Berbalten febr abwei= denter Gangwitmern finbet fids sin sinfadser graber Darmfanal, ber aber ftets afterlos ift. In ben meiften föllent find bie gatelfïr migen Darmfdy länd)e cinfadye blinte Gäte von meift gleidger 2 Bsite, rft aber geben won ben beiben Santefiümmen febr viele werjweigte Rebenäte aแs, bie fir burd) ben ganjen Sürter serbreiten unb

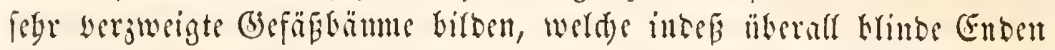

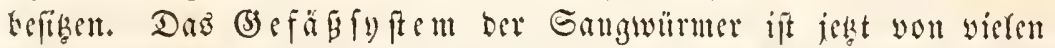

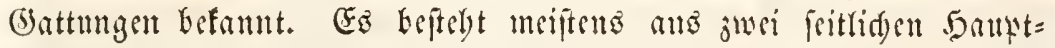
främmen, bie fid in ber Mitteflinie vereinigen un in ibrem Gunern Jimmerbewegnngen zeigen. Sn ben miften mo bänfigiten Fälfen

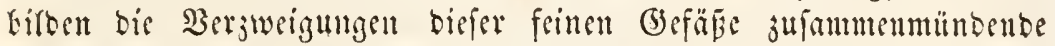

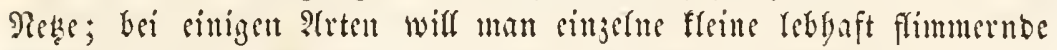

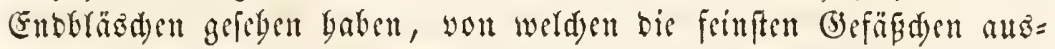
geben. Fud bat man bier cin mitteres, an bem Shinterleibsente ge=

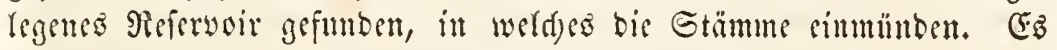

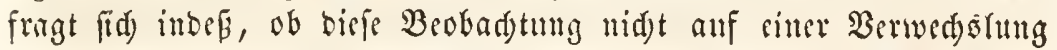
mit einem eigentbümliden Drïfenorgane berugt, weldes fajt bé allen Gangwirmern fith an bem bintern Enbe offtet, ans cinem sins fad)en gabelförmigen ober aus veräftelten Sd)ländyen teftebt, unb eine

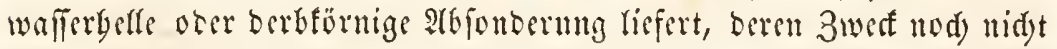

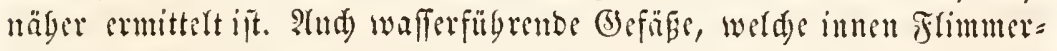

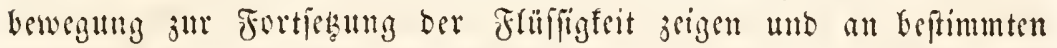

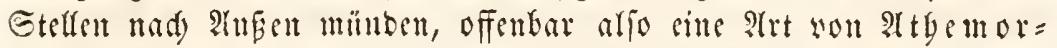
ganen baritellen, bat man bei mandyen Eangwürmern entbeft.

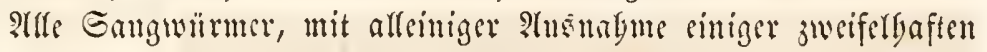

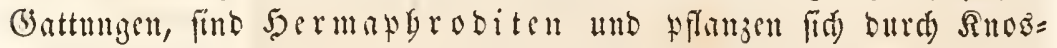

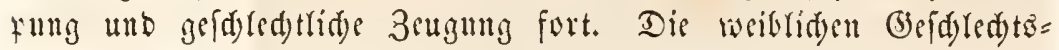
theife negmen meiftens ben größten Theil Des Reibes ein unb baben merfwillbiget SBeife bejonbare Bifoungsiftätten für bie cinjelnen

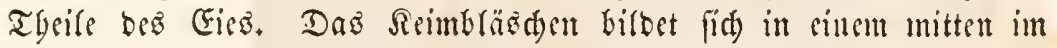

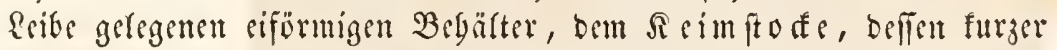

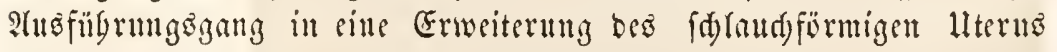

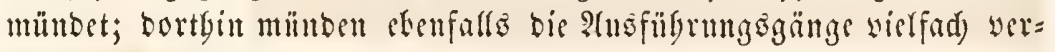

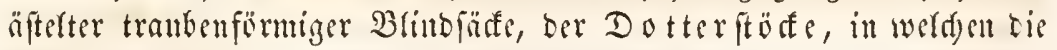
Dotteriubitanz gebilbet wirb. Dotterförndyen uno Seimbläв d)en treten in

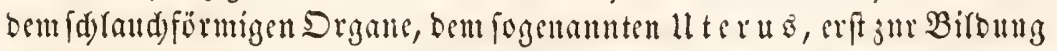

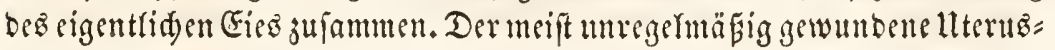
(d) laud) mündet gewögnlid an bem Borberranbe bes Förperō binter bem 


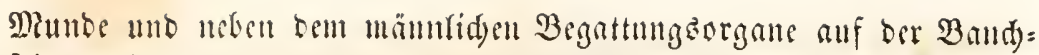
feite mad) angen. Groer Gangum entbät anberbem jwei 5oben, bie imeiptens bintereinander liegen und won welden jwa Gamenteiter abgeben; ber eine in ein inneres Gamenträsdyen, werdyes in ben

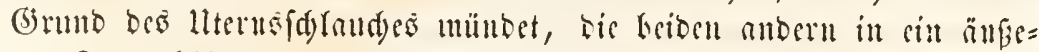
res Gamenbläsd)en, weldyes furd) eincn rangen bang in tas $\mathfrak{B} e=$

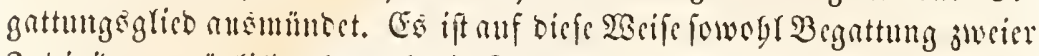
Jnbivibuen mïglidi, ars and) bie Gelbitbefrudbtung ber in eincm Jnbiri=

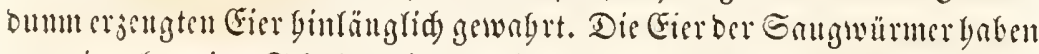
unr eine bornige Sdyare, bie juweilen mit cinem Deffer aufpringt; fis find mrift eiförmig, brämlid), batt uno bei sinigen Gattungen fo

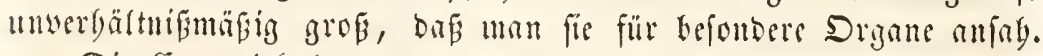

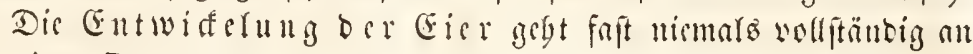

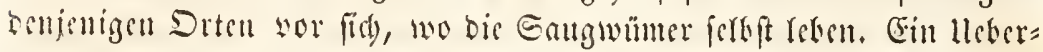
wanbern nad) anbern Thieren fdeint faft eine Rotbwenbigfeit für bie Sarsen unb Stmmen, fowie für bie Jungen, weldse fids unmittelbar

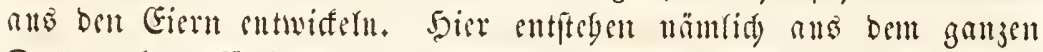
Dotter platte Cmbryonen, weldye meiftens mit Simperlyaren weriegen

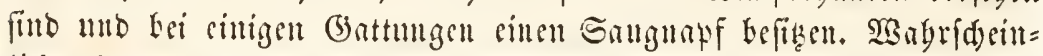
lid) ergarten biejenigen Embryonen, weldye sine Zcitlang in bem $\mathfrak{x}$ nffer frei umberfducifen mulfen, SBimperbaare, wäbrent fie anbern, bie

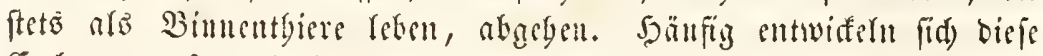
Gmbryonen fo weit im Itterns, bas fie bort fdon bie Eifdale ver: laffer unb lebentig getoren werben. Fïr bie weitere atukfloung be=

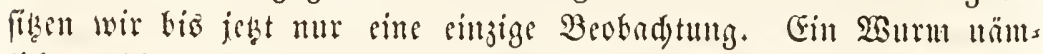

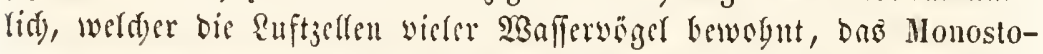

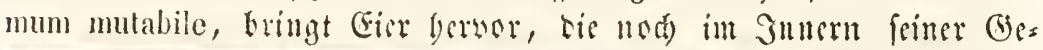

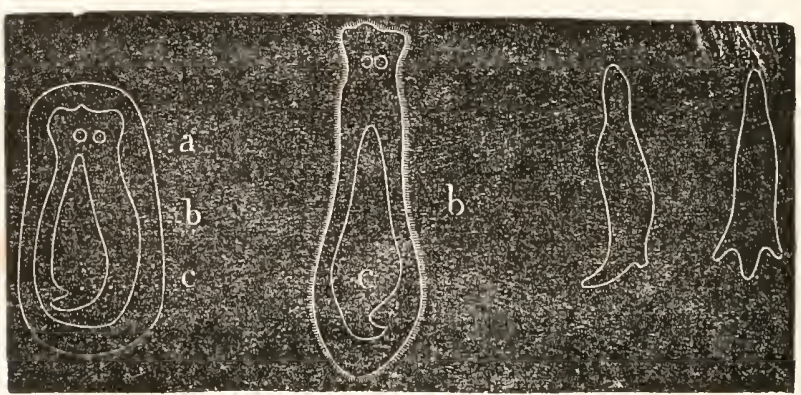

Jig. $19 \%$. oin 198 . Jij. 199.

Ammenjengung เeళ Monostomum mutabite.

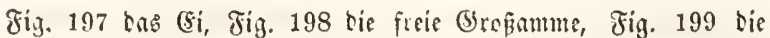

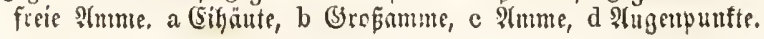

(d) ledotstbeile fid entwiafeln, fo safer julchetefor lebgnft fduwim= mente Jumgen ( (5rofanmen) gebiert, bie in bem Raden fo= gar önei ?lugen= funfte babell unb in berengmerem (id) $\operatorname{cin}$ (d) (aแd)= artiger Rörper 


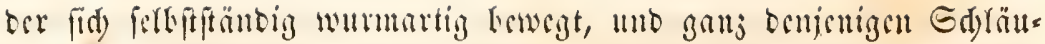
d)

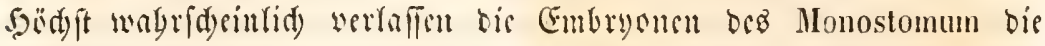
\&uftwege ber Bägel, wägrend bieje im şaffer fint unb bringen ban

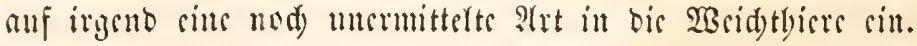

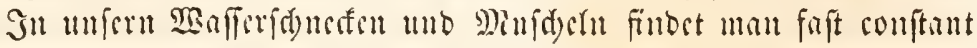

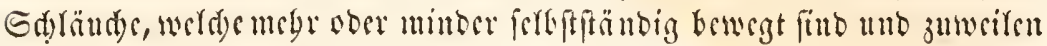

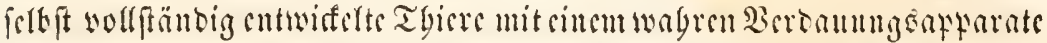

Jig 211. 210.

209. 208. 20\%. 206 .

205.

203.

202.
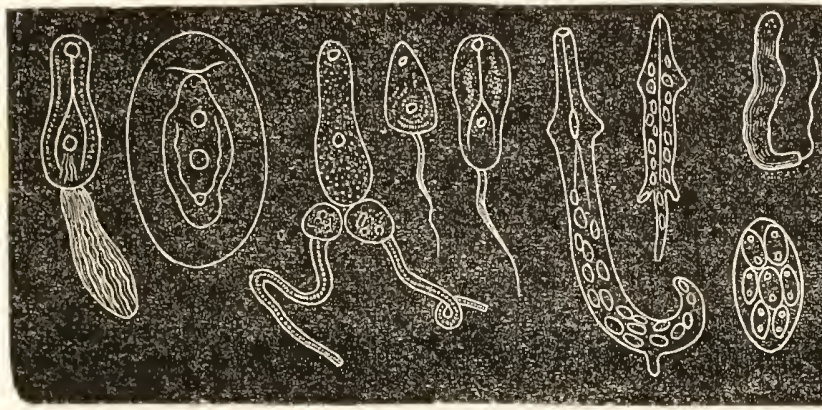

201.

201.

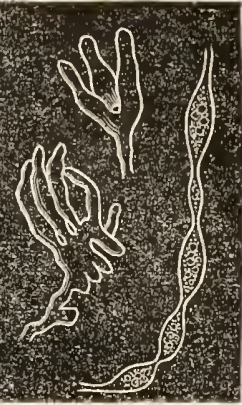

200.

Fig. 200-206. Sicimfdylündye unD Stmuten. Fig. 207-211. Die Darans

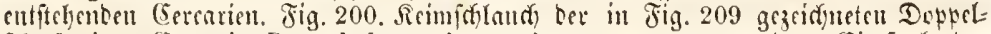

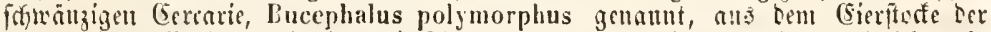

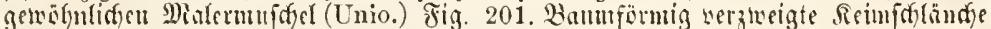

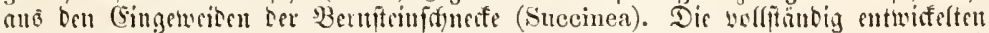

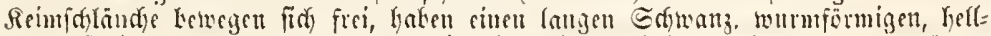
gringeftreiften forper mo wurben in biefer Form (Fig. 203) Lencochloridium paradoxum genamt. Die barin enthaltonen Eertation (Fig. 210) faten sinen

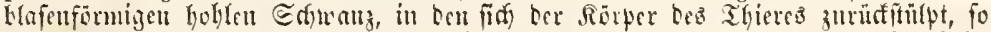

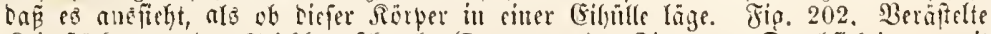

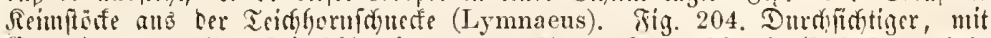

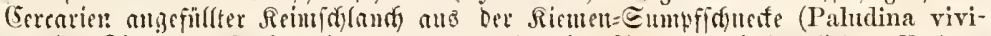
para). Fig. 205. Eebraft berwegte murmförmige 2 tmmen mit rentlidgem Berban=

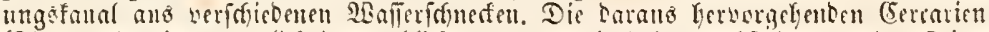

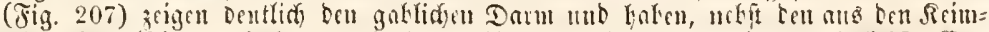

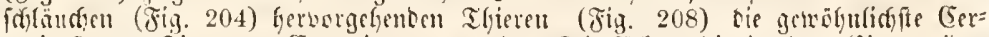

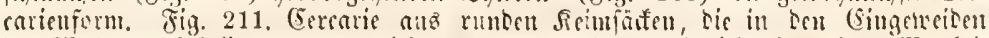

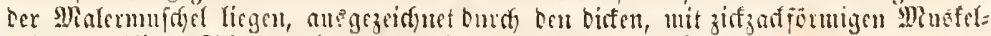
fajern erfïlften Esfuan; (Distoma duplicatum genamt.)

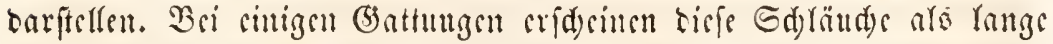

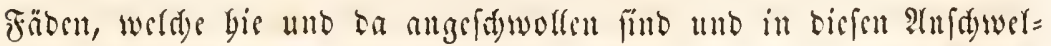
lungen burd) Sinosłung sinc Menge you Sungen erjengen. Meift

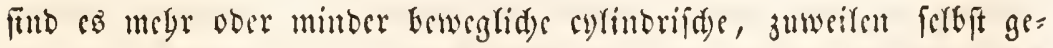
\{d)wängte Rörwer, bie fid mandmal lebbaft bewegen, und oft 
förmlidye Berbannngsorgane uno sine fo compricite innere Bito bung zeigen, bás man mandse biefer stmmen für feleftftändig or=

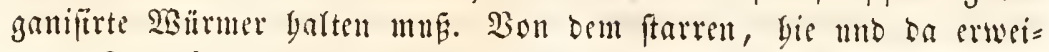

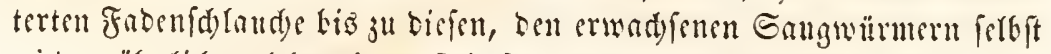

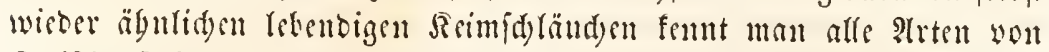
3wifdenftufen. In allen bisen 9mmen firben fith aber bis Sungen

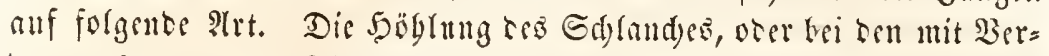

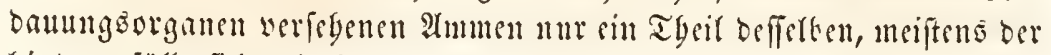

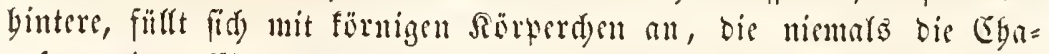
raftere sines (Firs an fid tragen uno nad) und nad) ju einem wurm=

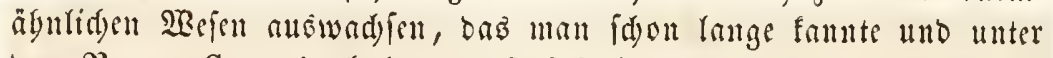
bem Pamen Cercaria bald ben Snfuforien anreibte, bald ferbft mit bent Samentbierden zufanmenbrad). CEs befteben nämlid bie faft mifroflopifden (ercarien nad) igrer wollfänoigen atustitsung inner=

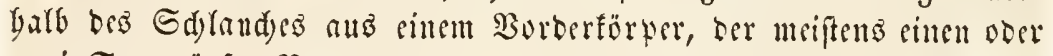

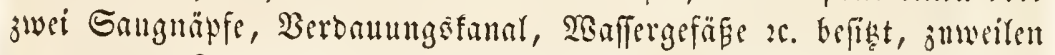
sornen am Sopfe mit Sornfpizen verfegen ift unt cinen vorffänbigen Saugwurmteib barfeflt, und sinem fdwanjfürmigen atnbange, welder bei ben meiften cinfad, bei ciner befannten art boppelt ift. Sobalo bis Cercarien fo meit entwidelt fint, fo bred)en fie aus ibrer enume,

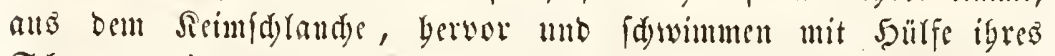

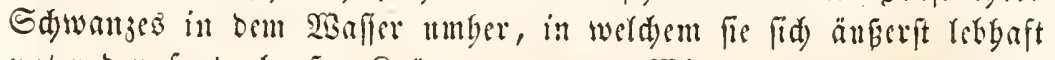
unter ben fonberkarfen Sirummungen und șinoungen unbertumueln. Man brand)t in Sommer nur einige SBafferfonedfon in sinem Bfafe

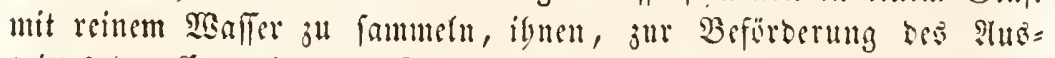

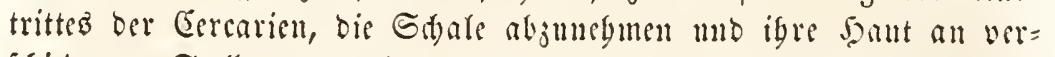

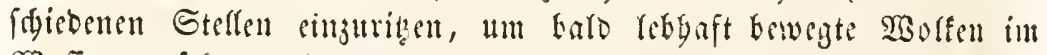

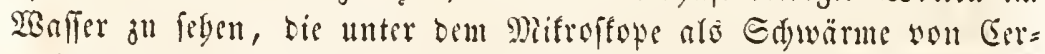

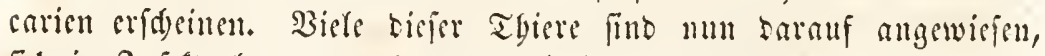

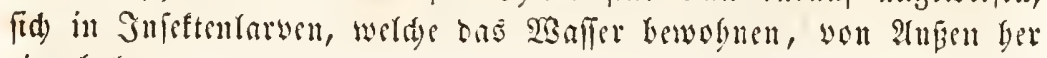

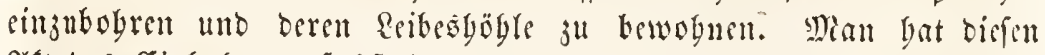
Ifft bes Ginfolrens ferbft beobaditet, wobei die fpitzigen Stimmaffen

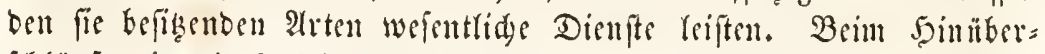

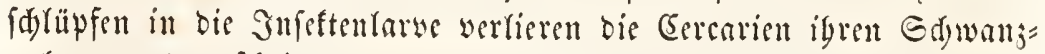
anbang und eridsinen num (d)on in ber form von Gangwïrmern.

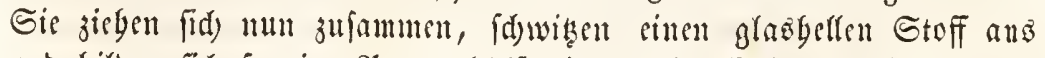

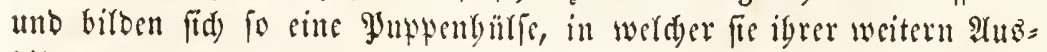
bifoung entgegen gelen. Gewis erfolgt biefe erfit, wenn bie Rarven sollfommene Snjeften geworben fimb, ober aud bann, wemn fie von 


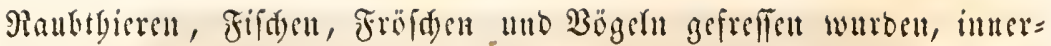

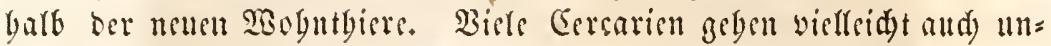

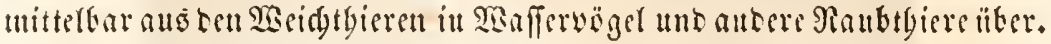

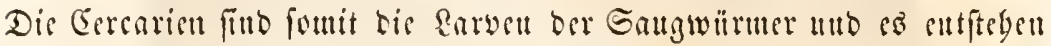

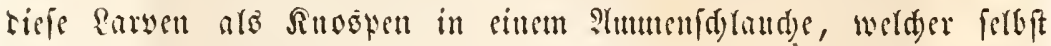

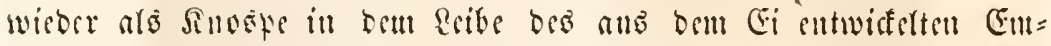
bryo entftatb. Sille biefe wutbertaren seandungspabien geben in

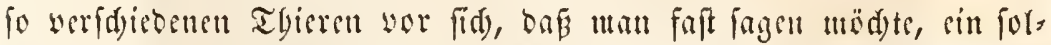

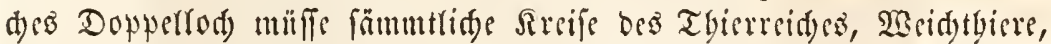

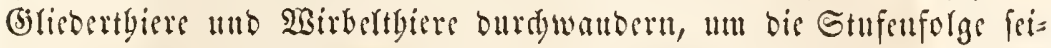
ner ?tusbiroung ju burd)hufen.

SSir tbeilen bie Saugmirmer nad ber Ratur, Strflung uno Befdaffengeit igrer Sanguäpfe in brei Famitien: Die Doppellöher (Distomida) Gaben ein ober jwet Ganguäpfe, you welden ber norbere alö Mund bient, wälgrento ber Gintere utrift größere, balo sort, baro utchr in ber Mitte, barb binten an been Rörperende reget ober and ganj feblt. 3u biefer Fantilie, bis in ben Gingeweiben, ja felbft

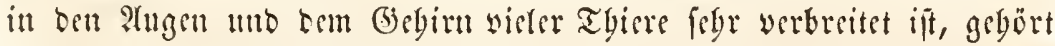
tratuentlid) Der Eeferegel (Distoma hepaticum), welder bejonbers in Den (ba)llengängen ber Sdafe auberorbentlid) yäufig yorfoumnt. Die joweite Fantilie ift ticjenige ber Dreilöber (Tristomida), bei welden



Jig. 212 un 113. Tristoma coccineum.

3u beiben Esiten bes Piundes juci fleillere

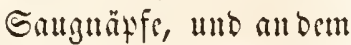
Gintertl Fube sin gro= fer, meift runber Gaug= napf eriftirt. Manu findet

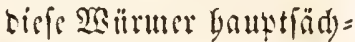
(id) mur auf ben Siemen won Fifden. Entlidi Dis Familie ber Biellöefler (Polystomida) bat ftets Gintere grofe Saugnäpfe, welde wou sinem

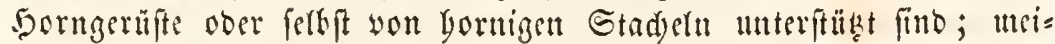
ftens feglen bie vorberen Sautgnäpfe und wenn biefelben vorlganben 


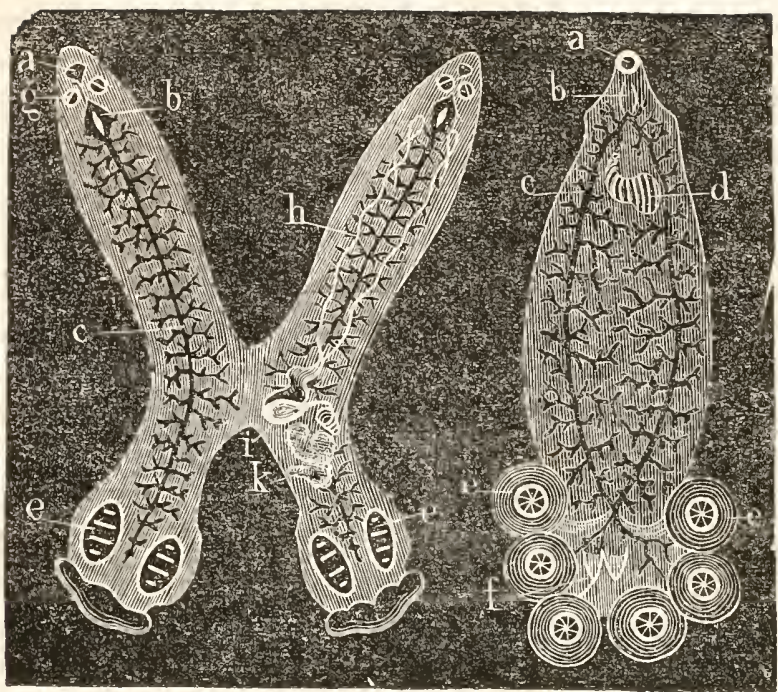

ชิti. 215

Jig. 211.

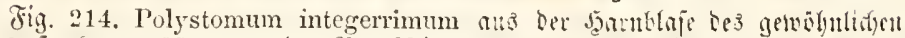

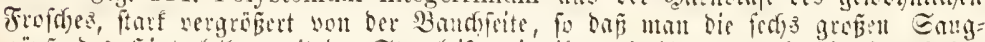

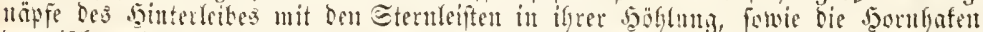

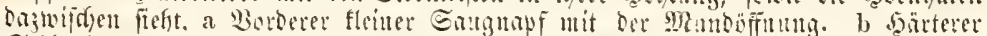

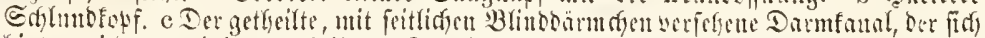

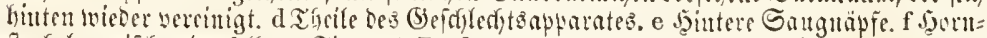

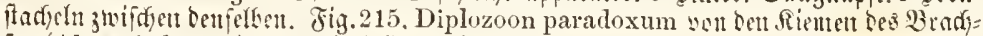

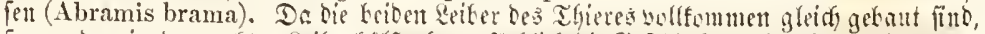

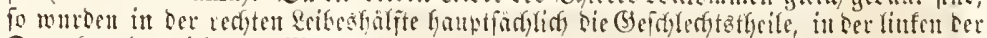

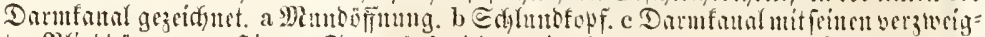

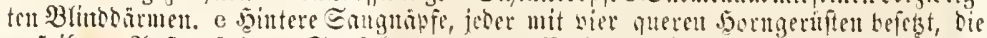

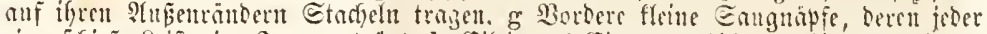

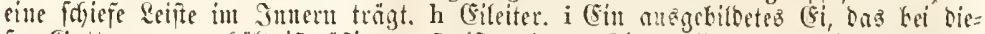

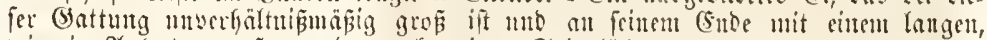

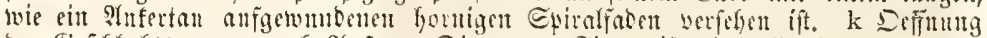

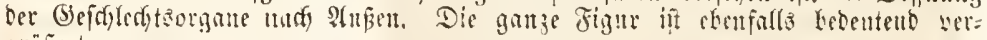
größ̈ert.

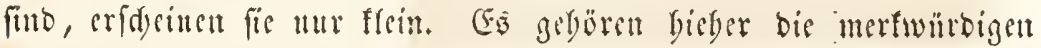
Dopkelmüruer (Diplozoon), wot benen mérere strten auf ben Siemen

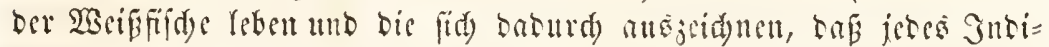

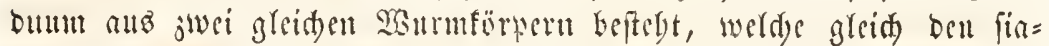

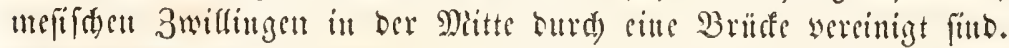

Biele STrten und Gattungen son Gambmürmern werben wabl:

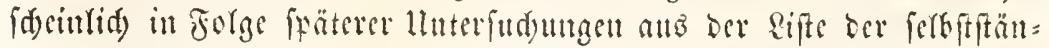
bigen Thiere geftriden werber. Go wurbe erft ueueroinga entoeft,

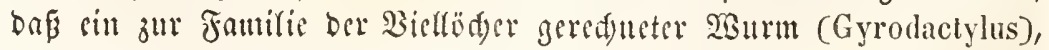

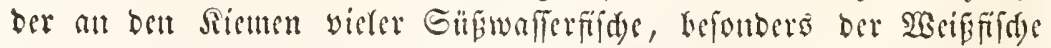
und Stidylinge lebt, nur sitte Entwidflugsfute ift, bie fid) ftets burd)

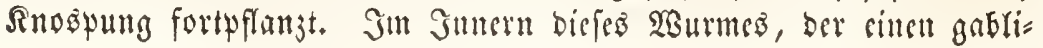




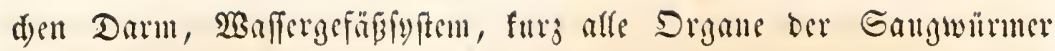

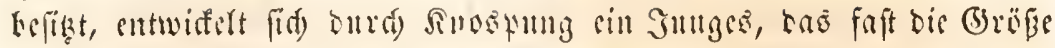

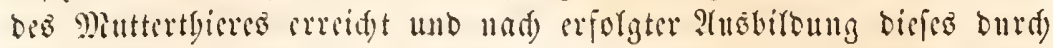

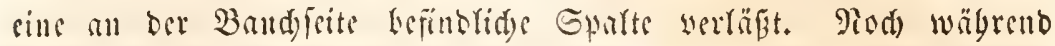

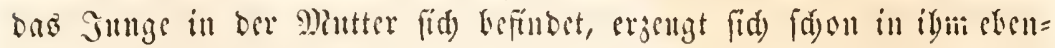

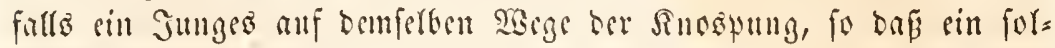
d)er trädiger S⿱⺈ Rcibe trägt. Die weitern Edjiffale siefer Wärmer find nod unbetannt.

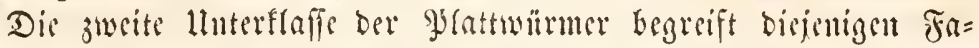
milien, weldye fref reben und anf bem ganjen rïrter sinen augges zeid)neten finmmeritbergug befitsen, ber meifteng igre Bewegung im 2arfer wermitteft.

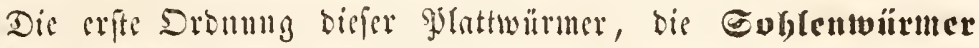

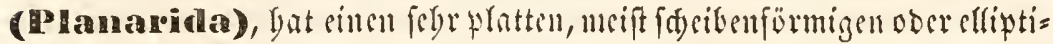

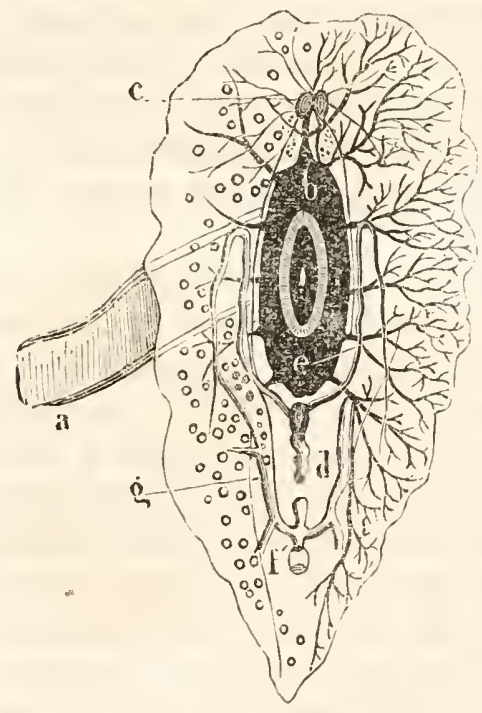

Fin. 216

2hatomie einer \$(amurie.

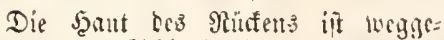
nomment. a Edylutiorilyre. b Magent= holde, you welofer bifle betziveigte Blitto= Därme augehen, bie mur auf ber redgten Seite gezcidyutet find. c Shervenfyiftem, Da=

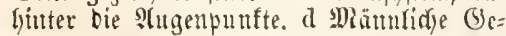

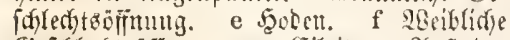
(3) linfen Eette pieft man Den (sifeiter mit (5iern angefullt, Die auperbem iut Servetse zerptrent finto. (d) en Sïryer, an weldsem fid mand)= mal simjelue lappige Thbänge zei= zell und ofr sille aufierorbentlidye Eontractilität befitzt. Das $\Re$ er ven (3) fite beftebt ang jued enge zu= fammenliegenden, oft yerid)morgenen Sinoten, you weldyen aus ziwei

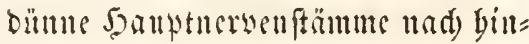
ten Yaufen, Die feine Sinötd)en ou befizen forillen. Ith bem vorbern Enbe bes $\Omega \ddot{u}$ ipers befintot fid) oft eine grofie 2 (njabl won alugentunt = tell, Die meift Durd) gुigment fdwar gefärbt find und in beren man sille runbe Sinfe unterid)citet. Das $\mathfrak{B}_{\text {er }}=$ D a $u$ u wisfelt, zeigt aber niemals sinell Ifter. Der Muno befinbet fidy an oer Bandyflädye, bald mebr nad worn, bald ferkft in Der Mitte Des Sïrpere oder fogar binter oerierben. Fr fïbrt bei ber sillen frmmilie in

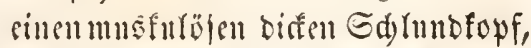
in wefrem sine äuferft bemeglide Ed)lunbröbreverborgen liegt, bie beim Jreffen beryorgeftereft werben fann 
unb oft länger alo ber Sörter ferbit ift. Bei ben meiften Giattungen Gat biefe rifferartige Edylubröbre sitte runbe Defintmg, bei anbern

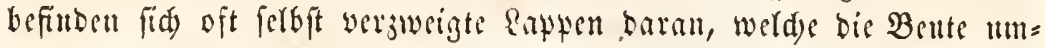
faffer. Diefe Edflubrögre fülyt in eine mebr ober minber runbe

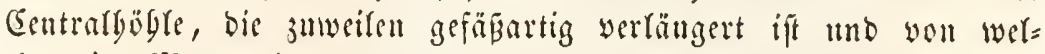
der eine Menge baumartig veräitelter blinbenbigenber 3weige ans: geben, werd)e ben ganjen Reib burdjieben. Bei ber allbern Familie finbet fid unr ein einfadyer geraber Darm ofme Gdylunbrible und after. Das (5) fäß contractilen Blafe, von weld)er aus feitte biefäpe fíd in bem siöper metgartig werbreiten. Alfe Goblenwitrmer find Sermapgrobiten

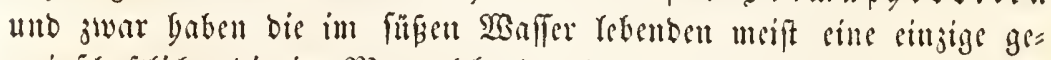
meinidgaftlide, bie im Meere lebenden bagegen gejonberte Deffunngen

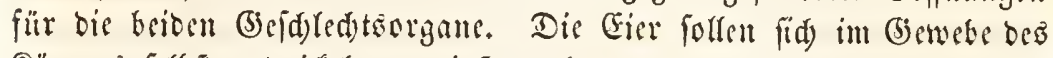
Rörpers felbft entwiffeln, wenigitens bat man bis jelgt nob feinen be= fonbers abgegrenjten Gierfor wabruclumen fömen. Sie gelangen in

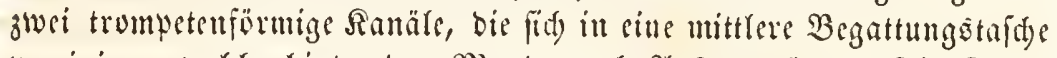
vereinigen, weld) binter bem Munbe nad) 2 trgen münbet. Die $50 b e n$

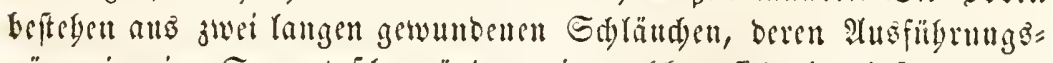
gänge in sine Gamentalde münocn, in welcier fid) sin einfad)es $\mathfrak{B} c=$ gattungöorgan befindet.

Die Ertwiffung ber (5ier weidyt auf nod) unerfläte $2 B$ eife yon

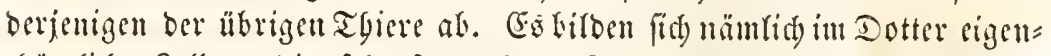
thütmlide 3ellen, die fegr fonberbare felbftiändige 3ufanmenjiegun: gen jeigen. Rad einiger Zeit bören bieje Bewegungen auf, bis Zellen fliefen bie unb ba jufammen, bilden Gnjeln von Dottermaffen it unbe= ftimunter $3 a b l$, bie fid aflmäblig abgrenjen, mit Simperbaaren tibers

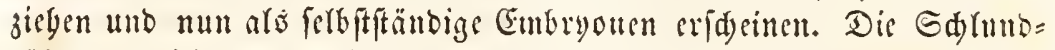
röbre entwiftelt fid) bei biefen Embrenonen juerft, werid)luat bie nod übrigen Dotterzellen uno nun plattet fid ber frïber fugelförmige Gut:

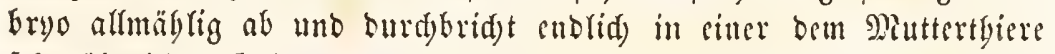
febr ägnliden beptalt bie (Fifdale. Se mebr (Embryonen fies in cinem Ei bilben (wovon ibre $3 a g l$ abgängt ift nod) cin Rätbjel), befto fleiner fint bie fleimen Goblemwinmer, wenn fie bas Gi verlaffen.

Sir unterfdeiben bei biefer Dronung zwei Familien. Die sine Familic, bie Schmarzwürmer (Rhabdocoela), beftebt aแb mebren, meift febr unvolffänbig gefannten (5attmigen, bie alle cinen geraben, after= rofen Darm, feine Reflelorgane in ber 5aut und eitten glcidförmigen

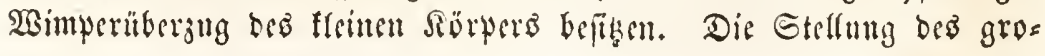


Fen, mit feiner Sd)lunbröbre verfebenen Munbes wedjelt febr. Die (befd)ledstatbeife fint, wie bei der folgenten Familie, Germaphrobitifd. Sie finben fint int füben 2 saffer wie int Micere.

Die zablreiden Gonttmingen ber sigentliden Soblentürmer (Planarida $s$. Dendrocoela), bie man befubers nad) ben füblerartigen Anbüngen des Rörpers, fowie nad) 3abl uno Gtellung oer 2Hgen

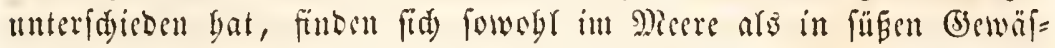
fert febr bäufig auf Eteincn mb saffertfanjen, wo fie mit groper Sd)nelligfeit cinberfrieden tho fid) son mifroftopifden Tbierd)en tub SIflanjen nägren. Sie erreidgen nur eine untebentende Gröpe und bie befleren Strten fint oft nidgt leidyt ju finben, ba fie fid zu einem

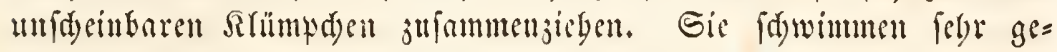

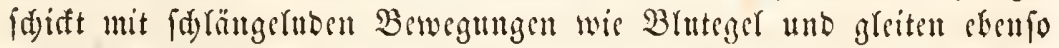

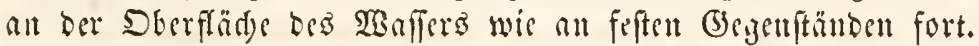

Dic Drontny ber Ģunrwärnter (Nementina) begreift meift jiemlid) lantg geffredte plattgebrücte 2 sürmer, von weld)en einige 2lrten eine ungebentre Sänge erreidyen. Der Sörper ift platt wie sine Gd)แr, glatt unb ourd)aus mit flummernben SBimpern bebedt, feite Bontractilität augerordentlid) grof. Das Rervenfy ftem beftebt bei oer böberen Familie aus zuvei feitliden, meift ziemlid bebeutenben Ruoten, bie aus megreren anfdwellungen jufanmengefest finb unb Durd) einen breiten Serfindungsitrang auf Der Baudjeite vereinigt werben. Bon biefen Sincten aus frablen Rerven nad vorne und jwei jientid Gedeutende Sanutnervenftränge laufen läng ben Seiten tes Rörwers nad) binten. Die cbenlo wie bei ben Goblentwitmern gebauten $\mathfrak{A}$ ngen finden fid) num vorberen Ende bes Ropfes unb außer

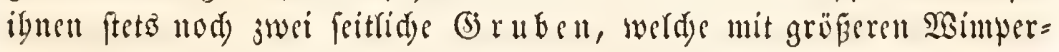
baaren verjeben fitto als bie übrige Santoberfläde, beren Bebentung für tie Defonomie bes Thieres aber nod) nidgt enträtbjelt ift. Der Berbau ung a aparat erfdeint bei ben beiben Fomilien biefer Srb= nung verjdieben getildet; bei ben Struberwürmern fübrt ber an ber Bandjfäd)e befintlid)e, balo mebr vorme, bald weiter binten angebradjte Mntul in sinen cinfaden Darmfanal, Der gerabe nad) binten länft unb nut binteren Enbe in einen engen 2rfter enbet. Bei ben eigent= lidyen Remertiben bilbet ber Mimb cine \&ängsjpalte, bie in simen ge= räumigen Darmfanal fübrt, ber ganz gerabe vertäuft, viele ringfür= mige Einfdnürungen befitgt unt ebenfn!(B nad) binten in sinem 2lfter entet. Bei biefen Thieren ift liber Dem Barme unt unabgängig von Demielben eine an vorberen Enbe des Rörpers geöfnete Räre ange= 
bradyt, welde cincen oft bebeuteno langen Rüffel entbält, Der nad)

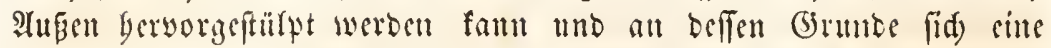

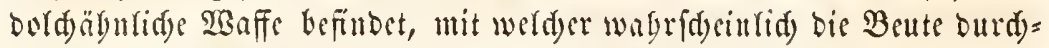

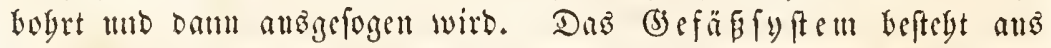
jwei feitricfen unb sinem mittleren, anf ber Piüfenflüd) verfanfenden Strume, in benen sitte lebbafte Shmmerbewernug lemerft werben fant mub bie fid) vorn unb binten burd Dueridylingen vereinigen.

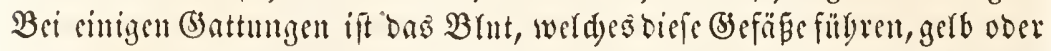

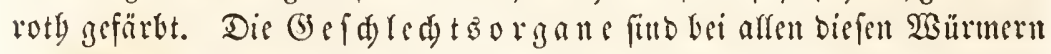

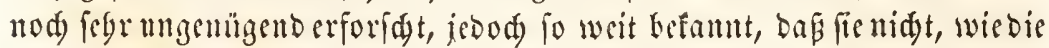
Soglenwürmer, Sermaphrobiten, foubern cingeddeledtige Thiere find, beren (Seld)led)totbeile fid) meift periobifd) entwifeln. Bei ben nieber=

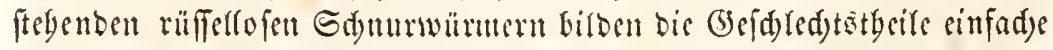
Säne, in benen fids Gier ober bödst fomberbare Samentbierden ent= wifeln. Bei ben cigentliden Remertiben fdseinen fie aus trauben=

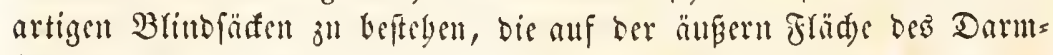
fanales anferten mo die bei Dem einen Snoivibum Gier, bei bem anbern Samen erjengen. Die entwifferten Sier fallen in feitlid) Räume und (d)einen burd) Deffmungen au ben Geiten uad) Ausen ju gelangen. Begattungsorgane bat man nod nidjt gefeben. Die Eier werben in Sdüren gelegt und es entwiffelt fid in ignen aus jebem Dotter,

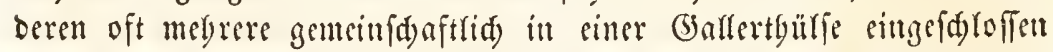
fint, ein rumblider, mit Simpern verfebente Simbryo, Der uad sini= ger 3cit bie Sallerthulffe Durd)brid)t. Diefe Embryonen faffen in igrem Inneren sinen bunfleren Siern wabrelymen, oer fid barb fdärfer ab= grenjt und eigene whrmförmige Bewegungen mad)t. (Enblid) Durd $=$

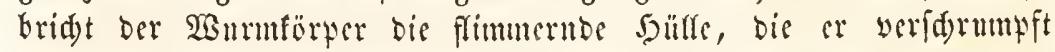

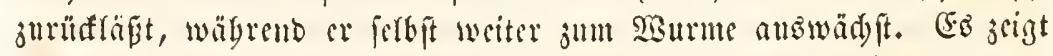
fï arfo bier cin ganj älntider grojera, wie bei Den Embryonen ber

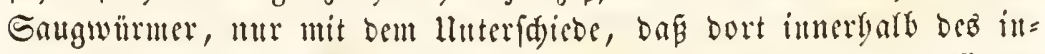

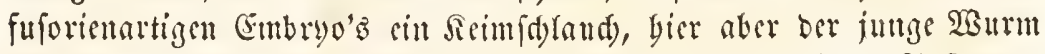

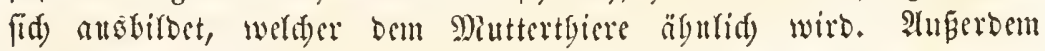

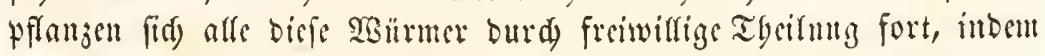
Der abgefdnürte sörpertbeil zu eillem neuen Thieve auș wäd) 


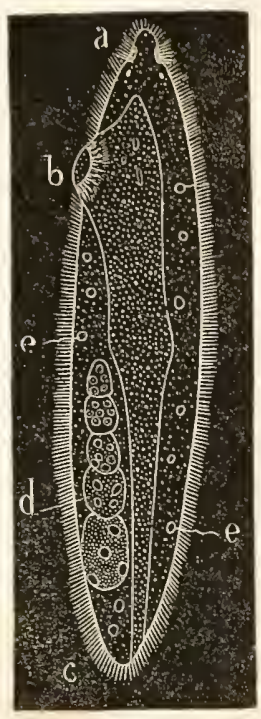

Jig. $21 \%$

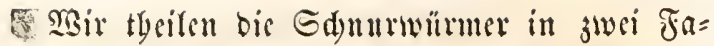
milien. Dis sinch, bis rinfestofen Echnurwär= mer (Hicrostomida), meift łleine fdjwimmente Sลี艹

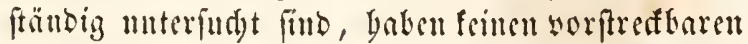
Plüflel, sinen geraben Darm unb in ber Sant zerftrente Reflelorgane ägnlid bencu ber Afrmpo= rapen. Der ferre ausbebubare Mimb regt meift fritlid) aut vorberen Rörperente. SGren 2ngen= Funften feblen bredsente Debien; Rerveniyfem, Be = fäвiglten fint faum in Epuren sutbraft. Die cigentfiden Sdhunrwürmer (Nemertida) lings= gen baben sinen voridiebbaren Riulfer und jei= gen alle jene antomifiden Gigentbümlidfeiten bes Bancs, beren wir bei ser Dromung erwägn= ten. Ulnter biefen gicbt es Gattungen, wie bie Borlasia, bie an ben Sïliten won Englant und Franfrcidy sorfoumut, weldye eine Sänge von 50 Microstomm tineare.

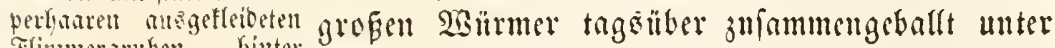

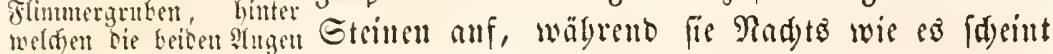

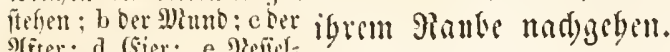
Pfiter; d (Sier; e Preffirt-

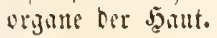




\section{faluffe Der kiüierthierchen. (Rotatoria,)}

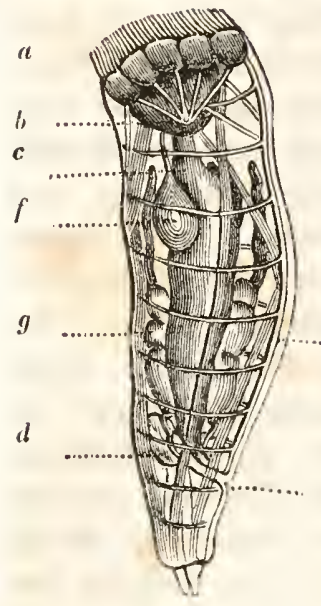

Sig. 218.

Shrer mifroffopifden Sirinbeitwegen, (bem

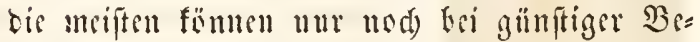

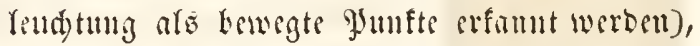
Lat man biefe Thiere früber allgemein zu ben Sufuforien gef́tellt, bis man igren fo befontero eigenen Drganifationsoplan gennuer crfant Gatte. Epäter entftanden vielfade 3weifer über ${ }_{h}$ ilye Eterfung mo mandje Foridjer glauten fogar, fie ber Siruftentbieren bciorbuen ful fol= Ien. Shgleid) aber bei ben meifter (battun=

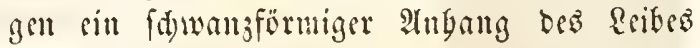
e eriftirt, welder gegliebert erfdecint, fo ift in= beffen bod) biefe (3) licberung unr in ber gemögn= (id) bei ben sisürmern yorfoumenten form worlyanden, inben bie eingefnen Brieber des

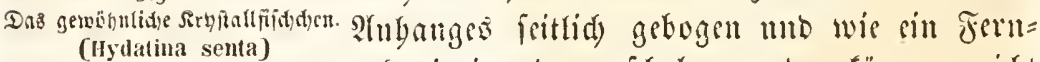

Fefye furf wergusiert. a bie im Rerife um ben sisun ge= ftellten Räberorgante; b Der Ed)luntenf; c Der s!nagen: d Cloafe; e Tfiter; $f$ Epei= dfelorüfen; g Stertiote; h Falten ber jount, bie für $(5)=$ finge angefeften wuben. roge incinanber gef d ob en werben föm aher Dumd fërmlide betenfe mit cinanber ver= Kunden find. Gine Gtellung muter ben Gitis= berthieren, beren Beweenutgöorgane ftet wa wate (serenfe jeigen, iff benmad) fdjon ans biefent (Sormbe unitattlaft. llebertem entfernt bis

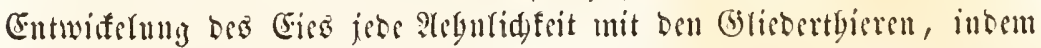

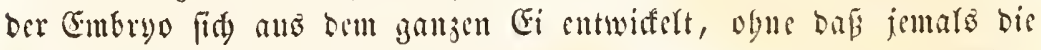
geringite Efur sines ben giärfen jugewanden Dotters vorbanden wïrs.

Der $\mathfrak{R}$ är

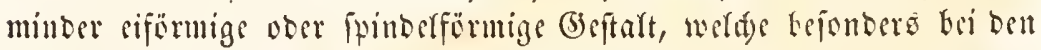

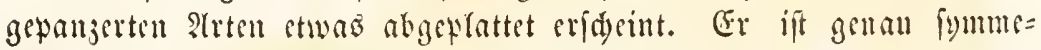

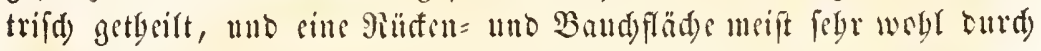

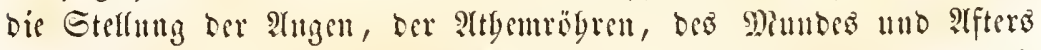

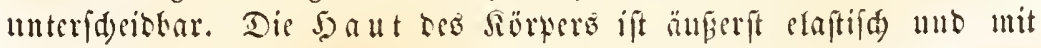

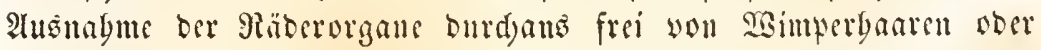
ägntidgen Stngängen. Bei siefen Atrten fiegt man fowogr auf bem

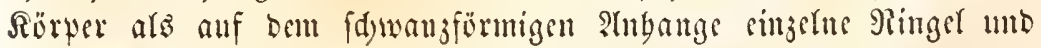

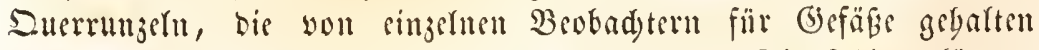
wurben, aber gewiés unr Faften ber bant fint. Die Thiere fömnen

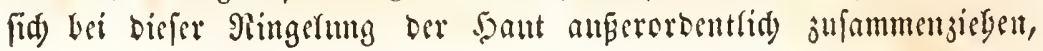




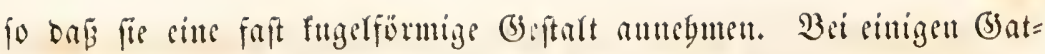
tuntgen eridecint bic 5aut wirffid) als cin Gornartiger, oft mit fouter=

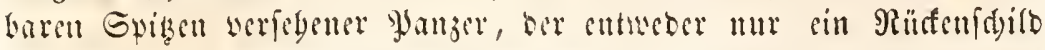

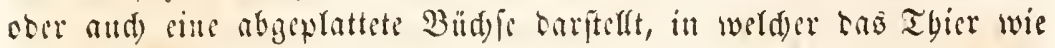

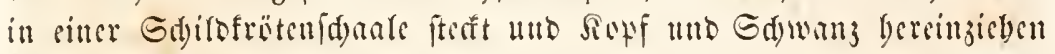

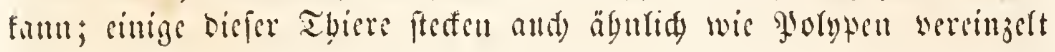

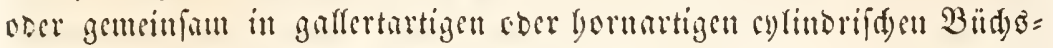

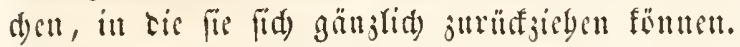

Die Räsertbiere baben ifren Mamen yon cincen sigentgüntiden Bewegungsapparate, weldyer an bem yorberen Ende, bent Siopfe,

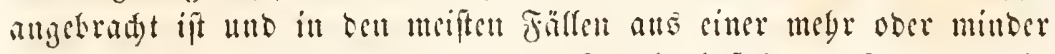
sinjichbaren sinfaden ober boptecten Gdjeibe beitebt, auf welder cin

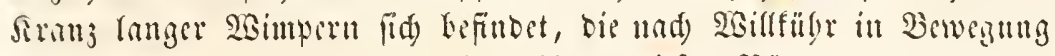

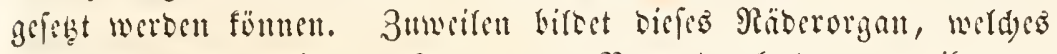
jun Sd)wimmen wis jum fangen ber Bante burd) Den von ifut er=

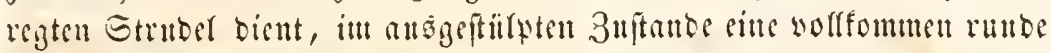

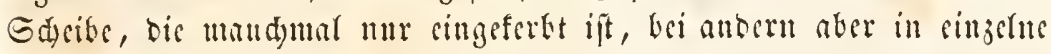
gefonterte Ră̈berorgane zarfällt. Dicfe Drignue ftégen daun bald ju beiden

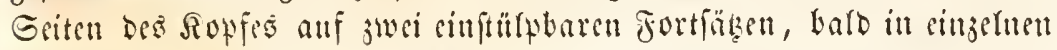
Santen, bie meifens einen Sireis bilben, juweilen and, find cigene

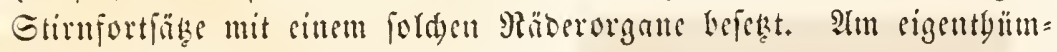

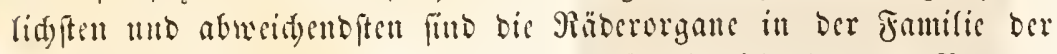

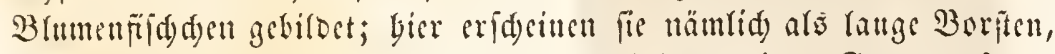
bie meifit utr träge bewegt werten unb bei ber cincm banttung fogar

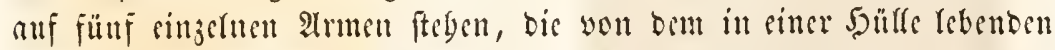

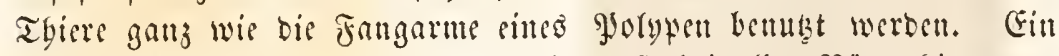

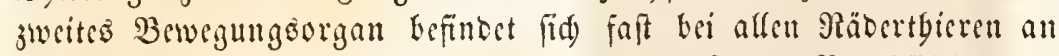

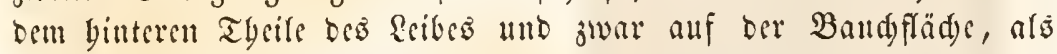

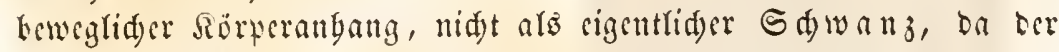

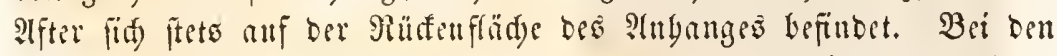

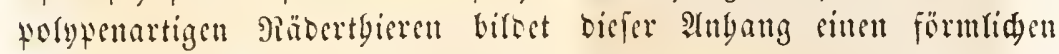
Gticl, ber an fritem Gintern Ende mit cinem Saugnäpfden werfeben ift, mitterfit befien fid) bie Theiere anbeften; bei ben übrigen (Battungen ijt es meifi eitte melye oder minter lange, fermrolrartige Berlättgerung, die an ibrer bintern Spiţe oft cine gabelfürmige Esnbigung trägt.

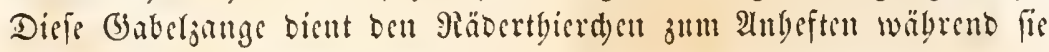

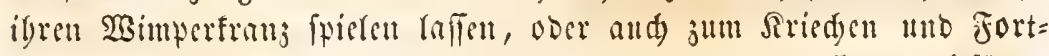

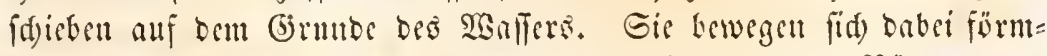
lid wis bic Gpannraupen, indem fic bei cingezogenem Präberorgaute (iid) abivedjernt mit bem Siopfe anbeften, Den (Baberfdwanz nadjsiegen 
unb baun auf biefen geftübt teu Sörper ausbelneub fortipannen. Bei

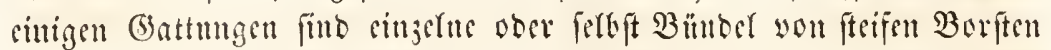

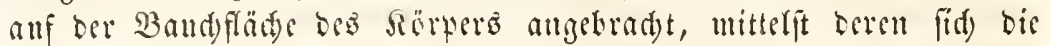
Thiere vollig fandlent unt büpfent im 2 affer fortberwegen. An ber 3afto ber Sin̈berorgane firbt man meiftens fafermaffen in Snollen= zeftalt, werde offenbar zut Bewegung ber Simperorgane diench, fo

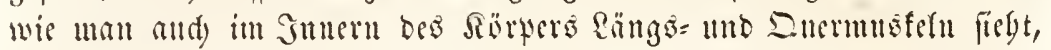
melde zur 3ufaumenzislyug beftimmt finb.

Dbglcidy Las Rervenfy ftem nod) nid)t mit alfer Deutlidfeit ermittelt ift, fo ift ood) fo siel fiduer, bab bei allen Ribertbieren cin

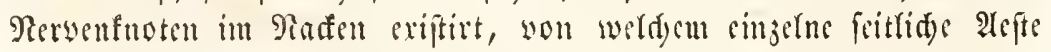

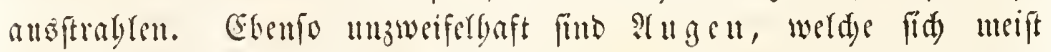
ourd rotbe grigmentflete fenntlidy mad)en, Die gepanjerten Räber:

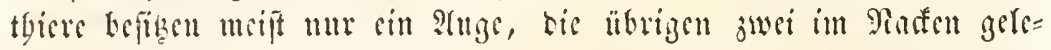
gene; unt febr felten fommen brei ober vier Alugenpunfte wor unb bet

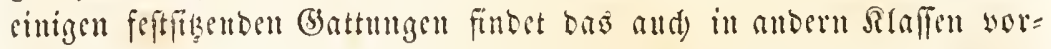

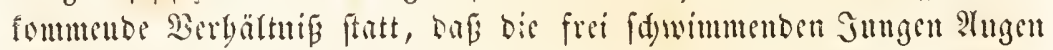

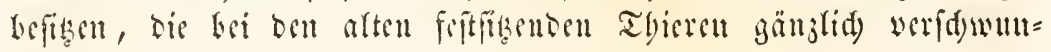
ben fint.

ชิ $22 \%$,

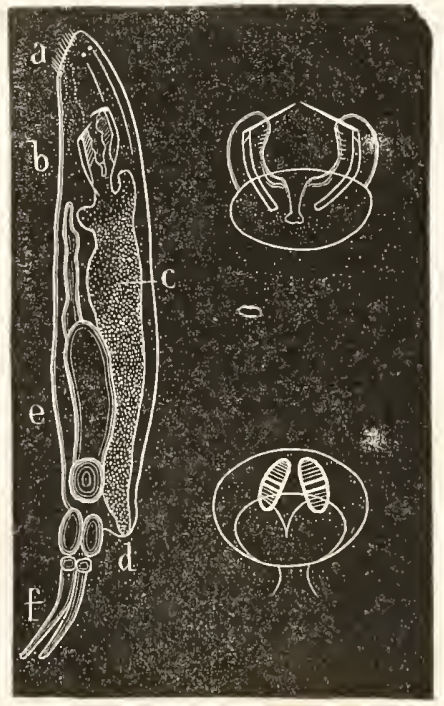

ชุ่ง. 219.

รiģ. 221.

Fị\}. 219. Diglena forcipata firef vergrifert bou fer Eeite. a bas Raberorgan, Giuter weldyem bie jwei Manfen= aitgen fids jeigent b Der mit juei fogarfen

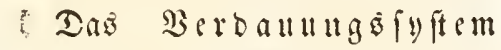
ou Päbertbiere bilbet fete einen gerneen in Eer Mittellinic gelegenen Darmid)laud, ter mit cinem beut= liden Pfier an bem Grunbe best (d)wanjförmigen Plnganges entet. Sn bem Derlanfe bes Darmfanales felbit faun man folgenbe atbrbei= Imugen unterfdeiton. Der Mamo liegt ftets am vorberen Ende bes

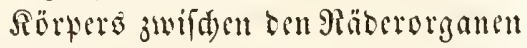
ill Folder Siscife angebradyt, taß Der erregte Etrubel gegen ifn bin= gebt. Zumeifen fülyrt ber Miuno in sine weite Mad)engoble, an beren (5) runde ftets sin fugeliger Sd)luntfopf angebtadyt ift, ber cime äuberft ftarfe Rustulatur befitut uno in ben meiften Fällen mit 3äbnen bewaff= net erfdseint, weldse nuf bornige Siefer nufgefert fint. Die Sicfer 


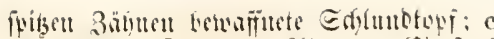
Whingen Into Darm; d 9ffter: e Girrituef f Datrlidwant. Fig. 220. Dor Edyuth.

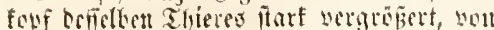
what het griegen, une bis beisen 3äfute, ifre Einfobuty in bis Risfer unto bie

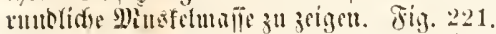
Der Edyluttofopi you Philodina citrina, wo jebe wale Ratulatte zori werptelente inere Eciftell jeigt.

Griffe kefeftigt fint. Die Gabeljälne ter leştern art werben son ben Thieren jugleid) als (breiforgane bennits, inbem fie ben Ed)lunb= fopf lebbaft aub oer Muntöfnung berworitilfen unb mit ben fdarfen 3angen bie Beute paden mo ourd)bogren. Der Galmofopf ferbit

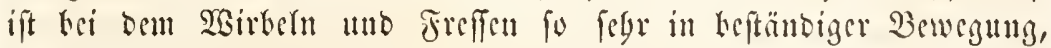

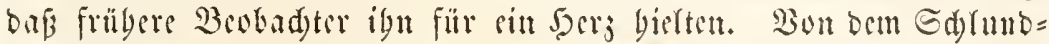
fopfe ans erfteeft fid ber bifwandige, reberartig geförnte, innen mit 2Bimperbaaren befeste Darm mad, binten, inbem er meift eine an= fänglide Ermeiterung, cinen Diagen, bann cime Berengerung unt an Maftoarme cine jweite Erweiterung, eine Sit vou Rloafe jeigt. Iln= mittitbar binter bem Gd)lunbeffe münben bei allen Päbertyieren jwei biffe fnollige Drïfen, bie man als Speid)erb rüje n Eetradyten fantt, in ten Darm ein. Dic Rabrung ber Päbertbiere bejtelt bei ben mit

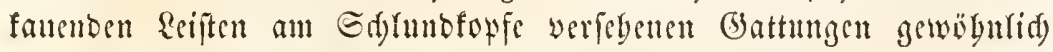
aus pflanjliden Stoffen, wäbrend dic mit Gabelzäbnen bewaffneten

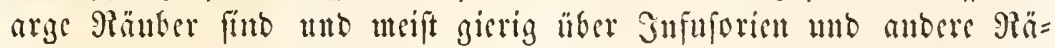
bertbiere berfallen.

Fin (b) fäbfy ftem bat man bei ben Räbertbieren nod) nid)t entoeft; - waz man für Giefäbe anfprad, fino mur Falten ber reberartigen baut; oagegen fennt man ein intueres 2 th ftem mit jiemlider Genanigteit. Sn ber Madengegenb, meift in cintiger Entfermung binter oen ?hagen, befindet fid eine Defrmung, weld) bei vielen battungen auf ciner cin= nub ausziebsaren Röbre jtebt. Rur bödfft felten ift dicje Röbre auf oer Baud) feite augebrad)t. Zon

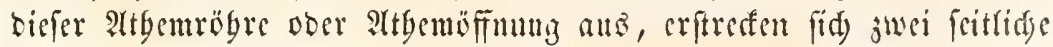

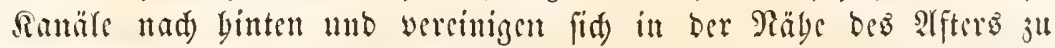
ciner Yebbaft zufammenziebbaren Blafe, bis oft furd bis affteriffmung ibren wafferflaren Snbalt im Strabl nad) SHgen ergiḉt. In ticfon Sanälen felbit fiebt man in gröferer ober geringerer 3abl furje Seitengefäpe, welde frei in bie Scibeghale münben umo an berin Münoung ein welfenförmig zitternbes Simperläppden angebrad)t ift, weldes faft in feiner flimmernben Bewegung bem flafern cincs flüm đens gleidt. Dffenbar bienen bieje Röbren mit igren 3itterorganen 
baju, Săfler in bas Suncre ber Seibesbïble ju brimgen und auf bicfe $\mathfrak{B e i f e}$ die 2 ttbmung ju unterbalten.

Die Räbertbiere fint 3 witter unb swar findes fid bei igmen

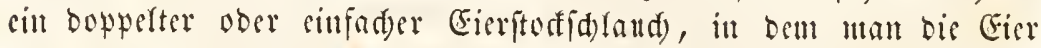
mit ifren Reimbläzdgen febr wogl unterfiteiten famu. Diefer Eierftod

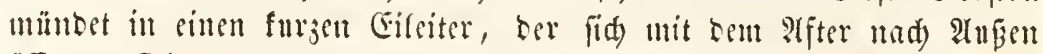

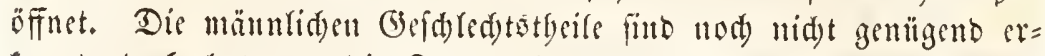
fannt, ond bat man bie Gamentbierdyen frei in oet Ecibesgöble ge= funben unb jtwar bei foldsen Igieren, werde zugleid) Fier trugen, unb

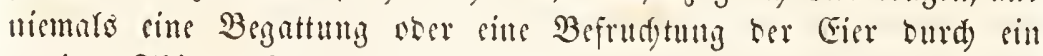
jweites Thier gefeben, wa bei of ungemeinen Bermblungefraft bicfer Thiere unt fo elger gejdeben fein mïbte, alo bei vielen bie Eier fid) nod im Seibe bes Muttertbieres fo weit entwidefu, bag man bis

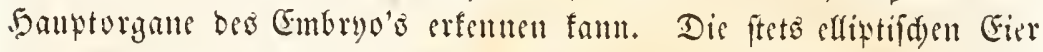
treten an ber afteriffnung Gervor unb werben von einigen (3attmngen

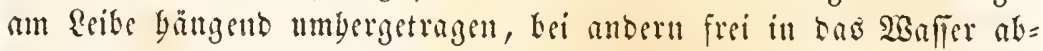

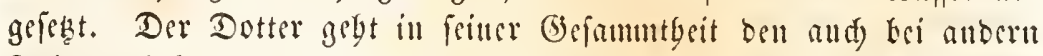
Thieren befannten Furdungsproję̧ sin und Der Embryo entwiffelt

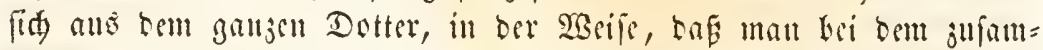
mengefugelten Thierden juerft ben Gd)lunbforf utb bas änge unb

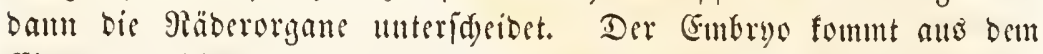
Fi ganz volffommen fo geftaltet, wie bas alte $\mathfrak{x}$ bier, fo baj aljo weder eille Metamorplofe tod) cille Raruenteriobe ftattfindet.

Die Räbertbiere fonmten an aflen Drten vor, wo mun Sufulo= rien funtet nub waren feit ben älteften 3citen kerübunt burd) bie Gigenjdaft einiger Gattungen, nad) langer Cintrofnung bei 3nbringen

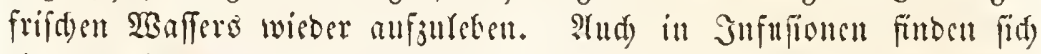
cinzelue Gattungen berferten bäufig.

Die Drganifation ber Räbertbiere ift Mad) Ansfdecibung jueier Gattungen, weldse viefmebr ben Gtruberwürmern angebören, (Ichthydium uno Chactonotus] eitue fo libereinftimuente, baf es fdwer bält

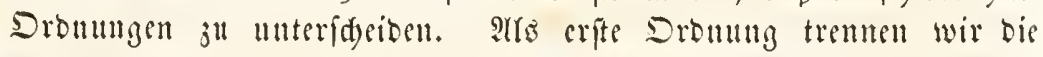
polnpenartigen Päbertbicre (Sessilia) ab, bie meiftenb eille ganje 2simperfdeibe befusen, fie mebr ober minber eingeferbt ift mo beim 2 sirbeln ben Ginbrud sines roffenden Rabes madyt. Bei sinigen eridgsint biefes Mab in ter Mitte an ber Bandfeite eingefert, bei alloern mebrfad) geffalten, bei andern entidy in Fortfäze ober ferbit in Fangarme aแbgejogen. Der gloftenförmige Rörter gebt nad) bint= ten in eilten langen Etiel über, ber oft gegliebert erid)eint unb an feinem Enbe sine faugnapfartige fäblung trägt, mit welder fid die 
Thiere feftetsen. Die Familie ber Bhtumentbierthen (Floscularida) beftegt aแs zwei Gattmugen, bie in gallertartigen bürfen anf 2 anfer: flanjen anfingen. Der Sdlunbfopf ift mit getogenen 3ägnen be=

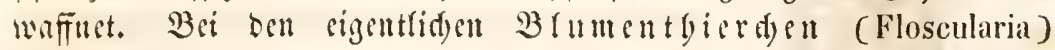

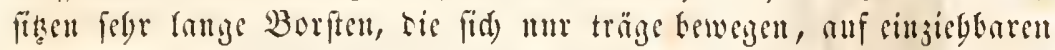

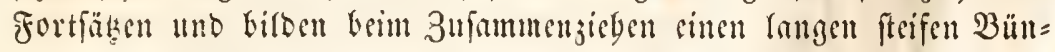
Del, Der ams ber Pröbre bervorragt. Die jungen Thiere baben jwei atugen, weldye ben Ermadjenen feblen. Bei ben Sronentbierdyen (Stephanoceros) fint fünf förmlid)s Jangarme entwifelt, bis in

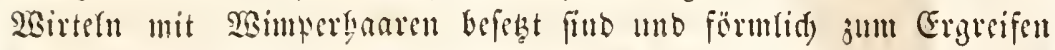
Det Beuti benugest werten.

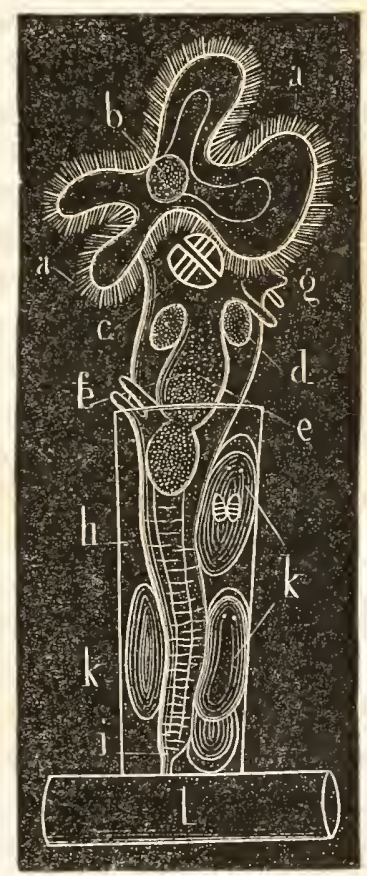

Jig. $2 \div 2$. Melicerta ringens

wout ter Eeite gefetyen. a tie say= pen te Mänetorgans; b ter Mimo; c tor mit ztoei treileifigen $\Omega_{a n=}$ platteu bemaifiete Edylunstopi: d Epeidyelorüent ; e Magen; f 2 fter;

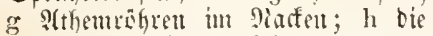
Sianzertüdfe, burdofidyrig rargettellt; i Etiel teö sfyiers; $\mathrm{k}$ (Sier mit meht ober mincer entwifelten $\left(5_{\mathrm{m}}=\right.$ bryonet, bei weldyen man jult sheil Ingen fieht, melde tie (Exwadjenen nidgt gaten; 1 IEalfetraben, moran baร Thierdyen fejtïbt.
In ber Familie ter Gropzräber (Megalotrochida) fintet fid) sin cinfad)

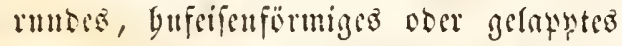
Räberurgan, weldes lebbaft wirbelt unb sin mit Reiften jum Ranen singeridyteter nid)t aber mit fdarfen Gabeljäbnen be= Wafineter Sd)luntopf. Die Tliere find entweder frei mit ifrem Sowwangende an 2anfertffanjen angebeftet, ober, barb cin= fam, balo gefellig in Gallertlÿlfen wet = pteft. Bei einigen Gattungen (Ptygura, Oecistes) ift bas Räororgan ganj rmo, Eei andern (Negalolrocha, Limnias, Lacinularia) Durd) einen mittlelen (Finfdritt bufeifen = ober nierenförmi be bei ciner an= bern (Gruppe (Melicerta) felbit vielge= rappt; - rie Sungen kefiben meift gwei Plugen, weldye beu Erwaddenen öftero abgeben.

\section{Dif Sitmung Der fortwinuenden} giäbertbierdyen (Batantia) jeiduet (id) Durd) einen meift fpindelfürmigen $\Omega$ är= fer alla, all beffen Ginterem Enbe cin Dentlid) abgefester, meift in sine Babel= fpize enbenber, fermrobrartiger Sdyanj= anbang fid) befintet. Man theilt fie je nad) Der Anorbum Der Ritoerorgani in zwei grofie familien ab, weldye mierer แad) Der Befdarfenbeit Der äแfern J̧aut jwei Ulnterfamilien bilben. 


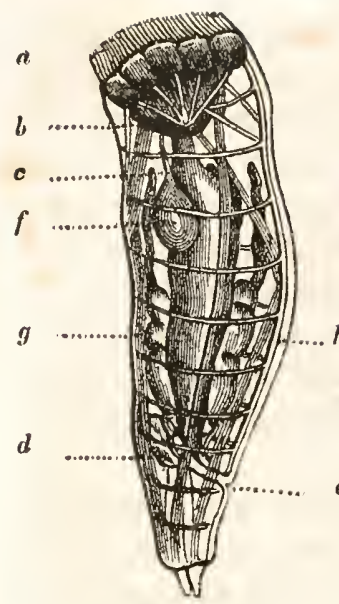

8ij. 223. Hydatina.

Dic Familic ber Bicluäberthicre (Polytrocha) Gat all beil vorberen Ende bes̃ Royfez

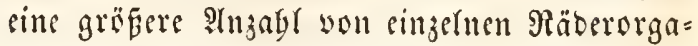

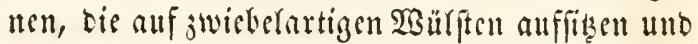
bei einzeluen Battungen, wie z. B. beim $\mathfrak{R} \mathbf{r} y=$ ftarffifdden (Hydatina) nod yon sillem sinfaden runben Simpertranje ungeben fint. 3 3umsilen ftegen bicfe cinjechen Räbcrorgante auf cimftilfpbaren fortfäzscn (Notommata), in antern Fällen fdscinen fie in bie Borberfläd)e ocs sopfes angefflanjt. Der Ed)funbfopf ift

" bei bicfer ganjen gamuilie, weld)e dic grë̈ten Prten ber Räbertbicre entbält, mit fpizen $59 a=$

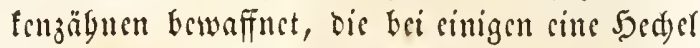
barifellen, bei anbern aber nur zwei auberor= bentrid) fpitec Stadych bilden, bic aus boun Munde Gervorgeftreft werben, um bie Bente anjuthofyren. ESinige battungen, bic ftreng ge= nommen wogr nidft jur Familie gebären bürften (Triarthra, Polyarthra), baben vorn und Ginten aun Seibe lange ftiefartige 2 tnlyänge, womit fic

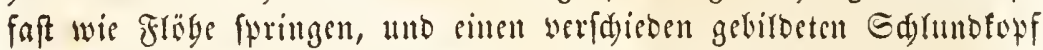
mit gerippten Ranpratten. Eine lluterfamilie wird burd biejenigen Gattungen gebirset, welde sinen Ycoerartigen ober Gornartigen Yjanjer

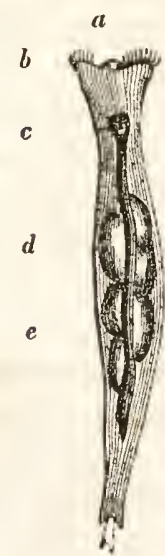
ซig. 221. Rotifer. laben, wie 3. B. Euchlanis, Brachionus ze. Die (3attungen bicier Familic baben meift un sine cin= fad)e 2ttbemüfrnumg im. Rafen mo cin ober zluci, febr ferten brei 2tugen Eintige fogar find 3cittebens blint.

\section{Die Familie ber Doppelräberthiere (Zygolrocha)} bat nur żwei fritlidye, auf cimftülpbaren Fortfäzen ffegenoe $\Re$ äber, jmifden welden meift nod) ein Stirmüffer mit einem jürteren SBimpertranje an ber

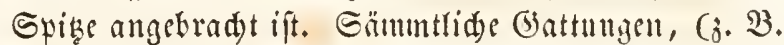 Philodina) bicfer Familic baben sincu Edyrunotopf mit gerciften Sauplatten, uno cinc Obattung (Pterodina) cinen Gärteren Ylanjer, wägrend bis ïbrigen varf=

a Ropicube. b $\Re$ in= ber. $\mathrm{c}$ Edflunbfopf. d Eirrtterf. e Darm. 


\section{filaffi ber himgelwinturer. (Annelida.)}

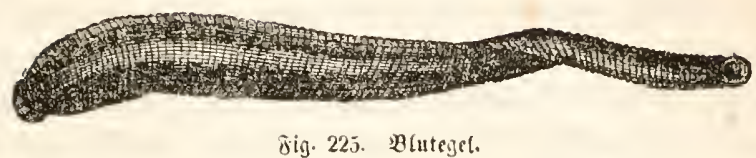

Die grofise Silaffe ber Pingerwärmer, seren ?(ngegörige meiftens frei im 2Baffer ober in fendten Erogöblen reben mo nur forly ferten

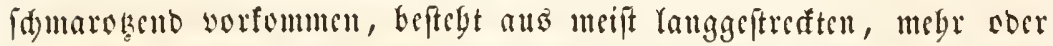

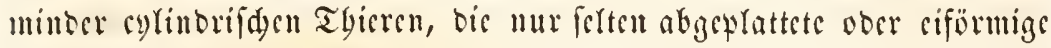
Formen barbicten. She Sï̈rer bejtegt fajt immer aus cingernen que= ren Ningeln, bie in ben meiften Fö̈lfen Deattlide Rörperabidnitte bit= ben unt une bei ben nieberften (Jratyen megr ober minder verwifdst

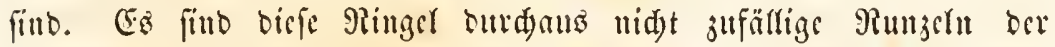

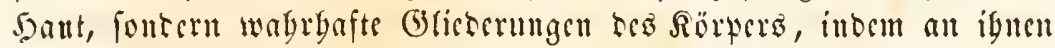
fid) äurertid bejonbers sic Bewegungeorgane, imnerlid) aber veridjic=

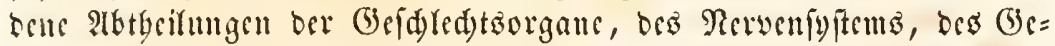

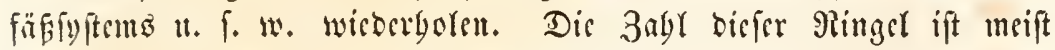

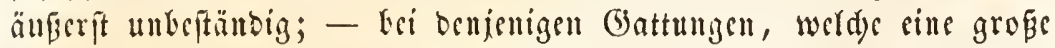

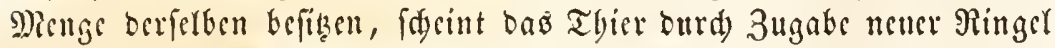

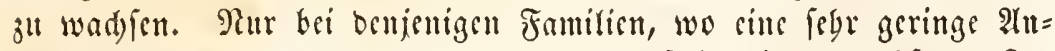

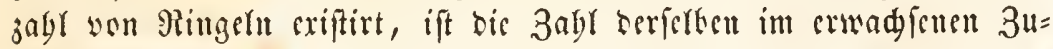
ftanbe conftant.

Bei oen Gögern Ringehwärmern unterfdeibet man

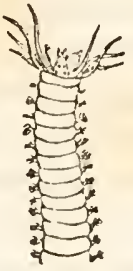

Jin. 226 Rovif

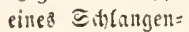
wurmes (Nereis) mit tem mittleren Fortiabe, ber rie Sutuftangeแ trägt, but peitlidget $\Re$ opf $=$ füflerti und ben Fïiselt z" teiben Eritenter Jörer
ringel. einen beutliden, won ben übrigen Ringern abgeieg̨ten Sopf, welder bic Sentralfdeside bes Rervenfyfems, bie Sinnesorgane, 2tugen, Fübler, Taftwerf jethge und die Munberfnung mit igren Raumerfiłengen trägt. Bai ben nicbrigen Fanilien in Bisgentlysile ift meiftens bas vor=

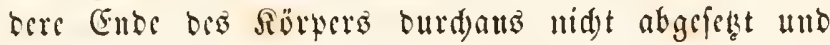

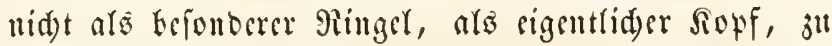

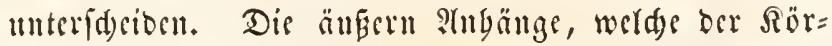

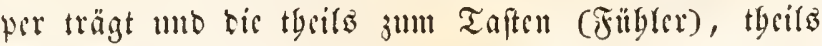

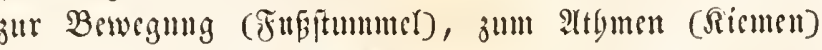

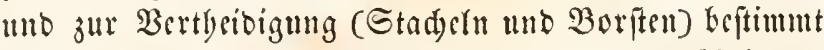

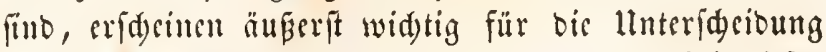
ber Familien unto Gattungen mut merben bei biejen nod) Gefonders betradtet werben. 
Die $5 a$ a ber Plingefwillmer bejtegt aus einet mebr ober mill= ber bornigen Dberbant, welde niemals flimmert unb aแs einer meift Derben Rederbaut, beren getrengte Fafern Durd bie Bred)ung Der Rid)t= ftrablen oft fegr fdëne fdillernde Farben berworbringen. Bei vielen

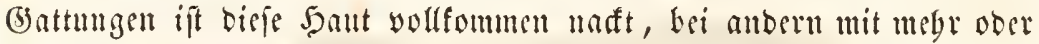
minber langen gornigen Saaren kefełzt unb bei ben Seranpen won bäutigen Sdibern liberbeft, bis oft mit ben serfilaten Saaren eine förmlidas

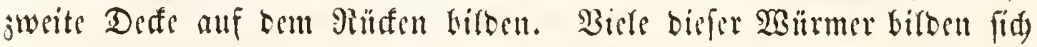
Röbren, in bencn fie entweber gänjlic) gaufen ober nur jeitweife ver= fteft finb. Sn lebeterem Falle fint es Gallerien im Sand ober in

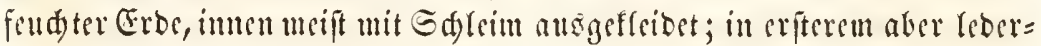

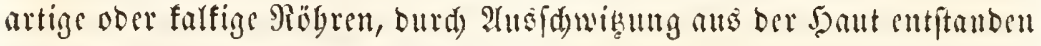
unto meift wou d)arafteriftifdyer Form für bic cillgetmen (5attungen un âten.

Die Bewegungsorgane Der Ringelwïmer finb febr mannig=

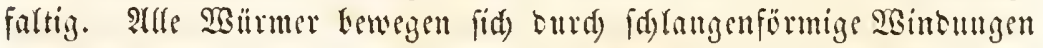

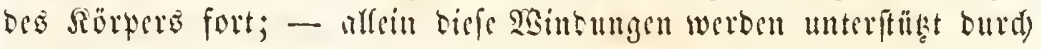
werfdyiebene spparate. Bei ben Egeln fibt man ftets simen bintern, oft aber aud) cinen yorberen $S_{a} \| \mathfrak{g} a f f$, mittelft beren fid bicje Thiere frannend fortbewegen. Bas sell libricen Dronmugn fintet man oft äuferft fonbertar geftaltete Boriten, Etudgefn und 5 afen, die

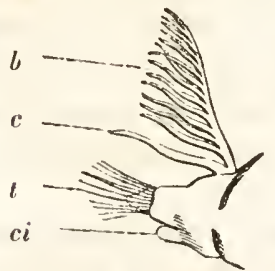

5i. 227.

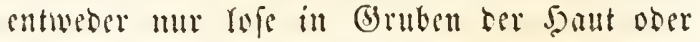
auf tefonoern feitlid)en Stummeln fteben, werdye (id) längs ber Rörterringel wicberbolen und

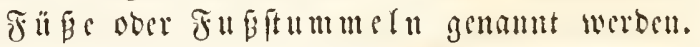
Meifens unterid)eibet man an jebem Jusftum= mel einen oberen unb unteren fleifdigen 5ä̈ar,

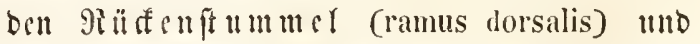

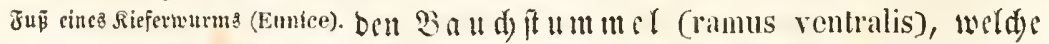

b bie Sieme: e obere nad) affon Pidstungen bin bewegt werben fïn=

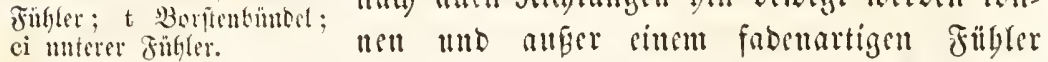

(cirrhus) cinen Bündel sou Borften ober feimen

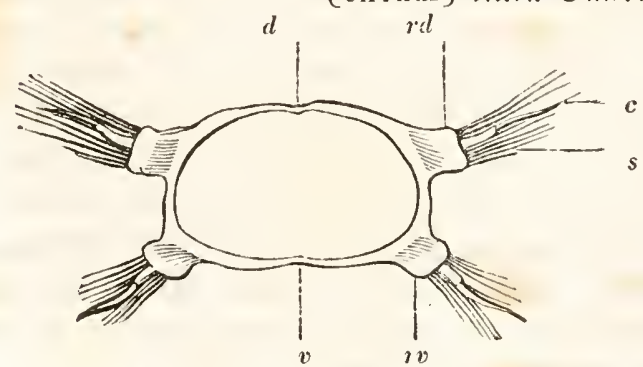

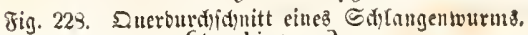

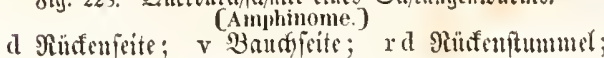
Stadjeln tragen. Die fe Boritenbünbel leiften fowobl feim Sirieden, afร beim Sdwimmen bis wejentlidyten Dienjte. Man bat is nad) Der Form Diefer Boriter:, Fefonders gy fiemen= borften (festucae), Stadelboriten yon rv Bautfifummet; s Bortenthindel; c Finfler. 
bebententerer Diffe (aciculae) unb bafenboriten (uncinuli) mit ge=

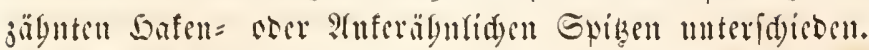

Das Rervenfy ftem Der Ringelwhinmer ftebt in Berbältníz zu

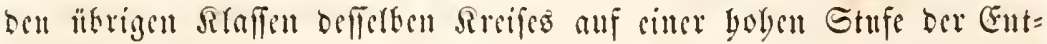
wiatung. Es beftebt in allen Fällen ans cincr vorberen, in Sopfe

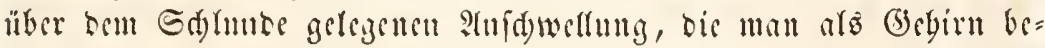
zeiduen fann unb bic bald mebr, bald minder beutlid) aus zurei feit=

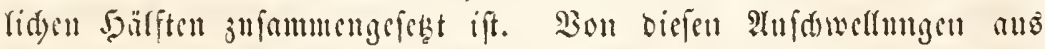

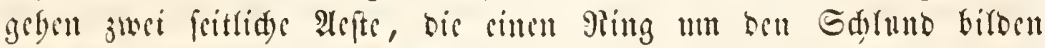

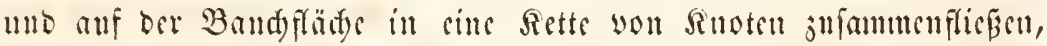

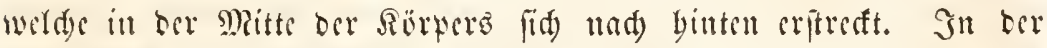
Pingel liegt in jebem Mingel bes Seifes sin Perventuten, ber Pefte nad) allen Seiten bin, befoncers an bie Jugftummeln ansfentet. Ë

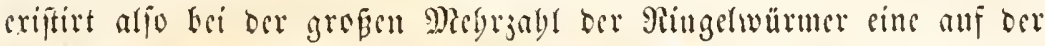

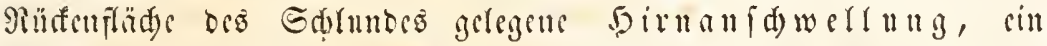

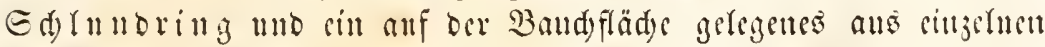

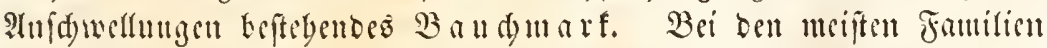
ijt biefes Bandymarf (d)eintar cinfad), wenn and) ftets ans jwet fritliden Gträngen gethilbet, bie in ben einjelnen Snoten burd) (Sang=

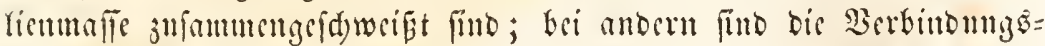
ftrünge jwiftsen ben finoten gettennt nub bei einigen niebern Typen

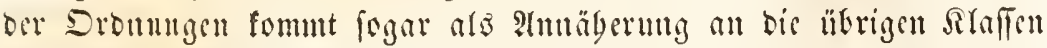

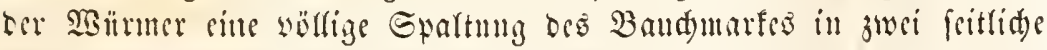

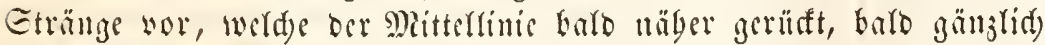
auf bribe Griten bin geworfen fint. Man bat bicfen llmptant, wenn aud) wobl mit llnted)t, oaju benแben wollen, oie mit feitlid)en Strän=

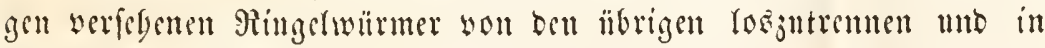
andere Siaffen ju verfescet.

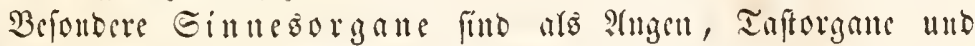

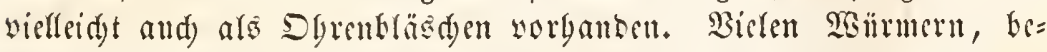

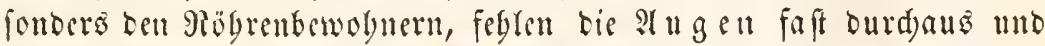
fitto unr bei cinigen wentgen battungen aufgefunben worben; bei ben

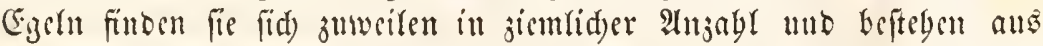

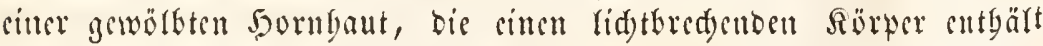

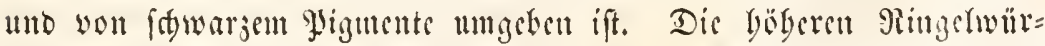
mer befizen meift nux jwei ober orei fummetrifd gefteffte Ientlide Itugen; bei sinigen gibt es beren fogar am binteren Enoc, fowic an

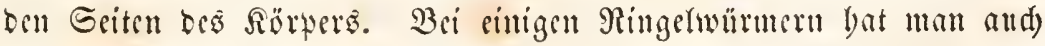
auf Len Gelgirnfuoten ferbft fleine runbe Bläsd)en mit cinem fteinar = tigen Inbalte gefunden, welde man für (b) 


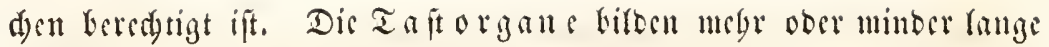
Fäben, welde sutweber an sopfe ober aud feitlid, an ben Fugftum= metn angebrad)t find. Die G) liebfäben (cirrhi) brê Sörterè fte= ben fowobl anf ben Rüfen, als auf ben Baudftummeln; br wo sin Deutlidjer Ropf yorbanten ift, find fie nady vorn geridtet unb werben banu unit bem Ramen $\mathfrak{R}$ opf übler (antennae) bezeidnet. Bei cinigen Gattungen erjd)einen fowobl bie (5)liebfäben ars bie Sopf=

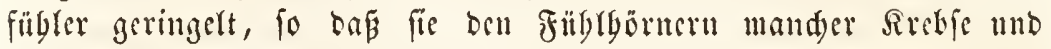
Sufeften nidyt unäbnlid) feben. Sic unterfdeiben fith aber ftets non Den âtennen ber Galiebertbiere baburd, Daf fis contraftil find und

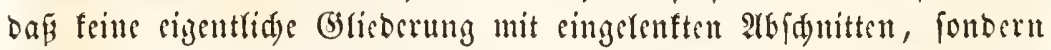
nur cine mebr boer minber beutlide Ringelung ocr bant sor= bauben ift.

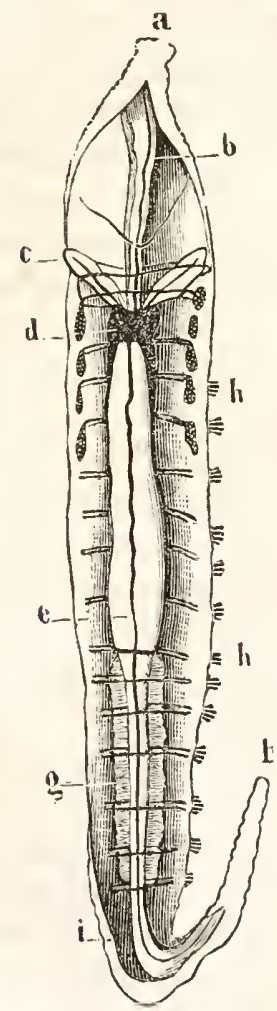

Fig. 229. Anatomic bes \$ieres. (Arenicola piscatorum)

Dex Soum ift son oben ber länge nadf aufgefdyliģt, bie

Der Perbau ungo apparat tor Ringelwärmer bejtebt in ben meiften Fällen auz cinem geraben Darmfanale, ocr son Dem an Borberentse angebradyten Munoc Durd ben gamjen Riorper nad) Ginten ver= läuft tno fid) in eiment endftänbigen affer iffuet, weldser meift sin wenig nad ber Rürfenfeite jull angebradyt ift. Nur felten ift ber After näber an Munde angebradt. Der Miund ift bei ben Meiften mit wulftigen Ränbern verfeben uno oft and von fdar = fen Riefern mmftellt, weld)e jum Durd)bob= ren ber Beute ober zum 2nbeipen ibrer

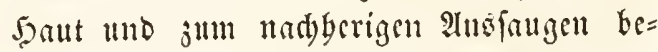

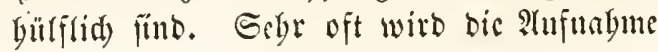

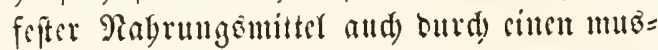
fulöpen Gd)lund unb oas Fangen ber Bente burd) cinen Riıffer unterftütst, welder ans ber Mandeffintug bervorgefdoben werben fanl. Die mciften Mingelwitrmer fino and in Der That febr räuberifde Thiers uno bas Fangen ber Beute wird bei benen, wel= d)e Rëgren bewobnen, oft nod) ourd) bic ungebener langen Sopffübler unterftüt, welde jugleid als Sdlingen benutst wetben. IIn bem Darmfanale felbit fann man meifteno cinen Sdylund, ber bald länger bald fürzer 
(Singemeite in iffer naturlidgen Eaige Eefalten, a Bontte, b

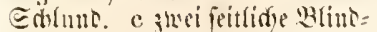

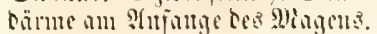
d Gerzähntide coutraftile Blafe, meld) ben Ed) won melder die Gefingitamme alzigelyen, ven cenen man hior

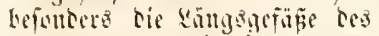
Darmes nut rie surigeräje fieft, werfle tie Riemen jucifen. e Darnt. f $\mathfrak{A}$ fiter. ge echerar= tige Blincoündyen. h תiemen. i hinterea fiemenlopes fienterento. ift แInD Den Dïnuläntigen Darm unterfdei= ben, Der Imrd) feitlidse Brinden wou Berfitoff, mandunar and Durda cin förmlides Gefröfe in frince sage erbatten wird. Meift bat bicfer Darm cinjelue fnotenfürmige Infduel= rungen ober zumecilen förmlide Blindfäte,

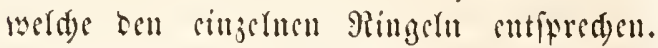
Bei einjelnen Gattungen bat man an biefm Darme theils Epeidgeldrifin, thetlo eiten lekerartigen llekerjug wou gerber, geförnter Mafle unteridicoen.

Bei ben meiften gingerwïrumern laffen fid befondere 9 tbemor: gane unterfdeiben, weldye in ocr Form bammartig veräfelter Siemen, bald an bem Sopfe, bald an ber Biuffenflädse liber ben Prïfenftum=

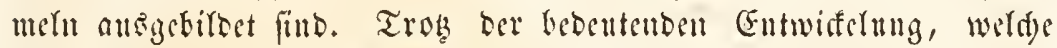
Liefe Riemen bei wielen SButmern jeigen, feblen fie oft nabe verwand = ten Fantifu, wo bann Die Saant ober Dis imnere Darmfläbe die Pttgemfunction zu überucbuen fdeint. Bei Den Erowitumern unb ben Eigeln fïben fid innere Gäfe obcr Sinäud mit id)leifenartigen Ranä= ren, in welden cine febr lebbafte Flimmerbemegung exiftirt unb bie mit engen Definungen mad) ?tußen münden. Db biefe Sianäle wirf= (id) innere 2 Bafferfanäle und $9 t h$ cmorgane fint, wofïr man fie an=

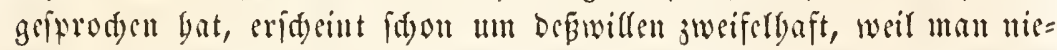

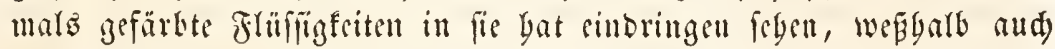
viele Foridyer bicfe Sdyleifen=Drgane, viclecid)t mit grö̈erem SRed)te, für abjonbernbe Brüfen anjeben.

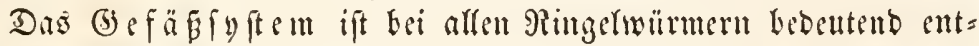
wiffelt, feime gefd)loffenen Rögren laffen fidg fajt überall leidt nad)weifen, ta fidy in ignen cin meift rotb, juwcilen aud gelb ober

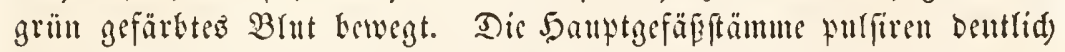
ibrer ganjen Qänge mad) und oft exiftiren nod) cinige befonbers ans̄ge=

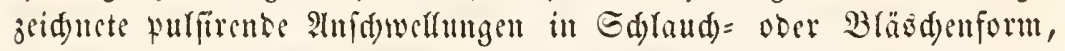

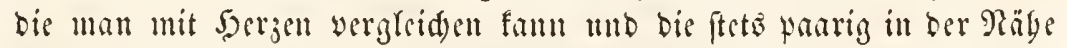

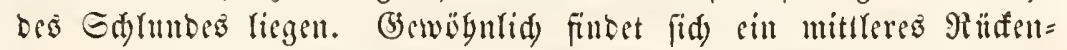

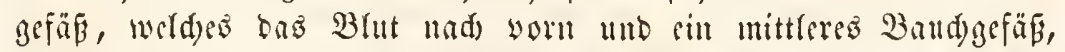
weldes baffelbe nad) binten treibt. Bei ben Ggeln futb inber jwei feitlid)e (5efäв meifi ftärfer entwidelt als bie mittleren. (5B werben Diefe (befäpe Durd) zablreide Duerbogen und Reşe mit einanber ver= bunben und ba wo Riemen exiftiren, erbalten biefe ftets einen 3 fuily= renben unb einen rïffübrenoen 2 ft won ben 5amptgefäfen. 
(5) efd led)tog entwifern fid aber meift unt periodif) zul gemiffen Jabreszeiten, fo

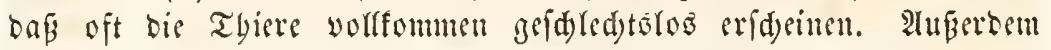

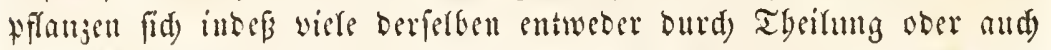

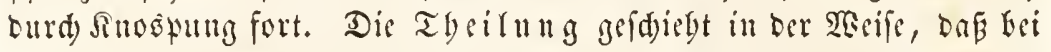
folden Snbivinuen, bie nod feine (befdeledtrorgane jeigen, etwa in

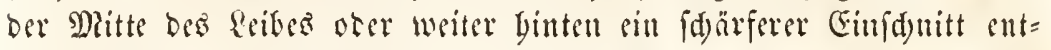
ftebt, an weldem fid) ein neuer Sopf mit mebren Ringeln bifbet. Sokard nun ber 2 surm aus Borbertbier unb Seintertbier beftegt, fo

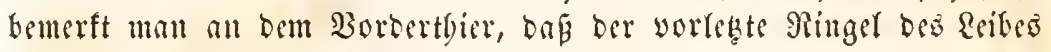
fid) mebr abfanut unb baß aus biefem fid thid) getrennten Ringel, wälyreno or nod contimuridi mit bem Borber = und

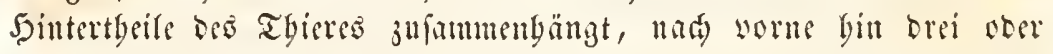
vier Ropfringe, mit atugen und finglern, nad) binten bin Reikes=

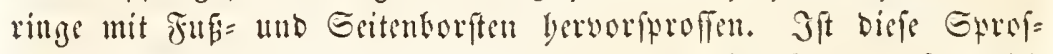

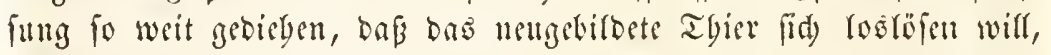
fo beftegt arfo Das (banje yon worn nad) binten ats brei Stüfen, Dem Borberleibe bes Muttertbieres, Dem jungen, aus cinem Mingel Des Matterthieres entitandenen Mittertbiere uno Dem mit einem Sopfe ver=

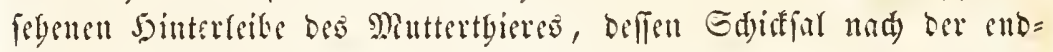
liden goślöfung nod unbefannt ift. Das Borbertbeil bis Mitter= tbieres pflangt fird juweilen nod) mebrfad) burd) Theifung forl, befommt aber baun (befd)led)tîtbeile und legt bann mur nod) (Eier. Bei biefen Pingetwärmern finbet and) nod) bie Gigentgümlidfeit ftatt,

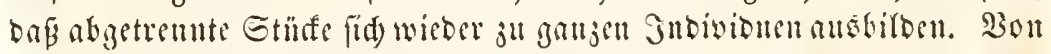

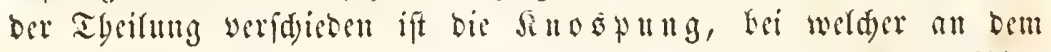

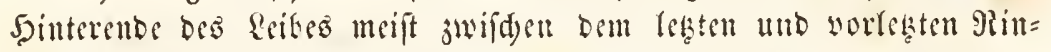

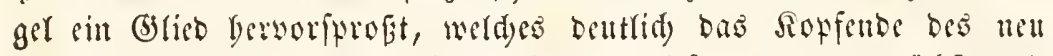

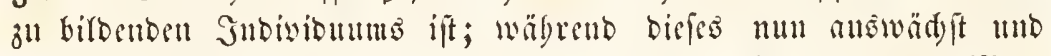
Ringel an Ringer reigt, entitegt wieber jwifden ifu unb bem Mrut=

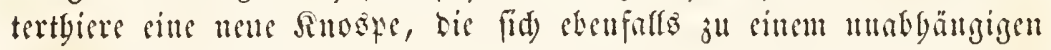

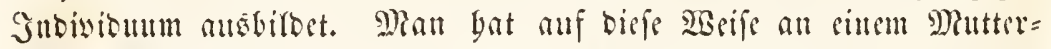
thicre bis ju fed) Sanospen bängenb gefutten, wowon bie binterite,

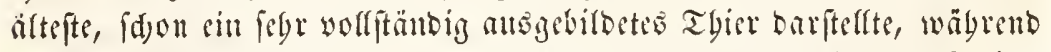
bie vorberite, jüngfte, mur erft ben Ropfringel jeigte. Gio unterfdeibet fid, bie Rnospung alfo baburd wefentlid) yon ber Theilung, Daf bei lebsterer wirffid) ein Theil bes Mluttertbieres (wenigftens cin Pingel) in bas neue Juvitum übergegt, wägretto bei erferer biefes ganj tell gebiloet ift.

Die Eget und die Srowlirmer find Sermaplyo biten und jebes 
Snbivisun! mit männlidfen unt weir(id)en Begattungsònganen wer=

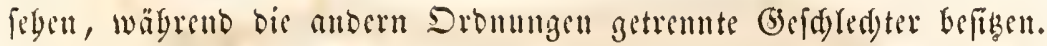

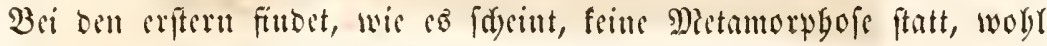

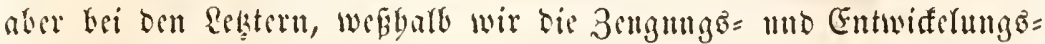
verbältmilfe bei ben cingeluen Dromungen fetradten weroen. So vier

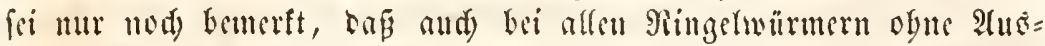

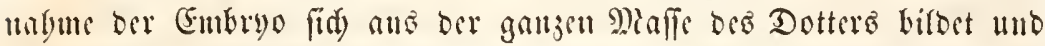

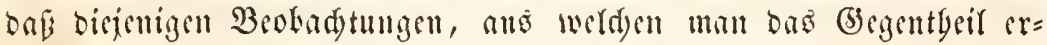

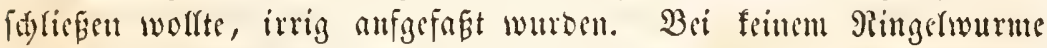

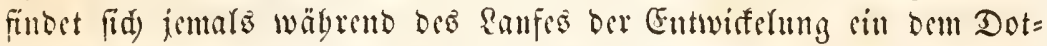
ter gegenilbergeftellter (Fmbryonaltyeif unb Gierburd), fowic burd ben Miangel jebes geglieberten Bewegungsonganes trenuen fid bic Ringet=

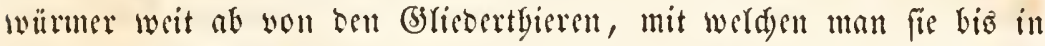
bie neuefte 3eit in Beziegung bringen wollte. CBs ift aber biefe $\mathfrak{B}_{c}=$

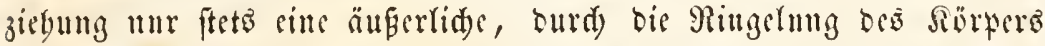
uno feine Theilung in gleidnamige 2(rid)uitte Gervorgebrudste unt

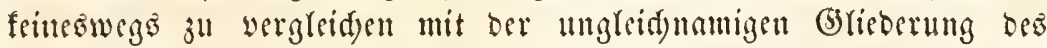

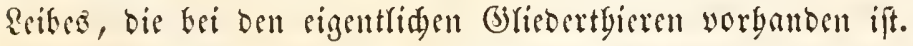

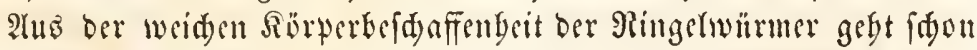

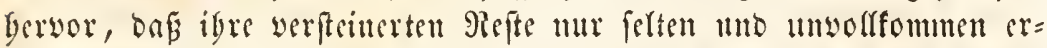
Galten fein föntuen. 3war findet man wou ben lligefterinen an oft in

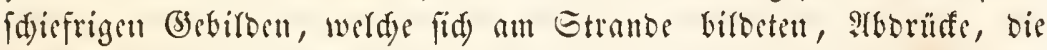
offenbar won Ringerwürmern Gerritgren, benen afer bie darafterifti=

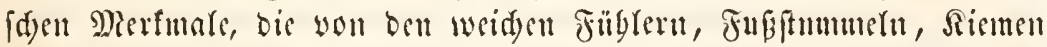
2c. Gergenomment finto, gänjlid) abgeben, fo bafi ifre Beftimmung uno

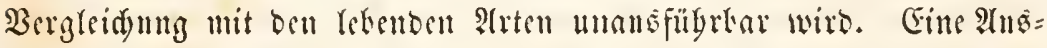

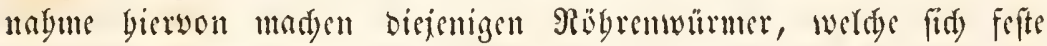
Raffrögren bauen, bie woble crbalten bleiben unt meift dyarafteriftifdse Mierfmale bietert.

Sir tgeilen tie Silaffe Der Mingelwärmer in fünf Dronungen,

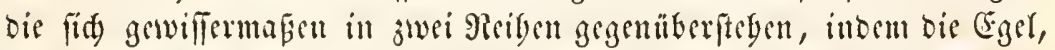

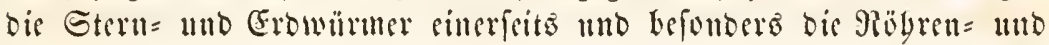

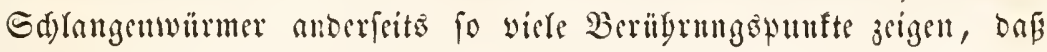

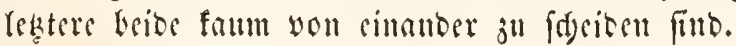




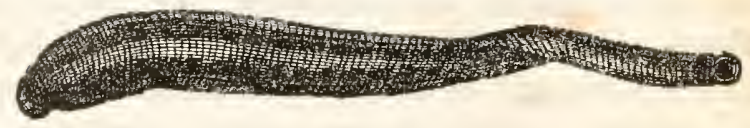

бig. 230. Sanguisuga medicinalis. Ter mebicinifide $\mathfrak{B}$ (uteryel.

Die Dromung ber Egel (MTirudinea) begraft meift lange, (d) (ante, runblidye ober abgeplattete Säirmer, bie eine follüprige aber berbe 5aut befizen unt auf Der Dberfläde febr viele Duerrunzeln zeigen, welde inber ben burd) bie inneren Drgane angebeuteten (blie= rerungen nur in Ams̄nabmsfällen entfpreden. Der Sörter ift meift nad) worn verid)mälert, nad) binten breiter unt trägt an Dem biutern

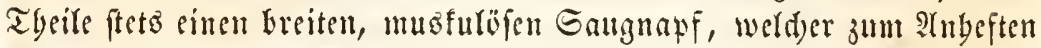

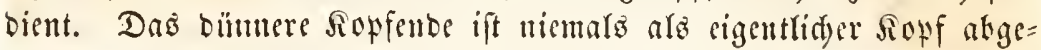
Fetst, zeigt aber bei ben meiften Soattungen ebenfalls einen runben oder

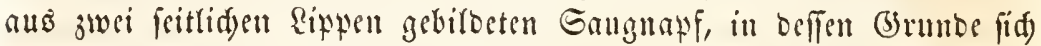
Der Mund befitbet. Dem fiorper feglen affe fonftigen Bewegungs: organe, nautentlid) jebe Gpur von Fufftummeln ober Borften; er be= wegt fid beim Sried)en nad) Art ber Spannraupen ourd) abwed)felnt= Des Anbeften ber Gaugnäpfe ober mittelft fd)längelnber WBindungen beim Gdwimmen. Das $\mathfrak{R}$ ervenfy ftem ift febr entwidelt; - es

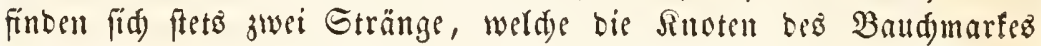
mit einanber verbinbet. 2 ei ber am niebrigften ftebenten Familie

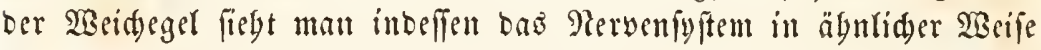
wie bei ben Gangwürmern angeorbnet, inbem nur jwei feitlide $\Omega$ no $=$ ten exiftiren, bie burd) eine binne unter ben Gdylunb berjiebende Sdinge verbunben fint unt zwei feitlid)e Aejte nad) binten idifen, Die feine Snoten ju befisen ideinen. 3um Taften bient bejonbers Das vorbere Ropfente; $\mathfrak{A} u g e n$ firten fid bei alien frei rebenoen Egeln in ber 3 abl won zwei bis zeln, feblen aber ben fdymarobenden (5)attungen.

Die Egel reben bauptfädlid won bem Blute anberer Thiere mb

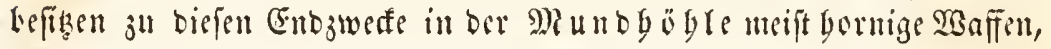




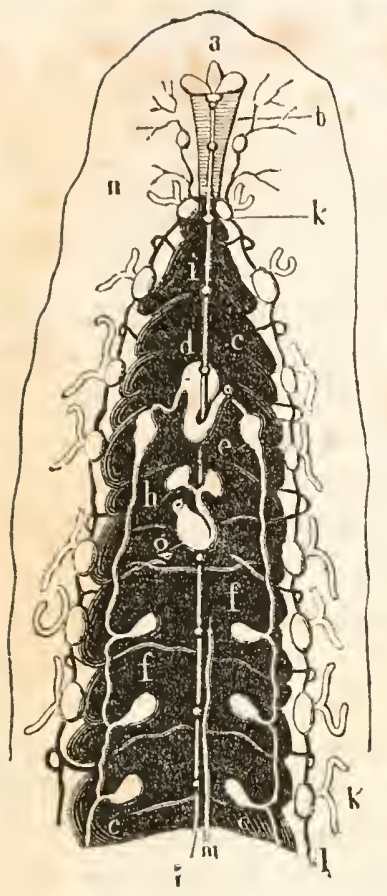

Fig. 231. Fillatomie bes 23 futegets. (Hirudo s. Sanguisuga medicinalis.)

Das Thier it vou ber Baud)= feite Ker burd eincn Räng ofinet und bie saut nad) beibeu ভeitent zurüifgefd)lagen worben. Nar Die woidere jälfte bez Rörpers ift Dargeftellt, fo Das unan bejoubers bie (B) dideditstheile, baz Nerbentyizem, ben fomarzen Darm, mit feiten un= vollftändigen, feitlidien 3 lindjärfen, Die Stfleimbrüfen ( Refirationshla= (en) Deutlidf fieft, a bie 3 Riefer. b ber musfulófe Sdflunb. c Der Darm. d Ruthenklap̃e. e Samen= blafe. f 5yobelt, g tlterns, h (5iet:

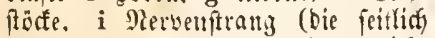
abgelgenben Rerwen wurben nidgt Dargeitellt. k Repirationsbläzdyen

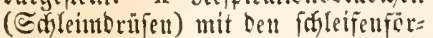
migen Flimmerfanàlent. I Seitenge=

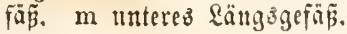

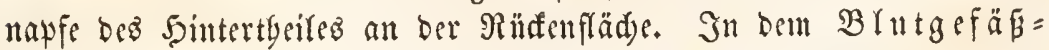
iy fiteme findet fid bald rotbes, bald farblofes Brut und man unters

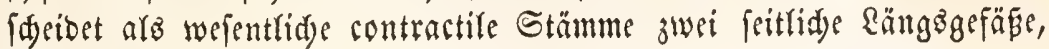

Dogt, Soologifors briefe. I.

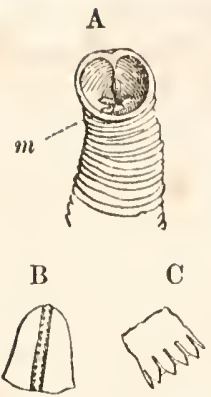

8ig. 232.

A ber worbere Sang = 3 äbuen bejekt find uno mapf cines Blutegela unit ben Riefern m iu natülidyer Enge; B ein R̂̉efer ftärfer ver= gröpert; C cinige $3 \mathfrak{a} \mathfrak{l})=$

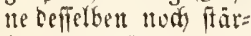
fer vergrifiert.

Sant wie eine Säge. Der Bruteger be= wegt dicfe Bogenfägen untet befändigem Mnforücfen fo lange bin und ber, biz er rie Saaut butd)bobrt bat, wo er bann bie Sicfer zแtidfiebt แub bas Brut burd)

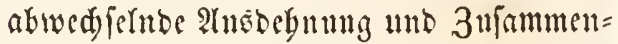
ziebung bes musfulöfen Sd)lundes anf= pumpt. Bei ben Siemenegeln finden fid Inur zwei Riefer yor, bei ben Rüferegeln bagegen eine Gd)lunoröbre äbnlid Det= jenigen ber Goblenwürmer. Der auf ben musfulöfen Galund folgende Darm ift meiftens burd) melyr ober minder ftarfe sinfdunurmugen in eingelne Särfe getbeilt uno seigt nod) anferbem in bäuftgen Fällen im bintern Theile des Rörpers gelegene Blinbfäte, welde zuneilen ver: äfert find. Der Dlaftoarm ift von bem übrigen Darme meift burd) eine enge Slappe getremnt mo öfnet fid) mit cinem engen Rfter, mmmittelonr yor bem Gang= 


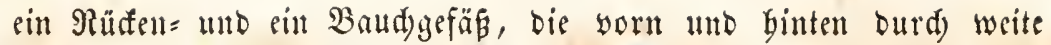
Suerbogen unb in ben Rörperringeln burd) feinere Swifhenäfte mit= cinanber in Berbinbung frelyen. Ant bent Seiten bes Rörpers fiebt

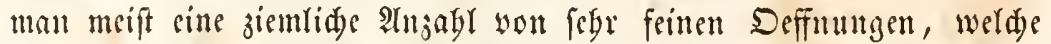

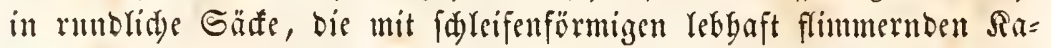
nälen in Berbindung fteben, einmünden. Die Bebentung diefer Sanäle ift nod nidat genauer feifgefterlt.

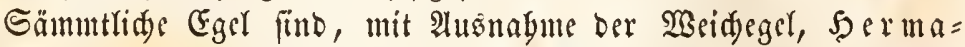
phrobiten uno fflanjen fid nur Durd) (Fier, nidyt burd) Snospung ober Theilung fort. Die (Seld)ledtsöffrungen liegen auf ber Baud)= leite meift in ber $\mathfrak{R a ̈ g e ~ D e s ~} \mathfrak{M}$ undes unmittelbar bintereinander. Die vorbere mäunlide Deffnung fübrt in ein zwebelförmiges Säcd d)en, att weldem bas lange fabenförmige Begattungsorgan berworgeftreft wer= Den fann. In jebem Ringel bes Borberleibes liegt ein Jyaar Sobell, welde mit langen, an ben Seiten binlaufenden Samengängen in $\mathfrak{B e r}=$ binbung fteben. Die weibliden (befdled)tororgate befteben aus zwei bobnenförmigen Eierfitiden, bie in eitten furgen Eifeiter mo einen

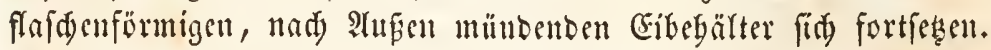

Die Entwidelung ber (Fgel ift böd) eigenthümlid), gleid)t inbeffen in bieler $\mathfrak{B}$ ezicbung berienigen ber Soblenwämer, wie bent liberbaut jwifden biefen beiben Dronungen fid) vielfadje Beziebungen zeigen, bie vielleidst nod) zu siner näbern $\mathfrak{B e r e i n i g u n g}$ fübren bürften. $\mathfrak{B}$ ei ben sierlegenten Egeln fduwht am Borbertbeile Des Reibes cill gallert=

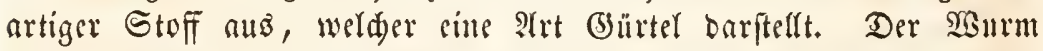
legt bie Cier in bicjen (S)intel, jiebt fid Dann aus Demfelben beraus,

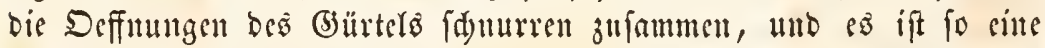
Gornartige eifapfer gebildet, welde an $\mathfrak{B a f f e r}$ flanzen angeflebt wirb, und bie man mit ben Gocons ber Geibenrauten vergliden bat. Die Cocons Der Blutegel find son bebeutender Gröpe und entyalten fitets viele Gier. In ben Giern felbit ideint fid nun Der Funbryo gemif=

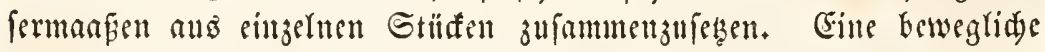
Sd)lunbröbre bilbet fid zuerft an bem mit 2 simperbanten tiberzogenen (Embryo. Diefer Mlagenfdlaud tritt bann mit cittem Saugnapfe it Berbintung unt (d)luft, wägrent fid ber (Embryo fortentwifelt, bic nod) übrigell Dotterzedlen auf. Der Attfangs fuglide Embryo wiro nad) Mnd nad) platt, länglid), verliert feine Simperbaare unt (d) lüpft cutblidi in ber Geftalt Des Muttertbieres aus bem Ei Gervor. Es

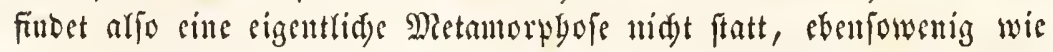
bei ben Goblenwinmern. 


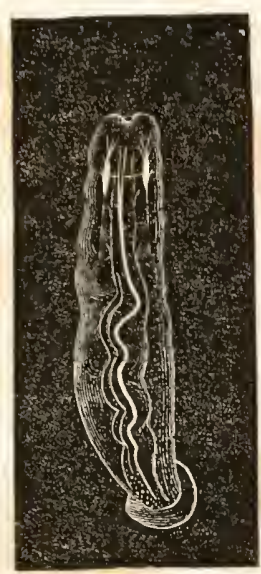

WBir thatlen dic Egget it Drci Familien. Die

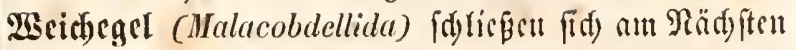
oen Sangwärmern an. Sgr Rörper ift abgeplattet, vorn ftumpf, binten mit sittem groben Saugnapfe verfeben; ber Miunb weidy, nubewafintet, ntit fleitucn Tärad)en befekst; Der Darmfanal gerabe, obue Blinb= fäfe uno Serzweigungen; bas Nervenfyftem Keftebt

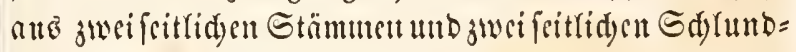
fnoten. Die Befdulcater finto getrennt - änfere

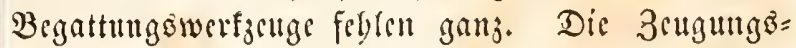
ftoffe entwideln fid in zelligen Ramunern ber Reibes = böble und bringen burd) feitlide Deffunngen Derfelben berwor. Dis Rörperbant ift balb Durdjitutig unb

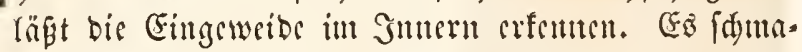

8ig. 233. Malacobuella. rotzen bicfe (5igel, yon welden man mur sine (b)attung (Malacobdella) fennt, in ber Mantelgögle verfdiebcuer Mecrmuldectu, bejonbero ber Trogunfduch.

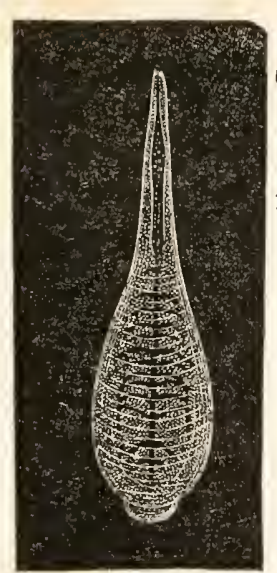

Sig. 234.

Clepsine hyalina.

Die jweite Familie, biejenige ber Rülielegel (Clepsinida) Gat cinen binten breiten, worne febr idyalen $\Omega$ öper, mit einem breiten, biutern Sang= napfe, einen vorftreftbaren $\Re$ itffer obue Bewaffuth unb sinen mit Kangen Blinbbärmen verfebenen Darm= fanal. Gis reben befonbers bäufig it fitßen siffern, wo utan fie an $\mathfrak{B a f f e r p f l a n g e n ~ f r i e d s h o ~ a n t r i f f t ~ u n o ~}$

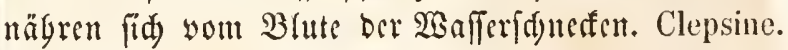

Dic Familie ber $\mathfrak{B l u t e g e l}$ (Ilimdinida) yat sinent unchr gleidjförmig brciten Sïrter, zuwcilen mit bent= lidyen Ringeln unb auber bem grofien biutern Gaug= napf einen vorberen Ditnonapf, welder bald fer= manent ift, bald aud, wie bei bem utebijinifiden

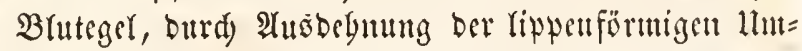
gebung bes Mlundes gebilbet werben fann. Der Miund ift fets obue

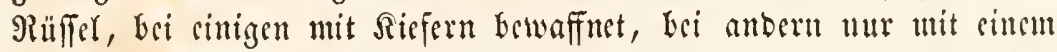
fleifdigen Signlite verfeben. Zu biefer Familie gebört ber gewögnlide Blutegel (Sanguisuga), in Mitteleuropa, Rleinaficn unb Ditindicn einbsimifas, ber jun Blutfangen aun Menfd)en benubt wirb; ber Moks= egel (Haemopis) unb viele auf Fifden (Piscicola) tutb auf Rrebfen (Branchiobdella) [dmarogenden $\mathfrak{B}$ ürmer. Die meiften Blutegel Kauern

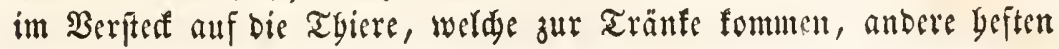


fid) an bie änsere Sant an und laffen fid fo Gerumtragen. Gine ganz angenlofe Gattung (Branchiobdella) lebt befonbers yäufig aut ben

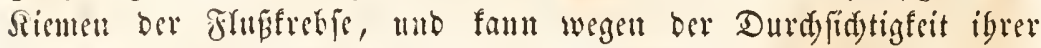
Saut reidyt 3n mifroffopifasn Beobad)tungen benutst werben. Der

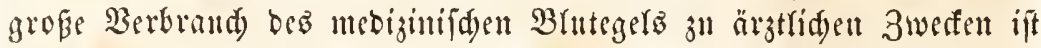
befannt. Man regt 3n feiner 2ufbewabrung rigene 3ud)tteide unb Tïmper an, beren Beyandrung viele Sorgfalt erforbert unb beziegt jetst bie meifen aus Dftindien unb 2legypten, ba bie ungarifden unb polnifden Gïmpfe, werde fie früber in ungebeurer angabl rieferten, faft erfdönft fint. Aulacostomum; Pentobdella.

Die Srbnung ber Cternwürmer (Geplnyrea) witb won

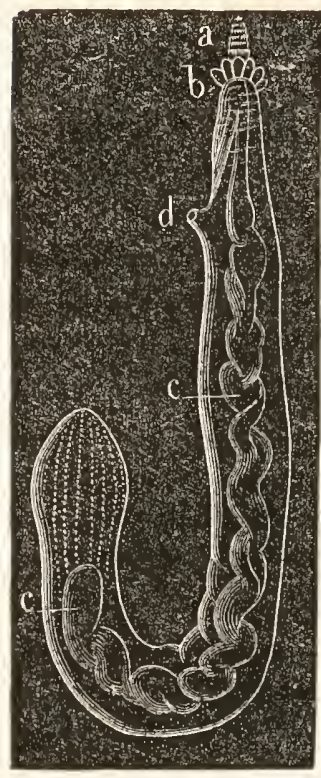

8i.j. 235. Sipunculus.

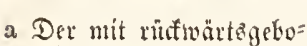
genen in Suerretigen fteken= Den Saten Sejegte suiffel; b bie Fühlwargen; c Der Durdy bie Rörpergout burdf= fde einende Darm; d Der 9 ffter.

(d)eint bei ben meiften

einer bödpt eigentbümlidgen (Sruppe von Dier= wärmern gebilbet, weld)e man bis jest grofent theits ars zu ben Strabltbieren gebörig be= traditete, inbem mant fie ben Seewarzen an= reigte. Der Sörper biejer Thiere ift walz= enförmig, brebrund, won ciner berben reber= artigen Sant umbüllt unb meif́t naft, bod) fiebt man bei sinigen Battungen fteife, in bie Saut eingepflangte, unberweglide Borften, ober aud) an bem $\mathfrak{B o r b e r e n b e ~ e i n i g e ~ S ̧ a f e n , ~ b i e ~ j u m ~}$ Feftyalten bienen. 2rke biefe Thiere leben im Sanbe, in \&ödern unb in Söblen in äbulider

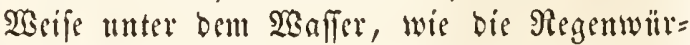
mer anf bem feften Ranbe. Sie zeigen frimen befonders abgefetzten Sopf und teine Sin= nesorgane. Das Rervenfyftem beftebt aus sinem Bandmarfe unb cinem Gdymbringe, an bem fith ein unbebentenber Jirnfinotent erfennen läpt. Der Diunb befinbet fid ant bem vorbern Enbe bes Rörpers unb ift bei ben meiften (5)attungen mit eittem lan= gen Rüffer yerfeben, welder in äbnlider Weife twie bei ben Rrabern, mit rỉctwärto ge= bogenen Jafen befest ift. Der Darmfanal er= tund öfnet fíd an bem bintern (Enbe Des Rörpers; nur bei einer (5ats tung finbet fidy ber after auf ber Baudjeite in ber vorbern 5 älfte

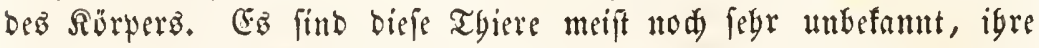
Inatomie fonie igre Entwirflung bebarf nod) vieler Aluffärung, bevor 
igre Steffung mit Genanigfeit angegethen werben faut. E\& gegüren 3n biefer Dronung bie beferwatrmer (Sipunculus), bie Stadel= whrmer (Echiurus) und einige altbere Gattminget, weldge man tur bemt "̈แßern Stureben nad) fetunt. Thalassema; Priapulus.

Die Dronnng ber Erowiiruter (Scole ina) yat citen lan= gen rutben $\Re$ örper, ber nur unbeutlid) gegliebert erfádeint. Die Saut ift berb, zuweifen ferbeft reterartig unt anf beiben Geiten bes Sörpers fint Borjert in bieferle singefenft, weld)e zur lluterplützung ber $\mathfrak{B} e=$ wegungen bienen. EEz ftrben inter bieje Boríten niemalö wie bei ben

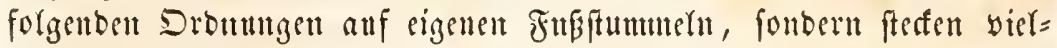
megr oft faft gänzfid) verborgen in paarigent (5ruben ber bant. Mant unterfdseibet feinen beutlid) abgefonberten Sopf, wogl aber bei ber sinen Familie jwei Rafenaugen, bie Den Negenwürment abgegen. Der $\mathscr{M}$ und jeigt niemars నiefer ober ritteferförmige Drgane, ber Darm

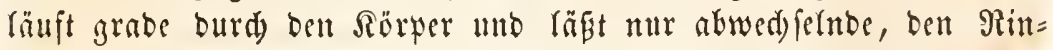

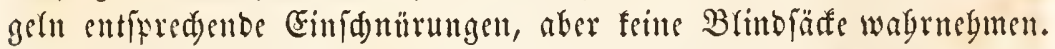

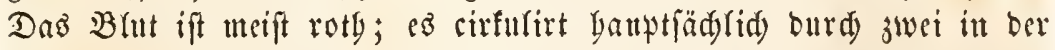

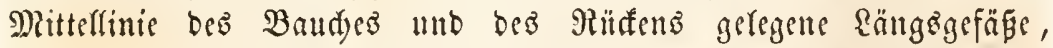
welde burd Dueräfte verbunben fint, bie bei ben Regenwürmern $\mathfrak{n} a=$

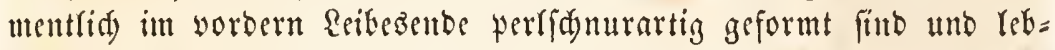
Gaft pulfiren. Man finbet aud bei biefen Tgieren ägnlide fdjleifents förmige Sanäle mit innerer $\mathfrak{S}$ simperbewegnng wie bei ben Ëgeln unt ift ebenfo weniz wie bei biejen n̈ter igre Bebeutung flar geworben. Sämmtlide Erbwärmer fint Sermapgrobiten und Gaben auf ber $\mathfrak{B o r}=$

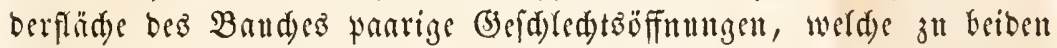
Seiten ber Mittellintie liegen, jum llnterfdejebe vout ben Gigeln, weldye

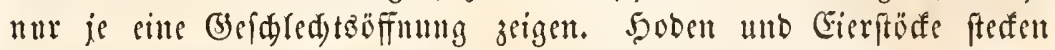
äbrigens öfters fo in einanber, $b a \beta$ es unmöglid if, fie zu trennen,

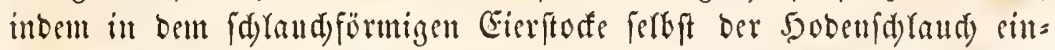
gefd)adtelt iff. Lleber bie Entwifflung ber Erbivürmer int Ei liegen

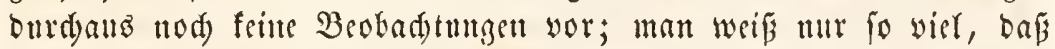
bis Sungen feine fpätere Distamorphofe megr burdmadjen, fonbern vorffonment aukgesbitbet bas Gi vertaffen.

Dis Fanilie ber Megenwürmer (Lumbricida) Feftelyt ans warzenförmigen, Gödft ungleid) geglieberten TGieren ogue gefdiebenen

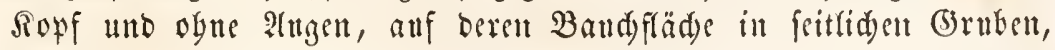
welde nabe an ber Mittellinie angebradyt fint, Padete gefrünmuter

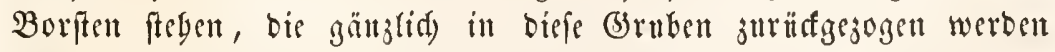

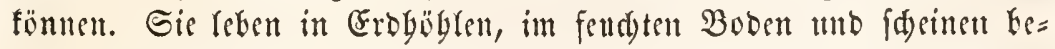

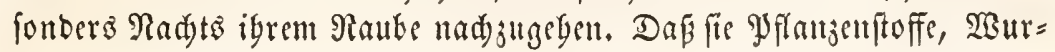


betn uno Sdy difen abfreffen, ift sine Fabel. 3ur Brumftzeit entwiffelt

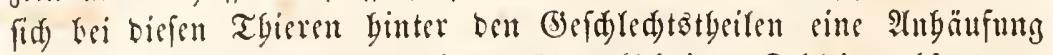
yon Drüfenbälgen, weld)e sinen zäben flebrigen Edj) reim abjontern, ber Gefonters zum Fefthalten Lei ber Begattung sient. Die Driifen=

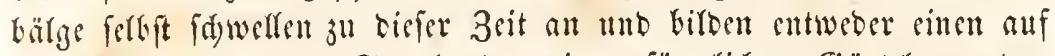

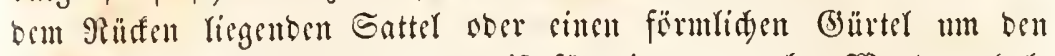
Reib, welder yon llufunbigen meift für cine vernarbte Ssunbe gebal= ten wirb. Cinige (Sattungen biefer (srowürmer bauen fid) förmlide

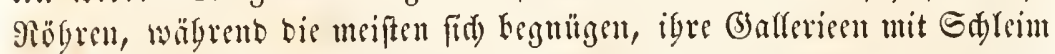

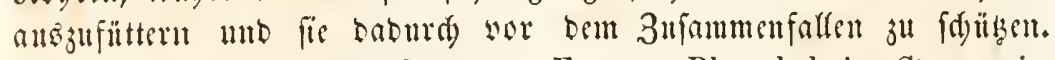
Lumbricus; Saenuris; Enchytraeus; Euaxes; Rhynchelmis; Sternaspis.

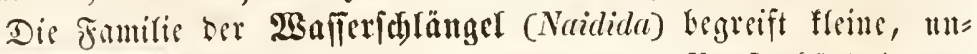

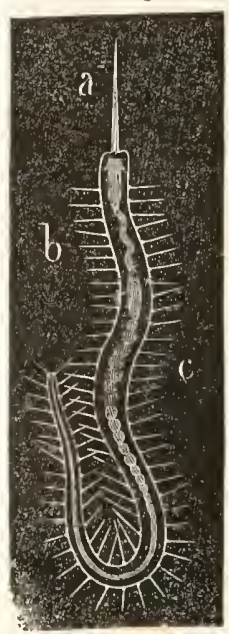

Jig 236.

Nais (Stylaria) proboscidea.

a girfifelartiger Furtiats beo Ropfes, finter bem man ben Strfang bes Dar= mez nuto bie briț Slugen fitht. Erilutub und Mia = geti. c Darm, burdydacimentsurd tet Rörper.
Dentlid) gegliederte, anker ben Borftenbüntegt am esibe aud nods mit sinfaden Seitentorfen werfergene

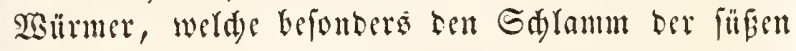
(5) wäfler bewobnen und baria fid Gaterien gra=

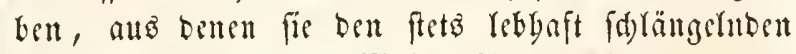
Sopf Gervorifteden. Einige Irten (Chaetogaster)

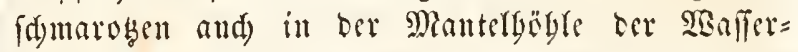

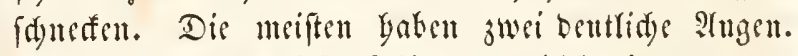

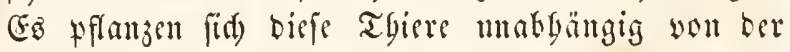
geideleditliden (Entwifluntg and nod) in ber been

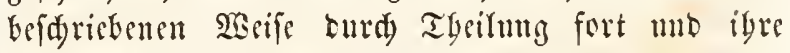

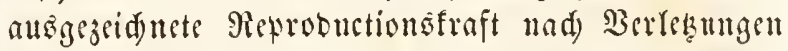
ift fidon oft ber Begenftand vieffadjer Beobadjtmugen gewefen. Nais; Chaetogaster; Stylaria ; Proto; Aeolosoma.

\section{Die Dromm ber giobrentiurmer ('Tubicola)} Bebürt anşd)lieglidf bem Miecre an unb filbet mit ber folgenten Dromung eime natiirlide orruppe in

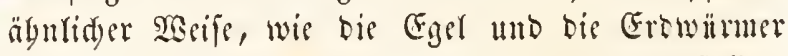
sine größere zufammengängente Groppe darfeften. Slle biefe 2 sithmer wobnen in bem autgerwadjemen

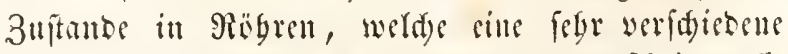
Beidjaffenteit zeigen. Bei ben cinen eridecinent fie

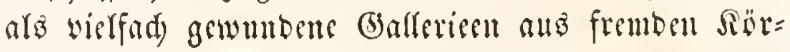




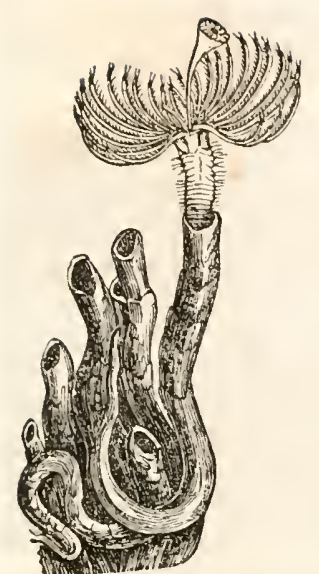

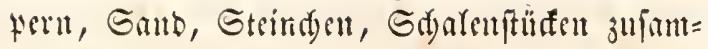
mengeflebt und itm Junern mit einer feiben= artigen Gdjidgt vergärteten Sdyleimes anşge= flebt; tei anbert ferflt fid bie Päbre perga= mentartig ober ferbef yornig bar, unb nod) bei aubern Gattungen ift fie feit unt ans foblen= faurem Raff gefilbet. Dic Tsintongen biefer TEurmršbren, igre äufere Berjierungen fitto it biefom falle meift fo doarafteriftifa), bafi man aud) ans ber Yeeren Röbre Garttnng und Itrt beftimmen faut. Die Santt, Der in biefen

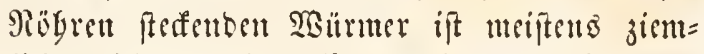
(id) weid) und igre contractifität ift fegr be=

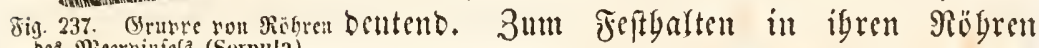

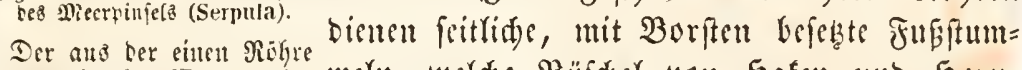

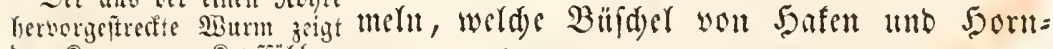

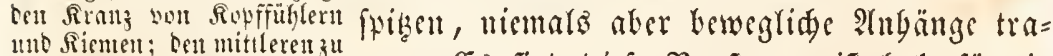

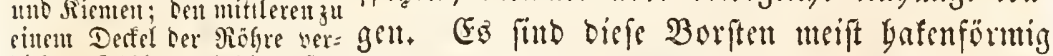

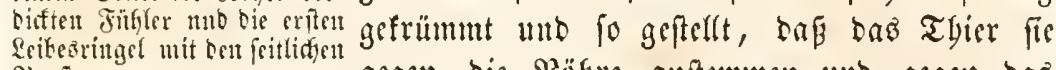
3oriten. gegen bie Reügre antermmen unt gegen bas

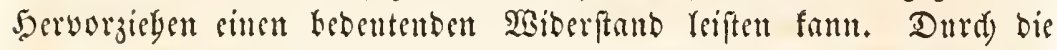

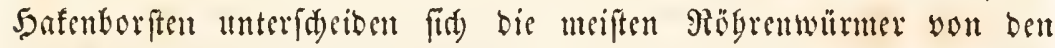
Sd)langenwärmern, weldye niematz Safenborften befitent.

Mant fant bei ben Mä̈brenwürmern feinen gefonderten Ropf uth= terideiben. Simtegorgane feglen faft inmer; mur bei cinigent Gattut=

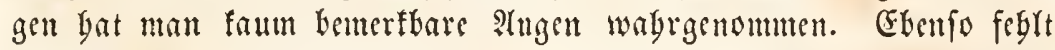
fters irgento weldye Bewaftuntg Les Borberentes, Riefer, Rüffel obev bergleiden. Dagegen finten find tei affen Rögrenmürmern an bem

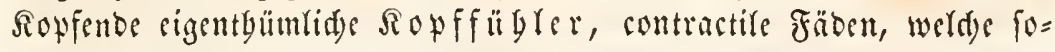
wogr zunt Taften ald and jum Fangen ber Bente bienen. Bei eitti=

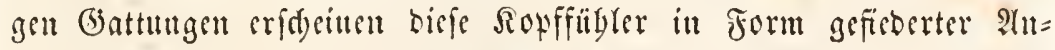
Gänge, weldye eine 2trt Feberfrome in Tridter= ober Spiralform bit=

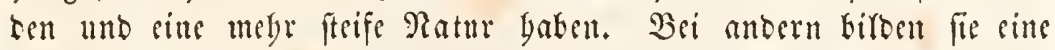
Menge auberorbentlidjer bünner rauger Fäben, welde cine wumbers bare Beweglidffeit befiten und sic man abgetrent für felbiftänbige 2Bürmer Galtent föutute. Mit biefen Fäben, welde man frïber irr=

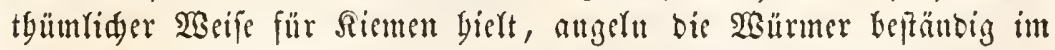

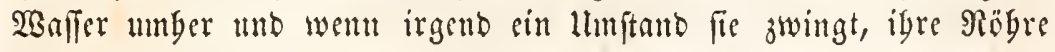

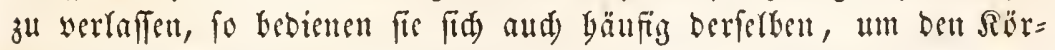

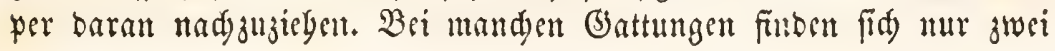


folder Sopffübler, wovon ber sine oftmals zu siner art gyfropf um=

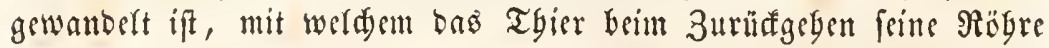
fisliegrt.

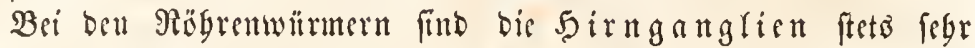

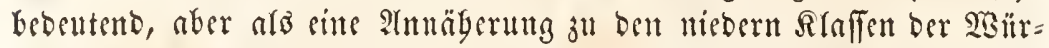

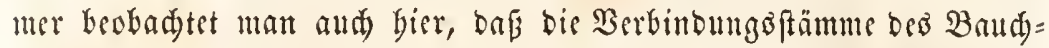
marfes ato sinander weid)en uno zu beiben Esiten ber Mittelfinie mit sigenen Rntoten fid Gingichen.

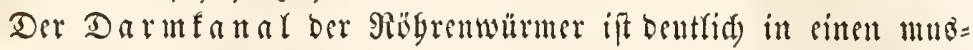

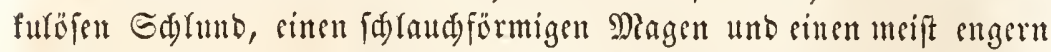
Darm getbsilt. Er werläuft zuweifen in feinem Gintern Theife fpirns

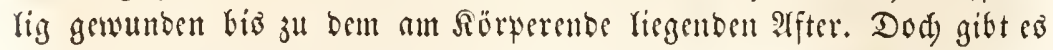

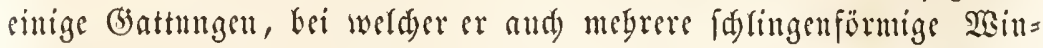
bungen madyt. Sn biefen Darm münden meift unmitterfar binter bem Ropfe zwei Speiderbriafert sint.

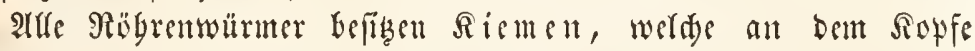
in Form baumartig verältelter Atnbänge, zuweilen aber aud zur Geite

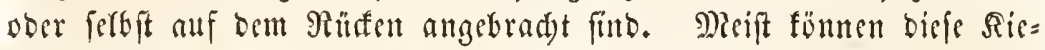
men nad) Wrilfür aubgeitreft und singejogen mo auf bieje scerfe die Girculation Les Blutes in ignent gebemme ober geförbert werbent.

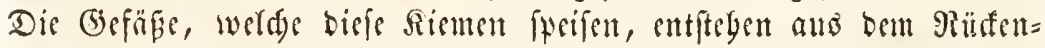

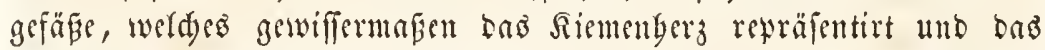
oftmal in zwei Etämme geipalten ift, woyon ber eine unter ber $\mathfrak{b a u t , ~}$ ber andere Yängs des Darmfana sine fegr rebgafte frimmerberwegung und find inmer fo geftellt, onfis

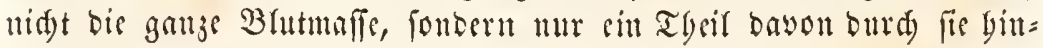
burdigetrieben wirb.

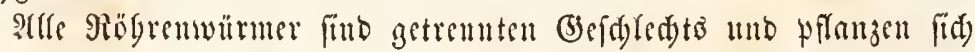

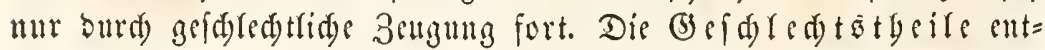
wiffeln fiđ) periwbifd) als innere Drülenbälge, beren Sngalt nad) ber

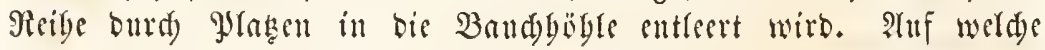

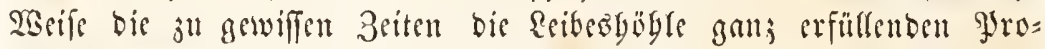

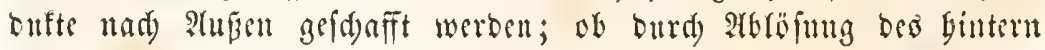
Sörperentes, ob burd bejondere Deffnumgen am Sapfe ober an ben

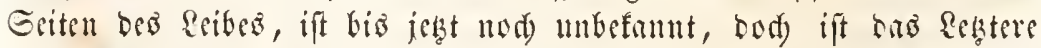
wabridgentider. Die meiften Rübrenmürmer regen igre Eier in

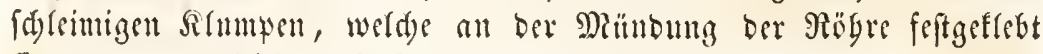
find unt Dort Yeidgt aufgefunden werben fötunen. 
Die Eutwifelung ber Röbrentürmer wurbe erft in neuefter Zeit befinut unb lief nod unchr als alle anbern Egaraftere

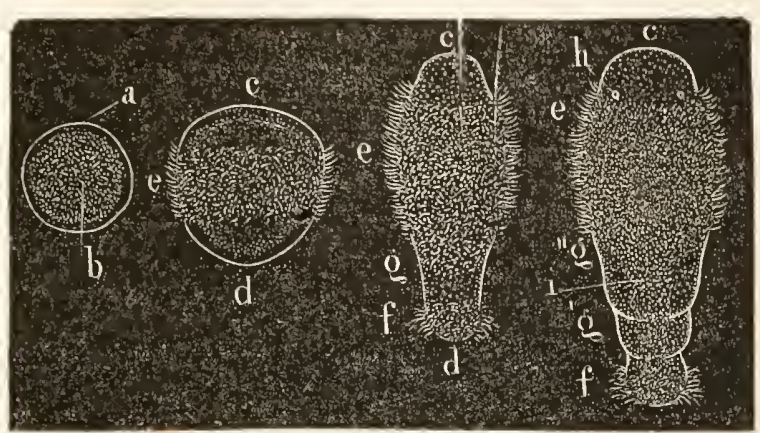

sig. 230.

240.

241.

Erite (Entridetumy cines Röbrenwurnes (Terebella)

Fig. 238. Der reife Dotter. Fig 239. (Ein (Smbryo,

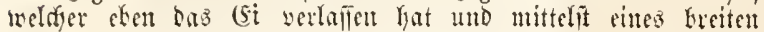

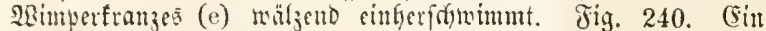

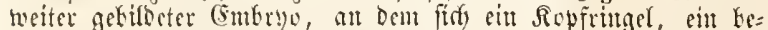

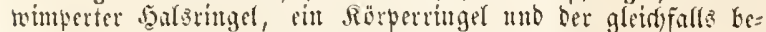
wimpecte Entoringel unterfdetien läst. Fig. 241. (Ein nods

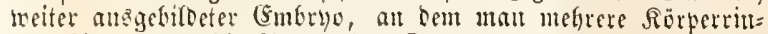
gel, SAtugen unt bie Antlage bes Darms unterigeidet. a Dut= terfiant. b Dotter. c Sopfente. d Shinterende. e Betuimuer=

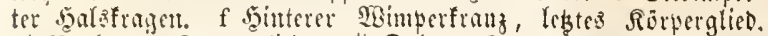

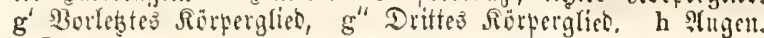
i Darm.

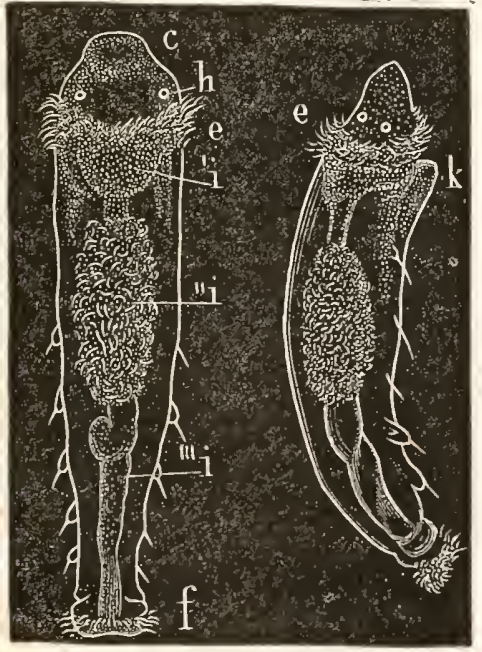

jig. 212.

213.

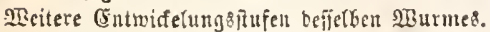
Fig. 242, Bon ofen. Fig. 243. Bon Der Seite gejeken. Der Darm hat fid jebst it eituen die nabe $\mathfrak{B e r}=$ wandifaaft zwi= (d)en ibuen und ben umberidjwei= fruben Ringel= wïrmern, ben Sd)langen= : merll, erfennen. Man fand, baß biefe Jungen sine vollptüubige Mes tamorphofedurd. maden, uno baj fie im anfauge gani auf bicfelte 2Beife wis bie Jungen orr um= berid)weifenten Riungel, $\mathfrak{B}$ ïrmer gefildert find, io baß es fdwer bält, biefelben ju unterfdeioen. Rad) yoffendetem Furdungêprozeffe verwanbelt fid nämlid) ber Dotter im (Banzen in eimen faft fugelrumben Fmbryo, welder bidt mit Simferbaren befect ift. Dab fugelförmige Thier burdbridyt mun umeift bie (5ibülle unb fdwimmt frei im Saffer unber. Dic Rarve witb eifürmig, an bem vorbern Ende fielyt man zwei bentlid) 2 tugen= punfte. Die saimpern jieben fid) jufaumen unb bilben un= mittelbar binter ben 2tugen eine Art Jaleztragen. Der תörper verlängert fid) ftet mebr, man fiegt Duerabtyeilumgen und an 
Edlunb (i'), Magen ( $\left.i^{\prime \prime}\right)$ mub Darm (i" $\left.{ }^{\prime \prime \prime}\right)$ gethrilt,

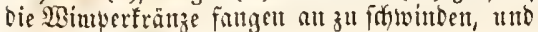

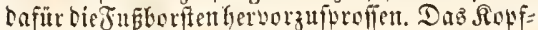
enbe ift fuib getworben mit eite beutlidye lluter= lippe (k) Gervorgefprofit. Bebeutung Der Butr)= ftaben wie in ben werigen Figuren.

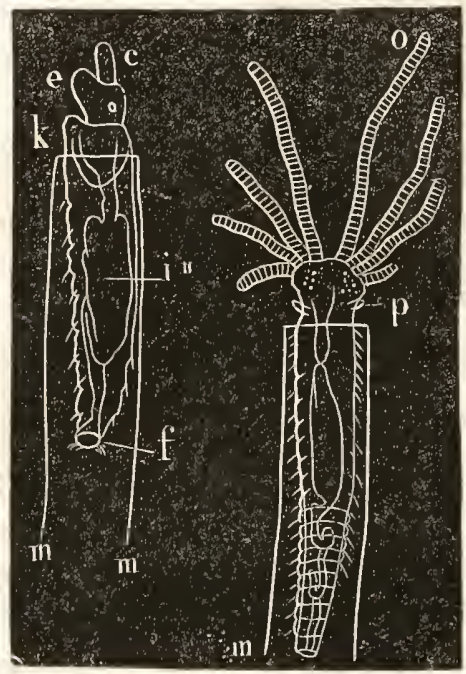

8ig. $21 \%$

215.

Terebella.

Fig. 244 11. 245. Der BBurm hat fid

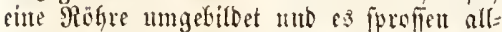
mâlylig Füfler und Riemen hervor. In Tig. 244. foumt ber erfte Fibfer in Geft nlt eines 3apfens am Ropfente hervor; itt Jig. 245.

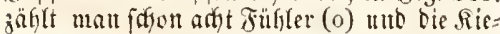
ment erifgeitent it ber ?affengegend itt (5)eftalt fleiter Etummeln. m Röhre. o Finfler. p Riemen; Die n̈brigen Butdptatent wie obett.
Dem binteren Ende Des Sörters einen zweiten Simperfranz. Dis Rarve (d)wimmt mun febr (d) nell

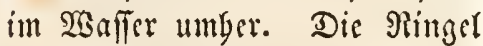
vermebren fid und werben beut= (id)er, bie beiben Wimperfränje veridwinden allmäblig, wäbreno zugleid) an ben Seiten dez $\Omega u ̈ r=$ pers fid cinzelne $\mathfrak{B o r f t e n}$ zeigen. So ift allmäblig กuв Der ciförmi= gen Rarve cin ränglidar 2 Burm mit beuttidsem Sioffe, zwei stugen, cinem flimmernben Sals̆tragen und mebrfaden sörperringeln gewor= ben, werde mit Borften Eefegt find unb bem Thiere beim Srieden bienen. Run beginnt bis Rarbe fid) feftureseen unb cinte Röbre umjubitoen, wäbrento jugleid an Der Stelle des Jalkftrageng dic Riemen bervorfproffen. Dic IHgen verfdyinden, bie Ropffübre fprof= fen an ifrer Statt berwor nub bei zunebmenter Entwiffelung rifoet (iid) Daz Thier auf Dicje racife ftets mebr unb mebr jum erwads. fenen 9ügrenwurm um, weldsem

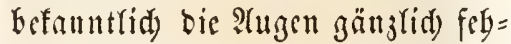
len. Bei ben Rarven ber umber= (d)weifenben Ringelwärmer, weld) S(nfang vollfommen mit ben

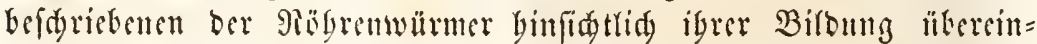
fommen, fdurcitet bagegen bie Entwiftelung bes Seffes fowobl wie bie bes fonftigen Sïrpers in gleidam Maaßje fort. Man fann

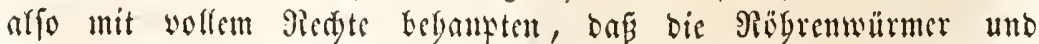




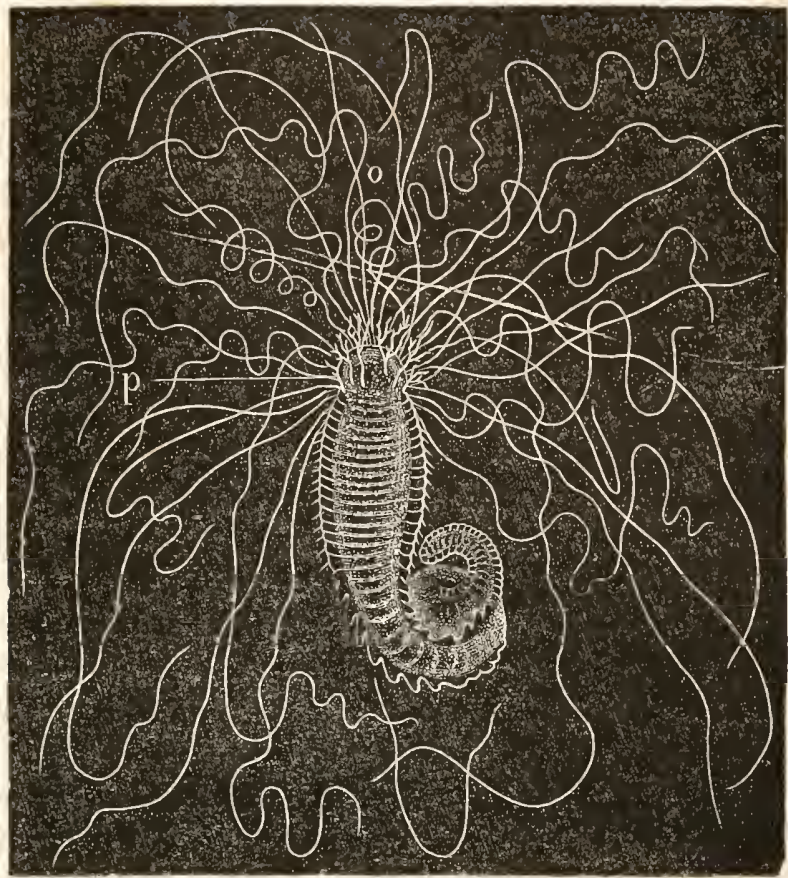

Jig. 246. Terebella.

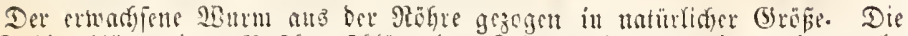

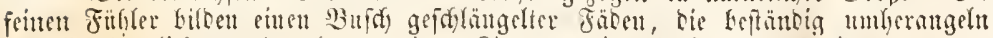

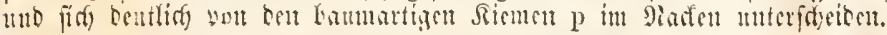
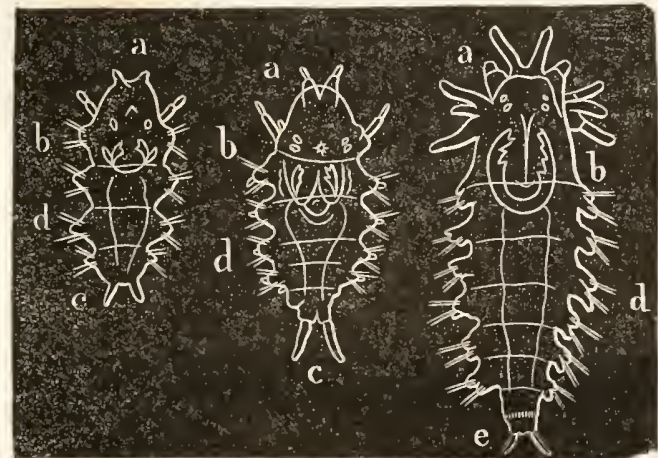

ชิig. $21 \%$. 218.

219.

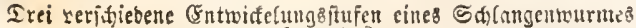
(Nereis.)

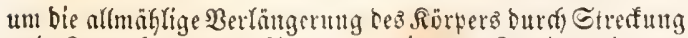
uno 3umadfz netter Ringe z" zeigen. In tem jungen Embryo Fig. 247. Heginnen bie Ropffutyler erft zu foro

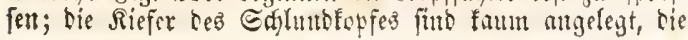

bis Gd)langentwätmet oufammen nur eimen Typus bilben แแD dấ bie erfferen Durd rünt= foretenter Mietamor= Wbofe ju ber fizenden eebentart umgebildet werben, welde fie in cruadfenen 3uftande bebaupten. Dis Fixa= tion ciltes Thieres an cinem beftumten Drte, das Reben in Röbren und Gdualem, die fept= fitzen, wirft ftets ganz in ägnlider Seife be= 
Pugent nur eitnad, man unterfdeibet nur swei Reibe: ringe. In Fig. 248. Gaben firf bie Reibesinge vermehrt,

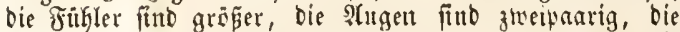
Riefer beutlid getworten. In Fig. 249. entolidy fint bie Füblet auszebilbet, ebenfo bie Riefer, bie Finfie ber Sei= kedtune getheilt, bas (5anze, bis allf bie Ränge, bem (stwadjpenen äfulid). a Ropfeube mit Delt Finfleru. b

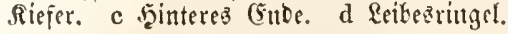

grabirend auf bafferte sith, wic Dnis Sdjma: roberlebert, inbem bei beiben 3uftäuben ric eoleren Simnežorgane utto bie actinen Bewe= gungrorgane verfütmmern, um 5aftorganen tutb megr ober minter aużgebirbeten $\mathfrak{Z}$ aftwerf

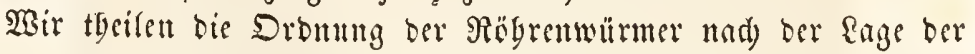
Riemen unb ber Form ber Borfen in Drei Famifien. Bei ben erften, ben 2 uffernwïrmern (IIermellida) fteben bis Siemen paarweife zu

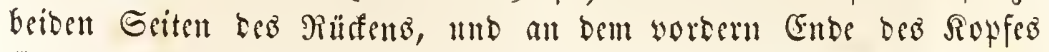
fiegt man außer cinem baufen baumartig verzweigter fritgler zwei

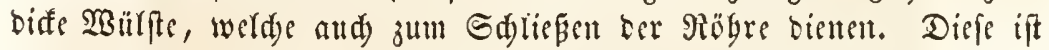
uncift runt unt aus Gandförnern zufammengeflebt. Arten biefer alu=

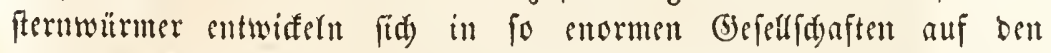

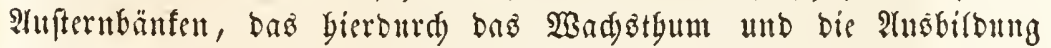
Derferfent vielfad) befduräntt wirb. Hermella.

Dic Familie Der Meerpinfel (Sabellida)

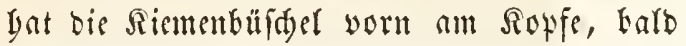
in Form eines ats zwei 5 ärftent gebilbeten STeifes von Federn, bald nats feitlide ver=

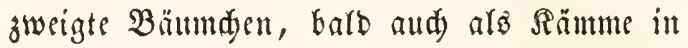
Der Jatęgegeno. Dicjentigen (Jattungen, welde falfige Rögren befişen, bitben oft grebe Grup= pen, weldye fid befonbers auf Miufdern, $\mathfrak{S O}_{0}=$

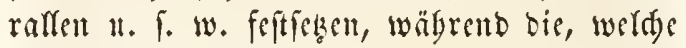
Rögren anb Sand ober verbärtetem Sdreime befizen, megr cinjern reben. 2lan bat be= gänfe, welde meerpinfelartigen Thieren an= gegören, faft in allen Edjidyten ber Erbe son

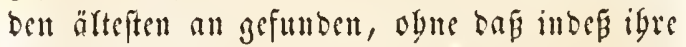
gennuere Beftimmunt bis jegt möglid gewefen

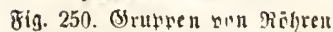
bes yicerpinets (Serpula).

wäre. Mantye giöbren biefer $\mathfrak{B}$ ürmer (Spirorbis) funo wolfommen (d) neffenartig gewuthben; anbere (Serpula) แnregelmäpig geid)längelt; andere (Sabella) gerabe unb bautartig; nod) anbere (Terebella) aub Steinden jufammengcflebt. Amphicora; Amplitrite; Peclinaria.

Den llebergang ou ben Sdylangenwitrmern bilbet bie Familie ber (Srïnwïmer (Chloraemida), bie eitten imebr ober minber beutliden

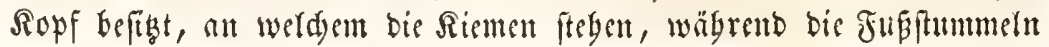


ganj fo gebilbet fint, wis bei ben Gdylangenwämern, unb Durdanb feine Safenborften tragen.

Die Drbun! ber Grolangenwïruter (Empantia) begreift nlle biejenigen Ringelwitmer, Deren Röper beutlidge Duergliebes rungen jeigt, welde mit Fusftummeln verfeben find, unb bei benen meift cin bentlids abgetrennter Sopf mit entwiferten $\mathfrak{x a f t}=$ unb Sinneb. organen unb Riemen vorbanben fint, bie zu beiben Seiten bes Rüfenz in Büfdeln vertbeilt fteben. Die Sant biefer Thiere ift febr berb uno aus gefrenten Gebnenfafern gewebt, weldye bie fä̈n= ften Sdjillerfarben erzengen. Der bentlid getrenute Sopf trägt furje coutractile Sopffïbler, beren oft mur zwei, oft aber megrere vorbanden fint. Eaz bienen biefe Drgane zum Iaften, wägreno zwei peitlidje einfad)e $\mathfrak{A}$ gen bas Geben vermitteln.

Die Bewegungzorgane befteben ftetz aus

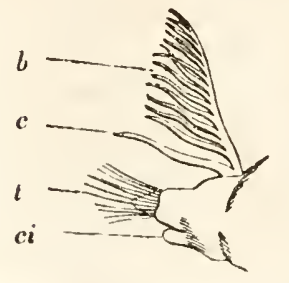

5ig. 251. Jufitummeln, bie nur felten einfad) ober fo miteinanber veridumoljen find wie bei ben $R$ öb $=$ renwürmern, vielmegr in oer $\mathfrak{B e i f e}$ boppelt fitto, bafi fie in einem obern unb untern $\mathfrak{Z}$ ulft enben, welde beibe Borftenbilider tragen, weps=

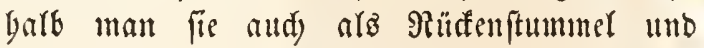

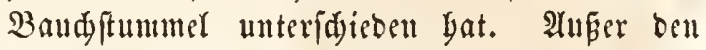
Biifdeln werfdiebenartiger Borften, welde auperorbentlid) wed) felube Formen befisen unb guß eineฐ Riefertwurms (Eunice).

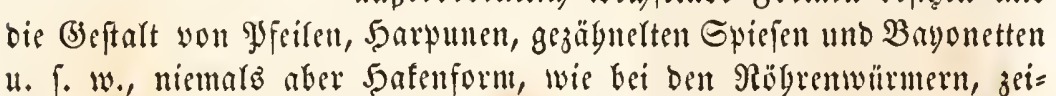
gent, tragen biefe Fïßje faft immer nod fabenförmige Siörperfübler, ober Cirrben, bis meift an bent ?Rüfenftummel angebradt fint, liber weldem außjerbem nod) bie baumförmigen Siemen befeftigt erfdecinen.

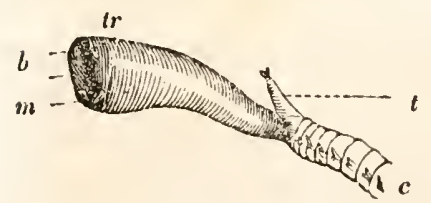

8ig. 252. Ter surf eines ๔d) (angen= wurmes (Glycere) mit entwideltem

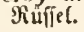

tr ber Milijel; b ber Mlunb; $m$ bie baran Yiegenben Sieper; $t$ Der verhältuíß̈mäßig ferge łleme Ropf; c bie erften söpperringel.

Siefer ftets yon ber Geite ber gegen einanber. Buweilen ftellen fie einfade 3angen bar, zuweilen aud fint fie vielfad geferbt unb in 
ungleider 3abl auf Eeiben Seiten angebradyt. Der übrige Berban=

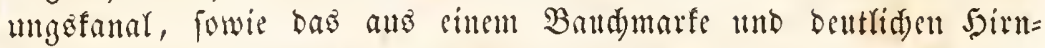
fnoten beftegende Rerbenjyftem, bieten feine wefentliden Berfideden= Geiten von Den Päbrenwärmern bar. Das befäpfyftem ift au= Ferorbentlia) entwiaf won Bebentung. Erfteres fpeif dis Siemen, weldye meift in Bamm=

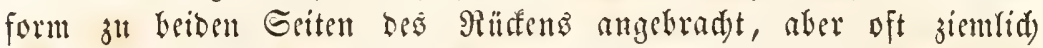
rubimentär fint, wäbrent fie bet alloern Battungen eine snorme Entwiffelung uns 3ablerreiden. Die Gefd)led)ter find gerrent, die

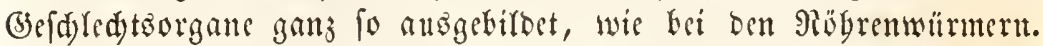
Die Cier werden entweber an Gteine ober Sanferpflanzen gelegt oder, in idleimige Särfe gebüllt, von Der Mutter an Dem Reibe mit berum=

ซึig. 253.

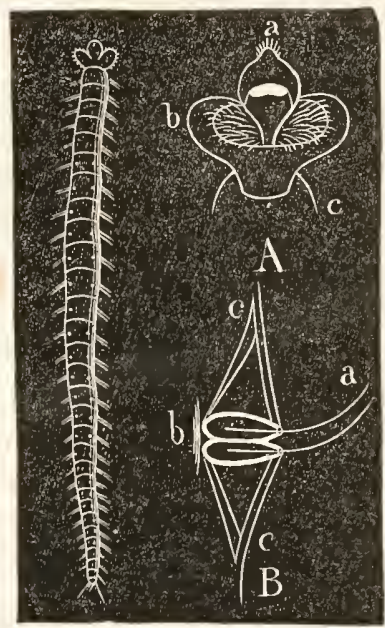

รig 255.

Fig. 253. (5in Bitange (Polyophthalmus). Wian jiefyt die entwiffelten wimpernbon Ropflappen umb anf bem Reibe bie rettictien

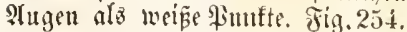
A. Daz Ropfento vergrëвert. a bie Skerlippe mit dem Eentralues= veuipleme; b die raberlatpen, c Der Leif. Fig. 255. B. Die Bemegungergante, a bie Fubler = felt. b bie beiben nuzknlofen Särfden, in weldyent fie fteifen. c obere unb untere Minstelbündel. getragen. Die Entwiffelung gefdiebt ganj in Derferben 2 seife wie bei ben $\Re o ̈ b=$ ronwürmern, uแr mit Dem llnterfdiebe, Daj bie Anfangs siförmigen \&arven ben நarb= fragen wie es fdesint nod) lange bebalten

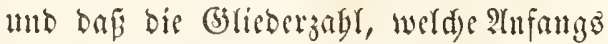

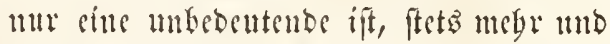

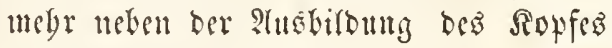
ebenfalfz junimment.

Reten ber gefdredthtiden Zeugung ift aud bei einigen Ed)langemmürmern wabre Sinospenbiloung beobad) tet worben, und zwar in ber Sacife, dap die Jumgen an bem Sointerleiberende Gervorfproffen und bie ucuen Rnosipen fid) f(d)on entwifern, elye mod) bis ältern fid) losgetremt batten.

llnter Den vielen Familielt, in wel= de fid bie Dromung ber Sdylangenwitr= uter tyeilt, zeigen bie Siclattgen (Polyophthalmida) cine merfwitrbige Bejiegung z"l ben Miäbertbieren. An Der Gpize Des Sopfez fteben mämlid) 3n beiben Geiten cinces furjen, mit 2 Bimpern befesten rilffelartigen Füblers, sube feitlidge mit langen Simperbaren befetzte 2 Bitlfte, bie wie bie Päber ber Mäbertbiere eingejogen und augeftilft werben fömuen. Die Jiife biefer Bielaugen find 
Denen ber Regentürmer ägnlid; die Fngborften ftefen in (B)ruben, Dis auf faum bemerfbaren Stmmmern fteben. Fuperdem baben diefe

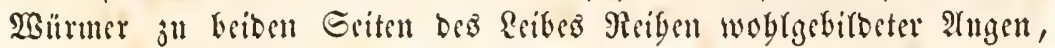
fu welden nod) befondere Sopfaugen fommen. S(n bem Baudgefä ftamme findet fid sin bentlid)es, aus cimer mittleren unb juei feit=

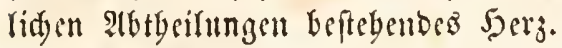

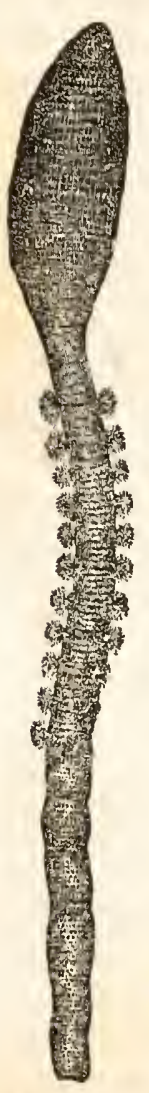

8is. 256.

Die Familie bet Piere ober Sandwärmer (Arenicolida) wirb yon Silirmern gebilbet, bie am Strande Des Meeres wobnen und in igrem Aenßern viele Rebnlidfeit mit ben Regenwïmern baben. Das Sopfente ift gleidmäpig abgermmot und zeigt weber Fübler nod Stugen. Der voriftrestbare Riuffer ift furj, nayfförmig, unbewaffut. Dis unr an ber worberen Rörperbälfte augebrad) Fen Fuftummeln finb angeroroentlid) fleit mo mit $\mathfrak{B o r f t e n b u ̈ f d ) e ( n ~} \mathfrak{b}$ eję̧t. Die grofen bammartigen Rismenbüfder fteben zu bei= Den Seiten in Der Mitte Des Seibes, Der Sointerleib ift maft tut quer germngett. Die Thiere bobren fidf) Baflericen in bem Gande, yorługstucife in ber Region, welde won ber sebe entblöbt wirb uno es wirb ignen an allen süften febr nadigeftellt, ba fie sinen vortreffliden Röber für ben Fifdfang bitoen.

Die Jamilie ber Eecranpen (Aphroditida) zeigt einen unr rubimentären Sopf mit febr furzen Füb= rern unb einen mebr ober minber breiten Sïrper, Der zuweilen ganj eiförmig rifdeint. Sie baben

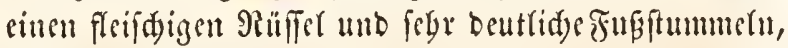
welde meift ungebsure Stadyeln unb Boriten der verfdicbenften Gejtalt, fowie Fublerfäben tragen. Dis Siemen find Göd) r rubimentär und anf Dem Pä̈fen angebradt. Bor allen anbern sisurmern ift

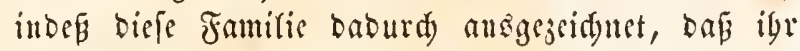

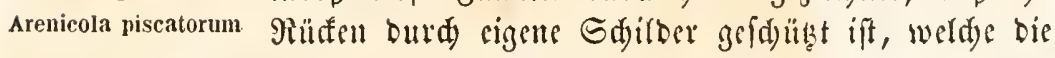
(B) falt von Sduppen baben uno pariveife in ber Art anf ben Ringeln angebradyt find, baj ftetz ein Ringel bamit verfeben ift, wäbrento Der näd)fffolgende igrer entbegrt. Bei ben sigentliden Seeraupen (Aphrodite) bifoen bie febre lebbaft gefärbten 5aane unb Borften einen

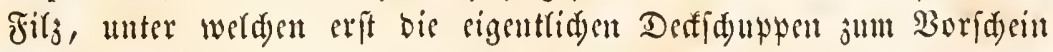
fommen, wäbreno die mebr längliden (battmingen (Hermione, Polynoe) nafte, unverfilgte Rüffenfduppen tragen. Man findet biefe Seeraupen 
wie bie übrigen Sd)langenwürmer Gauptfäd)lid unter Steinen แn meift in ziemlider Tiefe. Sigalion; Eumolpe.

Die Famitic ber fduppentojen Eecruitpen (Amphinomida) theilt

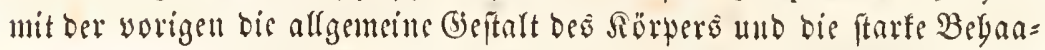
rung, unterideibet fid) aber woul inuen turd ben Mangel ber Dedts

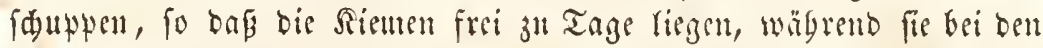
Seeraupen burd bie Siliffenfduppen serbect fitto. Amphinome; Chloeia; Pleione; Euphrosyne.

Eine fünfte Familie wiro burd) ein nur in wentgen (Ex rmuraren vorgandenes Thier gefirbet, weldes Peripalus genannt wurbe, zwei

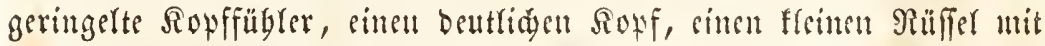

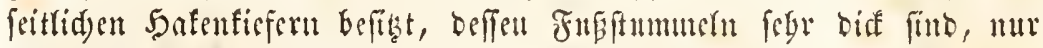
Borften und feine Fübler zeigen, unb oeffen Rervenfyitem merfwitr= Digerweife ans jwei feitliden Eträngen beftegt, wäbrend alfe übrigen

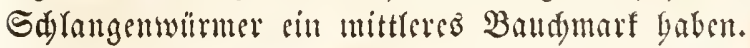

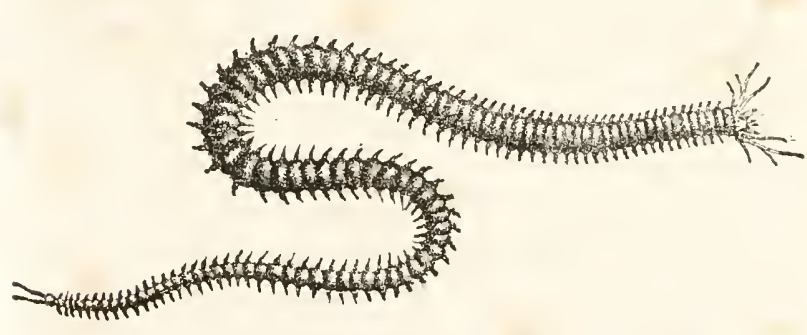

8ig. 257. Nereis

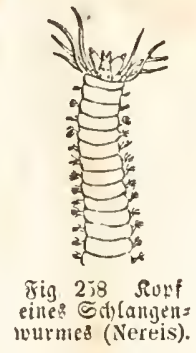

Die Janifie ber Ranfenwärmer (Nereida) bat meift nur un=

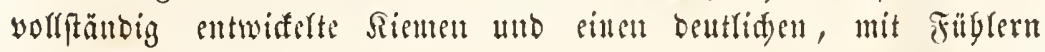

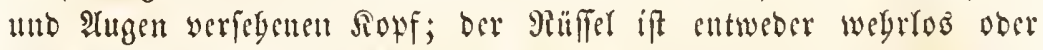
aber mit cin bis zwei gaar fafarfen, berworftebentoen 3angentiefern bewaffnet. Die Rörperfübrer fint oft fegr lang und bei eintigen bat= tungen (Syllis) fogar geringert. Die Sörpergeftalt fdulanf, rang= geftrefft. Nereis; Lycoris; Aricia; Aonia; Cirrlonereis; Alciope; Glycere.

Snt ber Fanitlie ber Rieferwürmer (Eunicida) finben fï) 7 bis 9 gezäburte, Gafenförmige Riefer anf cinem Yaugen Rärffer utb meift fegr bentlid) entwidelte, gefieberte Sienten yor. Sn ben fübriden Miceren

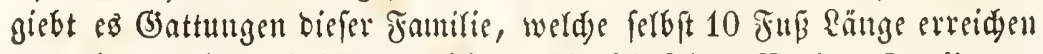
und einer ffeinen Sdjlange nidjt unägnlid) Fegen. Eunice; Leodice. 


\title{
Pleutter Brief.
}

\author{
fireis Der Weillfiere. (Mollusca.)
}

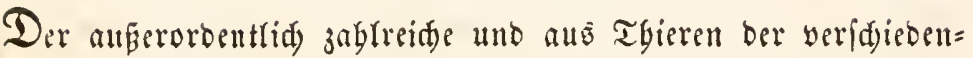

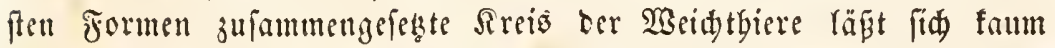
outrd) cin gentigendes Mierfual d)arafterifiren, weldes ben verfdjiebe= nen Rlaffar, bie jener Rreis umidjlięt, ganj eigentyümlid, wäre.

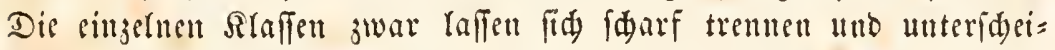
ben; aber in igrer Drganifation und ben Befonderbeiten igreß Baues zeigen fitd überall allmäblige llebergänge, woburd fid theilo

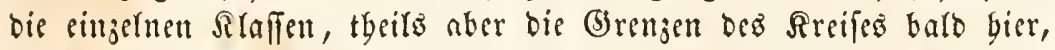
bald bort, an andere Rreife anfd)tießen. Rirgends fo wie bei ben Weidatbieren fann man bie Degrabation eitres jeben organifaen $S_{y}$ = ftemes bei ben eingernen Typen nadivei fen unt begründen, nirgenbo

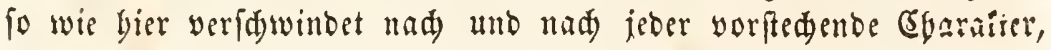
ie weiter man ign nad) ben Grenjpunften serforgt, nirgento vers fdjwimmt fo jeoes doarafterifififde Merfmal alfmäblig in unteftimuten llumiffen unt finft nad) uno nad) zur Hthbebeutendbeit berab, wo feine

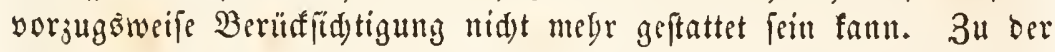
Edwierigfeit ber Begrenjung, bie alts biefen, mannigfad) wedfernben Berbärtniffen berworgebt, tritt nod ber llmftano binju, baß man bei

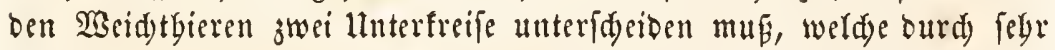
wifentlide utto beftimmte Ggaraftere, namentlid burd bie Befdaffen=

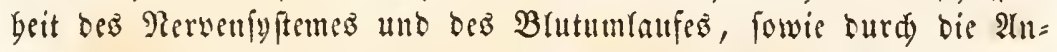
ragerung ber Drgane im attgemeinen sou sinanber getrenut find uno

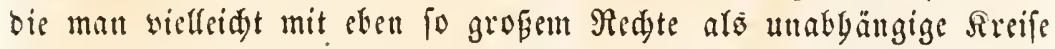
betrad)ten fümute.

Die fymmetrifde $\mathfrak{A}$ nlagerung oer Drgane zu beiben Geiten einer Mittelebene, weldye wir bei bent meiften $\mathfrak{B}$ Bürmern in io

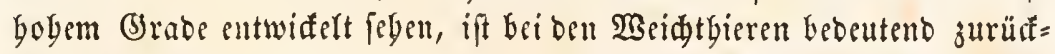
gefunfen uno nod) weniger läßt fid eine ftrablenförmige ?tuoronung um eine Mittelaxe erfennen. Bei vielen Meidtthieren zwar eridseitten

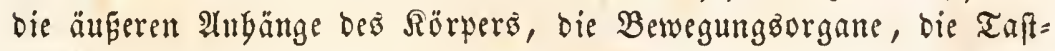

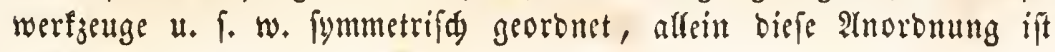


weit entfernt, im äbrigen Sörperbau burdjugreifen unb man findet Desbarb meift die imneren Drgane, bejonbers bie Serbaungs = und

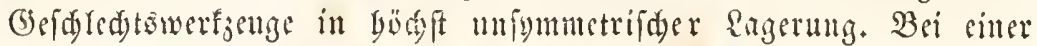

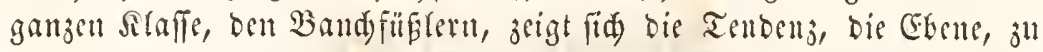
Deren Geiten Die Drgane vertbrilt futb, fpiralig aufunollen uno fo Die Geftalt Der Sdneffendalen beruftellen. Da Rervenfy ftem if $\mathfrak{b e i}$ ben Unterfreifen nad) zwei verfdiebenen Typen entwifelt. Bei

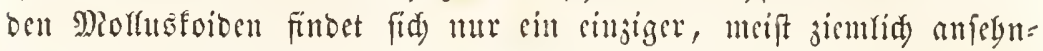

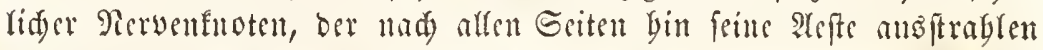

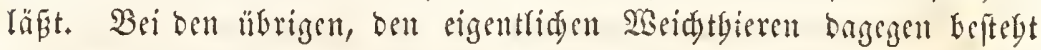
bas Rervenfyftem aus zerftrenten Suoten, welâe burdy Fäben mitein=

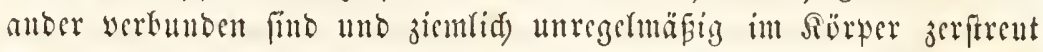
mmberfiegen. Gis bifbet aber sin Tyeil biefer Nuoten mit iblen $3 e r=$

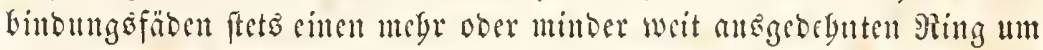
ben Gdlunb uno bei ben göbern (Gattmugen lägt fid and cine beben= tendere Eentralifation su fömtiden Sirnfuoten liber bem Sdlunbe wabrnebmen. Die Rnorbnung ber cinjelnen Snoten im siötwer ift

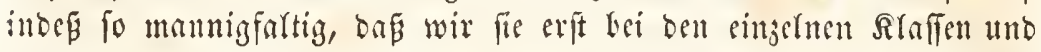
Drommgen bebandeln fünnen. Entfpred)end biejer Mamnigfaltigfeit find and bie Sinnesorgane angcoronet, bie barb gänjlid feblen,

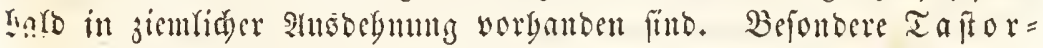

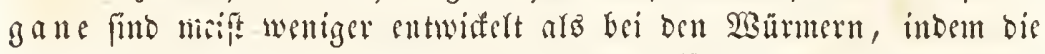

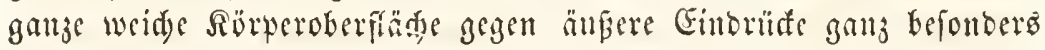

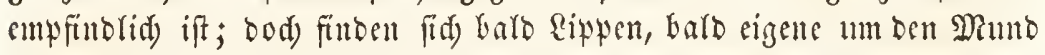
geftellte Rappen, Saare obre arme, balo cinjieblere föbler, weld)e befonbers zu bem 3ెueffe des Taftens vorbanben fint. Die Sey= werfaenge fitto nidyt iiberall vorbanben unb bei vielen finbet fid

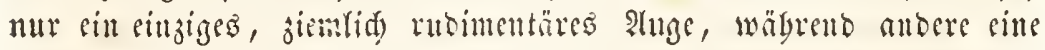

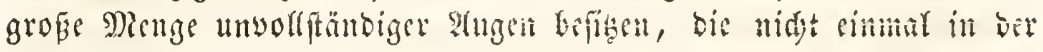

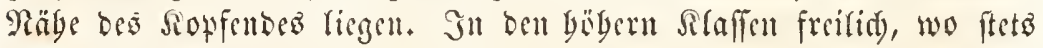

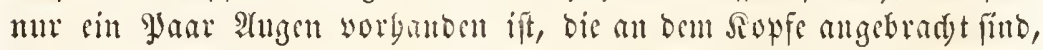

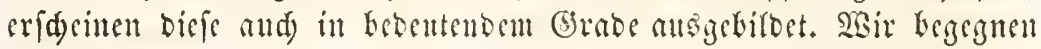

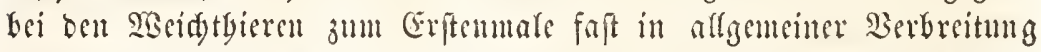
muvertentbaren Gebörorganen, rumben Brösden, welde meiftens bem (befirnfnoten ummittelkar anffiben ooer bod) nut einen furjen aber ziemridy bebentenden Gebirnerwen zerigen. Sm Junern biefer faft ftets fugeligen $\mathfrak{B l a ̈ s}$ den finbet fid eine flare Flitfig feit und eine fefte Con= cretion won foblenfanrem Sarfe, die bald nur cinen runben, bald

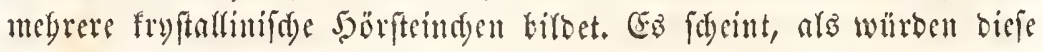




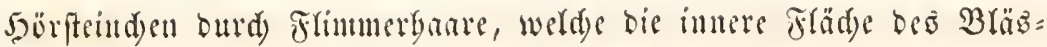
d)ens ansffrident, in ftets jitternder Bewegutg erbalten.

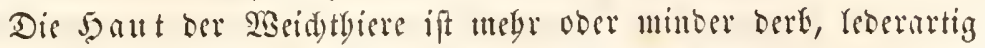

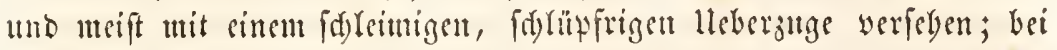

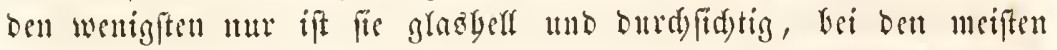

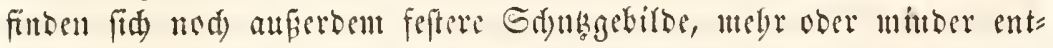

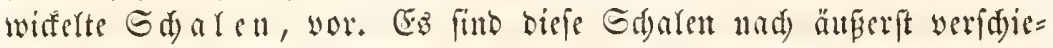

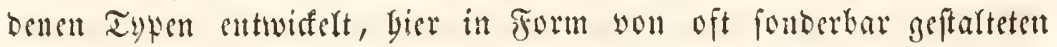

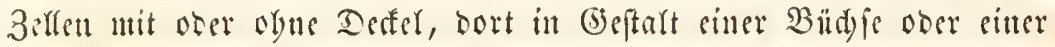
barb utegr graben, farb inegr gewutubenen Rögre; in anderen fä̈lfen

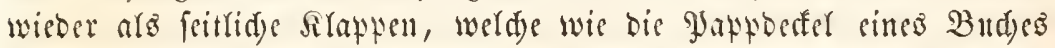

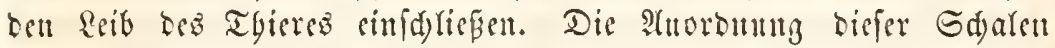

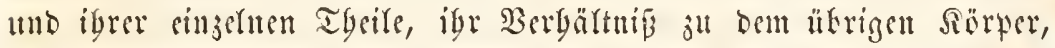
igre Bergierungen u. f. w. Kitben in vielen Silaffen ber siseidtgiere

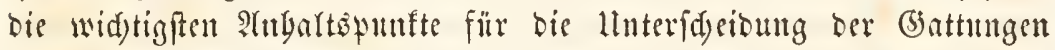

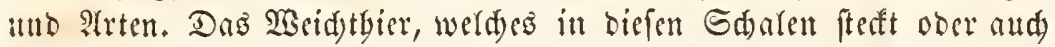

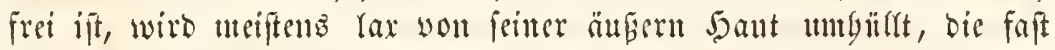

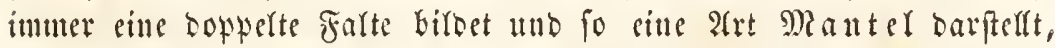

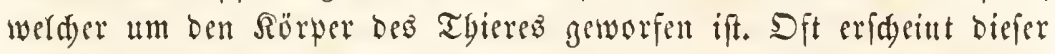

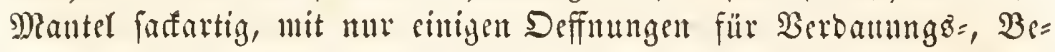

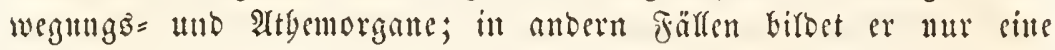

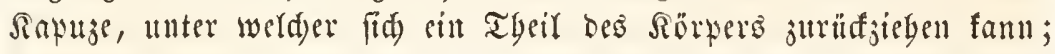

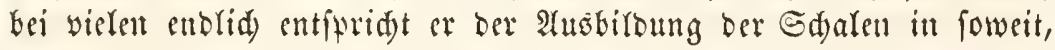

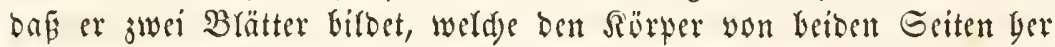
ummaten.

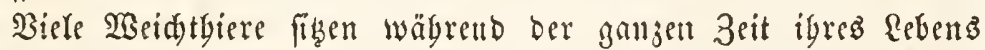

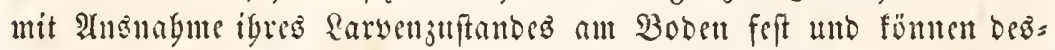

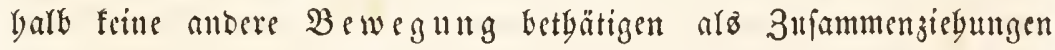

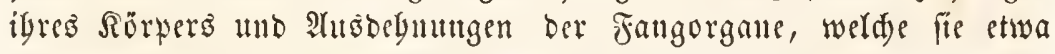
befizen. Siele fried)en mittelft sintes bejontern Drganes, bas atto

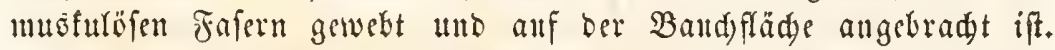
Die Freiffmaffe, welde man ofu ftaltell, ift aber niemalz weber geringelt, atody zsigt fie foldse llnter=

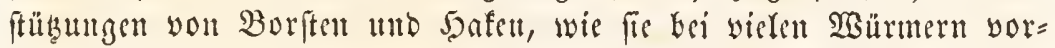
fonmen. Biele $\mathfrak{B}$ siddthiere (d)wimmen; bis einen fd)ludfen zu biefent Ente lebgaft 2 saffer ein unt indent fie s's burd eine lebgafte 3 ufammen=

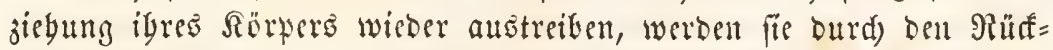

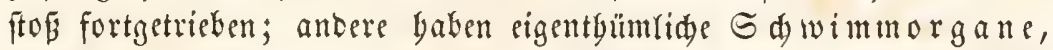
die balo in Jicigent von $\mathfrak{B}$ lättden beftegen, weldye tnit borftenartigen 


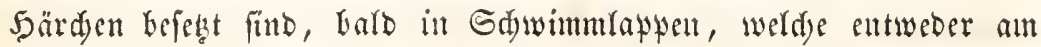
wordern Rörperente voer an Der Baudfläde angebradt fint.

Die Drgame bes vegetativen Rebens find änjerít mannigfaltig ausigebirbet. $\mathfrak{B o n}$ einer einfaden böble an, weldye nad binten zu

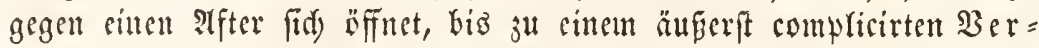

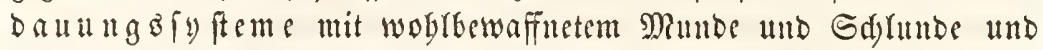

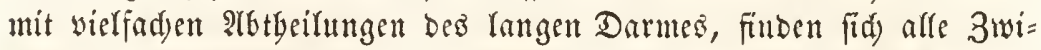

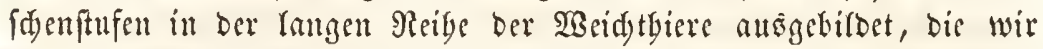

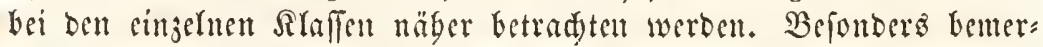

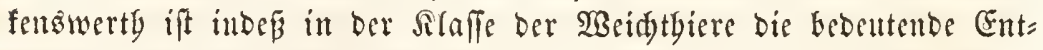
faltung ber Drififengebilde und bejenders ber \&eber, weldye bei mant=

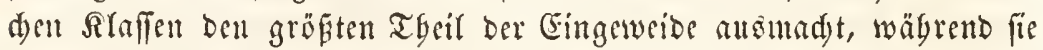
bei Den Säurmern mur eine unbedentende Sdjidjt Der Darmwantougen Darferfte. Gin ?ffer fümmt übrigens bei affen siseidythieren vor. Die Form Des Darmfanates, in welder un cine gemeinidaftlide Män=

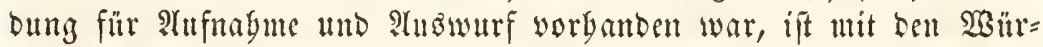
mern verfdjunben, um uidyt melys aufjutreten.

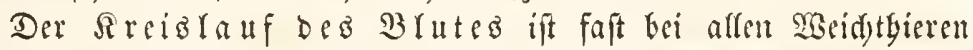

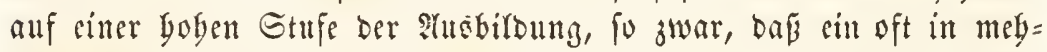

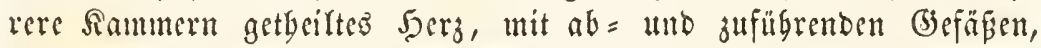

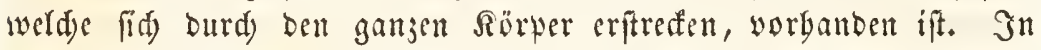
einigen $\mathbb{N}$ Taffen aber iff biefe cigene Brutcirfulation, werdje ftetż won

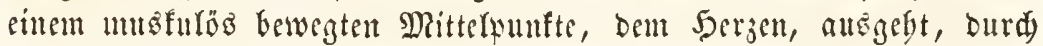
Strömungen erfest, welde theilo in ber Reibeşgogle, theilo in eigenen Befäpen vor fid gelyen uno Durd Flimmerbewegung bedingt werben.

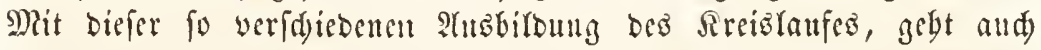
biejenige ber it tyemorgane Sand in 5amb. Bei ben niederifen Slaffen fommen feine fpeciell für biefen Zwedf bejtimmte Drgane vor;

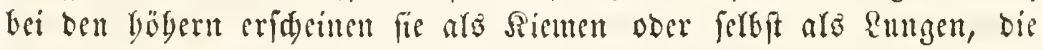
mur zum (Finatbmen Der reinen atmofpbärifd)en Suft beftimnt find. Die ftets rebbaft flimmernben Riemen treten it Der inamnigfartigften

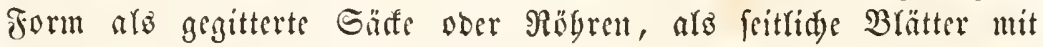
Fäd)er und Sd)lizen, alz baumartig veräftedte Inbänge auf und fteben ftets in nädjter Besiegung zu Dem $\mathfrak{B}$ (ute, Deffen ganje Mlaffe meift

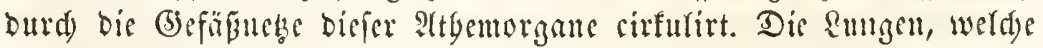
uns juerfit in Der Thierwelt entgegen treten, bitben sinen einfadyen

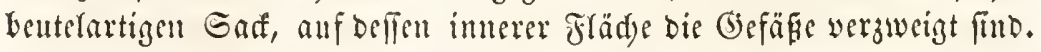

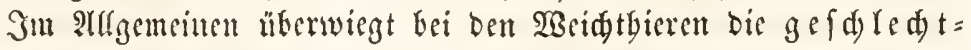

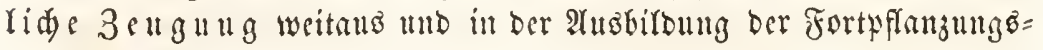
organe fint auferorbentlid) siele verfdiebene formen entwiffert. Sn 


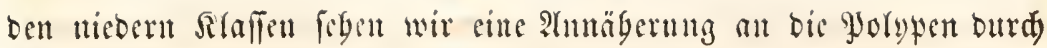
förmlide Sinogwenbiloutg, weld) golypenftöde bervorbringt, bie mane d)en Sorallentypen fo älulid) finto, baß aud jest nod) viele Sdrifts fteller, troł ber lluäbulidfeit ber Thire, bieferten fu ben Jolypen fitlen; bei eittigen Dronumgen finbet ?tumenjengung ftatt unb zwar it ber $\mathfrak{B e i f e , ~ b a ß j ~ b i e ~ R n o s ̌ p e n j e n g e n b e n ~ A m m e n t ~ e b e n ~ f o ~ b o d ~ o r ~}$ ganifitte Igiere fitto, ars bie gefdredstlid) jeugenten. Die mit (5)e

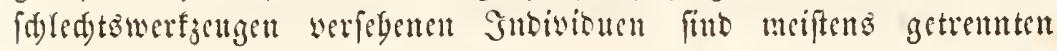
(5efd)ledtò, oft aber aud) 3witter und meiftens mit Begattungoor= ganen ausgerniftet, bie oft äแß̧erft complicirt erfdeinen.

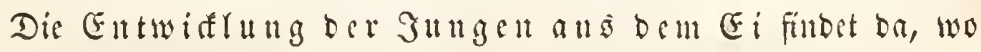
fie befannt ift, ftets in ber 2 eife ftatt, Dafi Der gatije Dotter fid

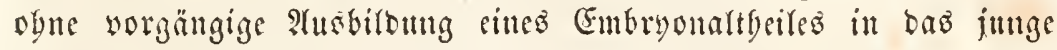
Thier umwandelt. Bei allen bis jekt befannt gemorbenen RIaflen,

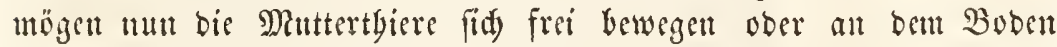

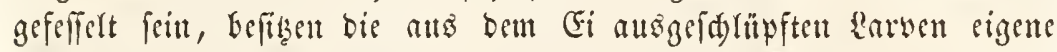
Bewegungsorgatte, bis bald in fdwanzäbnliden Ingätrgen, bald it wimpernoen Rappen weridsicbener Geftalt befteben unb mittelit beren fidi bie Rarwen entweber in (Fi ober in einer gemeinfdaftliden Sapfer

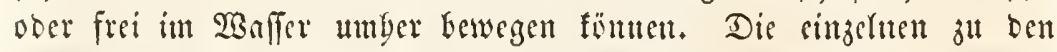
2Seidtyieren gebörenden Rlaffen futt im Durdyfdnitte felyr (d)arf Durd bie Gejtalt igrer Rarven darafterifirt, wesbalb wir bieferben kei ben Rraffen ferbft it's stuge falfen werben.

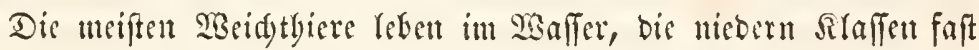

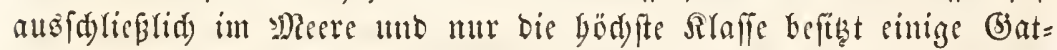
tungen, welde bas fejte Rand bewobnen. A(ber aud biefe Randbe= wogner bebürfen in gleider $2 B e i f e$ wie bie Erowürmer ftetõ eines feud)ten Aufentbaltes uto geben bei volfommener Troffenbeit zu Grunbe. Sie balten fid) beşbalb vorjugșweife an Dumpfen, uro= raftigen Drten unter Steitten und Sräuterut auf. Die friedenden

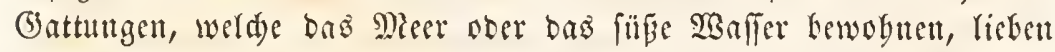

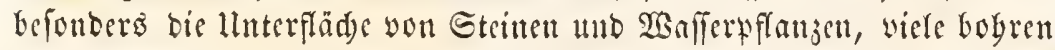

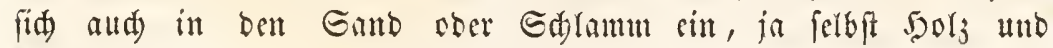
Rarffteine werben vorgugšweife won gewiffen Gattungen angefrefifen unb Durdjlödert. Die eigentlidsen Sdwimmer bewofuen affe bas Meer und fitto oft weit bittaus in offener Gee anzutreffen.

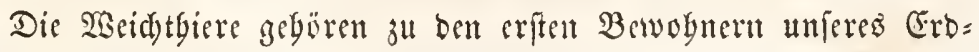
balts uno ourd) bie Fefitigfeit ibrer Gdyalen, welde in Maffen erbal= ten fint, gebören fie zu ben wid)tigften Gegenftänden für bie Ber= 


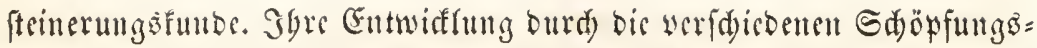
perioben ginburd) werben wir inbefien erft betradten fönnen, fokrto wir bie Riaffen uno zantilien felbft in igren Eingelgeiten fennen ges lernt baben.

\section{Lluterkreis inr Alulluskitien. (Molluscoida.)}

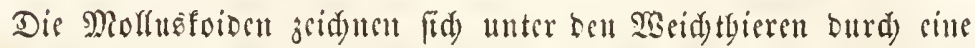

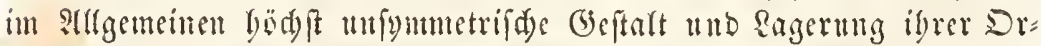

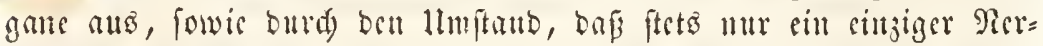
venfnoten exiftirt, welder meiftens mit eincur einjigen angenägnliden Drgane, weldes igm unmittersar auffist, in Serbintung ftegt. Ein

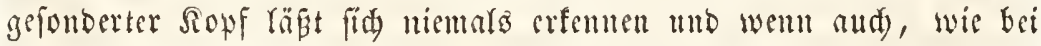

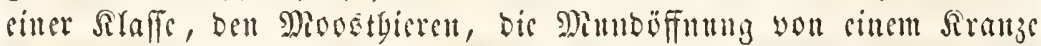

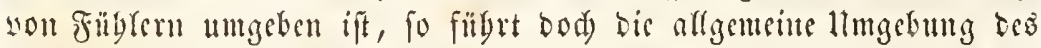

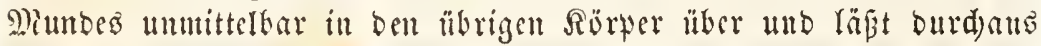

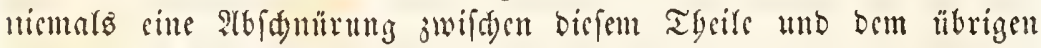

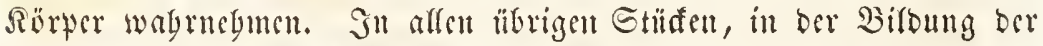
äufrere baut, ber Bewegungsorgane, ber Berbaumngswerf

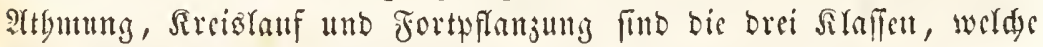
Den Unterfreis ber Miolluafoiben birben, siemlid) son citander wer=

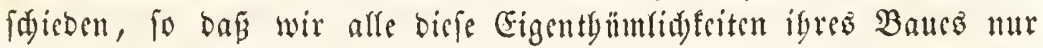
bei ben einzetnen Siraffen betradjten fönuen. Sämmtlid) Molfuâfoi ben bewobnen dag Sagffer; aber nur febr wenige Grattungen einer

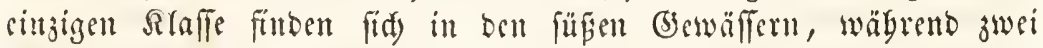

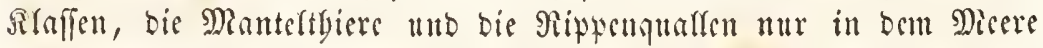

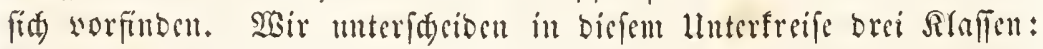
dic Mooǵtgicre (Bryozoa) ausgegeidnet burd) porypenäbntide Geftalt Des Sörpers, der Fangarme und ber focialen Formen; bic Rippenquallen (Ctenophora) mit gallertartigem Rörper uno

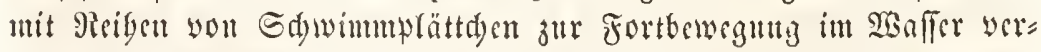

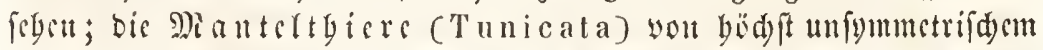

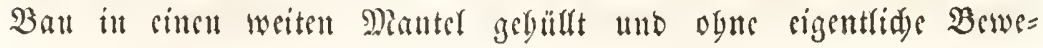
gungsorgane. 


\section{filuffi dor Atloostlitere. (Bryozoa.)}

Sn ífrem äแ

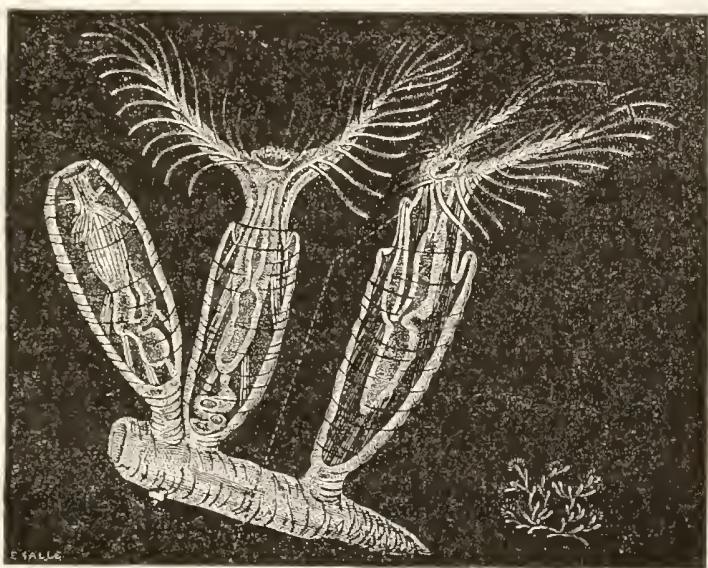

Fig. 259. Jeberfufigyolypen. (Plumatella.)

a Gime Sruppe in natürlidger Ströne. b Sintige Smbivi=

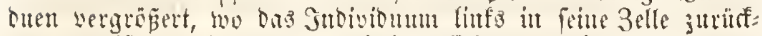
gezogent ift, mäfrent bas mittlere fith wou fiuten, von ber

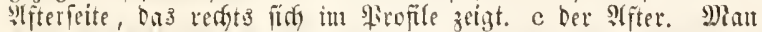

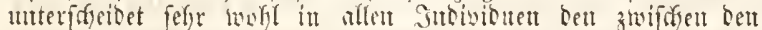
beiben Fülerarmen liegenden Miun, Den fadföntgen Darm,

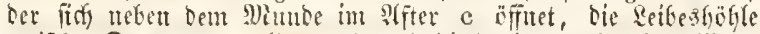

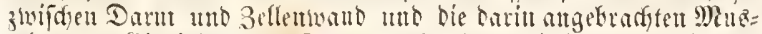

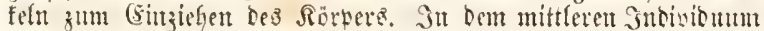

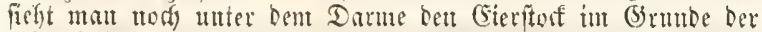
Leibeagögle.

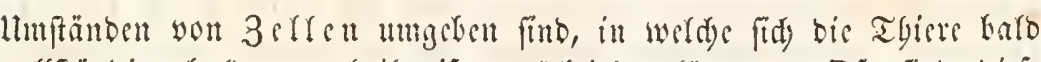

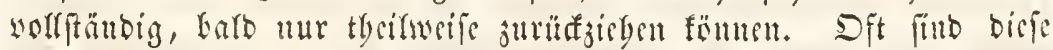
3elfen mur Gornig ober bieglam wie Ylergantent, ja fogar zutweilent fely zartgäntig unt gallertartig; oft ftegen fie auf eigenen Sticlen,

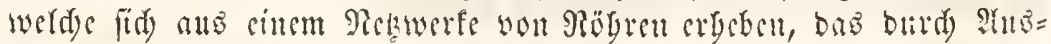

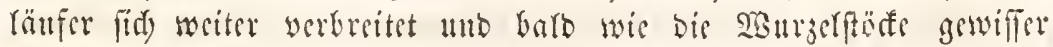

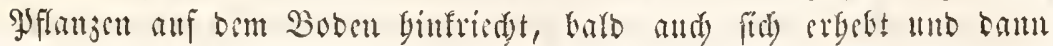


meiftens baumartig veräftelt fid zrigt. In Den meiften Föllen aber unb namentlidy bei ben in Meere lebenben Moostbieren finb bie 3ellen falfiger Ratur mub wieberbolen bann namentlid bie Formen ber Dr: gelforallen, ber Geeforfe unt der Rindenforallen. Gewögntid breiben bie balo eiförmigen, bald in Giefalt won Bäbren gebelnten 3ellen

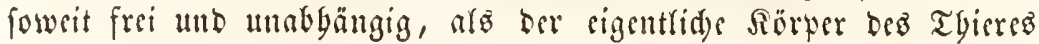

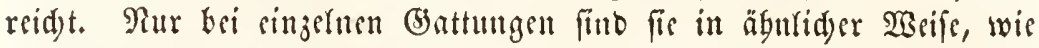
viefe Stöfe äd)ter Syolypen, Durd) cine 3 wifdenmafe mit sinnalder werbunden. Es finden fid) inber in biefen 3ellen niemals Gtrablen ober inmere Sadidewältbe, ägnlita benen, weld)e in ben siorallen yorfomuten und in vielen Fälle fiebt man angen an Denferben Spi= ben, Stadeln und 5örucr, welde ganj conjtant find, febr wobr jur llnterfd)sioung Der Arten benth werben föment uno bie ben Sorallen

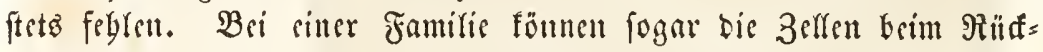
juge Des Thieres Durd sinen flappenartigen bewegliden Deffel ges đdloffen werben, wälrend bei benen, weld) ill leberartigen Jellen

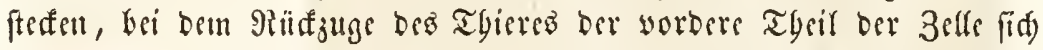
feleft mit einftülyt unb fo ber volffändige Sdlub bewerffelligt wirb.

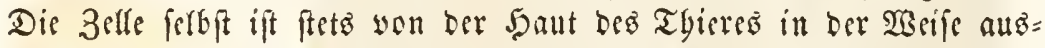
gefleibet, Dafi biefes gewiffermafen cinen boppelten Gaf bildet, wo= burd sine eigene Reibesböble Gergeftellt wirb, welde mit ben Fangarmen in 3ufammenbange ftegt unb in ber ber Darmfanal fret aufgesängt erfd) cint.

Da alfe Moośtbiere obแe Puğnabme jufammengefezte Rolonieen bilben, fo fant bon eigentliden Drtabewezungent ferme Rebe frin. Dod) Gat man bei sinigen Güpwaffermoostbieren, beren jufammenges fegter Jolypenftod nidyt feftgewadyjen ift, sill febr langfames fort= gleiten bes ganjen Gtodes beobadytet. Die Beivegungen ber

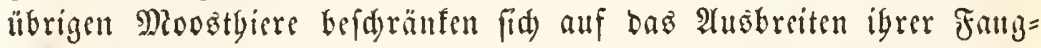
arme, fowie auf ons Entfarten utb oas 3urüajichen igres Sörters

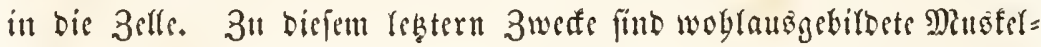
bündel vorbanden, weldye an veridjicbenen Stelfen ber bie Zefle ausz= flribenden \&eibeșwandung entipringen und fid meiftens am 5 alje in

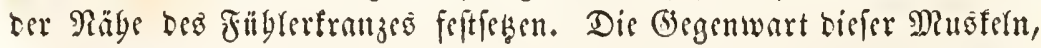
welde man fowobl in jufammengezogenen afs im ausgebebnten 3 th ftande ber Yorypen febr leidst feebt, unterid)eibet allf ben eriten Brif die Moostbiere yon Den eigentlid)en Jolypen.

Bei sinigen im Meere lebenden Sattungen (Cellularia, Bicellaria, Flustra, Telegraphina) bat man bödjít eigentyiunlide Drgane entbect', 
Deren Bebentung nod) Durdans unbefannt ift. Fis find Zangen ober

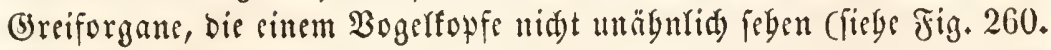
Cellularia) indem fie einen ftarfen oberen unb einen bünnen unteren 3angenarm befiken. Bei einigen Gattungen Gaben bicfe Dogelfopf= organe sinen kefonberen Etiel, bei anderen nidgt. Diefe Drgate fint in befändiger, pendelartig fdwingender Bewegung, wäbrent zugleid bie 3ange vou 3eit ju Zeit geiffnet und geid)(offen wirb, was burd) boutride Musterbündel gefdiebt. Dffenbar find biefe Bogerfopforgane analog Den Pebicellarien Der Etaderlyäuter. Die Bewegungen Dauert nod lange nad) Dem Tobe bes Moostbierdyeng fort. Bei Der Gats tung Telegraphina finben fid ftatt biefer $\mathfrak{B}$ ogelfowforgane lange ftrife

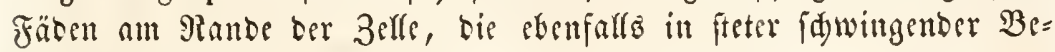
wogung find.

Der Rervenfnoten, welder bei vielen Meostbieren erfant ift, liegt in unmittelbarer Räbe e swifden biefem und Dem affer. (Fr ift febr flein und fdeint bei eini=

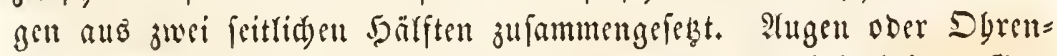

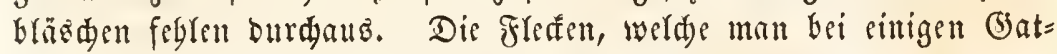
tungen als atugen gebeutet bat, find feine Gebwerfjeuge.

In Dem Borberende ber Rürpers befindet fid bei allen Moos:

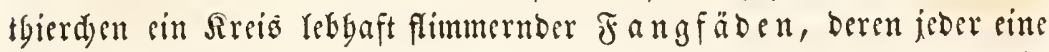

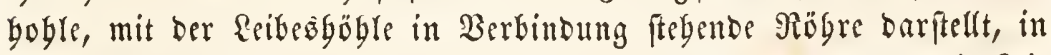
welder rurd) innere Bimpertewegung bic Jfüff̈gfeit, welde bie \&ei= begböble erfüllt, auf= und niebergetrieben wirb. Der Gtrubel, ben bie äuberen, auf biefen Fangarmen befinbliden $\mathfrak{B}$ impern im $\mathfrak{B a}$ affer

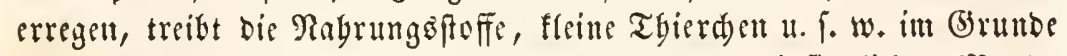
bes Füblerfranzes zแfammen uno nad) Dem bort befindlid)en Munde

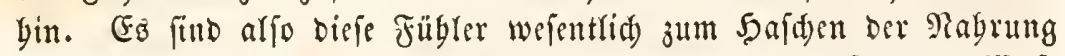

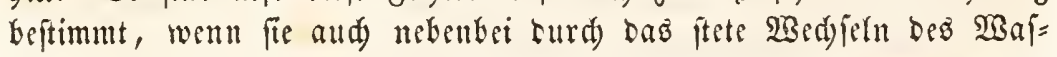
fers auf Der Dberfläde, mittelfi ber Frimmerftrömung, als Ittbem= werfzeuge bienen fömen, bie im llebrigen Den Moosttyierden ganz abgeben. 3wifden biejen Fangfäben, weldye bald einfad in einem Sreife fteben, balb aud) won zwei feitlid) angebrad) ten ?limen getragen werben, befindet fid) oer $\mathfrak{M} u \mathfrak{n} D$, oer meif in sine weite flimmernde Munbyögle unb von ba in eillen musfulöfen, oft fuglid verbiften Sd) Yu ftellt einen meift büntelartigen Saf bar, ber fid) nad) vorn in einen Darm fortfezt, welder fid in sinem an bem vorberen Enbe auber 
Dem Jüblerfrange neben Dem Munbe befindliden aftet öfinet. Der Darmfanal bilbet alfo eine förmlide Edylinge, Deten beide Deffnungen

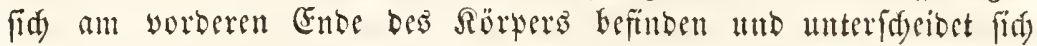
baburd wejentlidy you bem Darmfanale ber eigentliden Wolypen und ber Suallentyolyen.

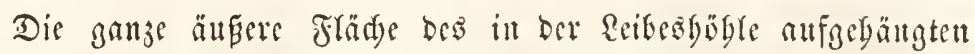
Darmfdyladyes wirb von ber wafferbellen flüfigfeit, welde biefe

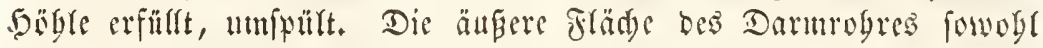
wie bie innere ber Reibeswandung ift mit simperbaaren bejest, welde

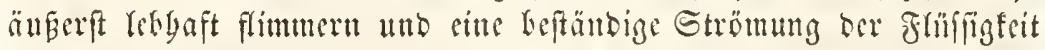

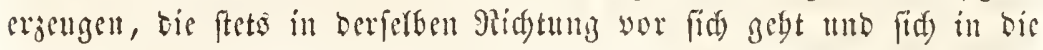

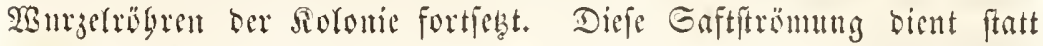

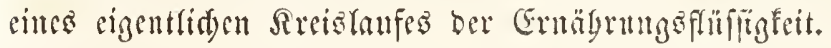

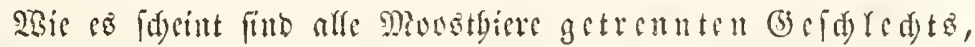

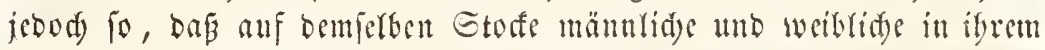

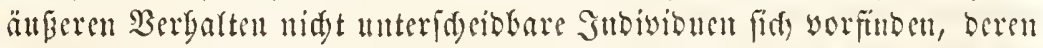

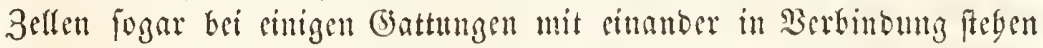
fulfen, fo baf bie Samentbierden ummittelbar j"t ben weibliden Jn= biviouen Ginuber fdrlipfen fönnen. Die Soben unb Eierfte dfe fimb banoförmige, an bem Miagen ober an ber äแferen Reibesิwanb befeftigte Streifen, in welden nur wenige Eier ober serbältnifmäfig fegr grofie Samentbiertion in 3eflen fid entwidetn. Die mureifen Eier, fowie bie Samentgierdyen breden it die Reibesbegle burd) unb wer=

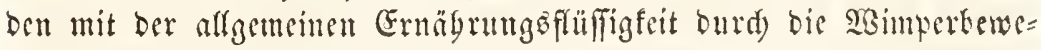
gung bin unb ber getrieben. Die reifen Eier werkaffen bie Scibeg̈büble Durd cine unmittelbar utben bem Iffer befindlide Deffmung. Sie

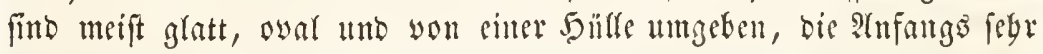
nad)giebig ift, fpäter aber erbärtet unb bei cinigen Gattungen mit fonberbaren Stadyeln unb Sistorbafen bejetst ift, burd) welde fids bic Eicr an sisaffertflanjen anbeften föunen.

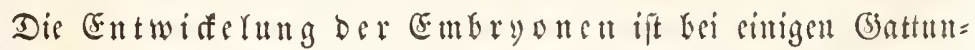
gen jiemlid) genau beobadstet worben. Der ganje Dotter bifoet fids in cinen infurorienartigen, über mo über mit 2 simperbaaren befetsen Embryo um, ber fid) lebgaft im Ei bewegt. Bei einigen (battmugen fdeint biefer Embryo in biefer Beftalt unmittelbar bie Cifanale ju burdbreden und eine Britlang umberjufdwitmmen; Dann wiro of bedberförmig, bie

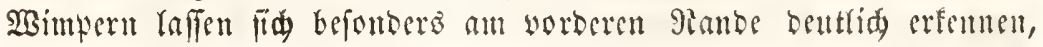

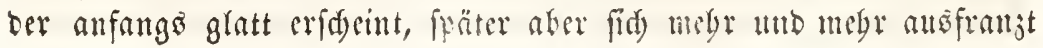




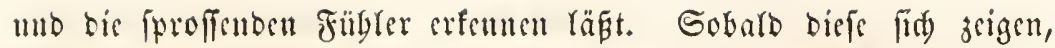
unterfdecibet man aud) im Snnem ben Darmfanal uno an bem bin= tern (Enbe sinen zapfenartigen 2fmbang, mit weldem find oas junge

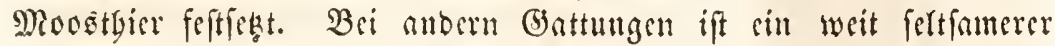

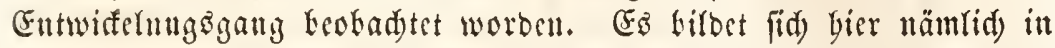
jebem Ei cin flimmernber Embryo, in beffen Snnern, wägreno er nod)

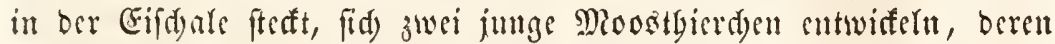

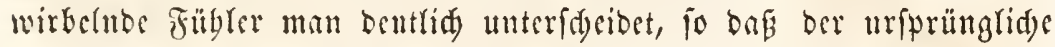

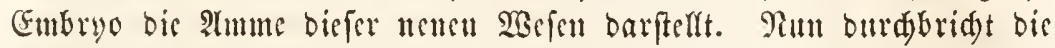

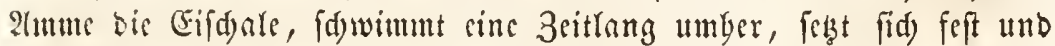

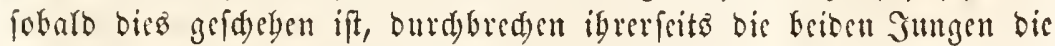

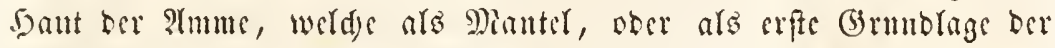

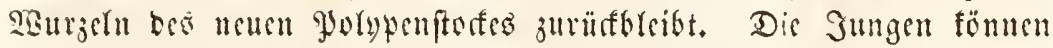

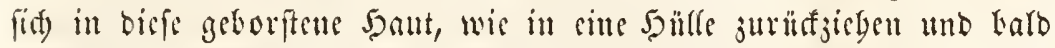

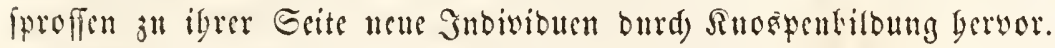

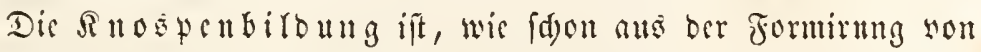
Solonicen bervorgegt, bei oen Mroosthieren sine iegr geträud)lide ?lrt Der Jortpflanjung. E bato ndben ben 3eflen Snosppen, in Deren Sunerem anfänglids bie

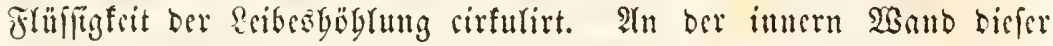

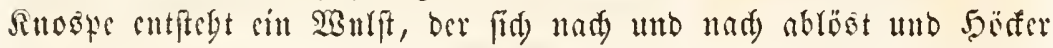

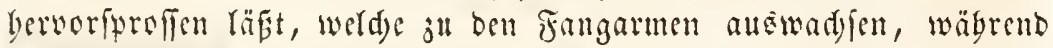

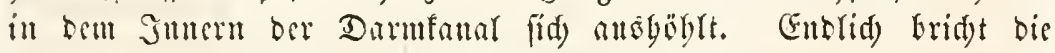
vorbere Mïndung Der Snospe anf und fteflt to bis Befle bar, in

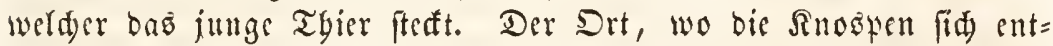
wifern ift wie bei ben gorypen ftets cin beftimmter, woburd bie

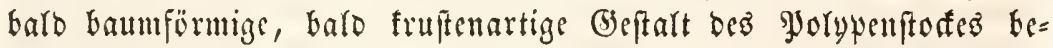
bingt wirb.

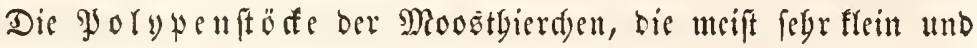

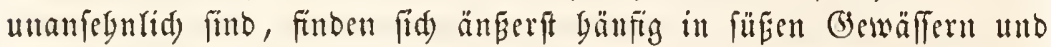
in Meeren, auf allen mögliden Begenftänden unter bem 2 Baffer. Ridyt minber bänfig fimb fie in ben verfdicbenen Sdidjten ber Ertoe, wo fie befonders vom Sura an fegr bebeutend junegmen, wägreno in ben Hebergangågebitocn nur fettene Repräfentanten biefer Rlaffe vor= fommen. 


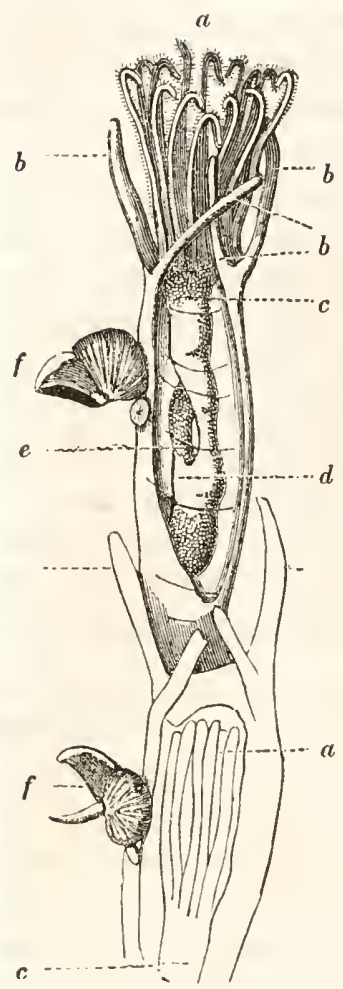

Fig. 260. Cellularia.

3 wei 3ellen you Cellularia avicularia mit ben baran be= fintlidgen Bogelforf = Drgaten, vou tueldien bas obere geidslof= fen, baz untere gesifnet ift. a Der Fithlerfranz; Hei Dem nn= teren Thiere in bie Belle zurtit: gezugen. b 50 ormattige $3 e$ e: längerungen uth Spiben bor 3ellen. c Ed)hutt. d \$liaget. e Darm. f Bogelfopforgane.

Wir theiten bie Rlafle nad) Det Gtel= lung Der Fübler in zwei Dronmugen. Bei Den Sreiswirblern (Stelmalopoda) fteben bie fingler in einem Sireife mn ben Mund berum. Alle Grattungen, welde ju biefer Dronming gebören, bewobmen bas Meer. Es find bie Cinjigen, welde thcil= weife farfige (5)bäure baben unb beghalb im foffiten 3uftande gefunden werben. Şier= nad, fowis nad ber $\mathfrak{B e f d}$ affenbeit ber $3 e$ ls len fann man vier Familien unterideiden. Dic Familic Der Taufentwirbler (Milleporida) zeigt fartige, meift fingerartig ober baumförmig veräftelte Jyolypentëte, bei wel= den bie cinfad) runoen 3ellen burd) cilte Berbintungsmaffe fo jufamment verfduolzen find, Dafi bödfteno ein Theil ibrer vorbern Münoung frei auf ber Sberfläde cridecint. Dic Thiere ferbit find nut febr unvolftän= big gefannt, fdeinen fid aber Durd ifre langen Fübler bejonbers auşวujeidjnen. Millepora; Retepora.

Sn Der Familic Der Möhrenmirbler (Tubuliporida) crid)einen bie runben, ribren= förmigen Zellen, bie ebenfallo falfiger Ratur fino, fajt gänjlid frei umb uux an igrem Ginteren Ende in bie allgemeine Mafle cin= gegolfen. Sie finten fid jest bejonders in fiibliden Meeren mo bie verfdiebenen Gat= tungen biefer Familie find in allen Sdjidten Der Erbe won ben ältefiten an vorgefunten wor= ocn. Tubulipora; Cellularia; Crisia; Hornera.

Man unterfdeibet won iguen fegr leid)t bie Familie ber Sruften. wirbler (Escharida), beren meift baudjige ober eiförmige $3 \mathrm{ellen}$ mit cinem bewegliden Dedel werfdrloflen werben, fobald fid Das Thict zurïfjicht. Die Gattungen, welde zu bicfer Familie gegören, fom= men febr bäufig, fowobl in umfern jekigen Mecren alo aud in frï= beren Sdyidten vor und birben meift bünne farfige lleberjüge, welde

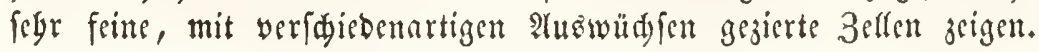


Eschara; Flustra. Die Familie Der (SIlodentwirbler (Lagunculida) entidg begreift afle biejenigen Dloostbierdyen, welde mit eimem Fübs rerfrange unr leberartige Zellen befizen, die meift auf langen Stielen fteben uno auf beweglidaen 2 Burgerfïsten aufitzen. Laguncula; Tendra; Bowerbankia; Halodactylus.

Die Dromutg ber armwirbler (Eophopoda) begreift mur

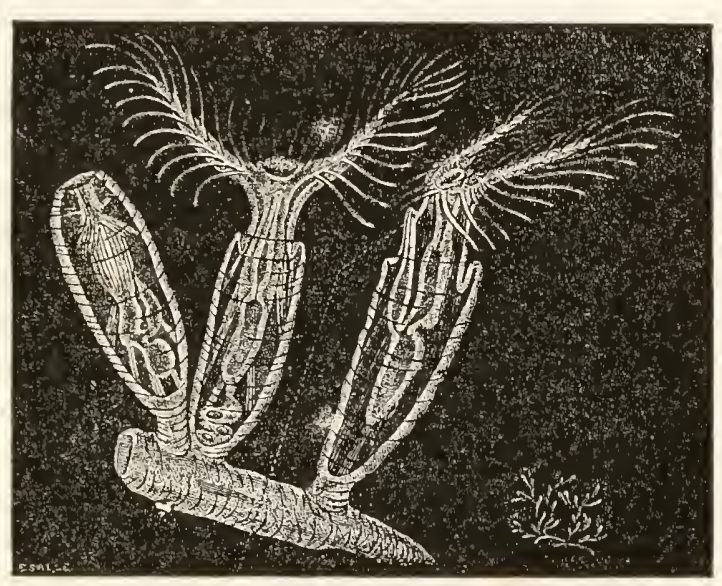

$\begin{array}{ccc}c & b & a \\ \text { 8ig. 261. Jeberbufiffultuen. (Plumatella.) }\end{array}$

sine einjige Framis ric, biejenige ber Jederbufdwirb= Ier (Plumatellida) und zeiduet fid baburd) vor ben übrigen Moostbic= ren aub, baßj bie zablreiden Fübler allf zwei feitliden Fortfäken ober $\mathfrak{A} r=$ men fteben, weldye fait bie Form sines 5)โeifeng baben. atre biefe 2rms wirbler fommen it fïвen (5emäjpern anf Steimen unb an bet Unter $=$ fläd) fer Blätter von $\mathfrak{B a f f e r p f l a n =}$ zen ziemlid) bälnfiy vor. Die 3effen, Duen yengente

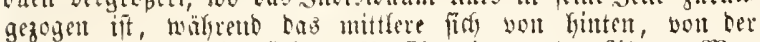

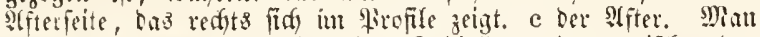

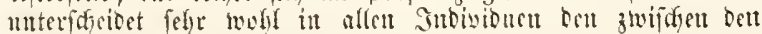

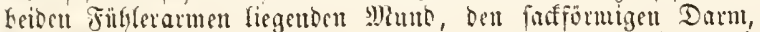

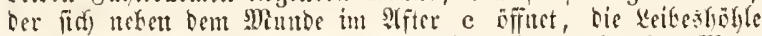

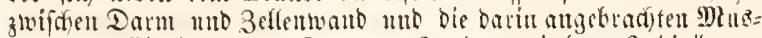
fefu zun Gingiehen Des Rospers. 3n Dem mittleren Sntwivibum

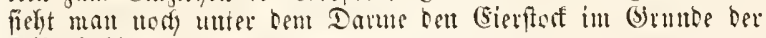
zeitipargafle.

in welden fie ftesten, finb reberartig und ebenfo wie bie Röbren mei= ftentbeirs volfommen burdifidtig. Man Gat mand)e (jattmugen unter biefen jeberbufdyolypen unterfdieben, die inber nidst foldse Berfdje= benbeit in ibrer Drganifation jeigen, baij man eigene Familien barauf grünoen fönnte. Cristatella. Alcyonella. Plumatella. Paludicella. 


\section{filaffe ore hipperiquallen. (Ctenophora.)}

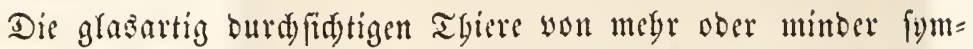
metrijder bejtalt, welde zu Diefer Rlaffe gebören und im Deete (d) wimment angstroffen werben, bat man bisber mit ben Sdyeiben= quallen und ben Röbrenquallen in cine befondere STaffe Der Duallen (Acalephae) vereinigt, obgleid) fie auper ber glasebllen Durdyfidtig= frit aud nidst cinen 3 ung Der Drgnnifation mit benfelben gemein baben.

Die rippenquallen baben einen meift eiförmigen ober gurfenarti=

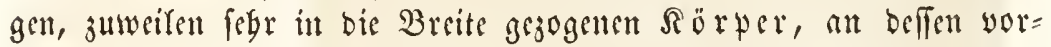
Derem Enbe fid ber Mimb, an Dem binteren ber atfer befindet. Die Bervegungororgane und bie (5efäpe fint meift fo angetradt, bafis

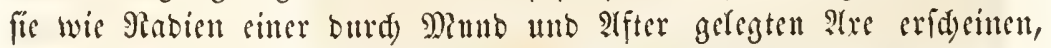
wäbrend Ragen unb Rervenfnoten ben Eilateralen Typus berfeffen. Bei manden Rippenquallen wirb ber fymmetrifde Typus nod Deut= lider, indem ber Rörwer feitlid) ansigezogen wirb unb juweilen ferkit in

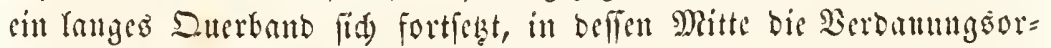
gane riegen.

Dis $\mathfrak{5} \mathfrak{a}$ t ber Pippenquallen ift ftets naft und juweifen, ägn= lid) wie bei ben sampelypen, mit Saftorganen bejekt, atts welden

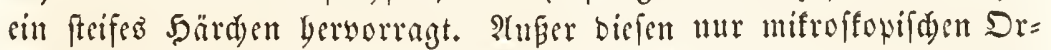
ganen zeigen fid auf ber Dberfläd) Des Särpers ftets rippenartige Sinien, auf welden bie $S_{d}$ wimmorga ue angebradyt fint. Diefe befteben aแt langen, etwaz fteifen, in Dmerlinien aufgefreflen Saaren, bie zuweilen an igrer Bafis vereinigt find unt wie eben fo viel anf

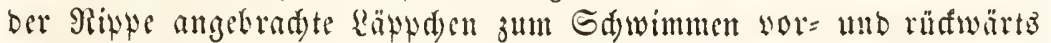
bewegt werben. Sis bäıgen fowobl cingeln, als in igrer Gefanmt=

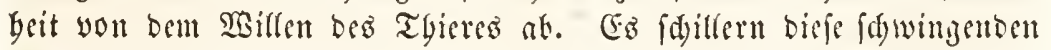
Rippen bei ber Bewegutg Des Thieres in Den wuberidgenten Regen= bogenfarben und man fregt bentlid, wie bas Thier bsi feitliden 2 sen= Dungen und Drebungen bald Diefen, bald jenen Ganm fpielen, die anbern aber ruben läpt. Die Thiele gleiten fo mit grofer Gduel= rigfeit obne weitere fidjtbare Bewegung ígres bod jirmlid contracti= Ien Rörpers burd) bas $\mathfrak{Z a f f e r ~ f o r t . ~}$ 


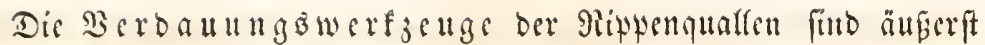

זin. 262

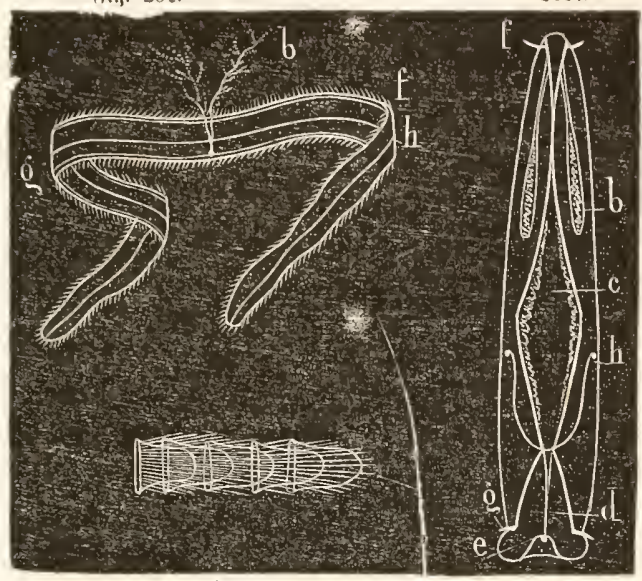

Jig. 262 b.

Der $\mathfrak{B e n t}$ gürted (Cestum Veneris).

Fig. 262 bas Thier fominmento, mit ansgeitrefften Fratgarmen, forf werfleinert. (Es wiro fis 4 Jub breit.)

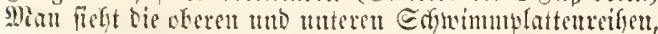
bie mittleren SBaffergefäßze, ben Siervenfnoten. Jig. $262 \mathrm{~b}$ cinige Edfmimmutattdyen, wergrisert. Fig. 262a jent= redfer Duerburdifonitt bes Thieres, mitten burd) ben Nangen geriifyet, in natïrlider Gräbe. In aflen Figu=

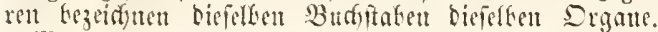
a Mutuo. b Fangräben (bei Fig. 262 a in ifre Esfeibent

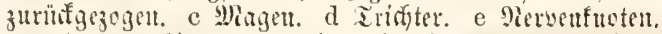

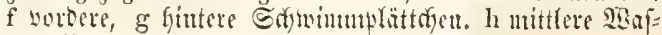

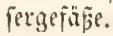

ftä̈riger, wurmförmiger Bewegung befinsen. Diefe Fangarme finb mit Reffel = unb Giftorganen Eefezzt und werben, wie ed fdeint, nur bum Taften und lluftriffen ber Beute bentht.

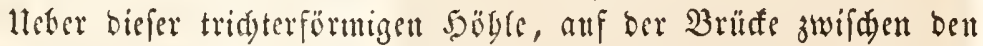
Spartöfuntugen bes Mirgens, Yiegt Der einfadye Rerventnoten, won welduem beutlidse Aefre nad) alfen Geiten ftrablen unb auf Dem ein

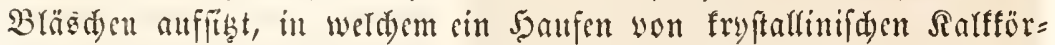

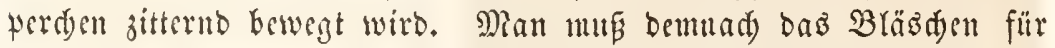
cin Rubiment cines Syrbläsdens balten. Sonftige Rerven ober Sin= nesorgane fommen thid wor uno namentlid fein Sdylunbring, wie romantifde Beobadster falfden analogien zu Siebe bebautet baben. Bon bem Trideter aus, worin ber Niagen mündet, entfpringen $\mathfrak{R} a=$

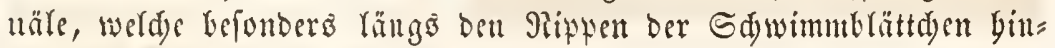
raufen mo in ibrem Snnern Flimmerbewegung zeigen. Sie bienen

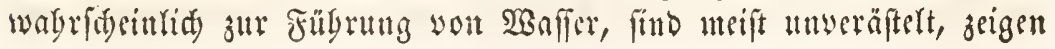


aber zumeilen aud baumartige blinbgeenbete Bergweigungen. Fb fdeis nen Diefe Santale Bertreter ber $\mathfrak{A}$ themorgate fu fein, von Denen man eben fo wentig wie von Sreislauförganen fonft cine Spur vor= findet.

Die Rippenquallen follen 3 witter fein, wentgftens will man

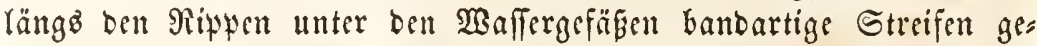
feben baben, welde abwedjeltto in bemiclben Thiere 5oben ober Eies: fröce frin follen; - eine Angabe, bie i屯 biỏ zur weiteren Beftätigung fegr bezweifeln mus. Das man an ben genannten Stcllen Cier fins Det, ift fidser, ob aber biefelben bort entifteben, ober bie $\mathfrak{Y a} a$ fergefäpe

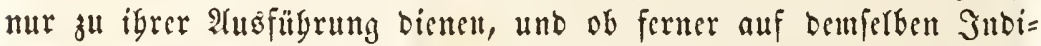
vibum beibe Geideledter verinigt finb, büfte weniger glaubbaft fein.

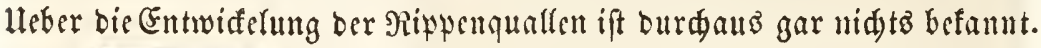

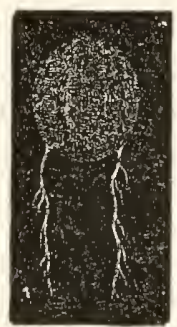

Fig. 263. Beroe.

Mit aukgeitrecten Fangfitiden.

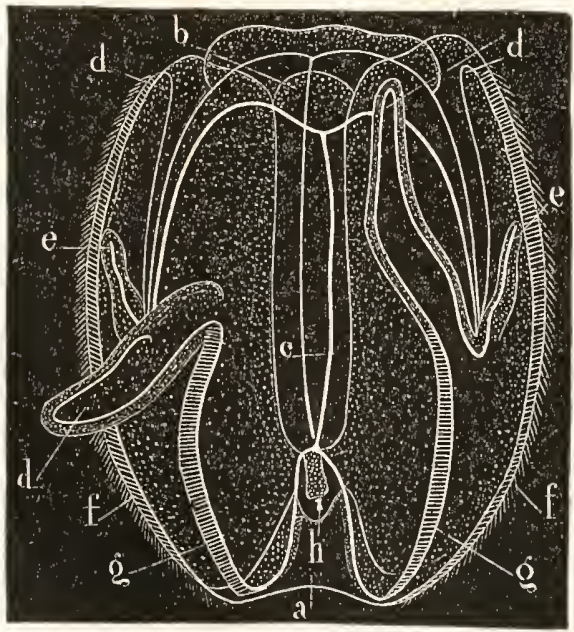

Fig. 264. Lesueuria vitrea

in boppelt matürlider Gróäe von ber Eeite ge=

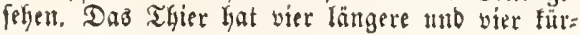

Die Drganifation biefer Thicre, bie man băufig in Sđwärmen in allen Dieeren finbet, ift fo übercimftimmeno, daß man feine hejon= Deren Dronungen anfuffellen nöbig bat. Wir unterid)eiden zroei Familien: bie (Gurkenquallen (Beroida) baben eillen meift eiförmigen ober runbliden \&eib mit weitem Daule, grojer Dagenböble uno ad)t Reiben Sdmimmblätt= d)en, welde in regelmäfig georbneten Rinten

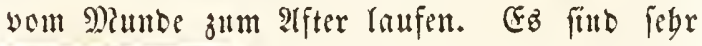
agile unt zugleid aud febr gefräsige Tbiere, weldye be= fonbers ben übrigen Duallen nadjagen. Beroe; Lesueuria; Medea.

Die Familie ber Bant. quallen (Callianirida) befigt nur eine febr fleine $\mathfrak{M u n d}=$ öfrumg unb cimen ăuferft cngen Mlagen, Dagegen mei= ftens Fangarme und oft feit= lide Rappen, auf welden bie Sduwimmblättden angebradt fint. Merift finben fid vier folder Rappen vor; zumeilen iít Der Röryer von oben mad unten zufammengebrũăt uno 
3ere Edgmimmblattenteifyen, won benten man je

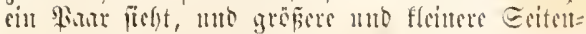

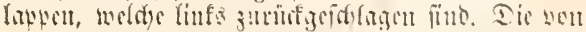

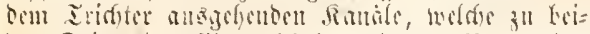

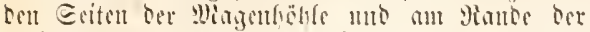

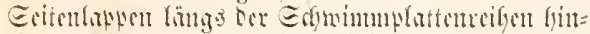

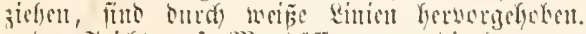

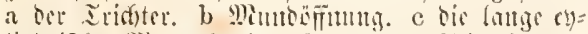
lintrifare Mingentyogle. a grëpere Eeitentapton.

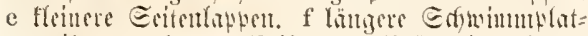

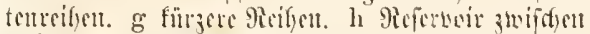

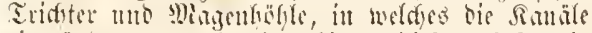

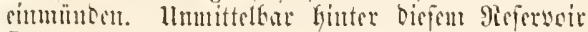
fitht man ben einfarben, weiž banbartig แad) Der Geite aub= gejoyen. 3u biefer Familic ge= bïrt ber Gefannte Bemแลูürtel, cilt etwa orei Finger breites

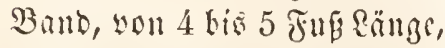
mit Sdwimmrityen an aĺ(en Ränbern unb mit cinem engen Munoe in ber Mitte biefes in ben fäniten Farben faillern= ben Banbes.

Cestum; Callianira; Alcinoe; Cydippe; Eucharis; Mnemia.

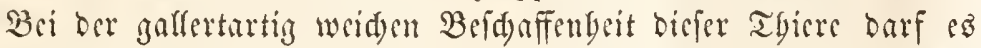

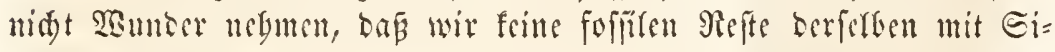
derbcit fennen. 


\section{filaffe Der ftlunteltl)iere. (Tunicata.)}

Die Thiere, welde biefe Slaffe tirben, zeidnuten fird vor allen

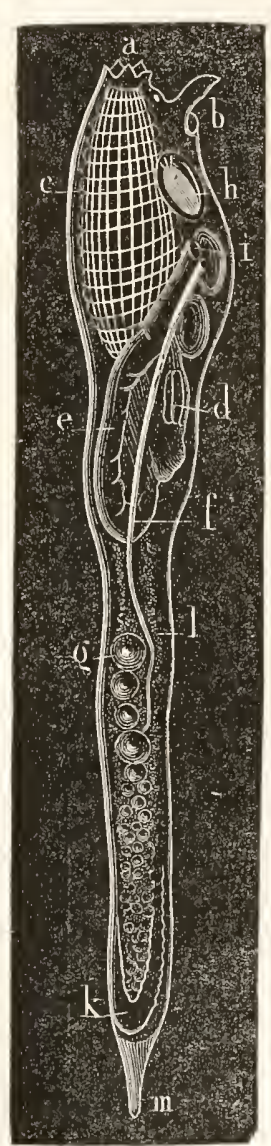

Jic. 265 .

Seitenanfidt cines cimselnch Thieres you Amarucium,

aแถ ถex gemeinfamen ร̧ülle genomment und bergröfert.

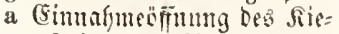

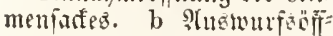
zumg befielben, mit einer becte. 3wifdet beisen Seffe= allocrn burd) eillen böd)ft $u \mathfrak{n}$ (y) metrifden

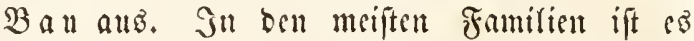
rein unmëglid, , eine Mittelfinie ober sine $2 x$ ¡u erfentuen, um weldye bermm bie Drgane ent: weter feitlid ober itrablig angelagert wären; nut bei ben böbern Familien läßst fid vielleidt sine feitlid)e Gymmetrie nadyweifen. P(lein aud) biefe wirb befonbers ourd) bie Rage ber $\mathfrak{B e r}=$

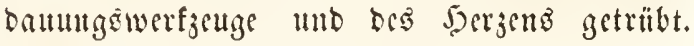
Dar אärper ber Thiere ift beôbalb aud) meift tufïrmlid), untegelmä̧ig cylinbrifd, ei= ober warzenförmig, obne alle äufere ?llzeiden einer Theilung in befonbere Piegionen.

Dis äusere llunbülfung oes Sörpero biefer Thiere wirb ftets won einer rofen, melyr ober mintoer berben \$antfdjidyt gebiloet, welde bent ganzen Rörper wie ein Gaf cinfdrlefit unb nur jwei Deffnungen, cine für bic 2 (ufnabme Der Rabrungsimittel und Des : Baffers, bie

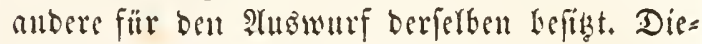
fer Mantel, weldyer bald mebr fuorplid, bald reber = ober gallertartig erfd)cint, ift merf= wätoiger Seife bem gröpten Theile feiner Maffe nad) aus wirflider 50 orjafer ober Cellulose gewebt, alfo aub siner frififofflofen Subfanj, welde fid weber in Sätre nod) in Arfarien röft tnto bem gröpten Theile nady bie Garten Bejtandtbeile Der yflanzen bildet. Die iuncre Etruftur diefes Mantelo ift febr genan er=

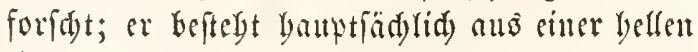
(3) runbiubftanz, ill welder Fafern und 3ellen, oft aber and verfdjiebenartig geformte fryftal= Yinifde ?̂̉bäufungen wou foblenfautem Ralfe fid finten. Son ben beiben Deffunngen, werdye 
nut genliegt ter Mervenfuten. im Mianter sorbanten find, famn bis sine vor= c Risumenfaf mit son gegit= terten Rismen. d Siagen unt

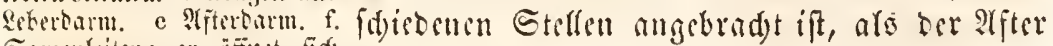

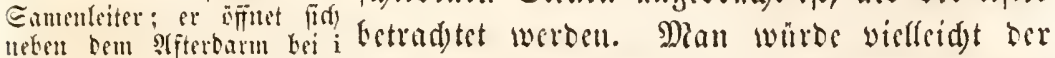

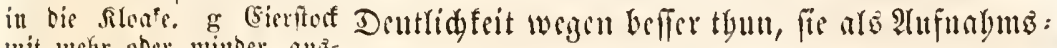
mit mefre cber minter anz

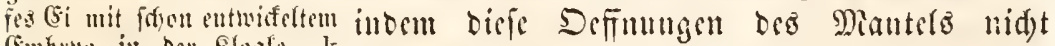
(smbrys in Der Ninufe. $k$

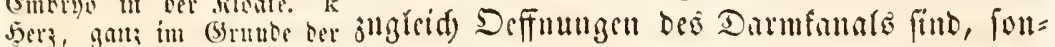

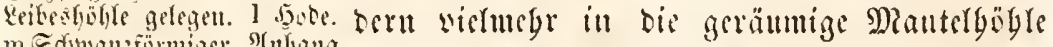

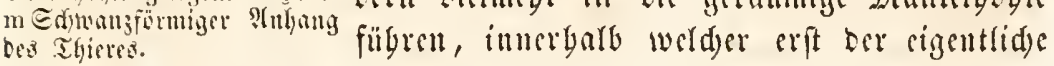

Rörper des T Tieres fid befintet. Bei Den gemein=

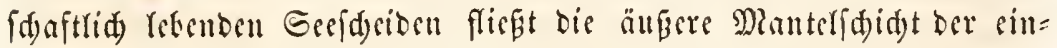

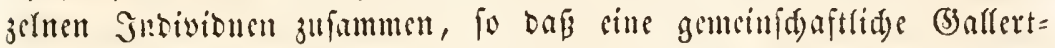

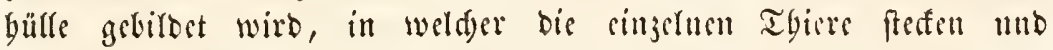

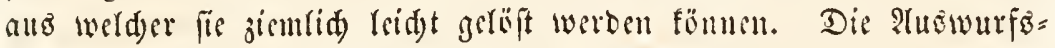

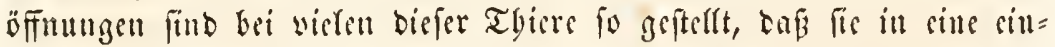

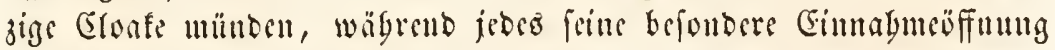
befizt.

Die Yez̧teren Manteltbiere Yeten entweder in Solonicen coer vers

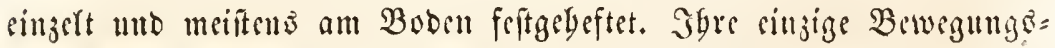
tyätigfcit befdränft fin in bicicm Falle auf Deffunng unb Ed)licenug Der Deffmungen ibres Mantels unb meift mur geringe 3u[aumenzie= bungen befferen. Die Freilebenten finb Gewimmer unb bewerffer=

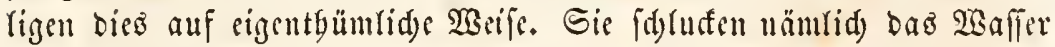

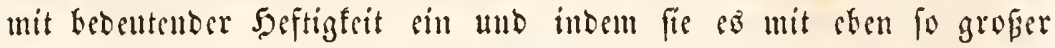
Rebendigfeit wicber auspreffell, werben fie burd) Den Rüfftó bes

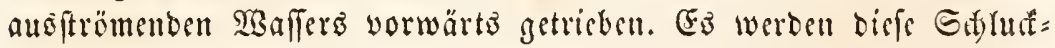
bewegungen bei benjenigen Jndiviouen, welde in Setten vereinigt find, gemeinfdaftlid ausgefïbrt uno bei ben Fenerzapfen wo viele Sndi. vibuen gemeinfdaftrid in einem fdwimmenten Manter fteffen, won Diefem Manter felbft bewerfitelligt.

Das Rervenfy ftem ber Dentertbiere beftebt immer mur aub einem einjigen grögern Nervenfnoten, weld)er ftets in ber Näbe Der

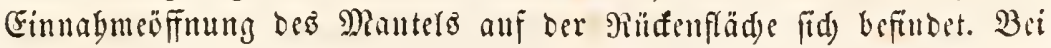

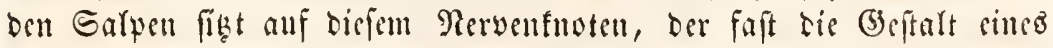
Refferz bat, ummittelbar bas einzige $\mathfrak{A}$ uge auf, weldes meift von Dunfelrotben Sigmente umgeben ift. Bei mandjen Secfdyciocn bat man in ber llungebung Der Manteliffnungen, die burd sillen Stern brei= efiger Franzen gefdloflen werben fünuen, ebenfo viel gerb gefärbte Flefen wabrgetwommen, als Franzell vorbanden filld. Mlan bat jwat 
Diefe Flecten für 2 ugen erflärt, aber obme diefe Bebentung näber nadweifa ju fönuen. Anbere Sinneșmerfjenge exiftiren bei ben Manteltyieren nidyt.

Der Darmfanal ift bei ben meiften Danteltbieren unt unvolls

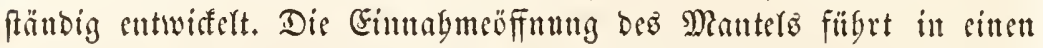
febr geräumigen weiten Saf́, weld)er bie Siemen entbält. (3anj in Sointergrunte biefes Safes finbet fid meift jiemlid werborgen dic einfade, fdlizartige, ftets waffenlofe Miunoöffnung, welde in eitten gewögurid Dïnubäutigen Darm fübrt, Der mebr ober weniger Deut= lid) in einen Magen uno sinen auşfügrenton Darm jerfällt. Der Darmfanal ferbit if meift mebrfad gewumben mto effuet fid in bie

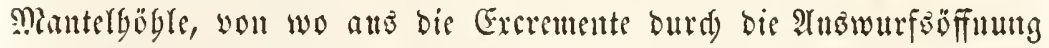
atrgeftofen werben. Die Entiguth bes Darmfanalz, ber eigentlide

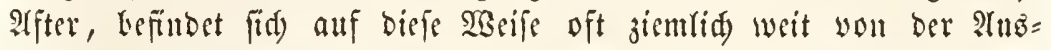
wurfëffrnutg Des Dantels und zwifden biefen beiben Deffuntugen ift ein jiemlid) weiter Raum, eine wabre Rloafe, in welde anjer ben

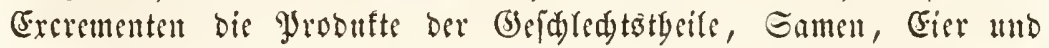
Junge, entleert, und fpäter burd) bie Diantelöftung auggeworfent werben.

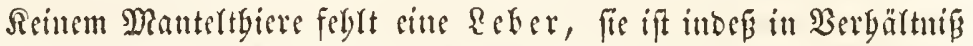
ju Den „lbrigen SEeidtbieren unt äuferft gering entwicfert. Sie beftebt meift ttur in einer gelblitaen ober brätmlidgen Dritfentdjidst, welde

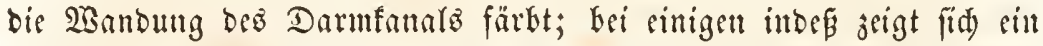

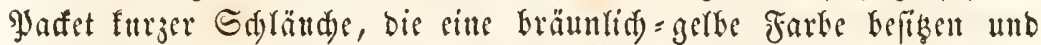
alo eeber angefprod)en werben.

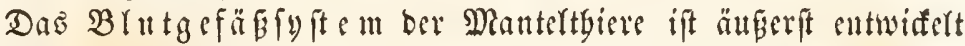
und bie Bewegung Deffelfen ftets von einem eigenen fdylaudförmigen 5erzen vermittelt, weld)es entweber in ber Räbe bes̀ Âtbemorganes ober anti tief im (5runde bes Sörpers liegt. Bon diefem Serzent

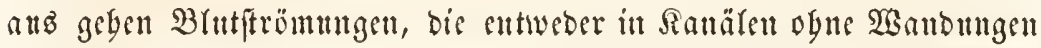

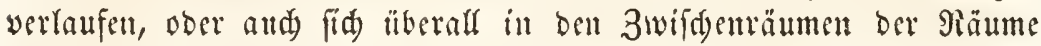
unb Drgane verbreiten. Derfwitroig und cigentbümlid ift aber ber Ulmitanto, oaf bei allen Manteltbieren die Ridjtung Des Brutftromez periobifd) wedfert. Dav 5 sers, weldes fid) wurmförmig fortidureitento

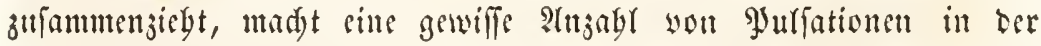

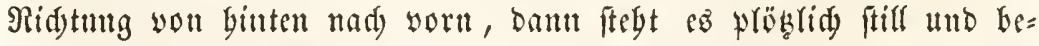

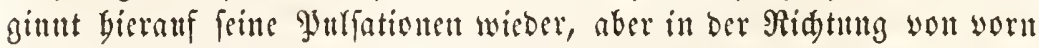
uad) binten. So wed) felt es̃ in unregelmäß̈igen 3wifdenräumen, oft von mebren Minuten, ab uno in alfen befäfien fielyt man bas Blut abwed)= fe(no won Sinfs nad) Redjte ftrümen, bann ftoden mo bierauf bie 


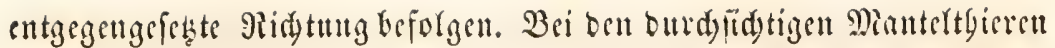

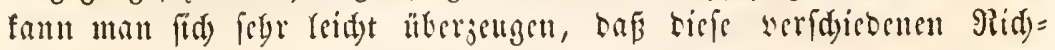

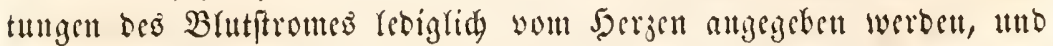

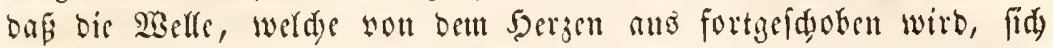

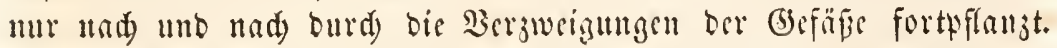

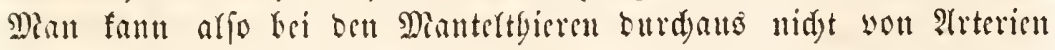

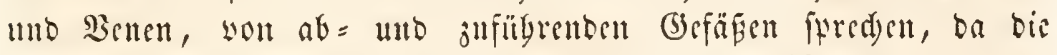

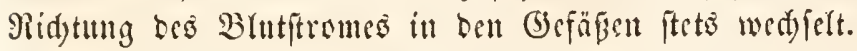

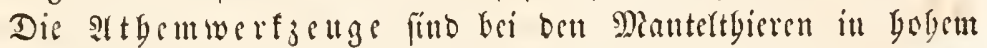
(brabe entwiffert und nad) jwei werfdjiebenen Typen geftaltet. Bei

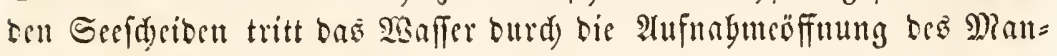

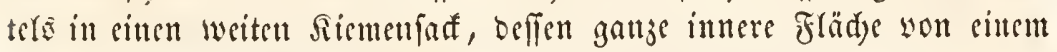
Gitterwerfe ausgeffetoet ift, bas quere Mafden jeigt und wo jebe

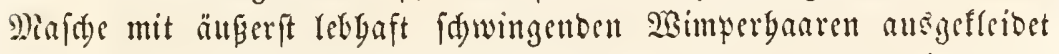

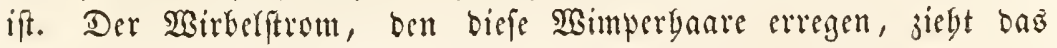

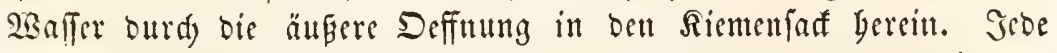

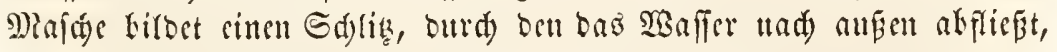

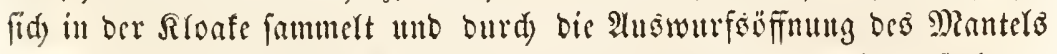

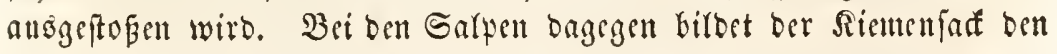

0 $p$

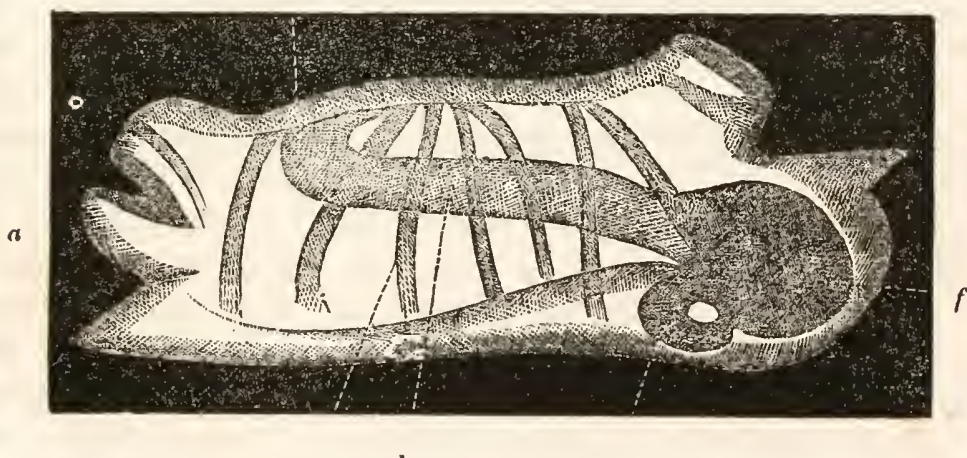

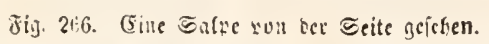

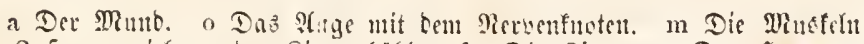

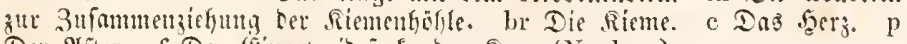
Der Affer. f Der (Singemsibefar ober Rern (Nucleus).

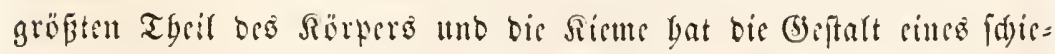
fen Balfens, ber fduräg son oben nad) wtten wto son yortt nad)

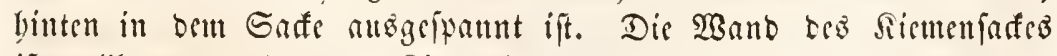
ift vollfommen glatt, ber Riemenbalfen aber rttnbum mit flitumernben

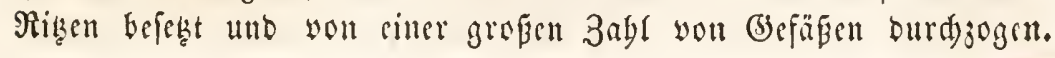




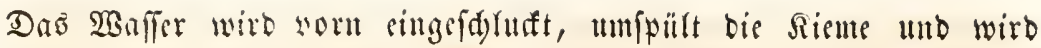
binten wicber anşgemorfen.

Itte Manteltgiere fimb 3 witter, pflanjen fid aber, auber burd

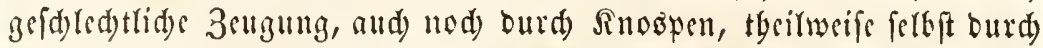

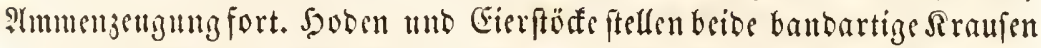
Dar, weldie gewögntid an bem Darmfintal ferbft angebeftet find und entwiffern fid meif nur periodifd, fo da Irüfung kebarf, um nad) bem Sngalte bie Drgane zu unteriderben. Begattugasorgane feblen burdjans. SBis jebes Snbivibum feine sigenen (Eier burd bie von igm bervorgebrad)= ten Samentbierden. Dis Entwifltung bes Embryo's fo wie bie Art und SEsife ier jortpflanzung ift hei jeber cinjernen Dronung fo sigens tyümlidy, Daß wir fie bei biefen begandern werden.

Dis Drontny bir Eecicheiben (Ascidiae) feftebt aus völlig unfyumetrifden Thieren, beren beibe Miantelöfnungen uneift febr nabe

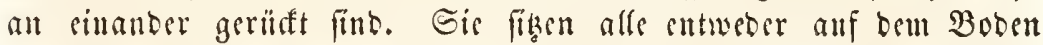
oder in sinem fduwimmenden Mantel feft unb bitben bänfỉ Golonieen

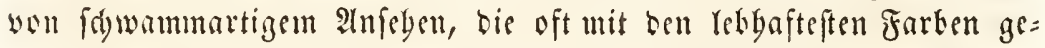

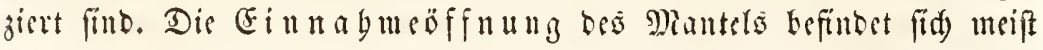
an bem worbern Ende bes. Thieres und ift faft immer rutto ober si= förmin; fie fann Durd jaffenfürmige Rappen gefdroflen werben, bie

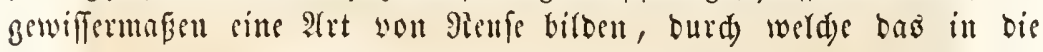

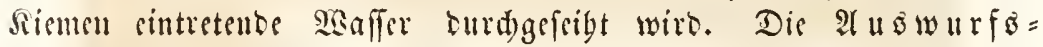

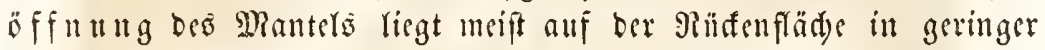

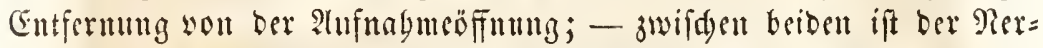

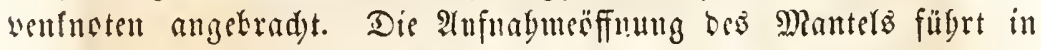

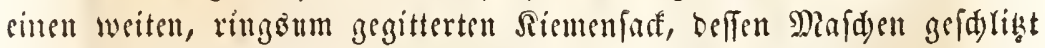

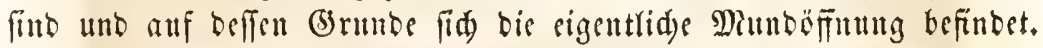

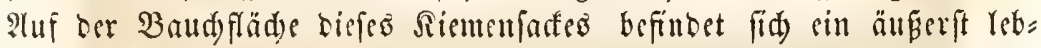
baft flimmernber barbfanal, welder bie Beftimmung ju baben fdeent,

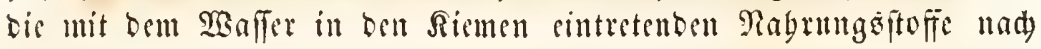
Dem sigentliden Mande Ginzuleiten. Der Darmtanal, ber in Grante

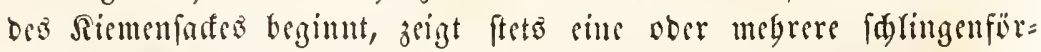
mige Biegungen mud siffuet firt) meift in siniger Entfermung von ber

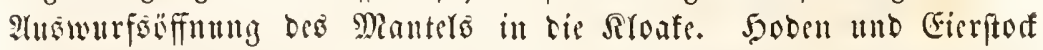

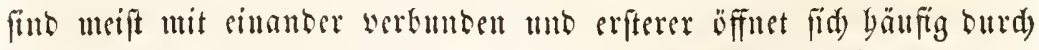
sinen längern gewmbenen Sant cbenfaltö in bie Sloafe, wo aud) bie Eier fo range verbreiben, bis bis Rarve in ibrem Junern

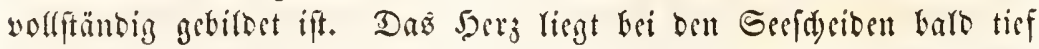
im Gronde bes Rörpers, barb megr nad vorn, neben bem Riemen= 
Fare; es if an briben Enbon offen mo theibt bie farblofe Ermäb= rungefliiffigfeit in aflen 3wifdenräumen ocr Drgane umber, ogne baß

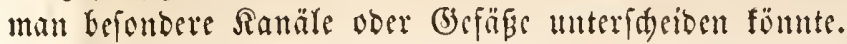

Die Fortpfranjunng ber Serfderiben ift Gefonders bei ben=

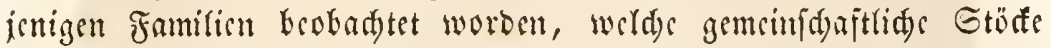
biloen. Sier fiebt man bie mebr ober minber entwifferten Eier, welde aus einem meift gerblid)en Dotter, cinem belfen Sirmbläşd)

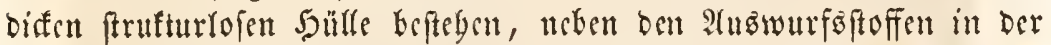
Rloafe fid fammeln, wo fie oft fo grof werben, dabi fie sine alrt Brudfar bilben. Der ganje Dotter fpaltet fid, bildet einjelne Zeffen uno baro unterfderibet man einen fugelfürmigen Embryo, an seffen

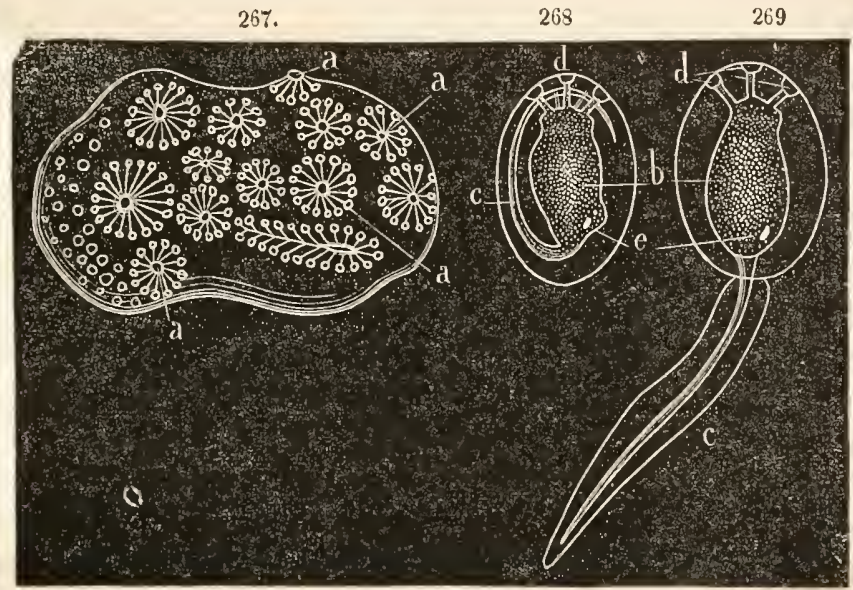

Fig. 267. (5ine z!lfammengejebte Eeeidgrite (Amarucium Nordmanni)

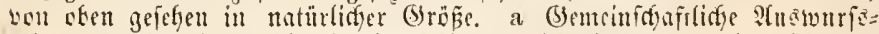

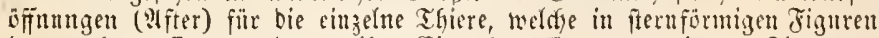

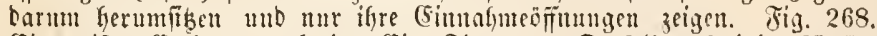
(Sin reifer Embryo nod) im (si. Fig. 269. Derfelte, frei in Baffer fdiwimmend. In beiben Fignten bezeidjuet b ben Rirper, c ben fpater abfallenben ๔dyanz, d bic Eangnäpfe ter Smbryonalmalle, e nodf rätfy= felfafte fepte Rerperdyell int Leibe tes (Entryo's.

cincr Seite ein ranger Sdwanj berumgebogen ift. Dicfer Sdwanz löft fid nad) und nad) $a \mathfrak{b}$, und ber Embryo befect nun aus cinem

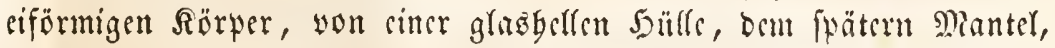
umgeben, und cinem langen Sdwanze, in weld)en bincin fid) bic gelbe Dotteriubitanj fortickt. Durd) peitfdenförmige Bewegungen biefes Sd)wanzes fowwimmt ber (Embryo ganz in äbulidar SBeife wis bies won ben Cercarien fruber befdrieben wurbe, im Sasfer umber. Nun beginnt alfmäblig bie writere Augbiroung ber immeren Maffe; 
270.

271.

$2 \pi 2$.

273.

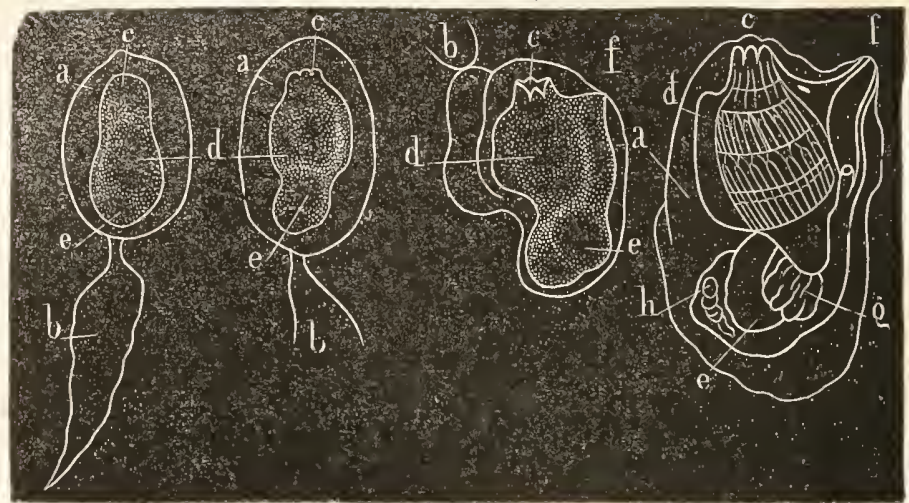

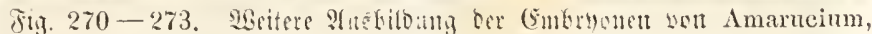

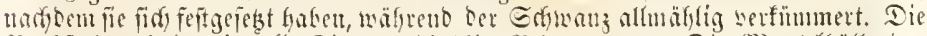

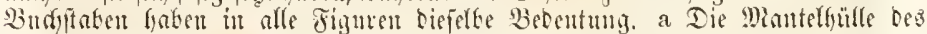

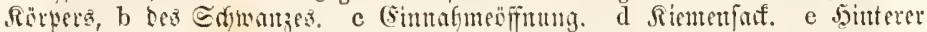

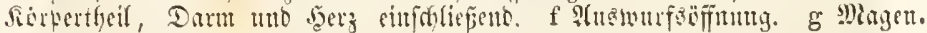
h Seliz.

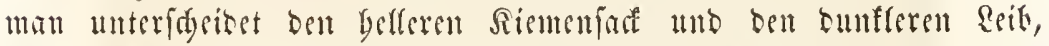
welder ben Dammfanal unt bie übrigent Eingeweibe entyält. Die Bewegnngen ber Rarve werben träger; - ber Sdyanz febt fid mebr und mebr ab. Dis in ifm entbaltene Dotterfubitanz fdymindet unb

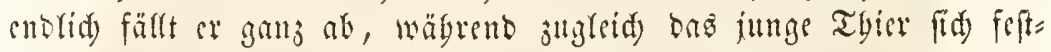

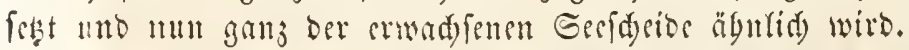

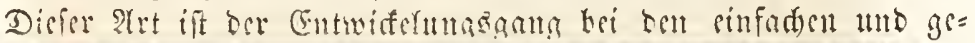

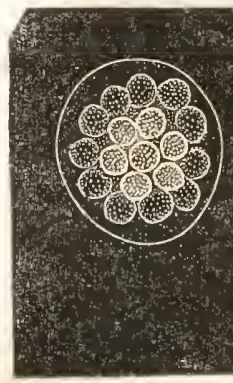

Sig $2 \pi \%$.

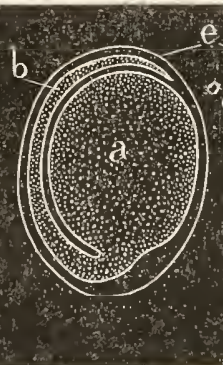

275

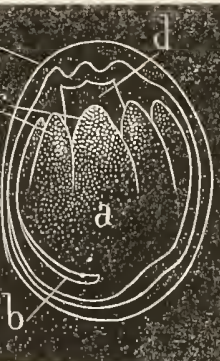

276.

Fig 27t -277 . Ëntnifelung bes Eies von Botryllus.

Fig. 27f. Det in Bilomingzellen zerlegte Dotter. Fig. 275. Edomanz mo Totter fino Differenzitt. Jig. 276. Die gemeinjdyaftlidse Rloafe tuno bie einzeluen Ifyerdien fermm find bentlidy. รib. 277. शीแ

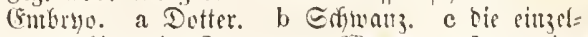
nen Thiere in Form won $2 b^{2}$ ijen. d genein=

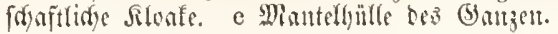

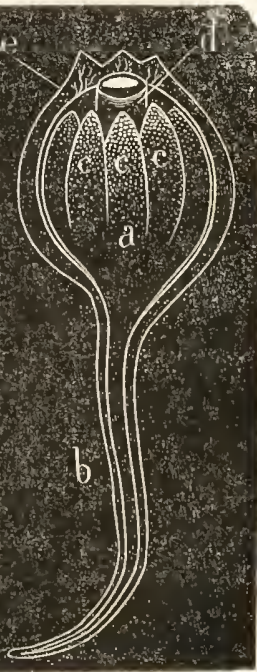

งig. 273. 


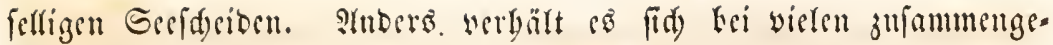

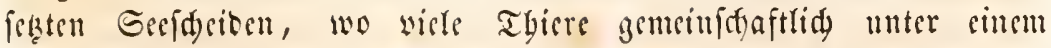

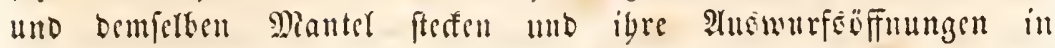

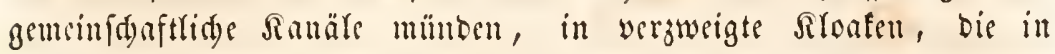
siucr sinjigen grofien Deffrnug zufammenfleşen. Bei biefen zu=

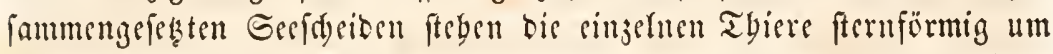

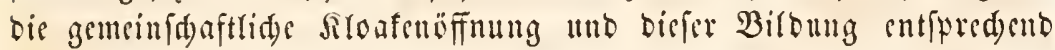
entffegt in bem (Eis ans bem cinfad)en Dotter nidst sin (Embryo, fons Dern cin Sirsis won Embryonen mit sinter gemsinfdanftlidsen $\mathfrak{i}$ toafen= öfinung. Shan fiegt Den Dotter ebenfo wie bei Den sinfad)en Eiern, (iid) Fralten, Bellen birben, baun finbet man einen einfad)en Dotter=

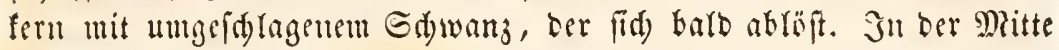
biefes geid,wänjten Dotters, ber fid) cbenlo berwegt, wie ein cinfadser

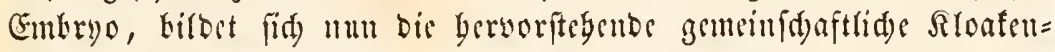

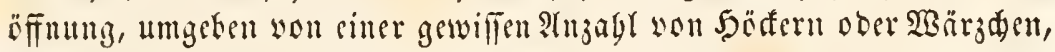

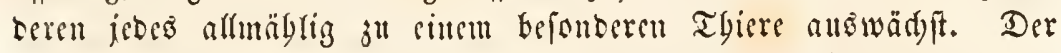

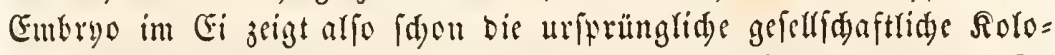
nie, weld)e fid bann burd) Ekroffentilbung weiter ausbegnt. Sn

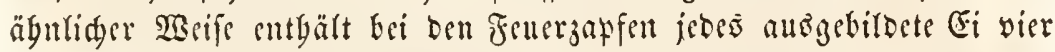
Sunge, weld)e gemesuldaftlid) im Etern un cine mittlere 2 tre berum= ftegen und bie Gronnolage bes ganjen 3ałfens barjtellen.

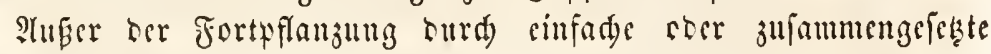
Ginbryourn foumt bei ben geferligen und zufammengefekten Serfapeiben bie gortpflingung burd) Sinosipen jiemlid) bäufig sor. Eso bitben fid

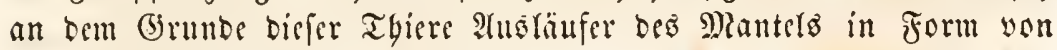
boblen $\mathfrak{B}$ arzerfafern, in welde binsin bis Brutftrömung fid fortfegt. Sn ben fnopförmigen Enten tiefer SEurjerfaforn faumelt fid) sime granulirte Maffe au, welde immer megr wädjft und bald bie form

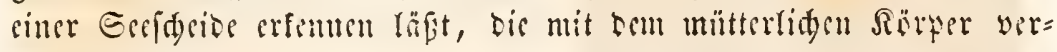
bundon breit.

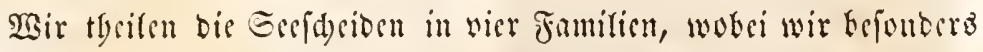

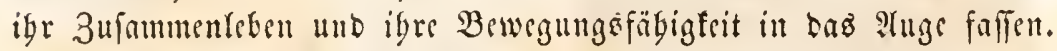

Dir zulummengcieften Eecid)ciben (Ascidiae compositae) (ธ.

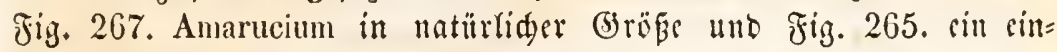

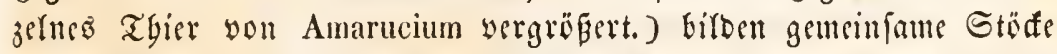
yon meift fdwammiger ober leberartiger Befdaffentgeit, welde wie ge.

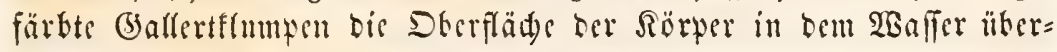

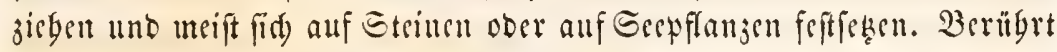
unan sinen folden Silumpen, ber wie sille Yeblofe, yarbweide, leserartige Maffe erfdgeint, fo fprizen pröglid) aus cincr Menge von Deffrungen 


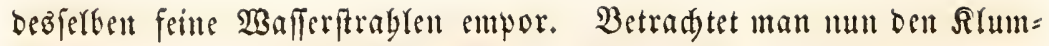
fen genauer, fo unterideibet man balo bie einjelnen Aufnabmeöfrnut= gen ber Thiere, welde meift fteruförmig um bie gemeinjdaftliden Aloafenöffungen gruppirt find, aแร benen bå $\mathfrak{B a f f e r}$ bei ber $31=$ fammenjiegung berworgefprigt wurbe. Die Thiere ftefen mebr ober minter fenfredt in ben fdwammförmigen Maffen und baben meift sime cylinbrifde ober fpindelförmige (5eftalt, die gewöbnlid

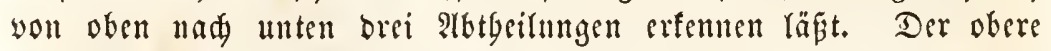
weitere Tbcil Des Rïrpers enthält Den Riemenfaf unb bie Rloafe, ber mittlere bie Sd)linge des Darmfanalez, Der untere oft ftabförmig

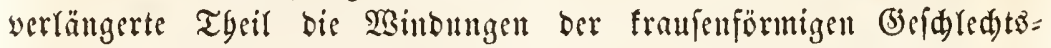
theile unb im ticfiten Grmnos bas Serg. Diefe sinzelnen oft wobl

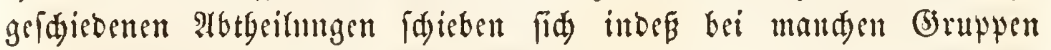
won (battungen fo zujammen, baj entlid bas Thier nur eine einfade eiförmige Maffe barfterft, in weld)er an ben Seiten unto aul Girutos

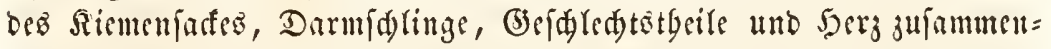
gebrängt fït. Dian Gat dic Gattungen befonbers nad) oer größeren ober geringeren 3ufammenfs sbung ber Rörperabtgeilung ber Cinzeln= tbiere, thad) ber Stellung Derfelten um bie gemteinfdaftlidgen Siloafen=

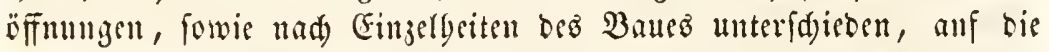
näber einzugeben unfer Raum nid)t geftattet. Amarucium; Botryllus; Polyclinum; Didemnum.

Fine jweite Familie, weldye ben llebergang ju ben cinfad)en See= fdeiben bilbet, umfaght bis gejelligen Eceicheiben (Ascidiae sociales). $b$ a Der Sörper Diefer Thiete ift meift

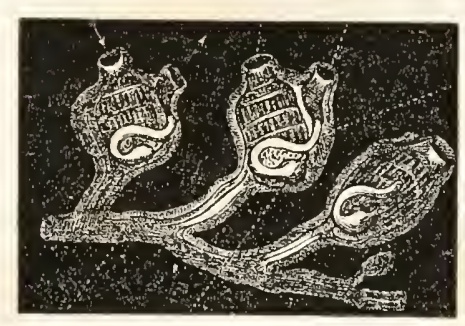

$1 \quad e$

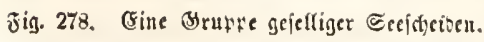

t ber gemeinidanfilidfe Etanm, e Miagen. i 2 fferdarm. Die (Eituahme= (b) unb

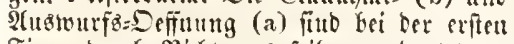

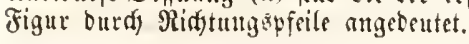
Sdjöblinge, bie cinjelnen Thiere, treibt. Tä̈brend bie zujammenge= festen Seejdeiden meift wunberberrlid gefärbte Maffen birben, fino feulenförmig, inbem bie Anj wellung ber Siente von bem Sitemenjate ge= "Girbet, Der Dünnere Fur aber von Der Darmidylinge und ben ïbrigen Fingeweiben cingenommen wirb. Bon bem Fube geben Tomizelaub= läuf̣er nạb allen Seiten bill, auf weldaen fids in ber befdriebenen Beife Snogent birten, bie fo nad) und und eine atrt Straud) ober eine Jflanze nadabmen, weldye chror wie die Eroberentlanze aแf vergweigten 2 Burzelamgläu fern 


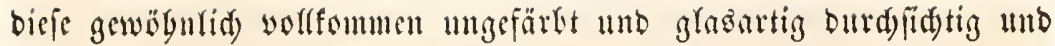
rigute fid) an Bepten jur lluterfudung Der Struftur. Clavelina.

Die britte Familie wirb yon ben einfarben Sechtheiben (Ascidiae simplices) gebilbet. Meift unförmlide warjige Rörper yon fnorplider

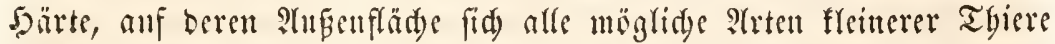
anfiebeln, fo bafi man oft Mlïbe bat, an bev fdyammigen llngeftalt

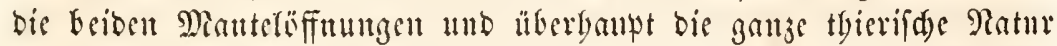
on erfemen. Sn bem biffen Dentelfafe liegen bie ringeweibe neben bem weiten Siemenfacte anf einen gencinfidaftlid)en Snäul zufammen= georängt. Die cinfad)en Geefdeiden bilben niemals 2ustänfer ober Snoŝpen wie bie gefelligen, fonbern pflanjen fith ur burd) Sier fort. Ascidia; Cynthia.

Die vierte Jamilie birbet gewiffermagen simen llebergang won Den zufanmengefegten Seefdeiben z" ber forgenden Dronung. Eg find Dic Fenerjapfen (Pyrosomida). Mlan fïloet bäufig in ben füblident

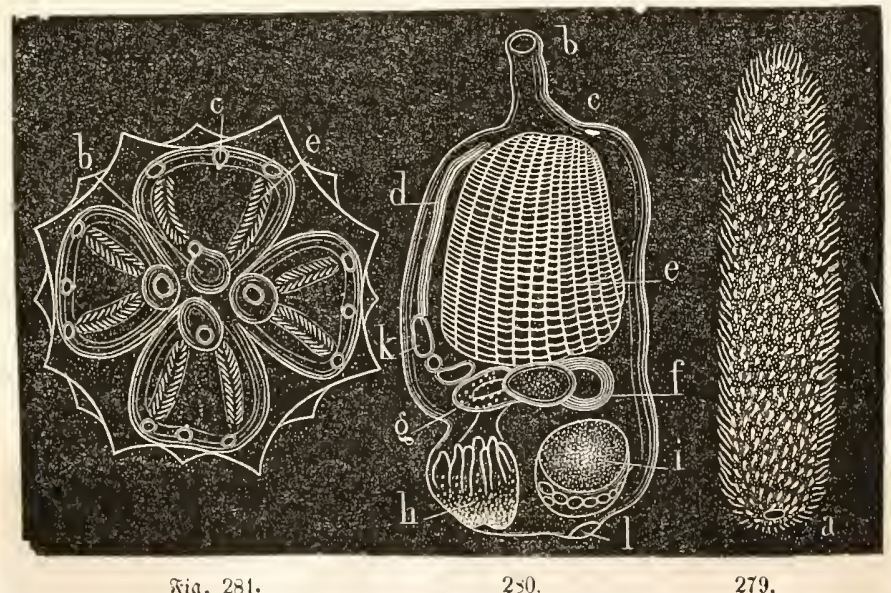

รig. 281.

$2>0$

279.

Jig. 279. (Sin Fenergapfen (Pyrosoma) ftatf werfleinert. a bie Seffinung hes 3apfens. Fig. 280. (Sin eitrzelues Thier farf vergrëpert, won ber Seite ge:

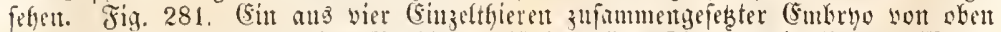

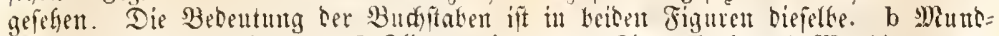

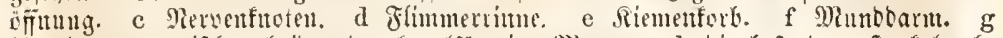

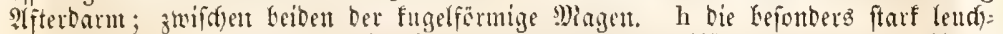

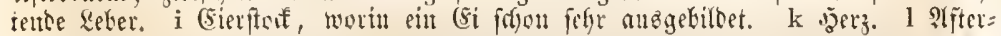
sifintutig.

Diecren farwimment, gallertartige, zuweilen fuflange Sörper, weld)e

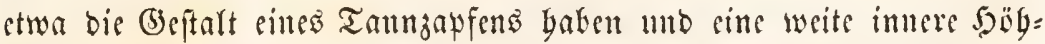
rung jeigen, bie eitte freigrunde Deffnnng an bem breiten Eube befitet. Der Gylinber fdwimmt langfan mit abmedjefnben Zu[ammenjichun= 


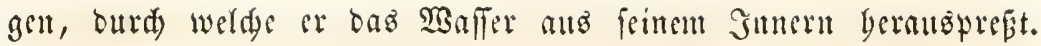
Bei Nadt leudtet er in beflem Glanje wie weibglübentos Eifen. Das Seudten beginnt an einem fleinen günftden uno verbreitet fï bann

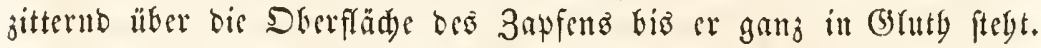
Unteriudet man eintel forden 3ayfen genauer, fo findet man, baß mur einen gemeinjdaftliden Mantel barftelt, bab feine innere Şögle,

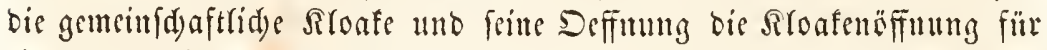
sine ungemein grofie sujabl flemer Thiere ift, bie in bem Miantel

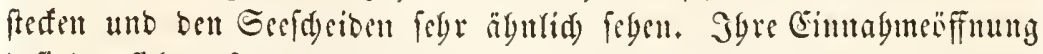
lefintet fid anf ber Aupenfläde bes Gylinbers, wälrent oer gerabe gegenibberfebende after in bie innere böglung bes 3apfens eimmüntet. Es befiten Diefe Tbiere sinen weiten gegitterten Riemenjaf, wie bie Erefderiben, an beffen Grunde bas 5erj, oer gewumbene Darmfanal, ter febr grofe fugelige Gierftof uno cine ano rojettenartig jufammen= gejetzten Blinbjäcten gebiloete Reber liegt. Sn ber Rloafe fiebt man bäufig megr ober minber ausgebilbete Sungen, weld) ju vieren ju= fammengeftellt erfdecineu. Sebr beutlid) ift auf ber Rüfenfläd)e bes

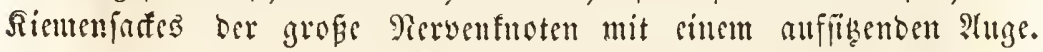
Durd) bie Struftur igres Siemenfafes näberm fid bie Fetterzatfen ben Eefderiben, mit weld)en fie aud in ber Fortpflanjungstweife über= cinfommen, wägrento bie fdwimmente Drtšbewegung, ber Ieud)tente

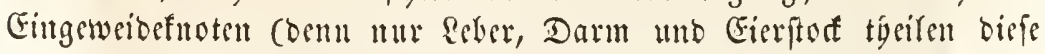

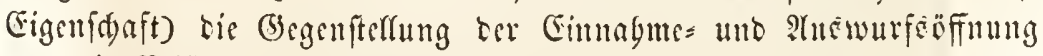

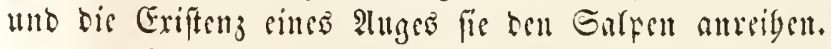

Die Dronung oet asaljenfbeiben ober Ealpen (Biplnora) $b$

$p$

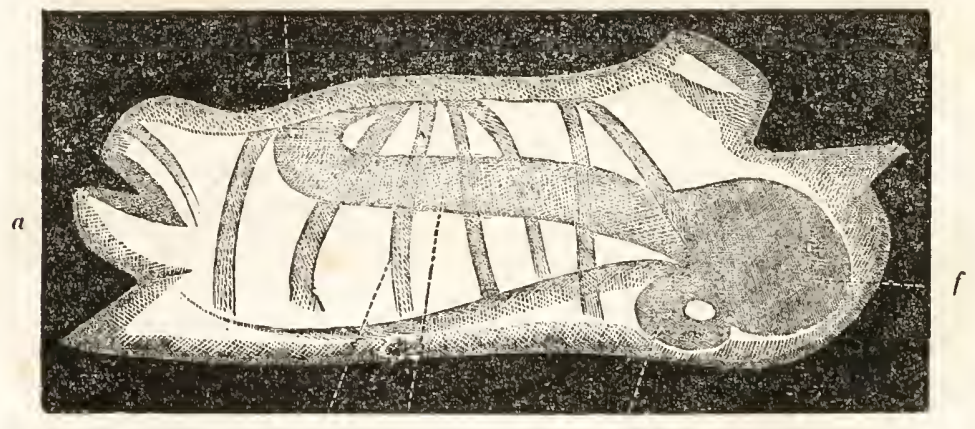

$\begin{array}{cc}m & \text { lr } \\ \text { Jig. 2s2. (5ille Ealfe von ber Eeite gefegea. }\end{array}$

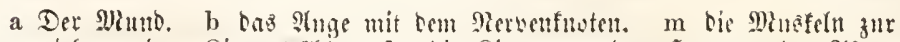

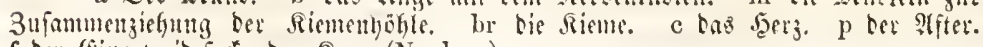
f ber (singetweibefaf ober Rern (Nucleus). 


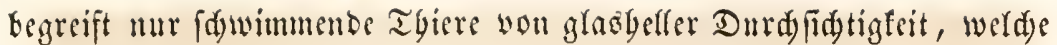
bejonders in wärmeren Dleeren fegr bänfig worfommen. Der gröfte Theil Des Rörpers wirb won sinem Yänglidyen, oft mit fonderbaren Spizen und Anbängen verfebenen Siemenfate gebildet, Der Dentrid ans einer äuBeren Dianteffdidt uno siner inneren 5 autfdidyt beftegt, in welder Bündel ober franjweife Bänder won Mugefelfafern angefradt fint. Dic Eingeweibe find in einen fleinen runben finoten jufammengeorängt, ben man ben Sern ober Nucleus nennt, und ber meift eite rotbe ober gelbe, ferten sine blaue Jarbe Gat unb in ber Nadyt mit Yebbaftem, rotbgelbem Ridnte leudjtet. S(n Dem vorberen Ende bes waljenförmigen förpers befubet fid eine quere, von bewegliden sippen umgebene Deffrung, welde in ben weiten Siemenfarf fübrt. Şinter biefem Maule auf ber Rüffenfläd)e ift ber meift runbe Riemenbalfen angebeftet, ber

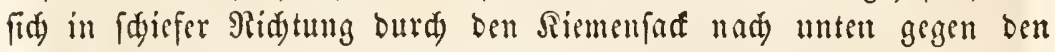
Sern bin fpannt, wo feine Gintere Inbeftungsifelfe fid befindet. Der Riemenbalfen ift eigentlid) ein runblides bobles Robr, weld)es auf feiner P(ufenfläd) eine Menge von Snerfd)lizen zeigt, die mit lebbaft flimmernben Simperbaaren befest fint. Fuf ber Rüdenfläd)e und 子war an ber 2nbeftungsftefle bes Siemenbalfens fiegt man febr Deut= lid) ben Rerwenfnoten mit feinen nad) alfen Seiten bin ausftrablenden Rerven und bem unmittelfar barauf fitzenden, von Dunfelbraunrotbem

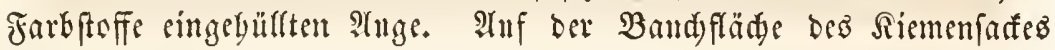
gewabrt man sime äbnlid)e Rinne mit Flimmerbaaren ausgefleibet, wie wir fie fidon bei ben Geefdeiden srwägnten und nod anberbem vorn an bem Maule eime meift fdlingenförmig gewundene Flimmer= furde, Deren Bebeutung trod nid)t weiter ergrintoet ift.

Der meift runde, roth ober gelb gefärbte Cingetveidefnältel wirb won Dem Darmfanal, Der Reber, Den (Gefd)led)tstbeilen und bem Ser= zen gebildet. Der eigentlide Mund ëffnet fid in ber Näbe Der bin=

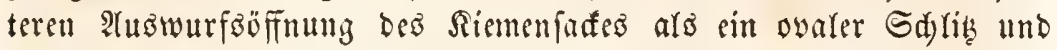
fübrt in ben einfaden Darmfdlaud, welder überall won Der Reber unt ben (3efd)led)tstbeilen umgeben ober gleidfiam in biefelben einge= graben ift, fo baßi es febr fower bält, biefe cinjelnen Eingeweide won einander s" ifoliren.

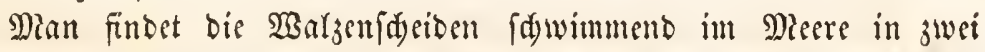
verfdiebenen gerellidaftliden 3uftänden. Meiftens bilden fie setten, il ber $\mathfrak{A} r t$, Dak lange Reiben von Jubivionen burdy die Spizenfort= fätze igres sörpers ober mit Den Geiten aneinander verflebt find, to Dafi malt in bem Meere ein langes Band fowimmen field, weldes mit eimer grofen 2 njabl rotber Sierne in abwed)felnden Peiben befest 


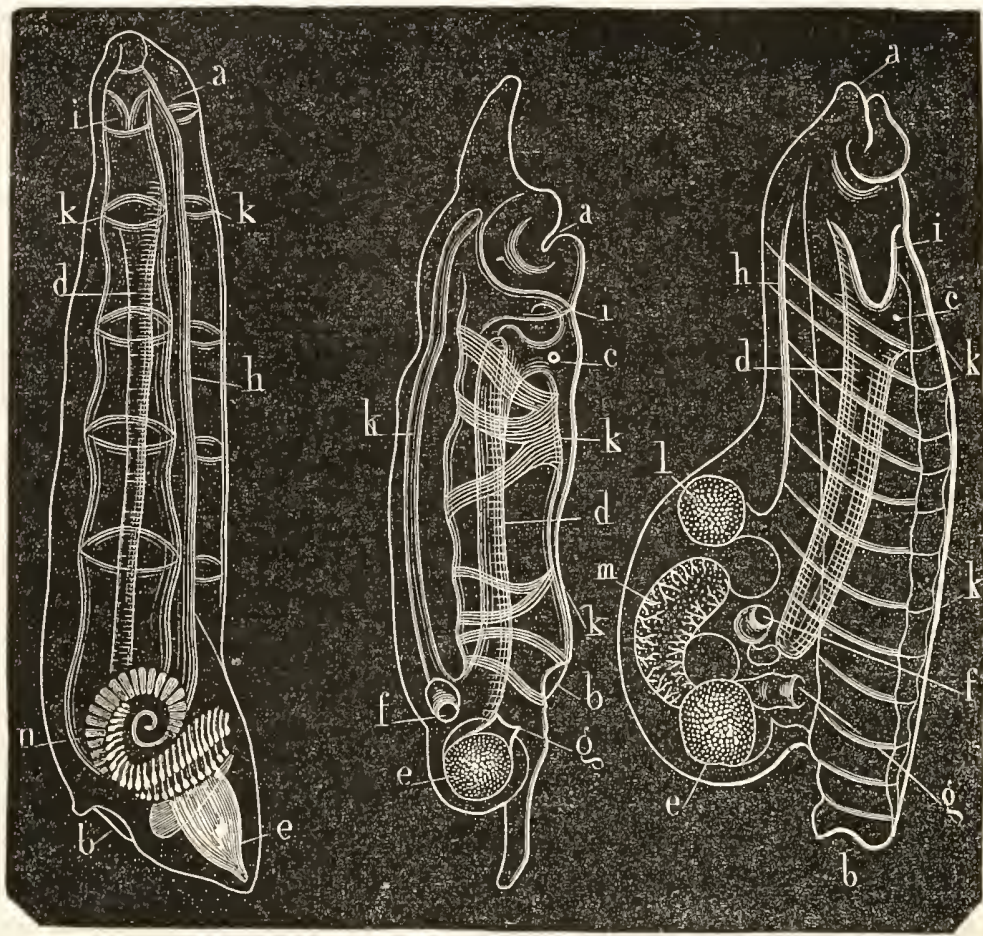

รig. 283.

254.

235

Fig. 283. Salpa cordiformis mit ciner Rette not Sungen, fyalb won Der Geite gejefien. - Jig. 284. Salpa maxima, cill Indivioum aus eitter Rette, ebenfalls you ber Eeite geiden. - Jig. 285. Salpa africana - bas wex=

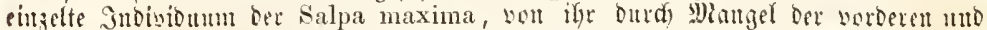

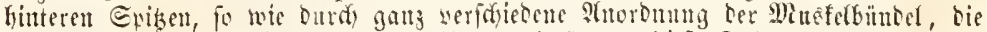

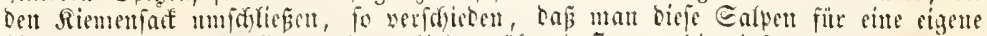

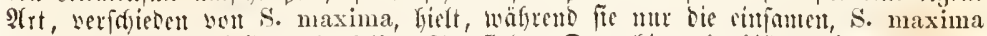

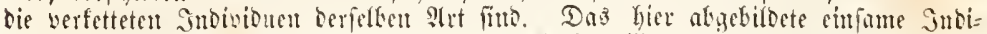
vionum Ser S. africana hat nod) Den Mutterfudyet (l) mo ben Selförper (m), ift

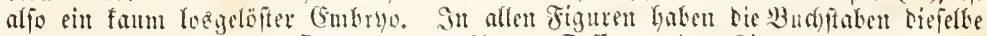

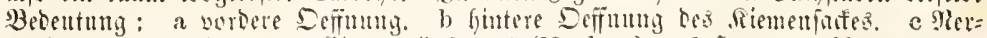

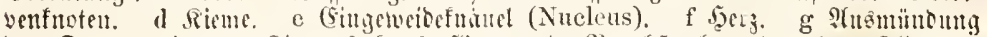

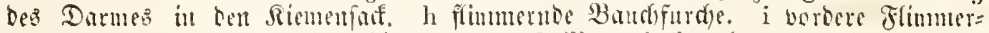

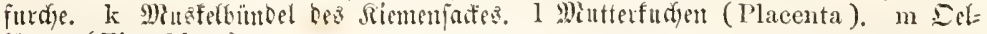
förper (Elaeoblast).

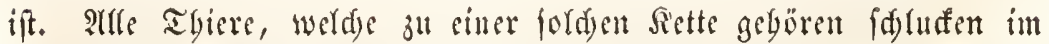
Taftmaß̧e Taffer cin, um es burd) bie bintere Deffnung wieber nub= jutreiben, uno fo bewegt fid bie Sette fofiweife fort. Fin Ibier, weldes cimmal wou ber Rette getrennt ift, faun fid uid)t mebr mit Derferten vereinigen, denn es flebt mit feinen bienoffen nur turd verbärteten Shleim ऑjammen. Flüer Diejen ju Retten verbunbenen 
Jnbivituen giebt es aber and) $\mathfrak{B}$ aljenfldeiben, die niemarz und unter feinen llmftänden ju Setten werkumben gefunden werben unb bie in igrer Geftalt nidgt mit ben werfetteten Snbivibuen ilbercinftimmen. Man Gat aแz biefen eigene Sirten gemad)t, bis man in ber neneren 3eit entbef́te, baś verfettete und vereinjefte Snoiviouen, wenn aud oft fegr verfdjeben in igrer änjern form, bennod nur fegr verfdjie=

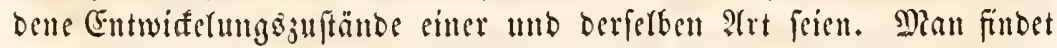

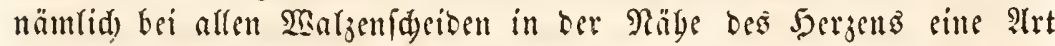
Snopf ober sinen $3 a f f e n$, in weldem sin frarfer $\mathfrak{B}$ futftrom anf $=$ umb

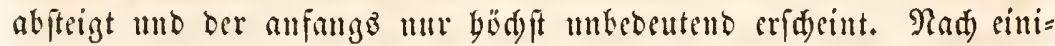
ger 3eit bemerft man auf biefem 3apfen einige Eryabenbeiten wis

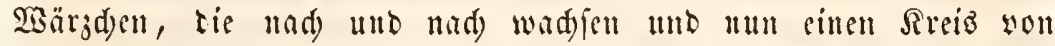
Gimbryonen Fildon, weldye um ben 3apfen bermm gelagert fint. Es

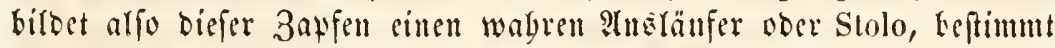

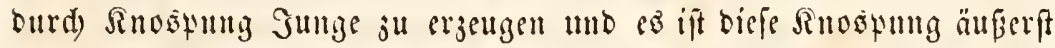
produftiv, indem man aft brei oder vier Gintereinanter folgende Reiben yon Embryonen veridjiebenen Ytters bei einem und bemferben Inbi=

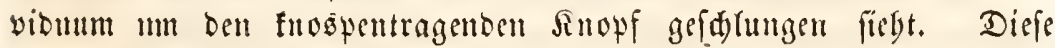
fuccefïen (benerationen trennen fid) nad) einiger Beit, wemn fie igre

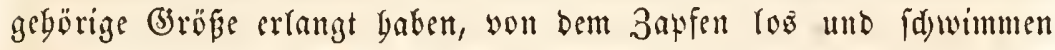

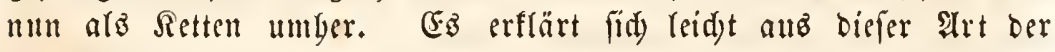
Entwiafelung, warum in ben Sietten, weld)e von 2nfang an jufammen=

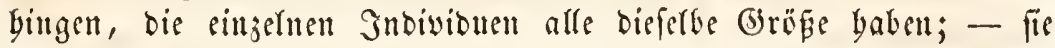

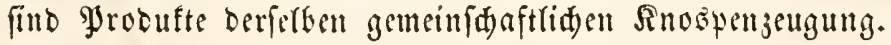

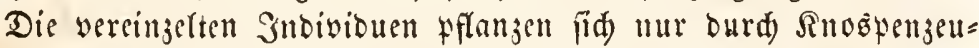
gung fort und man wiro besgafb felten ein foldjes Gnoivionum tref= fen, weldes nidyt eine ober megreve Sietten won Embryonen an feinem Sinospenjapfen umbertrïge. Die verfetteten Inbivionen Dagegen befitgen auß̧er Der Rettenjengung burd) Sinošpung nod) cine geid)led)t= ride 3engung, burd) weldye jebes Thier nur sinen einzigen (Embryo erzengt. Sdjon wäbrent Der Zeit nämrid, wo die verfetteten Thiere nod) in jiemlid unentwifeltem 3utante um ben Snošpenjayfen ge=

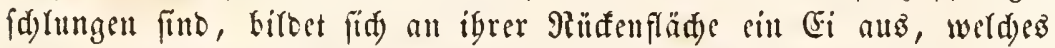
nad) und nad) fo fegr anwädjt, $b a \tilde{\beta}$ es weit in bie Riementöble Gincinragt. Reten biefem Gi birbet fid eine 2 rt $\mathfrak{M u t t e r f n d}$ )en (pla-

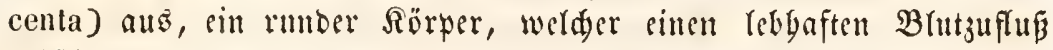
ergält und mit Dem anf ber anbern Ecite bie Brntzirfuration bes werbenden (Fmbryo's in Berbindung fitegt. Reben biefem Mutterfuden

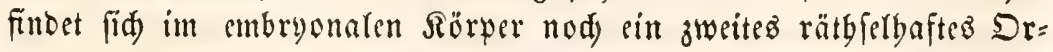
gan aนs̃ cinjelnen Deljellen zufammengelest, daz man ben Delförper 


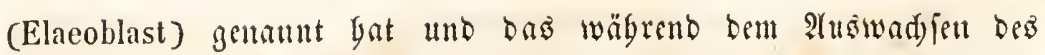
Embryo's affmaglig vergefrt wirb. Die genaucre Entwiffelung bes (Fmbryo's felbft ift nod nid)t im (Fingeluen befannt, obgleid) man bäufig junge serfettete Secidjeiben fincet, welde (Embryonen entbalten, bie wod) ourd) ben Mutterfuden mit bem Muttertbiere verbutben

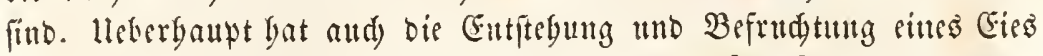
in nod) thidt entwiffelten Thieren mandes Rätbjelbafte.

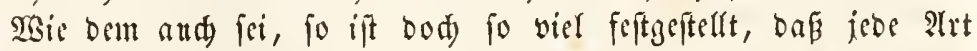
you Salpen ats jwei abwed) felnben Reiben yon Subivibuen jufam= mengejęst wirb: aus verfetteten unb vercingelten Tbieren. Jebes vercinjerte Inbivioum erjeugt Durd) Sinosłung Sietten und jebes in ciner Sette befindide erjellgt wieber sinen vereinzelten Embryo, ber näbrent feittes ganzen Eebents vereingelt breibt. Die vercinzelten $\mathfrak{I n}=$ bivibuen fönuen bemuad) gleid)fan ars ammen angefeben werben uno find and in ber That igrer äuberen (Erfdeinung mad) meift febr von ben werfetteten Jnbivibuen berjefben îrt veridicben.

Die $\mathfrak{B a r g e m i d j e i b e n ~ b i r b e n ~ n u r ~ e i n e ~ F a m i l i e , ~ i n ~ b e r ~ v i e l f e i d s t ~}$ mebrere battungen anjunebuen fint, inbem man einige Arten femen gelernt bat, weld)e jum Beifpiel ourd die Struftur ibres Darmfanals ober burd) bie Ergeuguth mebrerer Jungen in sinem Retteninbivibum yon ben lürigen Arten abweiden. Salpa.

Bon ber ganjen Rlaffe ber Manteltgiere tennt man feine foffifent Repräpentanten.

\section{Luterkreis Der sigentlichen Weitht)jere. (Mollusca.)}

Die eigentlidyen $\mathfrak{B}$ eidstgiere unterid)eiben fid werentlid) brourd von ben Mloflusfoiben, daß bei ignen die Drgane bes Sïrpers ${ }^{4}$ beiben Geiten einer Mittelebene mebr ober minber fummetrifd ange= brad)t fint. Dit freilid ift diefe Symmetrie geftört, zuweilen aud) erfdecut bie Mittelebene des Sörpers nidgt gerabe, fonbern mebr ober minber (d)nectenförmig gewuttoen. Itlein troks biefer bäufigen Aแb =

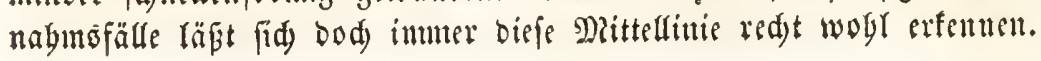




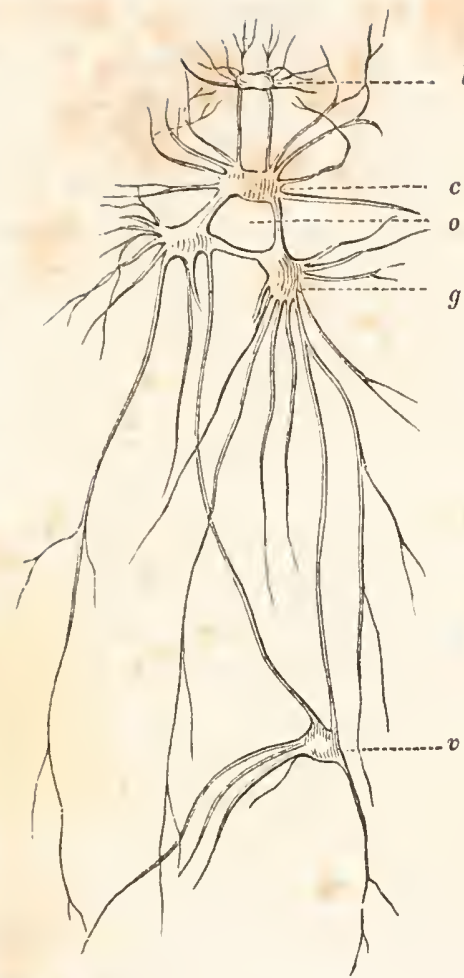

Eig 236. Nerwenthpiem bes ๔eetajen (Aplysia).

1 Borberer Eippenftroten. c Jaimfututen, uber bom Edjlunbe gelegen. o Durds=

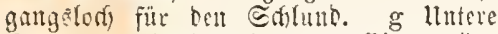
Rnoten Dea Edilumbringes. v cingemcibe= fnoten. ben Söruer won ber Geite Ger umidjliefen und an bem oberen Pande burd) eine 2trt GGarnier, weldes man bas Galofi nennt, miteinanoer

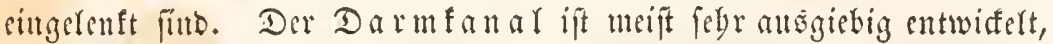

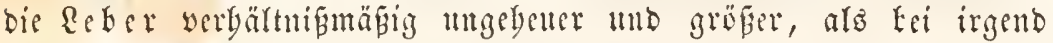

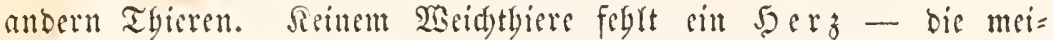
ften befizen sime febr angabildete Cirfulation bes Brutes, bie aber niemals it ganj wollftändig gefdeloffenen (befäpbabuen wor fid gebt uno befondere oft fegt entwictelte at themorgane, meift in form von

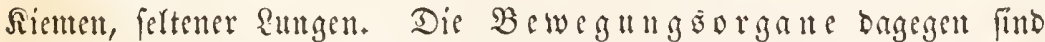

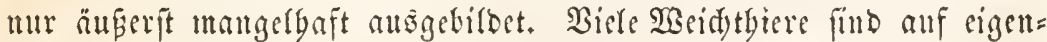

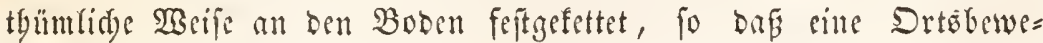
gung ignen volffommen unmöglid) ift; bie andern friedsen, mittelft

3ogt, Zoologifdbe Briefe, I. 
eines fleifdigen Fortiatses, ₹uß genannt, umber; nur febr wenige

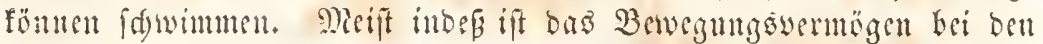

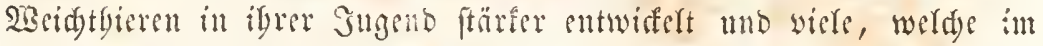
IYter feitfitsen, ober nur fried)end fid bewegen fönnen, füb in ber

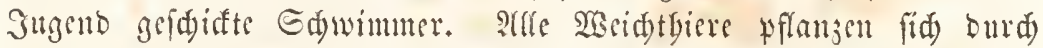

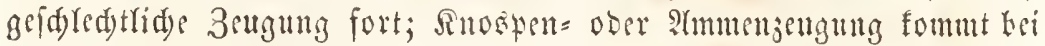
ínen nidyt vor. Mande find 3witter, Die Meiften getrennten Ge= fd)led)tes; - 2rme entwideln fid) ałs (5anjes aแs bem Dotter, obne

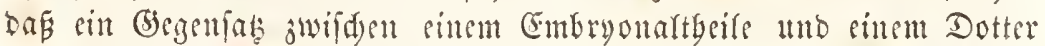
beftänoe. Sie unterideiben fid bierburd wejentfid won ben Sopf= füblern, bei welden ein folder Bergenjas som erifen Beginn an exiftit.

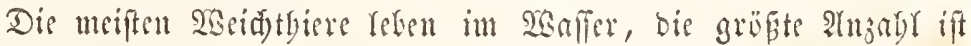

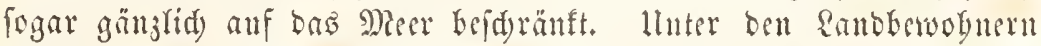
atgmen bie Reijten bennod) Saffer burd) Siemen, nur wenige \&uft

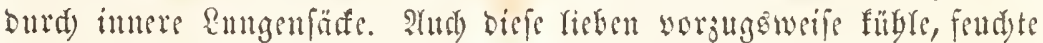
Drte unt fint gewögnlidy uädtige Thiere, welde uad Than unb

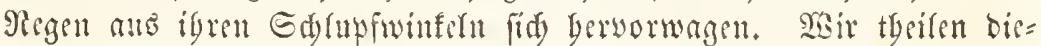
fen lluterfueis in swei grope Rlaffen: Die Mithertbiete ober

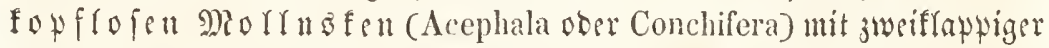

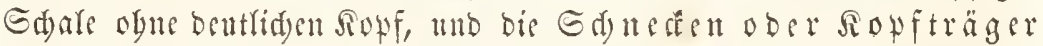
(Cephalophora) mit meift seutlid)en Sowf und cinfadyer röbrenförmiger Edale. Sebe diefer Sraffen bat wieder veridiebene lluterfiaffen. Der meift vorfommensen barten Edjalen wegen, welde tiefe Tbiere mus

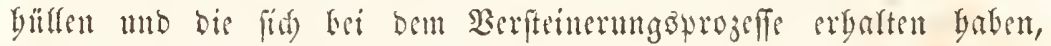

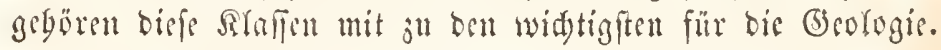

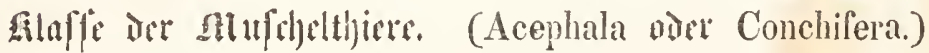

Die Ihiere, weyde diefer hiberanz jablreiden Rlaffe angebören, baben mit ben Moflusfoiben ben Manger eines gejonberten Sopfes gemein, unteridesion fid aber wefentlid) yon ignen burd) ein Rerven=

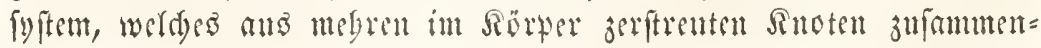




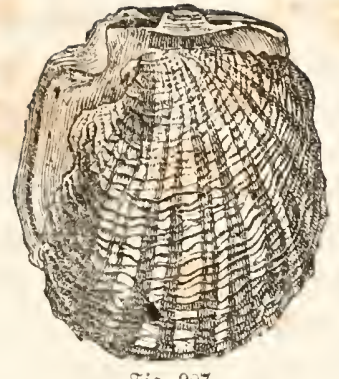

Tig 257.

Enten rer Pertmufdyel.

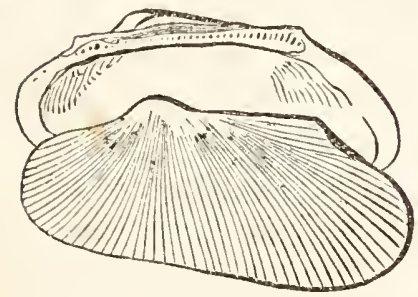

Jis 289.

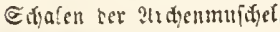

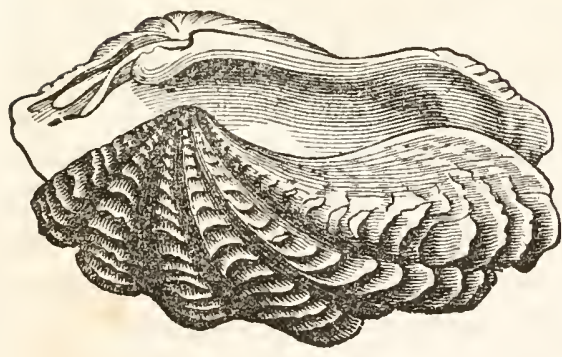

8iq. 289

Eđalen rer Ricfenumidel.

gefeld ift mub burd) bic (Exiftems jweier, meift falfiger Edalen, weldye den flatten Sörwer won Den Griten ber cinfdyließnen, wie bie Deffer ciu $\mathfrak{B u d}_{\mathfrak{4}}$. Da im llekrigen bie bciocn llnterflafien, in weldye biefe Thicte jerfalfen, Dic $\mathfrak{A} \mathfrak{r}$ m fü B̈fr (Brachiopoda) uto bie Brattiemer (Lamellibranchia) cine jicmlid ver= frjebcute Drganifation befitisen, fo befd)ränfeแ wir แแเ bicr auf bic Betradytung Der Edalen, bas llebrige allf dic Gyarat= teriftif ber lluterfaffen werfdic= bent.

Die Sdyaren Der Mufder = tbicre find auberordentrid) da $a=$ rafteriftifd fït bie ganze STafle, inbeut nur bei ignen, aber aud ganz affgemein, bicke Edaren anz juci Srapten gebirbet finto, weldye ben Sïrper von beiben Griten ber eimfdrlicien. Selbit bei Denjenigen Muldorltbierin, bei welden ipäter dicfe P(tords nung fid berwifdst, fintet man in Der Suzend biefe beiden Gdyalen volffommen aนถึ่gebirbet.

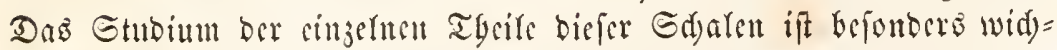

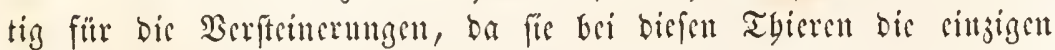
Theile find, weldye erbalten bleiben. Faft liberall befteben biefe bei= ben Sarfoefer aus brei verfdjebenen Edjiden, weldy von auben nad imen in folyenber Dromung fid erfennen laffen.

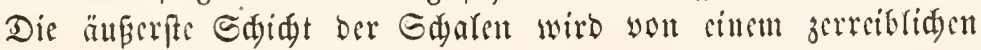
Heberjuge yorniger Ratur gebildet, Der Dberbalt, welde offenbar mit ber ben Mantel bebectenden Dberbantfdidyt in Bejiebung fteyt.

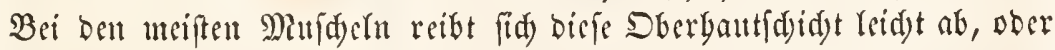
wirb ferbft fünftlid an ben in Gammlungen bewabrten Thieren ent= fernt. Auf bicie Edjidyt folgt nad) innen bin sine sweite, bie aus 


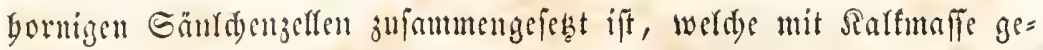

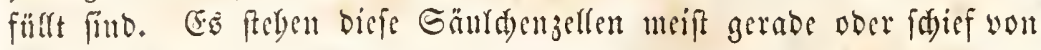
atben nad) innen; - ifre stefonderung, fo wie biejenige bes foblen= fauren Sarfes, wclder fie erfüllt, geght offentar yon bem verbiaften

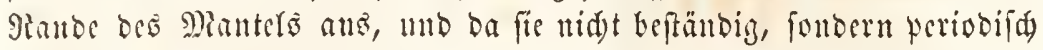
ftattfinbet, io werben bierdurd) singsthe Blätter gefiroct, weldye ond $=$

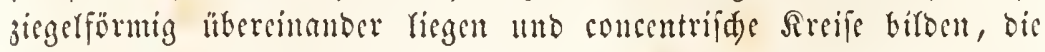

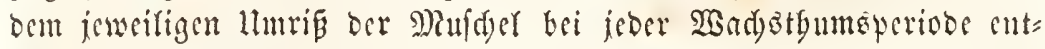
fpred)en. Die $2 \mathfrak{n} w \mathfrak{a}$ d) nen Ramelfen gebifocten Sinten genannt bat, bieten mandse 2hubatts=

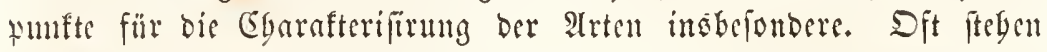

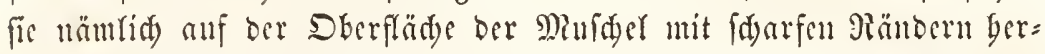

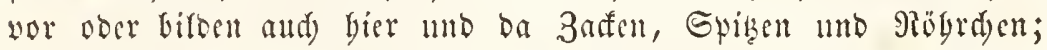
meift aber zeigen fie fidd nur arz feine Rinien, bie gewögntida bem

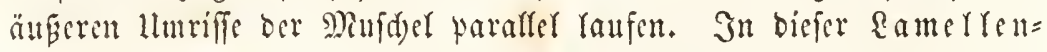

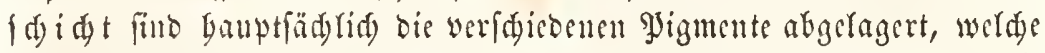

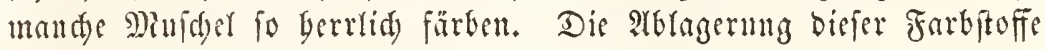

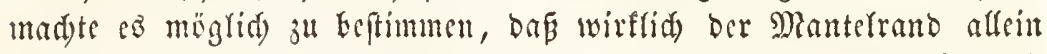

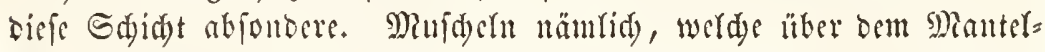

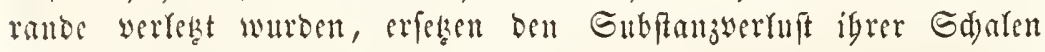
Durdd sine Maffe, weldye ber mingefärbten Edjidjte ber imeren Edjale entipridst; gefdiclyt aber bie Berlestutg an Miantefrante, fo erbält

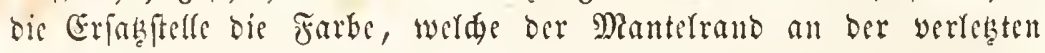

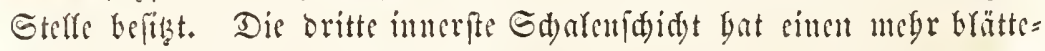
rigen Ban umb sine gleidförmige Grunomaffe, weldye äuserft fein

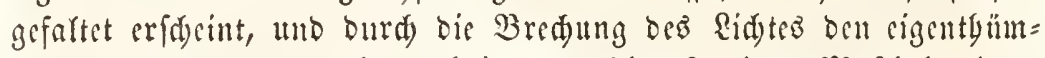

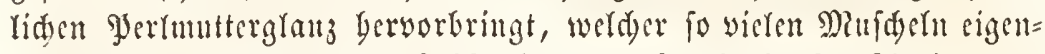

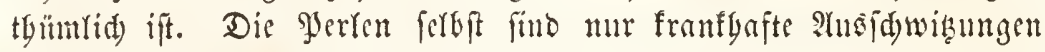

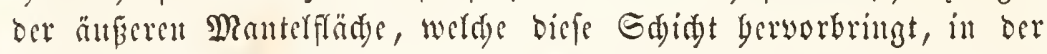
nur feYten Farbefteffe abgelagert werden.

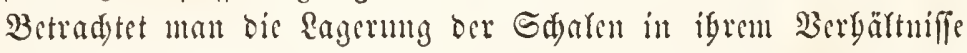

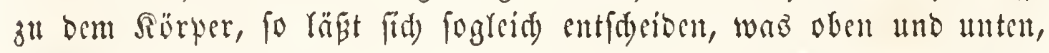

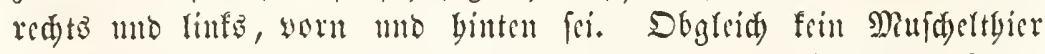

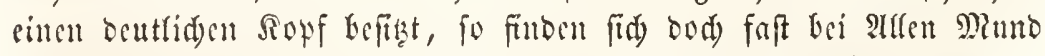
und $\mathfrak{A}$ fter an entgegengefesten Ginden uno bei ben Freilebenden baz

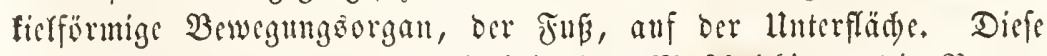
orci Drgane beitimment bemunath bei affen Minfdertgieren bie Benen=

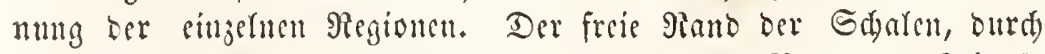
werdyen ber Fun Gervorgeftreatt wirb, ift ber untere Nanto; ber Sdylog = rand, wo bie beiben Sajalen jufammengefügt futt, ber obere Rand; 
rickenige Seite, nad welder bin ber Mund geridet ift, bie yorbere

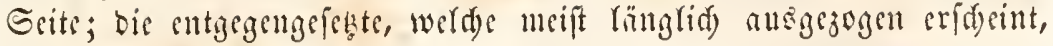
bie Gintere Geite ber Mufder. Stelft man bie Muldel fo wor fid bin, baß fie mit bem freien Sdyalemante auf bem Tifde mbt, wäb= rend ber Gdylofrand nad oben fant, unt bas wordere Ende von bem $\mathfrak{B}$ ejdaucr ab, bas bintere ibm jugefebrt ift, fo bat mant rints bie linfe, reshts bie red)te Sd)ale. Die Ränge ber Mufder

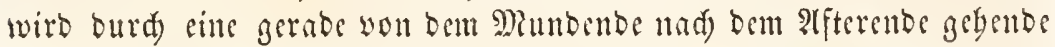
finie gemeffen; bie Säbe won bem bödften Sunte bes Salofirandes bis ju bem niberifen Junte bes freien Edarenranbes; bie Dife quer burd) Den Rörper vou ber 2 öbrang siner Sdyle jur andern.

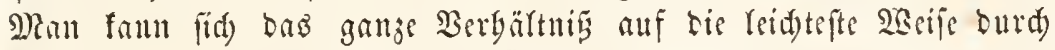
sin Bud) verfinnliden. Die Deffer fteflen bie Edjalen, fie Brättet

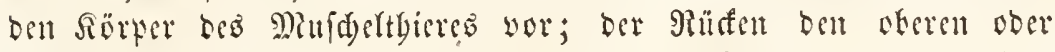
Shlofirand; die freie Esite ben unteren ober Mantelranb; ber obere Blattrant, wo sie Gritenzall ftebt, bie vorbere ober Miunbfeite, ber untere $\mathfrak{B}$ lattrand bie bintere ober Prferfeite bes Mufdertbierez. Steflt man bas $\mathfrak{B}$ ud fo wor fid bin, bafis es auf ber Bratterte rugt unb ben Rülfen nad) oben febrt, wärento ber obere Blattrand von bem $\mathfrak{B}_{e}=$ (d)auer $a b=$, ber untere ibm zugefelyet ift, fo gat maut bas $\mathfrak{B}$ ud in fer Stellung, in welder wir uns bie Milfder benfen unb es wirb in biefer Stelfung ber ben Titel befende Ylappoefel bes Einbanbes

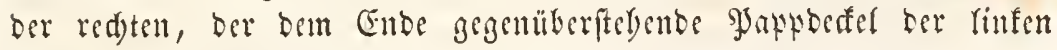

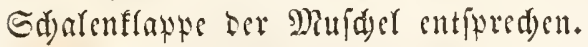

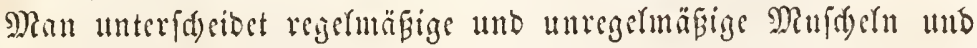

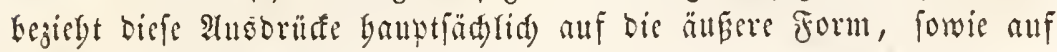

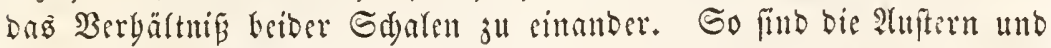
5ammermufdeln febr unregetmäfige, bie Mater= uno berzmuldelu fegr

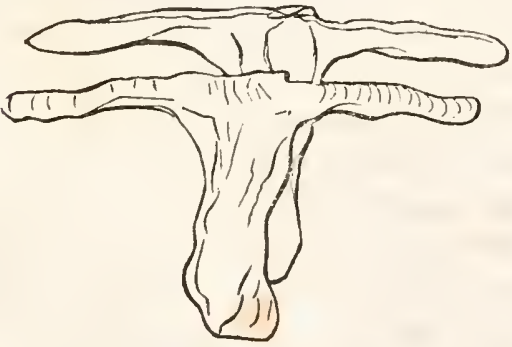

Sig. 290. Şammermuichel. (Malleus.)

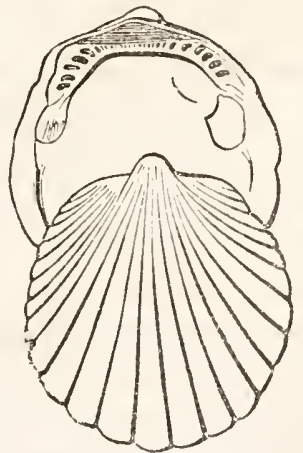

ริ่ใ. 291. Pectanculus. 
regehnäßige Mindueln. Bei ben meiften Mufdeln find die beiben

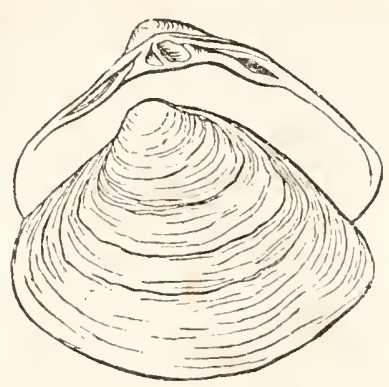

Jig. 292. Trugmuidfl, (Iactra.)

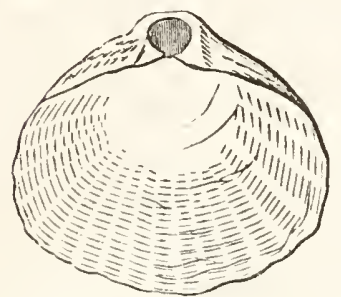

8ig. 293. sodjmujdel. (Terebratula.) Rlappen wolfommen gleid), fie beifen Greid) falige; bei anbern lingegen wie 3. B. bei ben Fujtern cber ben Raum= muldeln ift bie sine Gdyale freiner als bie anbere ober wou veridjicbencr (5) feftalt, fie beisen llugleidydarlig. (5) reid) feitig nent man bie Mitideln, weun bas vor= bere Ende oem binteren wolfommen greidy ift, fo bafi sin querer, burd) tic Diffe gefïfrter Sdyitt jede Giale in jwei voll= fommen gleidye 5älften tycilen wäroe. Die Rodmuidefn uno Sattermuideln bies ten bierson Beifpiele, wäbreno umere gewöbnliden Mealermuideln ungleidfritig fint, inbem bas vorbere Enbe mebr ju= gerunbet, bas bintere mebr anşgezogen ift. Bei ben meiften Mufdeln fdbliefen bie briben Sidalemränber, bie oft gezact unt gefaltet fitlo, volfommen in cinander,

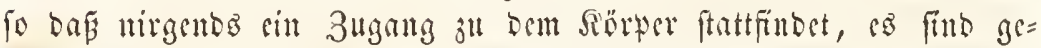
fd)loffene Puldelu, wie 3. B. unfere Teidumfdelt. Antre fömen

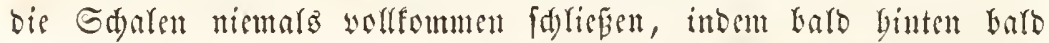
yorn sin bebeutender offener アanm breits; man nennt fie flaffente Mruidelu; bie Gandmufdelu und Meffermufdedn find in biefen farle.

Die Gdalen ber Mufdeltbicre find in beu meiften Fälfen in eitter gröperen ober geringeren Creftreftung längit bes Diürens aneint= anber gefdroffen. Tur in felre wenigen föllen ift burdants feim Sd) ro b vorbanben, und bann war bie gröfere Gdale mbeweglid an ben Booen gebeftet unb tie fleinere beweglide Sdale fpielte bie

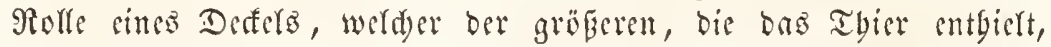
nuftag. Die Betrad)tung Des Gdyloffes und bie Senntnifí feiner cin=

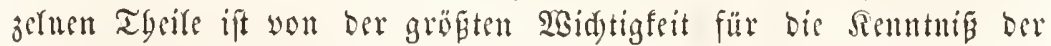
Gattungen unb 2trten. Sn ben wentigfen Fällen Eirbet ons Gd)lof

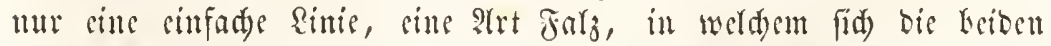

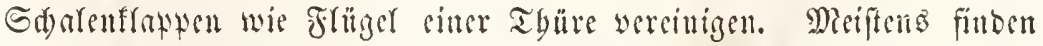
(id) Borfaringe, esiften unb Zarten auf ber einen Gdalenflapte, wel= d)en Dam Rerben, Gruben ober Ginfdutte allf ber anderen Seite entfpreden. Man bat bicfe Sorfprünge, woburd, bie Ränder bes Sdloffes fejter incinanber greifen, febr unpaffenber Saseife 3 ägne 


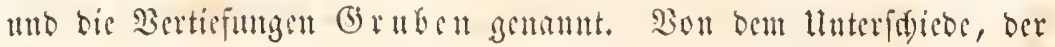

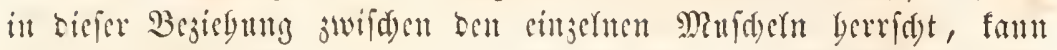
tman fids reidst cine Borfelfung maden, went man mur unfere ges

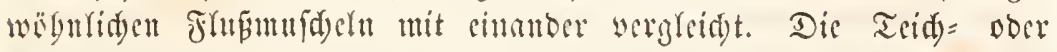

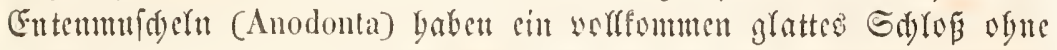
cine Spur won Boripringen, wäbrend dic Malermmideln (Unio) auf

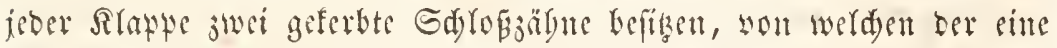

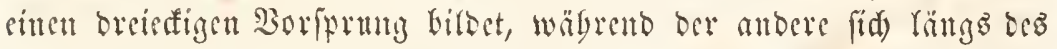
binteren Sdyloprandes binzicht. Frïber regte man anjerorbentliá)

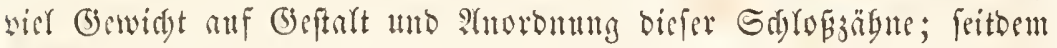
man fid) aber überjengt lat, bar oft feldr c̈bulid)s Thiere Sd)alen befigen, weldse in biefer Bejtelung ungemein von cinattoer abweidyen, wie gerabe bic Maler = nnb Entenmuideln, räumt man bicien Syarat= teren nur cine untergeodonete Bebeutung cint.

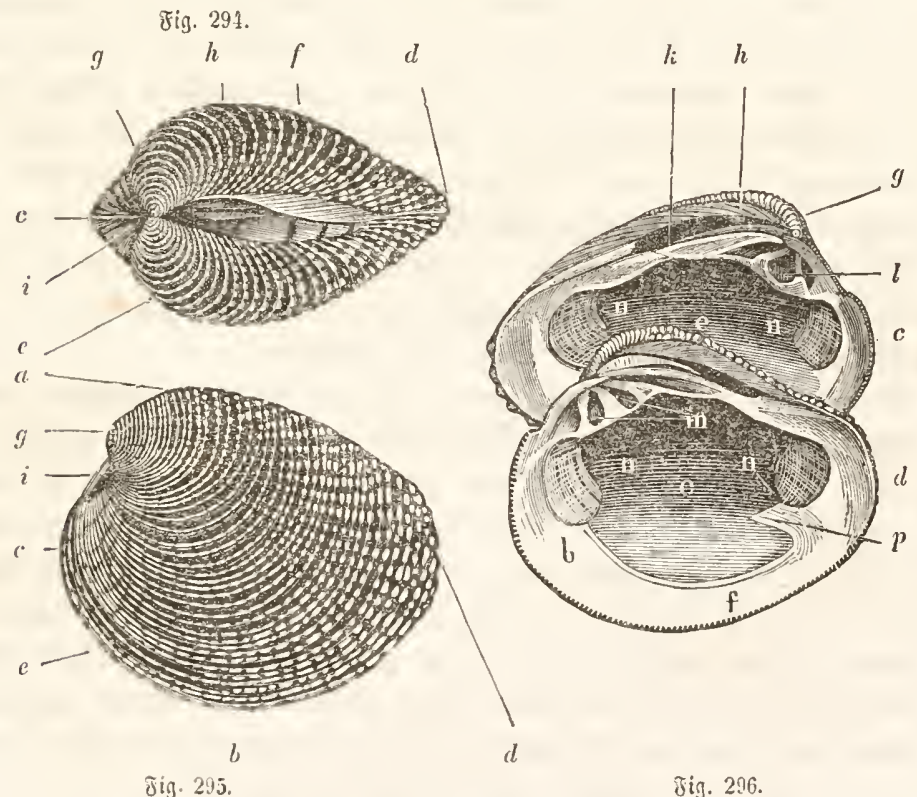

Cd)ate ber Vellus verrucosil.

Fig. 294. Bon wern. Fig. 295. Bon ber Grite. Fig. 296. Beibe Enalen

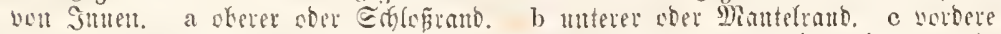

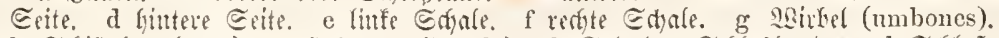

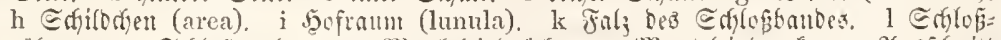

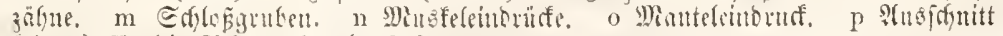
(sinus) für bie Ithemtogre (sipho).

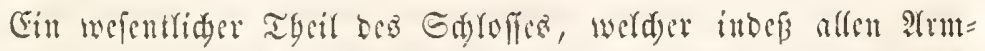

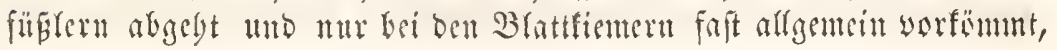




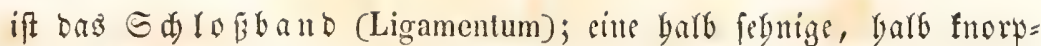
lige Malle, welde meift eine grofe Feptigfeit und cine bebeutende Elaftigität befigt. Sn ben meiften Fällen finb bie elaftidan Fajern

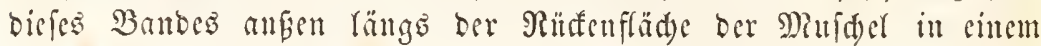

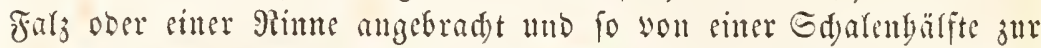
anbern binubergefpannt, bas bei bem Sdyliesen ber Sdale die Fafern gebernt und gezert werben und burd) inge Elafticität bie Edalen

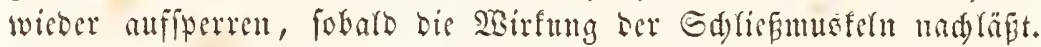
Sebe Sduatenbälfte bilbet bei diefer Anorbnung Des Sdylofles einen

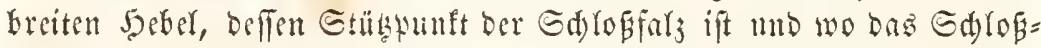

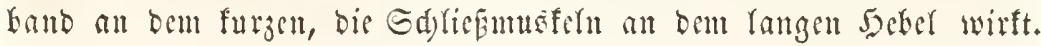

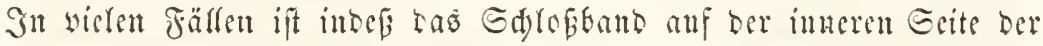
Sthaten angebradt, wo eq eillen geferbten ATtsfdutt ober viele sin= zelme Gruben in Gdylofle erfüllt. In biefem Falle werben die Fafern

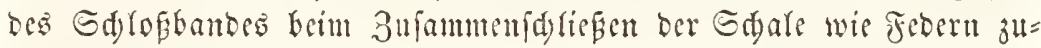

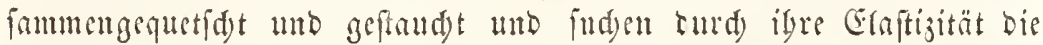
Edyalen wicber ausimander jul treiben. Sn manden gällen finbet

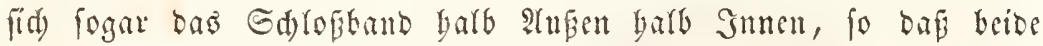
(Effette beim Deffuen und Gdylefen ber Gdale verinigt werben. Die

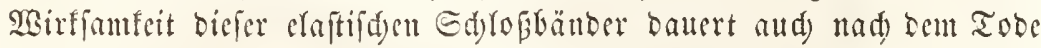
bes Thieres fort und sa bann bie Begenwirfung ber lebendig jufam= mengezogenen Gdliefmustern anfyört, fo flafien bie Gdalen ber mi= ften Muddertbiere nad) Sem Tobe won cintanber.

Bei ben meiften Dinfdeltbieren beginnen bie concentrifden 2 sad) thumejitreifen, welde auf ber Sberfläde ber Gdule fid zeigen, auf Der Mitte Der Rüfenfeite in jwet cinanber entfpredenden Erbögun= gen, welde man die Saitbel (Umbones) nentt. Meiftens bitben

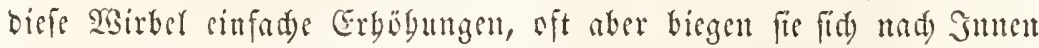

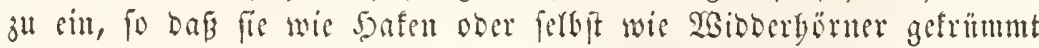

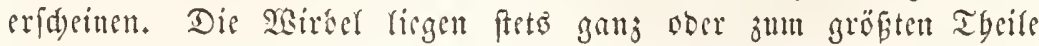

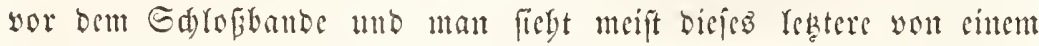
befonders abgegrengten Raume umgeben, den man bas $S_{d}$ ild d en (Area) genannt bat. Cin äbnlider 9iaum fittoet fid) bei vielen Miu= fdeln vor efe Sirbeln und wirb baun ber 5 ofranm (Lunula) ges

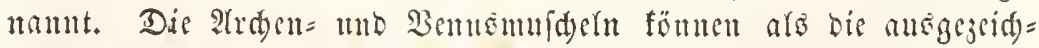

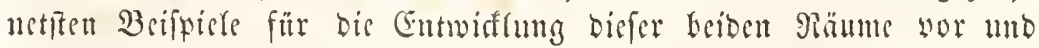
Ginter ben Sisirbeln genamt werden.

Pud bis imnere fläde ber Sdyalen läpt bei genamerer Unterfu= d)ung (Figentbümlidfeiten wabruebmen, welde jur llnterid)eibung von Jamilien, Battungen uno Âten vortrefflidge Merfutale riefern. Die 


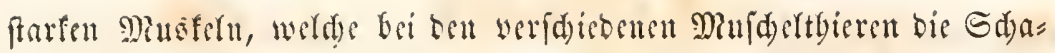

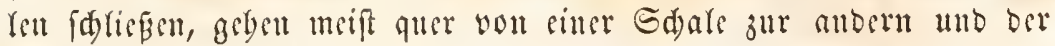
গianm, wo fie angeleftet fint, zeigt sincen tiefen Eindruf, an bem man oft nod bie cinjelnen Ragen, burd) welde fid bie imtere Sdyn=

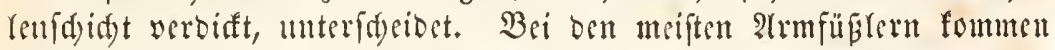

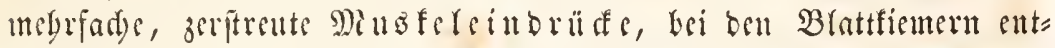
weber jusi auf jeber Sdakle, bie bann an bem vorberen unb Ginteren Ertbe liegen (f. Fig. 296.n) ober nur siner vor, ber banu megr in ber Mitte ber inneren Sdatenfläde fid jeigt. - Der Mantel, welder

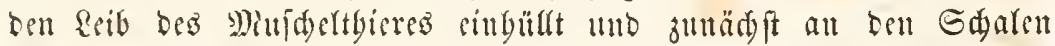

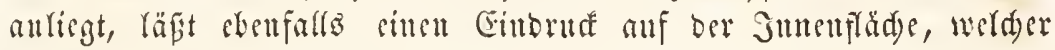
frinem llumriffe in Reben entfaridst. Dft ift biefer Cindruf ganj-

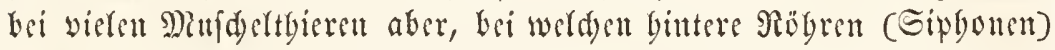

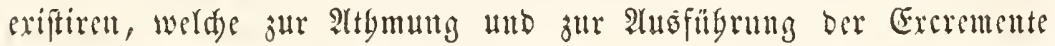

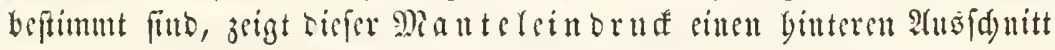
oder Sinus (f. Fig. 296. p), welder in Form, (3rö̈se und Tiefe meift

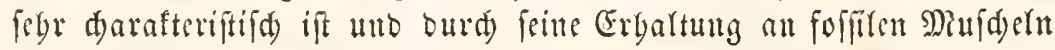
mit Sidgrbsit auf bie 2 nnwermbeit sines Sipgo bei benferben fidlies

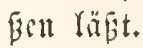

atte Muldertbiere fint 2afferbewogner und bis meiften nur siner

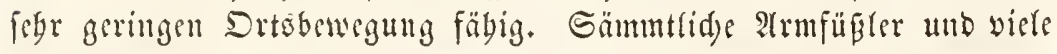
Blattliemer find entweder unuittelbar burd) cine igre Sdarlen, ober

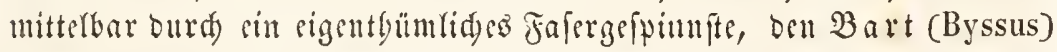

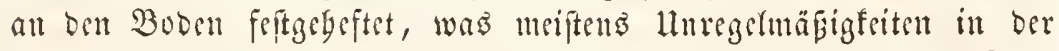

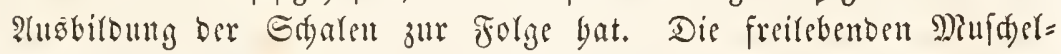

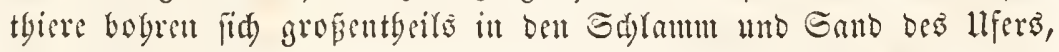

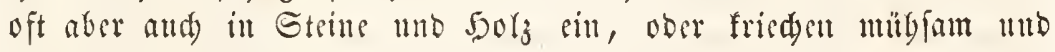

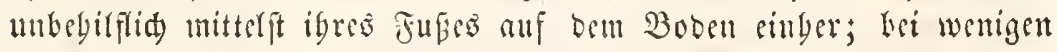

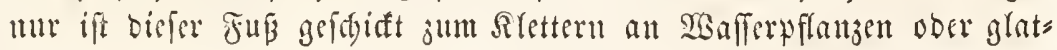
teren Giegenftänben, unb wnt bei ciner einjigen Jamitie, bei ben Sanmmuf(d) men, inbem fie bie beiben Edjalengarften lokgaft auf = uno zutrafpen

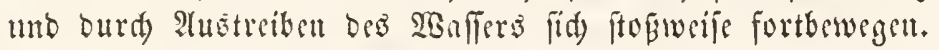

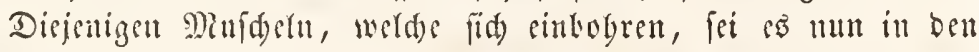

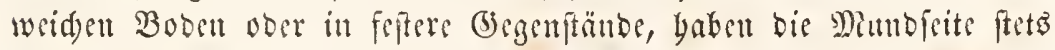

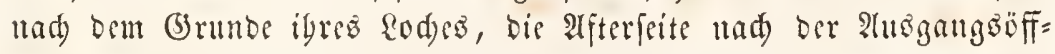

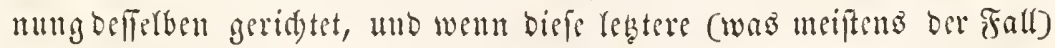

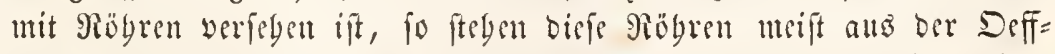

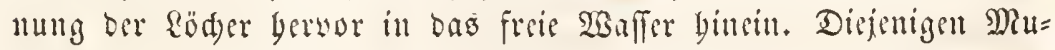
fidern alfo, welde fid auf bem Boben ber Beswäfer sintbogren, baben 
wäbrend Dez Rebens sine fenfucd)te Gteffung, ben Munt nad) unten, Len after und oben; bie 5alz= und Strinbobrer bagegen, welde ifre Rad)er in fenfredste wänos cintretben, ftecten meifit in borizontaler sagerung in igren (bäugen. Die angebefteten Minfdelu ruben auf ber einen Gadale, wäbreno die andere frei beweglidy ift, unb bie freien

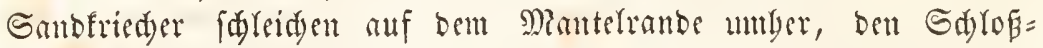
ranb nad oben geridetet, inbem fie mit Dem aus ben Sd)alen vor=

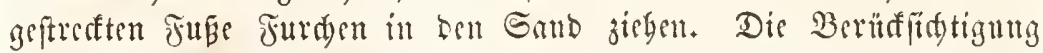
biefer verfdiebenen Stelfungen, weldy die Minfdelthiere wägrent bet 3rit igres Rebens cinnelymen, ift bejonbere widtig für bic Geologen, inbeut man Darans oft Sdytaffe auf bie urfpringlide Ragerung ber Sdjidten maden faun, in weldan bie Muidertbiers jur 3eit ifres

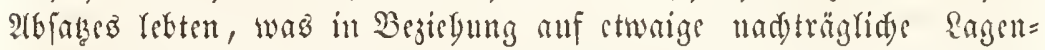
veränberungen ber Sdjidten von Jutereffe frit faun. Jebenfalla aber war es unridgtig, went man die gemöbulide Station ber llfer=

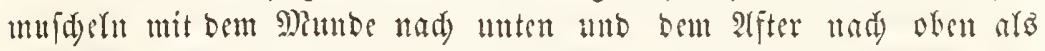
Rorm fitr Die Bezsidung Der Sdaren gebranden worlte und bis Ifferfeite bie cbere, die Mintofeite bie untere Gdalenfsite nannts.

Die numittelbare Ingeftung ber Salaten, wie fie 3.3 . bei ben

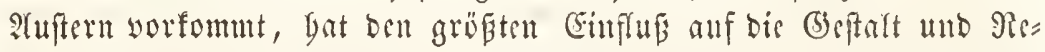
getmäaigfeit ber Gdaten, bie fidh oft ibrer lluterlage anfdumiegen uno fo bie Gejtalt berjelben wieberbolen. Sneit wentiger ift biefer Eimfluf bei ber freieren art Der anbeftung burd) Fabengefpinnfte vorbanden. Die Segnenfäben, weldye biefe Anlgeftung bewirten, treten entweocr burd) sin Rod ober burd) cinen susfdynitt ber sinten Sdale, ober burd sine süfle zwifden beiben Gdalen, bis unsift an ber vorteren Seite bes Sdylofrandes fid befindet, bervor. Sine sigentbümlidse Drüfe, weldye an ber Bafis des Jupes liegt mo die Durdy eine Riune unit bem jungenfürmigen Juße ferbit in Berbintung ftegt, refert sine

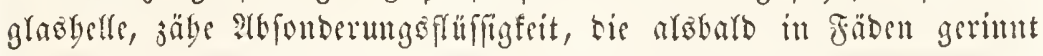
und erbärtet. Dic Blatfiemer, welde fird burd foldye säoen feft=

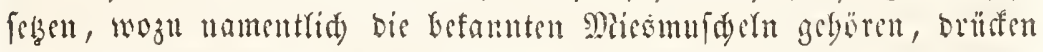
Den jungenförmigen Jub an Den Drt an, wo fie fid fejtiesen wolfen, und ziegen Durd) brebende Bewegntigen sitten Faben tady bem antern,

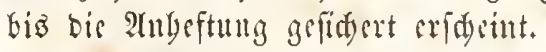

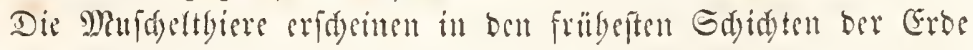

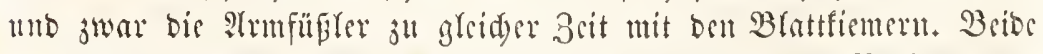

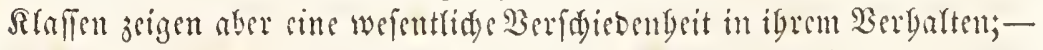
Denn wägreno bie Armfügler maffenbaft an 3abl ber Gnbivituen, Arten und (Sattungen auftreten, alfmäblig aber zurïfiuten und in unferer 


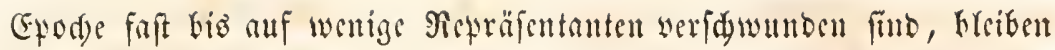
bie Bhattfiemer stwa in bemferten Durd)greffenden Derbältniffe von

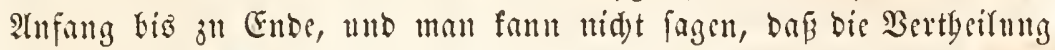
igrer Familien in Den äteren 3citen wejenttid verfdebon wäre won

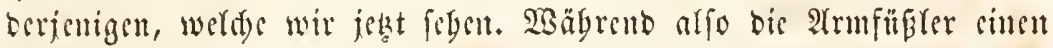

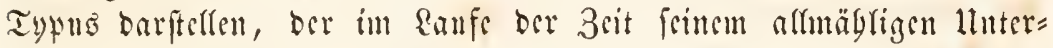
gange cutgegen ging unb von bom nurfere jekgige Sdjöpfnutg nur cintige wenige, glesdefan jerftrente Radjü̆gler anfanweifen bat, zeigen bie

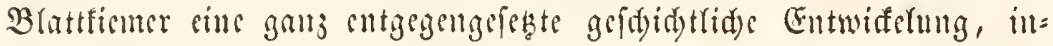

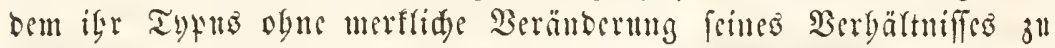

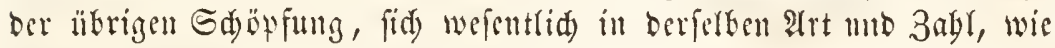
or von ?infang an auftrat, crbalten bat.

\section{Lutrrklaffe Ier Armfiifiler. (Brachiopoda.)}

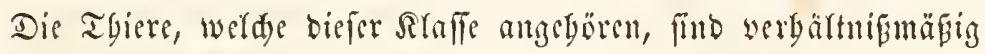
nur forge ferten in unfern jetzigen Deeren, fpicten aber eine bejto grö= fere Nolle in ben Edüpfungen ber ältern Meriobe Der Eroe, wo fie

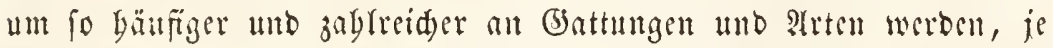

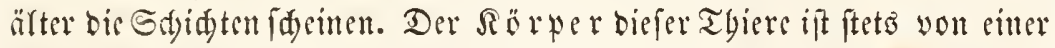

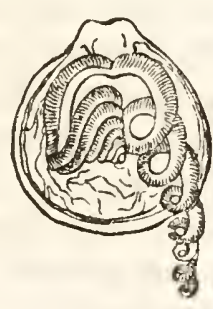

8ig. $23 \%$.

Gine Terebratel, bereu rinte Edjale weggentumen if, um bie keiten Fangarme zll zeigen, bon meldyen ber

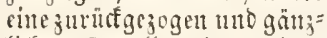
lidy aufgecollt, ber mbete (a) misgebchnt ntid vorge= fitedft ift.

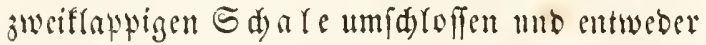
surd) sine Styate ober burd eince balo fegnigen, barb fleifdigen Stiel an bem Boben angebeftet.

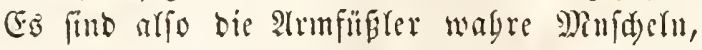
die aber burd megrere bödjt merfwürbige ci= genthüunlidefeiten igres Rörper= und Gdalen= Gaues wefentlity won ben übrigen Mlujaeln ab= wridsu. Dic beiben Edfatengärten fint nic= matz cinauber volfomment gleid) und ferfit in Denjenigen Föllen, wo ibr äuberer llmrís faft iocutifa cridseint, zeigen fie in Sumern ver= idjesenartige (sinbrüfe unb Reiftu, burd) bic

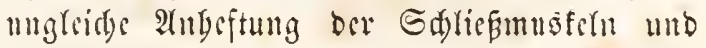
Dav ?rmgerüfte Gerworgebradt. Sn bei writem

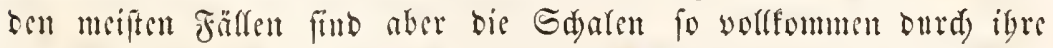

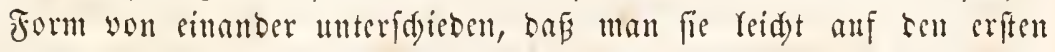
Blif erfount. Sierans ift namentlid für tie Befdreibung ber Sda len eine grofe Berwirrung erwadfen, indem mant rein willfürlid, 
obne mur im Minbejten auf bic Structur ber in ben Sdaren einge=

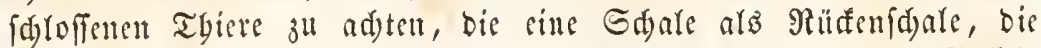

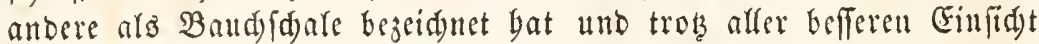
twod immer bejeidnet. Sn ber That fint bei biefen twie bei allen andorn Miufdertbieren cine red)te mo cine linfe Sdyale vorbandent

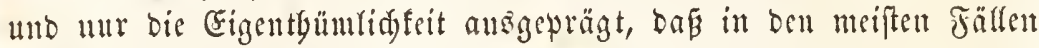

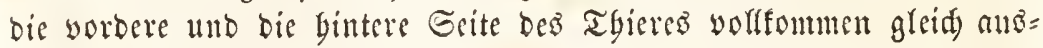
gebilbet erfdeiten.

Der Rörwer ber atrmfüfler ift, fowcit bicfe Thiers befannt fint,

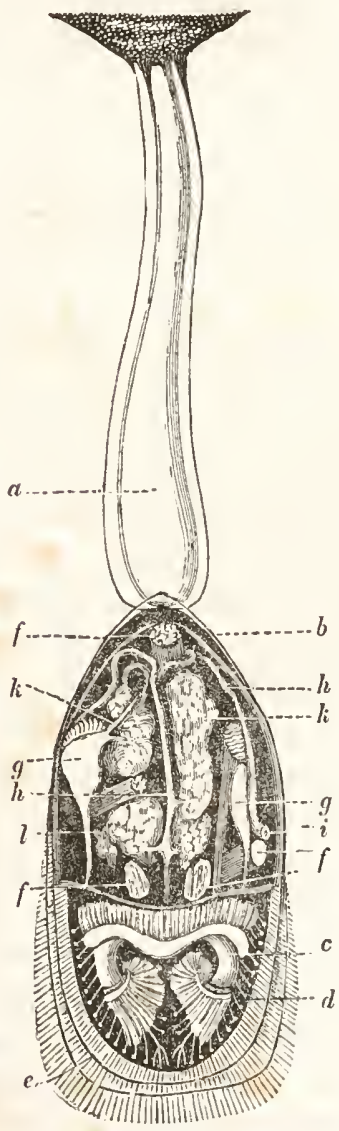

8ig. 298.

2natomie ber (Entenmuitel (Lingula anatina).

Man febt bie Mutfycl in natûnfidyer

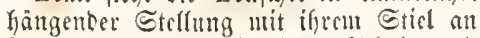
Felfen befeftigt. Die linte Estrale mb interbalb der Sdalen won jwei nus legnigen und contractilen Fäben gewebten Blätern eingefajt, weldye uad) unten fu frei find, uad) oben bin aber cinen Gat birben, intwel= d)en bis Cingerweibe singefdloffen find. Die frecien Blätter diefes

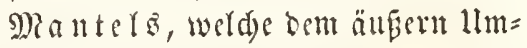
riffe ber Sdale nad)gebirbet find und unumittelbar an ber Jmutufläd)e ber= ferben anliegen, bejteben aแs jwei ant cinanber riegenben Samellen, won weld)en bis änécre, ben Sd) $a=$ lea jugefelerte am Rabe mit fprï= ben fteifen Borften Kefetst ift, wäb= vello bie innere zablreide blafige (3) efäpucrawsigungen trägt uno of $=$ foubar eit siementatt dar= fiellt. Sd)lägt man biefe Mantel= blätter jurïf, fo entbeft man ju= erit zwei cigentbümlide $\mathfrak{A} r m e$, won benen ber eite vor, cer andere bin= ter beut Munbe augebradyt ift. Diefe Atrme, weldye Der ganjen Rlaffe deu Ramen gegeben baben, find meiftens fairalförmig anfge= roflt unb beftelyen ans siner mus= fulöfen Piogre, dis mad) beiben $5 n=$ beat bin gefalofien und wäbrento bes Rebens mit Flüifigteit erfüllt iff. Durb bie 3ufammenzislung 
Das Cinfe Mnanteldratt find meggensmmen uno bie Drgane in ifrer gegenfeitigen Eage in Det Erfale belañent. a ter Etiel. b dif redite Gdyale. c Fonyaume, zu= fammengerdlt, whe fie das Thier bei ge= fd)lofiener Enjale falt. d tedites immeres Biantelblatt mit betl stthemblafen. e

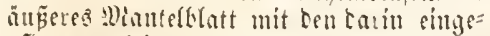

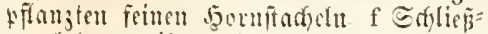

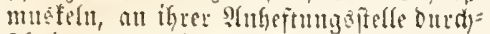
fduitten goie beiben berzen mit ben gefalteten Sorfummern baruber. h ber Darm. i Der Alfter. $\mathrm{k}$ bie Reter. 1 Epei= d)eloritert.

lidi vielen contractilen Jüblfäben Eefect, welde wayridscintid wäbrent des Rebens sine bebentente Flimmerbewegung befisen. Der Raum jwifden ben freien Mantels

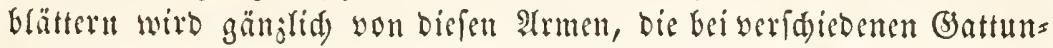
gen verfdiebene Ränge und Itufrolung jeigen, auşgefült.

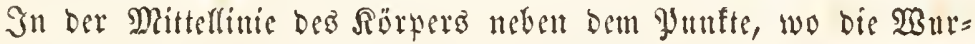
zeln ber Eeiben Arme jufammenftofen, befindet fid ber uad unten geridete $\mathfrak{M} u \mathfrak{n} b$, welder nad) oben in einen unr furzen Sd)lund fï fortfegt, ber innerbalb bes Gingeweibefafes it einen meift mur

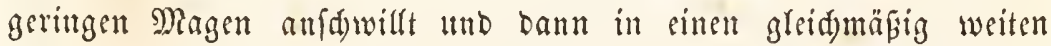
Darmfaual fid fortfest, welder zwifden ben Rebermaffen intuer= yalb bes Eingeweibejafes cine ober mertere SBintungen madyt und bant auf ber Ginteren Seite zwifden Den Mantellappen nad PHen

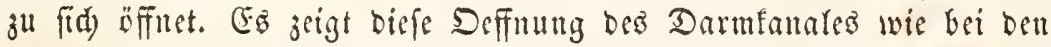
übrigen Mufdertbieren fo aud) bier bie bintere 2lre bes Rörpers an. Die Rebermaffen find febr bedentend und meift in mebrere atbthei=

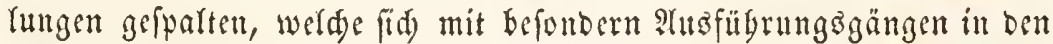
Darmfanal öfren.

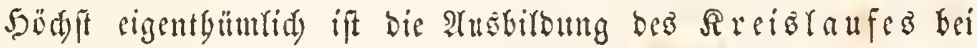

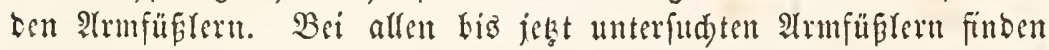
(it) nämlid ftets zwei grofie, megr ober minber fd)(nudförmige Şer= zell, bie sort und binten itt Dem Cingemeibefacte riegen und von wels d)en ans bebentente (befäfe fowobl nad bem Cringeweibefacte als aud namentlid, nady Dem Mantel abgeben, um fid atf ber innern Ramelle Derferben ju vergweigen. Meiftens finben fid auf biefer Ramelle bla = fenartige Anfdwellungen, Die offenbar als Siemenblafen gelten fünnen

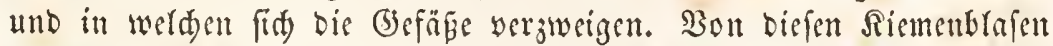

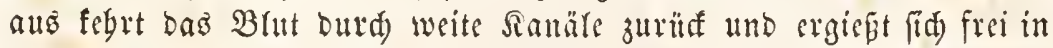

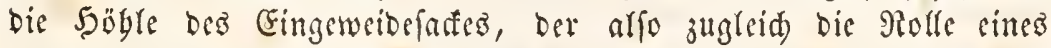
Blutbebältero fpielt. Sin jeocm Saerzen befindet fid ein fraufenartíg gefaltetes Bräzd)en, Der Borbof, welder eine weite Deffrung gegen 
Den Cingeweibefar bin bat unb auf ber anbern Seite in bas Jers eimmïndet. Sbne 3weifel wirb burdy biefen Borbof bas bie Finge: weibe umpälende $\mathfrak{B}$ lut aufgenommen und in bas Serg bineingetrie= $\mathfrak{b e n}$, tho es werben bei bicfen Thieren bie rüdfübrenden Benen Durd)

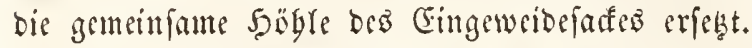

Da bis jest nod) fein Inatom frifde (Exmplare vou armfïblem beobaditen founte unt bie ganje llnterfudung lebiglid anf 2 seingeif: exemplare bejdräntt war, fo ift man liber bie Berbältuiffe oer (5)

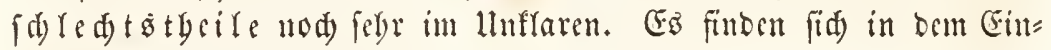

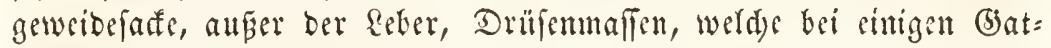
tungen fids fogar bis auf ben Manter bin erftreden uno bie wobl je

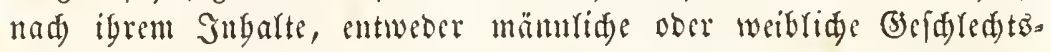
oriffen fein bürften, alfcin weiteres ïber bie Berbältniffe dicfer Tyeite,

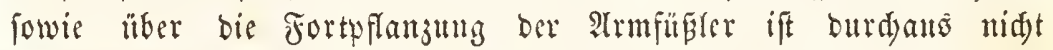
betannt.

Die Sdalen ber Atrmfïgler find alle falfiger Ratur uno mei= ftens, wenigftens bei oen lebenden arten, ziemlid biun unt felbft eini= germáen biegfam. Bei mifroffopifder Interfudumg unterfdecibet man ferbit an biefen bünnen Shalen bie jwei obenerwägnten Gdjichten, von

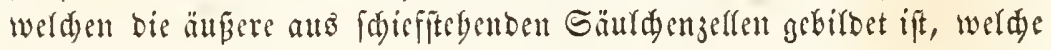
im Smnern mit Rarfablagcrungen erfüllt funt, bie man burd) Säure anbjieben fant, wo bann bie leeren bornigen 3ellen zurübbleiben; bie tumere Sdjidt ber Sdale bingegen brätterig tmb ba einigen Gattungen fo porös erfdecint, bafi fie bei ber Berfeinerung zuweilen verfdwunben ift. Die Sd)alenfubftanj ferbit wirb entweber mur in igrer innern Gdjidyt ober in igrer ganjen Diffe you eigentbümliden Seanälen burdjogen, welde änferft eng uno wie es fdeint mit Siale ablagerungen erfüllt fitt. Bei ber ungemein grofen Berbreitung

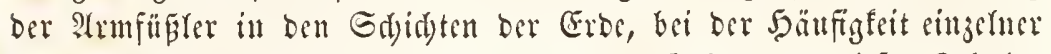
Arten bat man auf bie ätfere Form und Giftaltung biefer Sdalen befonbers vicle sïffidyt genommen und ju ibrer $\mathfrak{B e f d j e i b u n g ~ v e r = ~}$

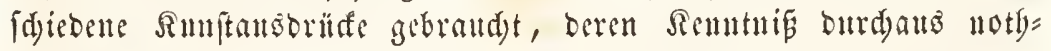
wentig ift.

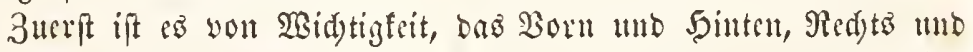
Sinfs, Sben und llnten zu beftimmen, sine Beftimmung, bie nid)t leidt ift bei Tgieren, welde feinen Sopf uno feine regelmäpige Stellung befizen. Bicle 2lrmfübler find nämlid) mit ber cimen Sdale befeftigt, fo baß bis angebeftete Gdjale die untere, bie freis bis obere wäre; andere Dagegen Gängen an sinem Gtiele feft, ber in ber Räbe bes Sd)loffes, wo beibe Sdalen zulammengefügt flut, berwortritt. Soir 


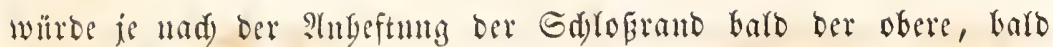

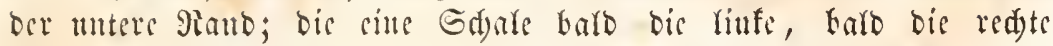

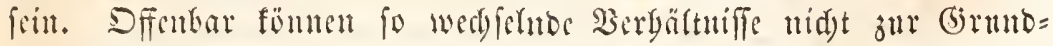
rage ber $\mathfrak{B}$ cidercibung genommen werben tho nur bie Ragerung bes

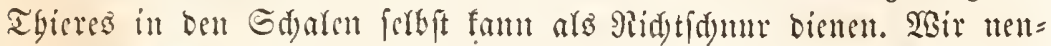

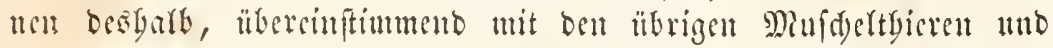
ans ber oben anseintantorgeferten Bejcidnnngsweife, bicienige Seite, auf

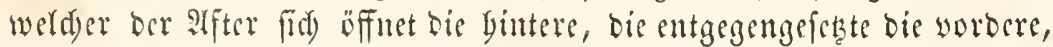
obgleid) biefe beiben Sciten bei allen 2 (rmfüblern sinander vollfommen

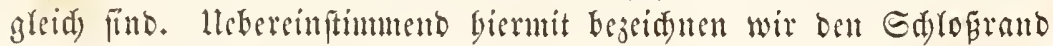
Der Armfüfer ale ben oberen, Den freien Sdatentand, wo bie Frme berwortreten, als ben unteren Rant mo baben bemnad) bier, wie bei bent antern Mindeltbieren, eine ved) te und eitte linfe Sdale.

Bet ben meifen $\mathfrak{A}$ mfüglern ift die linfe Gdale gröper als bie ved)te tuto dient entweder unmittelbar oder burd) ben Stiel, weldsen

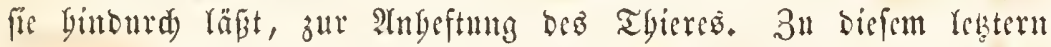

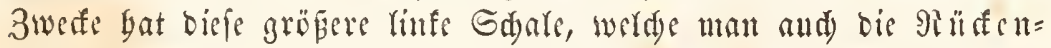
(d) ale genant bat, bei ben meiften (3)attungen sine fduaberfürmige Berlängerung, welde oft wie ein Safell über ben Sdylofranto ber=

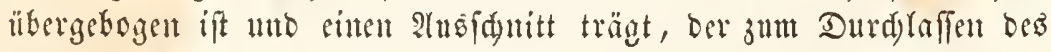
Eticles beftimmt ift. Bei vielen (5attungen wiro biefer Ingfd)nitt son bem Sdylofirande burd eit ober swei beweglide Gtüfe abge=

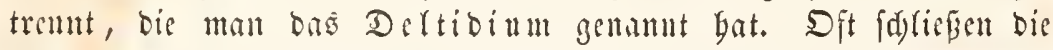

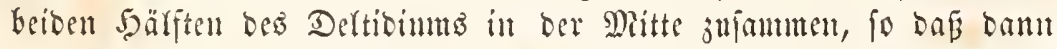
ber Shs sollftändigt wirb, wie bieß namentfich) bei ber battung Terebratula ber Fall ifit; in antorn Fällen begrenzen die beiben Ģälften bez Del= tibiums, bie wie Thürflugh auseinander fteben, cine mittrere Spalte. Den Ramm jwifden dem Sdyabel cinerfeits und bem Sdylofrande antererfeits, ber meift eine Dreierfige (beftalt bat, bat man bas Sd)lofifeld (Area) genant. Die ted)te Sdare (Bandjidale von Biefen genanth) ift meiftens die flemere mo eridgeint bei mattden (5)attungen nut wie cin Deffer, ber auf ber gröperen Sdjale anfliegt.

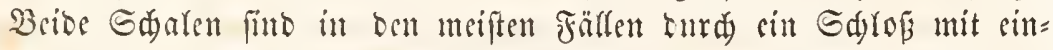
ander yerbunben, an weldem inten won ber grofat Sdare ber zwei 3orfaringe, fogenante 3äbne, in swei cinfdumitte eincs auf ocr in= neren Geite ber fleinen Gdale voripringenden Blatte eingreifen. Bon bemfelben Blatte entfringen bei vielen (5)attungen bödft eigen= 


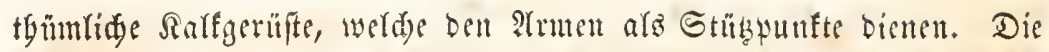

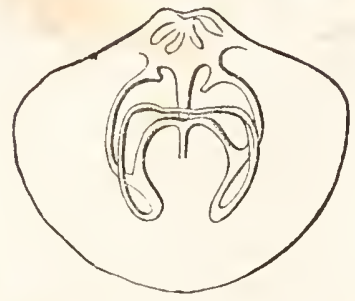

8ig. 299.

Redjte Sdyale eitrex Sudymuider (Terebratula) von innen gejefyen,

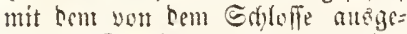
hemben Gerifite jum Tragen ber Strme. einjelten Theile Des Éd)loffer greifen bei Den meifen Brattungen fo genalt in ein= attor, bafi bie Gdalen nur wening ge= offuet werden fönten und ba bei allen

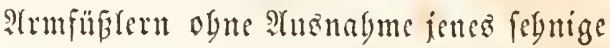
Sd)lofiband feblt, werdes bei ben ütri= gen Mufdeltbieren ourd) feine Elajticität Die Deffnung Der Edaren bewirft, wäg= rent Gier bie Defftung burd) rie reben= Dige Tyätigfeit oer atrme beoingt wirb, fo findet man aud meift bie veriteinerten P(rmfühler, nid)t wie bie übrigen $M$ Muj) eln mit flaffenden, fondern mit velltommen gefdroffenen Sdalen. Die Shliefung oer Sdaten wiro bei allen

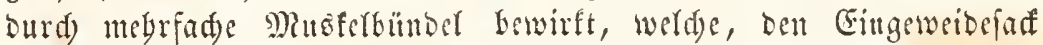
in verfdjedenen Ridytungen Durdjesend, fid) an Der imnern Fläd) Der Ed)alen anbeften und bier verfdiebene Eindrüfe bilden, bie zuweilen für Die Beftimmung Der Arten yon Sidstigfeit find.

Die Armfüfler fommen befonders in ber äfteren Sdjidte der Erbe in ungemeiner Şäufigfeit vor und igre $3 a b r$ nimmt mmfomebr ab, jemegr wir uns oer lebenden Gdöpfung nägern. Sn bem Heber. gangşgebirge jäblen fie fïr fid) allein mebr als bie Sälfte fämmelid)er SBeid)tgiere, wenn man bie Arten berüffidetigt, wäbrend fie jest famm

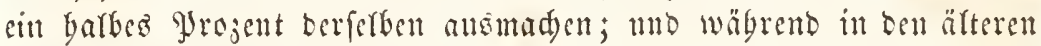
Sd)idten die Sndiviouen einjefner ?rten fo bälfïg find, bas fie ganje Bänfe bilben, fo gegöen fie jetst on Den feltueren Arten, die nur bie und ba vereinjelt vorfommen. Bieferidst indeß bernbt diefe ver=

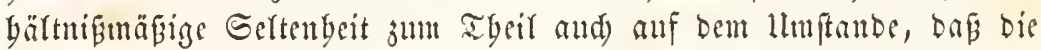
Armfïgler meift mur febr grope Tiefen bewobnen, wo fie weniger ju= gänglich find.

Woir tyeilen die Slaffe Der Armfïfler in zwei Drbunugen, welde bauptfädlid Durd bie Struttur ifrer Gdyalen fid von sinanber mu= terfaciben. Die Drbunng ber Brubiften (Rnalsta) wirb von Broben, fdweren Sdyalen getildet, Die meiftens fing ungleid in ibrer Entwifelung find und bie 3njammenfesung ans juei Sdjidten auper= orbentrid) Deutlid) jeigen. Die äurere Gdiant Der Gdale ift bidt, blätterig ober faferig, bie innere porög nud äukerft reid)t jerfeşbar,

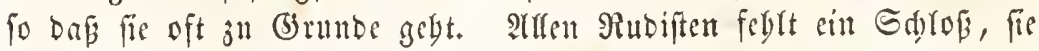
fitzen mit Det biffern Sd)ale ummittelbar anf Dem Boben feft und zeigen 
nimats cine Durdbobrung zum Durd) Iaffen citles Stieles, wie die

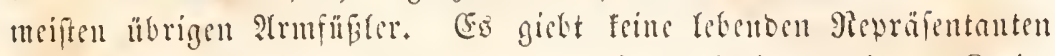

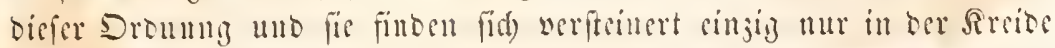

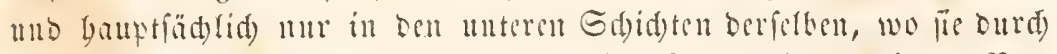

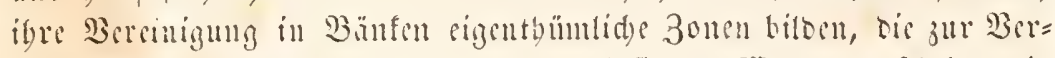

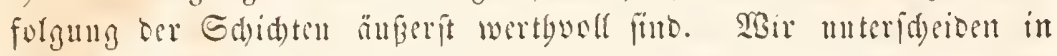
biefer Dronung jmei Jamiticn.

Die Mop̈muidheln (Hippurida) find ftets aus juet แngleid)en Gdalen jufammengefert, bie beide cine fegelförmige Geftalt babent. Die untere Gdale ift bei wcitent bis gröbte, unten mut oft and) aut

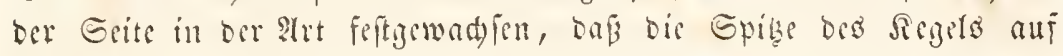
sem Boben anfïkt, wäbreno bie goble Bafis nad) oben gewendet if. Die ofere Edare ijt mebr ober minter flad), bectelartig; cin

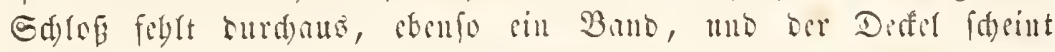
mur Durd frite Sdawere auf ber Söblung ber unteren Gdale firit.

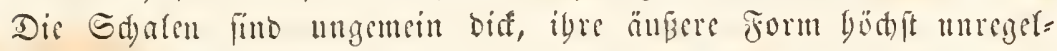
mäвỉ, wie bies bei alfen angebefteten, Bänfe bifoenden Minf́efn vor=

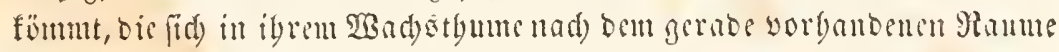
rid)ten müfle. Dis Gtruftur ber Gdulen ift jellig; dic inneren $50 ̈ b=$ ren, worin bns Thier lebt, énigermaben ter conifden beftalt ber

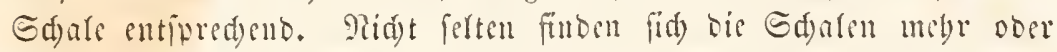

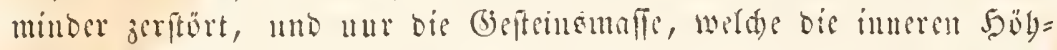
len erfülte, erbatten. Diefe Etcinferne eridectuen bann ans jwei ungleid)en Sirgeln jufammengeistat, welde mit ibrer Bafis an einanter fecben und früber als bejonbere Battungen muter ben Tamen Birostrites uno Sodamia aufgefübrt wurben. Sn ben unteren Theifen ber

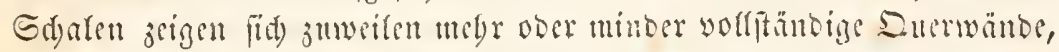
dic man mit Den Sammern ber Eefbalopoben verwed)fete. Da man

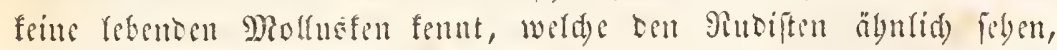

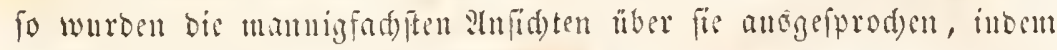
die Finen fie in bie Rabe der Secideciben ober Der Mantenfüber, bie

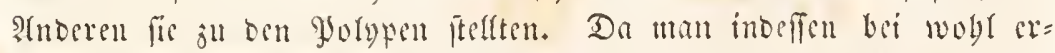
Galtenen Excmplaren nid)t nur mebrfade Musfereinoriade, fonbern ald) Epuren won bafbmonoförmig gebogenen Strmen fiebt, fo fann jetzt wobl hber ifre Gteflung tein 3weifel mefr obwalten. Hippurites; Sphaerulites; Radiolites.

Die Familien ber Biegemmufdeln (Caprinida), weldye ebenfallo

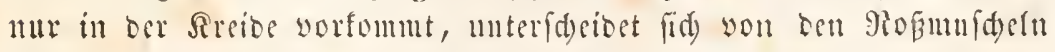
baburd), baß bis beiben Gdyaten nidst conifd, fondern fpiratig einge=

Dogt. 3oologifde Briefe. I. 
wouben find, woburd fie zwei Bodeggörnern nidyt unägnlid fegen. Caprina; Caprotina.

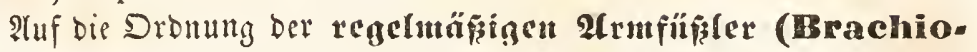

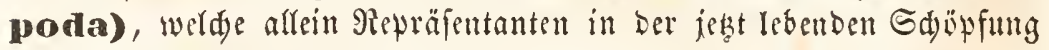
jüblt, fann alles basjentige bejogen werden, waz wir oben wou ben Thieren bicfer Rlaffe übergaupt fagten. Die Sdaaten find in bicfer

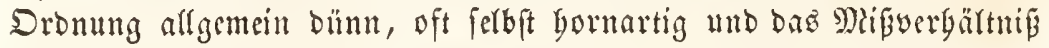

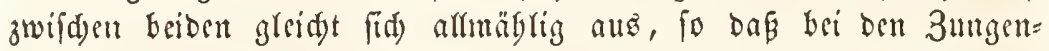

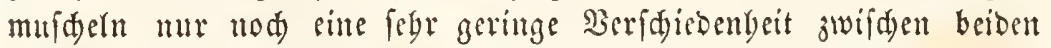
STappen wabrgenommen wird. Die Bieftalten Der Dhufdeln näbern fid) weit megr Denjenigen Der gewöbntidjent Mufdeltgiere unto jeigen

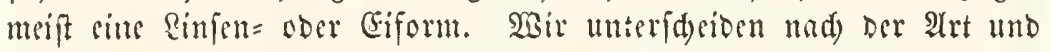

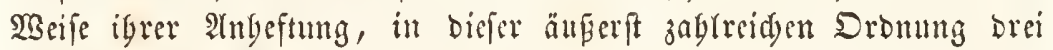
Familien.

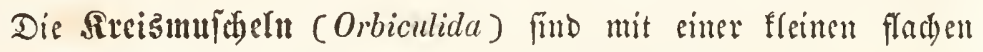
Sdare unmitterbar an Den Boben feifgelgeftet, wägrend bie redte freie

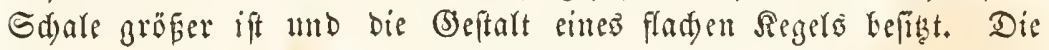

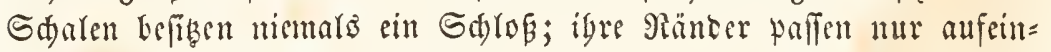

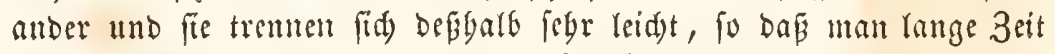
yon siner battung unr bie obern lofen Sdaten fantte. Die eigent= liden $\mathbb{R} r$ eis mufdern (Orbicula) zeigen in Der Mitte Der angebefteten

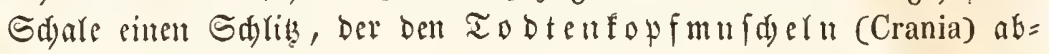
gebt. Beibe Gattungen reben nod jeşt, aber mur ferten, in unjern Meeren.

Die grofe Frmilie ber Rochmuldheln (Terebratulida) jeidyutet fid Durd zwei frrie Sdjaten aus, bie Durd ein Sdjlop mit cinander ver= bunden find, in beffen Räge fegnige Fäben austreten, weld)e bie $\mathfrak{R u}=$

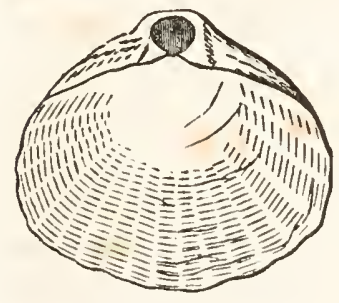

8is. 300. Terebratula. idel an Den Boben befeftigen. In Den mei= ften Fällen, wie namenttidy bei ben eigent= liden $\mathfrak{R}_{\mathrm{odj}}$ mufdeln (Terebratula), bie aflein nod) rebend yorfommen, birben biefe Selgnen cinen Bäjdsel, Der Durd) sin Rod) Der Sdiloßi= felder Gerwortritt. Gelten nur feglt biefes Sod) gänglid) und bie fäben treten burdy Sierber an bem Sdjlofirande berwor. Dab̉ Sd) pelzägnen verjegen, bie nur eine felsr geringe Deffinutg geftatten. Die Sirme werben burdy sigentyümlidye Rarfgerilfte getragen, bie ber fleine=

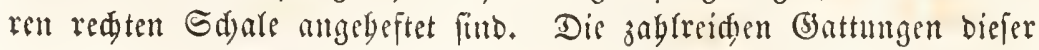
Familie waren namentlid in Den älteren Sdjid)ten entwiffelt; und 


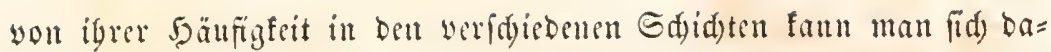
Durd́) einen Begriff maden, wenn man erwägt, Daß́ man vou ber (5)attung Terebratula meit über bundert foffere mo nur etwa ein

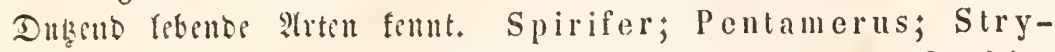
gocephalus; Leptaena; Productus; Chonetes; Orthis; Thecidea; Calceola. *)

Dis Familie ber 3ungemmuigheln (Lingulida) unterforibet fid) wou ber sorigen Frmilie baturd, bafi ibre faft volffommen gleidse Sd)aren fein sigentlides Sd) log befizen, fondern nur mit ibren $\Re$ än= bern ancinandertaffen mo nad) oben atseinander weiden, wo fie einem biffen, fleijdigen Gtiel jum 2 Hạk bienen, an bem bie Muld)el befeftigt ift. Diefar Etier beftebt aus einex änzeren bieglamen Sducibe,

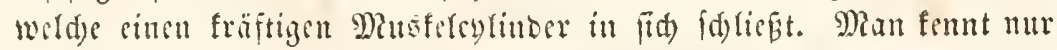

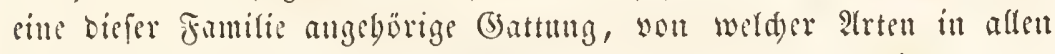
Sdidten bis in dis iesigen Meere, aber überall mar vereingelt vor= geftuden werben. Lingula.

\section{Lluterliluffe Ier Blattlitmer. (Lamellibranchia.)}

3on Den äteifen 3eiten Der Frogefdidte an birben bie Blatt= fiemer eime bedentende gropurtion ber in ben Gewäfirn febenden

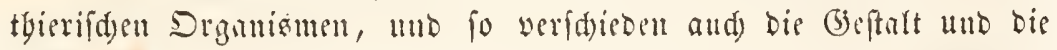
Atnofdmüfung igrex Gdalen fein mag, fo fam man bod) begaupten, Dafj es wobl wenige Silaffen des Tbierreidyes geben mag, weldye fo viele Hebereinftimmung in ber Struftur ibres $\Re$ örpers zeigen, als gerade diele.

Gämuntlidye Blattfiemer find yon einer jweiflappigen Gdale tmm=

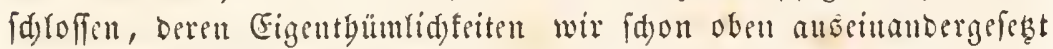
baben. Interbalb biefer Sdalen liegt Der pratte won Der Seite ber

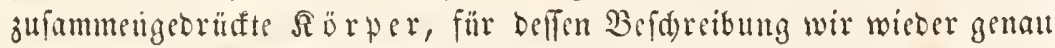
Dieferben Beftimmungen anmegmen, wie für diefenigen ber Sdjalen. Diefer Rörper wird juerif eingeid)lolfen won zwei feitlid)en Brättern,

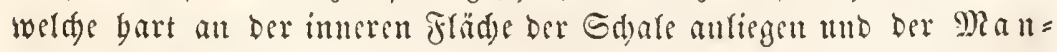
tel genannt werden. In Den meiften Fällen find bie beioen Diantel=

*) Die gejperrt gedrudten (3)attungen fommen nur foffit nor. 


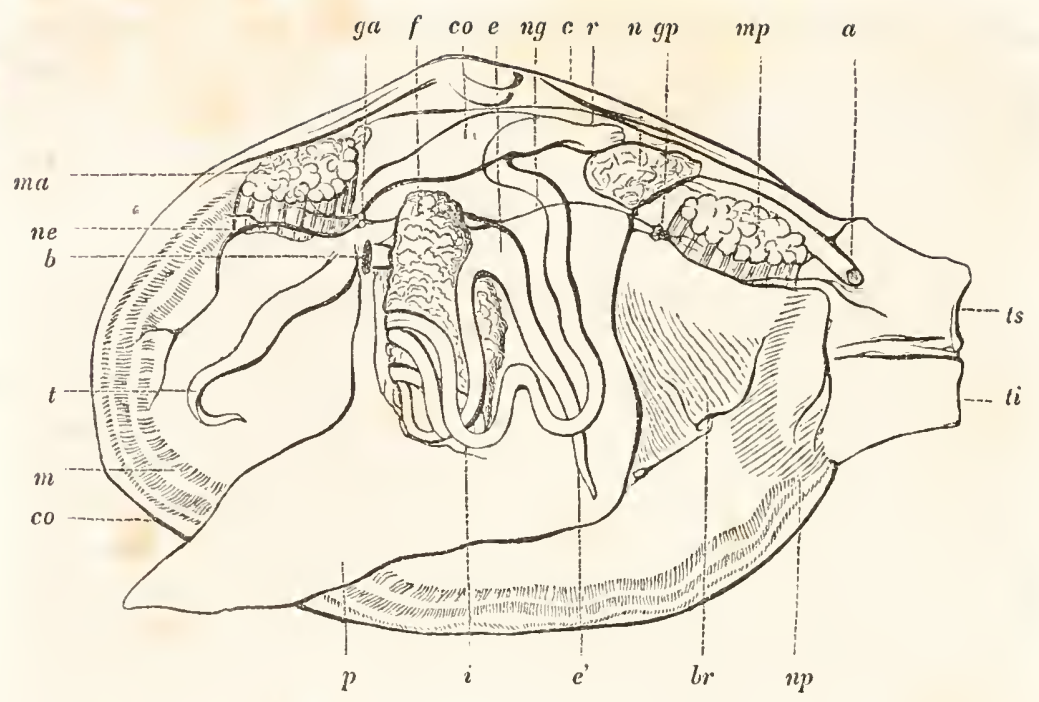

छig. 301. शిnntomie einer Trogmuifiel (Mactra).

Eabale, Mantel uno beibe Riemtenklätter ber linfent Seite finto weggentemnten,

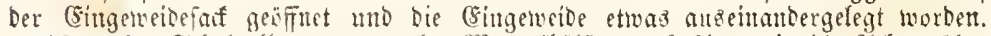
co bie trofte Edyalenflappe; $m$ tedfte stattelfälfte, und hinten in bie sithemishte ti unb in bis Darïberliegento Saterröre ts ïbergehent. ma vorderer, mp finterer

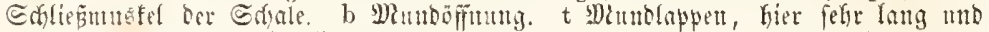

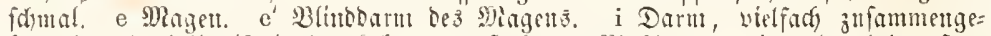

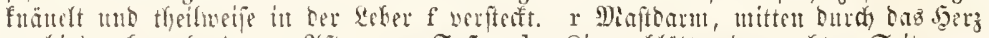

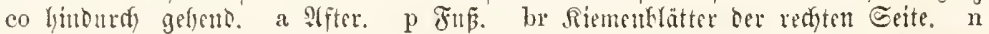

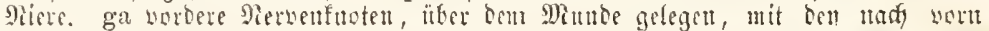

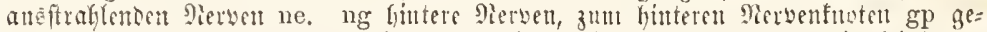
Gono. np Siewen, bie von biejen angegenen und fid befonters an bie Eiphonen vertfieilent.

blätter uad) unten bitt frei, wäbreno fie an bem Sdyloprande ber Sd)ale und an bem Sate, twerdyer bie Cingeweibe tumbüllt, ange=

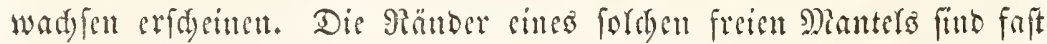

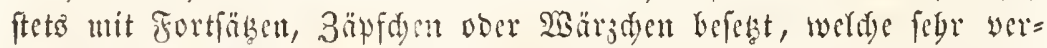

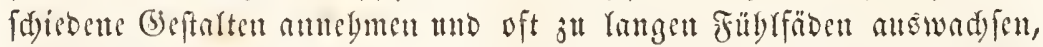
Dis in mebrfadjen Reiben ten Manterfan befeiden. Ju Der Regel

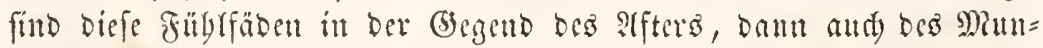

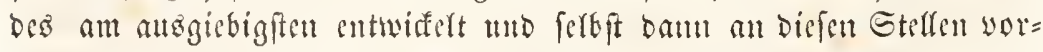
Ganben, wenn fonft Der freie Manterfaum glatt iff. 2(m 2rfter nament=

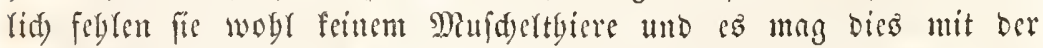

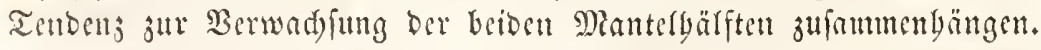
Bei viełen Mufdertbieren nämlid vereinigen fid bie beioen Mantel= yärfen mit ibren untern freien Ränoern anf cine grëpere ober geringere 


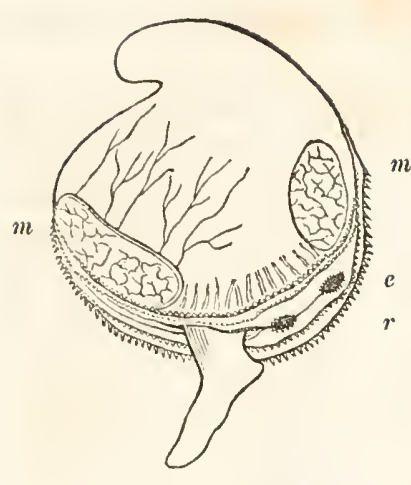

$p$

Fig. 302.

Das รhier cinter (Sictmubred (Chama)

ans rer Eshale gettommen ttmo you Dent faif ring tel eingefüllt. p Der Fuß, mether ats ben ibm entipredoendon @dslibe herworgeftredt ift. $x$ bie stryement=

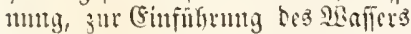
feptimmt, e Die $\mathcal{A}$ (1)

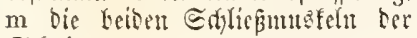
corale. (öder, weld) bie Thiere fid mad)en, in Berbältnif. Die Taftwär =

Stredfe und es breiben bann $114 \mathrm{r}$ einige

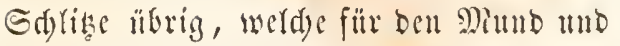
ben 3utritt beg ben \#ttgemorganen be=

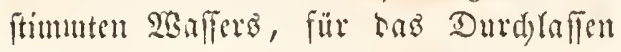
Des Bewegungagrganes oder Jubes unb für ben sfter beftimmt fint. Bei Denje= nigen Diufdeln, weldye fid in Gd)lamm, Sand ober Steme cinbohren, idsliebt fid Der Diantel nod) mebr, fo tafis ex wölig

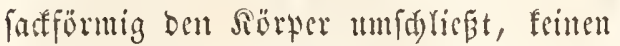
yorberen Mundedis bat, fondern nur nad) binten in jwei, mely ober minder lange Röbren (Siphones) fid anşziebt, won welden bie eime, bie sthemröbre, bas für Die Siemen beftimmte 2 saffer unb Dant aud) Die Rabrungşftoffe einjiebt, die an= bere, bie afferrögre, biefes ख̂anfer mit bem llnuatbe wieber austreten läst. Beibe Röbren fint zuweiłen in sine cinzige Dopperröbre mit einander verwad) fen und ifre Ränge ftelyt mit Der Ränge Der Bobr= den und Fübler fteben in forden gällen bei mebr ober minoer ge= fd) loffenem Mantel nur an ben Rändern ber Sdlige ober an ber Miünong Der Röfren.

Dic Struftur bes Mantels felbeft ift nid)t yolfommen erötert. Die Sauptmaffe Der bünten, an ben freien Ränbern verbiften Man= terblätter beftegt auz mannigfad) gefreuzten Segnen mb Miusteffajern, bie von vielen (befäfen nto Retwen burdjogen werben. Anf finer inneren Flädye ift ber Dantel son fteto flimmernben SBimpern befert, bie firt) überbaupt anf faft affen Dberfäd)en, inmeren wie äuperen ber Munfertbieve vorfinden und für bas Ptgmen mo Ernägren ber= felben you ber gröften Bebentung fint. Su bem Mantelrande finben fid) Drüfige Bitoungen, welde jut stbjonberung ber Stoffe bienen, ans benen bie Gdyale jufammengeiegt ift. Man findet befigalb ju ben 3eiten, wo bie Sdyalenbilonng befonbers reblaft ift, eine mildige Flïfïgfeit in bem Mantelranbe, bie mit Sämen aufbrauft mo vielen Rieberid)lag won fobremfarem Rarfe entbält. Die Hmriffe bes Man= terz zeigen fid) bei ben meiften Miufdeln fegr bentlid) auf ter innern 


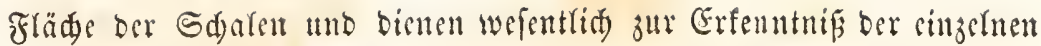
Arten uno Familien.

Die $\mathfrak{B}$ ewegungsorgane ber Blattficmer find ziveierlei Atrt.

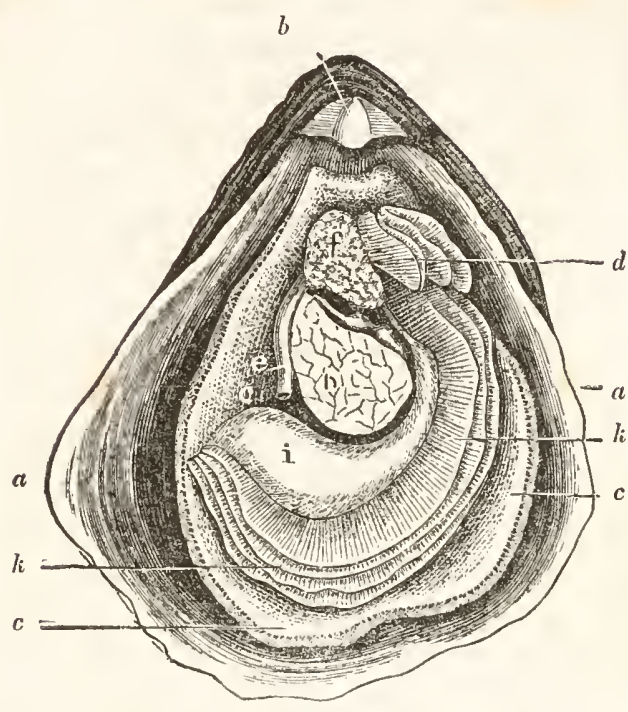

[ii]. 302.

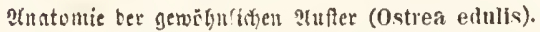

Die rectote Edrale, weldie bei ber SIufer ben Dedfel fritbet nub kei weitem fleiner ift als bie linfe, ift mit bem redaten Mantelblatte meggenummen, ber Singemeide= fact afer unereffitet gelafifen worbon. a imere Flädse bet grefen Edyale, in melder tas Thier trie in cinter

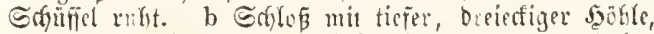

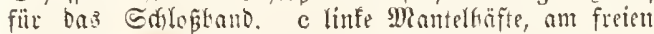

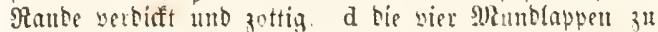

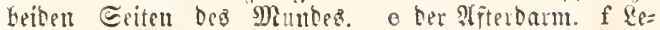
ber. $g$ Bas 5erz. h Der cinzige Edyliepmuefel. i Der (Singemeibefact. k bie 4 Siementhäter. Sin Fitz feflt gänzlid
Man findet bei ibnen befondere Miafelbündel jum Sdlié̈en ber Sdy $=$ Yen und ein au ber Baudj rite gelegenes $\mathfrak{B}_{e}=$ เพeguแgรี้อ Die S d) lie grben quer ourd) ben Fingeweibefact wou ciner STappe ber Edyale zut antern, und ibre 2ubef= tungeftelle läpt fich febt leidet an ber inneren Mautelfläd)e als cint meyr ober minber tiefer Cinbrut mabruchmen. Bei mebreren Fumilien, wie bei ben Pafterm แnb Sammmu|d)efn finbet fid) nut ein einziger Sdylief = musfer, Der mebr in bie Mitte ber Sdale ge= rüft ift; bei ton meiften, wis namentl:dy bei uns feren gewöbuliden $\mathfrak{D a}=$ lermuldeln, gibt Dagegen ziwei foldyer

Musfelu, yon welden der sine megr yorn über bem Miunde, Der

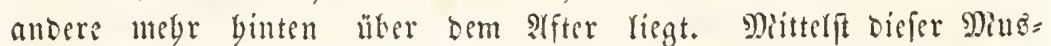

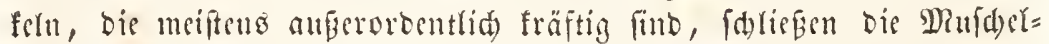
tbiere ibre Edalen mit grober firaft jufammen, fotalo fie ingent wie beunrubigt werben. Dis (jegenwirfung biefer Rusfeln ober bie Deff= nung ber Gdjalen wirb, wie fdon bemerft, won einem ftarfen Geb=

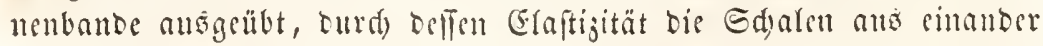
gefpert weroen. Dis 2Birfung biefes Bantes ift gänjlid) von bem 2sillen bes Thieres und felbit von feinem Seben unabbängig, unb fobalo bie Sdylesmusteln nidyt mebr wirten, fo tritt biefes elaptifide 


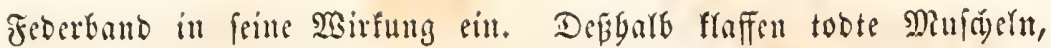
wäbrenb rebende igre Gdalen bartnätig gefdloffen balten. Man Gat frillyer oen llmptand, bafis sin ober jwei Sdyefimusefn vorbanden waren, zur Cintbeilung ber Mnddeltyiere bentht, inbem man fie it

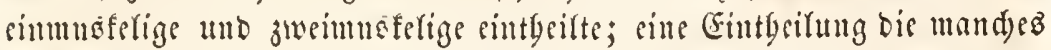
Gdywanfende bat, ba es eimige Familien giebt, bsi welden man bariber im 3weifel feint fönnte, ob zwei Särften cines Mušlels ober zwei cinander genäberte Mustern vorbanden find.

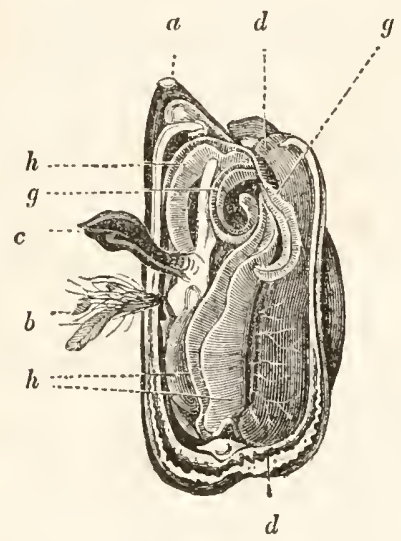

gig. 305.

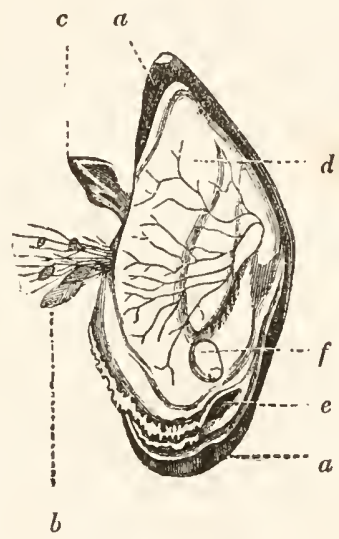

Fig. 304.

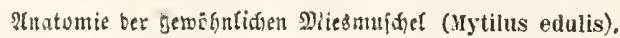

In Fig. 304. ift mur bie linfe Sdyale afgenommen, fonft abe: bas Thier in feiner natürlidgen Eage gelafen worben, in Fig 305. bagegen gat man bie

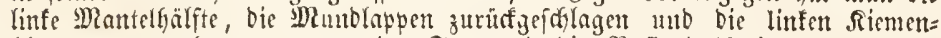

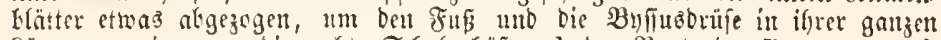
Ränge jul zeigent. a bie redfte હdjalenfäfte. b ber $23 a r t$ ober Byssus, womit

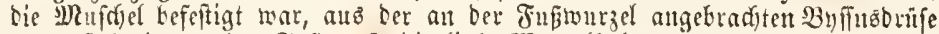

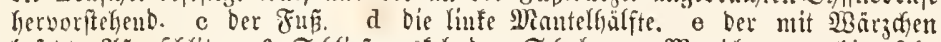

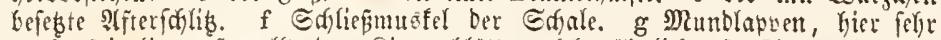

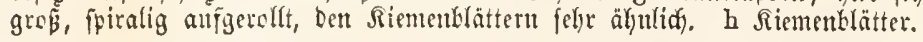

Das Drgan ber Drtstemegung, ber Fuf, ift fets auf ber Baudfeite ber Mufdel und meiftens in folder (5) röße ausgebiloet, bá er zwifden ben Sdjalen bervorgeftredt werben fann. Bei benjenigent Muideln, welde fid anbeften, ift biefe frei beweglide Musfelmaffe nur febr rubimentär ober feglt aud gänzlid, wäbrend fie bei anbern, bie im Sande frieden, oft eine bebeutende (3röpe erreidt. Meifiens ift ber Fub beilförmig uttb bilbet bie vorbere Sdneibe bes Einge= weibefactes, an beffen Seiten feine Sebnenfäben binauffeigen, um fid

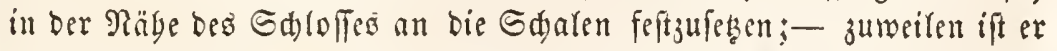
bünn, lang, zungenförmig obet bafig gefrümmt, in andern jällen 


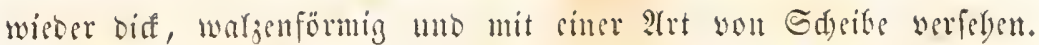
Es bängt Dief: Form Des Fufres wefentlid) mit feiner uäberen Beftim= mung für sas Thier jufammen. Die bcifförmige oder jungenförmige (5)eftalt findet fid bei fordacn Bratticmern, die, wic unfere fingmu= fdrt, im Sande friedyen; die 9 ?ufdern mit fnieförmig singebogenem

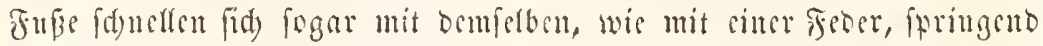

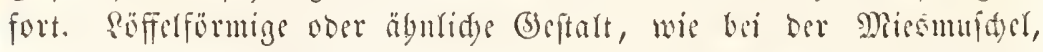
Dient weientlid zum Spinnen Des Barteş, womit fid bie Miufderu anbeften. Baci folden Thieren finbet fid) am (brumbe bes jungen=

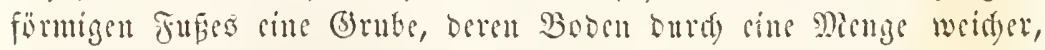
aufred)tfebenoer Rameften quer gefurdyt erfdesint und fo sine Menge

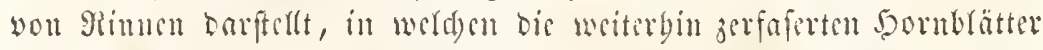

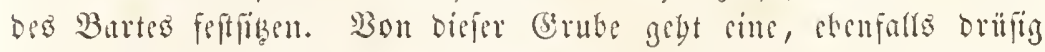

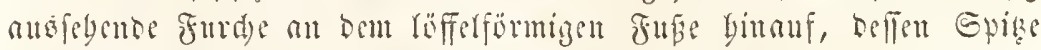
befombers als Iaftorizan bient. Der Stoff ber Byllugfäben ift anfangs flebrig, erbärtet aber bant ju sintem bowartigen Giswebe, bas

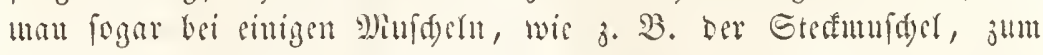
Spimen eines fribunatigen Stoffes bemmt.

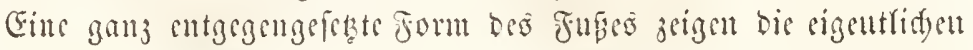
Bobrmuidelu (Plolas, Saxicava, Teredo, Gastrochaena 2e.). Bicle biefer Tyire fobren in 5olj, ferbit in Gidenbolj und Nabagoni, anbere in Gtein mo jwar meiftens Barfitein ober Sdjefer, tiefe rögrenartige bänge, in benen fie Zcitlebeng fteften treiben. Sic baben

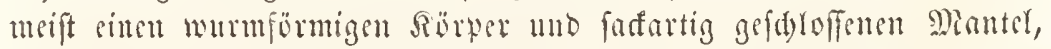

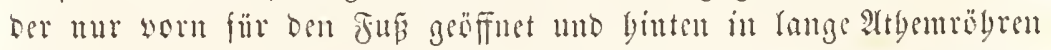

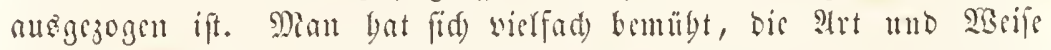
Diefes Bobrens ju ergrünocu, und yat bald bebauptet, oaß die Thicre mit igren oft feinen ober geripten Ed)aten ris Rüber glcidfam ans= feitten, balo daß fie sine Säme abjonberten, welde befonders bis

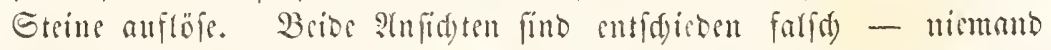

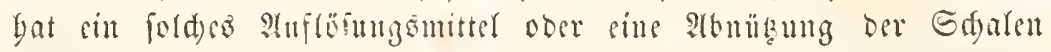
Durd) oas Feilen gefeben. Da bie Dherfläd)e ocs ganjen Thieres

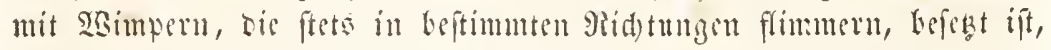

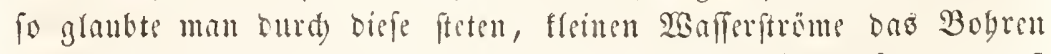

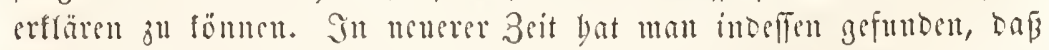

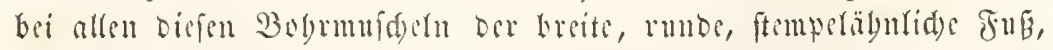
Der vorn jwifden ben flaffenden Sdalen vorgeftedt wiro unb meift genan in bas vorbere Enhe Des Bobrtodes thaft, fowie bie verbiaften

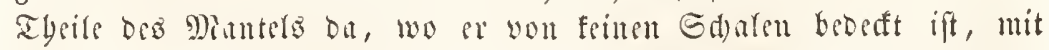

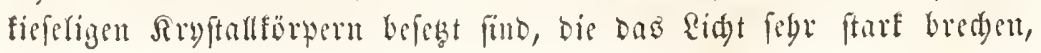


burd) Drud in fdarfertige Stüfe jerfyringen nub ebeuro fdarfe rainfer jeigen. Dffenbar tienten biefe unjäbrigen, fdjarfen Sirfeffryftalle in Den febr mustulöen Theifen mie ebenfoviel Griffel, und ber gange

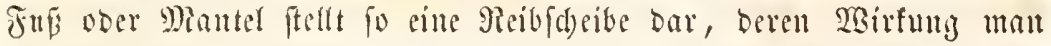
mit berjeniget bes Edadjelyatmes ober eitter Sdymirgerfdeibe ver= greiden fant. Geringe, wurmförmige Bemegungen Diefer Tbeile rei=

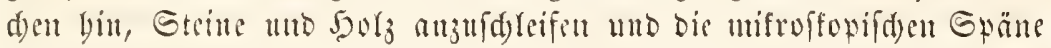
Dicfer Bsbratbeit werben you ben Flimmerftrömen oer Dberfläd)e ftetö fortgefdafft, fo bafi felbit eime fduefle SBirfung möglid) ift.

Sein Mind elthier befint einen eigentlichen Sopf; bie Mimblpalte befimbet fït) an bem worberen Ënde des Rörpers und nirgends fiebt

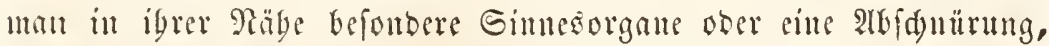
welde einelt Ropf berfelfte. Das Rervenfypem beftebt ans ein= jefusu (banglien, bie burd) Etränge mit einanber verturben fint und

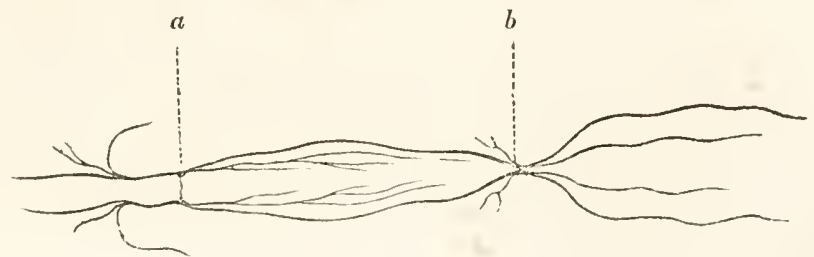

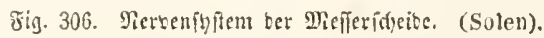

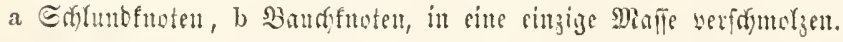

son benen unat it Ser Regel brei PJar unterfdeibent faum. Fin Jaar folder Sinoten liegt munttelbar ueben bent Munbe anf ber oberen

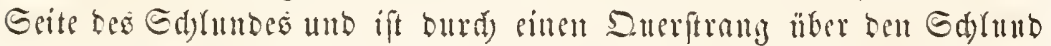
limiler trïfenartiy mit einander serbunden. Bon biefen Gdylmbfno= tentaare geben jwei Sanpterbinbungêftränge ab, Die cinen nad) unten,

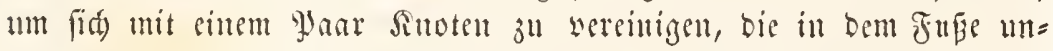
mittelbar unter ben Cingeweiben liegen, bie anbern uad) biuten, wo

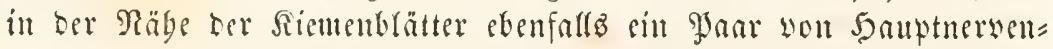
fuoten riegt. 3nweilen werfdueljen bie Baud)= ober FuEnervenfuoten, juweifen and) bie Sirmenfuoten in eine einjige Maffe, fo ong bier= burd), Cowie burd) bie wed)felnbe sage ber Sinoten sille giemlide Mannigfaltigfeit in bie ?(norbnung bes Rervenfyfentes gebrad)t wirb.

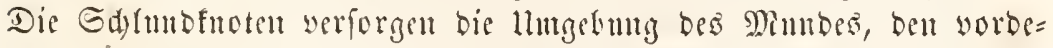

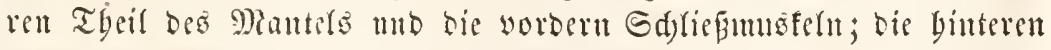
Rnoten bie Riemen, bie biutere Mantelbälfte und beren Röbren; bas Juß̧aar ben Juß mit Rervenfäben. 
Sinnesorgane finben fid bet vielen Blattfiemern und zwar fowobl (bigürorgane als sugen. Die (5) börorgane befteben anz runben Durdfidtigen, aber ziemlid) feften $\mathfrak{S} a$ flelu, bie sine Flitfifigfeit einfdyliegen, in weld)er eill burd)fidstiger, fryftallinifder Sern von

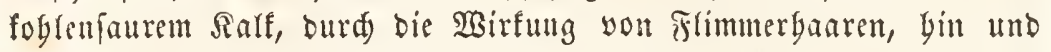
ber getrieben wird. Es liegen biefe beide Gebỏrfapieln unmittelbar yor Den Rervenfnoten Des Fufes, mit benen fie meift nur burd einen fegr furzen sebörnerven verbutben fint, wno fie fommen wobl allen

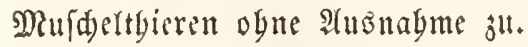

Weniger verbreitet find bie $\mathfrak{A} u g e n$, welde man befonders bei ben Rammumidgeln als runbe, wie Ebeliteine glänzeltbe Junfte an Den Manterränoen erfannte. Bei genauterer llnterfudung erfbeinen Dieje braun, grün ober rotg gefärbten fugelförmigen :Hgen, welde meiftens auf furjen Stielen fteben, beutlid aus ciner burdfildtigen 5ornbaut, einer Pigmentbaut, bie zuweilen ferbft eine Gris bilbet, aus einem lidetbred)enden Rörper zufammengeferst. Biele Bebcutung für bas Thiar mögen biefe Plugen wobl nidt baben, ba fie bent meiften übrigen $B$ lattfemern abgeben, wenigitens fonten bie slugen, welche

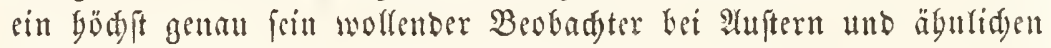
Mufdeln beobadtet Gaben wolfte, yon fpäteren Foridern burd)aus nid)t gefunden werben.

Die Berbauนnģorgane Der Blattfemer find äuperft cin= fad. 3 u beiben Seiten bes Mundes befinden fid) faft immer zwei, nur felten ein Jaar, meift breictiger Räpd den, bie fogenannten 193 u $D=$ lappen, welde in igrer Structur ben Riemen gleid)en, unb mit einem äuEerit Yebbaften Simperüberzuge verfegen futd. Diefe Dundlappen, welde nur bẹi febr wenigen (5)attungen verfïmmert erfideinen, oft aber fegr lang, riemenförmig ober fpiralig gewutben fint, wereinigen fid zu einer Ninne, bie zu bem Munbe binfübrt unb in welde burd bie Simperbewegung bie fein zertbeilten Futterftoffe zufammen getricben werben. Angerbem bienen bieje sappen wobl nod obne 3weifel als Iajtorgane in äbulider $\mathfrak{B e i}$ e wie bie Mantelränter.

Die Mundöffnung ber Blattiemer ift ftets unbewaffuet und zeigt namentria) nie eine Spur von Sirferm, 3ähnen oder einer 3unge; fie fïbrt entweder unmittelbar ober mittelit ciner furzen Speifröbre in eimen gerümnigen Magen, ber ebenfo wie bor fd)laud)förmige, balo megr balo minber gewundene Darmfanal in ber Mnlfe ber Reber, theifweife ferbft Des CFierftofes, vergraben liegt. Der Maftbarm wen= Det fid) bei allen Muidjeftyieren mebr uad) oben gegen bas Sdló ber Swale bin, burdbogrt meiftens bas Saers und effuet fid in bem bin= 


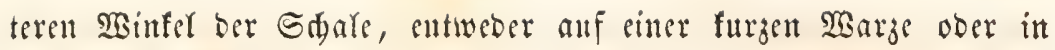

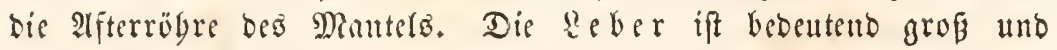

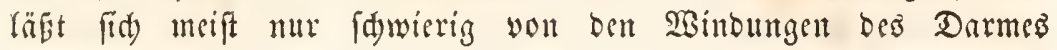
tremten.

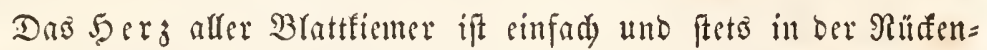

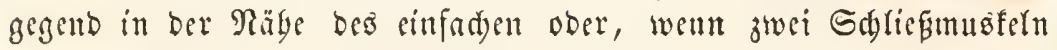
vorbanden, in ber Räbe bes binteren Saliésmustets gelegen; es ift

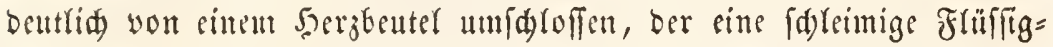

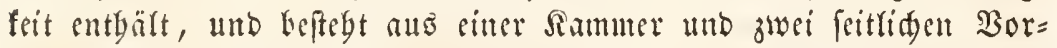
Güfen, bie weit bünnere $\mathfrak{B a ̈ n}$ be Gaben. Die Serjfammer wirb faft bei affen Muffesttgieren igrer ganzent Ränge nad) yon bem Maft=

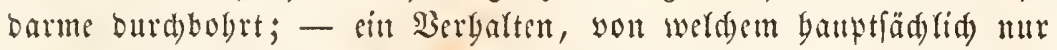

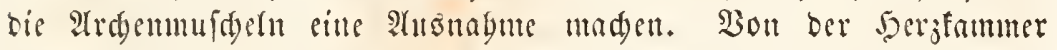

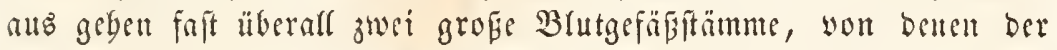
eitte uad) binten, ber anbere nad) vorn fid eriftredt unb gauptfäd fid in ben Mrantel mo bie Cingeweibe fith vertheitt. Pon bier aus felgrt

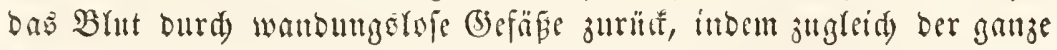

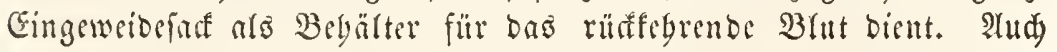

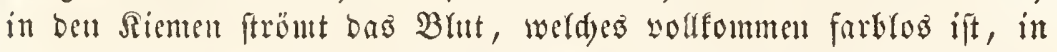

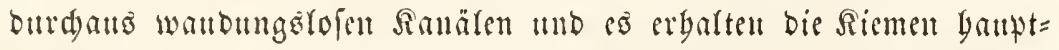

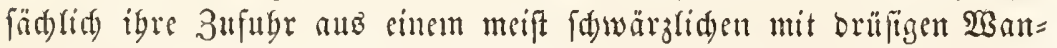

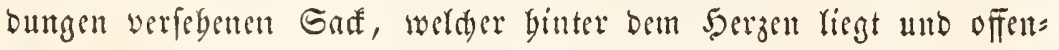
bar bas erifte Plubiment cinter $\Re$ ier e barfélt.

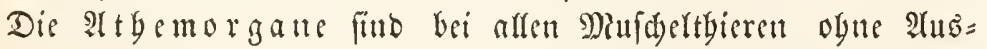
nabme aus blättrigen ßienen gebildet, weld)e unmittelbar unter ben Miantel, zu beiben Geiten bes Eingeweibefarfes fidd befinden. Faft niberall fittben fid) auf jeoer Seite zwei Riemenblätter, won benem bas

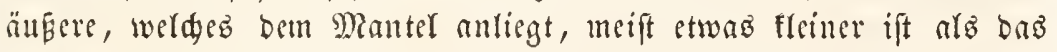

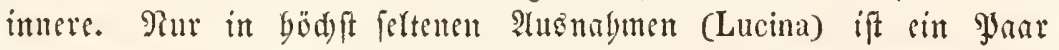
biefer Siemenbrätter vertümmert und auf jeber Seite mur sin Blatt vorbanden. Rad) unten bin finto bie Riemenblätter liberall frei, yer= wadjen aber zuweilen an igrem bintern (sube; - nad) oben find fie an ben Eingeweideface befeftigt. Die Structur biefer Siemenblätter ift

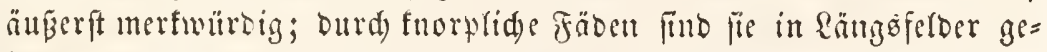
idfieben, bie wieber burd Duerbaften in einzelne fdgmate fä̈der ges theilt finto. Da ntm jebes Siemenblatt aus siner bopperten Ramelle beftegt, fo entfeben eben fo wiele Tafden mit Duerfalten, welde alle in bie Mantelbüble ausumünden. Die Ränber ber Fulten mo Tafden

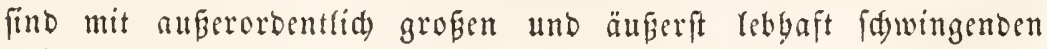

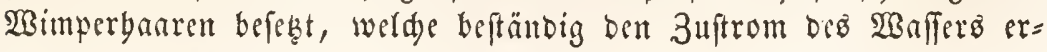


neuern. Fine S(bweid)ung yon biefen Typus findet fid) bejonders bei

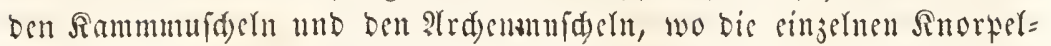
fäben ifolitt find und fo das Riemenblatt ats eimer Neige eingeluer, oft bafenfürmig gefrummter, parfifabenartig nebencinander fitebentor Bläăden gebildet witr.

Die meiften Blattfiemer find getrenten (5) fd led tes und

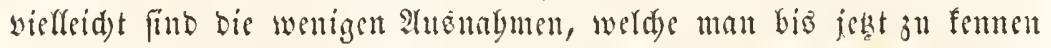
geglaubt bat, auf irriger अaldauung begrünbet. Die Ceierfiöre soer 5oben find übrigens im Ienfiren ganj gleid gebildet, แnd nur burd mifroffopifde llnterfurdug fann man ibren Snbalt genauer unters fdeiben. Sie bilden eine bebentende Maffe unter uno binter ber ses ber, bie theifweife bie winoungen bes Dammanales umbültt unb bei einigen fogar in bie Mantelblätter vorbringt. Die Eier baben meift

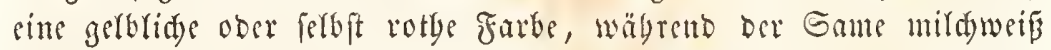

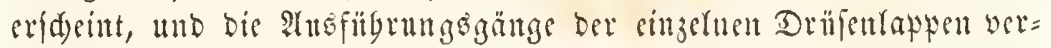
einigen fid zulebst in einem Sdylize, Der entweber neben Dem Sd) litze Der Riere fid befindet ober ferbit mit biejem gemeinfdaftlids mündet.

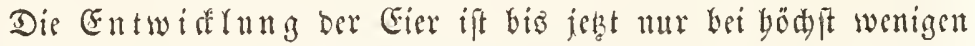
Arten und aud bier nur unvolfftänig beobadtet. Die Eier, in wet= d)en man anfangs sime eiwcípartige Dotterbülle, sinen förnigen Dot=

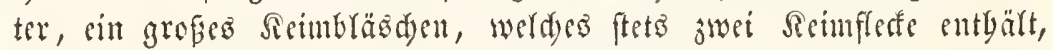

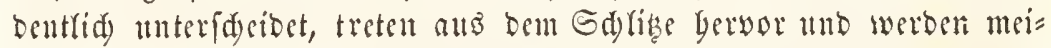

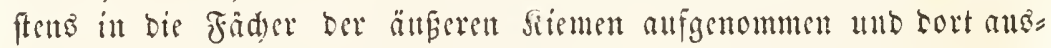

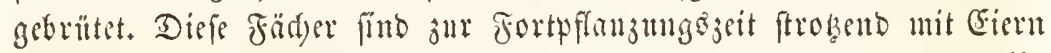
exfürtt unb bei manden (battungen eridgeinen die Sdyalen ber weib=

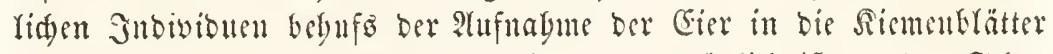

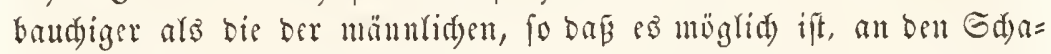

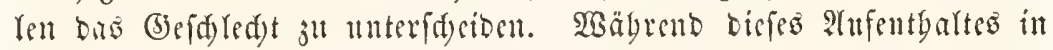
Den Riemenblättern gegt bie ganje llmbilomg Des Gies ju einer völ= rigen Rarve wor fids, weldye in vieler Bejtelung won bem erwadjenen Tlere feldr verfdicoen ift.

Die 3ertlïfung bes Dotters bis zux worftänoigen Bilbung ter Zeflen, weldye ben Sï̈per bes Eutbryos jufammenfezen, gebt ganj

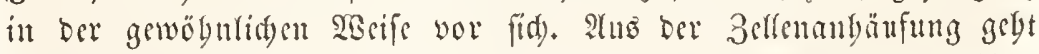
ein fugelförmiger Embryo berwor, ber auf feiner ganzen Docrfläde

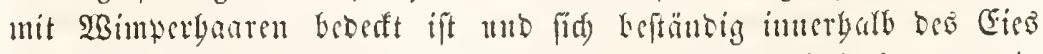

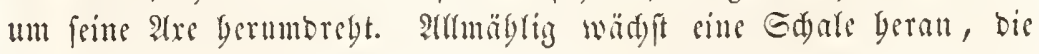




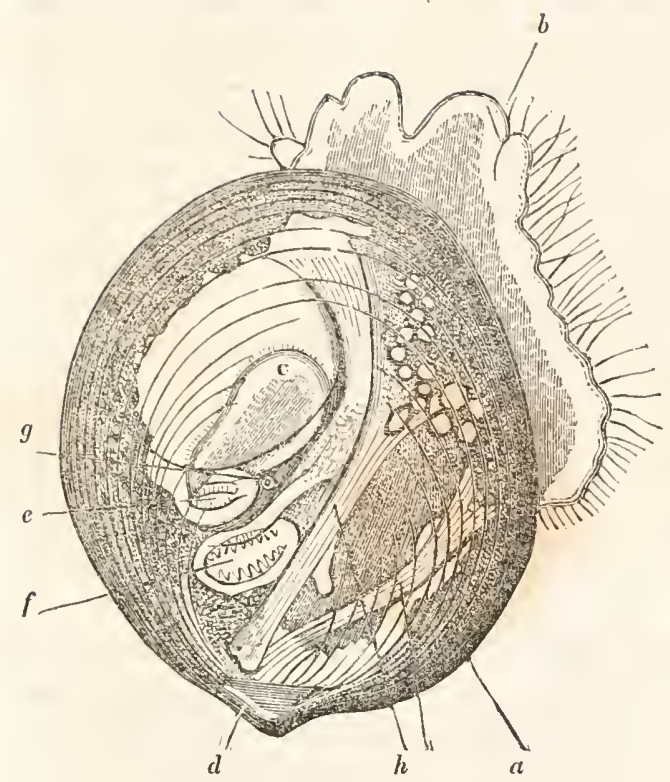

ซึig. 303.
Eig. 307.
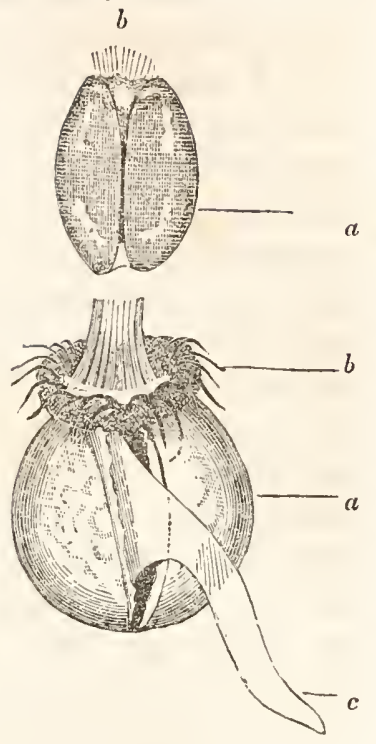

Fig. 309.

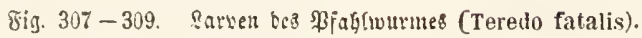

Fig. 307. Cinte ned junge, in Rimenklatte geborgene Rarwe, bei weldyer

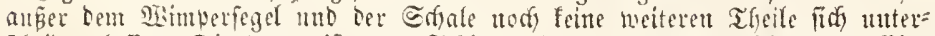

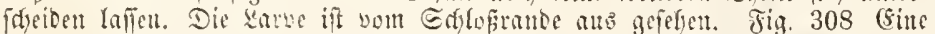

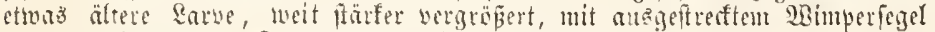

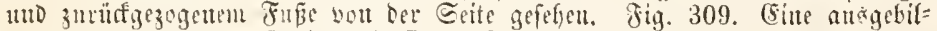
Dete encue in Dem 3ufrude, wie fie bie Brutitatte in Den Riemen bes smutter:

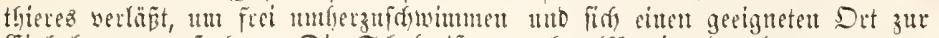

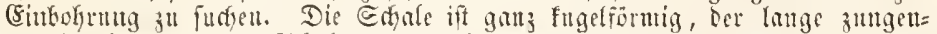

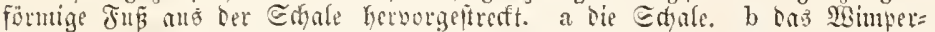

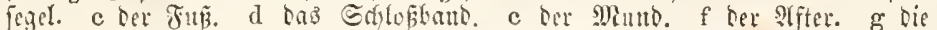

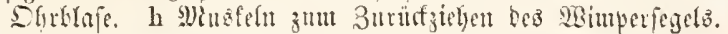

ziemlid allgemein ans swei bieglamen, breiestigen bärften beftebt, welde mit sinem graben Gdylofrande an einanber ftopen und :th= fango wie sin Gattel anf Der Embryonalmaffe anfliegen. Die Sda ren wadjen mebr mo mebr und die flimmerbewegung, welde anfangz auf ber gaujen Dberfläd)e beftand, concentrirt fid urd) und uad) auf einen wulffïrmigen Theil, ber bem Sd)loprande gegenẗber berworgeftedt und jurüfgejogen werden fann. Diefes Ssimperfegel ift mit langen

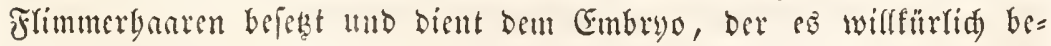
wegen fann, zum Gdwimmen. Barb unterfdyetbet man aud bie bei= Den Sälften Des Mantele und einen anfang einfaden Musfer, Der

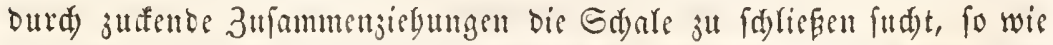
längere jum Zuritájieben bes 2 Bimperfegels beftimute Musfelmaflen. 


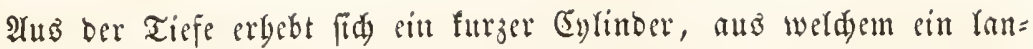
get fpirafförmiger Faden bervorragt. Man bielt bisher biefen Faben für eitt Analogon jenes Drgans, weldes bei vielen Middeln jur Fubeftung bient und Der $B$ art (Byssus) genanut wirb; neuere $\mathfrak{B}$ cob=

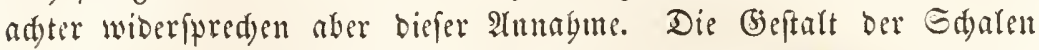
ift zu biefer 3eit fo auferorbentlid) verfdieben von berjenigen Der er= wadjenen Gnbivionen, bafi man bie Jutgen unjerer Silßwaffermuldefn range 3eil für Sdmarobertbiere bielt, welde in ben Siemenfädsern

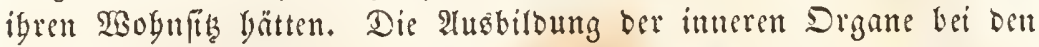

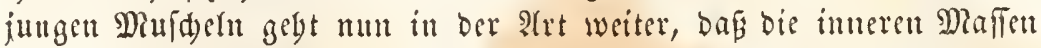
fid trennen und anfangs folibe Bellengaufen birden, welde Der Eeber, Dem Magen unb bem Darme entfpreden. Diefe Maflen göblen fid

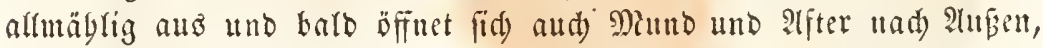

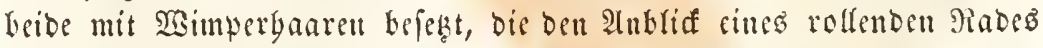
erzengen und febr nabe neben einander gelegen. Später fiebt man

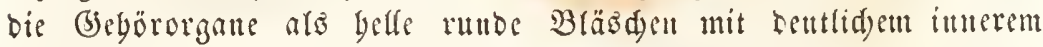
Strinferne, ber fid rotirend bewegt. Dann erfd)eint binter bem $\mathfrak{B}$ int =

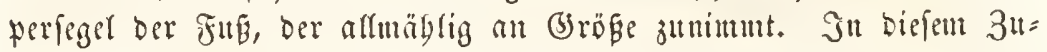
ftande verlaffen die jungen Earven meift die Sicmenböble Der Mutter utlo fegeln it Sdwwärmen auf Dem $\mathfrak{B} a f f e r$ tmber, bis allmäblig bas SBimperfegel zuritigebt, wo fie fid bann zu Boben fenten uno iynen balo mur oer Juß als einjiges Berwegungsorgan bleibt. Jul allge= meinen gleid)en fing bie Rarven ber verfdyiebenen Irten, welde man bis jebt unterfud bat, in Gobem Mage, wenn aud) ourd) (pätere

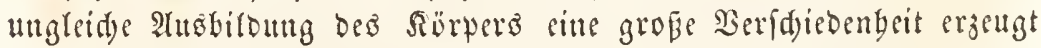
wirb. So find bie Rarven unferer gewöbnliden Teidumfder in ber erften yeriobe faum zut unterideriben won ben oben abgebiloeten bes IJ faglwurmes, wälrent bie erwad) fenen Thiere einander fo wenig gleiden, baf fritbere Naturforfder Den SPablwurm fogar feiner lang= geftrefften (5eftalt wegen für einen Wurm bielten.

SBir tyeifen bie STafle ber Blattiemer, befonoers in Bertiffif = tigut!g ber Regelmäbigfeit ibrer Sdyalen und ber Daraus bervol= gebenden Ragerung, fowie Der Anordunng ibres Mantels, in oret Dromungen, Deten (brenjen freilid) nidyt volfommen idarf yerjuftelfen fins. Dic Eciteunuidbeln (Plennoconcha) baben cine meift

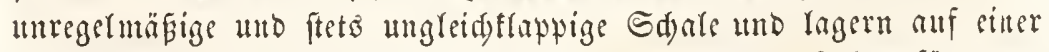
ibrer Geiten, welde meiftens untuittelbar ober Durd) Gibnenfäben an ben $\mathfrak{B} o$ ben befeftigt ift; igr Mautel ift ftetso offen uno bei ben meiften

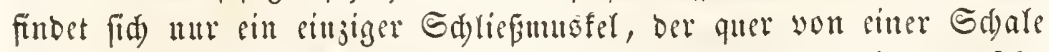
zur andern geyt. Der Jup ift in Jolge Det Anbeftung meift ur fegr 
rubimentät ober feblt aud gan. Wit Thonabme einer einzigen Fas milie, bie nur wenig verbreitet ift, fommen alle biefe Muidgeln im Meere vor, wo fie oft $3 a ̈ n f e$ bilben, in benen fids eine grofe Anjagl einjerner Gnbivibuen belfelben $\mathfrak{A}$ rt juanmenbäufen.

Die Familie ber $\mathfrak{A}$ ufern (Ostreida) wirb won meift faweren,

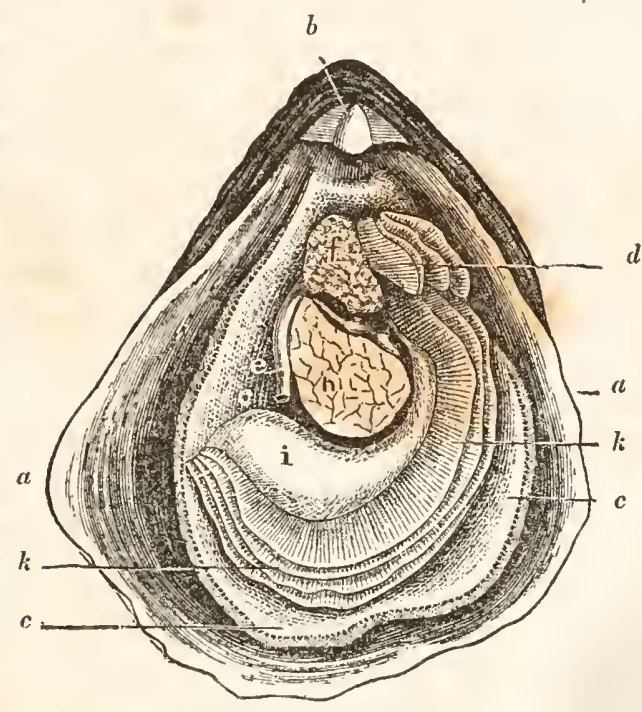

8ig. 310 .

Das Thier ber 2 thter (Ostrea edulis) in feiner Sdyate.

bifen Shalen gebildet, bie gewöbulid) febr un= regelmägig แกD ungleid)= fdalig fint. Die $\mathfrak{M n t}$ (d)efu baben eine meift wlatte Riulengeftalt uno Dif meiften (S)attungen find mit ber Yinfen tie= feren Sduale angebeftet, wäbrent bie redte flade Sdjale als Dedtel bient. Das Thier ift in $\mathfrak{B e r}=$ bälntíg a den Ed)alen meift nur flein mob bat entweber wie bai ben eigentriben 2uptern gar feimen Fuß oder nur cinten böd) fit rubimentä= ren. Die Mantefränoer fint in ibrem ganjen llmfange frei; bie Sirmen bagegen an igrem

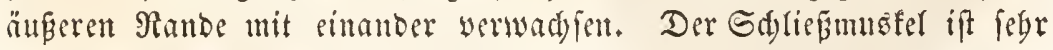
grofi, in Der Ditte Des Thieres gelegen und Deutlich aus megreren

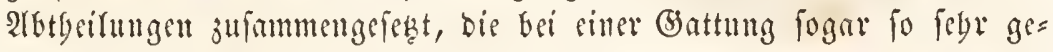
tremut find, bas fie brei bentlide, nebeneinanber liegende Ginbritfe anf Der einen Shale ginterlaften. Das Salogi ift flcin, oreieffig unb zahulos ober göd)fens aus zwei im SBinfel zufammenlaufenben Eeiften

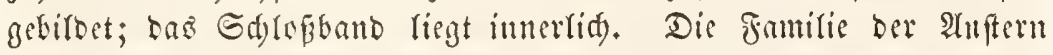

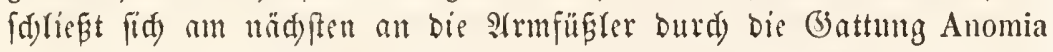
an, bei welder bie untere flade Sdyale von einem fnorpeligen fort=

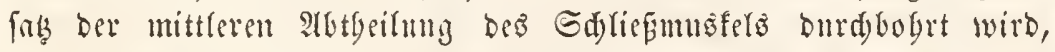
welder Fortiaz jum 2ulyejten an Ferfen bient. Bei ben meiften Gat= tungen biefer Familie find bie Gdalen änferft blättrig, etwa wie bei Der gewöbulidjen aluper. Diefe, weldye faft an allen enropäifden Süften vorfömunt und befanntlid) cime leffere Speife birbet, fiebelt fid) auf beut $\mathfrak{B}$ oben bes Meres oft auf weite Stredten bin in bebeutenden 


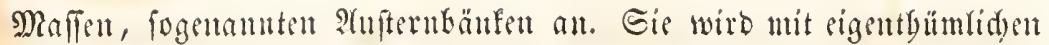

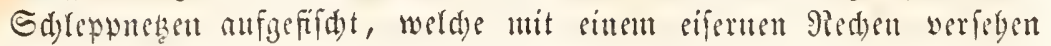
finto, Den man auf bem Meeresgrunde bin und ber fdfeift. Mau

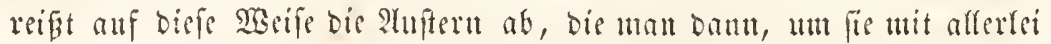

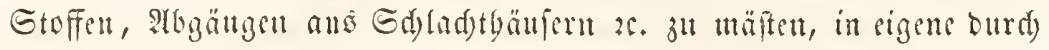
Meerwaffer gefpeifte Bebäter bringt, wefde man Atfermparfs nennt, tmb von wo fie bant wobl verpadt, lebend verfendet werden Durd

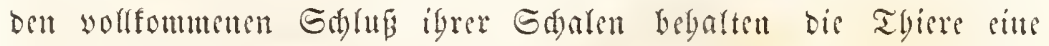
grofie Suantität von Mecrwaffer, Das zur Interbaltung ibrer 2 (t) $=$ mung bient unt laffen fid) auf biefe Saeife lange aut Rebent erbalten. Die fofftlen Atuftern fommen bauptfäblid) bäufig it ben juraffichen

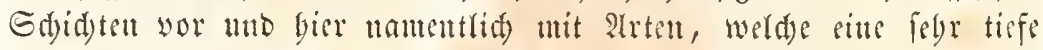
länglid) Sd)ale bejiłzen, beren Wirbel bafenförmig sigebogen ift, wäb) rend bie andere freic Gdare berferförmig mo abgeplattet erfocint. Ostrea; Gryphaea; Placuna; Anomia.

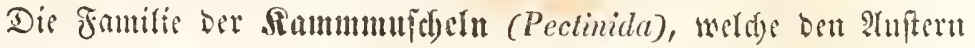

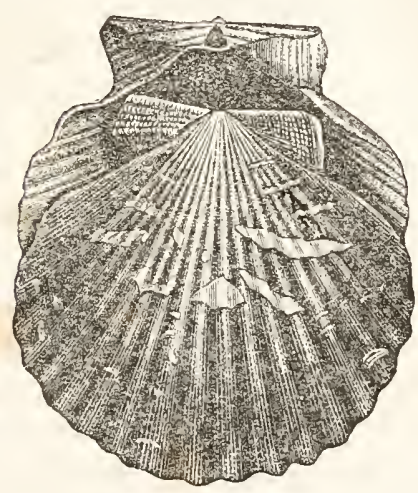

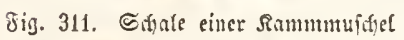
(Pecten opercularis), am tädyften ftebt, tuteridycibet fid wou ifuen auf Den eriften Bliaf Durd) bie fait regelmäbige, beinabe gleid $=$ flappige Sdale, die meijtens aud) fajt gleidfreitig ift tut Durd) bie Feftigfeit Der Etruftur, weldye feitte foldye Blätter jeigt, wie bei bent Muftern, Faft alle Sdyalen biefer Fumilie seigen auf ibrer äuferen

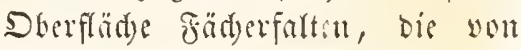
Den SBirbeln uad) beul freien Gdan= remranbe angftrablen. Die Tbiere fitto im Berbältnín zul oer Edare weit gröper als die Alutern, int Ulebrigen aber benferben auBerorbentlid) älulidy. Der Manterand ift volffommen frei, meiftens aber mit feldr langen und Difen föbl=

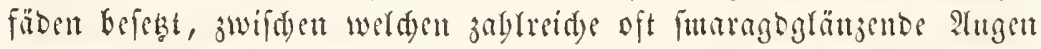

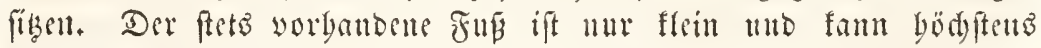

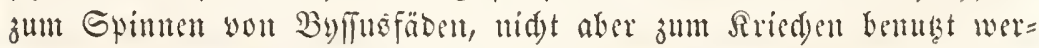
Den. Die uneiften Gattungen biefer Fantilie fitzen auf Der simen Gdare

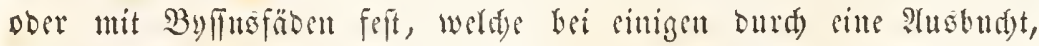

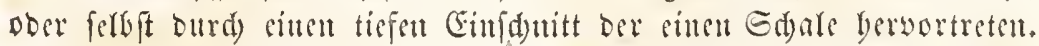

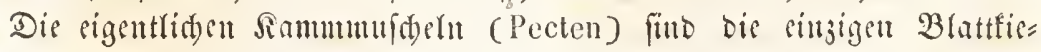

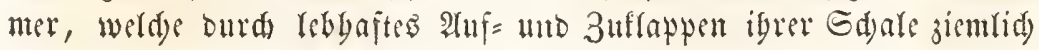




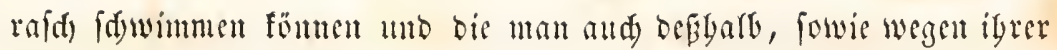
rebbaften bunten Farben, oft bir Edymetteringe bes Meeres genannt bat. Die Sammmuidefn treten fdon in ber früleften geriobe ber

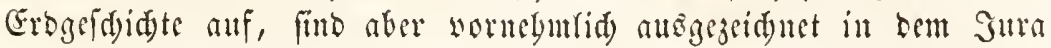
Durd) bänfige unb grofie Prten. Pecten; Lima; Spondylus; Plicatula; Pedum; Hinnites.

Die Famifie ber Flupantern (Etherida) fommt nur in einigen Fritfen ber fübridyen 3one, wie namentlidy in bem Rife wor. Die Sdarlen fint ungleidjdarig, brätterig uno wou febr unbeftimmter

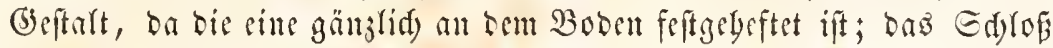
jabulos, wie bei unferen Teidmufdern; bas Thier grofi uno wefent=

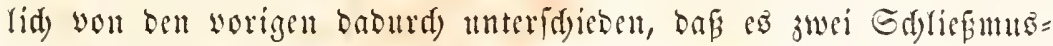
felu, einen vorberen unb einen binteren, utb einen biffen fleifdigen Fub befigt, ber aus oer Gdale berworgeftreft werben fantu. Etheria.

Die Sthmalmuidgeln (Mlalleida) baben meift gleidfdalige aber

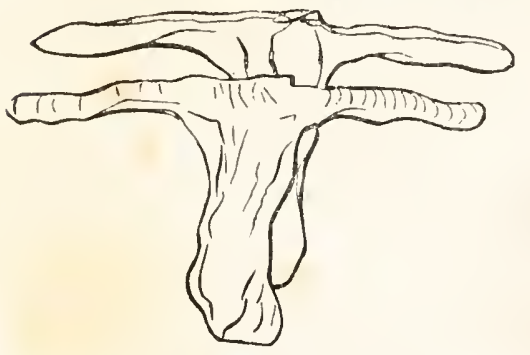

จig. 312. Bemeine 5ammermuifyet. Malleus vulgaris.

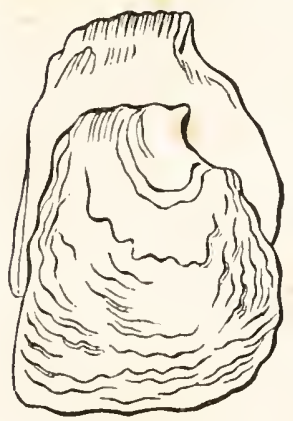

8ig. 313. Perna.

fobr unregetimäßige Mufdjelu, bei welden ber Sobgedurdumeffer won bem Sirber jum Sdjalen= ranbe bebeutend über ben Rängs= burd)mefler überliegt. Das Sdy lo ift meiftensin bie Ränge gejogen, to bap es eitnen ober zwei flit= gelfürmige Fortfätze bilbet; - oft ift ber ganje Edjlofirand mit Serben verfelyen, in weldyen viele fleitte Sdybobanber verborgen fint, bei anbern exiftirt nur eine einjige mittlere oreiestige Sornbe für bas Salobiant. Meift findet fid an ciucr ober an beioen Sdaren vor bem Sdyloffe

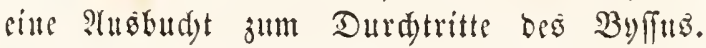
Die Tlyiere fino fdumal, ber Mantel grofi mo uad) vorn unb binten in bie flingeffürmigen $\subseteq$ d)lof $=$

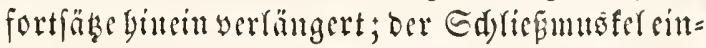
fad); ber Fuf flein, (d)mal mit cinem fabenförmigen Rnbange. Die bijarren Edyalen, welde mant ben fortifiden 5ammer genannt bat, und wo bie beicen frügelfort=

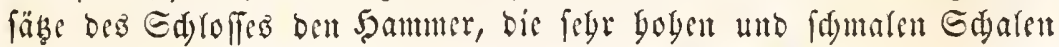


ben Stiel bitben, gebören in biefe Familie. Malleus; Vulsella; Perna; Crenatula; Gervillia.

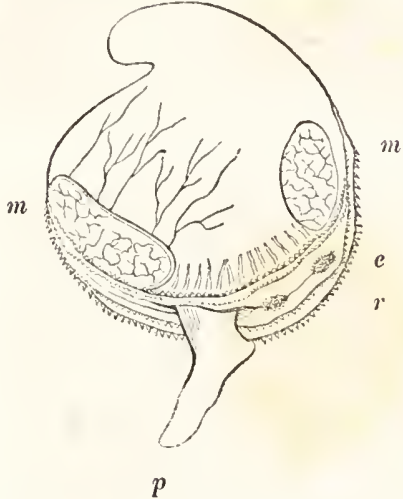

Jig 314. Thier eiter Chama, nus ter Ed)afe genumut.

Dic (Gicmunfurch (Chamida) befte= fteben aus biffidaligen, ungleid) feitigen, blätterigen, meipt ungemein gropien utb fidweren Muldeln, sis gewsintidy ein fegr ftarfes mol feftes, mit fart incin= ander vorfpringenten 3äGnen und Gruben

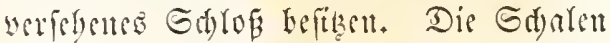
find ungleid)fritig, die șiver treten frarf bervor und find meift bafenförmig mit= getogen, ober ferbit bornförmig gewuil = bell. Sie find entweber mit ber cinent

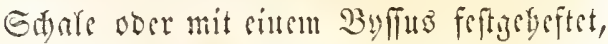
ber bei cinigen (jattungen Duta) sinten 2usfduitt bes boframes berwortritt.

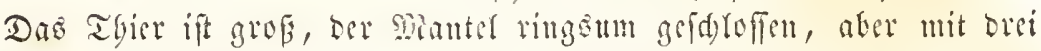
Gd) lisen verfegen, wowon einer fïr ton fremen Jub, sin jweiter für bie Siemen tub ben Miuns, tho sin britter für ben Plfter beftimmt ift.

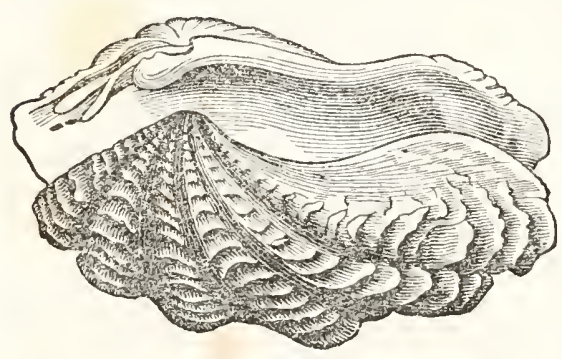

ซig. $3 ! 5$.

Ricienmuitel (Triclarna).

3u disfer familie gebsiten bis

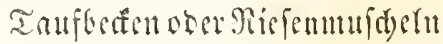
(Tridacna), welde im intifden Seean sorfommen, cine Ränge son mebreren Jusen erreids und bis ơ 500 mit mebr gy futtoen fowet werdost. Dis Gerlente bebaupten, Daj sine forbe Minfuel beim Sdyliegen Der Gidalen ein ?tutertan jer=

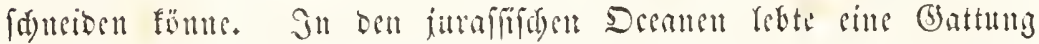
bicfer Jamilie, Die 3weigiture (Diceras), weldys ourd) ibre gornartig

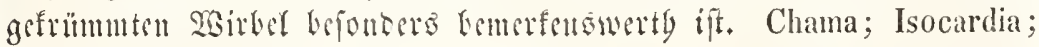
Tridacna; Hippopus.

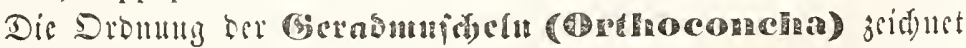

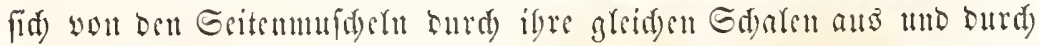

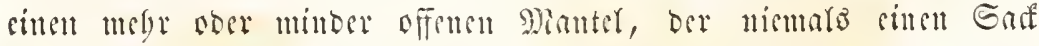

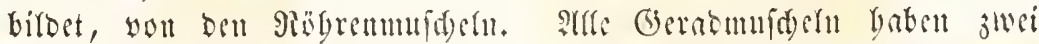

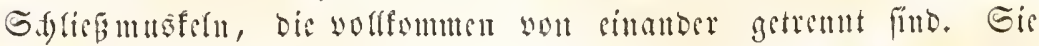

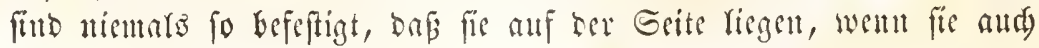


oft citt fratfer Bart an ben Boben feffert. Shre Samilien find weit jablreid)er alé biejenigen ber Geitenmufdeln.

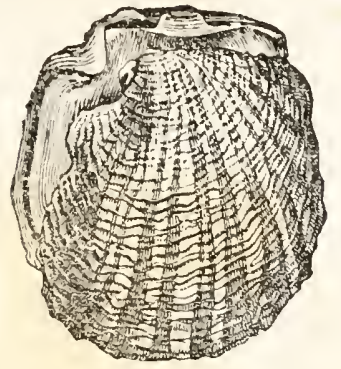

ซig. 316.

Die äd) ßerlenumfit)l (Meleagrina margaritifera).

Die siserlemmindn (Aviculida) zeigen gleidnfdalige, auben blätterige, in= nen febr glatte Gduren, in welden bie

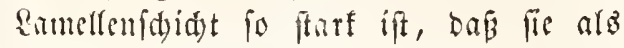
äd) Jerlemmutter verarbeitet werben fann. Dis Mufdech fund gleidyldalig und gleidfertig, bie 2 Birlel nad) worn gencigt, oas Gd)lop geritbe, linienförmig, entweder ganj jabntog ober mur mit einem ferer unbedententen 3orfirunge werjeben. Dro Gdylogband liegt fait anben in rinem Fulje Des Gd)lofrantos, ber un= mittelbar yor ben sisibeln einen SHofdutt für ben Durd)tritt Des Bartes zeigt. Der söper ift meift fegr bünn, flatt unb flein im Berbältnif zul bem grofien Mantel, der an feimem ganjen Piande frei ijt. Der Jun ift flein, runblid) Imb ber bintere Dinsfel fo ïberwie= gent gegen ben vorberen, beffen Cindrute oft gar nidt bemerfbar ift, Daf man mand)e Sattungen für cimmusfelig bieft. Die Mundrapen find grob, liegen aber weit mad) binten in jiemfider Entfermung yon

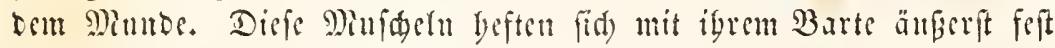

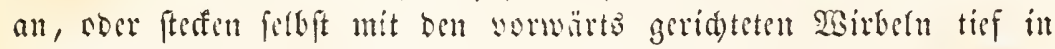
oem Boben, fo baß mur igre flaffenden Gdalemränor bervoridanen. Man zäblt ju biefer Familie die äd)te gerlemmufd)el (Neleagrina),

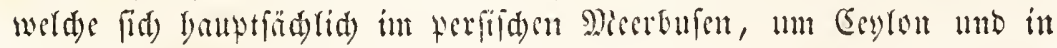
bem fïbliden Theile bes retgen Meeres fintet und beren Fifderei

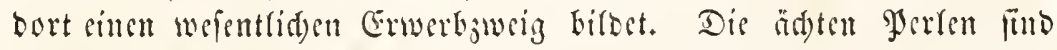
franfgafte Erjengniffe und aus concentrifden Sdidsten derfelben Sub

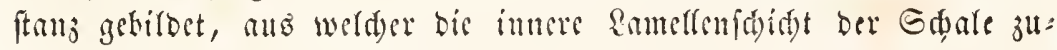

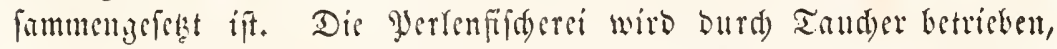
welde mit Gewideten befdwert, mit cinem Gart am bijrtel und cinem Fifen jum stofofen ber Milldefn bewafinet, fid anf den Boben bin= ablaffer und bort bie Minfdeln abftofien. Der grofien 5aififde wegen, welde in biefen fübliden Meeren yorfommen, erfacint bas Tander= gefdät ziemlid) gefölgrfid), aud) ift für jeben Tauder wenigitens cin

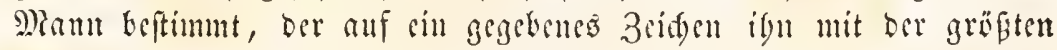
(Sefdwindigfeit in bie Barfe binanfieben mus. (Ein Tander läßt fid) etwa viergig bis fünfgig mal im Tage binab, unb foll an günftigen Drten bio ju megreren Taufent Mrujdeh in biefer 3eit fammefn 
fönnen. Die gefanmelten Mafdelu werben an bie Gonne gelegt, wo fie barb abferben, flaffen und in Fäulnip übergésen. Man fudt unn

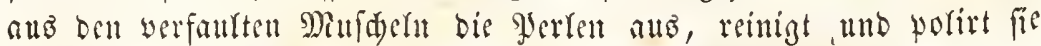
unit jerfofiener Perfenmutterfubftanj mo refert fie bann it ben 5an= Der. Meleagrina; Avicula; Posidonia; Pinna.

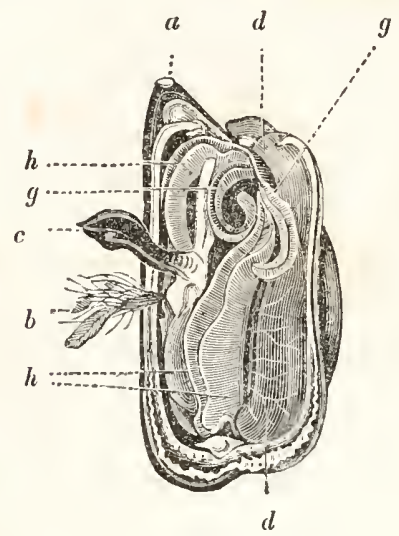

fig. 318.

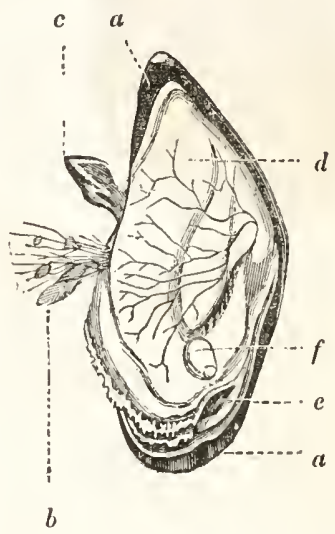

Jig. 317.

8in. 317 แnb 318.

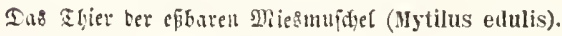

Dis Miesిmutheln (Mytilida) fteben burd) bie Form igrer Sha=

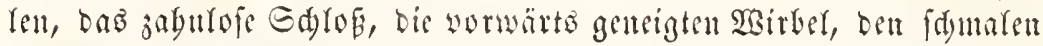

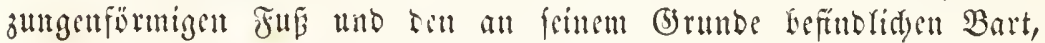

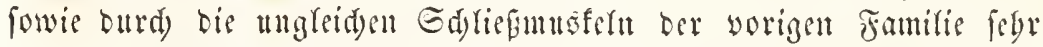
nabe, unterfaciben fid) aber babur(h), baj binten in bem Mantel cine bejondere Deffuntrg für oen Slfter fid) Kefübet, unter weldem eine furje, mit

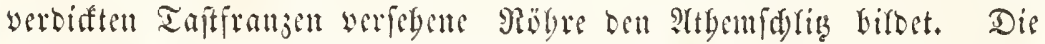

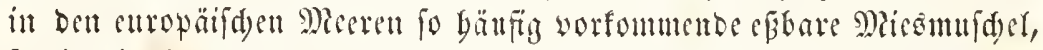
fowie bie Etentoattel, wedde sie Etranbferfen bes Mittelmeeres an= bohrt, gebören zu bicfer Jantilie. Hytilus; Hodiolus; Lithodomus; Dreissena.

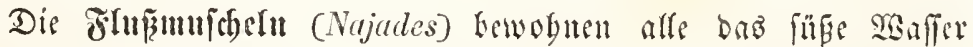
und fut befonbers in ber gemin̈igten 3one Rorbamerifa's in ämperft

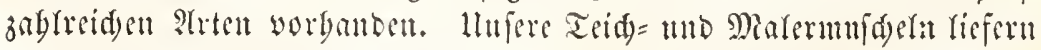

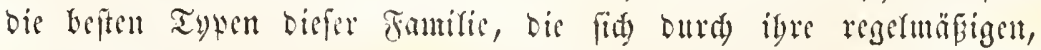

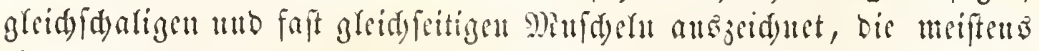

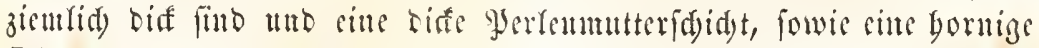

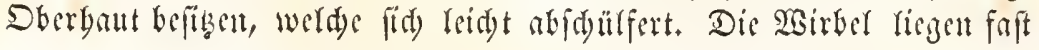


in ber Mitte des Sd)loffes, das bald jabulos, hald mit frart wor= fpringenoen geferbten 3äbuen verichen ift, bie sinen volffändigen

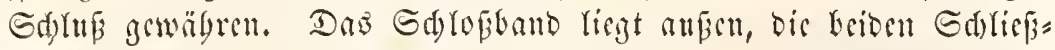
musfeln liegen mabe an bem Borber= แnd Sointerrande Der Sdyale

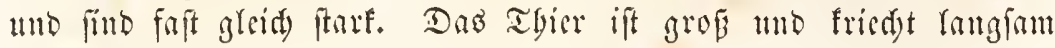
im Sande doer im Sdylamme auf bem Kamgen fielfürmigen Fube. Der Mrantel ift feiner ganjen Ränge nad) volffommen fref und alt feinem binteren, meift etwas verlängerten Enbe mit ftumffen Taftwargen be= figt. Die Siemententter find jeberfeits binter bem Jußse miteinander

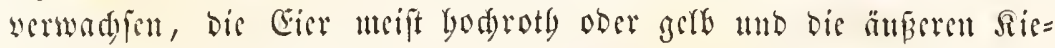

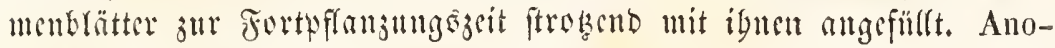
donta; Unio; Ilyria; Iridina.

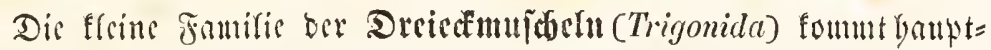

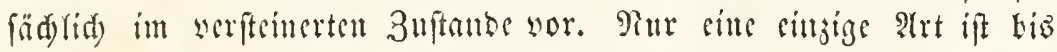
jegat it ber Räbe von Renbolfand lebend gejunben worben, wäb= rend dic Gajalen bejoubers bänfig in Saljgebirge, im Sura und in Der Sreibe worfoumen. Diefe Miufdern find bift mit ftarfer Jerlen=

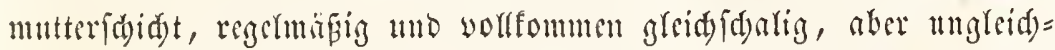

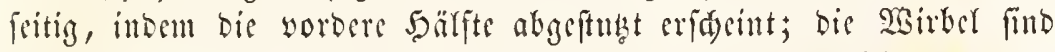

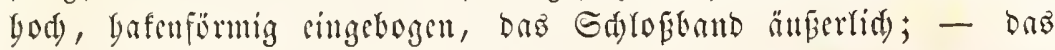

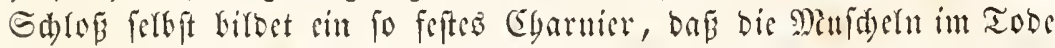

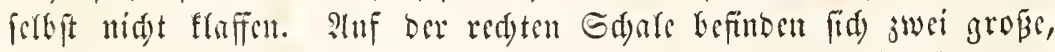
im 2Binfel geftelte 3ägne, bie anf beiben Geiten geferbt find und weld)en auf Ier linfen Geite cin mittlerer oreicfiger Borfprung uno swei geferbte Seitenjöbne entfpreden, fo bais bas jufammengefïgte

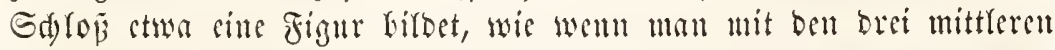
Fingern ber linfen Sand o on cingefniften 3eige= und Mittelfinger ber anbern 5and umfät. Die scibesmaffe bre Thieres ift unbebcutcub,

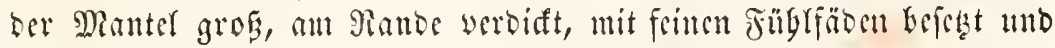

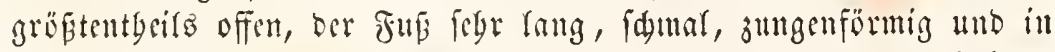
Der Ditte wie cin Snie getogen. Der vorbere umgebogene Thril fant

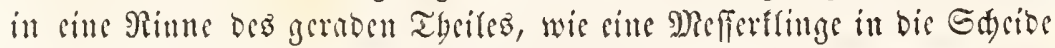

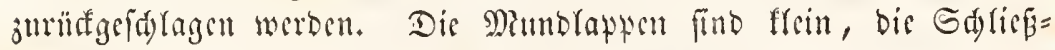
musfefn großa uno wou glcidget Gröbe. Trigonia.

Die Ardacumuidscln (Arcida) baben Diafidalige, gleidflaptige,

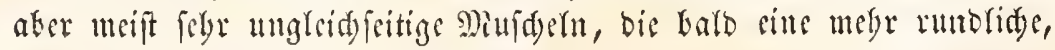




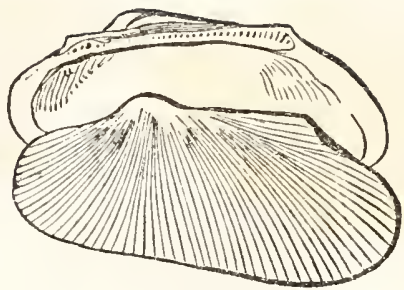

Fin. 319.

शrifyenmuidtel (Arca).

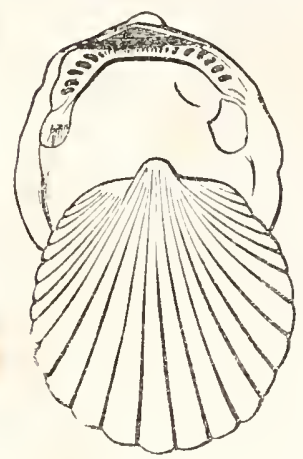

sig. 3.0.

Sinmmden (Pectunculus.)

balo eine jientlid unregelmäęige Form baben. Die sirter fund bent. (id) entwistelt uno umgebogen, meift

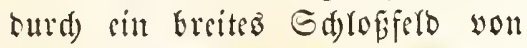
sinanber getrennt. Das Gdjló ber Sd)ale ift än Eerit d)arafteriftifd:

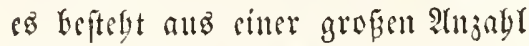
son abwed) feterten Creböbungen und Berticfungen, welde in cinanter greifen uno bie baro nuf cinet geraben Sinie, balo all einem Bogen, balo in

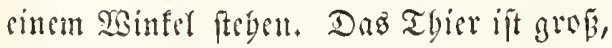
bict, ber Diantel in Frinem ganjen llu= fange offen und frime Sxur you giögren= biloung am biuteren Igcile. Der Fun ift febr grofí uno auf feiner unteren fräd) mit ciner gime serfeben, bie igu cinen Dopkelten Siel giebt. Die Sicmentätter find in paliflabenartige Misigen son cin= zeluen Fäton jerlegt; bie Mimblappen unt flcin mo rubimentitl. Die strdene

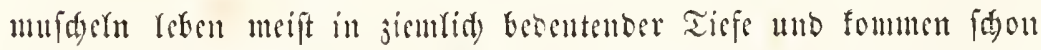
in ben älteften Gdidten Der Croe sor, wou wo fie fid olue llnter= bredung bis in bie beutige Sobpfung burdfgejogen baben. Arca; Pectunculus; Nucula.

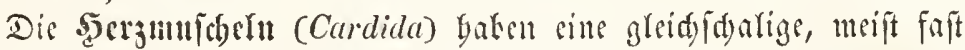

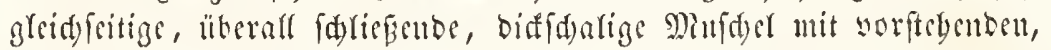
uncift ungebogenen 2 Bibefu, bie son worn ofer binten tetrad)tet, faft

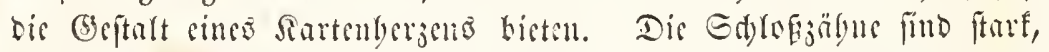

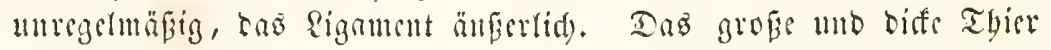

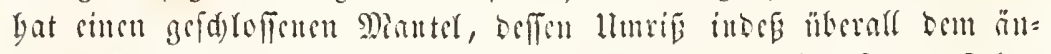

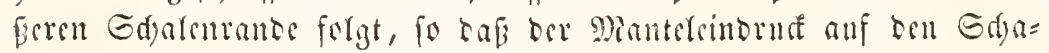

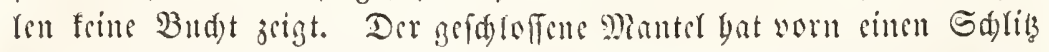

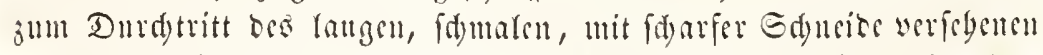

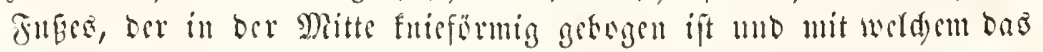
Ther fdueffent anf bem Boren sinberfpringt. Nade binten ift ber

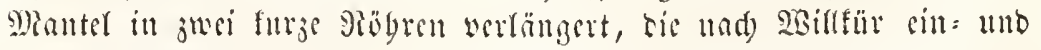

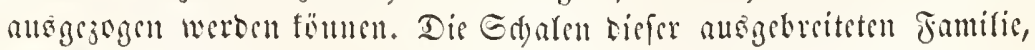
meld)e nur in bem Dieete letet, fint in jablreiden Gattungen und 
Frten sou ber ätefiten 3rit an in Den Gadidten ber Grbe sorbanden. Cardium; Opis; Crassalella; Cypricardium; Corbis; Lucina.

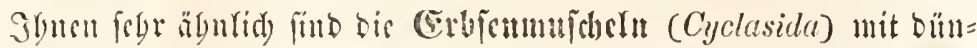
ner Sd)ale, welde mit cincr tiden rungerigen Dberbant bebedt ift

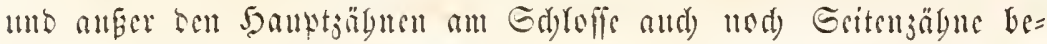
fint. Die I

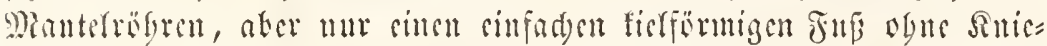

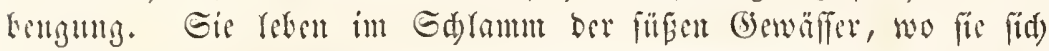

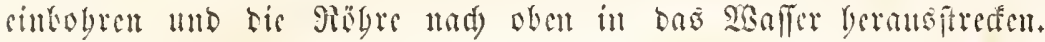
Rad) Son bis jeket nngefterlten llnterfud)ungen folfen biefe Mujder=

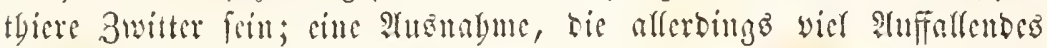
gat. Cyclas; Pisidium; Cyrene.

Die Trogumfdeln (Hactrida) entipred)en in ber Form, ber

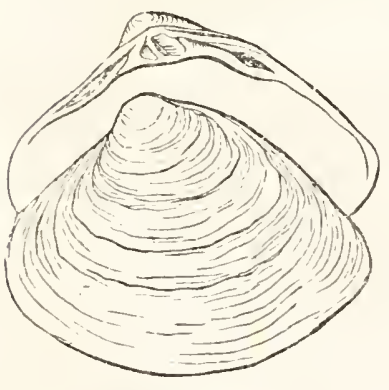

รig. 321.

Trugmufitel (Mactra)

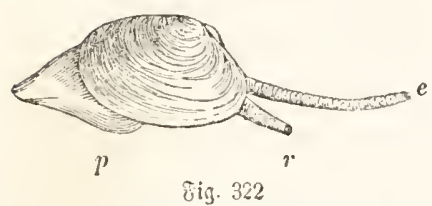

Tellina, mit nusgebefutcm Thicre.

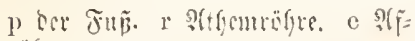
terriblet.

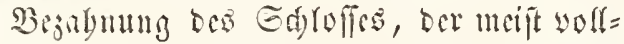
ftänoigen Gdyrisung ber Edjalen, ben berjumifdern; entfernen fid aber sout

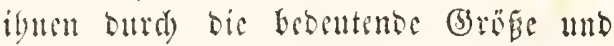

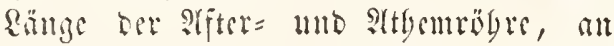

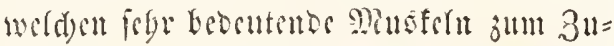

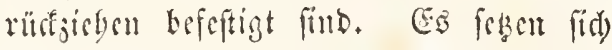

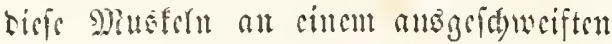
Plante innen an ber Edale an, fo bab

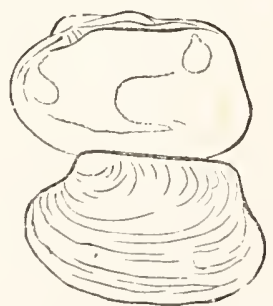

Jig. 323. Venerupis.

Dor Miantelein= Druf ber Edara auf Der binteren Srite eine ftarfe

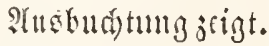

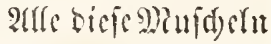
groben fid mit ib= rem ftarfen:, meift Erciectigen fure itt

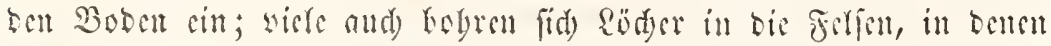

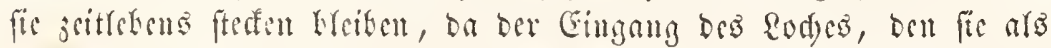
junge Thiere kobrten, for fräteren Gröfe bes erwadjenen Ibieres nidat mebr sutpridgt. Haclra; Venus; Tellina; Cythera; Venerupis; Petricola; Donax; Corbula.

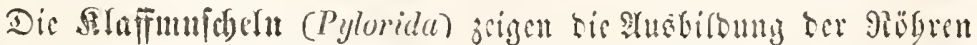

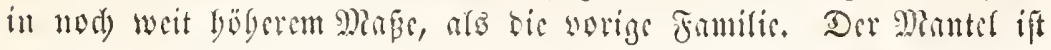


Fig. 321.

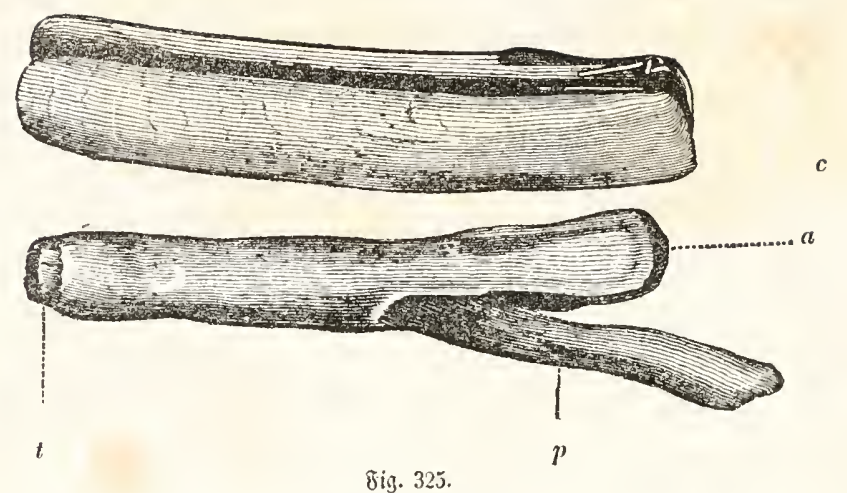

Mictierideixe (Solen).

Fig. 323. Die Effalen. Sig. 324. Das herangenummente Thier.

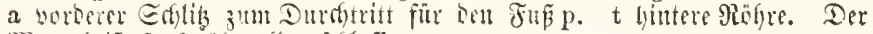
mantel ift fouft nerall geidtlufict.

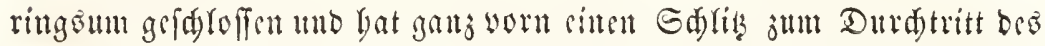

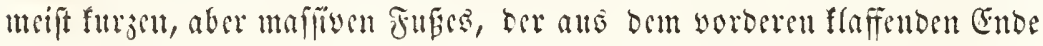
Der Mufder bervorgeftreft witb. Die Ginteren Manteleögren find nur felten, wie bei ben Defferidecioen, febr ftrij, bei ben meiften ungebener

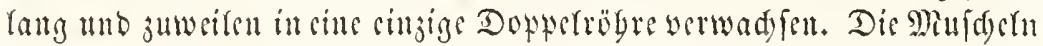

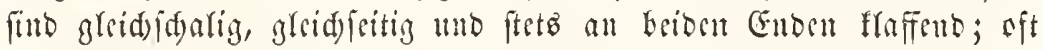

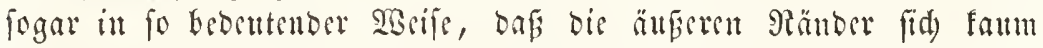

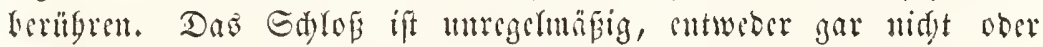

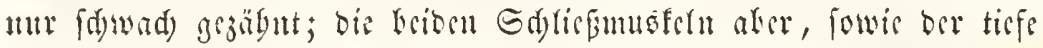
PUs

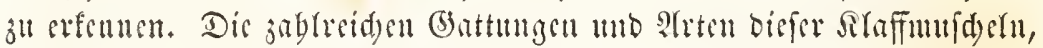
werdye alfe int Grylamme utb Gande fid sinbobren, baben ju allen

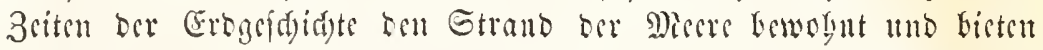

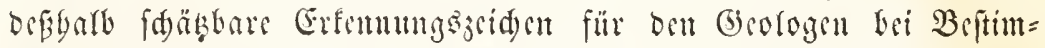
muniz ber cinjernen Edjidsten. Mya; Lutraria; Solemya; Solen; Pholadomya; Solecurtus; Sanguinolaria; Psammobia; Glycimeris.

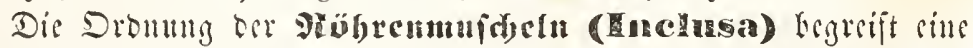

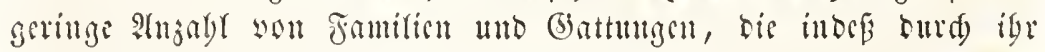

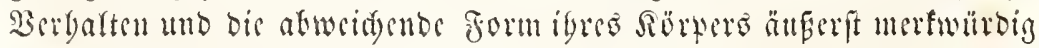

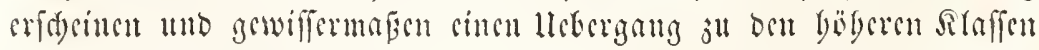
filben. Der Siantel ift bei bicfen Thieren ju sintu volffändigen, langen Gaffe gridylofien, ber und allen Griten bin bie Miufdel be=

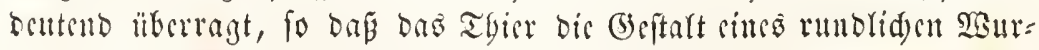
mes bat. Mesift ift biefer Mintel nad) binten in sille lange Pögre 


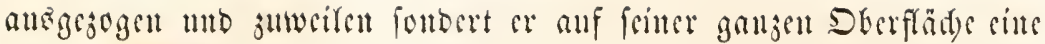
bïnne Ralflage ab, bie sine Mïgre bilbet, in welder bag Thier fteft. Die Edalen biefer fämmtlidgen Thiere find febr bïnn, geripst mo baben meifens feit beutlides Sdylog; fie flaffen und allen Seiten

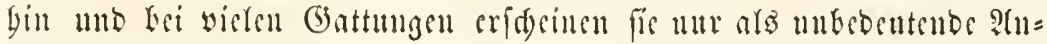

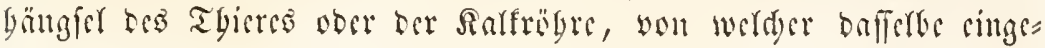
id)loflen ift.

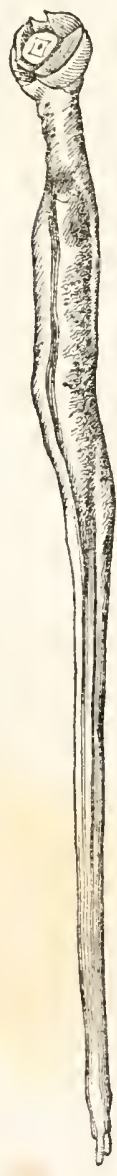

ซึig. 326 .

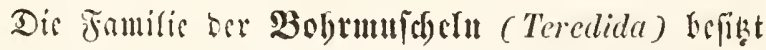

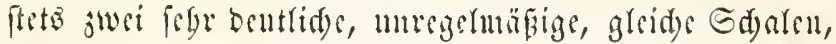

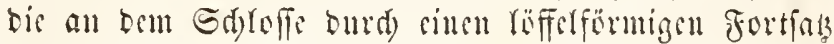
miteinalloer vereinigt fint. Der wumförmize Mantel ift frei, ebento bis Ed)alen, mto went bie Thiere sine Ralfrübre bilden, fo fleibet biefelbe die ballerie, weldye fie bohren, nus, obue bent Diantel felbit anjugängen. Bei ben rigentliden 2 obrmulder fu (Pholas) ift bie

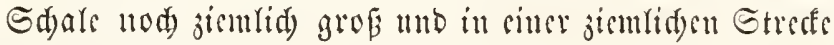

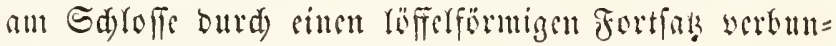
Den. Der Fub ift furz, bidf uno runb, bis binters

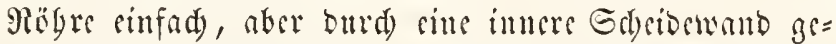
theilt. Die Bobrmuldelu bobren fid in sincr gewiflen Tiefe unter bem 2Bafferfpiegel, au liebften in falfige fenfued)te

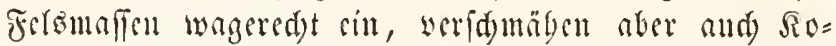
raflen uno ferteft Gd)lamm nidyt. Sgre Galericen find äuperft glatt, gleid) fan polirt mo bieten bejonbers an ftrini= gen uno felfigen llfern burd) bie confante Syöbe unter ben Safferfpiegel, in welder fie fid rinboleren, eitt ganj vortrefficlye Renujcidan für alte Stranblinisu

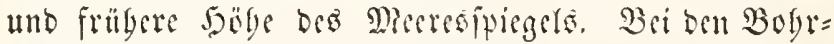

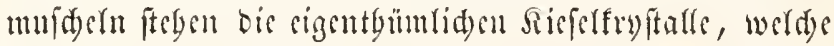
ibuen zun Bobren und S(bfdreifen ber Felpen Dianen, bejonbers auf bem runben zapfenförmigen Jupe, wä́)=

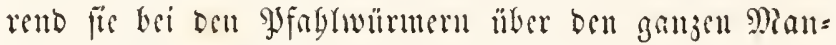
tel, fejonders aber über beffen worberen 2 Gulfi, ber wou bem Sfablwarme bebentent aufgeblägt werben fam, jerftrent fint.

Dis gुfablüurmer (Teredo), welde ebenfalts Ter Pfaktwurm

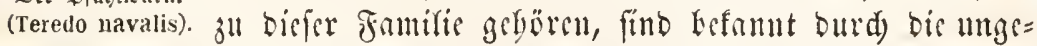
beneren Berberumgen, bis fie in Säfen mo 2 Berften alt bem unter Waffer befindidyen Solge anridten. Daz Thier bat etwa bis Dife und \&änge eittes Regenwurmes uno entet nad finten in jwei lange, 


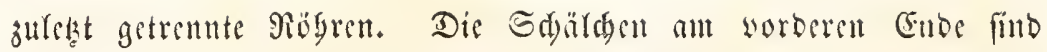

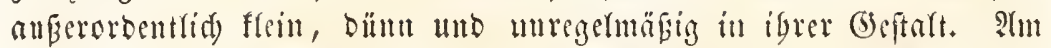
Ginteren Ente bes Sörpers, wo bis Röbren anfangen, finten fid

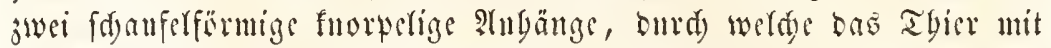

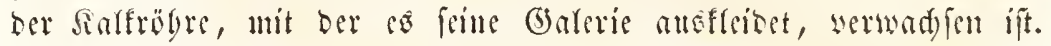

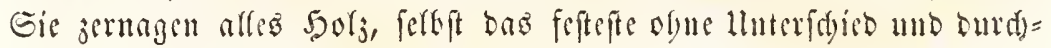
bohren ea mit Miflionen fid) fo febr burdfrengenter (bsänge, baf es wolffontmen mbaftbar wird und zufammenbrid)t. Dis Sungen

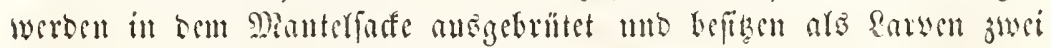

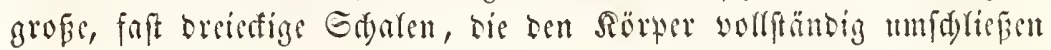

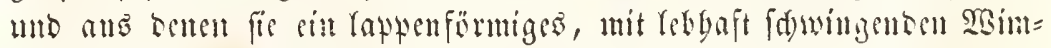
perorganen bejęteo Gdymmorgan bervorftecten fïmen. Später wirb Diefes ourd) einch langen jungenförmigen fun erfest, ber bei bem er= wad) fenten Thiere ebenfaltg volffänbig verfdyunten ift. Teredo; FisLulana; Gastrochaena.

Die Sicbmufbeln (Aspergillida) baben cbenfalts einen wum=

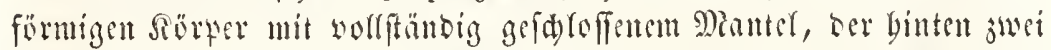

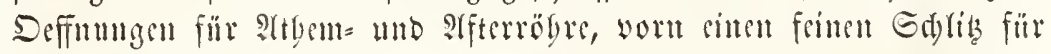

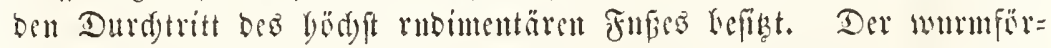
mige Mantel fontert in feiner ganjen Ränge cinte Salffdyale ab, welde

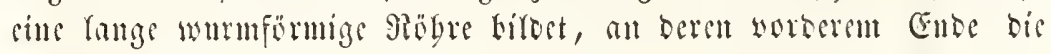

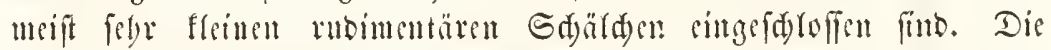

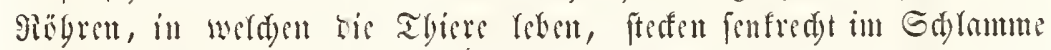
aber in Ferfen, find unten offen mo baben oben meift fiebrërnig

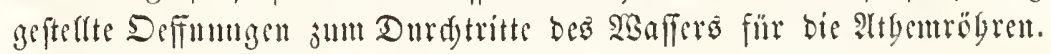
Clavagella; Aspergillum.

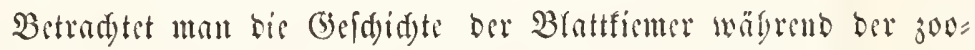

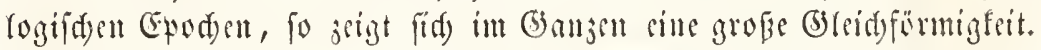
Die Seitemmudyeln eriagenen in sen äleften jormationen fdom mit

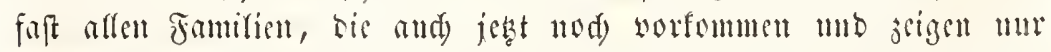
wenige aแşgeftorthene Gattmugen; - einige familion, wie $3 . \mathfrak{3}$.

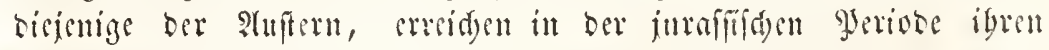

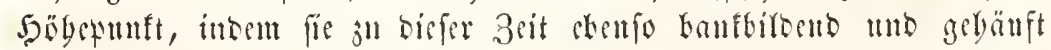
sorfommen, wie jetst. Ilnter ben Gerabmuldeln fint befonders die Familien mit weit angुgefdnittenem Diantef tub Kangen 9iögren bäแfig

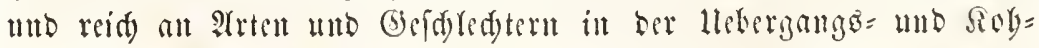
Yemperiobe und zeigen einige Gattungen (wie z. $\mathfrak{B}$. Pholadomya), die 


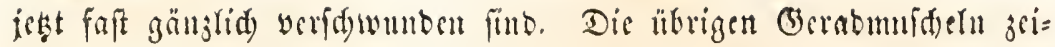
gen etwa bie nämlid) 2 Berbältniffe, wis bent z̆ Tage. Die Röbren= mufdeln bagegen fint cutfdjecoen fpäteren ltriprunges; fie beginnen

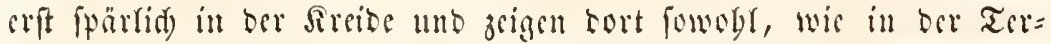
tiärperiode meber fo siels ?(rten, und fo grobe Säufung ber Snbivi= buen, wie in ber Jestrueft.

filaffe ior Sidpurdim. (Cephalophora.)

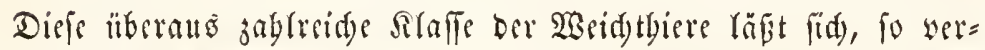

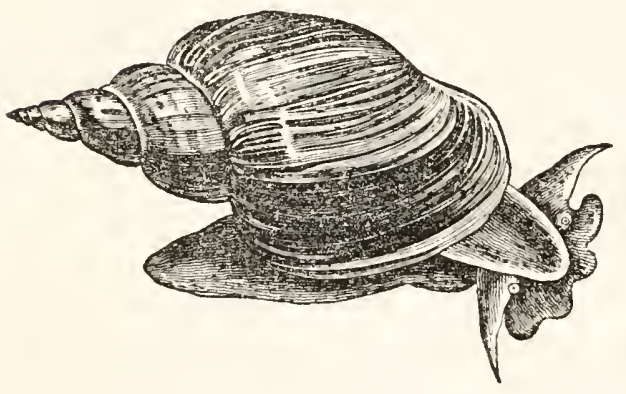

Fiv. 327.

Teidburnf(f)nede (Lymnaeus stagnalis). fajisbenartig bis bei igr vorfommenden formge= ftarten aud) fein mögen, bennod) Veidft umfderci= ben unb d)arafterifiten, Da fie weisutlids won ber verigen $\mathfrak{N} \mathfrak{T}$ alfe abweid)t. Die Edurefon unter= idsciben fid won ben Minfdertbieren gaupt=

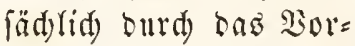
Ganbenlasin sines megr ober minder getrenuten bentliden Soffes, ber mur in ben nicberfen

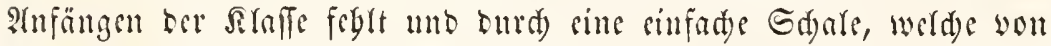

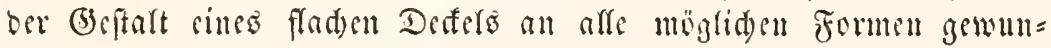

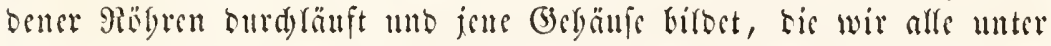

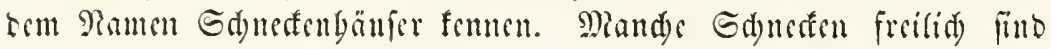

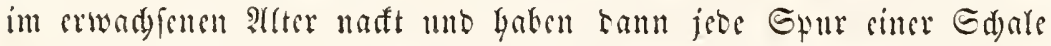

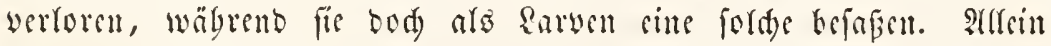

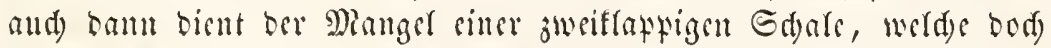
ben Mufdertbicren ganj allgemein zufommt, auf ben crften Bliff zur llnteridycitung won bicfer.

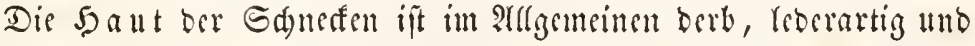

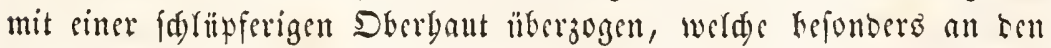
jur Bewegung bienenden Stelfen mit șimpergaaren befeg̨t ift; แur 
lei einigen in Meere rebenten Gdunefen iff bie Sant, trog aller

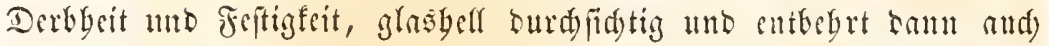

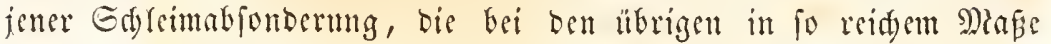
vorfommt. Bei ben meiften Gdueffen bifdet Die ben Rörper überalf

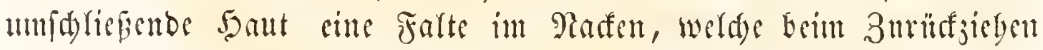
bes Sörpers wie cine Sapuje hber ben Sopf weggeidoben werden

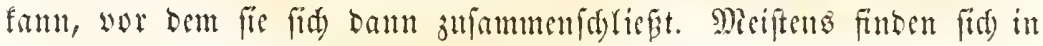

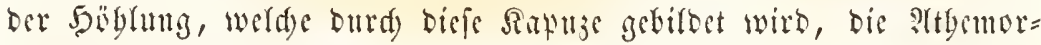
gane, fowie bie Deffunngen ber (5iefdyled)torgane und bes Berban=

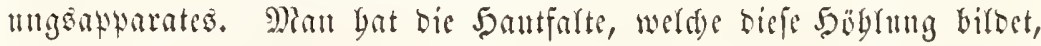

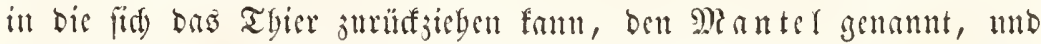

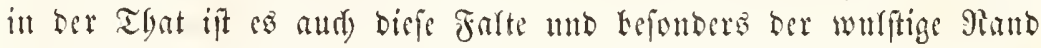
berielben, ber Mantelfaum, weldyer die Raltjdale abjonbert, bie bei

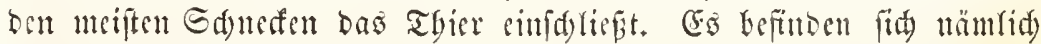
nuf biefem wulfigen Diantelfante cine Denge furjer Drüfenfd)länd)e in faft fenfredter Stelfung, in Deren grofen Drüfenzelfen fids cin feinförniger Salfnieberfdylag Gildet, Der jum Siseiterban ber Gdyale serwentet wirb. Der Mantelrand, weldyer ber äuperen Diänonth ber Gdale bart anliegt, iest in einjelnen Blättden eine jö́le, jur bornigen Daffe erbärtente Gubfanj ab, weldye alfmäblig fefter wirb, mebr und mebr salf in fid aufnimmt und fo zu fortwadjenden Sdyn= lenfdidsten fid umgeftaltet. Betrad)tet man bas Gebällfe siner Gas=

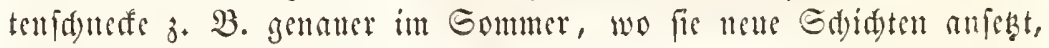

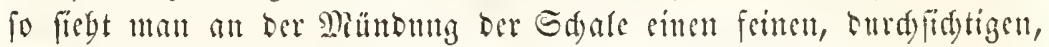
bornig bieglamen Boritop, welder bie in Birbunt begriffene Sdya lenlamelle ift. Da biefe Bifoung nidyt gleidumäbig, fentern periobifidy

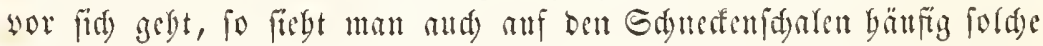
Amwad) sftreifen, wie wir fie aud) bei ben Mufdelfalden fennen ge= rernt baben, fowie grögere Sätfe ober Bertiefungen, welabe 3eiten bebentenderen Saddstyums, oder längerer luterbredung Darin ent= Fpredur. Die Struftur ber Gduectendalen ferbit ift weit sinfader als bie ber Peufdelfdalen, bent fie beftefen nur ans ber cinjigen

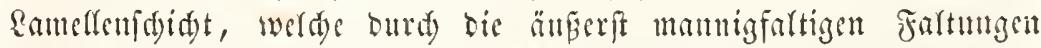

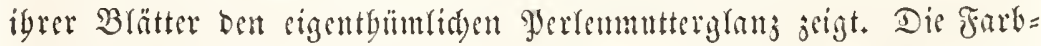
froffe, welde in biefer Sdidgt abgelngert werben, find oft änferft

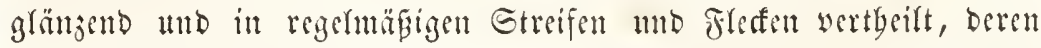

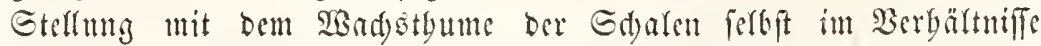
ftebt. Durd Faltungen Des Diantelfaums entiteben oft Biegutigen

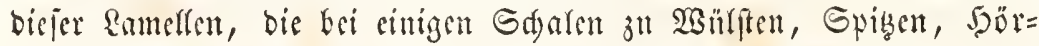




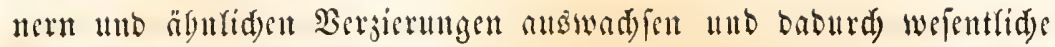

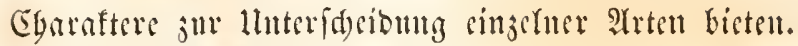

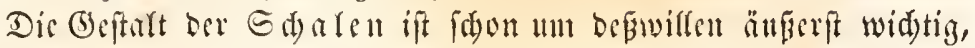
weil man jur Beftimunung Der verifteinerten Piefte fid mu an bicfe balten fant. Man bat Defbalb bier eben fo wie tei ben Danfern

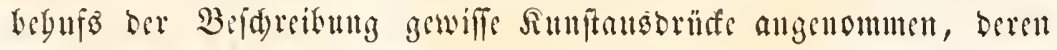
Senntmif nötbig ift.

Faft alle Gduefen fommen atts ben Gi mit einter füttten, born=

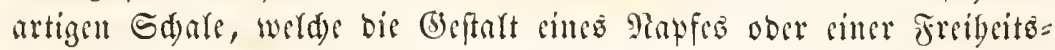

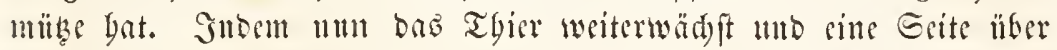
bie anbere ein gewilfes llebergewidgt erbäl, entitegt sine fpiralförmige Drebung des Söbers, an weld)er bic fejte Rarfröbre, welde bas

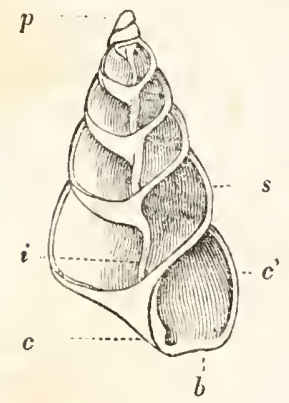

รig. 328.

(Sine thum förmige Ed)ale, ienfedit burdfidsuitten, un! iffe intere Etruftur zu zei= get. b Munberitumig ber Edirle (apertura). c Epill= Defrano (labium). e' Éppen= ober Shęentano (labrum), i Evimbel (columella). s simoungen (spira). p 厄pibe (apex).

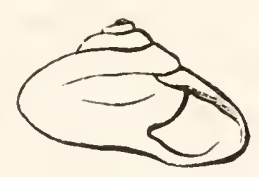

8ig. 330.

Sreifelfatuche (Turbo). Thier untleidet, ebenfalls stutbeil nimmt. Die Sd)ale erfdyeint alfo bei ben mriften Edurden

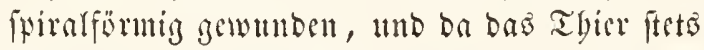
wäb) unb an llufang junimut, fo fint bis rezten Saithongen ber Gdale weiter als bie worbergebenden, die oft gängliá) woul ber Yebs ten sintoug verbeft und singefd)loffen werben. 3uweilen erfolgt biefe scindung ber Gdaren= röbre it berferben esbene, fo Dafi bas Gebüm
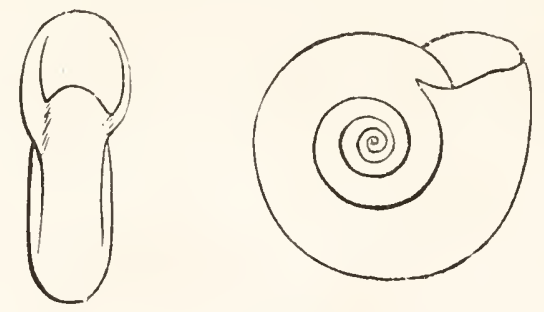

ริฐ. 329.

Befferfinede (PIanorbis).

ganj flad) erfdecint แnto in ber Mitte als 2 (nt= fangŝpunft ber ganjen Sdunefentwindung bie mprprünglide, ans bem (si mitgebrad)te Gdale erfderint. Die gewölnuliden Tellerfduneften (Planorbis), welde mat fo bänfig in alfen un= fren $\mathfrak{B a ̈ d}$ en fintet, liefern yon bicfer Tnorb= แung cin reid)t öngänglid)e Brifkier. Sn ben

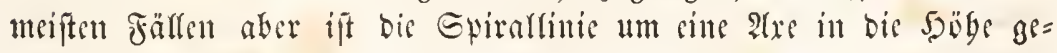
wutben unb bilbet fo sine warbrbafte Sduraen= unb Saraubentinie; 


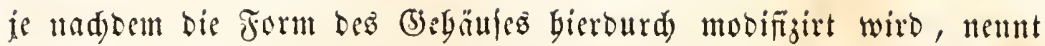
man biefes frefifeffürmig, thurm=, fpindelförmig u. f. w. Bei biefen

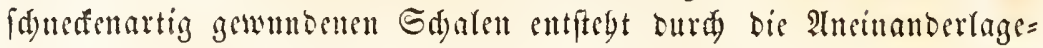

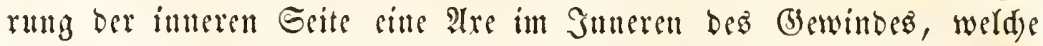
man die Spinbel (columella) nent und bie man beim ?tufbred)en

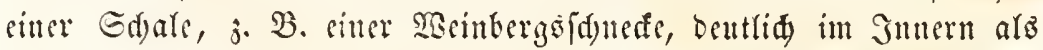

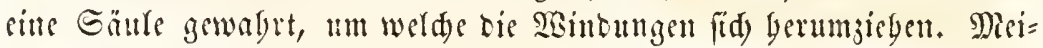

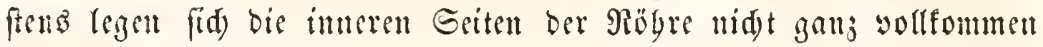
ancinanter, fo Dafs, went aud eime Spinter gebiloct wiro, biefe

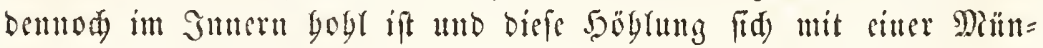

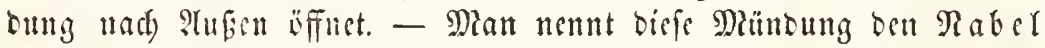
(umbilicus). Berübren lidd bie cinzelnen SBintungen ber Ed)ale gar nidst, wie 3. B. Lei ben $\mathfrak{Z}$ endeltreppen, fo ift begreifliderweife biefer

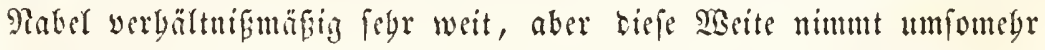

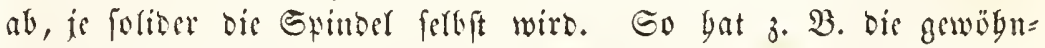

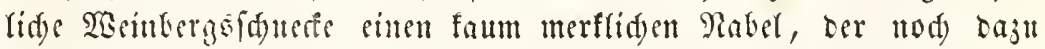

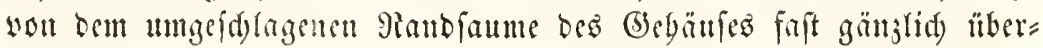
Defit wirb. Die Deffinung, burd) welde bno Thier aus oer Sdate

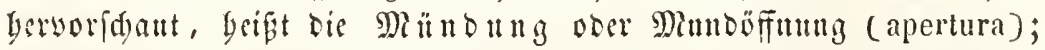

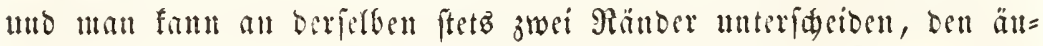

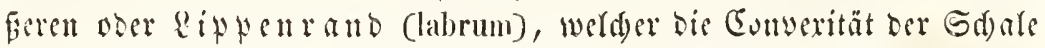

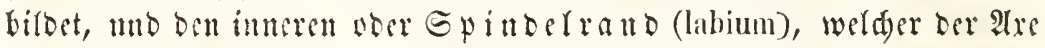

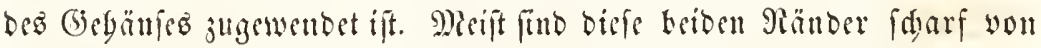
cintander getreutut, ittoem bie Deffnung megr oder minber Yänglid) ober

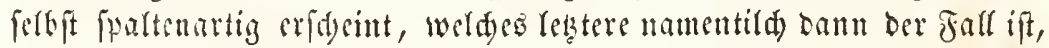

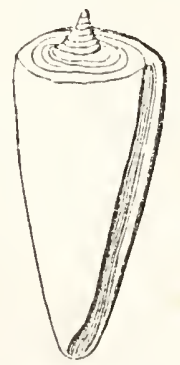

ธีig. 331.

Regeffituede (Conus).

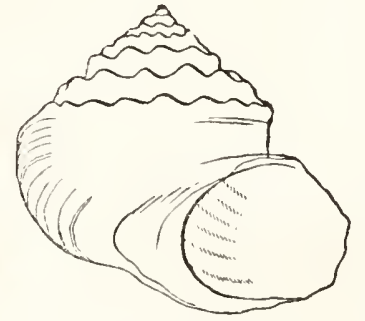

ฐig. 332 .

Sreilelid)uefe mit ganzeut Minofaแm. wenn, wie bei ben $\Omega_{e}=$ gel= ober $\operatorname{sor}_{\mathfrak{g}} \mathrm{elland}$ ) ffen, bie lekste sinonng Dic worberigen sinfdelickt, fo bá dicfe fanm ober gar nid)t fidjetuar futb. (B)chäule Diefer ?trt bat maneingerollte Gda $=$ len genaunt. In man= d)en fö̈llen inber, wie namentlid) bei ben Sirei=

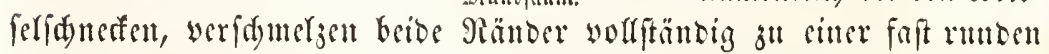
Deffunng, und man fagt baun, Daß bas bebäufe cinen ganjen

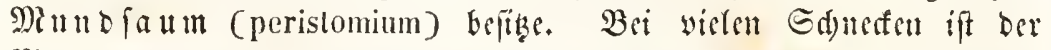

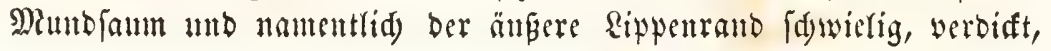


mit Farten mo Borfprüngen verfeben, bis bann beim teriubifden

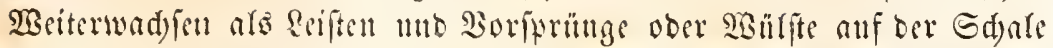

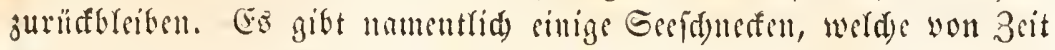
3"l 3eit fid) sinen febr ftarf wulfigen Mumbjamm bilben, ber bann alo Ring auf ten 2Binbungen fich oarfefft.

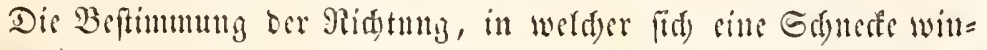
bet, gefdiebt uneigentlider 2 seife in ber Art, on man fid bis Sdale

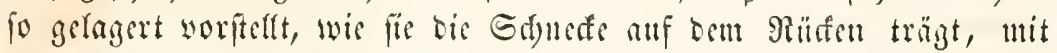
Der Miünung nady unten unb ber Spitze nad) oben. Betradytet man tie Ed)uefe nuf biefe 2 seife, fo liegt bei ben linfö gewuntenten ber

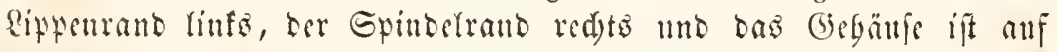
bis red)te Geite geneigt. Bei oen red)to gewnubenen lingt ber Rippen=

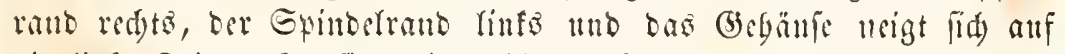
bie linte Gsite. Go find die meiften unferer 2 seinkergidnefen o. $\mathfrak{B}$.

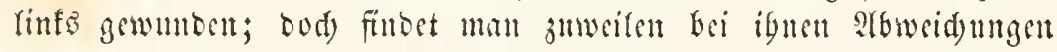

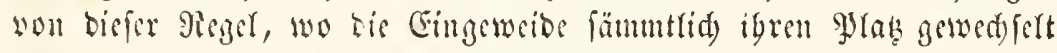

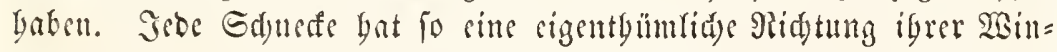
suth, welde normal fïr fie erfdyeint.

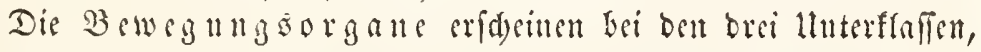

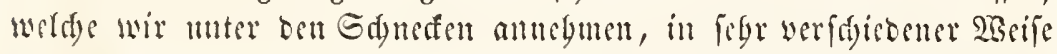

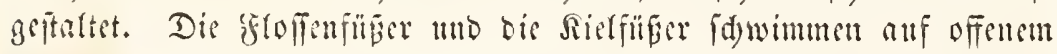

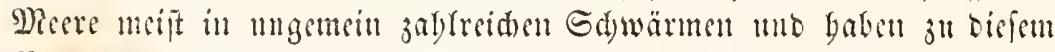

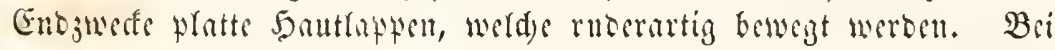
oen Floffenfïbern fteben diefe Sautlappen, weldy farig fund, ju

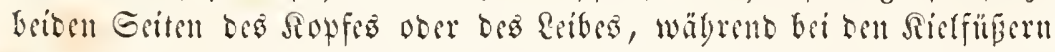
an ber Baudfeite nur cin mitterer Puberlapten angebrad ipt, mit= telf beffen die Thire igren Sïrper etwa in ägntidyer Sirt fortbewegen, wie man cin Boot mittelit sines an Şintertbeife angebrad)ten Muber Durd) SBirbelorebungen worwärts betwegt. Bei ben Bandfïfren ift

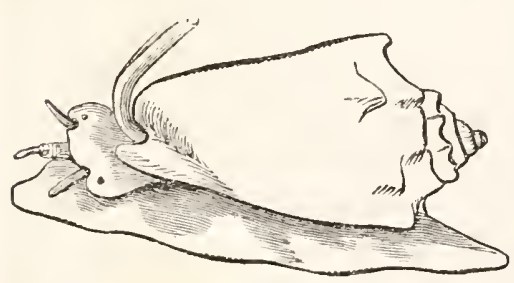

ơig. 333. Voluta

friedsento, mit worgefterftem Rüinel, ent= wifelten Fifflem uno in Siafen worte= henter Sitgemtêbre.

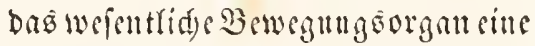
fleifdige Golgle, Der o $n$ fi, weldyer mit vielfad) fit) burdfrenzenten Fafern Durduebt uno auf ber Batdjerite bes Thieres angebradjt ift. Mit= telit diefes Jubes gleiten die Baud $=$ füber anf oen glatteften glädyen uad) allen Ridstungen bin, unb wif= fen ibn and meifter jum Sdym men an ber Sberflädye bes 2 Bnflers zu gebranden. Durd) Anşböblung 


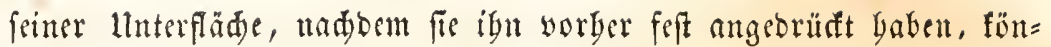

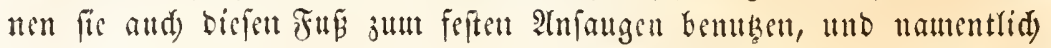

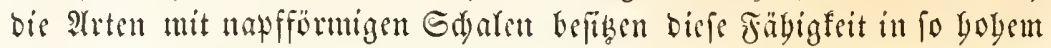
Grabe, dáp แtan vergebchs werjuden würbe, ein Seeobr ober eine

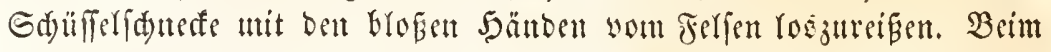
3urürfichen ber Ed)uefe bient ber Fü nteiftens baju, bie Mündung

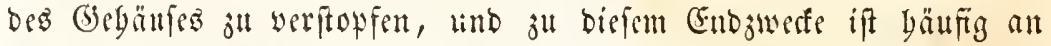

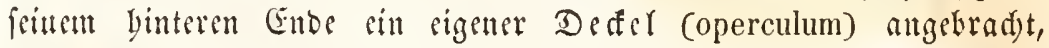

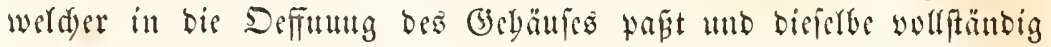

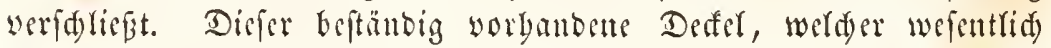
mit zur Ggarafteriftif ter cinzertnen Gattungen bient, Gat barb sitte

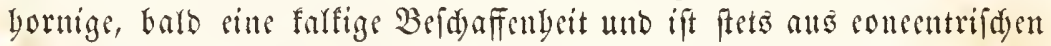

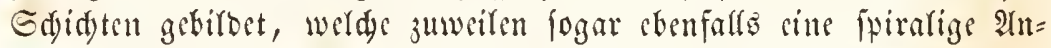
orbunt Gaben. Midjt ju verwedfertu mit bisem permanenten Defer find biejeniget borïbergebenden, aus unregelmägiger Sarfmatle gebirbeten Deffer, womit unfere Randidneffen int rsinter igr

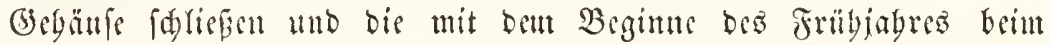

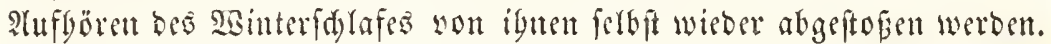

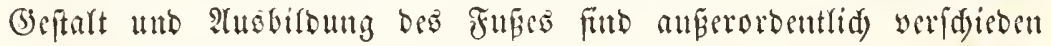

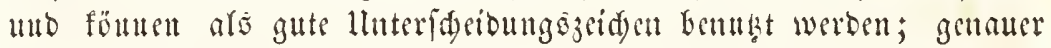
betradiet ift berferbe unr sine bebeutendere rofate Entmisfertung ber

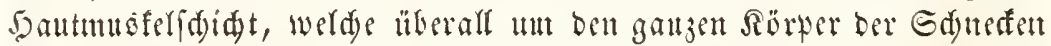

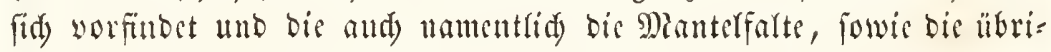
gent Theile Des Sïrpers fo äแBerft contractil madjt.

Das Rervenfyftem Der Gdyeden wariitt itt feiner freciefleren

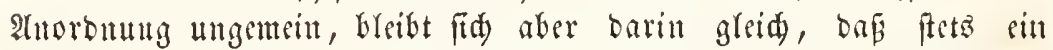
Gd)lunbring entwifert ift, thit weldyen werfdgiebene, in bem Rörper zerfirente Ganglien in Berbinbung ftegen. Bei affen Edyneffen, weldse

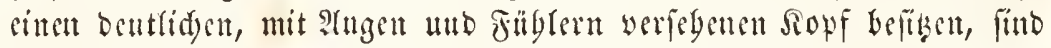

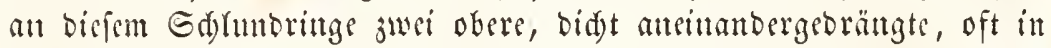

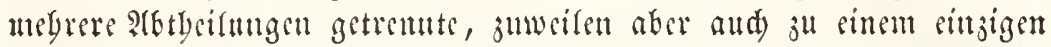
Sunten verfoutulzente Banglien ju erfennen, weld)e man als Gegirn

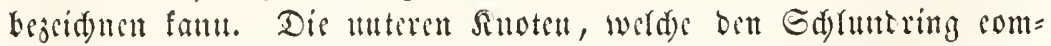
prettiren, fowie bie Sierbindungsiftränge jwifd)en beiden bälften, zeigen

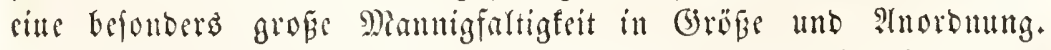

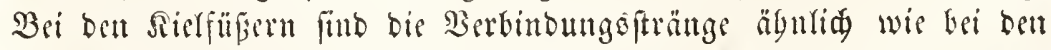

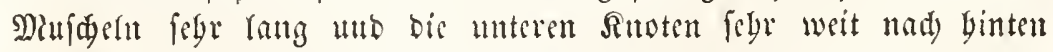
gerüft. Bei Denienigen Edyerfent bingegen, wo ?tugen und Fübler 


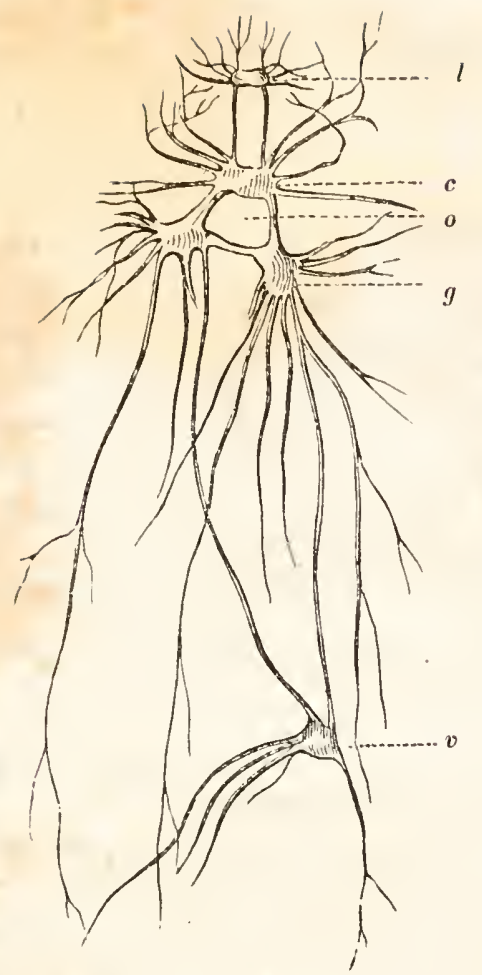

8ig. 335. Derrenfiliem beڤ Eeehajen (Aplysia).

1 Borberez Rippenganglion. c Sterer Sauptfnoten, itker bem Edylunbe gelegen (Sirnfuoten). g lluterer Situten, mit wo=

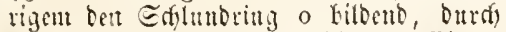
bent ber Ealunt tritt. v Şinteret Einge= meirefnoten.

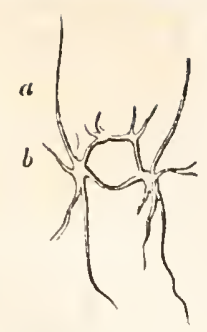

8is. 336. Shlunbring eincr Sonnimmidneffe (Janthina),

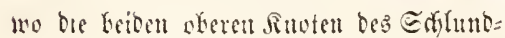
ringez (a) fefy. flem unb yon cinatiber entfernt - bie unteren (b) weit gröépr, aler ebeñallo wou cimmber entfertit fint.

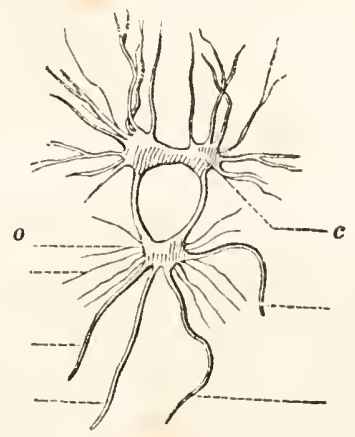

Sig. 337. Golunbring einer SEegífuede. (Limax).

Die Geisen derin sainfunten (c)

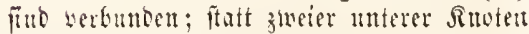
exiftirt unt ein eingiger (o).

feglen, fund bauptfäd)lid) and bie unteren Snoten entwidelt unt bie

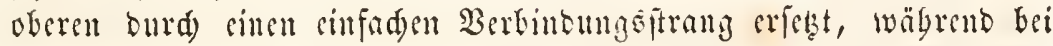
manden Irten, wo ber Jup unr geringe Entwidfelung jeigt, bie nn= teren Rnoten rubinentär werben. Won Den Sanptnerventuoten bes Shlunbringes werden beionbers bie Sinnes = uno Mumborgane, bie Sant mitb ber Fus, fowis einjelme Eingeweibe verforgt. Slle Rerwent

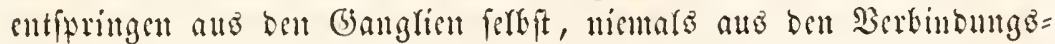

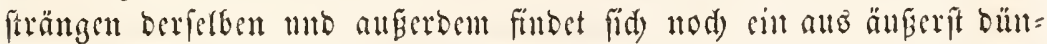

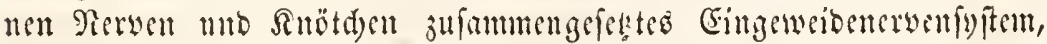

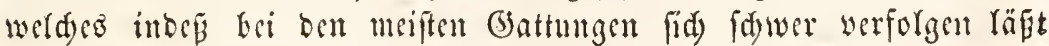

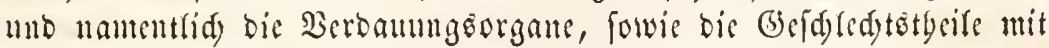
feinen fäben verjorgt. 
Sinnesorgane find bei Den meifen Sdumefen vorbanden. Befondere Tafter oder Jübler fïzen faft bei allen an Dem Ropfe

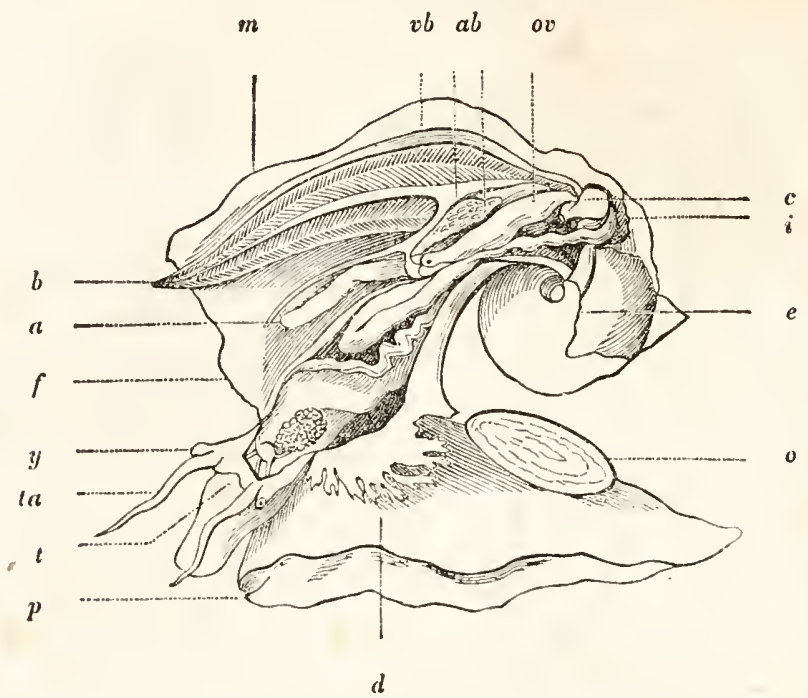

Fị̣. 338. Innatomie cincr Sreifelífguede. (Turbo pica.)

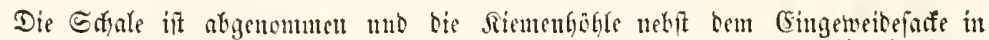

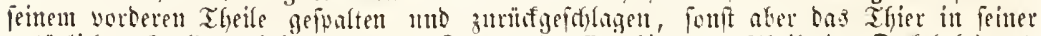

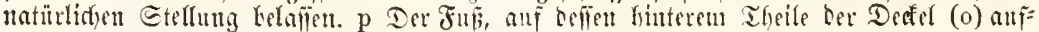

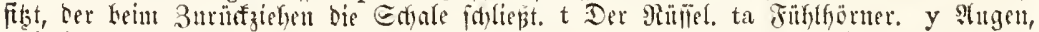

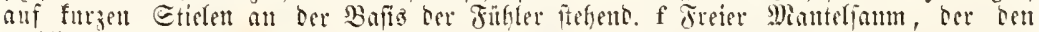

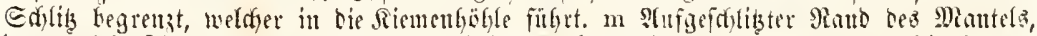

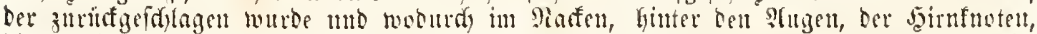

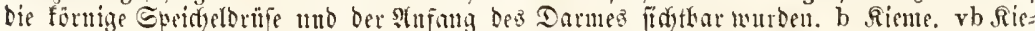

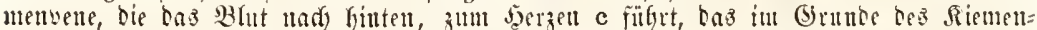

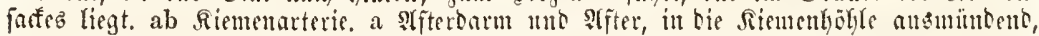

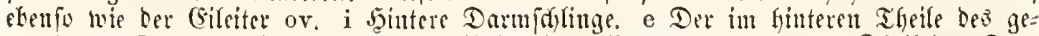
wunbenen (Sehäujez liegence Rörpertheil, Der ben Magen, ben norberen Theil beş Dar=

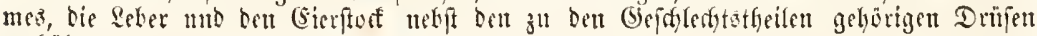
enthält.

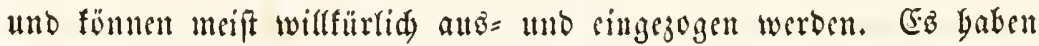
diefe Füblgörner oder Tentufeln bie verfdeiebenften Geftalten, bald wie

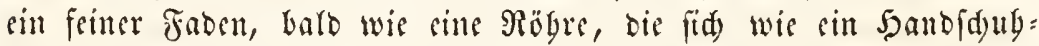
finger aubs = tmb cinftülpt, balo wie sin zugefpiztes ober singerolltes Blatt, ober wie sime breite gylatte, die Durd) Berfdueljumg Der beibent Fübler im Nafen entitegt. Meift fonment nur cin Yjaar foldaer Fïbler vor. Rur uniere Ranbidneffen und einige Jabenfdnerfen baben ju= weilen zivei Şar. Die Taftnewen, weldye in biefe Drgane treten,

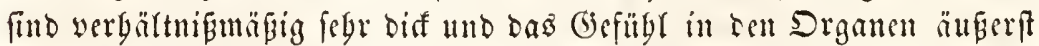
fein. Aufier ignen bienen nod) öfters bejondere Munblappen und weide

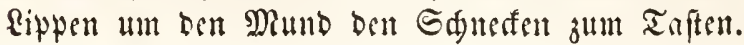




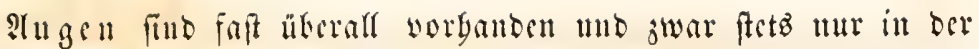
3abl won jweicu. Tim ber nicberften lluterffafle, ben Froffenfübern

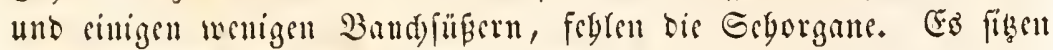
bieferfen entweber in Rafell ober an verfdiebenen Gtellen ber Filly=

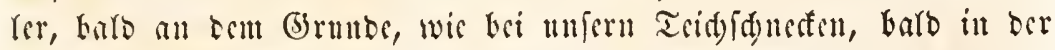
balben Ränge, balo aud) an bon yorocriten Ende ber Fübler, wie bei

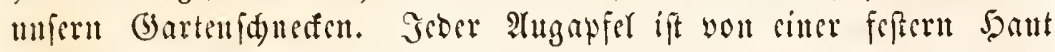

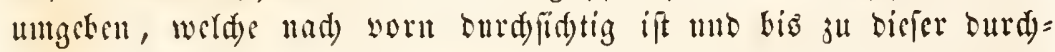

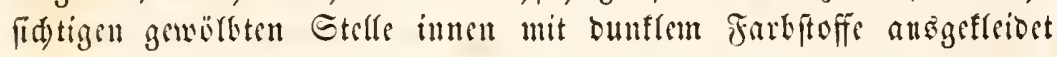
iff. Der Gernerv onrdbobrt vou binten ber bie äufere Itugenbant unb breitet fid anf ber iuneren fläde berferben jul siner Rebgaut

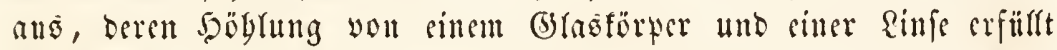
wirb. Die Gebuerven fut meift jicmlid voluminös, feblen aber bei

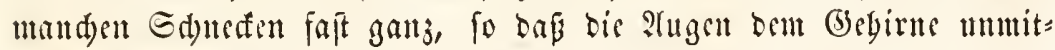
tcrbar aufiften.

(5) ö rorgane frmment wobl affen Gduefen obue Tusnabme 311, uno troks ber nicorigen Stufe igrer Eutwistung fdeinen fie von grofer Beocutung für bis Defononte Der Thiere, da fie bei ben Em= bryouen febr früb eridsiuten. Sie fiken meift unmittelbar auf bem (5)birne auf ober zeigen nur citten furzen Söruterven, welder nur bei cinigen wenigen Sirffübrern bebentend verlängert ift. Es befteben bieje Bjebörorgane nur aus siuer runben ober längliden Sapfel, in welder cutweder sin Engelfürmiger oder viele fryftallinifde Gebür freinden ferfen, weldye surd) $\mathfrak{B}$ impern in fteter jitternber unt wäl= zenter Betwegutg gebalten werben.

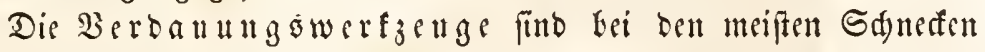
in weit güberem Grabe entwifelt, als bei ben Plufdert unb befonders zcidnen fid) febr vicle burd) cine ftarfe Bewaffuntg bes Mundein= ganges aus. Bei ben meiften Gduncefen finben fid jwei fritlide ober cin mittlerer, in bie Deffe orr Munbböble eingefenter Ricfer, beren

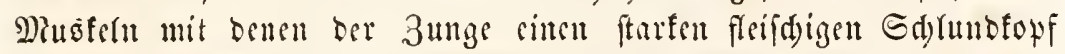
bilben, weld)er meift unmittelfar binter ber Munböfnung liegt unb febr oft, bejonoers bei Miecridnedten, felbft an einem unebr ober min=

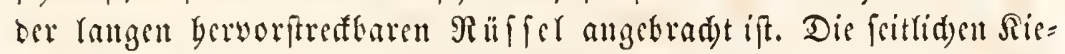
fer fitto 2 Bülife, weld)e oft mit 5ornplatten, in anbern sällent mit fdarfen, aus Riefeletoe beftebenten seiften ausgefleibet futo unb borigontal gegentinantor wirfen. Zuweilen intoé fint biefe feitfiden ficfer ver= fiimmert unb bafï in ber Defe ber Munbböble ein Galbmontoförs miges, mit ecijten uno Boriprüngen verfebenes, Gartes Bratt ange= bradyt, gegen werdaes bie 3 unge gericben werdent faum. Diefe beftegt 
meiftenz aแz einer riemenförmigen, febr beweglidyen, mit langen Dus = feln verfegenen Santeleifte, weldye zuweiten viel ränger als ber Rörper ift, tunb in siner eigenen Tafdse yor ober neben bem Gdluntopfe eingerollt reget. Diefe 3utige, weldye ein eigentlidjes (3reif= unb Sd)öpf=

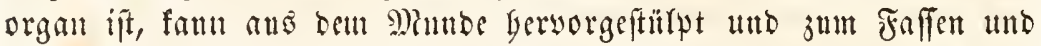
3ermalmett ber Beute kenust werben. 3u biefem Endjwesfe ift fie auf ifrer Anfenfläbse entweber mit queren gejägnelten Jlatten, beren 3ägne it Rängšreigen ftebet, ober mit zwei Neiben langer und fpitzer

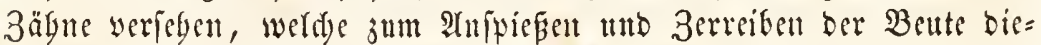
nen. Biele Gduedfen näbren fid) won gुolypen tno dieje traben meift

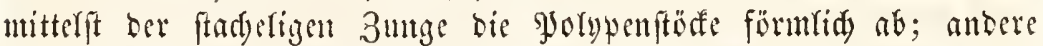

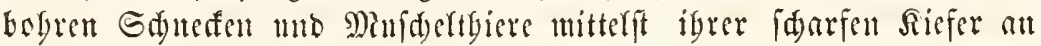

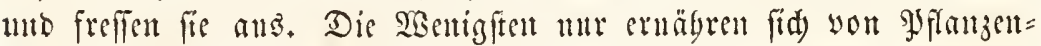
ftoffen, weldye fie mit 3unge mo Riefern jernagelt. Die meiften fimb

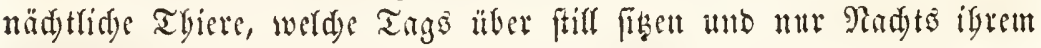
Ranbe nadgeben.

Der Darmfanal, in welden fid die fo ftarf bewaffuete Mlund:

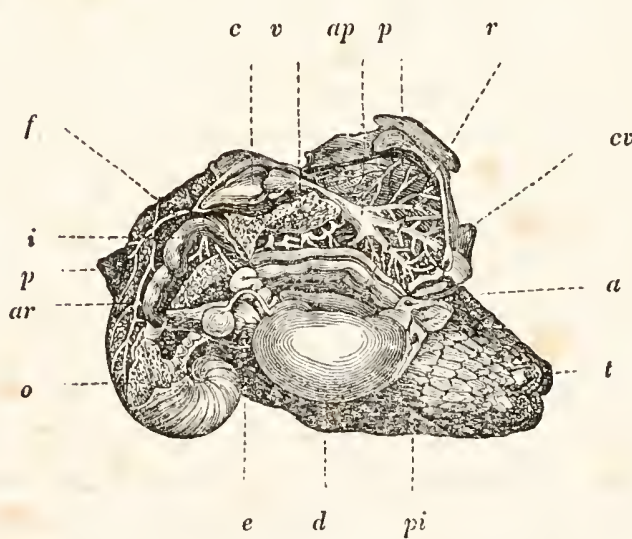

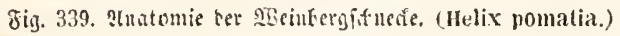

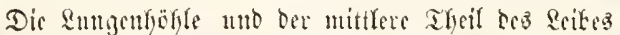

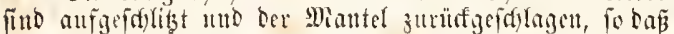

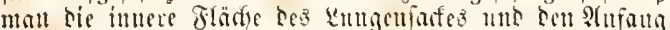

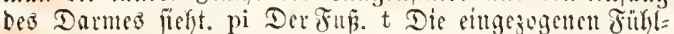
hörner, bie mur ned margenartig berteten, d-e Der

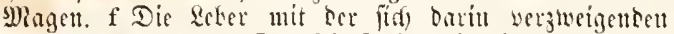

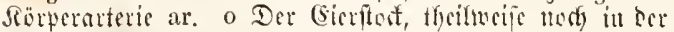

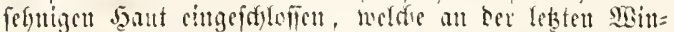

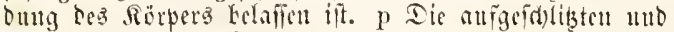

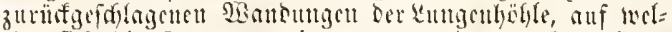

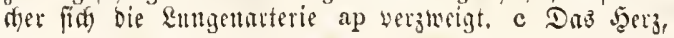

böble fortiest, if mei= ftens febr einfad) gebil= bet. Fine ntebr ober mitt= Der range Speiferögre, bie meift mit \&ängsfalten

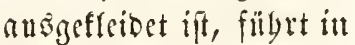
cinen Magen, ber ge= wögnlid büttnwantig, bei sittigen battungen aber fogar anf feiuer innern Seite mit barten Reiften ober ferbit bor= nigen 3ägnen bejetst iff. 3on bier aus wimbet fid ein fegr büntuwandiger Darm burdy die Maffen Der Cingeweibe, bejon= Ders ber Seber, binturd) mito sffinet fidf meift att der reduten Geite des̃ Sörpers it ber Räbe der 


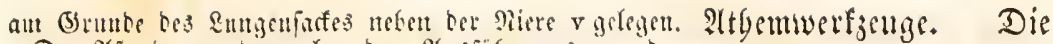

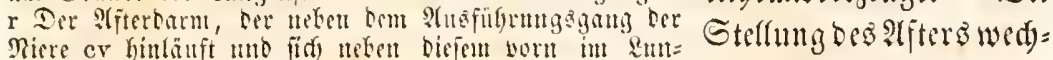
genfarfe im Sifter a sifitut.

felt ganj auferorbent= (id). Desiftens riegt er yorn auf oer red)ten Geite, oft mumitterfar Ginter bem red)ten Fïbler, bei anbern liegt er linfö, nod) bei anbern auf ber Rüafen= ober Bald fläde, Gald weiter binten, bald näber nIII Ropfe.

Speidyerbrüfen, welde in ben Gdylubfopf mo 3ungenfad münoen, feblen fajt feiner Sduede, ebenfowentig dic Reberorgane,

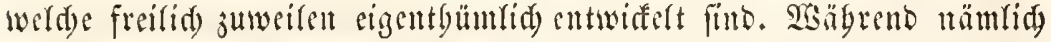
bei ben meiften Gduefen sine woblgebilbete Reberbritje worbanton ift,

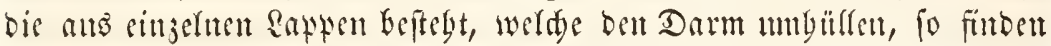

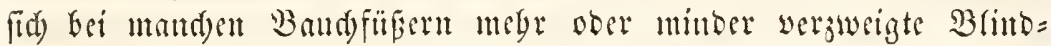
günge, bie meiftens in zwei gabelförmige Sanäle atsomünben, weld)e mit bem Miagen in Serbindung fteben unb oft gan; fas 2urfeben bes baumförmig verzweigten Darmfanales Gaken, welden wir bei ben Sambürmern uno ben Goblemwirmern fenten rernten. Die vet= 3'weigten Aefte biefer (5)änge enten blind auf Dem Rühen bes Thieres fait inmer in eigentyümlidyen fingerfơrmigen 2lubängen, welde wabr= (d)einlid) jugleid) alö Pthemorgane bienen. Die 2 Bandungen biefer blinben Sanäle, it welde ganj olye 3weifel aud bic Rabrungigitoffe eintreten, finto unt rigentbümliden 3effen ausgefleibet, beren Jubalt

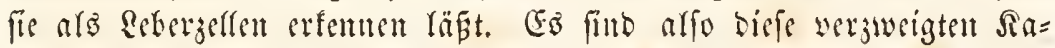

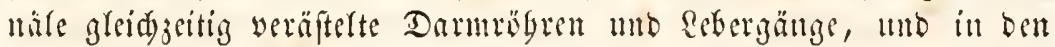

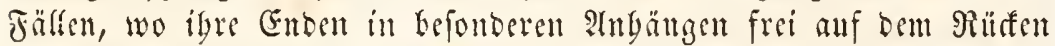

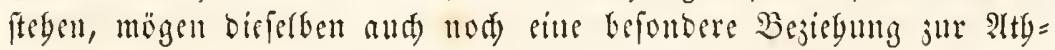
mung baben. Man wnrbe erit in nenerer Zeit anf biefe eigentbümliden

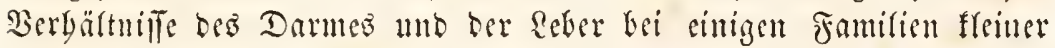

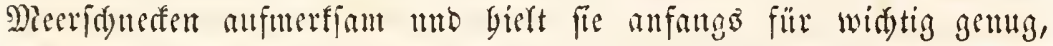
um Darauf sine eigene Drbunng, bie Darmgefäßler (Phlebenterata) ou grüben, bie aber bald wieber anfgegeben wurbe.

Gigentlide it themorgane feglen mur ben wenigften Sduneften, wo bant einzelne Etellen ber Syant die Function berfelfen üfermely= men. Dies dacint namentlidy bet Falt tei ben meiften Floffenfüpern

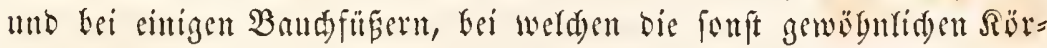
perangänge in siner blattartigen Maffe verfamolzeit finb. Sm llebri= gen find bie Atbemorgane bem shefentgalte ber Thiere entfpredent entweber in ber form yon Riemen ober aud als Sungen entwiffert. Die $\Omega i$ emen befteben ans feberartig geftellten ober baumartig weräftelten $\mathfrak{B}$ rättden, welde meiftens in eimer eigentyüm= 
liden Säbre bes Mantels in Rafen verborgen fint und burd) sillen

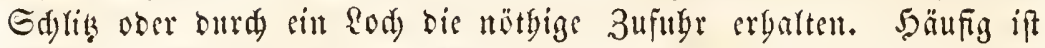

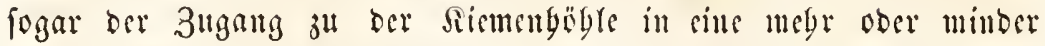

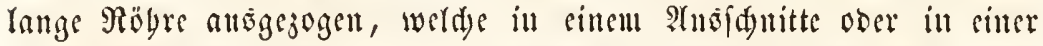
fduabelartigen Berlüngerung bes Gpindelrandes ber Mündung gele=

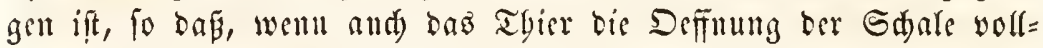
foumen mit feinem Deffer (d) ließ̧, Dentod) ber Zugang ju ber Riemen=

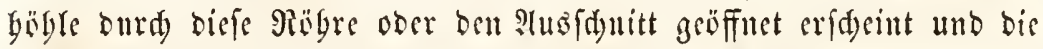
Pthmung unterbalteu werben tann. Die Ragerung ber ficuten wed) jelt auBerorbentlid); - febr felten nur find fie fummetrifa auf bem biu= teren Theile Des Rüffens ober im llmfreife bes Siörpers unter einer Rauterfalte angebrad)t. Bei ben uneiften liegen fie unfyumetrifd bald anf ber rediten, balb allf ber lintell Geite, wo bemlt igre Ragerung

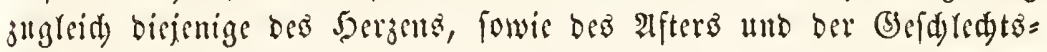
miltioung lebingt.

Die $\&$ ungen, werdje fid mur bei $\& a n b=$ mno Gïfwafferfdueffen vorfinben, bilben cinen ueift anf ber redten Seite geöfneten, gewöbn= (id) in ber Ratengegent gelegenen Saf, beffen innere Fläde mit

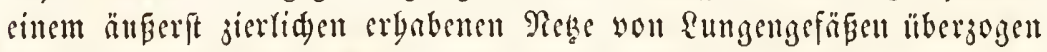
ift, welde fid gewölutid in sinen sinjigen Sauptoenenftamm faut: melu, ber fid mumittelbar in ben Borbof bes ant \&ungenfade gelege=

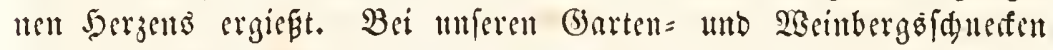

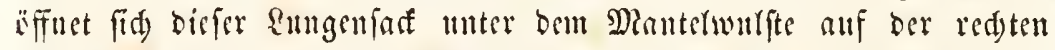

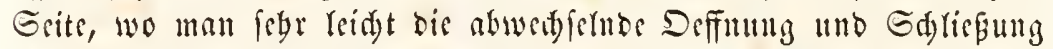
Des P(themlod)es beobaden famm.

Ein 5 gerz ift wobl bei allen Edueden vorbanden und ebento sin geregetter Błutfreislauf, ber indeffen bas Eigentbünlide bat, bag entweber die ganje 3eneubabn ober sin groper Theil berfertent burd)

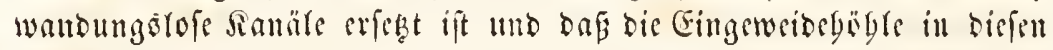
Sireis unit cingefd)loffen ift. Das Bhat ferbft ijt farblos, ofalifirent

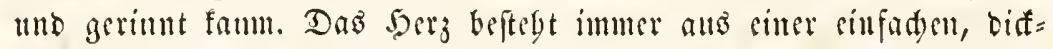
wantigen, rebbaft furfirenden Sammer mit siller cinfadsen coer bop=

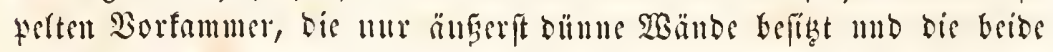
meift in rinem befonderen serjbeutel an ber Bafiz ber Sirme ober bes \&ungenfares riegen. Sou ber berjfummer gebt mumittelbar bie grope Sïrper=edlagnter aแz, bie fid) meift und furjem Berlnufe in

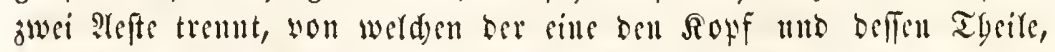
ber andere bie mebr uad) binten gelegenen Eingeweibe werforgt. Dis

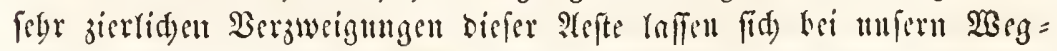
fducfen auf bem meift bramen Darme febr reidyt burdy ibre milds= 


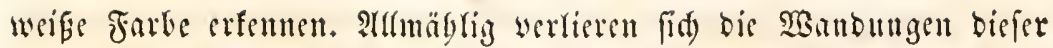

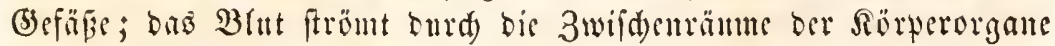

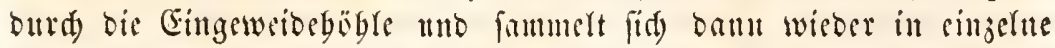

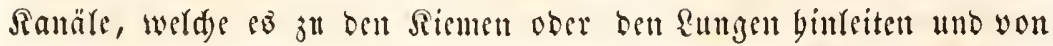
ba burd, die Riemenvenen bem berjen jufübren. Sb anfer biefen

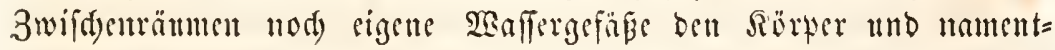
(id) Den Fub ourdjejeben, ift nod) nidgt genauer erörtert.

Reben ben Serjen tub meiftens in Berbintung mit ín einer= feitso und bem Maftoarme antorerfeits liegt fait bei allen Sdunefen ein eigentgjtmlider Drüfenfact vou blätteriger Structur, weld)er offen= bar sine $\mathfrak{B}$ iere ift, ba bie Jlüfingfeit, weld) er altsionbert, beutli= den (begalt an Jarmfänre erfemuen łäß̈t. Bei vielen Geefduefen

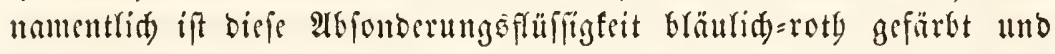

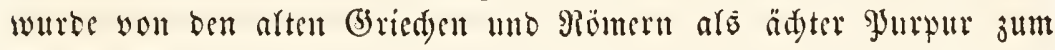
Färben bentizt.

Sproflen= ober Snospenbilonng, fowie Ammenzengung fomment bei ben Edyneffen nid)t vor. Alle baben (5) fdyled)töorgane, beten Bau

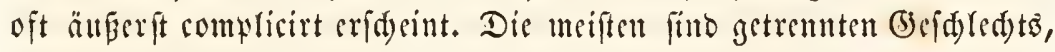
mande aber alld, wie nanentlid unfere Ranbidneten, Zwitter in

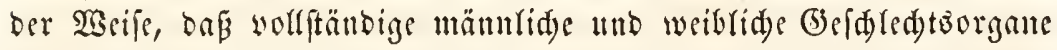
bei bemferben Gnbivionum vorbanben find mo gegenfeitige Sefruds)= tung jweier Indivionen ftattfindet. Die Entwirrung ber veridsicbenen

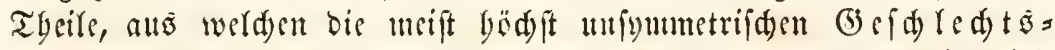
organe zufammengeferet fimb, bat bie Anatomen antierorbentlid viele

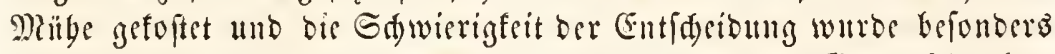

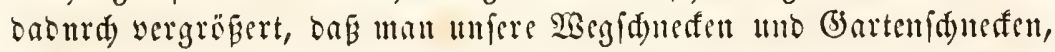

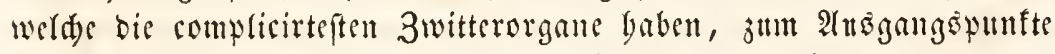

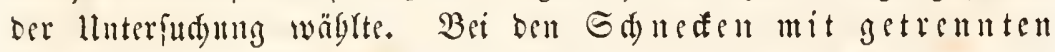

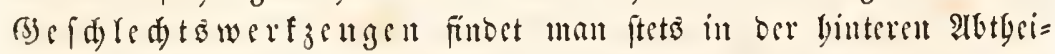

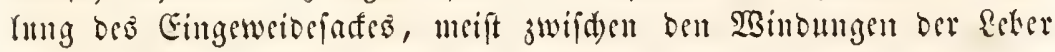
nerborgen, sine Driile, weldye ie nad) bem werfdsebenen Jubalte, fids als Eierito of ooer 5oos ju erfemen gibt. Bon biefer Drilfe gebt ein gewmbener si= ober Gamenteiter aus, ber fid nad worn begibt

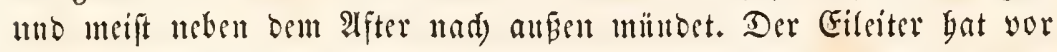

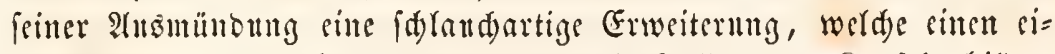
weifartigen Gaft abjonbert, ber fidser bie Sultlen und Siapleln bildet, in welde bie Eier ber Sduefen oft singefdyoffen fint. Diefe Siap= feln, welde man bejonber bätfig an Sanferpflanzen ober Etcinen findet, baben mandmal sine fegr fonberbare Gefalt und finto mit eigentbümliden Defeln werfeben, weldse oft erft burdy bis erwadenent 
Earyen aufgefpren gt werben. Bei ben mämuliden Sduefen getrennten (befdedeto fetzt fid) Der Samengang in eine meift lange, mebr ober minber gefrümmte, zungen= ober bafenförmige Rutbe fort, bie meift binter bem redsten Fübler berworgeftillpt werben fann ober and) in

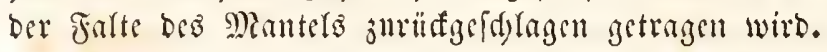

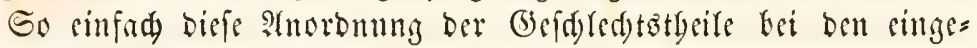
(d) led)tigen Gdenefen erfdyeint, fo verwifelt ift bie Bifoung bei ben 3 wittern. Dod) rägt fid iun ?tergemeinen folgender Typus ber Bit= bung etfentren. In bem Grunbe bes Eingeweibefafes liegt cine Drüle, weldy aแz in cinander geidadytelten Blinbläten werfdyiebener Ratur

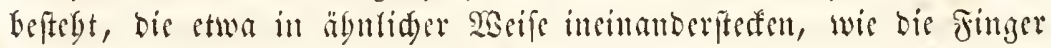

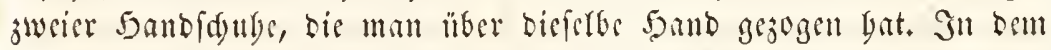
inneren Drüfenbalge entwidetn fid) bie Samentbierdifn, in beut äll= fieren bis cier. Es ift alfo sine förmlide Butterorüpe vorbanden. Die fämmtliden Drüfenbälge vereinigen fid juleţ่ zu zwei gefonder:

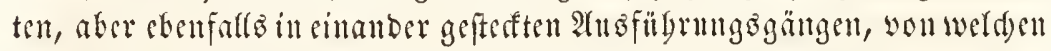
ber äufere ber Eifeiter, ber innere eingeid)loffene ber Smmenteiter ift. Sm weiteren Berlaufe trenmen fíd biefe beiben Röbren megr ober

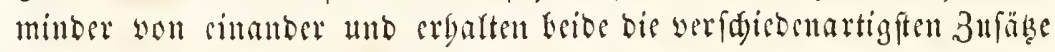
ourd) Drüfengebito aller art, welde oft bödsf merfwürbige, afer fegr

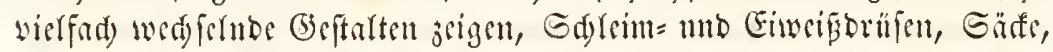
in weldyen eigentgümlidse Ralfeneremente fid bitben, weld)e wis co fdeint, fur Reijung bei ber Begattung benutgt wetoen (bie fogenann=

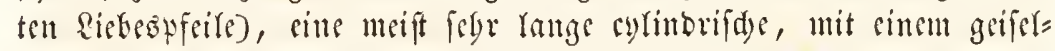

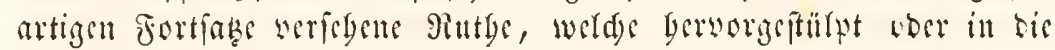
Reibegböble jurüfgetragen werben fann, vermebren bie Malfe biejer

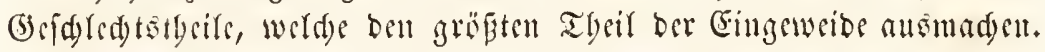
Die (berd)led)töbffum und meiftens anf ber red)ten Geite angebrad). Gewöbulid liegen

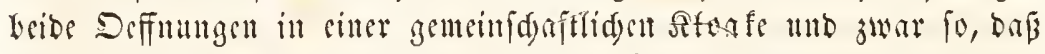

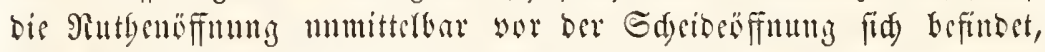
zuweilen aber aud trenten fid bribe und baun rifft bie Deffutitg, aus welder bie rutlye Gervorgeftülpt wirb, medyr nad) vorn gegen beu

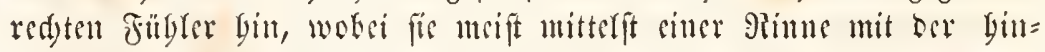

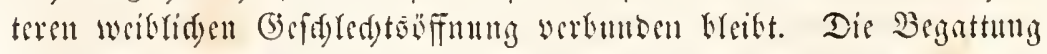

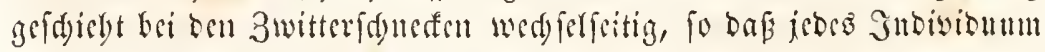
gleidgseitig befrudstet uno befrudstet wiro; bod) find and unjweifel=

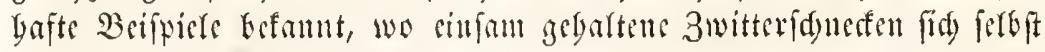
befrudteten uno entwiffungsfäbige (Eier berworkraden.

Die Fiet der meiften Gduefen entyalten nut cinen werbärtmis: 


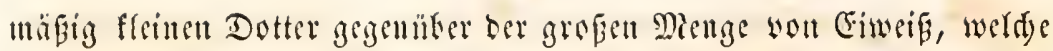

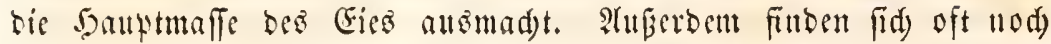

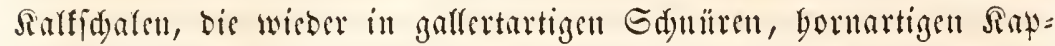
feln unb mandertei fertianen lumbüllungsgebilden eingefdroffen fint.

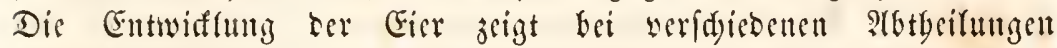

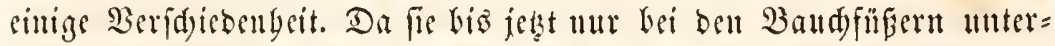
fud t ift und aud bier mur bei febr wenigen strten, fo werben wir erft bei biefen bie Entwiffung ber verfdebenen, bis jekt befannten Typen genauer in bas Fuge faffen. So wiel ftegt feít, bap alle Sdueffen mit bent ganjen Rörter aus ben Gie entiteben unb baj niemals eine

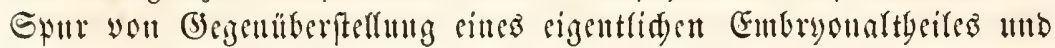
eines yon biefem verfdiebenen Dotterjates vorbanben ift, fo wie baß bie meiften Gdueden eine Sarwenteriobe burdmadyen, wäbrenb wet= d)er fie eigentbizmlide Gdymmapparate befizen, sie ignen geftatten,

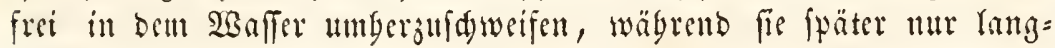
fam fried)en fönnen.

SBir theilen bie Gdunefen bauptfäd)lid nad ibren Bewegungs = organen in brei Unterfalfen ab, won welden bie lekgte bie zabl= reidgle und entwiffeltite ift.

\section{Hutcrlitufe ine Itoffenfüffer. (Pteropoda, )}

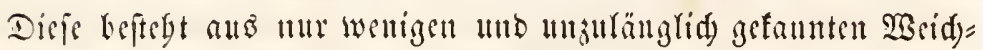
tyieren, welde fid) alle baturd) auszeiduen, baf vorn aut Ropfe flïgelartige Fortfäze angebrad)t finb, bie man früber fïr Siencu bielt,

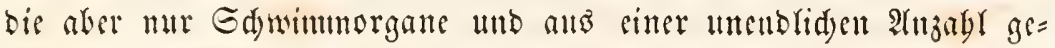
frenjter Matofelfajern gebildet fitto. Die meift febr fleillen Thiere treiben fid mitterft biejer Gdwiummlappen alt ber Dberflädse Dez Meeres uแber und werben nur felten burd) Serfd)lagen in ber Räbe bes Etranbes angetroffen. Sie finb alle Naduttbiers, beben fid) erft

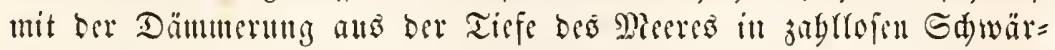
men Gerauf und finfen mit ben Morgenlidyte wieter binab. Tagz über trifit man feine Spur von ignen unb mande arten foumen nur 
in ganj finferen Rädten an bic Dberflidge. Dic Ed)wimmlapten find and bei rubigem Salweben in feter fdjuingender Bewegung,

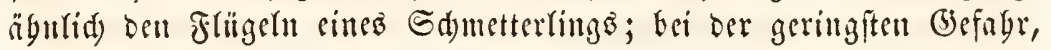
bie fie merfen, jieben fie bie Mindertapten sin und finfen in bie bunfle

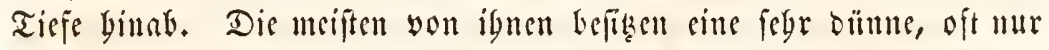

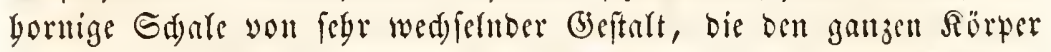

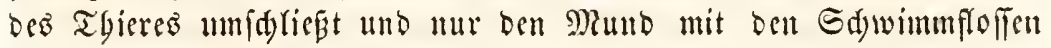

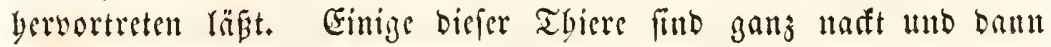
von einer fefteren 5aut umgeken.

Sn alfen Sörperorganen obue Stus̆nabme zeigt fid ber nicbere Stand ter Drganifation biejer Ibiere. Den meifen feblt cin eigent=

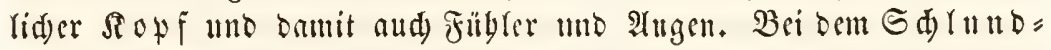
ringe finb bie oberen bianglien meift ound) einen cinfaden Berbin=

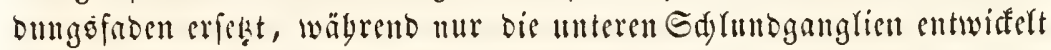
finto. Nar zwei Gattungen beritzen 2 ngen, den übrigen feblen fie, wälrend bie (B)

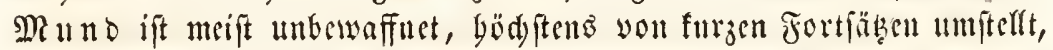
welde zuweiten Sangnäpfe tragen. Er fübrt in cincu muğfulöfen

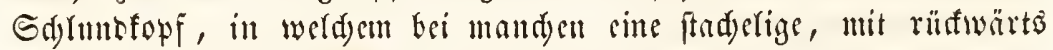

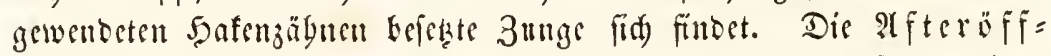

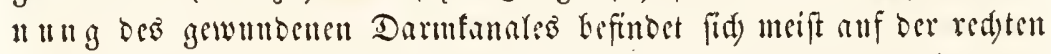
Geite, juweiten aber aud anf tor Baudjpeite in ber Mittelfinic, oocr

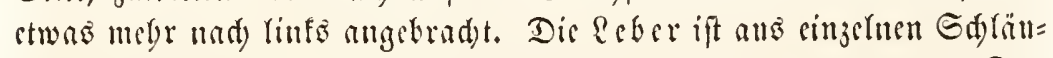
d)en zufanmengefest, weldye numittelbar in son Darm münden. Das

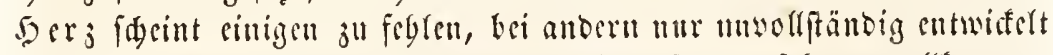

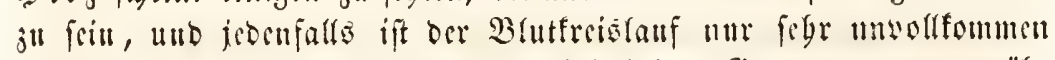
bergefferlt. St be morgane fegren bei cinigen battungen ganz, wäb= reno anbere cine geränmige Diantergöble gaben, in weldyer sine fädere artige Sieme servorgen liegt. Die Gleflenfüber fotten 3 witter fein,

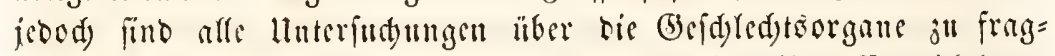

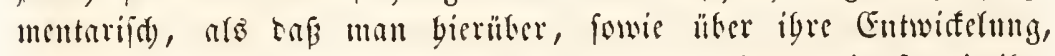

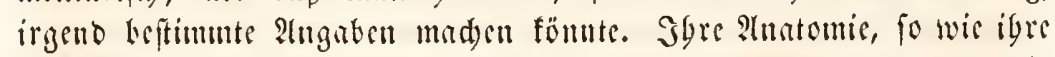

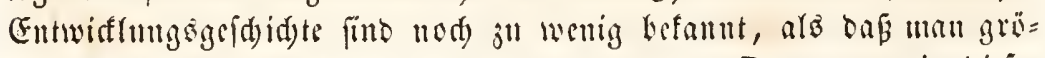

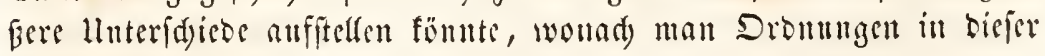
llnterflafle anerfenuen mübte.

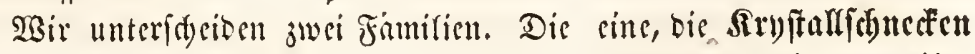

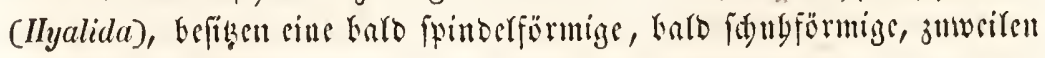




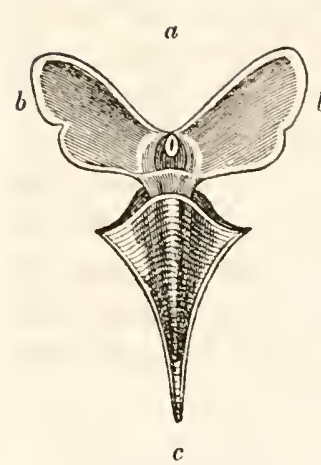

ซึig. 310. Hỵalea.

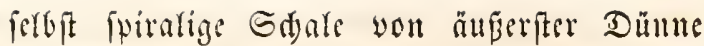

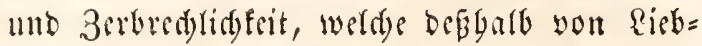
baberu meift tbeuer bejablt mirb; fübler, 2 as= gen feblen ourdans, wie bent hberbant fein Deutlider Sepf zu feben ift. Die Mrunböfmung befilloet fid swifden ben beiben Sd)wimmlay = fen, weldae borijoutnl ju beiben Geiten fteben unt meiftens in bie Sd)ale jurliffgezogen wer= ben fömtell. Sie leben in allen Deeren und fteigen namentlid) $96 b^{2}$ bs it $G_{d}$ wärmen an die Dberfläd)e, um fid fä fäter ju verfenfen. Sdaten, weldye biefer Jamilie angebören, bat a Der mifdsuben Edymum= man in ben tertiären Edyidten gefunben. Sb Iappen liegonte whutb. bb bie fogentanten Gomularion, welde fids in ben lapten. c Die burdfindtige llebergangsgebilben it jiemlid) groper ATnjabl Edrate.

finden, bant aber verfdwinden, wirflid biefer Fantile angebrinen, büfte wobl nod) sweifergaft fert. Hyalea; Limacina; Cymbulia; Cleodora; Eurybia.

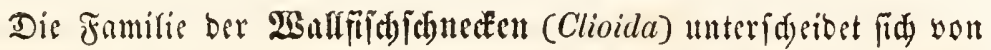

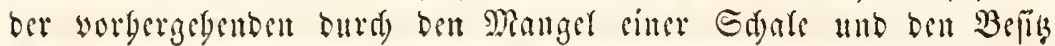

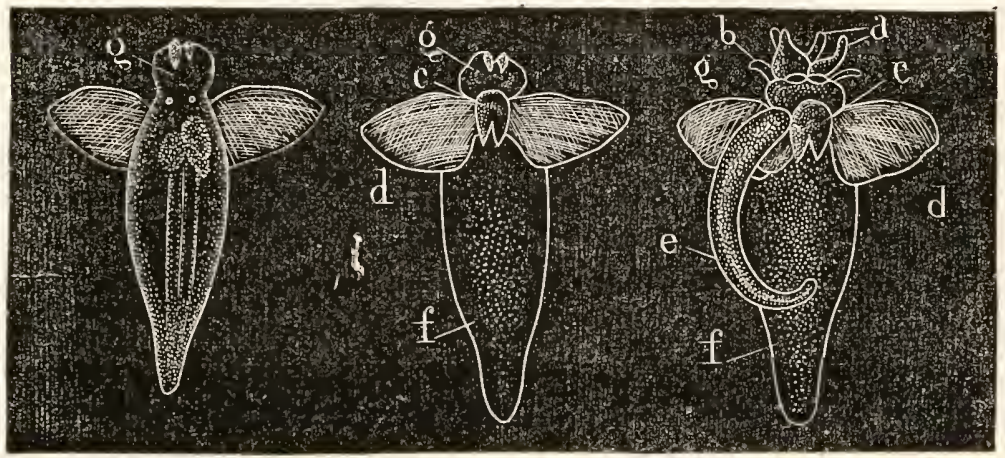

Jis 311.

Eis. $3: 2$.

Jiv. $3 \div 3$.

clio borea!is.

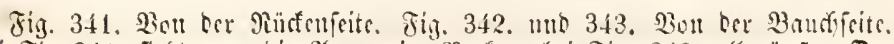

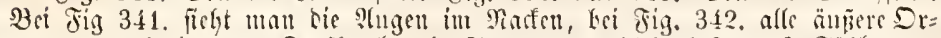

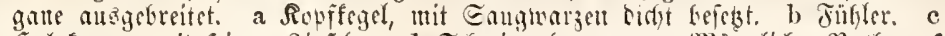

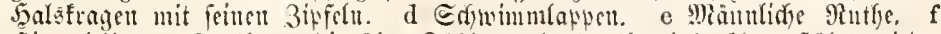
Sinterteib, g Ropffutte, hie jiter Füfler und Ropffeget berübergeftulpt wirt. 
simes eigentriden Soyfes, ber beutfidy won Dem Sïrper getrent ift unb meijtens Fübler, bei einer Gattung fogar atugen trägt. Dis (3)attungen, welde befonders in ben YJolarmeeren ber Morb= und

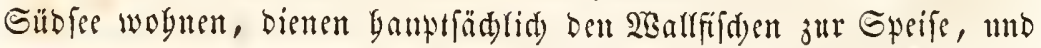
ba bas ganje Thterden faum einen 3ull rang ift, fo fann manl leidst ermeflen, welde ungebeuere Maflen son ignen nötgig find, un ibre

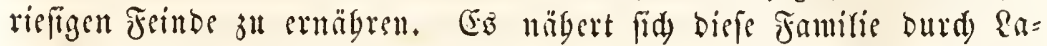

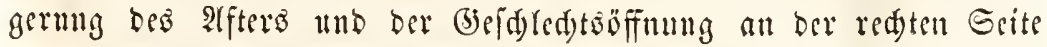
bes̃ Jarfes fdon megr ben sigentliden Ğuecten. Clio; Pneumoderma.

\section{Lunterliluffe ier fairlfiufict. (Heteropoda.)}

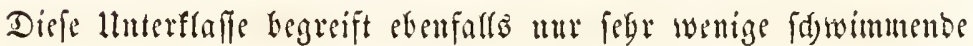
Thiere mit fpindelfürntigem Sörper, ber ganz glasartig burdyjuthtig

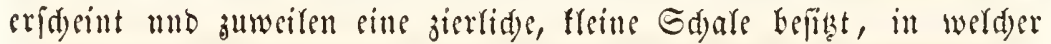
aber unr bie 5ampteingeweibe verborgen find. Das Edjwimmorgan beftegt aus sincr fielartig jufanmmengebrüaten froffe, welde in ber

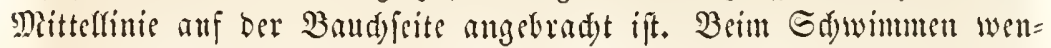
ben bie Thiere biefe floffe nady oben, wäbrend bie Müffenflide nad) unten gebregt ift. Der Sorf ift bentfids, mit megr ober minder aus=

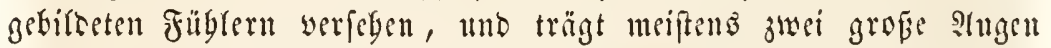
mo einen langen Plüffer, an befien vorberem Ende bie mit Etadyern

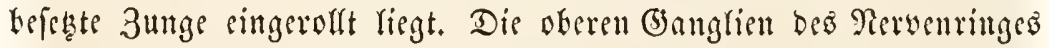
find uncift bebentend entwiffert, bie unteren weit nad binten $g e=$ fa)oken unb liegen in ber Räbe bes Gingemeibefnänets, weld)er bei

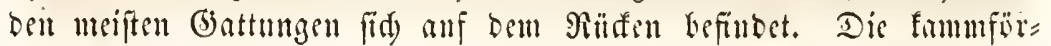

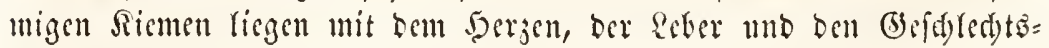

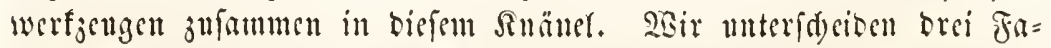
unticu. Die 2 (t)

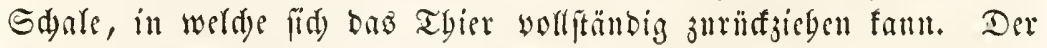

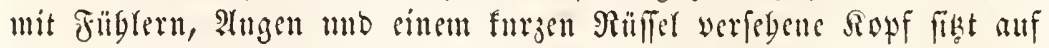
einem verlängerten 5arfe, anf Deffen Bandjecite ber Yanzettförmige, mit sinem Sanguatfe werfegene Sdyimntapten und nod sin jungen= 


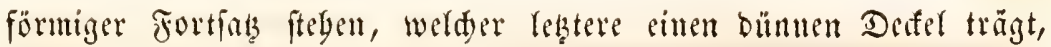
mit bem bas Thier beim 3urïfjieben bie Sdyalenöffung verfd)liepen fann. Die Siemen liegen im Gumeren ber Gdale verborgen. Der

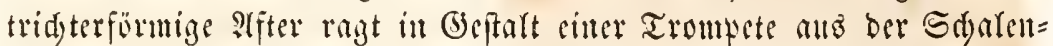
öfinting bervor. Atlanta.

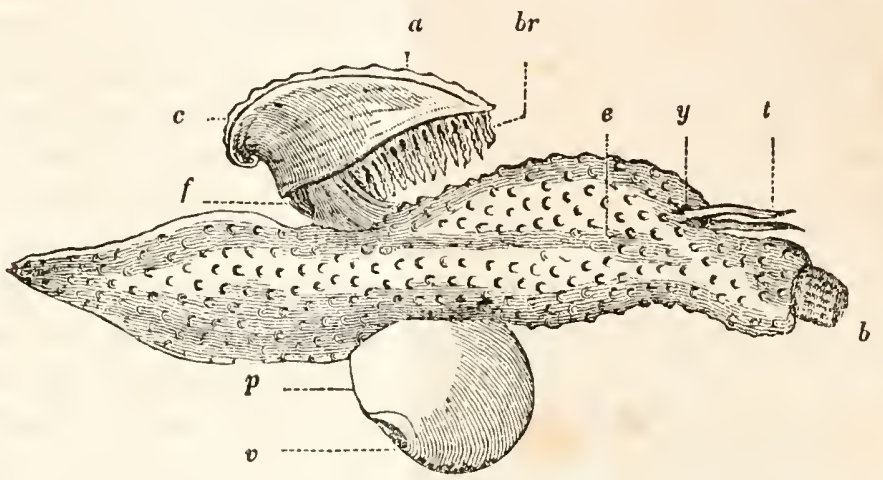

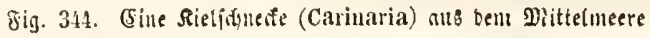

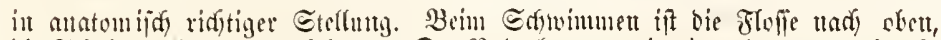
die Edfale nad) unten gefefrt. p Der Ruberlappen mit citter Daran angebrad)=

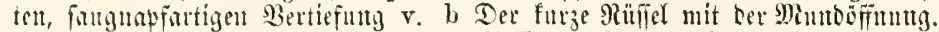

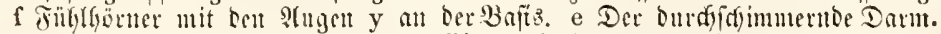

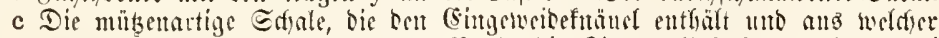

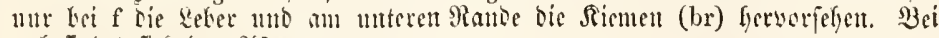
a befindet fict) ber sifter.

Die Familie ber Sidfeftueden (Firolida) ift entweber nadt, ober bat unr eine fleime, milzenfürmige Sdale, weldye ben Cringenveibe=

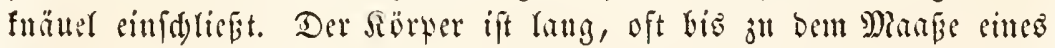
Fubes, frinbelförmig mo fo bud fidstig, baß man alle Finjelubeiten Der Drganifation bei bom unverlesten Thiere verfolgen fant. Die Thiere erfd)einen (d)on in bem Mittelmeere juweilen in grufen Sd)wär=

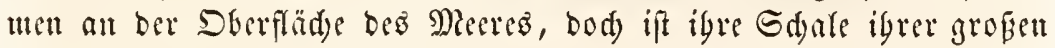
3erbred lidfeit wegen mur ferten unverlest ju erbalten. Carinaria; Firola; Pterotrachea.

Rur proviforifd) ftelfen wir als britte Fantilie, bie un sitte ein= jige Gattung entyält, bierber die Pfoilïhueden (Sagillida), fleime Thieve yon fpindelförmiger (beftalt, mit beutlid) abgefestem Sopfe

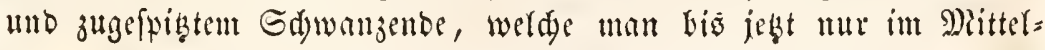


8iร. 346.

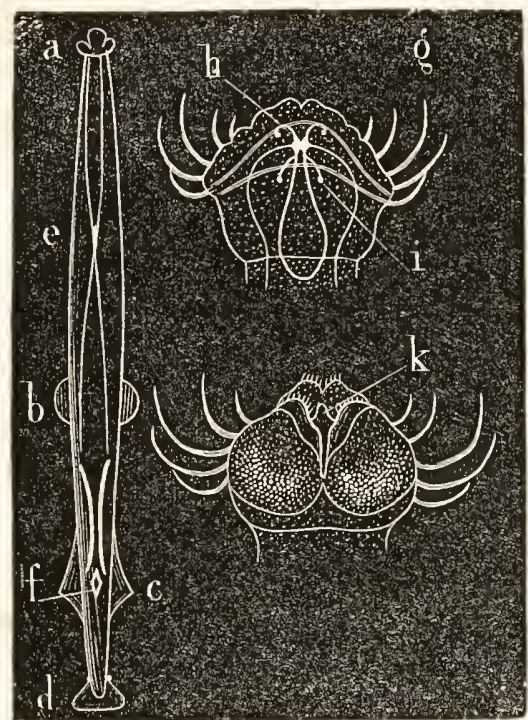

ชิiฐ. 345 .

J̛ig. $34 \%$.

Sagitta.

Tig. 345. is a ganje Thier bon eten. Fig. 346. Der Ropf you ofen, fiatfer ver= grepert. Fig. 347. Der fopf wou unter. a foof. b Borbere, c mittlere, d Gintere Edyminmfoffe. e Jinterer 9ervenfnotin. f Slfter, banor bie meiblifyen, weiter linten bie

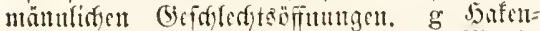
fiefer. $h$ fgirmfneten. i sfugen. $k$ slinto. meere und ber Norblee gefun= ben bat. Der Sopf ift Deutlidy ifolint und unter ciner fapuzen= artigen Berlängerung oer fonit burdfidtigen Saut verforgen.

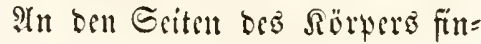
ben fid mebr in Der Mlitte mo nad, binten bin siwei Paar bori= sontales Gduwimmlappen, unb bas Gdimanzende ferbit ift von sinem Gdumimmlappen umgeben, welder stwa die (j)eftalt des fe. Derbartes an einem Syfeile bat. Der Minno ift mit fritliden $\mathfrak{S a}=$ fenfiefern bewaffnet und auf Dem Solfe fiebt man in bem Raden öwei wenig entwidelte $\mathfrak{T}$ ungen unb Filgler, wabrent oer alfer it ber Mittellinis ber Baudfläd)e,

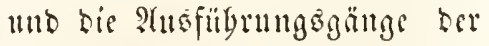
juitterartigen Gerdsed)tötbeile Haarweije auf Der Riufenfeite fit offnen. Dic Gduelligłeit Der $\mathfrak{B} e=$ wegungen diefer Thiers ift Deutens. Sagilta.

Lutcrlitaffe Der Bunchfulf;et: (Gasteropoda.)

Die britte, bei writum grögte lluterfaffe ber Edjuefen wirb you ben Bandfï̈ßrern (Gasteropoda) gebildet. Sic unterfdeibent fid) won

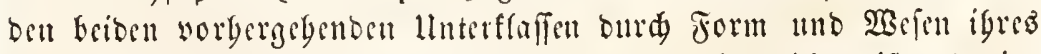
Bewweguแ

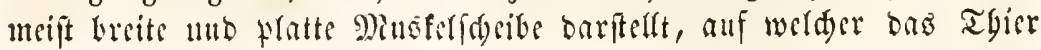

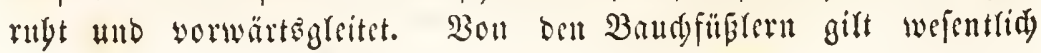


Dasienige, was wir won ben Gduefen liberbant fagten. TBir theilen fie, Had) ber 3iloung ibrer Pttgemorgane, in zwei Dronungen, bie Riemenfduefen (Branchiata) und bie \&ungenidnefen (Pulmonala), weltye wiber Durdi andere Drganifationsverbälniffe in flemere llnterabtbeifungen jerfallen.

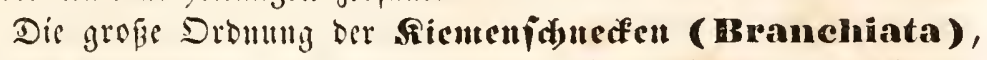
welde baupträd)(id) bas Mieer bewobnen, zeidnet fid) außer ber Struf=

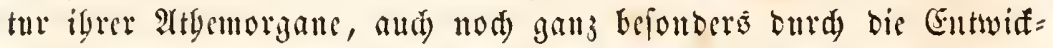

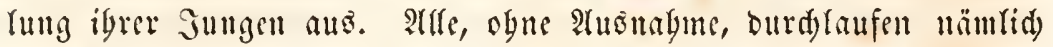
cinen Rarvenjuftand, wäbrent deffen fie burd bemimperte Siopfrappen jum Sdymimmen befäbigt fint. Radbem die Jurdumg bes Dotters

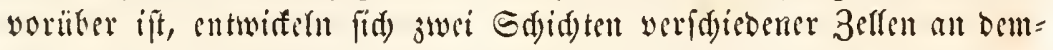
ferben, yon bellen bie äufere, Geflere Den Mantel, bie Saut unb ben Ropf, bie innere, Dunflere bie Eingerweide bilbet. Der ganje neu ge= bilbete Embryo gleidyt nady der atubildung biefer Sdjidten cincm Rudben, an beffen eintr Sälfte fid Frimmerbanre von mebr ober

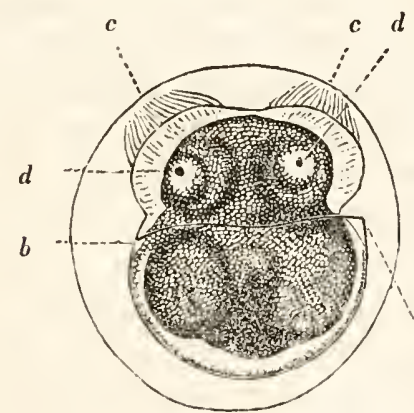

Sịg. 3 หุ.

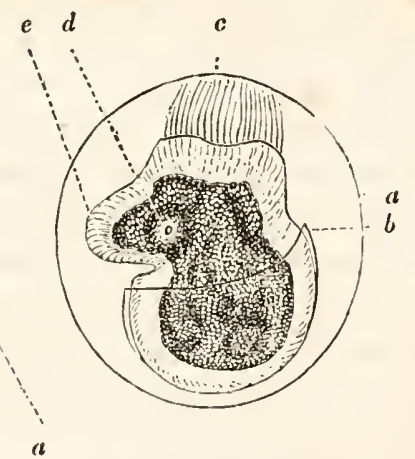

ชิiง. : :19

Der Gmbryo eimer Sternidnefe (Doris)

im Beginne feituer (5ntmilfelung uno nod) im (sie eingeforslofien. Fig. 348. Bout

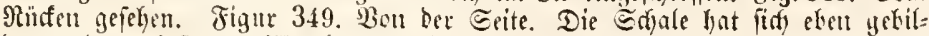

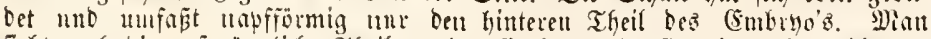

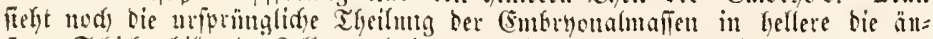

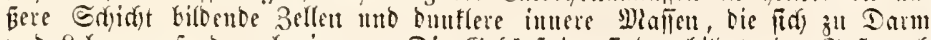

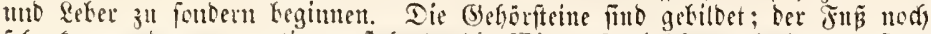

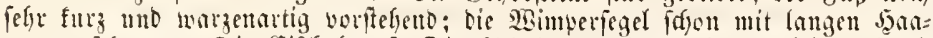
ren verfeter. a Die Siidate. b Die Sdjale des (smbryo's, c IRimperfeget.

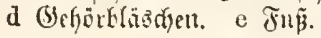

minber bebeutenter \&änge entwiafeln. Der Embryo, befien Flimmer. Gaare anfangs in keftändiger Bewegnng fint und cine fete Drebung แm bie Are bewirfen, jeigt fid) nun aus jwei Regionen jufammen=

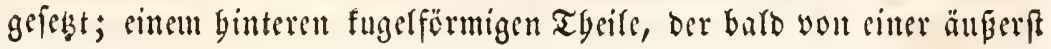




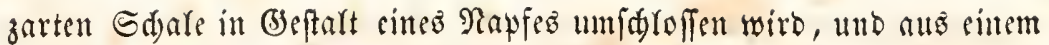

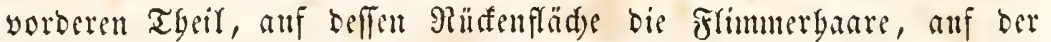
Bandffläde bingegen sin zungenförmiger Fortfaz fid befinbet, ber (iid) allmäbrig zum forpe ausbiloct, wäbrent man jugleid) im Juteren bumfrere Zeflenbanfen wabrnimmt, welde die Entwiffelung bes Darms

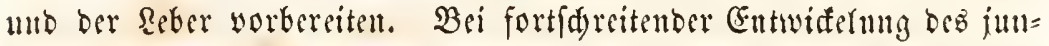
gen Thieres birben fid) alle fo angeregten Srgane nad) mo nad) ans. Die Stelle im Raden, wo bic frimmerbaare fid befinben, wäd it $z^{4}$ zwei bäutigen Gegeln aus, bie meif mit auberorbentlid) Yangen sim=

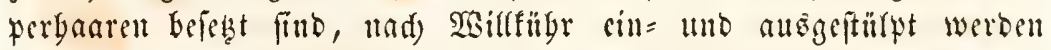
fönnen uno ein fegr wirffancs Sd)wimmorgan für bie freigeworocnen

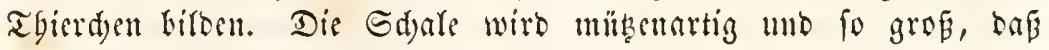
bas ganje Tbier fid in fie zurüfjieben uno mit cinem an ber Soill=

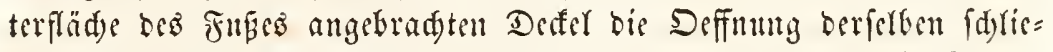
fen fant. Bon ben inmeren Drganent fiebt man zueret bie Gebör= organe mit ben in ifuen befinbliden beböritemen erfdeitnen, bann ben gewunbenen Darmfanal, beffen Manbüffnung fïh zwifden ben SBimperfegeln befindet, wäbreno Der Iffer anf ber red)ten Seite in

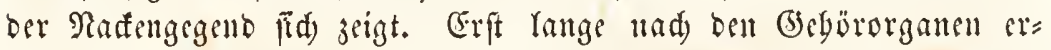
(d) cinen bie angen unt zulest von allen immeren Drganen bas berg, to baß bei faft allen biefen Sduefen bie ganje embryonale (5ntwiffe=

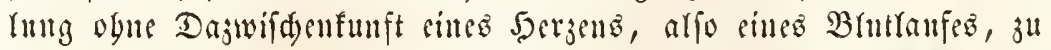
Etanbe fommt. Inbeffen feglt auth bei ben Cimbryonen sin llmtreiben

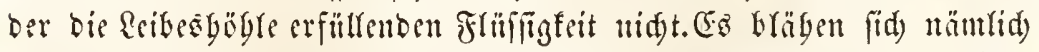

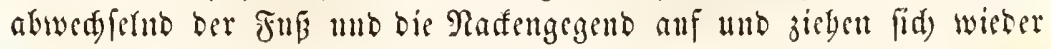
zujammen, fo baß anf bicie : Jlinfigteit won vorn nad) Giuten unb umgeferrt Statt findet. Dic

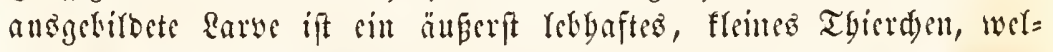

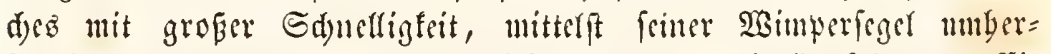
(d)wimmt uno meiftenz aud) in biefen 3uitande bie Sapfeln ober Fi= fd) fäude ourdbrid)t, in welden bie Gier fid befanben. Bumeilen (Paludina) geidjebt dice Durdbred)en fdon im Cilciter ber Mintter,

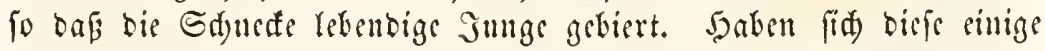

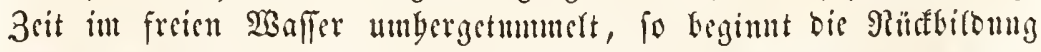

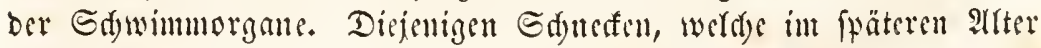
naft funb, werfen bie Sdale ab, wagrent bei ben anberen fie fid) nad) uno nad ju igrer bleibenben Form geftaltet. Şinter ben Gegelu, welde affmäglig cinfdrmmpfen unb enolid) vollitünbig verloren geben, fproffen bie Fibgler bervor uno ber Fus entwiatelt fid mebr uno megr

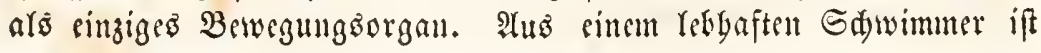




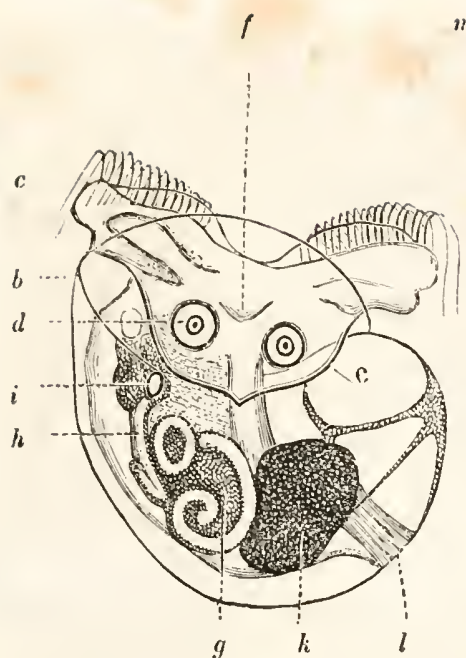

ซig. 351 .
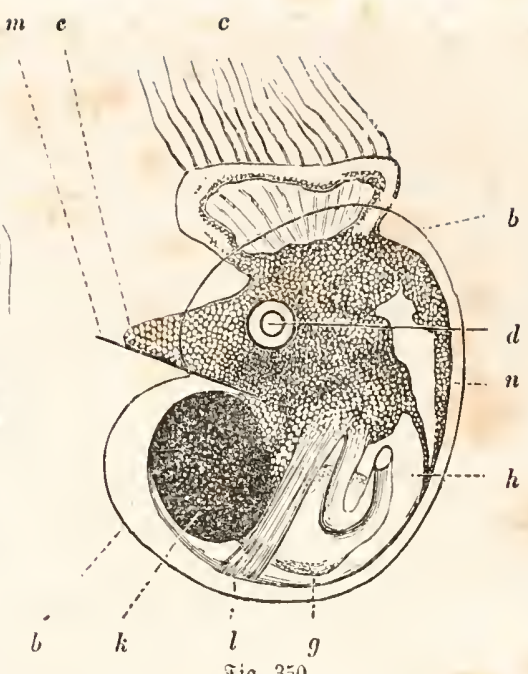

ฮin. 350 .

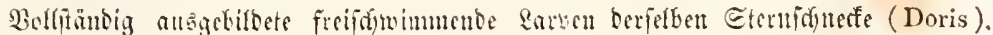

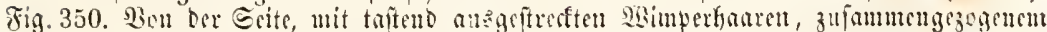

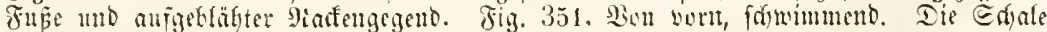

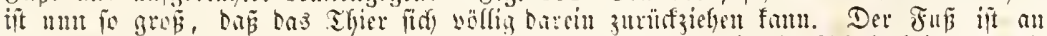

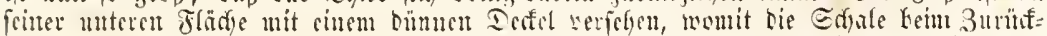

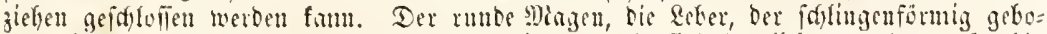

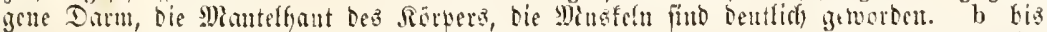

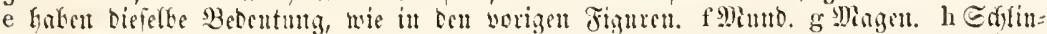

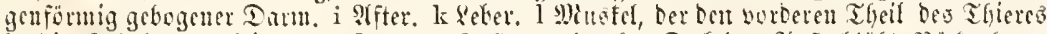

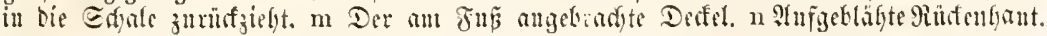

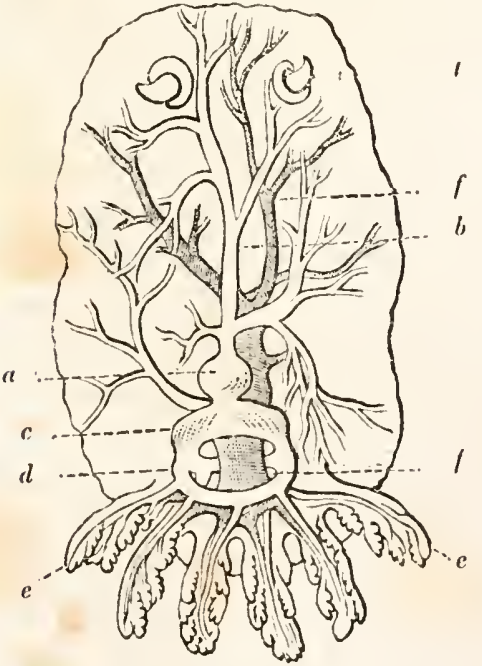

Jig. 232.

cine langfam fried)ende Grbuefe ge= worben. Die Gröge mo Thasbil= Dung Der SBimperfeger, die Beftnlt uno Fns Barbätmif ber Gdale buloen bie weientlityifen lluteridjese juifden ben Embryouen jener Thiere, welde im ermatd fenen शlter fo anfer= ortentlid veridjeben finto.

Tad) ber Enge fer Altgemor= gane, Gauptiäd)lid) im Serbätntís jum 5erzen, unterforioen wit zwei grögere llnteroronungen. Bei ben Diúcuficuevu (Pisthobranchia) frömt bno 3 rut you ben nuf bem Rüfen gelegenen Rie men ber gegen Eno Sarij ju und die

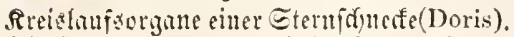

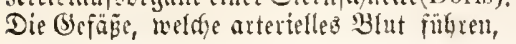
Degt. Boologifite Biriefe. I. Sorfanmer befinter fid) in Jolge 
find buth cinfartye Einten angegeben, bie Benen into froattict. a Die serjfammer.

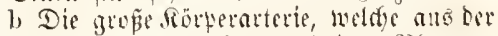
Sergfammet cutpringt mo das Silat ju Den Drgane! res Röpero fringt. e Die finter bet Rammer gelegene Sorfammer bes jelzens, welife bas won bon rie

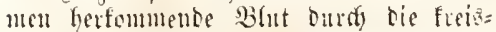
formige sientensene d ethäl me es bent 5erzen zupentet. f Die Sanptëtpervente,

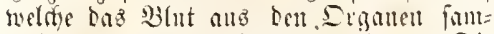
melt uto es Den Riumen zufullut. $t$ Dic Fïblet Del Edfuerte. bicfer Ragerung biuter der sigent= Yidsen Jerjfammer. Dis Rismen

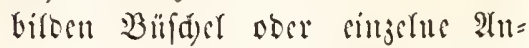
bängfel, melde megr socr minber unbebeft auf Dem Piüfen ober au Den Seiten Yisgen; fapt niematö fin= Det firt) sin sigentlid)er Mantelum= (d) lag in (beftalt einer Siaflize, weld)e sine Riementiogls in Der Ratemge= gend birtet. Alle zat diefer atbetbei=

rung gebibrigen Gdueden fint 3witter mo bie meipten von igmen baben utr cine fegr bourtig sutwidfelte Gdyale, ober find itn erwad)= fenen arter solfomment madt.

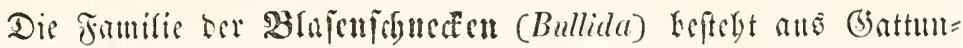

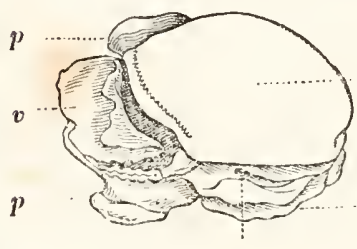

c gen, weldye fid) Den Flïgelfloffert nod) am meiften näberth. Dis blattartigen

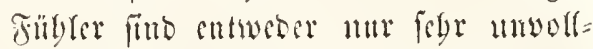
ftïnbig entwirfert und alf Dem giliten $p^{6}$ ju eimer Santhlatte werwad) fen, ober fie feblen aud gänjlidy und ber Sorf jeigt fid) nur alo cin vorberer Sittopf, it 8ig. 353. Tas Thier her Bulla hydatis weldyem bic breite, mit Sucrplatten be
aus ber Edyale genument.

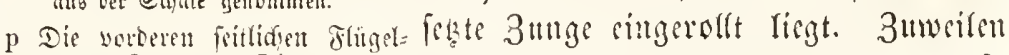

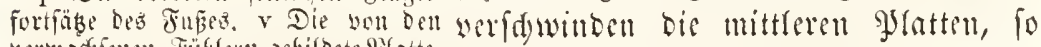

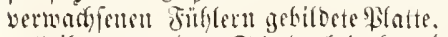

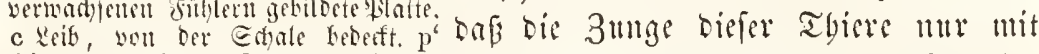

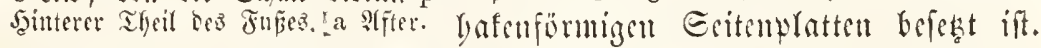
Biele find ganj naft, antore baben sine bünne, baudige, mit geringer

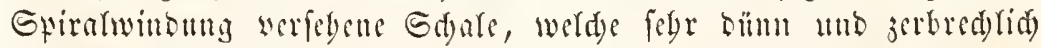
ift, und tysifweife ober ganj in ben Mantel cingelaffen erfasint. Dei ben meiften ift ber Fuß mad) ben Geiten bitt blattartig ausgebegnt,

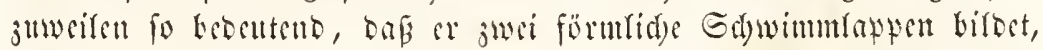

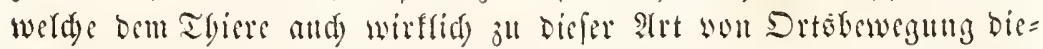

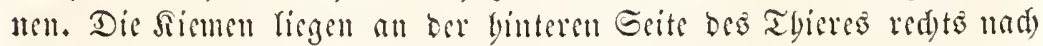
Dem Siüfen ju unter citter Mantelfalte verborgen und befteben meift

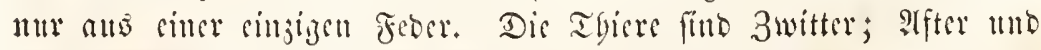

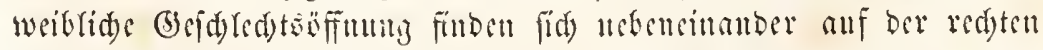

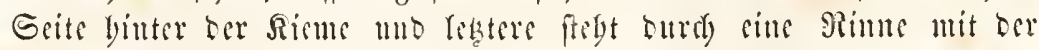

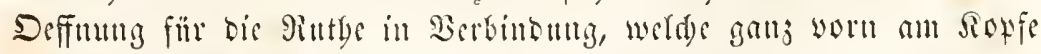
binter bem red)ten Fübler berwortritt. Sie Eduncten biefer Familie wobnen battptäd)lidy in wärmeten Mecren, wom Mittelmeere an fïb= 


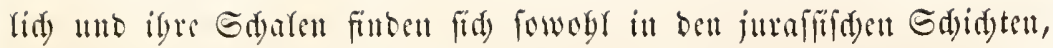
ałs in sen Tertiärgebitenen. Bulla, Bullaca, Doridium, Gasteropteron.

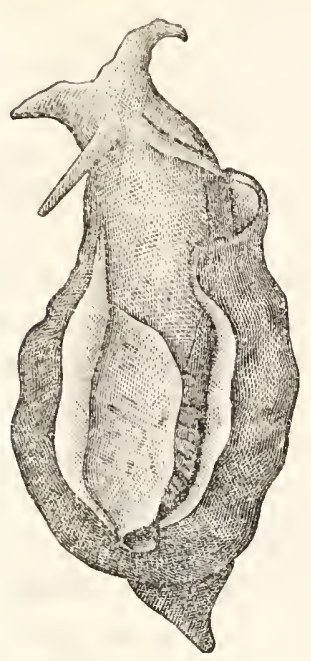

8ij. 35\%. Gewibntifyer Gee= baje (Aplysia depilans).

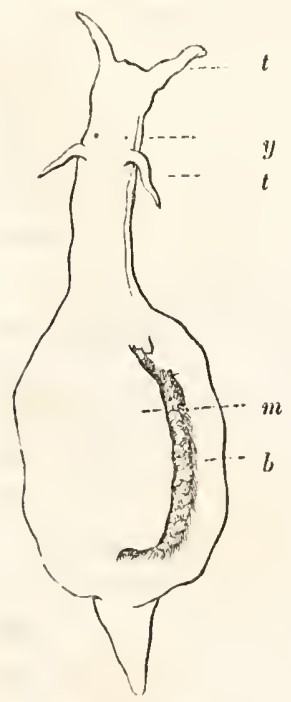

8ig. 355 llumrí bes Ecehafu you obes mit zuriafgefolage= neui Miantel.

tt Bortere nito rintere Futhler. y Salugen, m Der zuritfigejd)lagetle slliantel. b Riement.

Die Jamilie ser Sechajen (Aplysida), der worigen ferge ägulids, wirb son grofien, oft fubs langen, fait gänzlids nactent Ed)neften gebilbet,

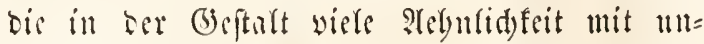
feren madten Randidueffen Gaben. Der Siöracr ift nad) Ginten breiter, nad) vorn barsartig werfomatert, who ber sopf mit juei baar Füblern verlegen, you weldsen bie worberen breit und Grattartig, die binteren runo and

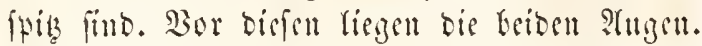
Der Jufi ift ziemlid) fdmal, ber Miantel baje= gen breit unt feine freien Panter werben meif

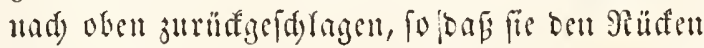
grögtentbeifs biffu. Die Sicmen befundu (iid) Ginten uno redists unter sinter jwsiten Mian= teffalte, in weldere cine bünne Gornartige Sdgale

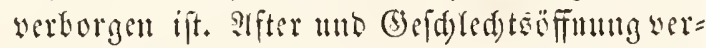
Galten fid) wie boi ter vorigen Familie. Dor Mrtmo ift mit sincr breiten, mit vielen grjäb= meiten Surrpratton bereşten 3unge bowaffintet. Die Thiore foubern, wic es fdjeint ju ifrer Dirtbribigung, ats ben fritliden Rapwen bis

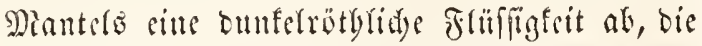

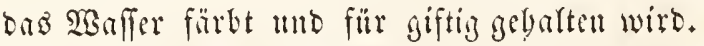
Gie frisden bauptfädylidy unter Den Tantgen an Dor Silifte umber mol fintoen fid mand)mal fo zablreidy, zấ man bei ftarfer Gabe den Strand ganj baunit befäet findet. Aplysia, Lophocercus, Lobiger, Dolabella.

Dir Fubenidnusten (Eolida) birbsu cine

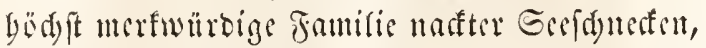
welde bejonders in ben neueren 3riten virk

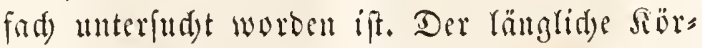
fer gleidgt faft beur ciucr gewöbuliden siseg= fdueffe unto trägt meifens aud) vier frübles, bie oft blattartig singerolft find. Thuf bem $\Re$ in̈afen

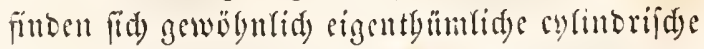

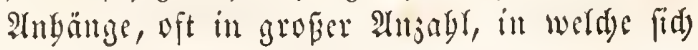




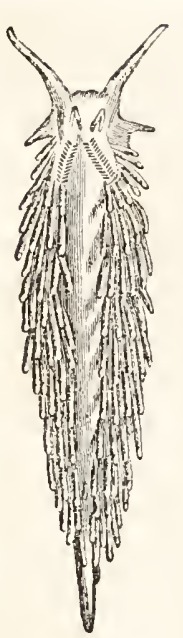

Jij. 3̌̌6. Eolislia.

Dis wergwsigten Sesergänge binein erftresten. Meift find bicfe stubänge an ber Epitze mit eillem Drifen= fopfe werfersen, ans werdem Reflerorgane berworgereret werben fönnen, und in ben göbren, werd)e mit seber.

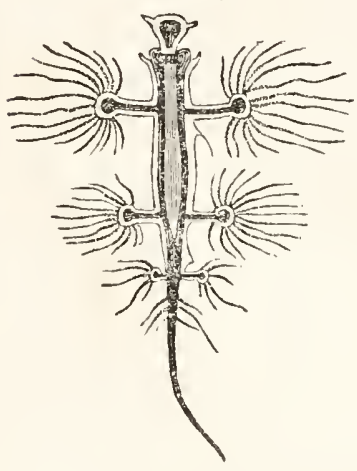

ซ่ง. $35 \%$. Giaucus.

föruern belegt, fid in biefe PInbänge erftreften, fiebt man

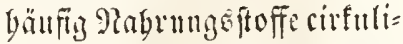
ren. Dor Plfterliegt Ealo mebr nad) sorn, fald mebl nad binten meift anf Der red)ten Grite des Thictes, nor ibm auf Der red)ten Esite dir (3) $=$ (d) (ed) 1 to Pä́ge des redten Füblemed dic Deffunng füt Dic Rintge. Die

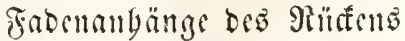

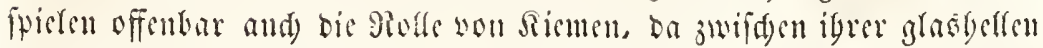
Sant unb bem barin entyaltenen Rebergange cin bebententer Raum ift, worin baร 3 lut cirfulirt. Bei cinigen Battungen find bicje Anbänge

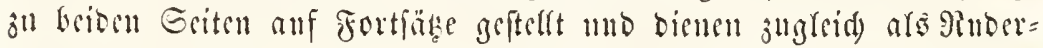
lappen jum Gdwimmen alf bem boben Misere, Kei anderen futb fie

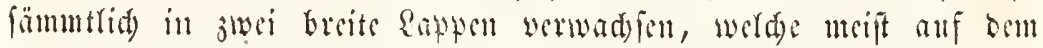
Sin̈sen zufantmengefdragen getragen werben (Actaeon). Die fleinen

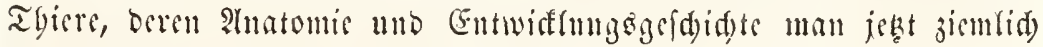
genau fennt, friedsn worginglid an Gectang umber. Ga finben

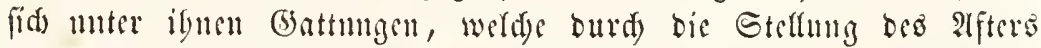
binten alf bem Rüfen Don llekergang ju ber folgenben Familis bil= ren. Eolidia, Janus, Glancus, Actacon, Tergipes.

Die Etrmidnetion (Dorida) find ebenfalls meift fleine Tgiere

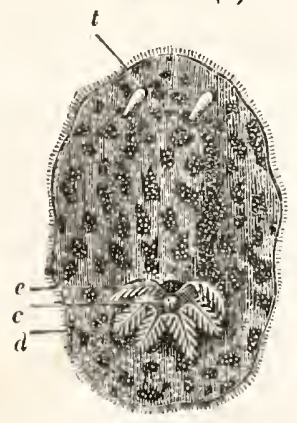

ซig. $33 \%$.

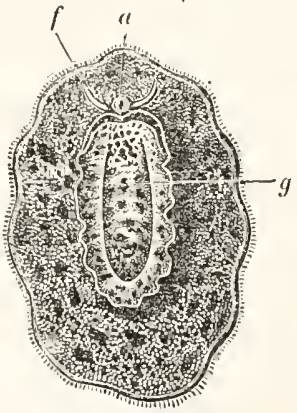

Jin. 3.39.

Doris tuberculata.

Fig. 358 von when, Fig. 359 yon unten, a Der

won rebgafter Fäbung mit vier filblern, wo= woll just allf bem Pant= en, zwei alloce worn an Sopfe fteben. Der Mfter befindert fid an bem binteren Theile des 9rüfens in เor Dittel= rinis unt ift won cincm Eterme hammatig wer: äftelter Sirmen numge= ben. Die (befd)led)tą) 
Munb. c Ter Sfter. d Die Riment. e Sitte Santern

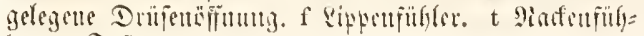
ler. $g$ Fाँ nungen liegen auf ber ischten Grite unter brm Miantrliande. Doris, Euplocamus, Idalia.

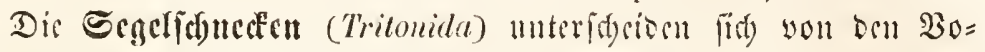

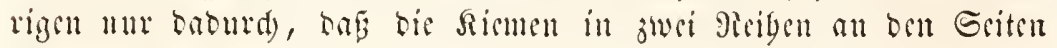
bes Rüctus angebradt find unb ber affer anf Der redten Geite bin= ter ben Gefoled tsöffummgen liegt. Bei eince Gattung ift ser sopf won sincm freiten gefranjten Geget mugebon, weldes offentar cin llebereft ber bei Den Rarwen yorbandenen 2 Bimperfegel ift. Tritonia, Scyllaea, Thelis.

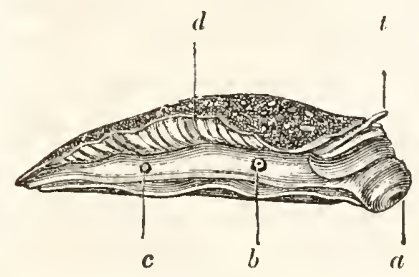

8ig. 36). Diphyllidia ocellata ron ter Site.

a Der Munio. b Die (Sieffrledfrez=

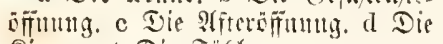
Riemett. $t$ Die subler.

Gattungen leben bathtfäd)lidy phyllidia.

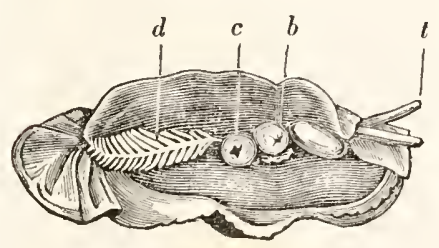

ซig. 361. Pleurobranchus Peroni.

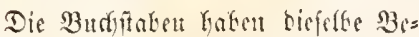
Dentung wie fei Diphyllidia.

Die Blättchenífonedécu (Phyllidida) entyalten cine geringe $2(n j a b l$ matter Sdynefen mit breiter Soble uno furgem bifem Sorfe, bai weldyen bie blattartigen Riemen ju briben Sri= ten bes Siorters in sinem Falge jul folden bem Mantel unb ben Fube lie= gen. Die (jeid)ledytsöfunng befindet firf) ftets red)to, ber atfer baro auf bem Mären, bald anf orr redten Geite

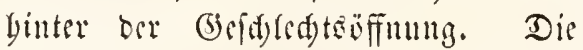
in fïbliden Mierent. Phyllidia, Di-

\section{Die Soitenfiemer (Pleurobran-} chida) fint suberif jiertidye, oft balb

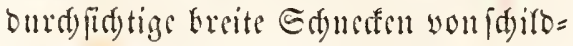
förmiger Geftalt, welde auf Der reds)= ten Grite unter bem Mantel in eincm Falze eime frotartige Nieme tragen, Dic oft nod won sincr bilnnen, im Minntel berborgenen voer freifiegenton Guale groct wirt. Sn bem Griten=

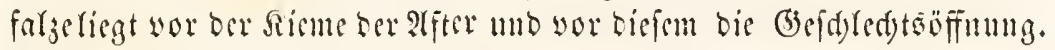
Der Mund ift ju einem Räffer verlängert mob mit eincr fereiten vicl= Wrattigen 3 unge bewaffnet. Die Gattungen find im Mittermecte und an ben Süjten Des̃ Serans nicht feften. Pleurobranchus, Pleurobranchaea, Umbrella.

Der vorigen Familie entfpredyen in ben füfen Gewäffern unferet

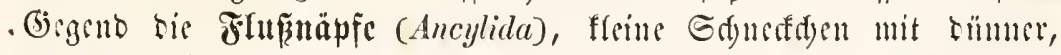

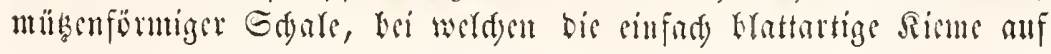




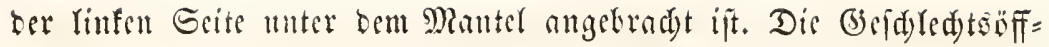

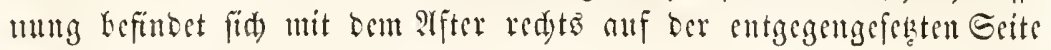
DeE Thierer. Ancylus.

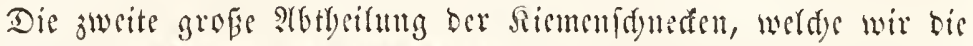

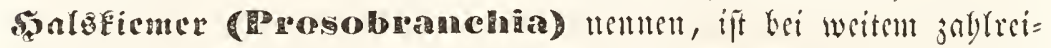
dyer, als bie worbergebente mo befizt mebrere Gbaraftere, burd welde

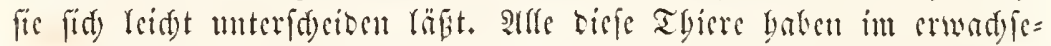
men 3uftanbe sitte meift geroflte Gdale, in weldse fie fid woliftänig

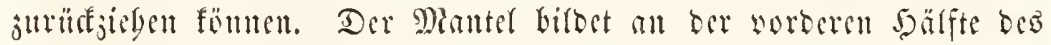

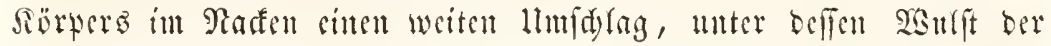

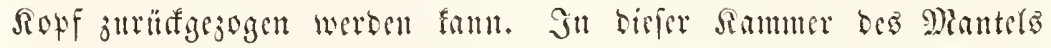

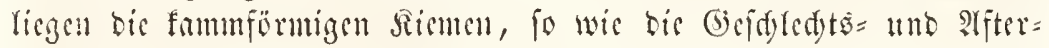

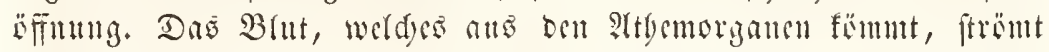
uad) bintell ju gegen bas berj bin, beffen Borfammer แad) vorn

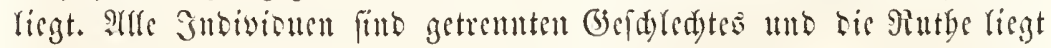
bei ben Miännd)en meift anf Der red)ten Gsite, jurüdfgeids)(agen in cinct Falte bes Miantels. Die meiften Familien biefer inberans jablreidyen

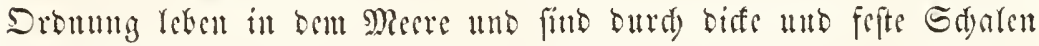
nแล่gezcid)net.

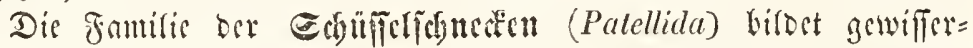

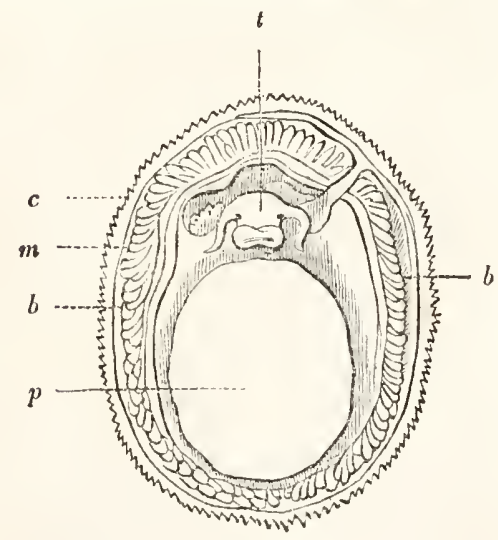

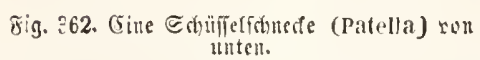

$t$ Ior Sowf mit ben an Gimnbe Der

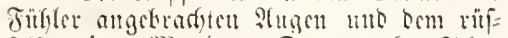
felförmigen Munoe. c Der gezartie ๔ria Ieurante. $m$ Die Miantelfalte. b Die Sie=

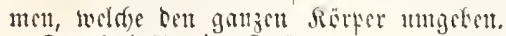
p Ter freisförmige Juß. mafen ben llebergang won ber vorigen Srommng ju bicfer. Dif fditflelformige Sdyale bat Die Geftalt cimes flad en Sie= gets, won beffen Exige nteift ftrablig seipiten nad unten berabranfen. Dis immere söb = lung diefes Segels ift glatt, obne vorfpringenoe eciften und Falten. Das Toier fült diefe Deblulutg faft ganz ans nub fangt fide mit oem breiten, freisförmigen Fube fo feft an, ong bie Edyale wie cin Edyript= fowf anf bent Jerfen anfïkt. Der Sopf ift riffelfömig wor= gejogen, mit subei langen bön= uen Fïblern befelat, an oeren (5) run bie sugen fteben. Die 
ftudyelige 3unge ift meift länger, alo ber Sïtwer und liegt oft mebl=

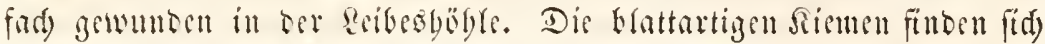
im Sreife um ben sierper in Der rimenartigen Berticfmb jwijden oem fuprande mo bem Mnantel. Gie find bänfig in allen Meeren

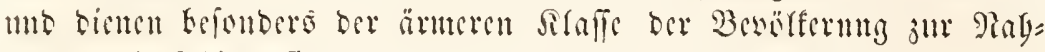
rung. Die Thiere fiben änferft fejt an ben Feffen mo mand) alten

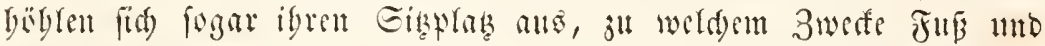

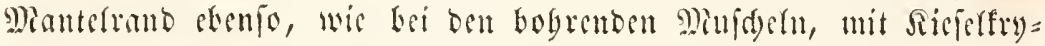

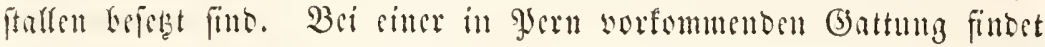
fidf auper ben feitliden Sicmen in cinter Manteffalte bes Raftens,

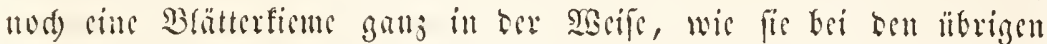
Sarficutern vorfommt. Acmaea, Patella.

Die Famílie ber 3abnidgnedent (Dentalida) beftebt ans cinter

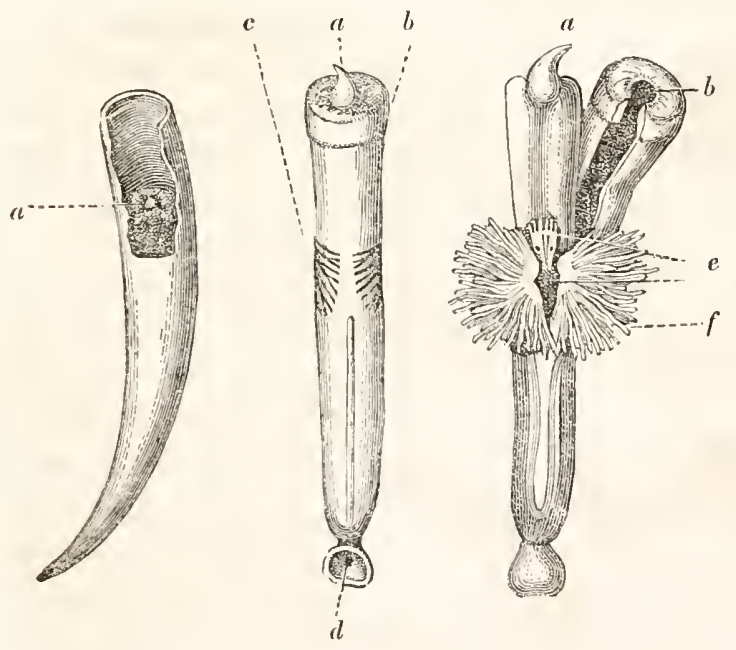

3ig. 363.

Jig. 364.

8ig. 365.

Dentalium entalis.

Jig. 363. Die Eifale it when etwas zerterden, tm

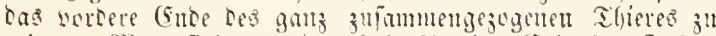

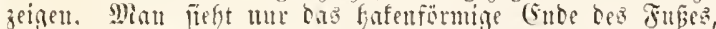

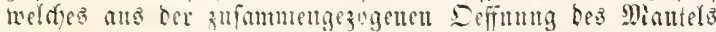
herworteft. Fig. 364. Das Thter ans ber Edale gettommen,

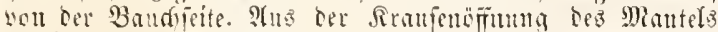
forant ber foufenförmige Jub herwer ; in ber shitte formmert onted den Diantel bie fungerfämig berzweigte Reker, weited

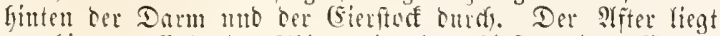
am hinteren (Snte des Tfretes in éner Hajenatigen (Ermei=

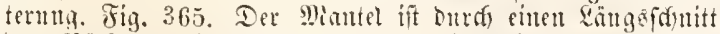

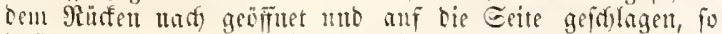

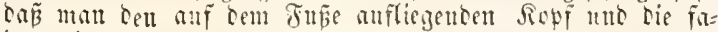
beturtigen Riemen fiebt. a Der Jun; b ter forformige Mantel; c bie Leter; d ber Ifter ; f die Riemen; e ber Sopr. biolit fortorbaren (3)attung, Eerentwe= nig gebogene, frits julanfende, an bei= ben Cinben offerte Edale ctwa die (3) fefalt cines Stofi= jaburs som Gre phanten nadjagmt. "Gibe man bas Thier fannte, reibte mant Diefe Gdalen mutr bie Risgrentuitrmer; IIII in Der Tgatift ons Thict fo ab= weideno getant, ba

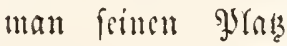
IIII unfider beftim= men fann, mob in igmeinen llebergang yon ben Röbren= muldetit ju ben Eduncten erfennen muß. Der Siörter ift lanb, rurmför= mig, von siltcm billt= neu Diantel singe= 


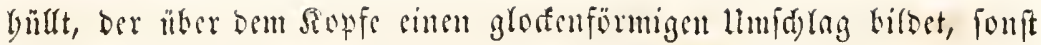

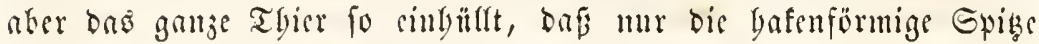
Des Fußes ano ber vorberen Definung Vervoridant. Der Sopf ferbit

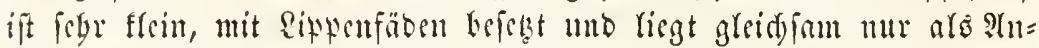
fang auf oem cylindrifden, langen, fleifdigen Jupe, of weit uad worn

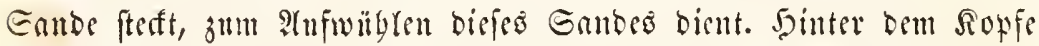
liegen in einer gerämmigen bêgle bes Mantelò zu beiben Griten bie

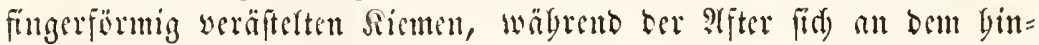

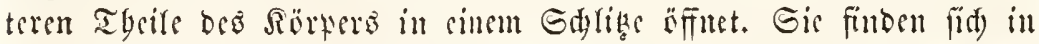

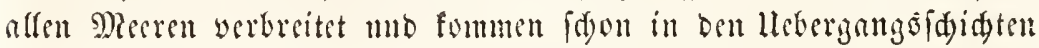

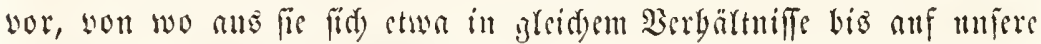
jestigs Gobifung fortietsen. Dentalium.

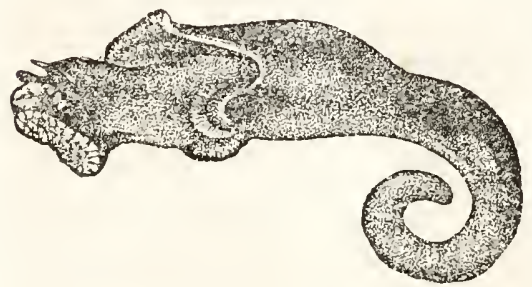

Fig. 366. Das Thier bes Vermetus gigas aus ber હ્d)ale getummen.

Die $\mathfrak{Z}$ urmidneden (Vermetida) fitto in Der bieftalt bes Sörpero sinigermagen ben vor: bergebenden ägulid. Der Jus ift soenfallô feifförmig, rund, aber bet weitem fleiner unb an jeinem gernde akgeidunittenen Borberente mit cinem bornigen Deffel veris: ben, weld)e beim Zurü fistben bno

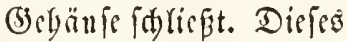

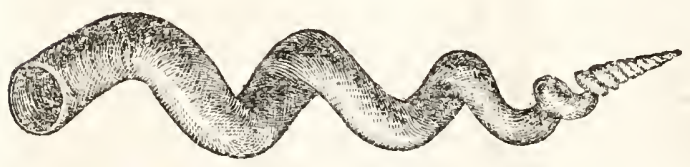

Fig. 367. Tie E(f)ale bes vermetus.

biloct sine lange, unsift uad) unten fpizz zufan= fende Piöbre, bie gewöhn= (id) wis sin Sdranben= zisber gewunden und wis sine 2 surmtöbre an Gteinen unb Rorallen feft geflebt ift. Das Thier, weldes bicfe Gdyale nid)t vertaffen fann, bat cinen Elcinen אopf mit Yängeren Rippenfüblern uno flcinen, platten,

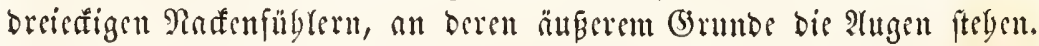
Der Mantel bilbet um den Rafen cinen febr langen llmid)lag und

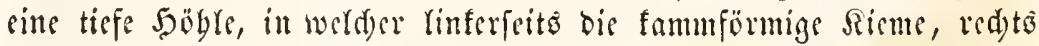

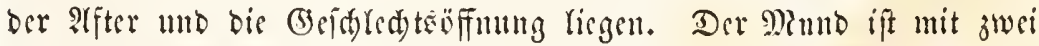
feitlidyen fowad)en Ricfern mo siner breiten Junge bewafinet, anf werd)er fieten Rängereiben won gezäbnelten Sornteiften fteben. Einige Gattungen, tie zn bisfer Familie gebaren, birben in ber Jugento sine regelmärige Spiralfdale, weldye erft in steter untegelmäßsiger wirb. Vermetus; Siliquaria; Magilus. 


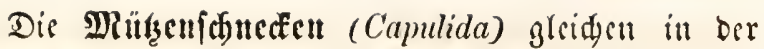

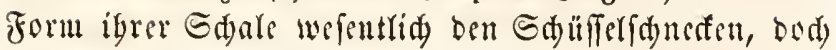

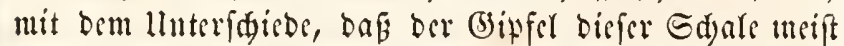
ercentrifa) nad) Ginten jebt, Gpuren cimer beginnenden Ssintung zeigt und inten sine gebogene Raffplatte $\mathfrak{b e}=$

Fig. 368. Calyntraea run oben.

Pian niefyt you tem rafiere mut ten Renfmit ten Füfletn.

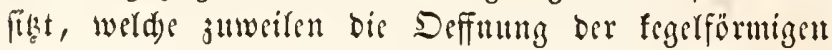

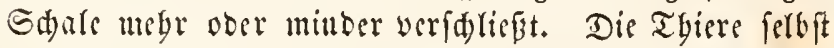

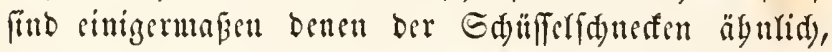
aber wefentlid) baburd verfdicben, dak fie bie fein

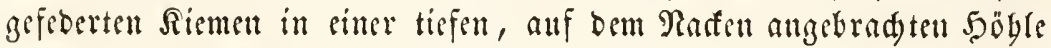
tragsu unt eine banbförmige, unit ficten Rängşplattenrsigen befeßzte

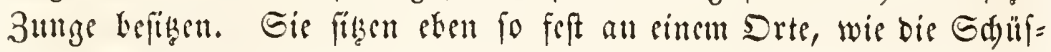

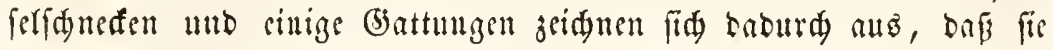

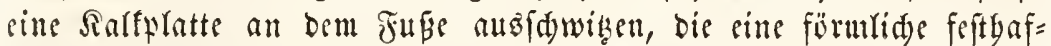

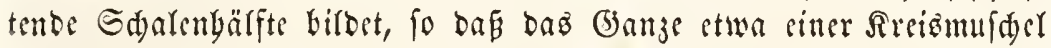
(Orbicula) ägulid fiegt. Die Edjale ift niemalz ausgefdnitten ober burdibobrt, sin Ggarafter, ber ju igrer Unterideitung vou antern Famifirn bient. Calyptraca; Pileopsis; Capulus; Hipponyce.

Die Rapffeneden (Sigaretida) geiduen fin burd) Den ungemein

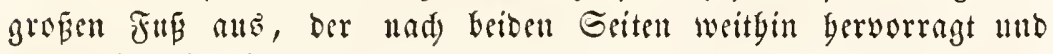
Durd) cine tiefe Duerfalte, welde von einem Rappen überragt ift, con Dem Eleinen oft unbeutliden אopfe getrennt wirb. Die flade, gewun= bene Edjale, bie eine fehr grofie Miundung befiģ, wird jun Their in Mautel singsidgloffen. Die Fübler fitto fegr furb, flein und tras

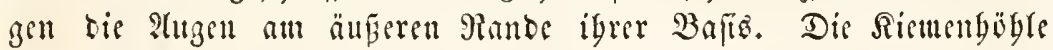

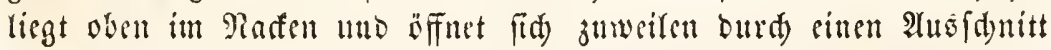

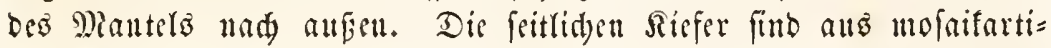

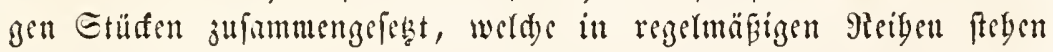

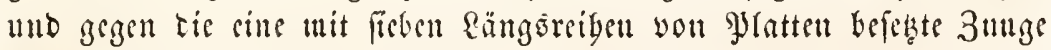
reibt. Sigaretus Natica.

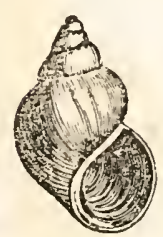

ซig. 369. Paludina.

Dis Sumpffoneden (Paludinida) finb bie sinjige Familie Diefer Sronmng, Deren 2Hgebörige fid in füben Gewäffern vorfinden. Das Gebäufe biefer Sdneț ift meifteno febr bünu, von faft bornartiger Befdaffen= geit uno wedyjelt binfidytid) ber form feiner simbun= gen vou tor Gdeifenform bis zll thurmfürmiger Erbe=

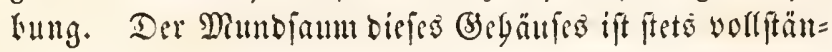




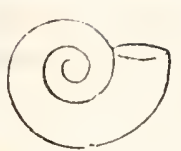

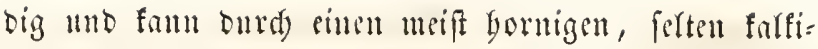
gen Dedfel gänjlid) gefdeloffen werben. Sth tom Srunde der fabenförmigen Fübler, son welden nur jwei sorbanden fint, ftegen die Attben. Die weite

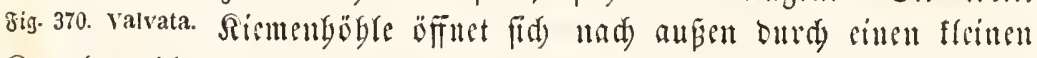
Sanal, welder burd) Fintollung oes Minutelfaumes bebingt ift. Einige (5)attungen fredfen sie froerförmigen Riemen aus ber Defrum ber. wor, wenn fie iut $\mathfrak{S a f f e r}$ frieden; andere begalten bie Gier fo lange

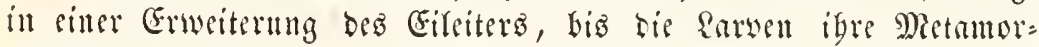
Wofe Durdgemadyt Gaben, fo ong fie rebendige Gungen gebären. (Paludina). Die Bimperfegel find bei biefen Rarven jwar flein, aber bennod rutimentiar entwidfelt. Gis leben ziemlid) bänfig in fumpfigen und ftegenoen Gewäfern. Sguen jebr unge ftegen bie Stranbfaneden

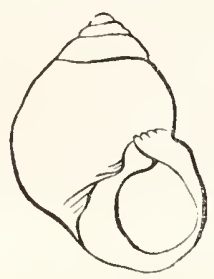

Eig 371. Littorina.

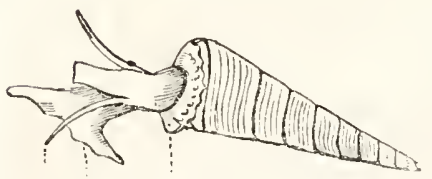

t p m

Jign. 372. Turritella. p Der $\underset{\mathcal{F} u \tilde{p}}{\operatorname{Der}}$

(Littorinida), Deren Thier fid iun ?rter frum von bempenigen ber Sumpffd)neden unteridgeioen läpt, it oer Sugenb aber mit gropen Gdwimmlapten werfegen ift. Die febr oft lang ausgegogenen oder ganj platt georünten Gebünfe bie= fer Gtrandinueden find wie bie Gda len aller Mierrduneffen weit biffer, als bie ingen entipredenden Rnofdueften= fdulen. Sie funben fid theils in ben ellropäifchen Meeren, theils in Ien füb= liden Deennen in grofer Menge. Valvata; Paludina; Helania imt fuß frr; Liltorina; Turritella; Rissoa; Solarium in Meere.

Die Raberfhnefen (Cerithida) Gaten ein fegr in bie Ränge ge=

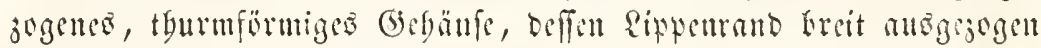
ift, wäbrent an bem idwielig werbiften Spintelrabe ein furger ?tus=

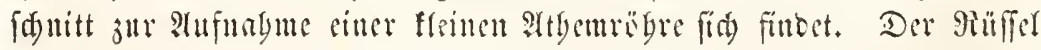
Des Thieres, an wefdem nur rubimentäre siefer angebrad find, ifit

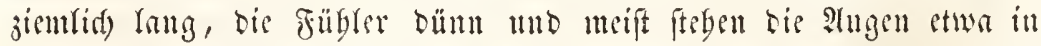

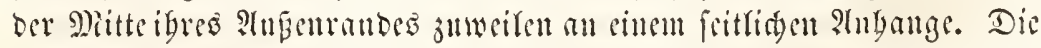
Siemen fund jiemlid) grof und in bopperte Reiben geftelft. Sie fommen bejonders in ben Tertiärgebilden felv bäufig verfteinert vor. Cerihium. 


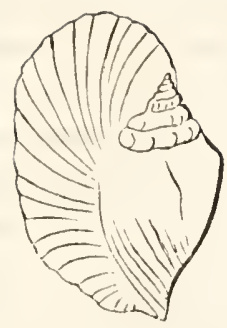

Jig. 373. Strombus scorpio yoll obert.

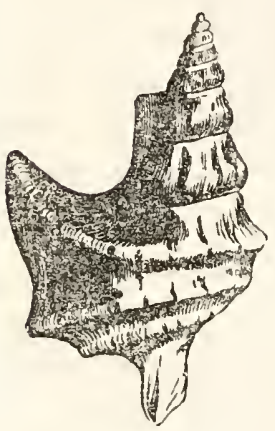

sig. 374. Rostellaria.

Die Flügerfdueden (Strombida) jeidunen fid) auf oen erften Brift ourd) ify ftartes läuglides

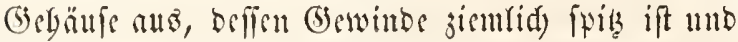
uad) unten an bem Spindelranbe in einen furzen

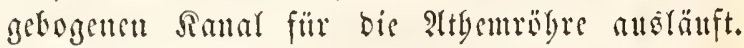
Der Riftentrato ter Mithlung zeigt vorn eime Eebentente 3 und, in weldar ber Sopf liegt uno ift saun flibglartig ausgebretet, fo baß bic Mund =

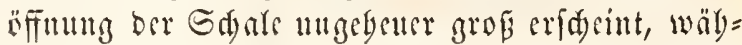
rent fie, abgefeben yon biefer flügelartigen ?tub= freitumg, bod) un sine fdutule Spalte bilbet. Das Thier, weldes bieje Gidalen bewolgnt, bat sine jegr bigarme Geftalt. Der Räffer ift febr grofs und biff, geringelt uno weit voritredfar; er fitlt be=

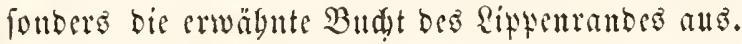
Die Fübler fitto nut fleit, die Sticle bagegen, welde bie Plugent tragen, ungemein grof und ftarf, unt meben benlelben ein sigentyümlider jungen= förmiger Fortfaz bes Jufses angerradjt, weldjer Den fdualen firizen bornigen Deffel trägt, ber zur Sryliefung ber Sdyale beftimmt ift. Gie fomment

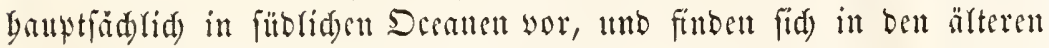

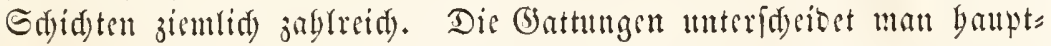
fäd)(id) nad) ber (jeftalt bes Sifpemrantes, ber bei eittigen ganjrandig ift, bei anberen bie jonberbarften fingerfirmigen fortfätze trägt. Rostellaria; Pterocera; Strombus.

Dis (Eijchnecten (Ovulida) Gaben sin meift ciför=

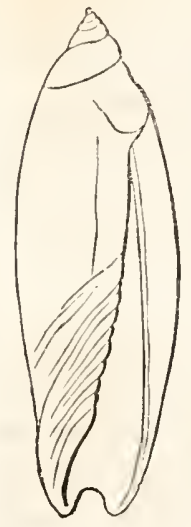

Eig. 375 . Oliva

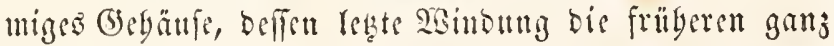
verbitllt, fo bafi man mur bidgiteno an ber sillen Eeite

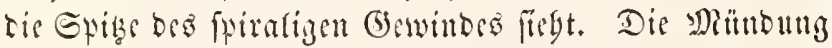
Firost cinen langen fdumalen Epalt, won bem balo beibe Pänoer, balo nur simer untreftig unb gezäluslt ift. Deift

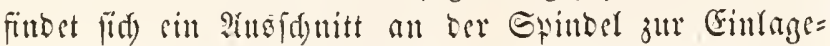
rung ber furgen Ptgemtrobe. Das Thier yat sincu furzen Rüflel, range runblid)e Fübler, weldye in ber Mitte igres 24 bis ?ugen tragen. Der fuf ift breit, blattförmig uno feine beiben Särften weroen beim 3urtefficben in bie enge Gdaleniritumn in ber Mitte zulammengeld)lagen. Der Mantel beftegt aus cinem ober zwei fegr bïnnen 


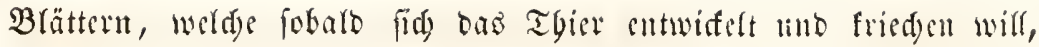

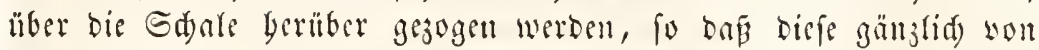
bem Manterblatte bebefft ift. Die Grätte ber biffen und idweren Edjaten, werde meift mit rebgaften Farben gejiert find, wird burd) ben

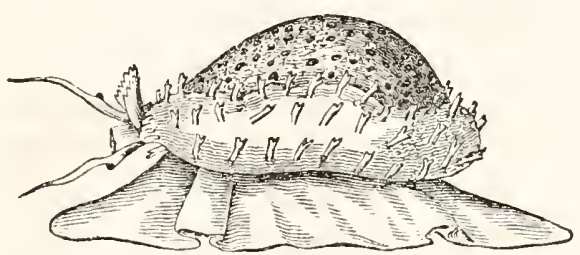

8ig. 376. Forzelfumidnerfe (Cypraea)

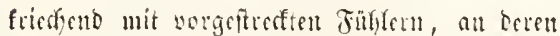
Eeiten bie Baigen itefren. Dor mit Fortiäizen

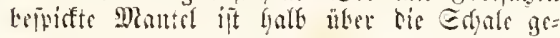
jogett. 2forag meucr Salffdjidten auf Der Aupenfläd) Der urfprintg= liden Gidale, ber you biefem hbergiebaren Minutereratte ausgebt, bewirft. Die gyor= jellanfdueden, welde ju bic= ier Familic gebör ten, find bin= ränglid) befaunt alo Zierrath unferer Möel, fo wie burd)

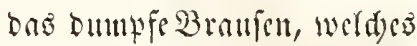
fie, vor bas Sobr gebalten, vernegmen Kaffen. Oliva; Cypraea; Ovula.

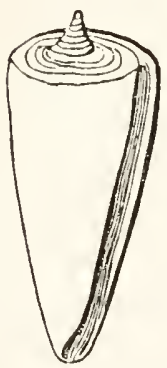

Die Argelfaneden (Conida) freben Durd) bis Form igrer Edyale ben worigen am näd)ften. Das Gebäufe ift fegerförmig, oas regelmänig gerollte Ge winte an bem biferen Ende Des Regels fidtbat; bie Deffunt fipalteirmig, nad) unten bin ctwas erwei= tert unb meift an ber Spinder etwas ansoged für ben Durdetritt ber langen Atbemröbre; oer Rit: femmant ber Edale if gerabe, bütu unb farif und fo mie ber Sprnderand obne alle 3äbne ober Fal=

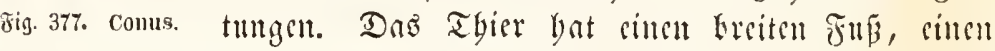

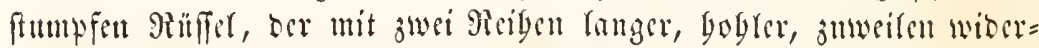

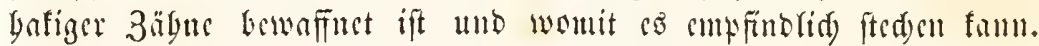

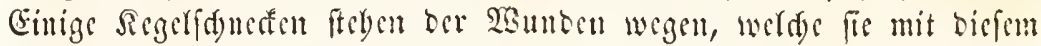

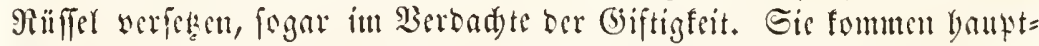
fäd)(id) in fübliden Mecrent vor, mo bilbeten frïber bei Sammlern

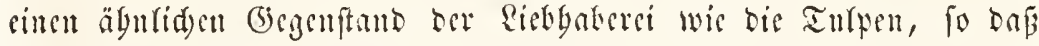

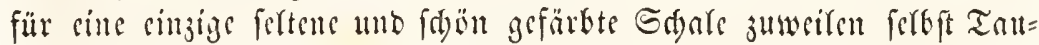
fende wou Guldoen bejablt wurben. Conus.

Bei alfen Familien Det Riemenfduefen, welde wir von jekst an

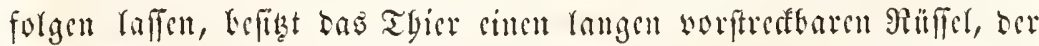
mit fleinen feitliden Siefern und siner fdmalen 3unge bewaffnet ift,

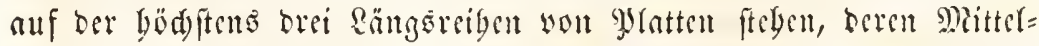
flatte breit uno mit fdarfen Bägnen bewaffnet ift. Sic bobren mittelft

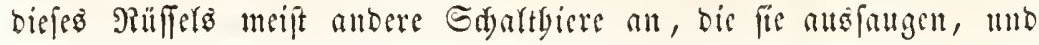




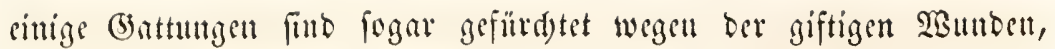
bie fie bamit werfesen folfen. Aluperben baben biefe Thiere ftets eitte

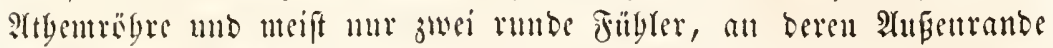

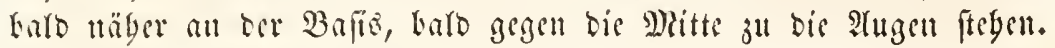
Sisir unterfdeiben forgente Fanilien:

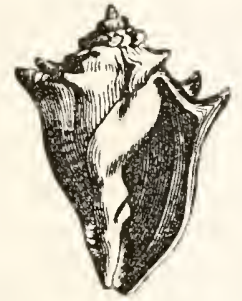

テig. 3:8. Voluta.

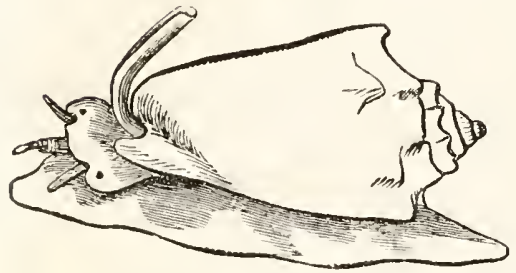

Jig 379. Voluta

friedyent, mit borgeitrestem Rinfiel, ent= mifelten Fufylem ano im Shafen yerifte=

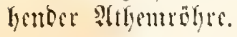

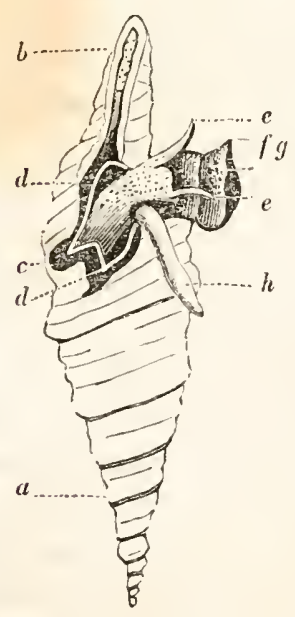

ơig 330. Pleurotoma babylouia mit tent Thiere.

a Die Edfale. b Dir Sant, in bent manbie 2 them=

\section{Dic Faltemichuccten (Volutida)} babeli cint fd)uerres, meift thurmför=

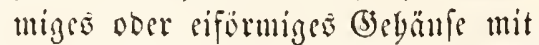
Hhatem Rippemrande und wulfitigem Spinderrante, an beun einige ftart voripringende fodräge Falten fid befutben; ber Fuls ift meift ferd breit obue eine Spur sines Deffets, ber Siopf flein, bic Fübler fleit unt meift pratt, Der Riffier oft anges Geuer lang und der Saft ber gulr= furbriife äkent, frifent unt wie belyauptet wird, feleft giftig. Die Sirten diefer Familie foumen baupt= fäd)lid) untr in ben füblidjen Sceanten sor. Voluta; Mitra; Cymbium; Marginclla.

Dic Thurmidntecten (Pleurotomida) babent sin fobr langes thurmfërntiges Gseminde unt sitet anferorbentlid) langen geraben Ranal aun unteren Gande jur Bergatug Der Attyentübre, fo bap bie gange Sdjale bie Gejtalt siner lang geftreften Spinder bat, Deren gröpte Dife im Riveau ber Yescten Mäntoung Yiegt. Die Mund=

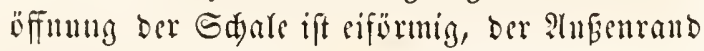
glatt und fdarf utto wabe an ber vorreseten simbing thit einem (Finfdutte verfegent, in

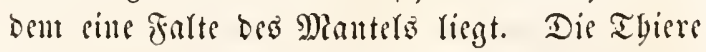

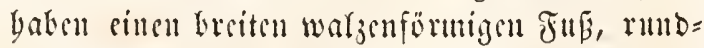
lidje, funze Fihbler, aut beren $\mathfrak{B a f i s}$ tie 2 tugen fityen, ullo sine anferorbentlid bife unt range Prutbe, weld)e fie feitlid) berworbäugen laffen. Sie unterfdesioen fid wou Den Thieren Der nadjolgenton jautilis ganptfädylid) baburd), 
röfre eingebettet jefyt. c Der feitlideceimiduitt ber Edale, in betl ein Fal; Des Mantel= rantoes a paift. e Filfiler. f Der Fus. g Der an fei= nem Enoe befeptigte Derfer. h Die Ruthe.
Safs bie 3unge, womit igr Rilfer bewaffuet ift, feime Eriten glatten, fondern cben fo fribe 3äbme trïgt, wie bicjenige ber Regelidneden. Sie re= ben banptä̆d)(id) unt in beifan Meeren, einige Prten indef bod) in ber Rotbfee. Pleurotoma,

Dic Familie ber Epintelfaneden (Fusida) unterfdecibet fid) vou ber vorigen burd) ein fïrzeres Gewinde, an bem ein febr langer Sianal frizt, fo baf bie Edalen juweilen bie Geftalt einel Birne jet=

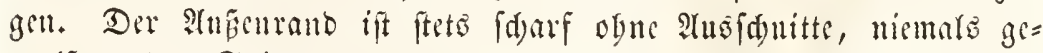
wulftet; ber Exindelrand entweber glatt ober mit niebrigen Falten verfeben. Der fegr lange Rilfer bes Thieres ift wie bet ben folgen= Den Frmilien, tund jum lluterificbe von ber vorbergebenden, mit ge= zäbuten Duerwlatten befezt. Die Igiere findon fid bauptiäd)(id) nur in fïbliden Mecrin. Fusus; Pyrula; Columbella; Fasciolaria.

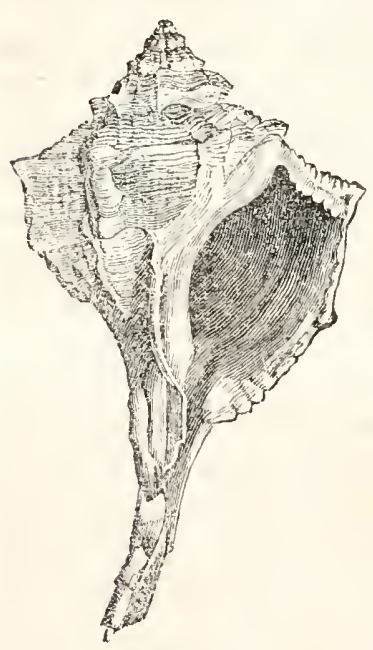

8ig. 391. Murex.

Biemlia werfdetedn in ber Biroung ber Edare, aber febr ägnlid binfidstlid) Der Tbiere, fint Der Familie oer Spindel= (d)uesten bie Felienflineden (Muricida).

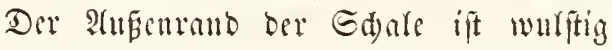
uno tmmgeld)lagen, juweilen jaftig ge= faltet ober ferbit ferlemweife in Dornen atsgejegen. Dis Sdyale befümmt Daburd

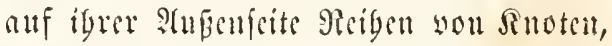
Strat)eln ober Zarten, weldye ben Gicbätt= fen vft ein fonberbares ?tnşeben geben. Die erriptifd) gebirbeten Deffer, weld)e bie Tgiere aut Futie tragen, wurben in $J_{h}=$ bicn als Räuderwert betmbt. Dic Thicre, welde fid won benen ber vorbergebenten Familie nidgt unterfderben, unb gäufig gegeffen werben, Keben in affen Meeren. Murex; Ranella; Tritonium.

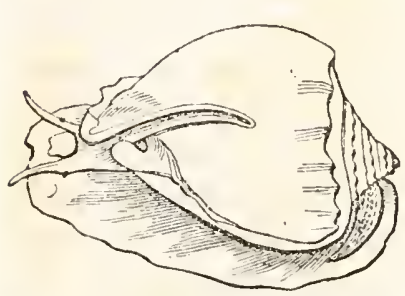

Fig. 382. Cassis fricitent.

Die Şermidneden (Cassida) baben cin futries cifürmigez bebänje vou be= bententor Diffe, beffen Yetzte simbung bie

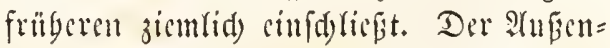
ranb ifit biff, wulfitig, umcift ctwas gefaltet, ber Eximberrano umgeidlagen, zuweilen mit moentriden Farten verfegen. Der

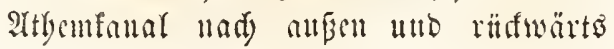




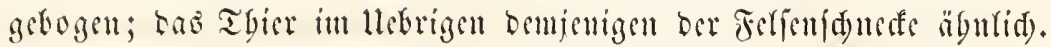

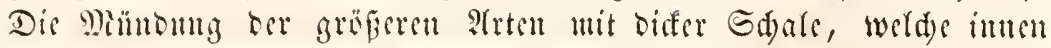

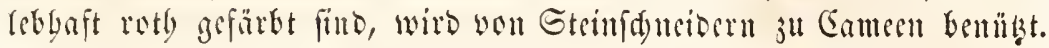
Cassis.

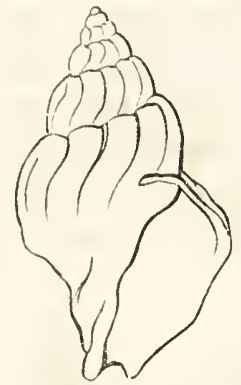

Fin. $3 \times 3$. Buccinum undatmus.

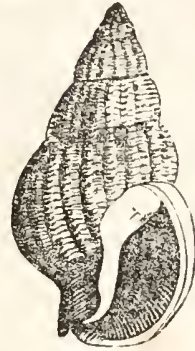

Jiig. 381.

Buccituum prisma-

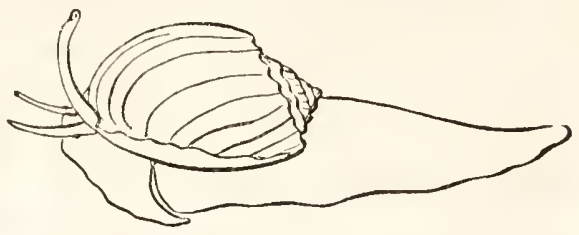

Jig. 395. IIarpa,

fried)enb mit ausgefterften attgentibre.

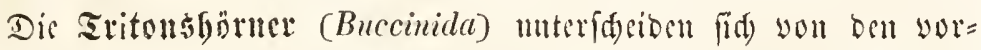

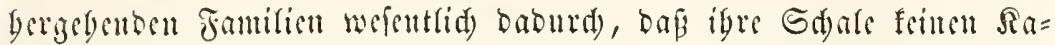

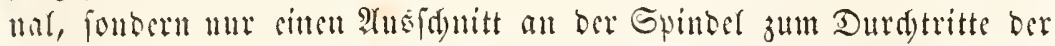

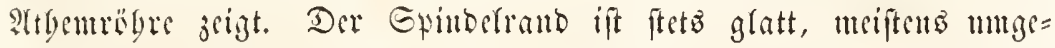

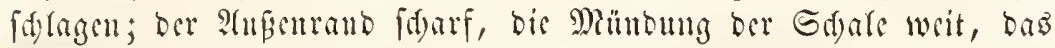
Thier mit sincm breten Eube verfegen. Sie fommen in alfen Mes= ren mob in jaffreiden (battungen vor. Buccinum; Nassa; Purpura; Harpa ; Dolium.

Bei ben nadffolgenten Familien fergen auf Der 3unge mefr alo

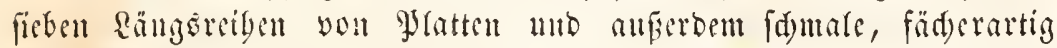

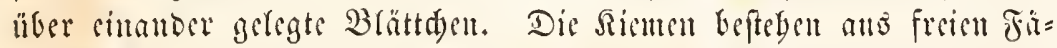
Den, bie nur an ibrem (Brunte angewad) jen fint, fouft aber frei flots tiren. S⿱乛龰ir zäglen gier folgende Fantilien:

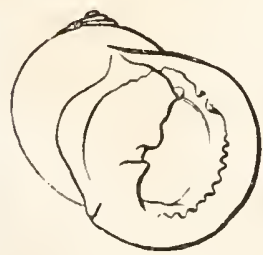

ช̛ig. 356 Nerita sallguinea.

Dis Monsiffurefen (Neritida) mit furjem,

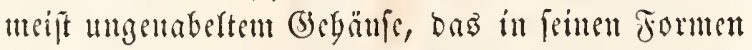

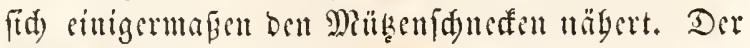
Spindelrant ifit mugejd) (agen und feine nad) anfen gewande Seite fo verbift, bar fie wie sine gori= zontale gylatte in bie Mänoung Gincintragt, borch 2ungentano fegr verbift nub meift gejülunct ift. Der Deffel ber fofweren Sclyale ift falfig, fritlid)

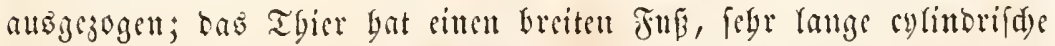

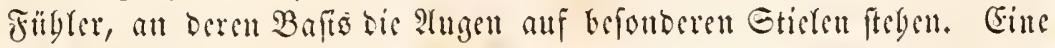

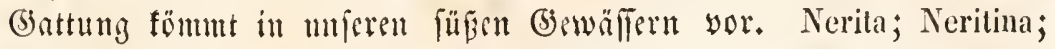
Navicella. 


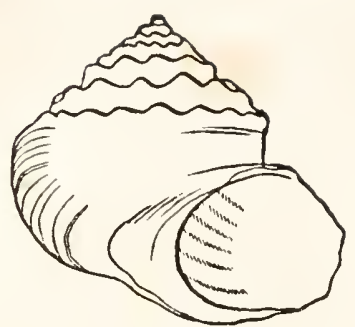

Siis 337. Trockus.

Die Arcifelifhneden (Trochida) ba= ben sin bifę fegelförmiges (3) meift febr beutlidem Raber und faft rund = lid)er Mamböfnung, beren Gaum nur felten ganz, meift nuterbroden ift. Die Jüblföben find febr lang, bie 2Angen meift geftielt, ber furze Rüffer mit ciner fegr furjen 3unge bemaftut. Die Battungen fino än हerfit mannid)fartig und in alfen Miceren bäufig. Delphinula; Trochus;

Turbo; Scalaria ; Phasianclla.

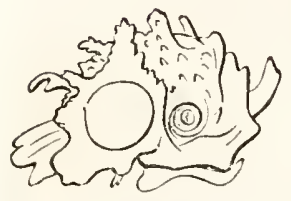

sin. 398 Delphisula.

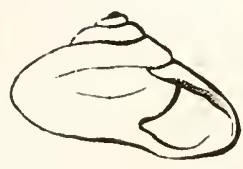

ซit.]. 339. Turbo roseus.

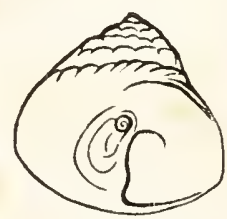

รiv. 390.

Troclius magus.

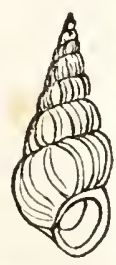

Jis. 391. scalaria.

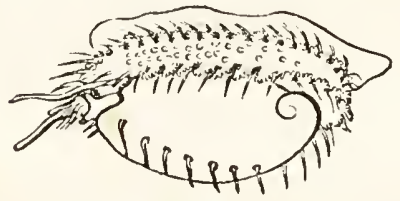

8ig. 392. Ilaliotis Iriedenb.

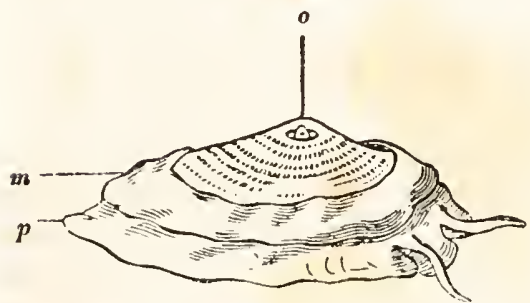

8ig. 393. Fissurella friedyent.

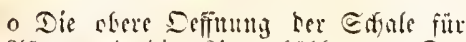
ben slfter und bif Rimentsoble. $m$ Der Mantel. p Det Flip.

Die Frmilie Der Ecrohren (Haliotida) begreift sime spenge veridsicbener (jattungen, you wel= d) en wicle in igrer beftalt ben Rapfiduefen febr uabe foumen, andere flad) und obrförmig ge= wunben erfdesinen. Dic Sdalen baben entweber am änperen Pande

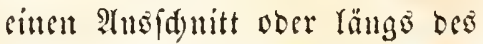
Mandes sine Reibe woul Röd)ern ober ferbit anf Dem Bithil ber Sdule sin Rod, burd) welde Deffum gen nuld an bie Riemen treten fann. Die Riemengëble, weldyc jwei fobernatige sicmen entyärt, liegt anf bem giüfen, zuweilen nad) ber linfen Seite bin. Die Fübler find meift lang, ber Mantel in feincun llmfreife gefranjt. Bei einigen (3)attungen gebt ber Mapt=

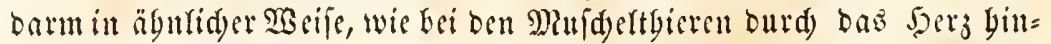
Durd). Die Thiere fitzen wie bic Gdüferfaneden feit an ben Ferfen an, und verfaffen mur ferten igre Gtelle. Haliotis. Fissurella; Emarginula. 


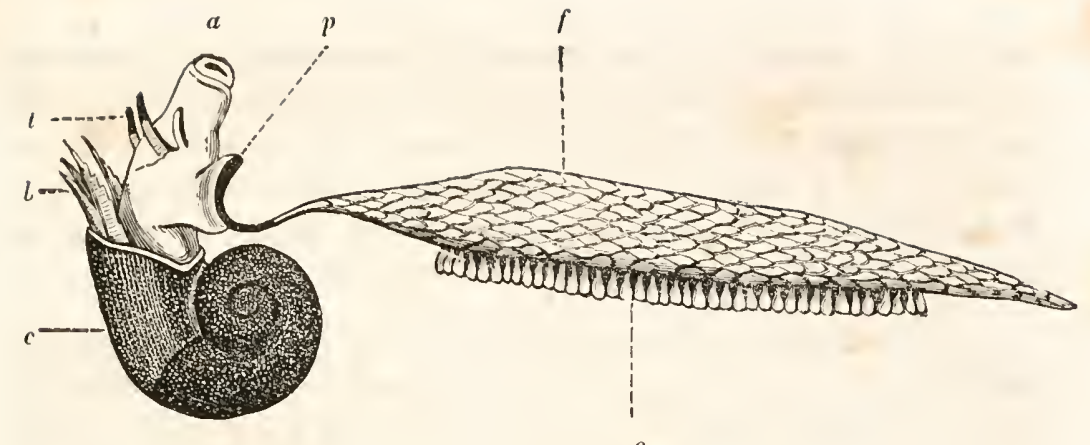

Jig. 394. Janthiua communis auf bem Neere fanmimment.

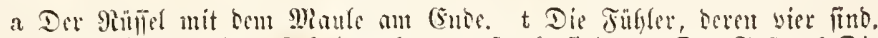

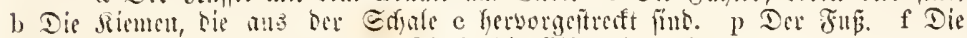

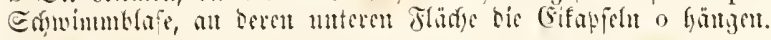

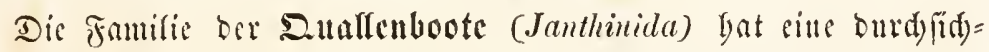

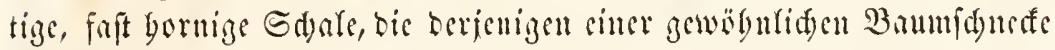

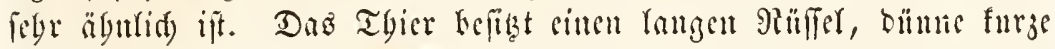
Jiiblfäben und febcrartige Siemen, weld)e es meift ans ber Sdale

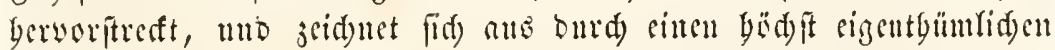
Gdwimmaptarat, weld)er cigentlid) unr sine Mobification Des Dectelo ift. Der Finf nämlid) bifoet nur einen furjen Stmmmel, nu bem mit= telit cincs Eticles cinc frintelförmige, lange Blaje bängt, bie ans

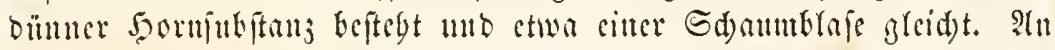
bie lluterfäbe biejer Sd)wimmblafe freben bie Thiere igre birmför= migen Eifapfeln. Sie erfdermen in zablreiden Sdwärmen fdwimment

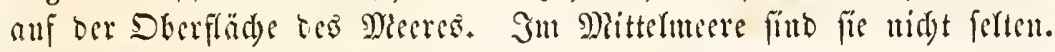
Santhina.

Dic Dronung ber Rungenjotyedfen (Pullamonata), welde

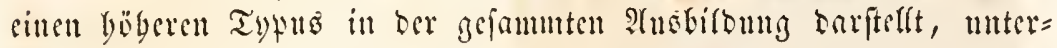
(d)eitet fids wejentlid) wou alfen vorbergebenden eben surd) bicie Run= zenböble, weld) bas Thier fäbig mad)t, ummittelbar suft ju ntbmen.

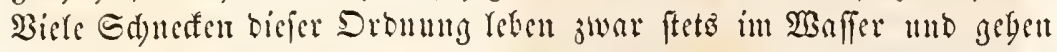

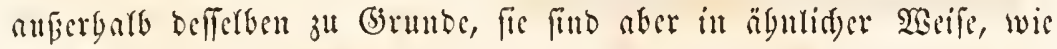

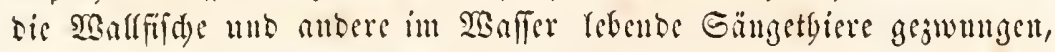
yon 3rit j"l 3eit an bie Dberfläd)e ju foumen, un wieber Suft einju= atgmen. Dis Rungenbögle liegt meift in bent Raten bes Thicres in

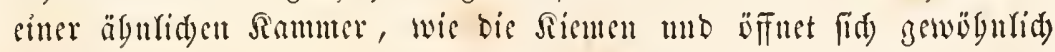

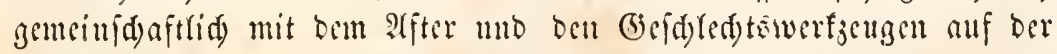
red)ten Geite. Die meiften Eungenfdyecten find 3witter, inbeffen giebt es nud) viele, welde getremten (befd)led)tes fint. Fajt alle baten

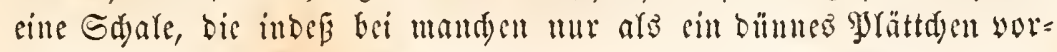


banben if, weldes in bem Mantel felfit vertorgen riegt, wäbrent

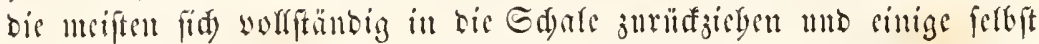

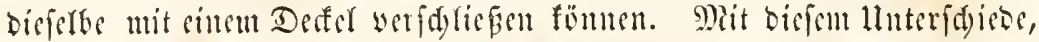
fowie mit bem Bane bet (befd)led)tötbeile bängen and wejentlid)e Berfdebentseiten in ben Bane oer Munbtheife jufammen, bie wir bei ben cingefnen lluteroronutage betrad)ten werben.

Die Entwiffelung ber Rungenjduesten int Eie weidyt in mandyent \$unften febr you Eerjenigen ber Siemenfducten ab. Die SBimpern, werde bei biejen banptiäd)lid) unr an ber Stefle ber Ropfieger eridsé=

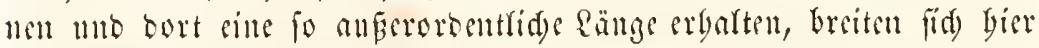

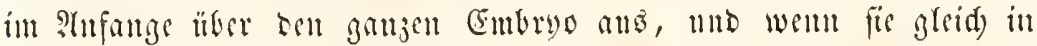

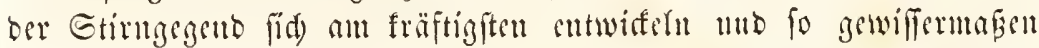
cinen Erfakg fïr bie Segel fitben, fo werten fie bod niemate feben= teno genng, un jene Bitomng wou Gdwimmiegeln, wis fie tei ben Siemenjonefen sorfömm, werand

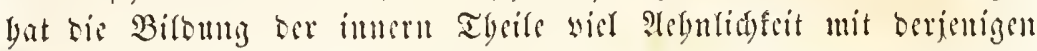
ber Siemenfunefen, intom and) lier ber Dotter fid) gemiffermaben in jwei Theile tbeilt, won welden ber vortere ben Ropf, bie Gimešre gane unt Den Fub, ber bintere bie horigen Cingeweibe in fid) ents

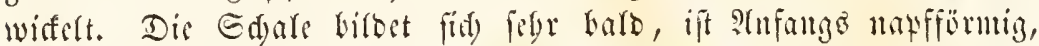

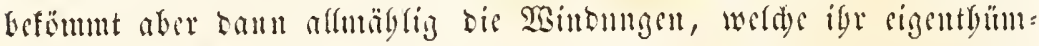

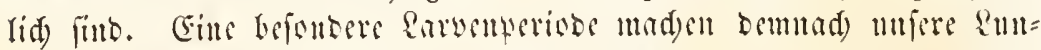
genfdueden nidft Iurd); fie werlaffen bas (Fi in einer Geftalt, weld) yolfoumen berienigen bes Mintertbieres entfprid)t.

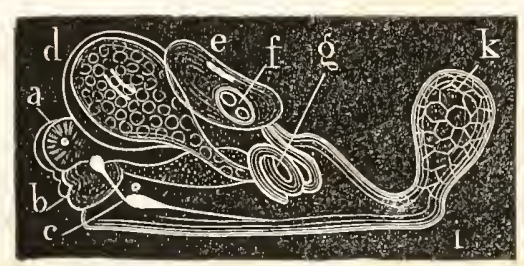

8iis 395.

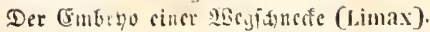

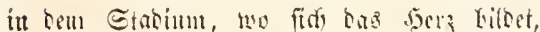
wou der Eite gefrien. a Die gregen Jüblet

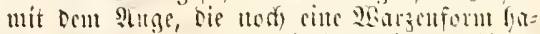

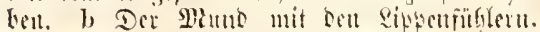

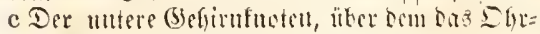
blizasen lieat mo ber mad) wern mit tom

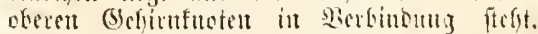
d Die Sactenklaje, ats Selfen jufummenge=

Cine anffallento 2tusinabme won allen hubrigen 2Beid)tbieren mad)en unferenateten isegidunerfen. :Ind) lier bitben fid anfang ric Leiben gegentereritebenoen

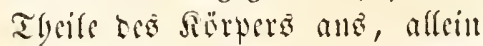
jwifden brioen bleibt ein mit grofien 3illen befester Ramm Ees Dottere übrig, welder bei fort= (d) reitentser Entwidferma on ciner leflen Blafe wirs, bic im Raffen liegt mut fid Durda inge lebgaf=

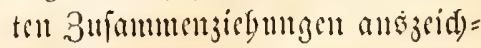
uet. Pn bem Sointerenbe DeB 
Febt. e Das slere Mantelidgilo, in weldyem man bas Pubiment Det Edale unt barunter bas bety fileft. g Der Darm. k Die Ent= hlate ter Jubes i.

Reibes bilbet fid) zoll gleider 3rit

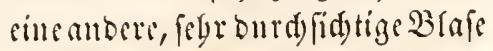
aus, welde cbenfallo lebgafte 3 u=

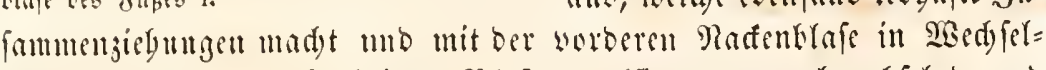

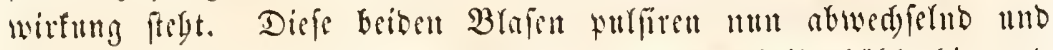

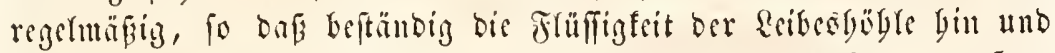

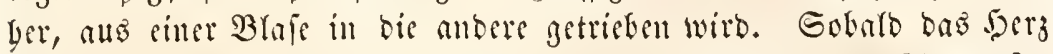

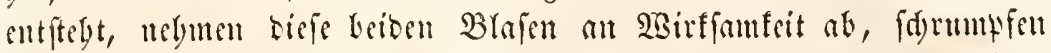

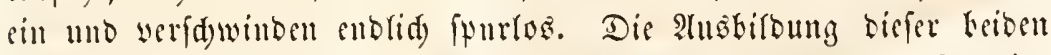
Blafen, wou benten man bie in Raden liegente fälfdy)lids) für sine Dotterblafe angefogen bat, fterft offenbar sine weitere Entwiffelung

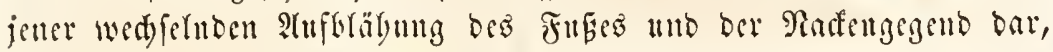

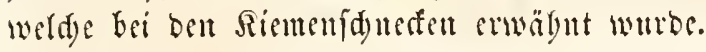

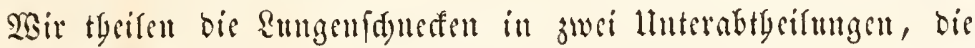

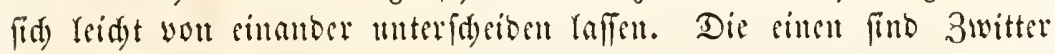

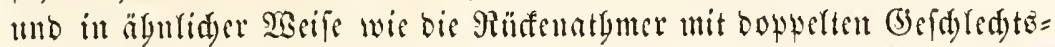

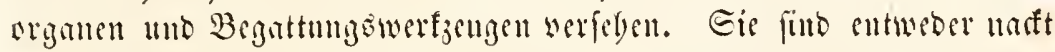

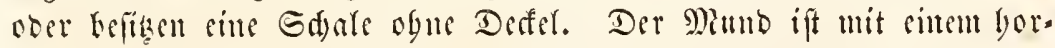
nigen Dberfiefer bemaffuct, ber uncift ftarfe Rängofatten zeigt; tie 3unge

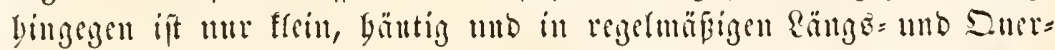

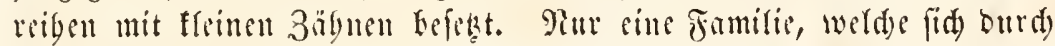

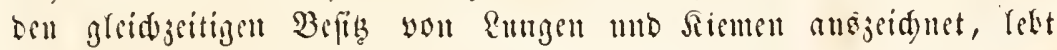

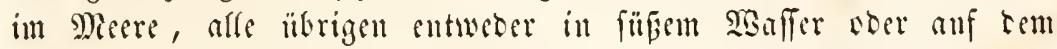

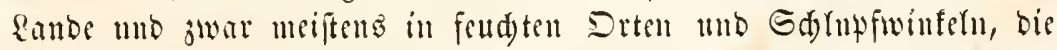

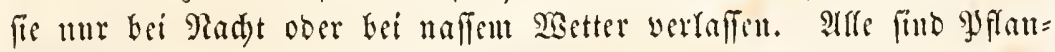

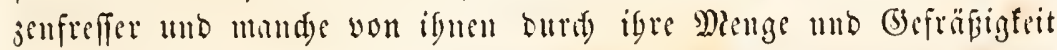

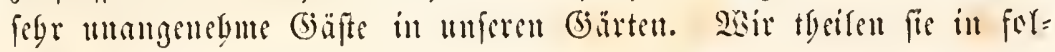
gente Frumitien:

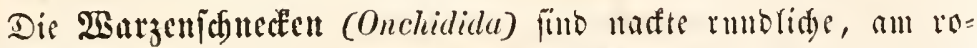

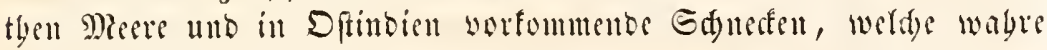
Doppefatgmer finto. Das agier gat jwei fleitne rumblide Fingler, an

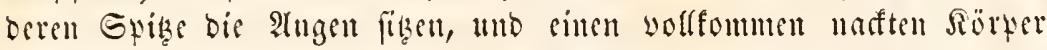
ogne Spur ciner Sdjate. Die warsige Rüfentyant ift mit fingurartiz veräfelten Riemen beosat, weld)e entfaltet und wieber eingejogen werben fömen. Sm binteren Theile bes Reibes befinbet fid cine \&un=

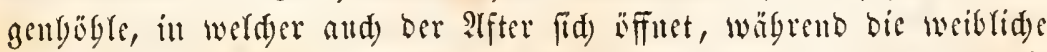

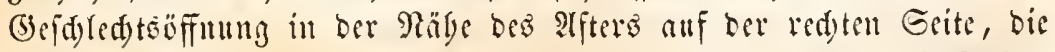

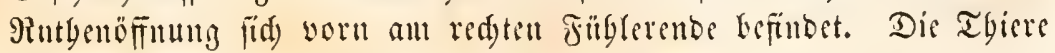

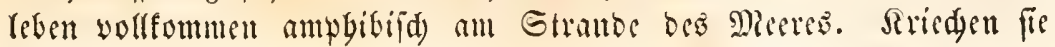




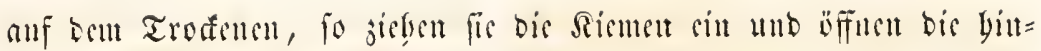
ten gelegene Rurgengöble, wälrend fie im 2 affer bie Sirmen entfalten unt bie Rungentgöble fdiliefin. Onchidium.

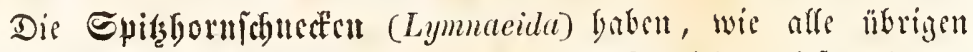

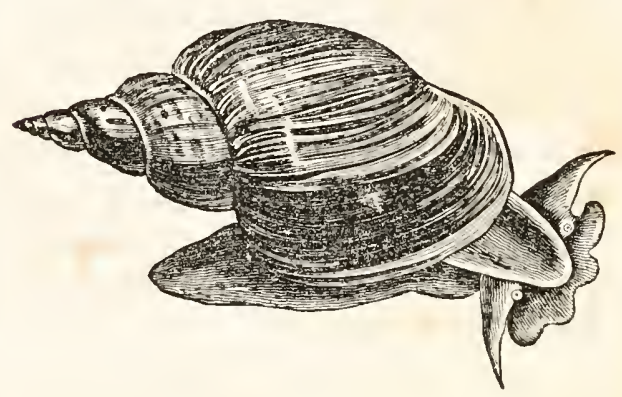

Fin 396 .

Teifflomfonefi (Lymunetis slagualis)

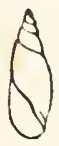

Jig 397.

Physa.
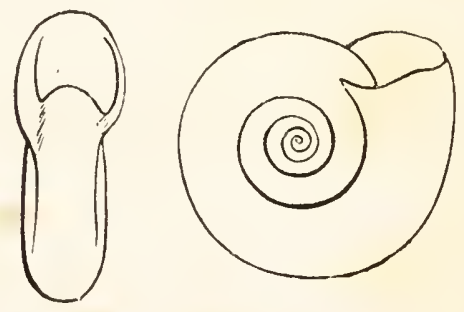

ซitg. 393.

seflerjónafe (Planonbis). Familien biefer lluter= orbunng, mur sille $2 u n=$ grubüble obne Stur von Sirmen. Sgle Gegän fino barb thurmfirmin, bald mill in einer etene getwmosn, meift jiemlidy Dïnn uno jerbred)lids uno wou bormiger Befdaffen= brit. Sic Gaben mur jwei Fïbler, die barb breictig Ersit, bald lang, fitis IIID bïn! find 111 b an beren Grumbe all bem inneren Ranbe bis ?(1)= gen fizen. Eicleben flets im simaler, an beflen Sobrfläd) fie meift ber= ImI fd) wimmen tmb ba= Lei mittelft bes aufige fperrten Pttyemfod)es? (d)öffen. Lymnaeus;

Physa; Planorbis; Chilina; Amphipeplea.

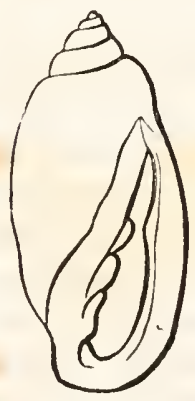

5in 399.

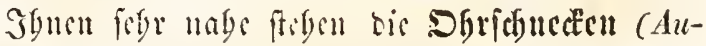
riculida), weld)e meift in füblid)en Rälloern vorfom= men mo nidyt im Saffer, fonbern an fendeten $D_{r}=$ ten, bcjonbers int Mloofe letent. Dic Thicte find ben vorigen felgr äbulid), dis Sdaren aber bif,

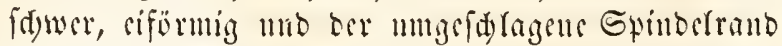
mit Falten un Borfprüngen verfeben. Meiftens ift ber ?ngentrand glatt, juweilen aber bat er etenfalle auf friner imnern Geite vorfpringend Reiftel. Auricula; Scarabus; Carychium, 


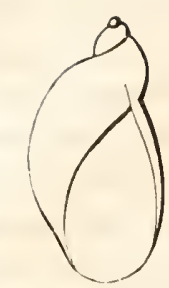

Jiin. 400.

Estale nun Succinea amphibia.

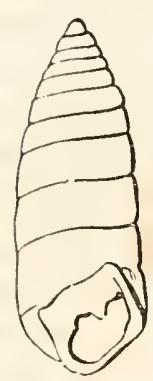

Jig. 401 Puln:t.

Die Ednutreliffucten (Ilelicida) bitsen sine

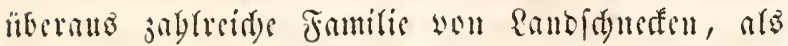

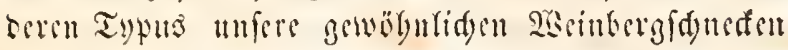

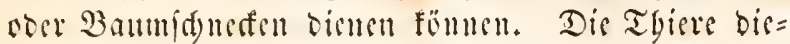
fer Fantie baben wier Jihbler, you welden bie flei= neren oft zicmlids rubimentären neben an Mlunbe,

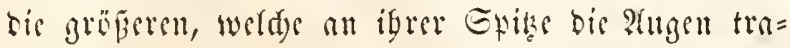
gen, sorm am Soffe fteben. Die Gegätfe, welde

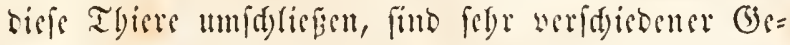

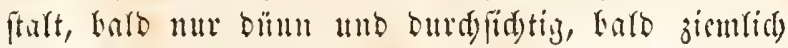
riff unb fduwer mo mit fdönen Farben gejiert. Bar

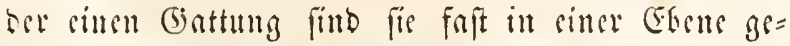
wutben, bei siner andern fefer lang und fpis, faft wa ber Geftalt eines yfriemen. Bei manden find die Ränber ber Deffunth fdarf gefdeteden, bei an= bern ift sill volfftäbiger Mimbfaum vorbanden;

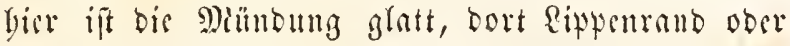
Epinderand ober aud beibe jugleid) mit woriprin=

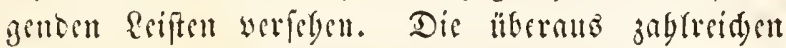

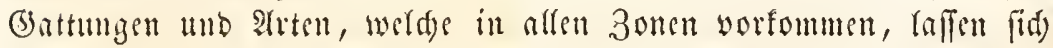
fft mu (e)r fdrmierig unterfdeciben. Helix; Bulimus; Succinea; Pupa; Clausilia; Chondrus; Achalina; Vitrina.

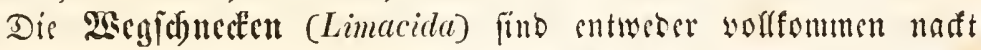

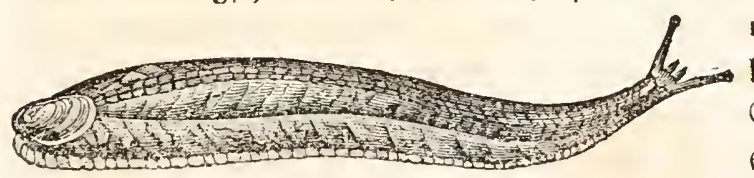

noet baben nur sin freines unbedeutendes Ed)äld)en, weld): entweber in bem Man= 8ig. 402 Testacella. telielfit vertorgen ift, ober wie sin fleines Gditoden an Dem Sinterembe Des Rörters anfs

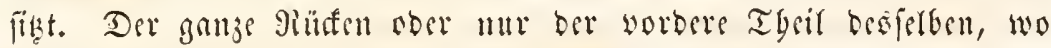
bie Rungenbëble und die afferöfrnung liegen, ift mit cincm fleifdigen Gdilde bebeft. Dne Thier bat vier Füblet, bie ganj wie bicjenigen Ier vorbergebenden Jamilie geftaltet find. Bei ten mit siner äuberen Gdale werfebenen Gattungen liegen affer unb Qungengöble unter bic= fer Edale am binteren Ende bes Sörpers. Limax; Arion; Testacella; Vaginulus.

Gine anbere Gruple ber Eungenfdunefen wirb you einigen flei= nen Familien getiloet, welde sin meift thutmeörmiges (jebänfe baten, beffen Deffung mit sinem am Fußis angebradten Deffel wolfommen gefd)loffen werben famt. Die Thiere biefer Gruppe find getrenntent 


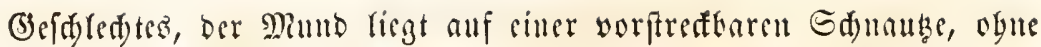

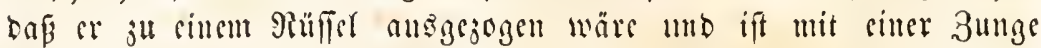
bewaftuct, auf weldyer fieben Rängercigen grjäguelter gyatten fteben.

Die Samifie Dor Fauffancelen (Ampullarida) entiprid)t bent

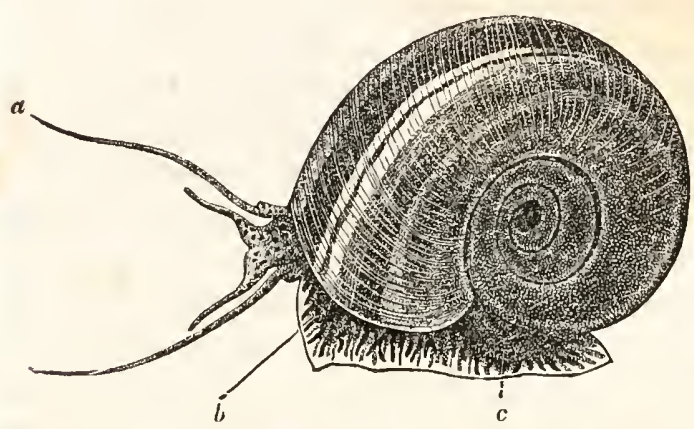

Rig. 403. Das Rsibterturn,

(Ampullaria conu arietis) triedfent.

a Die laugen Fülyler, an beren Bafiz bie : Pugen fte= hen. b Die ju ten Sthemorganen füfrenten Pegren. c Der Dertel.

tragen. Sic fint Doy $=$

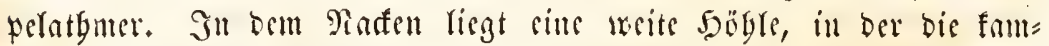
merartigen Siemen befeftigt fimb, unb von welder aus sine Definum in sine barïber liegente Sungengöble fübrt, bie burd) eine Slapte

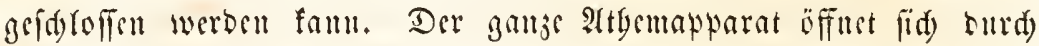
eine furje Piobre nad) angen, bie ano ber Gdale berworgeftredt wer=

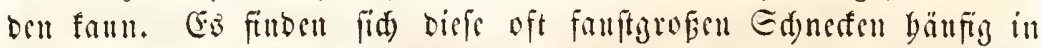
Den Flïffen ber beifen 3one, wo fie zmwsilem monatlang im Ed)lamme

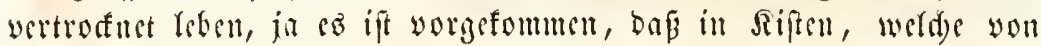
Plegyten aus nad) Gtäbten bes Fefflanbes Nionate Yang unterwegs

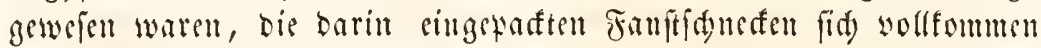
am Reben erbalten batten. Ampullaria; Lanister.

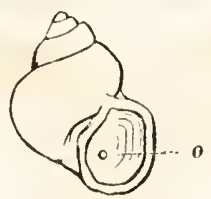

Gine sweite familie, dis Shärichneden (Cyclostomida), wicberbolt gewiffermafen in biefer (bruppe orr \&ungenfdusfen bic Jumilis ber Gdurferfduerten, bod) mit Dem lluteridjicbe, baßj bie Thiere mur juet Filbler befitzen, an beren brumbe die Angen ange=

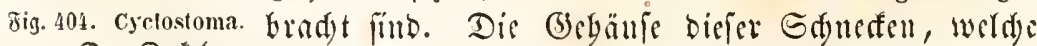
o Der Deffel.

fowobl bei แnts, als in beif́en \&äแbern yorfommen, yaben eine runbe ober Galbfreişörmige Mündung, bie mit simem Deffel volffändig verfdyloffen werben fan. Sie atbmen aber nur burd) 


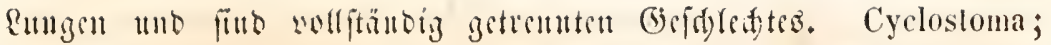
Helicina.

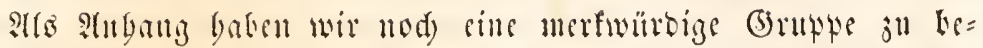

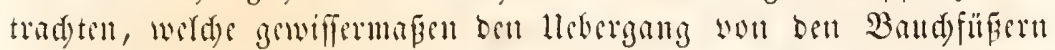

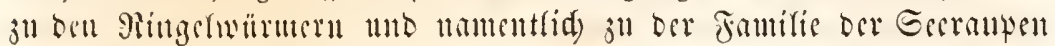

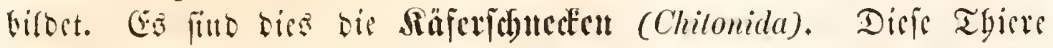

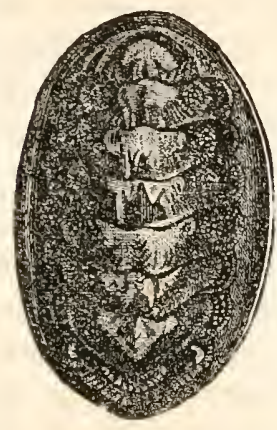

Fig. 405. Chiton sun vien. finb won owaler, juweiren etwas länglider, plattgebrilfter beftalt und jeigen anf ber llu:

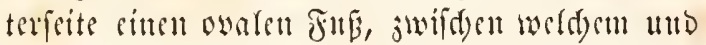
bem Mantefrande, ber ben fun weit luberagt,

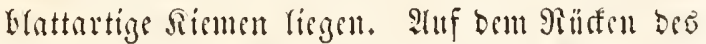

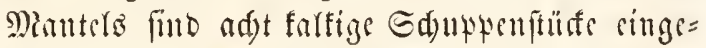
fïgt, welde entweber badjojegerförmig libereint= anderliegen ober aud fo weit wout eimander cutfernt fint, bap fie nidyt simmal fid) berilb= ren. Der Mantel ift fonft mit Gtad)elt, Sanaru, Borftentuffuelt ooer ffeimen Gdünpdyen meift über mo üler bebertt, sine Befleiomng, weldye bei feimer anderen Edueffe vorfommt mo febr ocrienigen ber Ger= raupen äbnlidy ift. Der Sopf ift frein, rmolidy, obue Angen mu

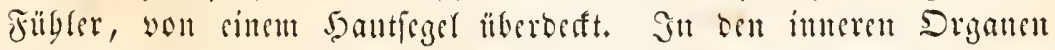

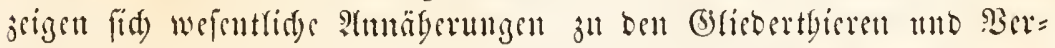

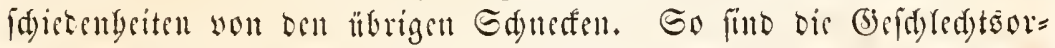

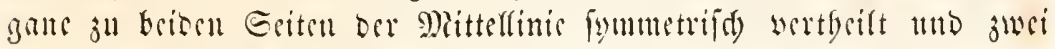
feitlide (befdy)dedseffimuthen sorbanden, wis fie fonft bei feinet ande=

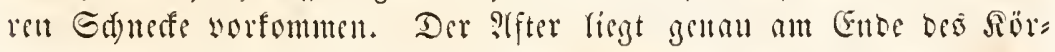

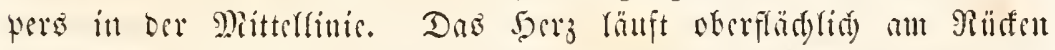

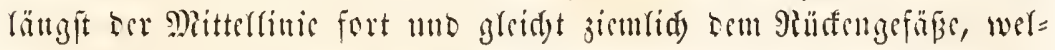
d)es bei ben meiften Gilisertbieren wortemmt. Alle bicle Eizenid)af=

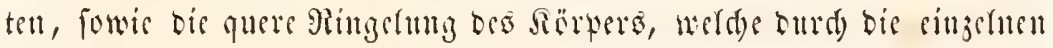
Deffylatten angebentet ift, mäbern bas Thier in Der That Den Riuger= mürmern frbr, tuto es bebliffe genauer jorfdungen tiber bis Eut=

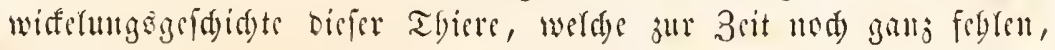
un ju entedeiben, wedden sou beiben Sereifen fie angegörn. Chiton; Chitonella.

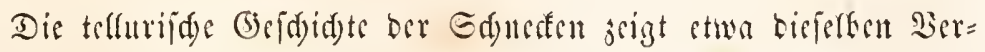
bältuiffe, wie dis der Blattiemer. Gie baben jwat an abjoluter, wie 
an relativer 3abl in ben eitjeluen Formationen jugenommen, aber

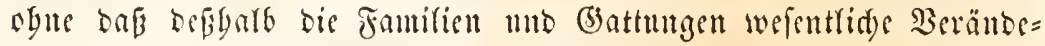
rutgen erlitten bätten. In ben llebergangşgebirgen fommen wenig= ftens eben fo siel : Irten nod letenter battungen wor, alo foldse, sie untergegnugenen (5)attungen angebören und anffarlent verfd iebene Typen finben fid) faum, mit Atsinagme ber biattung Belierophon, bie aus

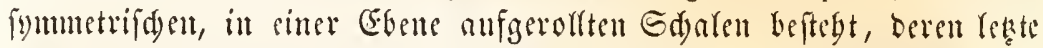
Binbung febr weit if, einen balbmonbförmigen, fduribenben Diunto

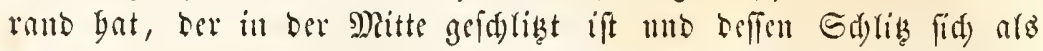
Rirl anf ber äuperen Geite ber Gdale fortfetzt. Dian bat biefe Gdan= Yeu ralo in bie Räbe ber Blafenfdueden, meift aber ju tent Jloffen=

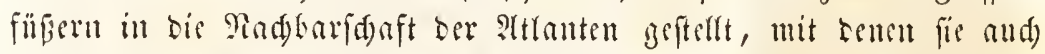

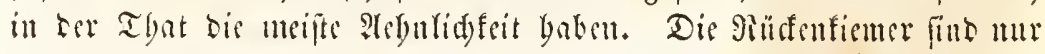
ourd) bie Blafenfdueden (Bulla) mo jwar erit won ben jurafiriden

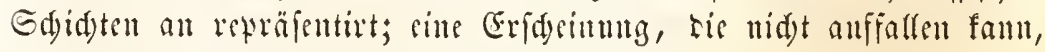

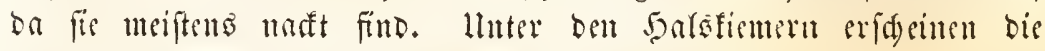

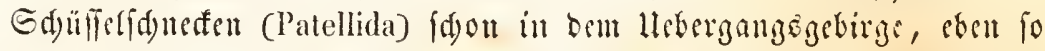

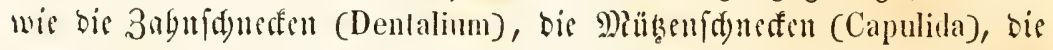
Raffid)nedfen (Sigaretida), bie Strandidnedten (Litorina, Turritella), bie Raberfdueftu (Cerithida), Die Tritonsbörmer (Buccinda), Dis Mombfduefen (Neritida), bie Sirifelifmeden (Trochida), bie Eses

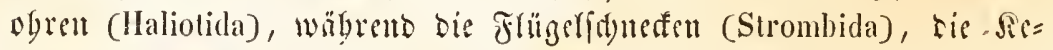

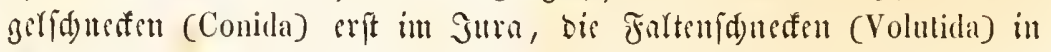
Eer Sreibe, bic Gifdueftu (Ovulida), Igurmidueden (Pleurolomida), Epinderfduefen (Fusida) mo Felfemfduefen (Muricida) erft in ter Tertiärzeit ju woller Entwiffermb gelangen. Die Rungenidumeften,

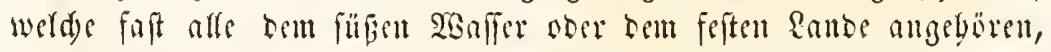
begimen erft in ber befanten SBälberformation, jener rofalen Gäß wafferbiloung bet unteren Sirsibe, find aber bam in alfen Gümaffer ablagerungen zablereid) wertreten.

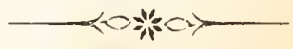




\section{Bebuter Brief.}

fireis der fiopffüfier. (Cephalopora.)

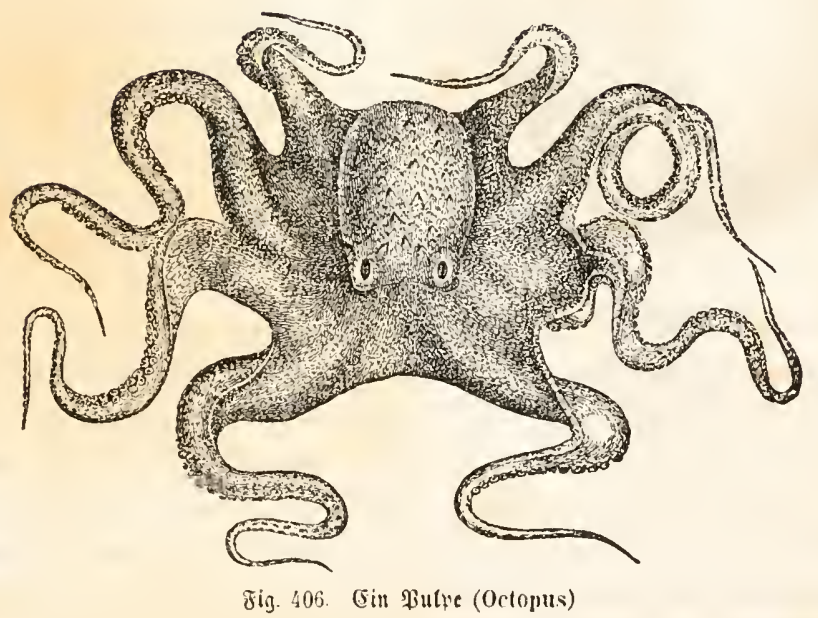

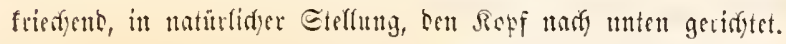

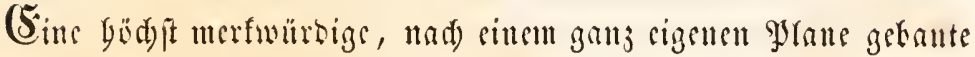

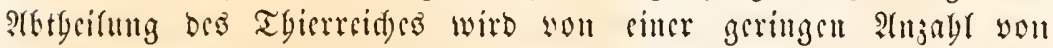
Thieren gefilbet, bic in allen Meeren vorfommen unb cine Menge vo: Borfagren in ben älteren Edjidften ber Groe jäblen. Sn ber That eridseinen bie Ropffübler, werd)e in unferen jeţigen Miecren Ysben,

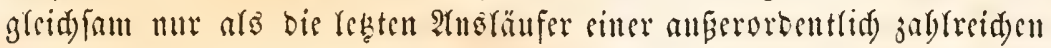
unt in igren Formen äuperft mannigfaltigen Bevöftermng, welde um fo bebentender ausgebirbet war, ie weiter wir in ber Erogejdjidte ju frïberen Jerioben jurürfgelden. 
Die Soyffïgler tragen igren Ramen won ter eigentbünliden ?II =

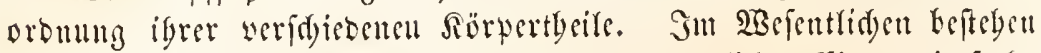
fie aus cinem grofien, meipt längliden ober runblid)en Eingeweibefacte, auf welden nad) einer mebr ober minter bentidgen Finfdührung ber Soff folgt, ber init gewaltigen, ill Sireife geftellten Alrmen umgeben

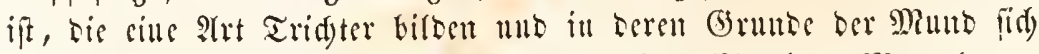

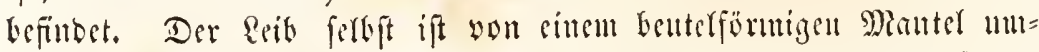

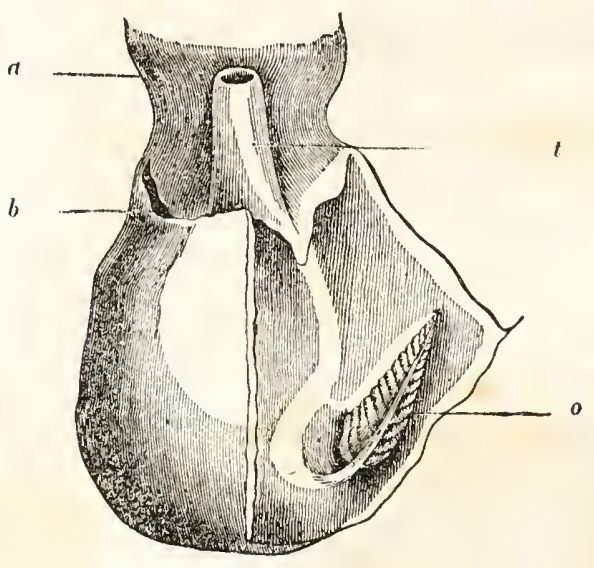

Jig. 407.

(Eiu Buffe [Octopus] von ber Bandycite

Der Mantel ifit ber Mittellinie mady gefpattell unb auf Ler sinen Esite zutuiffgeids)lagen, io

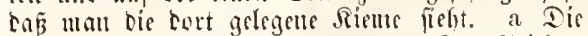
Simfdutumg unter bem Ropfe. t Der Tridster

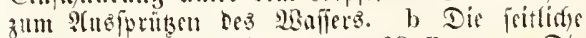

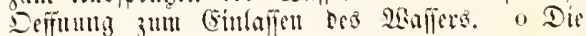
liufe תisme. fdr)lofen, ter lur auf ber Band) feite nad) vortle geöftnet ijt unt bier sie 3ugänge zu oer Riemengöble jeigt. 3wi= (d)en ull vor biefen Deffmul= geu fiebt man cille trid)terför= mige Riobre, surd) weldye bas Maffer, weldaco jux Atgmung gerientbat, ausgeworfen wirs. 3ux Geite des Ropfes fteben jweigrobe, meift sorgenuollene Nugen, beren Etructur biu= fidstrich ifuer Somplication in friner raseife Derjenigen ter böberen Tbiere nad)fteben Diifte. Die Arme felbft, wet= d)e um ben Mant fteben, fiub mustulöf Fortfäke, rie fowobr jur Drtabewegung alo aud) jum Fangen or Bente Dicuen

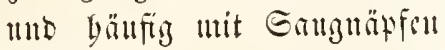

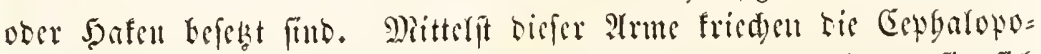

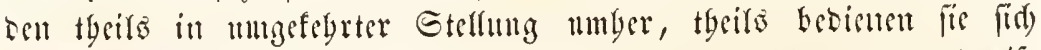

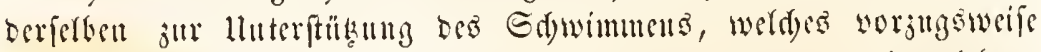

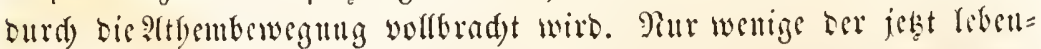

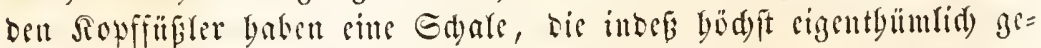

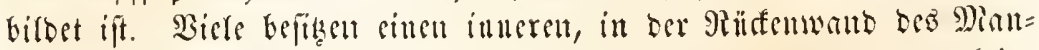
tels gelegenen Sinod)en, ser oft verfteiuert ergalten wurde ull feitte entbebren aller fejteren Theile, on bei alfen eill foliber, uncift aus meb=

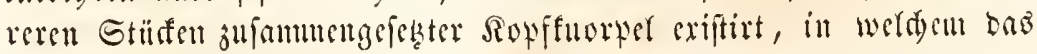
(b)birn singefd)loffen ift.

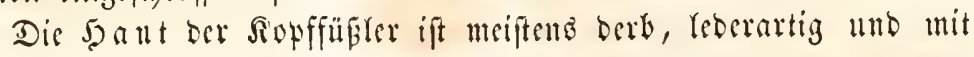


cimer zarten Dberbaut weriegen, welde nirgenbs SBimperbaare trägt.

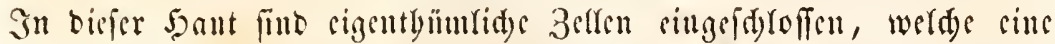

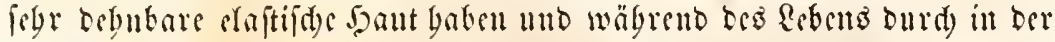

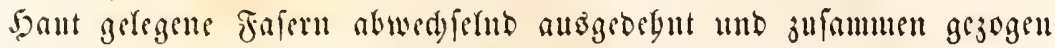
werben. Dicje Zeffen (Egromatopboren genannt) fint mit blanen, wioletten, rotben, gelben vor braunen Farbenfoffen gefüllt, bie bei

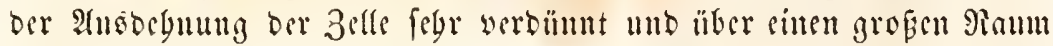
aแsigebreitet erfdesinen uno bebbalk faft ber fawinoch, wäbrent fie bei ocr 3nfammenjiegung ber 3elfe Durd) igre Angänfung igre Tinte ins

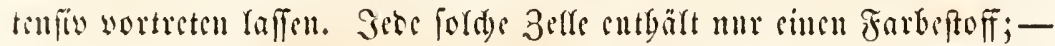

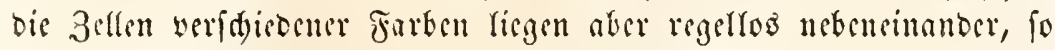

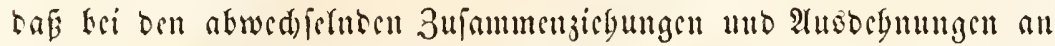
sincm beftimunten Junte balo diefe, balo jene Jarbe bervortritt. Dis

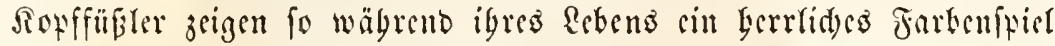
son blauen, rotben uno gelben Tünen, bic fdillernt liter ben Rörter

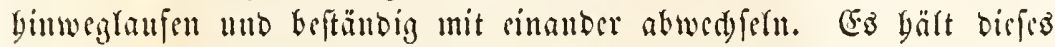

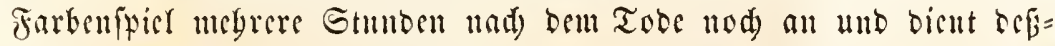
balb auf ten Märften ber אillften, wo man bie Thiere ift, zun Zci= den ibrer jrifde. Man bat cinc äbnlide Srganifation oer 5amt nod) bei feimem anberen Thicre gefunten unb ift nad) unferem jesigen Gtandpunfte ber Renntuif vollfommen bered)tigt, jebes Thirr, bei wel= d)em man cine foldye finbet, alo zu ber Rlaffe ber Soyffübler gebörin anzufeben. Der Farbenwed)fer jelbit und bas abwed)jelube Spiel ber Farbenzelten ftegen lubrigens offenbar unter ocm Einfluffe oco Merven=

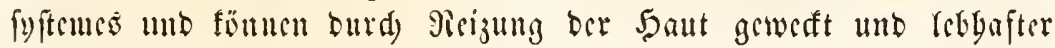
gemadit werben.

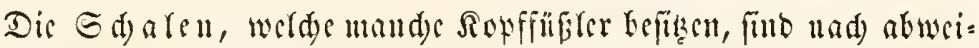
d)enten Tupen geftaltet und fümuen nidst mit benen ocr Eduefen serwedjalt werten. Sic fint fteto im Berbältniffe igrer bröfie, bünn

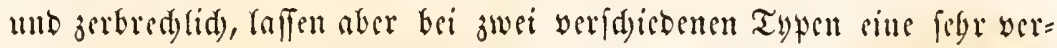

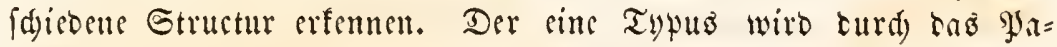
picrboot (Argonauta) bargefteflt, sin Thicr, Das fid) bäufig in bem

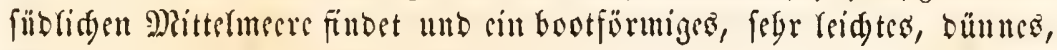




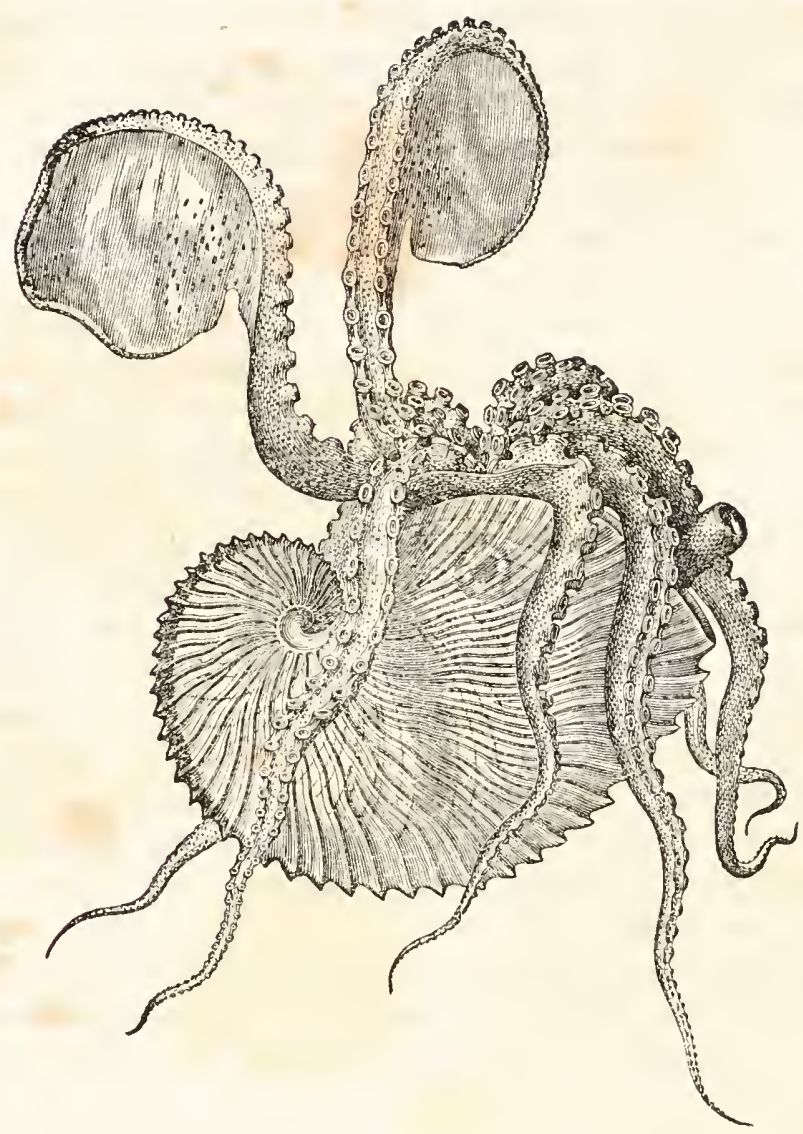

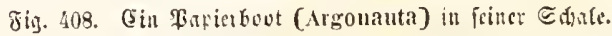

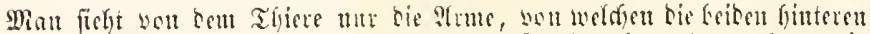
fegelformigen iffe äusere, bie Edjale abjubernoe slädye jeigen, on rofyrenartig

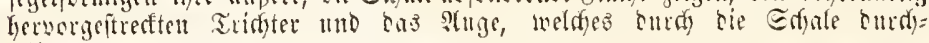
foimmert.

binten fpiralig eingerolltes, quer gereiftes bebäule Kewobnt, das

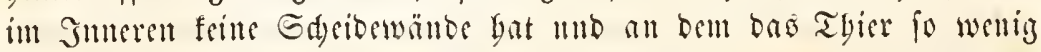

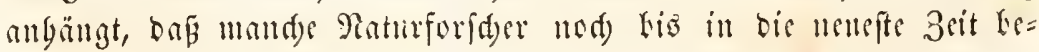
baupteten, es balte fid) mur alo Gdumaroker in biefer Gdale all, bic

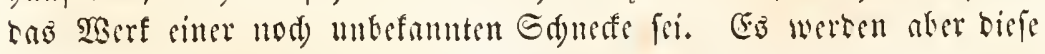
Ganten offenbar nidt won bem Mantel bes Theres, welder nirgento tamit zufammentängt, fonbern von ben leiben fegelartig ansebrei= teten, Ginteren Âmen bes Thieres gebiloet, weld)e nad) unten jurürt= geflappt getragen werben uno anf ibrer nełartig gegitterten 2 แbenfläd) 


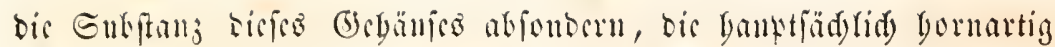

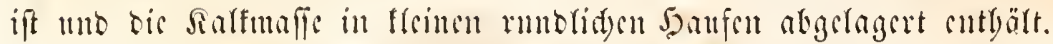

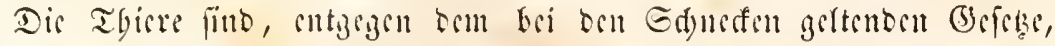
iun Cis solfommen naft mo crbalten bick Gdare srit fräter mu= gerifiet.

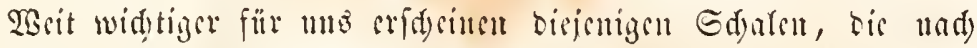
siucm Ty

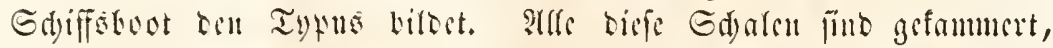

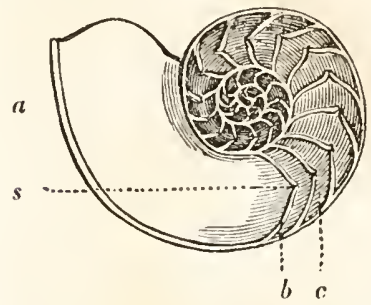

isig. 409.

Die $\mathbb{E}$ dyule cines Bertroutio (Natitilus)

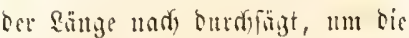
Simrollung lutlo bie Rammern ju zeigen. a Eetste fimmute, bie cint=

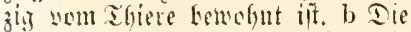
erite Edyeisematio, metdye bis mad)= folyenton finmmern e abtremt. $s$ Der Eipfo, wefdet die Semment in Serbindung fetst.

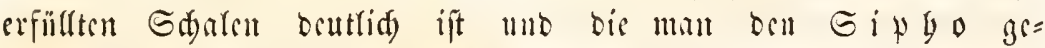
nannt bat. Bei beu tobten Edaren fdeint fo jebe vorberigebribe Sammer nad) binten in bis folgenoe geöffuct; unter fud t man aler bie

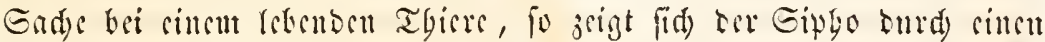

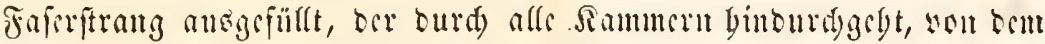

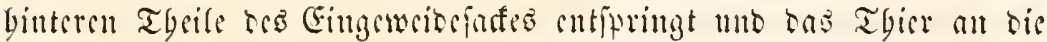
Edale befeftigt. Cege man bas Thier, won bem erit in ber neneren

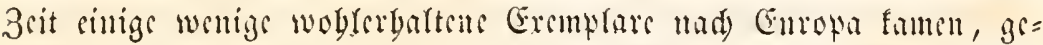
naner fannte, glanbte man, sap bicfer Sipbo in for Defonsmie bes

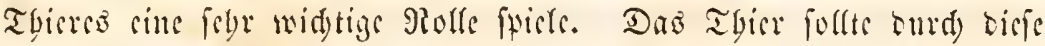

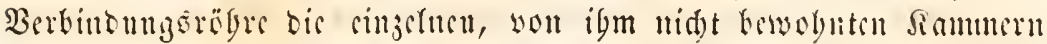

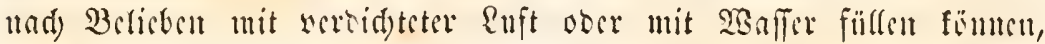

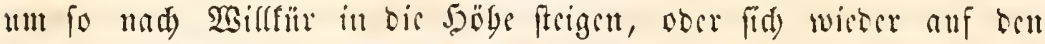

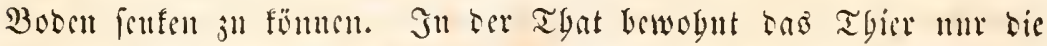
regete Sammer feiner Edale unb alle binteren Sammern erfabinen 


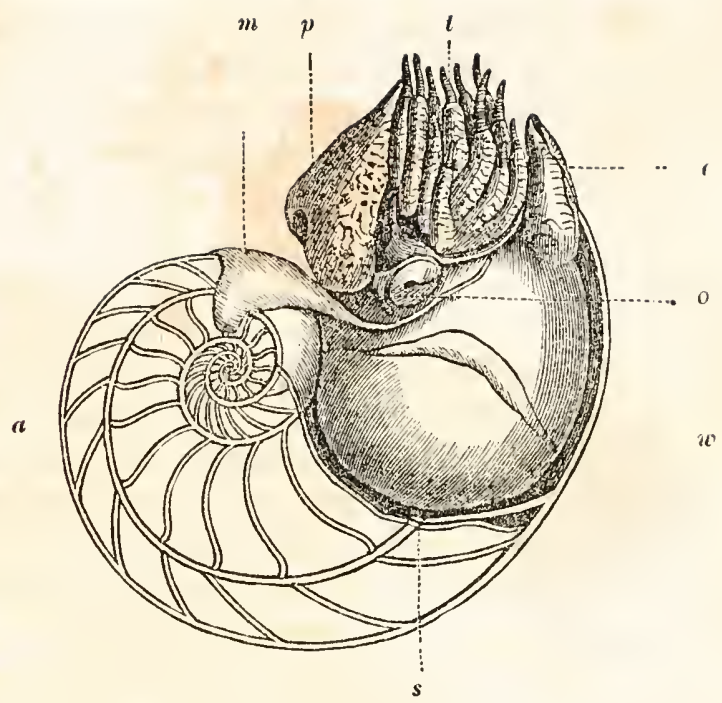

8ig. 110. Das Perlfout (Nantilus) in feiner Estjale.

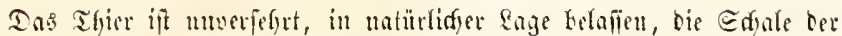
Ränge mad) halfit, um bie Rammern und ben Durd) bie Rammern laufenten

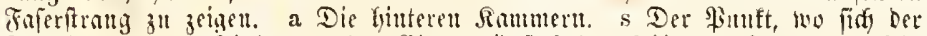

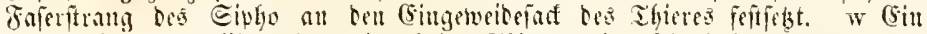

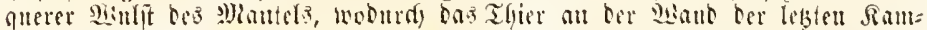

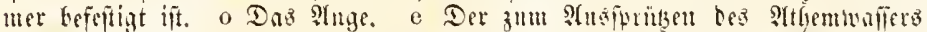

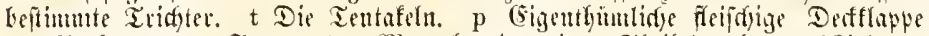

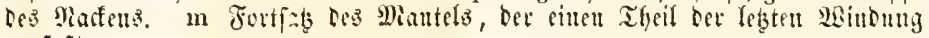
mแm fât.

yollfonmen Yerr, aber fie bilben burd biefe Rere un cincn bybro=

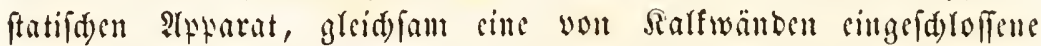

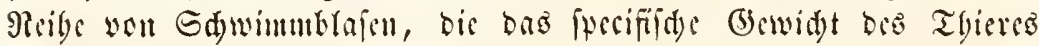
Wabrid)eintid) Demienigen bes sanfers jemlidy gleid) maden. Da alle biefe gefammerten Gdalen nur cimer Dromung ber Ropffüfter, Den Bierfiemern angebören, fo werben wir igre befonders für bie

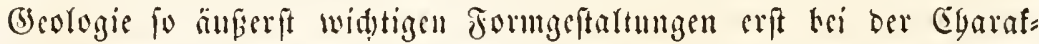
trifirung ber Dronungen näber betrad)ten, und in gleidyer 2Beife biul= (iid)tidy ber imeren Gdalen verfabren, welde ber andern Drommis ber Prmfü̈ßler, ben Zweifiemern, cigentbümlidy find.

2uber Den veridjedenen Gdyalenfüten bejüen de Sopffïbler ein befonderes inneres Efelett, weldyes ftets ans Sundpelftüfen feftebt,

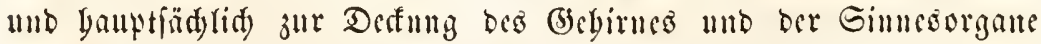
bejtimmt ift. Dic Sampmaffe bicfes interen Gfelettes wirb won cintem Sopffnorper gebifbet, ber rund un ben Gdylund Gerum liegt und alo

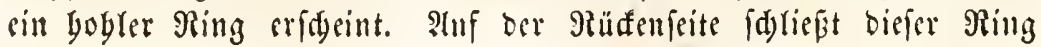


Das Grbirn und bie Gebürorgane cin und nad ber Geite fdyift er

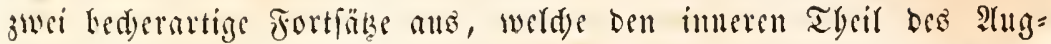

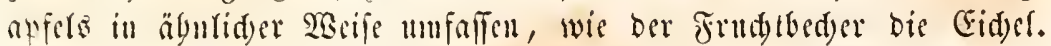

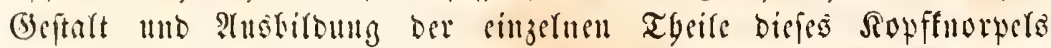

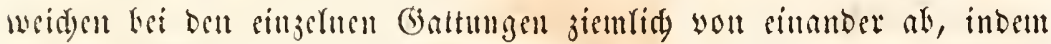

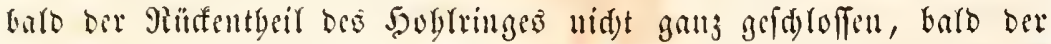

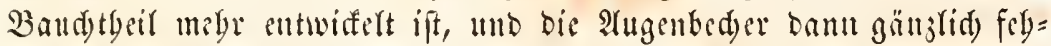

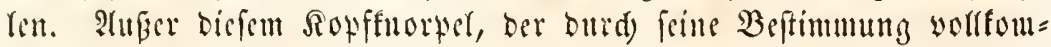

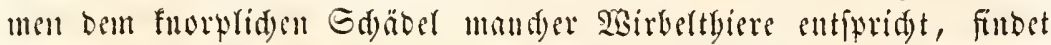
man nur Lei cinjeluen Battungen, balo in ber Plïfenfette bes Mian= tels, bald an Dem Trid)ter, bald an ber Baftio Der Irme, wereinjelte Sucrkelftüfe won geringerer 2 ebentung, bie bejontores zul Serfteflung fifter Sunfte für die 2 Birfung ber Mugfeln ricuen.

Die Bewegung ôgane oer Sopffïbler befizen förmlide Mugfeln, bie fid) in eingelne, wobgeorduete Bünber tremen raffen und Gauptfäd)lid) in Mantel und Den Armen entwicfelt find. Der

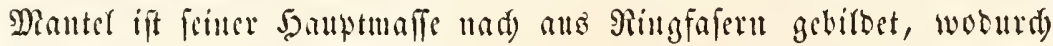
befonber bie Sicuenbügle febre fräftig jufammengejogen und bas it

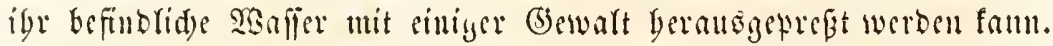

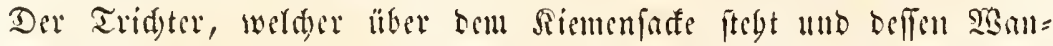

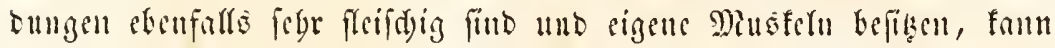

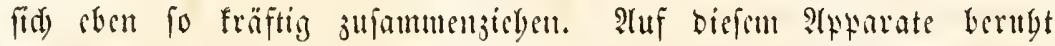

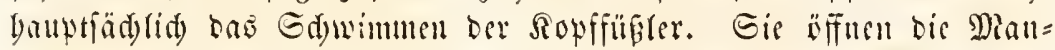

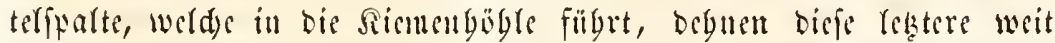

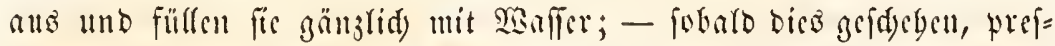
fen fie Durd) 3 manmmenjiegung ber Ringmusteln bie beiben Rifpen

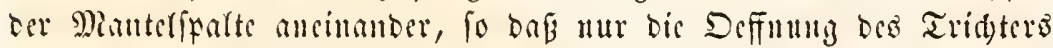

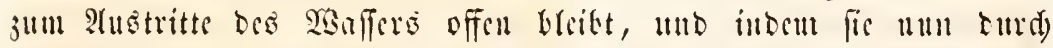

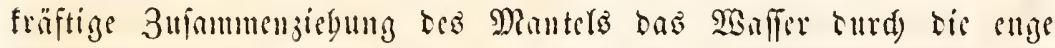

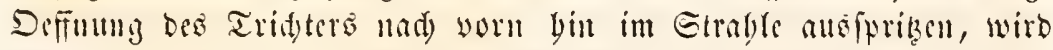

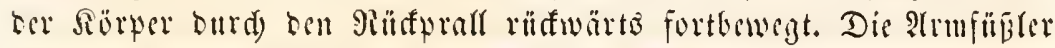
(d) wimmen arjo alle rinfwäts, bie bintere Spike bes Eingeweibefactes woran, und fie find meift un fo beffere Gdymimmer, je fpiker mo

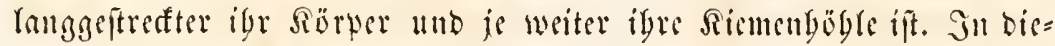
fer Bewegung weroen siele wou ígnen unterftët turd) jwei feitlide Sautlappell oder Floffon, weldse bald mebre ginten all Sïrper in Dreicfisform, balo mebr uad) Der Mitte ju angebrad)t finto und offen= bar nur jur Cryaltumig des Rörters in borizontaler Etellung be= fitumt fint.

Die It me, weldse um ben Sopf in Sieife geftellt unb befonters 


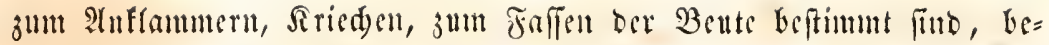

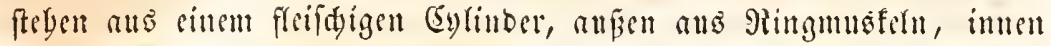

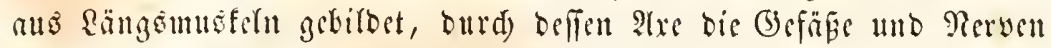

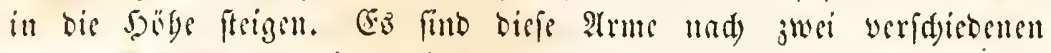

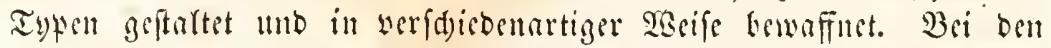
Werlbovten nämridy fint bie 2(rme in grofier Anjabl vorbanden unb

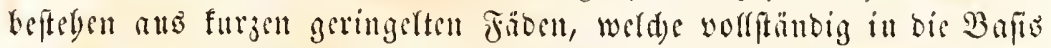

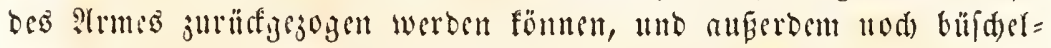
weife unter sincu fleiforigen Decfer fid) bergen, beffen äupere Fläd)e,

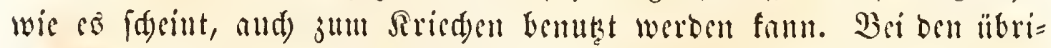
gen Supfïilern find bie ?trme mit einfad)en ober bopperten Reigen won Ganguapfen auf ibrel inneren, ocm Munbe jugcwanden Fläd)e befest, womit fid) bie Thiere äujerft feft anfaugen fönuen. Jeber

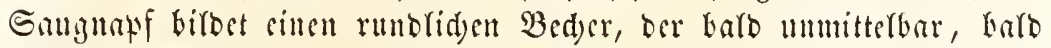

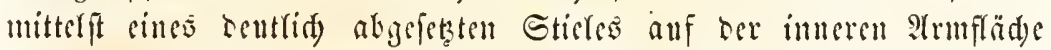

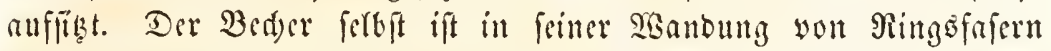
unt ftrablig gefterten Masfelfafern gebirbet, unb feine Münbung meift mit ciner bornigen 5ant werid)loffen, bie in ber Mitte sin lod bat,

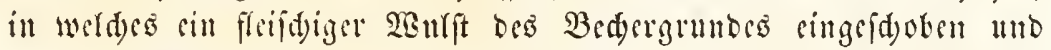
wis ein Gtemper nad) dem Anpaffen des Gangnapframbes zurüfige=

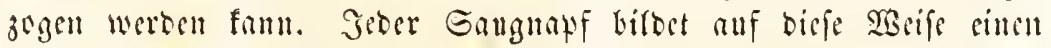

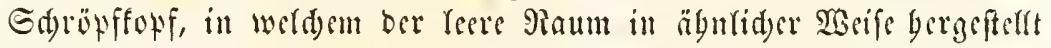

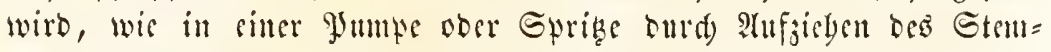

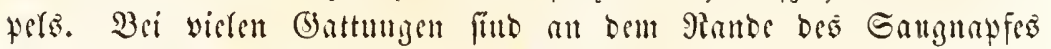

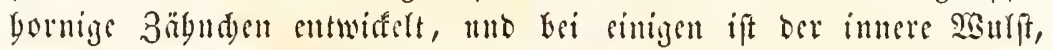
welder aus bem (3runbe des Gaugnapfes bervoridaut, mit einem bornigen 5äfden befetet. Diefer Safen entwiffelt fids baun oft un=

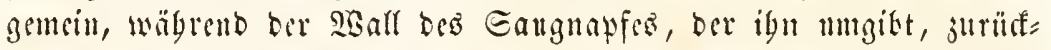
fintt, unb es erfescint bam ber Arm mit siner ofer mebrexen Reigen

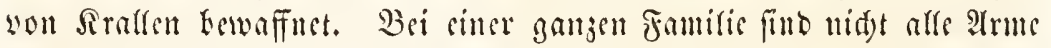

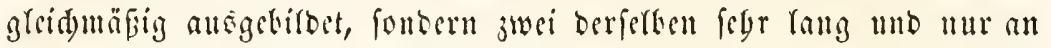
ibrer Gpitze werbertert mo mit Gamgun̈pfen werfegen, wägrend ibre

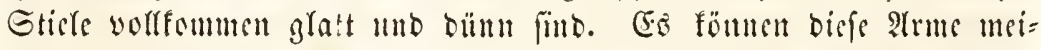
ftens in sigene Edjeiben, bie zu beiben Geiten bes Ropfes angebrad)t finb, jurürfgejegen weroen.

Das Reryenfyftem Der Soyffügler erteidst einen Grad der

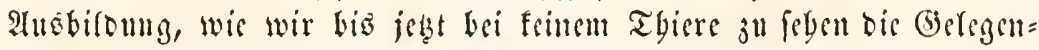

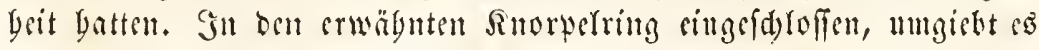
Immitterfar ben Gd)lunb unb fann bier it zwei Jyanptmaffen, sin (3)birn unb einen unteren Theil, unterfdeben werben. Die obere 
Marfmafle, weldye etwaz unbebentenber iff, entfenbet nur wenige frine Rerven ju ben Piundtgcilen, wälrent bie untere Revvenmnffe bie

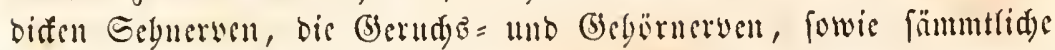

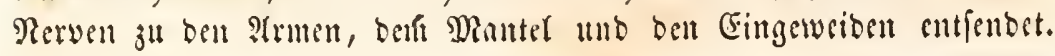

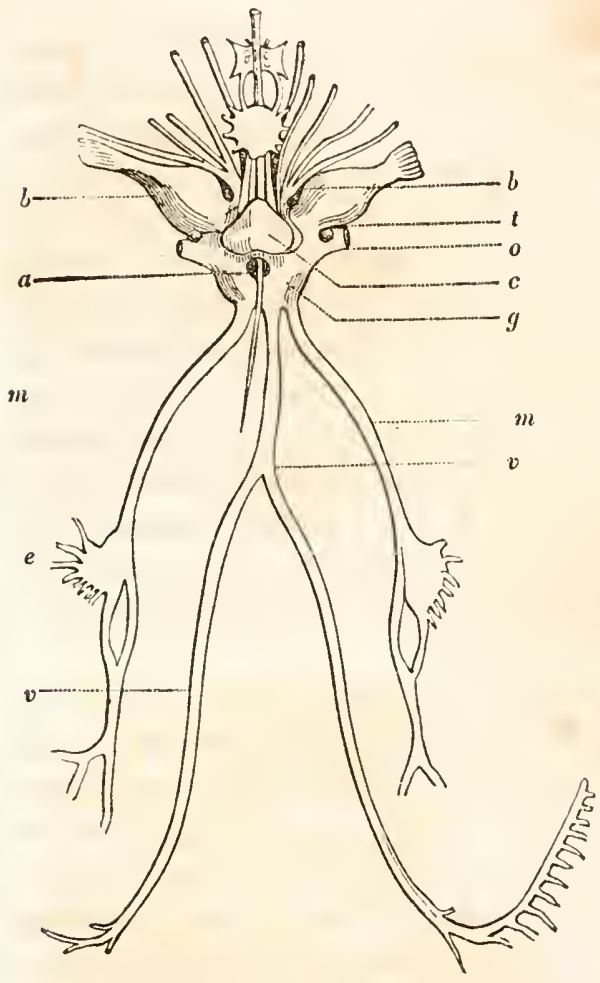

Fiij. 411.

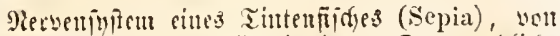
obent gejehen nut günglid ifslict. a Das rundidye

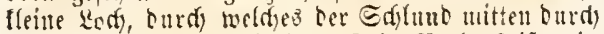

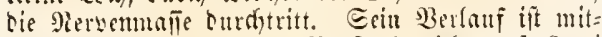

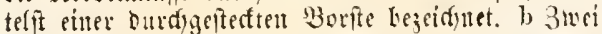

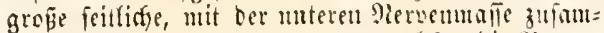
monfängende Sierwenfuten, yon weldyon bic Merwen Dor zefin Alme entipringen. c Ebere Yerucumalie, bas (S)efirm. Sadd worn entipringen aus bicfen

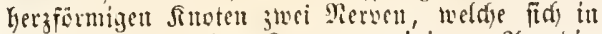

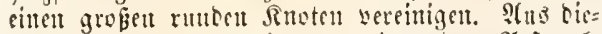

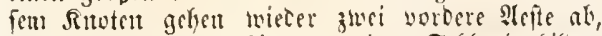
bie pinen zweiten Ring nm Den Edylunb filoon unt ind unter bemfelken zll sinem vierestigat sip= penganglion wereitigen. g Die mutere Siervemuafic, aแs weldyer worn bie stugenterven o entipringen,

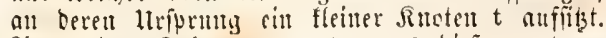
P(uper ben Eefnerven treten anz biejer unteren

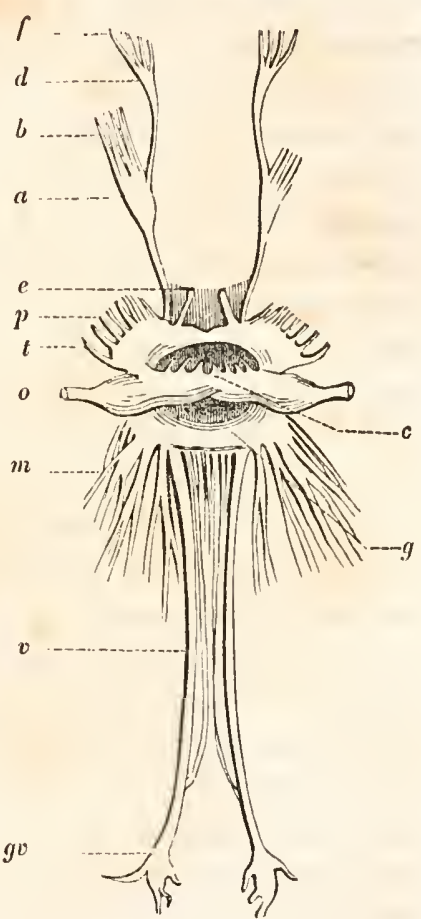

siis. 412.

Scruerinitem bes Derlbootes (Nautilus). c Das Brbirn, aแล bem bie Eefnerven o feitfid ents furingen. g lintere Rerwenmafle, in eincen vorteren unb fintersil jalking geidjetent. $t$ Eritlidge finoten bes vorteren 5albringes, aแล weld) ren Temtafelu $\mathrm{p}$ entipringen. Mad worn gehell woul bicier servett= malle zwei Fan glerven ab; bie

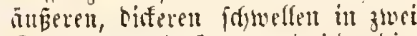
Sincten a und d ant nut jeter cie= fer finten giebt Sierven b utto $f_{\text {, }}$ Dic z̆ ben worteren Fühlfä̀ en gehen. Das intuere, dinnere Nieruempan e geft fum Tridgter. Bon Der hint= teren, unteren Siervenmalle g ftrah= 
Rervenmafie nod bie Diantelnerben $m$ herbor, welde hart an ber Epaltêfm!ng Des Riemenfafes jederfeits ein fiarfes ftemformiges (Sianglion e bil= ben unb ferner in ber sDitte ber grefe (Singemeide nery $v$, ber fird in zwei Ifepte theilt, bie alle (5in= gemeibe mo bejunters bie Siement mit 3weigen verforgent.
Ien ummittelbar bie Diantelfäbent m tub bie keiben grepent Siugereibe: merven $\mathrm{v}$ ans, bie in ifrem Ber= Iarfe zu einem bebentenden (Sanglion gv anjajwellen.

Die Irmmerven erfd)einen in igrer ganjen Ränge in cingelne Snoten angefduwllen, beren jeber einem Ganguapfe entpridyt unb in biefen feine Rervenfäben fendet. Die beiben feitliden Mantelnerwen fduel= len sbenfalls am Cringange bet Riemenböble ju einem bebententen (3anglion an, bas nad) allen Geiten Nerven aušftrablen läp̈t uno unmittelbar unter ber Sanut liegt, fo baß man es febr leid)t erfennt, fobald man mur die Siemenbëgle aufgeidnitten bat. Aluser biefen be= beutenden peripberifden Rervenäpen eriftirt aud) nod cin cigenes Rer= wenfyfem, weldes mit bünnen fäben vom unteren Sirnfuoten ent= fpringt und manderlei Sinötdyen unb Rege filbet, bie auf Ed)lunt unb Magen auflegen und nad) ben verfdebenen Fingeweiben 3 weige

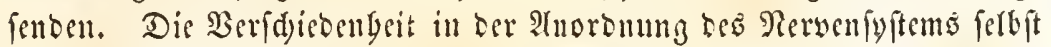
ift inbeffen bei ben werfdebenen Sopffüblem bebcutend. So if bei ben गerlbooten ber Gd)lunbring weit gröper, baz Gebirn aus zwei Snoten zulammengefest $\mathfrak{u}$. T. w.

Dem Rerwentylteme entipredyend, fund die Sinneborgane aub=

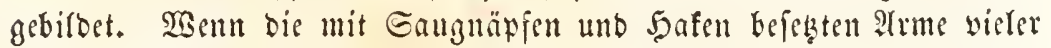
Gattungen weniger zum Taften geeiguet erfdeinen bürftell, fo baben bod) gewiß bie einjiebleren fäben auf bem Sopfe ber Yerlboote bie= fen 3wert, für ben fie ganj geeignet erfdeinen. Die 2 ugen funb bei Den meifen Soyffüblern auperorbentlid) entwidelt, fie fteben, wie (d)on crwägnt, ju beiben Geiten bes Sopfes, meif mit igrem Grunbe it ciner fapfelartigen Berlängerung bes Ropffnorpels singefenft uno zei= gen eine äuperit zufammengefeste Etruftur. Bei ben meiften ift ber AHgapfel won ciner Sreisfalte ber Şaut umgeten, welde bie Rolle yon Alugenlibern fpielt. 3wifden biefen Rioern ift bie Jaut verbünnt unto bilbet eine ourdfidytige Sornbant, binter weldyer ber faft freie Augapfer regt, ber nad) worn nid)t gefd) loffen ift. Der Atugapfer ferbit beftebt zunädjt aus ciner Sinorpergaut, weld) voll bem Sefnerven Durdbogrt wirb, ber interbalb berfelben sine wabre Retsant bildet, in welder cine Gdjidt won rotbbraunen Farbenjellen abgelagert ift. Dis Rinle, weldye von biefen Säuten umfd)loffen wirb, bat bie Seftalt siner Doppelfugel, mit einem mittleren eingefdultirten Falje, in weld)en

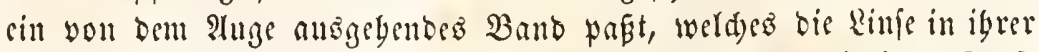

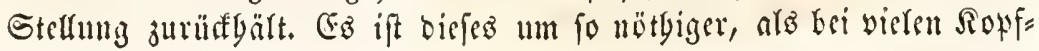




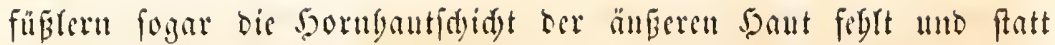

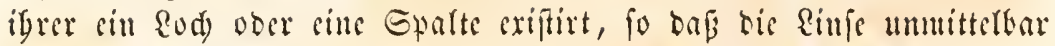
mit Dem Secwaffr in Berillyrung fommt.

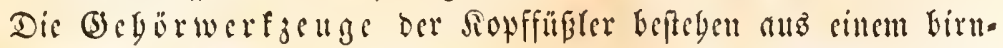

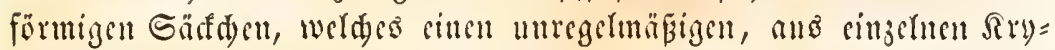

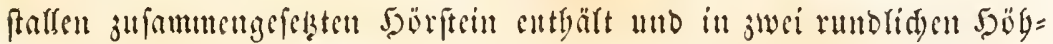
Ien eingegraten liegt, bie in ber unteren 5älfte bes Sopffnorpels

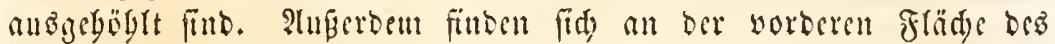
Sopfes, neben ben ?tugen, zwei 5oblen, won bantwülfen untgeben, aแb beren (brumbe fid) ein weipez 2 särjden erbebt, bas offenbar alb bas eríte Rubiment cines Ricdorgntmes angefeben werben mus. DR mun auperbem nod) in bem Cingange Der Mumoböble cin fleifdiger Borfprung fid befindet, ber jiemlid) bebeutenoe Sierven erbät uno auf feiner Doerfläde nit weiden 3otten befegt ift, alfo firfer bie $\mathfrak{B}_{\mathfrak{c}}=$ beutung siner Zunge bat, fo fint bie Sopfiübler mit allen jenen Sins

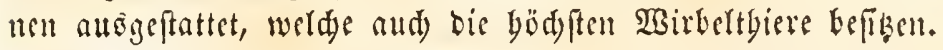

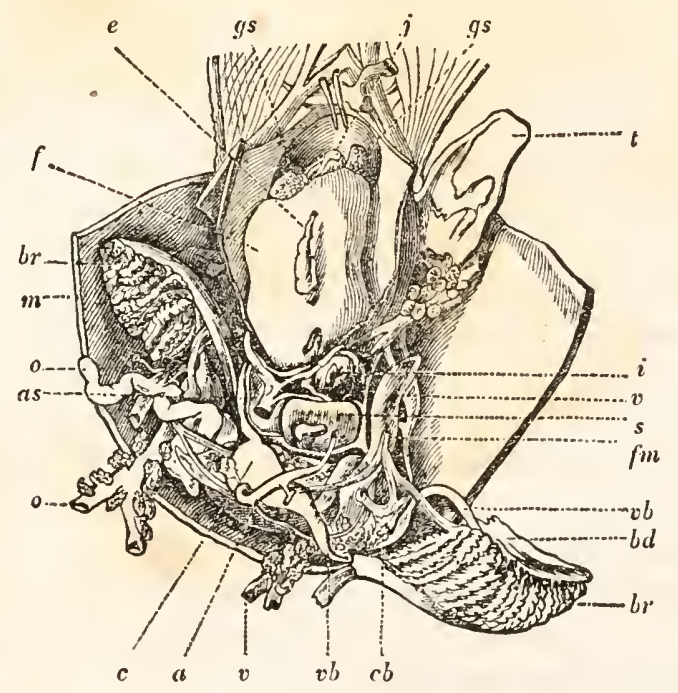

ธิin. $\$ 13$.

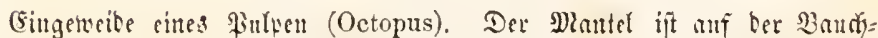

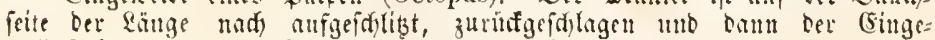
weibejace geöñut. j Der Bormagen, mmittelbar unter bem Ropffnorpel

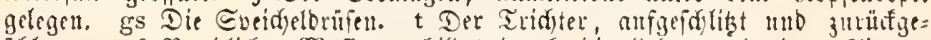

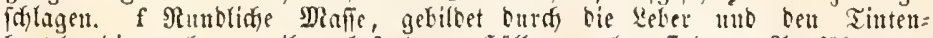

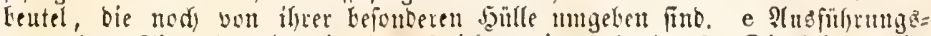
gaug bes Tintententels, in ben Trideter einumbento. br Die beiben Rie= men, bie redyte in ifrec natintidyen Eage, bie linfe berabgezogen. m Dor aufgeid)litste zurnafgeid)lagene Mittelranb, o (siteiter, as (Eingemeibearterie.

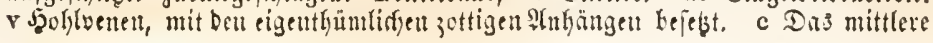


Sörpertyerz, weldes bas burd) bie Siemenvenen vb ans ben Riemen zu=

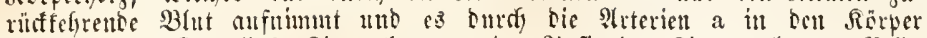
wertheill. cb Das Yinfe Riementyerz, an ber Bafis Ser Rieme gelegen. Bethe

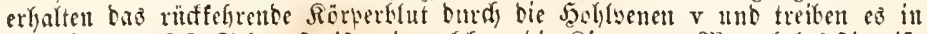

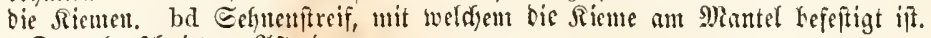
i Det abgejdnittene Sffterbarm.

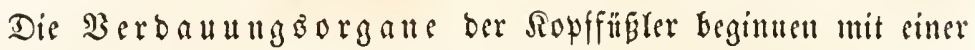
freisfö̌rmigen, von einer gefrangten Sippe umgebenen Mundöftumg, binter welder unmittelbar ein ftarfer musfulöfer Sdlunbfopf ange= brad)t ift, ber mit zwei gefrümmten, eitnem Sapagaifdnaber nidyt un= äGnlid febenben Sornfiefern bewaffnet ift. Diefe Riefer fteben nidd Gorizontal, wie bei ben Siseidtbieren, fonbern fenfredt einanber gegen= itber, und befteben jeber ats jwei flïgelartigen Seitenäften, bie fid) yorn in einer bafenförmig umgebogenen Spize wereinigen. Beibe waffen fo incinanber, bas bei bem Sdyliefen ber beiben Riefer ber Dberfiefer ben Unterfiefer umfät. 3wifden Den Aeften bez lluter= fiefers liegt bie fleifdige, äuferft nervenreide 3 mugentwarje. Bon bem musfulöfen Gdylunbfopfe, welder bie Bewegungen ber Riefer vermits telt, fteigt unn eitl bünner Ed)lund nad unten in ben Eingerweibefact, Der zuweiten in eine $\mathfrak{A}$ rt Bormagen ober Sropf anfdwillt, in allbern

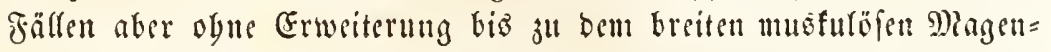
facfe fid fortferst. Der Magen bilbet sinen Britblaf, aus weld)em Der Darmfanal in ber Ridtung nad) vorn berworgebt, unb batb nad)

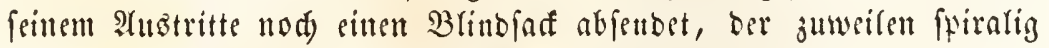

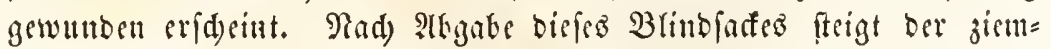
lid enge, bünnyäutige Darmfanal meift in geraber Sinie nad) vorn in bie Sobye und offnet fid in bem Grunbe bes Tridsers mit sincm

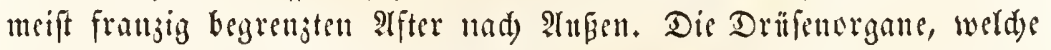
an biefem Darmfanale fid befinden, find ungemein grof und zablreid), benu meift finb jwei gaar von Speideldrilen entwifelt, wowon bas cille am Gdulubfopfe, bas andere am Siopfe liegt, unb auserbem sine Seber, bie jutweilen in mebrere 2rbtgeilungen jerfälft und you einer befonderen Rapfer ungeben ift.

Die Atbmung gefdebt bei ben Ropffifilern burd $\Omega$ iemen, welde in Der Diantelböble zu beiben Geiten bervortreten, unb anz franfigen Blättd)en befteben, bie mit igrer Bafis anfgewad) fen fitto, mit bem gefraufen Ranbe aber frei gervorfeben. Bei ben gerwöbuliden Sopf= fitslern finbet fith mur eille Sietue auf jeber Soite, bei ben Jerlboo= ten bagegen zwei ummittelbar untersimander, arjo vier im Banzen. 


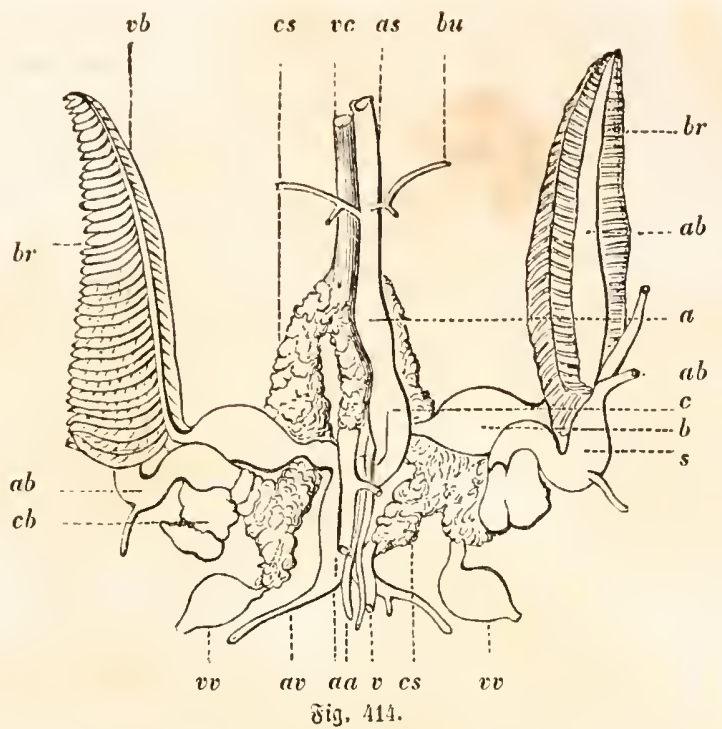

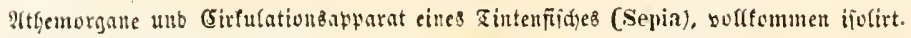

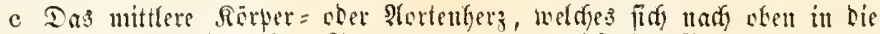

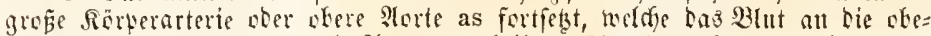

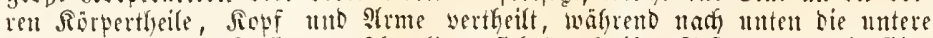

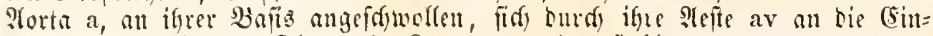

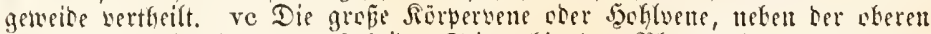

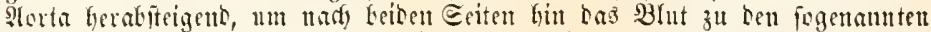

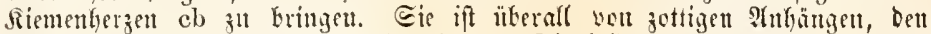

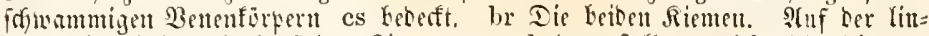
fen @eite ift Der Berlanf ber Siemenvene vb bargepteflt, melde jeberpeits an

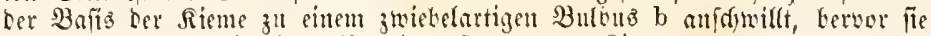

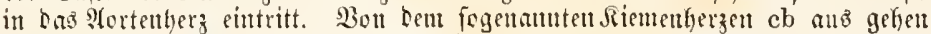
rie Riemenarterien ab aus, bie an ifrem ltriprunge efenfalls pine ziviebel=

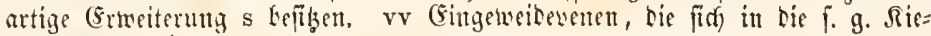

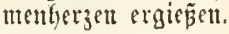

In bet Bafiz siter jeben Riome liegt sitt weiter pulfirender Sad, welder bas von ben Siemen zurüdfebrenoe Błut, bas blafroty ober violet gefärbt ift, in bas in ber Mittellinie gelegene 5 er 3 treibt. Diefes bilbet einen bato mebr runben, bald mebr länglidyen Sdyland, yon bem aus

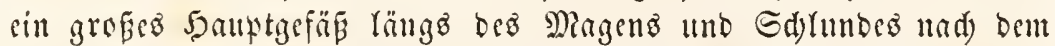

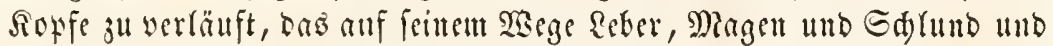
ben ganzen Roff mit 3weigen verfiegt. Cine fleinere untere Arterie verjorgt bie librigen Eingeweide. Das $\mathfrak{B}$ lut, weldes burd) biefe (b)e fäße voun Sergen weggetrieben wirb, faumelt fid) in eingelnen Präumen Les Rörpers und ferbft in ber Eingeweibebögle an, unb gebt bant in rïffübrende Befäße liber, welde entid eine groge Mittervente birben, die neben ber arta berläuft, und fid) in Grunde bes Eingeneide= 
fares in swei feitlicte 9 efte tyeilt, weldye bas Blut nad) beiben Sei= ten bin ju ben siemen fübren. Es ift alpo aud bei biefen Thieren Der Sireiglanf nidat vollftändig gefdrloffen, fonbern ftatt eines baar= gefäвfyftemes jwifden Den Atterien und Benen ein Syftem von 9äu= uten singefdoben, bie wie es fdseint wandungslos fint uno juifden

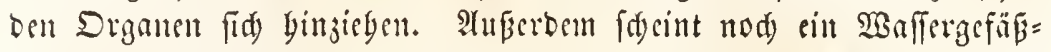
fyfteut ju exiftiren, deffen Deffuntgen an weridjedenen Theilen, beion= Ders an ber Siemenbible fid) finten, beffen Sdyeionng bou bem Bluts gefäfigfteme aber nod) nidgt gebörig bewerffelligt ift.

2ufer ben erwäbnten Drganen befitzen die Rupffüb(er nod) zwei bödft eigentgümlide ?thfonterungsorgane, won welden bas eine burd feinen 3ugalt fogar für bie Berfeinerungen SBidtigfeit ertangt bat. Die beioen 50 broenen, werdye das Brnt nad) Den Siemen binfïgren, fint mit eigentbinmtiden jottigen ober fdwammigen Sinollen bejest,

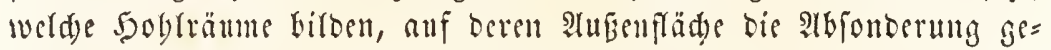

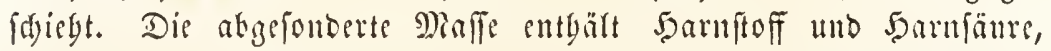

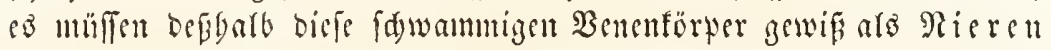
angefrben werben. 2uperben liegt aber in sinem gemeinfdaftliden

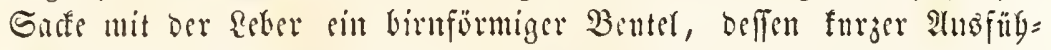
rungsgang unmittelfar neben bem iffer in ben Trideter milnbet mo

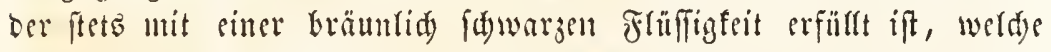
Durdy ben Tridter entleert weroen fann mo bas 2 Bafler in weitem llutange ounfer färbt. Cę fintet biefe braun = fatwärglide Maffe als Farbeftoff, bejonbers in ber Dalerei vielfade sumentung, mo if unter bem 2ianen Sepia Gefaunt. Bei folfiren Rörpern bat man

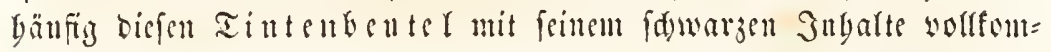

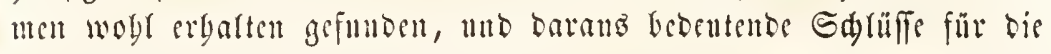
rätbferbafte Ratur mander Sörtwer entnebmen fümen.

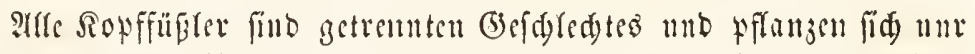
burd) befrudgtete (Fiet fort; wäbrent ater bei vielen (Sattungen bicfer

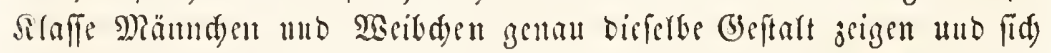

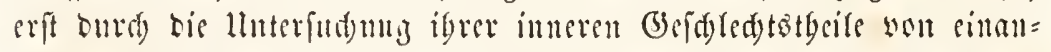
ber unterfdecioen laffen, fommt bei andern battungen die bödft cigen= thüuride Merfwiltoigfeit vor, Daß̧ bie Mäunden anberorbentlich ver=

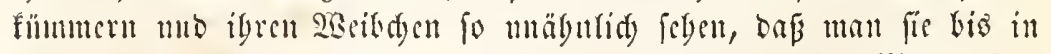

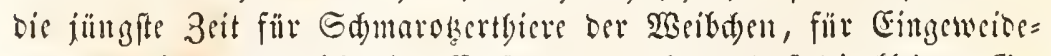
whimel bielt und nidyt im Entfernteften abute, Daßj bie flecinen (B)e=

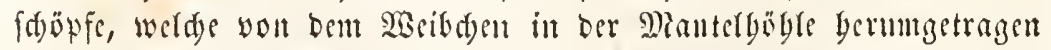
werbell, bie wertifbeten Männdyen iber Beberberger feien. Die 


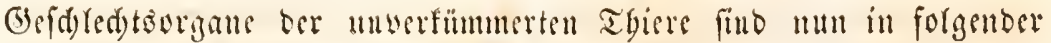

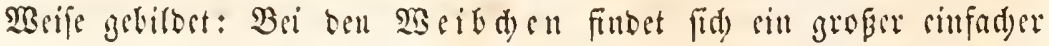

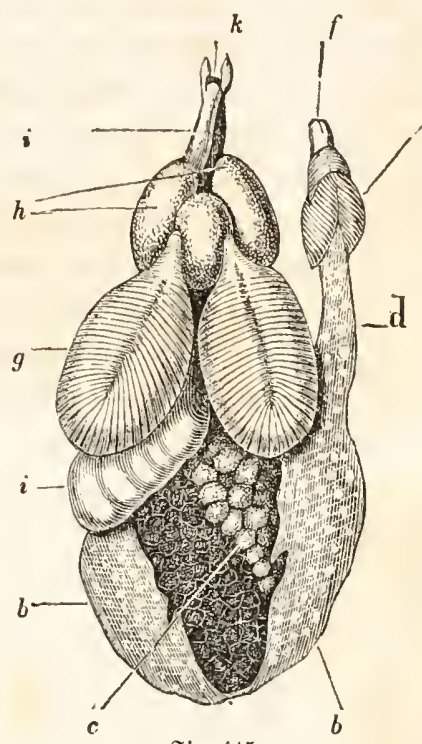

8ig. 415.

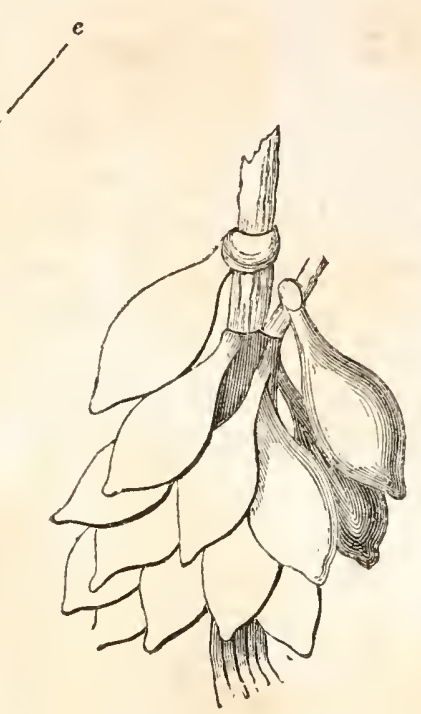

8ig. 416.

Fig. 415. Dieiblidye (B)efdledtsorgane bes Tintentiathes (Sepia).

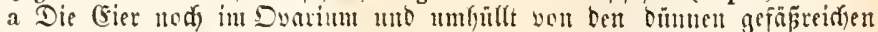

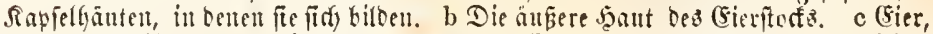

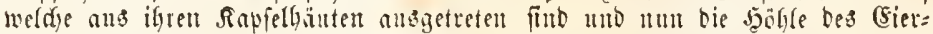

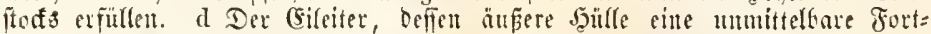

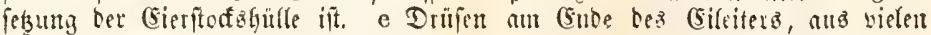

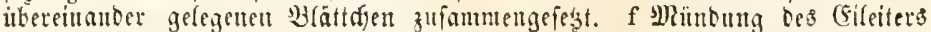

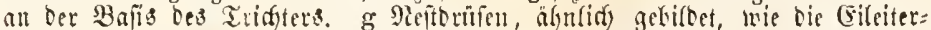

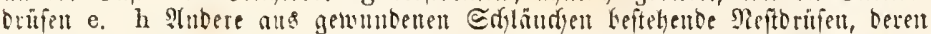

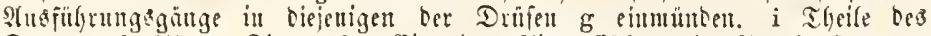
Darms. $k$ sifter. Fig. 416. Siev tes Tinteñ̄inges, in Tranbenform an

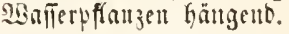

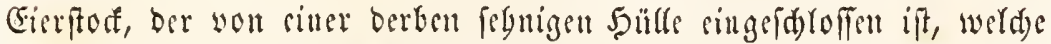
fid) unnittelbar in ben Eileiter fortfert. Sn bem Eirritede wad) fen tie Eier ju siner forden bröge beran, baje endid, bei ben reifen (Fiern bas ganze (Fierfortsgewebe nur nod) bünne, bäutige, gefäpreidye Sapferlitergüge liber bie (Fier bilbet, welde fpäter praken und bie reifen Eier in ben Eileiter übertreten laffen, ber entweber sinfad) ober boppert ift und gewögnlid) im (3runbe bes Trid)ters altem mïn= bet, wo er meift von siner Driffe ungeben if. Anber biefer Eileiter= brilfe fommen bei ben meiften Ropffithlern nod) sigentyümlide Rebene briifen ober Reftoriffen vor, welde ebenfallo in ben Tridter aแtün

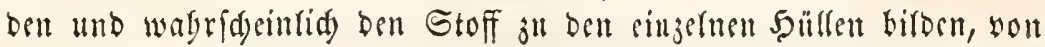


welder die gelegten Eier umgeben find. Die Eier ferbjt nämlid ba= ben meift sine mit nebartigen, nad innen vorfpringenden fralten ver= febene Dottergant und fteden felbft wieder in einer bornigen Sdjale, bis zuweilen fduäraglia gefärbt ift. Biele folder Fier werben nun von Den cingeluen (Gattungen wisber in sigenthümlid) d)aratteriftifder 2 sife ju Maffen sersinigt. So biloen bie gemögntiden Tintenfifde birn= äbulidje Flafden, welde traubenartig zulammengebäuft an Diecrpflan= zen angelieftet werden, und unter bem Ramen Meertranben befant find. Die Ralmare ergengen lange Strängs, die julammengetleste Saufen bifoen. Die Japierboote fpinnen an jebem Ci sitten langen Faben aus, ben fie mit benen ser andern Fier jufanmentwifeln, uno fo simen trabbenartigen baufen biloen, welden fie an ibrer Sd)ale angebeftet mit fid) bermutragen.

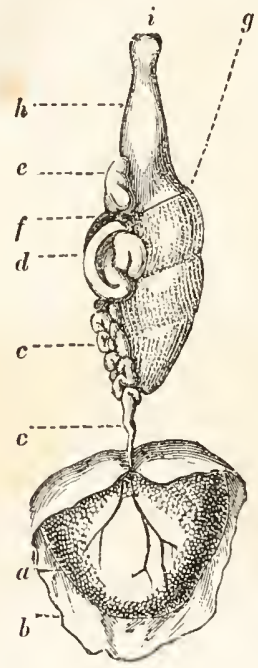

Fig. $41 \%$.

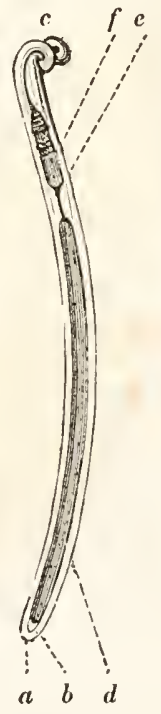

8ig. 418.

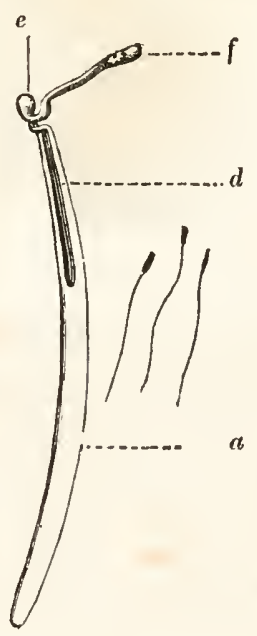

Fig. 419

ซึig. 419 a.

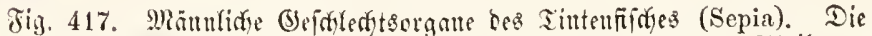
Srgane wou ber Bandfecte gefehen. a Der cinfadye boben, zum Theil wou

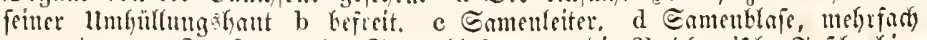

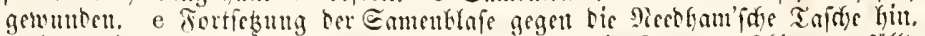

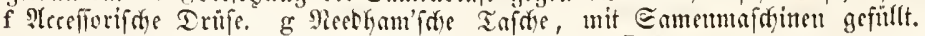

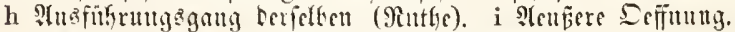

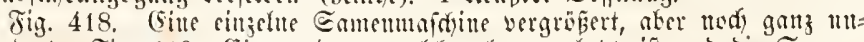
veräntert. Fig. 419. (Eime anbere, welde oken geflabt ift unb ric Samen=

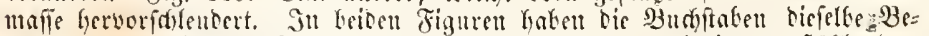
bentung. a Die feite Estribe ber Eamemmathine. b Die innere boble ber= ferten. c Das worbere Ente, d Die Maffe ber in eine feime Sallte cinge=

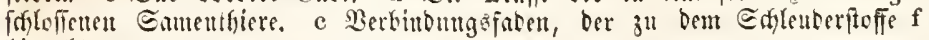
Gittyeht.

Fig. 419 a. Einzelne 巨amentfierdyen, fehr ftarf wergröpert. 
Die männliden (3) efd ledtoorgane fint bei benjenigen Ropffüglern, beren Männd) cinfaden Sooben gebiloet, welder an ber Stelle bes Crieritores liegt

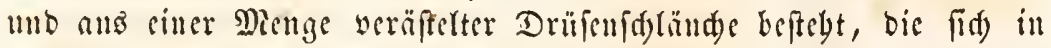
ciner mittleren Sö̈le vereingen. Die Samenmalfe gefangt von bier aus burd) sinen vielfad) gewundenen Gamenleiter unb sine gewumbene

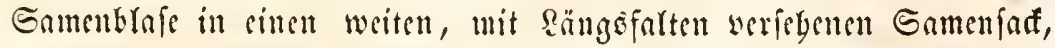

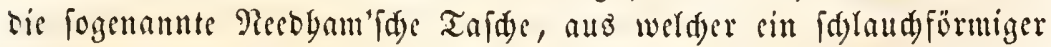
TuĖ̆übrungsgang, ber in ber Mantelgöble frei bervorftebt, bie Ga= menmaffe und augen reitet. Diefe felbif ift inber bei ben meiften

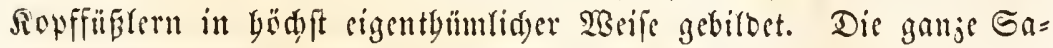

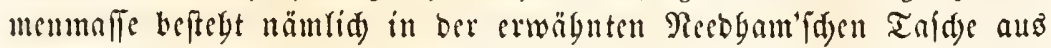
rigentbümliden gropen cylinbrifden Sdyländen, Spermatopboren ober Eamenmaidinen, welde einen febr fonterbaren Ban baben. Seber Sdylaud fteflt sin glaşbelles PRobr bar, in beffen binterem Enbe sine febr jartbäntige Blafe soll Samentbiete fid) befinbet, bie auf sinem meift fpiralförmig gebrebten Banbe rugt, weldes bis an bas Porber=

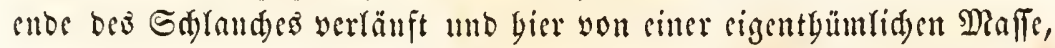
cinem Sd)lenberftoffe, umgeben ift, welder surd) Einfaugung von 2 saffer auferorbentlidy anjdwillt. Sobald bieje Gamenid)läude aus ber Rechbam'iden Tafde, in ber fie bidyt gebrängt neten einautoer liegen,

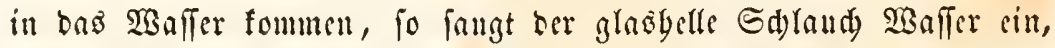
fduillt an feimem Borberende anf unb plaset enblid, wobei bie innere

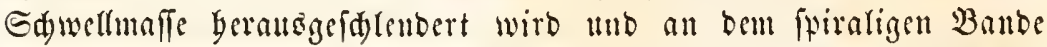
Das mit Samentyierden gefüllte Sänd) aแo bem Sdylande beraub=

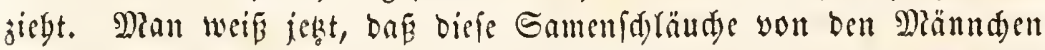
it bie Mantelgoble ber $\mathfrak{B}$ eibden gefradyt werben, wo bann burd) igr \$ुlaken ber Gamen in ben Gileiter ḧbergefübrt mo bie Fier in Fierforfe ferbft befrudtet werben. Die Samentbierden ferbit baben bie gewögntide form. 


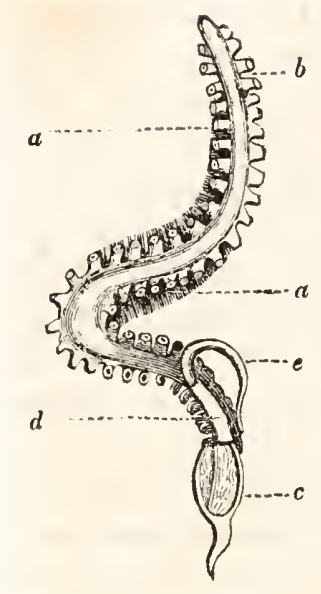

Jig 420. Ilectocotylas. Tremoctopodis.

Das Thier wot bet Baudjeite gefebett. a Jic= men. b Eanguäyรe. c ๔a= mentact. d Mutbenidycibs. e $\mathfrak{i} u t$ tye.

Die verfüumerten $\mathfrak{D a u n}$ ă man bis jeşt nur bei ber Familie Der ad)tfüpi= gen Sapierboote gefelsen hat, baben etwa bie (5)eftalt eines 2 surmez, beflen Siörper ou beiben Seiten mit siner Menge von Saugnäpfen be= festet ift. Man bat fie bis jest mur in ber Mantelgöble ober in bem Trideter, felten nur auf ber inneren Fläde ber Arme ber $\mathfrak{B}$ eibden figetto gefunden, wo fie rebyaft mit igren Saug= näpfen muberfred)en, ober felbjt mit idlängeln= Den Bewegungen im Saffer fdwimment. Sis waren bis̆ber grilz allgemein fül Eingeweibewär= mer gebalten unb unter Dem Ramen Heclocolylts unter bie Sangwïmer eingereibt worben, bis

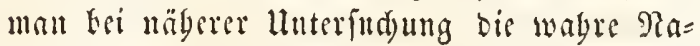
tur biefer Thicre erfannte, und fid bayon überzengen mupte, Daß in ber Tyat bei iderin= bar fegr unge ftebenden Thierent bis eitnen wolls fomuren entwidelte, bie anberen gänjlid) ver =

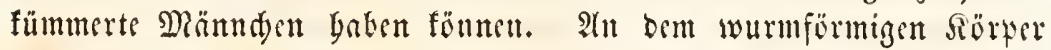
Diefer Mäund)en fallen zuerfit die Gaugnäpfe in bie Ahtgen, weld)e fait an ber gnnjen Ränge Des Siörpers zuvei Reiben längs Der Baud)= fläde bitben. Jgre Etructmr ift wolfonmen bisfelbe, wie biejenige bet Snugnäpfe ber Sopffïglet felbit, fo bas man aud) nid)t mit llured)t

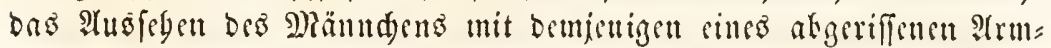
endes won sinem gewölutiden Tbiere wergliden bat. Die brioen Gang= unpfrsigen feben mebr anf Der Bandfsite, wäbrend die Rürenfeite in jwei

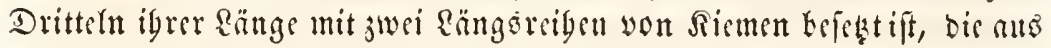
wielen langen weid)en 3öttd)en jufanmengefset find. Afm Ende Des mit

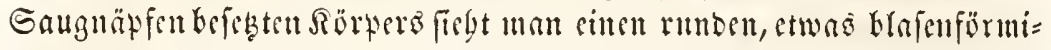

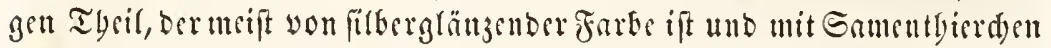

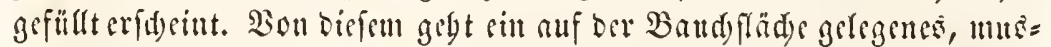
fulbers Rogr auz, bas nad) yorn ju sine Deffmtng bat, aus weldyer bie fabenförmige Rutbe bervortritt. Die inneren Drgane find nod nid)t mit folder Gennugfeit erforid)t, als es wobl wünfdenstwerth wäre. Die 5ant ift mit Denfelben Farbenjellen beferzt, Deren Spiel

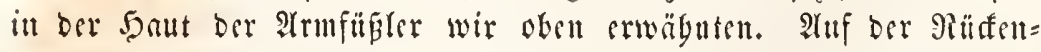
feite, unmittelbar unter ber Şaut foll fno berz liegen; jubeiben

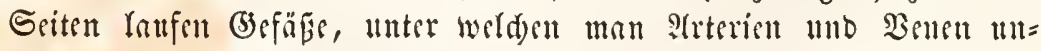

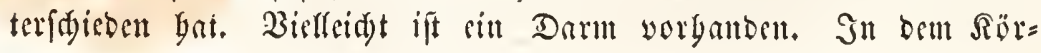




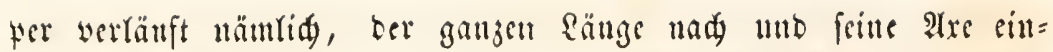
nebuend, ein binten blinb ententes Robr yon burdanb gleider $\mathfrak{B}$ eite, weldes vielleidt an bem Sorberende Des Rörpers mit einct febr fei= uen Deffung trad auben mündet, nub Saun wobl als Darmrobr angefproden werden bürfte. Der im Sointertbeile des Rörpers geles gene $50 b e$ bejtebt aus cincul cinjigen febr langen, in einen Rnäuel gewnแbenen Faben, Der ans innig mit einanter jufammenbängenben Sanentbierden gebirbet ift und in ben Samenteiter eintritt, welder

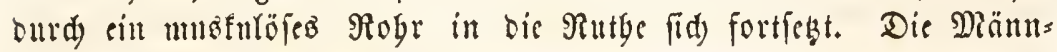
d)en anberer arten (d)einen nod) utegr verfiummert, inbem ibnen fogat bie Siemen feblen, une bie befdeled)tşwertzeuge cinen nod) grögerent Paum einnegmen, fo baß fie fapt mur als eine mit Gaugnäpfen verfebene

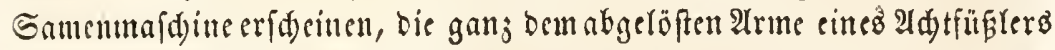
gleid)t. Dic Jectocotylen, weldyen bie Riemen feylen, finb vielleidt nur aloge=

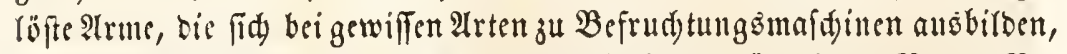
in äbnlider $\mathfrak{B}$ eife, wie bie Yyalpen ber Spinnenmännden. Reuere $\mathfrak{B} e=$ obadtungen fd)sinen auf eine Structur biefer 9 rt binzubeuten - ęa wären, folften fid biefe erwabren, bie Scctocotylen bann nid)t verfümmerte Dlänn=

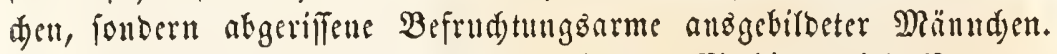
Die Entwirfelung Der Ropffïbler in Dem Eie bietet viele Diomente bar, welde fie von allen ibrigen Stbtyeilungen bes Thierreides wejent= lid) unterideciben. Inf Dem Dotter bes (Fies, ber vorber Durd) nek= fürmige, nad) innen vorifringenbe Falten ber Dotterbaut cin cigen=

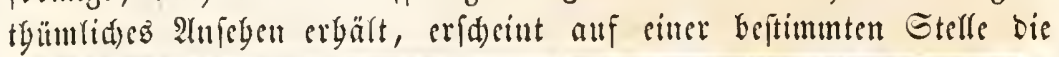

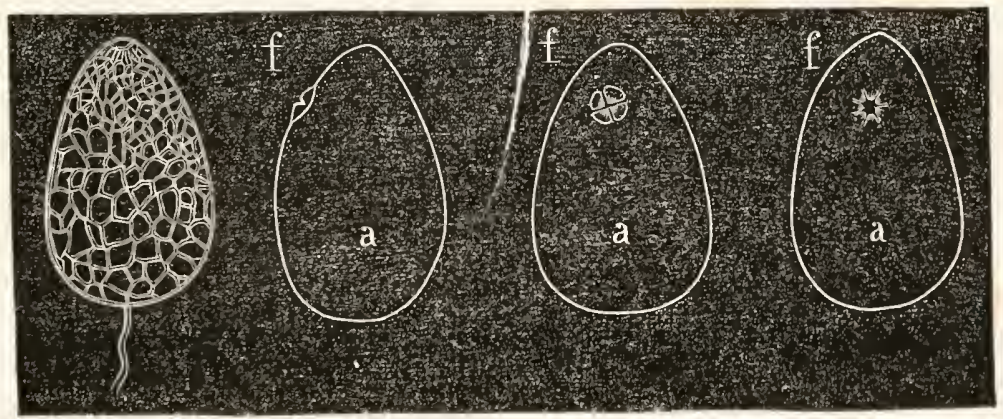

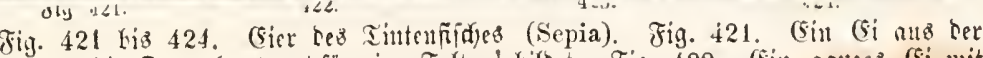

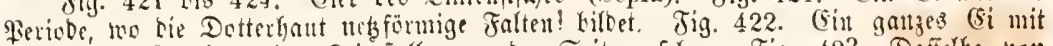

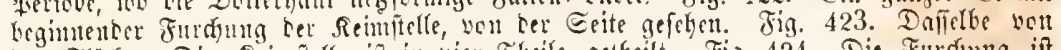
ber Jlide. Die Sermitelle ift in wier Theile getheilt. Fig. 424, Die Furdynng ift

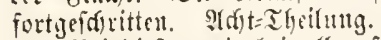

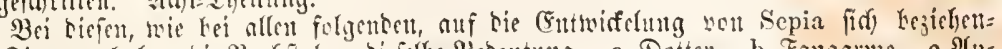

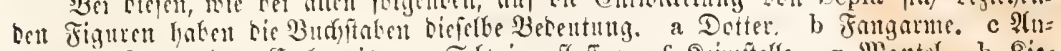

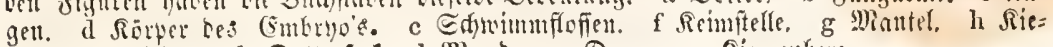
men. i Tridgter. k Dotterfaf, 1 Dumb. m Daim. n Siementhers. 
(Embryoualanlage, bie aus anfangs unbeutlid abgegrengten Furdungs= fugeln beftebt, weldye fid nad, nulo nady ju 3ellen unbiloen. Die übrige Dottermaffe erfeneint bei biefer Bitoung bes Embryonattbeiles volfommen unbetbeiligt. Der Embryonaltbeil breitet fid allmäblig

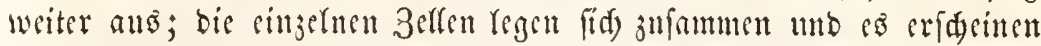
mun nad und nad) bie verfdicbenen Drgane bes Cimbryos, jucrit in ber Form you relifiten unb jwar in ber Eagerung, Daßi ber Ropf= tyeil bes Embryos bem Dotter jugewendet, bas Sintertyeil bes Band)=

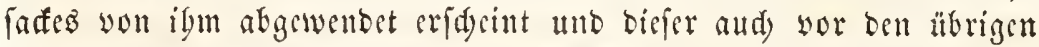

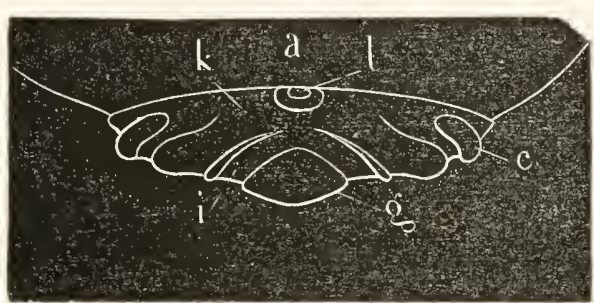

Ji่.j. 42.5 .

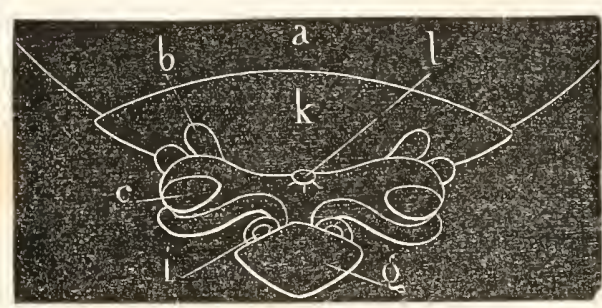

Jig. 426.

Fig. 425 1111 426. (sutwidflung Des Tinten=

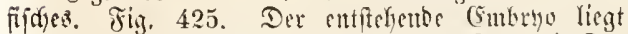
110 f) flad nut forcifenförmig auf bem Dotter.: Der

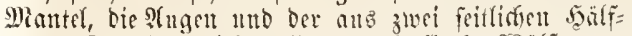

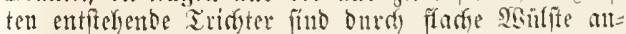

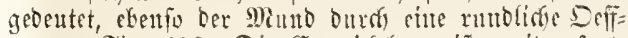
unng. Fig. 426. Die Entwifflung iit weiter fort= gefdritten, ber Mantel nebit bem (Embrys frat firs)

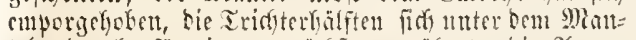
tel, ber Gutförmig berwädit, genäfert, bie Afuget uto fopflappen firs gefoutert. stan fieht bis erften

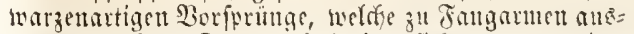
inadjen. Der Dotterfat feretet fís) ans, $14 m$ bent Dottex eitrulfolieñen.

Theile bes Damfanales in Berbinbung; er Gildet ftets esinen für fid) abgeid)loffenen Saf, beffen Stiel bart neben bem Miunbe in bie Rei= beşböble sinbringt, fo bas man fruther glantete, er gebe aus bem Diunde ferbit Gervor, ober febe weiter imnen mit bem Darmfanale in Berbindung. Beibes ift unridtig; aud in oer Reibesboble ift ber

Theilen fid) ausbilbet. An= fangs fitht ber Embryo gleidyfam wie sine flad ye Sderibe anf bem Dotter anf,

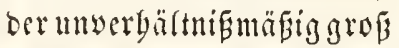
iit, bann bebt er fid mebr ab unt ber Cingeweibefact erbält allmäblig frine beu= tclförmige Siefalt. Sinte vom Embryo ansigebribe

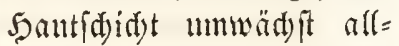
mábrig ben Dotter mo bil= Det eincu wabren Dotter= facf. Täbrend ber Dotter immer fleiner wiro uno ber Embryo ftetō melyr anf fine

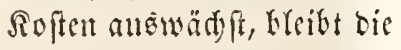
gegenfitige Ragerung biejer bciben Theile fteto biefelbe. Der Entryo erfafit mit fei= nen, mun berworgefproften Armen Den Dotter, welder feinem Ropfegegentiferliegt. Der Dotterfate ftebt zu fei= ner 3cit bes Embryonal= rebens mit irgento cincm

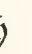

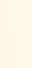




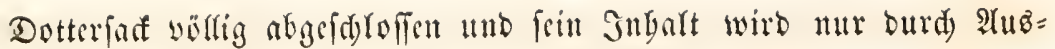

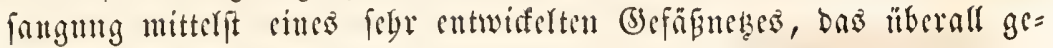
(d) Yolfene Tantomigen bat, bem Embryo jugefityrt.

Die Entwifelung ber cinzelnen Drgane if mit grofer Benanigs feit werfolgt worden. 3uerft entitelyt oer Mantel it oer Mitte, als

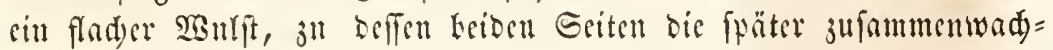

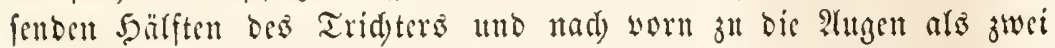

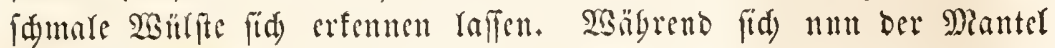
yom Dotter abbebt, erfecinen nad) sinamber bie verfdicbenen Jaare

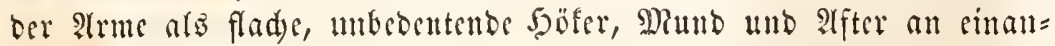
oer gegeniberifebenoen Stelfen nod) flad) anf bem Dotter auftiegento, Die Riemen mit igren Benenbergen unb bem bajwifden regenden 2 or $=$

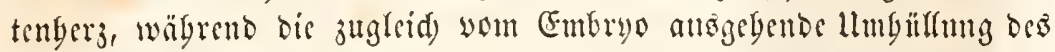
Dotters benfelben melyr mo megr mmändy Der. Embryo ift jest

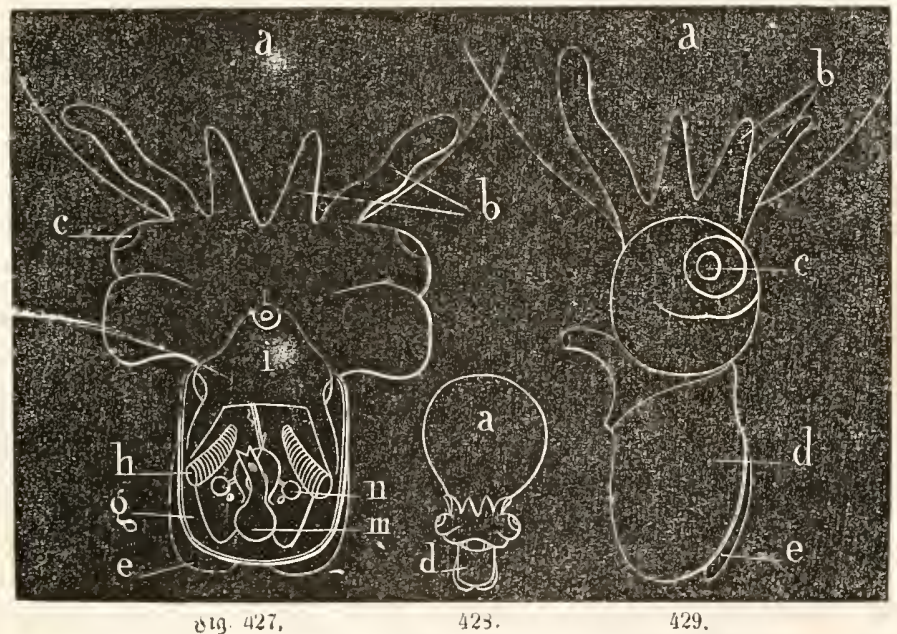

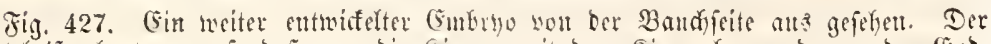

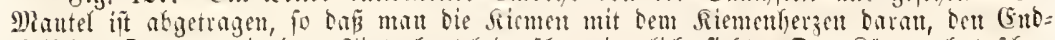

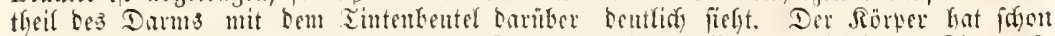

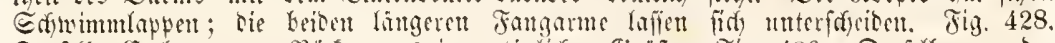

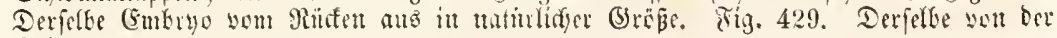
Erite.

nod) immer 4 bis 5 mar fleiner ars ber Dotter, flimmert auf feiner ganjen Doerfläde uno orebt fid bei oenjenigen (battungen, bei wel= den vier Eiweis uno ein fleiner Dotter vorbanten ift, wägrend er bei Sen anbern weber Sraft nod) Siaum Fefizt, diefe llmwäljungen z"n

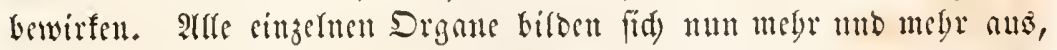

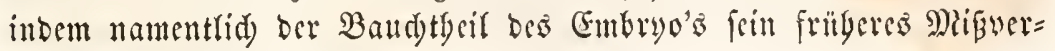




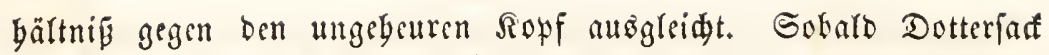

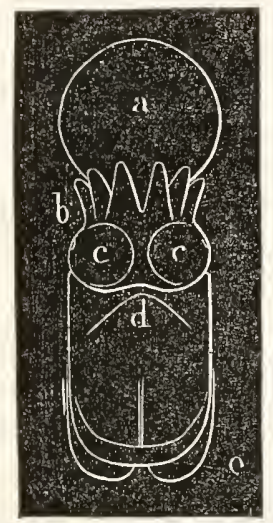

Fig. 130. Fnit reifer Embryo ron ber Rürenfeite. tho Cubryo etwa gleid grob fino, baben idon die Embryonen faft gnus die (jeptalt bes jufünf= tigen Thieres unb berwegen fid) nud ziemlid raid) in bem (Fi, ober tad) ifrer Speraubarme aแร ben (Eigullen, bie fie jebod) nid)t eber ver= Inflet, als bis Der Dotterfact gänzlid) geid)wun= Delt, unb ber junge Soyffingler in nllen Tbei= ren volfommen bem Ermady jenen ägnlid fielyt. Dant Fefyt aus Dicfer Darftellung ocs Ent=

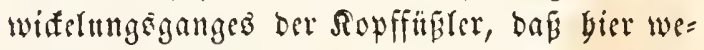
fentlid) zwei Moutente ing 2uge gefafit werben mïflet. Wä̆brend bei allett übrigen Tbieren, bis wir in ben vorigen 9 tbtyeifungen betradte=

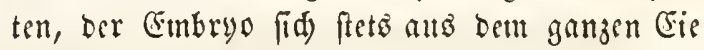
entwidelt tho von Thfang an fänuntlid)e Theile Des Cies bei ber Birbung ber Drgane intereffirt fint, erfdseint bier Anfangs mur cine fleine Embryonalanlage, weld)e nflmäbrig Den Dot= ter itberwähft und fur Birbung igrer Drgane verwendet. Das jweite Dioment ift bie Ragerung bes Dotters itt ber Axe bes Rörters bem

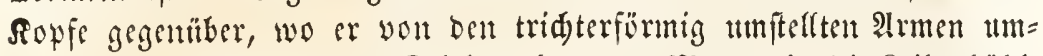

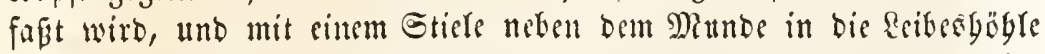
einbringt, - cine Ragerung, welde gänglid won ber verfdjeben ift, bie mir bei ben fpätern grof̧en (3) rappen Des̃ Thierreides finben wer= Den, wo Der Dotter entweder wie bei ben Griebertbieren allf ber

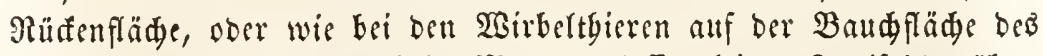
Cmbryo's fity befindet. Beide Momente laffen feinen 3weifel barüber, bap trog ber geringen ?nzabl won ?trmfïflern, welde wir in unferer

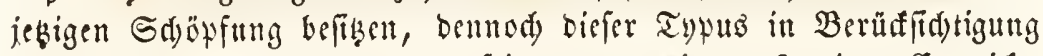
friner Eigentbiumlidfeiten tuto feiner ungemein grofartigen Entwife= lutg, in fritgeren Jerioben ser Erogefdidste mit ben anderen grofen Abtheilungen bes Thierreides auf cine Etufe geftellt werben milfen.

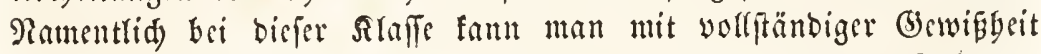

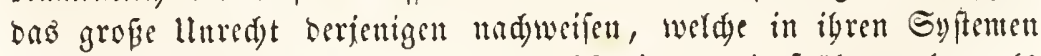
tur bie jest rebente Gdopfung beritfifdtigen, bie fribgere aber als nidgt in ibren Sreiz gebörig our Srite feften möd)ten. -

SBir theilen Den Sreis Der Sopffüfler, Der nur eine Slaffe ent= bä(t, nad) ber Befd)affenlyeit oer Jangarme tmo Der Siemen in swei Dronungen. Bei Den (Eittet, Den Bierfiemern, (Tetrabranchiata), weldye ben anbern in Der Erogeidjidyte vorangeben, feben zwei Rie= 
men auf jeber Seite und bie Fangarme frub in sime grope 2 tujabl eingeluer Tentafel aufgelüf, mälend bei ben 3 weifiemern (Dibranchiata) unr jwei Riemen im Ganjen fid finden und bie Fang= arme, beren bödftets zegn find, mit Saugnäpfen ober Şafen be= fekt finto.

Die Dibunng brr 3icreicuter (Tetrabranchiata) bat

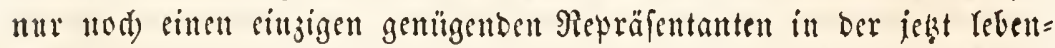
ben Edöpfung, beffen Gdalen febr bäufig in allen Gammlungen ju finben waren, wäbrend bas Thier erft in neuefter 3eit Durds singe wenige nad) Europa getommene Exemplare befannt uno näberen llt= terfud)ungen unterworfen wurbe. Ilm to bäufiger find bie Sdalen biefer Thieve in ben älteften Sdjidten namentlid, wo fid) aud bie mannigfaltigfen Formen berfelben zeigen.

Sämmtlide Bierfiemer befỉ̧en vielfammerige Sd)alen, inbem baß

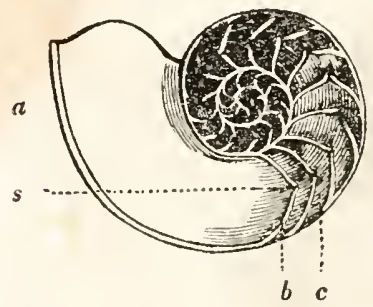

รig. 431.

(j) bäufe burd Abtbeilungen zerlegt ift, beren

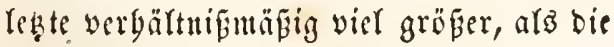
worbergebenben ift unb bem Ibiete alleit zur

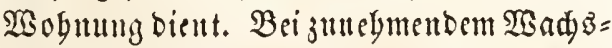
thume vergrögert biefes feine Sdale nad vorn, räpt aber jugleid) naळ binten eine Strefe Der Sdarle, welde ibm zu eng geworben ift, frei unb bilbet fid) sine neue

Die Sdyate cines \$ertbuotes (Nautilus)

ber Rănge nady burdirägt, um bie Ginrollung nut bie Sammernt औu zeigen. a Sebte Rammer, bie ein= zig yom Thiere kewohnt ift. b Die erite Erfeitemand, meldye bie nady= folgenben Raumem c aftremt. s Der Eiplyo, welder Die Sammern in Serbinbung feģt.

Sdeibematto, welde die Bobufammer nad) biuten abjd)liept. Die Structur bie= fer Sd)cibetwäne felbft ift febr mannig= fartig. Bei Dem rebenden \$serlboote und ter ganzen Familie Der Perlboote (Nautilida) \#̈berbaupt, fint dicfe Sd)eibewänbe einfad) ausigeidweift unt igre Converität nad binten, igre boble Seite nad) ber Miundung Der Sdale bin ge= ridtet. Bei ben geraben Shaten, welde bejonbers in ben lleber= gangégebirgen yorfoumen, gleid)t defbarb Reibe aufrinanbergejebter llnterid)alen von Talfen, bie alluäblig an

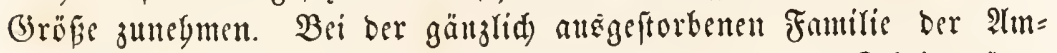
monsbörner (Ammonitida) bagegen finto die 9?änber ber Sdeibewänbe mebr ober mineer eingebogen und oft vielfältig ausgejact, io baf man an ben verfteinerten Sdyalen, wo meiftens bie biune Sthale feblt und nur ber Steitfern vorbanben ift, biefe Sderbewände als mannig=

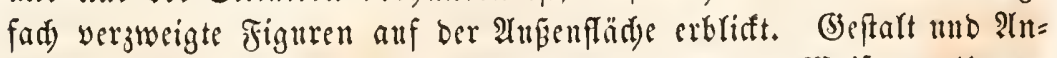
orbnung biefer Crinbiegungen baben in mannigfader Siseife jur llnter= 
fdeibung ber $\mathfrak{T}$ rten und Gattungen, fowie eingetner Bruppent in ber zamitie ferbft bienen müfien.

Cinte zweite Gigentgümlidfeit biefer gefammerten Edjalen ift, wie figon oben bemerft, bie Exifen's eines Sipgo, einer megr ober minder

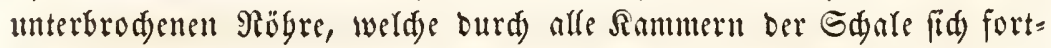

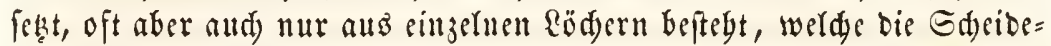
wänbe an correfponbirenden Etellen Durdbogren. Durd) biefe Mägre ober burd bie entfpredjenben Röder erfitreft fid ein fegniger Strang, werdjer baz Thier an ber Edjale befeftigt. Bei bem Yebenden gerl= boote, fowie bei ben foffilen verwanden Battungen, liegt ber Sipgo in ber Mitte, bei andern oft gantz all bem äuperen vber inneren glante ber Sdale.

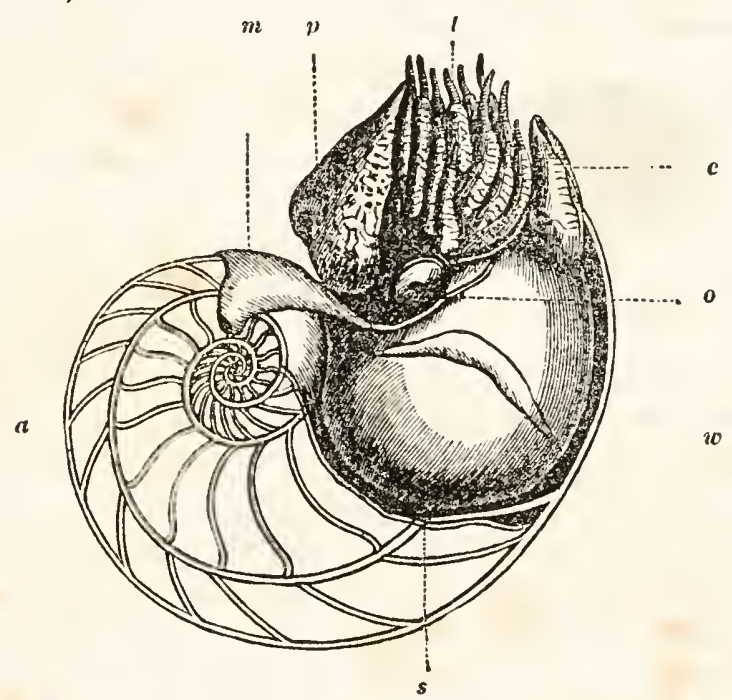

8ig. 132. Das \$eribuot (Nautilus) in jeiner Edale.

Daz Thier if unverfehrt, it natürlider Iage belafien, bie Edjale ber sänge แadf Galbirt, um bie গammern unb ben burd bie Rammern laufenbent Faferitrang zu zeipen. a Die fiuteren תammern. s Der \$anft, wo fid ber

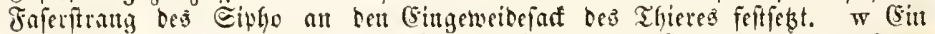

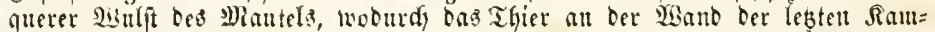

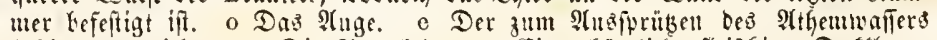

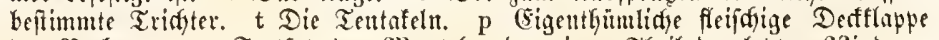

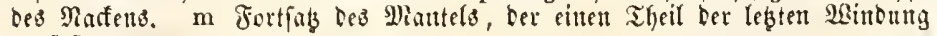

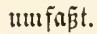

Der Souffüiler felbft, welder biefe Sdyalen bewognt, bat eine furze cylinbrifde (jeptalt und ift größtentbeils won feinem farfförmigen Whantel eingefdloffen, Der fid) überall genau an ber Yeģten Rammer 
Der Sd)ale antegt. Das Thier riegt fo in Dicfer Rammer, bafi feine

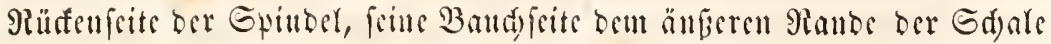

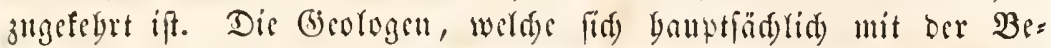
fdreifumg ber gefummerten Sd)alen algaben, Gaben itt ibrer glüflid)en

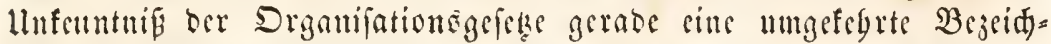
unng ber Gdalen angenommen und Rürfenfeite ben äufreren, Baud)feite ben inneren Ranb biefer Gdyalen genaunt. Der Mantel bifbet nad

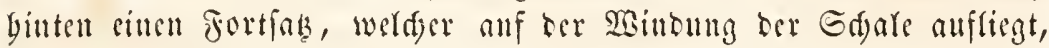

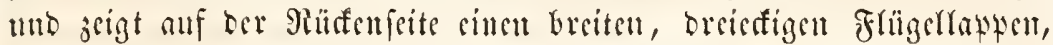

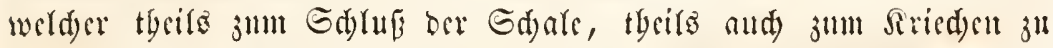

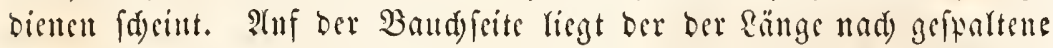
Tridater unb zwifden igm und bem fogenanuten Fubse sine Mienge won 2trmen, weld) feine Sanguäpfe tragen, fonbern fddwad) gerimgelt

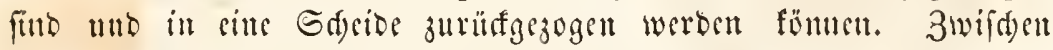
Diefen Fübrfäben liegt ber mit jwei bornigen Riefern bewaffnete Minno

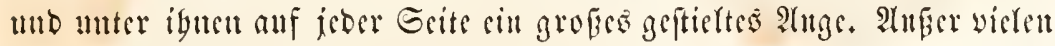

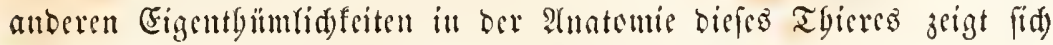
befonders bie, baj alif jeber Geite zwei sitemen vorbanben fint, welde

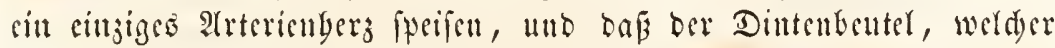

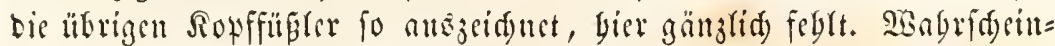

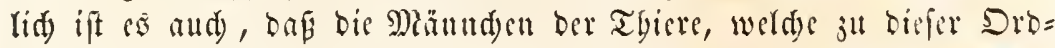

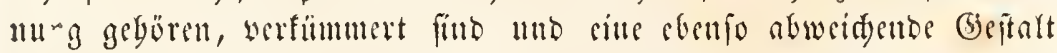
baben, wie bicienigen, welde man bei ben gJapierbooten fentt. TSe=

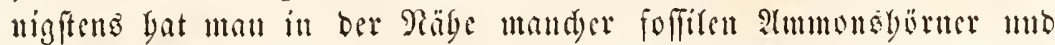
febr oft in ber worberen Sammer berfelben bödsft eigentbümlide Gdalen gefunoen, bie man unter bem Ramen $\Lambda$ plychus bezciduet unb

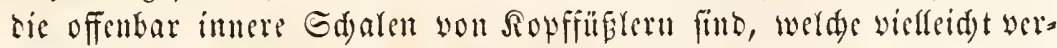
fümmerten Männden angebörten, bie ebculo, wie bie verfümmerten

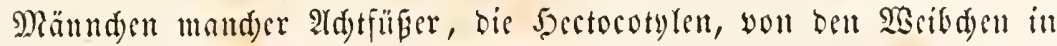
igrer Mantelgöble mit berum getragen wnrben.

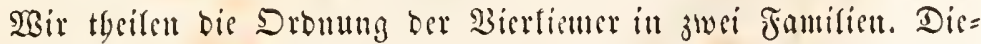

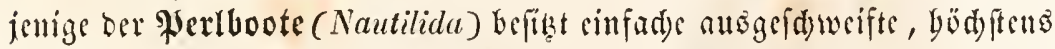

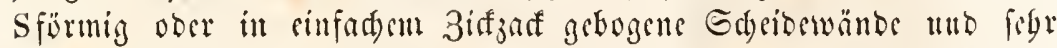

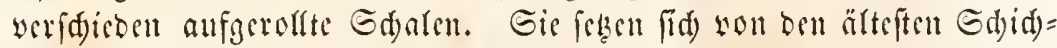
ten an bis itl bie neuefte Zeit fort, wo ber cilljige Reprëfentant it

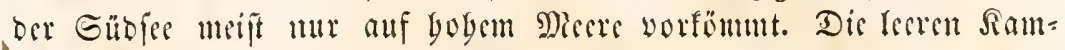
"mern ber Edjale, weldse bei allen biefen Thieren febr bünn war,

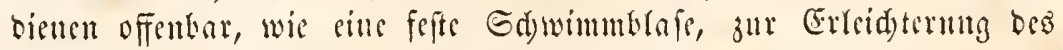

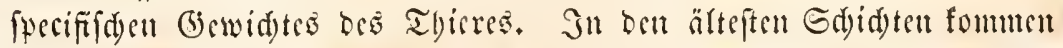
Rautiliden vor, welde vollfommen getabe find und teite Gpur von

Bogt, Boologifale Briefe I. 
Iufrolfung jeigen (Orthoceratites); anbere, welde chwa bie bieftalt eines Bifdofoffabes (Lituites) baben; nsd) andere, weld) unvollfom= men eingerolft eridgeinen (Pluragmoceras), wäbrent won ben mittleren Sdid)ten bes Gura an und aud fdon früber äd) Werlboote (Nautilus) mit solfommen singerdlten Gdalen fid finben. Rad) ber $\&_{n}=$ gertng bes Sipbo unb ber Ginfuifung ber Sdjeibewände Gat man viele ausgeftorbene Gattungen unterfdieten. Clymenia.

Die Fantile ber Ammonşörner (Ammonitida) unterfdeibet fid)

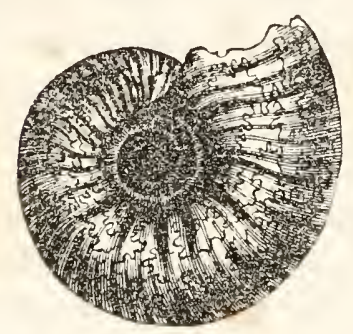

ฮig. 433

von ber vorigen burd) cingebogene und gezndte Edseibemände, weld)e entweber in Biffjactlinien gefnitft ober gänglid aแs่gezant und fogar wis cine sranfe gefaltet erfdeinen. Der Gipbo liegt bei ignen ftets an bem ?tubemrante Der Ed)ale, wägrent er bei ber Familie ber yerlboote in ber Mitte ober bem Sunemante nabe liegt. Die Stmmonebürner fint gänjlid ansigeftorben, fommen Dagegen in ben älteren $\Theta_{d j}$ id)ten auberorbentidy jablreit) vor uno zeigen gewiffermapen eine umgefelyrte (befdichte wie bie \$erlboote.

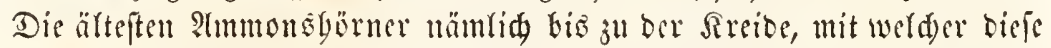
Familie gänjlid aufgört, finb alle in einer Gebene gewunden, wäbrent in ber Jireibe felbft fid) alle jene Formen von geraben (Baculites), baftgewun= benen (Scaphites), bafenfürmig gebogenin (Hamites) Sd)alen worfinden,

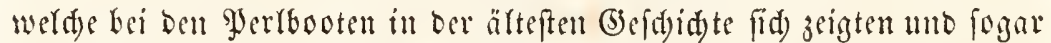
nod) fdueffenförmig gewundene Formen (Turrilites) vorfommen. Mian bat mad) biefen Formen Der:ufrolfung, fonie nad) ber (beftalt ber Sdeibe= wände, werfdiebene großze Gattungen unterfdeieben unb es ift bier affer=

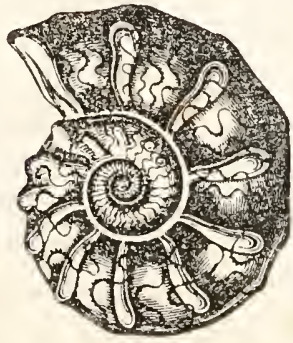

ซig. 434.

Ceratites nodosus ans bem Miuidetfalfe.

Dings merfwäbig, baß̉ in ben älteren Sdyid)ten ris jum Mufduelfalfe bin, mแ

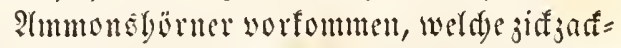
förmig gehogene, ungejülnelte Sぬeibewän= De Gaben (Goniatites), baß bei ben im Mn= (d)elfalfe vorfammenden 2rten (Ceratites) nur die nad) binten ansgebogenen Rappen ber Sd)eibewänbe, welde man bic Soben ge= mannt bat, gezälunelt, bie nad) worn geridgte= ten (bie Sättel) bingegen, glatt fint, wäl)= reno bei benjenigen (5attungen, welde wom Mujderfarf an aujwätö in ben 
Sdjidten bes Jura uno ser Sreibe gefunten werben, alfe Stugbe=

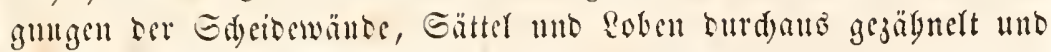
gejaft fint. Ammonites; Hamites; Scaphites; Turrilites

Die Drtunng Der 3weificuter (Dibranchiata), welde weit jablreidyer in unfern Meeren vertreten ift, in ber (Erogeidid)te aber aud erft sier fpäter mit Den unterften Surafdidsten auftrat, unterfdeibet fid wou ber vorigen baburd), baß ftets sine beftimmte

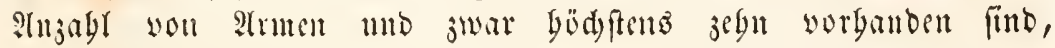
alle mit Ganguäpfen ober 5ormbafen bewaffuet, uno baß man anEerbem in ber Mantergöbre nur zwei Riemen vorfindet. Diefe Thiere baben niemare sine vielfammerige Sdyale, beren Gebte Fianmer fie bewobnen uno in weldye fie fid) zurüffieben fömen, fonbern wenn sine fordye exiftirt, was bei ciner Gattuny ber Fall ift, fo fiect fie jum Theile in bem Mantel bes Thierez, wou weld)em fie eingebiullt

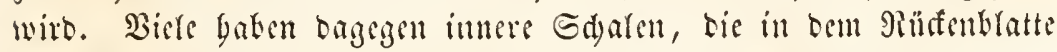

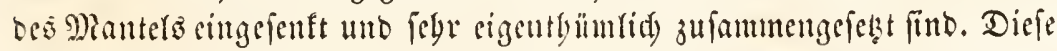
Rünfenfdalen befteben mämlid) ans einem yorberen bornigen Bratte, weld) es entweber natft, febr bïnn, bieglam und burd)fidstig ifi, ober

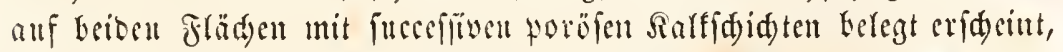
in Deren 3wijdenrämunen fï) sine gallertartige Sulje befintet. 9Rad)

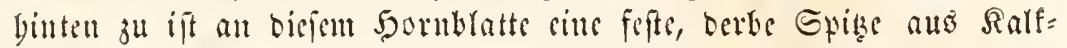
maffe angebradyt. Diefer ganje Rüfenfurdyen riegt in cincr Sö̈gle

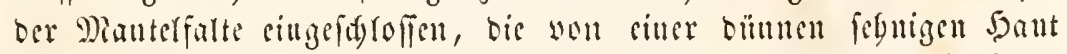

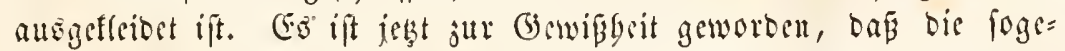
nanuten Belemuten ober Donnerfeile, weld)e man von ben unteriten Gajidten Des Jura bis in bie oberiten ber Sireid fo bäuñig verftei=

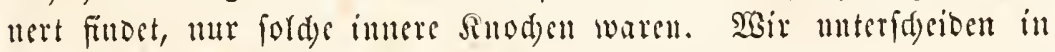
biefer Dronung forgente Fantilin:

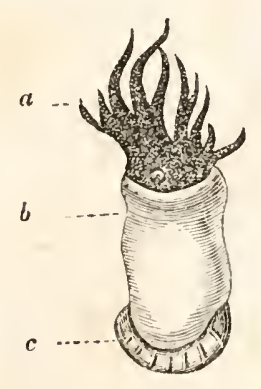

ซig. 437.

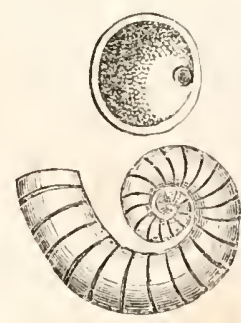

Jig. 435. Spirula Peronii,

Fiy. 435. Das ז̧ier. a Der Ropf mit
Die Famitie ter \$opts börncbsat (Spirulida) ift unr Durd) eine sinzige battung befant, beren Edjate ans wirlen Ranumern beftegt nulo in einer cagene fo gewunten ift, Dáp fid) Lie SSintoungen nid)t vorlfänobig berügren. Der Sipgo liegt auf oer in= neren Seite der Sammern, bis Edyeidewände find sinfady

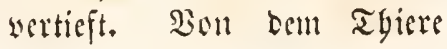
$25^{*}$ 
Den Fangamen แแb bem Sิlnge. b Der Miantel. c Die aus bem unteren Sheile herwortagento Gathale. Fig. 436. Eine ganze Erbale. Fig. 437.

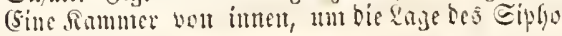
fll zeigett. wrifi man nur fo viel, daf co cintu langen Rörperiaf Gat, ber nad binten mit jwei fritlidyen Sappen bie Sdyale

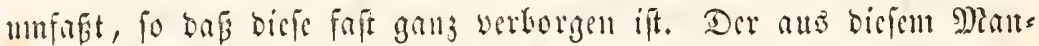

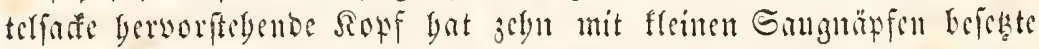
Irme, von benth jwei länger mo biffer fint, alo bie übrigen. Das Tfier farwinmt in ber Slible werfibrt, mit bem fiopfe nad unten, ift aber nod nie gans unteidäsigt anfgefunoen worben, wägrend man

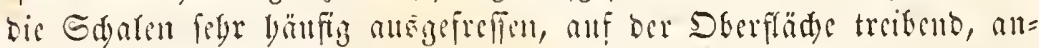
trifft. Febnlide foffite Gattungen bat man bis jest nod nirgento aufgefumben.

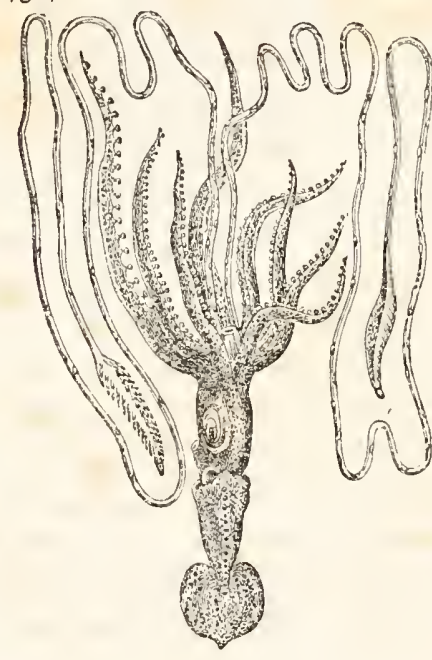

ซig. 438. Loligonsis Veranii.

Dis Samilie ber Tintenfildbe (Sepida) beftelyt aus nateten Thic= ren, mit meift länglidem abgeplat= tetein Sö̈per, an beffen Scitell jwei mebr ober mintor bebentenoe 5aut= floffen fitselt. Die Thicre baben jebn strme, you benen add fürzer fint, fpitzig julanfen unb ibrer gan= zen Ränge mad) Grugnäpfe tragen, mäbremb die juci allocren Itrme oft unverbättuifmägig lang finto unt ans rumblianen Etieren befte= ben, bie fid all ber Spike langett= artig autureiten mo bier erft Saug= mäpfe ober Sirallen tragen. Dicfe langen strune fömuch in rigene

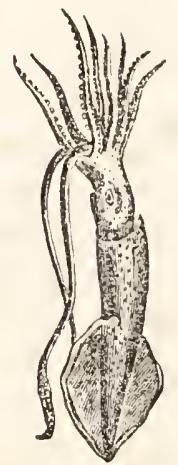

ซ̛ig. 439. Sintmar. Loligo vulgaris.
Gd) eiben, bie am Jiopfe riegen, jurtifgejogen wersen. Salfe baben cin inneres Gfelctitüat in ber Püfentgant bes Siantelo, bod fonn man nad) Deffen $\mathfrak{B}$ cfdyaffentyeit mebrere (5ruppen it ber Familic unteridacioen. Bas ben cigentfiden

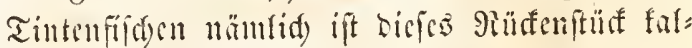
fig, ber Söpter mér Ereit, bic Floflenbänte jicurliaf ftymal mo sie Gauguäpfe fizcu mu= mitterkar anf bor Frädye ber Arme auf, wäb= rento bei ben Sarmaren (Loligida) ber Sï̈ter= farf mebr lang ansgejogen ift, bic orcieffigen

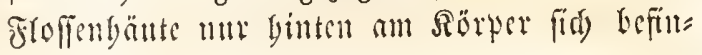




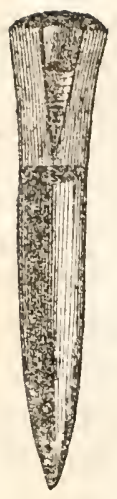

ซig. 440

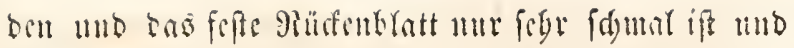
rime Gornige Befdyafrenbeit bat. Die Gamgnn̈pfe fmo bei bicfer lluterfamifie gefitelt unt juweilen burd) 5orn= Gafen eriptz̧t. Loligo; Loligopsis; Sepia; Sepiola; Onychotheulis.

Die Frmmilif ber Donnerfeile (Belemnitida)

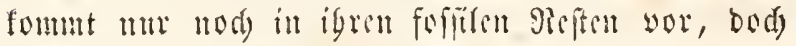
bat man in singelen fels feinfürnigen (5seftemen fo

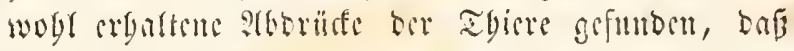
man fie faft wolftäntig reftanriren fonnte. Dio 2 bist bejaf adjt gleide strme, wedde an ífrem inneren Manbe mit siner gieibe fdarfer Jafen befetet waren.

(Ëin Belenmit, wie mon fie istwithlit fonbet, mit eill cm गlicit ber $\$ 11=$

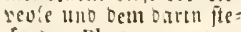
denten Phragnoconus.

Der Sïrtwer war fobr in bic Ränge gejogen, thad) binten

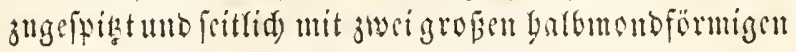

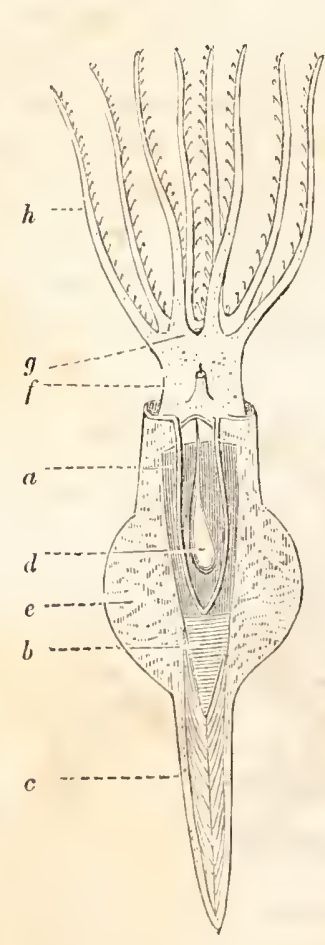

รi.]. 411.

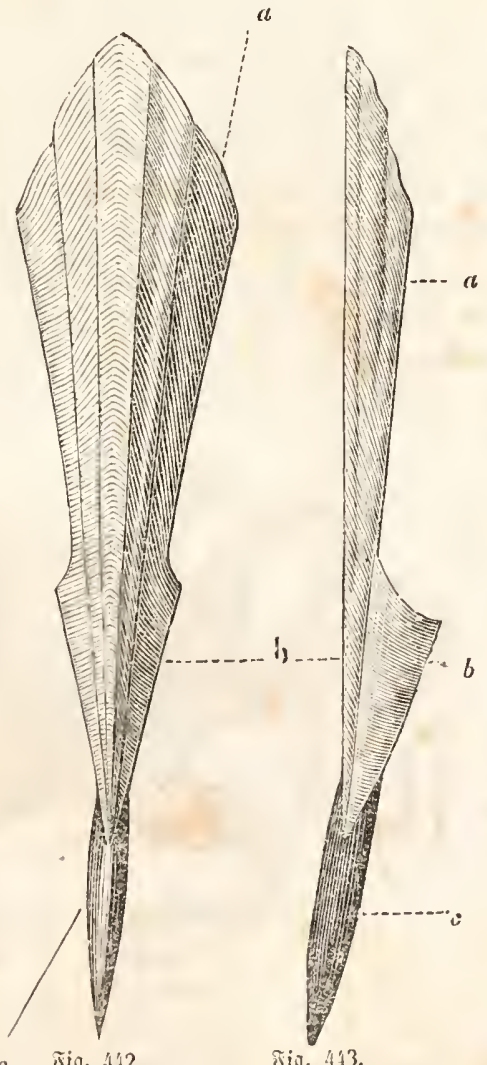

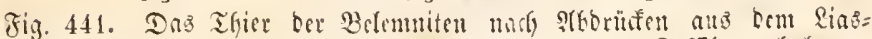

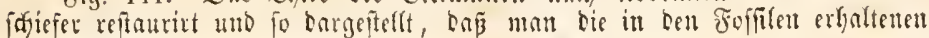


Theile, ben Mintenfuochen ober Belemtuten uno ben Tiutententel fiefit. Fig. 442. Ein vollftänoiger Belemmit mit allen Theilen, vent finten. Fig. 443. Derfelbe von ter Erite. a Da . Dornblatt. b Der Regel (Phragmoconus).

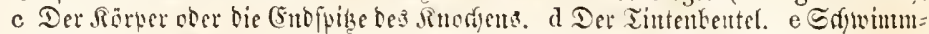

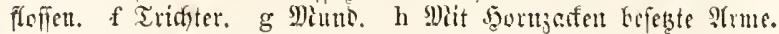

Sdyimmfleflen befest. Der Tintenbeutel, welden man fegr oft wobl erbalten funbet, wat birnförmig, ziemlid) lang unb you anfebnlider

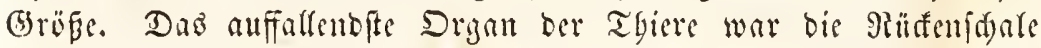
foer Der fogennnnte Belemnit. Cin volfftübiger Belemnit ift ans Drei Stüfen jufammengefekst, won Denen man aber meift mur bno untere, ben Eduabel ober Sïrper, erbalten finbet, ber, wie fdon bes merft, cylmbrifd) mo folib ift. Dns obere Enbe biejes Rörters bes Belemniten bifoet eine conifde bedserförmige bögle, in welder bie

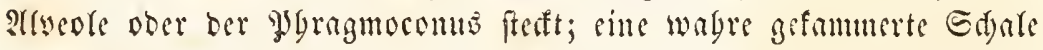
mit Enftfanmern, bie wie llgrgläer anfrinander gefdidtet fino, mo

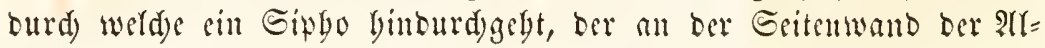

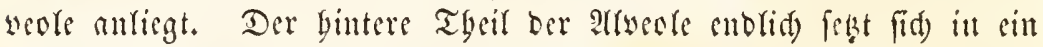

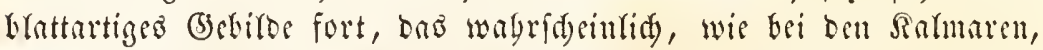
bornartig war, mo beşalb das 5ornblatt gennut wirb. Das 5orn: blatt ift nur febr felten erbalten; bie Afueole meift won bem sörper ober Sdunbel getrennt und biefer nod) auberbem meift oben zerbro= dyen. AHo ber geftreften Sïrperform biefer Thiere nno ber gemal=

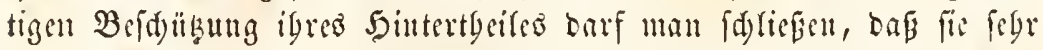
fanelle Sdwimmit waren, weld)e fid meifeno an tem Strante nuf= bielten. Belemnites; Belemnitella.

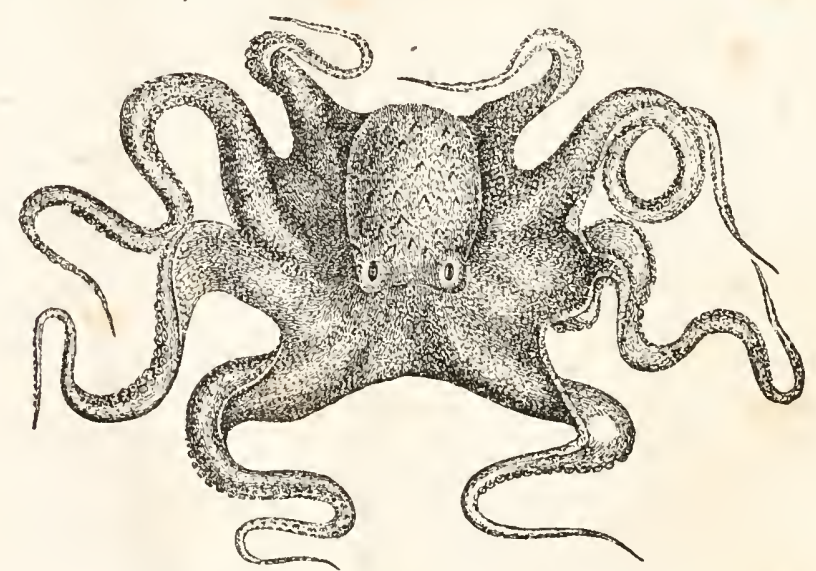

8ig 414. Bemeine: Puffe (Octopus vulgarts/, friectent.

Die Familie oer 2 ddftïner (Octopodida) befitht nur ad)t gleid) lange Irme und einent meift runbliden Rörperfar ofue alle Seiten= 
foffen uno obne sine Ełm sincs giüfenfnodens. Die Gangnäpfe anf Een ad)t Füben fergen bato in siner (Eledone), baro in jwei süngb= reiben (Octopus). Der sörter ift mur bei ciner (5attung, bem glapier= boote, in ciner ungefoumerten, wenty gebogenen Sdyale cingefd)tollen,

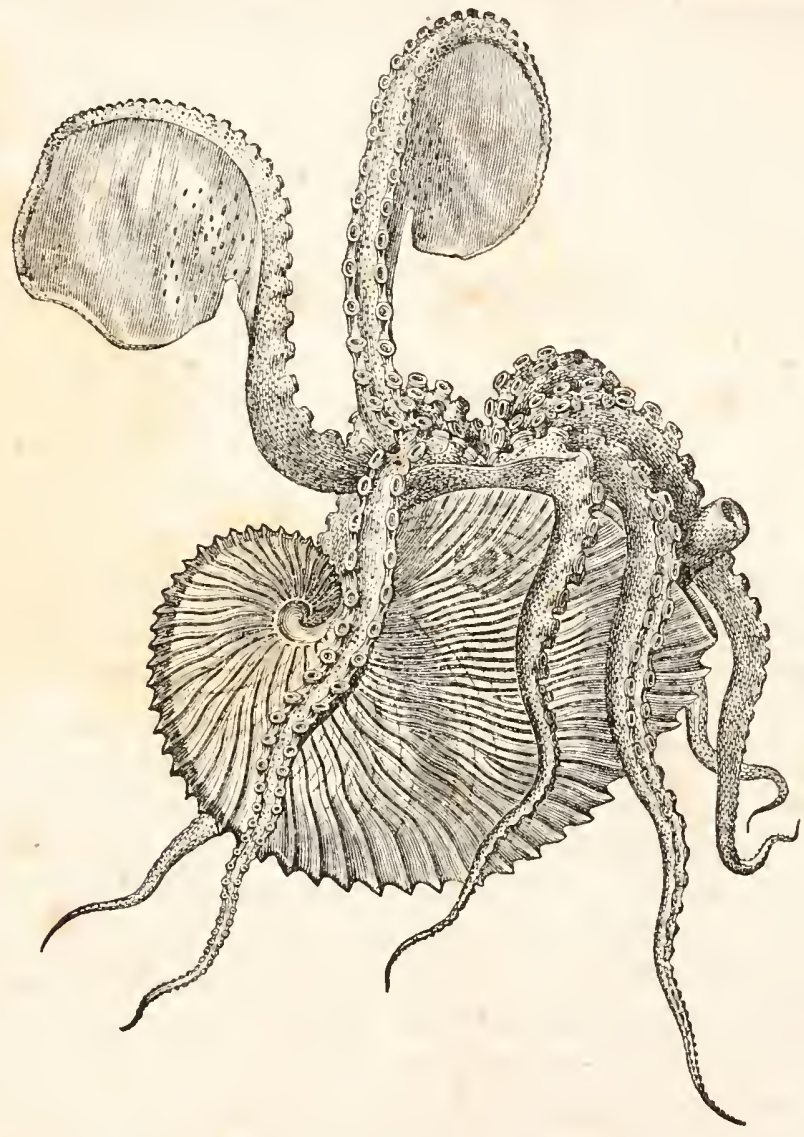

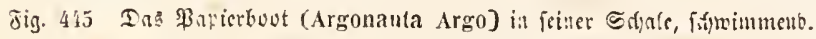

welde sou ber äuseren Fläd)e ber atrme abgefontert wirb, woyou

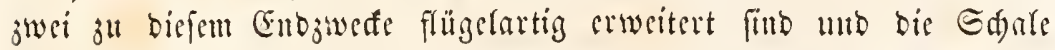
umffammern. Das Tbier gebraudt inder sic atrme nid)t wie Eeges,

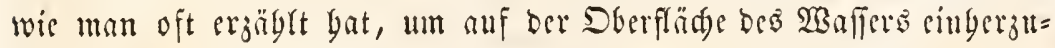

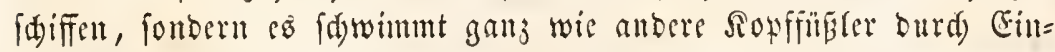
zichengyon 2 affer unb 2tusfto

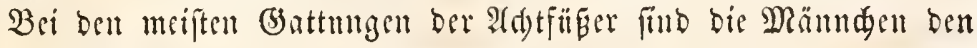

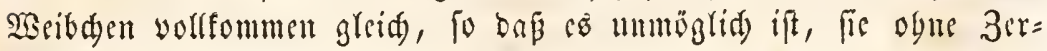


gliebernth j"t unterfdeiben (Octopus; Eledone); bei ben Argonauten aber, fowie bei sincr naften Gattung, Tremoctopus, finten fid bie verfümmerten Mämnd)en, feren wir ofen gedad)ten, unb die es wabr=

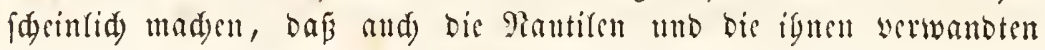

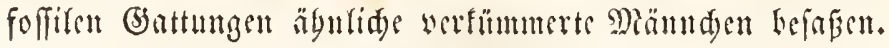

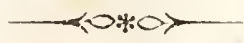

\section{Cilfter 28vich.}

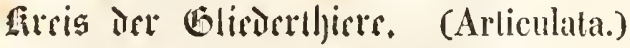

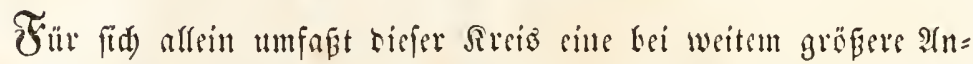

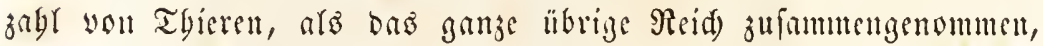
fowobl Hent man bie 3abl ber Gndiviouen, als and bie Mian= nigfartigfeit ber in Gattungen mo Irten repräpentiten formen in

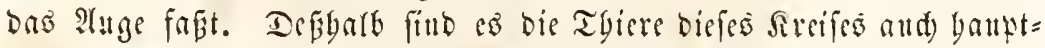

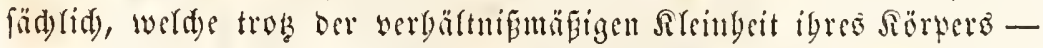
benn nut wenige (j)fiebertgiere fönnen fiid) Gierin mit bent fleineren Sisirbertbieren mefien - ben einternen Striden und 3onen ber Erbe

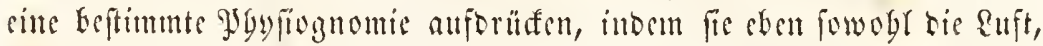

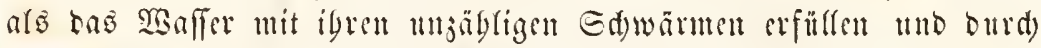

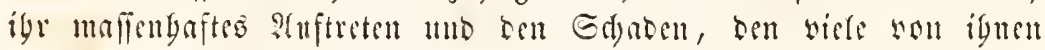
fitften, ferbft weniger anfurerffameren 3 cobadtem int bie ?agen fallen.

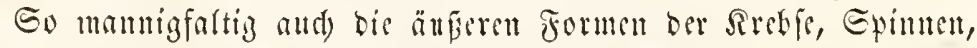

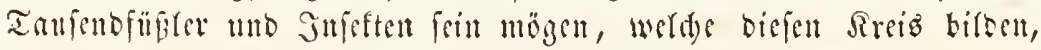

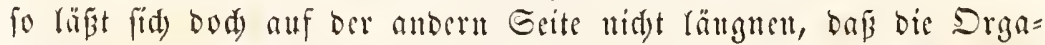

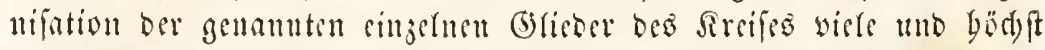

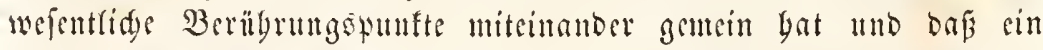

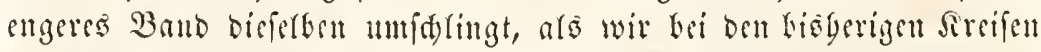

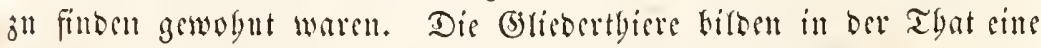

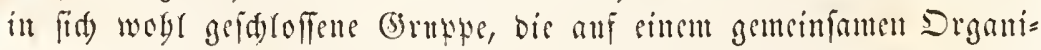
fationsplane berutgt, befien cinjelue Mobificationen it fiteng gefes:

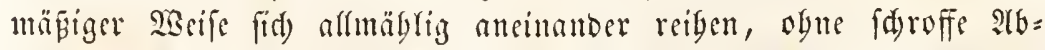
grenjungen ju zrigen. Dirfe Gejeçmäpigfeit ors Baues gebt fo weit, 
baß̧, bis in Dis flemiten Gingelbeiten ber Drganifation bincin uno bei

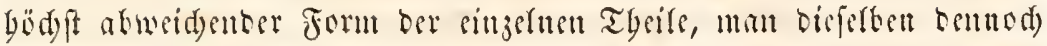

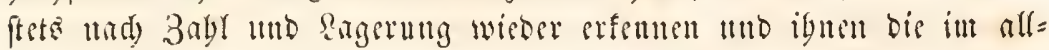
gemeinen glane vorgefebene Bebeutung juweifen fintl.

Die Grfebertbiere bieten wor alfen anbern bie groffte Gymmetrie

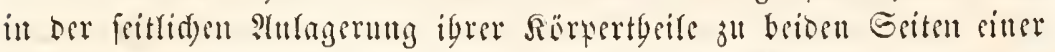
fenfled)ten (etene, weldye ourd) bie Rängsane des Sïrpers gelegt ift.

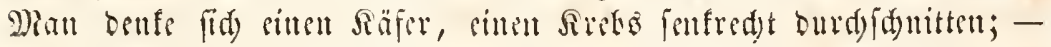
auf jeber Geite bes Gduittes wirb man genau biefelbe Zabl won Drganen und die sinfad) vorgandenen Drgane, wis Serj, Baudumarf, Darm, in jovei genau gleidye bälften zerlegt fïben. 3umeilen madgt

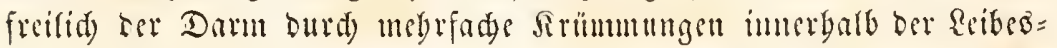

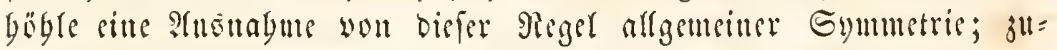
wrilen aud) findet man an ben äuberen Drganen sine ungleide Crut= widfung Der feitridyen Theile, wie 3. B. Der Sdeeren bei gewiffet Srebjen, ober jogar beö ganjen Rörperó bei cinigen Gdumaroberfrebjen.

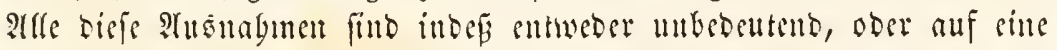
fo geringe ?Injabl wou Typen singefdränft, baß man bei ber bei weitem gröften Plujagl mit volfem Redste befrawten fam, ber Bau

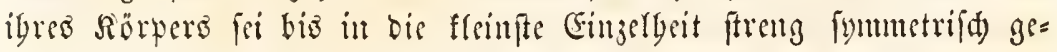
orouet.

Gime oweite Eigenthümlidfeit Der Brfiebertbiere beftegt in ber

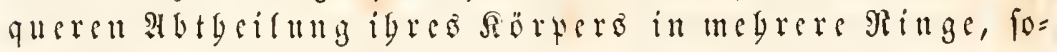

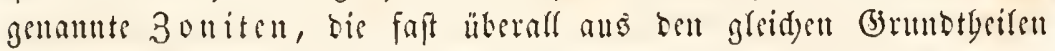

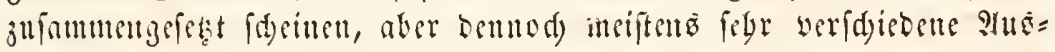
birbung zeigen. Die nicberen Formen or Griebertbiere, fowie die erfien Gtufen, weldye die böberen Formen in igrer (5ntwidtung burd)=

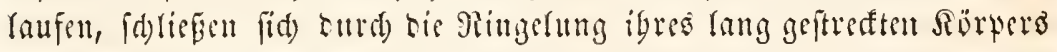

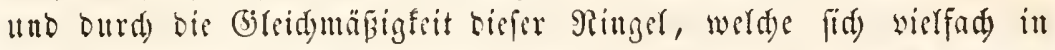
Derferten serife wiedergoren, nay an die Pingelwürmer an, fo baf

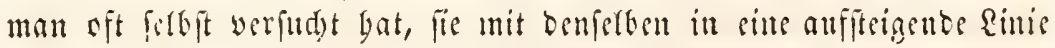

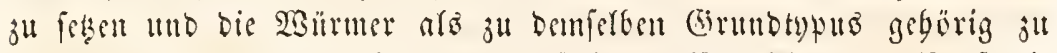

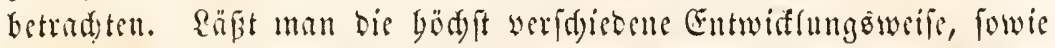

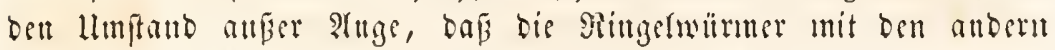

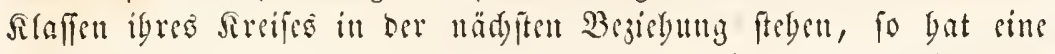

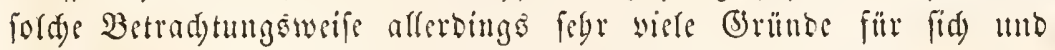
ber Abjand you einer Raupe ju sinem Ringetwurm 3. $\mathfrak{B}$. erid)eint bann bei weitem nidyt fo bebeutetto, als Derjenige zwifden simem burd)

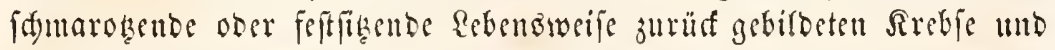

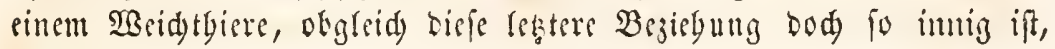




\section{4}

Dá Die jetst ju Den Sebfen gered)neten Ranfenfüber nod) bis in rie

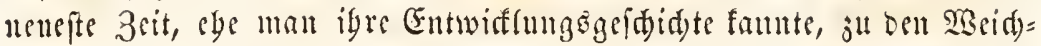
thieren geftellt wurben. Mit tiejer Erfenntuifs ber Beziebungen, in

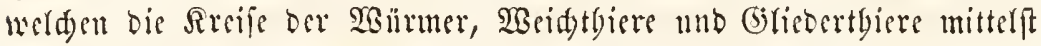
ibrer Durdgangsoruppen fteben, bängt ber oft mieberlyolte Streit ïber bie gegenfeitige Pangorbunng zufammen, ben biricnigen Patur= forfder utit sinander fübrten, welda bas Thierreid in eine sinjige anffteigente Reige georbnet wiffen wollten. Die Finen räumten ben

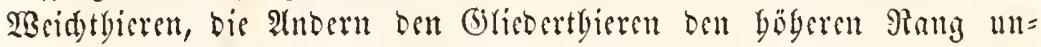
mittelfar unter ben 2 Birbeltgieren sin. Beibe waren in lluredyt eben weil bas Thierreid) fid nidt in auffergenter Rinie anfbaut, font= beru fid) unr mat) mantigfad) jeritruten (jruppen oronen läpt, die uad) allen Griten Bejiebungen ju ciunatser baben.

Die Bingelming bes Sörters, welde wir bei alfen Glicbertgieren genabren, wirb bei ben uteifen Typen eine ungleidartige, fo bag wer=

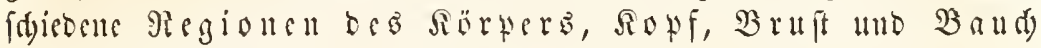
fid) unterideioen laffen. Sebe diefer Rörperabthcilungen beftebt aus ciner gewiflen Plugabl wou Ringeln, bie bald mebr, bald minter mit cinander veridulagen fint. Bei ben böberen Formen ift die Tremtung

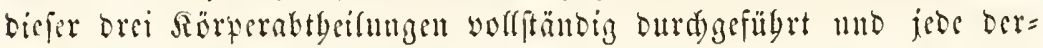

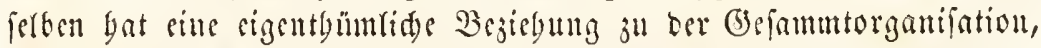

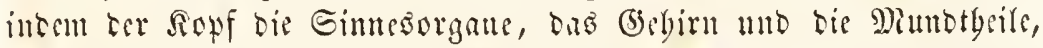

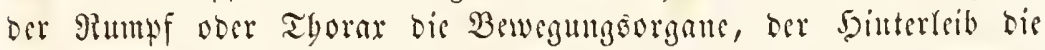
5auptorgane bes vegetativen efbens uno die Fortpflanjungswerfaenge trïgt. Bei ben nieberen Formen if́t bald bis eine, Kald bie antere Diefer Rörperabtgeilungen yerfïmmert ober mit ben allocrit ju ciner Daffe verfduorjen. Go findet man bei Den sigentliden Srimtn uno Sirebjen Ropf uno Bruft ju cinem cinjigen Tbeile, Der Ropforuft (Cephalothorax), veridumorjen, wägreno bei manden Rruftentbieren mur Der Sopf getremt, Bruft uno Sinterleib aber miteinander ber= cinigt, uno bei ben Maiben fogar alfe orei abtbeifungen in eine cinjige ratublitye Seritesmaffe zufammen gefloffen finto.

Betradyten wir Den allgemeinen Wlan, uad) weldyem ber Ban oer yerfdiedenen Drgane Des Rörpers bei Den (Sliedertbieren burdgefübrt 


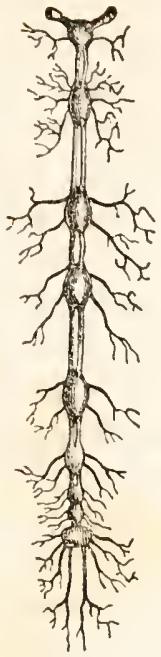

Jig. 446.

Nerwenititem cines (3) fieterthieres.

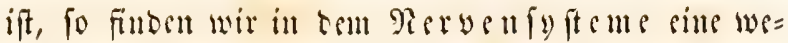

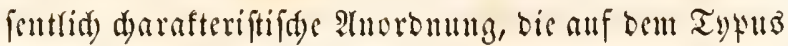
fubt, werdyen wir Vei ben böberen Pingerwürmern ansigetilbet fanben. Ein fuotiger Strang, Deflen meift bopperte Berbinoungaffäben oft feitlid) altsein= alloct weidyen, jeflyt fid in ber Mrittertinie bes Rör= ferè an oer Bandfläd) fort, unb entfentet aus fei= nen sinjelnen Sinoten bie Rerben ber veridededen Drgane. Ge ränger geftrefft ber Rörter erfdecint, ie gleid)artiger bie werfd febenen ringel find, in befto gleid)mäßigeren abftänben forgen fid bie Situten

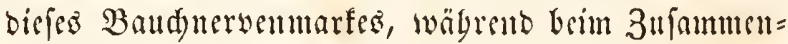
idmergen ber Ringer, fowie ber Rörperabtyeilungen, aud) bie cinjelnen Sinoten miteinnober in größsere Maffen verfdumcljen. Bas̉ ganje Band)marf nimmt foinen llriprung vou ciuemt ober melyeren keträdt= riden Syirnfutete, weldye in Dem Sopfe hiber bem

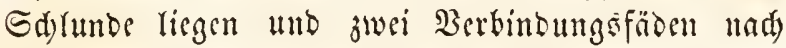
unten fdicfen, Die fid in ben erfen Baudfunten vereinigen. (Es ift alfo sin fürmlider Sd) Junbritig voryanben, ber fid aber nad) binten in ein ftreng fynmetrifdes, in Ler Mitterlinie bes Rörpers gelegenes

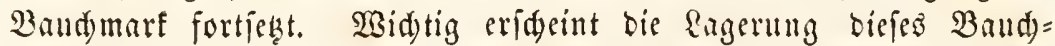
marfes unter allen Eingeweiben unmittelbar an ber Sunenfläde ber

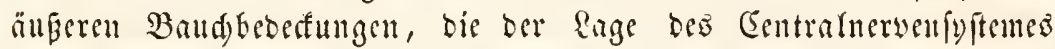
bei ben 2 Birfeltbieren gerabe entgegen gejest ift.

(Sin wefentrider lluterfdjeb ber Gricbertbiere you aflen übrigen Typen ber Thicrwelt beftegt in ber Biroung ber Bewegung

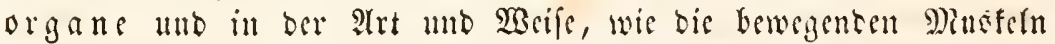
(iid) ju ben fefteren Theifen, zum ftarren (beriffte ocs Siörpers umb Der (5)lieber verbalten. Bei aflen (S)liebertyieren ift bie äufiere 5aut wer=

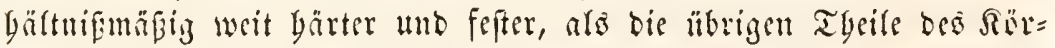
pers, unb bildet fo für ben Sörper fowobl, wie für bie Bewegungs =

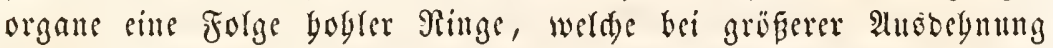
fürmlide Röbren Daritellen, in benen bie Drgane singefdyloffen fund. Die bewegenten Mugfern feben fid auf Der Snnenfeite biefer Siöbren all, find alfo im Sumern ber Sobel eingeid)roffen, beren Bewegunts fie bewirfen follen. Die Glieber ferbit bejteben aus eingefnen ftarren Stüfen, welde Durd betenfe miteinander verbunben find und un: burd) Diefe (5)erente bie ignen jufoumende Bieglanteit befitzen. Durd) biefe eigentbümlidye Anorbnung ber $\mathfrak{B} e$ wegunggorgane, bie man $j . \mathfrak{B}$. 
an Dem erften Sefen Beine stues Säfers ober siner Fliege Eeftätigen

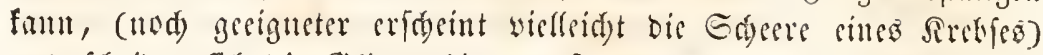
unterfdeiben fid bie (5)ficbertbiere wefentlid wou ben Mirbelthieren, bei wetden jwar cingelenfte, ftare 5 cbel fïr bie Bewegungen worfommen,

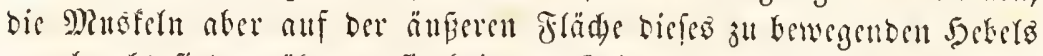
angebrad)t find, wägrend fie bei ten Girebertbieren anf for interen

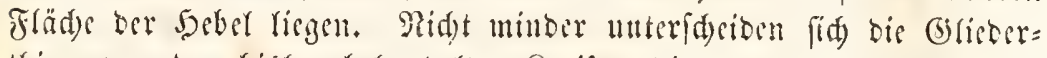
thiere vou ben bisher bebandelten Sreifen, die entweder gar fein frar =

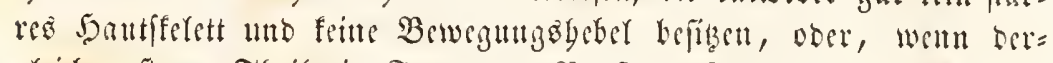
glcidsen ftarre Thaile in Form von Borften, Etadyeln 2 . worbanten finb, niemals cingerente (blicber tmo burd) birenfe verbunbene Seber jeigen. Die Brelente, welde bie werfdededent Theile ber Brieber mit

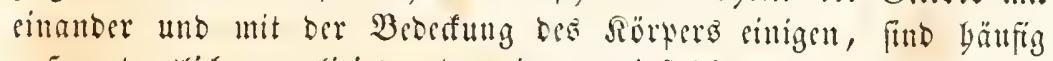
augerorbentlif complicirt tnb weit mannigfartiger in igren formen, alb bei ben șirlettbieren, fifon wegen ber form bes Sogleyltinders,

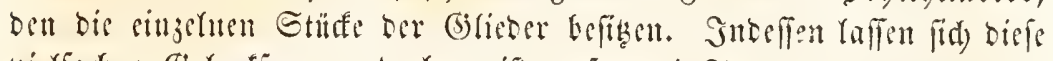
vielfaden Gelenfformen bod meift auf zwei Typen, benjentigen bes

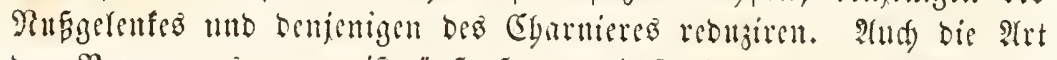

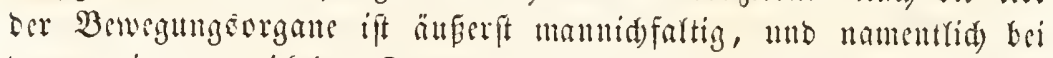
ben weniger entwidelten Typen begegnet man nod) oft jenen aenu=

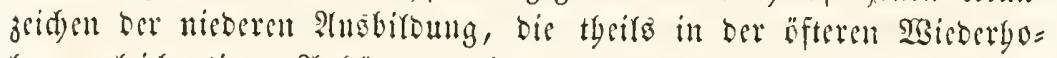
lung gletdartiger Thlbänge, wie 3. B. volffemmen gleid) gebilbeter sinfe, theirs in dem llmitande ju fuden find, oá cin uno baffelbe

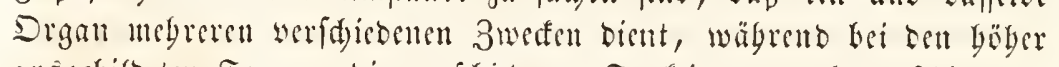

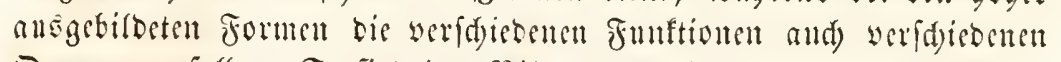
Drganen zufallen. So find jene Biroungen, bie jugleidy als Edywimn=

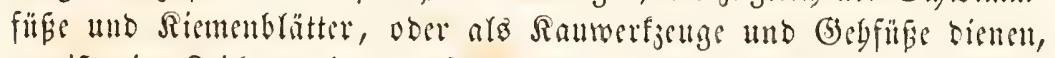
gewié cin 3eiden nicberer Drganifation. SSir begeguen in biefer

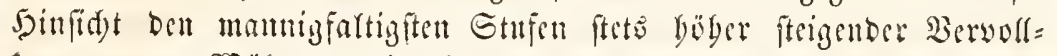
fommunng. Sägrent wir bis Dabin mur fordse Thiere fenten Tern= ten, weldye entweder an ten Boben gefeffelt fint, ober bëdjens burd

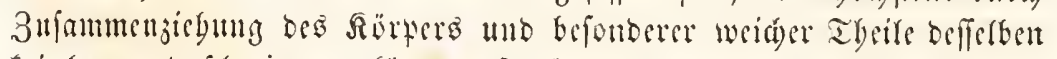

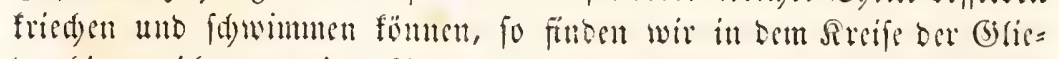

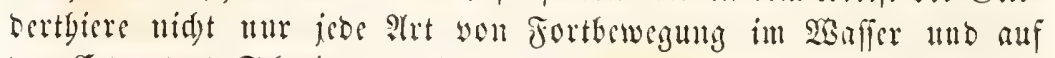

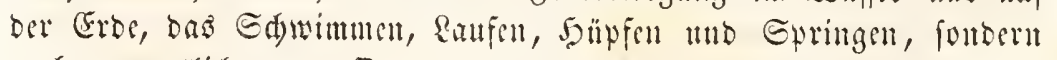

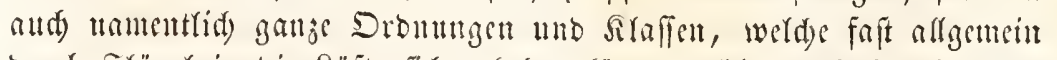

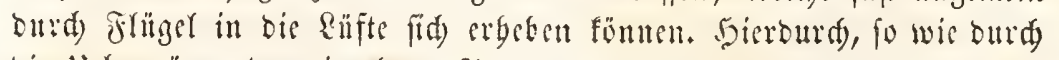
bie llebergänge ber eilljelnen 2trten won geglicoerten Ânbängen, bie

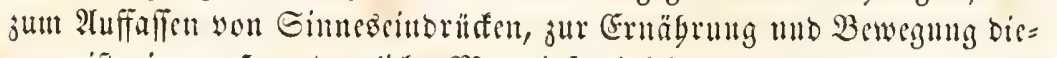
nen, ift cine auferorbentlide Manuigfaltigfeit ber Formen biefer Dre 
gane berworgernfen, beren Einceigung unter alfgemein Yeitenbe Pormen nur fower ju finben ift. SBir fönucu bier unr einzelne Anbeutungen in biefer Bejtefung geten.

Rur bei ber bödfen Entfaltung bes Typus oer bilicoertbiere

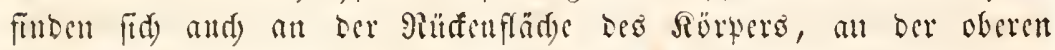

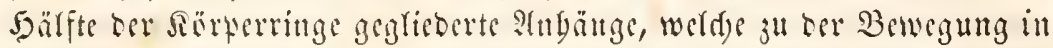

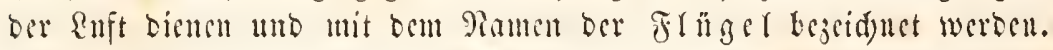

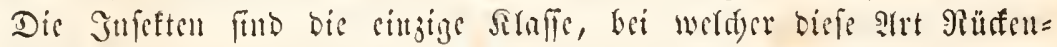
ftänbiger 2tubänge jur Entwiflung fommt, who and) fai ignen nur in Folge ber Mistamorwbofe nad) längerem ober fürjerem felbititändi=

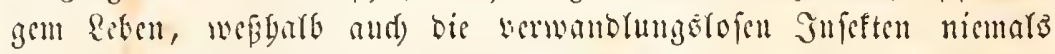

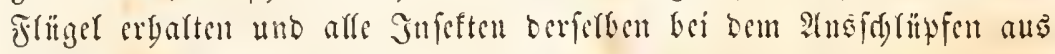
Dem Cie gänglid entebren. Alle librigen stugäuge gebören ber unte=

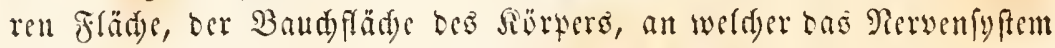
lecet, an, unb felbit für bicienigen Anbänge, weldye oft auf bis obere

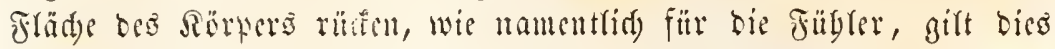

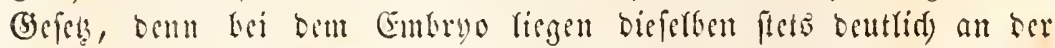

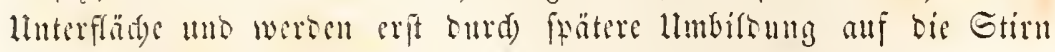
ober ferbit anf Den Gedeitel ber Siopfes geid)oben.

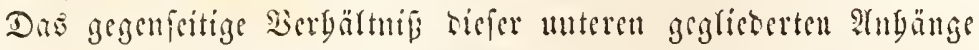

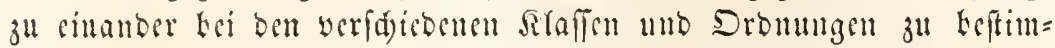
men, yält fogon um bef̧wiflen febr fower, weil igre 3abl, form,

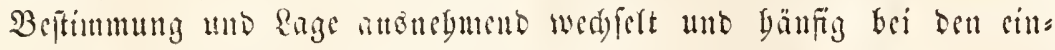

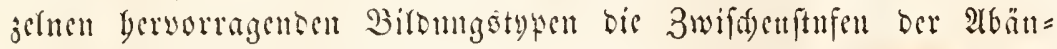
bermingen feblen, burd) Welde geleitet, man mit Gidgerbet won ber

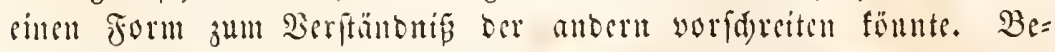

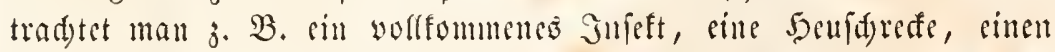
Räfer, fo ideincn sic subänge fdarf getrennt in Form, Rage unb Beftimmung. Born att Ism Soffe bie Fübler zur Auftabme von

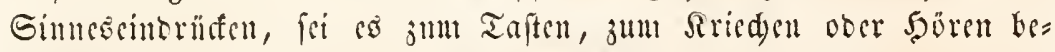

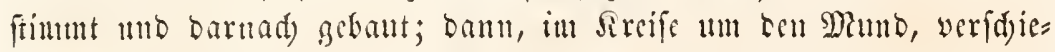

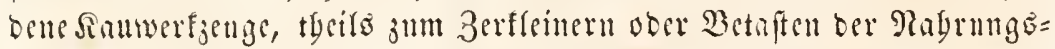

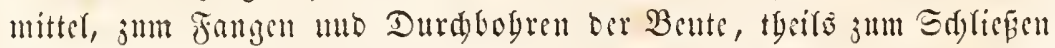
oes Diutbes beftumnt Dabinter, yon ben Bruftringen absüngis, bie

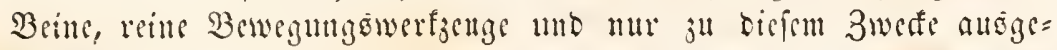

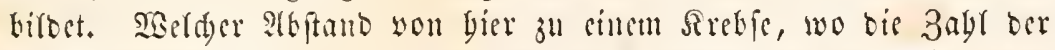
Jithler, oer Siefer, ber Beine fids vermegrt mo man faum mebr weí, welder Beftimmmg ben Borjug ju geben, inbem berielbe subang, ben wir bier als Bein tho reines Bewegungšwerfacng erfennen, bort als Ranwerf zeug, bier alo breiforgan, an einem britten Thiere als Rie= 
menblatt unb an einem vierten alo Taftwerfgeug fid wieberfintet! DBelder abftand jwifden ben Giftelauen ciner Grimne, ben Gdyeeren

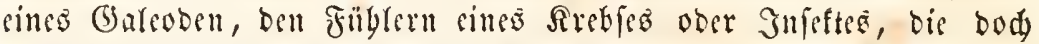

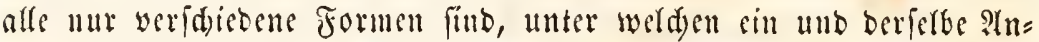
bany in bie Cridgeimmu tritt! Die meiften uno fiderften Inbartes= yunfte gewägren in biefem sabyrintbe die gegenjeitige Ragerung Det

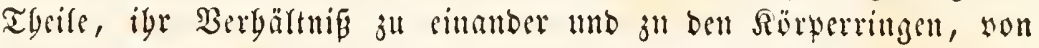
sweldyen fie abbängen.

Sn grëgter 3abl entwidfelt, werben biefe anbänge aus forgenden Grupten zufammengejetst:

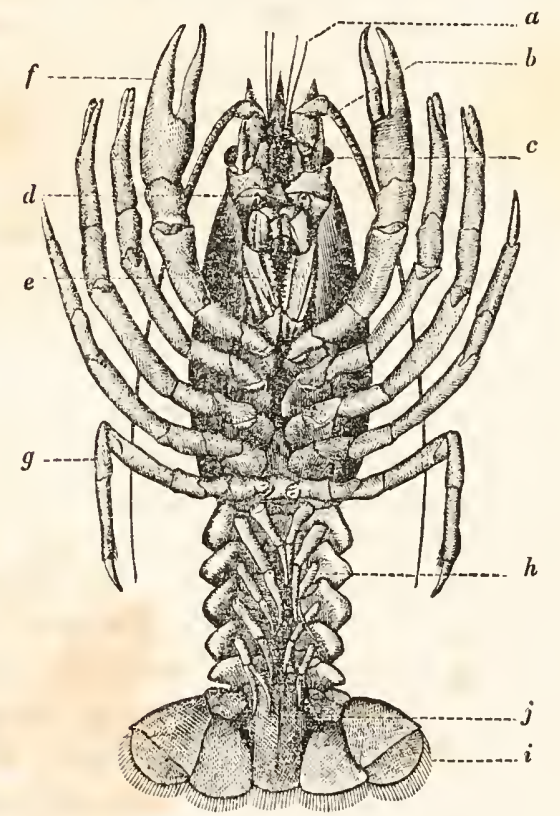

Bin. 447.

Der Jußfrebz (Astacus fluviatilis)

yon unten. a Smmere Fifyler. b Stencere Füh= ler. e Siugen. d Seforergan. e Lebtez Sara ber Saufüre, die ubrigen Muntwerfjenge fait

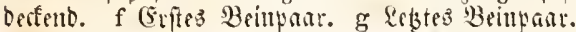

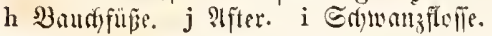

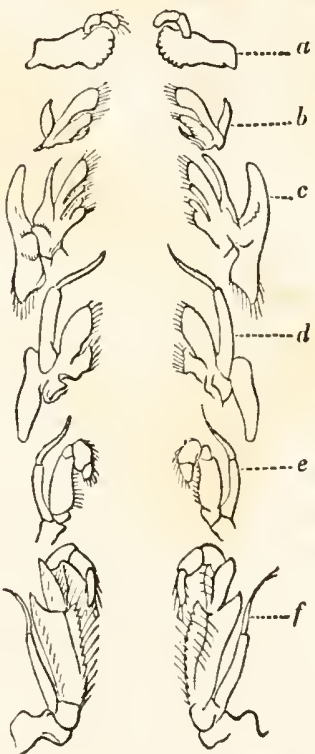

Sin. 448.

Die Rounerfjeuge

bejonders ausinumber gelegt. a Ricfer. b Eritez Simnla= Dempar. c 3meites Rinnla= Dempar (oie getromte linter= lippe). d, e, f Die brci תrul= fuppante.

1. Inz ziwei Jaar füblern (antennae), einem voroeren mo sinem binteren, bie meift fo neben einander ftegen, baf bie sorberen als innere Jïbler, bie Vinteren als änzere bejeiduet werben. Bei sinigen Rlaffen ift nur sin gaar Fübler entwidelt, bei anberen feblen fie fdeintar mb find in Greif= ober Beiforgane umigemantelt. Sie fegen fetes sor, meift ẗ̈ber bem Munbe auf ber Stirnfläde und find 


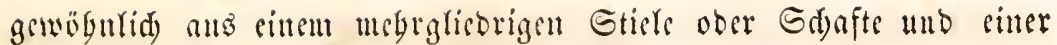

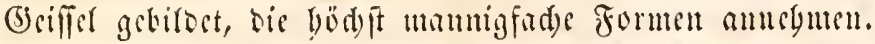

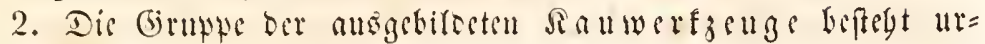

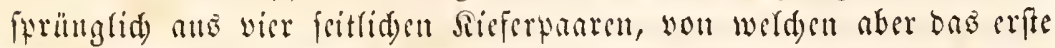

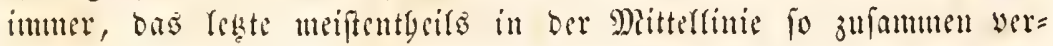

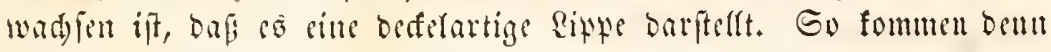
grwögulid) eins Dberripps (Labrum), cin srftes Sicferpan, meift

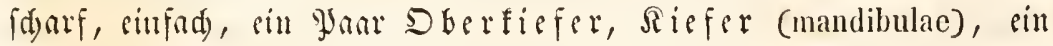

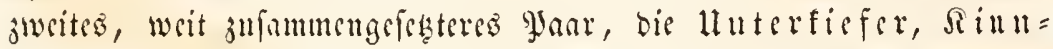

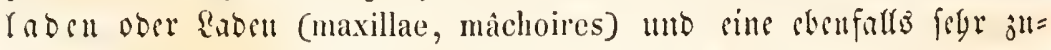
famunengefekte lltterlippe (Labium) am Eingange oer Miunbgüble

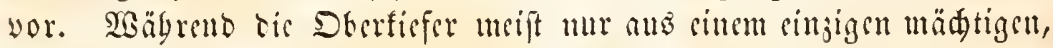

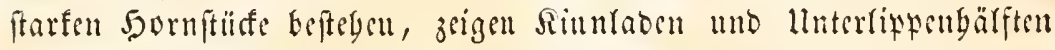

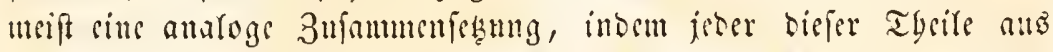
cincun Sd)aft ober Siörser, eincm inueren, meift zun Sauce ober Decten

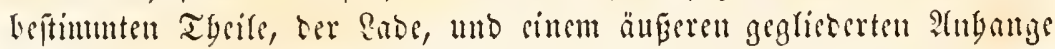
beftegt, bem Tafter ober ber Gesifer (palpus), welder wejentlid jum Bestaften ber Siagrungsemittel bisnt und Durd feine vislfaden form= ätoerungen gemaแt (Egaraftere jur llnterid)sibung bictet.

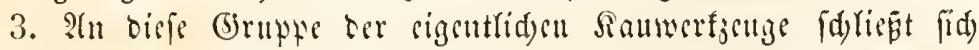
befonders bei benjenigen Grfiebertyiersu, beren Brufttgeil ganj ober

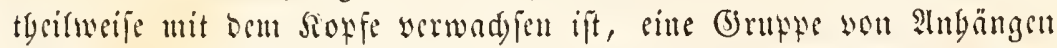

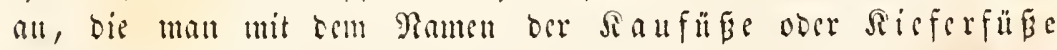

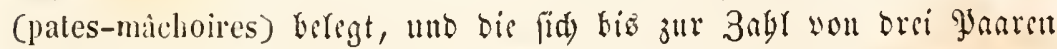

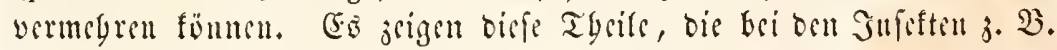
burdaus feglen, in igrer Birbung bie merfwüroigften llsbergänge von

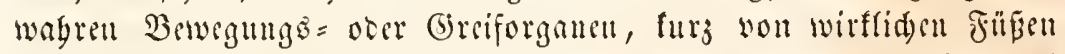
ju fürmlidsen Sinuwerfjeugen, und Yicfern baburd) ten Bawcie, bafi

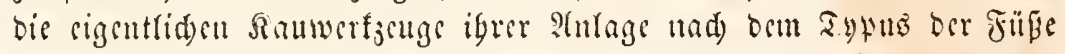
angegören und sigentlid unt bie Füße ber Sopfringel finb, welde zu befonocren 3weden fid) umgeftartet baben.

4. Sirrauf folgt erit bie (Srupte Der eigentliden 13 situe orer

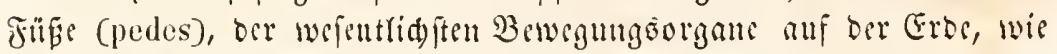

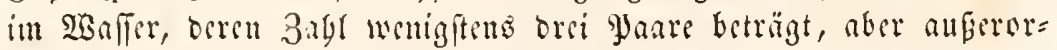
oentlid) vermegrt werbsu faun. Dis wogl ausogstitosten Fübe $\mathfrak{b}=$ ftegen inmer aus cinem, meift fugetiden orer cyliubrifden 5 ä renfe (coxa), an das grwögntid) sin unterweglides Etür, ber

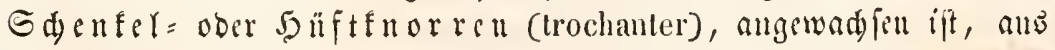
einem $S_{d}$ enfel (femur), einer Sd) iene (tibia) uno einem Enbtysile, bem Fü (tarsus), ber meift aus megreren Brficbern beftegt. Die 
Modificationen ber Form, woburd bie Beine oft igrer urfprüngliden

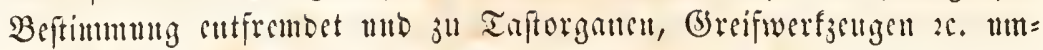
geftaltet werben, fint eben fo mannigfaltig als biejenigen, weldse fie

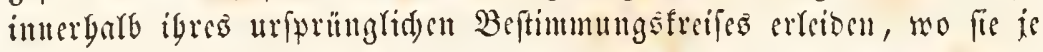
nad ber ifrt ber Bewegung ful Sdireit=, Rauf=, Spring=, Jirab=,

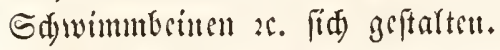

5. Cine Yeste Gruppe geglicberter IAtyänge, welde binter ben Beinen an ben Mingefn bes Shinterlecibes befeftigt finto, finbet fid mur bet ben Rrujtentbieren unto ift bort unter bem Rauten ber

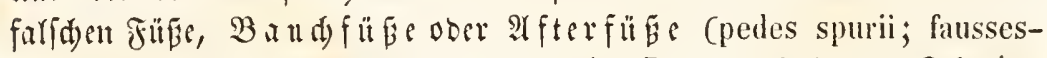
pates) befaunt. Meift fitud es blattfürmige Drgane, bald zum Sd)wim= men ober Strnbefn beftimmt, in anberen Frällen zu ?ttyemorganen

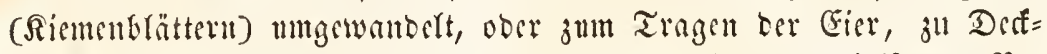
platten 2c. entwiffert; forten une bifoen fie fid zul wirffumen $\mathfrak{B}_{e}=$ wegungêorganten beran. Den Sufeftent mitd ?rad)nident feblen biefe

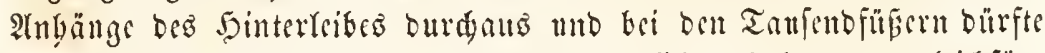

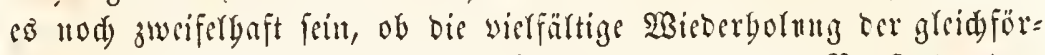
migen Pringe, weldse bei ignen Beine tragen, eber ber Brutt ober bem Sinterfeibe angegört.

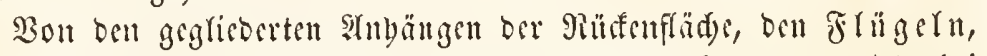
bic une bai ber bödjêten Silaffe, ocn Snjeften, vorfonmen, wirb bai diefen bir Pieder fritt.

Die inneren Drgane, bie bejonbers bem vegetativen Rebet yor=

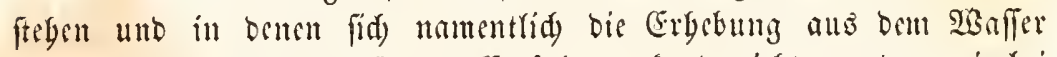

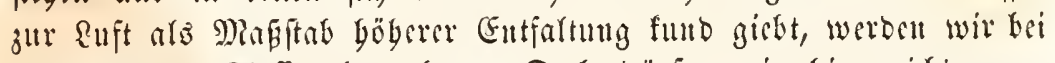
ben einjefnen Siraffen betradten. Dod) bürfan wir Gier nidft uner=

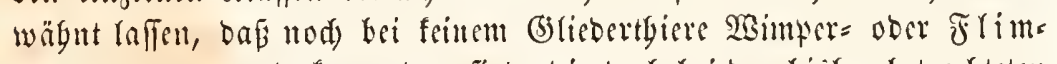

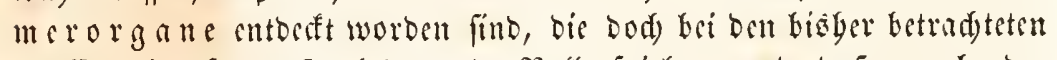

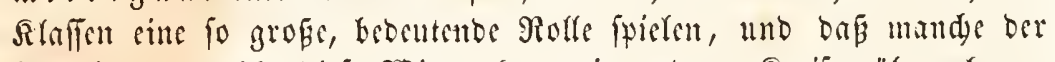
Funftionen, werde bicfe 2Bimpergaare in anberen Sircifen übernebmen,

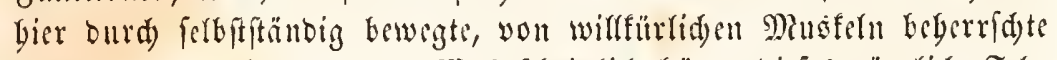

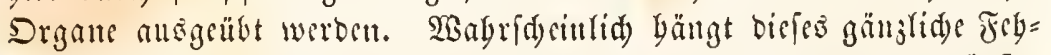

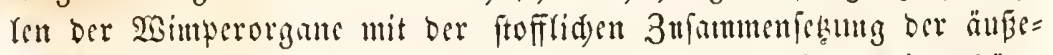
ren Siörperbüllfen zufammen, beren Brantolage ang sincm sigentbüu= lidgen Stoffe, bem CGitin, gebilbet ift, bas in frinen d) emifdsen Eigen=

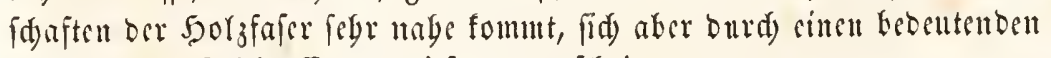

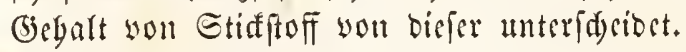

Mit ber boban Entwifflung, welde bie inueren Drgane, bejon=

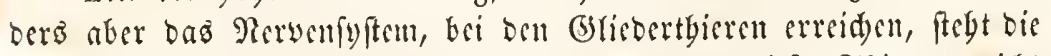
bebentenbe, geiptige 2ausbirbung, weldye won vielen biefer Tgicre erreidst 


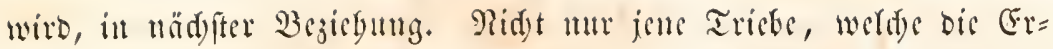
baltung bes Estens unb bic Jortiflanjung betreffen, finto oft eritauntid) ausgebildet, fo Dag fie ju fietten won banthugen fïbren, benen man sinch boben Grab wou lleberlegnng nidat abffredsen fant; bei ben

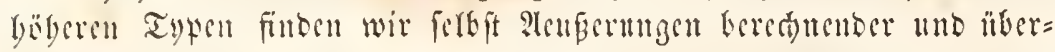
legener Gerifestbätigteit, welde fie anf cine weit bäbere Etmfe erbeben,

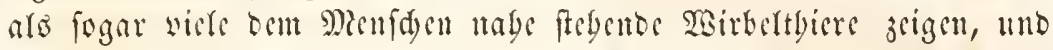
unr einen grabweifen lluteridjic won ben menfdliden Fäbigfeiten er=

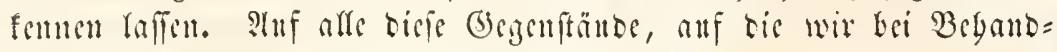

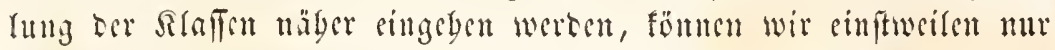

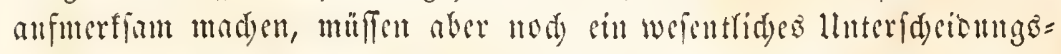
merfmal, bas allen Griebertbieren gemeinfam und in ore Entwiaftung begrïnoct ift, bejenters berworbetin.

Bei allen Gliebertbieren jeigt fid som eriten Beginne fer es nt

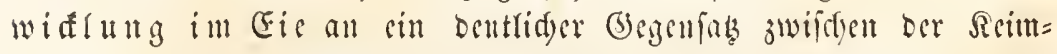
anlage, atto welder ber Embryo bervorgebt, unb bem Dotter; tub

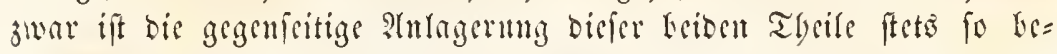

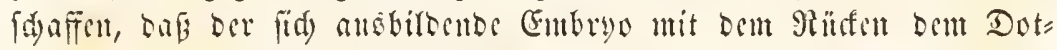
ter jugewand ift mo bafi bie Sirtung Der Drgane son ber Band)= flähe a

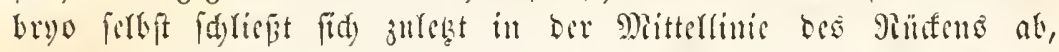

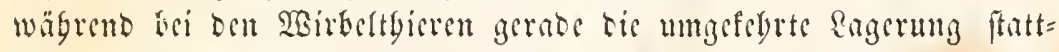
fintet und oer Embryo mit feiner Baudfläd) Dem Dotter jugetwand

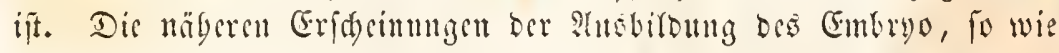
die Berwandhngen, weldye viele Gliebertbiere erleiben, gebüren Des Fecielleren Betrad)tung Der Rlaffen an.

Fafien wir sie cinjelnen bier anfgejäglten llnterfdscibungenterf= male Der Glicbertbiere jujammen, fo fönnen wir fie furj alo Tbiers

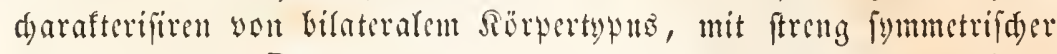
Anlagerung oer Drgane, welde geglicoerte Bewegungovigane beftęen,

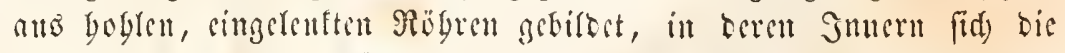

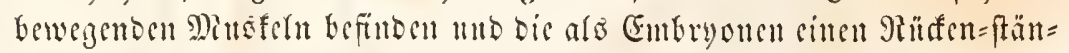
Digen Dotter baben, Der Dem Baudumarfe Diametral entigegengerest ift.

Gebr rebrreid) eridgeinen de Berbälniffe, unter welden der Jireis

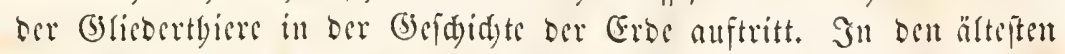
3riten, mit beut erifen Beginne oer Gdjopfung, treten cigentbïmlide frebsartige Thiere auf, beren Typus bald verfowindet, um ben Ber=

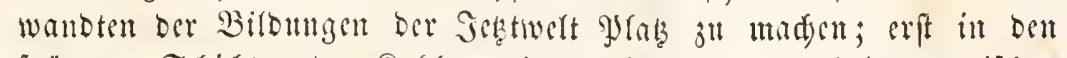
fpätren Gdjidten ber Roblemperive erfdecinen bie übrigen typifden

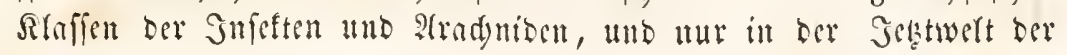


abweidsende Typus ber Taufendfüfer, bem nur eite geringe $\mathfrak{B}_{e}=$ beutunt gejient.

Wir theilen bie Myriaben ber Griebertbiere in vier Slaffen, beren Pngebörige fid meift leid)t unterfdeiben laffen:

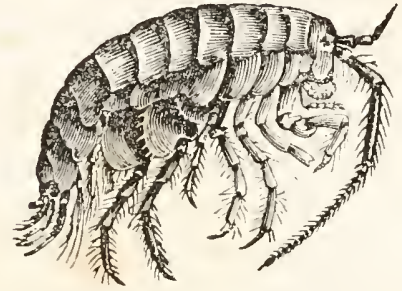

8ig. 449. Fluhfrebs (Talitrus).

1. Siuftentbiere (Crustacea) mit Füblgörnern, SBafferatbmung uno geglicberten 2ubängen an Ropf, Bruit und Şinterleib.

2. Taufenbfüfer (Myriapoda) mit Füblern, \&uftatbmung und

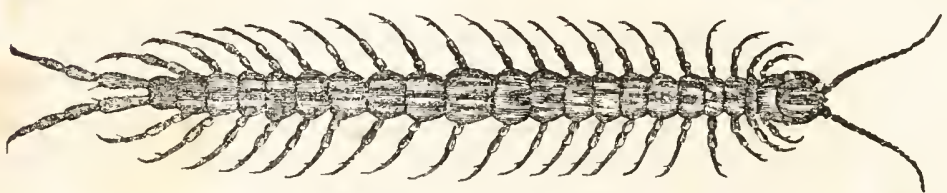

8ig. 450. Scolopendra.

gleidyartigen geglieberten Füßen an ben Pingeln bes Sörpers, bie fid uid)t in Bruit und Seib tremten Yaffen.

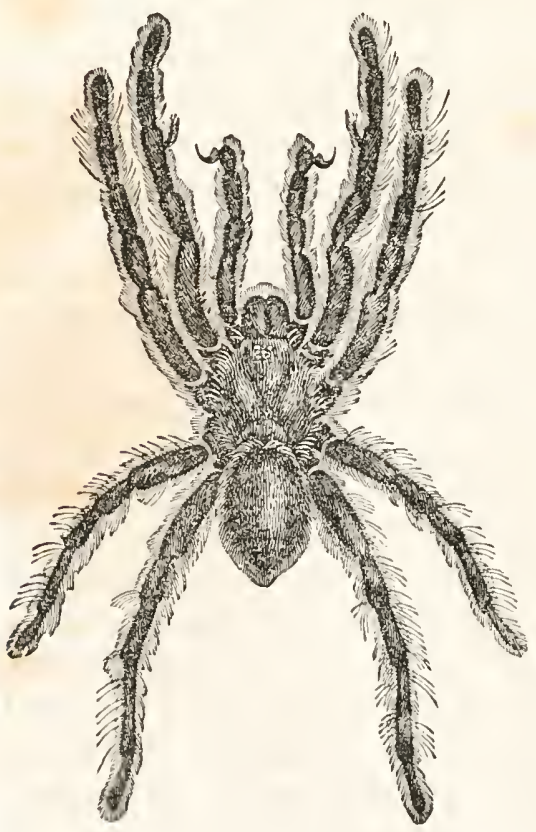

ซ̌ig. 451. Sugetipinne (Hygale).

3. Spinnentbiere (Arachnita) obme Fübler, mit vier FnB= parent, meift verfdumolgenem Ropf

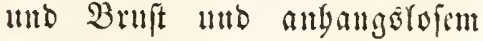
Jinterteib.

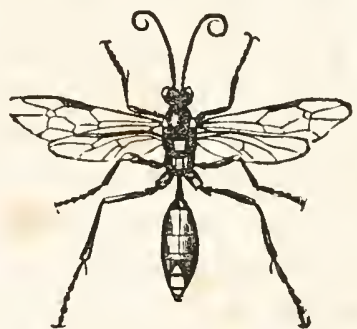

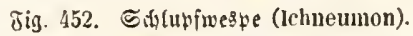

4. Surfeften (Insecta) mit Füblern, Enftatbmung, getrennten Rörtertegionen, anbangalofem Sinterteib, brei Jubparan unb meift mit Flügelt werfeben. 
filuffe ier firuftentl)iere. (Crustacea.)

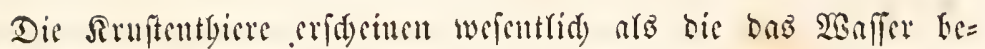

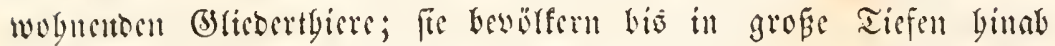

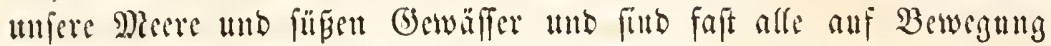

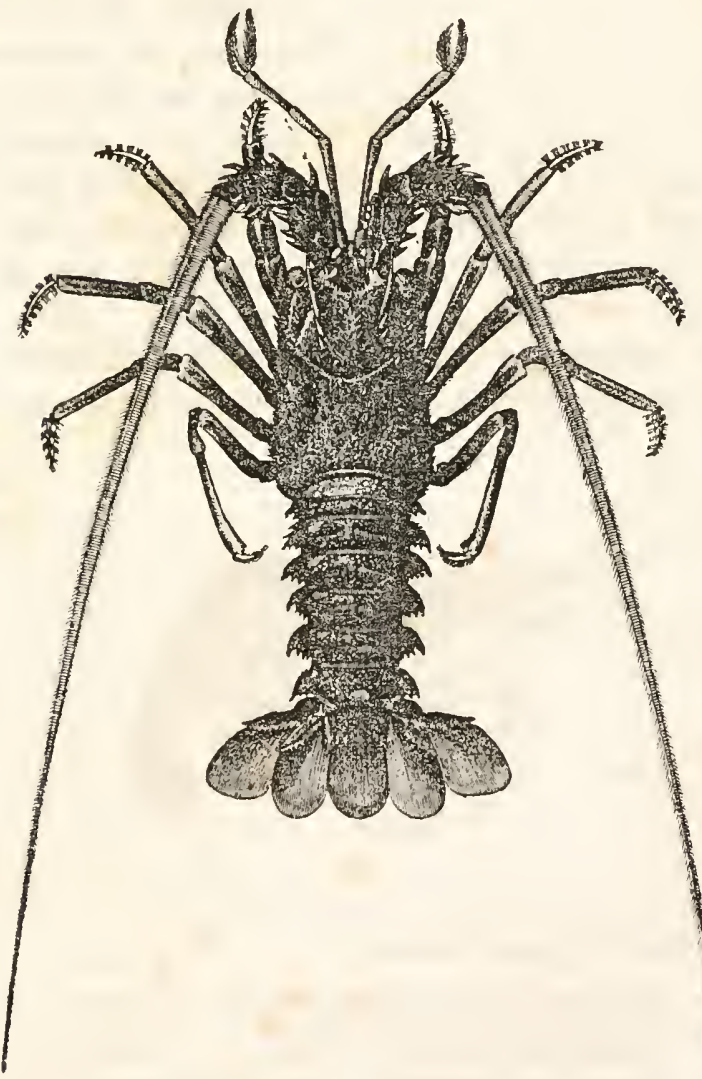

8ig. 453. Ramgute (Palinurus). und ?tgmung imsaf fir angewiefar. (5. bält inbeffen fduwer, bei ber auferorbent= (id)en Mamuidyfaltig= feit ber Formelt unt beiber mannidy fadsen Degrabatiou, welde bie verifhicbenen Ty= pen in biefr Siralfe ertriben, allgemeine Semuzid)en anfjufil = ben, weldye auf alle Tgiere berferben obne ?แรnabune faाাen, $\mathfrak{z}=$ marba fid in ibr cine unjweibentige Eut= wiffelung you ticferen Formen zu böberen Gieftaltungen funt = gicbt, die fo bebcus. tent ifi, baí bic $\mathfrak{A l l}_{11}=$ fünge ber Rlaffe in ibren verfümmerten Formen barto ben 28 cidstgieren oder ben

Cingeweibewärmern, bic Göberen ben eigentlidyen Snfeften zugewiefen wurben. Bei feiner Rlaffe zeigt fid) Der Finfluß bes Sdymaroker=

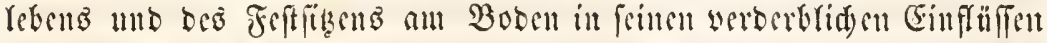
fo flat unb beutlid) wie bei ben Sruftentbieren, unb bei feinel gebt 


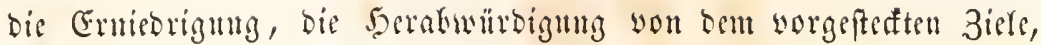

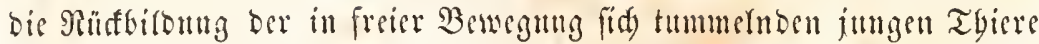
jil alten 5oofern, to weit als gerabe bei biefer Slaffe. Stlle jene Dr= gane, anf beren Berbalten man allgemeine Cgaraftere ftütsen fönnte, verfïmmern Durd) bie erwäguten yerberbliden Einflüfle. Die barte,

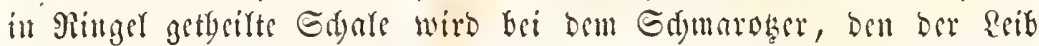

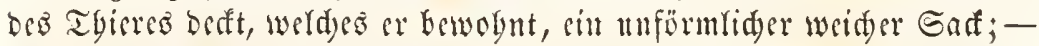
bie mäd)tigen (5)lieber, weldye sime fonelle Jortbewegung im Sigafier vermitteln, wanbeln fid sul faum beurerfiden Safenfraflen $\mathfrak{u m}$; bie Fïbler, bie Taftwerfzenge, bie Angen, bie Gimnesorgane l̈berbant werben zuriafgerifoet tub geben ferbit gänjlid) ju (stunde. So breibt am Cube wou einem frei fewegliden jungen Thiere mm ein erwad)=

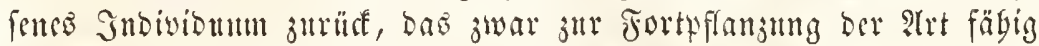
ift, aber fonft afle jeme Theife werloren ober werbildet bat, woburid

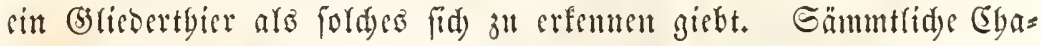
reftere, werdse man won Der STaffe Der Sruftentgicre angeben fann, bezichen fid Defigarb nur anj bie gröpere Megrzabl berferben und er= reiben bald Gier barb bort bebentende Fuonnamen.

Der Sïrper ber Sirnfentyiere bat meift sine mebr ober minder fyinderförmige (beftalt, bis fids inteffen bei mand)en Jamifien juweifen

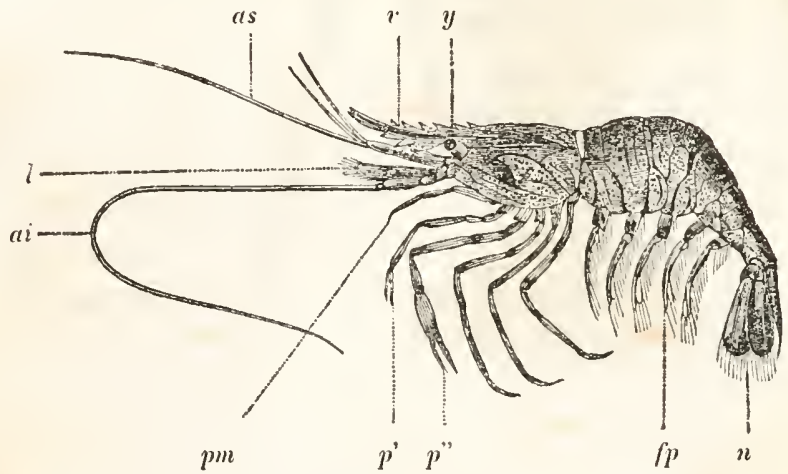

8ig. 45i. (Gmineels (Palaemon)

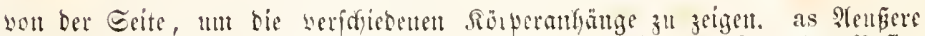

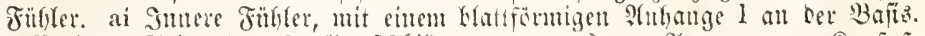

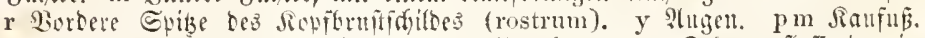

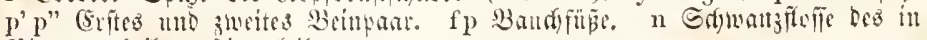
Singe getbeilten syinterleikes.

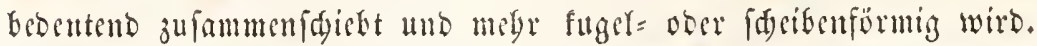
Die Bewegungsoorgane, die bei ben Gmbryonen uno Enrven niemalö feblen, bei den erwadjenen Thieren bagegen, znweiten in fonberbarer 


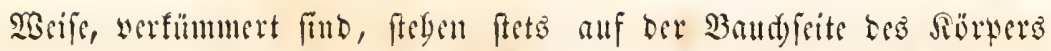
in Geftimnter Bejiebung ju Den Ringefn, aus weld)en Derfelbe Jufam=

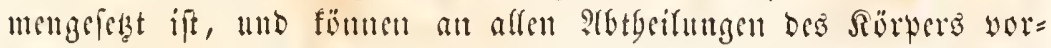

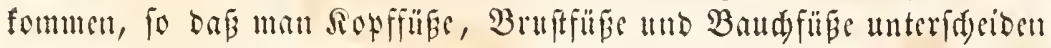
fann. Desiftens jeigt fid Der Sörper aud in Diefe orei s(btbeifungen,

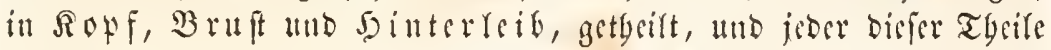

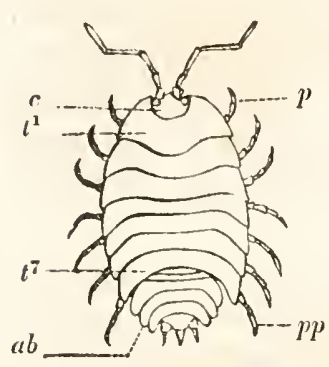

8ig. 455. 21fiel (Oniseus)

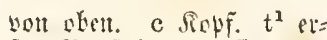
fite 3 tuttring. $t^{7}$ fitenter uno lebter Blutring. p bis pp Die fietert 2 einpare der

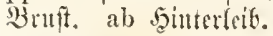
wicber aus sigenen Pingeln 3mfammengefert, bie urber ober minder beutlid von sinnder

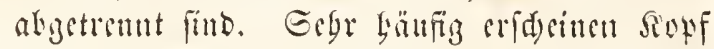
แto Bruft in sine cinjige Miaffe, in Das $\Omega$ of $f=$

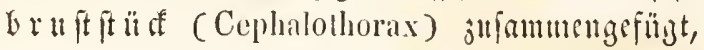

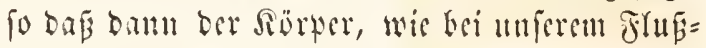
frebje nur aus jwei atbtyeifungen beftebt, bem Sopformftitite, weldes Sintesorgane, Sau= werfjenge unb bie wefentlidjen Jübe trägt und eincm binteren geglieberten Theile, ben man uneigentriduer Seife ben Edumanj nennt, ber aber, ba er ben Darm und die Jortferung Des Baud)marfes entgält แno sigentyümlide Gdwminnfübe trägt, als Şinteryeib bejeidnet werben mus. Meeif jeigt fid) in allen ben Fäflen, wo ber Sopf Deut= lid) wou ber Bruft getrennt ift, Diefe Testere fowie ber binterteí Dentlid) aแs eitjeluen Ringen jufammengefest, bic mux in feltenen Fällen worlftändig fint, aber ftets ats jwei gleidyen fymmetrifden

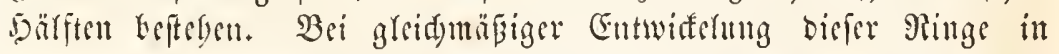
aften igren Theifen zeigen fit) bieferten aus folgenden Etḧten jufan=

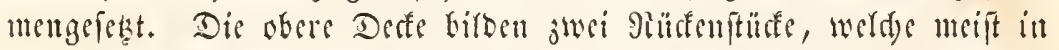

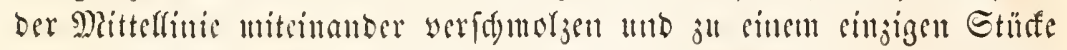

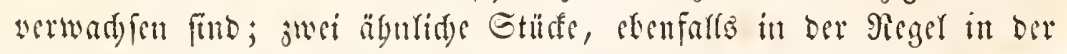
Mitterfinie jufammengewadjen, beffen wou unten ber ben Baud) unb werben bas $\mathfrak{B a u d}$ ftüf (Sternum) genannt. Die Geitin werben von Ethäen gebeft, werde oft beweglid) mit ben Siüfenftüfen unb Baud)=

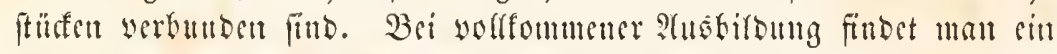

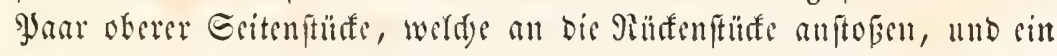

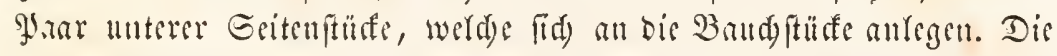
Bewegungsorgane find ftets nut ben unteren Gritenftüufen unb ben

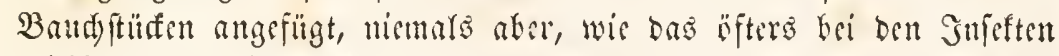
gefduicht, Den oberen Gtilten Des Pringes.

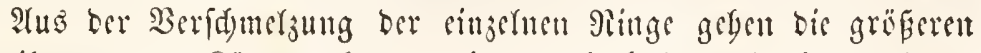
Arbtyeifungen bes Sëtpers bervor, inbem die bald mebr bald minber 
volftänbigen Ringe entwedet im Ganzen ober in igren cinzernen Tycilen mitcinanber verwadgen. Durd) Bergleidung ber mamnigfa =

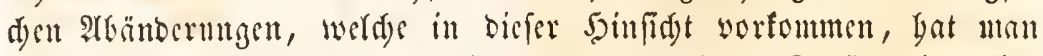
gefunden, baf bei ber bei weit gröpten Zahl ber Seruftentbiere sine normale 3agl won 21 Ringen vorbmoen ift, wou weld sen bis brei yorbern bie Simtesorgane tragen, alfo Den Sopf bilben, bie tubrigen in wed) felmber 3 abl ber Bruft und bem Bande anjugebörent (d)einen.

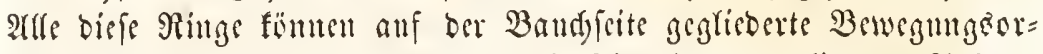

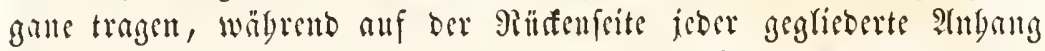

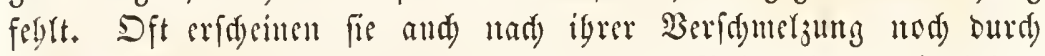
Rälyte femtlid), welde fid) zuweilen burd) Bebanblung mit Sönte wout eintrito tren then laflen.

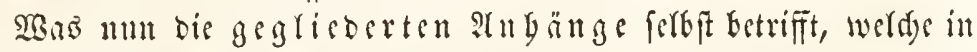
Der lluterfläd) biefer Binge singelenft find, fo find biefe ber verfdyie=

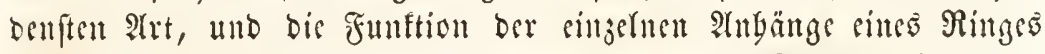

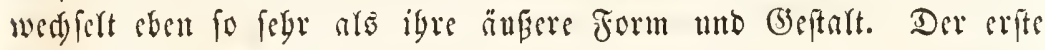
Sopfring if unr bei wenigen Sruftentberen frei, bei ben meiften mit

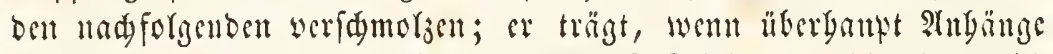
an igut entriffelt find, bie $\mathfrak{A}$ ugen anf Gticlen, weldye beweglid)

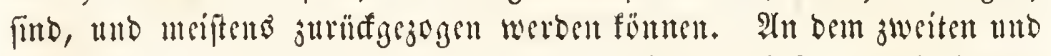
britten Sopfringe find bie geglicberten Füblorgme befeftigt, die inne=

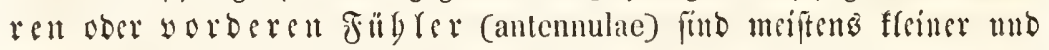
meiftens fteben auf sinem furgen Etiele sin ober smei fabenförmige :He Gänge, welde man bie (seifeln genaunt Lat. Dic äuferengübler,

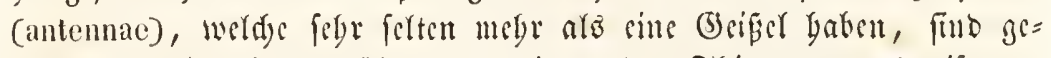

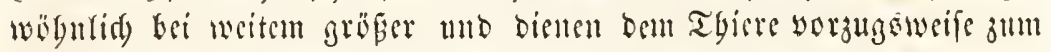

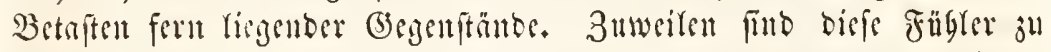
breiten Blättern un! geftaltet, in anderen fällen veräitelt unt bienen bann als Bewegungsolgane.

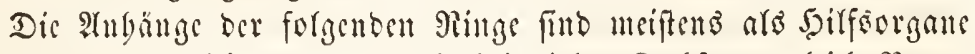
Les Mundes entwifelt, und on fie bei siclen Sirebien jugleids Bewe= gungsongane fint tuto allmäblig in wabre Finfe fid ungeftalten, fo

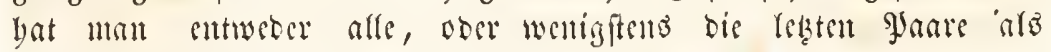

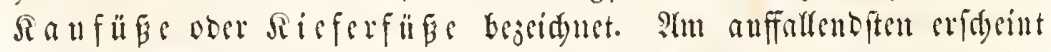

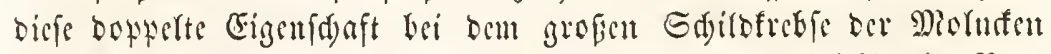

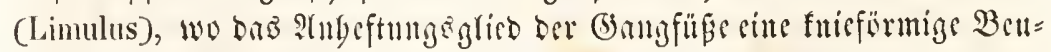
gung gegen ben Diund bat nulo bier mit barten 3ägnen bejebst ift, bie zum Zermatmen ber Bente bientu. 


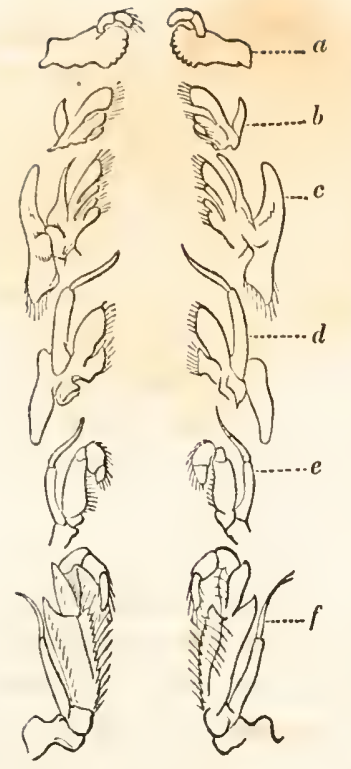

รig. 456.

Die Raumertzenge

lefonbers auseinander gelegt. a Ricfer, b Eritez Rimnla= Denpanr. c 3meites Riunla= benparr (bie getrente lluter= lippe). d, e, f Die brei গan= fuถpaare.

Betradytet man alz Beiftist bie wer= fdr) icbenen ?tubänge, weld)e man bei unferem gemögnlid)en Frufrebie zu beiben Seiten Des Miunder findet, fo zeigen fid juerit juwei barte nad) innen gezägnelte Stïfe, bie Dberfiefer (mandibulae), anf welden eit flemer juseigliebriger Tafter (palpus) einges Ienft ift. Sinter biefen Dberfiefern ftelen fer Reibe nad) zwei Jaar ll utetfiefer,

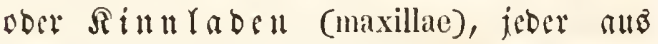
mebreren Stüfen jufammengeiegt, bic blatt= artiy unb mit fteifon Saaren befest fitub,

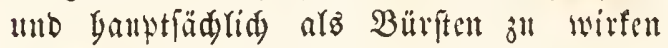
fdjeinen. Ituf biefe Rimnlaben ober llnter= fiefer folgen brei Yaar eigentlider $\mathfrak{I}_{\mathfrak{a}} \mathfrak{U}=$

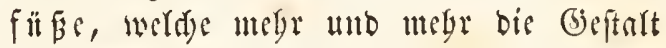

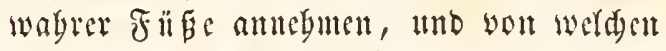
faft jeber ciuten äubern Gseifelanbang trägt.

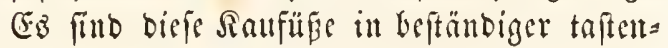
ber Bewegung, und fie forinen vorgüglid fum Feftgalten Der Rabrung und Borfdie= ben berjelben in ben Mlunb beftimm jut frit. Ereft jeb̧t folgen bei bem Sirbje bie eigent=

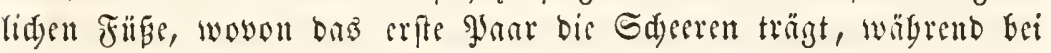

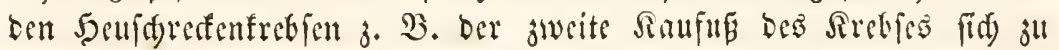
einem gewartigen. 3antgenfuke ausbilbet, ber bis Beute ergreift, unb

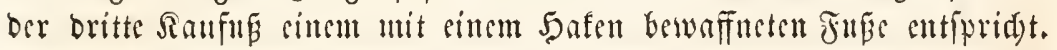

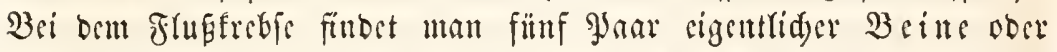

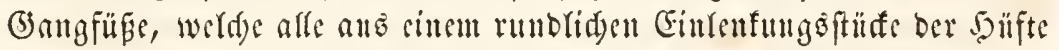
(coxa), einem Derridenferftüfe (femur), cintem Gdjienbeinftüfe (tibia),

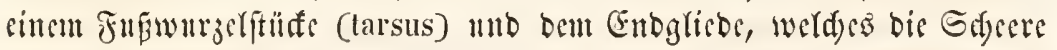
ift, zufaumengefelgt find. Die 3ngl biefer (5)angfübe wed felt anjeror=

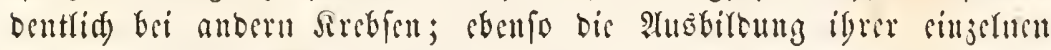

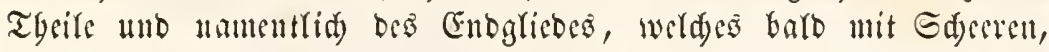

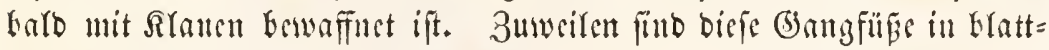
artige Sdywimmfüpe umgewanbelt, ober aud) nur ju Sirmmerorganen verfümmert. Bei bem Flüfrebfe folgen auf bicfe (jonngfïfe, welde unter bem Sopfbruftitite cingelentt fiub, fünf Jaar von geglicbers

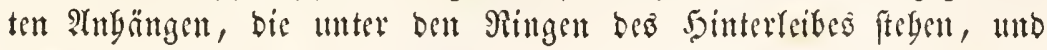




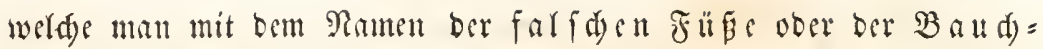
fï

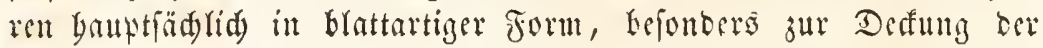
Siemen ober ber Fier entwidelt, unb aud bei ben weibliden Feftes= frebjen bienen biefe Angänge jur Befeftigung Der Ciertranben bis zum

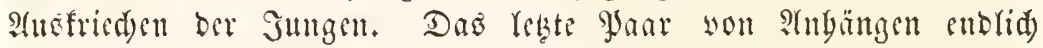
bilect bei bem Sirebfe bie feitlidyen Theile, welde mit bem blattartig

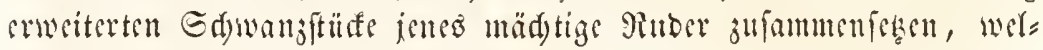
d)es fïr Den Sirebs Sas Gauptiädylidjte Edymmorgan ift. Die Mo=

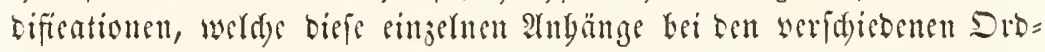
nungen uno jamilien streiben, fönnen wir bei biejen erft genauer in's

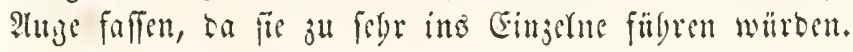

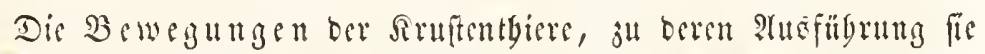

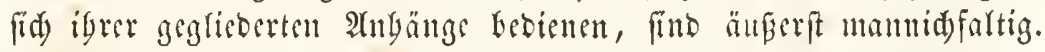
Die meiften leben im $\mathfrak{B a f f e r}$ uno baben bann wie ber Sirbo Edywimm= uno (bebörgane juglcid. Bas oen guten Edywimmern, bie fid) jugleid) (d) uelf forthewegen, trägt ber 5imterleib ftets sine foldye breite gloffe

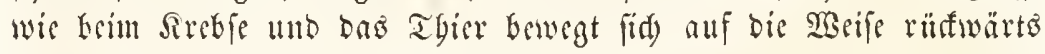
fort, Daßs co ben Sinterleib Yebyaft unter bie Bruft frimmt uno fo Das $\mathfrak{B a f f e r ~ w i r b e r l y o l t ~ m i t ~ b e m ~ b r s i t e n ~ E d y w a n j r u b e r ~ f d h l a ̈ g t . ~ B e i ~}$

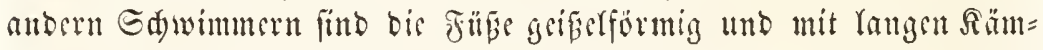
men von Borjten beję̧t, bie als mädtige Puber Dienen, wäbrent

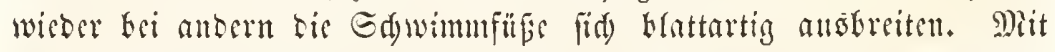
vieler Geridiflideit wiffen fid Die meiften Rruftentbiere ibrer Gang= fübe ju bebienen. Biele im Saffer rebenos atrten babeu nul foldye Gangfübe jut Bewegung, mittelft beren fie auf bem Brunbe umber= fried)en, ober fith beim Raben yon Gefabren mit grober Edyelligfeit in Edyamm und Sand simuliblen. Bei mandsen entwiffeln fid bis lointeren Baudfüfe ju langen griffelartigen Borften, bis als fduclents Etützen beim Eprunge bienen; und cinige Trten, weldse ben Mierese= ftrand ober bas trofine Rand bewobnen, fömen fo fduefl und mit

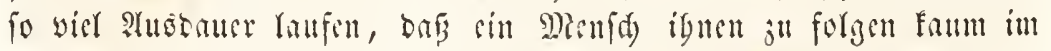
Gtanie ift. 


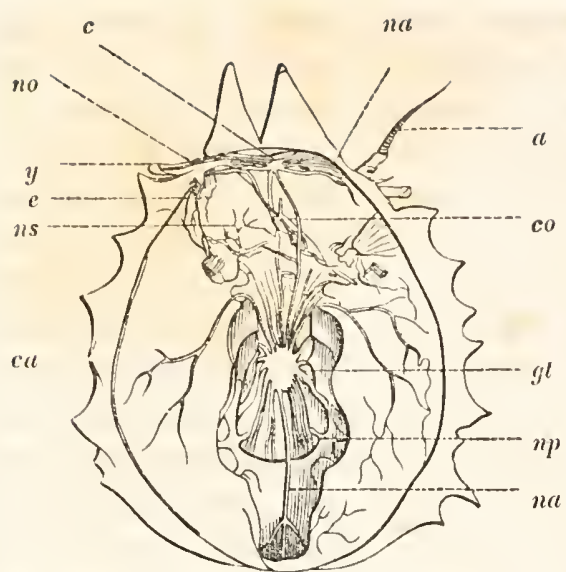

Oig. 45\%. Nerwenfyltem einer Sirkfe (Maja).

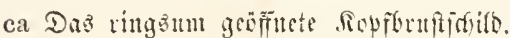

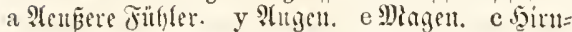

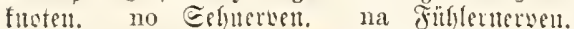

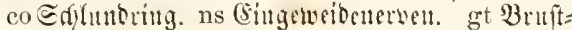

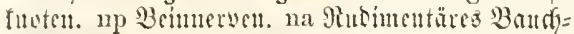

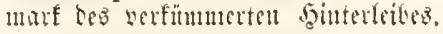

Daz Reryeufyftut Der Siruftentbiere jeigt febr wer= fdirbente Gtufen ber :Yusbil= bung, fejtebt aber bei allen aนô cincm fnotigen $\mathfrak{B a u d}$ = marfe, weldyeó surd) cinen Sdlunbring mit einer mebr ober minber verwifferten $6 s=$ birmmaffe in Bertintung fitebt. Diefe Gibirmmalle, watde batutfäd)lidy dis Simnerot= gane, dis an Siopfe liegen, Pugen, Shren unt fübler mit Rerven verfiest, fawindet mit ber Alubiroung biefer Gimesorgane und witb ent= (id) bei Denjenigen Sd)ma= rokern, bis im ermadjenen 3 uftande gar frine Gimnes=

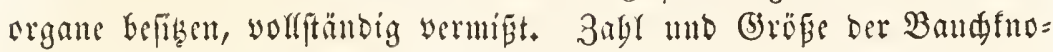
ten rid)tet fith) befonbers nad) Der Unabbängigfeit ber eillgetnen Ringe, fowic nad Der Entwiftelung ígrer Anbänge. Bet ben lang geftreft= ten Simftentyieren zäblt man mebrere mo gleidumäpig auşgebilbete

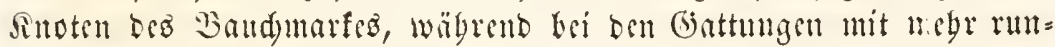

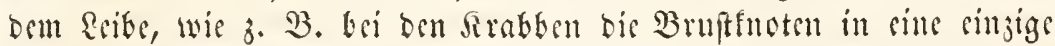

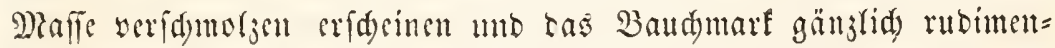
tär woirb. Bei ftarfer Entwiffelung ber 2(nbänge fint aud bie ent= fpredsenten Sinten, fowie bie non ignen abgebenten Rerven werbält= miømäßig ftärfer und fiäftiger.

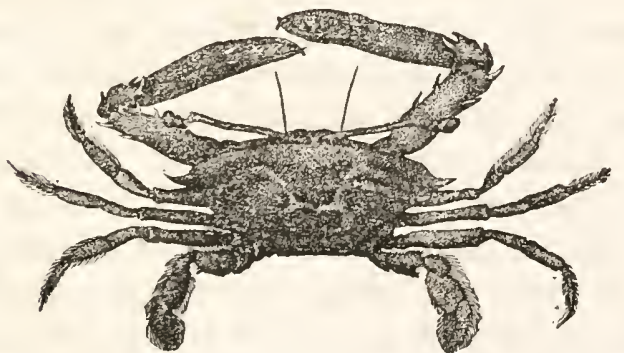

Fig. 458. 9ugentrabbe (Podophthalmus) mit ungemeit langen ?tugenficlen.

Dis Pr ugen Der Siruftentbiere feblen zwat im erivad) (ensu 3ujtande rinigen idmarotzenben ober fonit feftitienden Familien, fommen aber im jugendidyen 3uftande

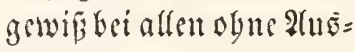
nabme vor. Sie fitehen auf febr verfducbener Stufe oer susbiroung, 
inbem bald unr sinfadge unbeweglide stugen, bald fobr jufammengejeste auf langen beweglidgen Stielen getragene vorbanden fint. Die eins

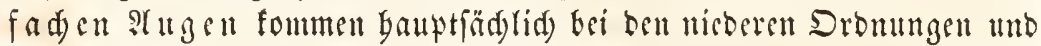
bei ben Embryonen ber Sdumarober yor mb finten fid bier oft logar aud) unr in ber Einjabl, wo baun biefes Auge mitten auf bem

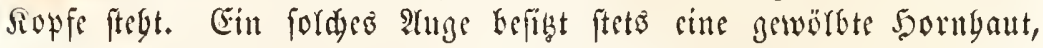
binter weldyer sine runbe ober eifürmige Rinfe liegt, beren binterer Theil von einer bed)erförmigen ?Hobreitung ber Sebnerven unb ciner ?צnbäแfung febr bunfer gefärbten Signented umgeben wirb. Das cin=

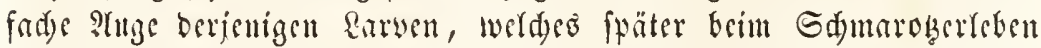
verlowen gebt, ift meift in biefer SBeife gebilbet, and foumen oft jwet fordyer THuen anf beiben Geiten bes Siopfes yor. Gin Fortfdritt ber

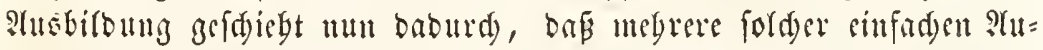
gen fid) gegen eimen Sunft bin jufanmenträngen, wobei inbeß nod) iumer jebes berferben volfonmen fïr fid gefonbert unb mit sigener Jorngaut verfeben ift. Bei sinem weiteren Grabe ber Atôbitbung veridmelgen bie 5ornbäute mitrinander. Minn findet bann mur sine

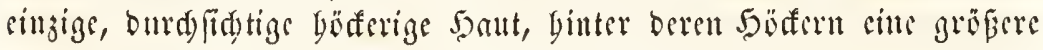
ober geringere Alujabl wou einjelnen Rinjen liegt, beren jebe von igrem sigenen Sigmentbed er ungeben unb von einem bejonberen 3weige ber Gebnerwen verfeben wirb. Man nenut biefe Prt you

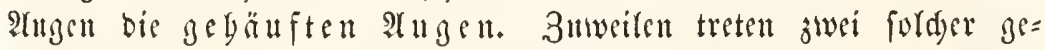
bäufter $\mathfrak{A}$ ngen in ber Mittellinie ju cinem einjigen jufrmmen, weld)e bann meifters yon befonberen Mntwfelı umgeroflt werben fant. 23ei

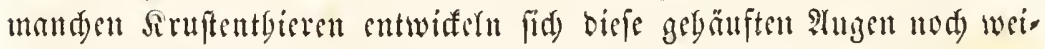
ter; man finbet auben cine glatte 5ornbaut, unter biefer aber sine zweite burdjlidgtige gefenterte 5aut, weldye in eingeluen facetten ge= (d) liffen ift und wo jebe Faeste siner fegerförmigen Rinfe entfpridgt, beren abgeituzte Grundfräde an ber Faette liegt, wäbrent igre Spibe

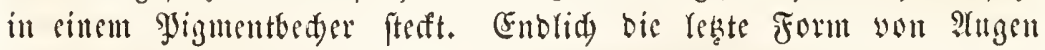

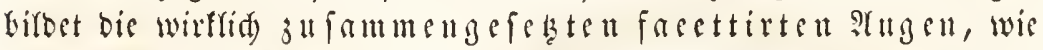
fie etwa bcim grubfreble utho ben übrigen büberen Sruftentbieren vor=

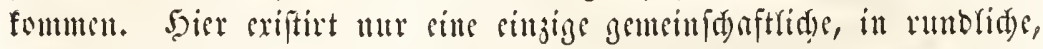

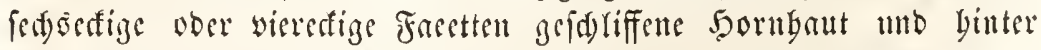
jeber Facette liegt eine fegelige Rinje, bie mit igrer Spilse in sinem bederförmigen Gilastärter ftefft, weldye wicber won eincr bejonberen bautausbritung bes Gebnerwen uno einem Sigmentbed)er umfät

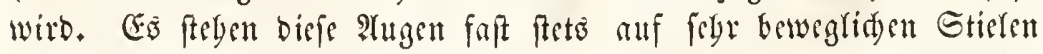

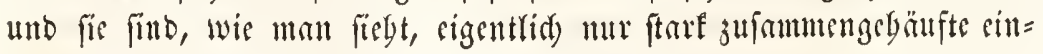




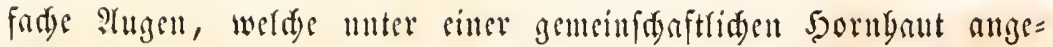
bradyt fint.

Die 5örorgane fommen wabrdacintid alfen Simfentlieren ju, Find aber bis jebt mur bei ben jebufübigen fireblen genaner madge= wiefen worten. Shier frnbet man, wie 3. B. bei unferem jhaftreb/e

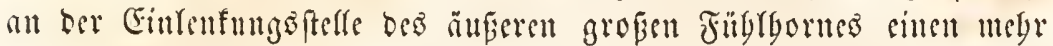
ober minter langen cylinbrifden Borfprung, mit einem mallartigen Nanbe, ber cine Bertiefung ungebt, welde von ciner bïnnen Sant, sinem Trommelfefl ïberfpannt wirb. Meeift ift biefes Trommelfeft won

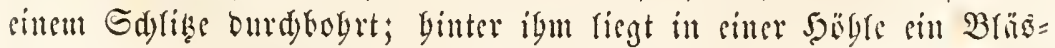

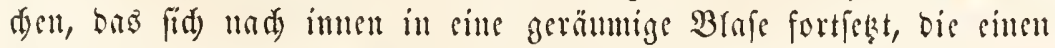

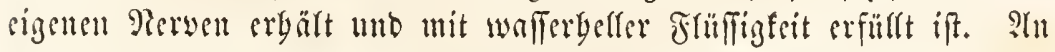

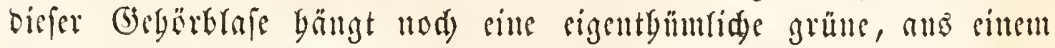
gewmbenen Sdyrade gebirbete Drïfe, beren Bebeutung nidyt näber befantut ijt.

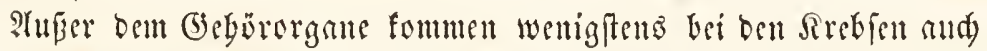

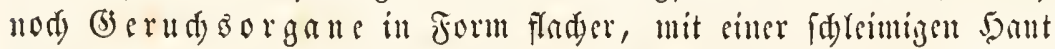

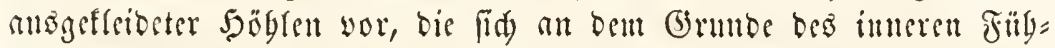
rerpares finben. Gin befonberer Rery tritt wom Gebirn ju bicfen Riedgruben, Deren fpaltenförmige Deffunng meift won feimen Borfen umiteflt ift.

Die Berbaung ơ Gem Grabe entwidelt unb unr ferten jeigen fith foldye rubintentäle Formen, wie wir früber juf finben gewobnt waren. Die Dinnowert= jenge finto, wie foon ans ber obigen Atnafyfe ber Anbänge bes Seres= fes berworgebt änserft mannigfaltig unb baupträdlid nad zwei Grmbridytungen bin angebilbet. Die meiften Sintentlyere Gaben finenbe Maunbtyeile; fie jerflrinern ibre Pabrung mittelft Garter Rie=

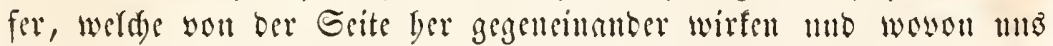
in bem Frngfreble cin Beifpiel gegeben war. Bei nuberen Sinten= tbieren aber wirb burd theifweife Berfïmmerung ober Berwadjinng Der fruenden Dunbtbeife cin Srugaptarat bergeftelft, ber meif rüfre förmig serlängert ift, mo oft nebenbei eigene ffike Saffen trägt, womit bie Thiere igre Bente antobren, un fie nadber susfangen ju fönuen. Die eigentyünlidyen Mobificationen, woourd bie fauchoen Mnnotbeife allmäblig ju fangenden begrabirt werben, find felyr man=

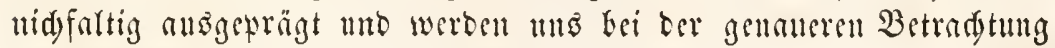
ber Sdymarolgerfreble nod bejonbers beidäftigen. 


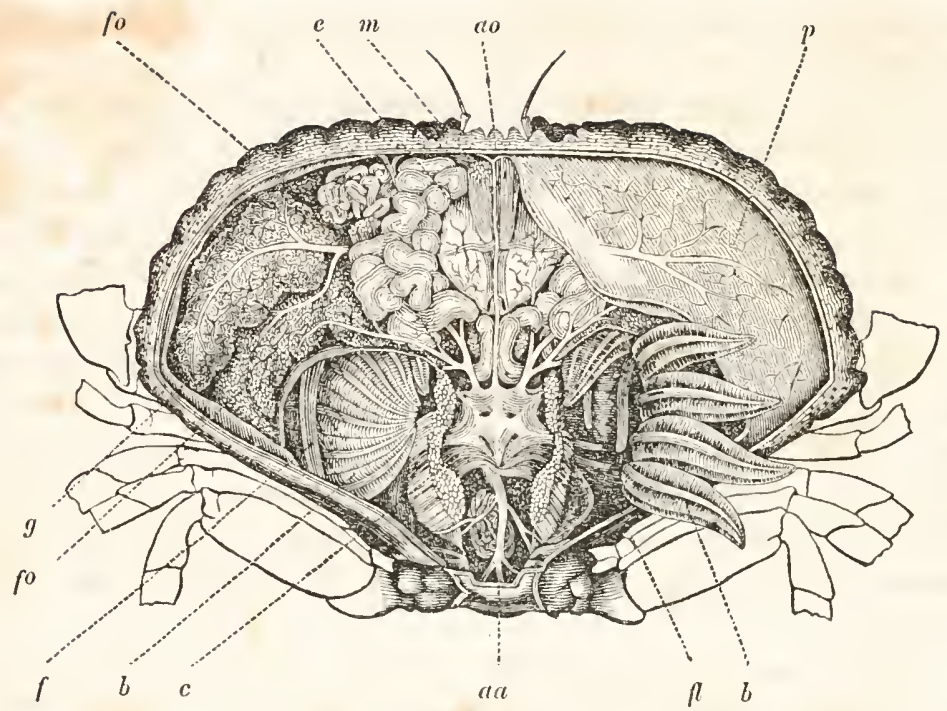

Fig. 459. Inntomie einer Sirabbe (Cancer.)

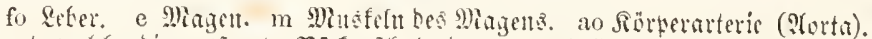

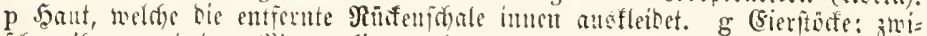

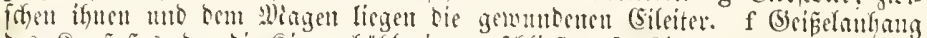

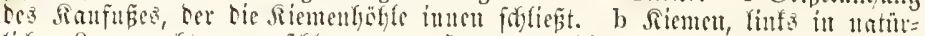

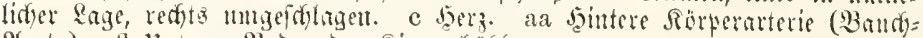

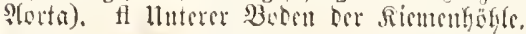

Dả Darmrobr ferbit vertäuft bei den meiften Siruftentgieren in geraber Sinie, won bem Munte bis ju bem am Sdywanjenbe be=

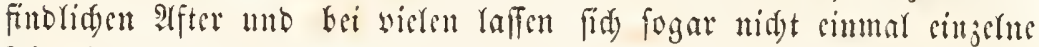
abthcifungen unterfdeciben. Pur ferten jeigt ber Darm fdrlingenfür= mige ober fdyrallenartige Biegungen, unt nut bei ciner sinjigen

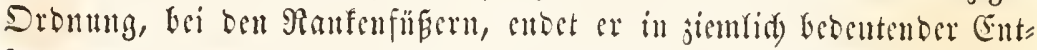
fernmg yon bem Edjwanjento. Bat ben gügeren formen laffen fid

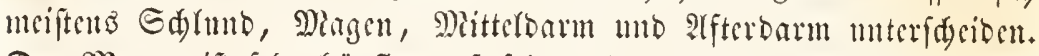
Der Magen ift febr bäufig auf feiner imneren fläd) nidjt nur mit Gornigen Borften unb 5aaren, fonbern and mit fürutliden 3 agnteifent

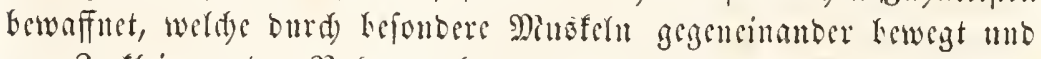

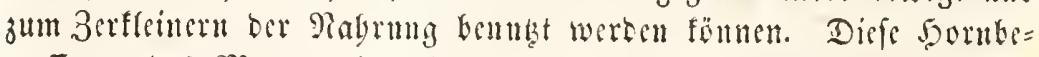

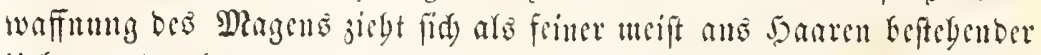

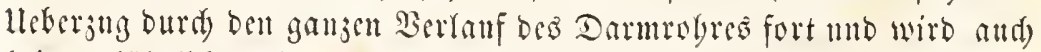
bei ber jäfrlident bäntumg gewedjeft, wo bant bie abgeftopenen Etüre

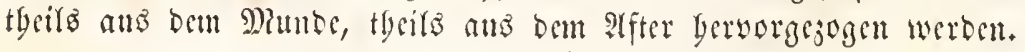

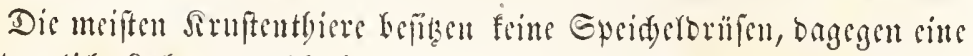

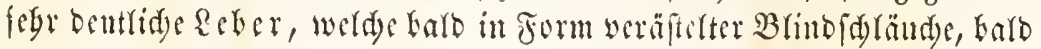


alofegr bebentente Drifjenmafen anftreten, Deren rögrige Struchur fid) Deut=

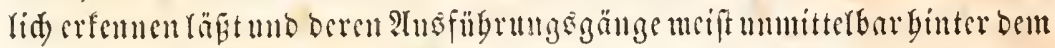

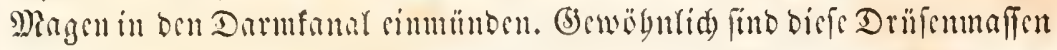

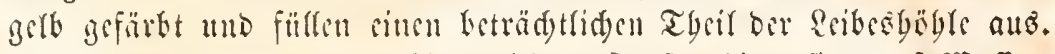

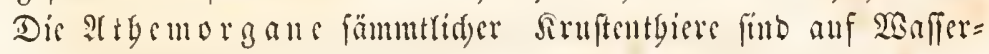

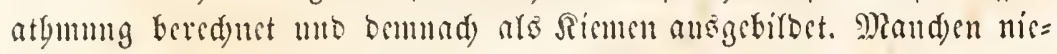

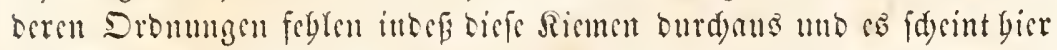

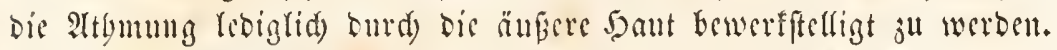
Bei Den meiften Rruftentbieren bingegen finten fid sigene Riemen, bie entweder frei an bem Siöter und jwat an ber Bafio ber Grieber= anbänge angebrad)t find, ober in befonderen Spübren unter fom Sopf=

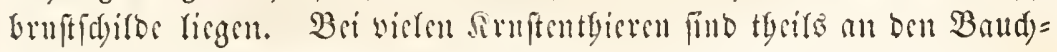
füßen, theits an oen vorberen siörteranbängen befonbere Fortfäke entwifelt, weldye in feter Bewegumg erbalten werben und cince leb=

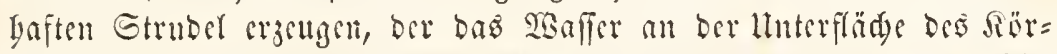

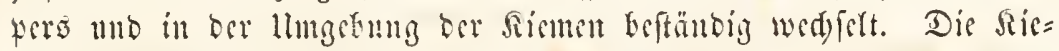
men felbit find entweber bammurtig veräfelt, ober won sinfaden ober jufammengeichten B̧ättern gebirbet, die von wantungstofen Gefäfen

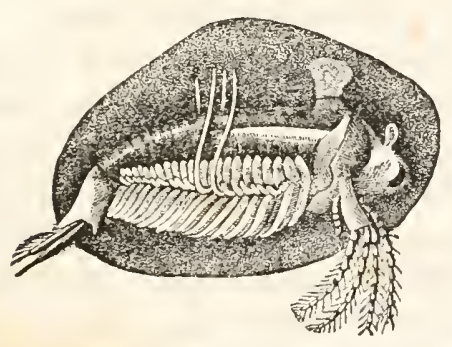

jig. 460. Limmanlia nou ber 厄rite, nath Dieguabme ber ballen Ed ale. Whan fiebt

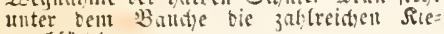
menbiattitien. ourdjogen werben. In ber cillfa= d)eren Form zeigen fid bicfe Jie= men befonbers Eei ben Blattfübern unb Den ignen nabe ftegenden Dro=

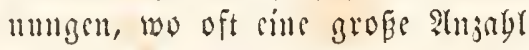
Erecter Bätter entwidelt ift, weldse

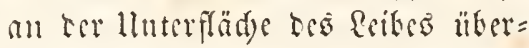
cinanberligen unb beftänbig auf= mino zugetlappt weroch. MReiftens fino bier nod) rigente Defel ent= witelt, welde dicfe mit äuferit zas" ter Şaut übergogenen Ricmenblättden vor llnbirben idühen. Die

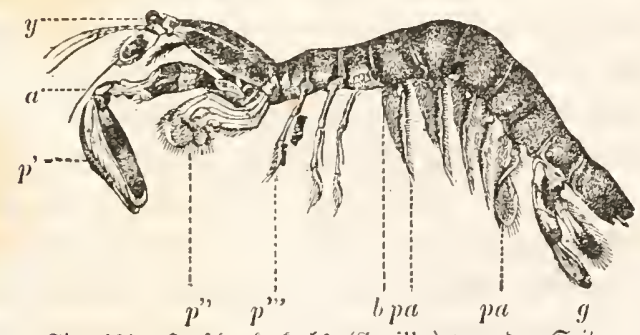

Jig. 461. Seentifyreffenfrebs (Sintillia) won her Seite.

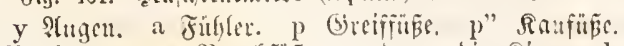

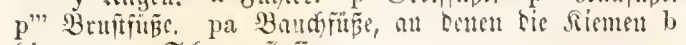

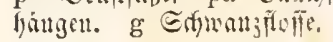
wanbung in werdan Daอ $\mathfrak{B}$ lut frömt, jicben fid jwi= fiden ben beiben bart an cinanber liggenoen binns nen Ramellen biefer Sie= menblättdyen bin. Bei anderen Drbunngen wie namentlid) beiden Maul= füвеm, bäแgen Diebaแm= 
artig veräftelten, zarten, röbrigen Riemen fret an ber ltuterfläd) bes Bandes, wägrent fie Eei ten 3egnfübern, wie namentlid bei muferem Frnffrebfe zu beiben Geiten unter bem Sopfbruftidilbe in eigenen

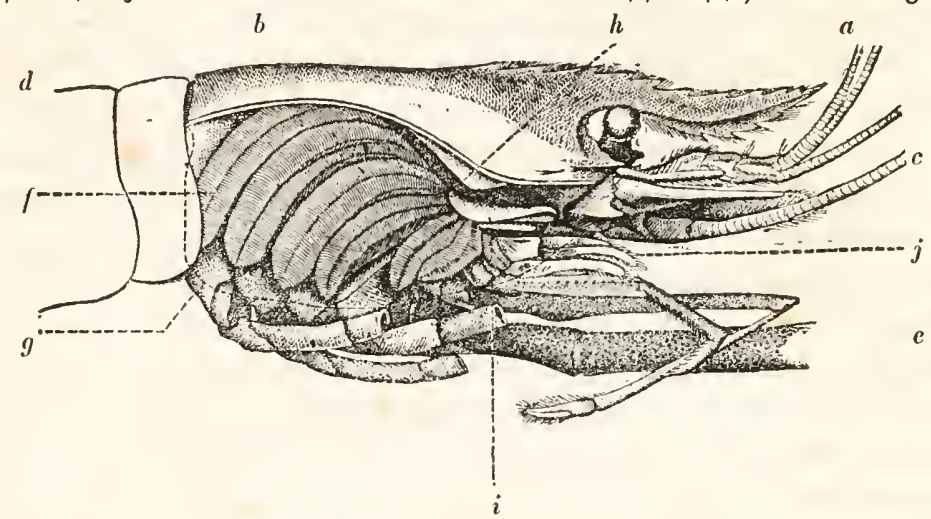

8i.j. 462. Siemenawarat cinec (5) rneele (Palaemon).

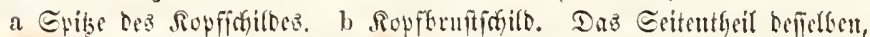

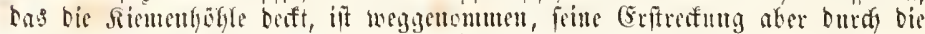

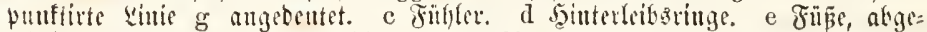

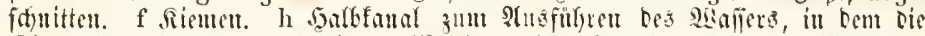

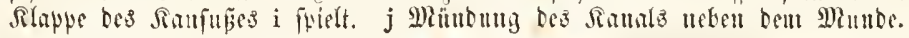

5öblen werborgen find. Diefe siemenböblen werben burd) eigene Sd) cibewänbe won ber Eigeweibeböble getrent, yon bem fiopfbrut -

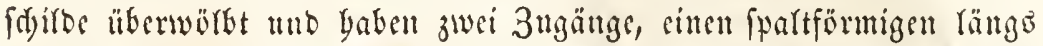

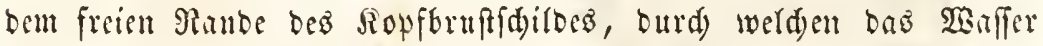
cinbringt und einen worberen Salbfanal, ber fid jur Geite bes Min=

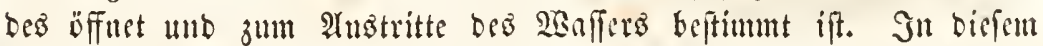
Sarbfanale fpieft ber Tafter bes binteren Sanfubes wie sime Slappe ober wie sin Sumpenftängel bin unb Ger, mn bewirft fo bie ftete

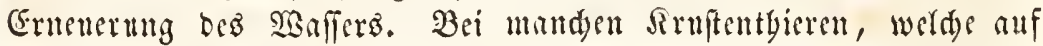
Dem Sande Yeben, fömen bie fpartförmigen Zngänge ber Riemenbüble wollfändig abgefdloffen werben, mo ba auberbem bei biefen Tyieren

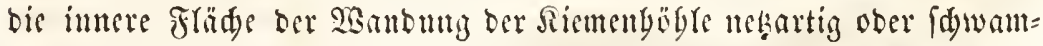
mig entwiffelt ift, fo föntuen fie bas jur Befendtung ber Siemen nö=

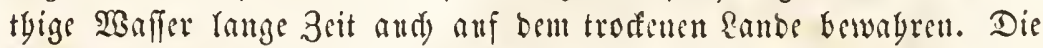
siemen ferbft, welde in biefen fitmentiblen vertorgen ftno, wed) feln febr an $3 a b r$ mb bilden meift fpige, oreifeitige gryramiden, die mit igrer $\mathfrak{B}$ afis an ben Jaufüpen feftgewadjen find und mit ber Spilse nad) oben feben. Art ber inmeren Seite biefer Syramiben funbet fid eine Art Sdyaft, in bem bie Situmengefäpe aufferigen, mo an welden bie borizontalen Siemenblättdyen angewad) fen fumb, bie nad ber Spilse ơ allmäblig an biröfie abuegmen. 
Bei sinigen Eanbaffeln finben fid auber ben Sicmen nod befon= bere böblen, welde offenbar zur \&uftatgmung bicuen unb bie wir bei ben Familien folbft genauer betradten werben.

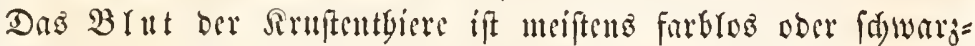

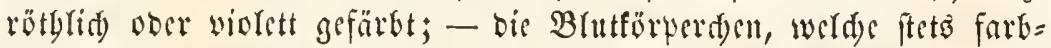
los find, erfdecinen ars runblidge raulge, frinfïrnige sörperden, bis

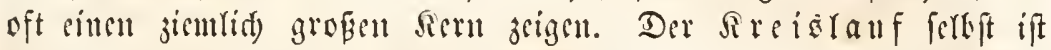
jwar regefmäfig, aber infofern nuvolffänbig, als esigene rüffülgrenbe

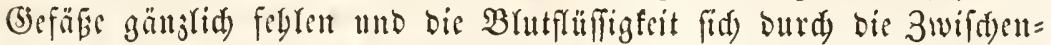

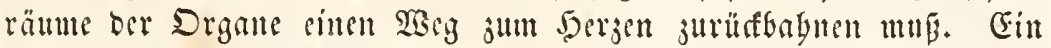
Syer; fordt feinem Siruftentbiere;

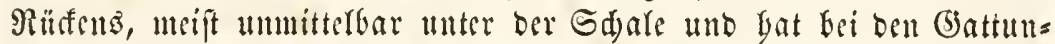

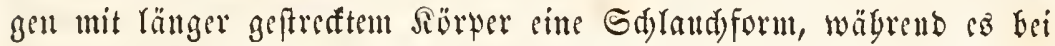

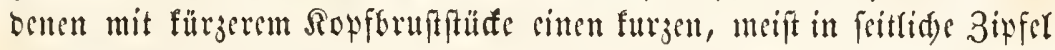

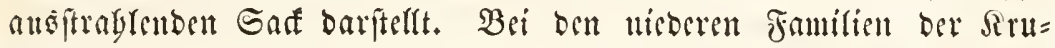

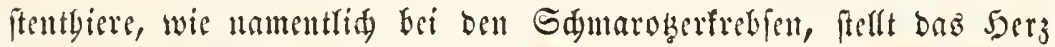
cinen an leiben Ënden offenen Sd)laud bar, werder bie in wan=

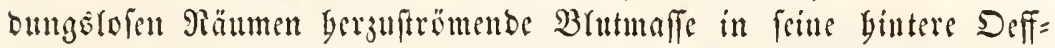
unng aufuinunt und burd bie vorbere wieber austreibt. Mieiftens

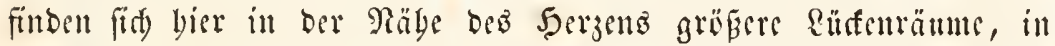

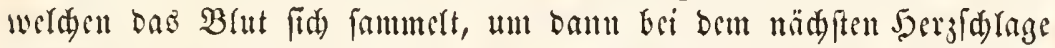
in ben S(j) raud) binüber ju treten. Bei biefem Typuz deş Sireis=

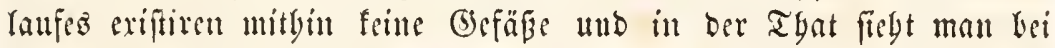

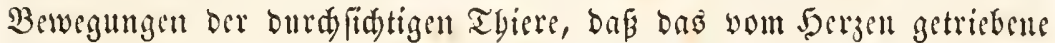

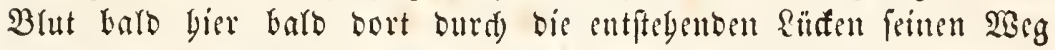
fud)t. Bei ben Göberen Stufen ber Siruftentyiere finden fidy Atrerien,

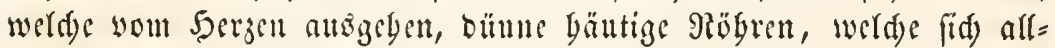

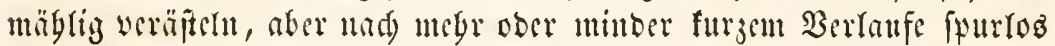

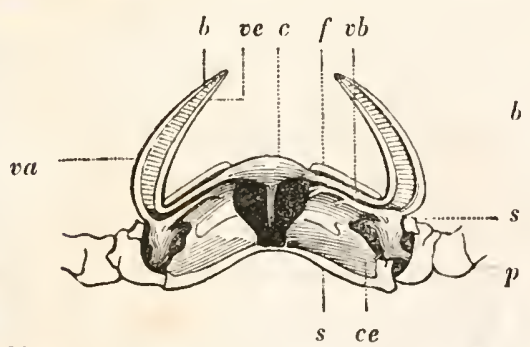

Fig. 463. Durdyicinitt ber Sobffruft eines Sirebics, un ben 18 (utlauf zu rerfinnliden.

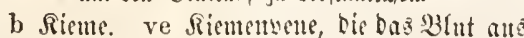
Der Rieme fammelt mo Dom jerzen c zufüf)t. f Brutiogild. vb Röperventuräme, die Daz Blut in bie gropen Sobltäume s fülyten, va Rie= werfdyinden. Das $\mathfrak{B l n t}$ ver= breitet fid) nut in ben 3 wi= ¡d) curäumen ber Drgane, fegrt แad) Dem Şerjen zurüd, fam= melt firit) aber in melyreren größern bä̈gren, die meijtens an Dem (5) runbe Der Beine an= gebrad)t finto, und yon welden aus es fofort in bie Siemen ftrömt. Son bell ?tthemor= ganen jurüufebreno fammert

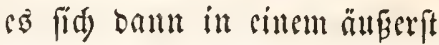




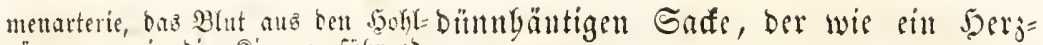

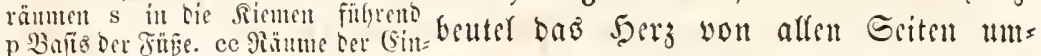
getweite.

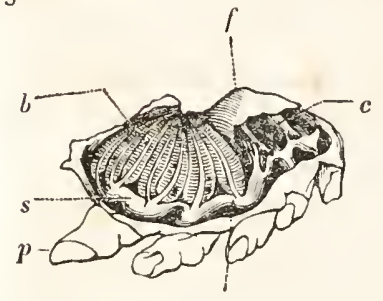

(

Fig. 467. Tie Riemenbigle einer

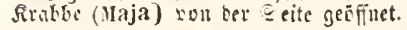

f Geitemwand Der (Simgetweite= häble. b Riemten. s Bentope

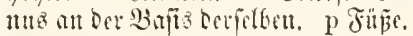
c $\mathfrak{5}$ ers.

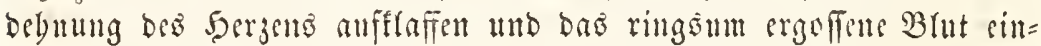
frömen raflert.

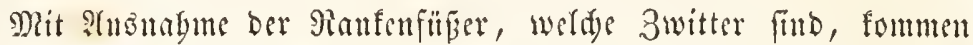
bei aflen übrigen Simftentl)ieren männlide und weiflide Snbivibuen vor,

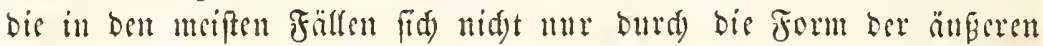

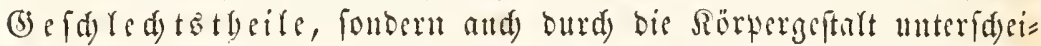

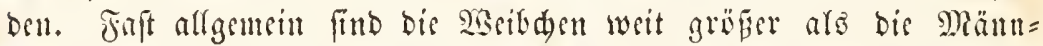
d)en, unb biefs Berfitmmerung gegt foweit, baf bei singigen Sdyma=

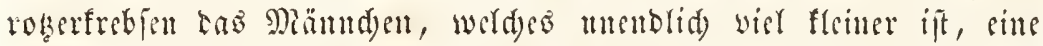
abusidycubs Geftalt bat nnb ftets an Dem Sastedsen angeffammert

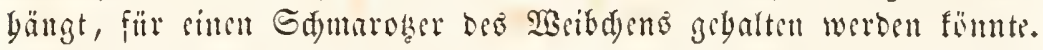

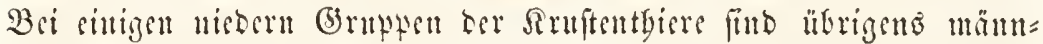
Yidge Subisibuen fo felten, Dafi viele Beobad)ter fie gänzlid) längneten

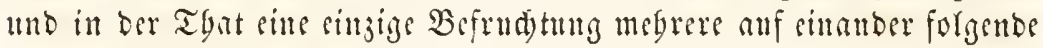

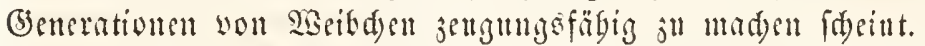

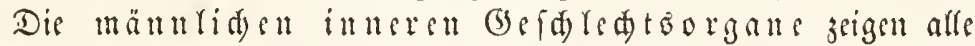
mögliden 3wifdenformen von ber beftalt eimes sinfad)en, blinbgeen=

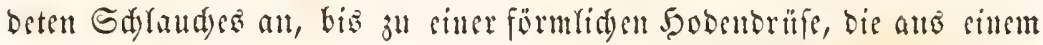

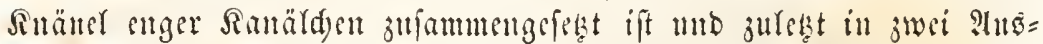

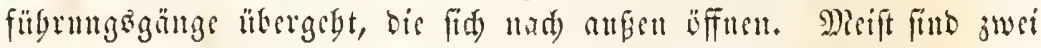

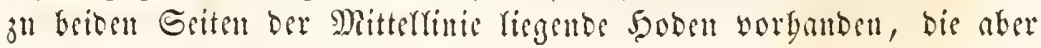
oft and) miteinanter verfdemeljen und fo unr sinen einjigen Driffen=

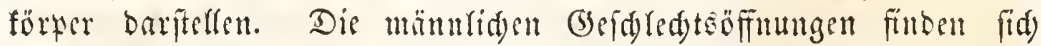
fteto au bem Bandje, oft mur arb zwei feine feitlidye Sd)like, wäb= renb bei Den Gögeren Sreblen fïrmlide Rutben vorbanten fint, Deren

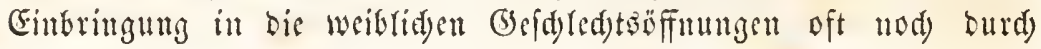




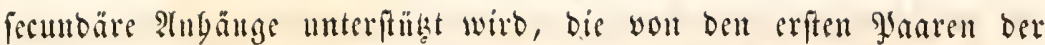

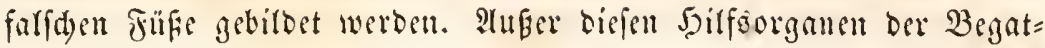
tung finden fid) bäufig bei ben Miänud)en nod) eigentbümlid)e llmge= ftaltungen einjeluer sörteranbänge, befonders bir Fübler mo ber

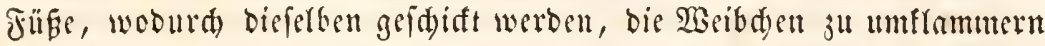
und feitzubalten. Die Gamenmaffe oer Sirmftentbire unterfdecidet fid meift wefentlid) won berjenigen aller anbern Thiere, itloem ftatt be= weglider, fabenartiger ober tentenförmiger Gamenelemente, rmolide, ftrare, unbeweglidise Rörper fid vorfinben, bie jeflenartig find uno meifteng in fture Gtrablen auslanfen, weld)e ebenfalls teine Beweg=

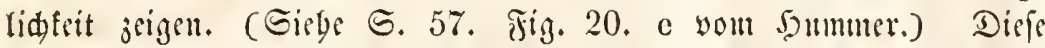
Bellen baben hald die Geftalt siner Dofe, bald die sinte tund = liden Toune, juweilen felbft erfdesinen fie in Der Mitte eingefduürt, bald unt einfad) fugelig und mit einem flemen Gritgen verfeben. Bei vielen Rrebjen fint diefe Grmenelemente aud in form von langen, borfentartigen 5aaren entwiffelt, welde zuweilen bie (5)= ftalt gemögnlid)er Samenfäben baben, aber fteto ftarr uno unbeweglid) fint. Bei manden Gattungen werben aud bie Gamenelemente in Sd)läud)e ägnlidyer Art eingefduloffu, wie fie bei ben Siopffüpern zu finden fint, went fie aud) jene Complication ber Bildung nid)t baben.

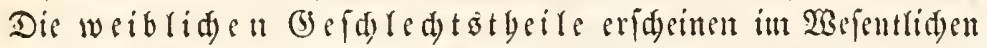
in äbnlider form wie die mäunlidyen, fo baj oft nut burd) ben Jn= balt die Natur ber inneren Gefdyledtstycile erfdloffen werben fann. Bei vielen Rrujtentbieren Gängen bie Gileiter mit aus Blinbbärmen gebilbeten Rittorganen zufammen, welde bie Fier berm Jeraustreten miteinander verfleben; - bei anderen vereinigen fid) bie Eileiter jeber=

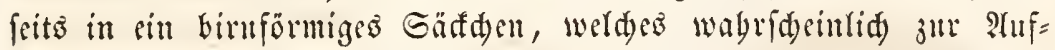
uabme des bei ber Begattung ergoffenen Gamens beftimmt ift, alfo bie Bebeutung siner Gamentafd)e Gat. Die Gefdledtsöffnungen find faft ftets bofpelt, eine auf jeber Srite, und funben fid meift an ber

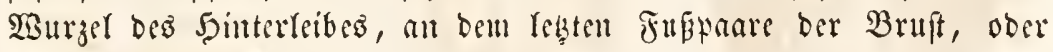
nod unter bem Sopformftidibe ferbft. Die Fuspanke, welde fid un= ter bem Sinterleibe befinben, fuld faft bei allen weibliden Sruften=

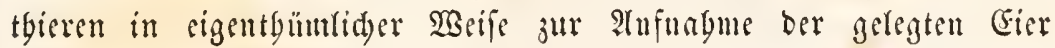
beftimmt, die mittelft eimes flebrigen Gtoffes an bie Blätter ober Borftenganre biefer Fübe in Beftalt von Trauben ober 5aufen be= fejtigt werben. Deift find in biefen fällent bie vorberen afferfüpe breit und blattartig, fo Daßj fie fürmlid)e Deffel \#̈ber biefe unter bem Sdwanje geborgenen Gierbaufen bilden. Sn ben nieberen Neiben ber Rruftentbiere werben aud) bäufig die Gier yon ben Weribden bio

3ogt, מoologifase Briefe. I. 
Jur vollfändigen Fntwictelung Der Rarven, in mebr ober minder lan= gen, Durdjifdtigen Gdländen getragen, bie zul beiben Griten am Reibe befejtigt fint.

Die Cier Der Sirnftentbiere baón meift einen Dunfeln, förnigen Dotter you brauner, rotber ober gelber Farbe, auf weldem fid nad) ber Befrud) tung burd theilweife furd)ung an sinem beftimuten Drte cine (d) eifenfürmige

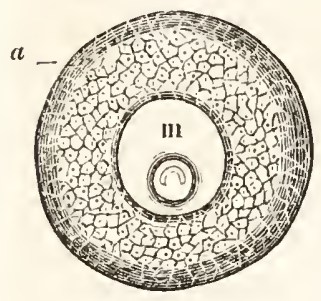

ซig. 465.

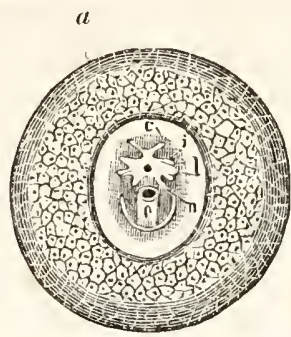

isis 466 .

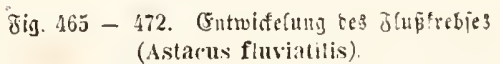

Bei allen Figntren gelten tiefelken S3udfitaken: a Dotter. b Ropfbrnitifullo. c Singe. $\mathrm{d}^{1}-\mathrm{d}^{j}$ Die fün Beintance. e Der biuterlub. f Daz Serz. g Die seber. I Die Rimme i Snnere Fübler. k ber-

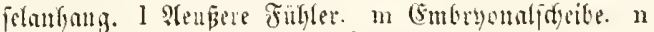

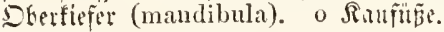

Fig. 465. Die idfeifentämige Emberyenalantaze.

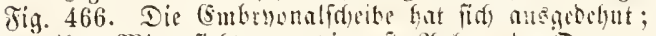
auf inter Mitte fieht man die exte Stulaye ber Drgane,

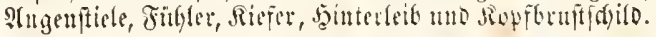

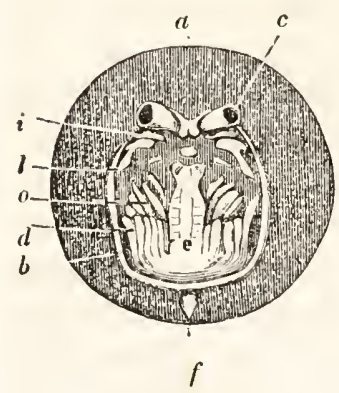

8ig. 467.

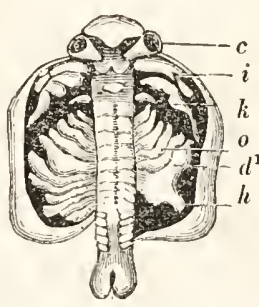

c
Fig. 467. Gin ganges Gi mit tem weiter ent=

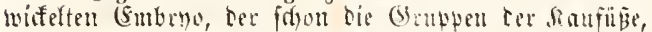

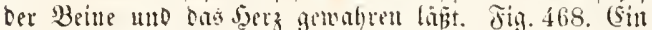

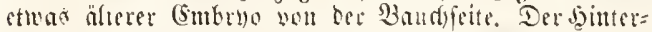

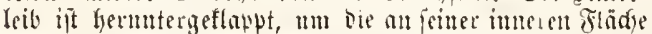

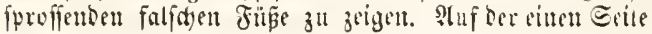

funbryoualanlage bildet.

Huf Diefer fdeiben= förmigen Finbryonalan= lage bebt fidt bei bem Sreble, Den wir bier alo Ty)แล่ an sine mittlere Erböbung $a b$, an welder man balo ciue frernförmige gigur, die einjelnen Thbänge des Sopforuftidildes, Den Sointerleib mid Den umgeid)lngenen Rano Des Sdyilber felbit erfennt. Go erfdecinen juext als flad)e פBulfite anf Der untereu Ffäd)e ber Eitt= bryoualideibe die ragen= ftiele, bis innerent und ätferen Jüblet mo die Riefer, weldse jufammen

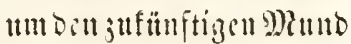
alo Mittelpunft fteben. Baro breitet fid Die $5 \mathrm{~m}=$ bryonalanlage wetter

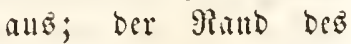
Sopformitidifoes wirb Deutlider, wie eill bitfer, umgelalagener Gaum umigicbt er Die fämutt= (id)en Sïrpertbsile, bie fid) Inun Dettlider mar= firen. Der Sointerleib löft fid) ganj lob, jeigt 


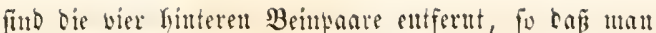
ben ficmenanthang bes erfen Fuppares, ber zu jprof= fou begint, fethen fant.

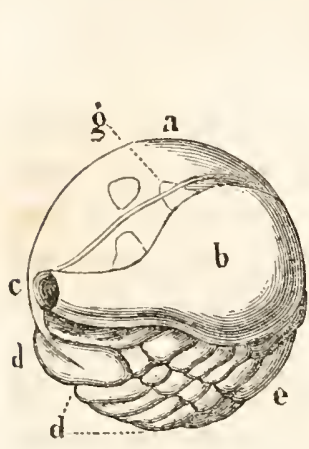

Jig. 4 i9

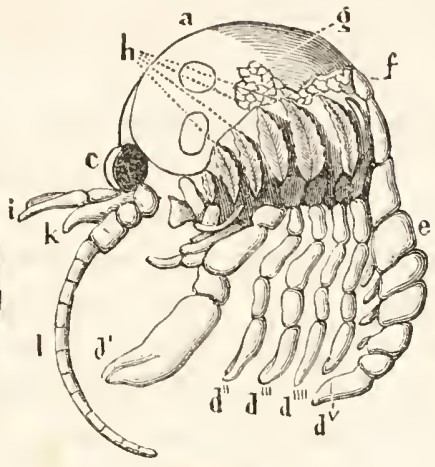

8ig. 170 .

Fig. 469. (Sin äterex (smbryo in foincr natürfidfent

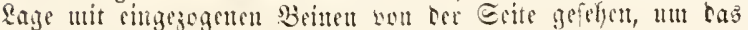

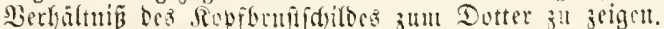

Fig. 470. Derfetre (smbity. Das Eritemidto it weg=

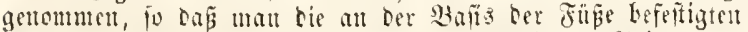

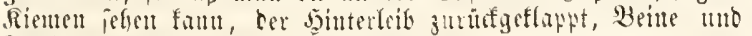
Fingler akgezogen uno ausgebreitet.

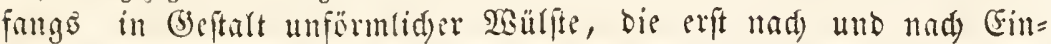

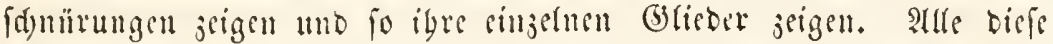

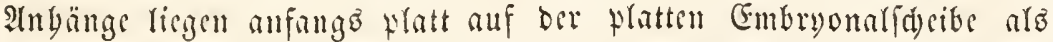

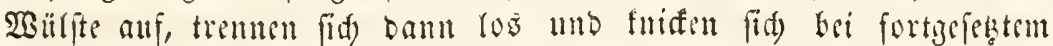

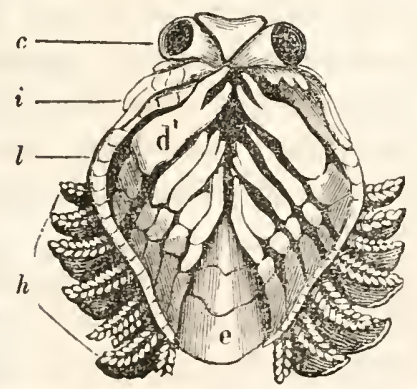

Jig. 471.

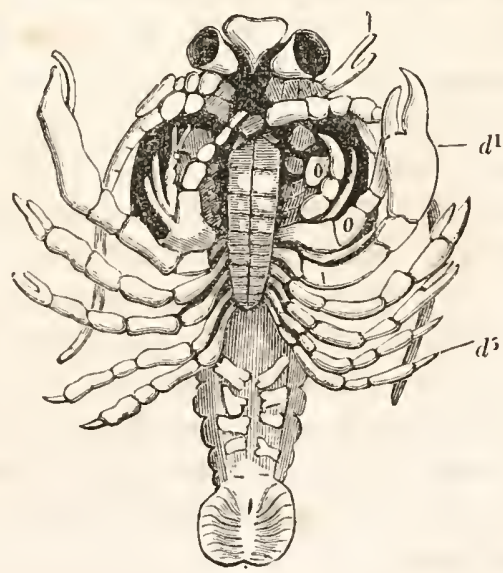

$e$

Jig. 472.

Fig. 471. (Sin reifer Embrys in jeiner naturlidacu Sage mit eingeidyla genem Jinterleibe unb eingezogenen Beinen und Jühlern vou unten gejelyen. 
Die Seitentheile bes Ropforntidsilbes finb entfernt unb bie Riemen Kerworge= zogen worten, um ifgr Berbälní̈ zur Bajtz ber Bcine zu zeigen.

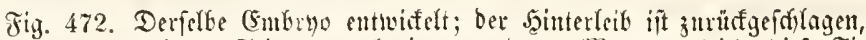

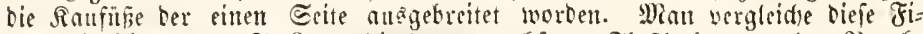
gur mit Fig. 447., Є. 398., die Den erwadfenen Fhfifrebz yon ber 23ad)= peite batififlt.

Tadysthume แad innen cin, fo bas ibre Spizen fid in ber Mittel= rinie berifbrent. Der Saum bes Sopfbruftidirbes wäd ft ftets mebr nad) oben üfer ben Dotter zufammen mil an feittem Rande ober zwifhen igm unb bem Dotter entfeben nun allmäblig bie Drgane bes vegetativen Rebens, Scrz, Seber, Darm, Siemen, wäbrend bie An=

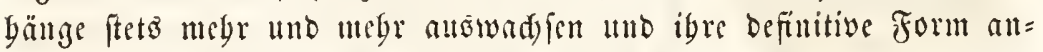
nebmen. Sn oer rezeten yeriobe ocs Embryonalfebens idslieft fid endlid) Dab Sopfbruftidilo gallj über bem Dotter, ber allmäblig fdwin= bet uno Der crmbryo liegt mun jufammengefugett, mit singefd)lngenem Shinterleibe, angezogenten Beinen uno Füblern in oer Fifdale, bie er bald burdbrid)t, um eilt felbititändiges Seben ju beginnen.

Die Entwisfelung fämmtlider Rruftentbiere, wie überbant aller Giliebertbiere ftimut in Den Samptpunten mit ben oben auseinander

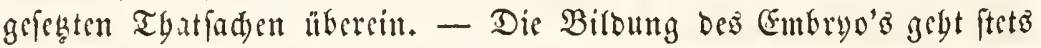
yon oer Mitterlinie ber 3 aud fläd)e aแล่, wo bas Rervenfyftem liegt;

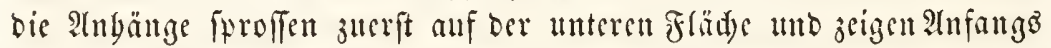
plumpe แnaแżgebiloste Formen. Sitber nidt alle Rruftentbiere fommen in siner, bem erwad) fenen suter fo äbnliden Biftalt aus bem Gie,

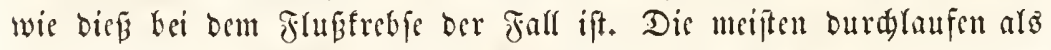
junge TGiere cine Ribe von Metantorplofen, Deren Remutnis um fo widtiger ift, als die urferünglid)en (beftalten ber Sungen oft auber=

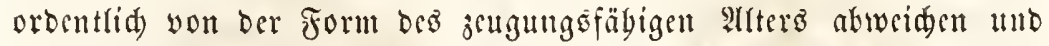

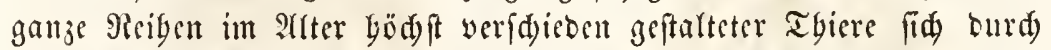
bie llebereinftummung ibrer Jugenduftände als Eproffen sinç แno Deffelben Stammbaumes aนs่veifen.

Dis Rlaffe Der Rruftentbiere erfdeint mit siner Menge cigen= tbümlidyer Formen mit Dem erften Beginne organifden Retents auf Der Erde und repräjentirt in ben Sdjidten bes llebergangşgetirgez

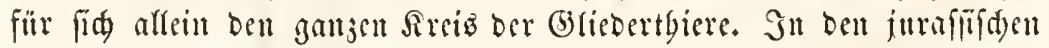
Meeren jeigt fie befonders cinte bebeutende Fillle veridjicbener formen unt fajt alfe wejentridusn Typen, bie nod) beute unfere Bsewäffer bevöltern.

Die Cintbeifung Der Siruftentbiere wirb auperorbentlid) erfdwert burd) bie ungemeit zablreidyen llebergänge, weldye mittelft allmäbliger llmgeftaltung ber Rörperform, wie ber einzelnen Anbänge jwifden 
Den veridiebenen Saupteypen bergeftellt werden. Raum ift es möglid irgenowo fefte Grenglinien zll jieben, fo febr verfdumimmen bie ein= jelnen Charaftere in cinander, ober werbinben fid in feltam abwei= d)ender SBeife, woburd) (5attungen entifteben, bie mant faft nad) Belieben ju ber einen ober anberen Samptgruppe jieben fönte. SBir erfenten in biefer jablreidyen Slaffe vier llnterflaffen, Deren llmgren= zung inteffen bier thb ba aแs ben angegebenen (Srünben zweifelyaft eriderinen bïrfte. $\mathfrak{B}$ ir unterid)ciben: 1) Die Ulnterfraffe ber sant= Erebie (Entomostraca) mit gewobntid) bünnbäntiger noer bitm = Gorniger Rörperbebefung, rie fid balo ju cincm breiten Sthilbe, bald

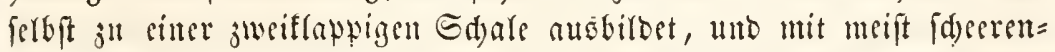

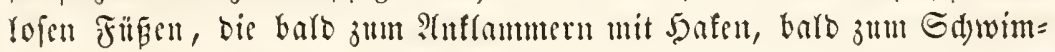
men mit rangen $\mathfrak{B o r f t e n}$ befeset finto, ober fidd ferbft ju sigentbümliden Ranten und fonberbaren fleifdigen anbängen ausbirben. Die Füblet fint gewölntidy bei ben (Embryonen und Rarven, fowie bei viclen er= wadfenen Tlyeren zu Edywimmorgnten ober Silammerwerfjengen um= gebilbet. Die meiften biefer Thiere fitzen in ibrent zeugungefäbigen Arter auf bem Boben ober als Sdmaroker an nnoeren Thieren feft; bie freiletenten finten fid) groben 2 beils in ben füben (5emäffern, nur wenige im Mleere, unto gebören ju ben fleiteren (5)attungen ber ganjen Siaffe. Die Embryonen ber Santfrebje find im Ganjen nad) sinem febr übereinftimmenten Slane gebaut, und zeigen gewöbntid) bei bem Sorvorfommen aus bem Cie jwei \$aar langer, mit Borften werfegener Fübler, bie z" Sd)wimmfü̈en ausgebiloet fino, mittelft beren (îe fid) febr burtig im 2 affer umberbewegen fönnen; fä̈ter vermebrt

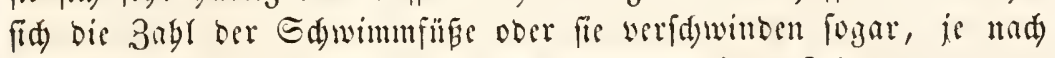
ber Ausbiloung oes volffommenen Thieres zu cinem Sdmmaroker ober

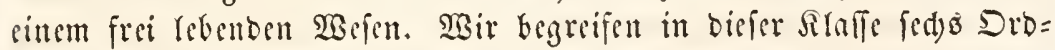

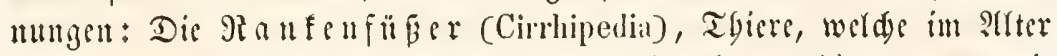
feit fitzen, Deren Finge fid) z" gegleberten Raufen untirben, und bie fid) mit Sdjalen umgeben, beren Form fo sigentbümlidy ift, onj man fie bis in bie nenefte 3eit, elye man igre Entwoitelung fannte, zn ben idalentragenten Iseid)tbieren zäblte, ober cine befonbere Zwildenflafle

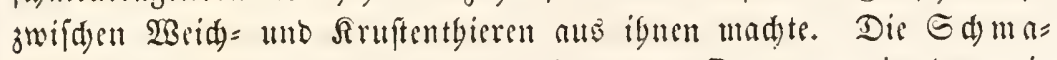
rogerfreble (Parasita) birben die zweite Drommin, in oer wir Thiere finten, Die burd bie gänjlid)e Jurüfbildung aller Simnes= unb Bewegungsorgane wägreno ber Jeriode igres Sdymaroberlebens fid, fo febr von bein Tupus oer (5sticoertyiere enternen, baf man fie

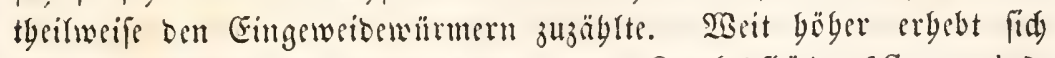
Die Drganifation in ber Drotung Der $\Re$ reboflöbe (Copepoda), 
freifdwimmenten, fleinen Tyierden mit borftentragenten Sdwimm= füfen und meiftens sinem Ange, bns ourd) Musfelu beweglid) ift uno mitten auf oer Stirne ftebt. Die Dronung oer Brattfü̈ zer (Phyllopoda), weldje wir bierauf folgen laffet, zeidenet fid ourd) eine grofie

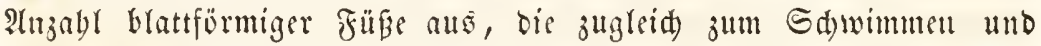

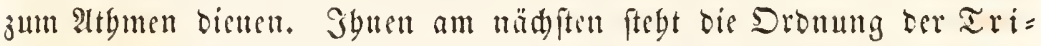
lobiten ober $\mathfrak{Y}$ aläaben (Trilobita), die volffommen anşgeftorben ift, und mur in ben älteiten Sdid)ten ber Cros vorfomment, bort

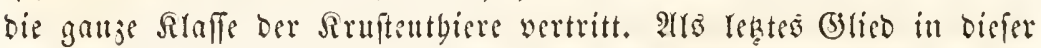
Unterflaffe betrad)ten wir bie Dronung oer Mufde lf rebie (Oslracoda), welde mit sitter ben Sirbsiöben älnliden Fubbiloung ben Befing ciner zweiflatpigen Sdule verbinden.

Gine jweite llutertaffe finten wir it bell 2) Pfeilfobwänjern

(Xyphosura s. Poecilopoda), bie mit einem barten, unge= theilten falfigen Ropforuftiditos, sillem ungetbeilten Batd foiloe uno

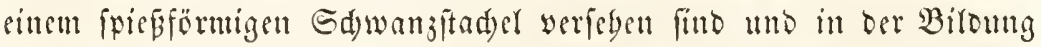

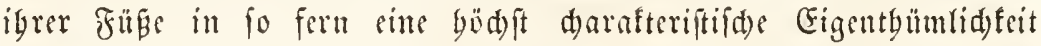
zeigen, als ibre wabren (Songfübe zugleid) Sanfüpe fitto uno burd) ibre gezäbnten $\mathfrak{B a f a l g l i e b e r ~ b u r d ) a u s ~ d i e ~ m a n g e l u b e n ~ M u n o w e r f = ~}$ jeuge erfesen. Die grofien, unbebolfenen Tbiere, weldye biefellnterflaffe biloen, gebören nur either cinzizen (5)attung an.

Dielluterffoffe ber 3) Eticlaugen (Podophthalna) Eegreift bis eigentlid) typifden Siruftentbiere mit ungetbeiltem Sopforuftidiloe, vor bem juweilen nod eill beweglider Ingenrittg ftebt, geringeltem Shinterleite, geitielten, zufammengefesten 2Hagen unb baumartig veräjtel= tell ober blättrig fvramibalifden Siemen, bie neben ben eigentrid)en Füfen exiftren. Wir unterfdeiben in biefer lluterflaffe jwei Dromm= gen: Die wenig zablreide ber $M \mathfrak{n}$ nofï zer (Stomapoda) mit freien, baumartigen Riemen und frei beweglidyem Iugenringe, und bie febr jablreidge oer 3 ebufüfer (Decapoda) mit volffänoigem Ropffruft= fdirbe, unter weldyem die Siemen in bejonteren büblen vertorgen liegen, uno fünf Fubparen, beren erites meift, bie anoern zuweilen Sdeeren traget. Diefe zablreidfite Dronung theilt fid wieber fe mad Der Insbiroung bes Siuterfeibes in mebrere lluteroronnugen.

Die vierte lluterfafle wiro son ben 4) Siugelérebien (Edrioplirhalma) gebiloet. Bruft uno Sopf jeigen fids bei ibuen ftets in äburicter $\mathfrak{Z}$ seife, wie bei ben Jufeften geglicoert uno bentid) yon

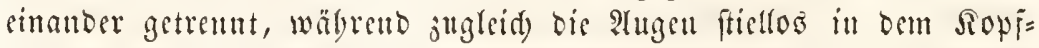
fdilte feitfizen. Sisir unterid)ciben bier wieber orei Dronungen: Die R'nopfteble (Laemipoda) mit ganz rubimentïrem Sinterlsibe; die 


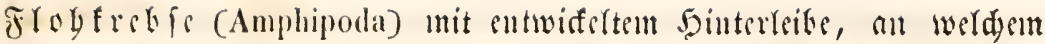

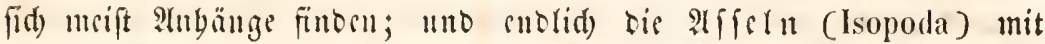

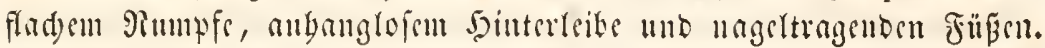

Luterlinffe ier foutlirebje. (Entomostraca.)

Dromug ber Stanfeniuger (Cyrrhipedia). Dis Thirre,

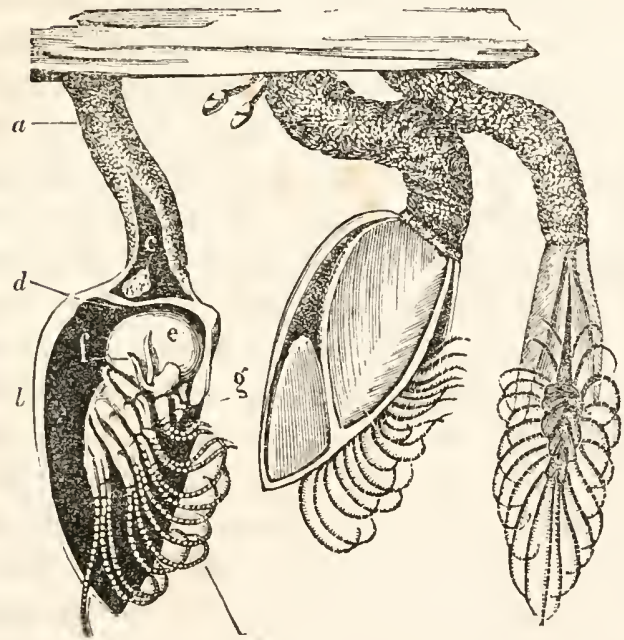

¿i่. 473.
Jig 471.

Sig 465.
(Ëltemunfidétll (Allatifa laevis).

Tig. 475. פout vorn. Jig. 474. \$su fel Geite.

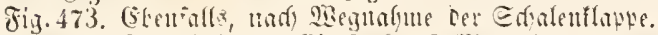

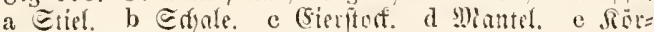

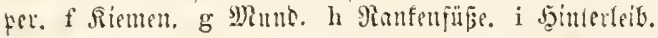

welde birfer bödjit $\mathfrak{a b}=$ normen Dromung ange= Görenl, fithen iml crivad)s

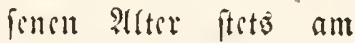
Boben, zutweilsn aud (d) marobertid auf ber Saut groficr Escthiere feft und find int sin ans megreren Etüfen befte= bendes (o) gerdylofien, bas fie brimt 3urtüfjichen noflitändig verid)liefisn fönnen, umb Das umciftenz sin falfigez

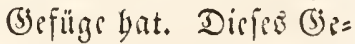
bäufe fitht bato unmit= tribar, bald mittelit sinez beweglidan Stirles foft, und entbält das Thier ill joldurer enge, bafi mit bem gemölbten Thsile

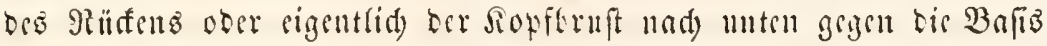

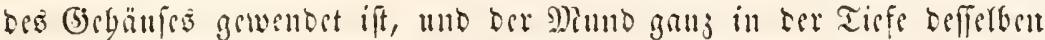

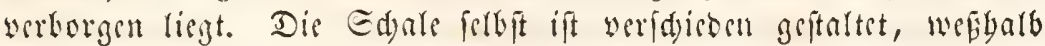
wir fie erift bei ben singshen fomilien betradyten werben. Stuf ibres

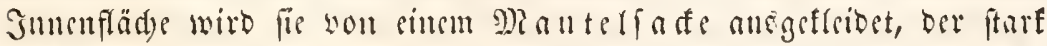
musfulös ift, uno auf ber unteren Geite sinen Edyliz zrigt, ans wers

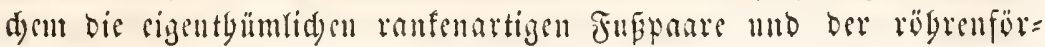


mige Sainterleib berwortreten. Die Grunblage Des Mantels wirb aus Sbitinblättern gebilbet, uno die ganje Sberbaut, mebịt Der Den Rör=

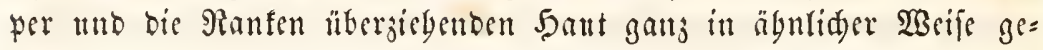
wedfert, wie aud) bie Sirbje von Zeit ju Zeit ibren Edalenpanzer abwerfen, wäbrens bie Sd)ale folbjt miemals ber Şäutung unterworfen ift, tho mityin sin (Sebilbe oariteflt, weld)es aud) burd) biefe Eigen= thümlid) feit fid) anferbarb des gemeinfamen Drganifationsplanes ber Siruftentbiere fteflt Dis Bewegung óoga Jaaren äuferit vielgliebriger, mit Borften bejekter Anbänge, beren fid) jeber alsbald in juei Ranten fpaltet, fo baj auf jeber Srite deó Sïrpere jwölf folde geglieberte Mianfen burd dis Miantelfalte ber: yortreten fönnen. Die bern Mimbe junäd) it Yiegenden Panfen find bie flemeren unb bienen alo Taftorgane; bie weiter entfernten größeren werben banpträblid jum Ergreifen Der Bente unb jur Erjengung cimes Strubelo benulst, ber frifd)e $\mathfrak{B a f f e r}$ in bie Mantelböble fïbrt. Ein eigentrider Ropf feblt burdyaus; ber Mund liegt in Der Tiefe Des Mantelfaltise und zeigt cin Wanr feitlider furjer Sitefer, bie auf ibrer Jumenfläd) gejäguelt find tub jum Siauen in sinandergreifen. 2Hber biefen Rauberfjengen bemerft man frine Spur yon Drganen irgeno welder sirt an bem Siopfe ober an bem meift rutbliden, beu= telförmigen Borberfürper, Der in ber Tiefe Des Miantelfadez vertor=

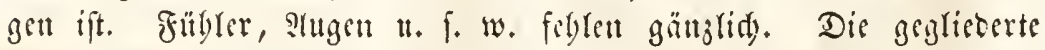

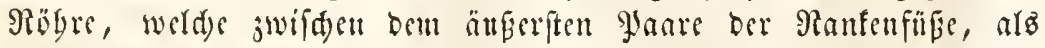

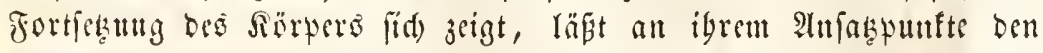
Ifter unb an ibrer Spize die Deffunng Des Samenleitero gewabren.

lluterfudt man bie imere Drganifation biefer Ibiere, fo finbet

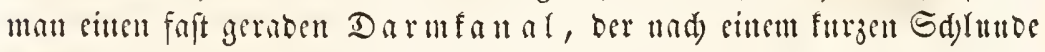
citten unfebentenben Diagen bifoet utto bant in geraber Pidstung biö

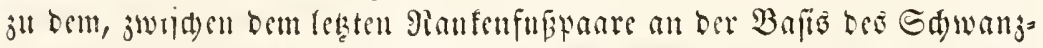
anl)anges angebrad)ten affer vorläuft. Dor Magen zeigt äแberlid sin Warjiges Anfeben, bas non febr furjen Reterid)lünden berworge= fradt ift, welde unmittelbar in ben Magen sinmünben. Der Błut= lanf ift mur wenig unterind, bod fincet fid) cin länglid)es, fd) (autd)= förmiges $\mathfrak{5}$ erj, weld) nad) werfdisbenen Seiten Sefte auşentet, namentlid) in bie 9Ranfen, in welden man fie bio jur Spize biu werfolgt bat. Befunbere sic= men fitto vorbanden, utto balo itt form jarter fpizer Blätd)en aแsz=

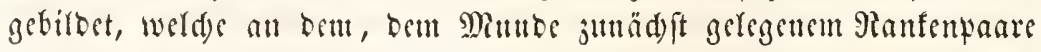
feffitzen, Larb in Geftalt jarter Santworfprünge entwifelt, bie an ber inneren frähe bes Mlantels bängen, uno in äbulidjer $\mathfrak{B e i f e , ~ w i e ~ b e i ~}$ 
Den Mafdertbieren mit jur ?ufnabme ber Eier beftimmt find. Seben= farls ift bie Igätigteit bicjer Ricmenorgane nur sine fegr geringe ju nemuen, oa vicle Piantenfüber fid an bem Nicereştrande fogar über ber gewöbnliden Flutbgrenje anfedeln, wo fie anßer bei Stümen mo Regen oft wodenlang vom 2 affer nidyt berithet werben. Das Rervenfy fem ber Ranfenfüper ift libercinftimment mit bem gewögn=

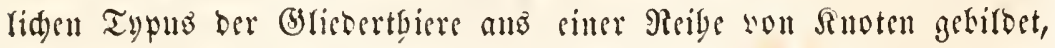
welde auf ber Bandjeite jwifden ben Rantenfüben binlaufen unb

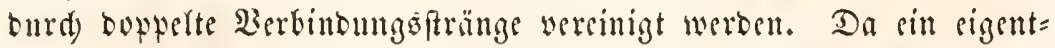
lidjer Sorf gar nidjt entwiffelt ijt unb bejondere Simnes = und Taft= werfjenge feblen, fo feblt and ein befonberer Sirntuoten, unb bie bem Mlunbe zunäd) getegenen Rnoten bes Bandumarfes fimb mur burd) sine sinfad)e Jatenbrüfe luber ben Sd)lunb Geruber mit einan= ber verbuntoen.

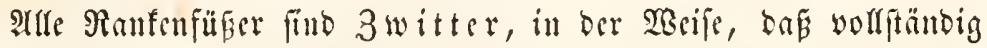

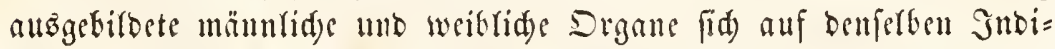

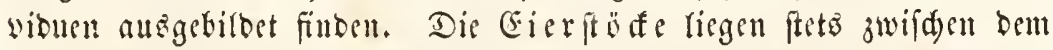
Röper uno bem Mantel, und jwar bei ben geftielten battungen in Der Joüble bes Fuber felbit, bei ben umgeqtielten jwifden ben Ramellen bes Mantels als cingelne Brinbld)länd)e. Rad) ber Befrud)tung ge= langen bie Eier in bie Säble bes Mlantels und werben bort fo weit auşgebrütet, bis bic (5mbryonen bie (Eifdale burd)broden baben und fäbig find, fid ferbittänoig fortzuberwegen, in weldem Zutande fie Dann bei ben Stbembewegungen in Saufen ausgeworfen werben. Die mäun veräfelter \$oobendaländ) zu beioen Eriten Des Darmfanales und \{esen fid) in gewunbene Samenleiter fort, welde fid in ber Räbe

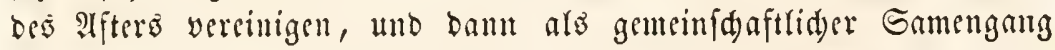
ben fđwanjförmigen geglieberten 2nbang Durd) faufen, um fid) an ber Srike desfelben ju öfnen. Dffenbar befrudten bie Ranfenfüber ibre Fier ferbft, inbem fie biefen geglieberten :Inbang in bie Sobjle bes

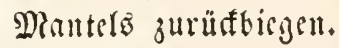

Doglcid) Die Entwidelungsgefdid)te ber Rantenfüber nod nid)t solftänoig befant ift, fo fint bod bie Embryonen berfelben nub ibre Metamorfbofen to weit unterfudt, um mit Siderbeit ibre äuserft nabe $\mathfrak{B}$ ejiebung ju ben lubrigen Sirebjen biefer llnterflafle barjutbun. 


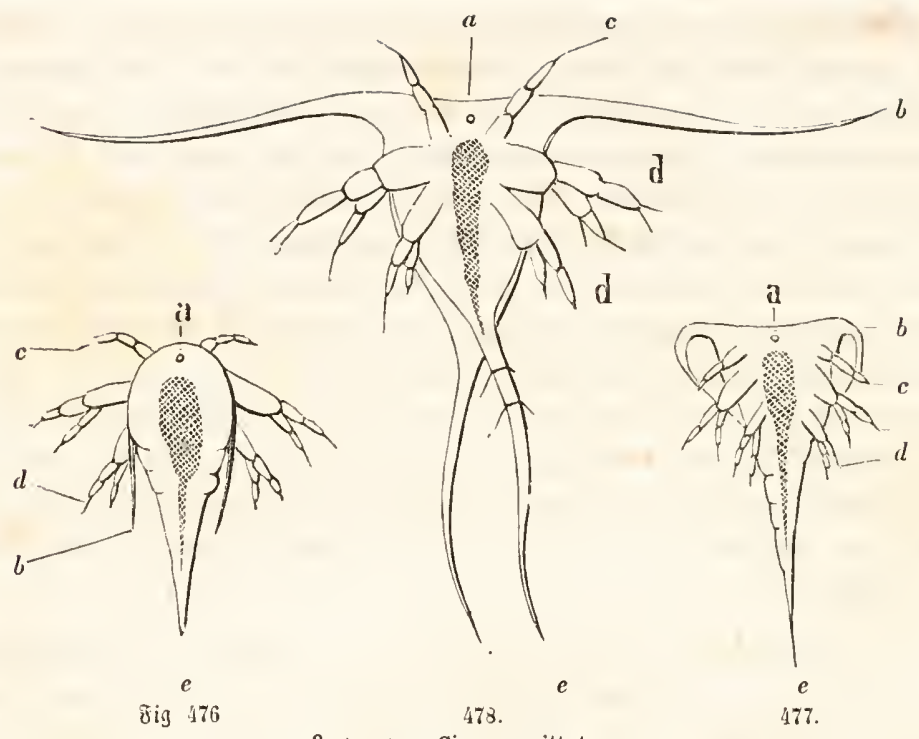

Qarten nou Cineras vittatus.

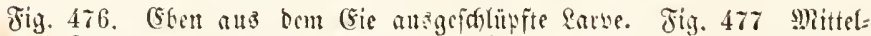

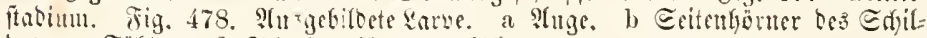

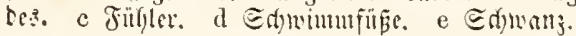

Die jungen Embryoun vertaffen bas Gi und bie Mantelgöble ber Mutter in einer Seftalt, welde oerjenigen ber jungen Sebsflöbe fo febr äbuelt, bafi faum cill lluterfdicb wabramegmen ift. Der fiöper biefer jungen Thierden ift lirnförmig, nad) binten jugeffiget, unb trägt

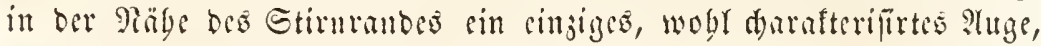

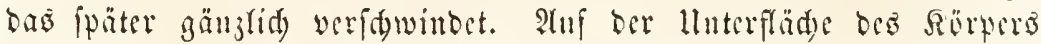

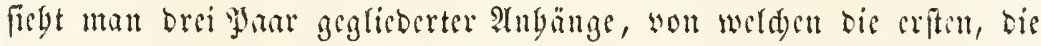
Fïbler, einfad, bic beiocn anderen gegen bas Ende bin boptelt ge= theift finb. Die fdildförmige Sant, welde Den Siörer beft, gebt Madh

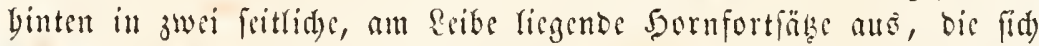

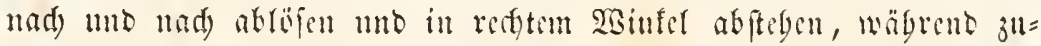

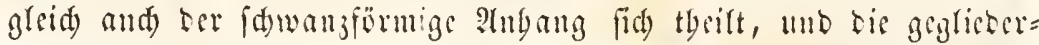
ten 2(nbänge nad) und nad) längere Sd)wimmbante entwifeln, fo tafi bas Sunge mun febr gefdift in bem 2 Saffer muberfdwimmt. Epäter

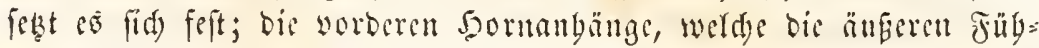
Ier barftelfen, bicnen jur Befeftigung, inbem fie Infange cine jwei=

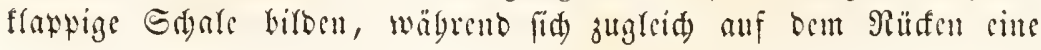
leberartige Edale cutwidelt, bie fid) nad) unb nad wergrö̈ert; tas Itnge bat fid) getheift, und bie beiben aus feiuer Theilung bervorge= gangenen $5 a ̈ l f t e n$ fiken an ber Bafiz ber umgewandelten Fübler; die 


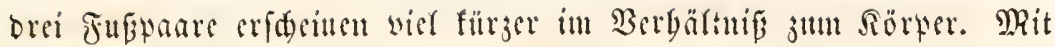

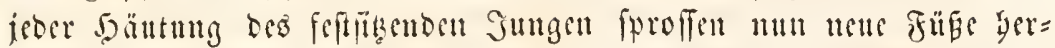

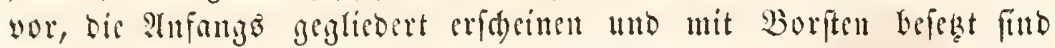

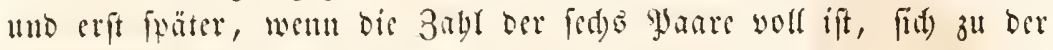

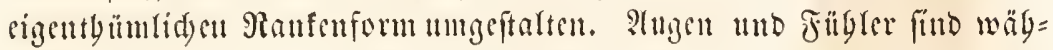

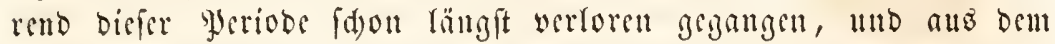

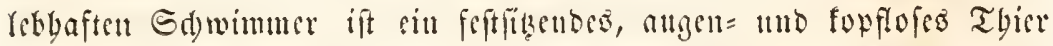

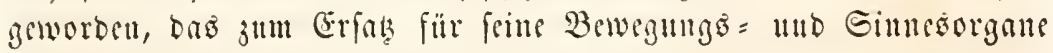
bic Fäbigfeit erbalten bat, fid) fortzuffanjan.

Man thcilt die Ranfenfüfer in Ulebersintimmung mit igrer ge= fammen Drganifation in jwir Familien: bic Entemmifdefn (Lepadida)

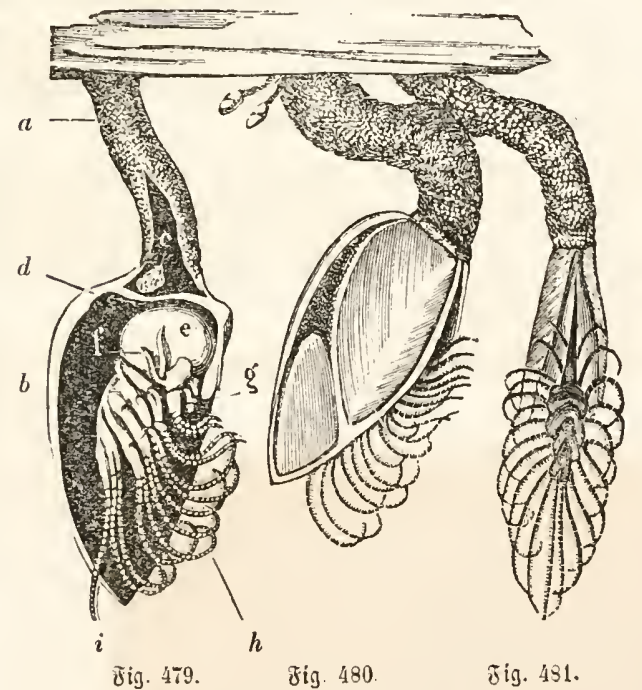

Entenmufdrel! [Anatifa laevis].

befiţ̨en sinen fleíddigan, zufammenziebrarenSticl, in befien Syöbluth bie Eicrifö de liegen, unt auf Dem ber eigentlide Sïr= per anffitit, ber gewions= (id) eilue jufaumenge=

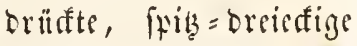
Bieftalt bat, mind bald mur wou Sitorpelfugftam3, Galo audid won melyerert Sdatent umgeben wird, bis falfiger Ratur finto. (jeswigntid) bejtelt bie = fis bु? Seite aแะ żwei brsicti= gen, Durd) Sinorpelgaut mit einander verbunde=

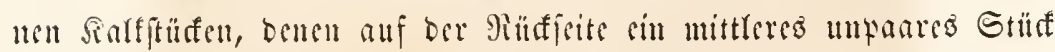
สโอ̇ Ed)

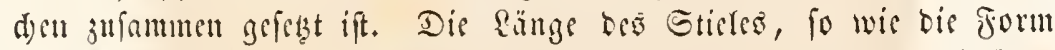

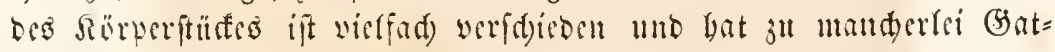
tungsmerfmaten gefübrt. Sie reben in alfen Dieren, unb beften fith

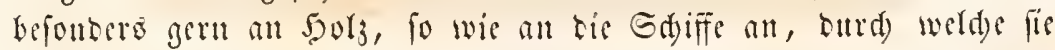
oft in antere Gergensen fortgerflanjt werbon. Lepas; Anatifa; Cineras; Otion; Pollicipes. 
Die Familie ber Meereicheln (Balanida) jeid)met fird Daburd) von

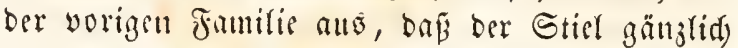

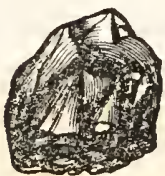

8ig. 482.

(a)nle ciner Mieereinter (Balinus) veriduwutoen, unb Durd) eine rögrenfürmige Sdale erfegt ift, bie gewöbulid) aus fed) vermadenen Stiifen beftelyt, oben offen ift, tunb ben ganjen

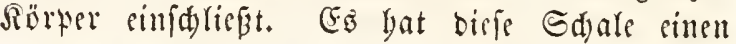
eigentbitmliden rögrigen $\mathfrak{B a u}$ แnd ift meiftenв un= ten burd) eilte quere Sialfplatte ober Fajermafle

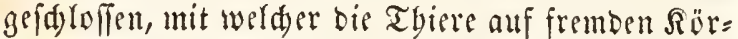

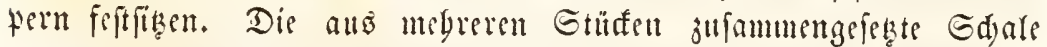
Der Entenmujdelu ift bier ju einem fleimen Deffelapparate jufammen=

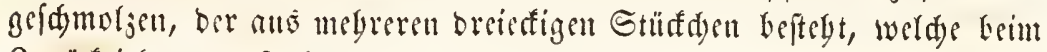

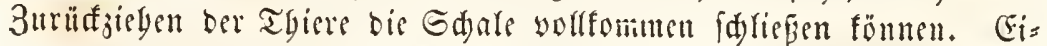
nige (Sattungen biefer Framilie (T'ubicinella; Coronula) leben fdma= robend alf ber Saut ber 9 sallfifde, in welde igre Sdale oft jolltief eingefenft ift. Balanus; Pyrgoma; Clisia; Creusia.

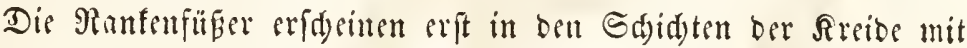
wenigen geftielten ?Neten, unb bie Familie ber Meereidelu filloet fid fogar mur in ben Sdjidten ber tertiären geriobe mit 2trten, weldye nod) jeşt lebenden (S)âttutigen angebören.

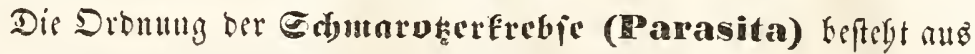
ช̃ig. 48.5.

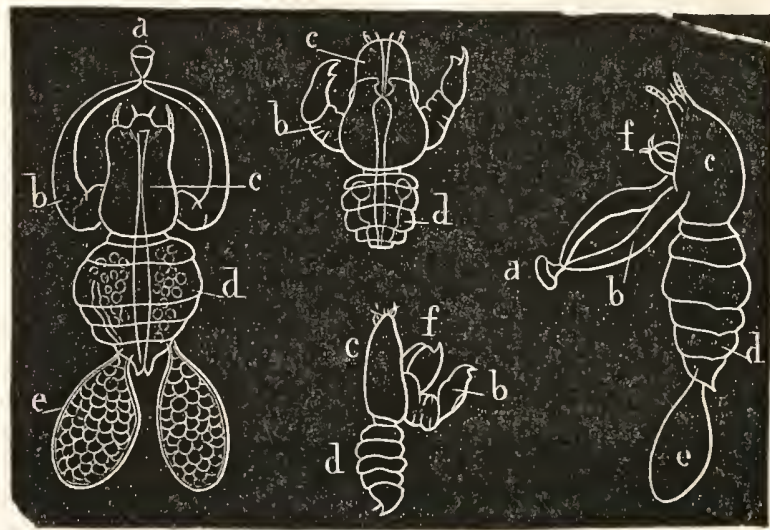

340.183.

450.

484.

Dic Baridglaแs (Achtheres percarum).

Fig. 483. Daz MEeibdy yom Rürfen ans. Fig. 484. Daflethe won

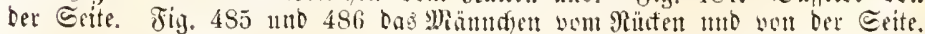

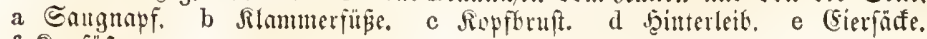
f Raufitie. 


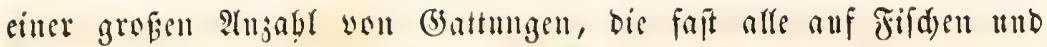
juar namentlid) alf oen Riemen ierferten fdumaroken, wo fie fid ge=

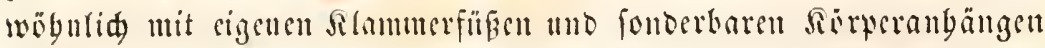
feftbaten. Der Sïrfer Diefer Tbicre zeigt die fertfamften Geftalten unb anberorbentlid) vieffad) 3 wijd)enftufen von siner wumförmigen, veränoerliden weiden Sörtergeftalt, biō zu einer ziemlid) feften Con= fiftenj uno einer burdgreifenten Pingelung Des ganjen Reibes, an Dem fid) Danu hald zwei Saupttbeile, Sopftruft und Sjinterleib, ober fagar brei unteridesiben raflen, inbem bie Sopffruft fid megr ober minber worffändig theilt. Sn feimer Dromung laffen fids), fo wie bier, dis Degrabationen ber Jübler, ber Angen mol ber $\mathfrak{B} e=$

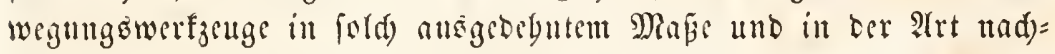
weifen, bak bie Entmiffelung Derfelben ftets mit ber mebr ober mill= Der parafitifden Ratur in Berbindung ftebt. Bei benjenigen Gattun= gen, Die fid unr zeitlid) firiren, im llebrigen aber fid ziemlid freier Bewegungen erferten, finbet man mobl ausgebiloete Sd)winmfǘpe

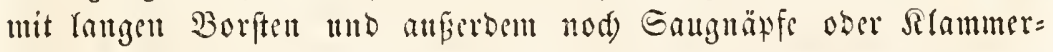
füßs jum SAlbeften. Bei anberen fïben fid nur nod) wenig beweg= lide SRranmerfüpe, bie zuwcilen felbit won beiden Seiten ber zu sinem

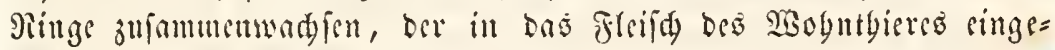
fenft iff. Bei benjenigen Gattmigen, bie am meiften jurïfgefunfen fint, fiebt man felbit gar feine geglieberte Anbänge mebr, unb fatt aller $\mathfrak{B}$ ewegungsmerfange nul sinige anf $\mathfrak{B a r}$ aen ftebente bafen ober

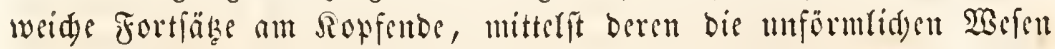

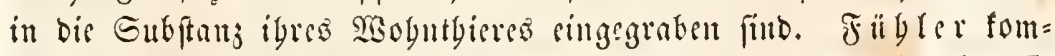
men nod) bei ben meiften biefer Sdmarober vor; gewibnlid) fitho fie nur furj, boritenförmig, juweiten and) jajammengebrüft unb jismlid platt; Plugen feblen ben meipten unb fommen nul bei ben böber fte= benden Typen in Form jwerer feitliden, Der Mitterfinie jismlidy nabe gerïateu gebäuften Augen vor.

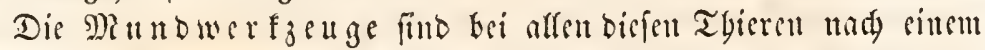

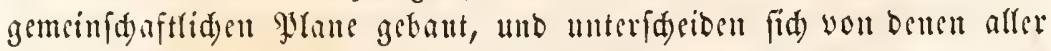

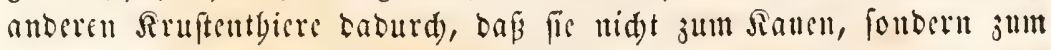
Saugen geeignet find; - fie befteben aus sinem meift furjen, fegel= förmigen Saugrüffer, der eine Röbre barftellt, welde aus ber כer= wadjung ber Dber = unt Ilnterlippe berworgegangen ift. Sn biefer Röbre, dis zuweilen zientidg lang ift und bann wis sin Fermobr sin = und aubgefdoben werben fanl, fpiefen gerwöbulid) jwei fpize Stüfe, welde jum anfteden ber 2Bobntbieve dienen unt offentiar bie umgewantelten Riefer fint. Die sigentliden Sieferfübse, weldse 
bei ben übrigen Rruftentbieren sortommen uno Dort theils jum Faffen, tbeits zum 3erfleinern ber Rabrung bienen, fteben Gier meift weiter you Mitnde enternt, und find ju Rlammerorganen umgewandelt.

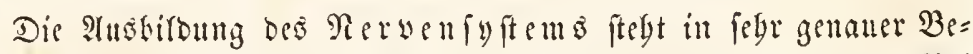
jiegung ju ber Entwiderung tes Ropfes uno Der Simnes̃organe. Bei Den nieberften formen finten fid) unt jwei feitlide, fait fnotestope Reryenfringi, die bei anteren Gattungen Snoten erbalten und in simem Bruftganglion Jufmmenlanfen, vor weldem ein Soirnfnoten gänjlid) feblt. Die Berbindungsfïben ber sinzelnen Sinoten find baun frets boppitt und jiemlid) weit son einander getrennt; - bei nod) böber ftebenden Formen fintet fid) ein Sirnfuoten, unb ein anv gebäuften Snoten bejtchender Baudfitrang. Der Darmfanal vertäuft ganj gerabe von ber Mimböfnung aus gegen bie am

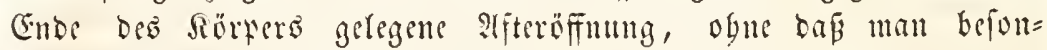

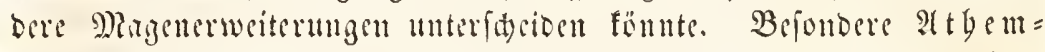
organe feblen in biefer Dronmy fait Durdanz; nut bei einigen (5)attungen finden fid) bhateförmige Inbänge, weld) vielfeid)t Riemen genannt werben bïriten. Bei allen übrigen (Sattungen ift obne 3wei= fel bie Sant ferbit 21tbemorgan, nub namentlid treten bei benienigen Familien, bei welden bie Rörperbaut blattartig aušgebrettet ift, lebbafte

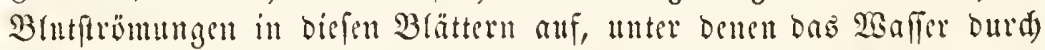

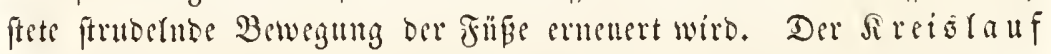

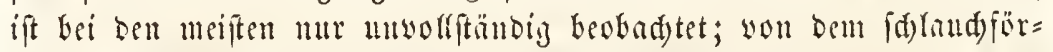

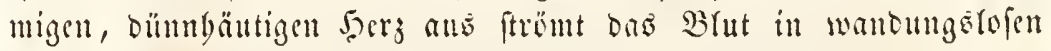
Sanälen burd) alle Theile und fammelt fid baun gewöbntid an ber Bafts ber Füfe in eigene Bebälter, aus werdyen es burd) bie feitli=

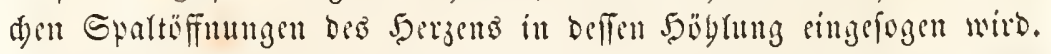

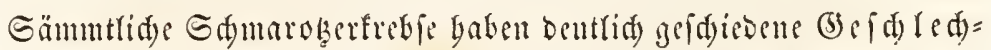
ter, mo meiftems ift foga: bie Berfidedenbeit ber Miännden und Sacibden auberorbentlid) grof. Die Männden find gewöbnlid ver=

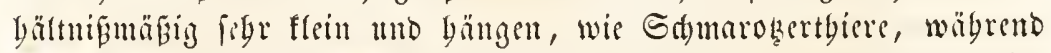

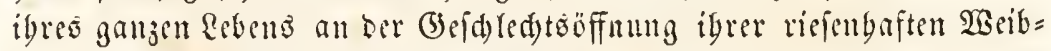

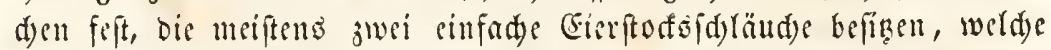

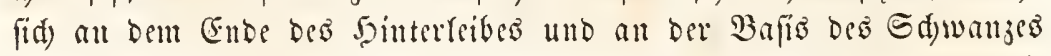
öfnen, wo fid nod) beiondere Rittorilifen befinden, Durd) welde die Fier in Gdüne verbunden werben, die bis zแm stusf)lüfen ber (Embryonen am Sinterleibe ber 2 seibd)en bängen bleiben. Die männlid)en (5) eid) led)totbeile fint nod) wenig tmerfudt, idseinen aber in igrer (Geftalt mit benen ber 2 eibden ïbereinjutommen. 


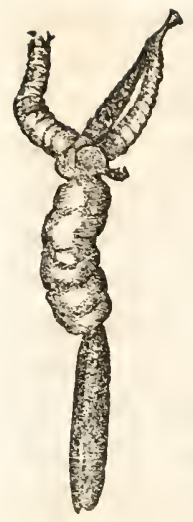

8ig. 437.

Fig. 487. Grmadjentes meit

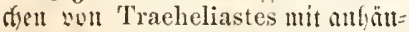
gemten Sirrfätent.

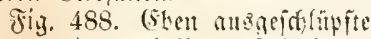
Sunge mit zlwe Fian Etfumm= beincrt.

Sig. 489. Sacteres Sultge mit Füflgönern, Deei Fitar ßlamme:= fǘpen und zwe fian binteren Sสminmteinen.
Die Entwifferung Der Sdma= rokerfreble ift bei vielen Battungen bcobad)tet und in Illgemcinen yollfom = men übersinftimnent befunben worben. Die Jungen fommen gewöbntict) mit jwa Praten yon Gdwimmfüben IIID cincm einfadyen Gtirnange in seriflent Geitalt, wie dic jungen Panfenfüвеr, mur mit für= jerem Raibe zur $2 \mathfrak{B} d t ;$ bei jeber fpäteren S马äntung änจern bieje lekgajt untyerfd)wim= menten IGierden igre form; rie urfpring $=$ (id)en Edwimmfïpe watbeln fid) zu Den

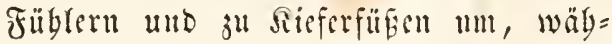
reno ber Shinterfeib fid glicoert, und an= fättglid) nene $S_{d}$ wimmfüpe an biefem Reibestbeile Gervoriproben, Die fpäter, fo= bald Das Tbierdyen fid feftgefert bat, fid wicber in ber verfalebenfen $\mathfrak{B a j e}$ m!n= wandeln. - Joffile Gdumarok̨ertrebje gat man nod nidyt gefunden.

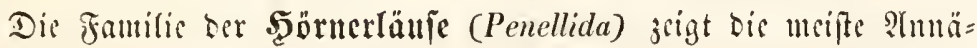
Germig in ibrer Gejtalt ju ber SBurmform mb bie beocutentite $11 m=$ geftaltung fer Fïfe, an Deren Statt meift nut ungeglieberte Rappen ober bie und da Sirmmerbafen zum Feftyalten vorbanden find. Sud Diefe Rlammerbafen fommen nur bei Dell Männd)en vor, das faft fugelförmig ift, cinen furjen Rüfier befigt unb jwei Baar warjiger Srammerfübe, mit Denen co fid) an Dem $\mathfrak{B}$ eibdacn feftyält. Diefes, von volfsumen wumförmiger (5)eftult, weid) m!D ogue eine Grur

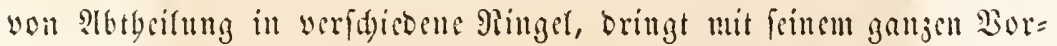
Dertbeile in Dic Subftanj Des Thicres sin, auf weldem sồ wobnt,

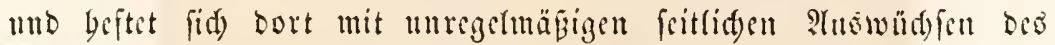
Sopfondes an, bie cine bornige 3 erdaffenbeit baben unb gleid) Sisi=

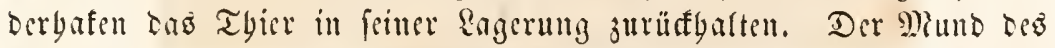
Weibd)ens, bas fo singebogrt ift, trägt mur jwei fleme furje bafen,

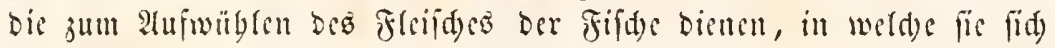

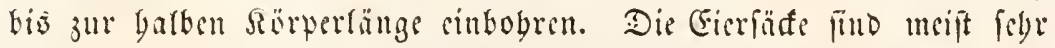
lang und Dünn, und bei sinigen battungen gerabe, fei anteren auf

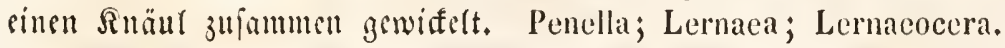




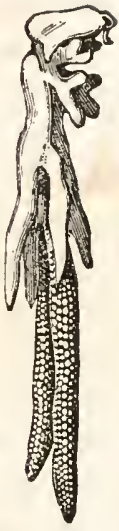

Sig. 490

Choudraranthus merlucci run ber scite mit anthängenten Eicrithuti= reu.

Der worigen Familie febr nabe ftebt Die Familis

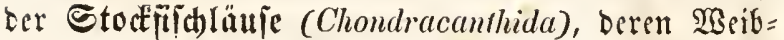
d)en fid mittelft fleiner bafenförmiger STammern be= feftigen, bis vorn on bem sopfe fteben, und offenbar Sieferfübe barftellen; ber oft breite ober unfürmlidse Sopf ift gewönulid) beutlid son Dem wurffförmigen Eeife getrennt, unb trägt geveignlid) ein gyanr rus Dimentärer fäbler uno jwei Jुanr ber erwägnten, flammerartigen Rieferfïße. Der mit fleinen, jumei= len gejäbnelten Riefern Kewaffnete Mund ftebt bei einigen Prten, namentlid) Den Männd)en febr weit

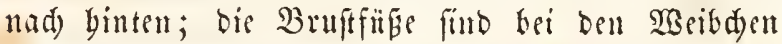
in fingerförmige ober wmptälntid)e Anbänge umge= wanbelt, beren 3abl wedjelt, wäbrent bei ben eifër= migen, bifanfacidwollenen Miänndyen gewöbntid vier Jaar ftummelartiger fïß̈ vorfommen, won benen Die vorberen ßlammerbafen, Die binteren sinige Borften alo Anbeutung igrer frügeren Ptughtoung in Form won St)wimmfüben trigen. Cliondracanthus; Peniculus;Cycnus; Aethon; Clavella.

Die Familie ber Barjaläufe (Achtherida) bat mit ben vorigen Jig. 493 .

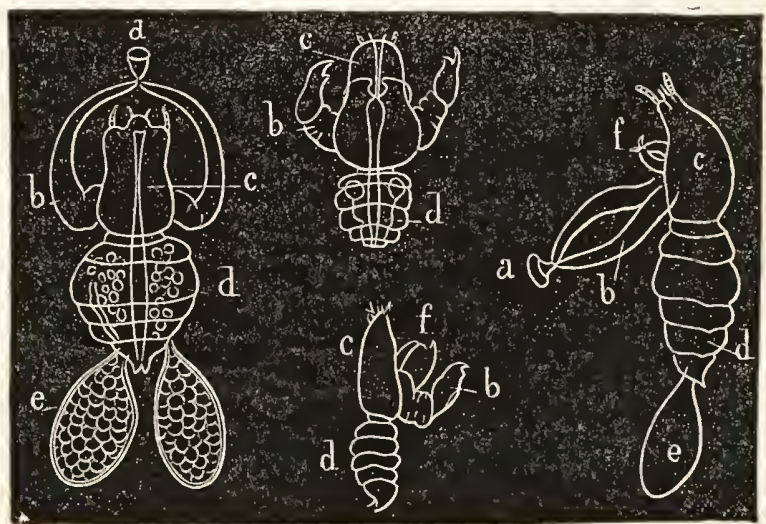

Sig 491.

494.

492.

Die Barialaus (Achtheres percarum).

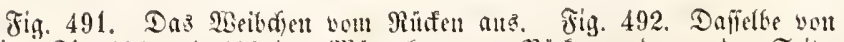

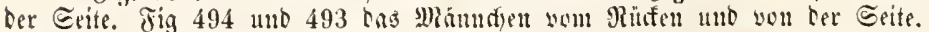

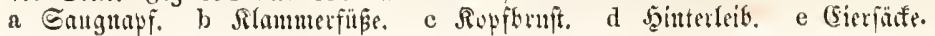
f $\Re$ antïise. 


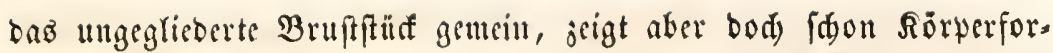
men, welde bentlid) Das Grlebertbier verratyen. Der Sörper ift aud nod) weid) ober mit balbfnorpliger Jaut kefleioet, in eine ungeglie= berte Ropfbruft und einen geglieberten Sointerleib gefdieben, unb an

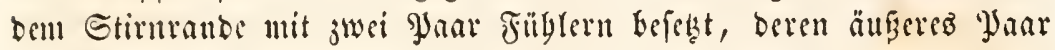
juweilen ju STammerbafen fids aubibildet. Jum Feftyalten bienen in=

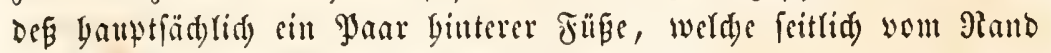

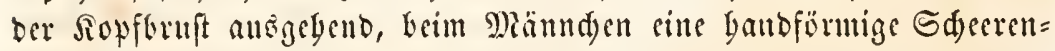
flammer tragen, beill Weibden aber bogenförmig ju[ammenwad) (en uno an igrer Bercingungšftelle cinen Gaugnapf tragen, ber in bas Freifd) cingefenft ift. Zwifden biefen grofen Rlammerfïfen ftebt nod) sin Yyar fleinerex, bie mit Safen bewaffuet find. Der Munb finbet

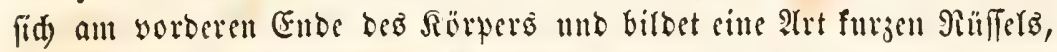
ber innen mit Gafenförmigen Siefern nno aufen mit jwei Jaar Simn= laben bewaffnet ift. Die Detamorpbofe ber Jungen ift ziemlid) ge=

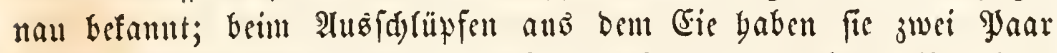
vorberer, mit rangen Borften verfebener Füßje, und einen ciförmigen Reib obne Spur von (3lieberung; nad ber erfen Säutung bagegen befizen fie sin Yaar borftiger Jübler, eime eiförmige Ropfbruft, an beren Mitte orei Jaar Gafiger Rlammerfüße, und am Enbe jwei gaar getbeilter Borftenfüfe fidt finben, wäbrend zugleid ein geglieberter Sitnterleib fid jeigt. Achtheres; Tracheliastes; Basanistes; Lernaeopoda; Anchorella.

Die Jantilie Der Gtörläure (Dichelestida) zeigt ciute furje, diffe

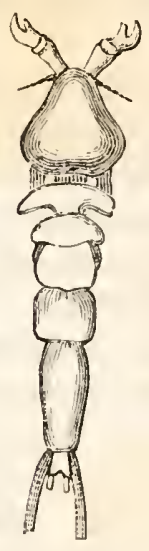

8ig. 495. Die Єtร̆rkus Dichelestium sturionis. Roufbruft, au welder jwei Jaar Fïbler fteben, von benen bie äuferen fdunrförmig, bie inmeren größeren meift mit Safen ober banbförmigen Gd)eeren zum Feftyalten verfeben fint. Der binterleib ift gewöln= (id) lang, beutlid geglicbert, juweilen mit fdupwenarti= gen Defarättern verfeben. Unter dem Siopfbruftidsilo findet man ben furjen Päfer, in Dem z'wei gezälnelte Sieferflingen verborgen find, und ju beffen Seiten orei gaar Sianfüpe fteben, won denen das zweite vorn gezäbnelt, das britte mit einem fdarfen 5afen verieben ift. Am binteren Theile ber Ropforuft fies ben nod zwei Baar breiter Sawimufüre, bie mit Borfen verfeben fillo. Bei ciner (5)attung jeigt fid) aud) im Alter cill mittleres, rotbes Gtirnauge, wet= des bie übrigen unr in ber Jugent befitzen. Dichelestium; Lamproglena; Anthosoma. 
Die Familie oer Sect)tläule (Ergasilida) zeigt cime gewöbultid) birnfürmige $\Re$ opforuft, bie fid berten binterreib fortfist. Die Thiere yaben vorn an ber Stirn cin Waar borftiger frübrgürner, jwifden benen ein mittleres ober zwei

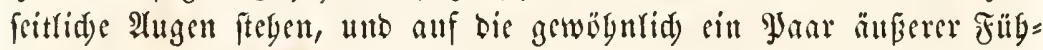
rer forgt, bie worn 5afen tragen und zu אTaumerorganten umgejtaltet find. Sulf ber lluterfeite ber Ropfbruft ftelyen brei gaar flammerar= tiger Risferfübe, utto weiter nad) Ginten utegrere Waare breiter, zluci=

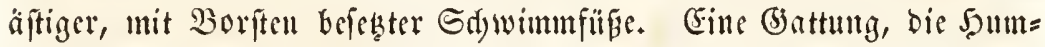

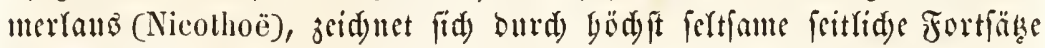

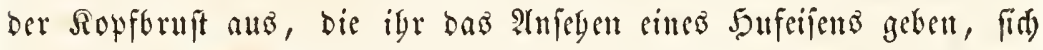
aber erfit im âter entwidferm, ba bie Sutngen burd)aus feine Gpur bavon zeigen und volffoumen ben fdjon bei ben frïgeren ramilien beidriebenen Jungen gleiden. Ergasilus; Bomolocus; Nicothoë.

Bei ber Familie ber Saifilidläule (Pandarida) ifí wie bei allen forgenden Familien ber Edjmaroberfrebfe bie $\Re$ opfbruft zu sinem brei= ten, meift rutbliden Edjiloe erweitert, unter werder bie tabrigen

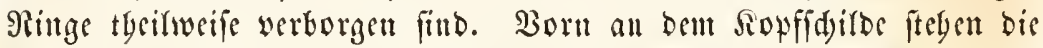
fleinen Fübler, und unter Demr(erben oer Mumt, Der gewöbntid) mit

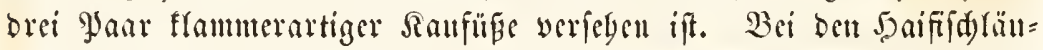

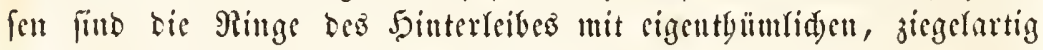
\#̈bercinander liegenden Deffidupten verfegen, beren man jumeifen bis

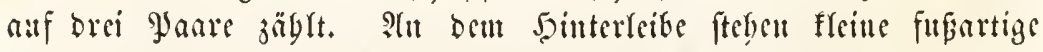
Stummefn auf breiten MJatten, Die ganje furze (Slicberantyänge zeigett

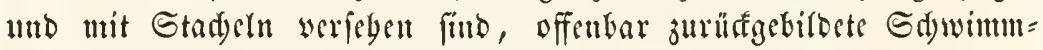
füßre. Pandarus; Cecrops; Laemargus.

Dis Fantilie ber frunderläule (Caligida) ift weit genauer unter= fudd, als bie vorige. Das Sopforutitidjild ift

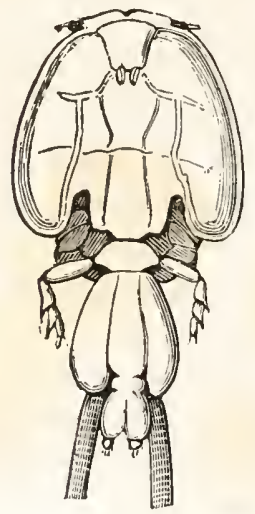

ซig. 496. Caligus. breit, runblid, bie änseren Fübler, an beren

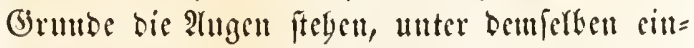
getentt. Reken bem rëgrenförnigen Eangrüfis

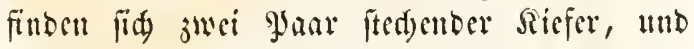
außerbem brei gyan Sieferfüßse, bie verjdjedene Formen antebmen; - - bis brei \$rar $\Theta_{d j}$ wimm: fübe, werdje bierauf forgen, tragen range ge= fieberte Boriten, und sbenfo fitto zwei Brättdent am Sointerreibe mit Sdywimmboriten befest;

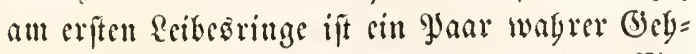
fübe cingerenft. Die Tyiere tragen inde Eier

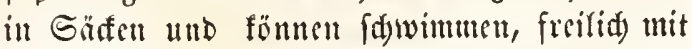
siniger llnteryulfentyeit. Caligus; Trebia; Nogagus. 


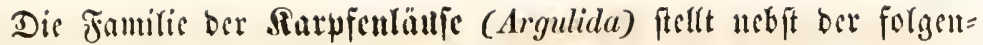

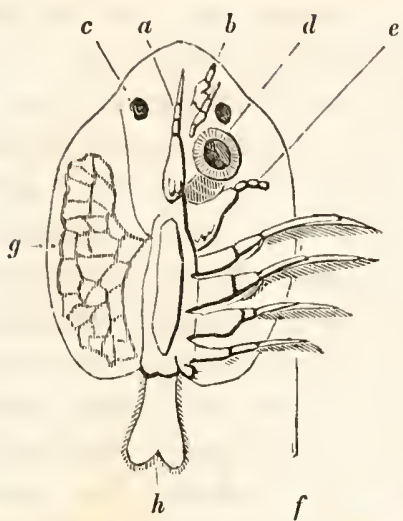

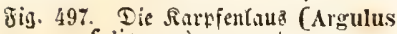
foliaceus) won untett.

Stuf ber einen @eite fint bie

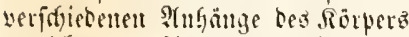
gezeidjut, auf ber andem aber meig=

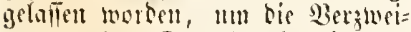
gungen bes Darmfanalez in bem Rërperiddilde zu zeigen. a Etedy=

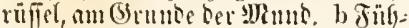
ler zu gegliederten Silammerhafen umgetwandelt. c Ituge. d Eatg=

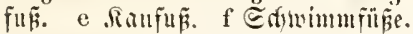
g Berzmeigungen bes Darmifanales. h Blattdyen tes Edymanzentes.

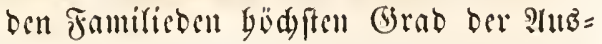
bitoung bei ben Sdmaroketfrebsu dar. Das Sopforuftidsito ift ungemein grof, uad) Den Seiten bitt ausgebebnt, bünn, biegfau unt won sielfad)en $\mathfrak{B}$ futfitrömun= gen, fo wie won weräftelten Brimbläfen Dev Magens burdjogent. Statt beó jwei= teit Yyares Der Rieferfüpe findet fid ein Jaar grofer, geftielter Gaugun̈pfe, mit= telft Ieren fid) Die Tbiere anbefter. Der Dritte, binter Den Gangnäpen ftebende

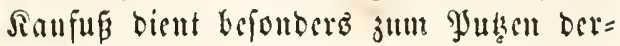
felben und zun Salten Der Bente. P(n Dem binteren Theile des Reibez fiebt man vier Faar beocutento grofacr jwein̈ftiger, langgefiederter Sd)wimmfïfe ullo an tem Sillterende Des Sdjwanjez jwei Brättd)en, Die cille befonbere $\mathfrak{B e z i e b u n g ~ z u r ~}$ Atbem = funttion ju baben ideillen. Die Thiere (d) wimmen mit grofer Sd)uelligfeit umber, beften fids nut zestweife alt bie Jifide ant unt plagen biefelben mittelft sines laugen,

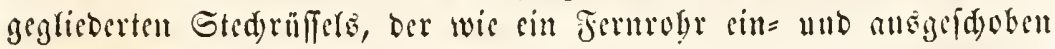
werben faun, und an Deffen fäulenförmiger Bafis fid ber Mind le finbet. Die Mäund)en find bei biefer, wie bei bent vorigen, mit sitter fdibförmigen Sopforuft verfebenen Familien, in ibrer Geftalt nidjt fo

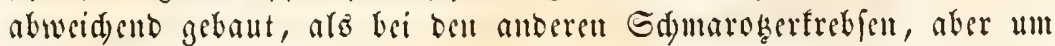
silt Bebeutendes fleiter, als die Siseibden. Die (Fier werten nidyt ill

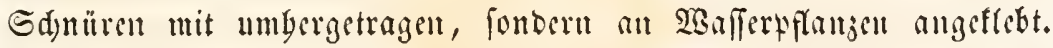
Die Jungen baben eine Der Beftalt Der jutgen Barfdräufe äbulide Bifoung nud weder Ganguäfe nod) dic fdifoförmige sopforuft. Argulus. 
Die Fantilie ber Eternlăuje (Myzostomida) ift bis jekzt nur in

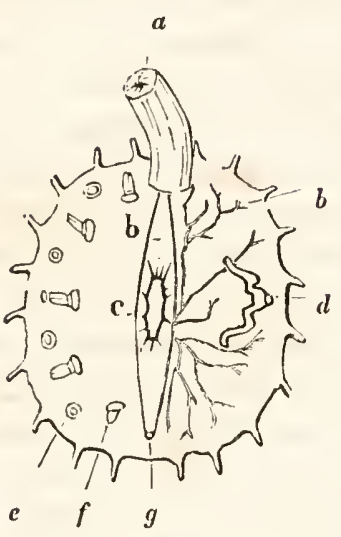

Fig. 498. Myzostomum.

Ituf ber eitren Grite find bie Füpe unb bie 厄augiffeibeu, auf ber anbern bie $\mathfrak{B e r}^{2}$ weigumgen bez Darms und bie máunlidgen (S): fofleditergane (?) Dargepteflt. a Rünel. b Darm. c Mervenfnoten. d (Sefdiledgtatheile, e Eatguäpfe. f Füpe. g Iffter. sincr cingigen (jattung anf Saariternen (Comatula) angetroffen worben, unb bat mit Der yorigen Das breite Sdild gemsin, in weldem fid blinbe Magennubänge verjweigen. Shier befft aber diefer faft freigrunbe Edjild den ganjen Rörper, tuld trägt an feintut Ranbe fünf Yliar furjer, jangenförmiger (5sebfüfe, in Denen gefrümmte 5ornbafen geborgen find, wit welden bas Tbierden febr foucll auf Der Dberfläde ber Saariterne umberläuft. Die 9lunbwerfieuge befteben nur ats

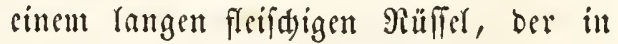
gewifler Beziebung Der Edlundröbre ocr Soblenwärmer gleidgt. Das Thier wurbe biober za ben Cingewsibewitrmetn ge=

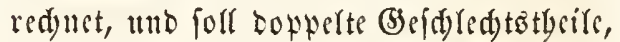
mäunlidye unt weiblidye, befizen, dic bei= Derfsito am Rande ber Rörperfdycibe münben.

Die Dibunng ber Srebsfübe (Copepoda) ftebt in ber

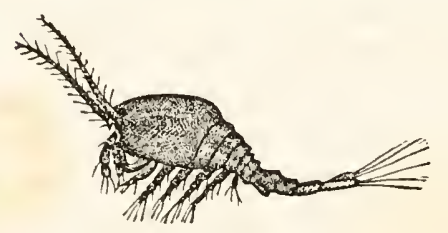

Big. 499. Mionutef (Cyclops).

engiten $\mathfrak{B e z i e b u n g}$ ju ber vorber= gebenden Droulung, fo dap man fie gewiflermafich als freifidwimmente Edumarobzerfroble, als ben eigent= lid)en unverfümmerten Typแร ber worigen Droulung, fo ivie berjeni= gen ber Ranfenfüper betradten fann.

Sic finden fid in grofen Mengen tbeits in Den füвen Gewäfern, theils in bem Meere, unb wurben ibrer faneffen, fdisßenden Bewe= gung wegen yon ben älteren Beobactern meif 23 afferflöbe genant, unter biefent Ramen aber and mit Thieren anberer Sronungen ver= wed) fert. Der Eeib biefer Thiere jeigt gewögnlid) orei bentlid)e $2(b=$ theilungen, eine vorbere Sopforuft, weld)e bie Finbler, stigen unb Sanfïfs trägt, citten gewölnlid) vierglicbrigen \&cib, mit vist Syaren

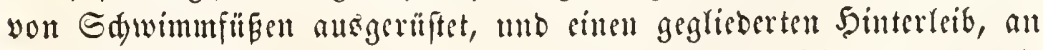
Dem Ende mit Edymumborften verfegen und an feiner Bafis bie Eierfäfe tragend. Daz vorbere Fü blerpaar ift meift lang, borften= 
förmig, oas bintere fleiner, zumeilen rubimentär, ober zu sinem Sd)mimmfuge umgewandelt. Die Mundorgane find zun Rauen cingeridetet und tragen sin Jaar bafiger Siefer, mb sin ober jwei Saar blattförmiger, mit Borften verfebener Rimulaben. Die Saufübe, Deren jwei ober brei gyane worbanten find, fdecinen ftets mit rangen Borften bejest und bicnen als Strubelorgane, weldye Durd) igre be=

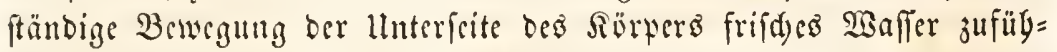
ren; Die Sdy wimmfübe find pets furz, jweiäfig und mit langen Borften befest. Dic Sinnesorgane find burd) sin sinfader, aus

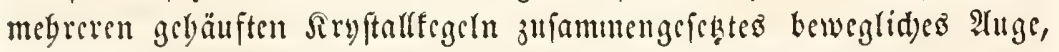
ober burd) jwei einfadje, nabe zufammenftebende ?tugen repräpentirt. Der Darmfanal ift vorffommen gerabe, in feincm Berlaufe ourds= aนs glcid) weit; bas 5 er z bïm, fdlaudfürmig, mur vorn unb binten geöfinet; befoubere Atgemorgane futo burdaus mibefannt; wie co fdeint, werfiebt bie gefammte Saut bes Siörpers diefe Funftion. Die

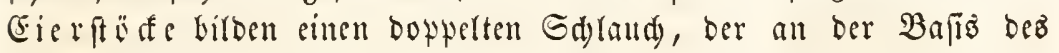

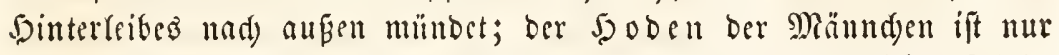
sinfad unb ber Gamenteiter nad) binten erweitert. Sn biefem Theile bes Gantuleiters birben fid) un bie aus baarförmigen unbetwegliden Samentbierden beitebenbe Maffe cigentbüm(id)e Samenfd)(äud), in welden, ägnlid) wie bei Den Gamenunafdinen ber Sopffüßzler, fid ein bejonberer Gtoff befindet, ber burd) Ginfangung won $\mathfrak{B a f f e r} a$ af $=$

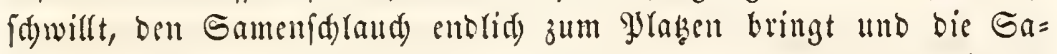
memmaffe berworfdyleubert. Die Männd)en der Sieboflübe verfolgen bie 2 seibdyen, faden fie mit ibren langen füblern, Deren Spige zu biefem Enojmecte oft ein befonderes (B)efent bat, fo bas fie fid bafen= förmig umid)lagen fünnen, und zieben bann citten Gamenfd)laud) Ger=

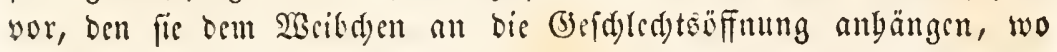
er fid) Durd) Wlataen entlert und bie (rier befrudstet. Die Fier wer=

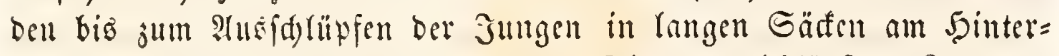

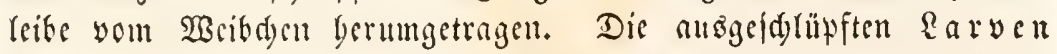

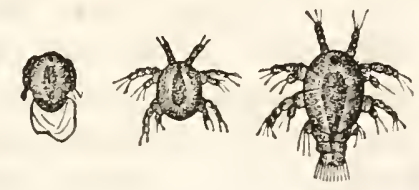

Jig. 500 . Jig. 501.

ชig. 502.

Earsen ron Cyclops.

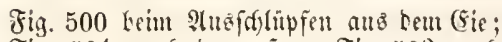
Fig. 501 แad ber eriten, Fig. 502 nady Ler jumeiten scäutung. befitzen 2ufang einen linfenförmi= gen, ungeglicberten Scib, mit einem cinjigen brinnend rotben Stirn= auge unt cintm unteren Fortfalze, vor weldem fid ber Diund befindet; unter bem ecibe fteben brei gुaar furjer, unförmetidyer, worn getbcifter Borftenfïfe, von benen tos vorbere fid) zu ben füblern, bie yinteren 


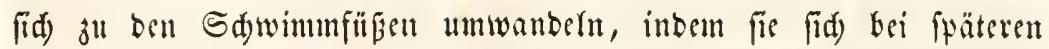
5jäutungen tyeiren, wo bann aud nebft ben anderen ałnbängen ber geglieberte Shinterteib altmäglig berworfprofit.

Man gat bieje Dronung, von ber man feine fojfilen Repräfen=

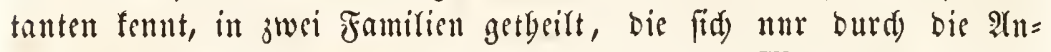
orbnung ber : Sugen unterideiben, indem bsi ben Meerflögen (Pontida) jwei $\mathfrak{2}$ nggen nabe ser Mitterfinie ftegen (Pontia; Saphirina; Hersilia.) wäbrent bei ben (Eyclopen ober Monofeln (Cyclopida) nur ein einjiges mitteres atuge vorbanben ift, bas zwifden ben beiben gropen Fühylern auf ber Stirn ftegt. (Cyclops; Cyclopsine).

\section{Dic Dronnng ber Miujbelfrebje ober Grhalenfrebje (Ost-}

racoda) witb ans meift fleinen (battnngen zufammengerstat, weld)e faft nur bic füben Gewäler bewolnen, und

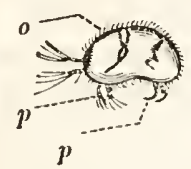

รig. 503.

๔d) alcufluh (Cypris) wou ber Erite gejefien. O

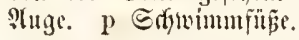

(iid) won ben meiften labrigen Rrmitentbieren burd) bie Exiftenz ciner zmeiftappigen Sdale unterfdeciben, bie ben ganjen sürper sinfdy)lief́t unb auf bem glüfen jufammengegeftet ift. Die

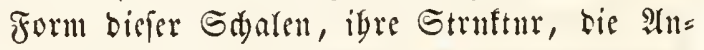
wadedftreifen, weld)e fid auf ibrer Doerfläde fincen, alles bief ftimmt fo volffommen mit ben Sdyalen ber gewögntid) Mith

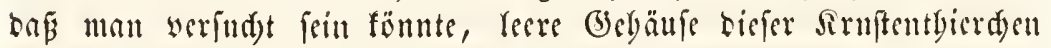

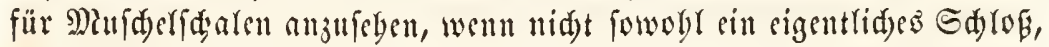

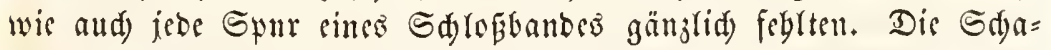
ren werben burd) Den Sïrper feleft, ber an ber Rinfengegento mit ignen burd cinen Minsfel verwadjen ift, jufammengeladten. Dis

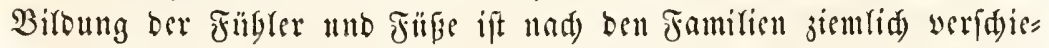
ben, inbem bei ben einen bas erife, bei ben anderen bas jweite grîy= rerpanr bauptfäd)lid) zur Bewegung bient. Der Sopf ber Tlgiere Gängt frei jwifden ben Sdyalen und trägt bei ben meiteen sin sinjiges ?tuge, weldes bei ber sinen Fanilie feiffitst, bei ber anderen burd) sinen jiemlid) bebeutenden Mensfelafparat nad allen Seiten bin be= wegt werben fann. Die sigentliden Jü̈be, welde an bem freien Şinterteibe auf ber Baudfeite befefitigt finto, find in megrfadyer 3abl worbanden unb an bem Panbe mit Borften befse, zuweilen a nd, Glattfürmig erweitert; fie bienen nidgt fowohl ăแr Drtêterwegung, alB viefmegr wefentlid in ber Gigenidaft won Strndelorganen, werd)e

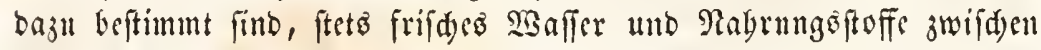
bie Sdatendäater sinzufïbren. Der Sinterteib ift gewöbulidg frei, 
oft fdwangartig werlängert, socr and) gegen beat Rüfen anfwärtb gebogen mub burd) sine ftumpfe Spizs gernbet. Die Anatomie ber

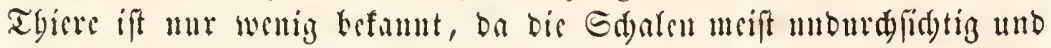
bie Thiere jur stuatomic ju fleiu find ; Der Darmfanal ift ganz gerabe, befitht aber bei sinigen (5)attungen an feiner vorberen Seite zwei ziem= lid) bebentente Blunbläfe; sigentlid)s Atbemorgane exiftiren nirgendo, Denn and) in Den fammartig a Sattungen sorfommen unt als Siemen angefrlyen wurben, fann man

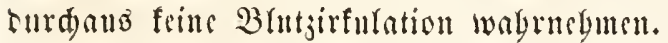

Dis (5) fidlecter fint getrennt, wie bei allen übrigen Rruftentbieren

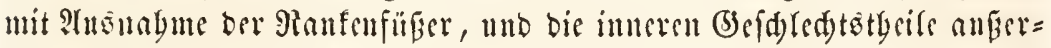
orentlid) cinfad). Bei ciner Familie bat man trob̧ igrer bänfigfeit Die Mä̈ndyen nod) nid)t entorfen fümurn; bei einer anderen find fie befaunt, und bie Begatmng gefeben worben. Dis Snngen fommen

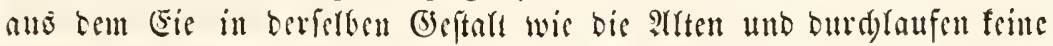

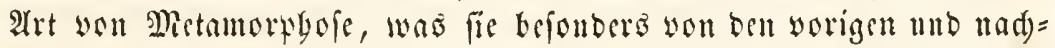
folgenten Drbuungen trennt. SBabridgeinlid) futb bie Stabien, welde ber Embryo innerbarb der Gifdale woul frimer erften Bitbung an burd)länft, oen Dictamorkgofen analog, welde bis Rarwen ber (d)a=

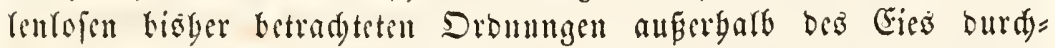

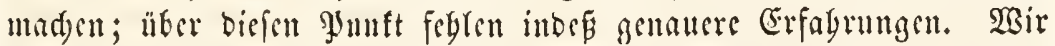
theilen bis Dromung in zwei Jamilien.

Die Fimnilic ber Sabafenflöbe (Cyprida) befiţt cine solffommen

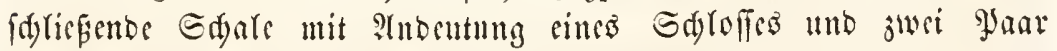

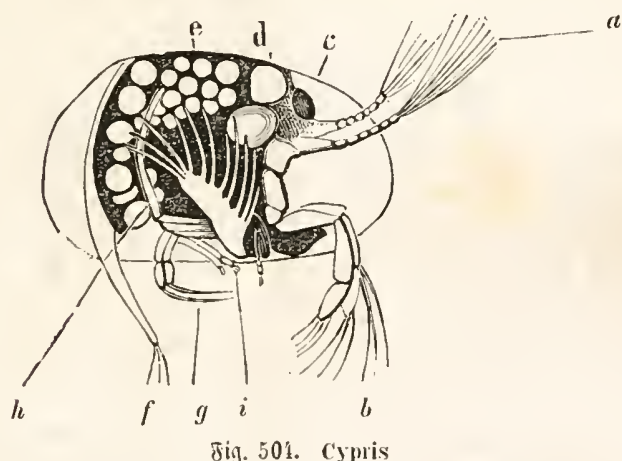

sun ber Geite, nat) IEegmatme ber citten Gdale.

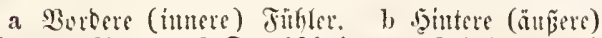
Fiibler, e Aluge, d Durdfidnittener Edgalemundel. e sier. f Erbmats. g sebtes Fuppan. h Borlets= tes, in bie jostge gejolagetres Jublant, i Etrubelorgant ber siunlade.
Fithlet, won weldyen bis worberen binn=boriten= förmig, nad) yorn ge= ridetet, bie binteren breit furfförmig gebogen unb mit rangen $B_{0}$ rften $\mathfrak{b} c=$ feşt fint, fo bas fic als Das bauptfäd)lidyfte $\mathfrak{B}_{\mathfrak{c}}=$ wegungsorgan biencu. Diefe Jithler tragen lan= geBorfen und Stadyerut mito treten an bem $11 \mathrm{t}=$ teren Sdyatemanoe bers vor. Der worfpringente Miund, ber in oer Mlitte jwifden biciem grofien Süblerpanie liegt, zeigt 
sime Dber= und Unterlippe, cilt Paar Riefer mo jwei Yaar Rinn= laben. An ber $\mathfrak{B a f i z}$ biefer Mundwerfaenge finden fid blattförmige Rappen, unter benen bie bes eriten Rimladenpanres bejondero gros,

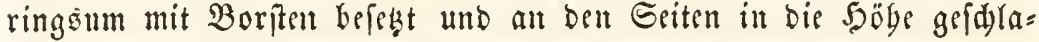
gen finto; fie wurben vorjugšweife als Siemen betradtet, fitlo aber offenbar nur Strubelorgane. Llnter Dem Seibe finbet man ziwei gyaar

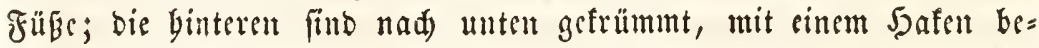
waffuct, bie vorberen gabelförmig in bie Şöbe gefd)lagen, zur Stïke bes bort liegenden Eierjtedis. Der Sinterleib endigt in zwei fpikse, fdwanzartige Stad)eln, bie nebit Dem vorberen Fuppaare uno ben beiben Füblerparen bie eilzigrn Drgane fint, welde aus ber Edale bervortreten. Bis jeket find dis $\mathfrak{R a ̈ u n d ) e n ~ i n ~ b i c j e r ~ F a m i l i e ~ u n b e = ~}$ fannt; bic Fier werben in sinem eigenen Ramme jwifden Gdale und Jjinterleib gefammelt, aber febr balo an Salferpflanzen gelegt. Die im Dece Kebenden Battungen tragen juei feitlide 2ugen fapt mitten nuf sent Rïfen, nabe ber Mittellinie, bie in Sïbwaffer wolynenten mebr auf ber vorberen Seite. Man bat fdon in ben Edjidten ber Soblemperiobe, baun aber namentlid in benen ber Sreibe und ber tertiären Giebilde oft in Maffen angebänfte fleime Gd)alen gefunben,

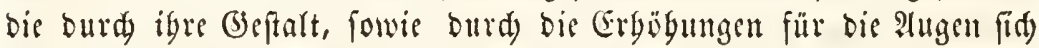

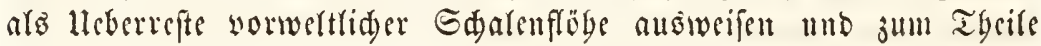
bejonberen aนต̉geftorbenen (5attungent (Cyprella, Cypridella) angebören. Cypris; Cypridina; Cytherea.

Die Familie ber Büfdgelfreble (Daplnida), dic anf unjere jeşige

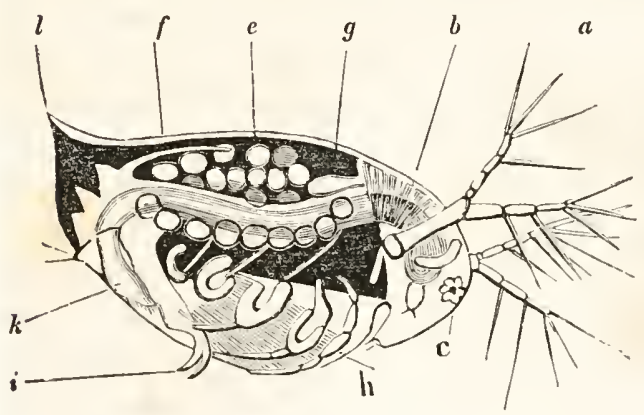

ซig. 505. Daphtnia

run ber Eete, thad) ahgenummencr Gibale.

a Bortere Fühler. b Darm. c SIlnge. e Sier. f Seibelfortfaz zur Gtüße ber Sier. g Serz. h

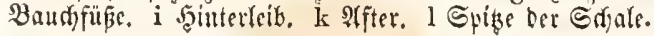

Sdopfung befdränft ît, Güngt unt mit sintent ge= ringen Theife bes 9Rï=

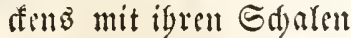
zufanmen, fo baß $\mathfrak{S}_{0+f}$ unt Rerib zismlid frei fiub. Der Siopf trïgt eint runtoes beweglider Stuge, sinen f(t) nabelför: migen Miuno uno jwei Yaar füblböruer. Die vorberengstiglyörner fin fogr flein, ftetỏ unter Der Edale geborgen, bie binteren bagegen fegr 


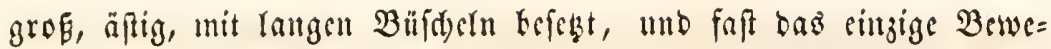
gungöorgan. Der Mund zeigt eine grobe Dberlippe, ftarfe, bafen= förmige Siefer, borizontale, mit bafenfürmigen Dornen befeste Simnlaben. Die vier vorberen Fubpanre finto breit, abgeplattet, mit langen $\mathfrak{5} a \mathfrak{a}=$

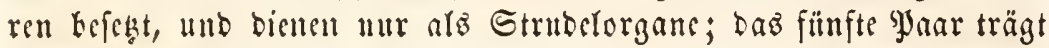
cinen geifelfürmigen Fortfaks, ber nad) oben gerid)tet ift uno bie Eier in ber Brutgëble umfäbt. Der Sinterleib if furj, enbigt in jwei

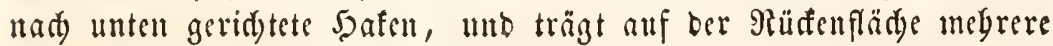
nad) oben geridtete $\mathfrak{2} a a_{j}$ en, bie burd ibre 2 thlagerung an bic Sdale

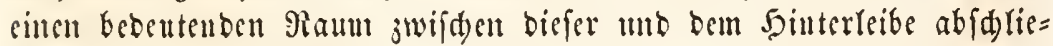
Ben, ber alz Brutbögle bient. SBägrent bes Sommerz werben in biefer 5öble bie (Eier mur wenige Tage binburd) autgegerütet, gegen

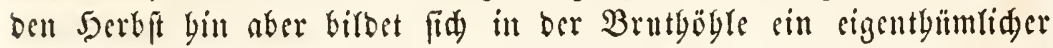
fattelfërnizer 2lpparat von bunfler Farbe, weldecr wefentlidy ans zwci RTappen befitebt, bie in igrem Snteren bejondere Rapjern entbalten; man bat biefen 21pparat baz Ephippium genaunt. Sebe ber beiben Siapfern biefes atpparatez entyält ein ober megrere Eier, bie bei ber

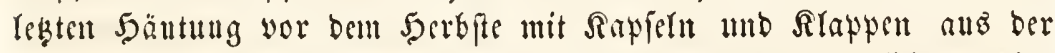
Brutgügle anżgeftofen werben. - Dic Thiere gegen ben Tsinter über ju Brunbe; bie in ben befdriebenen jweiflappigen Sapfén gefegten Fier aber yarren ben 2 sinter Ginburd ans und entwiffelu fid) in nädjten Jrübjabre. Daphnia; Lyncacus; Polyphemus; Evadne; Acanthocercus.

Dic Drbnung ber Binttiüzer (Phyllopoda) umfä́t Tgiere

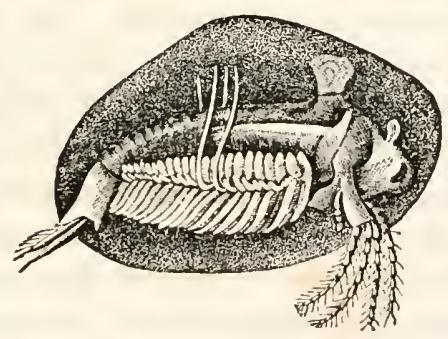

8ij. 506. Limnadia

ron ber Eeite nad) ahgenummenter Edyale. yon bebententerer Rörpergröpe, die fid) wor allen anberen Dronungen Durd) Die grofie 21nzabl igrer \{eiber = ringe unb ber unter ibnen anges

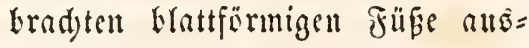
zeid)nen, Die zugleid) als $\mathfrak{B e w e}=$ gungsorgane unb als Siemen bienen. Der $\Omega$ ö rper biefer Thiere ift bald wollfommen naft, balb won sinem breiten, einfaden Edilbe, barb auda won eitrer bïnnen, jweiflappigen Saale umgeben; ber Sopf gewöhn= lid frei, mit jwei grepern, jufammengefekten Atugen, zuweifen and nod) mit cillem mittleren, unpaaren, cinfaden 2tuge uno jwei fïbler= paaren verfeben, bie oft firfiame llmgeftaltungen erleiben; ber Dent iff fets mit Siefern ober Sinnlaben bewaffuet; Ginter igm fteben bie 


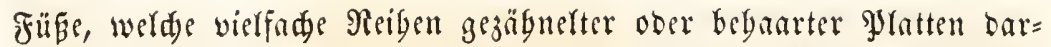
ftellen, die wälrento bes Rebens in befiändiger Bewegung fïto. Der Shinterteí ift fretso frei, mebrgliebrig, gewögnfid) mit lamgen, fabenfër= migen İngängen verfegen; bie Sdjitber unt Edjaten, weldje bei ben gepanzerten arten Den Rörper Deffen, find fegr bünn, Durdfindtig und bornartig.

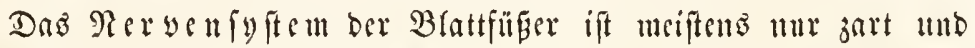
beftegt ans einem viereftigen bुirnfuoten, Deffen bintere TSinfer bie Berbindungşäben zu bem eriften Bruftnoten abgeten. Die bas Baud)= marf jufammenfş̨enben Sinoten liegen an zwori feitliden Strängen nutb finto Tnfangs burd boppelte Duerfäben, bann burd einfad)e mit

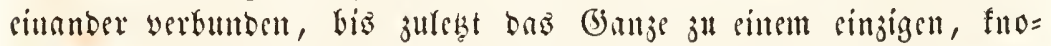

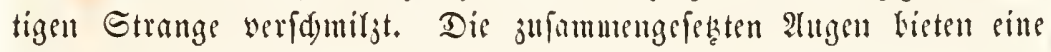
sigentÿüulidye Mobififation bar, intben unter igrer äußeren, glatten 5ornbaut cine zweite, fajettirte 5ornbant fid befindet, binter beren

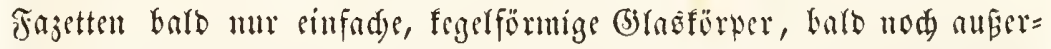

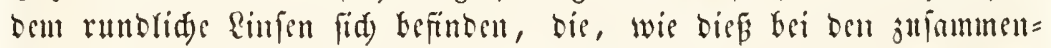

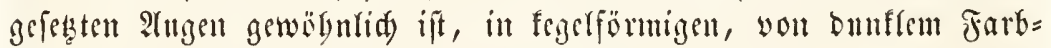

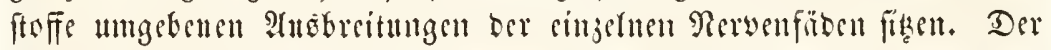
3̧erbaun a ga

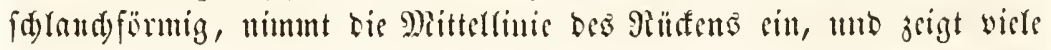

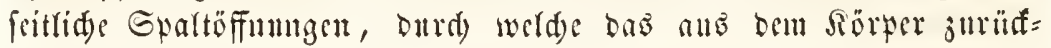

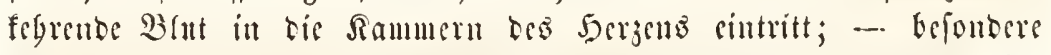

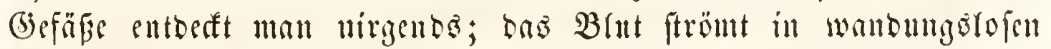
Sianälen, befonders innerbalb ber blattfürmigen Risuncufüpe, die oft

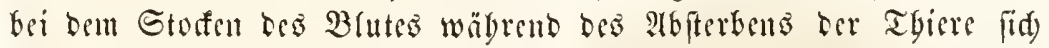
fo füllen, ba

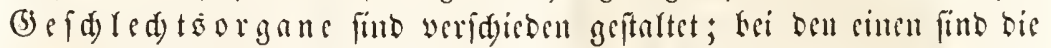
Sierfitöfe vierfad) veräftert, hei ben anberen sinfad) (d) (audartig. Meiftens finden fïd) befontere Gibegälter vor, welde Garb an eincen

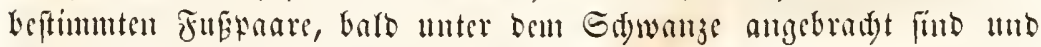
in benen bie Diffen, Gartfdarigen Eier berumgetragen merben. Bei bou

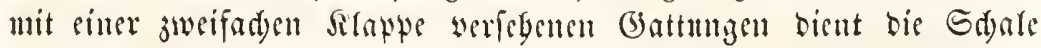
als Cibebälter. Bon cinigen Gattungen feunt man bic Mä̆muden

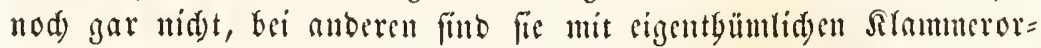
ganen verfeben, mit welden fie fid an ben 2 seibden feitgalten fön= wen. Die ans bem Eis friedenben Sumgen gleiden anferorbentlid ben Sungen der Sirebseflibe, uno baben wie biefe jwei doer brei gyan 
ranger, mit büfdelfürmigen Saaren veriefener Sdymimmfüfe, won welden bie beiben erften Ylane fid) fpäter zu Füblern mmgeftalten.

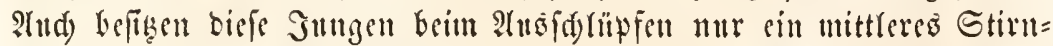
auge, ju weldem fid) erft bei fpäteren 5äutungen bie feitlid)en zufan=

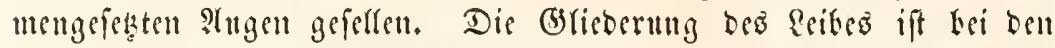
ausigefdlitpften Rarwen faum angebeutet und entwiffelt fids mit ben blattfürmigen Riemenfüвen erft bei ben fpäteren Säntungen. Foffite lleberefte bicfer Drbunng fommen wabrfadeinlid gat nidgt vor; wenig= ftens fdeinen Die Berfteinerungen aus bem Soblengebirge, bie man ben Gattungen Nebalia uno Apus bat jutbeilen wollen, nod) wiel zu un= solfiänoig gefount, unt fie mit Sidgerbeit bier sinreiben zn fönnen.

Die Fnmilie ber Blatterebje (Apusida) trïgt sine ungemein grofie Anjabl won Riemenfüßen, welde fajt ben ganjen unteren Raun bes

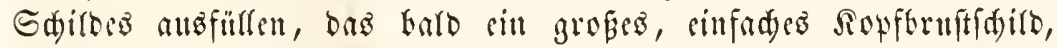
baro eine zweiflappige Sdare biloet, bie bann mur mit einem geringen

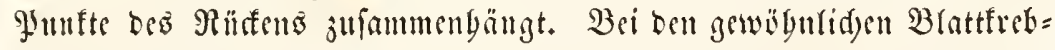

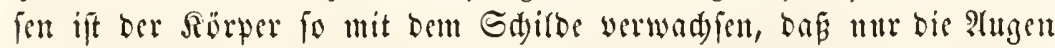
auf Der oberen Fläd) berworfeben. Diundwerfjeuge und Fübler un

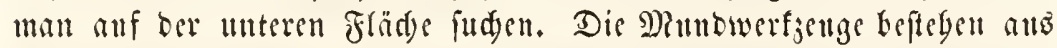
einer febr groben, vierestigen Sberlippe, neten welder bie furjen, Dreiglieberigen Fübler fteben, aus einem Jaar ftarfer, biffer, gejäly=

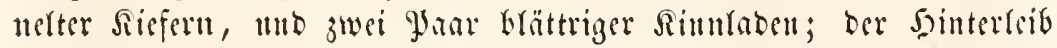

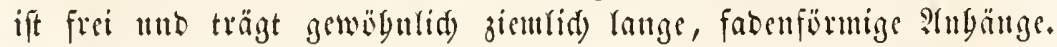

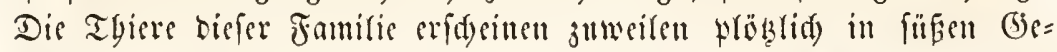

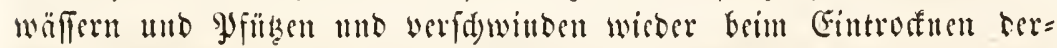
feleen, inbem fie fids mit igren sarven in ben fendeten Gdylamm bes Bobens singrabell. Apus; Limnadia; Nebalia.

Dis Jantis ber Riemenfïßs (Branchipida) wito won sentigen wenigen, langgeftresten Gattungen gebilbet, beren Sïrper wolfoumen

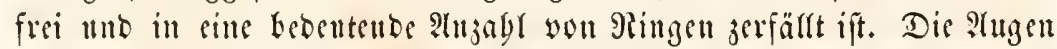
fint geftielt, bie worberen Füglbörner oft jul bafenförmigen Drganen umgewanbelt, wäbrend bie binteren fabenförmtg find. (Fo finben fid) 
รig. 50\%.

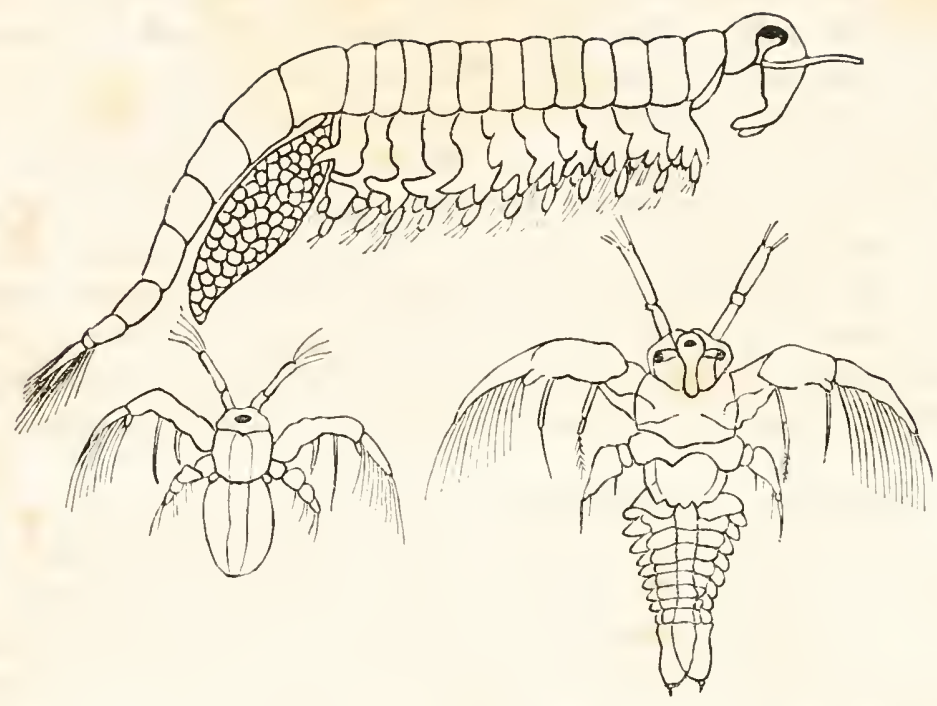

Fig 508.

Fig. 509.

Der gemeine Siemenfü (Branchipus stagnalis).

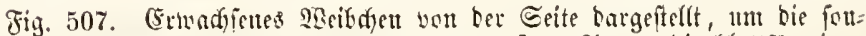

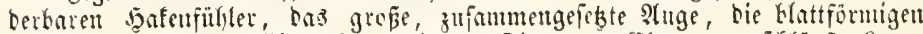

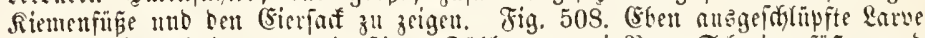

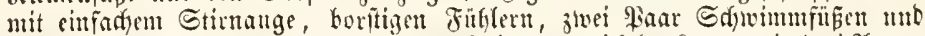

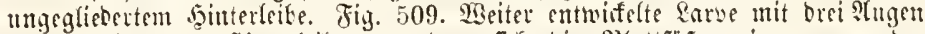

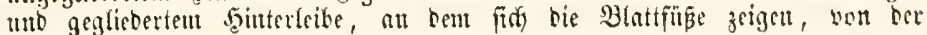
Baudfipite.

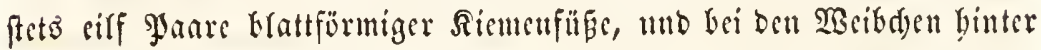

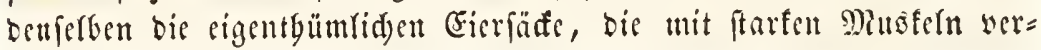
feben find, burd) Deren 3nfammenjichung bie (Fier beftändig bin und Gergeworfen werben. Die Thiere fdwimmen wie bie ber vorigen Fa= milie auf bem Rüfen, ben 3 aud thad oben getebut, unb finben fid

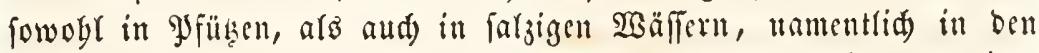
Saljpolen, felbjt bei einem bebeutencen Grabe igrer Eoncentration. Branchipus; Artemia; Eulimena.

Mhit ber Dronung ber Blattfüber jebenfallo febr nabe verwandt ift bie Dronung Der Srilubiten ober \$alänben (Trilobita), weldye nur in ben äleften erofdjidjen vorfommt, utto bort fait fïr fids

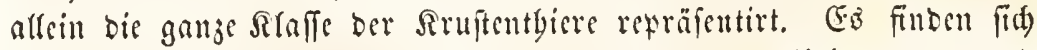
bie lleberrefte biefer Drbunng eingig und allecin in bem llebergangs = und 


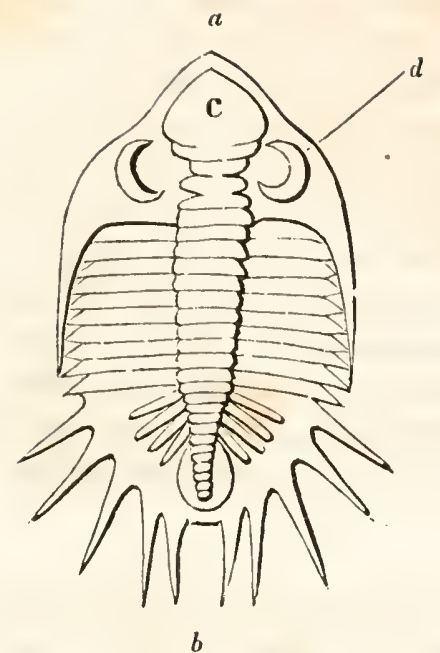

Jig. 510.

Phacops arachnoides.

a Ropfiffilo. b Edyroanjaffito. c Soptbufer (glabella). d शitugent.

Roblengebirge wor, unt find fdon iti Dem lekzteren felten, in fpäteren Sdjideten aber Durdjans nid)t mebr anjutreffen. (5: ift baber begreif= lid, Daf ilber ibre Drganifation nod) jekt vielfadye 3weifer berriden, Die um fo mebr erbalten werben, arz man bie Thiere meift nur von Der Plifenfeite fiegt und bie wid)= tigen Theile, welde altf ber llnter. feite riegen, nod) jeg̨t faft ourdanto untefannt fitid.

Dis Irifobiten bisten im (5) ant= jen bis Form sincz mebr ober minber länglidsı Edjilbes Dar, an weldem man brei eillzelne atbtbei= lutgen unteridseiben fann, bie man gewögnlid) mit bem Ramen

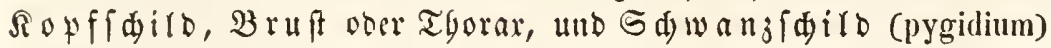
belegt Gat, wovon inder offenbar bas Ropfidild sine Ropforuft bar= ftellt, gebildot alls ber Berwadjung bes Ropfes und bes vorberen

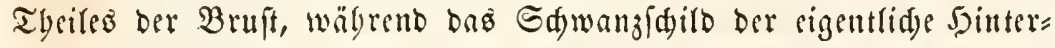
reib ift. Das Ropfictild bat gewögulich eine yalbmondörmige ober balbeiförmige Geftalt, megr ober minoer nad yorn abgeftust ober jugefpizt, tmb oft nadi biuten in lauge Spizen mo Dornen ausge= zogen. Sn ben meifen Fällent Interfdscibet man auf Dem Sopffdilde

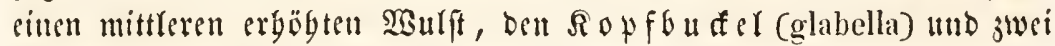

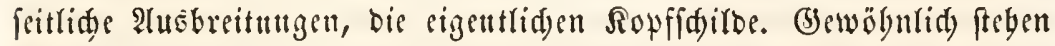

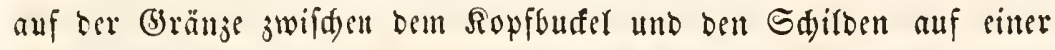
Natb, welde fid) bort binjebt, jwei grobe, bervorgequollene, jufam= mengefekete 2t ugen yon balbmondörmiger Geftalt, Deren Eonvexität

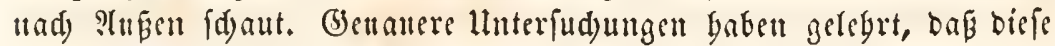
Angen urfprïnglid) ben Bau ber Augen des Riemenfües befaßen unb fomit eine glatte äußsere Şornbaut batten, bittter weld)er eitte jweite fajettirte Sormbant lag. Bei mandjen (5)attungen find biefe 2lugen biz auf einen änßerft fleinen Streif zufammengefdwmben, ber oft fegr fdwierig zlt entberfen ift.

Die wertieften Rinien, welde Den Ropfbutel von bent feitliden 
Sdjirben trennen, fełen fid) gewögnlid weiter nad) binten über bie Ringer bes Thorax und über bas Sdwanjldild weg, fo baf ber ganze Siöper ber \&änge nad) ebenfallo in brei 2lbtbeilungen ge=

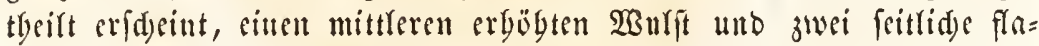
d)ere \$artbien. Die 3abr ber Ringe bes Thorax ift febr veridjeben

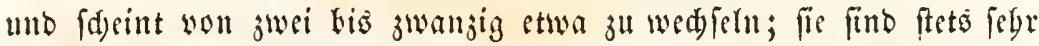
furz, bebeutend breiter als lang, und oft feitlid) in Epizen ober Dormen anşgejogen. Bei vielen Gattungen geben biefe Bruftringe nad) und nad) in bie Ringe bes Sd)wanzldilder über, fo bafi fid feine fiddere (bränze jieben räßt; bei anderen aber beftebt bas Sdwanj= f(d) a a cinem Stüffe, oas oft fäd)erfürmig geftreift, ober mit Dor= nell bejeçt ift, unb bann gewögnlid) mebr ber minder die Geftalt bes Sopfiditoes wiederbort.

Die äuberen Bebefungen ber Trilobiten waren bornig unb be= ftanben ans jwei Edjidten, von Denen die büntere äuß̉ere, bie sins förnige $3 e j d$ affenbeit Gatte, bei ber Berfteinerung meift verloren ge= gangen if. Heber bie Miunbwerfzenge unb bie Fitge bat man nur böd) ft unvorrftänbige Beobad)tungen; bod) Gat man an ber lluterfläd)e ber Thiere fleine runblidye, am Ranbe ausgejafte Räppden gefeben, welde offenbar bie beftalt und Bildung ber bei ben Brattfüpern vor= fommenben Riemenfü̈re Gaben. - Biele Gattungen Der Trifobiten

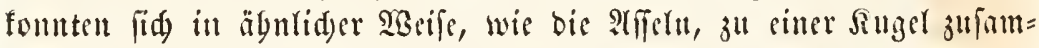

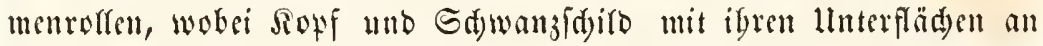
eimander gelegt wurben. Frithere Beobadter wodten fie begbals und wegen ber Rörperfurm aud) ben alfeln näber bringen, cine Meinutg,

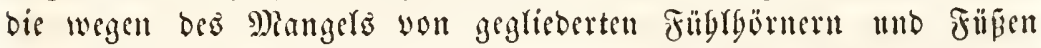
nid)t ftid) unfere jersigen Brattfüвer, an feidten Eteflen bes Strandes und in weniy tiefen Meereshuden, und zwar meiftens in Sdwärmen zuan= men. Sie waren faft alfe verbältnifmäвig tlcine Thiere, bod) giebt es cinige riefenbafte Plrten, weld)e beinabe zwei Fus \&änge erreid)ten. Sbre lleberefte finden fid) Sefonbers bänfig in Böbmen, Sd)weben, Rorbamerifa unb Pugrtanb, weniger zablreid) in bem rbeinifden lleber= gangsgebirge, in England und in ber Bretagne. Man bat fie tul

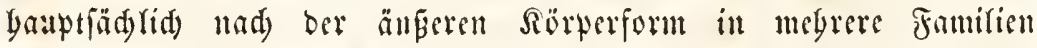
zerlegt.

Die Familie ber $\mathfrak{B a t t i b e n ~ ( B a t t i d a ) ~ b e g r e i f t ~ y a u p t r a ̈ d ) l i d ) ~ t r e i n e , ~}$ 


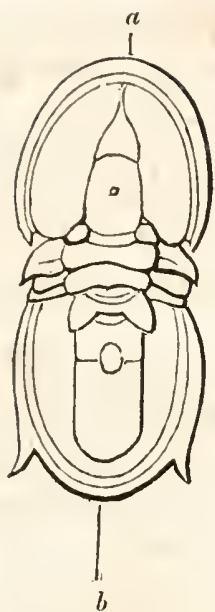

Jig. 511.

Batlus pisiformis.

a Ropifidilo. b Sdimany= idilto.

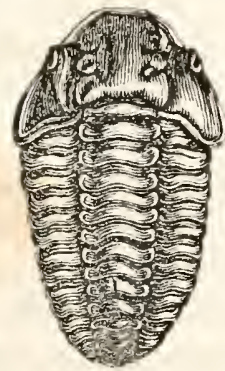

3ig. 512 .

Calymene Blumenbachi.

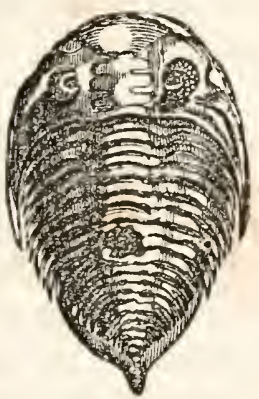

สig. 513.

Asaphus caudiger.

oft fanm birfeforngrobe Arten, beren Ropf = mnb Gd)wanjidhilo barbfreis̄örmig, faft gleid) grofi, und won fo äbulider Biloung fund, oap man fie leidt mit einander verwed) feln fann. 3wi= (d)en biefen briben grofien Shildern finden fid) $11 \pi r$ febr wenige Brmptringe, beren $3 a b l$ yon zwei bis fünf wed) felt. 2(11f Der Mitte bes Sopfbutels follen sinfad)e, glatte ?lugen fteben, woraus man gefdroffen bat, daß bie Thiere, welde diefe Familie bildeten, eigentlid) nut ben Jugendjuftano ber gewöbutiden Trifobiten bar= ftellten. Battus; Agnostus; Cyclus.

Mian fann unter Den n̈brigen Trilobiten jwei Sanptgruppen unterideciben; - bie einen befizen bie Fäbigteit, fid fugelförmig anfjurol= len, Den anbern gebt bieferte ab. $3 \mathfrak{b}$ ber erferen (3ruppe gebören folgende fantien: die Ealymeniben mit grannlirt böferiger Edale, vielglicberigem Tgorax und ftart bervorgebo= benem Sörferwulft, Der anf Dem Sdumanjidjilde

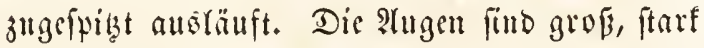
worfuringent, bas Edwanjidild ganjanbig, Deutlid) von ben Brufringen getrennt. 3n Dicfer Familie gebören bie gröpten befaunten (5attungen. Calymene; Ilomalonotus; Cyphaspis; Phacops. Jgr febr nabe febt bie Fat milie ber $\mathfrak{A}$ jupbiben, beren Siörperaxe fid nad) binten nityt zupibet, bie meift weniger als jebn Brutringe befisen und beren Edjale frine (5) $\mathfrak{a}=$ mulationen zeigt. Asaphus; Illaenus; Archegonus.

Dic übrigen Familien fömmen fid) nidat rollen, fonbern bleiben gerabe ausigefterft; bier= ber gebören bie Saygiben mit grofism, nad) binten in lange Spizen ansgezogenem sopf= fdilde, einfadsem Gdwanjidjilde, one ebenio lang ift ober länger, als ber Thorax, mo Gorijontalen Bruftringen, bie feitlid) in lange, nad, binten gerid)tete Spizen ausianfen. Ogy- 


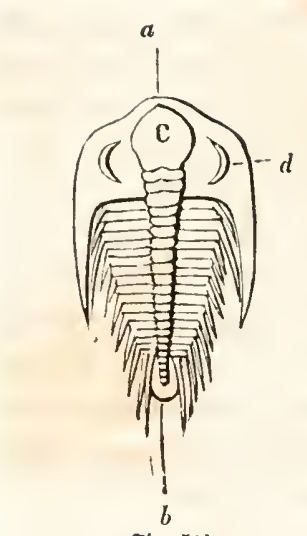

8ig. 514.

paradoxides bohemicus.

a Ropfidilo. b Edmant = fdill. c Ropfbufd (glabella). d Attgen. gia; Trinucleus. Bon ibnen unterideiben fin bie fonft gans ägulfid) geftalteten Doontopleus riben แur burd) cin fleitte gen bejtelyeubes Sd)wanziffirto, (Odontopleura; Arges; Brontes.) und Dic Dleniben burd) ein größeres Sdjwanjidjito, weldyes in sine grö= fere Prnjabl yon Pingen getgeilt iff. Paradoxides; Olenus; Triarthrus.

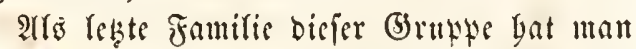
sic (Eampulopleuriben unteridieben, bei wel= deen bie Rittge bes Tyorax, bie ant igrer Spike

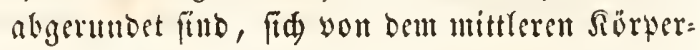
wurfte an trad unten unfrümmen, wäbrent fir trei ben vorgergetgenden Fonnilien fid faft borizontal erfitreffert. Conocephalus; Elliprocephalus; Harpes.

\section{Lunterklafle ire pfrilfst)wäm;cr. (Xiphosura s. Poecilopoda,)}

Die merfwürbige Gattung ber Morftuffenfrebje (Limulus), werd)e

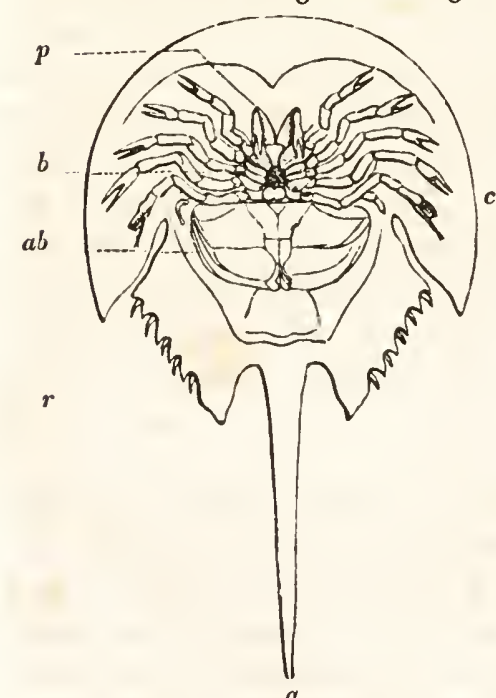

Fig. 515 .

Limulus, son ber $B$ aud flàde.

$\mathrm{p}$ Squerenfühler über bem Munbe. fiir fid alfein biefellnterflaffe bildet, ftelft ein merfwitrbiges lleberganges glied jmifden ber eben betradteten llnterffaffe und berientigent ber eigent.

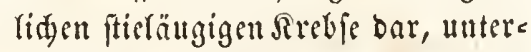
(d)eidet fid aber von beiben burd) bejonbere Cigentbümlidyteiten bet Dignnifation.

Der Rörper biefer Tyiere, Die mit zu belt gröpten $\Re$ rebjen $\mathfrak{g e}=$ bören, beftegt at b brei atbetbeilungen, cittem balbmontoförmigen Ropfbruft= d)irbe, beffen Converität nad vorn geridetet ift, wäbreno die zwei Spiben mad bintell idauten, einem

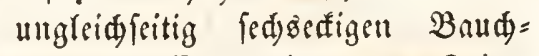
fillde, Deffen orei vorbere Seiten vou bem Einfdnitte ber Ropfbruft um= 
b 2 แแน

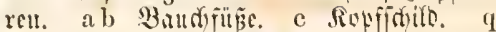

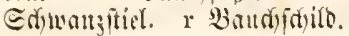

faptwerben, unb cintem Yangen, fticl= fïrmigen, ungeglieberten Sdwanj= find)el, ber an feinem binteren Ente

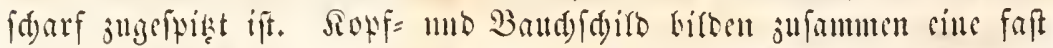

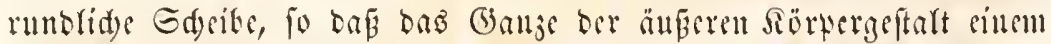

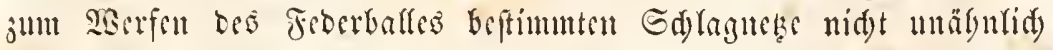

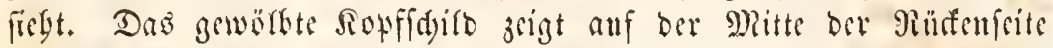
cine seifte, an beren fuopfiörmigem Eube jusi fergr fleine, erbabene Rebenaugen fieben uno jwei Sritenleiften, ju beren Seiten fid bie

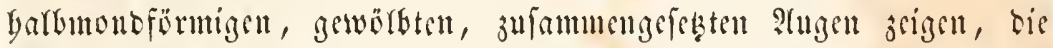
mitbin ganz riefelte Stelfung einnebmen, wie bie Angen ber Trifobi=

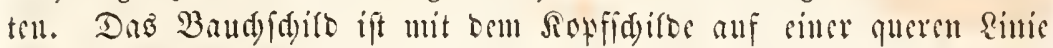

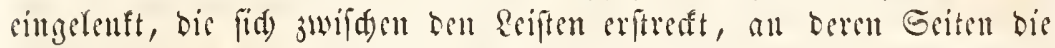
AYugen freben. Die beiben bintern Geitentänber brs Band)fyildes fint mit gefieberten mito bewegliden Gtadyeln befest; Der in ocr Mritte cint= belenfte Gdywanjtadel ift nad) allen Geiten bin beweglid. Betradjtet man Das Thich yon ber mnterent Geite, fo fiegt man in oer Mitte

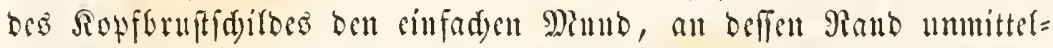
bar bie mit Gdyeren bewaffucten Gobfübe cingelenft find. Lleber bem

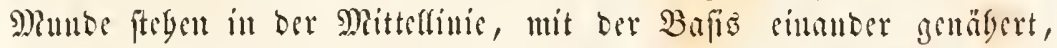

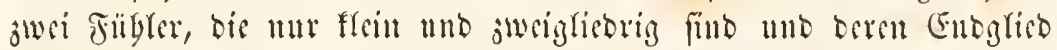
eine Sd)ere trägt. Gierauf folgen bie fïnf cigentliden Jubpanre,

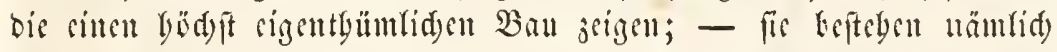

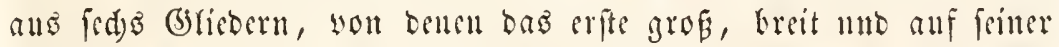
inneren Fläd) mit einem feften Sormblatte verfeben ift, das farfe Stadyclu trägt, uno beim Ranen gegen basjenige oer andern Geite wirfen fann. Die übrigen Glicber fint cylinbrif́ unt enden in cine

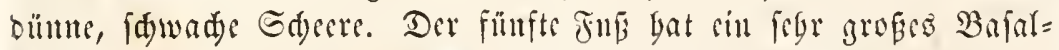

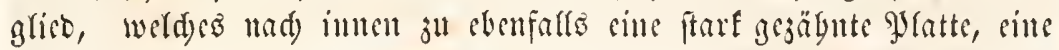
wabre Rinnlabe trïgt, nad) ausen bin aber mit cintem geifelförmigen

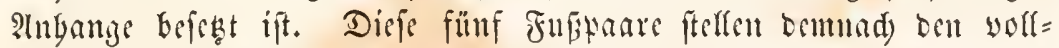
elloetiten Typus you Raufüpen bar, illoem fie wirf(id) ourd) igre Enoglieber bie cinzigen Bewegungeorgane fint, wägrent ibre 2 the fangsglieber bie cinjigen $\mathfrak{B}_{e r f}$ juge bicten, beren fid) bas Tgier jum Rauen unt Berflcitern Der Beute bebienen fant.

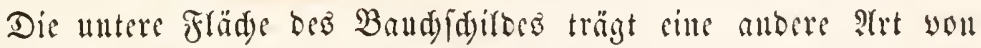

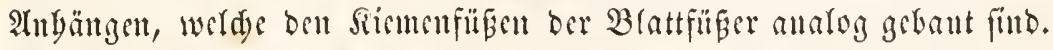

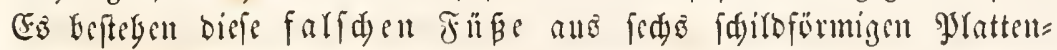

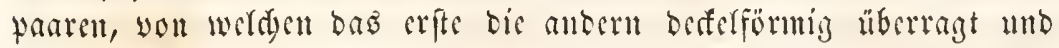
feine Rieme trägt, wägrend bie fünf binteren Saare all ibrer Sinter=

Bogt, 3ootogifone Briefe, I. 


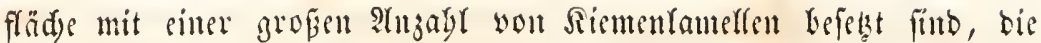
cime quere Eteftutg bahen. Llumittelbar binter bicfen Sitemenfüвen

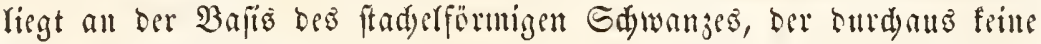
Citugeucibe birgt, ber affer.

Die $\mathfrak{A}$ un tomie biefer TGiere bietet mandes $\mathfrak{B}$ emerfenswerthe bar. Der Sdylund fteigt aแs ber Mutibiffunng zuerit gernbe und worn unt offuet fid bann in einen vorn in Sioffiditbe getegenen Magen, ber mit vorfpringenben Sornfalten ausgeriiftet ift, unb uad) biuten in einen geraben, überafl gleid) weiten Darm übergegt. Das Rerben= fyltem beftebt aus eillem mafïsen Sd)lunbringe, you beffen nuteres 5älfte sint biffer Rervenftrang abgebt, Der erft an feinem biuteren Enbe

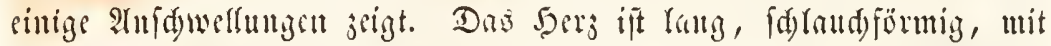

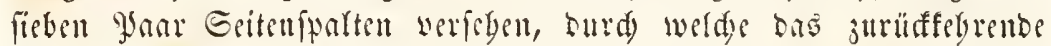

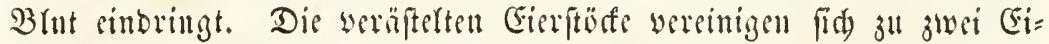
reitern, bie an ber $\mathfrak{B} a$ fis bes berfelfürmigen erften Riemenfubes nabe an Ser Mitteflinie auf Set oferen Fläd) aแsutuben, mo benen bie

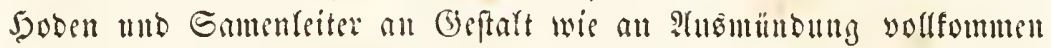
entiped)en. Lleber bie Entwittelung find uto frine lluterfudutugen

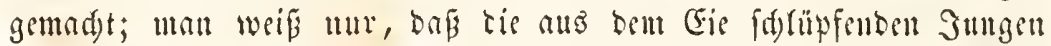

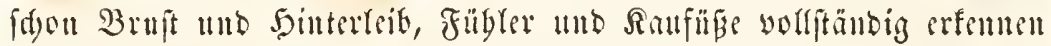

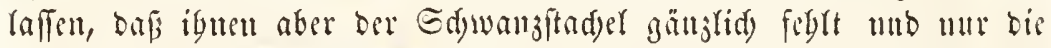
beiben vorberen sitemenjuptane worbanben, bas britte aber wolfom= men rubimentär ift. Die einjige Gattung biejer llnterflaffe, weld)e

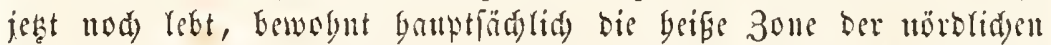

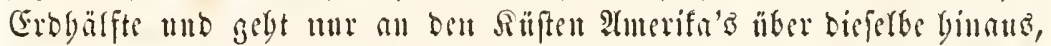

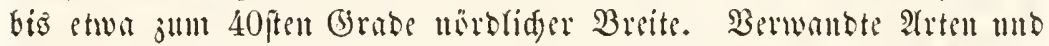
Gattungen bat man vereitjelt iut llebergangsgebirge, it ber soble,

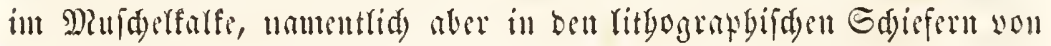
Soblengofen gefuntent.

\section{Lutrelitajfe ine stichunger. (Podophthalma.)}

Die Siruftentgiere, welde wir disfer Interfaffe zurednen, unter= (d)eiben fid in sielen wefentliden Syutten wou Den vorkergebenten, wie won ben nad)folgenben lluterf(aflen, nub bieten gewiffermaßgen ben 


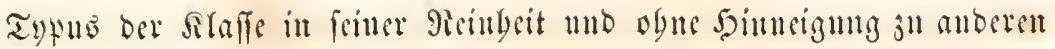

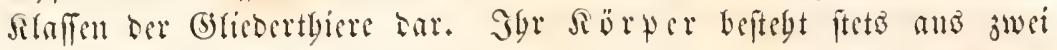

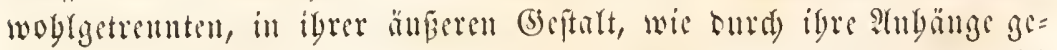

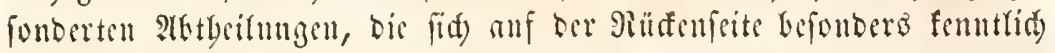
mad)en, nämlid aus simer Sopfbruft, welde bie Sinneswerfienge, ben

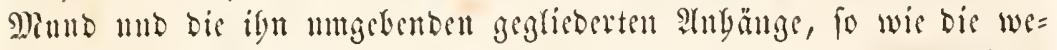

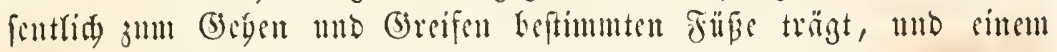
Şinterletfe, welder fteto ans einet grofferen ober geringeren ?tnzabl

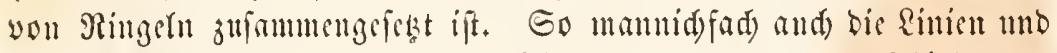
3eid)ungen ses Sopferuftids ito ses frin mögen, welde Darauf binbenten,

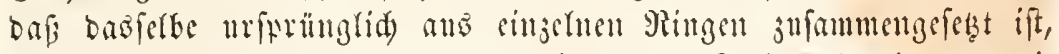

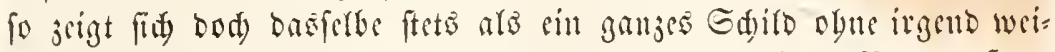
tere stbtheilungen; unt bei sinigen (5)attungen, wie 3. $\mathfrak{B}$. Den Sou=

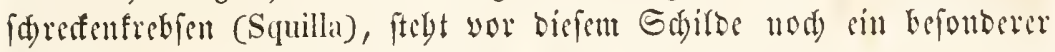
Pring, welder bie Angen mnd bie vorberen Fingler trägt, unb ben man

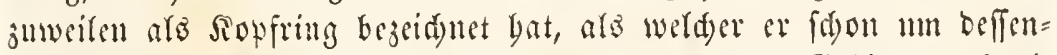
willen nidyt betrad)tet werben fann, weil weber bas (Sebirn, nod) bie Munböfrnung it biefen Ringe liegen. Bei benfelben Battungen ift

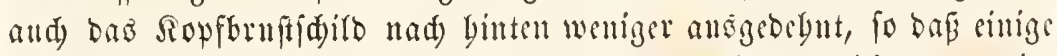

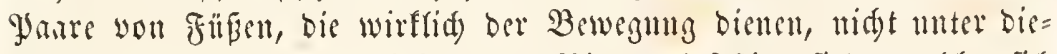

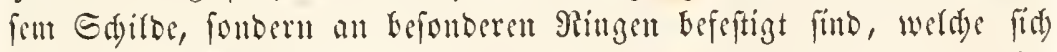

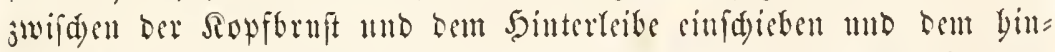
teren Theife ber Bruft angebiren; - afer trog bicfer Berfecinerung Der Sopformft trägt riefe bennod) bie wefentlidften, ju (s) reiforganen

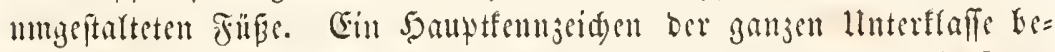

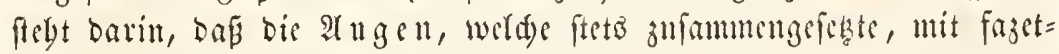
tirten 5ormbäuten veriebene Prugen fint, auf befonderen beweglidaen Gticlen frisen, die zuweiten eine bebentente fänge etteichen und ge=

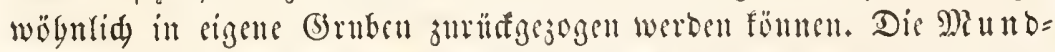

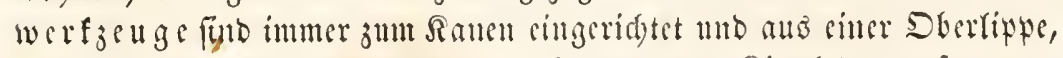
sinem Saare Riefer und meleren Saaren von Simnlaben jufammen= gefetzt; meift finden fid aud) nod) simige befondere gaare von Rau=

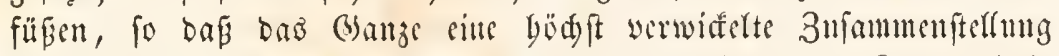
yeridiebener geglicberter Sigane zeigt, welde balb. zmun Rauen, barb jum Bürifen, Betaften und Picinigen Der Pabrungsimittel bejtimmt find.

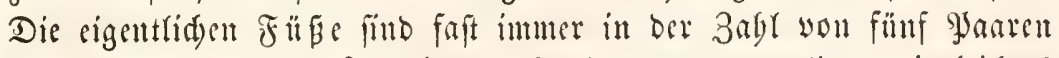
yorbanden, was eben fo, wie bas Feblen siner lluterlipte, sin leidsteb Sennjeiden jur lluterifgeibung won ber folgenden lluterflaffe abgiebt. Die Jinfe felbit find meiftens cylinbrifa, uno entweber jum Geben, 
Sdywimmen oder (Greifen cingeridytet, wound) namentlid) igre End: glieber febr veridyiebene formen jeigen.

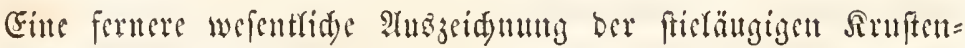

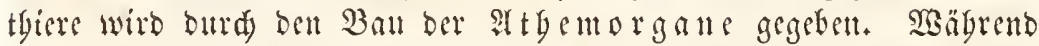
in alfen übrigen linterflaffen entweber die Jübe feleft, ober sin Theil

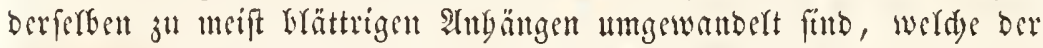
Stbmung vorfteben, finbet man bier eigene? Ptbentorgane, Sicmen, won ge=

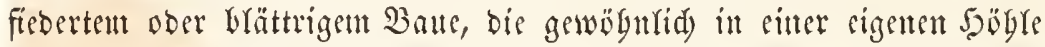
unter beut Sopformfteilde geborgen fint, zuweiten aber aud frei an Det llnterfläd) bes Rörpers, an ben Baudjfüpen angebeftet getragen wetben. Rur bei einigen wenigen Gattungen, bie burd igre librigen Cbaraftere inteffen biefer lluterflaffe angebören, fdeinen diefe fiegielfen Siemen an feblet, wäbrend fie bei feitter auberen lluterflaffe ber Irus fientbiere vorfoumen, fo baß man ifre Exiften wenigftent unbebingt

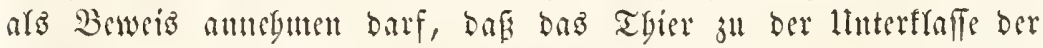

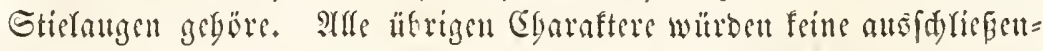
ben Merfmale Darbieten, baber wir Dieferben bei ben Dromungen feleft in bie *hagen faffen werben. Sair thetlen bie ganje lluterflaffe in zwei Sromugen, Yeid)t fenttlid) burd) bie Biroung igrer Siemenorgane.

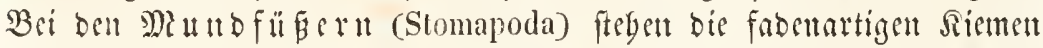

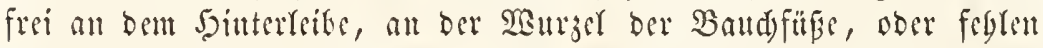

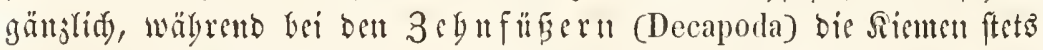
in befonderen 5öblen unter ber Sopfuruft geborgen fint.

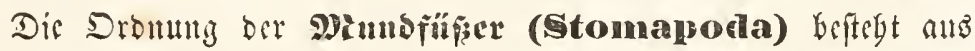
énigen wenigen, felgr cigentgütnliden Familien, welde verfdyebente

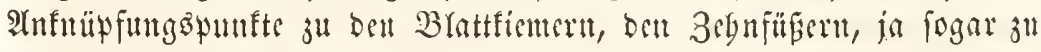

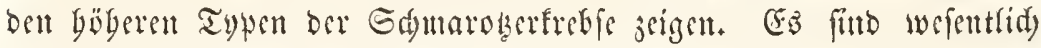
fdywiumenoe Thiere mit meift rangem Särper und furgem Ropfbruft= fdilos, wou bem gewöburtid) ber stugenring volffoumen getremt ift. Diejer trägt banu dic lang gefitielten, fajettirten 2 tugen unb bie vier Filigler, und juweilen ift er frlbit nod) in jwei Ringe gefpalten, you Denen bann ber bintere ben Gintenfungsopunft Der Fübler giebt. Die

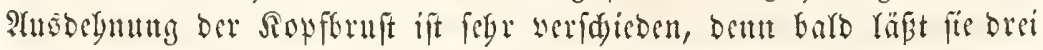

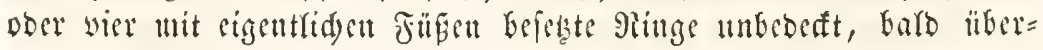

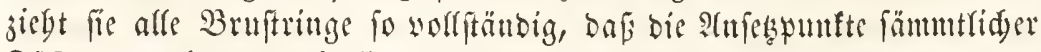
Fübe von oben gebert find, wobei indeflen bod bie Pinge auf ber unteren Seite erfenttridy Kreiben. Die Bifoung ber Fübe und bes Sinterteibes wed)fert auberorbentlid, bei ben verfojedenen Familien.

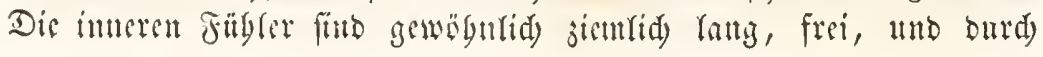


mebrere vichglictrige Fäben gentigt, bie änserent cinfad, an ibrer Bafis mit cincm grofien geficberten Batte mo an Ende mit einem vielgliebrigen Jaben verfebent.

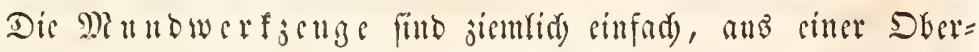
rippe, eincm Yyar Siefer tmo jwei Yyar Simnlaben, bie frime bejon=

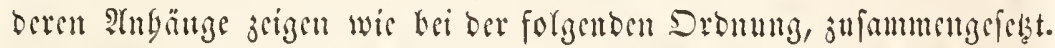

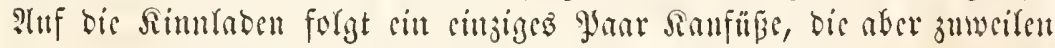
ganj feblen, oder ju Sdumumfüben umgewandelt find, tho ficken bis ad)t baat eigentfider Füpe, bie oft ganj gleich geftaltet find uno meiftens cinen triferartigen 2 thyang, fo wis an ber $23 a f i s$ sint weid) blattërmige Crrweiterung tragen. Die binteren finfe find gewöbnlid S(j) wimmfübe, die vorberen (5) reiforgane, bant aber niemals mit cinter

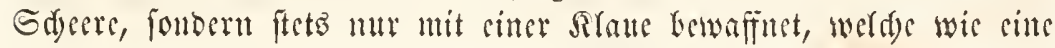
Silitige geigen bas vorbergebende (j) fied eingefdlagen werden fann. Mieifens werden afle bicfe Fupanbänge gegen ben Maut bin cinge= folagen, weber bic Dromung igre Pamen befoumen bat. Die Bands)=

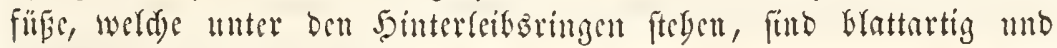
tragen an igrer Bafis gewöbntid) die büfderfürmigen, aแs veräftelten Fäben getritbeten Riemen, nur bei wenigen Gattungen fint biefe freien

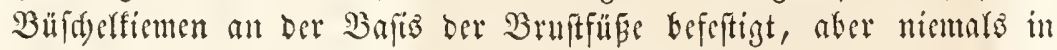
ciner eigenen 5̧ïgle cingefd)loffen.

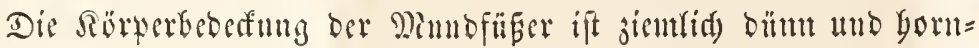

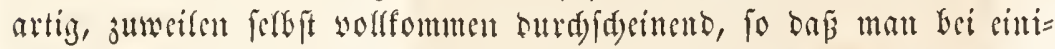
gen flemeren Thieren ber Drbunt faft alle Drgane burd) bie Sïrperbedeftung Gindurd erfemen famt. Das $\mathfrak{R e r y e n f y ~ f t e m ~ i f t ~}$ je uad) ber Söryerform verfdyeden angeorbnet, indem bei ben lang= reibigen Senfdereftentebfen cin langer Gtrang mit vielen Sinoten exiftirt, wäbrend bei oen furjleivigen die Berbindungeringe jwifden

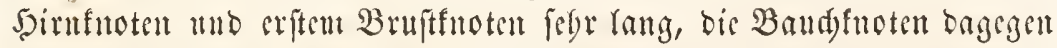
ju citter Saffe verfdumblzen find. Der Mimb liegt gewöbulidy febr writ uad bitten und fülut burd) einen furjen Gdylund in cincu feften Dragen, ber mit Sormplatten mo regetmäßigen 9ieigen won 5aaren Did) befeget ift. Bon ba aus gebt Der Darmfanal gerabe nad) binten mo ift auf beiben Seiten wäbrent feimer gaujen Erftrefung son ben Büfdeln Der Eeber untgeben, bie an werfducbenen Etellen int frime

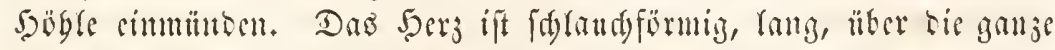
Mittelfinic Des Rüctens bintgejogen, giebt citte Mienge feitlider (Jefäse ab und bat vicle obere Spalten, Durd) welde das rühfebrente Błat

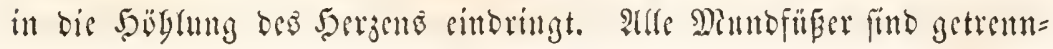




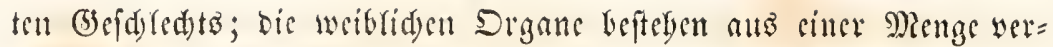
äftelter Rappen, werdye Detl Sointerleib ausfüllen unb fid in cinen rangen Sd)laud wereinigen, or mad) wort brei ringförmige fort: füze bat, bie wicber mit sillanber verbunbert fillo unb fid in oer

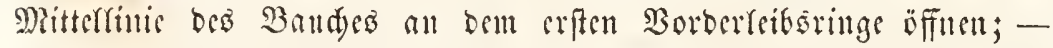

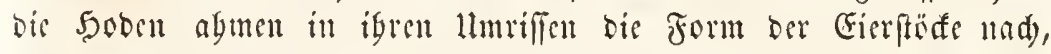
ëfuen fid ater an ber Bafis bes binterften Fufpaares it zwei bort befinblidge Gornige Ratben. Lleber dis Entwidelung ber Embryonen biefer Tgiere find nut wenige 3 cobadytunget gemadjt, weldye inbeffen

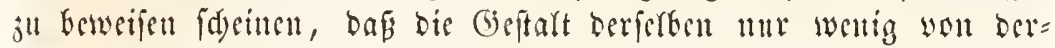

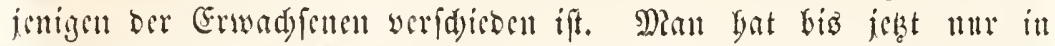
Ien Edjidfen beg Monte Bolea, bic ju ben unteren Tertiärgefilden

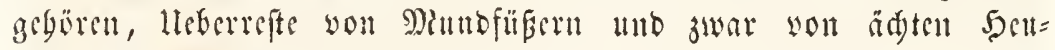
figreffentrebfen (Squilla) gefunben.

Dic Frmilit ber Flachfeble (Phyllosomida) beftebt aub anter:

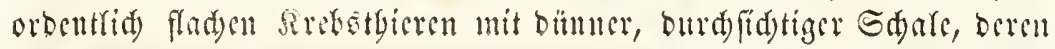

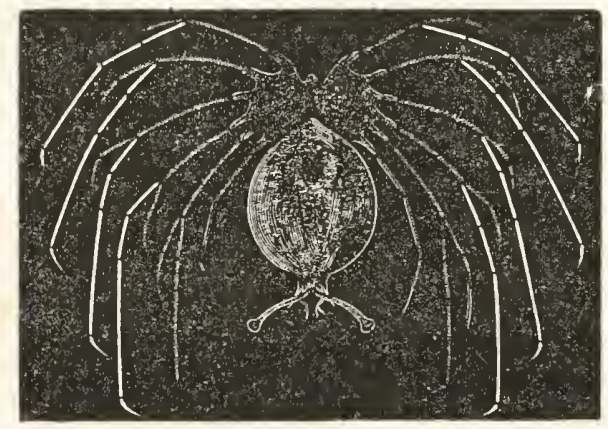

5ig. 516. Phyllosoma.

Söper to fegr abgeplat: tet ift, Dab faum cin Ramu für bie Ginge= weibe juifden oer obe= ren unb unteren Eda = Yenbälfte librig bleift. Das Sioffermftidsto ift gewëgulid breit ofer Yänglidg utlo bängt เtu: itl Der Mitte an Den Bruftringen an, wäb= rend cô fouft nad) allen Seiten frei ift uno wou unten ber mit ciucm sueiten jufammen=

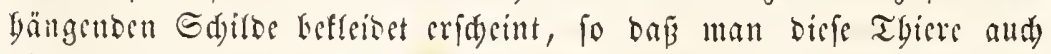
Die Dofkeltgesanzerten (Bipeltata) genanth bat. Dic Angen fino grof̈, auF büntu Etielen getragen, die inueren Füblet an Ende geiparten, bis änberen balo borfitig, Galo blattartig. Der Mnub riegt weit bin=

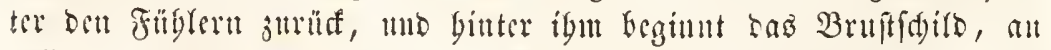

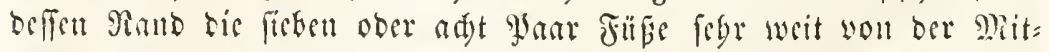

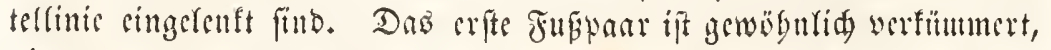
bie anberen lang, bünu, gefparten, jum Sthwintmen cingeridstet. Dir

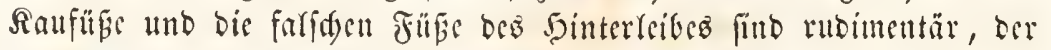
Sintterleib wentig entwidtelt, aber mit cincr fïnfblättrigen Edywimm= 


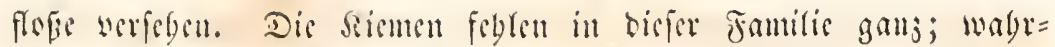

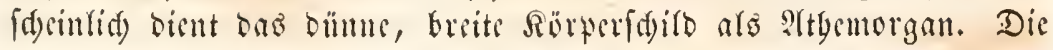
Thiers find Sdjwimmer mo werben une alf ber yogen See, meift in fiitriden Miecren angetroffen. Phyllosoma; Amplion.

Dic Familie ber Şenffgrectenfrebje (Squillida) bietet bie gröfiten Irten ber ganzen Dromung bar. Der 2 angenring ift beutlid getremnt,

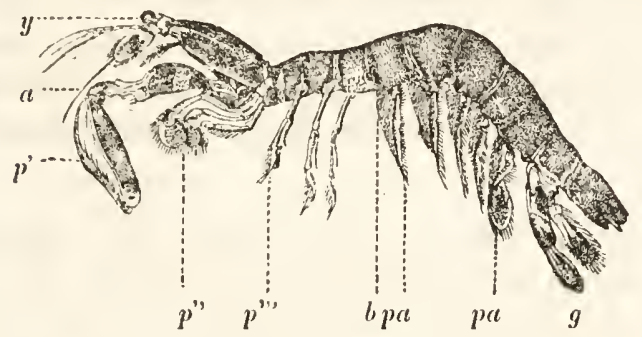

öig. 51\%. Şeuiduretenfrebs (Squilla) wou ber Seite.

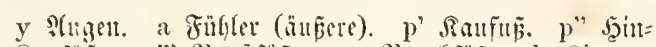

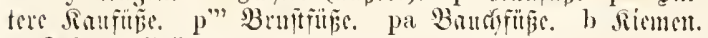
8 Esimamjfolle.

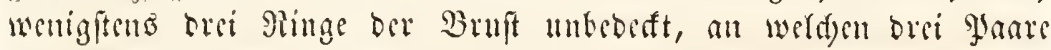
furzer, cylinbrifder, woin abgeplatteter silbe fteben, sie feine sianen tragen uno nur zum Gdyvimmen beftimmt find. Sor Mand liegt jiemlidy weit natf binten, ift mit sicfern, jwei glaar Sinnlaben mo fünf Jaar Aieferfüben bewaffuet, won benen bas erfe Jaar frielförmig unb bie brei legten Jaare mit cinem blafenförmigen shbange werfiben

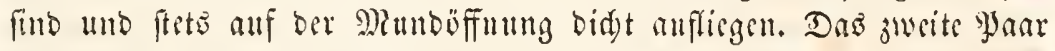
riffer Sieferfüpe ift auferorbentlid) grofi, ftate mo ju cincm $\Re a n b=$ fube ungeftaltet; fein reştes, gewöburtidy mit Gradjeln bewaffetes Silanenglic forlägt fia wie sine silinge gegen das vorbergebsube

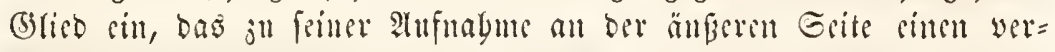
tieften, oft cbenfallo geftadselten Jarj befint. Der Sinterleib ift rang, febr ftarf mo fräftig, mo bas bauptiäd)lid)fte Ed)mimmorgan. (5)

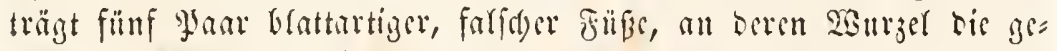
freberten siemen befeftigt fins, mnd ift an frincm binteren sube mit

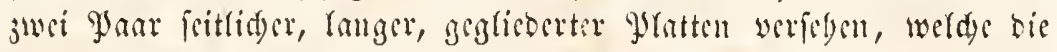
Dberfläde biefer floth beocutenb vergröbern. Die ränberifden Thiere

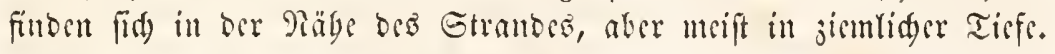
Squilla; Gonodactylus; Squillerichllıys.

Den llebergang ju ber nituften Dromuns madyt bie Familie or

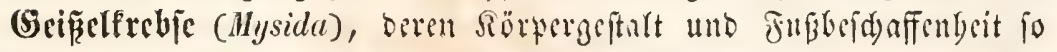
febr berjenigen ber Garneclen gleidst, baj̄ man fie frïber zu benfel= 


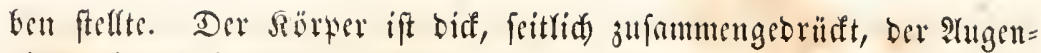
ling mit ber Ropforuft verfdumoljen, bie Bruftringe fämmelid won bem

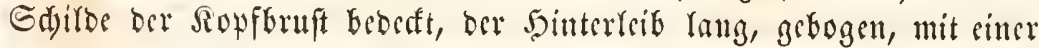
mäd)tigen, fünfblättrigen Sd)wimmflope verfeben, bic Bruftü̈pe alle untersinanber gleid, an 3abl wed)fertub, meift mit sinem langen, ge= glicberten Anbange verfeben. Die fismen feblen barb gänjlid, barb fitien fie in Büfd)en an ben fünf SJanen ber Baudffïfe, ober all ben

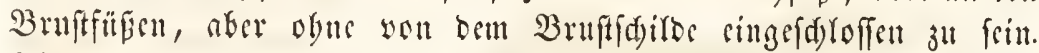
Die Thiere fdwimnten in Edwärmen in boben Meere, "nb sinige

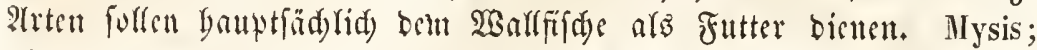
Thysanopus; Leucifer.

Dis anzerorbentlid) grofie mito zablecide Dromung ber Bebu=

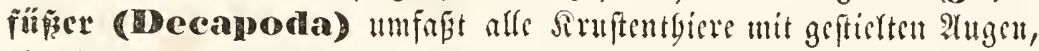
bie sine ungeglieberte Ropfbruft befitsen, unter welder in siner sige= nen Sö̈ble bie Sicment angebrad)t fitto. Es erfdesint biefe Dronumg

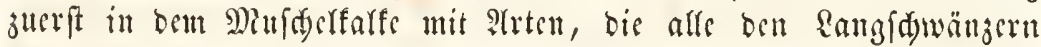

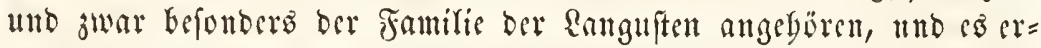
reidyen bicfe sangldwänjer in sen jurafinfden Sdidjten eime beben=

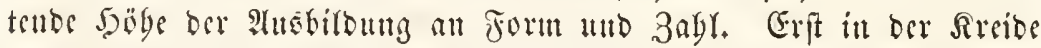
gefeflen fich bie Sirabben zu igren Sorgängern, fo bafi aud bier eine

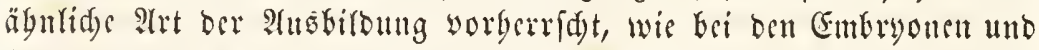
Rarven ber büberen Typen, indem, wie wir fegen werben, bie Rarven ber Siraben anfänglid) langldwänzigen Rrebjen glcidyen und erft

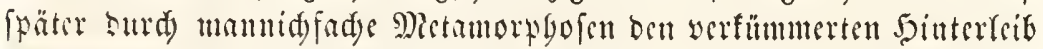
crbalten, ter fie in Dem alter darafterifirt. SBir theifen fie in orei

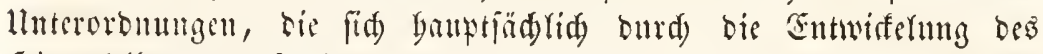
Şitterletbes anterfidgetben.

Die llnteroromng ber Arebie vocr Sangibuäujer (MTacroura) begreift langgeftrectte Thiere mit fräftig entwiffeltem binter: leibe, beren Bruftfdilo meift siel länger alo breit ift, and fid feitlid)

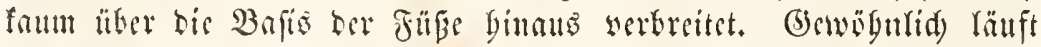

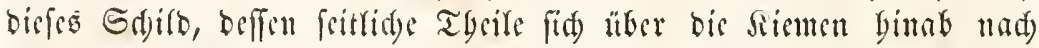
unten wölben, nad) vorn in eitte zwifden ben slugen frebentos Spike

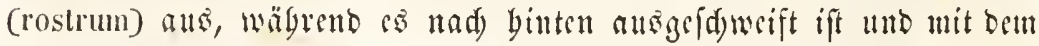

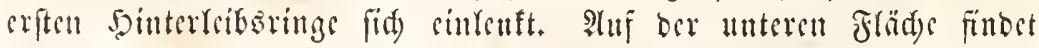

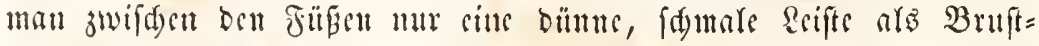

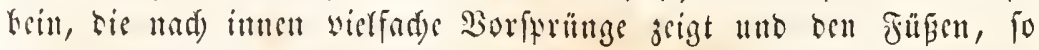

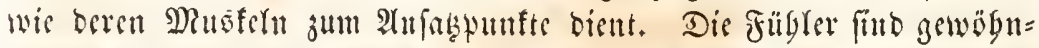
lid) fegr entwisfert unb fteben meift anf oerferben Rinie; bie inmeren 


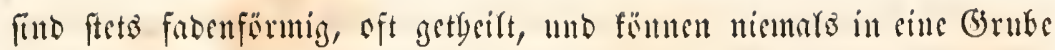

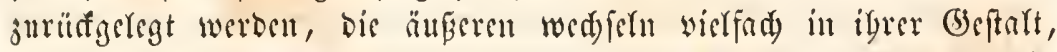

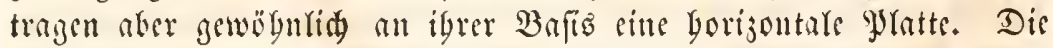
Minndwerfjenge, bie in ciner vertieftent Grube Yiegen, fint fegr com= plicirt, unb beftelyen aus ciner Dberlippe, cinem झsaare Siefer, weldjes

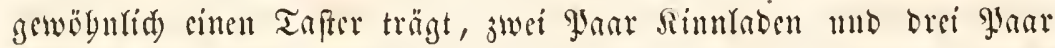
Saufüben, won welden bas erfte blüttrig ift, nub bie alle brei fowobl

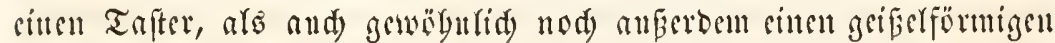
Itnlang tragen, weld)er in bem 2tusfülrungsgange Der Riementyöble

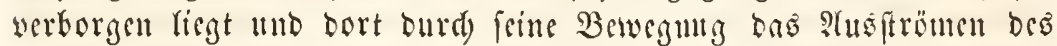

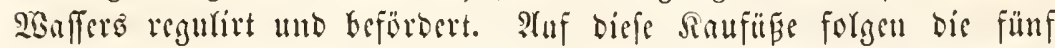

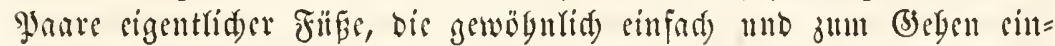

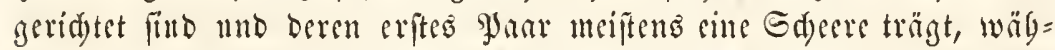
rend dis übrigen mit cinfadjen Sifanen bewaffuet find. Dis relative Ins ftimmte Negel aufanfelfen, wonad) biefe Modififationen fid ausbirben. Der binterleib ift ftets mäd)tig entwiefelt, meift nad) unten gebo=

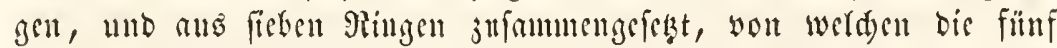

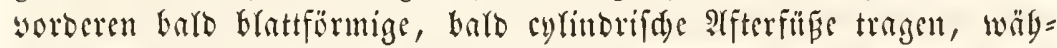
reno Der fedfite Ring jur Grite sin \$aar $\mathfrak{B}$ (ätter trägt, bie fid an

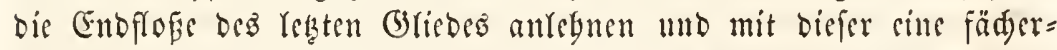

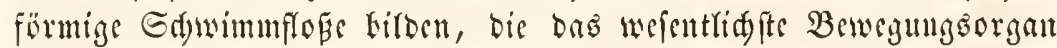

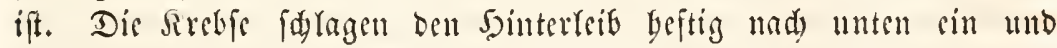

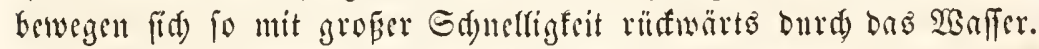

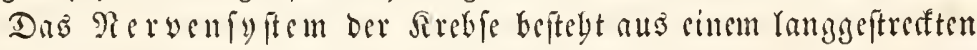
Bandmarfe, ona gewögulid zwörf Sinoten jeigt, bie burd boptelte

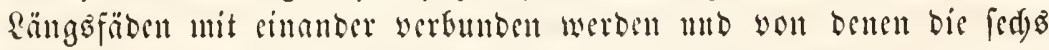

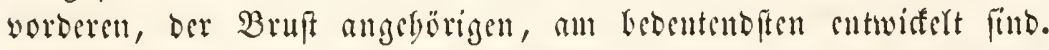
Der Soirufnoten ift meift jeentid) bebentend, quer gefiteft und burd)

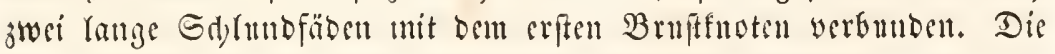

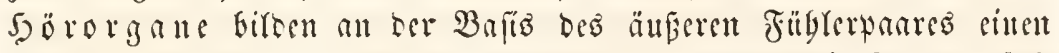
ftumpfen Borfprung, beffen rundride Deffnung burd ein Troumelfell, Das in ber Mitte meiftens sinen Ed)liz Yat, geidlofien ift; binter

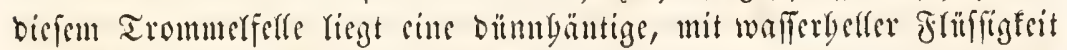

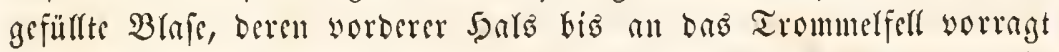

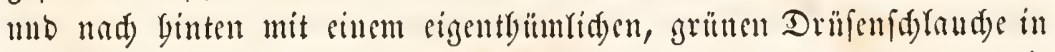

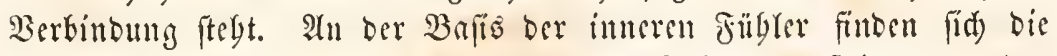

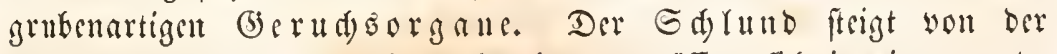

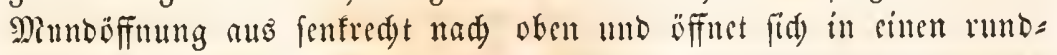

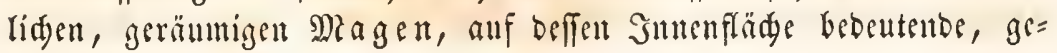


zäbnelte Sormplatten ober and) mur borngare frben, dic offentur

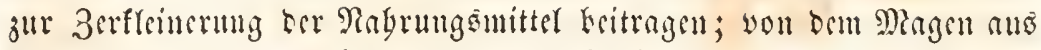
eriftereft fid Der Darmfanal gerabe nad) binten und öffuet fid an ber

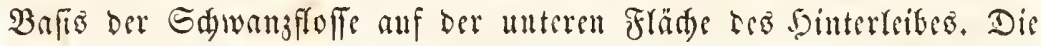
eeber ift bedeutend gróa und beftegt jederfeits ats cincm Bünder

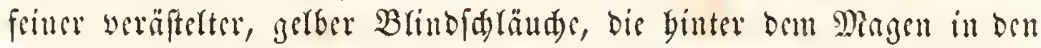
Darm münden. Dos $\mathfrak{S}_{\mathfrak{1}} \mathfrak{r}_{3}$ liegt ummittelbar unter bem Ginteren

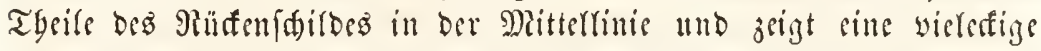

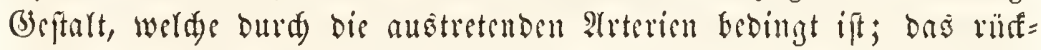
fegrente Bhut wirb gewögntid ourd) fedse, obere, untere und frittide Spalten aufgenommen, die inber oft nid)t ganj leidjt wabrjunclymen find. Die meift in beocutender 3agl worbandenen siemen beftelgen ans cinem Sdyate, ber anf bem Boden ber Mefpirationszögle feftge= beftet ift unto an ber Seite zarte Eylinter ober Blättd)en trägt, welde (iid) nad) ofen immer medr weriüngen, fo Dar jebe folde Rieme sis

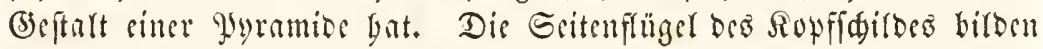
die Saantung Der Rismengögle und laffen unten mur an Der Bafis oer Beine cinen Sd)rits jum Ceintritte des SBaffers, weldes Dann

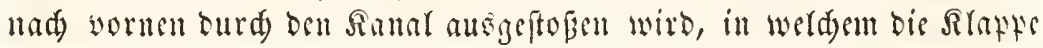

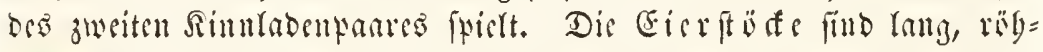

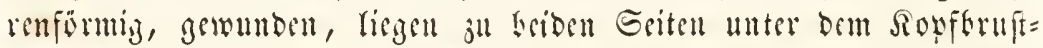

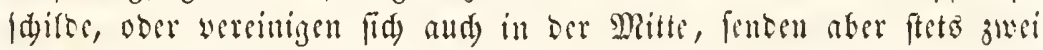

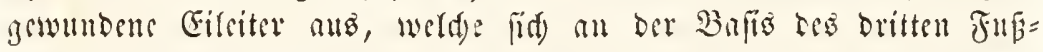

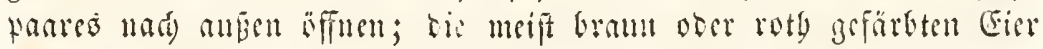
baben sine jiemlid) ride Edyate uno werben mittelit cimes flebrigen

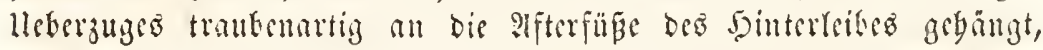

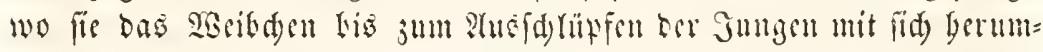
trägt. Die 50 ben Gifoen bard einen sinfacien, bald sinen boppelten Drüfenfürper, werder mit sincm erweiterten Enmengunge joberfeits

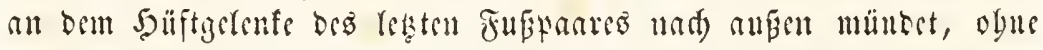
dap lier befonters 9uttyen wagrgenommen werben fümuten; bagegen

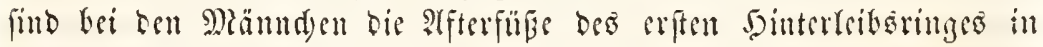

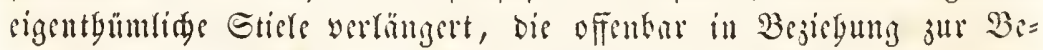

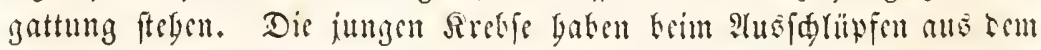

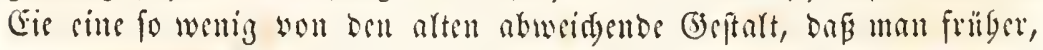

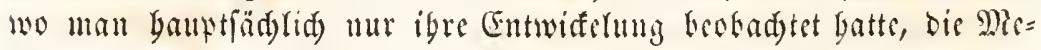

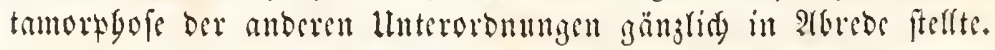

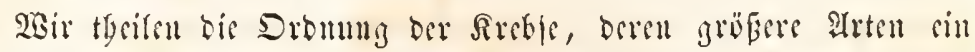

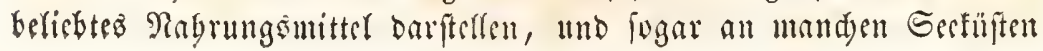




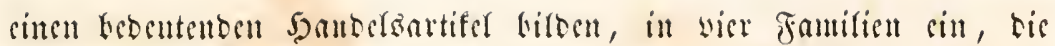
fid) surd) forgente charafters won sinanber unteridsciocn.

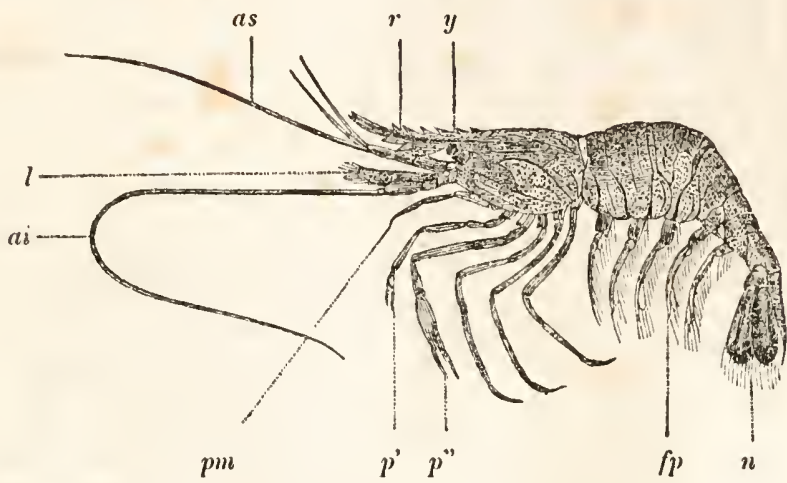

žig. 518. (Banecte (Palaemon)

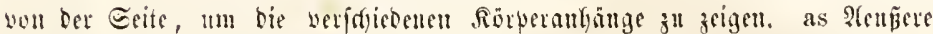

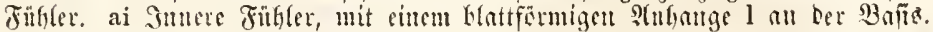

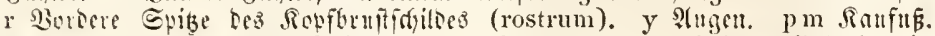

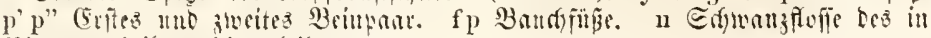
Singe getheilten sointerleites.

Die Familie ber (Sarneelen (Carida) bejtebt aub meift fresuen Srebfen mit bünner, Gornartiger Rörwerbebefung, beren Rumpf ge= wögulid von ter Geite zufammengebriaft und oben mit sincm fdar= fen Siele verfeben ift, welder nad) woun in einen langen, oft gezabnts

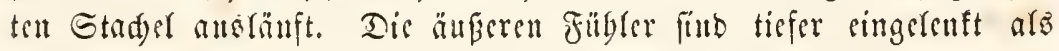
Lie mitteren, uno mit eimem groben Blattortiage verfeben, welder ben Stier bes Füblers nid)t mur bebeft, foubern meift aud üterragt. Die Jüje fint biun, lang nut cin ober juet Yyane berfelten ge= wögnlid) mit Edecten bewaffuct; Der Şinterleit ift lang, worn biff, nad) binten jugefpiet, gewobutid ftarf gebogen unt mit siner febr gropen Gd)manjfloffe verfeben, beren äußere Blätter aus jwei ver= madjienen Gtüfen befteben. Die Thiere leben alfe in ber Gee, mrift gefellin an ben Rinften, fint gewöbulid) nur fleir, bienen aber bennod) allyemein zur Ragrung. Die Familie ber Sarneden jeigt befonbers

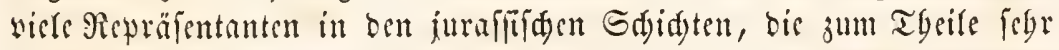
cigentbüutid)en (battungen angebören. Crangon; Alpheus; Caridina; Palaemon; Peneus; Scrgestes; Antrimpos; Aeges.

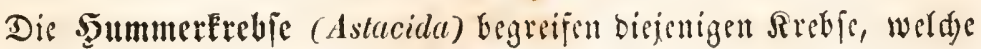




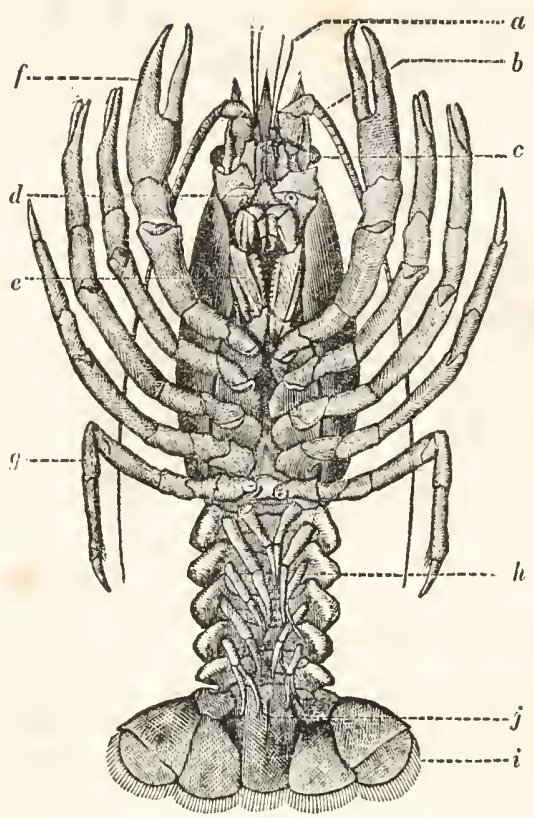

Jiฺ่. 519.

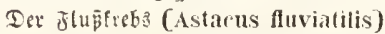

bou unten. a Snnere finfler. b Senfere Tüb= ler. c Stugett. d Befyörorgant. e Retatez ginar

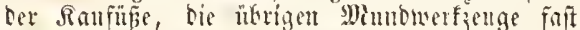
Derfent. f Erites Beintant. g Rebtes Beimuar. h Bandyfinte. j sifter. i Edwanzpluffe.

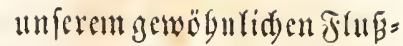
frebfe nabe fteln, who fid Durd) cine barte Sdaale, cine grope ungefielte Sorf= bruit und cinelt mebr plat= ten Shinterleib aแşzid)แen. Die betben Füblerpare find auf Derferfen Suertinie singelenft, Die intueren juei= fpaltig, bie äuferen cinfad), bebeutento verlängert, unb an inrer Bafis mit einer prefafürmigen Đुatte wer= feben, weld)e niemals die (5)öpe erreidt, wie bei ber worigen Familie. Der 5im= terleib if grof, in feiner gaujen sänge faft gleid) breit, nidyt jugefpibt; bie äแ⿰纟eren Brätter Der Sduvimuflofie Durd cin queres (belent getyeilt; bas vorberite Fubsant ift ftets weitgröper alo die übrigen,

und inmer mit einer bebentenden Gdeere bewaffut. Die Siemen find febr jaglreid) unb aus cylindrifden Fäben gefildet, wälrend fie bei Der vorigen Jamilie aแb borizontalen Blättern jufammengefest find. Die gröperen, in ber Gee lebenten ?trten bicjer Fantile, wie nament=

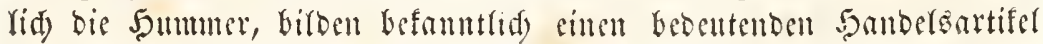
mand)er Sïiftu. Astacus; Homarus; Nephrops; Glyphea; Eryma; Megachirus.

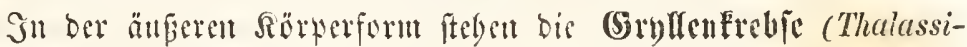
nida) Den vorigen febr mabe, fdyefien fid afer Dutd) igren langen binterteib mo die bormige Siörperfdale mebr an bie Garmeden an,

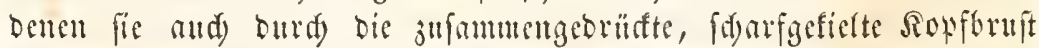
gleid)en. Die stugen find flem, bie imeren fübler botwelfiedrig, die äแperen cinfad) uto nie mit jenten Blattanbange werfeben, ber bie sorigan Familien atsogidyete; Die Borberfïbe find febr groß, mit Sd)eren bewaffuet, die Siemen ans bürtenförmigen Bylinbern ge=

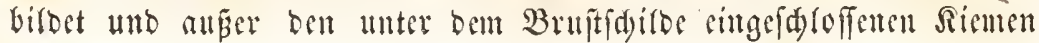


bei ciner (Battung nod) Sícmenangänge an ben Baudffïben entwidett. Die Jamilie ift, wie bie sorige, Kefonders in benl litbographifaen Etrmen won Soblenbofen, bie bem oberen Jura angebören, bänfig vertreten. Thalassina; $\Lambda$ xia; Callianassa; Callianida; Brisa; Magila.

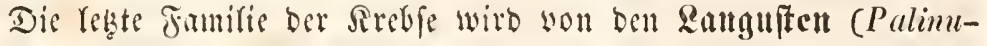

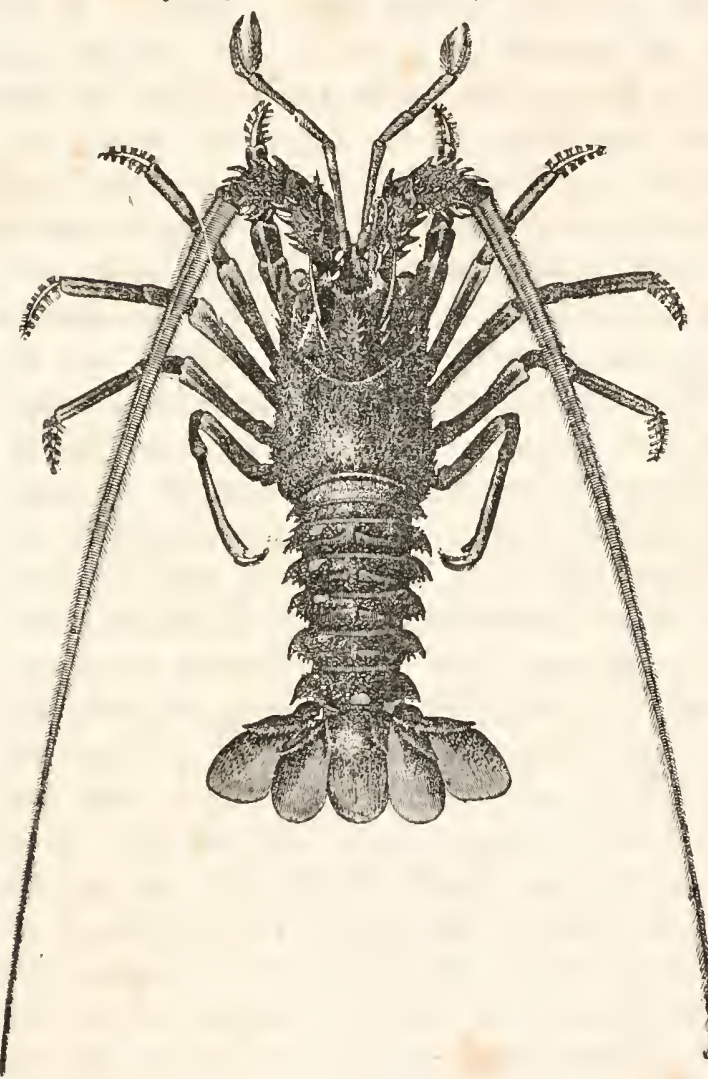

Fig. 520. Rangufte (Palinurus). rida) gebildet, meift groben, breiten, febr bartfdaligen Rrebjen mit furjem, plattem Sinterleibe und plat= tem Ropforufifólilde, Das uad) binten be= fonbers febr breit ift. Die inneren Fübler fitto furz, gewöbultid) ant Ento sweifiebrig, dis äuperen bald felyr rang und borftenför $=$ mig, balo in cine breite, fruftenartige Jlatte verwandelt. Die Birbung Der Jï̈ßе wed) felt, bod) bat bas erfte Jaar unt ferten eine Gdyere mo die anberen niemals̄, bas fünfte Jaar iff oft rubimentär; bie Sd)wanjfolfeift breit, aแsิ fïnf Rappen ge= bilbet, won benen die äußeren ftetsิ, oex mittlere bäufig faft in frinem gangen llmfange bäu= tig ift. Die meift grofien und fdweren Tbiere Yeben an ben Rititen in jiemlider Tiefe mo fint tyeifweife ebento, wie bie bummer, ein bedeutender Sandelöatifer. Befonders d)arafteriftifd) Piepräpentanten biefer Jamilie finben fid in bem Mufdelfalfe unb fpäter in ben juraf= fifden Edjidtent. Palimurus; Scyllarus; Eryon; Galathea; Grimolhea; Pemphix; Prosopon. 
you simigen Familien gebilbet, bie eine förmlide Stufenfolge von llebergängen vou ben langid)wäแzigen Sirebfen ju ben furzid)wänzigen Rrabben bieten, und ftetz dis CGaraftere fer citten, wie ber alloeren biefer llnteroromungen fo mitrinanber vereinigen, ba bie Thiere feiner you beiben Dronungen jugezäblt werben föntm. Die affgemeine Rörterform erimert bei ben eitren an bie Siebfe, mälrent fie bei ben anberen berjenigen ber $\Re$ rabben fo gleid) ift, baß erift eine ge= naucre lluterfud)ung beibe fdeciben Yäpt. Das Ropforuftidjito ift ftets febr anfebulid) unb weit entwiderter, alo ber Şinterfeib, weld)er nies mals, fo wie bei ben Rrebien, Durd) eille breite, fäd)erförmige floffe und

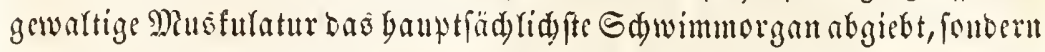
entweber, wic fei ben Siraben, unter ben Eeib gebogen uno rubimentär, ober beutelförmig uno yon weider $\mathfrak{B e f d}$ affenbsit ift. Dic inmeren

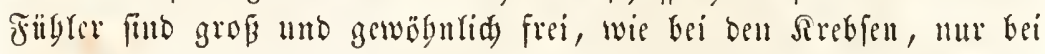

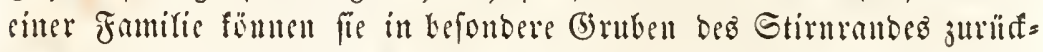
geidglagen werben, wie bies allgemein bei ben Srabben ber Fall ift. Die Struftur ber Bruft wed)felt ungemein; gewöbnlid) ift igr leteter Ning nidyt mit bem vorigen verwad) fen, fonbern mur eingelenft, utb

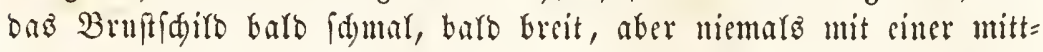

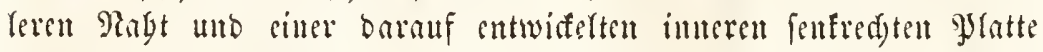

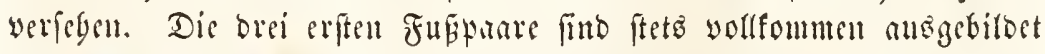
unb bas erfte bäufig mit simer grofent Gdecre verfeben, wäbrent bas fïnfte immer und bas vierte gewöbntid) rubimentär ift, unb bam als fdeinbar liberfliffiger SHbang auf bem Rürten getragen, ober zum Inflammern in Den Tobnungen bentht wirb. Der in feiner form to fegr wedfernde Sointerleib trägt niemals faride Fübe, wie bei der vorigen Drommin, foubern böd)fens an frinem vorlebten Ringe sin

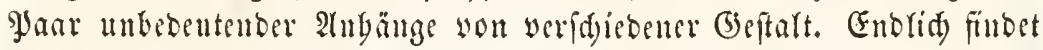
man ein unterfdecidenbes Rennjeiden you den Siraben barin, baß

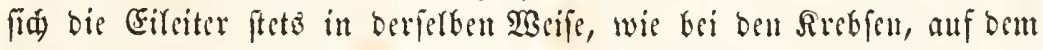

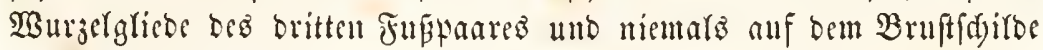

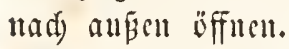

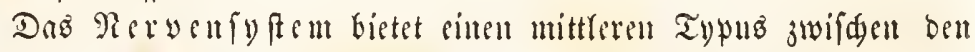
Rrebfen unb ben Rrabben Dar. Bei ben Yangleitigen Thomuran beftegt

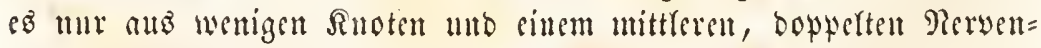

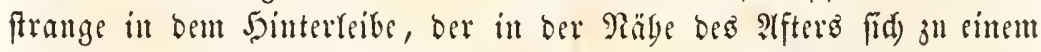
Rnoten veremigt; bei ben frabbenartigen bagegen ift bic ganje Rer= vemmaffe bes Reifes ju ciltem mittleren Snoten weridumolgen, ber nad) Ginten eincu cinfadyen Rerven für ben rubimentären Jiuterteib ab= giebt. Der Magen ift, wie bei ben Rreblen, mit iuneren Sornbaaten 
befetzt, bie Reberorgane bei cinigen febr bebentento entwicfelt, unb ju beiben Sciten bes Darmes cin Kanger Gallengang anşgebildet, Der แad) sorn gegen ben sliagen binläuft. Das Jaerg ift viclertig, bie

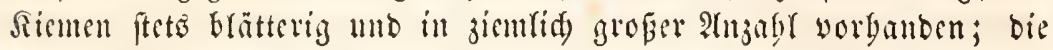

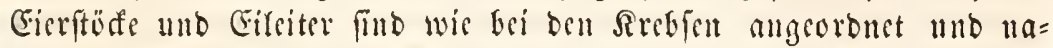
mentlid) feblen bie faffintmigen Gamentaiden, wefdye bei ben Srabben

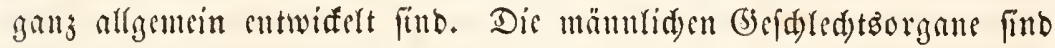

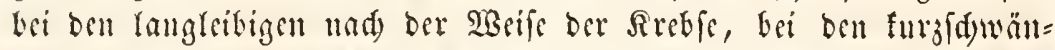
jigen in ber 9 ret ber Srabbell gebildot, mnb namentlid) fomment bei

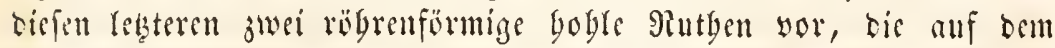

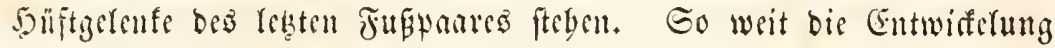
ser Jungen befannt ift, fo zeigen biefelben aud bei ben langleibigen (5)attungen bic dorafteriftifde Embryonenform Der fungen Jiraben, bie wir fä̈ter befdreiben werben, unb bie fid burd sin ranges ge=

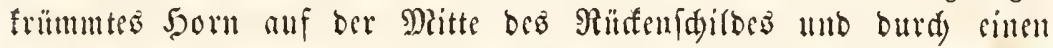
langen, bünnen Sjinterlitb ganz befonbers auşzeichnet.

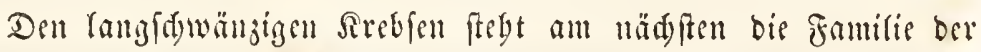
Berngarbincrefrebie (Pagurida), beren Sorfbruft bie geftredte Form

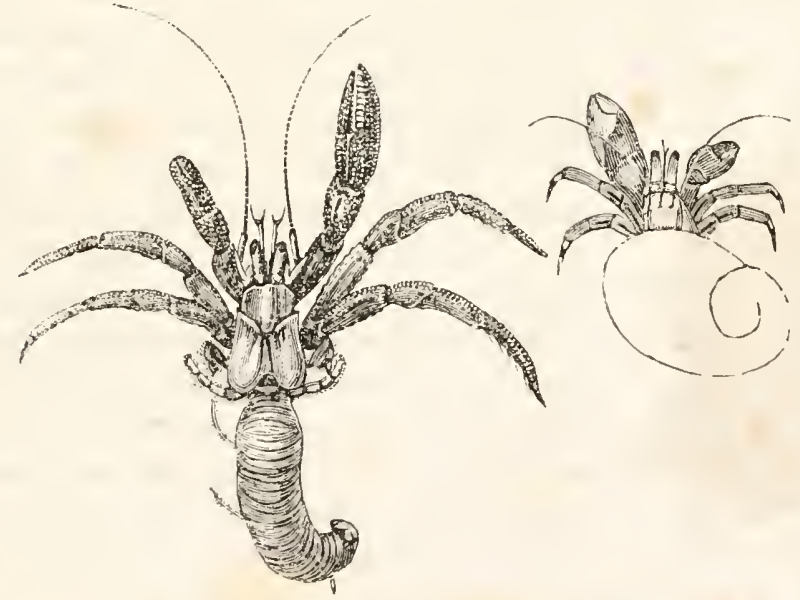

วิig. 522.

8is. 521.

Tet Bernharbiuerfrebs (Pagurus Bernhardus).

Jig. 521. Das Thier ill ber Edurafenjale pibent. Fig. 522. Daz= jelfe lietangenemmen.

Der Srebfe Gat, wäbrend ber Bandi) wollfommen weid) ift, lillo feille Floffe am Sinterende trï̈t. Die Ropferuft ift gewöbntidy burd) eine quere Furde in sine bintere unb vorbere 2tbtheifung oerlegt; bie vor= 


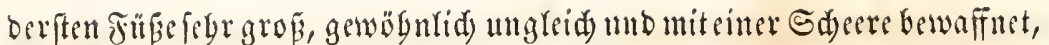
bis beiben folgenben mur mit siner Siraffe verfeben, aber fonft wobl ent=

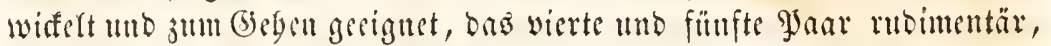
gewögnlid) mit jwei fdwad)en Fingern geentoet, bient meift nแt jum

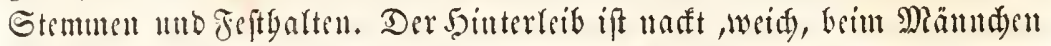

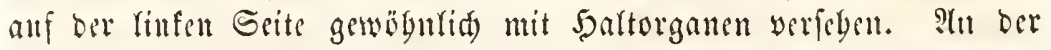
Spitze bes binterleibes befinden fid) jwei Sornbrättden, bie sill Jaar

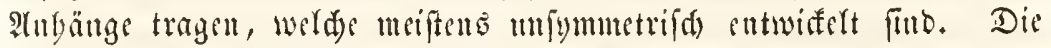
meiften Tbire biefer Fumilis fried)en mit igrem weiden binterteibe

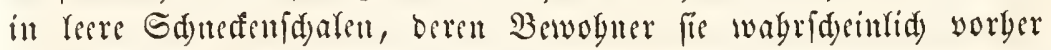
auffeffen, uno flammern fid utit iben binteren föfen unb mit ben 2Hbängen bes Reibes in ben Sduaten feit, bie fie beftändig mit

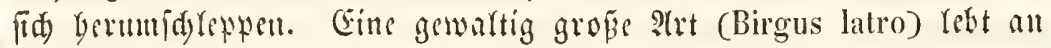

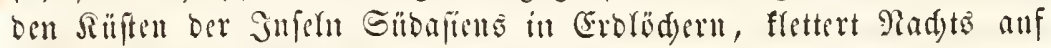

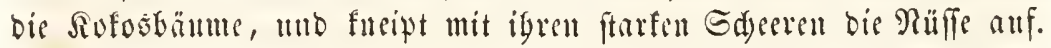
Foffile Repräfentanten bet Familie fimo mit Siderbeit nidjt befant. Pagurus; Cenobita; Birgus.

Die Famific ber Sanderebje (IIippida) bejtebt aus cimer Gruppe

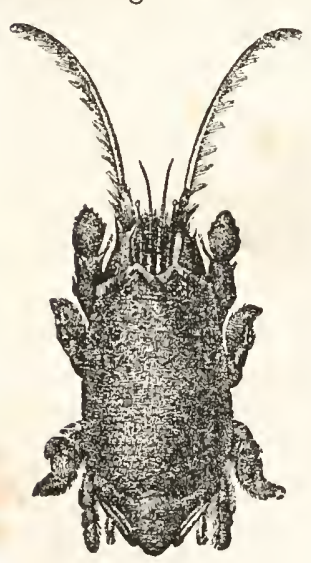

Jig. 523. 11 ippa. fegr fonberbarer Sirebje mit faft eifürmigem, febr gewölbtem Ratuenfdildoe, bas auf ber Seite fid blattförmig uad) unten biegt ullo bie Bafib ber Fübe befft. Der Siuterleib ift jismlids breit, in oer Daitte gewölbt, feitlid) bäutig, umo meift unter bie llnterfläd)e Des siörfers zuriafgefd) (a= gen; bald find bie äuperen, balo bie interen Fiibler verlängert, uno oft mit feitlid)en $\mathfrak{B o r}=$ ftenbuifdern befest; oas Bruffidiro ift Yinten= förmig, แ⿰氵 sie Jïße nur unbegorfen; bas worberite Jaar gewöbulid mit sinsut Safen bewafinet, bie nädjtiolgenten mit siner Emo= platte veriegen, welde fie jum Graben gefdift madyt; bis binteriten Fin̈e find meift rubimen=

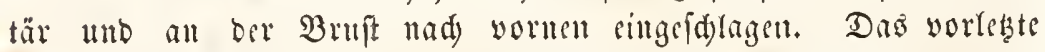

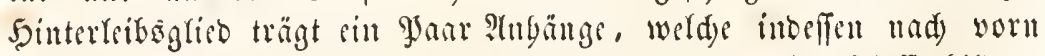
geridgtet fint unb niemals mit bem Yeşten Griebe eine floffe bifben. Die Thiere leben vergraben im Sanbe, meiftens in fübliden Meeren, fint aber bis jetzt nod) wenig unterfud)t. Hippa; Remipes; Albunea.

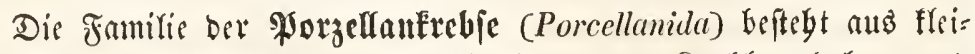
nen Senfentbieren, welda ganj die Jorm ber Srabken baben, nno 


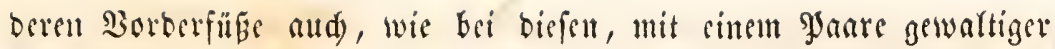
Sdesern bewaffuct finto. Dis änseren Frügler fint intoffen fegr laug unt bie imteren fömen nidyt in siue Grabe geborgen werben, wie bei

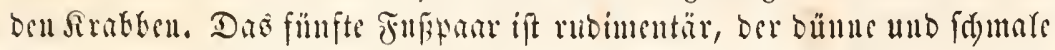

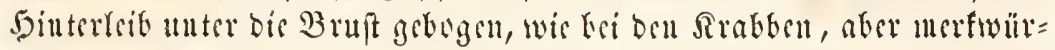
bigerwsife nidfts befto wentiger mit sincr (Enteftoffe verfslyen, wie bei ben Irebfat. Die ffrinen Irten Trben im Sanbs vergraben an unfe= ten $\Re$ äjtsu. Porcellana; Aeglea.

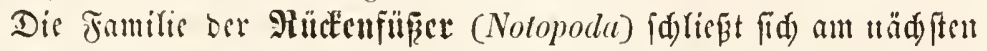

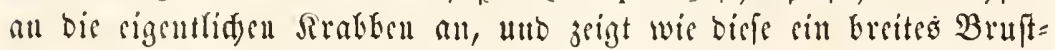

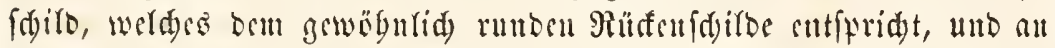
oeffer Geiten bie Funpe siugsteuft fiub. Der Shinterteíb ift ftets bünu,

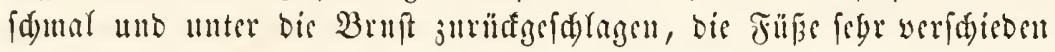

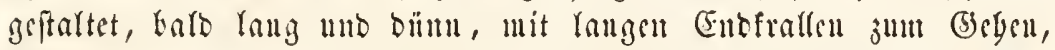

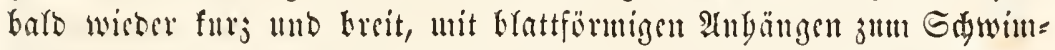

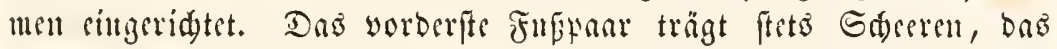
Ginterfte ift imuter verfitmunert, bard fabenförmig, ralo breiter, unb wirb entweber unter ben \&eib gefdylagen, ober alö 2 Thlyang auf bem

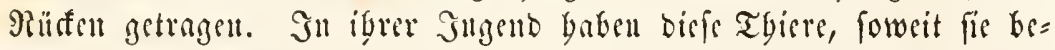
fannt find, sinen bebentend entwifferten Shinterreib mit siner Floffe

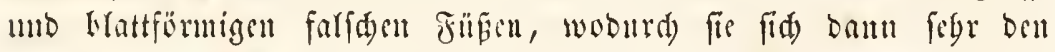
Sirsbjen annägern. Sie find die sinjigen ?tugrbörigen ber balb=

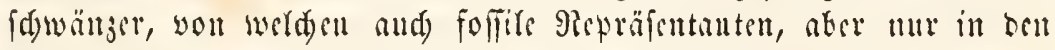
Icrtiärfojidten mub jwar ferten gefunben werben. Ranina; Pactolus; IIela; Homola; Lithodes; Dromia.

Dis lluterorbunng der Rrabben ober Sajd)enferbje (Bra-

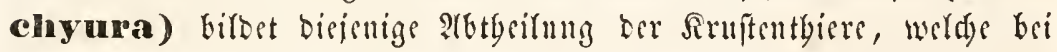

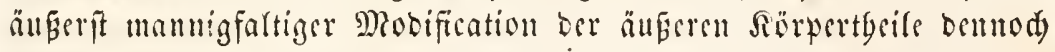
bis grö́te llsbercinftimumng in igrer Srganifation zsigt. Son obsu

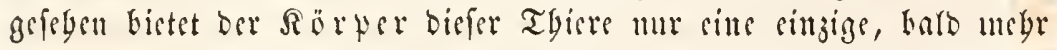

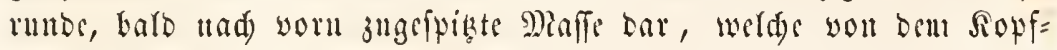

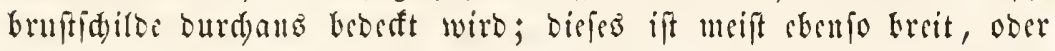

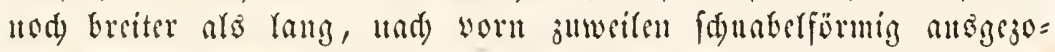
gert, uteift aber abgeftukgt ober itn $\mathfrak{B o g e n}$ gerunbet und bäufig burd)

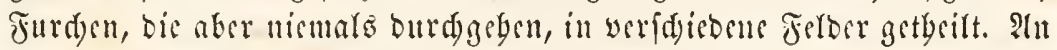

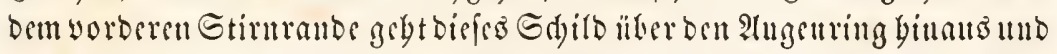

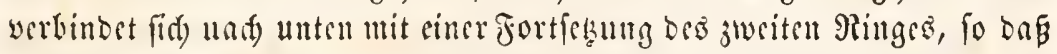
ber 2ugenring gan's innerbarb bes Sdjilbes liegt, unb bie anf bewegliden

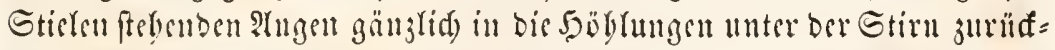

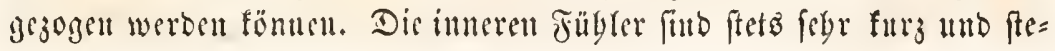

\$ogt. 3oologif be Sorieft, I. 


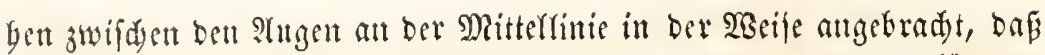
fie gănjlid in Dmergruten bes Stirmranbez zuritfigegogen werben fönnen. Die äuferen Füblex fitto ebenfalls fmz, aber nid)t zurütziebbar. Das Brmitfdiro biegt fid) yon allen Seiten nad) unten um, ano läpt auf ber un=

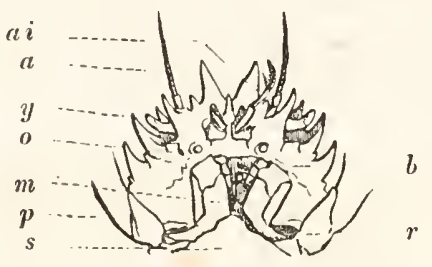

ซึig. 521.

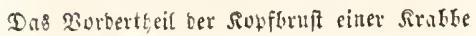
(Maja) rou unten geję̧en.

ai Smmere Titfler. a Senfere Füfler.

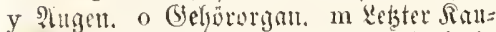

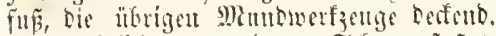
p Bafalglied tes wordereu Erberenfupes.

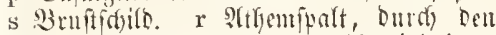
Das 28 afier in bie Riementyogle eindringt.

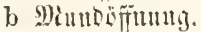
teren fläd) tuur einen geringen leeren Paum, ben $\mathfrak{M} \mathfrak{a}$ norabmen, itt weldem bie Sauwerfzenge angebradst find, und in beflen vorberen Eafen fid Dif ausfügrenden Santhle Der Riemengöblen öfnen; - nad bin=

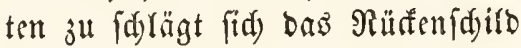
auf der Seite fo eill, bar es bie ganze Rimengüble Dert, and nur sinen id)malen Sd)liz zum Eintritte Des 2Bafler in bie Siementyöble rägt. Betrad)tet man eine Srabbe won anten, fo ficht man yorn in bem Diunbrabmen bes tutigefd)la=

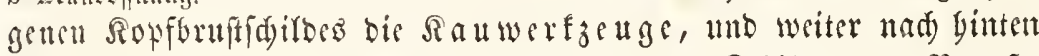
cin breites, bald eiförmiges, balo mebr rundes Sdjild, bas $\mathfrak{B} \mathfrak{r} u \mathfrak{f t}=$ bein ober $B a u d)\{$ ir gelenft fins, wägrent in ber Mitte in siner vertieften Minue ber un= tergec lagene, rubimentäre Şinterleib singelagert ift. Bei ben IBeifden ift Derferbe meift weit breiter, als bei ben Männdenen unb

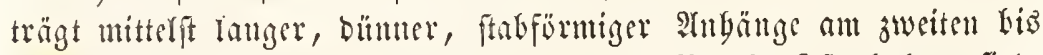
fünften Rintge bie Crer, welde unter bem Bande feitgebalten fint.

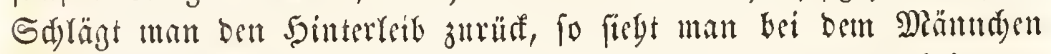
an feincm Grunbe die röbrenfürmigen Rutben, wäbrenb bei bem

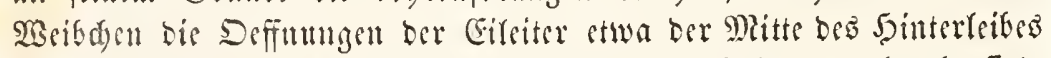

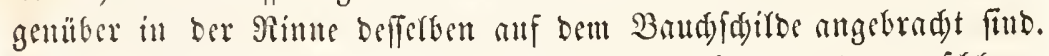
Die Ranwerfange, welde in bem Mantorabmen bes ungefd)lage= nen Bruftiditocs fteben, find förmlid) aufeinander gebäuft, fo baf

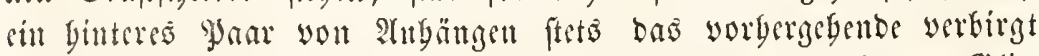

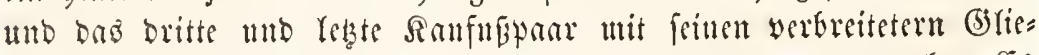

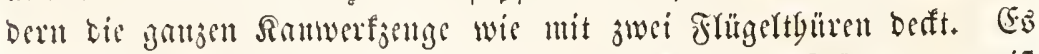

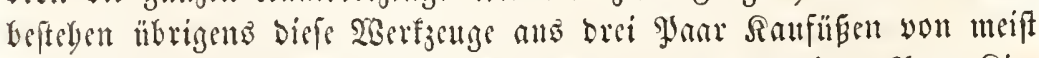

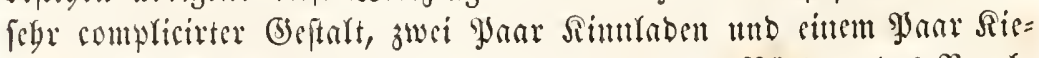
fern. SHefe Sirabben baben fünf cinfad)e, an ben Ränbern bes Band)=

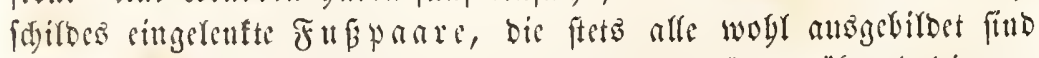
uttb yon benen bas erfte ittmer eitte Gdjeere trägt, wägretto dic alt= 


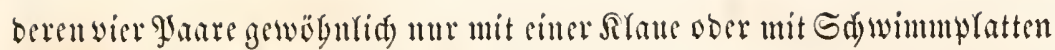
enben. Biele Sirbben find gefdifte Sdywimmer, bie anberen aber

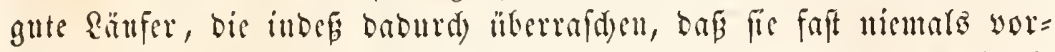
mäts, fonbern ftets แad) ber Seite laufen, was cinen zicmlid) fomi= (d)en :Inblita gewägrt.

Bei allen Siraben ift bie Centralifation Des Nervenfy ftem s mit ber gebrungenen Sörperform übereintimment. Sie Gaben cine Gebirmmaffe, weldge nad) binten zwei ziemtid) büme Fäben abgicbt, bie fid) in ben gropen, runbliden, sinjigen Rërperfnoten einfenten, ans weldem nad) Ginten ein cinfadyer, fnotenlofer Rervenftamm burd) Den rubimentären Sinterfeib entfendet wirb. Der Mag ge ll ift, wie bei ben sorigen llnteroronungen ber 3ebnfï̈er, iment mit 5ornzäb= men ober Şaaren ausgeriftet, mo fez̧t fid baun in ben geraben Darm fort, welder an ber Spitse bes eingefdlagenen Sointerleibes แad) aufen münbet. Die Rebermaffen erfüllen bie Seitentbeile bes

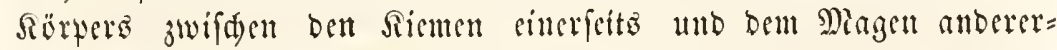

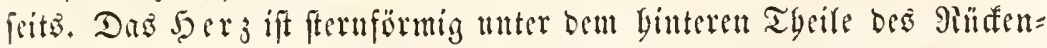
fdirbes in ber Mitte gelegen, fonft aber nidjt verfdeden in Bau unb Anorbung von bemienigen ber Rrebse. Die Riemen baben

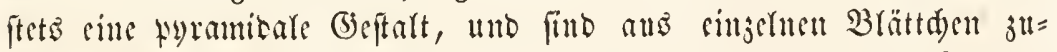
fammengefelst. Shre 3abl ift weit geringer, alō bei ben langid)wän= jigen Siebien und namentlic) ift ftets ber $\Re a u m$ über ben beiben

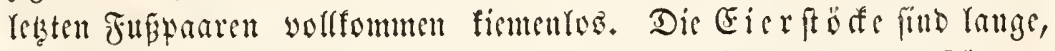
gewundene Räbren, die theits vorn, theils Ginten in Der Sïrper=

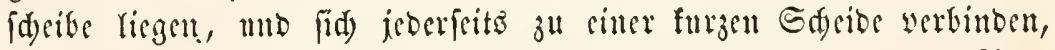

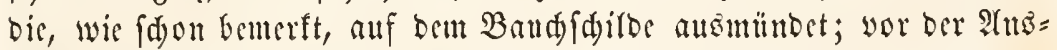
mündung befindet fid an jeber Sdacibe eine birnförmige Samentafde, in welder nad) ber Begattung ber Samen aufeewabrt wiro mo bie vorbeifdlïpfenben Cier befrudtet. Die aus febr engen Prübrasen zu= fammengewunbenen 5 o benf nä ue Ragerung ein, wie die Gierftöfe bei ben Weibden; Dagegen üffuen

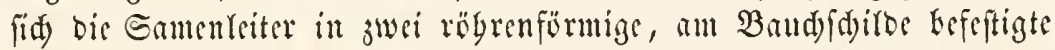
Sutben, welde you bem sinterleibe in ber Rube bebert werben.

Die fier werben won ben weibliden Srabben, wie forn be= merft, unter bem Baudse getragen, unb bie (Fmbryonen fditipfen in

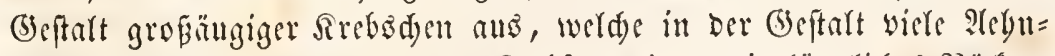

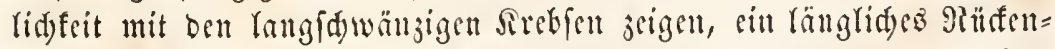
idjiro unb einen bebentenden Jinterleib befizen, mit bem fie fergr 


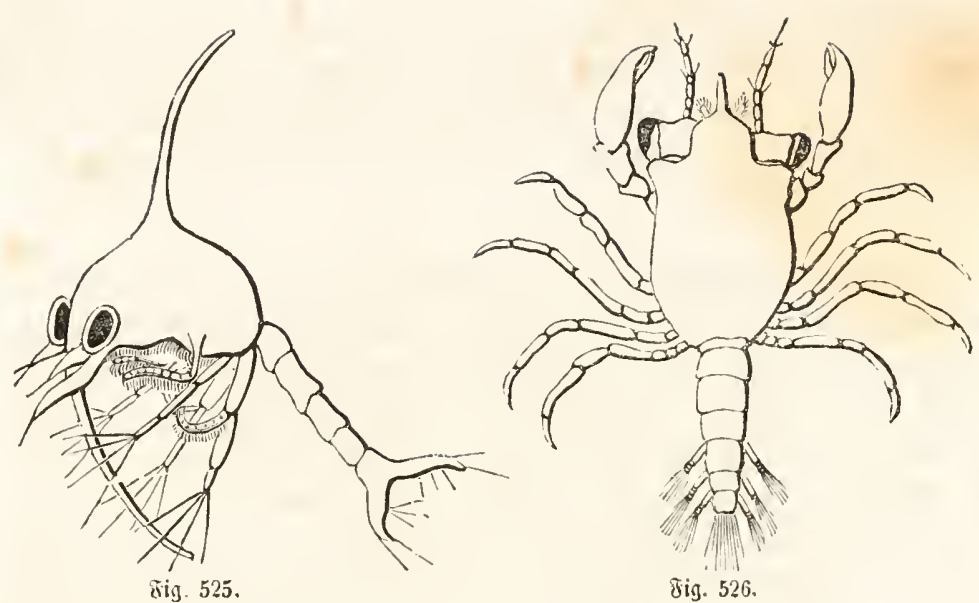

Emsenzuftanbe einer Sinbbe (Carcinus maenas).

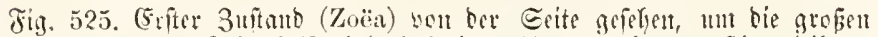

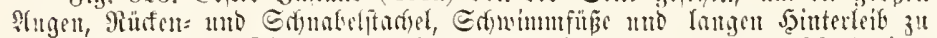

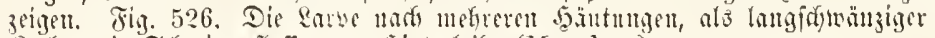

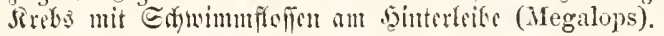

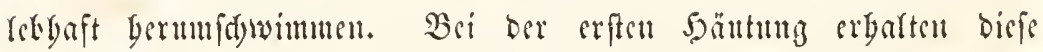

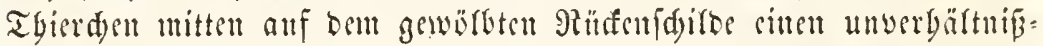

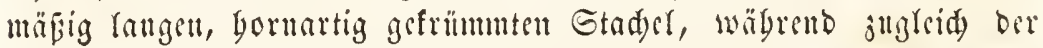
vorbere Eduabel Des Exjifoes cinen zweiten, nad) unten gefrümmten

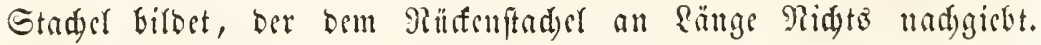
Die Angen fint ungebener grof mo feblen anf rewegliden Stielen;

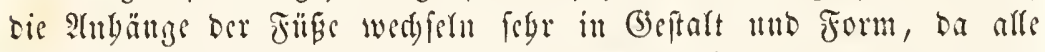

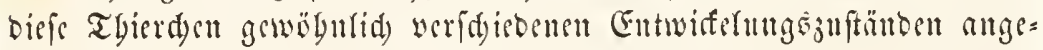
bören, Dic man früber unter Dem Gattungenamen Zoëa jufammen=

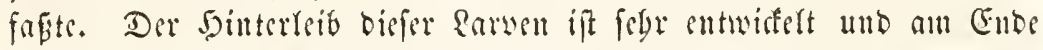
mit bebentenden Flofienborften verfeben. Rad) wirberbolten 5ä̈tun= gen exlangen diefe Sarwen sitte weitere Form, werdye man ebenfalfs als befondere Gattung unter bem Ramen Megalops befdrieben bat. In Disfer Geftalt baben sic Tbiere die beiben gefrümmten Sorn=

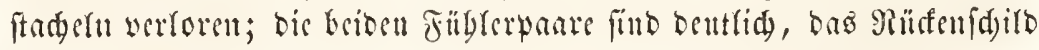
bat sime länglid reyerfërmige Geftalt, bis fünf Jufpare finb volls ftänbig Da, oaz yorberite mit Sdyeren bewaffnet, mu ber Dinterleib

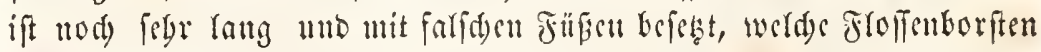
tragen; bisfe branden unt verloren ju geben nab ber rubimentäre

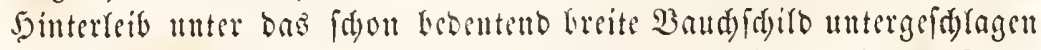
ou werben, fo ift bie junge sinble and in ber Geftalt igren Eettern 


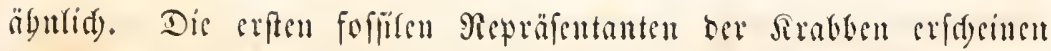

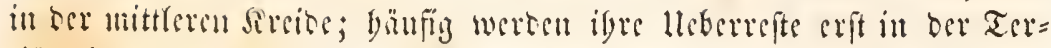

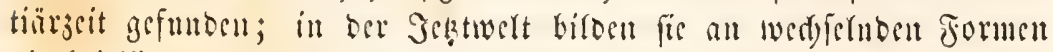

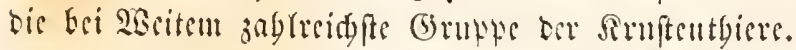

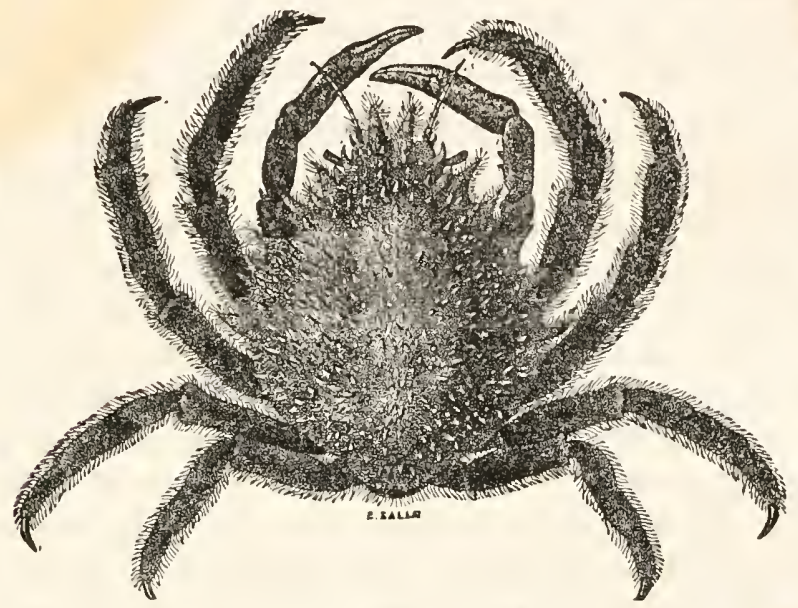

8ig. 527. Epinuentrubte (Maja).

Die Fanilie ber Spinmentrabben (Oxyrhyncha) bat sin gewöbn=

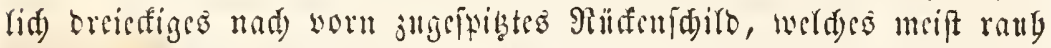

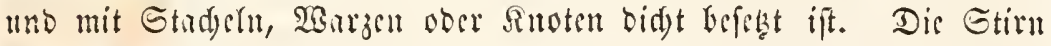
biroet gewögutidy sinen cinfadjen ober bopyerten fdjunaten Sdynaber,

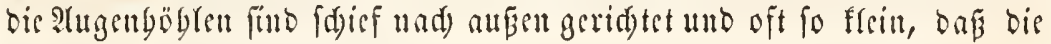

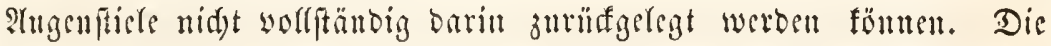

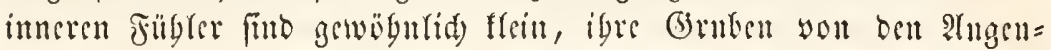
yöblen volftäubig getreunt; bic änferen Fübler Dagegen grof unt an

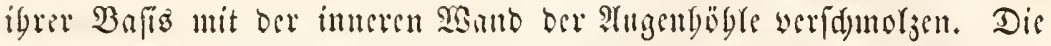

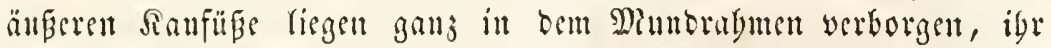
erftes Gried ift fogr grofi und bient als Sitappe yor bem Eingange

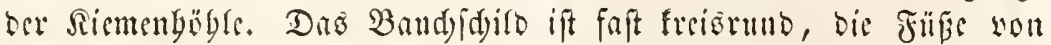
figr werfdricbener Entwiffelnug. Das vorbere Edyecrutpane ift meif

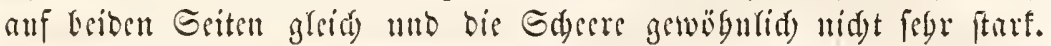

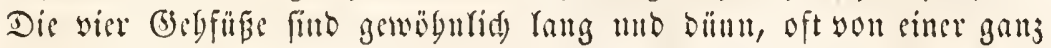

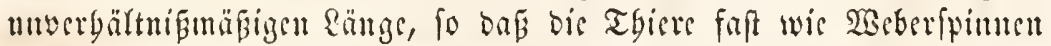

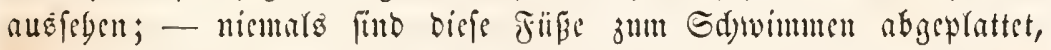

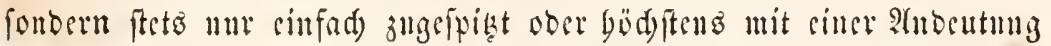
wout Sdecrentiroung werfeben. Die Puthenfanäle ftegen auf ber Bafiz

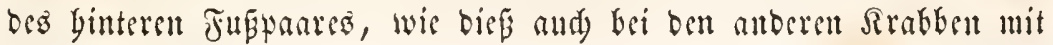




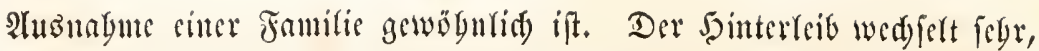
gewöbulidy jrigt er fieben Singe, oft aber finbet man bei ben 2 seib= den biefe 3nbl bis auf vier rebucirt. Die Rrabben biefer Familie wobnen affe in Meere mo bie meiften in bebententen Tiefen; feine Gattung lebt an bem $11 f e r$, unb bis meiften fterben febr balb, mad). bem man fie ans bem $\mathfrak{Z}$ affer bervorgegogen hat. Leptopodius; Stenorhynchus; Inachus; Hyas; Maja; Leucippe; Eurynome; Parthenope.

Die Fantifie bet Runberabben (Oxystomata) bat sinen mers ober minber freisförmigen Räfenfdeirb, ber barb megr mad binten,

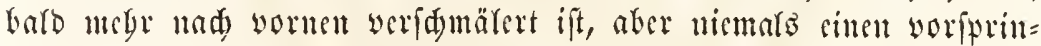
genden Gtirnfdyabel zeigt. Der Miundratumen ift gewöbntid brei=

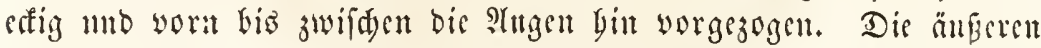

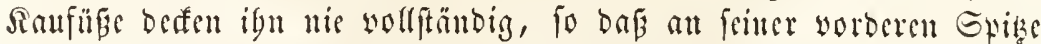
sime Deffnumg jum Durdtritte bes 2 affers für die Siemenböble exiftirt, wälrend ber fonft bei ben Sirabben vorfonmende Spart an ber Bafis Der Siemenböble feblt. Die Exiftenj Deg cruäbnten Sanales ift ber

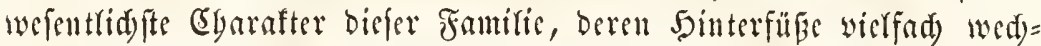
feln, inbem fie bald mit breiten Edwimmlappen, balo mit Rrallan enbigen. Dic vorberen Sdecrenfïbe fimb inber im strgemeinen fegr furz, bogenförmig gefrïmut, bicf unb maffes unb mciftens yon vorn

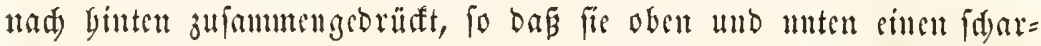
fen Sinmm zeigen und oft fo an ben Stimmand ber Sdjale angelegt werben fönten, bar man fie son oben im zufanmengejogenen 3uftanbe nidyt felden faun. Calappa; Matuta; Leucosia; Ilia; Corystes; Dorippe.

Die Fanitic Der BogenErabben (Cyclometopa) baben sin Riufen= fdatlo, weldes ftets breiter als lang ift, und namentlidy vorn biefe

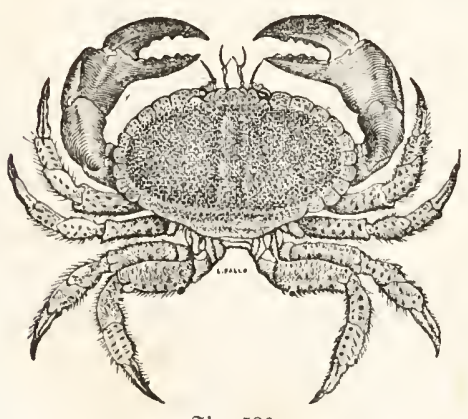

รig. 523.

Fukart = Sirafle (Cancer pagurus). bebentende 23reite befint, wo es einen regchmäsigen Bogen biloct, wäbreno eg binten quer abgeftuigt ift. Der worbere Bogenrand ift bald glatt, bald mit 3affen und Eprizen bejekt, aber micmats in sinen mittleten Ed) Haber aแะ่gezogen; Dic Pänber bes ganjen Edfitbes find gewbibn= (id) farrf, bic sugenbëblen ticf, nad) worn thlo oben geridjtet, bis Ingenftiele juweilen ungebener lang 


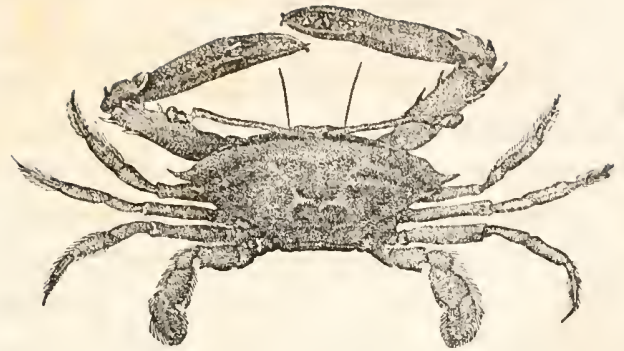

Jig. 529. Ittgenfrukbe (Podophthatmus).

unt febr berweglid). Dis Sd) cerenfüre fint int= mer felgr entwiffelt, bic Sdiecren felye fräftig, batt und innen gezälnt; Das bintere Yyan ber alloeren Fübe ift balb jum Sdyimmen abge plattet, balo jum Giebent mit sinct Siralle augige riliftet. Shiernady wedelt Dem and bie Retensart ber Gattungen, welde biefer Familie ange= bören, inben bie einen, bie Sdwimmer, mebr bas bobe Meer fuden, bie anberen an ben Silften Yeben mo oft fo god an Gtranbe, baf fie bei ber Ebbe alf bas Trofene geratben, wo fie fid bant im Sanbe singraben. Oethra; Cancer; Eryphia; Carcinus; Portunus; Podophthalmus; Polybia.

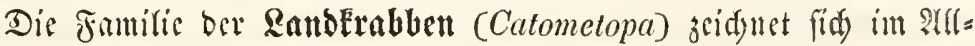
gemeinen Durd die Diffe igres Rörkers ans. Das Piüfenfdito ift

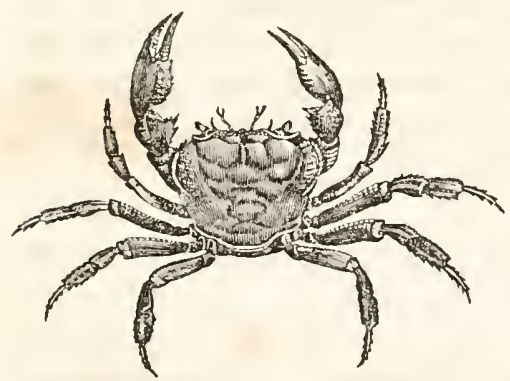

Fig. 530.

Stufrabte (Telphusa). gewögulid) länget als breit, faift viereffig, fein 3orbertant gerab= limig ober wenig gebogent, bie Gei=

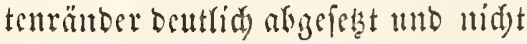
wie bei ben Ninbfrablen, mit ber Bogentinie Dez Sorderrandes עer= (d) wommen. Dif stugenftiele er= fdermen meift lang unb bïnn, bie

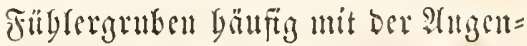
Göble wer fdmolzen, dic älberen Fïbler ferst furz, ber Mlunbrabmen faft immer victfeitig, nicmals bis jwifden bie Stugen sorgefdoben.

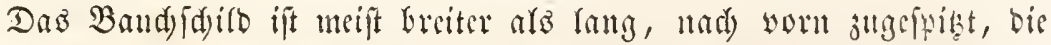

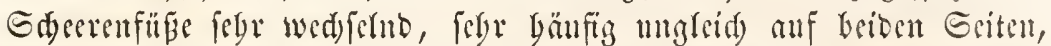
in anderen fällen maffis, aber bafïr faft immer fürzer als bie Gibs=

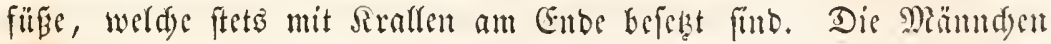
unterfdeiben fid) auf ben erften Blid von benen alfer Ḧrrigen fant= ren baburd, bag bic Deffunten ifrer Gamenteiter nid, wie bei ben

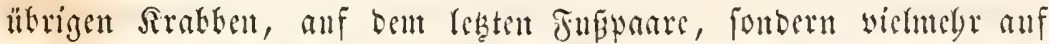
Dem Baudfdilde feleft angebrad find. Mebrere Gattungen biefer Familie bewobnen mut bas Meer in bedeutender Tiefe, unb eine 
(Pinnotheres) ift fogat son arters ber berübut, weil fie mur als

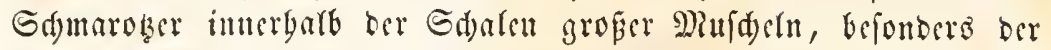

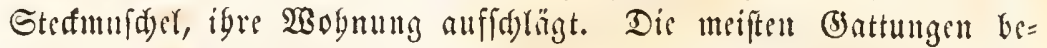
wobnen ben Mecrestrand, gewöbntid) in Erblödern ober in Gande vergraben, uno jagen bei Rad)t nad) ibrem Manbe muber, wobsi fie mit auberorbentlidser Sefdumbigfeit auf beun Sanbe lanfen; anbere

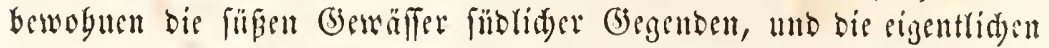

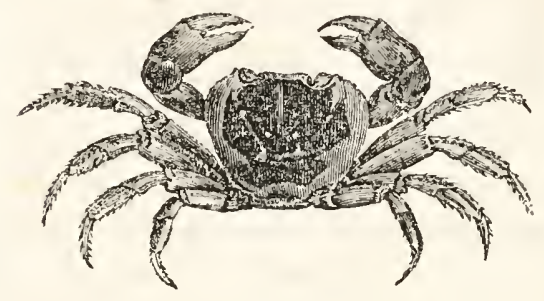

8ig. 531. Tuturu (Gecarcinus). Ranbfrablen entlids, weldse (iid) tur in Den tropifden 3 uten fittocu, leten vollitän= big auf bem Feftlande, befon= Dero an den 2ubängen Det Gerirge, wo fie fend)te $3 n=$ flud)tofftätten fïlocn, bie fie Radjto verlaffen, um threr Rabrung nadjugeben. Die Siemenböblen biefer Ranbfrabben, bie in ungebeuren Mengen gefangen und verfpeift werben, füt febr getäl= mig und mit einer Menge faltiger Blätter befekst, in welden bic Fendigfeit fid fegr lange crbält. Einmal in Gabre zieben biefe Rrabben in grofen Edaanen von ibren 3ufludytarten, bis oft mei= renweit sout Stranbe entfernt find, oen Mere ju, un bort ibre Eier abjulegen, woranf fie wieber in bas Jnmere bes Raubes zurüffebren. Thelphusa; Uca; Cardisoma; Gecarcinus; Pinnotheres; Ocypoda; Gelasimus; Gonoplacus: Hacrophthalmus; Grapsus.

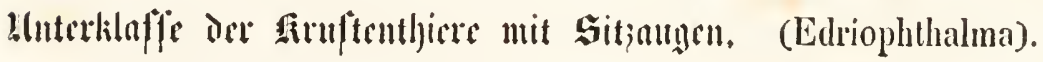

Diefe unterfdeitet fid wefentlid) won beu worbergebenten lluterflaffet burd) bie Cintbeilung igres sörpers, ber fowobl cillen gefouberten Jopf, alo aud) getreunte Bruftringe befitzt unb nismals jene Bermad) fungen Diefer cinjelnen Theile ju einer Soyfbrnft jeigt, welde wir bei ben worigen lluterflaffen antrafen. Der Sopf trägt fete bie fübler, bie Miunbwerfacnge und bie P(ugen, weld) niemals anf einem bewegliden Sticle fiben, foubern it bie Sdyale felbit siugelaffen fiub und bald aus gebäuften Rebenaugen jufammengefeşt, juwcilen aber aud mit 


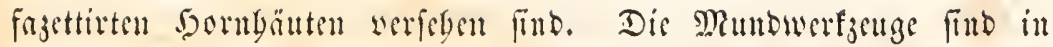
Defer lluterflafe gemignlid) weit cinfader geftaltet, aro bei ber wor= berigen, unb namentfid) ift meift uแL sin sinjiges yant von Rau= fïben worbanden, weldes in Der Mitterlinie ju simer Sitt you llnter=

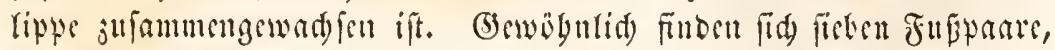
sic bei ben meiften (Bottungen it i⿹rer form sollfommen gleid) ge=

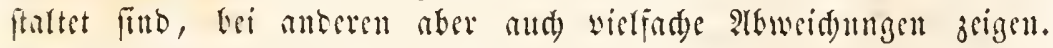

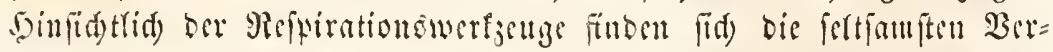
fdibenbeiten, inbem bei den sinen biefelben ganj feblen, bei anberen

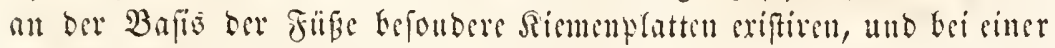

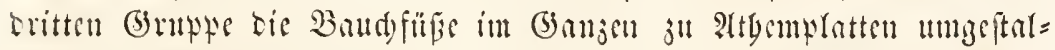
tet find. Bei sinigen Gattungen find fogar sigentgümlide Suftröbren

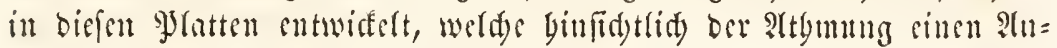

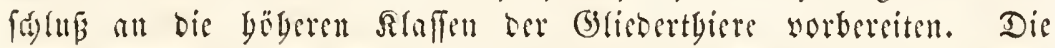
Entwictelung ber Sungen bat bei biejer ganjen flafle viefe Tegntidy=

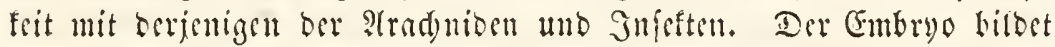
juerft eine fdumale, lange Ylatte, weldye mit ber Pilleffeite l̈ber bent

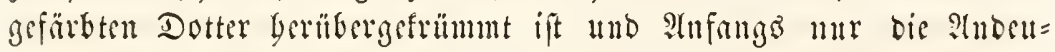

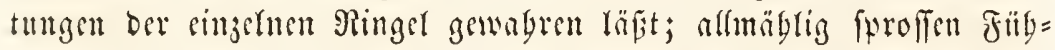
lex, Augen und Füpe bervor, wälrend fid) zugleid ber 2ufangs

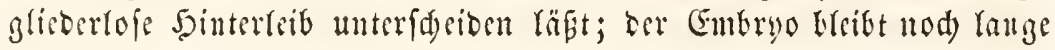
unit feiner Ritffeite unt Den Dotter berumgefrümmt, Deffen Refte fid fogar bei bem ?tusfdulüfen nod) erfennen laffen. Das junge Tbicr,

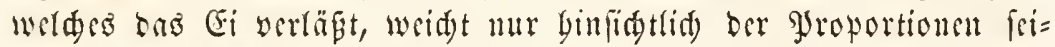
ner cimzeluen Sïrpertbeile, vieffeidgt aud) nad) oer 3abl ber Jübe, welde unter bem baudse befeftigt fint, wou Den erwadjenen Thieren ab, beftebt alfo feine sigentlide Mietamortyofe, wis simige lutterorb= nungen Der jebufïfigen Srekje.

Wir theiten biefe llnterflaffe bauptfäd)lid nad) ber Ausbitsung Des Sinterteifes und ber Fübe in orei Dronungen, won denen tie

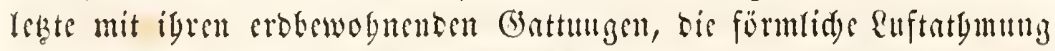

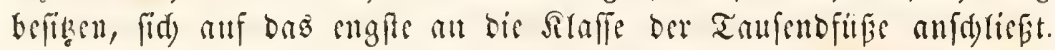

Dif Dromung ber fichlfïjzer (Eacmodipoda) beftebt nur aแts wenigen Gattungen, bie fid) auf ben erjen Bliff burd) oen gänj= 


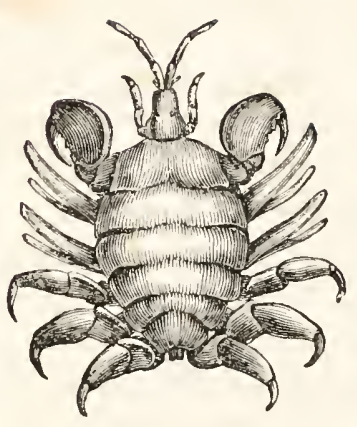

รig. 532.

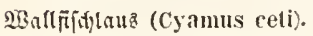

(id) verfümmerten binterleib unterider ben, ber meift mut burd) cinen faum bemertbaren, fnopfförmigen ?tubang bar= geftellt wirb. Der Sopf biefer Tgiere ift cylintrifd jufammengebrifft unt nod mit bem erften Bruftringe verwadjen, fo baf cr bas erfte Fuppar trägt; rint Bildung, weld)e offenbar ben llebergang jul ber vorigen llnterffaffe madyt, wo ber Sopf mit Det ganzen Bruft werwadjen war. Cos find ftets vier fibler vorlan= ben, bie immer cine cylintrifdye ober bor= ftenfürmige Geftalt baben. Dic Mimb = werf genge befteben aus ciner faft freisförmigen Rippe, cinfad)en, ftatf gejäbuelten Ricfern, jwei gyaar blättrigen Rimnlaben unb cinem Jaare grofer Saufüpe, bie lange Taftergeifeln tragen. Die Rormaljabl ber Fübe ift fieben, juveilen aber fint ftatt bez britten unb vierten

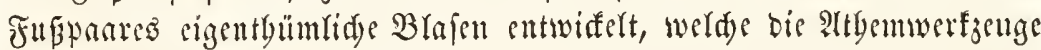
vervolfitübigen und meift aud) an bem jweiten Ringe vorfommen.

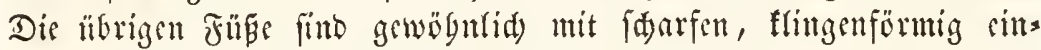
(d) Lagbaren Şafen, niemalz mit Sdyeren bewaffut.

Das Reryenfyfem beftebt aus adjt Rnoten, von benen bie beiben worberiten in bem gemeinidaftldasn Ropfbruftringe liegen, wäbrend bie Berbindungsfäben ber binteren mabe jufammen gerült fiito. Die Nugen baben sine glatte 5ornbaut, binter welder sine

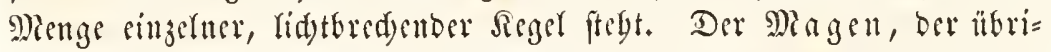
gens mid)t bedeutent ift, trägt imnen feitlidge gejägnte bormleiften.

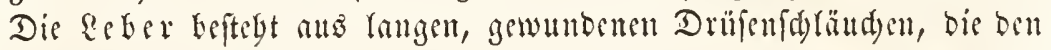
geraben Darmfanal auf feinem Sisege umgeben. Heber ben Błul= fretislauf find feine fideren Beobad)tungen vorbanben. Die sie: men beid)ränfen fid anf bald birnförmige, bald lange, cylintrifde

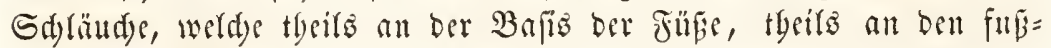

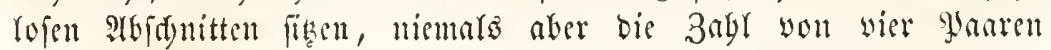

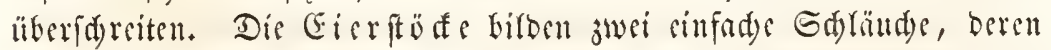

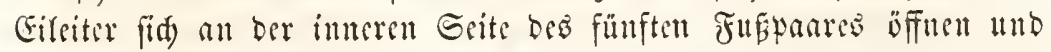

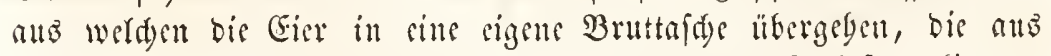
megreten Blättern getirbet wirb, welde an ben fublofen, fiement=

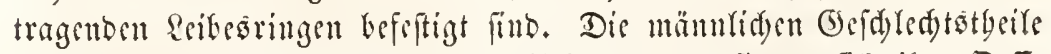
gleiden in ber Form gams ben weitididen, nur filloen fid igre Deff= 
Iungen weiter binten am Rörer, neben bem ?ffer, anf jwei weid)en, wargenartigen Mittben.

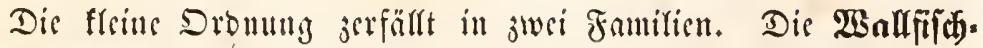
läule $(C y a m i d a)$, welde bie erifte biefer Fantilien bilden, leben alo

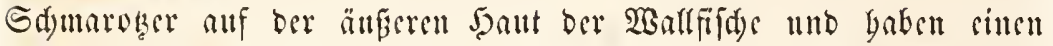

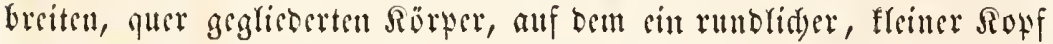
mit grofen', vierglicorigen Füblern anfitzt. Die mittleren Fübler, fo wie bie am Ropfringe befeftigten Fïne fint febr frein, bagegen bas jweite Jufpart, weldyes an Dem erften Bruftringe befeftigt ift, gewaltig grob und mit fdarfen Sirauen bewaffuet ift; - bie jwei folgenden Bruftringe tragen frine fübs, fonbern lange idstaudförmige Riemen

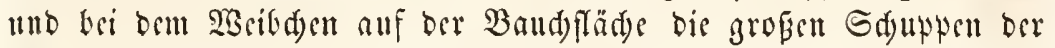
Bruttafde; bic brei binteren Fuppanre find, wie bas jweite, feyr mafiju und mit forarfen Siraflen ausgeriffet, Cyamus.

Die Familic ber (Gejpentfferbje (Caprellida) jeigt sinen Yangen,

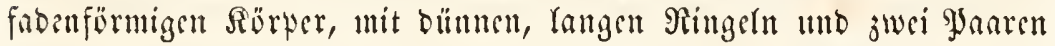

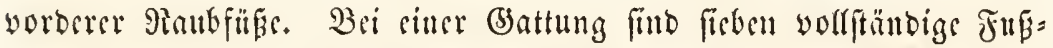
panre vorganden, bei ciner anderen feblt bas britte unb vierte und ift Durd) birnförmige Riemenfäre erfest; Die beiben Füblerpane fint fajt gleid)mäßig entwidfelt. Die fleinen, ftabfürmigen Thierden fiken meift angeflammert auf Tangen mo Decrpflanzen. Caprella; Leptomerus.

Die Dromung Der Globerebje (Amphipoda) begreift cine

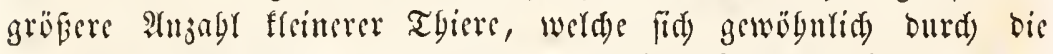

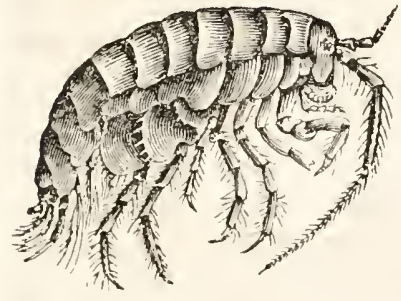

Fig. 533.

Ercrettiue (Talitrus). auberorbentlide Sduelligfeit ibret $\mathfrak{B} e=$

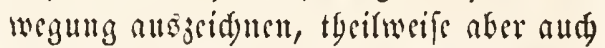
(d) marobertio in alloeren Gectbieren fid anfyalten. Secinez ber ju biefer Dro= แแแ gebörigen Thiere mag bie Ränge won 2 Jullen überfdreiten. Jyr Siopf ift wollfoumen won beut erften Bruftringe getrenut, nidst, wie bei ber vorigen Dro= nung, mit Demirlben veridmol trägt ftets juei jicmlid) bebentende, ge=

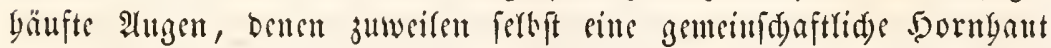
abjugeben ideint, wäbrento in anberen Fällen unter ber glatten 5̧orn= baut eime jweite fajettirte fid findet. Gewöbulid fint vicr Fithler vorbanden, die auf ben Seiten bes Sopfes unter simnder ferben uno 


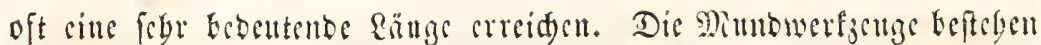

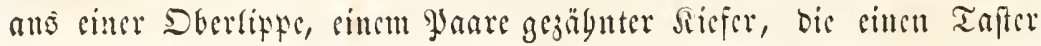
tragen, jwei gyar Sinnlaben unb cinem gaare Sanfüpe, dic it ber Mitte zu einet art lluterlipe werwad)[en. Dis Bruft ift ftets in

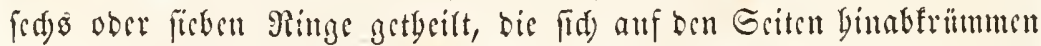
unto bier eigene Decifdutbe für bis $\mathfrak{B a f t s}$ ber Fübe bitben, bie ge=

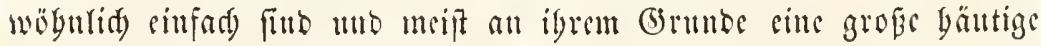
Siemenblape tragen. Die 2 Beifden jeigen oft an ber $2 a j i s$ igrer Fü̈se cigene cylinbrifde Inbänge, welde baju bejtimmt fino, bic Eict feftubarten, sie fie unter bem Bande tragen. Dor Sointerleib ift fegr entwicfelt unb ucift mit vieffaden Angängen serfeben; bie bref erfen

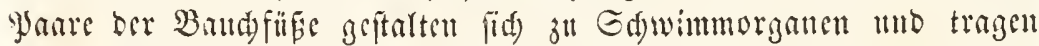
lange, bornige, ftart bebarte Enbblätter; bie binteren gaare fint

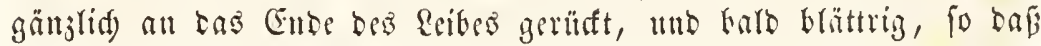
fie cine Edywimmfoffe biben, balb aud in Form langer, fticlfitmiges Griffer ansgrgogen, anf tie fid, bic Thiere bei untergeid)lagencm Band)

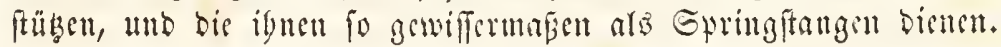

Das Reryenfyitem ber frobfreble seigt einen meift ziemlid

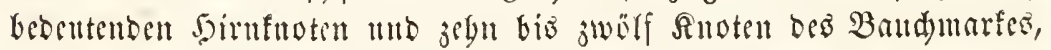

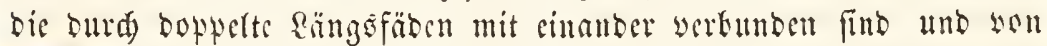
oenen bie vorberen grifjer füb, als bie binteren, bie in bem Berlaufe bes Bandes Yiegen. Der Magen ift flein, obne bornige intere Phts=

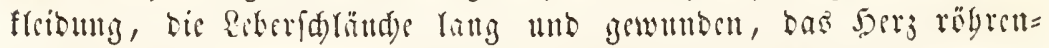

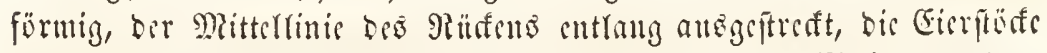
in Gd)landform ansgefilbet unb bie Deffnumgen oer Gileiter an bem

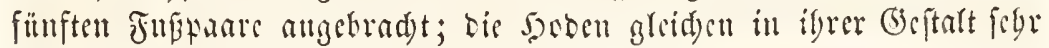

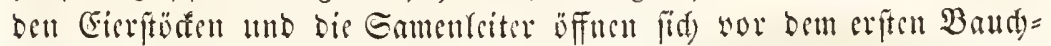

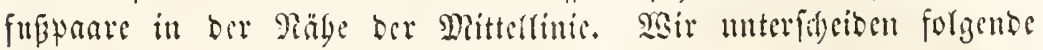
Familien, bie beibe im foffilen 3uftanbs, aber unt it ben jüngeren Tertiäridjidten vertecten find.

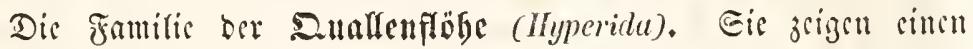

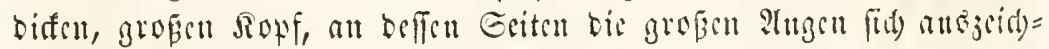

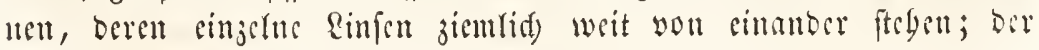

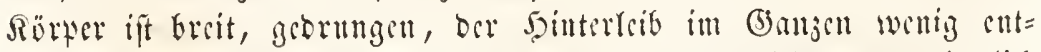

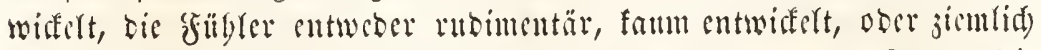
attgebilbet, baun aber gewägulid won fonberbar bijarter Jorm; bie

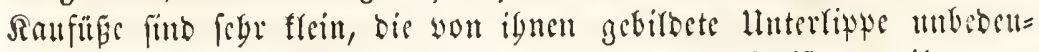

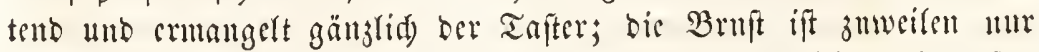

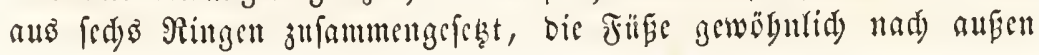




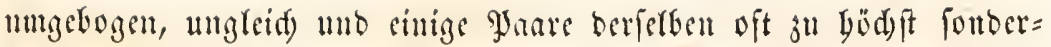
baren Greiforganen mit sinfdalagbaren 5ornftingen ausgebitbet. Der Sinterteib bildet sine Edjwimmfloffe, bie gewöbultid) ans megreren feitliden Bättern jufaumengefelet ift. Die Thiere bicfer Familie

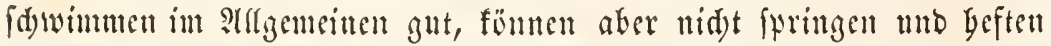
fird) gewögntid) an Dualfen uno äbulide galfertartige Sestbiere an, in beren Jnneres fie sintringen, num bie Rörperfubftant z" verzely= ren. Hyperia; Tyro; Lestrigon; Phronimus; Typhis.

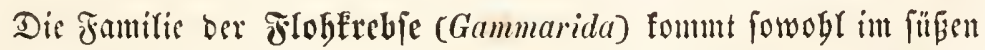
Taffer, als befonders yänfig int Meere an bem Stranbe vor, wo fie ju Taufenten in Sdywärmen umber Güpfen, ober mit ibren Yangen

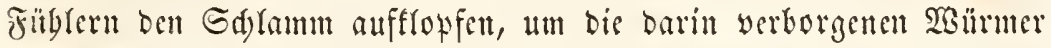
anfanjudyen. Der Sopf biefer Thierden ift weit fleiner, als in ber

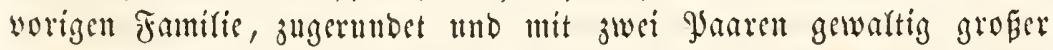

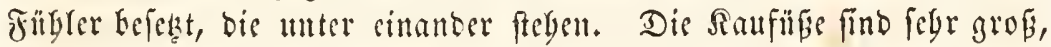
bie Itnterlippe besentend entwifelt und an ibrer Seite jwei Yange

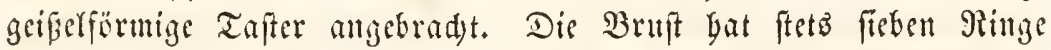

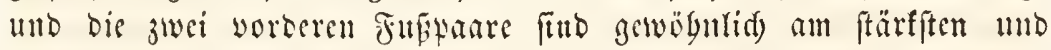

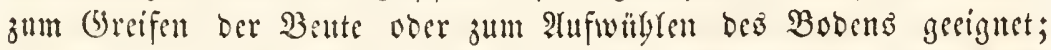

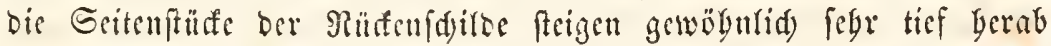

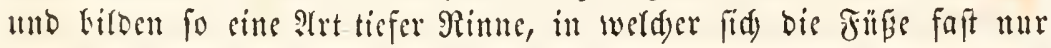

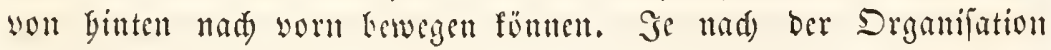

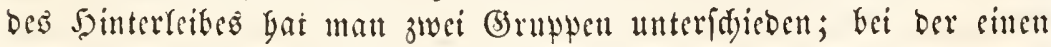

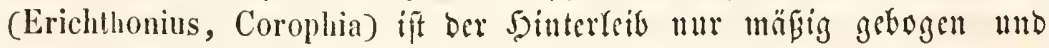

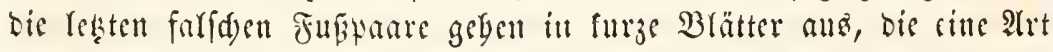
Jroffe Dariftelfen; bie Thiere diefer Grappe fpringen nidst, fondern laufen mur mit grofer Sd)uefligfeit, socr wäblen aud in Sallbe; bei ber (3) rupte ber eigentlid)en frogfrebe bingegen (Talitrus, Orchestia, Gammarus, Leucothoë) ijt Der Sjinterteib ftarf gebogen, feitlid) zulam= mengebrüat mo bic Ginteren efferfübe in lange Epringboriten nunge= mandert. Eine Gattung bicfer Gronple, bis fets auf ber Seite

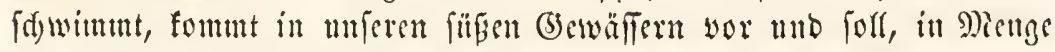

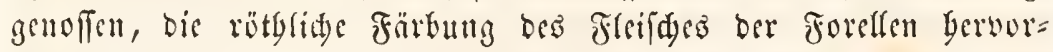
bringen.

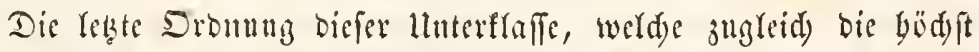

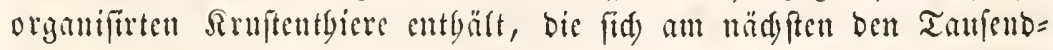

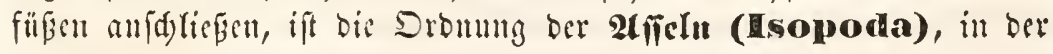




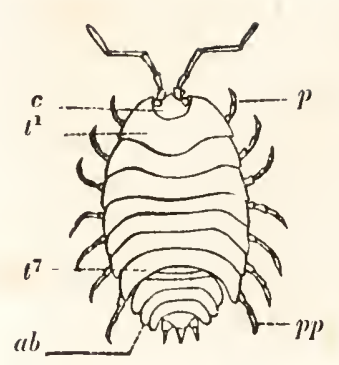

ซig. 531.

Refleraijel (Oniscus).

c Ronf. $t^{1}$ Kis $t^{7}$ Bratringe.

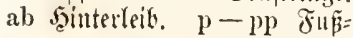
pare.

man sille förmlide Reibe, vou fdumaroken, ben Fornten an, beren Drganifation faft gänjlid) unfenntlid) wirb, bis zu bod) orga= nifiten, Inftatgmenden Sanbtgieren verfolgen fann.

Der Rörper ber affern ift gewöburidy Hatt, von oben nad) wten zulammengebrildt, bard imebr länglid), balo efförmig, ober felbft ber Sireisform fid näberno; ifr Sopf ift fleit, aber fets beutlidy von bem erfen Brtufringe getrennt; bie gewöbulid gebäuf= ten, feltener zufanmengefesten Yugen runb, juweilen won bebentender Grö̈re; die Fübler yon mäßiger Ränge, gewöbulid) quer nad) âfen gefteflt, bie vorberen ouweilen rubimentär; bie Mitndwerfjenge fitto wobl altogebildet, bie Siefer ftarf, gejäbnelt, bie Saufübe fely groß, aber yon wed)felnder Form; bie $\mathfrak{B} r$ ft bejtelt aus fieben Plingen, beren Geitenränder meift blattartig vorragen; jeber Bruftring trägt ein Jaan Füpe, bie fajt immer von gleidser form fitto unb an Enbe eitte fdarfe Rlaue, nie= mals eine Gdyere baben; an ibrer $\mathfrak{B a f i s s ~ t r a g e n ~ b i e f e ~ J u ̈ b e ~ b e i ~ b e n ~}$ 2Beibden eime breite Wlatte jur Aufbewabrung ber Eier, niemals aber foldye Riemenblätter, wie bei ben vorbergebenben Drbunngen. Der Sointerteib ift wobl ausgebilbet, urfprïnglid) aus fed sas Ringen zufam= mengefest, bie aber juweilen mit einanber verfdumolget fint. Die Baudfï fre tragen jeber jwei grofie, bäutige, efförmige Brätter, oerent inmeres Blatt febr jart ift und a!s Siementalt fungirt; bas fed ite Baud)fubaar bagegen weidst wou ben sorbergebenden in feiner Bit= bung ab unb jeigt fid) gewöbulid in (beftalt eines beffelartigen frit=

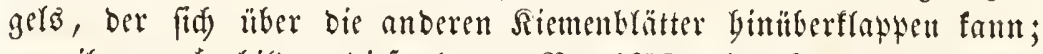

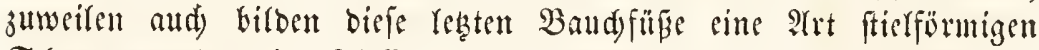
Sd)wanjeg ober sine Flofle.

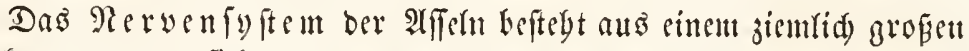
Sirnfnoten, ang fieben, gewöbulid) gleidumásig großjen Bruftnotett, bie burd) Rängşäben mit cinander verbutben find utb anf bie $31=$ weifen nod) mebreve fleitue Sirnfnütden forgen. Der Magen ift in=

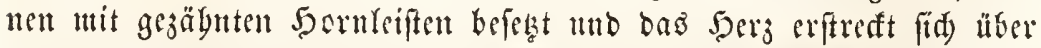

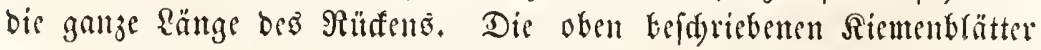
erleiben bei ben Ranbaffeln bemerfensinertbe Mobificationen, bie wir bei biefer Familie betradten werbett. Gieritüefe uttb 500 en gleidyen

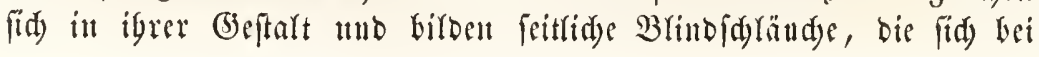




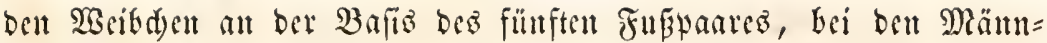
d) ant bent lesten Brnftringel, entweber anf boppelten, warjentarti= gen Pintsen, ober in einer einjigen furzen Rutbe öftuen, weldye burd) jwei lange Stiele, bie won bem jweiten Baud fuppaare auşgeben, tod unterftïbt wirb. SBir unteridaciben forgente Familien, won weld)en nur jwei int äteren $\Theta_{d j}$ id Sura au, bie Embaffeln bagegen erft in ben jüngeren Tertiäridjidsten.

Die Familie ber Rausa|felt (Bopyrida) wirb mut wou cinct

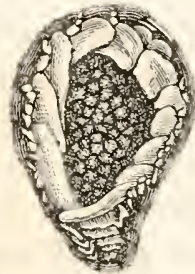

ชig. 535.

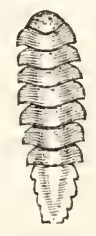

ชig. 536.

Bopyrus.

Fin. 535. 28cifuctu beg Bopyrus squillarum, won ber Bandfflädye gefegen, num tic Gier, bie Silammerfin̈e, sie fall=

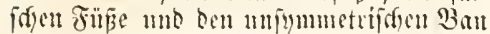

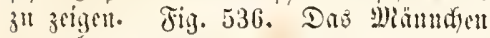
wotl sbett. einzigen Bjattung (Bopyrus) gebil= Det, welde fdutrobend in Der Sies menbögle ber barneelen lebt. Das Mäundyen bat cinen langgeftredten Rïrper mit fumalen, ausgezactent Bruftringen, werfdmoljenem bin= terleibe utb fleimen, mit Rrallen

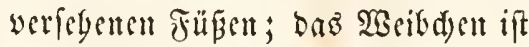
stwa fed)smal gröfer and bildet ein breites, verfebrt eiförmiges Gdjito, Das ftets unfymmetrifa ift, auf Der Pindfeite nur bie Furd)en Der wer= (d)molgenen Pinge, unt anf Der lluterfeite bie vierjebn yafenförmigen Rlammerfüßje jeigt. Der Ropf ift gänjlid) untergefd) oben und angen= lov, ber Sointerleib imuen mit bäutigen glatten verfegen. Die Sun=

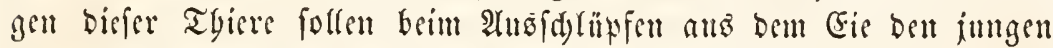
Safferflöbent ägntid) feben, was, wenn es fids erwabren follte, unbe= bingt bie Gtellung bicfer Jamilie you ben affeln weg ju bent eigent= (id)en Gdjmaroberfreblen bebingen wïrbe.

Die Familie ber Fifda feln (Cymothoida) rebt ebenfalls fduma=

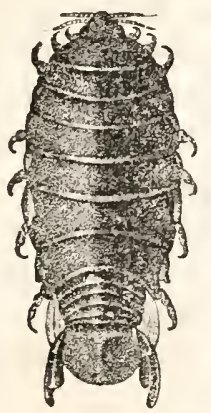

ซig. 537.

उifinaifel (Anilocrus). rokent, aber meiftents auf Fifden, an Deren Sdwans fie fid befonbers gern anflammern; ifr Sörper ift gewöbulid) läuglid) eiförmig, abgewlattet, Der Sowf flein, bie beiben Füblers paare furz; Die furzen Fitibe, welde unter ben woblgetrenten $\mathfrak{B r m f t}$ rimgen fteben, find fräftig, getrüumt und mit Jafen verfeben; die Şafen ber brei erften Juppaare find ftets fert ftart uno cimfd)lagfar, fo dap fie förmtide Nianmert bifoen. Die fünf erften Sinterleiborringe find (d) mal, aber beutlid) gefdjieben, Der lebate breit, blattërmig und za ciuter Edyinmmfloffe unge= 


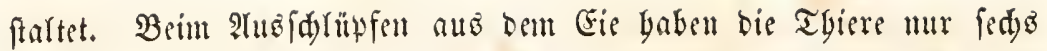

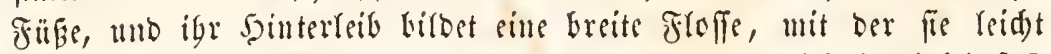

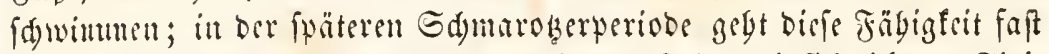
ganj vertoren. Dodj finben mandsertei llnterfdiebe ginfidgtlids ber Fixi=

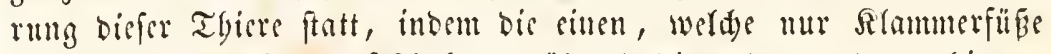

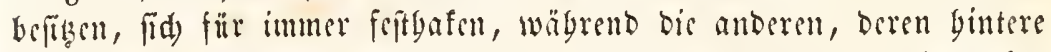

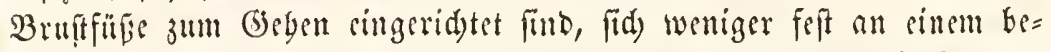
ftimmten Drte fixiren. Serolis; Cirolanus; Acga; Nerocilus; Anilocrus; Cymothoë; Jone.

Die Samilie ber ßungelalifeln (Sphaeromida) zeigt sinen Ereiten,

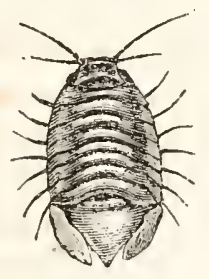

fig. 539. fdifoförmigen Rörper, grof̧en queren Sopf, mit feitlidy geftellten, cinanoer fegr genäberten Füblern, seren Füße giemlid) furj, aber bünn und unr zum Bseben singeridgtet find. Die fünf erfen sointerteibsringe find mit sinnoser

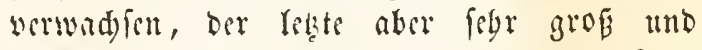
fdjitbförmig. Dis Taicre fönnen fid zufam=

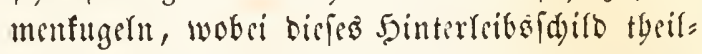

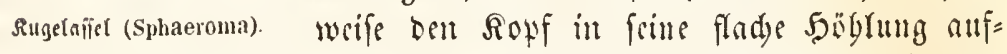

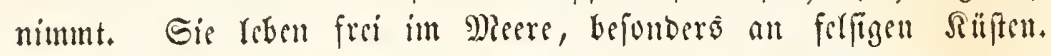
Sphaeroma; Cymodoce; Cerceis.

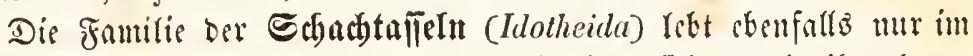
Meere und unteridecibet fids burd igre lange

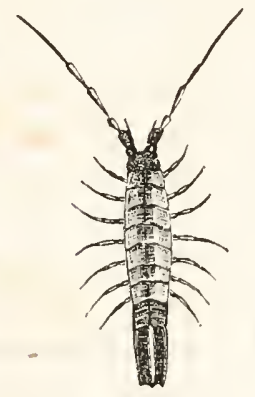

ธี่ง. 539. geftreftte $\Re$ örperform, die fleincn intercen und bie fegr bebeutend entwiffelten äuferen Fübler, auf Deren äuBerer Seite Die fleinen, rund lidjen 2tugen filient. Die fisben Fupware find bei Den veridiebenen Battungen verfdjicben geital= tet, inbem fie bei ben sinen yollfommen glsid),

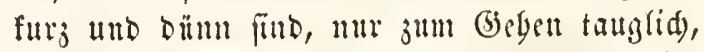
wäbrend bei anderen brattungen nur bie gin=

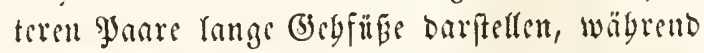
bis vorberen ju pinfelartigen Sd)winmfüßsen Ediratitaifich (Hothea). umgewandert fint. Die worberen 5interteibs=

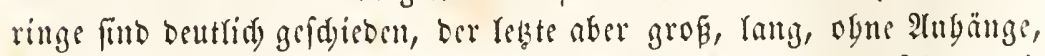

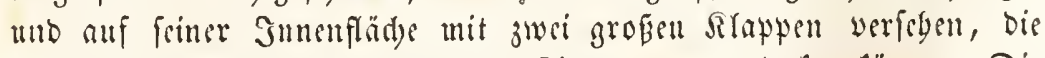
wie z'wei Flügettgüren ben ganzen Riemenapparat deffen fümncn. Dic

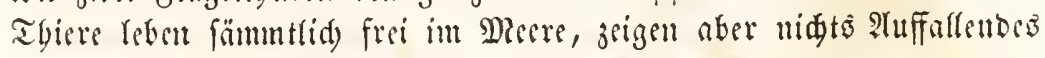
binfidtlid) igrer Rebensart. Arcturus; Idothea.

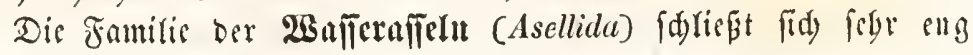


aut bie vorbergebente an, unterfdecibet fid aber you berferben burd)

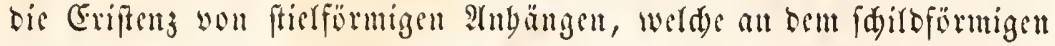

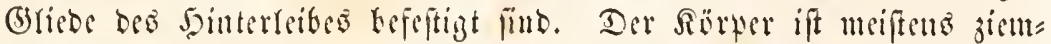

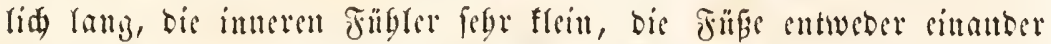

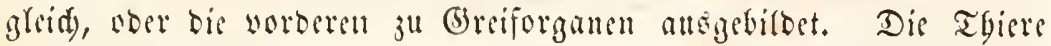

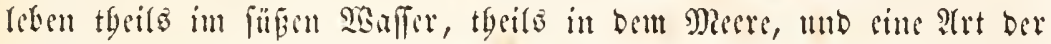
regateren (Limnoria) ridytet burd) Infreflen bes Soljwerfes in mandeแ Jäfen grofien Edjaben att. Asellus; Limnoria; Jaera; Apseudes; Tanais; Lygia.

Die Famifie ber Rambafieln (Oniscida) jeigt sinell meift ciförmigen

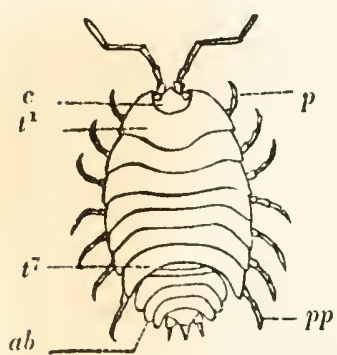

Jig. 510

Reflerailel (Oniscus). Sötyer, beffen wobl aneinanber fdselefende Pinge ilferall genan you eimander getrentut fint. Die äuperen Fübler fint gewölulid ciltzig fid)tbar, bie inneren böd fens zweigliebrig unb fo jwifden bie ätperen geftellt, baji man fie unr bei ber Pafidat vou unten an ibrer Bafio fiebt. Dit Sinterleib Diefer Tliere beftebt im= mer aแs fed) bentliden Ringen, yon weld)en Der lekete, im Segenfake zu ben vorigen Fami= lien, unr febr flein ift unb mandsunal faum

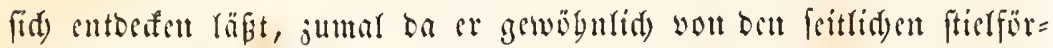
migen Angängen liberragt wirb. Die meiften biefer Tgiere leben anf bem Ranbe an fendtill, fdattigen Drten, unter Striten, im Moder, in Mauerrisen und Gewolken, und find ju biefem 3wede mit eigeneแ Drganen jur suftatgmung verfeben; bie Siemenbrättden ber binteren Band fïlfe fint nämlid, febr rubimentär, bie ber vorberen bagegen bedeutend entwidert tho an igrer $\mathfrak{B a f i z}$ mit sinter engen Spalte ver= feben, welde in sine gefäbartig verjweigte serble fübrt, bie jwifden

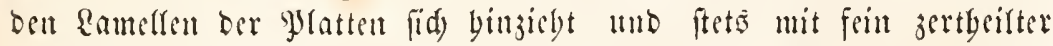

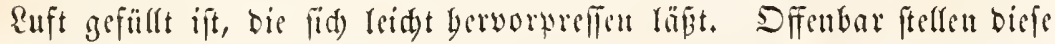
Brätter ben erfen :Hafang jur ?habiloung forder luftatbmender Dr= gane bar, wie wir fie fpäter namentlid) bei ben Gpinten in sinem weit Göberen Girabe ber ?tusbildmiz finden werben. Oniscus; Poreellio; Armadillo; Tylos. 


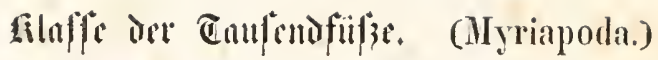

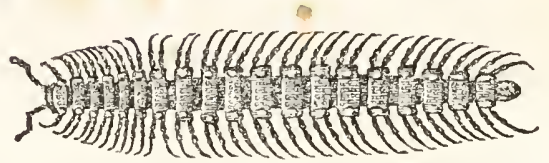

Jig. 511. Polydesmus.

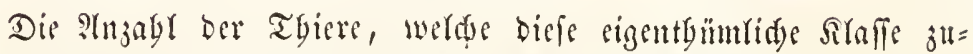

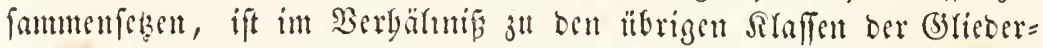

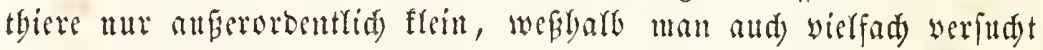
lyat, fie ars befoubere Dronung anderen Siraflen anjureigen, olue itto Defi in biefer Bejiegung glüaffid ju feit, ba bie veridjicbenen Egaraftere, weldye fie in fid vereinigen, fie sincreseits won bon Snfetten, andereeits won ben $\mathfrak{i}$ ruftentgieren entfernen, ju welden unan fie nod nenerbings

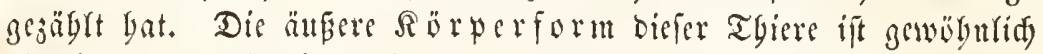

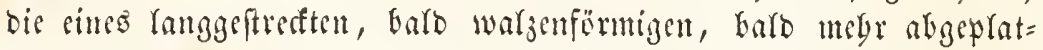

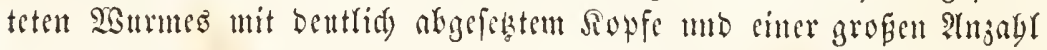

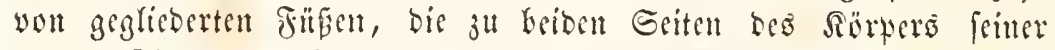

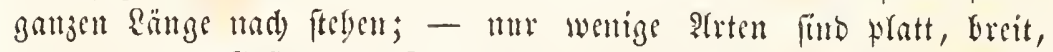
etwa von ber Beffalt ber Sefferaffern, mit werden ältere Raturforider

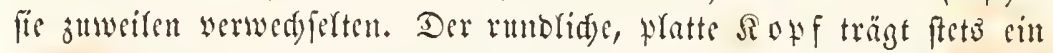

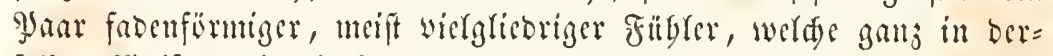

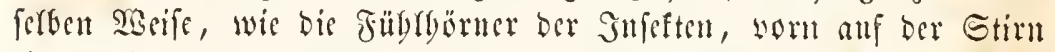

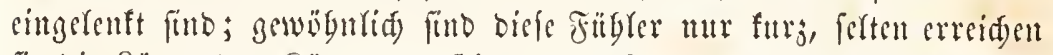

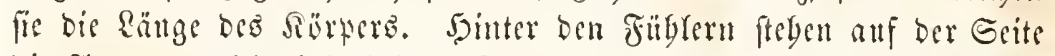
bie Âthen, weldes bei sinigen bsattungen fellen, mo immer aแz ge=

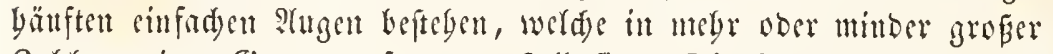

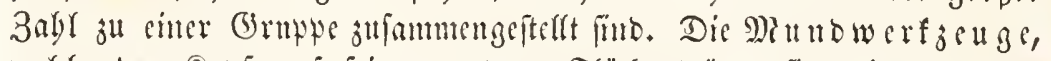
werdye ser soof auf feiner unteren fräd) trïgt, füt eigentbümtid

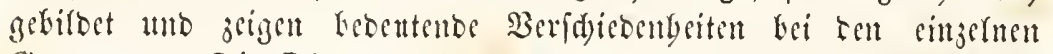
Gattungen. Die Drertipte ift fegr flein und meiffents mit bean Sopf= fditbe werwadjent; unter igr liegen jwei länglide, geglicberte, quer

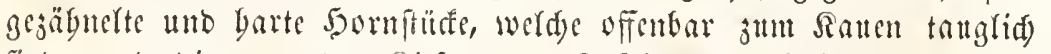

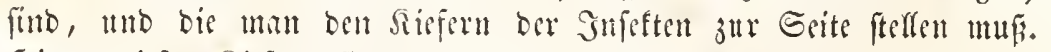
Sinter biefen Siefern findet man jwe anbere geglieberte Etücfe, bie

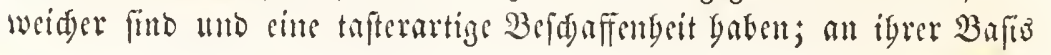




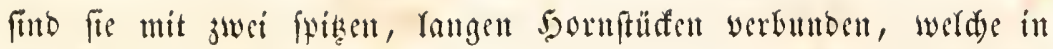

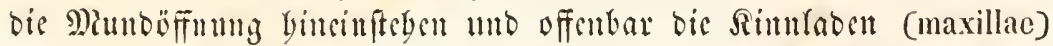

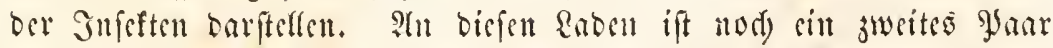
won Taftern singelenft, bis an ibrer Spike mit einer fleinen Silaue bewaffust tuno wogr bem inneren Radentafter ber Ranffäfer ana=

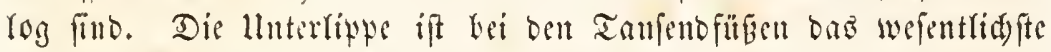
Drgan zum Ergreifen ber Beute unt zum Beifien gesworben. Die

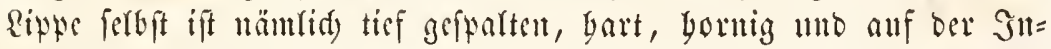
nenfeite mit ftarfen Bägnen befegt; auf igr singelenft fichen bic Rip= Fentafter, welde bier zwei ftarfe, geglisberte Safen barfteflen, bie wie

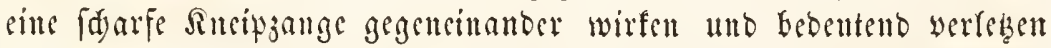

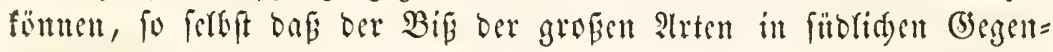
Den für cine gefägrtide Bermutubung gilt. Nidgt bei alfen Gattungen fitto intoes bie Sanwerf

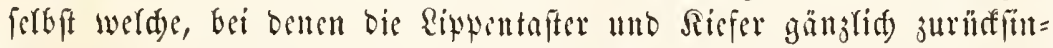

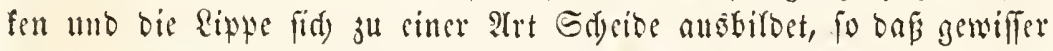
Diañen cin Gaugruiffer Gergeffellt wirb.

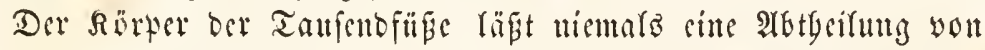
Bruft und Sinterteib erfennen. Er beftegt ans cinzernen Ringen,

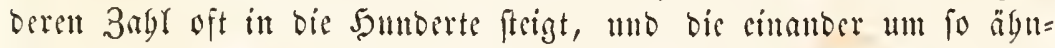

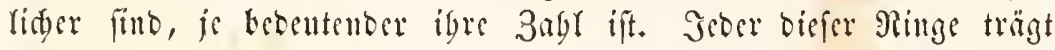

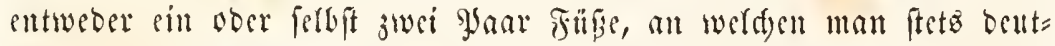
lid) bie beionteren, mit Rrallen berwaffueten Fungrgiscer unterideiben

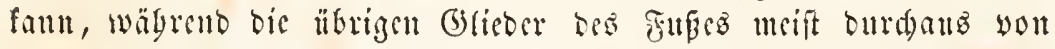

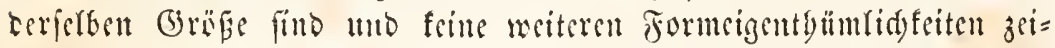
gen. 2uffaltent ift bie Bejonterbert, welde nur bei ber Familie ber Doppelfüber in biefer sitaffe unt fonft bei frinem (B) fictertbiere vor=

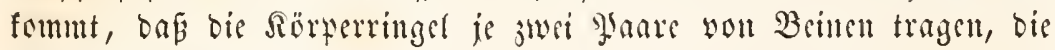
Ginter sinanter fteben.

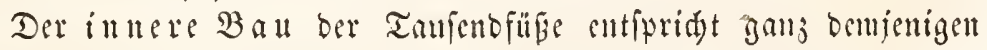

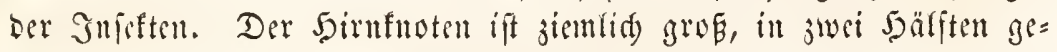

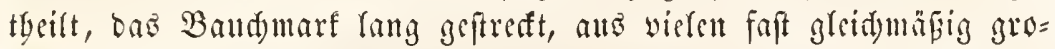

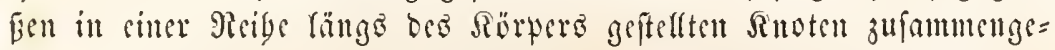

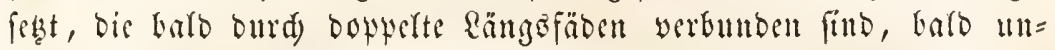
mittersar aneinander fto

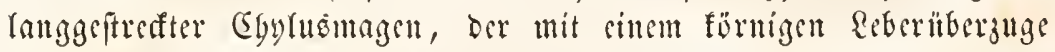
werfeben ift tho in beffen Ento bie fegr sinfadyen, wenig jableriden

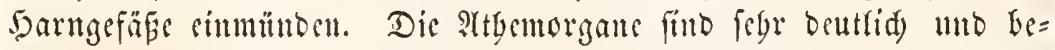

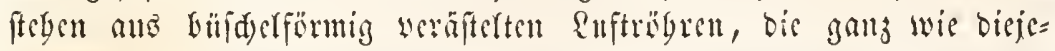

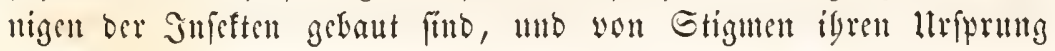


nebmen, bis meift fpultenförmig gebant, juweifen aber and) tutt tut

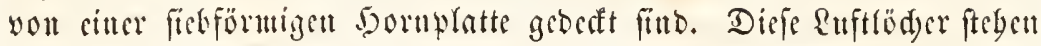

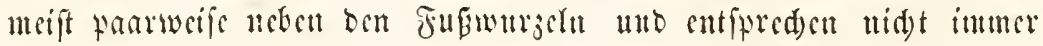
Den cillgelten Ringen, foubert wed)felt gewignlid) in untegelmä̈igen

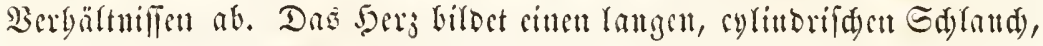
welder ber Rärfenfrite cutling läuft, cine Menge Arterten abgibt,

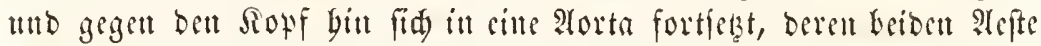
ben Ed)lund unfaffen und fid) auf ber Band)feite wirber wereinigen,

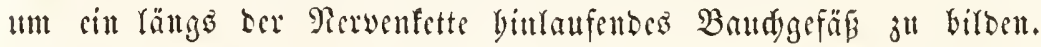
Die Arterien endigen mit rffenen Mïndungen; bas it bie Rcibcebögle ergoflene Brut fammelt fid) itl ber llugegent bes Sperzens, nto tritt

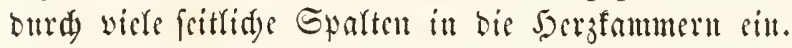

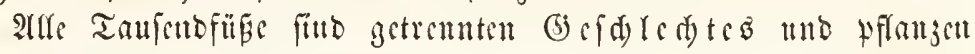

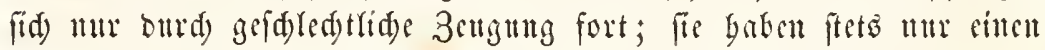

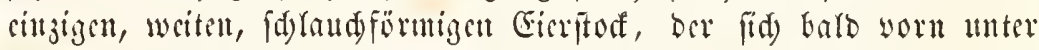

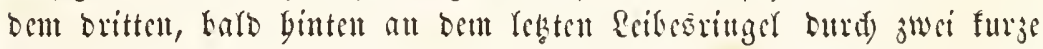

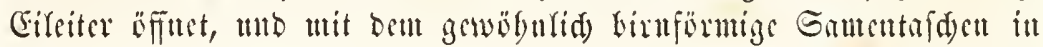

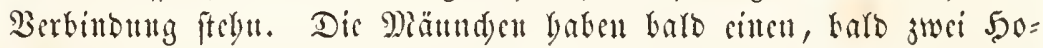

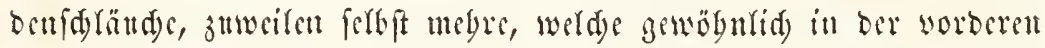

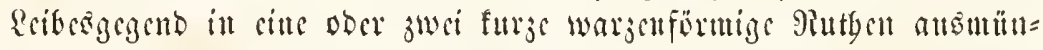

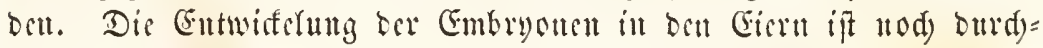
aus unbefunnt; nur fo vich weiß man, baß bie Thiere, wenn fie ans

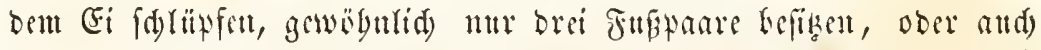

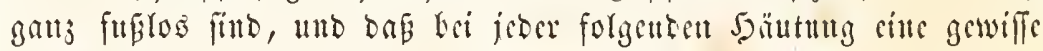

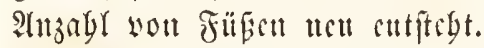

Die Taufubfübe letent meift anf ber Groe unter Strinen, Mroos,

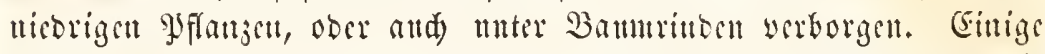

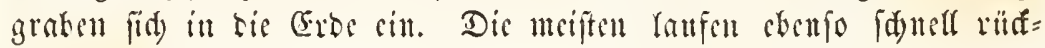
wärts, als vorwäts, ttto rolfett fid) in Gefagr lingförmig cin. 2ain tbeilen bie gatlo Niafle in zwei Familien.

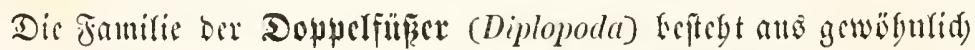

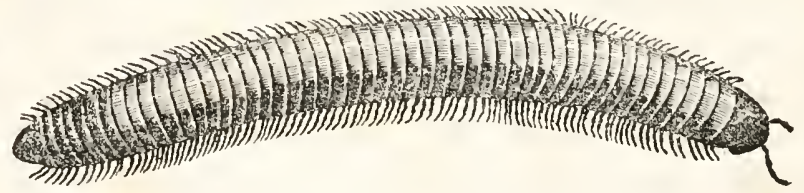

5ig. 5 i2. Julus.

wurmförmigen oder ftarf abgeylatteten Thieren mit Ringen, welde

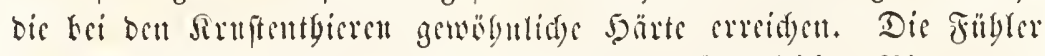

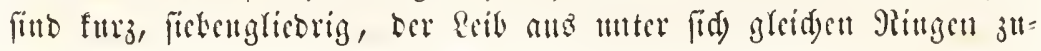




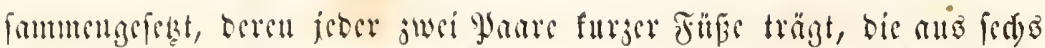

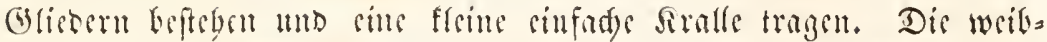
fidsen Thiere baben simen won worn mad) binten verlamenten Gire

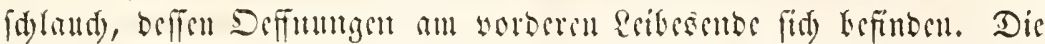

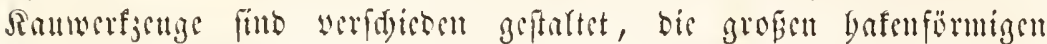
Slantutafter ber llntertipte mur rubimentär. Pollyxenus; Glomeris; Polydesmus ; Julus; Polyzonium.

Dis Jamilie ber (Einfïger (Chilopoda) beftebt aแz ftetỏ glattge=

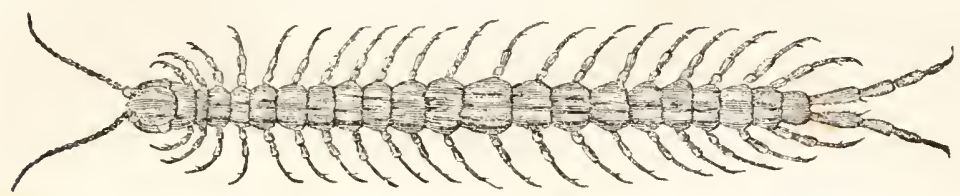

¿ig. 513. Scolopendra.

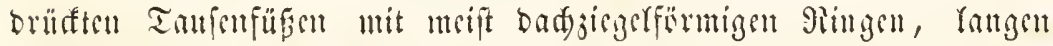
Jügrgörnern, bie wentgiteno vierjebn Glicber baben, unb beren Mamb=

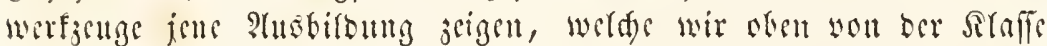

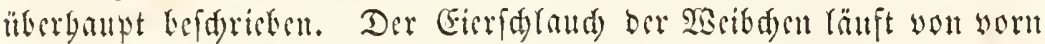
uad) binten, unb iffutet fid ummittelbar yor bom sifter. Die Ringe

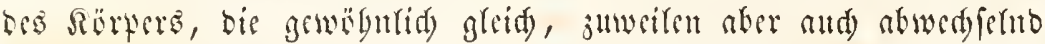

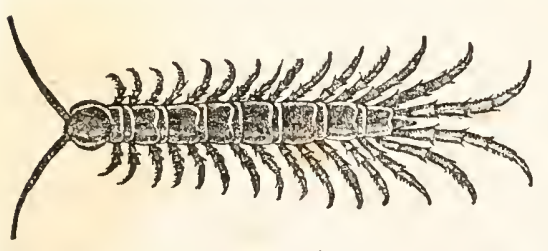

Tin. 511. Lithobius. ungleid) futto, befteben aus suci Jalbbogen, die an ber Erite bäutige 3erbintungen baben. Sober Ring trïgt mur cill cill= jigro Beimpar, bic oft sine $\mathfrak{b e}=$ Deutente Eutwifflumb und grofis Ränge erreidert. Der $\mathfrak{B}$ if Brofien 2reten, welde in ben beifen 3onen vorfonmen, wirb fitr gif= tig gebalten, whute baj man bis jest bejoubcre biftorganc bätte cut= beffen fïnten. Scutigera; Lithobius; Scolopendra; Geopliilus.

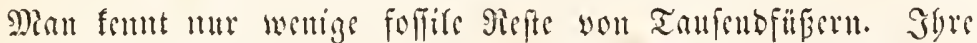

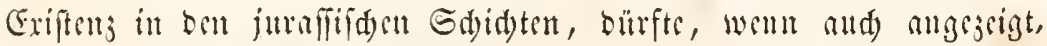
Dod) bejweifelt werben - bagegen find unyertennbare lleberrefte im Beruftein gefunben worben, bie beiben jamilien angegiren. 


\section{Elaffe sor Armilunion. (Arachnida.)}

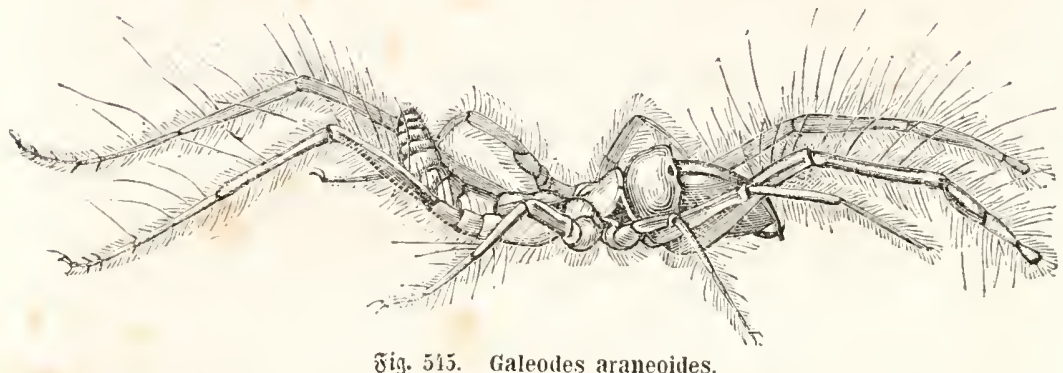

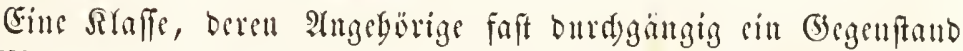

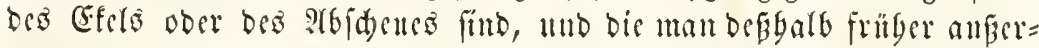

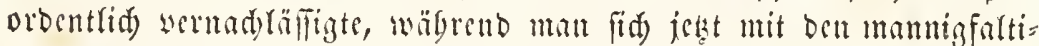

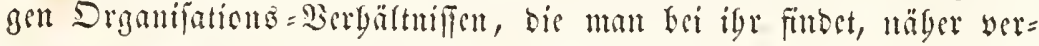
traut jut madyen gefudyt lyat.

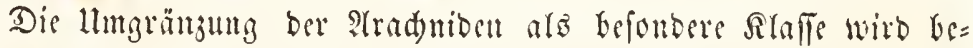
fonbers burd bie Steffung und 3ngl ber geglicberten Itngänge Gejtimmt,

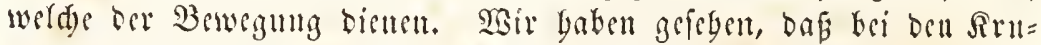

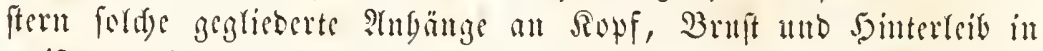

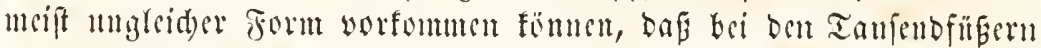

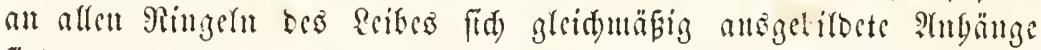

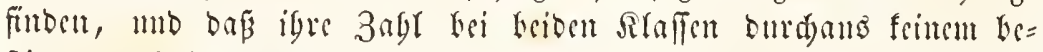

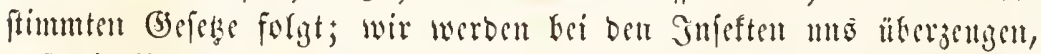

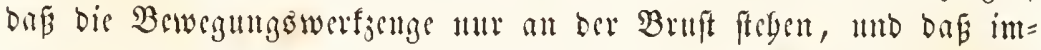

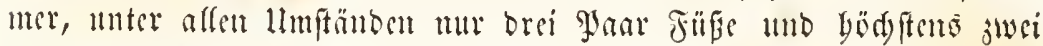

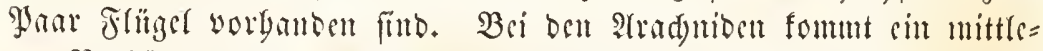

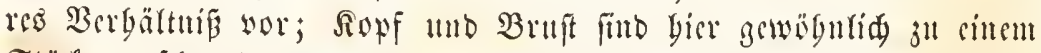

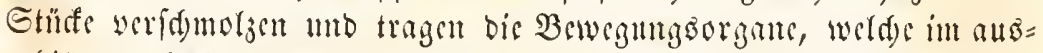

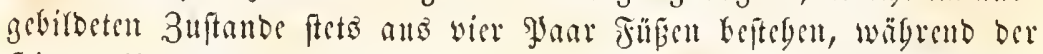

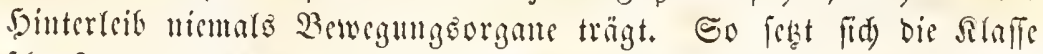

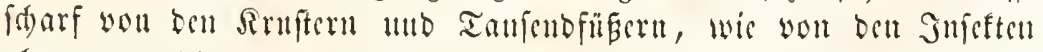

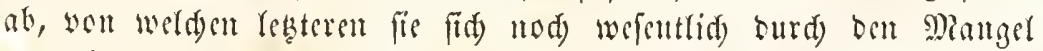

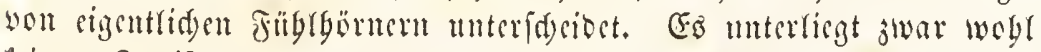
feinem 3weifst megr, baß die Drgane, weldye mant bei ben Epinnen 
it Form wou Sicfern Dber Giftzangen fintet, wirflide Pepräpentan=

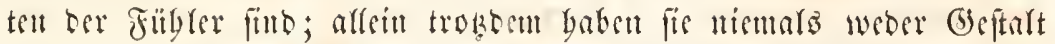
mod) Function ber wabren Fübler, weld) olue :Tnenabme allen Sn= feften jufomment.

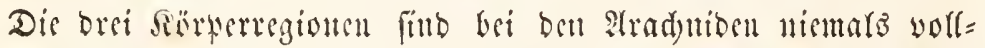
ftintig getrennt; Vei viclen nieber febenten formen bifbet ber unge= glieberte Sörper mur eitte sinjige megr ober minber rutholide Malfe, au welder worn bie Munbwerfienge, weiter gegen bie Mitte ju bie

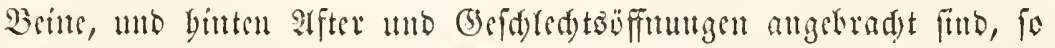

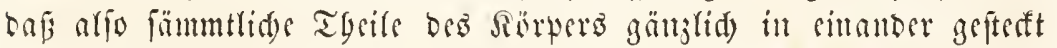

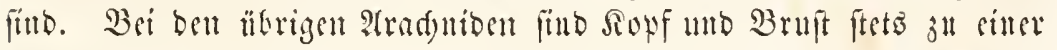

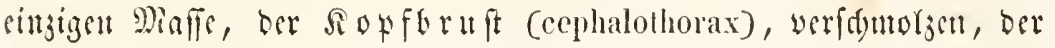

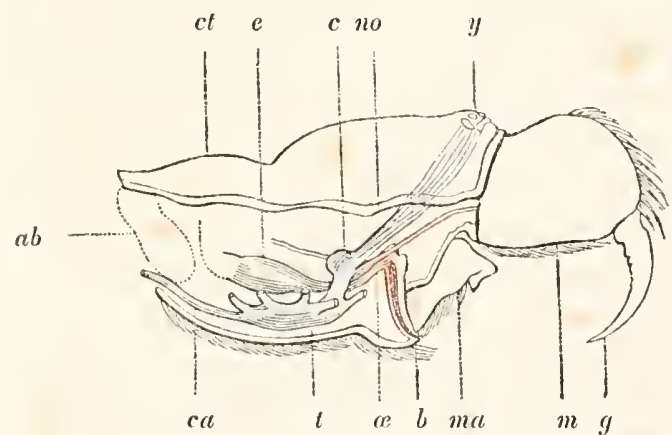

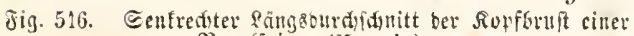
Bingefinine (Hygale).

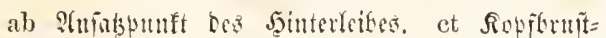
irsite. e Magen. c Şimfnoten. no Eefnerten.

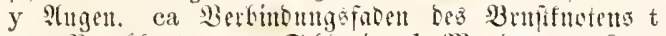

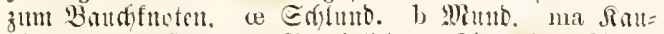

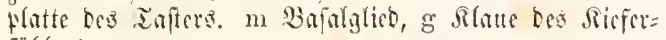
piithlers.

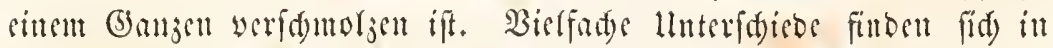

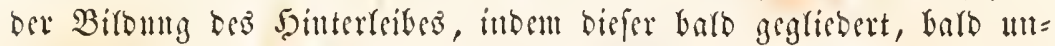
gegliebert ift.

Die Grmblage ber $5 a u t$ beftedt aus Chitin, Das meift weid, baut= ober leberartig erfdyeint, utto tur ill womigen fäflen sime gröfere Särte ober ferbft sime glasartige Gpröbigteit erbält. Troł ibrer grofen Debubarfeit, bie fid) Vejonbers nad) reid)lid)en Miablgeiten ober wäbrento ber (Fntwiffelung oer Cier funtogibt, beftizt bentrod) biefe Saaut, beren Etruftur febr wenig unterjud ift, frine Epur wou Goutrat=

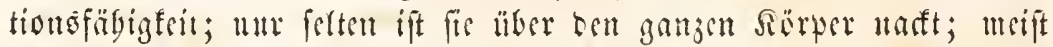

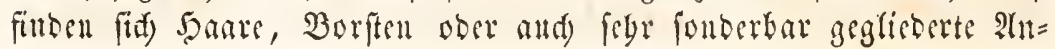


bänge uno Sdupten auf biefer 5aut, unter welder in form won

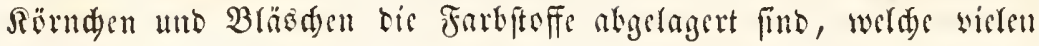

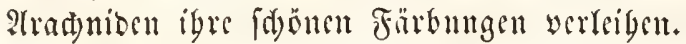

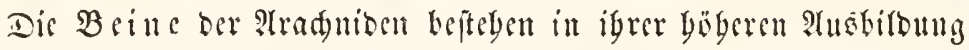
aus benfelben Theilen, welde man mit fo feftem Typus bei ben Sn= feften bergeftellt finoet; sin runblid)es bjüftglicb (coxa), an weldyez (id) sint furzer Süftnorren (trochanter) anfdliept, bient zur Einlen= fung bes Beines an ber Sopforutt; bicranf folgt gewögntid ein jiemlid) fräftiger Gdyenfer (femur) mu baun cine lamggeftecte Sdjiene (tibia), an weldye fid) cin gewöbnlidy jweiglicbriger Tarfus aureibt, an beffen sube eille ober unebrere Sraflen befeftigt find. Bei ben Milecn fältt es bäแfig febr fdyer, an ben meift in gleid) 9 lb=

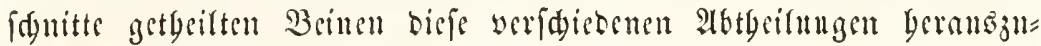
3iffern, uno bei ben langbeinigen Saeberfpinnen erfdemt bie Zabl ber Tarfalglieber oft fo febr vermebrt, bafi bie gennuere Beftimmung ebento fdwierig wirb. (B)wöbulid) gleid)en bie brei binteren Bain= paare einamber, wägrend bas worbere Beimanr febr mannigfad) Formen annimut unb fid) bierburd), wis burd) feille P(mmäberung nu bie Dinnowerfacnge, als einen eigentlid)en Rieferfub bartbnt, ber mebr bem Eyfteme bes Sopfes angegört. P(uperorbentlidy verfdécben ijt

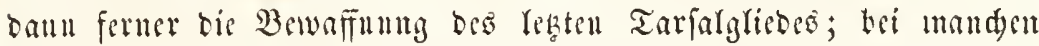

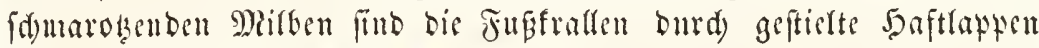
erfetst; bei ben tibrigen, welde ibre sübe mur zum Saufen ober jum

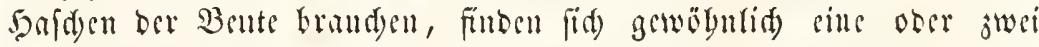
cinfad)e Ŝrallen; bei ben meiften fpintenben :Tradniben bingegen fino biefe Srallen anf ber inneren Seite mit Sämmen ober Borjenreiben befest, die offenbat jut Sanbbabung bes Fabens in Bejiegung fteben, unb benen oft nod eine britte fleinere Siralfe gegenilber ftebt.

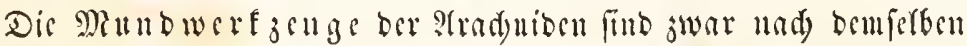

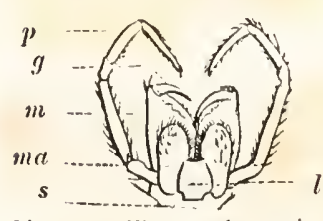

sig. 5\%7. Munonetientg citucr Rreujitune (Epeira.)

p Taiter, g Rlaue, m Baralglico bes Riefer: fïlylerg. ma Rouplatte bez

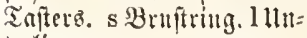
terlippe. Tykn ansigetirot, affein in fo verfdyebenen

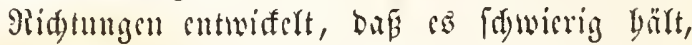

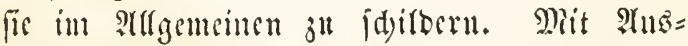
nabme siner sinjigen Familis fint fämutrid) Irad)niben fleifd)freflenbe Thiere, bie meiftens ine Bente mit Rift ober Bewalt liberfaften unb aแs่fangen, Had)bem fie igr eine vergiftete

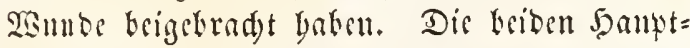
waffen an bem Minnbe weroen won ben um= gervandelten Füblern gebildet, bie bald Etilett= 
artig, soer wie Mefferflingen vorgeftuben werden fömen, bald zu

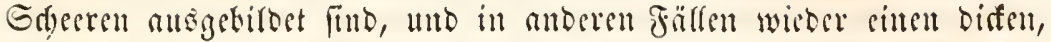

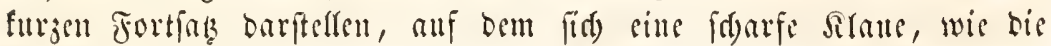
Singe cines Meffers bewegen läft; binter biefen sieferfübleru

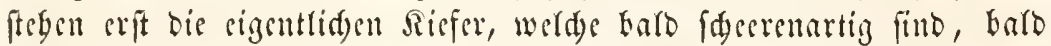
wirflide viefgliebrige Tafter barftellen, an beren $\mathfrak{B}$ afio fid nur sine

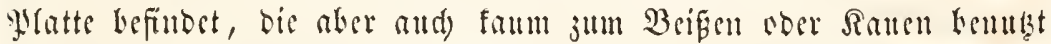
werten fann. Atuper biefen mannigfad wed) feluben Siefertaftern fin= bet man gemöbulid) mut nod febr weide wulfige Ripten, bie fei bent

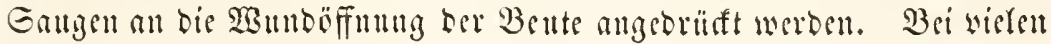

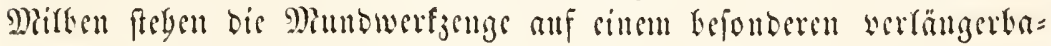

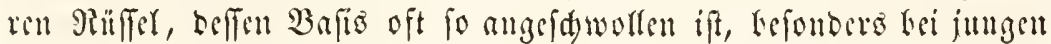
Tbieren, baf man cinen befonderen, vom Reite abgefęten Ropf ber:

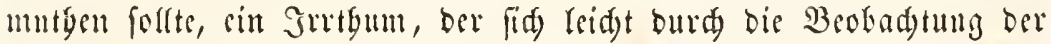
PHgenftelfung anffiacen ไäpt.

Das Rervenfy fem ber STadntoen jeigt, übercinftimmend mit

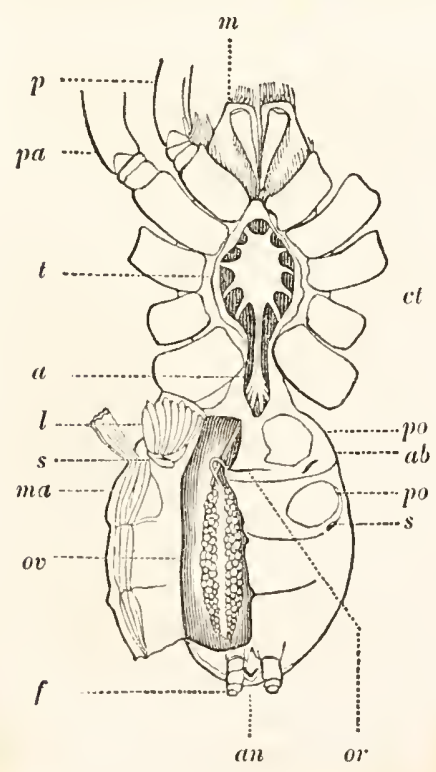

8is 518. Tuntumie ciner $\mathfrak{B r g e l f r i m e}$ (Mygale). Die Britt unt bie redte $\mathbb{B}_{\text {oud }}=$ billfte finb run unten ber gesfinet.

n Rieferfütyler, fier ju Beipflauen
Der Serfdumeljung ber einzetnen Sörtertbeife, aud meiftenz einen fely boben Grab Der Gonesntration. Bei ben einleibigen Milben exiftit nur ein sinziger $\mathfrak{B a u d f u o t e n , ~ u n b ~}$ ftatt cines Şimfnotens nur ein sint fades $\mathfrak{B a n d}$ über fen Sd)lund ber= über, wäbreno bei Den Spinnen sin ungebcures Bruffnoten fid fin= Det, oer faft unmittelbar in oas Gse= liun übergebt, fo bafi in Der Rer= venunafle nur sin flsines god) jum Durdyritte Des Ed)lundes bleibt. Im ?tufange bes Şinterleiber fin= Det (id) baun nod) ein verbältnib= mäßig fleiner Baudfuoten, ber in= beflen bifter aud) feblt, wälyreno bei ben langleibigen Sforpionen sine ben Mingeln bes Sointerleibes ent= fpred)ende Band fnotenfette exiftirt.

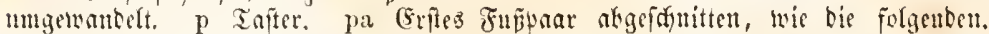

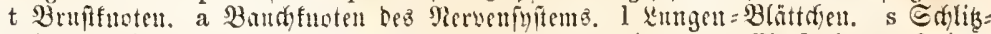

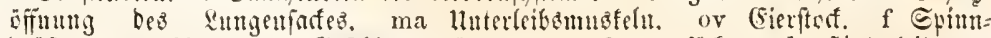

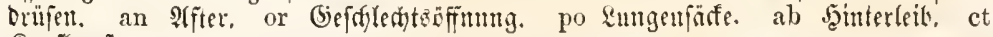
Ropformit. 


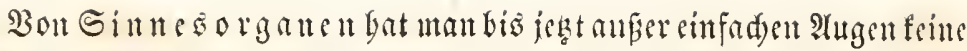

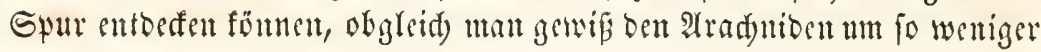

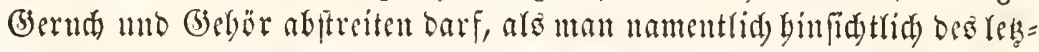
teren bei ber Zäbumm won Sfinnen bie Beobadytung gemadyt bat, baf fie auf mufifalifde Zeiden berbeifamen unb Das̄ ignen beftimmte Futter in Em= pfang nabmen. Die einfaden $\mathfrak{A}$ ngeat ber Araduben befteben aus simer bed)erförmigen ?agbreitumg oer Sebnerven, bie von einer fun=

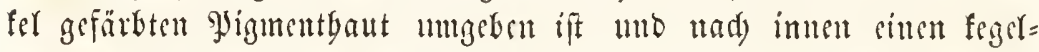

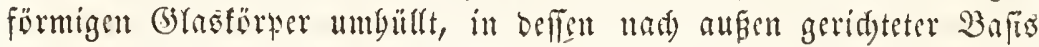
bie fugelfürmige Rinfe farft, welde won simer tunbliden 5ornbant liberwölet wirb. Die Zabl biefer ?Hgen wed)felt wou zwei biz adt, unt meiftens fitsen fere feitlids, ober nod) bäufiger in einer (Srmpte

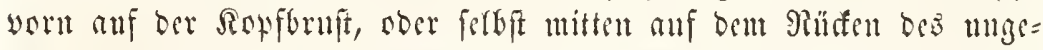

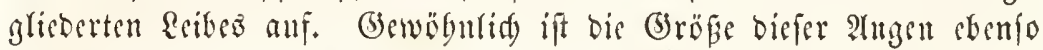

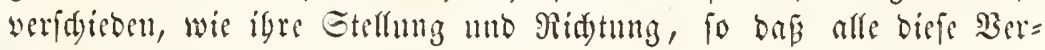
faicbenbeiten ganj wortrefflide fefte Merfmale jur lliterfd)eioung ber Gattungen mo 2lrten biloen.

Der Darmf a ual ber Pradyiben begintt gemögnlid mit cincm bïnten, fnieförmig getogenen, anfango bornigen, baun fegr mustulö= fen unb angefduolfenen Sdylunte, ber bei ben Sfortionent unt bent librigen, fruftenartigen 2 rad) niben in eimen geraben Darmidyland) fid fortfest, welder obne weitere Befunderbeiten in feinem Berfanfe ju seigen, am Ende bes binterletbes fid in cinen fpaltenartigen iffer ¿ifinet. Bei allen hibrigen ?rad)miben bagegen bilbet ber Magen ent= weber einen mittleren Gade, ober gar cimen bohlen Ping, son weldem aแg oft febr lange Bzinbfäfe entfpringen, bie bald auf bie Soffbruft Imb ben ecib befdränft find, oft aber and weit in bie Beine mo Siefertafter bincin felbft bis in bie Näbe bes Rlmengliebes fid er= ftresfen. Bon bicfem vielfad) werjweigten Magen aus cutfringt uad) binten ein Darmfanal, ber meiftens unmittelbar wor bem affer sine

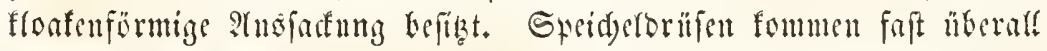
wor; bie Reber eridyeint bei ben nieberen Typen tunt als fïrniget lleberjug über oen Darm, wäbrento fie bei ben bïberen eine anlebn= lidge laptige Malle bildet, die aus furgen Blintofären beftebt. Die

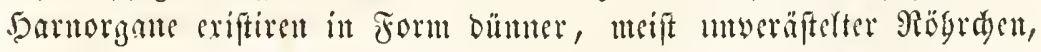
bie unter bem Magent in ben Darm cimmünoen.

Befondere 2t themorgane feblen mebrerent nederitebenton 3ra=

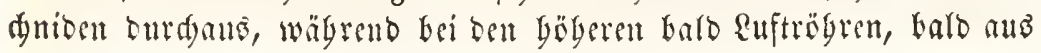




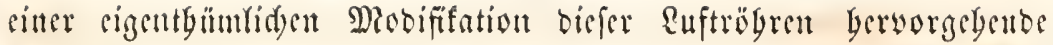
Sungen vorbanden fint. Die Ruftrïgren furb äuferft jart, mebr ober

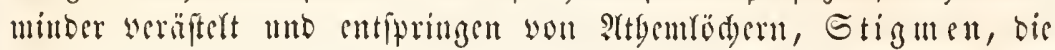
meifens febr veriteft unt panrig angebradyt fund. Bei ben Spimnen fommen ganj flatte Ruftrigren sor, weld)e bie \&uft febr frin jertbeilt entbalten unb ben llekergang ju ben fogenannten aungen bitoen. Dicje bejteben aus runtidgen Säden, bie fid auf ber Baudfläbs Des

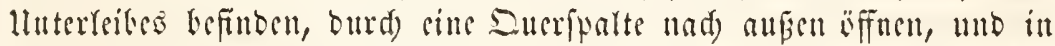
ibrem Jutern eine gewiffe SHzagl wou Wlatten in äbulidyer Weife geftellt, wie bie Blätter eines $\mathfrak{B} u d$ ) ftellt cigentlid) cine Peige vlattgebrïfter Ruftribrenftämme bor.

Die Iradjuben, weldye feine bejonberen Ityemwerfasuge befitisn, entrebren aud jeber Spur cinco sieisa

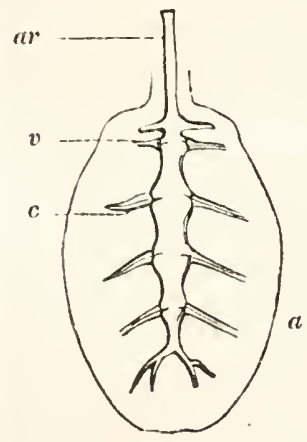

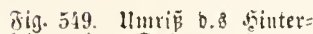
leites cinet Evimie mit oem Serjell.

ar Rörterateric. v vont ben Rungenfommento (S) $=$

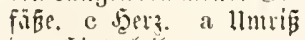
Dew jointerleithe anberen fid sin wobl ausgebildetes 5erz fintet, bas meiftens eine (d)laud)förmige (s) fitalt befibt. Dicies Sorg ift in mebrere siammern abge= (d)ürt, bie auf igren Seiten Spartöfrmm zeigen, wäbrent bas Sorz forbft sille grofie Anzabl won febr feimen Prterien ansjentert, bie fid) in bem siöper serjweigen unb obne 3wei= fer mit offenen Mänoungen enbigen, $b a$ nir=

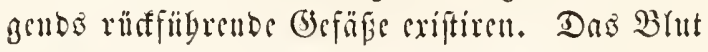
folf nad) Ler Babautung neuerer Beobadter fid) jwifhen bie \$änte ber Atbemorgane, feien bicke unn Rungen socr Ruftröbren, in wane Dungšlofen Sanälen ergiefien, unb yon oa ans balo Durd) cin Gyftem Felonberer Gefinge, balo Dur(h) mandungšlofe Janäle nad) bem Jerzen zurütfebren.

Fait alle straduiben find mit befonberen (b) iftorgane an auge frattet, werdae bei ben meiften an bem Sopfe liegen unb mit ben Minnd= werf zeugen in Serbinbung fteben, bei ben Gfortionen aker an ber

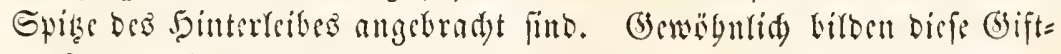

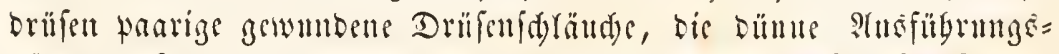
gänge entfenoen, welde it ben bafenförmig gebogenen, fdarfen Riauen ber Sieferfübler ober in bem gefrümmten Edwunzftad)el ber Sfor= pione nad) auben mümben. Bei grögeren Spinuen fam man Yeid)t beobaditen, wie in Dem 2tugenblite, wo bie 5afen Der Rieferfüglet in ben Sïrper eines gefangenen כ̄meftes geidlagen werben, ein Tröpf= 


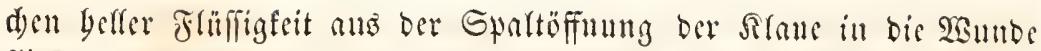

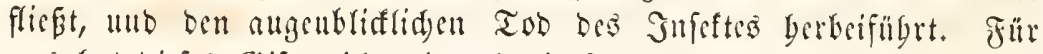
uns bat biefres bift nidgt cinmal bie Folge, wie basjenige, weldes

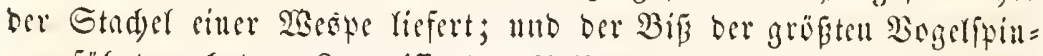

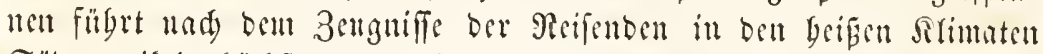

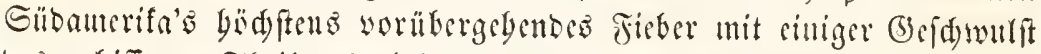
Des gebiffenen Theiles berbei. Bon unanden Gattungen beißer Rän= Der, beren $B$ Bís son ben Eingebornen für giftig gebalten wirb, feblen

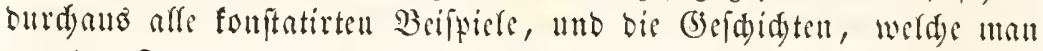

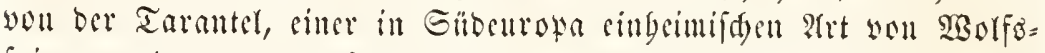
fFinuen, ober son ber Miarmignatte erjäglt, find infofern reine Jabern,

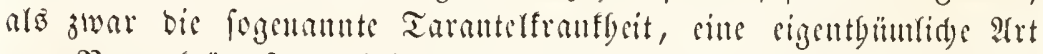
won Rervenfrämfen, eriftirt, igre llifad)e aber niemals in bem Biffe ber unfanuldigen Exime liegt, werdger fie jugefdricben wirb. (be= fägrtid) ifit afer alferbings ber Etidy ber groferen Efortione, welde

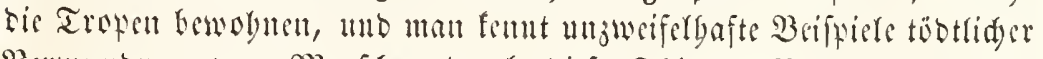
Berwunoung son Menfden burd biefe agiers. Bon ben Gpiun= britifen, weldje bei ben eigentlidsen Spimen in to auşgeseiduntem Grabe sutwifest fimb, wirb bei biefen ferbit bie Probe fein.

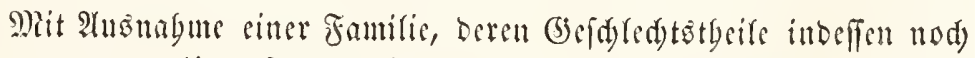

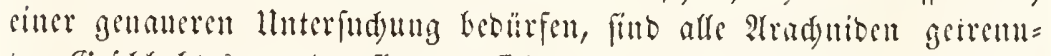

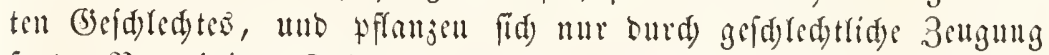
fort. Bor cintigen Gabren Yicf sin abgefdunaftes Mägrcher won ber

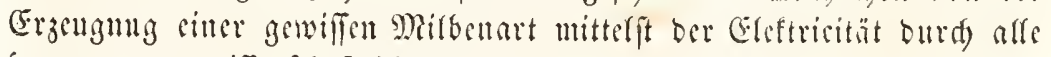

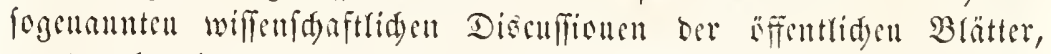
wurbe aber barb auf feinen wagren Gedyalt resujirt.

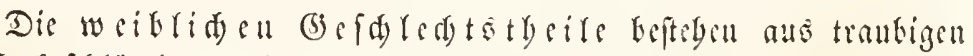

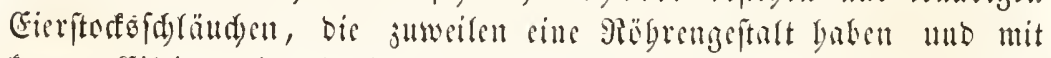

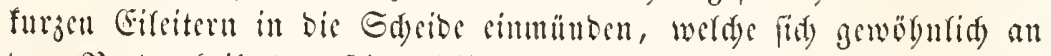

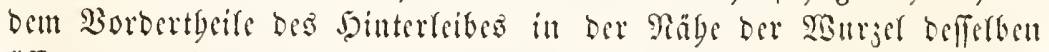

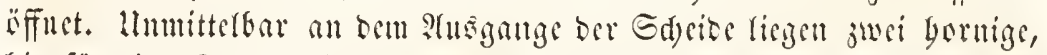
birnfürmige Samentafden, unt fegr oft jeigt fid cine Regerobre, bie

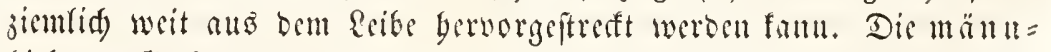

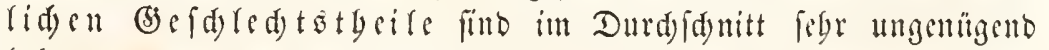

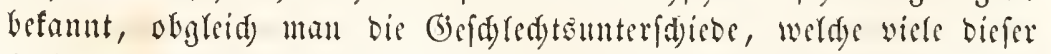

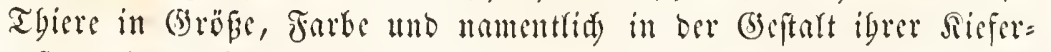

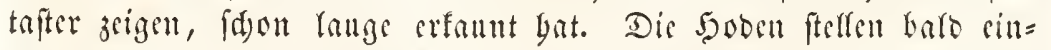

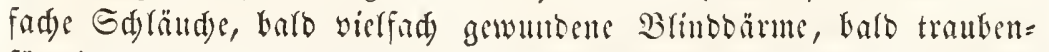

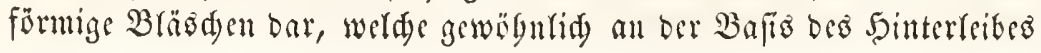


in siner cinfadyen Surrfalte fide sifnen. Bei sinigen Dilben, fowie

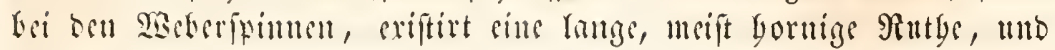

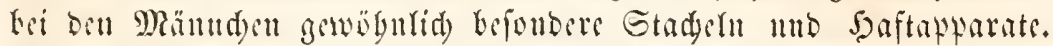

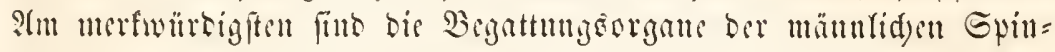

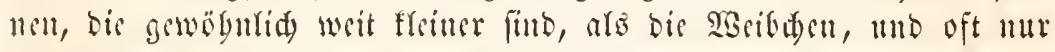

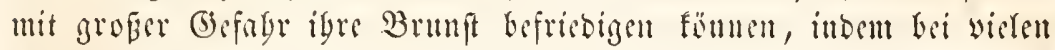

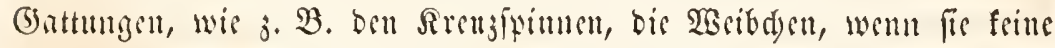
Suft jur Begatmug Garen, ober aud) unmitterbar nad) berferben luber

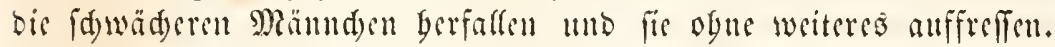
Bei anberen (battungen freifid) Gerridgt Cintradyt jwifden beisen Bje=

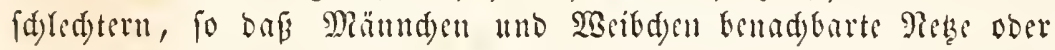

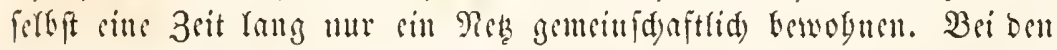
mäunlidsen Epinnen find bis Siefsrtafter serbiat und sntyalten it

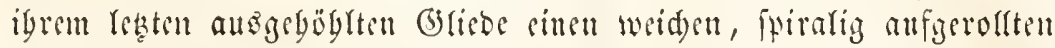

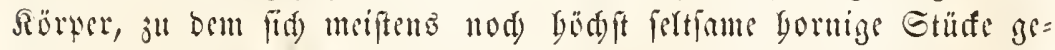

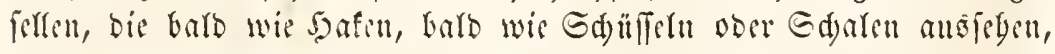

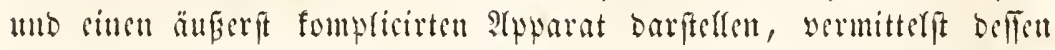

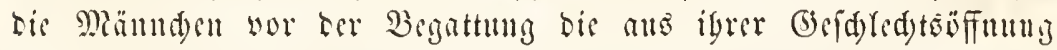

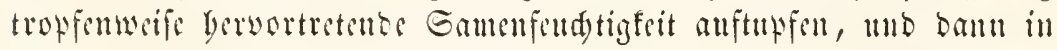

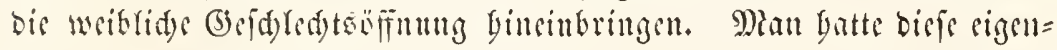

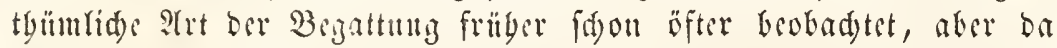

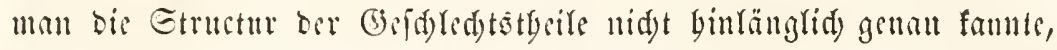
mo namentfids and bi: mifreffopifdse ?tratype ber Fraffigfeit in bon

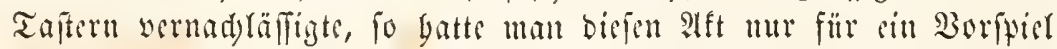
gergatten, bem bie sigentlidge Begattumg erft forgen folfte.

Die meifen ITraduben legen Eist, mur cinige Milben unb bie

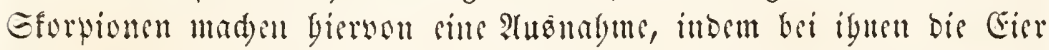

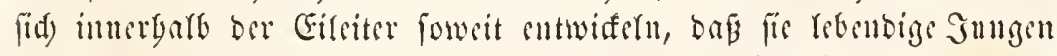
gebären. Die Eier baben gewöbulid) sine runblide Form, jumeiten

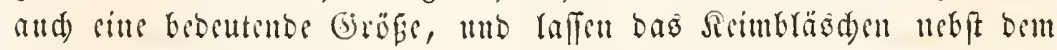

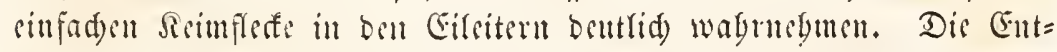

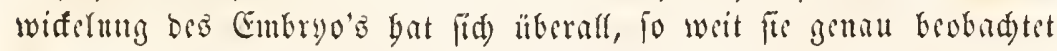

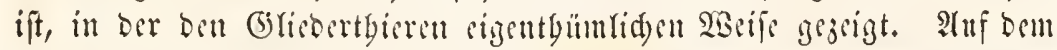

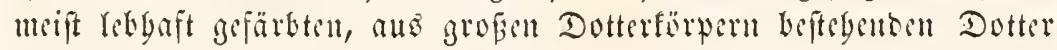

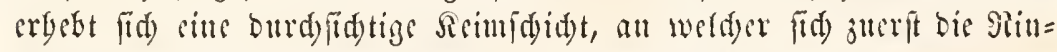

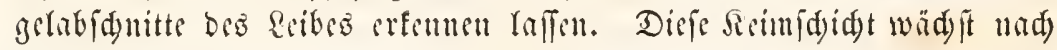
bintent über, unb indem fie nad unb nad) ben Dotter überjicht, Yafern

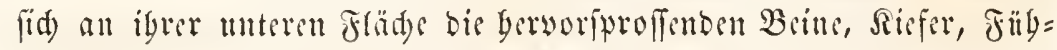

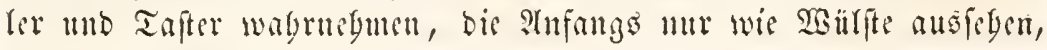
(id) aber alfmäbrig burd) Sinfduturung glisbern. Die Entwifelung 


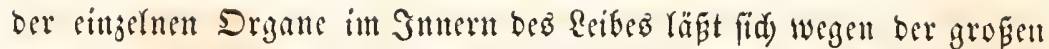
Dottermaffe, bie ferbft bei ben ausgefd)lüpften jungen Thieren nod) einen bebeutenden Theil beş Reibes erfüllt, nur fdwierig verfolgen. Die meiften Thiere ber STrffe, befondere bie ben büberen Typen an=

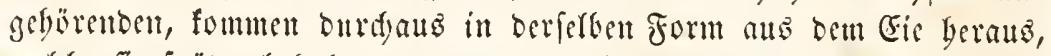
welde fie fräter bebalten werben, unb bie ganze alenterung, welde fie erletoen, bejiebt fid, auf untebentente farbenderänderungen wälreno ber megrfaden Säutungen; - bie nicberjegenden Aradniben bagegen,

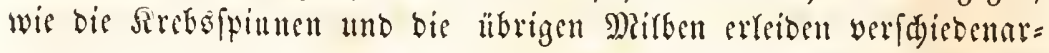

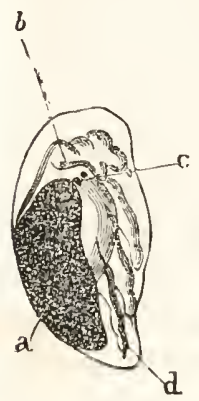

รiก. 550 .

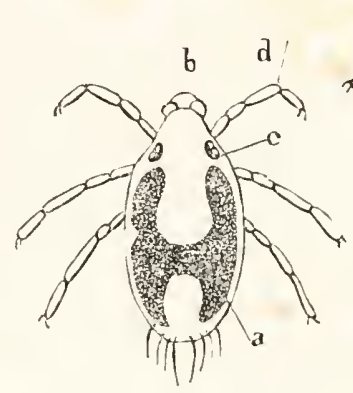

Jii. 551

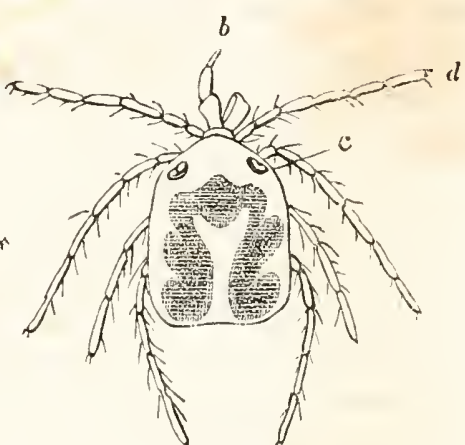

Tig. 552.

Fig. 550. Iluzgefildetes (5i. Fig. 551. Ravue. Fig. 552. Bodlitandig ent= wiffltes Thier bet $\mathfrak{M}$ ufidetmiffe (Limnochares Anodontae).

a Dotter. b תieferfübler. c SAgen. d Tï̈e.

tige Metamorpgofen, iubem fee entweder nur mit fegr unentwifelten

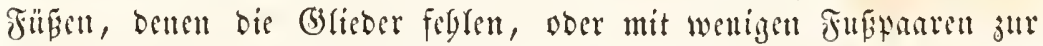
Belt fommen. Die unentwiadelen Mitben Gaben gewöbnlid) un orei Fubpaare, juweilen ferbif une jwei, und oft citte fegr abweidende Beftalt, indem ing Sïrper länger geftreft uno ber Borbertlyeil, wel= d)e bie bafigen Rieferfübler trägt, fnopfartig angefdwollen ift. Ges wölulid) wird bas mangelnoe Juppaar bet ber erften Säutung erfegt; bei einer fdtnarokenden Jamilie aber, ben 3ungenwärmert (Lingua(ula), geben die Fäpe im fräteren \&eben gänglid) verloren und bei

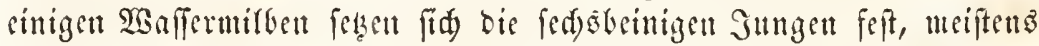

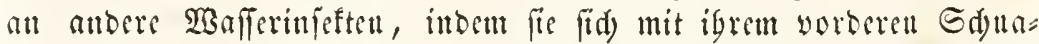
bel einbogren, uno mad)en einen förmlid)en Juppenfd)laf ourd), wäb=

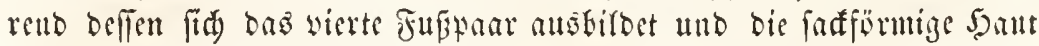
oer \&arve als \$uppenbülfe bieut.

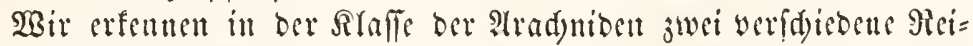
ben won Typen, welde fid) gewiffermafien gegentiber fteben. St ber Seibe der fpinnenartigen ataduiben werfolgen wir won Stufe 


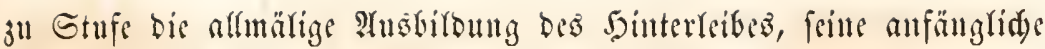
Berfdueljung mit ber Sopftruft, feine Trenunt von berjelben, uno auf Der bödften Gtufe fogar bie bentridse Trumnng ber Bruft you Dem eigentlid)en fiovfe, weld)er freilid) nod) fubartige ?(nbänge trägt. In biefer ganjen Picibe finten wir gewögntid) eine weide Rörterbe= Defung unb ftets sinen mit Bfittbfäfen veriebenen Darmfanal, Deffen Plefte oft bis ill bie Finge bincimeiden. Bei ber jweiten Reibe, ben

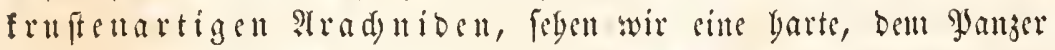
ber Sreble äbulide Sürperbebertung, eituen geraben Darmfanal und gewöbntid) (đeerenartige Sieferfïgler.

Die beiben Reiben ber Aradnioen treten gleidjeitig in ben Rob= ramidideten, arpo simer ziemlid alten Formation, mit einigen Sforpio= nen und Spitten auf. T(ud) in bem Jura fo wie in ben Tertiärge= feriten bat man sittige, in bem Bernfeit aber eitle grofie 2 (njabl von Grimten entoeft, bic grofentbeils nod) Yebenden battungen angegören, aber affe you ben Arten bex Selztwert fid verfdieden zeigen.

Sn Dem Miere findet man unter Gteinen, zuweilen and an Fi=

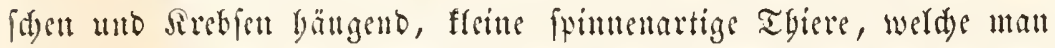
unter Dem Ramen ber Sircbsfpinnen (Pycnogonida) balo unter die

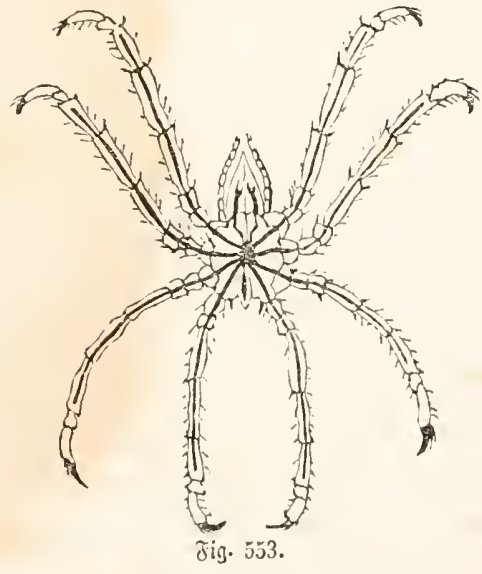

2Beitriáe Ammothoe, fo bargeitcllt, bar man ben Darm pieft, Der feme Blinditife bis in the Epizen tor Füne forict. Bmifden ten Minnowerfzengen unb bem criten Fugparte iteflen tie ta=

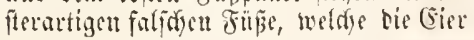
tragent.

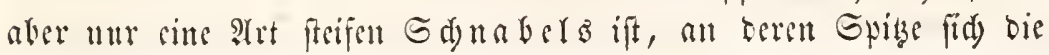
tgiere geftefft bat, sin beutlider $\mathfrak{B} e=$ weis, bafi fie jwifden beiben eitle Irt llebergangsglied biloen. SGr Rörper bejtegt regelmägig aแs vier mittleren Ringen, Deren jeber ein Jaar 2 sine trägt, unt die mit ein= ander ju ciner Solfferuft yerfd)mol= jen futb, anf beren vorberem Raube vier fleine cinfade ?lugen auf sittem

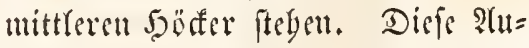
gen fitsen แmuittelbar auf Dem Jairn= fuoten auf, wou bent aus cin fur= jer Gdylubritg mad) binten gebt, an weldyen fid) vier breite Rerven= fnoten obue Berbinbungsinge ant= foliefien. Sor oer Ropfbruft ftegt eitte uncift fegelförmige Spize, weld)e man als Sopf betrad)tet bat, bis
bels ift, alt beren Spize fids bie

atraduiben, balo unter die Simfent = 
Mundöfnung befindet. Der $\mathfrak{b} i n t e r l e i b$ beftegt mur ans einem frei=

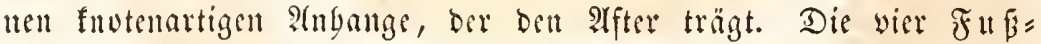

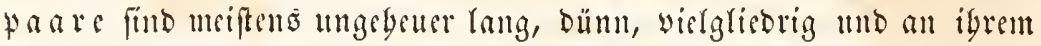
Ende mit siner grofen gitogenen Sralle bewafinet, neben weldyer oft tred) fleite, fraflenartige Dornen ftelyen. Bei mand)en Brattungen

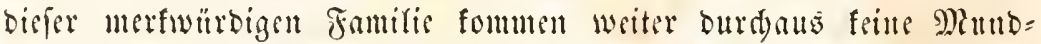
werf irnge sor, als ber erwägnte fteife Sdnabel, wäbrend bei anderen auf beul erften Ringe Der Ropferuft sin aus megreren Gbliebern ges

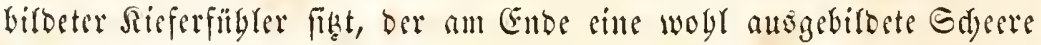

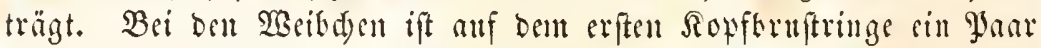

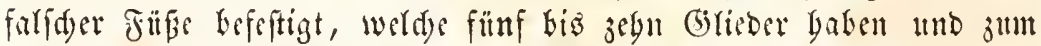
Tragen ber Gier beftimmt fint. Die innere ?tuatomie biefer Thiere

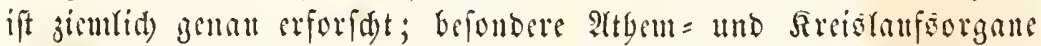

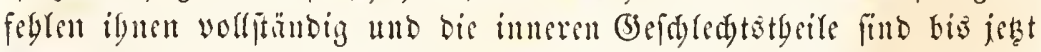

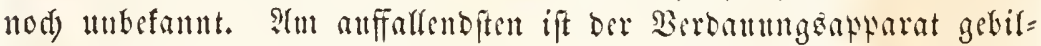

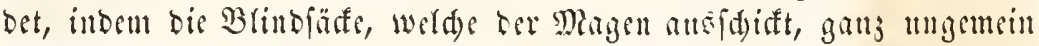
lang fint, thto faft bis in bie Nilanenglieber vorbritugen. Dis Sungen,

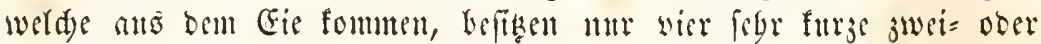
breiglicbrige Bsine, bie mit langen fäben befest find, unt sinen voll= fomment ungeglicberten Reib, fo dof fie alfo bebeutende Mitamorklyo=

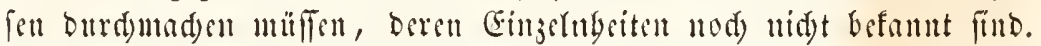
Nymphon; Phoxichilidium; Ammothoë; Pycnogonumt.

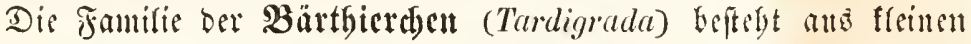

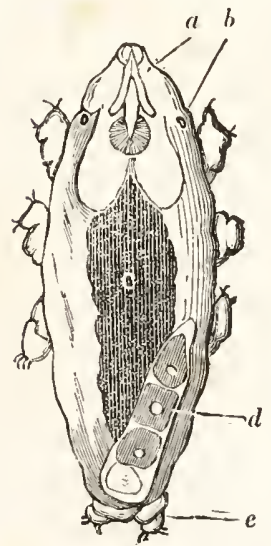

ชิig. 551 .

Macrobiotus Itufelandi you Rituen ats gefehen. a Etrdaptrat, b ?

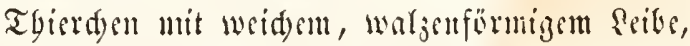
Die fid) fapt überall itt Dioofe, im Gatbe ber

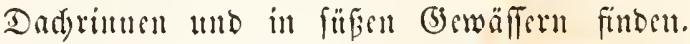

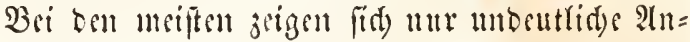
Denturgen siner Pingehtung in Eer fold weiden

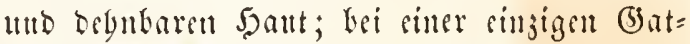
tumg (Enydium) fintost man sine feftere baut=

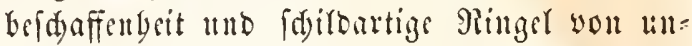
beiftumuter 3agl. Die adjt Bsine, werldye riefs Thiere befifisen, funo fegr furz, ftummelartig,

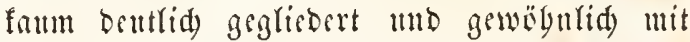
wier gropern, bato gleidsen, balo ungleidsen

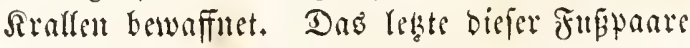
frist immer ganz binten an bom Rörwer, faft wie sin getbeitter Edywanjantang, fo das alfo cin sigentlid)er Jjinterteí gänjlid) foglt. Rad)

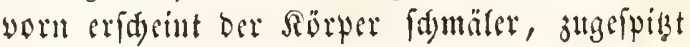


gett. c Diszen, d Eier= frot mit ber ontedifotigen Emmentaje bom finteren

Sure. c siuterfitios.

ober abgermets, ogme bof man cincu cigent= (id)en Ropf unterfd)ciben füunte. Mian fiegt

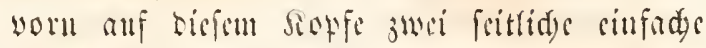

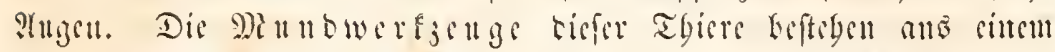

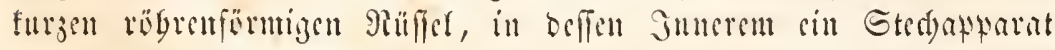

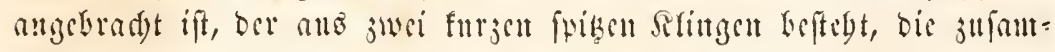

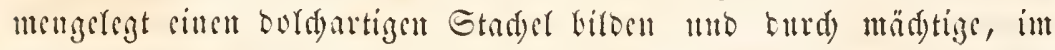

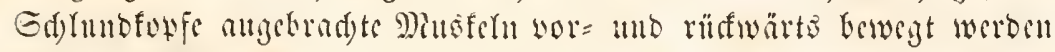
fünnen. Dor Darmf a na ( läuft gernoe burd) ben Siörper Gindurdy,

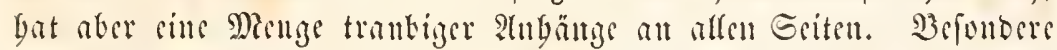

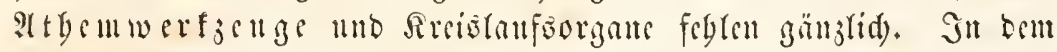

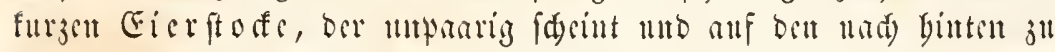

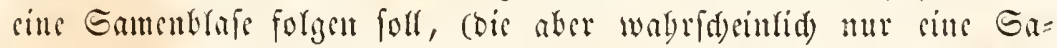

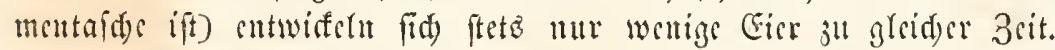

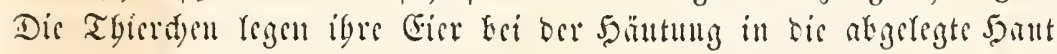

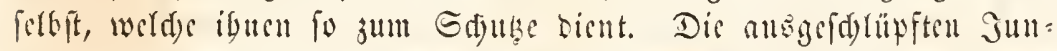

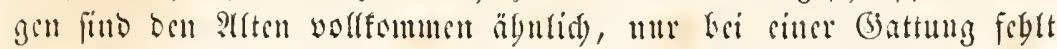

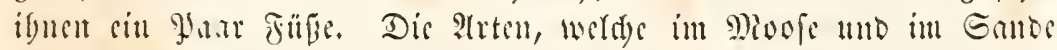

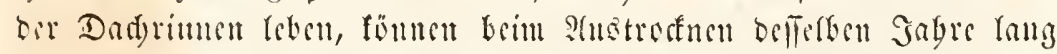
im fdecintoden 3uftande vergaren, und werben beim 3utritt won

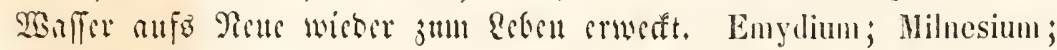
Macrobiotus; Aretiscon.

Dic zablreide Dronung ocr Mäilben (Mcaroma) begreift sill

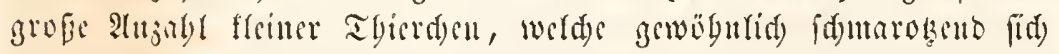

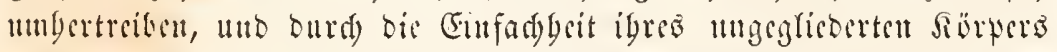

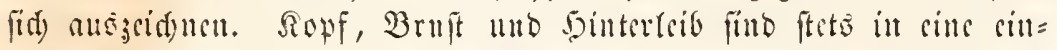

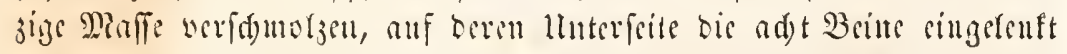

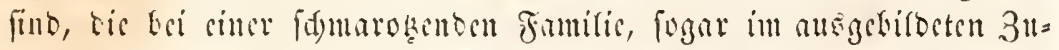

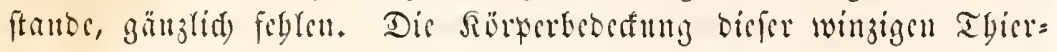

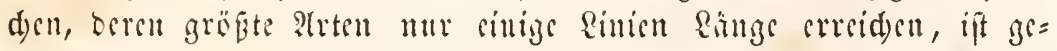

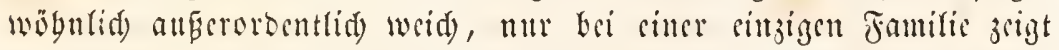

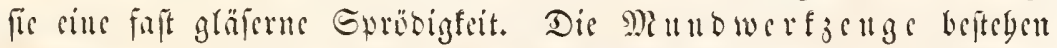
gewöbnlidy ans sincm stüfrer, in weldyem zwsi ids mfe flingenartige Stndefh verkorigen fint, sie jum Berwunten ber Bente bienen. 3u= weilen ift oer giüffer, weld)er biefe sisaffen trägt, fürmlid gegliebert, nut fann wie sin fernrogr ants = unt singefdaben werben. Der

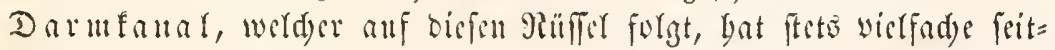

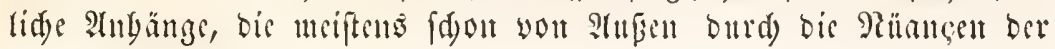

Bogt. 3colegifithe Briefe. I: 
Farbe erfannt werben fümnen. Bielen Milten, befonders benen, welde unter ber Jant anberer Tlyere folmaroken, feblen bie $\mathfrak{A}$ gen; bei ben meiften find fie in ber 3weizaly vorganton, und fteben bann feit= (id) auf bent worberen Theile ber Ropformit. $3 \mathfrak{u}$ beiben Geiten bes

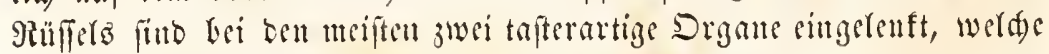
fegr verfdicoene darafteriftifde formen antuebuen fünnen uno $\mathfrak{g}^{\mathrm{e}}=$ wögnlid fünf Grieder befizen. Bei ber einen Familic eridement diefe Tafer flappenartig, innen bejägnt, in äbulid)er SBeife zแm Jangen

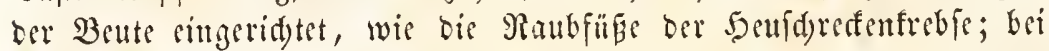
anberen bient bas cinfd)lagbare (3)(ieb biefes Tafters, bas mit cinem Jafen bewaffret ift, als infer zum Feftbalten unter bem Sisaffe; in anderen Fäffen fitto die Tajter fpindelförmig ober cinfad) Vorftenförmig, nod) in andern flappenartig unb utebr ober minter mit bem Piuffel

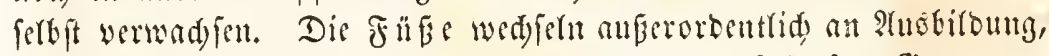

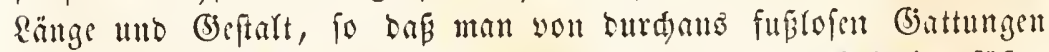

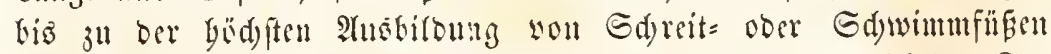
alle mögliden 3mifdenfufen finbet. Bei bon büber entwiffelten Fa=

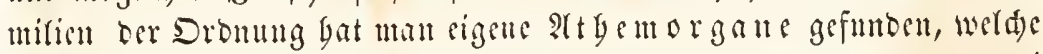
aแร Rügren befteben, die unverätelte Büfdel biloen und von juei

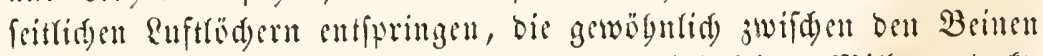
angebrad)t find. Fin 5 erj gat man nod bei feimer Mifbe entoeft.

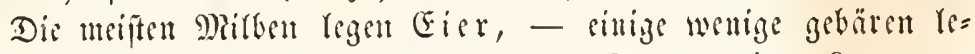
bentige Sungen; afle mad)en wägrent ber Jugend einen Rarvenju=

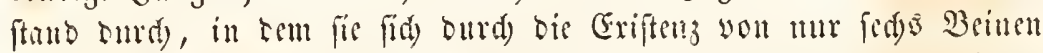

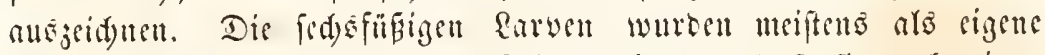

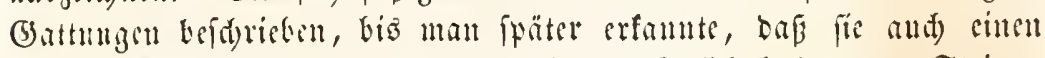
wabra lypenjuftano burd)leben, indem fie fing bald unter Gtrinent unt an auberen geqdüsten Drten, bulo an rebenten Snfeften aubeften

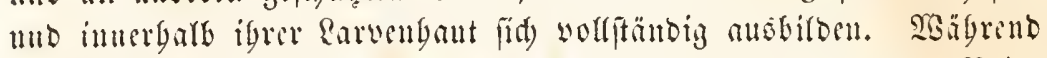

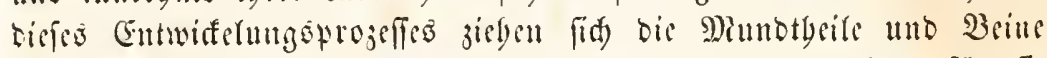
allmäblig aus ben Gdyciben beraus, welde die sarvenbaut für fie

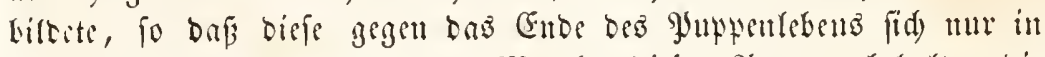
Form sines Gafes bariteft. Mhandye biefer gupten bebalten bie Fäbigfit, fid ju bewegen, wäbrent igre Mundöfrung volfommen

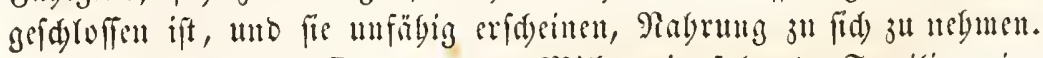

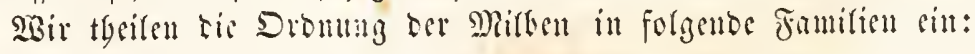


Famific Dor Bungenwärmer (Linguatulida), cinc (5rupps von

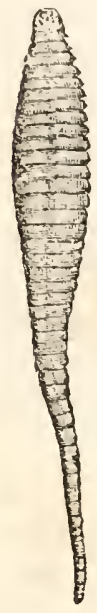

ชi.3. 555. Tbieren, bie man bio anf bie menefte Brit affgentein für Cingencibew ïmer gebalten bat, who fie in ten Etirmbäbren, ben Eungen ber Säugetbiere, vorr in

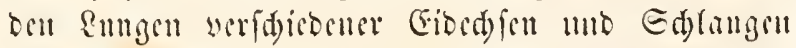
gefunben werten. Dis angefildeten Thiers baben rince wmmfïrmigen, balo rmoliden, balo abgetlat= teten Rïrter mit viefen bentliden Ringelu, unb slue cine Spur wa Gimeswerfigngen, fruben ober an= beren geglicbertin șbängen. Fut sorberen Crnbe Des Rïrters befindet fid ber Mund mid ju briben Eriten befferten jwei gyar frummer, beweglidar,

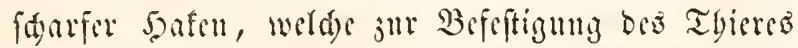
an frinen Itufentbalteont biencu und früber für Definungen gebalten wurben, wober ber muriditige Rame Pentastoma, bou man ber Gattung gab. Das

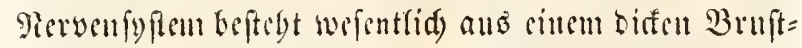
tulit. Enoten, ber mit cinem einfad)en Sdylubringe in $3 \mathrm{r}^{\mathrm{r}}=$

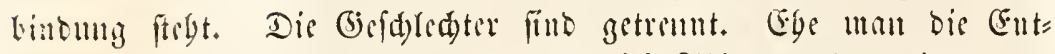

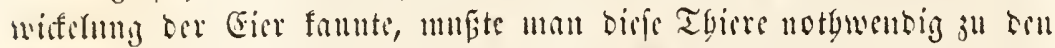

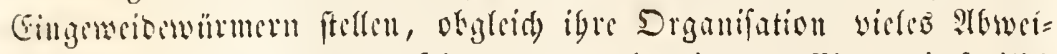

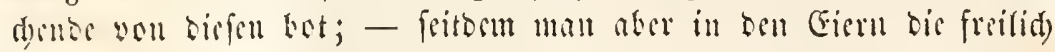

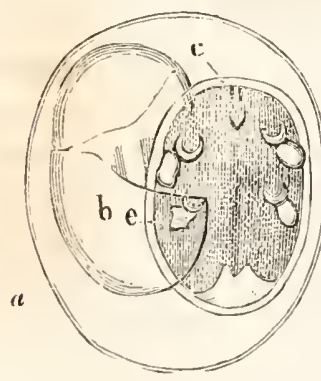

8ig. 556 .

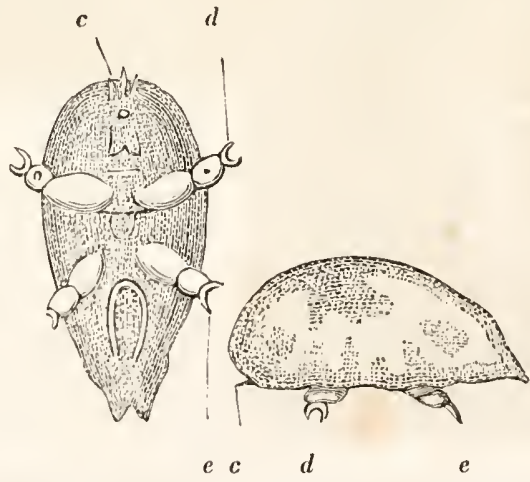

Jig. $557 . \quad$ รị. 558.

(Eubrbuneu ber linguatuia

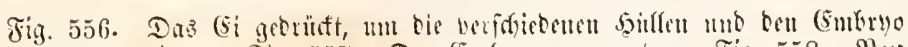

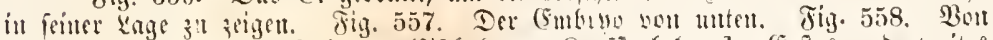

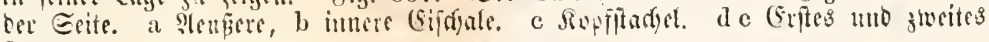

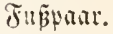

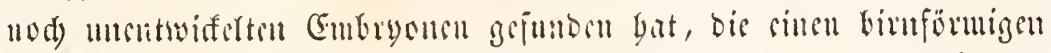

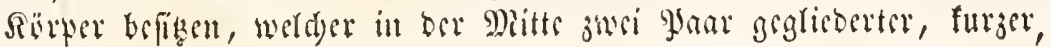


mit Doptelfraflen werfebener Fübe uno worn sinten Sted)aparat trägt,

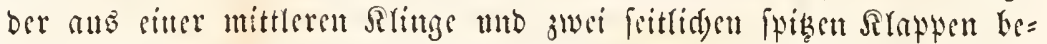

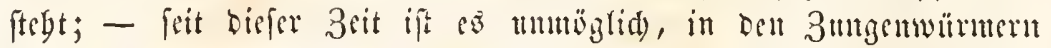

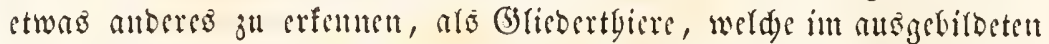

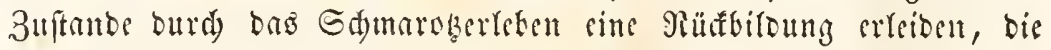
ben urfprüngliden Typus bis zum แnfentlid)werben verwifdst. Die (3eftalt ber (Fmbryouten näbert fich wiel mebr ben MRilben, als ber

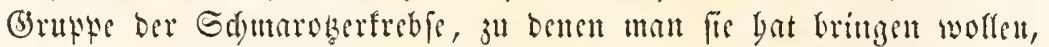
und die geftredte form bes Rürpers, weld)e defe Thiere in ber fä =

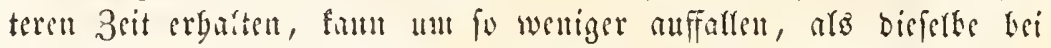
ber folgenten Familie ebenfalls vorfommt, Linguatula. (Pentastrma).

Die Balgmilben (Simonila) finben find) in jiemlid grofer 2 At= zabl, befontors in ben Saarbälgen bes Gefictes beim Menfd)en nub

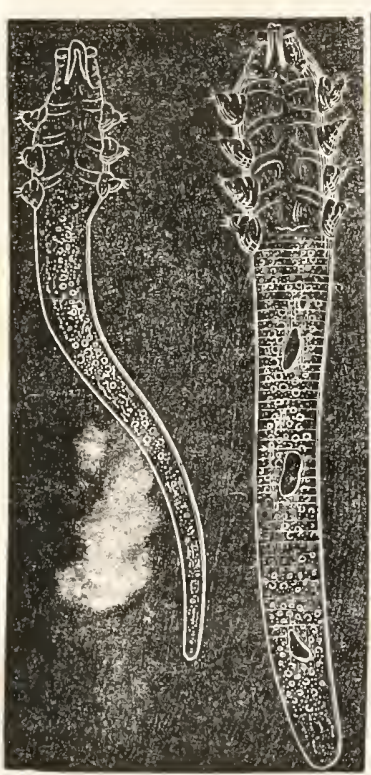

5is. $55 \%$

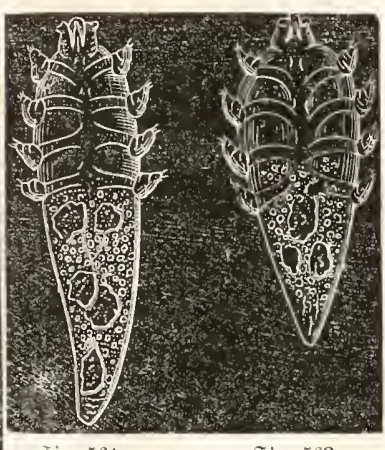

Jig. 561.

Balgmilte bes Dienfifen (Simi) nea (Demodex) folliculorum), in verfítiebcuen Etabicu ter Entwifelung.

Fig. 659. Eedfateinize sarte. Fig. 560-562. S(6)t= Eeinige Iflete mit ftets fürzet meroutum sianterlitie. namentlid) itt ben fogenannten Mrit= effern, bie tei wie= Yen auf ber গiafe yorfommen. Dis Tbiere Gaben bëd)= fteng dis Räuge eitter 3ebnterlinte unb bejtebent aแts sittem w gen Scite, Der fids bei jutebuttentan Ilter utrebr und titere serfïrst und atto ciner breite= rent, weid)en Sopf = bruft, weld)e bei benfiüngeren,lang= reibigen Setrivi=

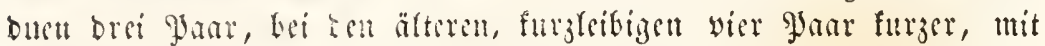

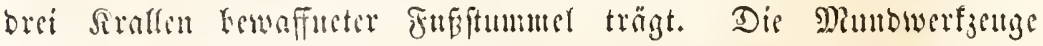

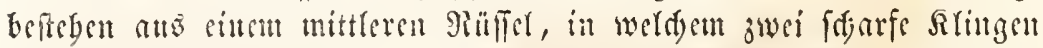

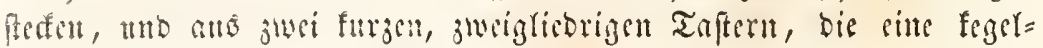
fobruige Ghenalt baten. (Simonea (Demodex)). 


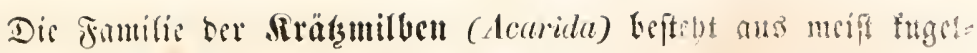

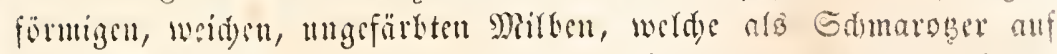

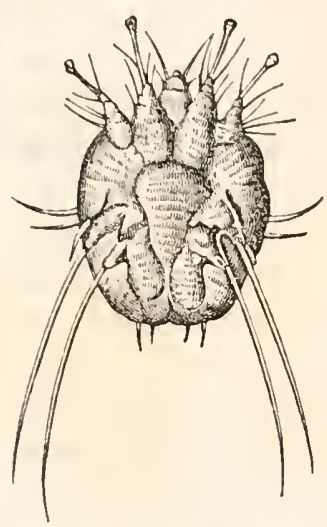

ふ̌iฺ, 563.

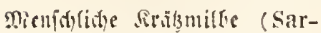
contes scabiei) vouber Bant)feits.

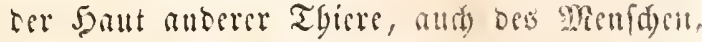
Yeben, bort Gänge graben, unb Dures Den fteten

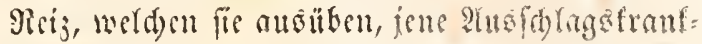
beiten erjengen, bie man muter bem Ramen ber

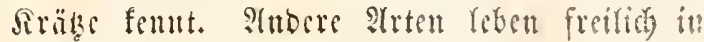
faulenoen Pflaujen= und Tbierfoffen, wis na= mentlid sine fobr bämfig in altem siafe, werdy you gefuriften Betringern benllnfunbigen juwei=

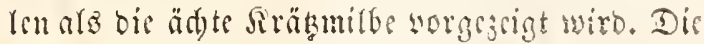

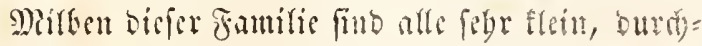
ณub blino uno mit meiftens furgen, unfömt liden früben werfoben, bie wurftërmig geglie= bert erfocinen uno fere weit wou ber Mittellime

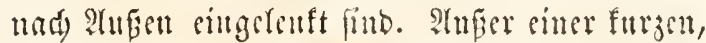

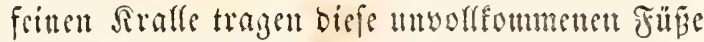
meift nod einen an eittem langen Stiele be= feftigten Jaftlappen und lange Keweglide Fäben, bie wie gyatiden= (a)muren umberbängen. Dor Rüfrl ift lany, birf, fegelförmig; die

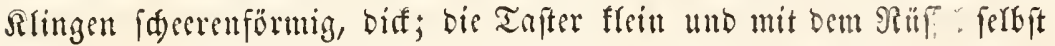
verwadfen. Die Jumgen baben nur fed,s fäbe, fonjt aber bie Rör= Werform ber ansigebilosten Thiri. Sarcoptes; Acarus; Pleroptus; Tyroglyphus; Melichares.

Die Familic ber Beren (Ixodida) beftebt aus jiemlid) grofien,

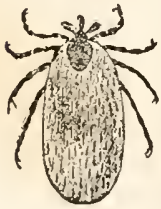

รig. 564 .

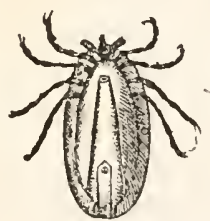

ơig. 565 .
Die Sgelzerfe (Ixodes Erinacei) sun ber

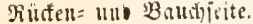

flatten Milten, beren yorberer Rör= pertbeil anf Dem Rüfen mit einem barten, bornigen Edjilo beoeft ift,

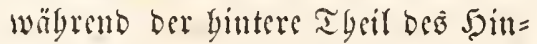
terleibes febr ausbenbar ift und anjerbem urcift gefaltet eridesint.

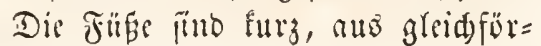
gen, rofenframartigen (5)feoern ge= bilbet, am Ende mit einer Siralle 


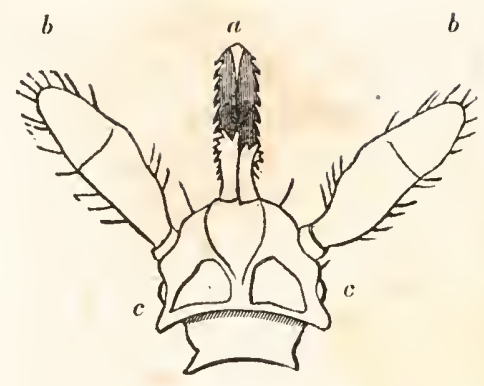

Jiis. 566.

gituromer:ienge cerfeiten 3erfe.

a Ritifl. b saiter. e sopfisgile.

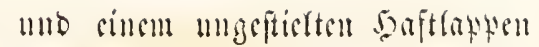
serfeben; ort Rallfer ift bersutento grob, yorftebent, bie Tafter fasci= renartig an ign angelegt, rie $l 1 n=$ terfipte berworgejogen, ill form siuer 5arkfeble anzgebildet mub mit

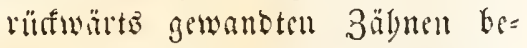
fest; rie silingen find fuld, biff, Ireiglistrig, Das äuperfte Gslied érenfalts gezägnelt mo fdarf. Dic angentofen Ibiere fanern in 28 äl octu mio (bebrifden anf soritter=

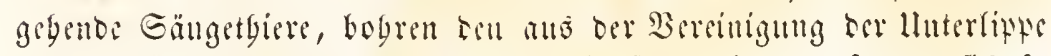
mo ber Silugen getiloets Räfiel in bis sant eill tmo fangen fids fo

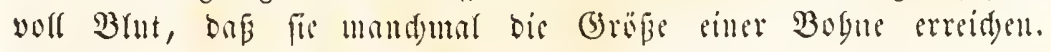
Ixodes.

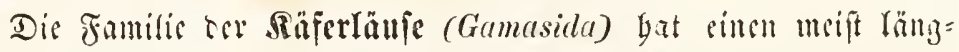

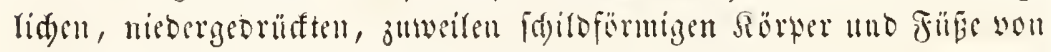

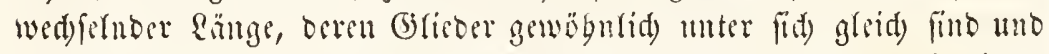
an ber Gpibs mit jwei fleiten Sirafen umb meiftens nod) mit cimem

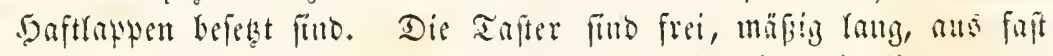

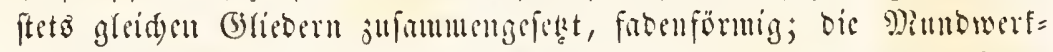
jenge jiemfid) seridicoen, Die Rlingen fdarf und jum Boblen einge=

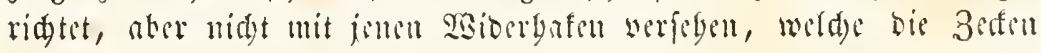

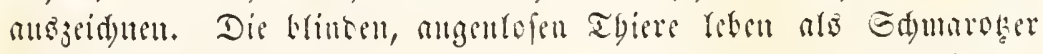

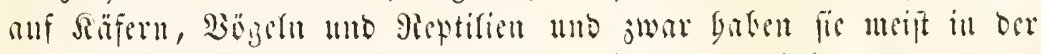

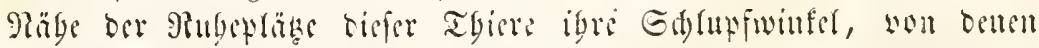

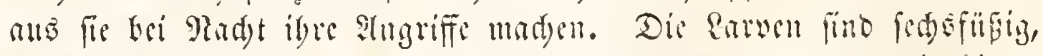
bie gupten feweglid, mit adjt güfen werfeben, son tenen rie biute=

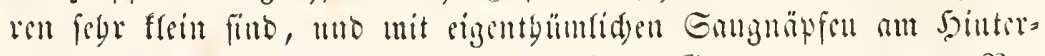

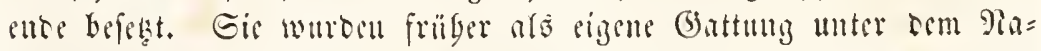
une IIypopus fefdriben. Dermanyssus; Gamasus; Uropoda; Argas.

Die Familie oet 2Gaffermilben (Hydrachida) Eegreift verbätt=

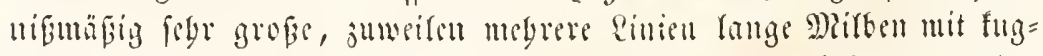
lidem ober eiförmigem fiörper llto langen, meift bebarten ofer

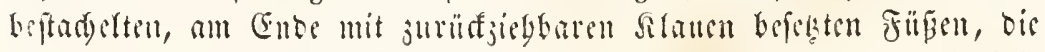
jum Edwimmen tanglid) erfdgitten. Dis Tafter finto lang, bic bei=

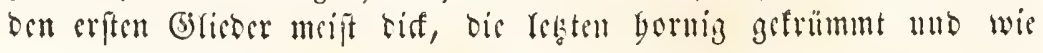




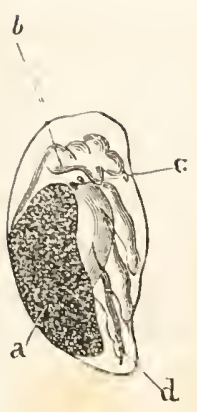

Jig. 567.

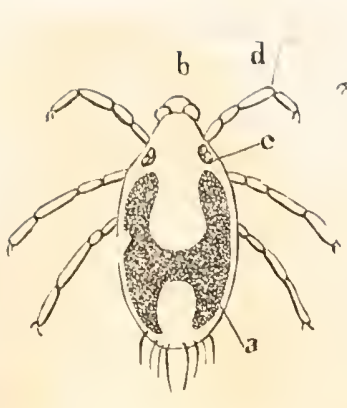

ii. 568.

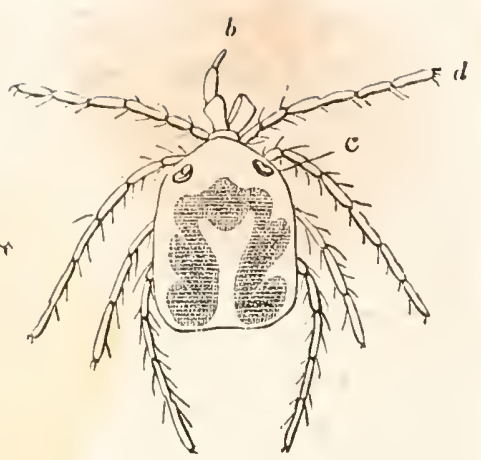

Jig. 569 .

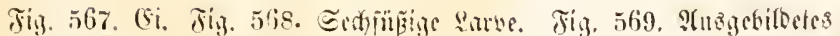

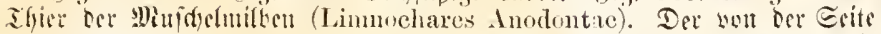

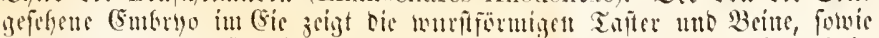
fell buteln, rinfmitubigen Dotter, ber and tei ter Earwe fid nd in

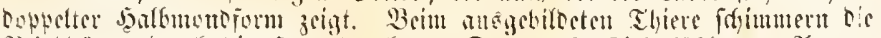
Slinboürme surd) bie saut burd). a Dotter. b Sícferfübler. c Angen. d Jïipe.

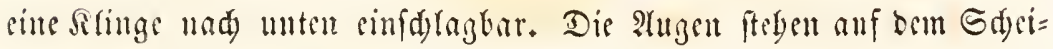
tel meift ju jweien ober sieren, juweifen aud fo gebänft, bafi baz

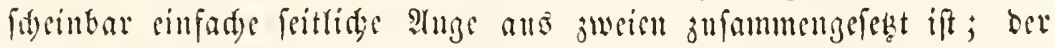
Edunter ift bart werborgen, hato worfebent. Die Thiere leben im 2Baffer mo befizen \&nftrögren, fommen aber nismals an bie Dber=

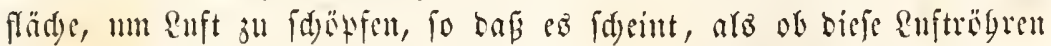
geriguet wären, mitterter anz Dem Baffer bie in ínen entbartene \&uft

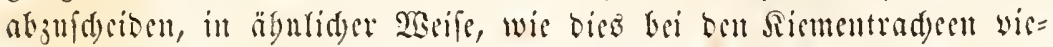

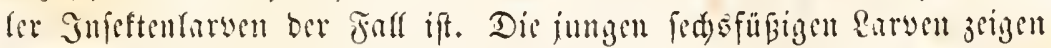

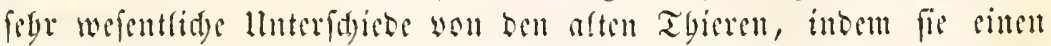

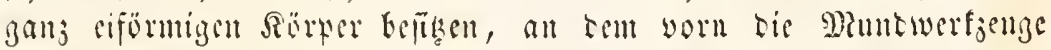
forfartio birworfityen; - jie beften fid an werfdedene 2 safferinfeten

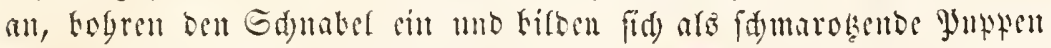

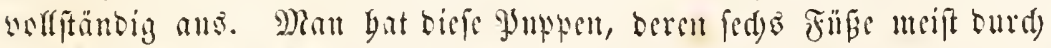

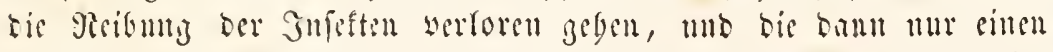

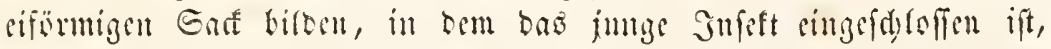

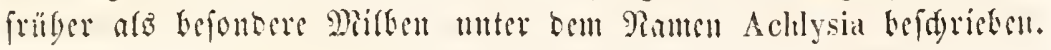

Die freifdwimmenton SEaffermifben Gaben wie die meiften hibri=

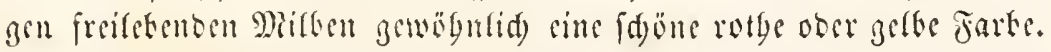
Ilydrachna; Limnochares; Euhas; Alax; Arrenurus.

Die Frmifie ber Pflanzennilben (Oribalida) fteft alo sine merf=

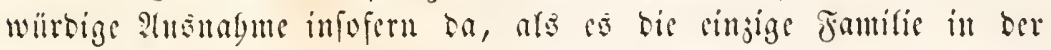

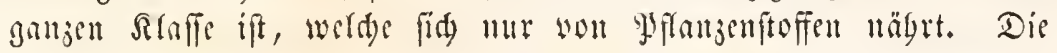




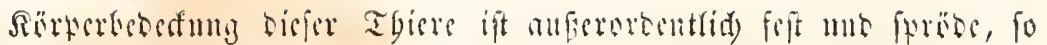

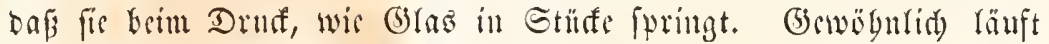
sine Furde quer luber ben Rörper und theilt ign fo, bap bie jwei sorberen Beine ber vorberen, bie anteren ber binteren bälfte anje=

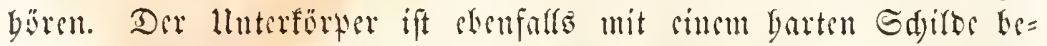

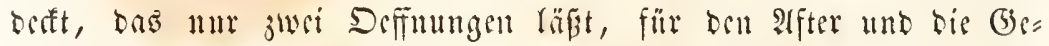

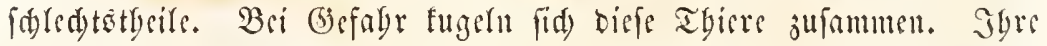
Beine fint furj, ftarf, mit 5aaren und jwe fodarfen Sifanen an Enbe befest; Tafter mo Miuntwerfjenge ganj unter bom vorberen Sdgifos verborgen, fo Dab man fie mit wou unten erblicten fanil. Dis Tafter

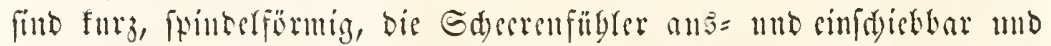
binter ignen nod) sin Jaar befonberer, gejäguelter, zmu Sauen sin= gerideteter Riefern angebradyt. Die Thiere leken in Reftern jufammen,

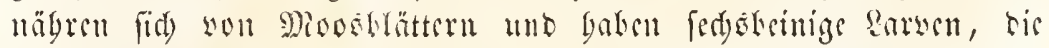
ignen im llebrigen figr ägntid) fegen. Oribates; Hoplophora; Pelops.

Sn oer Familte Der (Eromillen (Bdellida) Eegreift man sinige

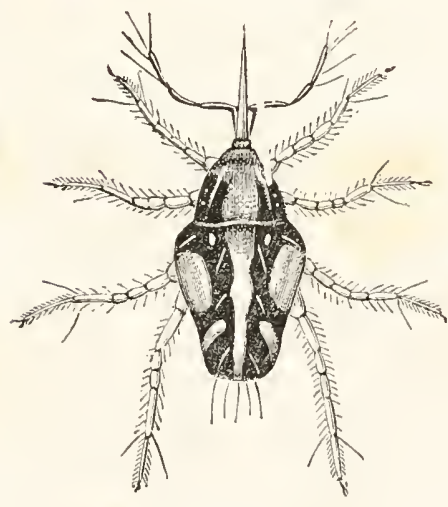

8ig. 570 . Bdella vestita. meijt roth ober gelb gefärbte, jiem= lid) tringe Tbiere, bie in feudster Groe unter Dom Moofe leken, mit oen Hbrigen Milben oen wridsen Sörer, mit Der vorigen Familic aber bie Thrilung bes Sï̈pers in jwsi Tbeile gemein baben. Der Eduabel ift febr lang, worftebent, Dis barin verborgench Rlingen meift fdeeren = ober Gafufürmig. Die Fübler ftelen an brioen Sriten bes Sduatels cingelenft, fund jiemlid) lang und borftenförmig; die finfs mäpig lang unb bünn, Der yorbere abgefdnüre Theil bes Sörters gegen ben Sdynbel bin zugefpiget, fo

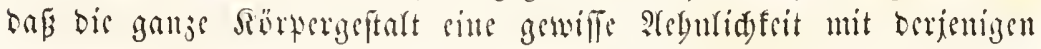
ciucs Rilfferfïfers bat. Bdella; Scirus; Molgus.

Dis Familie oer Raufmilben (Trombidida) wiro yon siller gro=

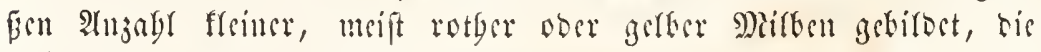

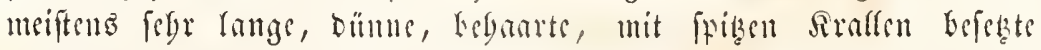
sauffinis baben, und reren Tafter gefnift mub mit ftmmpfom 


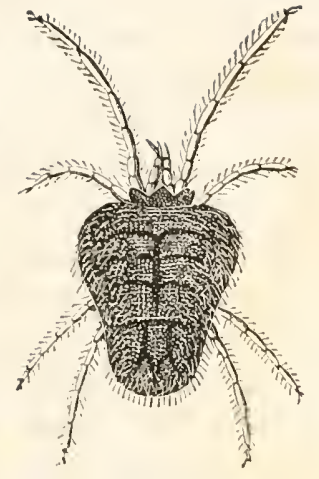

ชิ่ง 571.

Trombillimm Ptatlangii.

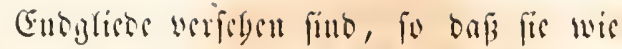
Raubfübe zum Fange benulzt werben föli=

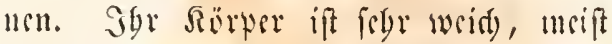
sidgt bebant, juwcilen gleidyfurmig, in anbersu Fäflen quer getbeilt, bis Plugen figr verfdicosu; bei sinigen frblen fie

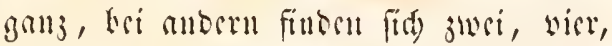

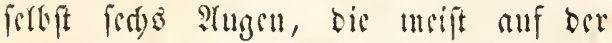
Srite, juwcilen foyar anf sigenen Gtic= ren anperbalb ber Tafter ftelen. Dis

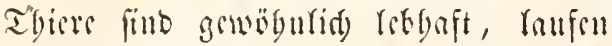

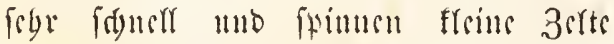

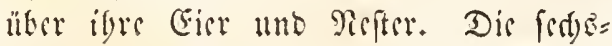
Keinigen Sungen, Deren Geftalt won Der=

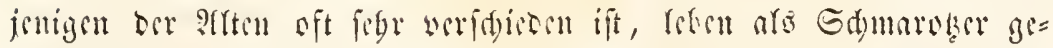

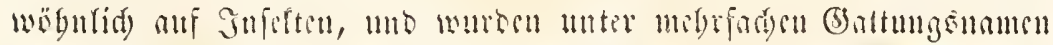
fritger beforichen. Trombidimn; Rhaphignallous; Tetranyclas; Rliyncholophus; Smaridia; Erythracus.

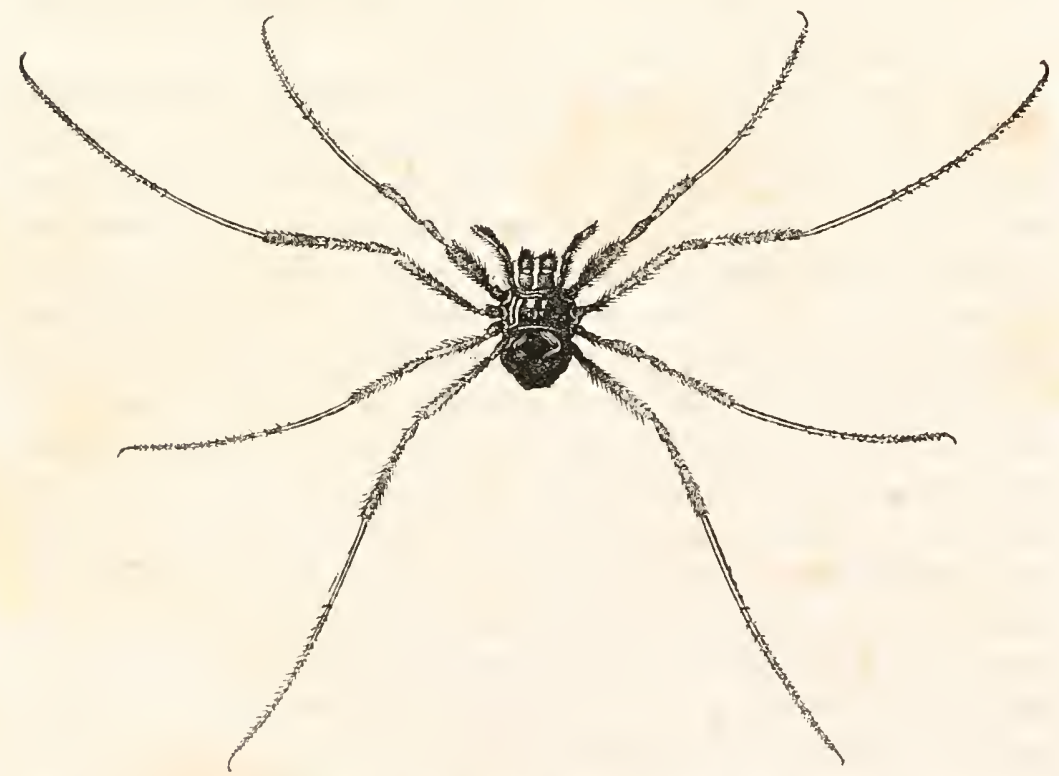

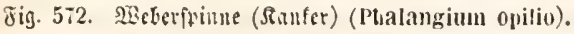

Dis 28 eberipimnen (Opilionida) befteben aus furjlribigen Thieren,

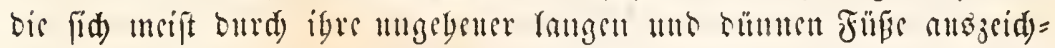

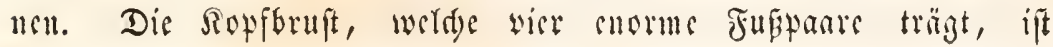




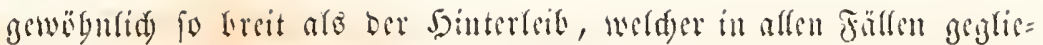

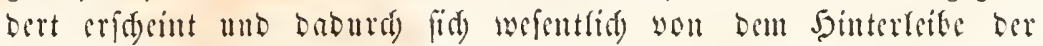

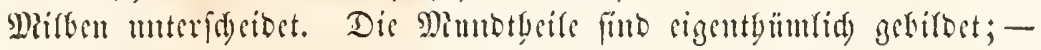
mad) amben fteben bie Tafer, welde gemögnlid fünfglebering fint, sime cimfad)e, borftenförmige Geftalt baten. 3wijhen biefen Tajtem, bie etwas mebr mad) binten cingelentt mo offentrar bie berwandelten Siefer find, f̈nben fid bie cigentlidyen Sieferfügler, werdye bier ano Drei Gliebern befteben, Deren etftes febr tirf und grofi, und bas reste als Gdeere geftaltet ift. Dieje Drgane werben meiftens mad) muten

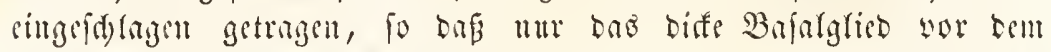
Sopfe in Form simes ftumpfen Fortiates worragt. Der Magen ber

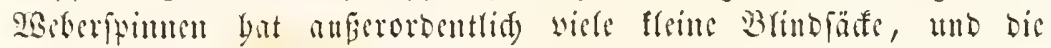
Eentralgangriommaffe sins fergr fonberbare Geftult, inbem fie flïgerat:

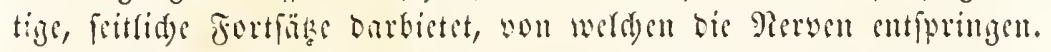
Das Suftrigrenfyfem ift figr entwitelt, Die Stigmen unter Den

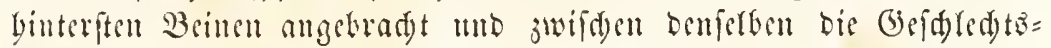

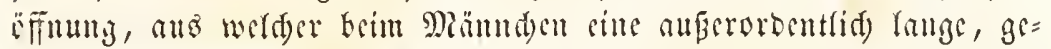
glieberte, worn mit Borften befezte Bintye bervorgeftreatt werben fam.

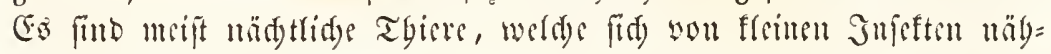
rin. Phalangiun; Eusarcus; Gonoleptes.

Dic jabreidye Drommi Der cigentfidgen Epinuen (Amaneida) umfagt dis wabrgaft typifden Thiere ort ganjen Rlafle, die tiberall

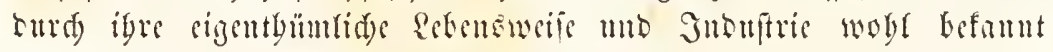

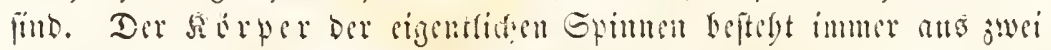
werfdededenen Plotbeifungen, ans ber cinfad)en, ungegleserten, gewöbutid

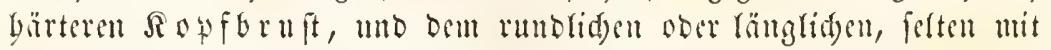

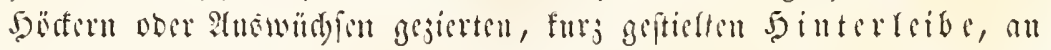

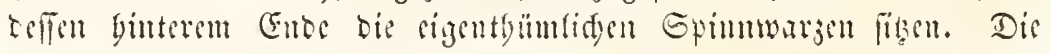

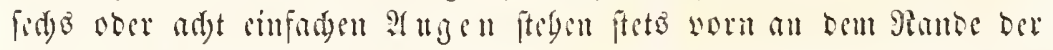

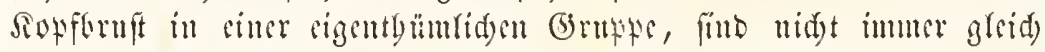

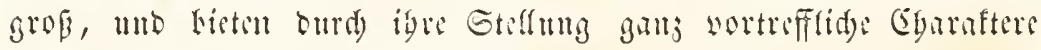
jut Ilnterfdeitmig fer Gatungen bar. Born an Dem Sopfe fint

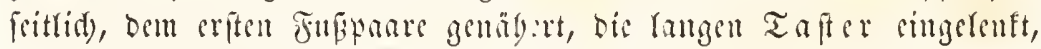

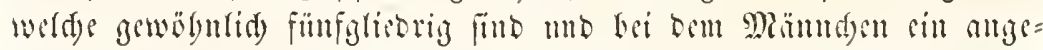

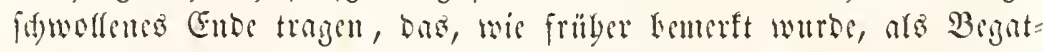

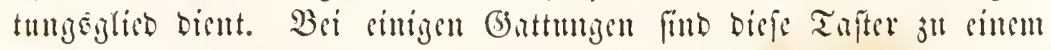
fïrmlidyen rubimentären Fubrane mit STane mb Eoble an ber th= teren Fräd)e mugewandeft. Rad) innen won biejen Taftern, bie offen=

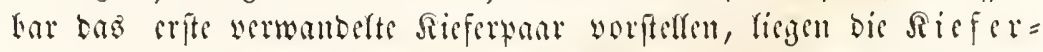
fügrer, bie bier ju cigentgümliden 2 affen umgewantelt fint. Gie 


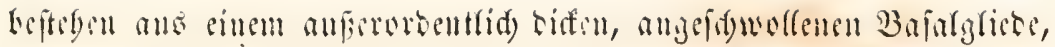
in Meldem bic Giftorife lisgt, mo alls eincm fdarfen, bafenfïrmign

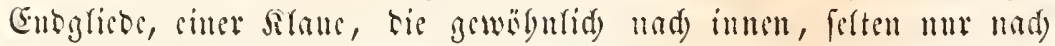

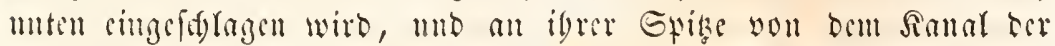

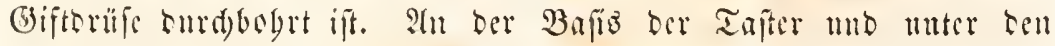

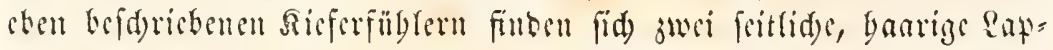

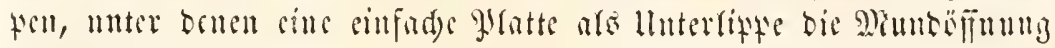
(a) ricfit.

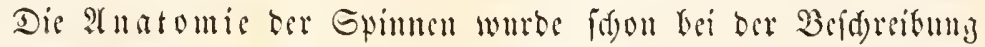

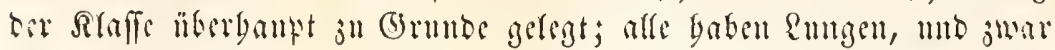
bis meiften nur zwei fritlide enftänfe, wabrento eine Familie biren viere bat. Gimige Spinmen befiken ftatt ber beison binteren \&mngen

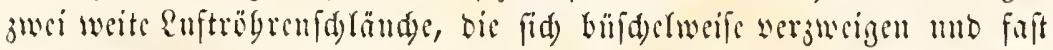
bei allen findet fid) an ber Epize bes Simterleifeo sine Dueripalte, son welder viet whatte, fanbartige enftrïgren ansgeben, bie pid) ourd)

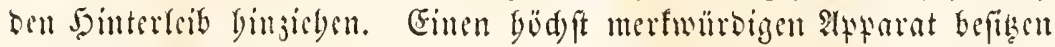

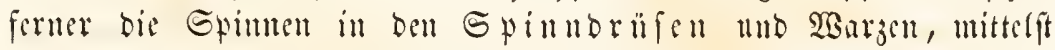
beren fie ilgre Gewebe anfertigen. Die Spinnwarjen, beren fid)

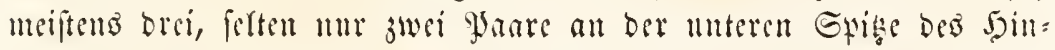
terfeites befinden, baben bie Geftalt ftmmpfer, meift juei= ober brci= glecriger, ofen abgerundeter Regel, beren jober anf friner Extize, ein yon einem Borftentranje umgebensỏ nafteo felo trägt, anf weldem

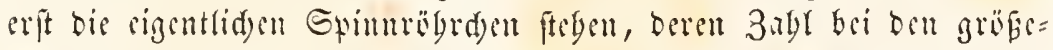

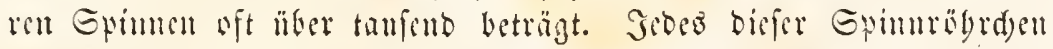

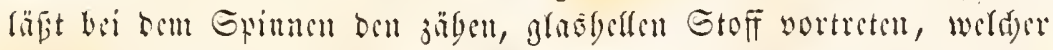

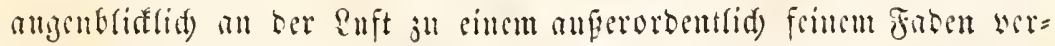
gärtet; - mittclit ber Fufflanen, ju benen oft nod cigentgumlidge,

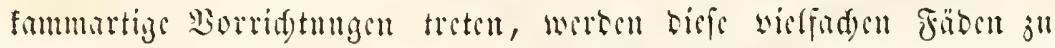
sinem einjigen sereinigt. Durd) biefs fäben, welde fie itterall bin

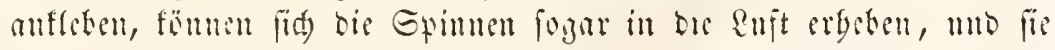

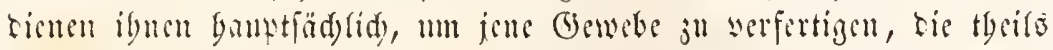

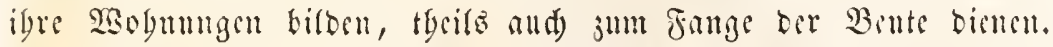
Die Drüfen, welde bicien Rlebfoff abfonbern, Gaben febr werfdicbene Giftulten, mrift aber sine fd) (nud)förmige, weräterte form.

Die Epimen fibcioen fid) nad) ibret Ectensant in zwei grofe (3rutpen; bie sinen bericnen fid) ibret Geibe mur zmm Tapejieren

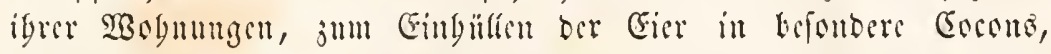
welde bei jeber Gattming sine rigentbümlide Geftalt baten, unb beren Föben man fogar, wem and) obme Erforg, in fer Jutufrie ju ver= wenten werfudt bat, fowie jum Feftgalten bei igren Bewegungen; - 
bic anberen aber bennzen anfer ju ben crmägnten 3maden ibre Gribs

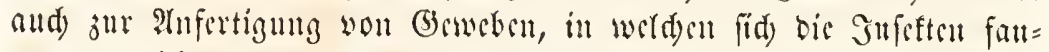
gen, werwiteln mo ansogrogen werben. Die Beftalt bicfer Rese ift

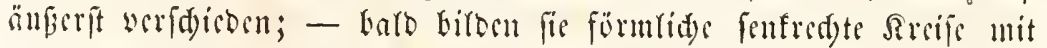
rabiären Gtrablen und änß̧erft regelmäßigen 3wifd) anberen Fälfen erfobeinen die efenfalfs fentredyt angelegten Reke mn=

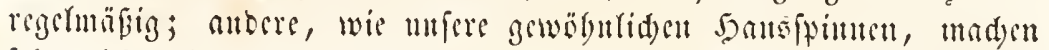

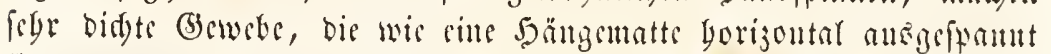

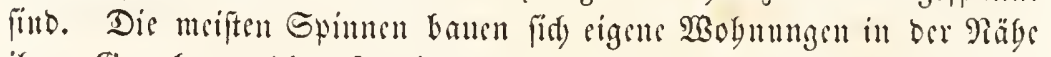

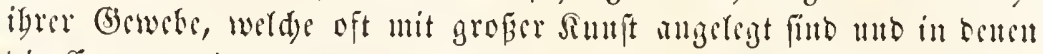
bie Gocons mit Den Eirn verborgen werben; antore foldetpen fogat Diefe Cricr in sincm sigencu Gaffe mit firt) bermm.

Sisir unteridgeioen in Eor Dronung Der Spinnen jwei Familian, won benen bie sinc, weit joblreidyere, in mebrere bunbert diattungen

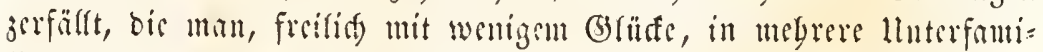
rien ju jertegen verfudjt but.

Die eigentlidyen Epimnen (Arancida) befizen fed)s Spimmarän,

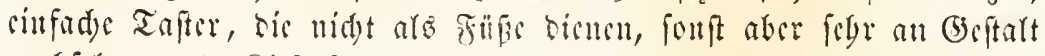

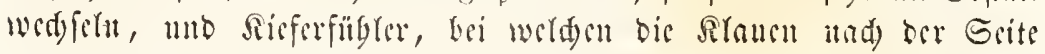

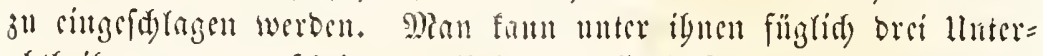

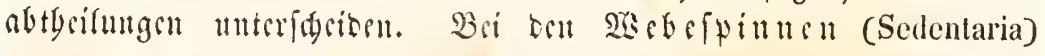

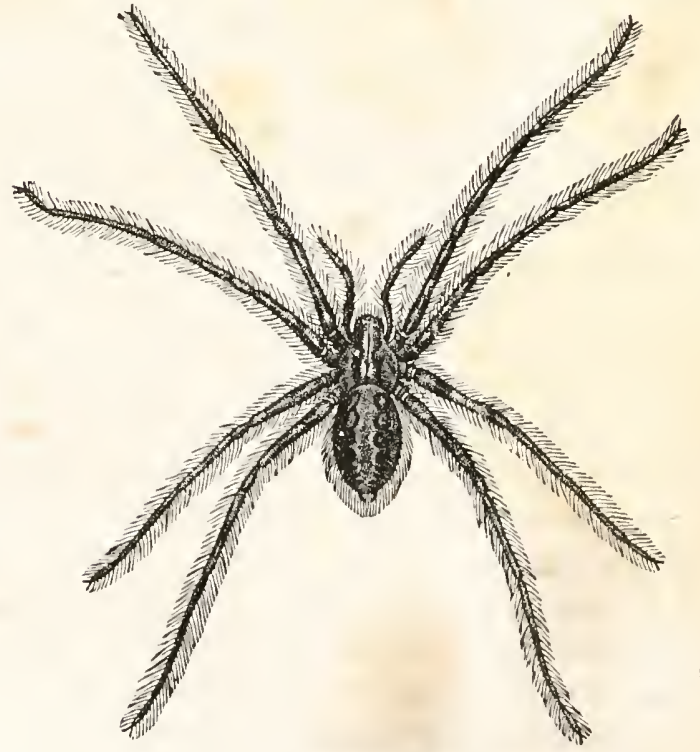

テ̛ig. 573. Şansipinne (Tegenaria domestica).

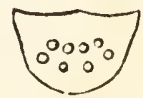

Sig $57 \%$.

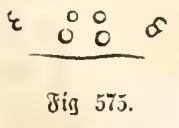

Jig. 571 นt. 575 .

2utgenfterlungent ciniger 20с6еріниси. 
feben bie Sangen in jwei geraben ober gefrünunten Duerreigen, bie barb in gleider Entfermung won einanber, bald an ben Enben cinan= ber genabert fimb. Dic Sekefpimen fangen affe igre Bente entweber

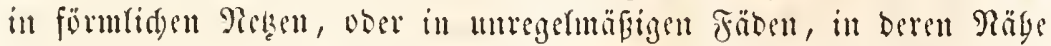

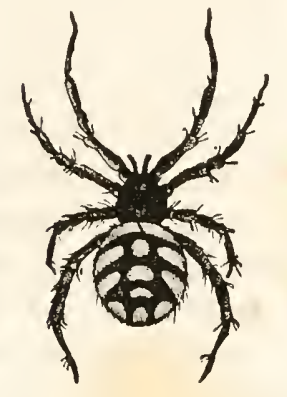

סig. 576.

Therilion malmignatla. fie igre 20 bum baben. Die gewögnliden Siruzifinnen (Epeira), uniere Sansipinnen (Tegenaria) und sine im fïbliden Emopa zicmlid) gefürd)tete ?at, tie Malmignatte, ge= büren zu bicier Grmple. Segestria; Dysdera; Tegenaria; Clubiona; Theridium; Epeira; Thomisus. - Cime jmette Grmple wirb yon ben Sa afferfpiun un (Argyronetida) getirbet, ei= gentliden (Gowebefpinnen, bie aber im $\mathfrak{B a f f e r}$

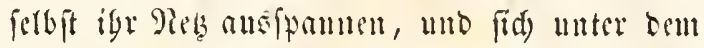

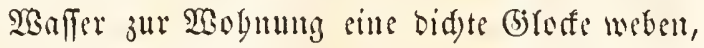
tis fie mit Ruft füllen, mo unter welder fie

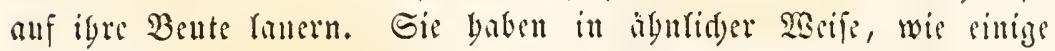

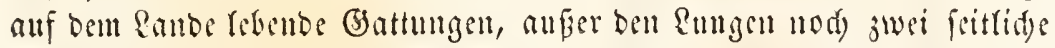

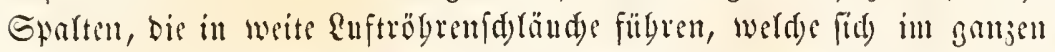
Sïrper werjweigen. Argyroneta. Die britte (5rmppe entid) wirb won ben

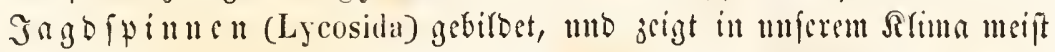
InIr fleine, in jübliden Gegenden aber beoentento grofie, fen Boget=

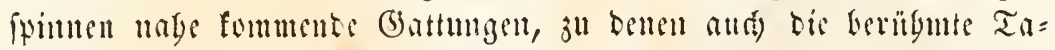
rantel (Lycosa tarantula) gebort. Jgre Angen fitben in brei Sirigen bintereinander; - Lie Thiere maden feil Gemebe, fondern beften fid) un mit Fäben jur Sorforge gegen bas Anşgleiten ma Fallen

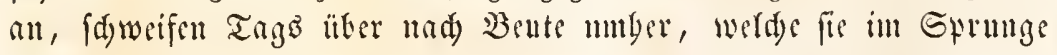
yajd)en. Lycosa; Dolomedes; Salticus.

Die Tamilie ber Bogelpipinnen (Mygalida) umfajt tie gröften alfer Gpinnenarten, bie mit ausgefpanten Fïßjen oft cinen banbgro= Gen Raum sinnelmen. Sis fommen nur in wärmeren Sänbern, bis nöblidgften an ben llfern beg̃ Mittelmeeres yor, fint meiftens bift

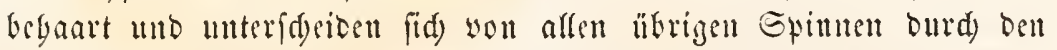
Ban igrer Tafter, ibrer Rieferfübler und die Zabl ibrer Spinmwarzen, teren $n$ ur vier fint, wägrento bie sigentliden Exinnen alle fod) Spinmwargen baben. Die Tafer fint lang, fupartig, in ägulider

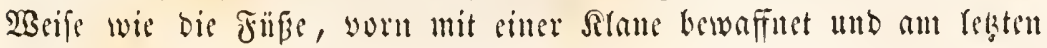




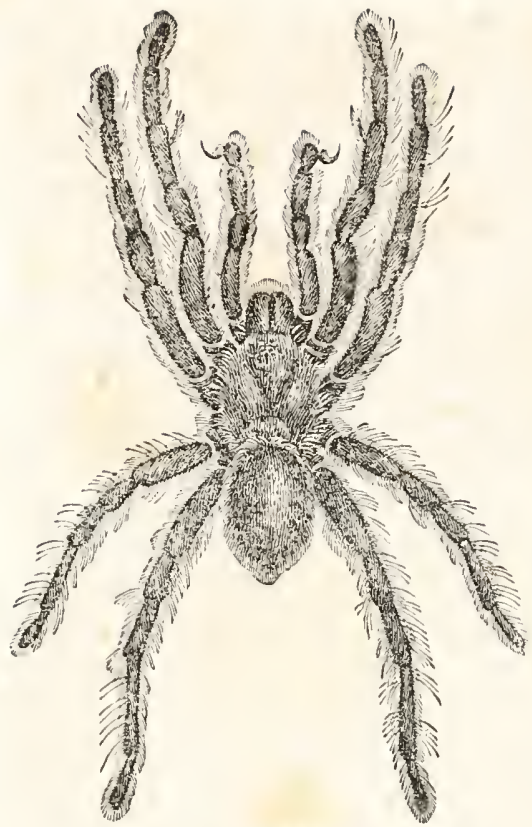

Jig. 577. Wogefinime (Hygale avioulatria).

(5) rebe Intill mit cinct Sogle verfebell, fo baf fie aljo förm= licise Sieferfïfe onrfteflen, wie fie bei ben Riebfen gewögnliá fint. Die gewaltigen Siteferfïy= ler baben cine grofie, gebogene Silane, bie nidut, wie bei ben äbrigen Spimmen nad) immen, fon= Dern nad) unten eingefd)lagen wirb. Die meift dunfelbraun ober fduärjlid) gefürbten Thiere wobnen in Erolöbern ober in Gparten, in Deten Răge fie un= regelmäpige fäben fpannen; merift jagen fie in Sprunge und follen fid fogar tleiner Bäget bemäd)tigen föntuen. Dic in Sibenrota cinbeimigde art fd)lest ibr mit Gribe ansgetlet= betes (Erolod) mittelft cines fertor

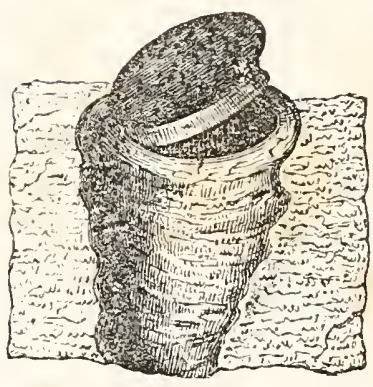

oin. 598 flinftictuen Deffers, in Den fie Eroe wer= wert nno ben fie mit vieler siraft feft= Galten fann, fokaro man ign ju bffuen serfudt. Mygale; Cteniza; Oletera; Sphodros; Filistala.

\section{Die Familie Der ERoruionfpinnen} (Solpugida) beftebt ans $n u r$ wentigen, meif grefen, fpimentatigen IGieren, bis (id) weicntlid) won ben eigentliden Eprin=

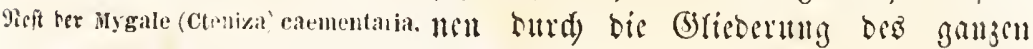

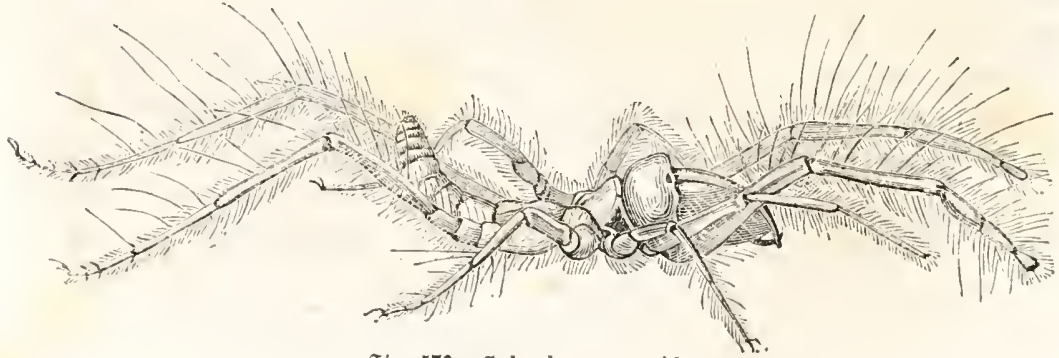

รig. 579. Galeodes araneoilles. 


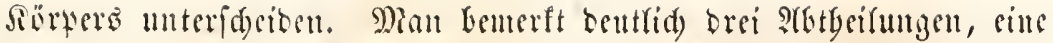
vortere, wetds man mit wolfem Redyte ben Ropf nemen fam uno

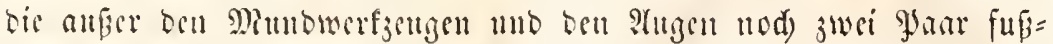

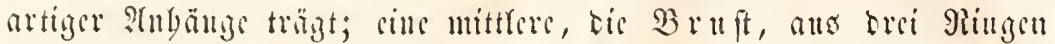

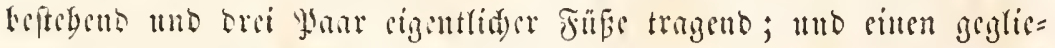

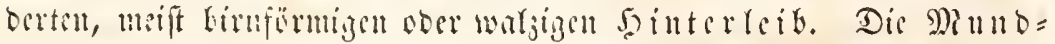

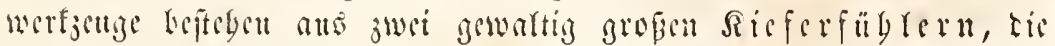

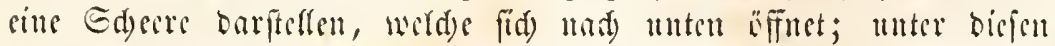
Sdaceren, anf beren oberem Samme cin bümer, geifelartiger ?thlyng

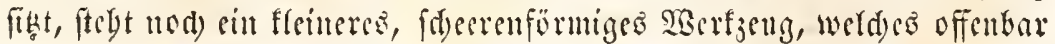

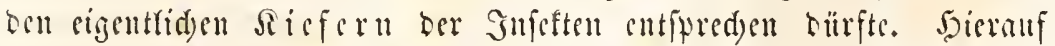

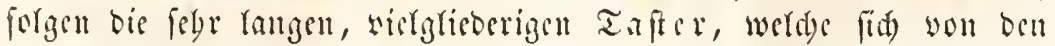

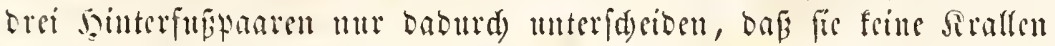

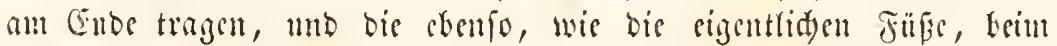

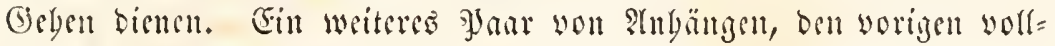

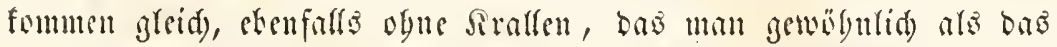

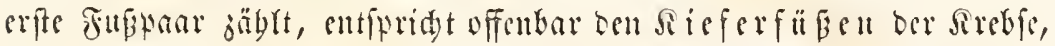

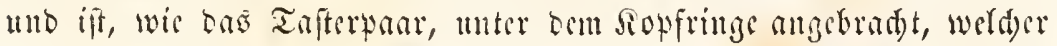

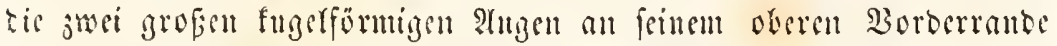

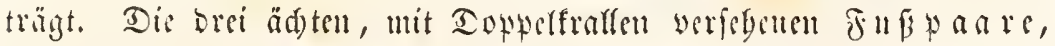

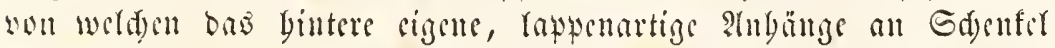

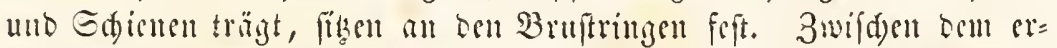
fien und jweiten Fupran befinden fid) feitfids, unb an ber lluterflädse

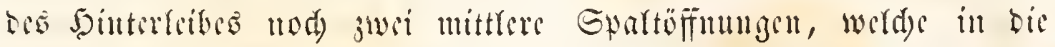
Eup̃tröbren fübren. Die Sforpionfpinnen fund änß̈rft gefrägige,

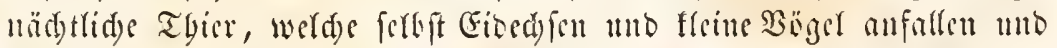

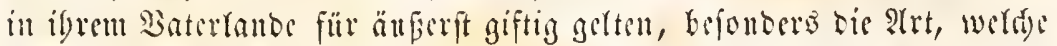

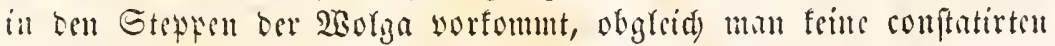
Bemeife für bicfe Bolfšmeinung gat. Galeodes (Solpuga).

Die Pribe Der Erebsartigen Epinnentbiere beftyt im Gan=

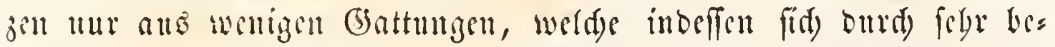
ftimme (Egaraftere in verfdeboene Fantilen jerfällen laffen. Gie zcid)= nen fid, wie fád frülyer bemerft, bejonters ourd sinen einfadsen Damilanal, fowic baburd) aus, baj ibre Tafter bato fdeerenförmig, bato flamenartig fint, ftits aber Greiforgane barfteflen. Weir unter= idacioen bei ignen folgente Familien:

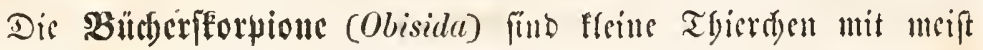




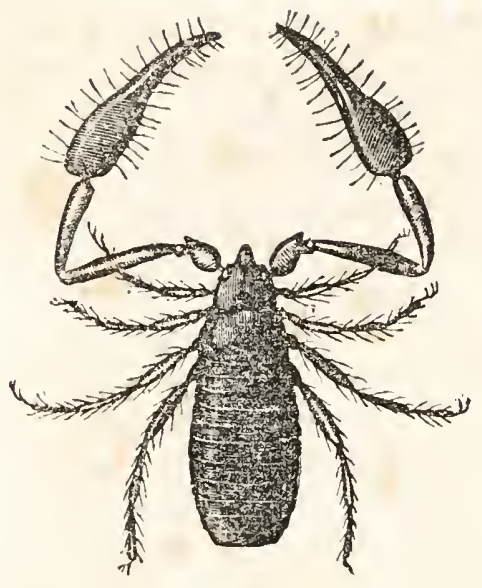

¿is 580 . Batiferoutun (Chelifer) Le"gré But.

waljenförmigem Sörper, ber viel= glicbering erfacint, unb vier Jaar gleidymäfiger föfie, fo wis cin fert langeo Tafterfant trägt, Deren vier= tro Girico in cinte bentlid)e Gdjerte entigt. 3wai ober viar ?lugen fitzent Eentlid anf Der Geite Der worberen affereifung ber Ropforuft. Dis Munbiwerfjenge find ans jueci flei= Hen, fdecrenförmigen Rieferfïblern gebilbet, welde mad) worn gerid)tet jwifden ben Edecrentaftern feben. PHe ber Bandfeite ber Keiben erifen Sinterteiferinge befinb at fid) cin Sant feitlider Stigurn, won weldyen ans unverjweigte Ruftrigren ben

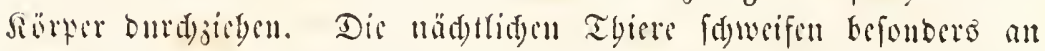

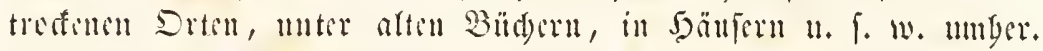
Cliclifer, Obisium.

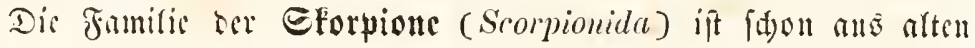

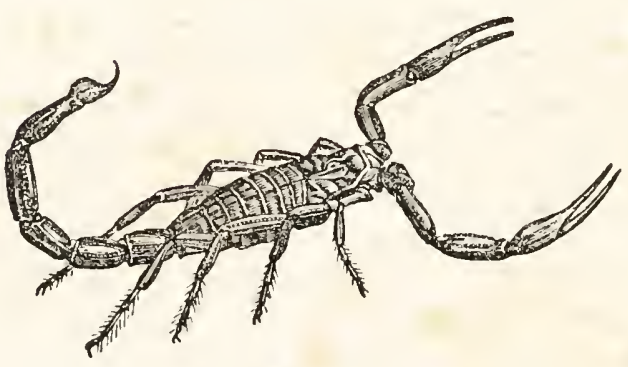

Jig. 591 (Eurwiiither Eforwiun (Scomio emopaeus). 3eiten wegen iguer gif= tigen Eiysufdaften be= rilbmt ntio lauge 3rit mit ben Sirebja jufam = mengemerfo morbell, mit milden fie aud in Der That burd) bic แaf fiven Gderen, bie fditoförmige Sopformt unb bell gegliederten,

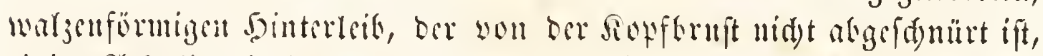
einige Slebulidfeit gat. Die ganje Familie ijt anf bie füblid)en 3onen lefdränt und unr cine fleine sat fommt anf bem Gïrabgange ber Stren in curopa yor.

Die fuiloförmige Sopformit ber Gforpione trägt anf bem Borber=

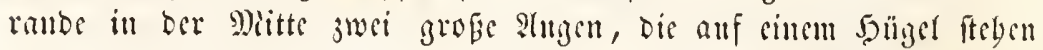
unb juci bis fünf feitfide glane an bem Sorberranbe. Dis Tafter

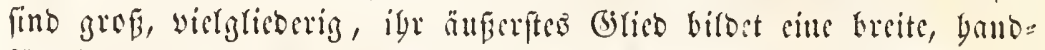

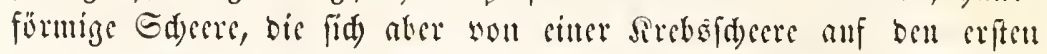
Briff baburd) unterfdeibet, brä Der änfere finger beweglidg ift unb 


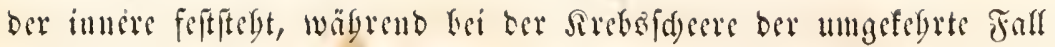

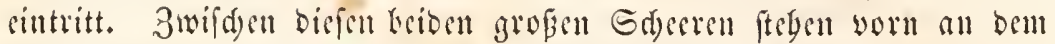

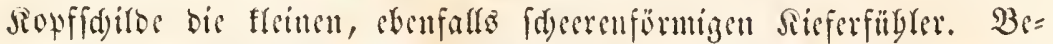
trad)tet man bic llnterfeite cinte Sforpions, fo firbt man binter ben

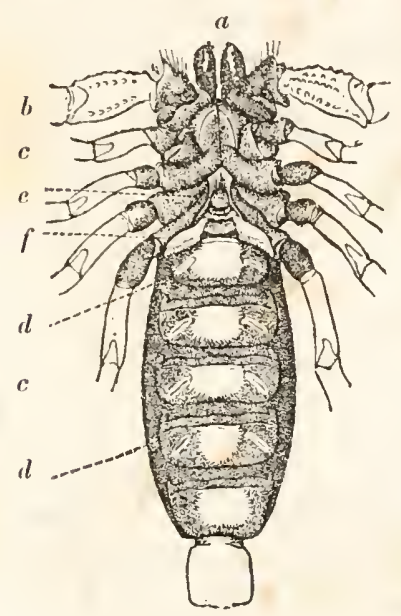

テig. 592.

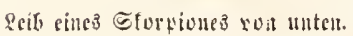

a Ediserenföming Rieferfïly= lex. b S) Sufatg Cer groipen Edyeren

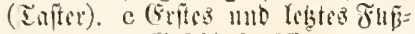

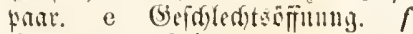
Rümme. d Etigmen. wier glevifgeftalteten, mit Dopperfiallen entenden Finsen, welde anf die Gdjerren folgen, unb Deren Bafalglieder fo bait ancinander fteben, baf fie zum 3erreiben Der Nabrung Dienen fömnen, jwe cigen= thïmlide fammartige Drgane, beren $\mathfrak{B}_{c}=$ beutung nod) nid)t befaunt ift, suifden benen fid) aber bic (bejd)ledtesffrmung $\mathfrak{b e}=$ finbet. Die wier erifen Ninge bez ange= (d) wolfenen Sinterleites tragen anf ber Iluterfläde bic paarueife gefteflten Sd) lize, weldse in bie sungenfärfe fübren. Der (d)wangartig verlängerte Sinterleib enbigt mit cinem etwas angefdyollenen Gricbe,

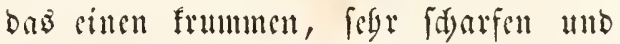
barten, bafenfürmigen Stadel trïgt, an Deffen Spitse bis Diffunntg ber Giftorïle fid Eefindet. Beim Geben triggen bis Sfortione bicjen Theil bes Gdwanzeg nad) ofen gebogen, fo baij fie ftet z zum Gteden bereit find. Gic näbren fid won Juleften, bie gröperen fïb= rid)en Prten aud) wou fleinen Peptilien unb äbnliden Thteren, bie

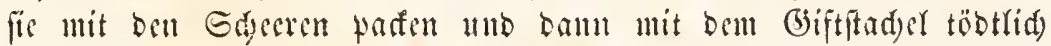
werwunben. Das Gift ber gröferen, fübliden atrten, weldye bie Ränge

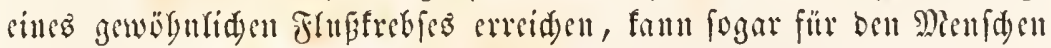
töbtlid) werben. Scorpio; Buthus; Androctonus; Centrurus.

Die (Siciferfterpione (Phrynida) wirberboblen in gewiffer Sin= fidyt in oer Areige ber frebsartigen Âradniben bie Sforpionpinnen,

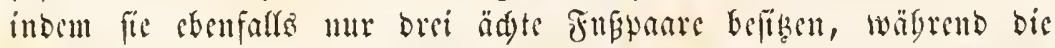
Borberfüfe zu taferartigen Drganen umgemandelt fint. Die Sopf= bruft biefer Tbiere ift fdilbförmig, oer bentlid) abgefecte, geringelte Jinterleib bald runblid, balo länger unb bann in sime vielglieberige Borfte endigend. Dic Tafter find anserorbentlid) bif, ftarf, und) 


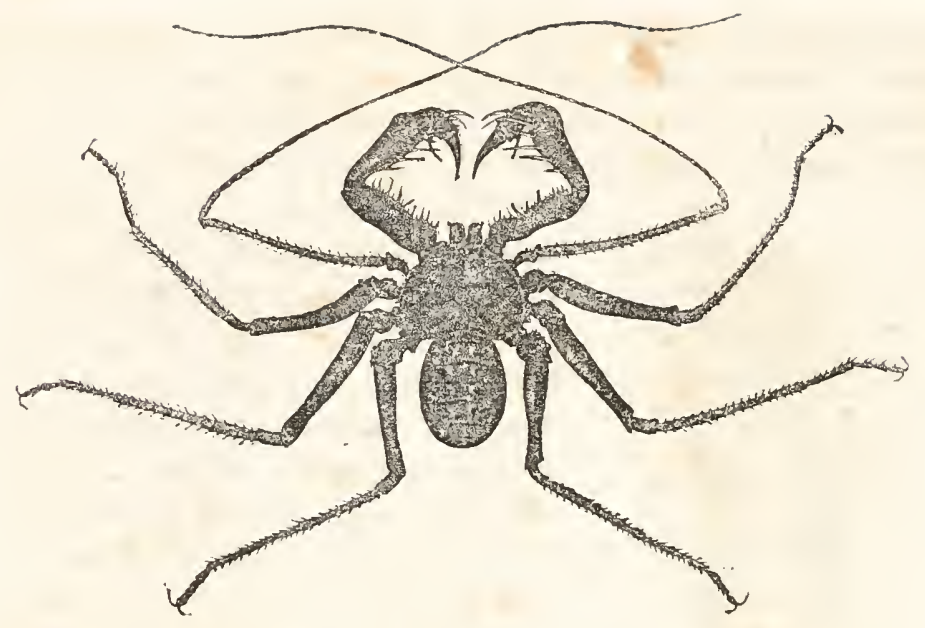

đig. 583. Phrynus reniformus.

inten grbogen und mit cincr bafenfürmigen, fajarfen Srafle bewaffuct,

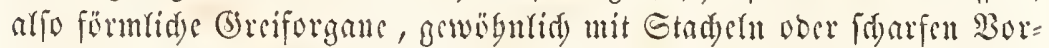

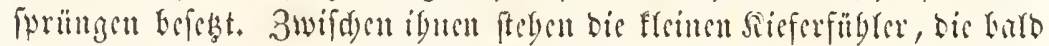

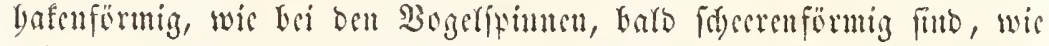

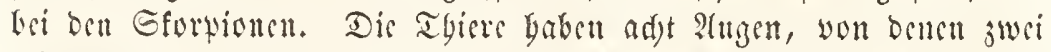

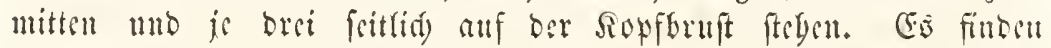

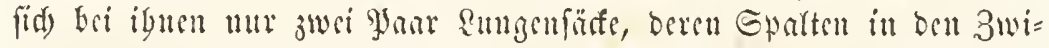
fósenräumen ber brế erften Bandringe liegen. Die wenigen Arten

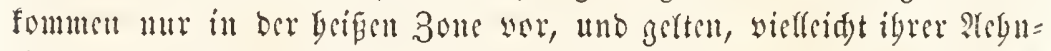
ridsfeit mit Efortionen wegen, für giftig. Phrynus; Thelyphonus.

\section{filaffe der 3nleliten. (Insecta.)}

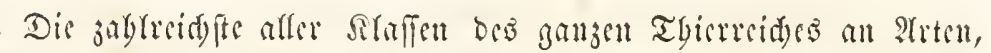

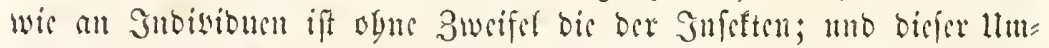
ftand fowogl, wie bis mannigfaltigen änferen formen unb sfit bers:

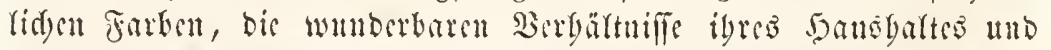

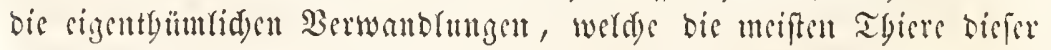

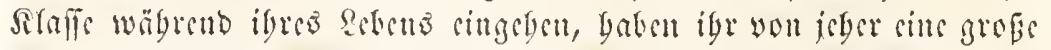

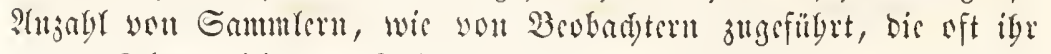

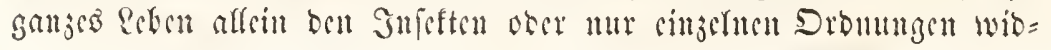


metell. Sair Gaben bie allgemsinen Ggarnfters, woburd) fie fidd yon ben äbrigen Siraffen ber Griebertbiere unterideiben laffen, idjon an= gefübrt; - fie beftegen wefentfid) in ber (Exiftenj von unr feds a Bei=

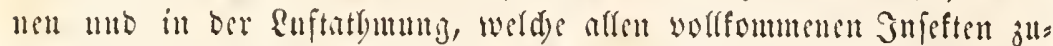

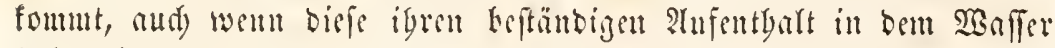
Gaben folten. Atuserbem fint grägel, wenn fie vorganden fint, sin

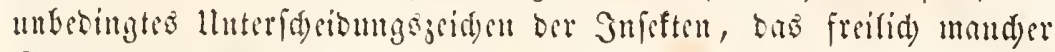
(Gattung wälfrent igres gangen Rebens abgeyt.

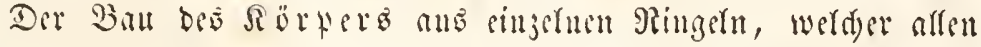

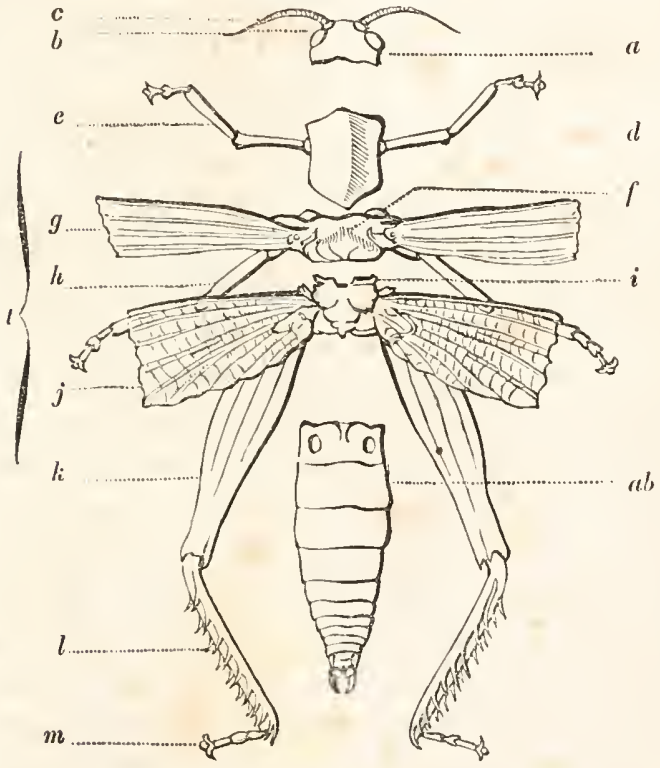

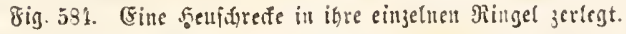

a Der Ropf mit Den $\mathfrak{A}$ ugen b und ben Füflern c. t Die Bruit, beftehend ans bem Borberbuftringel d, met=

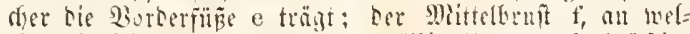

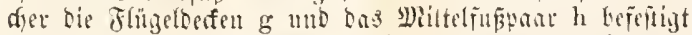

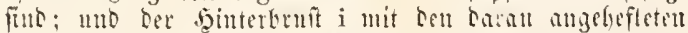

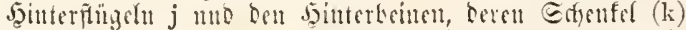
jum Epringent wertift, Die Edfienen (I) keptadyelt mo ris

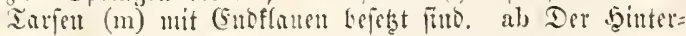
leit.

Blicbertbieren ge= mrinfan ift, räst fid) and) bei ben Jnfeften ftets nadjweifen, ob= gleid) uidyt fertent $\mathfrak{B}_{\mathrm{c}} \mathrm{i}=$ Firicle vorfommen, Don eingerme biefer gin= gel entweder in ban= jen ober nur in be= ftimuten Stüfen mit cinanber verwadjen

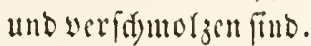
(bswögntid laffen fid ittoer brei stotgeilme. gen unterid)eiben, be= nen jufolge bisfe cin= jelnen Ringet grup= pirt find, Rorf, Bruft uno Sinterteib. Nur bei sintigen flügellofen Sd)maresern erfdei= nen $3 \mathrm{rmpt}$ unb bin= terteib mit sinander veridemolzen; bri vis= len bängen bie orei

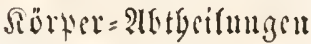
in igrer ganzen 3reite zufanmen; bei antern wister ift bie Berbin= Dung unr burd) bünne Sticle vermittert, fo bnß bie brei Theile anf ben eriften Bbliaf in bie 2 tugen fallen. Der Soff trägt unter allen

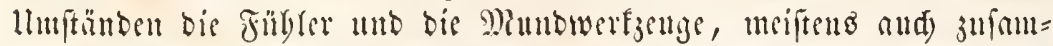

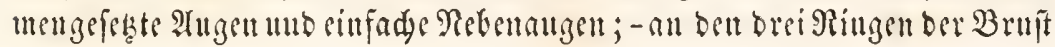




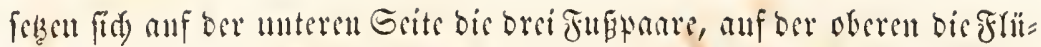

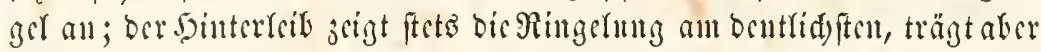

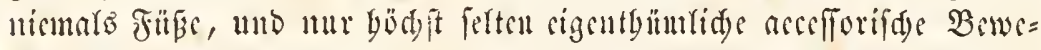

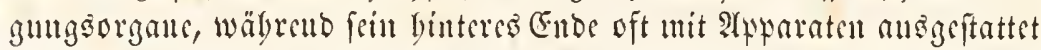

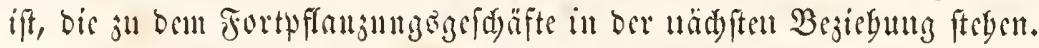

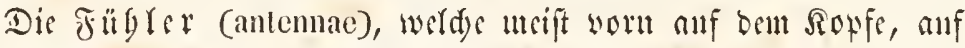

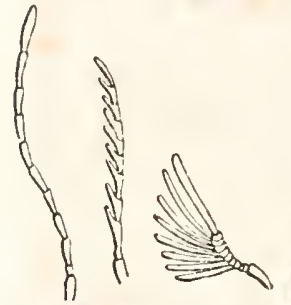

ชig. 595. 586.

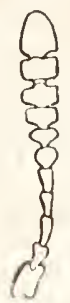

588.

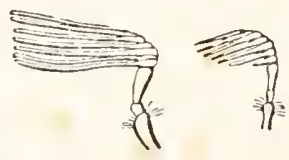

589.

Soridiebene formen wat Bühlerk.

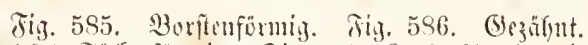

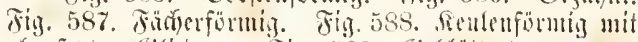
afgerebten Glidern. Sig. 589. Berlätert.

Der Stiru ober melyr zu briben Seiten singełentt

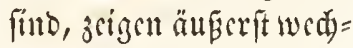
felnde Formen, bie fid illoç wejentlid) allf jusci (5runtotyen rebujiten laffen. (bewöbntid) ba= ben fie bic Geftalt sinct sinfaden Borite, siner Sirule ober cince Jiegetỏ und crid)cinen bann aแล einjeluen Ringeln obst

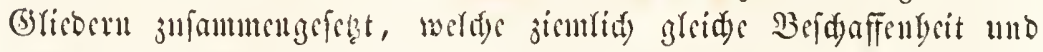
Structur zeigen. Iluterfudgt mat nämlid) bie Fübler unter ciner bint=

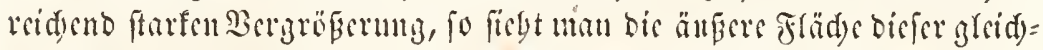

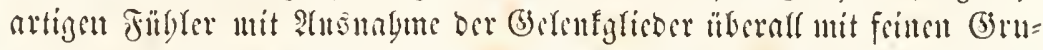
ben bejäet, beren brund utit cincr bïnucu, jarten Sant werid)loffen ift, welde mit febr jarten Flammbanten bidjt bejest erfdyeint. Bei bent ungleidartigen sitfleru, wo ftets ein bejouberer Sdjaft ober Gtiel

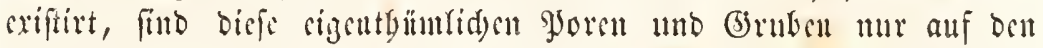

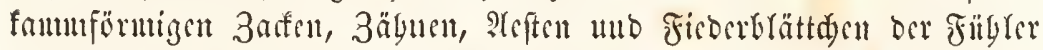

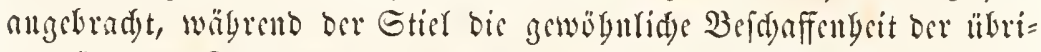

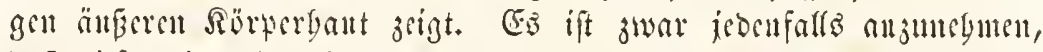

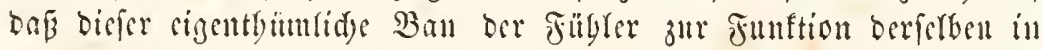

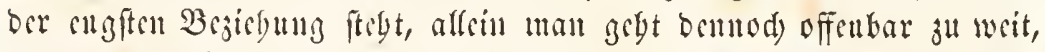
wenn man utit sinigen neneren Beobadytern bebaupten woflte, bicfer

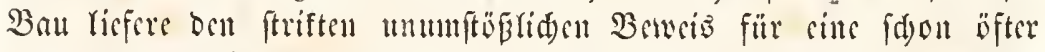

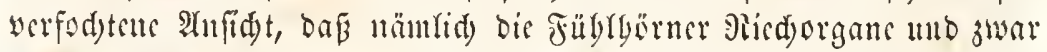

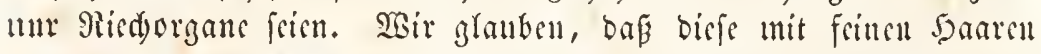

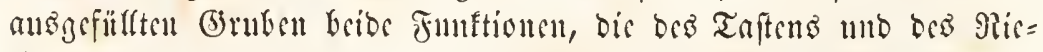
de)เร, it fid) versinigen. Denn auf ber siucu Geite unterliegt es

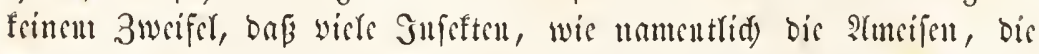

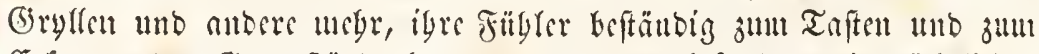

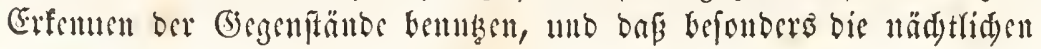




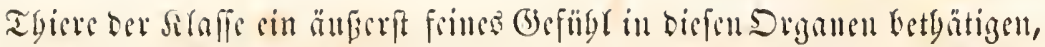

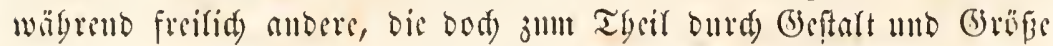

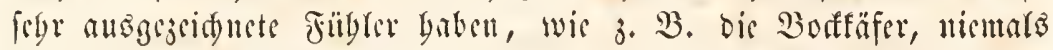

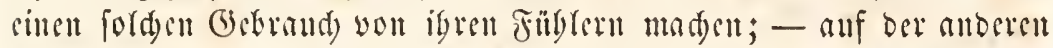

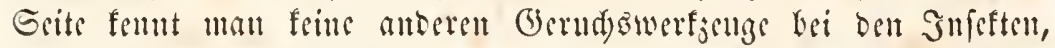

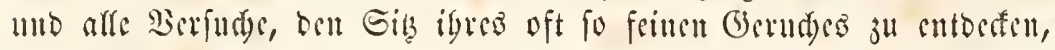

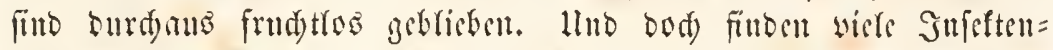

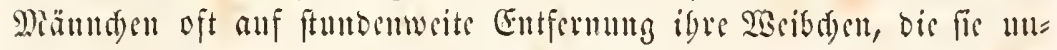
mïglidy feben fönten, utr burd) Sen Gerud; anbere Arten, wie na=

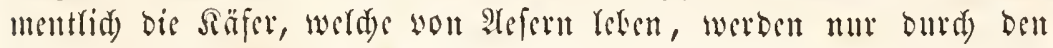
(5ernd) ju biefen bingeleitet, und von mandsen griegen, beren sarven

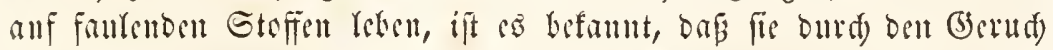

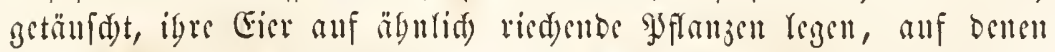

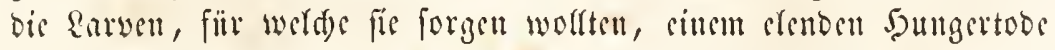

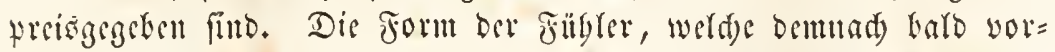

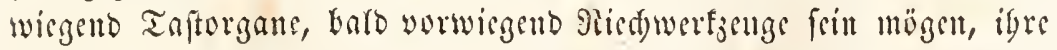

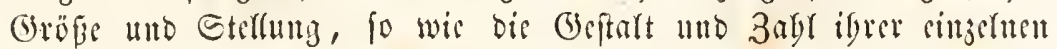

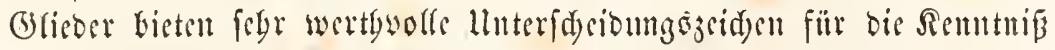
ber eiriseluen Gruppen unb atrent.

Das jweite widtige Simnçorgan, weldec der Sopf trägt, finto die $\mathfrak{A} u g e n$, die nux anferorbentlid) felten feblen und gewobutide in

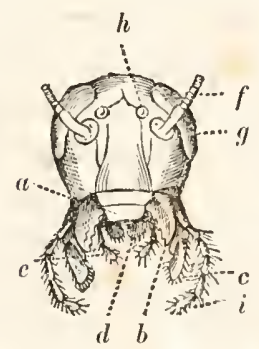

Jiq. 590. Sulf ciller Sodyke (blatta) rou pordic gefefen.

a $E e \tilde{f}$ e (labrum) autf cinet ferputereu filatte cimgelenft. b. Silefer (mandibulac). e Rimulaben (maxillae). d Dis grifaltme lluterlipte (labium). e sippentaiter (palpi labiales). f Jüblet (antemnac), g Tickangen (oenli). h झुsutrangen (stemmata). i rabcutaiter (palpi maxillares). 3wei Formett fid) oarftellen: alb zufammenge=

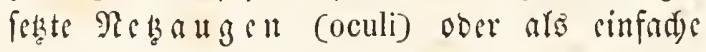
IJ $\mathfrak{u} \mathfrak{f} t=\mathfrak{o b e r} \Re \mathfrak{R} \mathfrak{b} \mathfrak{e} \mathfrak{a} \mathfrak{g} \mathfrak{c} \|$ (stemmata). Dft fommen bic gJuntrungen affin vor, mb bann find fie meiftens gebäuft und fteben in Gruy= fen an ben Griten bes Sopfes auf cigenen Sabiften von werfdicoener Geftalt mo Gröfe. Gind bis Retennugen jugleids mit ben jufant= mengeferten शugen vorbanben, fo finbet man meift mur juei noer brei biefer Drgane oben

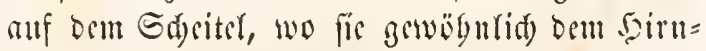
ftroten fo mabe aufitien, Eafigr Gefuterve mur

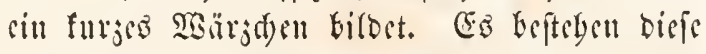

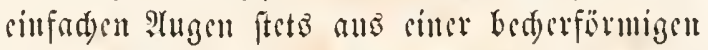
Retzbant, welde won cincm ounflen Farbftoffe umgeben ift, und in beren 50 blung sime rand = lidfe Riufe liegt, bie wou cimet voritebenten Sornbant ïberwölet ift. Der 3weat Der Res 


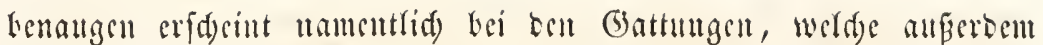

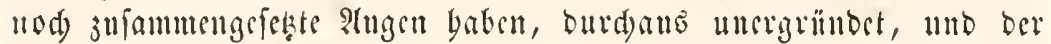
Bau igrer ftarf gewölsten Sornbant unt Ginfe fdecint ben Berfuden ocricuigen Beobad)ter z" wiberfpredsen, werde in ben gुunftangen

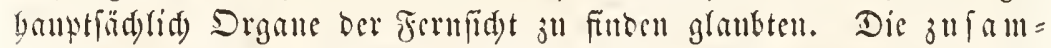

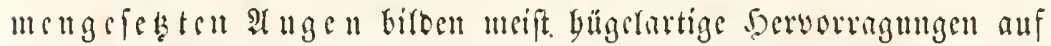
Eriben Sriten Des Royfes, die meift runblid, nierenförmig, zumsilen aud fror tief ausgefdutten find, mand)mal fo fibr anwad)fen, oaf

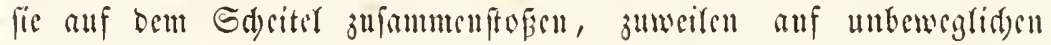

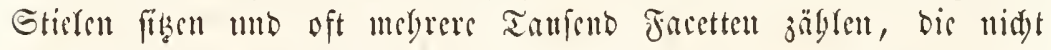

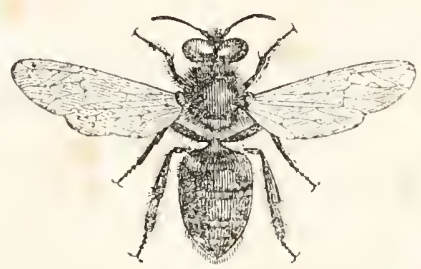

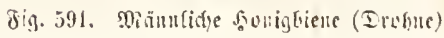

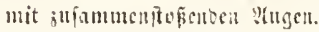

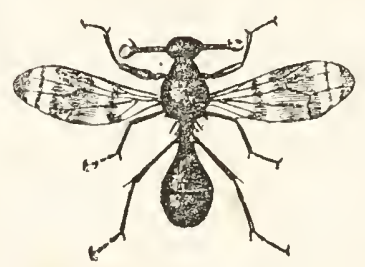

Jig. 592. 2 rillemfliege (Diopsis) mit geiteiten ?tunen.

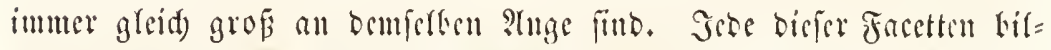
oct eigentlid) bie mit bon henad) barten 5orngänten werfdumolgene 5orn=

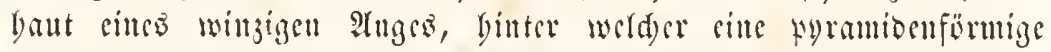

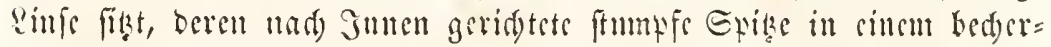

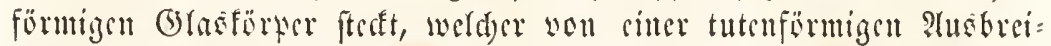
tung ors Seburwen unt eincs bunfen YSignentes umgeben wirb. Da bie ?Hgen unbemeglid) futb, fo bat jebe bicjer bornläute mur cin febr fleines Grbfeld, nnd es ift für uns volffommen unbegrefflid, wie

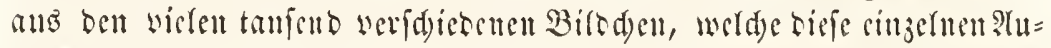

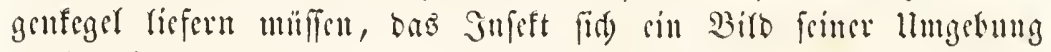
madt)ell foun.

Die Diul werfzenge, welde ber Ropf fets an feiter unteren

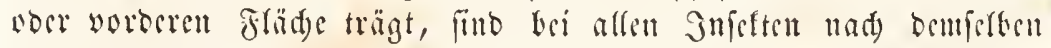

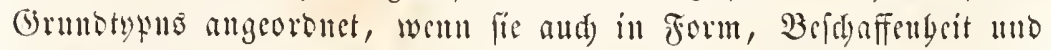
relativer ?lusbilonng unjäblige Modifitationen erteiren, mo is uad) Der Rabrung ber Jufften buro mebr jum Sinuen, baro mebr jum 


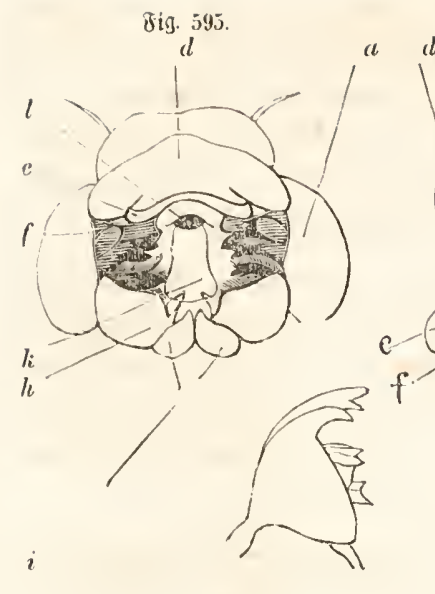

Fig. 596

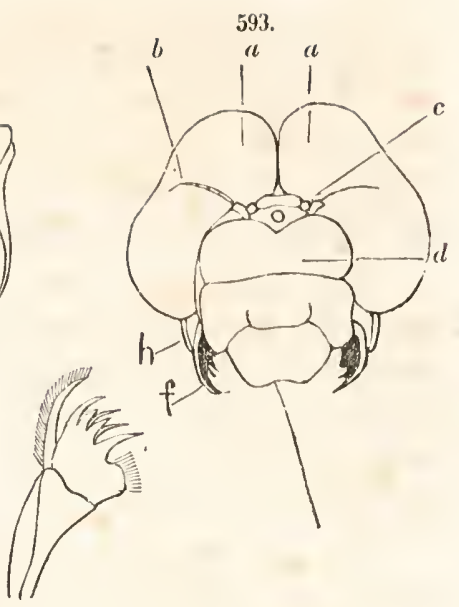

597.

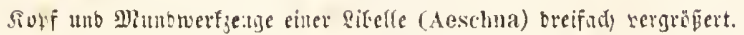

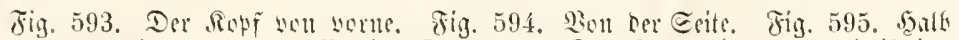
won unten mit gerĩntem Mauls. Jig. 596. Dor Ricfor (mandibula) ipolirt.

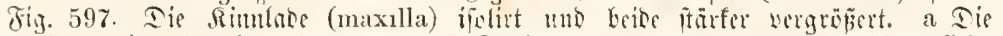

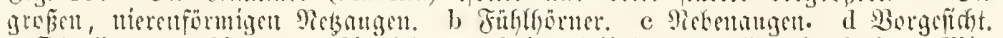

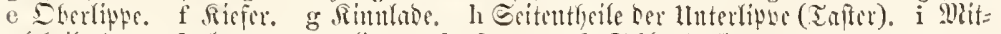

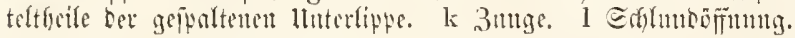

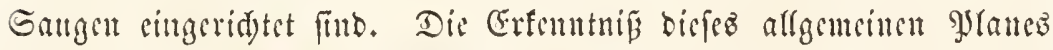

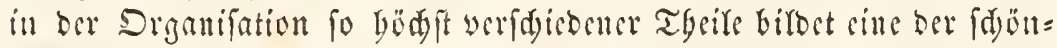

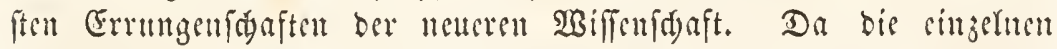

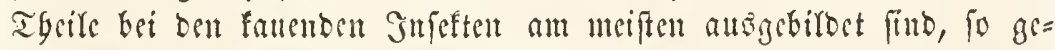

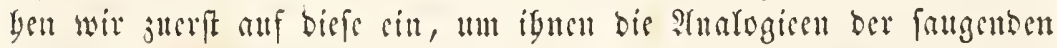

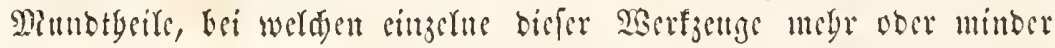

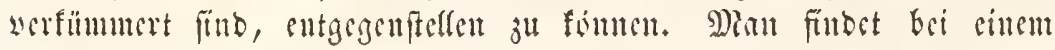

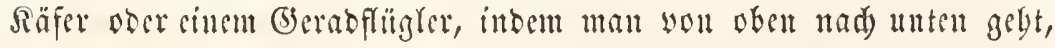

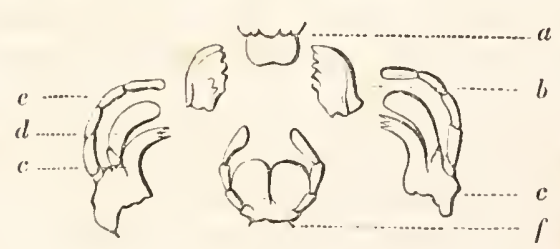

8i.j. 593.

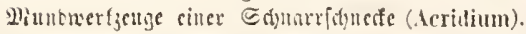

a Etertippe. b Riçper. e Situthate. d Rin:= frun oder berm (galea). c Estentriter. fllnterlipe mit oen vippentafern. zuerit cimen แmparen Dedel, Dic Dberlippe ober Eefac (labrum), banu zivei feitlidse maift bafenförmige 5ormftitef, bie Siefer, Dberfiefer ober $\Re \mathfrak{I} n \mathfrak{b} a \mathfrak{f} \in \mathfrak{n}$ (mandibulac) unter biefan juet andere feit= lid)e Stïfe, rie fill 1 rabu ober llutertiefer (maxillac), แno

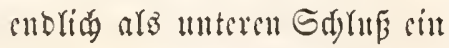
wie bis Derlipte yon oben nad) Inten beweglides Stüf, bic $l 1 n=$ 
terlippe ober Rippe (labium), bic man aud) als cill in ber Mitte

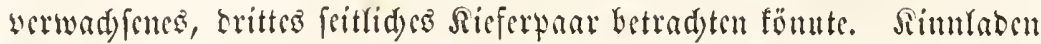
und llnterlippe tragen gewibulid feitlide geglieberte Inbänge, die sabentafter (palpi maxillares) und bic Ripentafter (palpi labiales). Die normalen Munbwerfacuge befteben alfo aus jwei untan= ren Ripwen, jwci Jana Sicfern und jwei Jुar Taftern.

Die Dberlippe beftebt meiftens nus einem mebr ober minter grofen Borfprunge, ere wie sine STapte an ber llnterfläde des Siotfes foweglid) ift unt gewögnlid) bie Sicfer beftt ober wentgftens anf igrem llrfprunge aufliegt. Zuwsilen ift bic Dberlipps unbeweglid) mit bom Gormigen Gfelette bes Sopfes werwad) fen, unb bei manden frugenben Jurften fudt man vergebens nad) sincr Gpur you ibr.

Die Riefer find bsi ben fauenben Jufeften ftets̃ aแts jus Goblen Jormftüfen gebildet, bie ju beiben Griten burd sin Gbarniergelenf fo mit bem Jopfe verbunben fint, Dab fic fid nur gegen simanber bewe= gen fömen. Gis find meiftens bafenfürmig, frum gebogen, gemöbn=

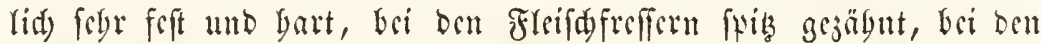
Sुflanjenfreflern mebr mit meifelartigen ober ftumpfen Borragungen jum Sanen verfeben: in vielen fällen ragen fie weit lïber ben Sopf berwor, und baben oft bei ben verfdededen Gejdededern berfelben (battung eine verfdededenc Form, wic 3. B. bei ben befannten birid)=

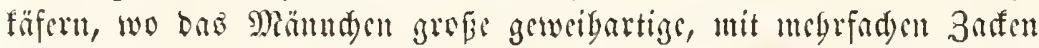

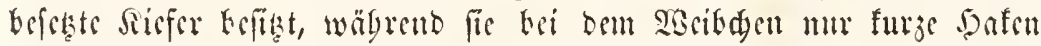

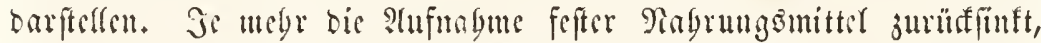
ocfto unfderintarer werben bie Siefer, und bei ben äd)ten Gangern feblen fie entweber ganj, ober fint alif jusi bornige Borften restijirt, weld ge gewöburid) jum Stedfen Eembt werben.

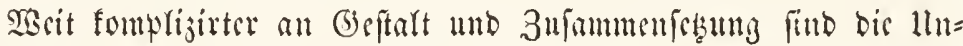

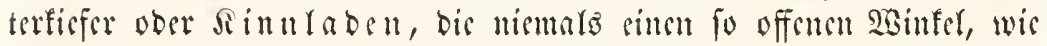
bic Siefer ju bilben im Gtante find, und mur felten bisfen an bärte

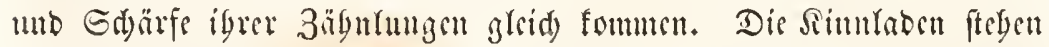

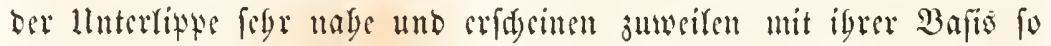

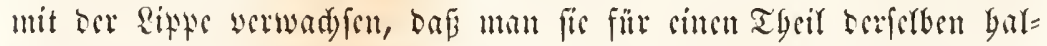
ten fünnte; - fir beftebcn meift aus mebreren cinjelnen Gtüsten, bic man in sinen $\sigma_{d}$ aft ober Gticl mo cinch freicn Theil, bie $\& a b c$

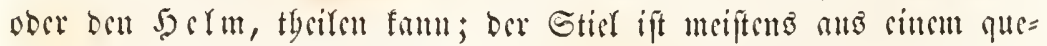

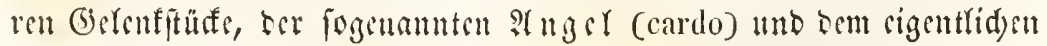
Sticle (stipes) jufrmmengefebt, ber an ber immeren Geite bic $\& a b e n$

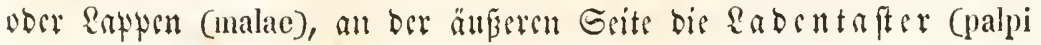


maxillares) trägt, unb an ber Skitge oft bafenförmig mmgebogen nut

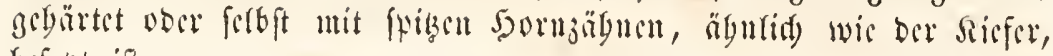
bejegt ift.

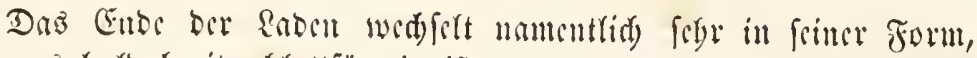
inbem co bald breit, Glattërmig ift mo wou ber Erite ber wis cin

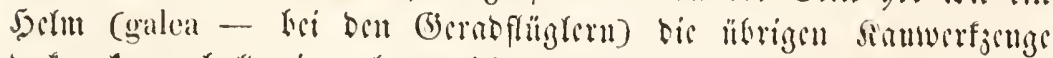
Deffen fam, Kald sinen kewegliden Ragel ober ferbit cincen tafterför

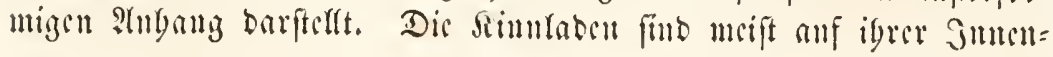

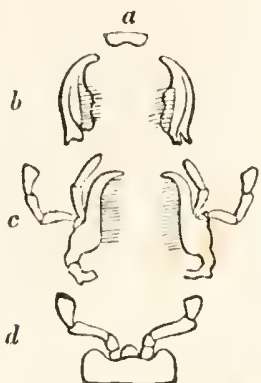

Jig. 599. Sinumertzenge eincs \&auftäfcrล (Carabus).

a Strotipte. b Ricrer. c Rimuladen, an benen man unten bits anere slagel, ben loafigen, mit Boriten beiph= ton Etix, bie z"l cincm in= ucrea żweiglicbrigen Eabeu= tapter ansagetilocte seabe 1 mb

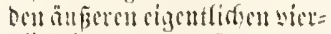
gliebrigen sabentaftet untc= foribet. d lluterlippe mit il)ren santerm.

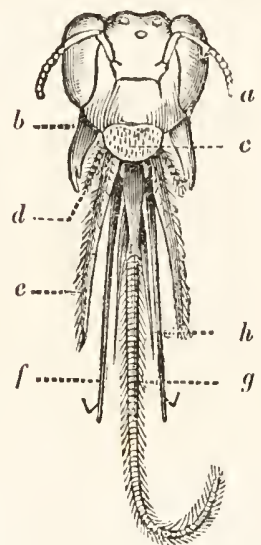

Jiv. 600. Fuyf einer 2 iene (Authophora)

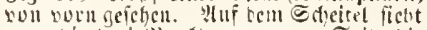
man bie brei biuntaugen, zur Ecite bie gropest Piezanger.

a Fithlet. b תicfer. c Ref̧́. d Eabentaiter, e Rimnlaben. f cip: pentaiter. g 3mige. I 9ielue zungen (paraglossae).

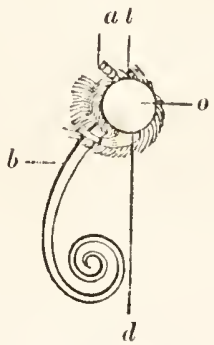

Jin. 101.

Sivtreme: a Finflex. b Dic 314 cinem Epiralrïjel zil= fanmengilegten Rintt= later. d vabentaftet. o stuge, $t$ Edritul.

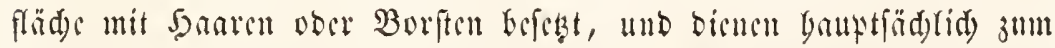
Bataften und Salten Der Ragrungsumittel. Bei ten fangenben Jurf= ten crlciben fir mamnigfartige Mobififationen, indem fie bald in ägn-

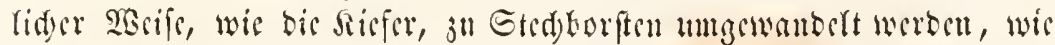
Disß namentlid) bei ben 3weiflüglern unb ben Jalbflïglem ber Fall ift, ober aber, indem fie fdscibenartige silatyen barferlen, wic bet ben

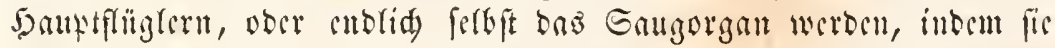

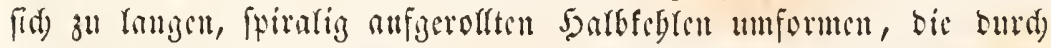

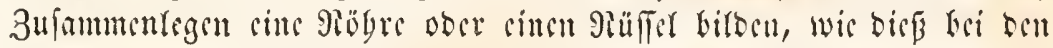
Sdumetterlingen grfdjicht. Die Sabontaiter, welde mur in fertencu

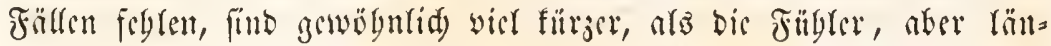

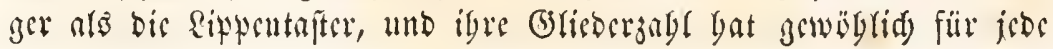




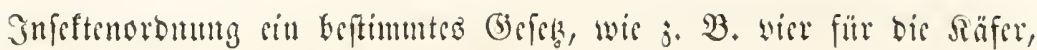

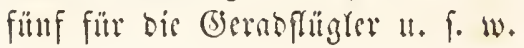

Die lluterlipps beftelyt auber ben Sippentafern, welde itt

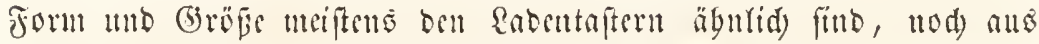

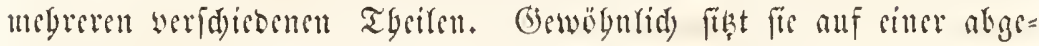

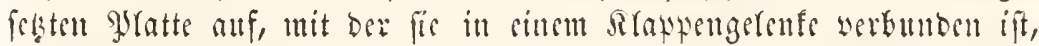

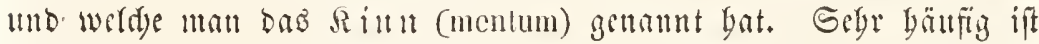

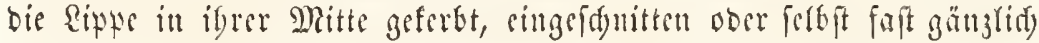

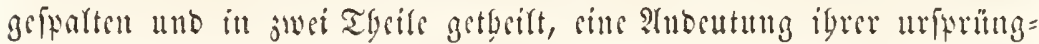

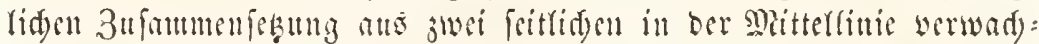

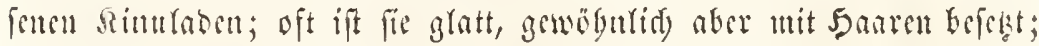

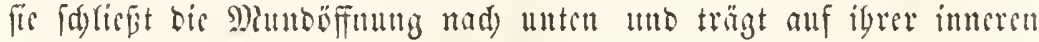

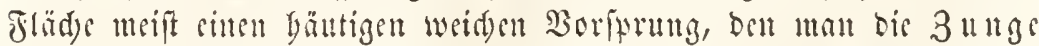
(lingula) genannt gat. (soswëgntid) ift biefe 3unge im Plunbe ver=

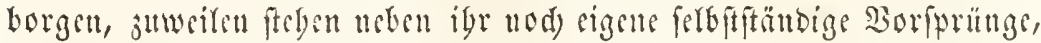

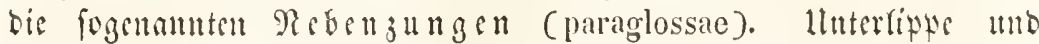
3unge zeigen nidgt mur uerfwürtige formweridgiebengriten, fonbern

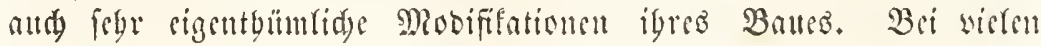
faugenten Snfften unt zwar namontfid) bei ben barkflüglern

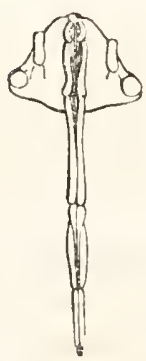

Fig. 602 .

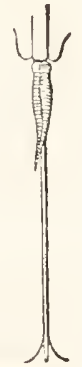

603 .

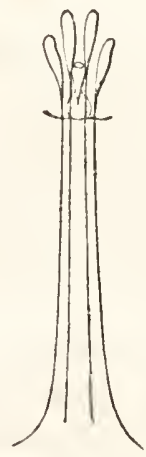

601 .

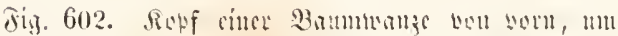

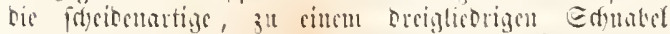

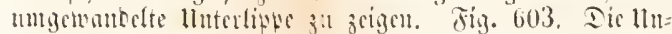

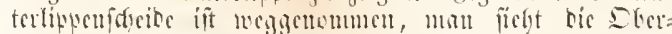

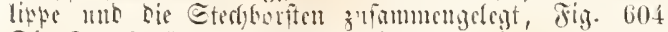

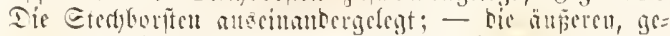

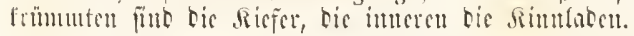

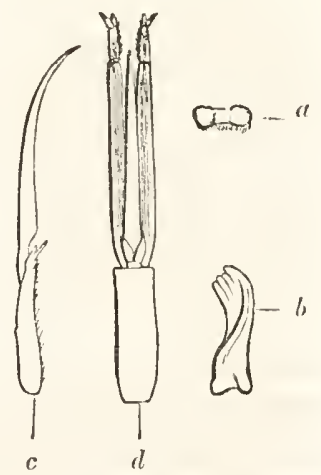

605 .

Simzche sinutherife cinci Bime. a Stertipte. 1, nîte fer. e Riunlate. d lluter: lipte, auf ber bie lange 3umbe

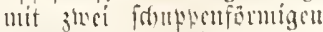

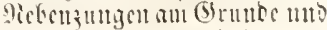

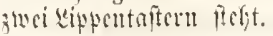

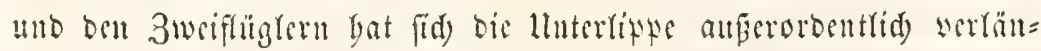

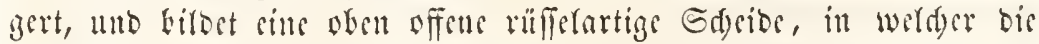

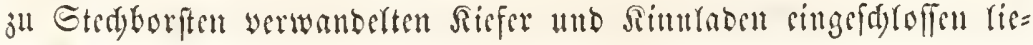


3en. Bei ben Salbflüglem if bie zum Sd)

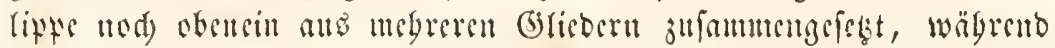

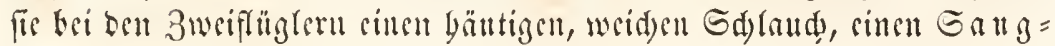

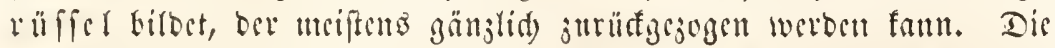

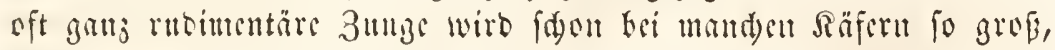
Daßs fie fists ans beur Diunde beworragt, mo bei ben Santflüglern

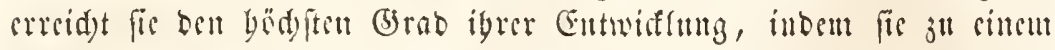

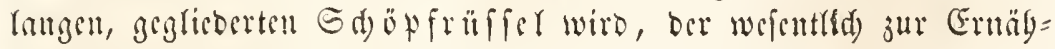

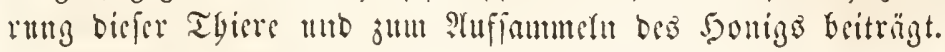

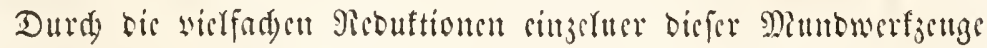

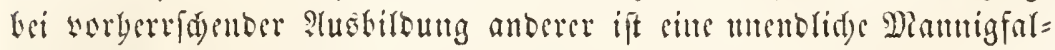
tigfeit workereitet, bie burd) ben $\mathfrak{B}$ eds fel ber Geftalt bei ben singeluen Theilen nod erbögt wirb. Es gibt mandse Sulften, wetden im wolle foumenen 3uptrnte bic Munbwerf genge gänglid) algeben, anbere, bii weldaen eingelne Theife gänjlid) feblen; bei ben meiften alver füb bie bauptifüate, welde wir srwäguten, alle sorbanden, mo ibre relative

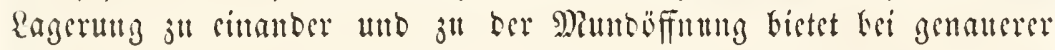
แnterfudmus ben Fabeu, an bem man ju igrer ridtigen Erfenutnis (ii) reiten fam.

Die $\mathfrak{B} r u f t$ (thorax ficbe Fig. 578) trägt, wie wir fdon ofen bemetten, in alfen Fällen bie Bewegungsorgane, illom an ber Dber=

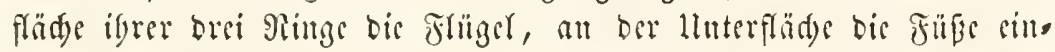

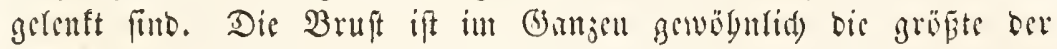

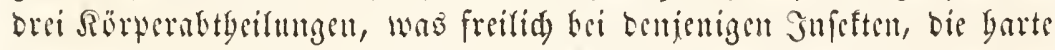
Flügelderfen befizen, (wie j. B. ben Siäfern) utr anf ber lluterfläd)

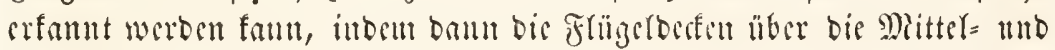

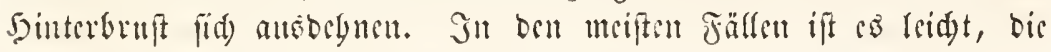
Drei ginge, weld)e man utit Dem Ramen ber Borberbruft (prothorax), oer s)itterbruft (mesolhorax) unb ber Siuterbruft (metathorax) unterid)eibet, trobs ibrer bänfigen Berwad) fungen ju et=

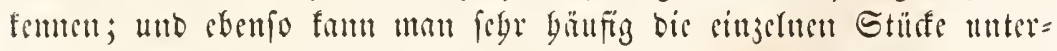

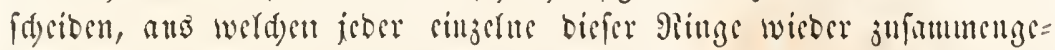

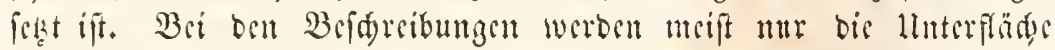

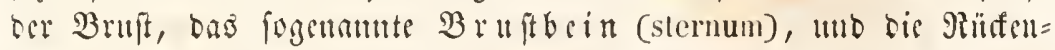

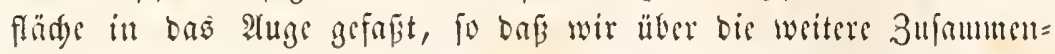

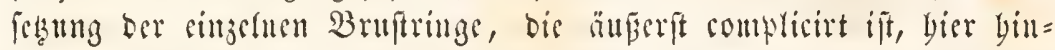
weggeben fïmnen. Gebr veridfeben fund die gegenfeitigen Derbärtmiffe

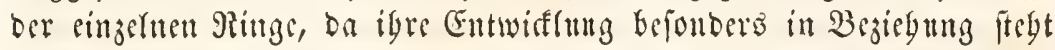
jt ben Funftionen ber Bewegungswerfzenge, die an ignen befeftigt 


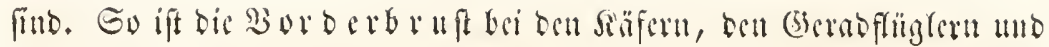

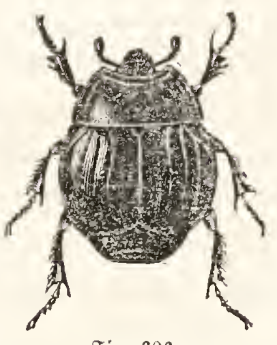

Fin 606.

Ier scidicutgfer (Ilister.)

Dor fleitte Ropf flectt bis an bic SHgent unter ber fefts Ereiton 93ortertwet voer bent

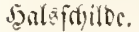

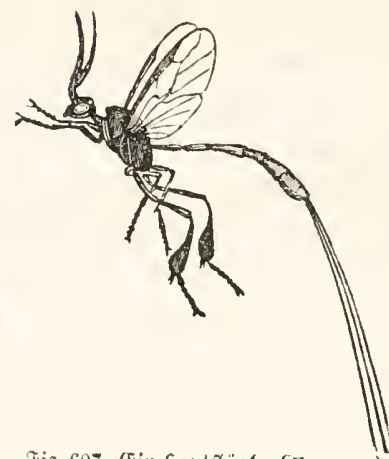

Jis. 607. (5in sexutfluigler (Foemus.)

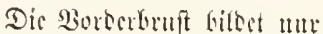
ciucu fommaten Etiol zwifidsu

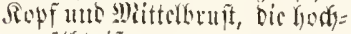
gerwolft it.

Salbflüglern utrift ganz bebeuteno snt= wiffelt, frei bewerg= lidf), unt trägt baun Den Ramen Des

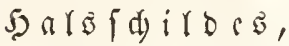
(thorax; corsclet) wälereno fie bei ans Deren, befonders flic= genocu Jujelten, wie bei bell Sdyetter= ringen, bon baut= und 3weiflinglern gewögnlidy nur bic Form sines jdmalen Ringes voer cimes bïnnen Sticles bat, werder ben Sinpf mit der Bruft vercint; juncilen ift ocr Sopf gänjlid) geborgen unter ber fdjibför: migen Sorberbuit, mandumal fogar fo, baj in bem Mande berferben Röder angebradyt find, um ben sthgen cinigen Spietraum nad) ofen

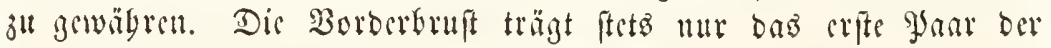
Beime, aber nismars Flïgel auf ber Müffite.

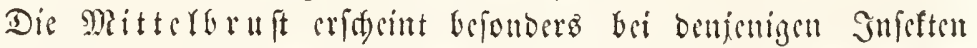

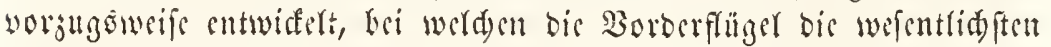
Flugorgane bilocn, wie namentlidy bei ben baut = unb 3weiflïglern, wäbrend bei benjenigen Snletten, wo bie \$orderflügel als Flïgelbeten

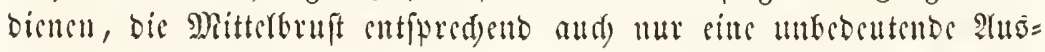
fildung zeigt, unb oft gar nidgt, oft um mit sincm fleiucu Theife auf

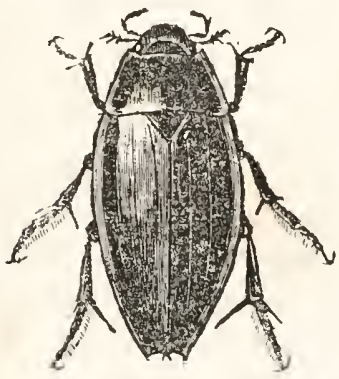

ชig. 608. Jiigftufer (Iydrophilus).

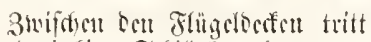

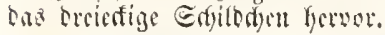
Der Dberfläde fidutbar ift, ben man baz Sdjirdan (scutellum) genannt bat. Dis biuterbatut endida, welde bei ben sorjugēwerife fliegenden Snfeften mur we= nig entweidelt ift, bilest fid) ba kefontere ans, wo bic Sinterflüger bas wejentlidsite fringorigan geworben finto, oder wo bic Sinterbcine ju Springfüsen benutht wer= Den แแb ju bicfen Enojwedfe mädtige Musestu erbalten. Dis Bruftringe im (3)anjen entbalten iun Sunern fait mur bic

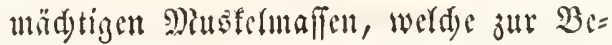


wegung ber Flïget unb Fürse bienen, woju fid) nod) ber Gdjlund, bis meift bebcutend grofien Bruftnoten uno bis vielfadyen \&uftigefäpe

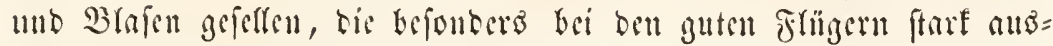
gebildet find.

Dic Fr ïger, werd)e ftetỏ auf ber Rüfenflüd) ber Mritter = unb Jinterbruft cingelenft fint, wed)fern auferorbentlid an beftalt wno Birbung. Sie frblen ganj bei ber Dronung ber Flïgerlofen, fo wie

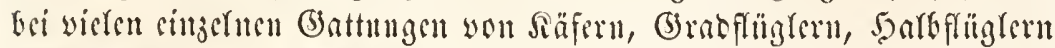

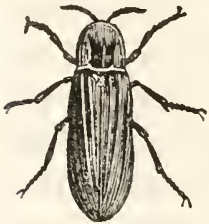

Tig. 609

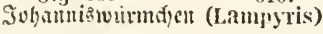

Fig. 609. (5)cflingetes 9)iämt= doct. Jig. 610. Jtingllopesiscrib= d)en.

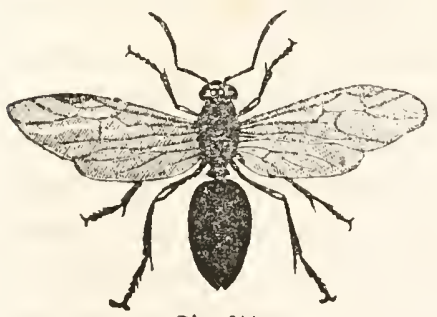

ซig. 611. unb 3weiflüglern, แnd bäufin geben fie ben Şabden ab, wäbrend bie Männdyen bant werfeben fiub; - jo finb aud bei ben in

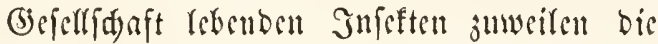
แnvolffommen ausgebilbeten gefdred torlofen Snbivibuen bie Itreiter flitgellvo, wägrent Männd)en unb 2asibd)en mit Jingorganen werfeben fint. Biele Jufeften, wie nament= ridj bie Dromung ber Dipteren, befizen Mm. juct ausgebildote Fliiger, mobei dab antere gaar jull sigenthüunlidyen (d) wingendoensiolts d)enserfümucrtift, unb swer find $\mathfrak{c o s}^{2}$ bei ben 3werfling= Iern bie Şinterflï=

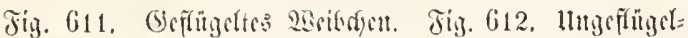
ter Sirbeiter.

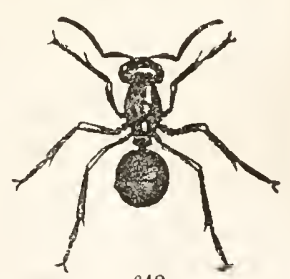

612. get, hei ben Gtrep=

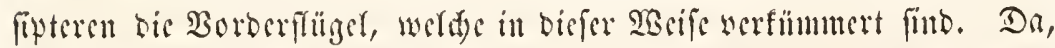
wo sier frügel vorbanben finb, finbet man fie oft von ungleider Biroung, indem bic Borberfliger megr reberartig, ober gornartig feit

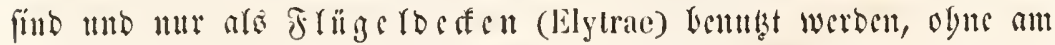




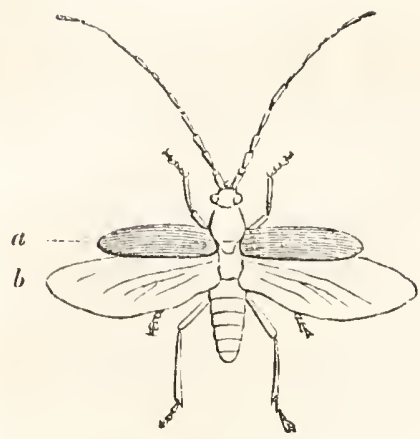

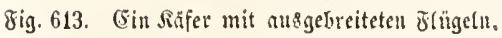
a Slïgelorfin, b Flïgel.

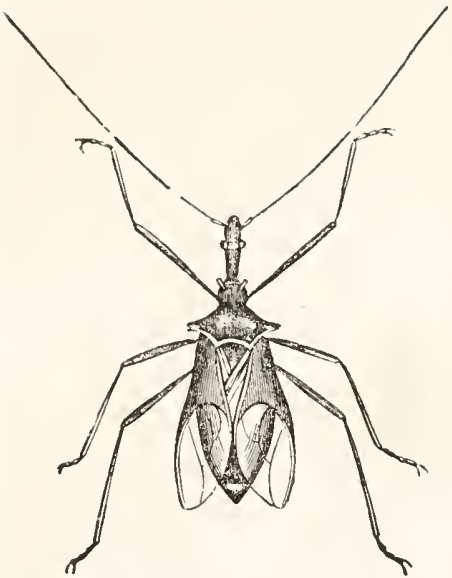

8ีig. 614. Sotfivanje (Reduvius) mit salb= befflungeln, bie finten båktig finb.

Fluge felbit einen wejentliden Antbeil ju uebmen. Mand)mal fint biefe glii= geldeden fogar fo werwad) fen, oab fie ourd)au moseweglid erfdeinen; in autbern Fällen ift nur ein Theil ber 3orberfligel leberartig und zur Deffe beftimmt, wäbrent oer äbrige Theil ebento wic bie Şinterflügel bäntig er (d) eint. Dic Flügel jelbft füb eigentlid) nur Doplifaturen Des \$autfelettrō, beren beibe Membranen febr bidst an= cinnuber liegen und mur an ben Drten, wo \&uftabern uno Befäpe fie ourdjiegen, won eimanber wei= d)en. Jeber fliiger bifoet fo cine anร zwei Brättern Eeftebande bän= tige glatte, bie je nad) ben (b)at= tungen wou mebr ober minder aแs gebilbeten ?roern ober $\Re$ e r y e Durd)jogent ift. Bei Snfeften, weldye eben aนs Der glutpe berworfried)en, mino bei benen bie flïgel nod) voll= foumen unausgebildet fint, faun

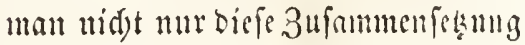
ber Flïgel aus zwei Blattern beob= adten, fonoern aud feben wie : $11=$

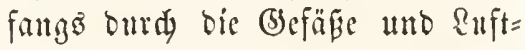
röbren Blut und ?uft in bie Frïger vororingt unb bicfe ausbegnt. Bei ben meiften Infeften fitto bie Flïgel nadet, cinfad) bäutig, yöd)ftents mit bümnen Şärd)en befez̧t, mo

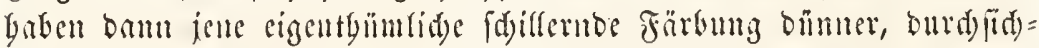
tiger Bä̈ttden; - oft aber finto fie mit befonderen Sdumpen bederft, weldye igre färbung bebingen. Zumeilen ift igre frëd)e nod) omb lunge Saane wermebrt, bie an ifrem Rande fteben. Die Bertbsilung ser Plorn ober Rerven auf ben flügeln mo ber jwifden ínen te: finbliden bald offenen, bald gefdyloflenen 3ellen erfdseint won grofer

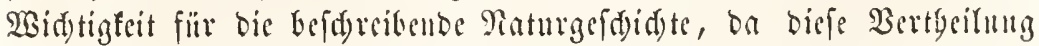
bei ben natïrliden (3rupen ftets übereinftimmeno ift. Man unterfdecioet 


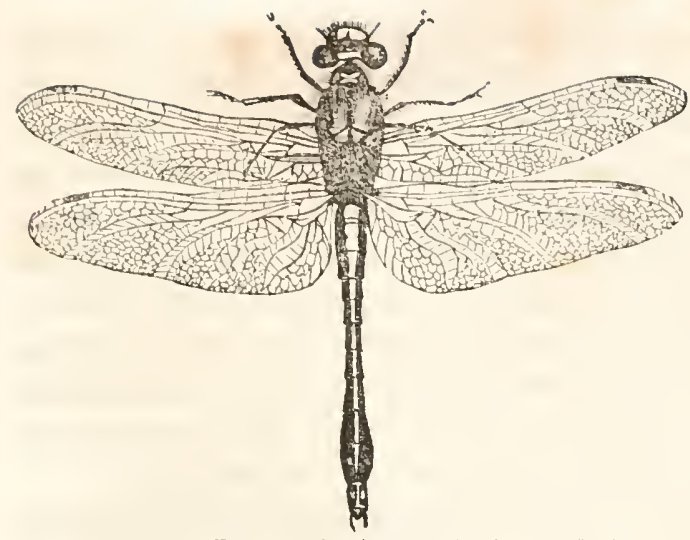

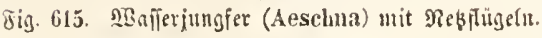

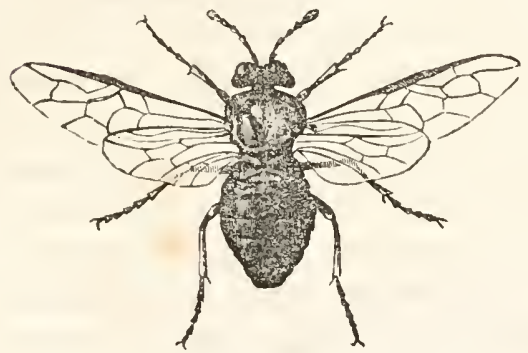

Jig. 616. Bุlatmer̊pe (Cimbex) mit 2roerifüge'm.

Gejonbers Retsflïger unb genocrte Jlüger; - es whïbe inders gu weit füb= ren, bier auf bie pecirl= reve Bildutg ber slocrm, 3erlen uno felder ber slïgel cinjugsben, ba namentfidy aud in ber

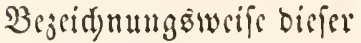
cinjelnon Ibeile eine un= fäglidye Dertvirrung berridt, insem fait jeber Monogratle antore Mias men ju gebrauden fíd bcmügigt frebt. Die ?rt แnb 2Beife, wis bie frii= gel in ber Rube getra= gen unt julammengelegt wriost, ift gewöbntict) febr bezeidunend für bis natürfidgen Gruppon, ja felbit für die Dro=

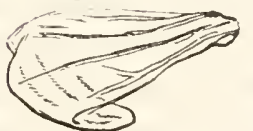

aunzen Det Gufaften. sic lluterflügrl sin, lum fie unter bie flügel= betell ju forben, wägrend bie bierablïgler fie fäd)rartig jufammenlegen, bie Tagidjmet=

öiis. 617. Ilnterflüisel cille Rafers ill ber \}iubs.

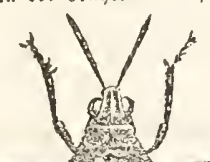

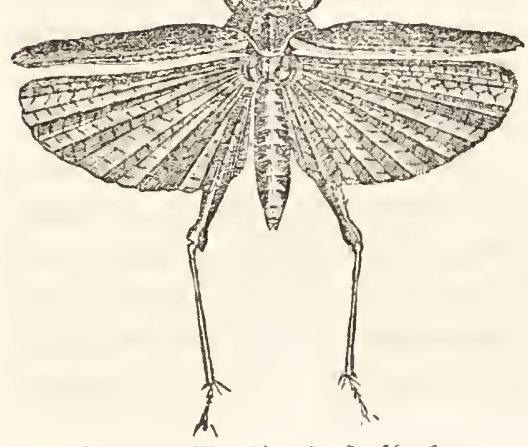

8ig. 618. (5iuc plegente Sentánterfe.

Die lluterflingel find födgerartig sefoltet.

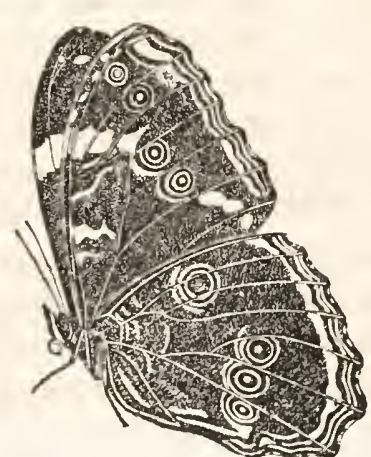

כig. 619. Cin Tagílunetterling (Nonhe IIelenor) jistent. 
terlinge aber fie und been jufammenfdylagen. Der fring ber gufet=

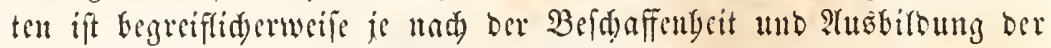

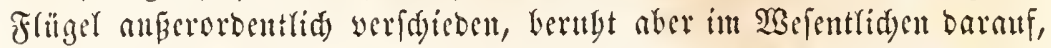
baß Der Flügel beim Ilufbeten Der \&uft cine geriugere Fläde barbietet, als beim Ricberfdylagen, woourdy fid) ber jwifd)en ben Flügeln ange= brad)te Sörter erbebt. Die Flugfraft vieler 5autflïgler, S(olerflïgler tub 3weiflïgler ḧberfeigt alfes, was wir an anberen Thieren fentuen. Fine Bremfe ift fäbig, beim fduefleten Fabren siner Cifenbabn ben Songen Dicilen weit ju verfolgen unb wäbrent ber Fabrt die Reifenden beitändig in Sireifen jul umidywärmen, mitbin ben $\mathfrak{B e g}$, welden ber खagen it gernber Ritie mad, in Rablinien ju befdreiben.

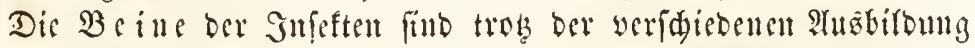
nad) Demferben (sintubgefse gebaut, uno entbalten ferfeft bei igrer Ber=

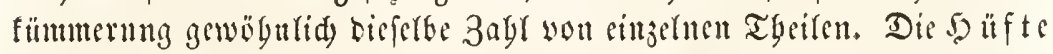
(coxa), mittelit weld)er bas Bein in bie Gerenfigrube des betreffenten

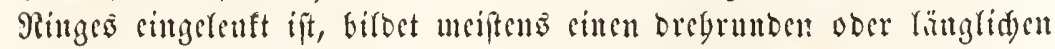
(3) elenffnopf, mit Dem ein jweitio Sornftür, Der Sdenferanbang ober Trodanter, mberweglid) verbunben ift. Gerwögnlid fünnen biefe

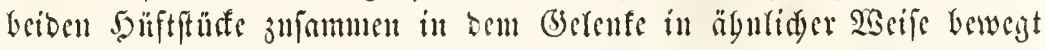
werben, wie unjer DKerarm, in anberen Fällen if bie Roffung $n=$

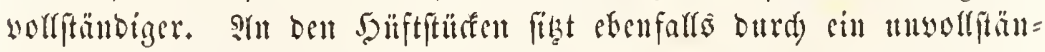
biges Rugelgetent mit íuen verbunben, ber Єdenfer (femur), Der faft immer eine waljenfürmige beftalt bat, oft beftadert oder bejälnt ift und an Den Sinterbeinen ber fpringenden Sufeften gemöbulid be= ocuteno verbift erfdeint. Mlit bent Sdenfer ftebt cin jueites, uncift rängeres uno bünneres Stḧf burd) cin (Egarniergelent in Serbinbung,

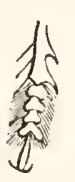
bas man bie $S_{\text {d) }}$ icne (tibia) nemut, unb bas an feinem Ende ben $\mathfrak{F} n \bar{B}$ (tarsus) trägt. Diefer leţtere beftegt num febr felten aแs Eittem, meift aแt mebreren, gewobntid aแts fïnf Glicbern, bie oft erweitert umb auf ibrer llnterfläde

zig. 620 . 8intufglisbriger ₹щв (Tarsus)

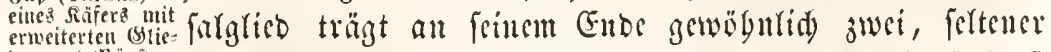

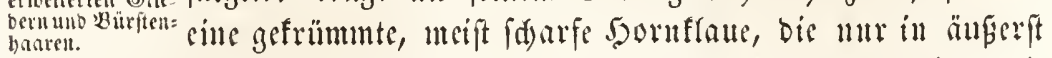

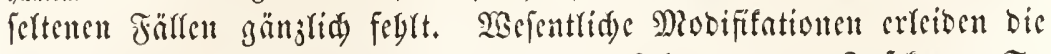

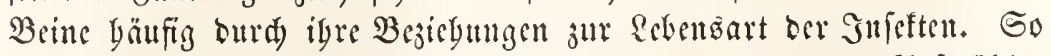

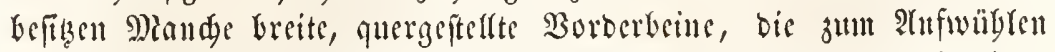

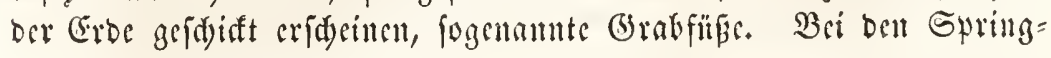




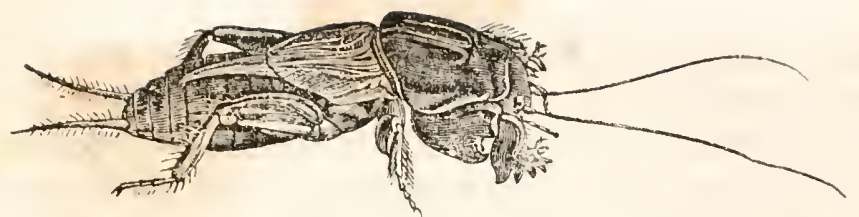

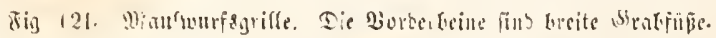

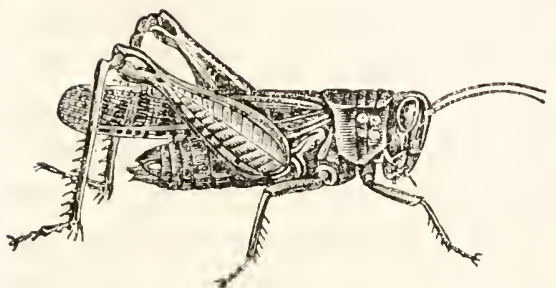

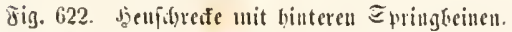

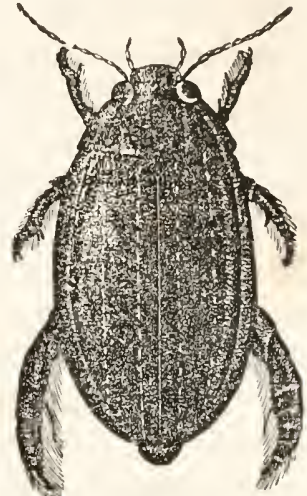

Jig 623. SBafierfifer (Dytiscus) mit Entmimbenen.

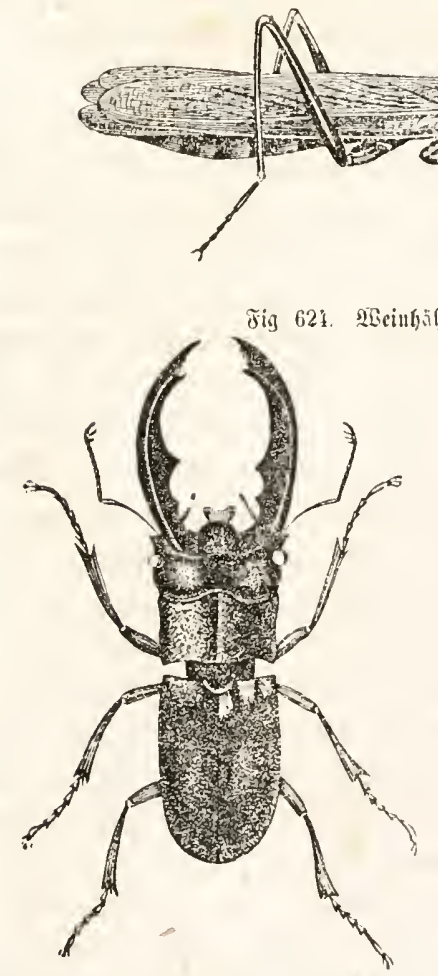

Fig. 625. Firigffaffer (Lupanus) mit Sdyreitiüen unb geweiffartig vertangerten Riefern(mandibulae), brinen fund bie binteren Sdanfer verbictt unb verfängert; bei ben Gdwimmbeinen bic cinjernen blie= ber argeplattet, bie Beime nur in wagred)ter Mict)tung beiveglid) unb mit freifen 5anren, bie igre Dber=

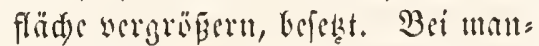
d)en Jufeften finb bie Sarberbcine zangenfürmig แ⿰t⿱丆贝⿰ gen ber Beute wis ein Tafden= meffer cingeffatyt werben -9 Rat $=$

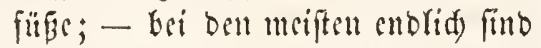

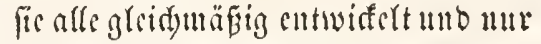

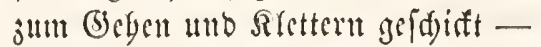
(G) $5=$ ober Gdyreitfübe. 


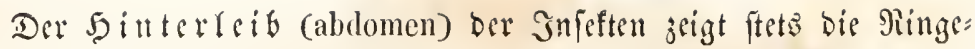

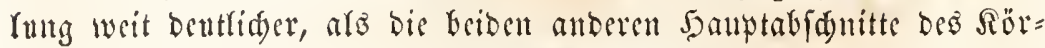
pers. Die Sinterleibsinge finto faft immer ans zwei Bogen, cinem

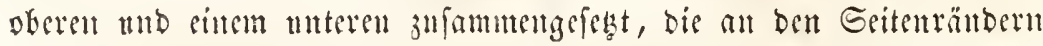

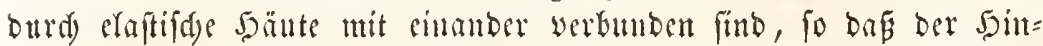
terfeib bierburd fowobl, wie burd) bie fduppige Pltorbung ber Ringe,

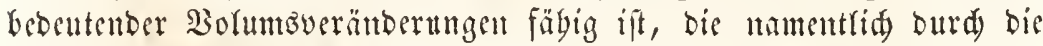

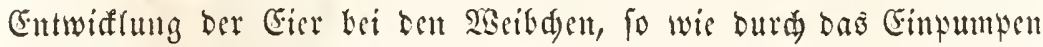
yon $2 u f t$ yor Deun 2Yffliegen bedingt werbent. 3nuveilen gebt diefe fduppige Ragerming ber Ringe, bie burd ansbebnbare Bänder verei= nigt find, fo weit, baf ber Şinterleib förmtid, wie die Röbre eines Jjerfpectivez, ein= unb ausgefdjoten werben famt. Die Rormarabl ber Santerfeitsoringe fdecint neun zu fein, inteffen wedjert bieferbe auperorbentlid) entweder burd) Berwadjungen ober baburd, daß bie Yeşten Ringe in bie Bandgögle ferbft Ginteingefdoben unb bort arz Deffidupwen ber Begattungäwerfjenge angebrad fint. Caigentlide Bewegungrapparate trägt Der binterteib nur bei einigen flügellofen Snfeften, bei welden bic fonft unbewegliden Boriten und Şarre, bie oft an ifm angebradat finto, ju Springorganen untewandert finto.

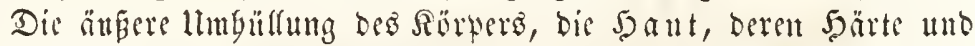

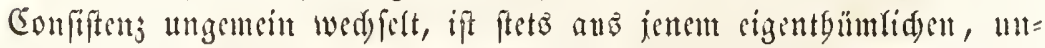
röbridyen Gtoffe gebildet, ben man Gbitil genam bat. Da biefer Stoff nul äufirft fdwer zerlegbar ift, fo exbalten fid and bie utei= ften Säute und Rörperidafon Der Snfeften fegr lange Zeit volfommen

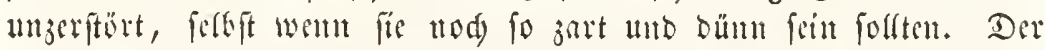
Ban Dicfes Santferettes feinten wefentfiden Jormbeftandtgeilen undy ift nod) Durdano nid)t bintlänglid) etforfd)t. F(n vieten Etelfen et:

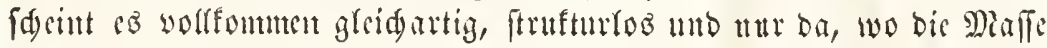

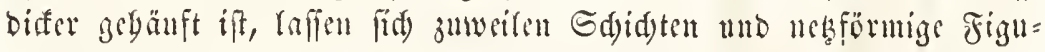
ren unterfdeiben, swifden welden oft prad)twolle Farbftoffe abgelagert

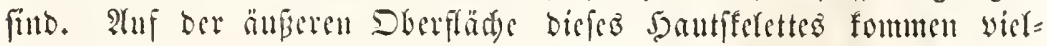
fade Anbänge in Form von Stadeln, Borften, baaren ober Sdup=

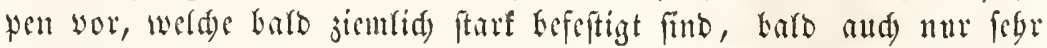

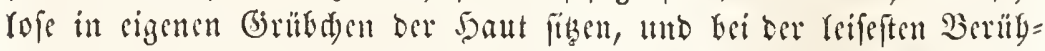

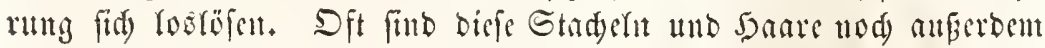

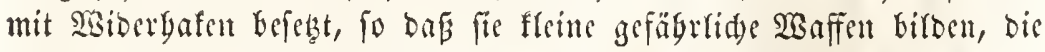
cinutal eingebobrt fteto weiter vorbringen. Die Mägen mander Ran=

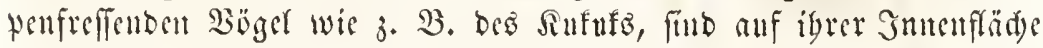
mit eintem fo bidsten lleberguge folder verfilgter it bie Magentant eingeftodener Saare bedefft, bas lange rebbafter Streit äber bic Jrage

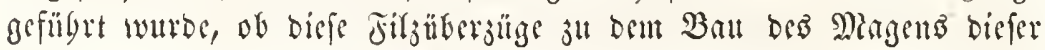


Bögel gebören ober yon ben serfduluften Pampen berribren. Rad)

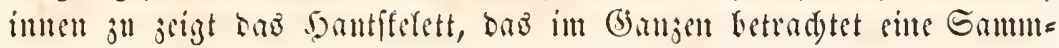

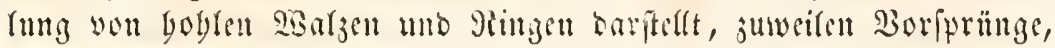

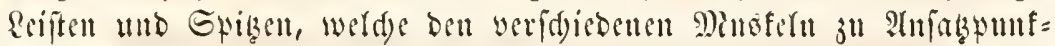
ten bienen. Dic änferen lluriffe bes Dantfelettes ftegen ḧbergant

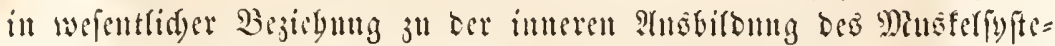
mes, unb ftets findet man ba, wo mädtige Minstefu zm Bewegung gewiffer Tbeile vorbanton finb, and entfpredend bas bautferett anf=

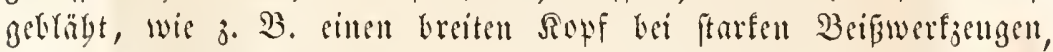

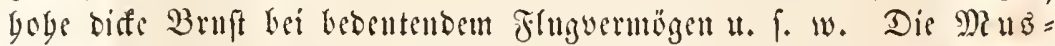

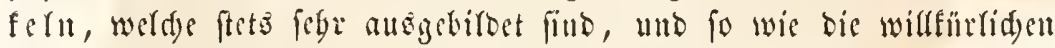
Marfern ber büberen Thiere febr Dentlide Suerfterfen zeigen, fteben im

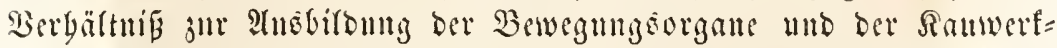

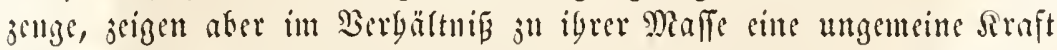
and Energie, bie fit befonders bei ben ?trbeiten ber Jufeften fund giebt. Dis meiften Räfer tringen mit Rsidutigfeit bas zebn= ober jwan=

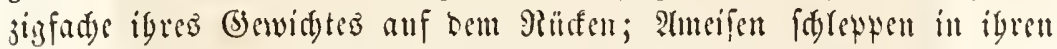
Siefern, alfo mit ungünftigem Sirnftmouttente, weit grö̈sere unt fdwerere (b) egentände, als fie felbft find, fort, und eine brabuespe ober Mant=

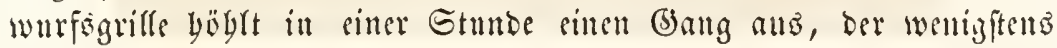

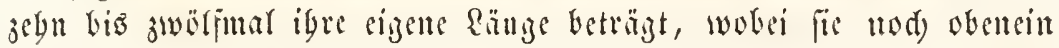

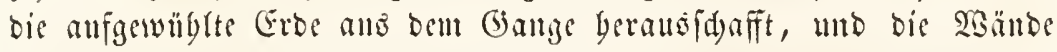
Desferfen vor Dem 3ufammenfaflen fidert! IIno fold)e Probeiten werden

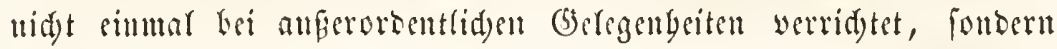
galten tagerang obue lluterbredung an, und obme baf man bem Thiere einige crmilomig anmerfte.

Das Reryen

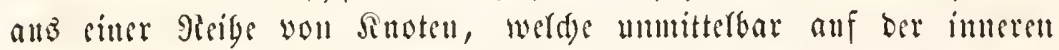

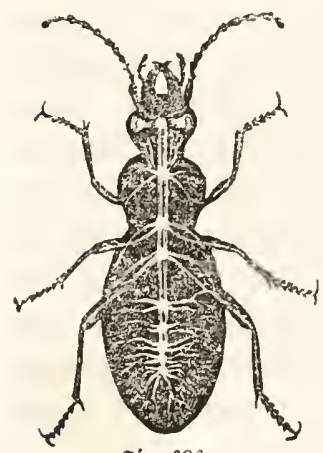

Jig. 626.

Das Tiexrenityftem cinez gauf: thferz in feiner gane tou oben gejeben nat) ber 23 egmatme al= ter übrigen Drgane.
Jläc)e ber unteren Santbedeffung anfliegen und meift burd) osppelte Rängsfäben mit ein= ander verbundell fitto. Sn den sopfe, itber rem Sdylunde liegt eine (B) birmutafle, weldse dis Füblernerven und die Sebuerven abgiebt แnto mad) unten jwet biffere Fäben um Den

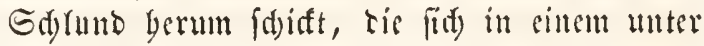
Dem Shlunde gelegenen Sinoten sereinigen uno fo eitten fürmliden Gd)lunbring birben. Bon Dem unteren Sinoten aus gebsu \&ängg̃fä: Den แad) binten, bis meiftens getrennt, zmwei= lett abet and) zul sincut cinzigen Jaben ver= 
fdumolgen fint und an benen fid) von 3eit ju Zeit ben sinjefuen Rin= gen entfpredjent, Sunten befinden, son welden bie Rerven ber Drgane

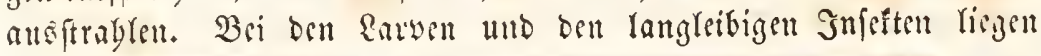

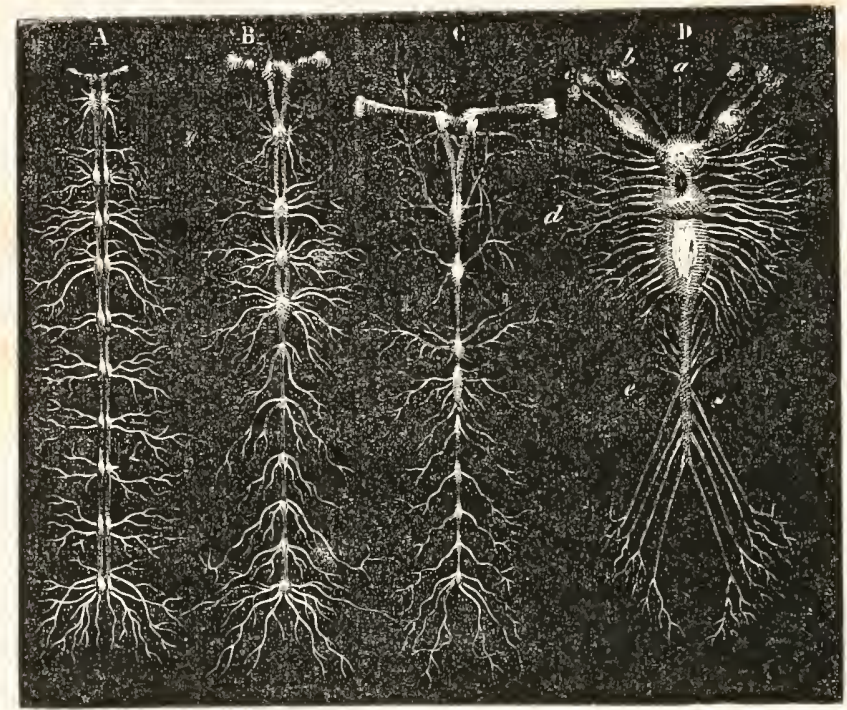

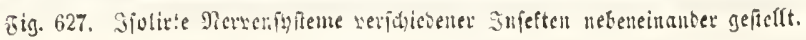

A Bou bem Shrmume (Forficula); B wou siner Senffrlesfe (Locusta);

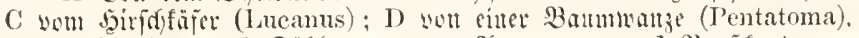

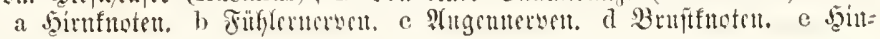
terleifiaftutent.

Diefe Snoten gemögnlid weit von sinanter, wägrent ba, wo bic cin= zetnen Sörpertinge mebr mit sinanber veridymolgen und unbeweglids) geworben find, bie cinjeluen Snoten aud näber aneinander rïfen, unb oft gänzlid) mit sinanber veridumeljen. Mian findet fo bie man= nigfartigften llebergänge yon sinem Bauduarfe, bas in feiner ganzen

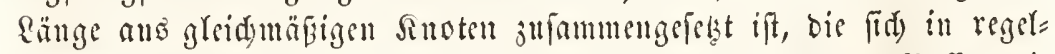

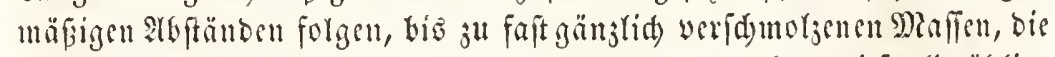
faum nod) igren ltrfprung gewabren laffen; uno man foun diefe allmäblige Concentration bes Rervenfyftemes aud) bei benjenigen Prten verfolgen, bie als Rarven eine langeftreffte Ganglienfette, als wollfommene In=

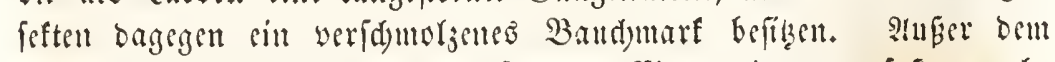

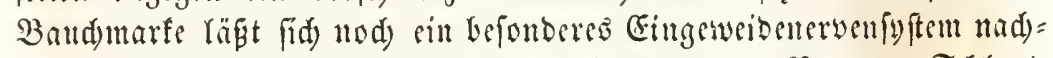
weifen, weldes als zwei parrige und sin unpaarer Rery an Sd)lun uno Miagen binläuft, uno biefe mit 3wcigen verforgt.

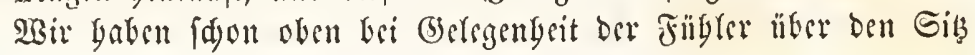


Des oft auferorbentlid) feituen (berud)finnes, fo wie bei Den P(ugen "̈ber Den Ban Der Eebwerfzenge gefprodyen. Der Taftinn, weldem

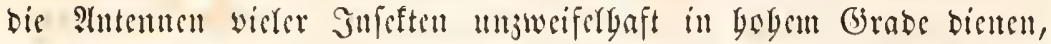
finoet auberbem nod in Den Taftern ber Sanwerfjeuge, in Den Epizen

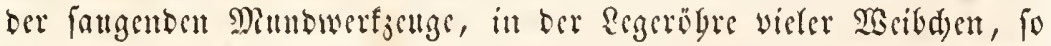

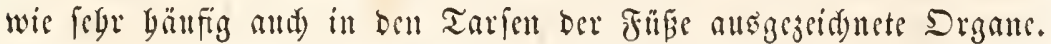
Sacuiger leidyt gelingt es, fid) liber ben (b)

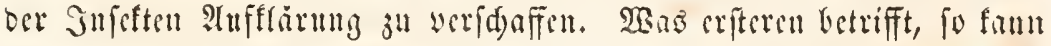

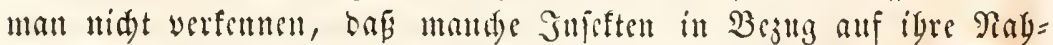
rung fegr wäblerifd find; tht es mögen wobl bejonders bie weide 3unge, wem cine folde vorbanden ift, ober bie weidsen Tafter mo

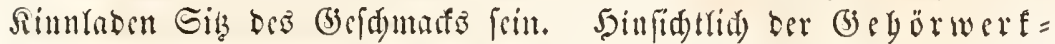

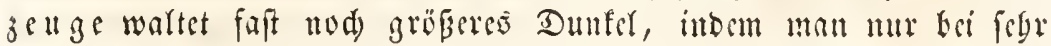
wenigen Gerablüglem wabre Syren entbeft bat, fei allen hbrigen Sneften aber burdaus fein Drgan für biejen Gim yat finben fön=

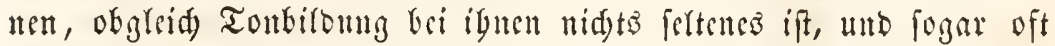
in Bejelung namentlid ju igren (befdyledstofunctionen ftegt. So

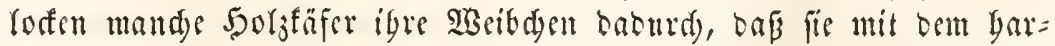
ten Sopfe ober Sinterteibe mit grofer Jeftigfeit auf bas 50$\}_{3}$ auf= fod)en; Dis Sdnarrfdreffen geigen mit igren Sinterbeinen an Dem

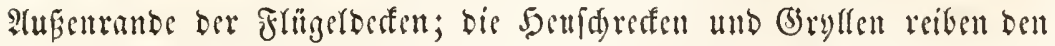

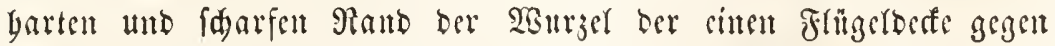

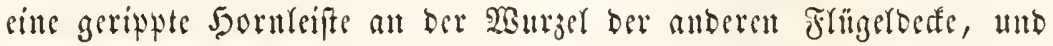
bringen Daburd) ben fdriflenten Rofton bervor. Biele Räfer unb TSanjen jirpen, indem fie bie Borberbruft zegen ben Mittelüfen ober Den Sinterleib gegen die Flügeldeffen reiben. Die Gingrifaden brint= gen igren unleibliden fogennunten Gejang mittelf einer trofenen Trommelyant berwor, weld)e an Dem erften Sinterleibsringe in ägn=

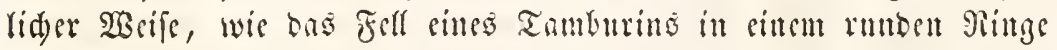
ausgefpant ift, burd) sinen eigenen 2 Rusfel gefpannt unb pröblids

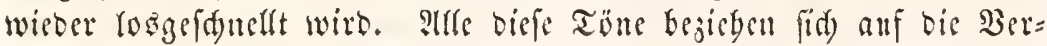

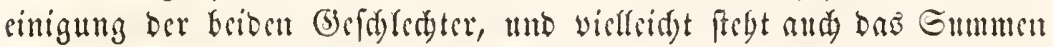
wirler fliegenten Sulften, weldyes offentrar Durd) bie abwedjernbe

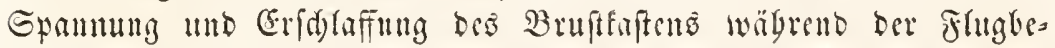
wegung unt ber Dicferbs begleitenden jablreiden Minsfelcontractionen

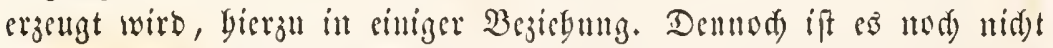

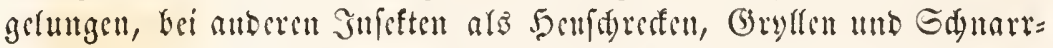

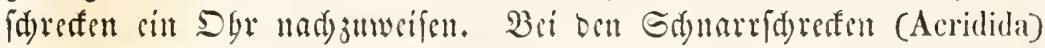

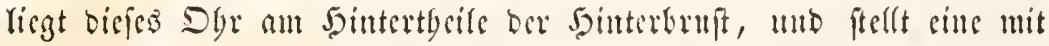
einem Trommelfelfe gefd)loflene (brube bar, binter weld)er cin jartes 


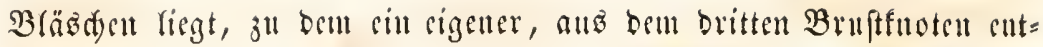
fpringenber 5örnerwe gebt. Bai beu cigentfidgen Gryllen (Gryllida) milb beu Semfdreffen (Locustida) futtost man gar unter bem Siniege= Yenfe bet briben Borberfdienen Gruben, weld)e burd) Tromulelfelle

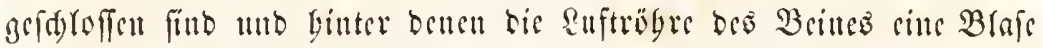
lifbet, 3ll bet fid sitt eigener Gebërnerve tegiebt.

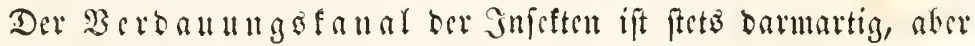

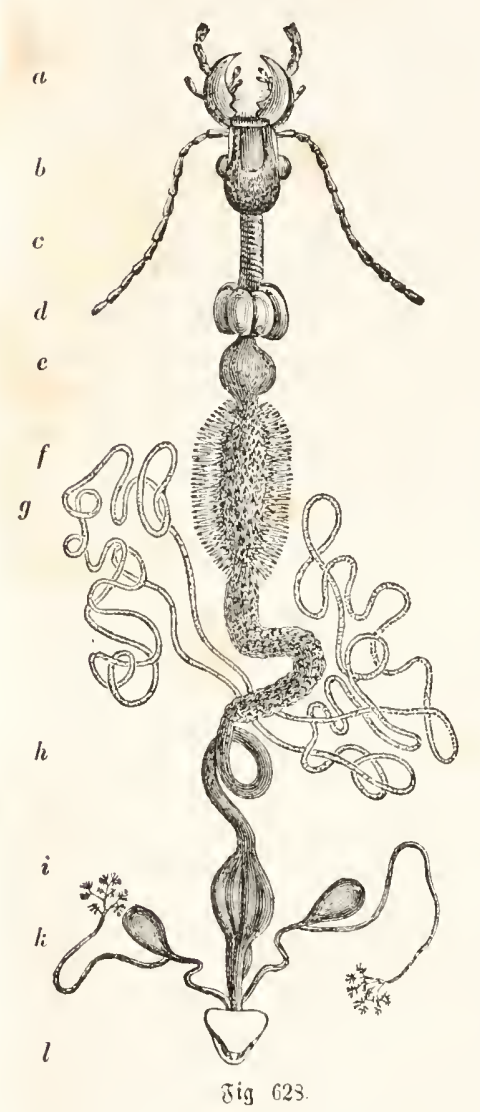

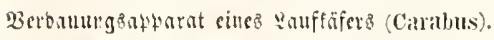

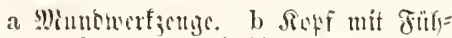

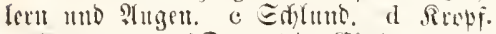
e Rommagen. f' Dar gattige Chytumagen.

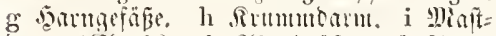

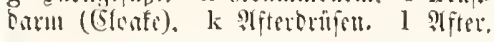
wou febr wedferluber Ränge, wno zcigt fid) immer aแs utbreren 5 än= ten jufammengeferst, Deren imuerfte all Dem oberen Hild unteren $9 \mathfrak{b}=$ (d) nitte bes Darmes mit bem 5 ant = ferlette in Serbindung ferbt, แnd and) bei Şäutungen mit bemfertoen gewed) felt wirb. Baci ben fleifd)= freflenten Suffeten, fowis bei ben Gaugern ift ber Darmfanal int ?Yll= gemeincn weit fïrjer, als bei ben Whanjenfrefferu, wo er oft wicle (d) fingenfürmige Biegungen im 5jin= terteibe bildet, die nismats burds siu Gströje, fonbern ftetō unr burd) vielfudge Berjweigungen ber \&uft= ribren in ibrer sage erbalten wer= ben. Gewrbultidy fann man brei 5auptabidutte und forgenbs cilt jefue Theile unteridesben: Bon Der Mitnobugle an jicbt fid furd) bic Bruft juifden ben Menstelmaflen Derferben bittourdy sinc büune, aber

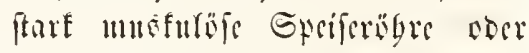
Sd) ( $u$, ber $u a d)$ biuten oft in cincu bäutigen, mebr ober mituber gefalteten Rerof mo baun iu

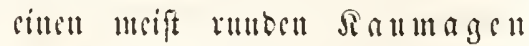
fid) erweitert, beffen innere glïds gemëgurids mit bornigen Sciften, Borften und ftumpfen 3̈̈buclungen

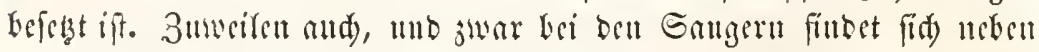

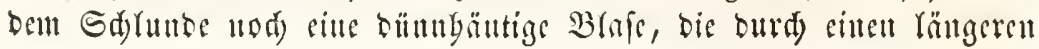


ober fürzeren Stiel mit igm in Berbinbung ftebt แแb als $S_{a}$ u gut $a=$ gell functionirt. Şänfig fut an biefer erften P(bt)eifung bes Darm= tanats nod) befondere ribrige ober tranbige Speidelorüfen ent= wirtelt, bie meiftens in bem Sioffe werkorgen Yiegen juweiten aber fidd

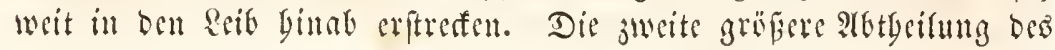
Darmfanals wiro wa bem fogenanten çgy

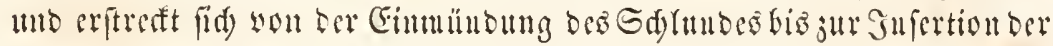

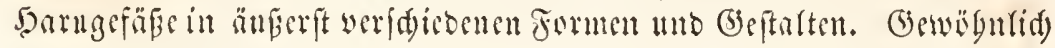
jeigt tiefe slbtheilung eine hedentendere Breite alo bie anderen unb vielfad)

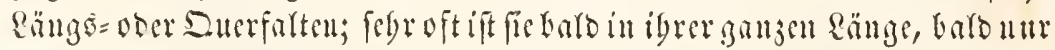

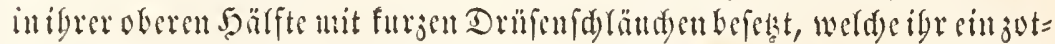
tiges An

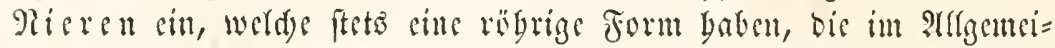
wen ben Drifienorganen ber Sufeften ïberbant jufommt. Die felyr bïnten und rangen barugefäbe, beren 3abl febr wedjelt, baten

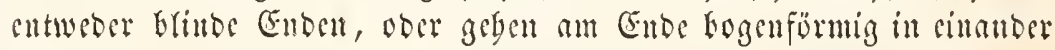
liber, unb ungeben meift in vielfad)en $\mathfrak{B i n b u n g e n ~ u n b ~ S d y l a ̈ n g e l u n g e n ~}$ ben Darmfant. Der getblide ober rötblidye Sarn, welden bieje

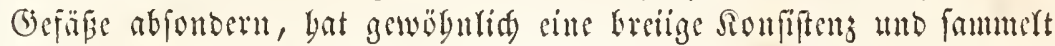
(id) wäbrend bes goupenfidafes in bebcutentor Dienge in bem bittes

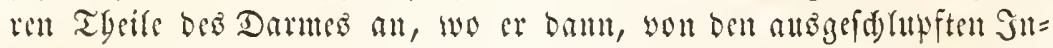
feften oft in grofer Menge entfert, ju Sagen yon Blttregen Berme Iaffung gegeben bat. Dic bintere 9tbtbeilung bes Darmes bat im

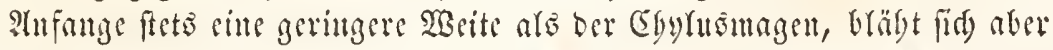

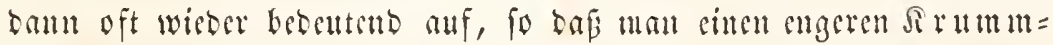
Darm, einen froafenfürmigen Difform, unb cinen furjen mustu=

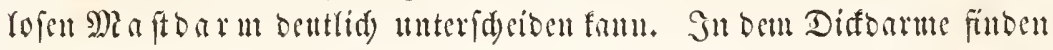

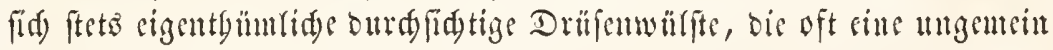

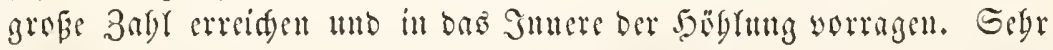
bälfig jeigt fid an biefen floafenfürmigen Difonme nod cin megr sber minter nusebifoeter Blinbonam, oer juweilen eime amelentide

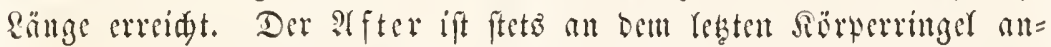

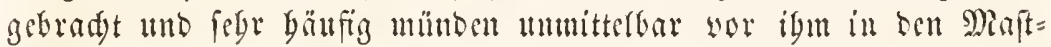

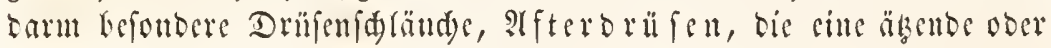

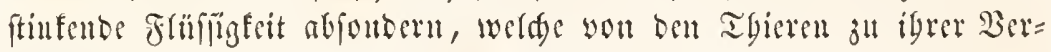
tbeibigung berworgefpritet wirb. Zuweilen finten fing and folde cine

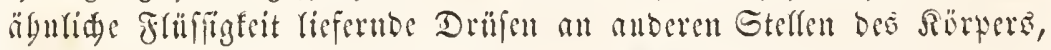
wie jum Beifpiel bei ben Maimürmen (Meloë) an ben Grfenfen ber

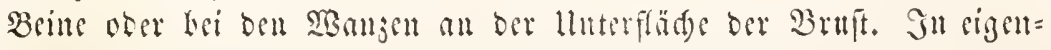

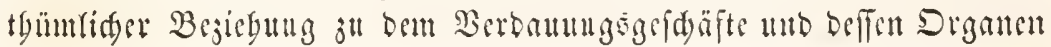




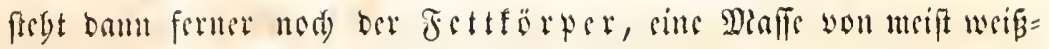
lidsen ober getblid)en Fettjellen, bis bei ben wolfommenen Jufetten

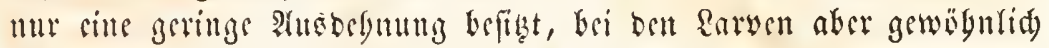
alle 3wifdenräume ber Drgane erfüllt unb wägrend bes YJuppenlebens juแ 9 Afbau ber Drgane verwentet wirt.

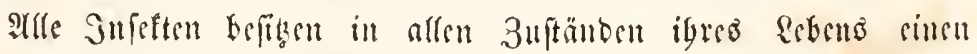

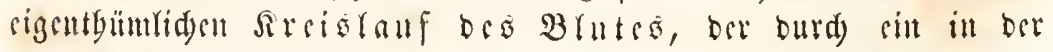

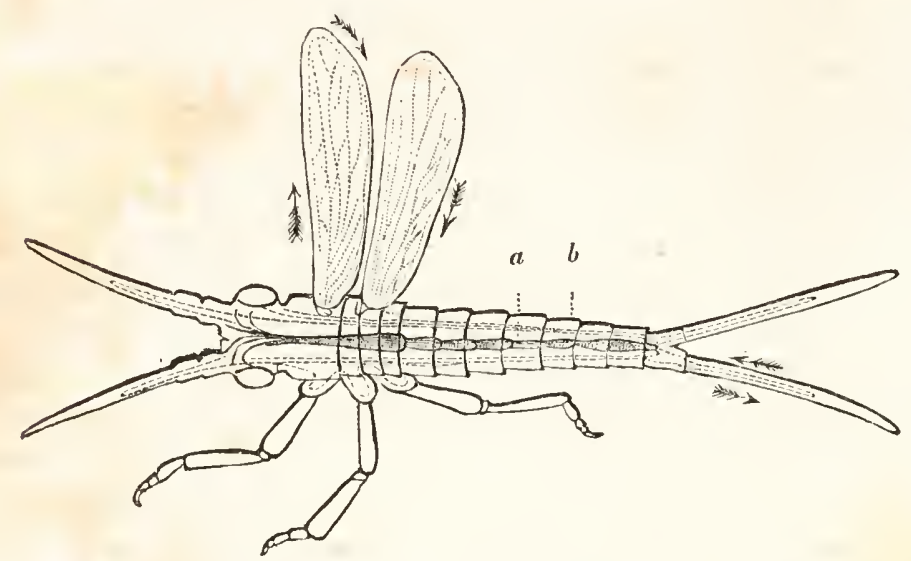

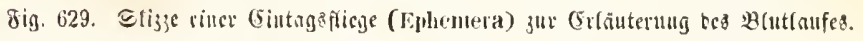

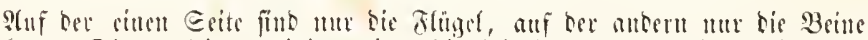

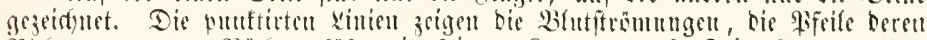

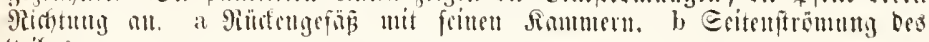
seites.

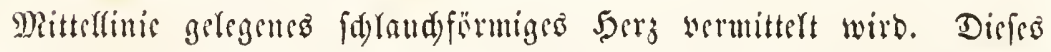

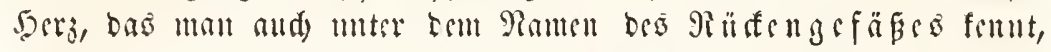

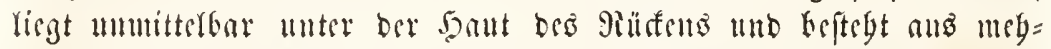

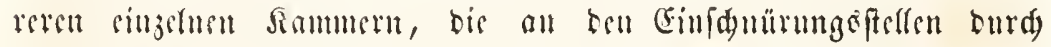

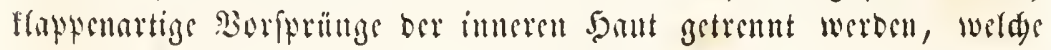




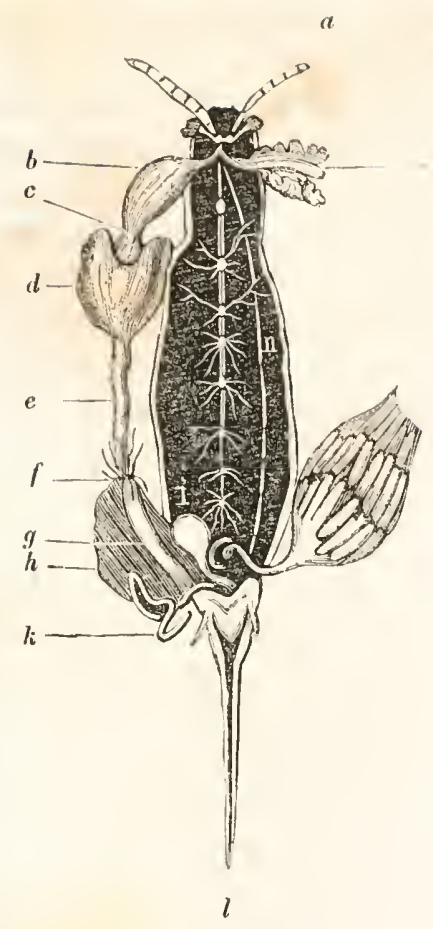

8ig. 630.

2unatomic ciner meikliden soujdrafe.

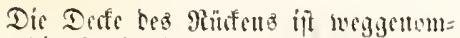

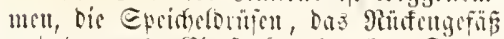

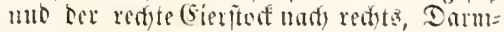

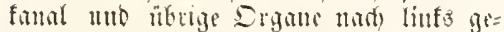

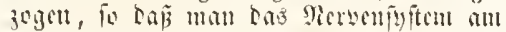
Silate fiekt. a Füblfounc: b Rrowf. c Raumagen. d Magcu. e Sitterer Theit

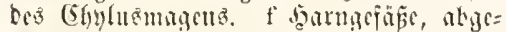
f́rtitten. g Difform. h Eieritsife. i

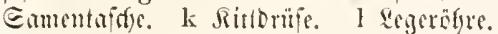
m Epridgloritjer. n Rïtentgeräв.
Dem Brute sime Strümung von biuten nad) vorn gegen ben Ropf anweifen. Die ciuzefuen Sinmmern find ourd) orcictige Miıfferbünoet all bie Sinterletosinge kefeftigt, tho jeigen jeber feits in ibrer yor=

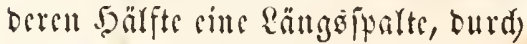
weld)e tas 3 lut wou auben mad) intten in bas 5erg cinbringen faun. Gewöburidy bat bas 5erz adyt fiam= mern uno fomit fedsizebu Griten= fpalten, beren Silappen ber ange= beuteten Ridutung gemäg angebrad)t fuld. Durd) Bruft und Soyf fest (iid) Dab Sacr mittelít eiluer in ocr Mittelfinie gelegenen Rörpernder fort, weldse plöglid) mit einer ober mebreren offenen Mänoungen enbigt. Diç ifit oer ganze Gefä̧apparat, weld)en bie Sufeften befizen. $\mathfrak{B e}=$ trad)tet man bei sinem fordyen Tbiere, Deffen Rïrfengaut burd) forinent ge= nug ifi, 3. V. bei ber Geibenraupe, bas Jacr itt feituch Thätigfeit, fo fiebt man, baß bic Sammern beffelberi fid wellenartig you binten แnd) worn jufammenjicben, wnb fid bei cer :HEbchnung wicber fïllen. Das $\mathfrak{B}$ fut freifet im beftäntigen

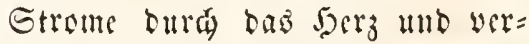
theilt fid onnn in ben 3wifd)en= räumen ber Rörterorgane, wo fid

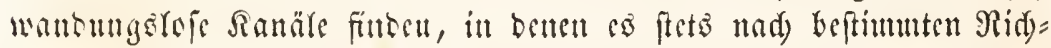

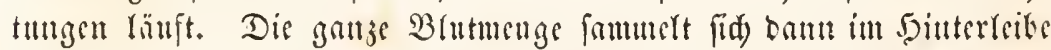

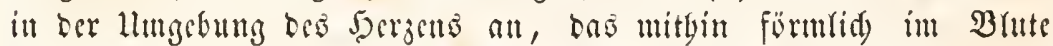

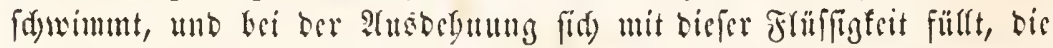

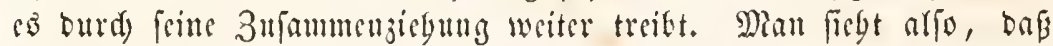

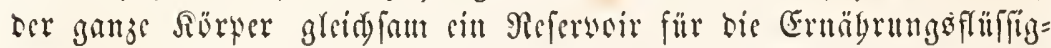
feit birbet, beffen Gubart burdy eine angebradyte Gaugiprize, bas bers, in Thätigfeit werfest wirb. Das Bht ferbit ift gewöbulid wolffom=

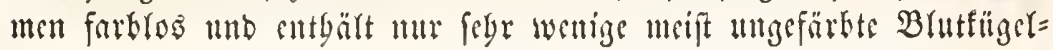




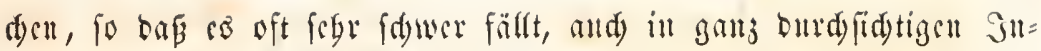
feften unter bem Difroffope dic Butfitrü ju feben.

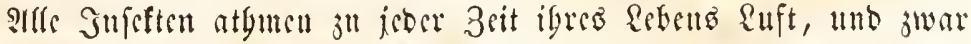

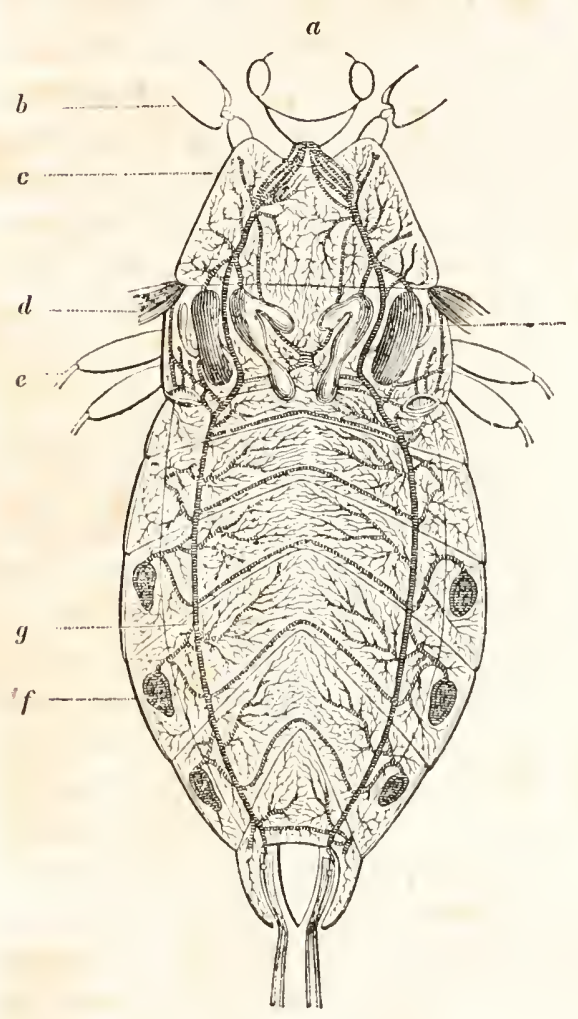

รig. 631 .

21tbenmerfzenge einer sanjermanze (Nepa).

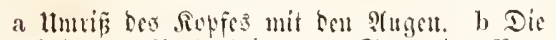

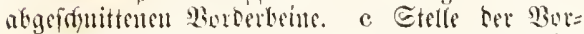
berfitigel. d binterfiagel. e sintertrine. f' Erig=

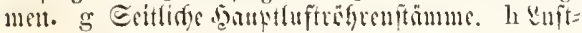
rifgrentapen.

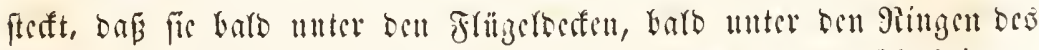
Rörpers aufgefudt werben milfen. Sgre $3 a b l$ ridutet fid bei ben

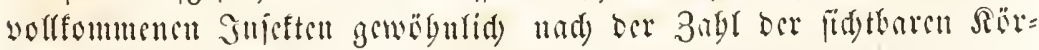

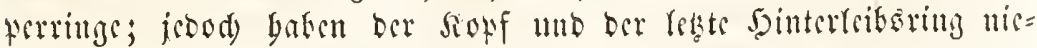

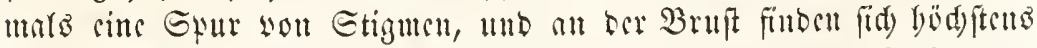

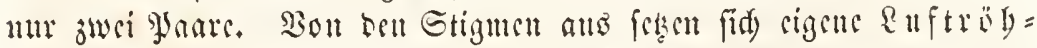

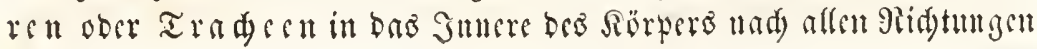




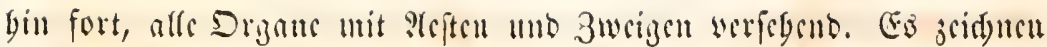
fid) bicie enftröbren mcift, went man fie bei cinem letenben Jufefte

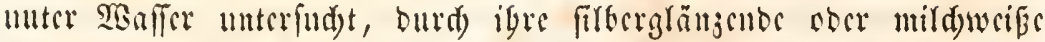

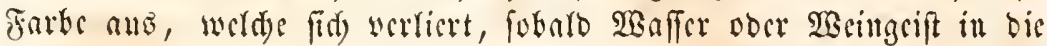
Pobren cingebrungen fund mo tie enft verorängt baten. Dor Ban

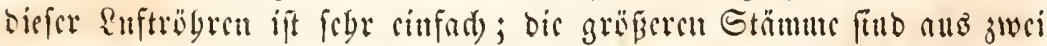

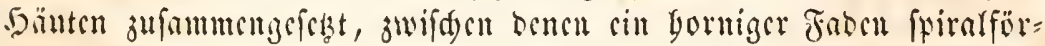

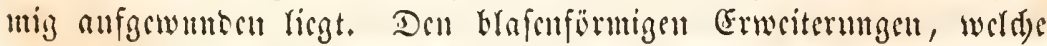
an ben Rufröbren sicker Infeften worfommen, feblen dic Syirnlfäbcu uno cbenfo beridumben fie nad) uno mad in ben feineren Aeften uno 3 wrigen or Pöbren, wo julcht mur nod) sine sinfad)e, ftrufturlofe

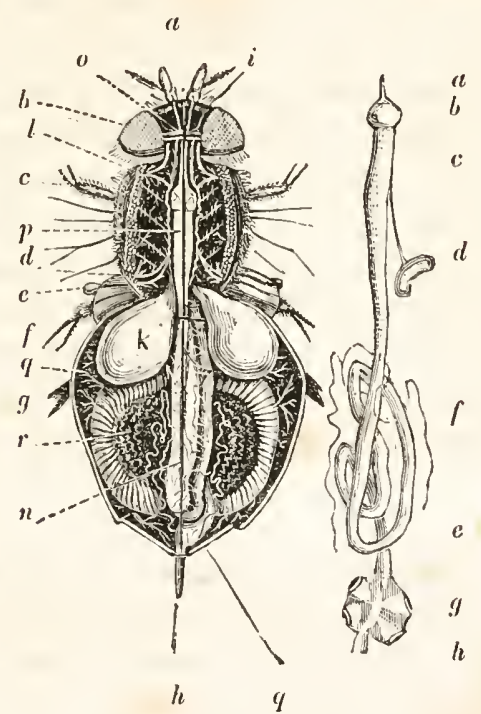

รig. 632.

Fig. 633 ,

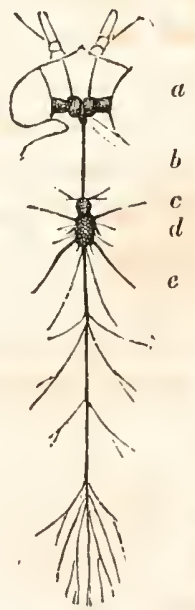

ซij. 631.

Rtatomie ter ङ

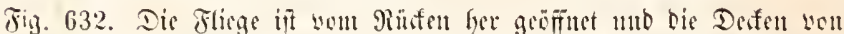

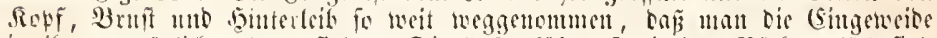

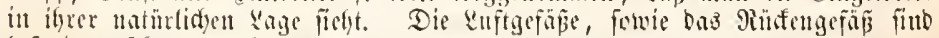
bejoubers idfwarz getgalter.

a Die Jubler mit ifrer Borte. b Dic Atugen. c Erites Fuppant.

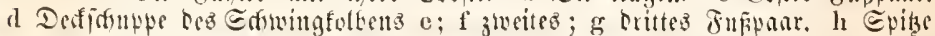

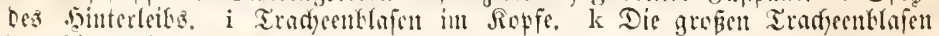

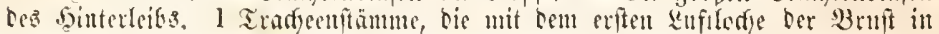

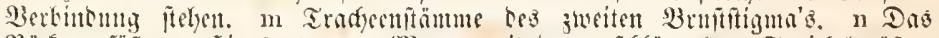

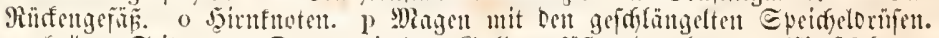

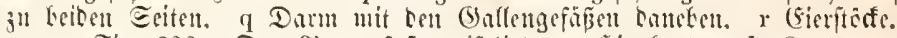

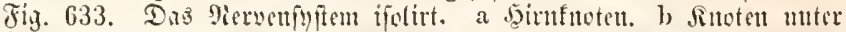

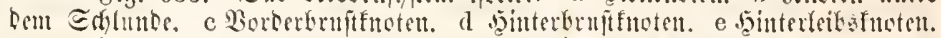

Fig. 634. Dis Berbannugzorgane ifotirt. a Edflunt. b Rropf. c

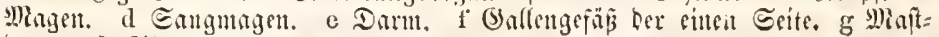
barm. I $\mathfrak{P}$ itter. 
Membran übrigbletbt. Bei vislen Sufeften verä|tefn fid bie Quftrögren mit ftets bünner werbenben 3weigen allmäblig, inbem fie zabreid)e Berbindungen unter cinander singegen. Bei anderent bagegen erwei= tern fie fid) oft zu vielfaden \&uftelafen, bie namentlid) bei ben burd)

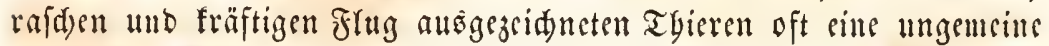

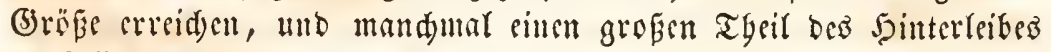

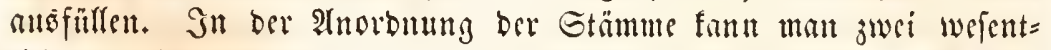

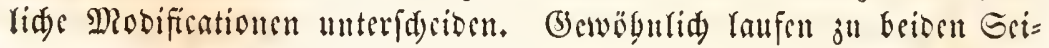

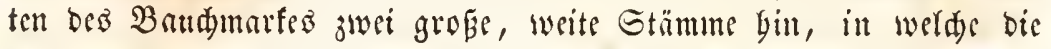
yon ben Stigmen berfommenben queren Enftftämme cimmïnden und yon welden ans bie Euftrïgren an bie verjdiebcuen Digane des Rörpers ftrablen; - bei der anderen, weniger gäufig vorfoumenden

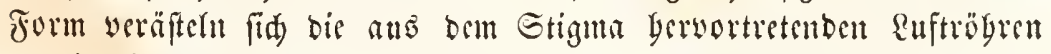
ummittelbar an bis Rörperorgane, jebod) nidat ogne feitlide Berbin=

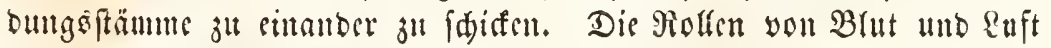
vergaften fith bemuad) bei ben Snjeften burdaus anbers, wie bei

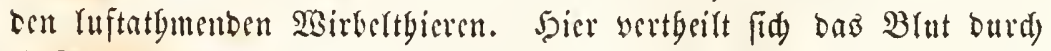

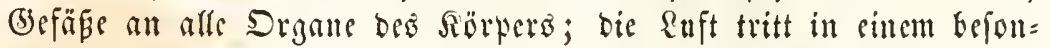

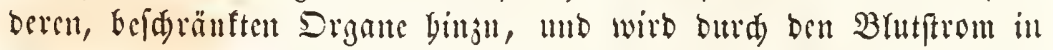

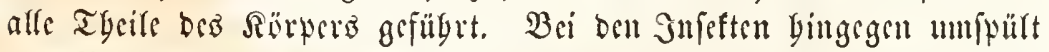
bas Brat frei alfe Drgane bes Rörpers, und bic \&uft wirb mitterfit

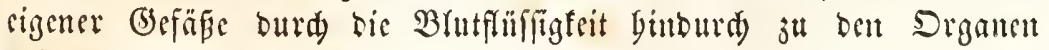
gefiilyrt.

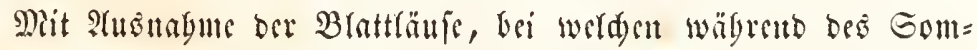

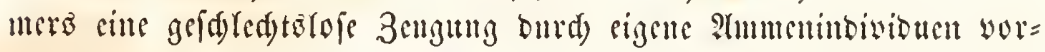
fommt, bie olgne vorgängige Befud)tntg rebendige Sunge gebären,

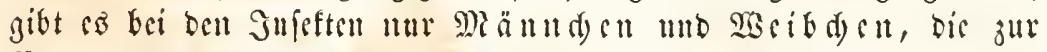

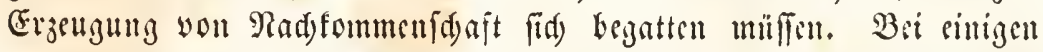

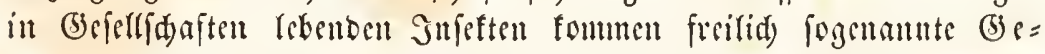

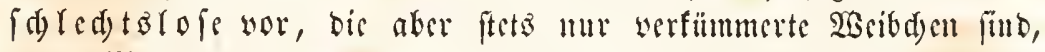
Derent Eicrfiöfe und Begattungşwerf Entwifflung fielden geblicben find, weldse fie in bem Rarwenzuftande

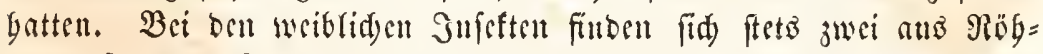

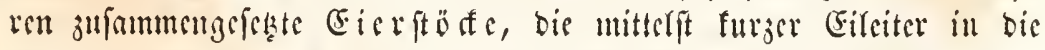

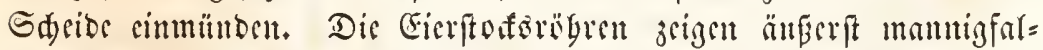

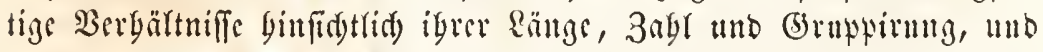

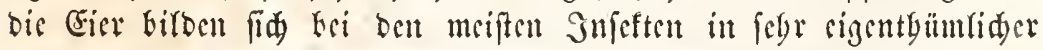

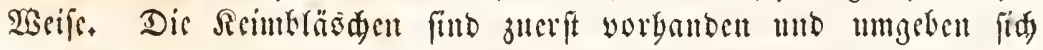

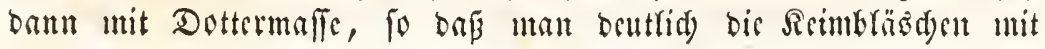




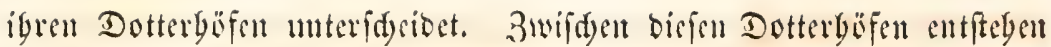

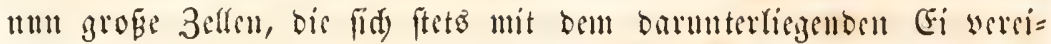

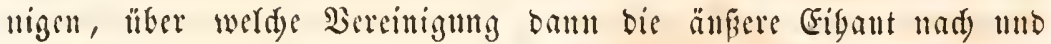

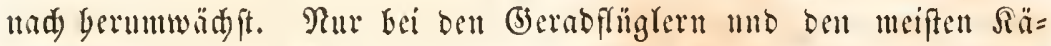

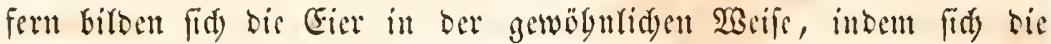
Dottergaut affmäblig im ltmfange bes Dotters confolioirt. Th ber Sdyeide befinten fid) meiftens eigentyüntide ?ngänge, gewigntid) in

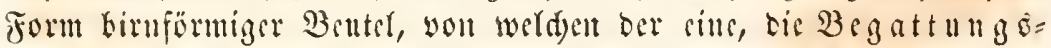
tafd)e, bei bicfem Iffe bis mämntide 9iutbe aufnimmt, wäbrend ber antore meift güber gelegente Bebälter dir Samentbierdjen bebertergt,

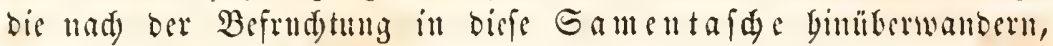
in werdjer fie fid Mionate lang rebeno srgalten. Befonders bei ben= jenigen Snfeftenweibden, bie nad) ber Begattung hiberwintern unto erft im Jrübjabre Eirr Yegon, ift biefe Eamentajdye, bie nur ferten frblt, bäufig in Breftalt grofier boppster Spiraliogrent entwiffelt. Die $S_{a}=$

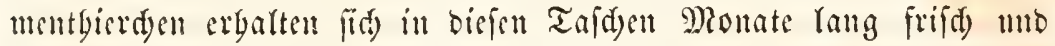

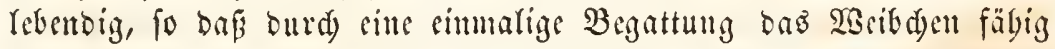

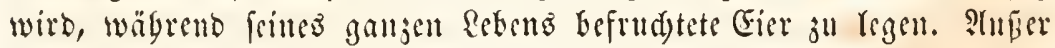

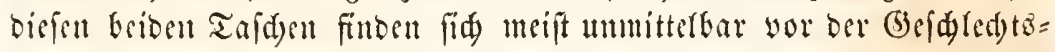

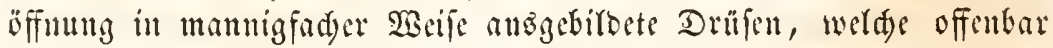
bie Stoffe abjondern, ans benen bie änferen Eifdaten aufgrbant wer= ben, unto die man befbarb mit bem Ramen ber Rittorgane be= jeidjet gat.

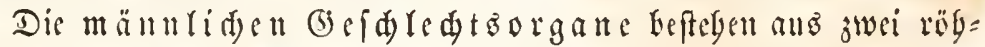
rigen ober tranbigen 5ooben, beren Formen auperorbentlid mannig= faltig fint, unt bis zulegt in zwei, oft vielfad) gewuthome Samen= gängr cimmünden, bie juwsilent mit fritliden Samenblajen befeģt find. SIn ber Stelfe wo beibe Samenteiter z̆ sinem sinjigen Samengange

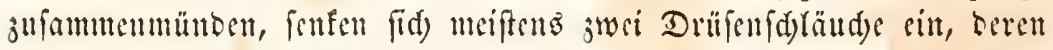
2tbfonterung offenbar Daju bient, bie Mienge orr Gamenfluffigfeit ju vergrëßern. Dirie beftegt wejentlid) aus baarförmigen Gamentbier= d)en, bie im waffer fogleid) eriftarren und fid) oft in yöd)p sigen= tyümtider 2 Beife innergalb ber Gamentsiter in Fäben, Febern ober Büntefln gruppiren. Bei cinigen Snjetten werben biefe Samentbier= gruppen nod) befonders von ftarren Sdjländen eingefdloffen, weldye

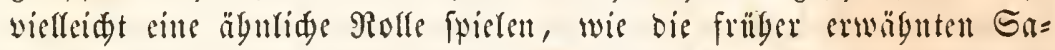
mentafdyenen mandyer nisberen Thiere.

Die Begattung if bei einer grofien 3abl you Juleften ber sinzige 3wed igrer Exiftent im volffommenten 3uftande. Biele ?reten nebmen burd $=$

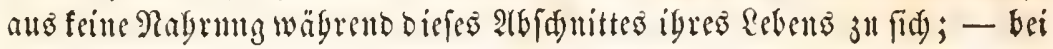


Den uneiften ftirbt Das Männdyen unmittelbar ober furje 3eit nad Det

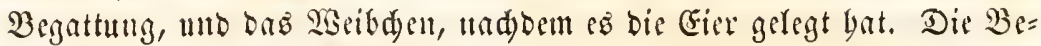

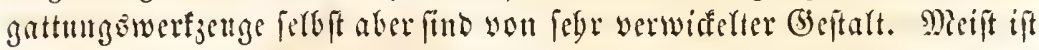
ber Fingang Der Sdyeide Dard) Sornleiften von eigentyümlider Gefptalt, beren form bei jeber alt eine anbere ift, flaptenartig bejetgt, utto febr oft jejeflell fid) bei ben weibden ju biejen Sirappen nod) bejon=

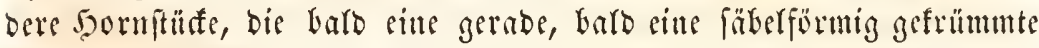
eegefdecide barftellen, Durd) weld)e die Fier tief ill bie Groe bin=

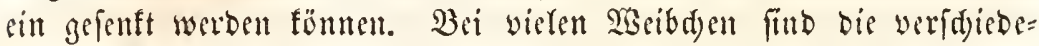
Iten 5oruftüfe, weldje Durd ibr flappenartiges 3u[ammentegen diefer eegeld)eibe bitben, zun Alteilen Der Blätter ober ztm Bobren won Rödern gezälymelt, fo baß fie cine wabre Segefäge bilben; bei ande=

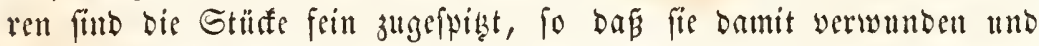
bei ber Werwutbung ein (5i burd) ben \&egeftadel in bas god) glei= ten laffen fönnen; Hod, bei anberen enblid Gat biefer Itparat mlit feine verwumbente (sigenfafaft beibebalten und ift sin wabres (3) ift= ft a del geworben, Der mit einer bejonderen Driife in Berbindutts

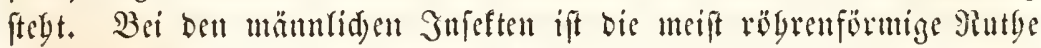
oft von febr fonberbaren Eeiften, Rlappen unb 3angen unftellt, beren eigentyn̈mlide Sorfprünge benjenigen ber barten $\mathfrak{x}$ beile an ben weib=

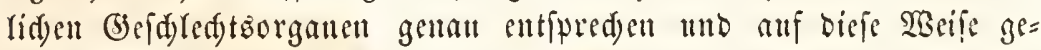

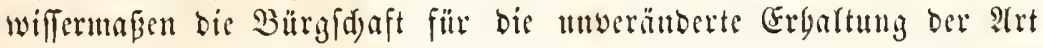
bilben. Wrir geben bei ben cinjelnen Dronnugen gentuet anf biefe Drgane ein.

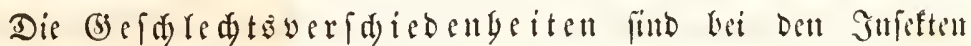

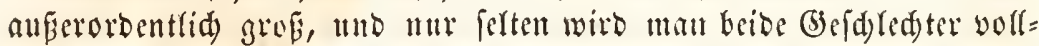
fommen übereinftinment finben. Die Männden fund forf inmer be=

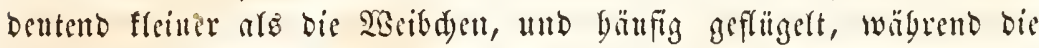

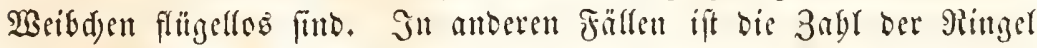

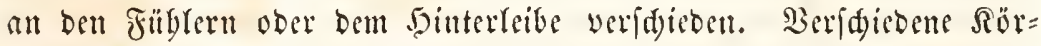

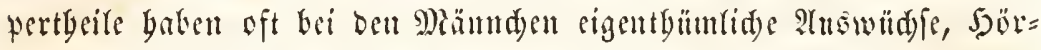
ner unb Bornen, wou benen bei ben Sacibden feite Spur zul feben ift. Sjier find bei ben Wiännden bie Riefer ungebener entwifelt, bort Die Fübrgörner burd)añ anters geftaltet; bei biefen die Füne mit beion= Deren 'Saftorganen verfeben, ober mit Sprizen und Dornen bejest, bie ben Sacibden gänjlid abgeben. Die Farben fütb bei ben Miänn= wen meift weit lebbafter und oft fo veridjeben vertbeilt, bas man

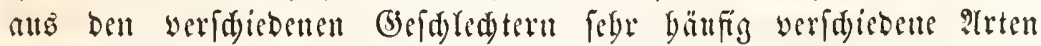
madyte, bis bie Beobadutung Der $\mathfrak{B e g a t t u n g}$ bas Ridjtige fennen Iebrte. Die Sorge für bie Eier und bie Rad)fommenfdyaft ift ftetz Den $\mathfrak{B}$ eib= 


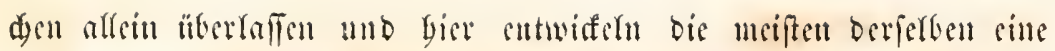

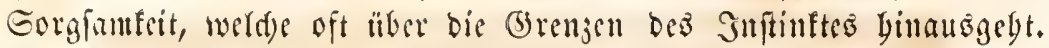
Bisle Prten freilid) Yegen die Gier nur sinfad) babin, wo fie vor Fein=

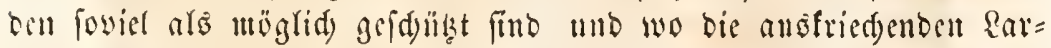
"su igren Rebensuntergalt findon föntnen; anbere aber bauen für bie

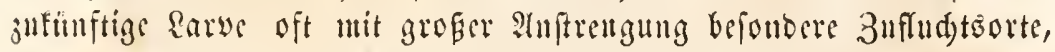

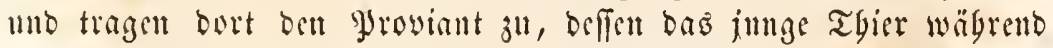
ber Rarvenjsit bedarf. Dic Arten, Deren Rarvent fdmarobeno im Guneren allocer Thisre wobnen, wiffen oft mit ungenteiter Edhanig= fsit und llmfidst bie vislfadjen (befabren zu vermeiben, weldye ignen son ben burd) fie bebrobten Thieren bereitet werben. Bei ben gödften Stufen fintoen wir eine mütterlide Sorgfalt, welde von feiner anbern תlaffe übertroffen wirb, inbem bie jungen sarven und glupten in

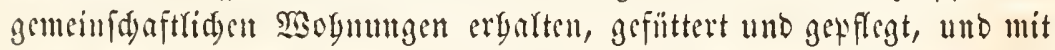
äuperfer bingrbung gegen igre Feinbe vertycibigt werben. Dieje

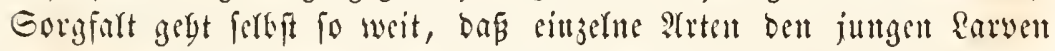
bei Berfertigung igrer \$upten berfen und jur redsten 3cit wieber

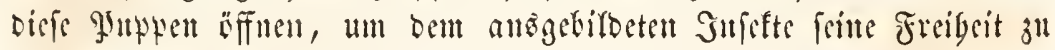
werid)affert.

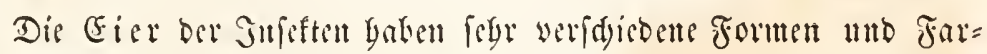
ben; boú findet man unciferes die Giform ober Cylittorform vorwis=

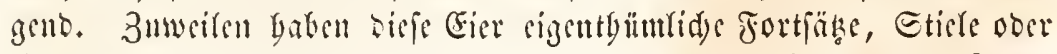

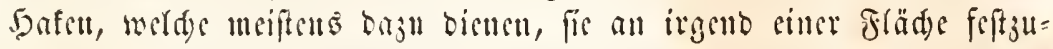

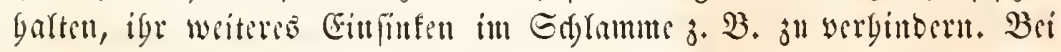

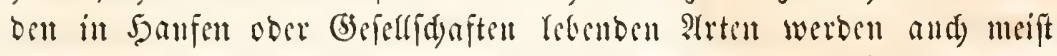
bie Eier fogon in Beginn jufmmengelegt, und burd) cinen Ritt in

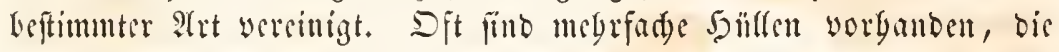

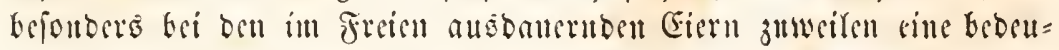
tellbe beärte jeigen und unmentlid) aud) bic Gier yor bem Einfluffe

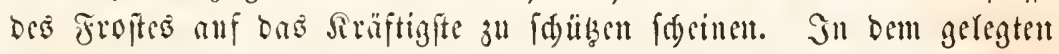
(Gie zrigt fïd) frets nur sit förniger, megr ober mintoer gefärbter

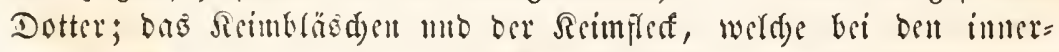
balb ber (Eierrögren befindliden unreifen Girn fo bentrid) waren,

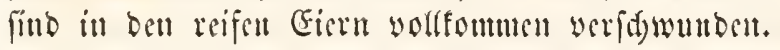

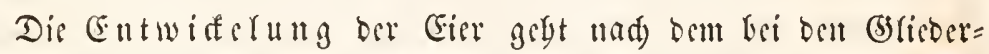

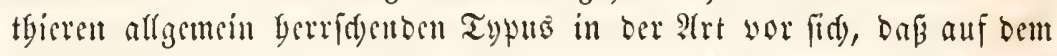
burd)ans Gomogenen (eic an einer beftimuten Stelle fid sin oberfläd)=

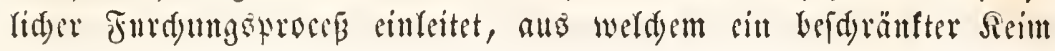


Fig. 635 .

636

638.

637.

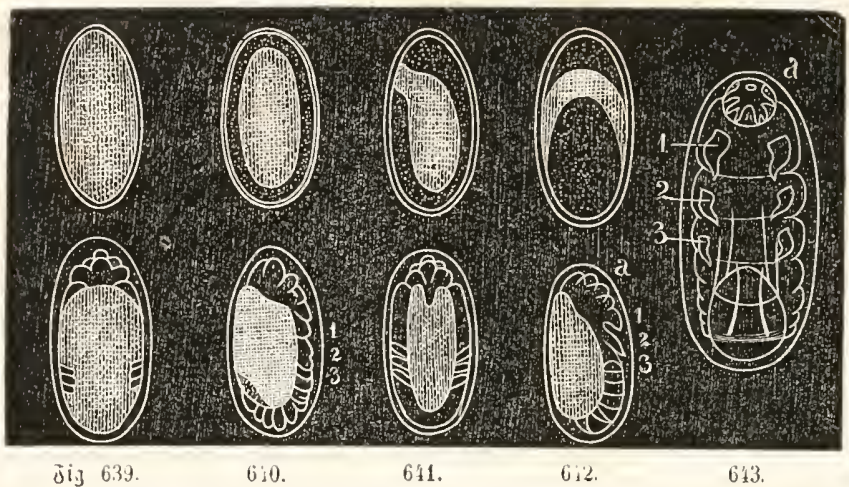

8ig. 635 - 613. E Eitwinclung ciucz Sinfers, ter Donacia crassipes, im Eie.

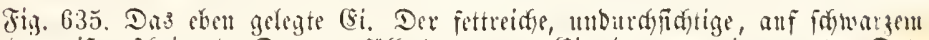

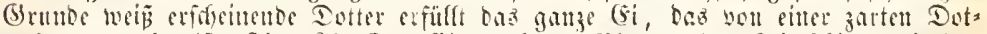

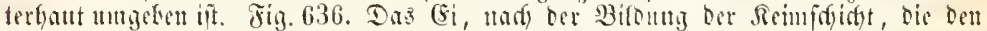
gatzen Dotter ungiebt. Bei ben folgenten Figuren geten ftet zwei zujammenge=

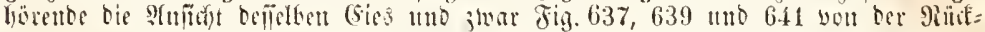

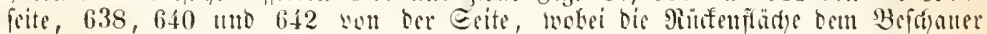

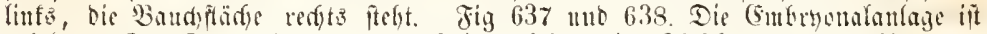

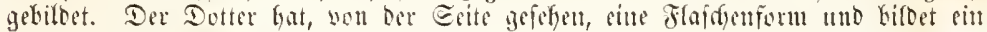

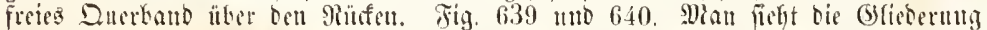
Des Rörpers mo die Juppante, auf Deut Dotter liegend. Fig. 641 und 642. Die

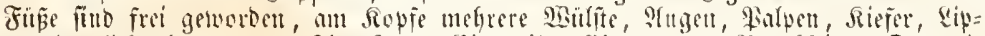

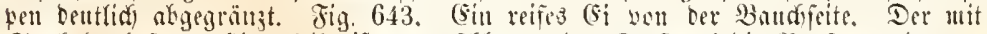

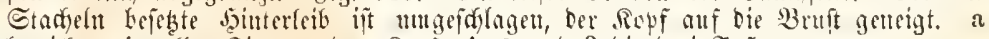

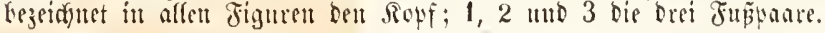

bervorgebt, oer Sanfange sine rumblidye Sdyeife Darfellt, fpäter aber

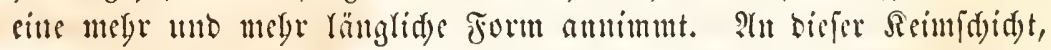
bic ftets megr und mebr um ben Dotter bermmwäd)ft unb burd) igre Durdjfidstigfeit wou bem gefärbten Dotter ferse abjtidst, laffen fids bald Einferbungen entoefen, bie ben singeluen Bingen ber Rörterabtbei= lungen entipred)en. Die Sicimfdidyt wäd immer weiter um ben Dot= ter berum, unb wäbrent bie Bingel fid bentlidyer abfdeston, febt man in ber Mitterfinie sine S(nbänfung fefterer Gubftanj, weld)e Dem

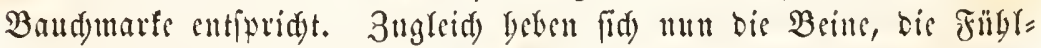

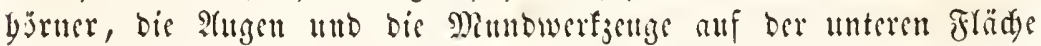

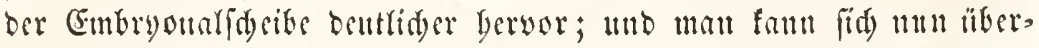
zentgen, baj ber Dotter ber Mürenfläd) bes werdenten Jnjeftes ent= fpridyt, mo bas bie Embryonalfdeife you unten mad) oben wablend ben Dotter allmäblig umfdrieft. Des (Embryo ift befbarb Atufangs, wo bie Dottermaffe nod) liberwiegt, rüffings um biefelbe berumge=

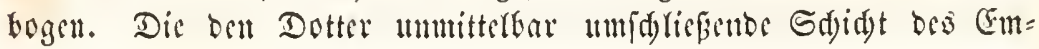


bryonattyciles rifbet fid)

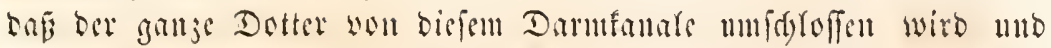
niemals sin sigener Dotterfacf sxiftirt. Der Doter jeflet fied unu

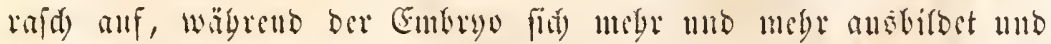

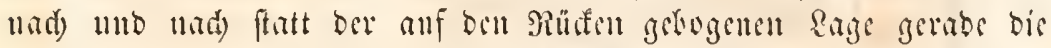

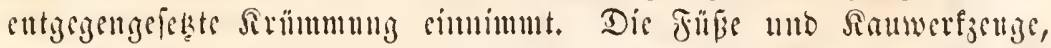

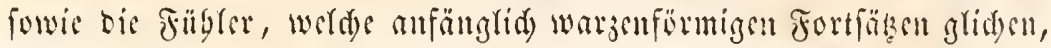

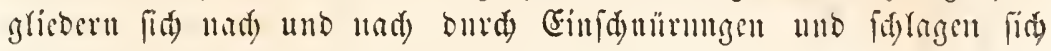

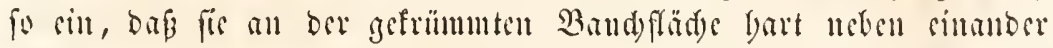

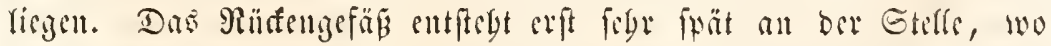

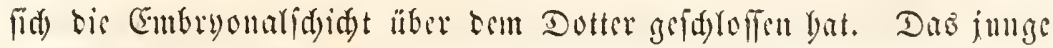

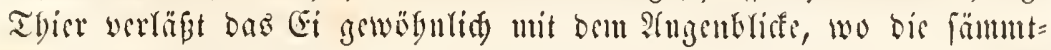
lide Dottermaffe aufgejerdt iff.

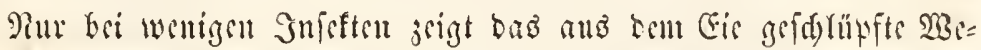

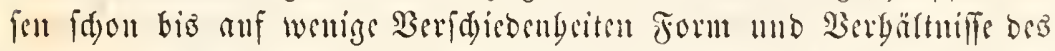

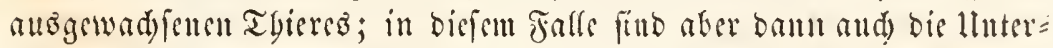

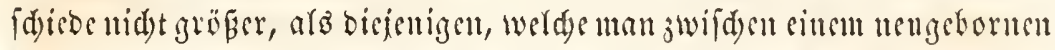

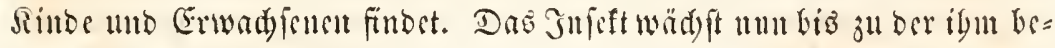

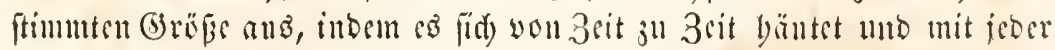

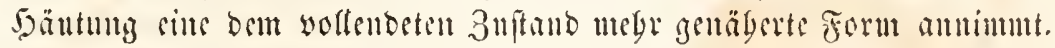

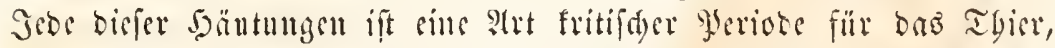

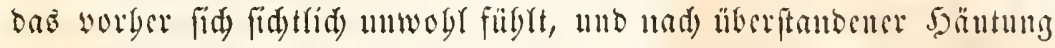

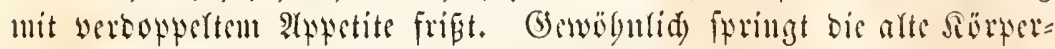

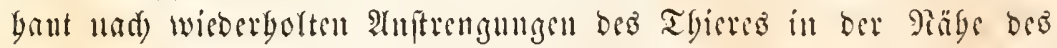

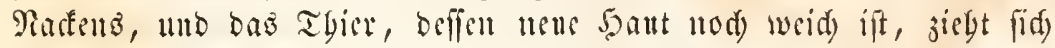

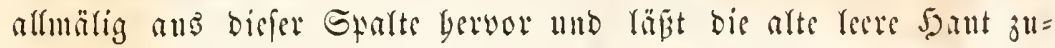

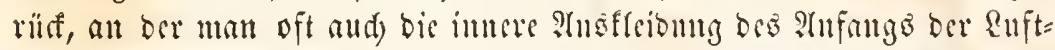

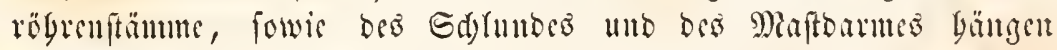

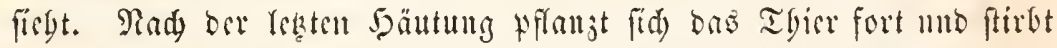

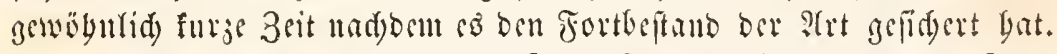

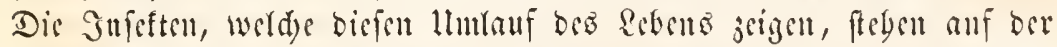

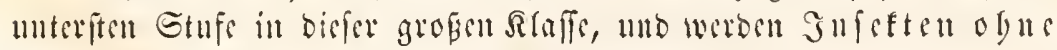
Berwa th brug (Ametabola) genaunt.

Gine jusite grofe Gruppe son Sulften, weldye bic Dronungen 


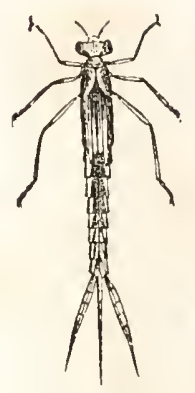

Fig. 611.

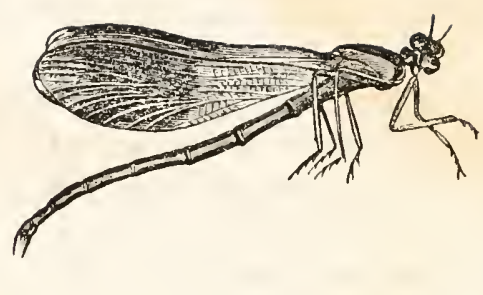

oig. 615.

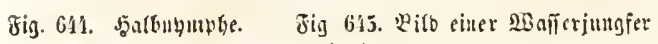
(Agrion).

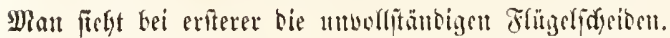

Der Jaalbflïglet und ber Gernbflügler umfapt, zrigt (d)on eine grifícte Berfojeosnbsit j'wifden ben 3 uftäแben bem Eis fried)enben Thie= res unt besิ vollfomme= nen Iniftes. Jnoeffen beziebt fid) biefe $\mathfrak{B e r}=$ (d) iebenbeit nidst fo fert auf bie allgameine Form beš Rürperö, die etwa Inแr in benfelben obrän= zent abweidst, wie bei ber vorigen bruppe, als viefmelys namentlids

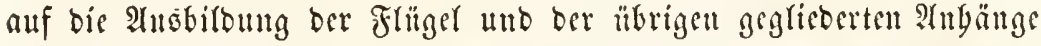

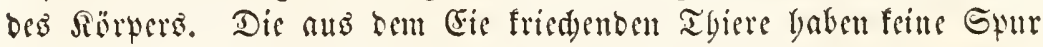
von Flügeln, mo zeigen oft wentiger Ringe an ben füblern, nnbere Formen ber Füre unb ägnlide foldse Berfdicbenlyeiten. Nan bat biefe unvolfommenen Thiere and) Jarbraryen genannt. Bei ben

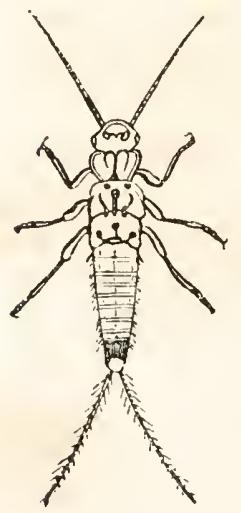

รig. 6:6.

Jig G'6. Solktarse.

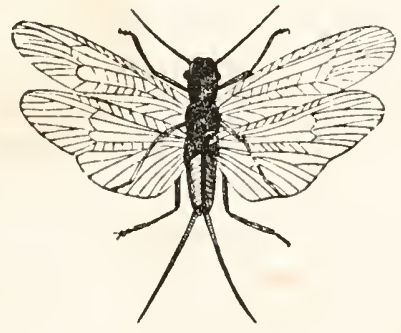

ชig. 647

5̧äutunget zeigen fitd) und) unb nad) Flüget= (d) eitu, bie thbeweglid)

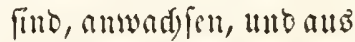
oenen endid) lei ber lese

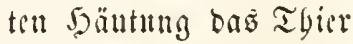
bic auşgerilocten Flingel berworjiblyt. Dis mit Jlïgerfd)eiden verfebene Contwiớchungstufe bat man aud bie $\mathfrak{Y}$ uppen

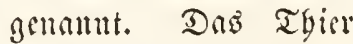
frift ju jeber 3eit frines sebens unt beivegt fid) fowobl als barblarve

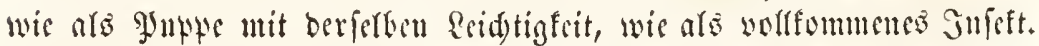

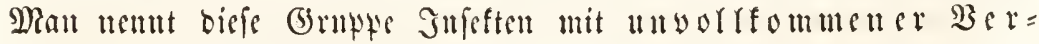
wa b (แn g (Hemimetabola).

Bai ber britten, grögten (somple bält

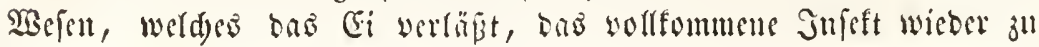


erfemen. Man unterfacibet bei biefen Tgieren brei veridebene, fibarf abgegränjte 3uftände, alo \&arve (larva), צy upe (pupa) und wollensetes Jujeft oder 3 ito (imago). 2Bägrend ber Rarvenzeit

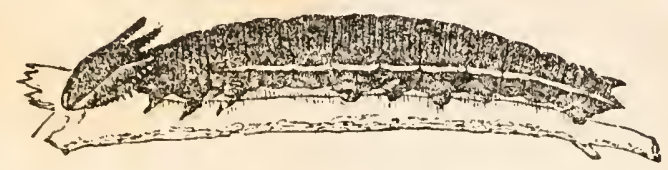

รig. 618.

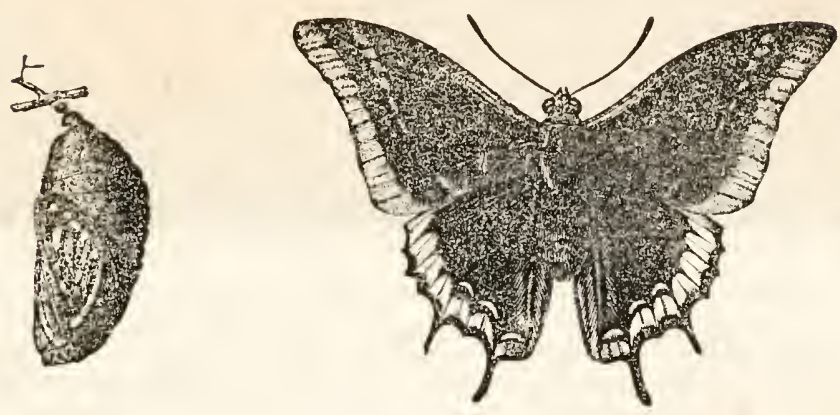

ชีig. 649

8ig. 650 .

Fig. 618, 619 unb 6.50. \&arbc, Puphe unb Bilb eines Tagiffmetterlings (Nymphalis Jasins).

befdäftigt fid bas Thier sinzig mit ber Ernäbrung; es frift und

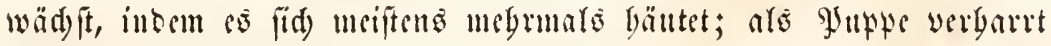
es in meift regungšlofem 3uftande, obue Rabrung zu fid) ju nebmen;

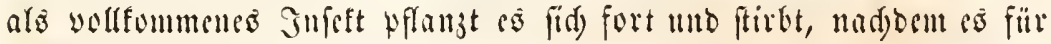
feine radjemmenfdaft geforgt bat.

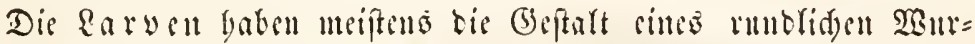
mes mit mebr oder minber beutliden atetbeifungen; biele find

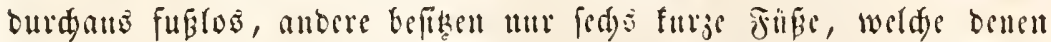
Des vollfommenen Snfetto entfpred)en, nod) andere (Fogenannte Pan=

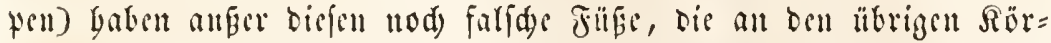
perfegmenten feben mo bei ber grupte solfommen verfdumben.

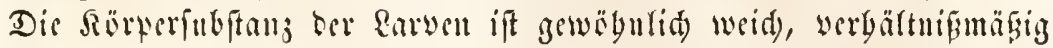

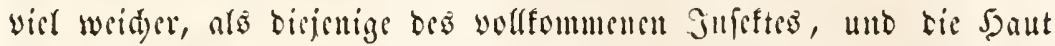

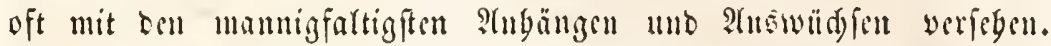
Bisle find burdaus glatt, antere find mit Saaren, Gtadyeln ober 
ฮิig. 652 .

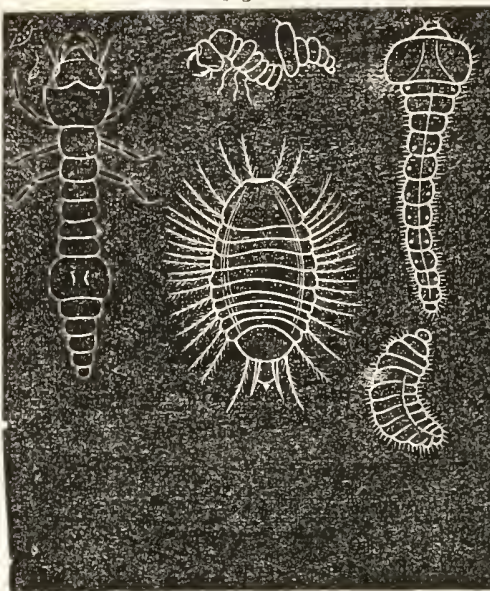

Fig. 651.

653.

655 .

$65 \%$.

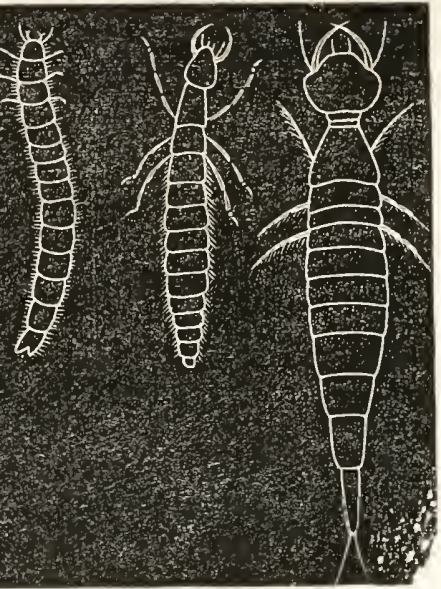

656.

658.

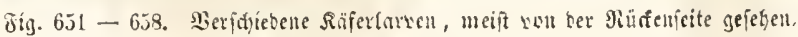

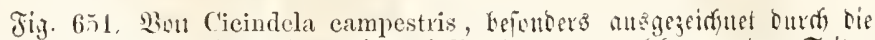

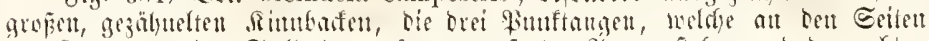

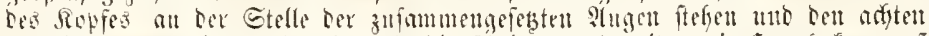

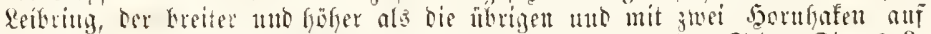

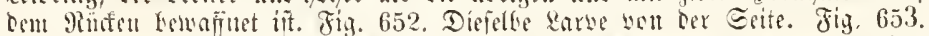
Yarve wou Cassida equestris. Tig. 654. But Buprestis manea, füfor.

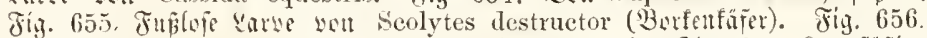

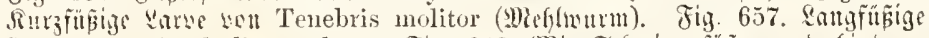

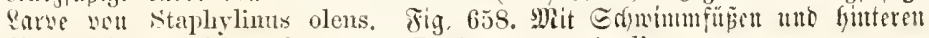
Stffemrofyen serfigue Earve won Dytisens marginalis.

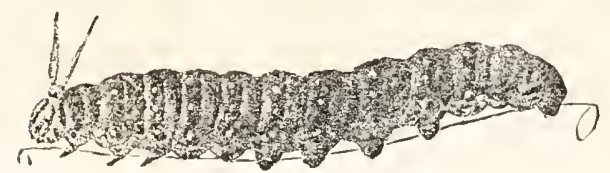

गig 659 .

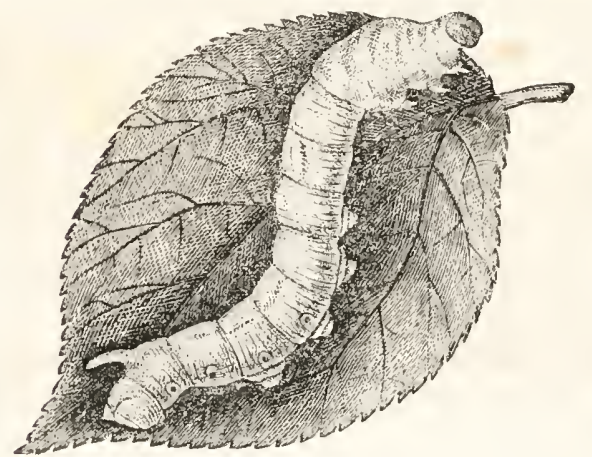

Fig 660 .

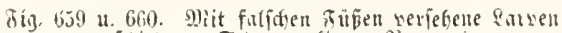
reridiecener Eitmettertinge (Manfen).
Jöruern befrigt, mantose baben fertlides ?nbäuge, oie besughlid find 1110 entweber fum Geben, ober zum Sd)wimmen dienen; im lekteren Fafle find es meift Borften= biifdel, werdac bic Deer= flädye fer Bowegutgs = organe sermebrea. Der Sopf oor Rorven ift 3umeifen, namentlid) bri Den 3 wriflüglern sbenfo weid tno ber Amerby = nung fäbig, wis bis iibrigen Sörperringe, befigt bingegent bei belt 


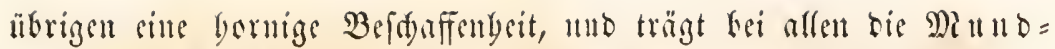

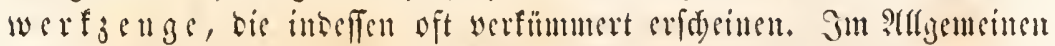

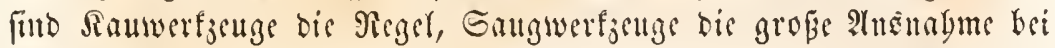

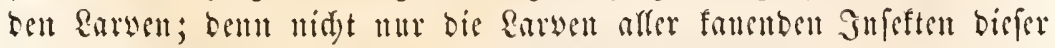

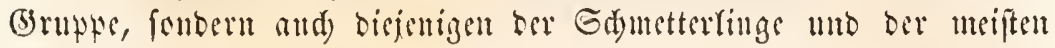
3weiflitgler, bie als Bitber fangen, fauen wälend igres earwenju= fantes ; nur bei einigen forflofen Fliegentarven unb bei singen 5ant=

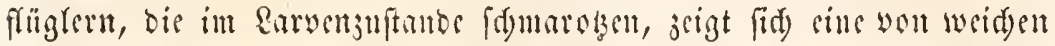

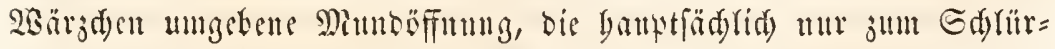
fen won Flüfïgfeit geriguet erfdeint. Bon ben früber befdriebenen Mundwerfjengen fommen die siefer faft burdgängig in äbnlider Geftalt vor, wis bei bem woffemmenen Gufefte, mto namentlid un=

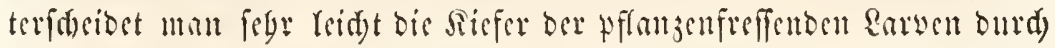

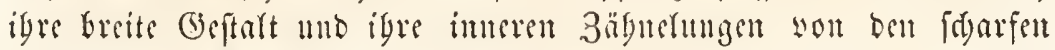

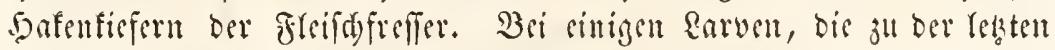

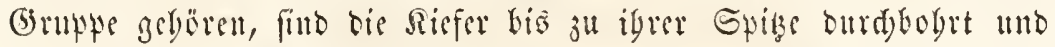

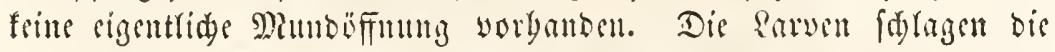
Gafenfïmigen Siefer in ben Seib igrer Dpfer und faugen bann burd bie Rieferfanäle sie sïnerfliffigfeit derferben sin. Dis Drertippe feblt öfter, bat aber fonft die Form, bic fie bei bem wollendeten Sn=

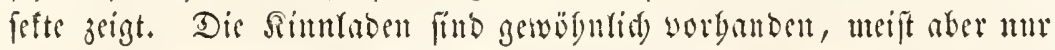
fegelfïrnig und obne Sappen; die Interlipte ift befontore bei benje=

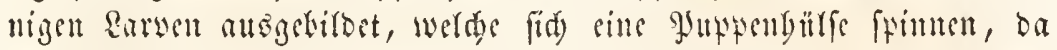
fie in ben meiften Fällen Die Deffunng ber Spimbrüfen trïgt. Die

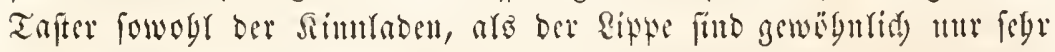

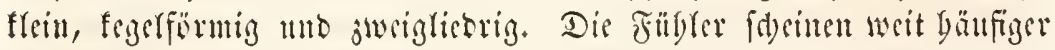

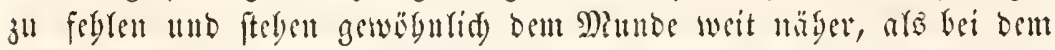

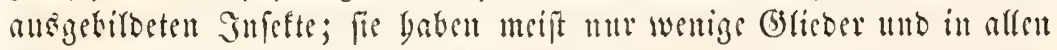

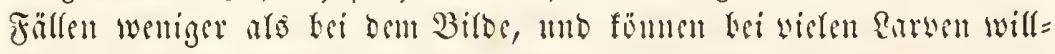

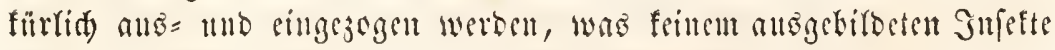

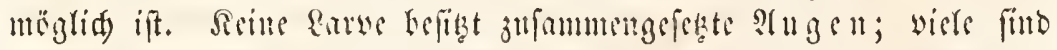
gïnglidy blind und bis meiften baben nur wenige cinfadis ?tugen,

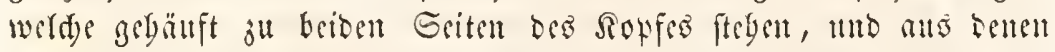
fid) fläter bie jufanmengefelzten ?Hgen bes Bilbes entwiffeln.

Faft alle Rarven, befondere aber die Yyflanjenfreflenden, befigen einte febr grofent uno weiten Darmfanal, welder fait bie ganze 


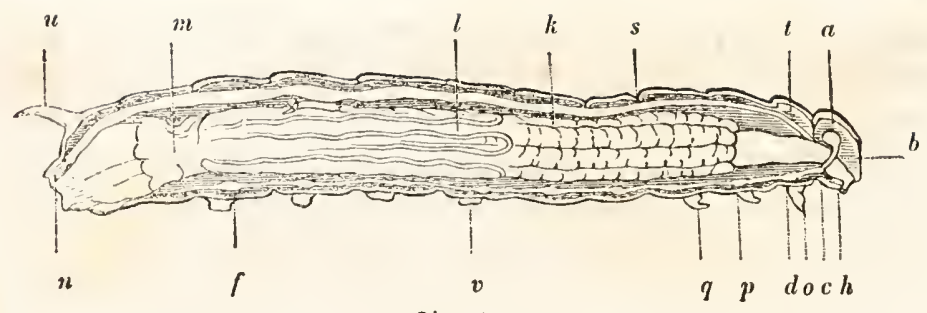

8ig. 661.

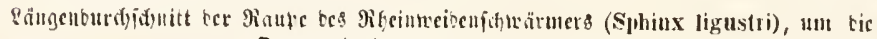
Drgane in iffrer Sagerntug zu zeigen.

a Sirnfuden. b Edytutoring. c lluterfoluntuduten. d Bandfmat.

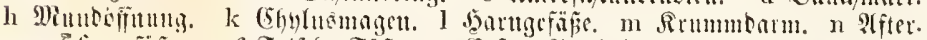

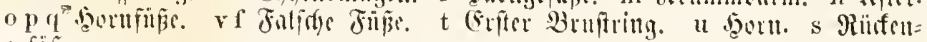
gefäิ

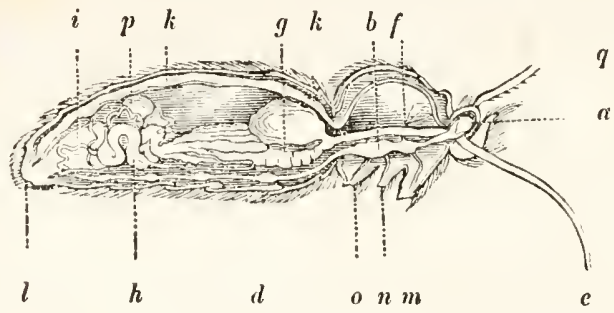

8ig. 662 .

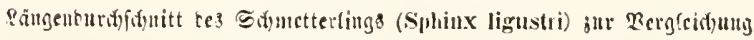

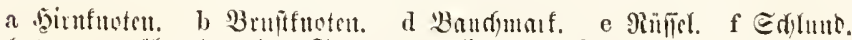

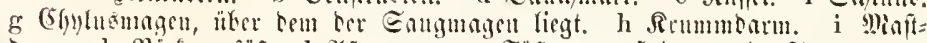

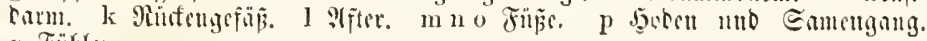
q Jilifler.

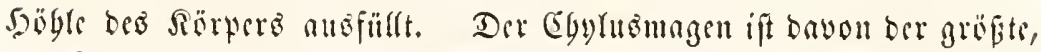

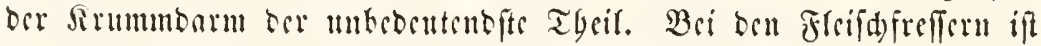
ber Darmfanal im (banjen bemienigen ber erwad) fencn Snfeften äbn=

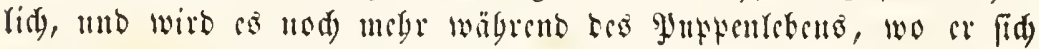
allmäblig ber bei oem Bilos worfommenoen form nunäbert. Die

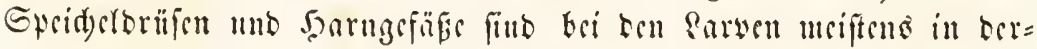

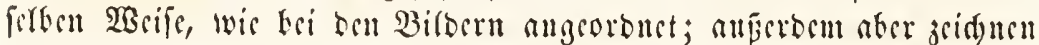

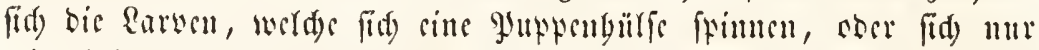

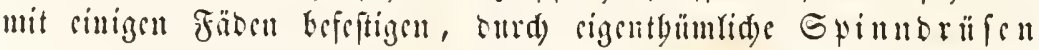

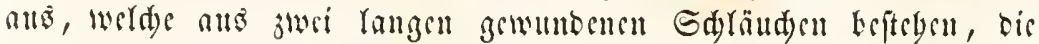

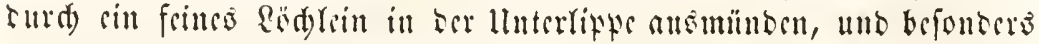

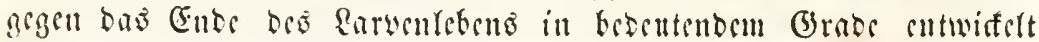

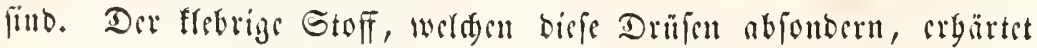
an ber Ruft fogleid) zu cincm frinen Geibenfaben, ben bic Rarwe surd

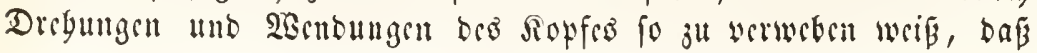




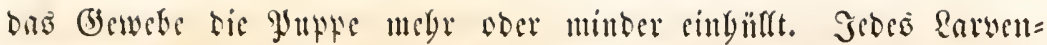

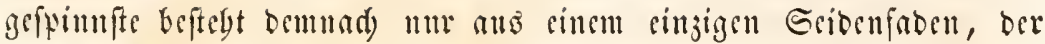
abgefponten werben fant, aber zu inbuftriellen 3weeten wiel ju fein ift. Alufer biefen beiben Samptorganen ber Rarven, bim Darmfanale mno oen Spimbrüfen, finbet man nod bas $\Re$ üa engefä meift in böberem Grabe entwiffelt, als bei bem Birbe, unb bas langge=

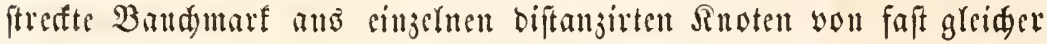

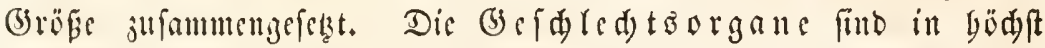
rubimentärem 3nftande vorbanden, unb befteben Gauptfäclida nur aus ben inneren, feimbereitenben Drganen, bis nod anferorbentlids tlein mind fdwet anfjufinden fint. Die meifte Berfdjebenbeit won bem Bilbe jeigen bie PYt leben. Die an freier \&uft lebenden \&arben baben ftets Stigmen und cinfad) vergweigte Ruftrögren obne blafenförmige Erweiterungen; juneilen fint bie Stigmen unter Falten verbedt, in anberen Fällen mit ciner firbartig surdblöderten Sormplatte verfd)loffen; - bei vielen

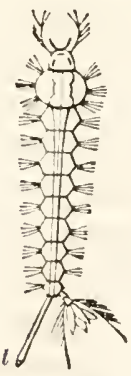

Jig. 663 .

Sarve siller कdyuafe (Culex).

t Die itifemröhle.

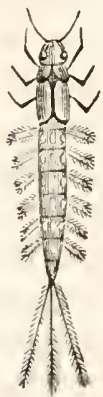

zig. 664 .

Sorve cincr (rintaga fliege (Ephemera) mit feitliden Tradicen: ficmen, bie 3ugteid) als Ruber bienelt.

iin Saffer ober im Sdylamme lebenben Rarven ift

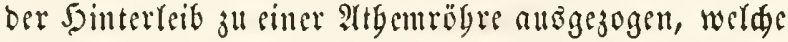

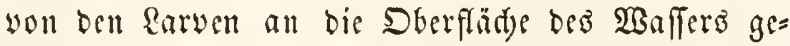
brad) wird, fo bafi fie woul bort ber unmittelbar Suft fäopfen. Sn bam Ylupenjuftande werben biefe am Şinterleibe angebradten 2 themröbren meift in bic Nafengegend verfest. Die mit fold)en Ittgemröbren werfebenen Sarven und gुupen milfen begreiflider Seife bie Deffumngen berfelben fteto an bie Dber= fläd)e bringen, um Suft føökfen zu fönnen, wälrend bies $\mathfrak{b e}$ ben searwen nidat mötyig ift, welde loges

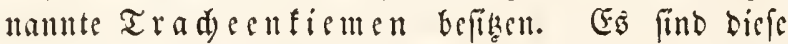
Drgane zarte bautfortfäge in Form von Büfdel= Gaaren, Febern ober Blättdyen, weld)e ju beiben Seiten des Reibes fieben, uno in benen unter ber zarten Dautbedefing fid fegr bünne, gefd)loffene Ruftrögren vielfad) werjweigen. Bei anberen Rarven ift logar bie ganze, bïnte Sanutoberfläd)e glcidfam Der Picfräfentant Dicfer Siententrad)een, wälrent be= fonbere Antänge bicfer art feblen. Dffentar gebt

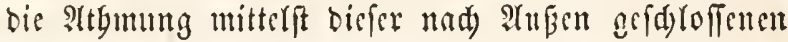
Enjtrögren in ber 2 seife vor fid), baf tie \&uft Durd) bie bünnen Şautïberjüge binburd ans bem 2 Bafler abgefdieben wirb unb nun in ben Euftröbren cirfulirt. 
Bei sinigen Rarven fint biefe Tradjentismen fogar in bem wei= ten Miaftoarme werferft, Der Durd) Ecfendere Slafpen befäbigt ift, ab=

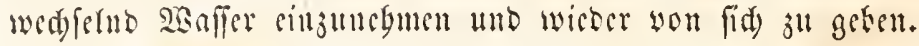

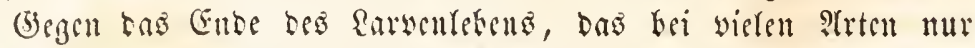
wenige Tage ober Sisoden, bei alberen aber viele Gabre bauert, wie

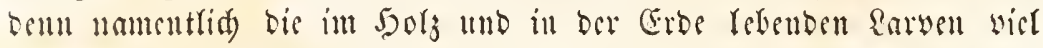
ränger leben, als bicknigen, bis fid in faulcuben Etoffen auflyal=

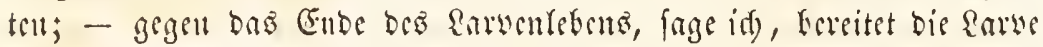

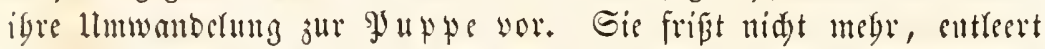
sen Darmfanat und fud)t bie zut Berwupung gesignete Stelle auf.

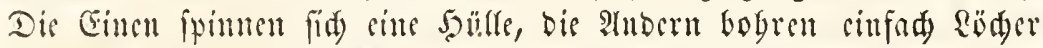
ill bie Erbe, ober werbergen fids in Murm und unter fautenden Stoffen; wicle bleiben nod) cinte 3sit lang in igrer byalle, bie fie alz Sarve bejaßen, bei anberen fpringt die Rarvengaut munitterbar auf, und bie bärtere glatpe tritt bervor. Bieren glappen bient bie eigene

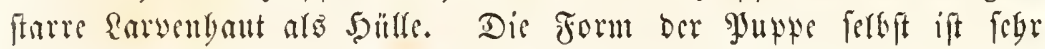

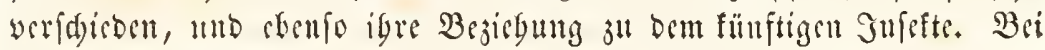

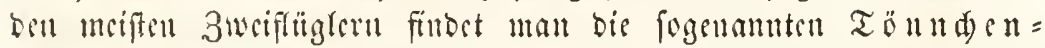
pupwen mit Garter Bebcfung in form sincs galles ober sincs

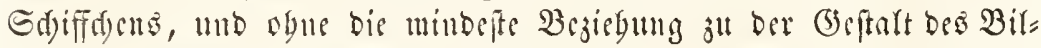

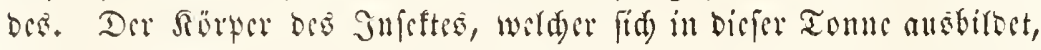

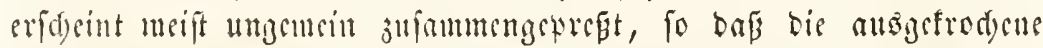

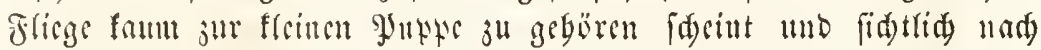

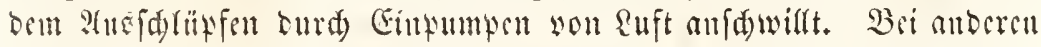

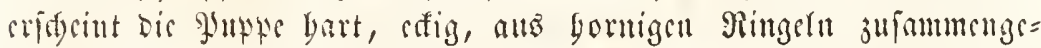

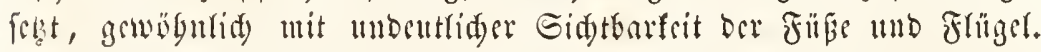

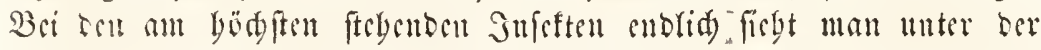

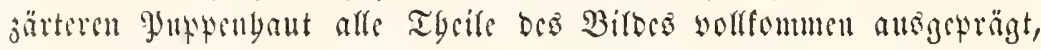

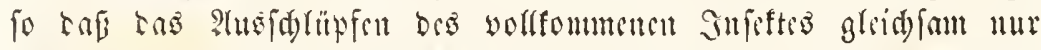
cine Eutfaltung ber in ber gruppe zufammengelegten Drgane barferft.

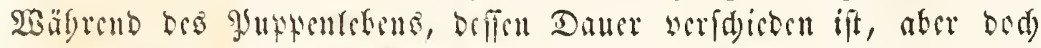

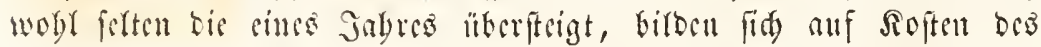

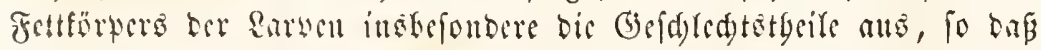

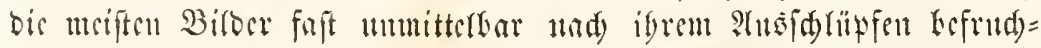

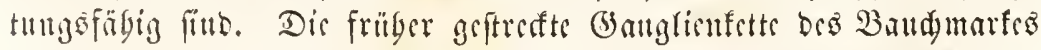

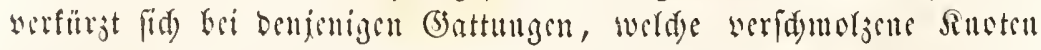

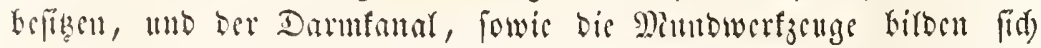

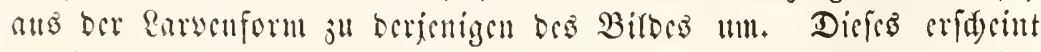

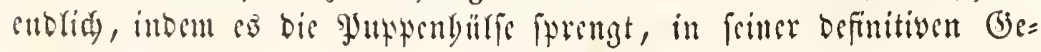




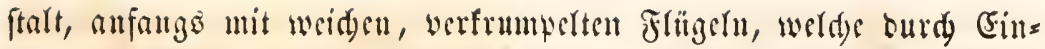

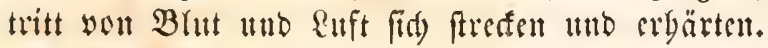

Dis geiftigen erigentdaften, welde sis vollfommenen $3 n=$

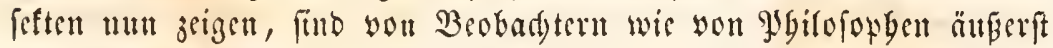
verfdeieben gescuttet worben. SBäbrend bie Einen alle Santohungen

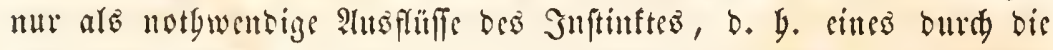
Structur bes Rörperô bebingten Raturgefesces betradten uno barin sinen Unteridjicb wou Mienfden finben worlten, bem fie freie Heber=

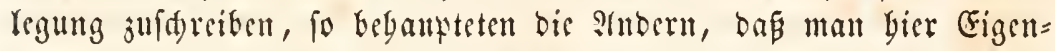
(d)aften unb Santhlungen finbe, welde bie Snfeftent wentigftens bem

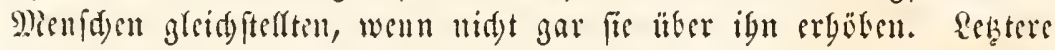
Bebauptung ift entidicben unridstig, tis erfere aber nidjt minber

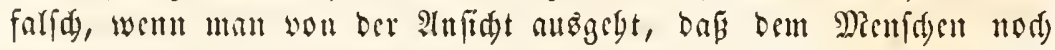

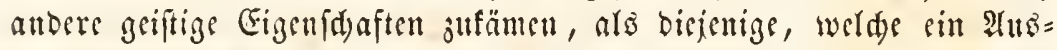

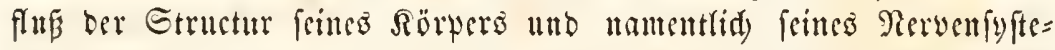

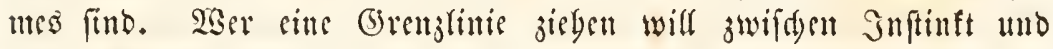

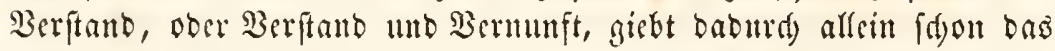
befte 3enguí̧ ab, baß watb Treiben ber Thiere und namentlid ber Sulsten beobadset babe.

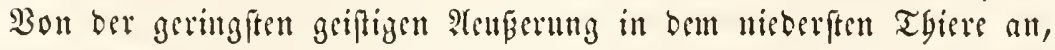

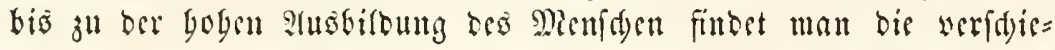

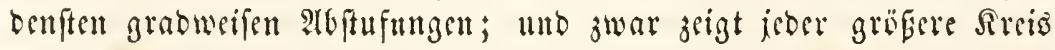
bes Thierreides sine eben foldse fufuntweife fortbitoung in feinen Gsiftesfäbigfesten, wie wir bies and in bem Sö̈rperban beobad)ten.

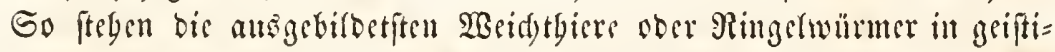
ger Sjittidet weit üter ben niebrigeren Suleten, wägrento bie gögeren Typen biefer Siafle ben bebententeften Sorfprung vor jenen 2 seids=

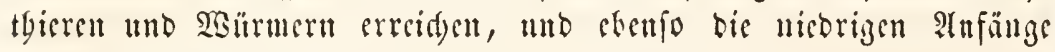

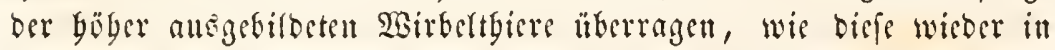

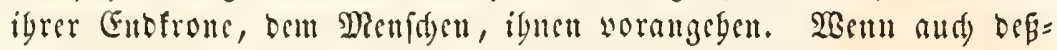

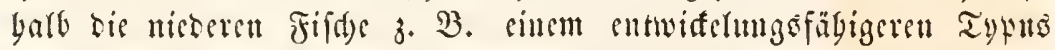

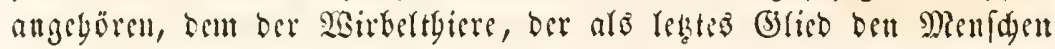
erjengt, fo fantu bod) fein 3weifer barüber frin, bas bie Enbfpisen

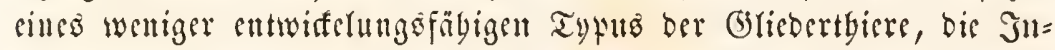
jeften, weit alle nicberen $r$ sirbeltbiere überragen und geiftige Fäbig= feiten und baraus entfließrente Szandrungen jeigen, bie fie in geiftiges Bejiegung bem Peniden in Eebeutende Räbe bringen. Es genügt,

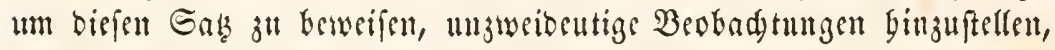
weldge für bie Jnfetten unzweiferlgaft sine vollfommen freie lleberlegung dartbun, in äbnlider $\mathfrak{B}$ sife, wie man fie bem Menjden feleft zutranen 


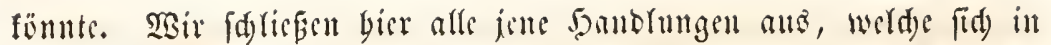

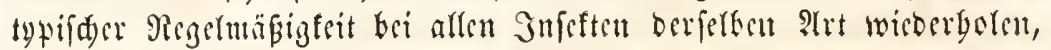
mögen fie aud nod, fo wmberbar fein mo aus sines Reibe von

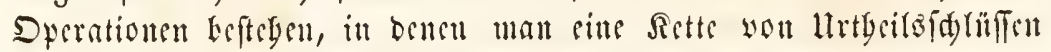
แnd Darans abgelciteten 5andrungen exfemen forlte. Wir wollen ferbft

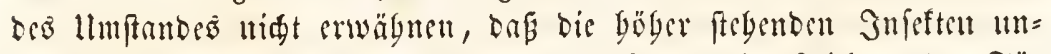

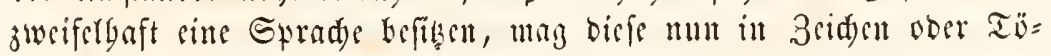
uen befteben, und daj fie einander gegenjeitige Mittbsilungen utnden fümuen l̈ber Dinge, welde fie intereffiren. Die Ballenbiene (Halictus), welde eine Goldwefpe (Chrysis) erblift, die neben igremt Refte lautert, แun sin Ei Gincinjulegen, ruft ourd) ängftlides Summen fo vicle ibres binoflen berbei, bis fie fid ftare genug glantet, tum anf ben Feint

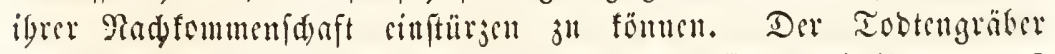
(Necrophorus), weld)er bic Reide cincs Thietes findet, bic ibu ju grobi ift, un! fie allein cinfd)arren on fünnen, ber smiftfäfer (Geotrupes), oeffen Sotbleallen in cine Bertiefung gefallen ift, aus welder or ifn mit aller suftrengung uidst weiter collen fann, fliegen fort uno fib: ren nad cimiger Zeit jurüf, won Genoflen gefolgt, weld) isnen tic

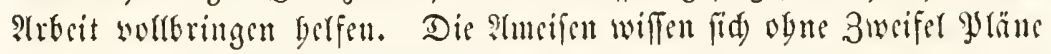
mito 2aege nid Futteritoffen ober ben Sot mitjutbeifen, aut ben fie

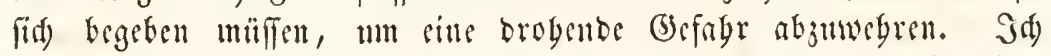
theife bier nod zwei Beokad)tungen mit, welde, wie mir (d)eint, jere

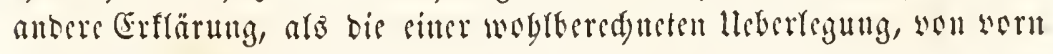
bercin abweifen.

Cine Golbwefpe (Hedychrum regium) Yegt ifre Gier in tie Refter Der genogutidyen Danerbiene (Osmia muraria), bie oft in beentento Säbe an alten Diatern angebrad) find und von ber Cretencrit mit Sonig unb Brumenftanb werproviantirt werben. Diefe Rabrung, welde bie Manertiens fïr ibre Sarwe fammelt, wiro vou ben fduma= rokenten Rarwen der Golbwespen worweg wergebrt, wenn es biefen

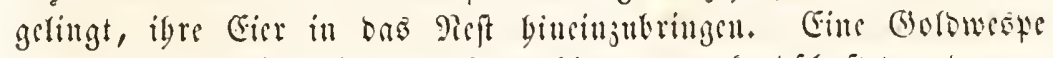

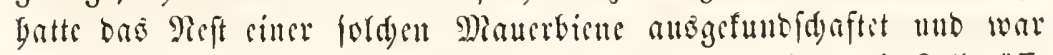

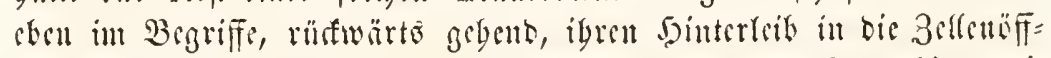

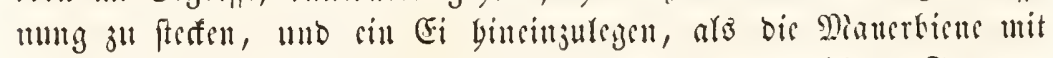

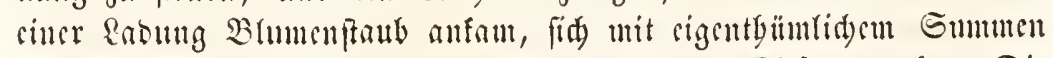
auf ben Frimo warf uno ign mit ibren fdarfen Siefern pafte. Dis

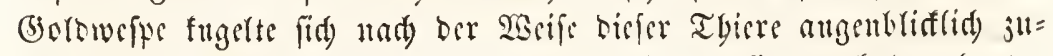
fammen. Dic Mianerhicne verfudte wergebens, fie ourd ben barten

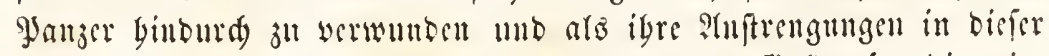

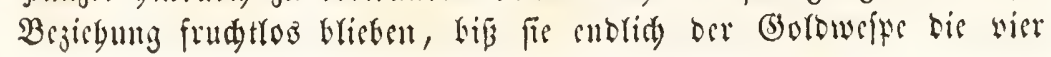




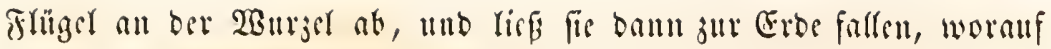

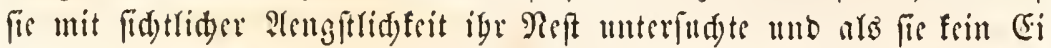
barin fanb, nuf's Reuc jun Einfammeln wegflog. Die Mauerbicue

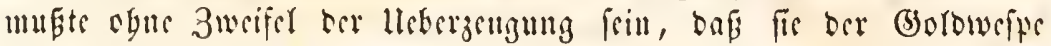

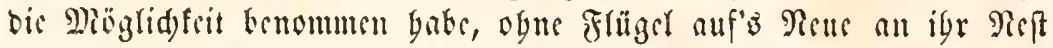
ju gelangen. Allfin bicfe Berednung war irrig. Die an ber EFrbe liegende Gorbuefpe entrolfte fid, fobald bie Mauerbiene igr $\mathfrak{R e f t}$ ver= raffer batte, frods in geraber Sinie ju sem Refte binauf und regte igr (ri it bafferbe.

Fincr meiner frentube madite folgente Beobadtung. Dis : Tmei= fen frafon igm sic grüdte sines Rirfabaumes meg. Llm fis $a b=$

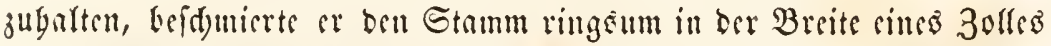
mit bifem Iabafúfdmante, ben or zu bicjem Begufe gefammelt Gatte. Dis Ameifa, wrldye in Sdyaren ben Baum binaufjogen, febrten an bem ïberriedsenten fretrigen Ringe um: bis, welde yon bem Baume

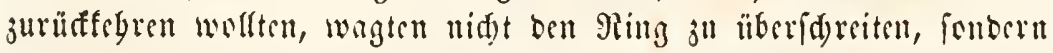

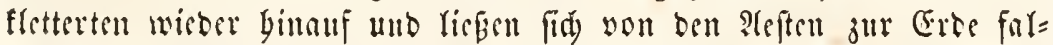

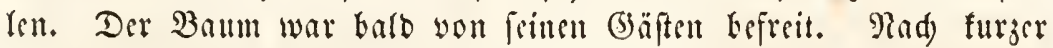
Brit aber marfdjirten bie 2 meifan in Sd)aaren an bem Stamme bin= auf. Srbe trug in igren Riefern cin Etüfden Crbe, unb mit äu=

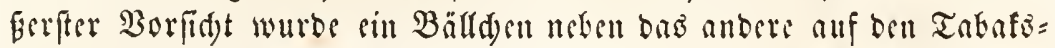
fdjmant gelegt und fo nad und mad) cine wabrbafte getflaperte Strapie bergeftellt, weld)s bie Thiere mit grofer Empigfeit befeftigten und

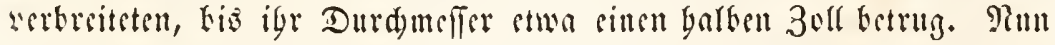
founte igre Colonne auf'B Reue mit Sidergeit bon Banm binnuf=

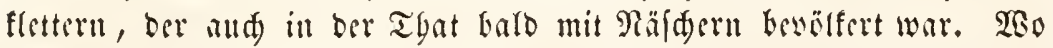
ift nun, bürfon wir wobl gegenüler folden Beobadtungen fragen, sis Gränje jwifden Suftinft unt 2ieriftand?

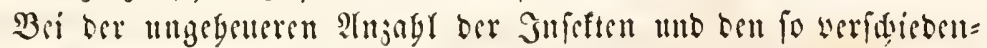
artigen Mobifentionen ibrer Typen ift igre Eintbeilung sine fdewierige 2tufgabs. Man Gat vislfad) bald bie Flïgst, bald bie Siaumerf balo bie ?trt ber Berwanderlung als erftes Samptmoment ber Cintbsi=

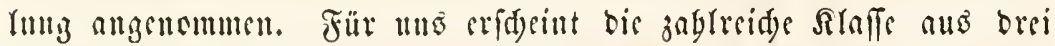

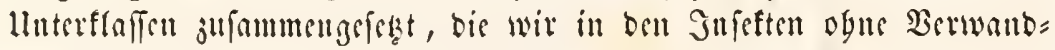

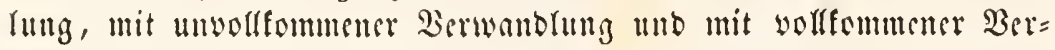
wantlung fiuben. Stbocm wir bann bie Munbwerf jange, fowic bic Beid)affengsit oer flügel in zweiter Sinic betradjten, ergalten wir forgenbes Sdyemn: 


\section{6}

Luterfaffe oer Snfeften obuc Berwath lung. (Ametabola).

Sic cutbält mur sinc Drbuung:

Dic Flügeflofen (Aptera), beren Diunbtgcile gewögntid ser= fitmmert unb is nad ben werfdjicbenen Familien balb mebr zum Ranen, barb megr zum Snugen eingeridgtet fint.

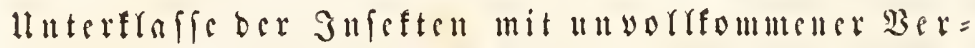
wnnblung. (Ilcmimelabola).

Sic entbält jwei Dromungen :

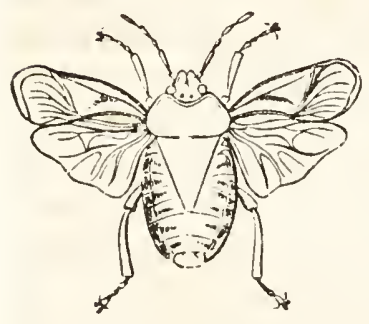

รig. 665. Pentatoma.

Dic Salbfrïglel (Hemiplera) mit vier oft ungleiden fringeln und sincm ge= glicocrten Sangfdunbel; und

Dic Gisadflügler (Orthoptera) mit vier incift unglei= d)en fringeln unb wobl nursege bilocten faucuben Miubtgcilen. 
Ilnterfaffe oer Gufeften mit vorffommener Ber= ivanblang. (llolomelabola).

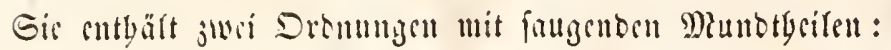

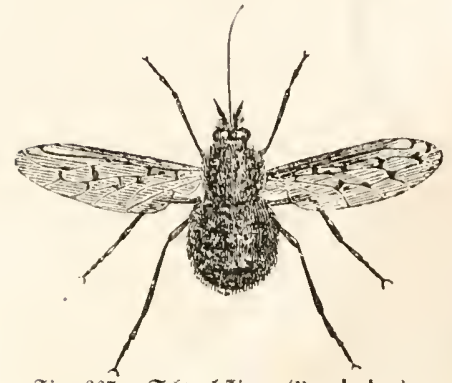

Ji.j. 667. Sinnebliege (Bombylus).

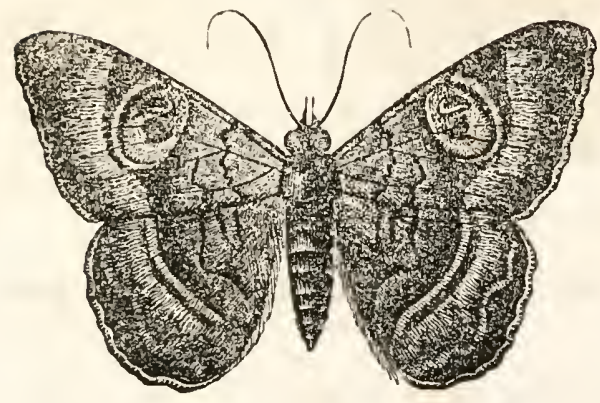

(ii). 668 Erebus.

Dis 3 wrifringler (Diplera) mit jwei bäntigen fitinglu, binteren

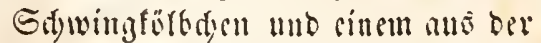
lliterfiple gebilocten, nicmale ge= glicberten Gangrinfer unb

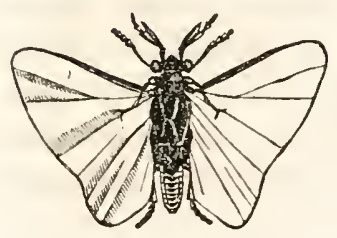

Dic $G$ d) metterliuge (Lepidoptera) mit vier gropen befduppten Frïgslı unb simem Saugrüfler, bor aแb ocr $\mathfrak{B} r=$ wanblung ber keiben Rimnla= ben bervorgegangen ift.

Dis mit rein fanentorn Munotbcilen ausgeftatteten $\Im n=$ feften bicfer lluterffaffe bifecn orci Dronungen:

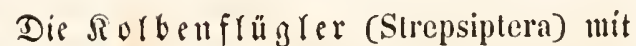
werfümmerten Borberflügeln uno fäderförmigen Sinterflïgern,

Jig. 669. Stylops.

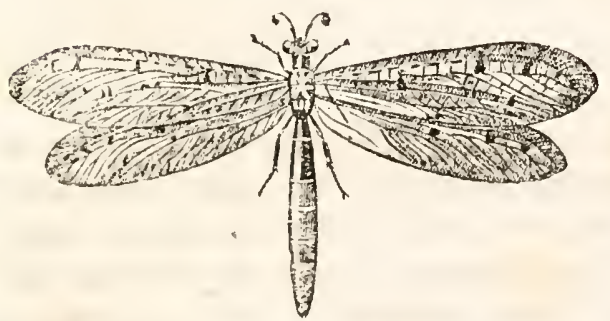

Die 2 egg frügler (Neuroptera) mit wier gleid)artis gen, Mebiformig gegitlerten Friigeln uno

8ig. 670. 2(neijenline (Myrmeleon). 


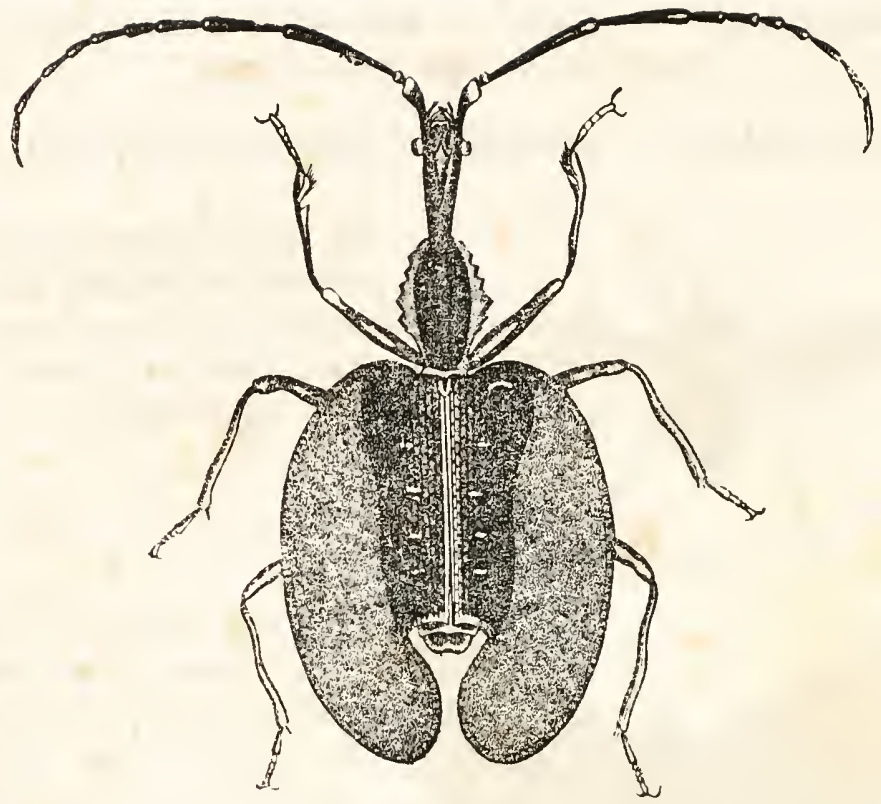

Fig. 671. Normolyce.

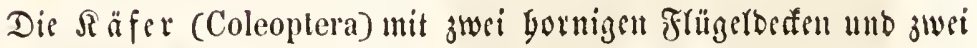
Gäutigen Sinterflïgsłn.

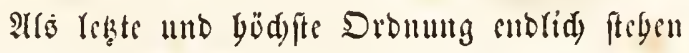

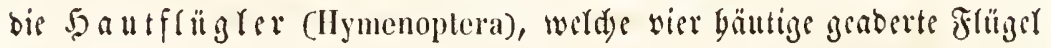

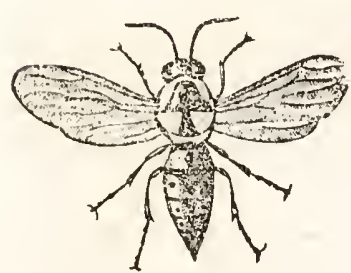
befigen und bsi bencu ju entwiffirten Raul= werfzengen nod) eine ju sincm Ed)ëfrüffer sertinngerte 3unge foummt, fo bar fie fauende

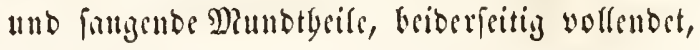
vereinigen.

ซig. 672. sgeipe.

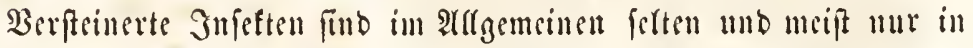

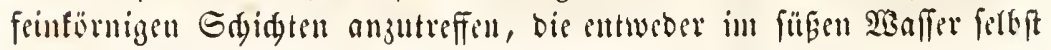
(id) abragerten unb bis barin Kebsnben Garven und volfommenen Thicre

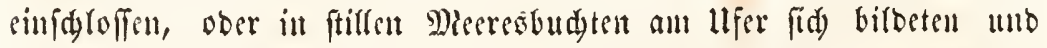
bis bort binein geiduwemmten Thiere aufngmen. Dic erften Sputen

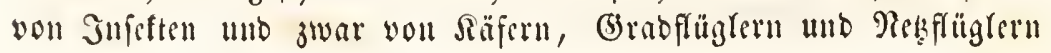


zeigen fid in ber Steinfogre; im Sura nuld zwar namentlid in ben

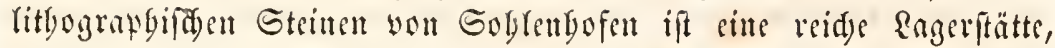
in welder fdon faft alle Drbunngen repräfentirt erifeinen; bie be= Dentendften Funbgruben aber referten in Der Tertiär jeit bie Süßwaf= ferfalfe von Plix, Deningen und Raboboj in Eroatien, fo wie ber

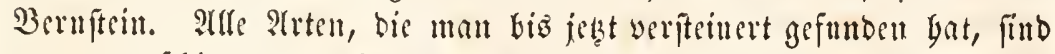

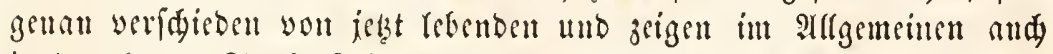
in ben Yeksten Tertiärifidgten auf tropifde C(imate in Guropa bint,

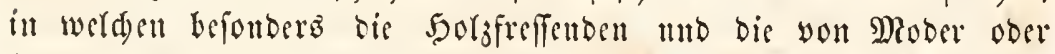
Gianbe Yebentoen Jnfeftent vorjugsweife entwiffelt waren. So ift $n a=$ mentfidy in ben tertiären Slbfagerungen bie 3abl ber Termiten unt

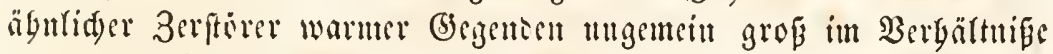
jll aubern Battutigen.

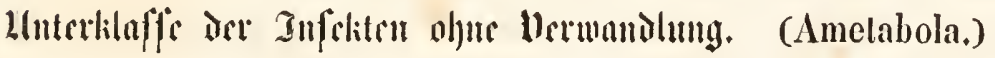

\section{Die Drbunng Der friigellojen Infekten (Aptera) begreift}

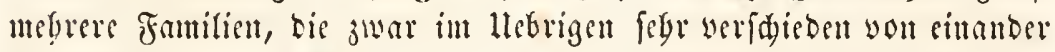

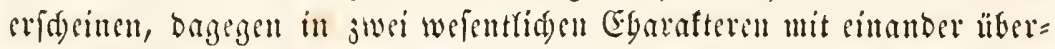
sinfommen, indem fie alle wägrent oer gangen 3eit igres sebens in

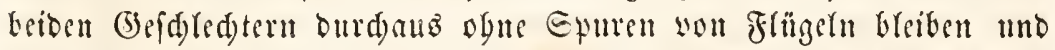

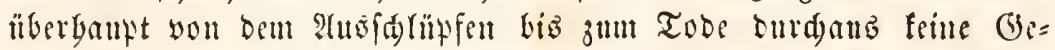

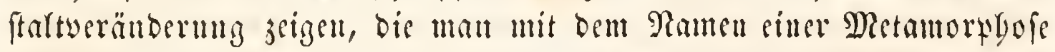

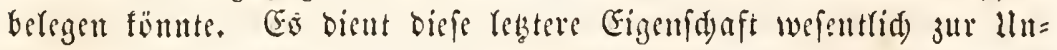
terfdeibung von cinigen Sdjmarokeringeften, welde ebenfaltż wäb=

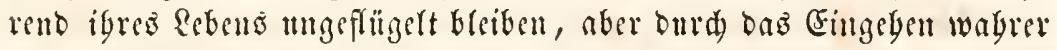

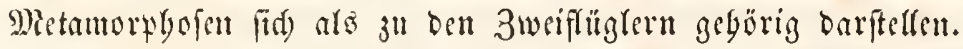

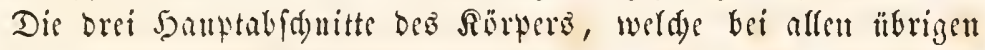

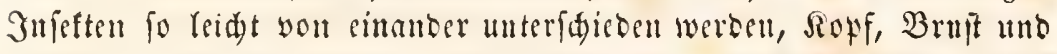

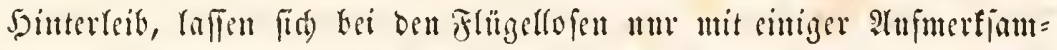
feit erfemen; am Gänfigften ift nod) ber Sopf megr soer minter ab=

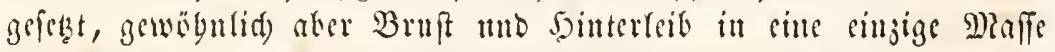

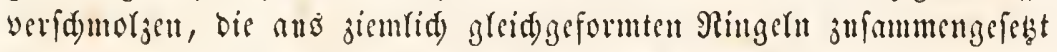
ift, von benen bie serei erfiten fid nut baburd als Bruftringer bofu= mentireu, daf fie auf igrer lluterfeite die Jübe tragen. Der binter= 
Teib biefer Thiere cridesent in ben meifen Fällen aus weit wentiger

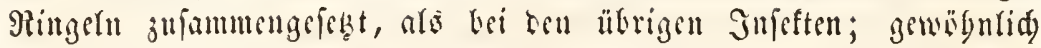
jöblt man mur fieken.

Der Sioff Der Flügellofar, Der meift frei, zumeiten aber gants

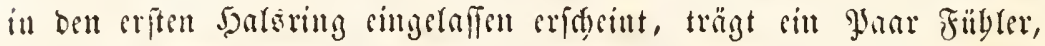
weldye in ben meiften fä̈ften nur furz finto, utto ftets sine borften=

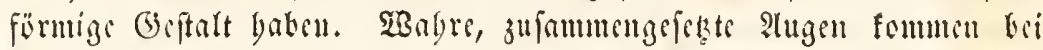
ben Flïgrllofan nidst vor, wogr aber ftegen gewögntid) mebrere sill=

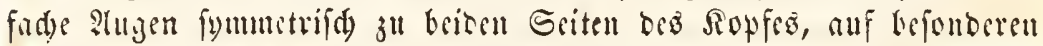

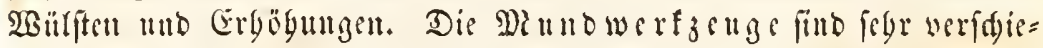
ocn geftaltet unt meift mur büdjif rubimentär; bei cintigen Sd)mareşern

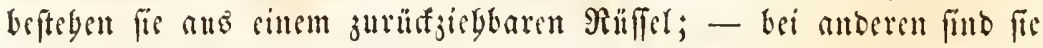

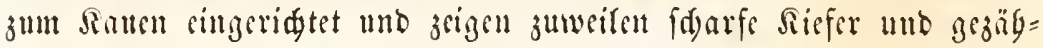
nelte Rimulaben, bie jun Bertleinern ber Beute bienen; eigene Rippent=

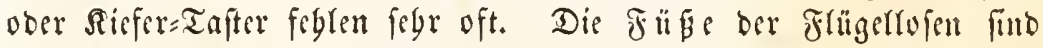
nad) zwei verfabicbenen Typen geftartet; bei ben Sduntrobern meift $\mathfrak{f u r}_{3}$, fräftỉ, mit fdarfent Sirallen zum Thtflammern an 5aaren uno Froern werfelen; bei ben frei lebenton bingegen meift fallant, rang unb bünu, unto ju lebbafter fortbewegung tauglids.

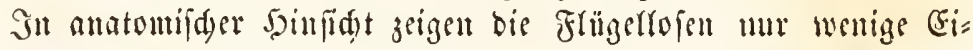

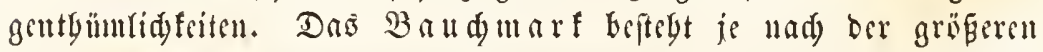

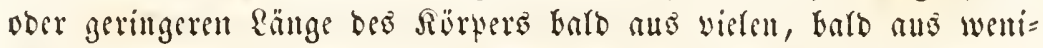

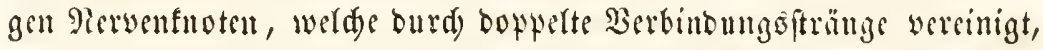

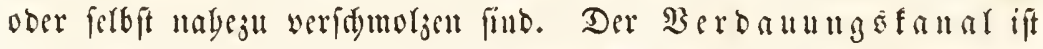
meift utr wenig gewutben; ber Magen fdlaudffürnig; dis Epeife= röbre am Endo fropfartig erweitert; ber sigentlide Darm ift ftets fegr furz, die 5arngefäpe mäpig rang, in ber 3agr wou wier biz fedjo vorbanben. Die Euftrügren vereinigen fid meift zu zwei

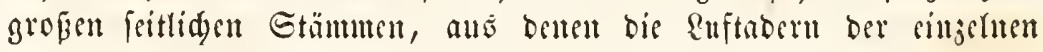

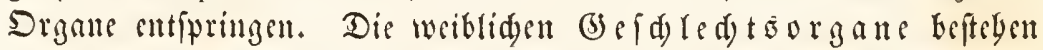

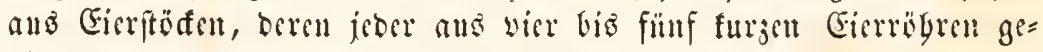

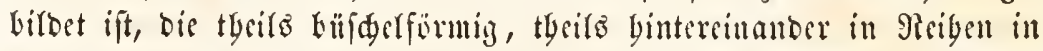

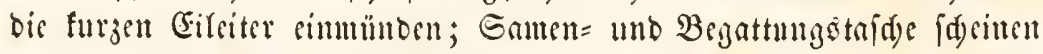

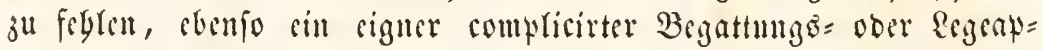

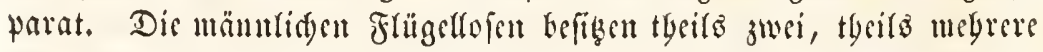

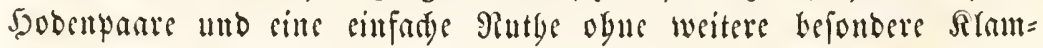
merorgate.

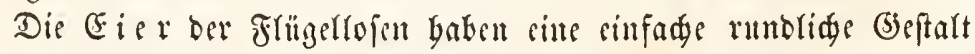
und ftefent zuweilen nod in lätgliden Sapfern. Die Sutgen ver= raffen bas eri meift in fegr furjer 3eit in ciner beftart, welde berje= 
nigen Ler erwadjenen Thiere außerortentid äbnett. TBir tbeilen ticfe in vier Familien, von weld)en jwei als Sd)marokger auf warmblütigen Thieren leben, wälrend die anderen in Freien unter Strinen uno in ben PRiß̨en Der Baumrindin anjutreffen find.

In Die Samilis ber Räure (Pediculida) gelyören sinige (5)attungen

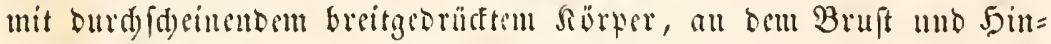

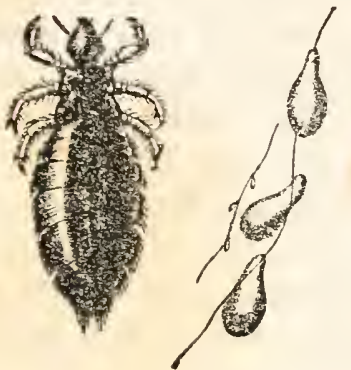

Jig. 673 .

Die Rงเffกนิ (Pediculus capitis).

a (Sier (MRī̄e), an eitrent Şaare băıgeกไ.

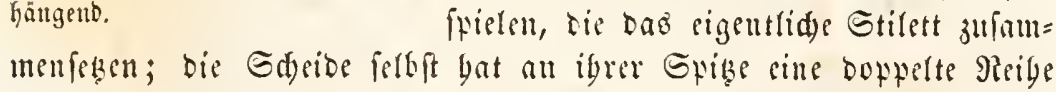
terteib nutr utuceutlidy ober gar nidst ge= trennt füt unb bie nut auf Sängetbieren (d)maroken. Der Sopf ift bentlid) abgsisest,

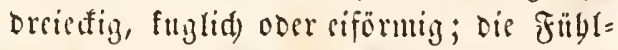
Görner furb, meift id widh bebant, aus fünf beinabe gleidgroficn blisbern $\mathfrak{u}=$

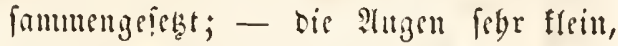
jederferto binter ben şüblern bemerflid); bie Mundwerfienge befteyen ats einem Rüllel, ber ganj in Den Ropf jurüdige= zogen werden fam tho aus einter wei= d)en, unten erweiterten Gdeide zufam= mengefeşt ift, in welder vier Stedbborten

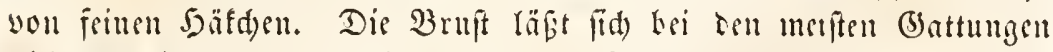
nift beutlich von bem Sointerteibe unteridseisen; fie trägt brei furze,

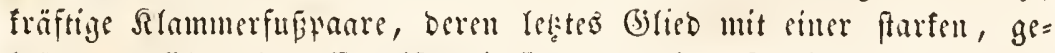

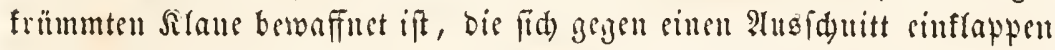
und fo bas Saar wie sine Bungenfdeere faffen taun.

Die veridisdenen Gattungen und Irten biejer Familie reben fdjmarokeno nur auf bem Menfden und auf Gängetbieren, beren

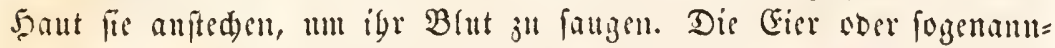
ten Piffe werben an bie 5aare angeflebt unt idjlüpfen in wentigen

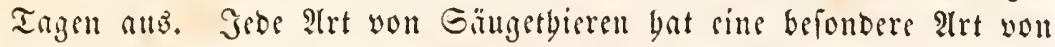
Räufen, unb ber MReula) allein näbrt vier Itrten, bie zmei veridjie= benen Gaattungen angebören. Pediculus; Plthirits; Iracmalopinus.

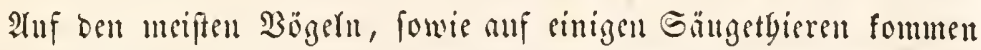

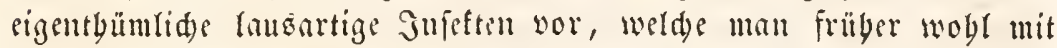
ben eigentlid)en \&äufen zufammentwarf, jest aber als bejondere fat= milie unter bem Rament Der $\mathfrak{B o g e l l a ̈ u f e ~ ( N i r m i d a ) ~ u n t e r i d e c i b e t . ~ D i e f e ~}$ Snjeften baben im SHllgemeinen bie bjeftalt ber Räule, zeigen aber ftets 


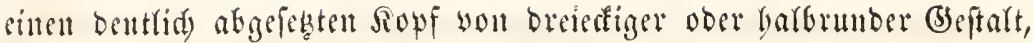
Det oft mit fonberbaren Gpiken bejebt ift. Die Fübler find ebenfallz fïnfyliebrig, bie Mnnowerfjenge aber jum Rauen eingeridytet. Sie baten nämlid) zwei beutlid)e, Gafenförmige Riefer, welde von oben unb unten burd) zwei breite Sippen bedertt find. Bei einigen Gat= tmungen füto aunerbem nod) büune, fdwadye Rinnlaben mit furzen, jweigliebrigen Taftern vorbanben; anberen Gattungen feblen mul bic

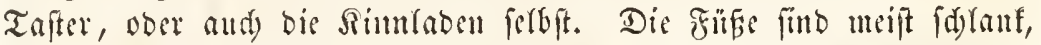

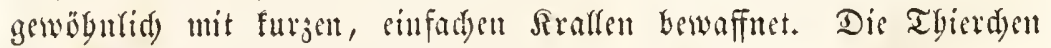

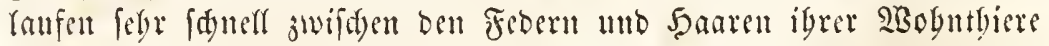

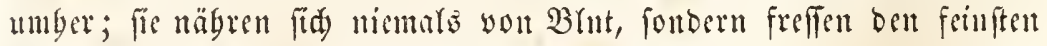
Fraum unt die jungen fproffenden Syame ab; nad dem Tobe dez $\mathfrak{B o g e t s}$ fammelt fie fid) meiftens an Den naften Siörperfteflen um Gduabel und Ingen an und verlaffen ben seridnam kein Erfalten.

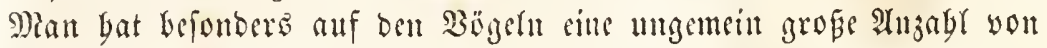
(5)attungen und atren diefer Familie gefunden. Philopterus; Nirmus; Goniodes; Trichodectes; Liothacum; Gyropus.

Die Familie ber Gabelfpringer (Podurida) veremigt eine ?tugabl

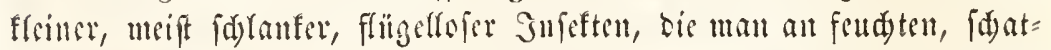

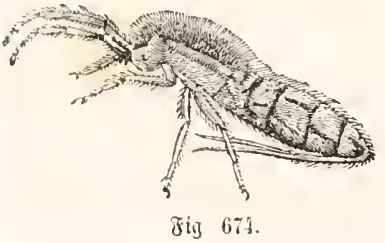

Podura, im Sugeubliffe, tov fis piti) zum Efrumge wortereitet. tigen Diten, anf bem Salfer und felbit auf Sdune und Gis in grofan Saufen mianmenfintet. Der Solf ift fets bent= rict) abgerest, alogerunbet, oreiertig ober ctwae länglid) unb mit bentlid)en, borften= förmigen, furgen, meift viergliebrigen Fïblern werfeben, biuter benen auf wor:

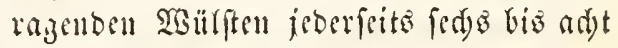

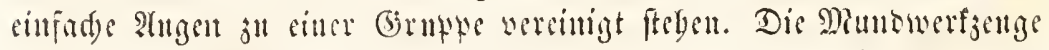

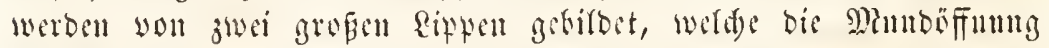

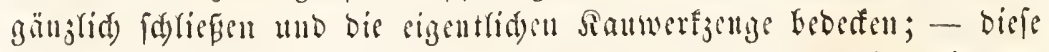
beftegen ans juei ftarfen, gejäluelten Sieferu nub jwei bafiz ge=

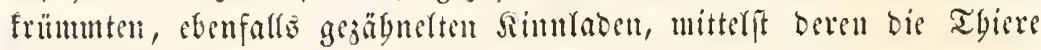

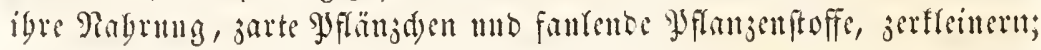

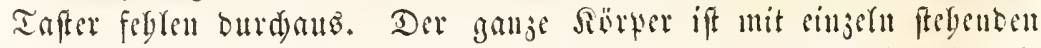

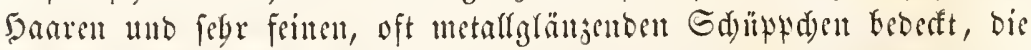

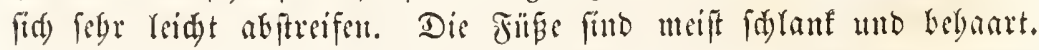

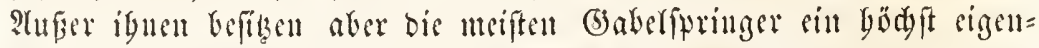

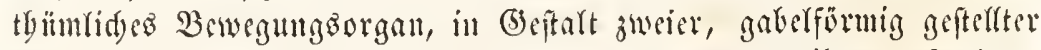
Borften, bis an bem biuterften brliebe bes llnterleibes anf cintem 
Hejonderen Gelenffnopfe fteben. Gewöhnlid wird biefe Springgaber feim (beben wagredt nad) binten geftedt; fobald aber baz Tbier fpringen will, fo fdy lägt es bie binbel unter ben Band, nno inbem

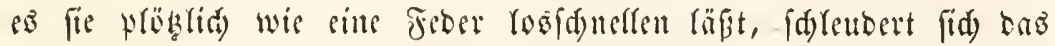
Thierden oft fubweit fort. Flnfer biefer Exringgaber, bie mur febr wentigen atrten feblt, befitsen mand)e biefer Sufetten nod) ein eigen= thünlides 5aftorgan, bas it Form sines flebrigen Sitopfes oder

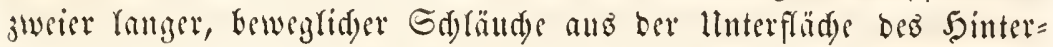
Yeibes Gervortritt, tho jum stubeften an glatten Fläd)en Dient. Podura; Sinynthurus; Desoria ; Orchesella; Achorutes ; Lipura.

Den vorigen nabe verwant ift bie Familie ber Butergäfte

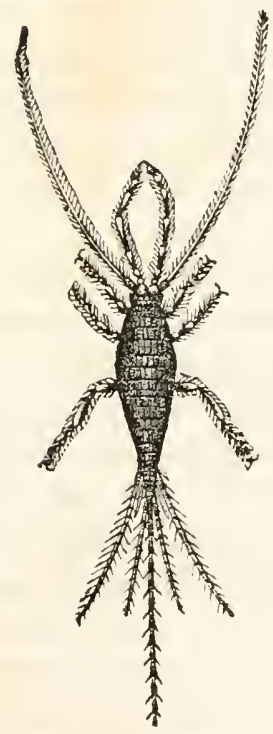

Jig. 675 .

Epringfijudyen (Marhilis),

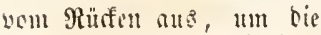
langent Finfler mo bie lau= geil zajtel baytuijdit, fo mie cie binteren Gyrimg = boriten zull zeigent. (Lepismida), fleitte, meiftens filberglänzente

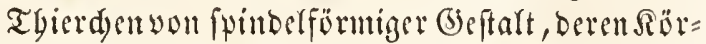

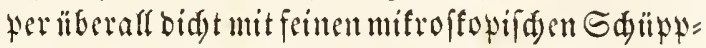

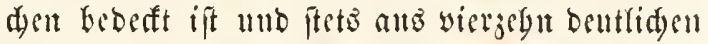
Ringeln beftebt. Der Soyf ift meift flein, tief unter bem erfen 5alertuge verborgen, bie Brujtringe in ber (jefitalt nidyt yon ben Rin= gen bes Şinterleibes veridjeden. Die Jübler find lnug, borftenförmig, ans vielen Glicbern jufammengefert; bie sinfaden श्tugen in beben= tender $3 a b$ anf juei fritliden 5aufen vereinigt. Die Minnowerfjenge befteben aus jwei fleinen, Gafenförntigen Siefern, fleinen, dïnten Simn. raben, bis aber febr lange, vielgliebrige, wie sin jweitez Yaar Füblgörner yor bem Sutfe vorftebente Tafter tragen, mo sinet lluterfippe mit furgen viargliebrigen Taftern. Fin binter= reite ber Thiere befinben fid) vielfad) geringelte, range Boriten, mitterjt beren sine Gottung in äbnlider $\mathfrak{B}$ seife, wie bie vorige Familie, fpringt. Die Thiere finten fid unter bem Miovie, anf

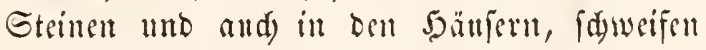
aber befonbers bei Nadjt umber. Lepisma; Machilis.

Dian fennt feitte folfilen Repräfentanten bet flïgrlofen Suleften. 


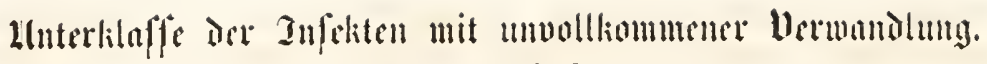
(Hemimeiabola).

\section{Die Dronumg ber Eefunbelferie ober Salbfiügler (Rhyn-} gota s. Hemiptera) bistet in ber linterflafle ber J̃ufeften mit unvolffommener Berwandrung oas cinzige Beiffier fangender Muno= theile, fonft aber mandertei weetjectude Formen, bie sine ftets zul grö=

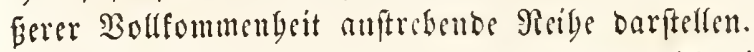

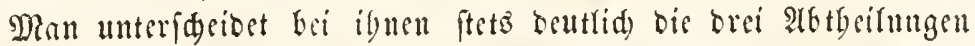

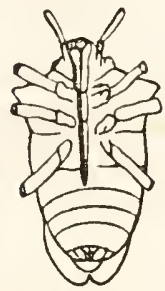

3ig. 676 .

bes Rörers. Der Ropf ift fleth, oft breit, meift

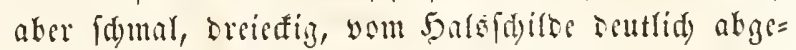
fert und und) mten in einen $S$ mated (rostrum) verlängert, ber bald mebr an Der Gxize Des Jiopfeż, barb mebr mad binten entipringt mo an ber llater= fläd) bes Reites, jwifden oen Einlenfungen ber Beine, zuweifen felbft in ciner Rime verborgen liegt. Man unteridecioet an biciem Sduabel, fobalo er vollftän= Pentatoma rou unten, mit angezongener, 3 twi $=$ fident bent sinftenl lie genter Edjuabelidieí= be. Die Beine finb abgerditnitten.

8ig. 677
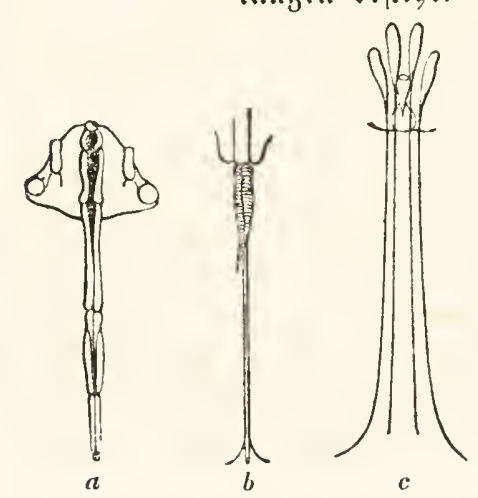

big autsertifoet ift, folgende Tyeife: Die Sauptmaffe biloet sine geglieberte, von vornber tief auşgeböblte Salbribre, Deren Rinne vorn offen ift unb bie mei=

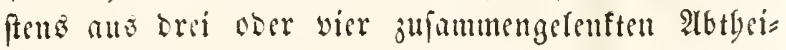
lungen Feitelyt. Diefe $\subseteq$ duaberfde eide gebt oben

a Sopf ciner Pentatoma you worn, mit unverfeyrter Edmateliffeits. b D ie Edyutelijeite it weggenumen, fo bas man bie Sberlippen unt bie vier zum Stifest vereinigten sorften fieft. c Die 3orften ifolirt. aแต ber llnterbaut des̃ Ropfes ber= yor uno ift offenbar bie nusigewad)= fene, quergeglieberte llnterlippe. In igr riegen vier feine 500 'n = borften, bic an igrem Urfprunge im Ropfe fpindelförmige Musfeln Gaben, woourdy fie bewegt werben und neben ber Miundöfrnung yer= sortreten. Die äuberen biefer $\mathfrak{B o r}=$ ften find meift an ber Sprize etwa umgebogen, ftärfer, Yeid)ter ju tren= nen, $e$ find bie yerwandelten $\Omega$ is $e=$ fer oder Miandibelu. Die innerent Borften riegen fefter zufammen es find die $\Omega$ inturadil doer Maxiffen. 3ufammen bilden die 
Borfen sin in ber Sdynatelideibe verforgenes Stilett, womit bie

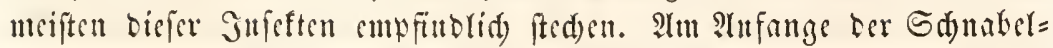

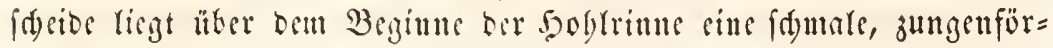
mige Deffe - Die Dberliphe - fo Dáb aljo ber Sdjnaber auto

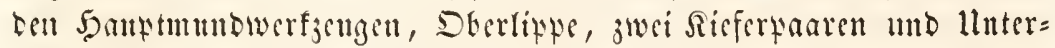
lippe, freilid) in fajt untenntlider $\mathfrak{S}_{\text {Beife }}$ motificirt und aller Tafter berattbt, jufammengsistat ift. - Die Föbler find meift fadenfürmig,

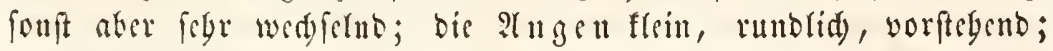
Rebenangen febren oft.

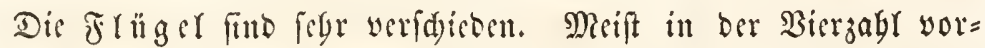

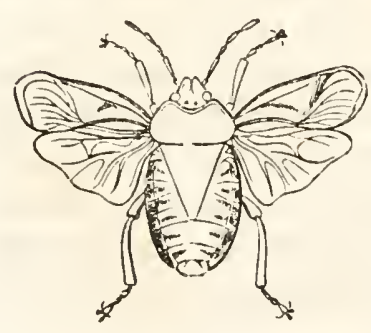

Jig. 678.

Pentatoma mit ausgętreften ठtügetı,

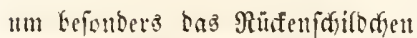
tub bie balk letcrartigen Borter=

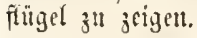

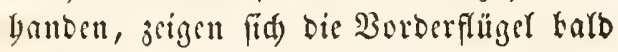
gani, bard theifweife gornig und bann mit einem bäutigen, geaberten Tbeile ver= fegen; bei andern wieber leberartig, eben= fallo mur zum Theile; bei nod andern gäı flidy ben lluterflügern in Baue gleid. Disfe reşteren find meift fleiner alz bie

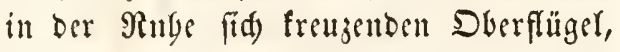
glasghefl und mit Rez̧adern yeriegen. Die

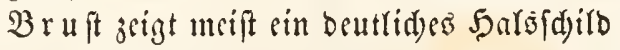
und oft tift zwifden ben Flügefn nod) ein megr

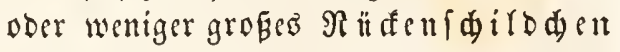
(Scutellum) ansgebildet. Bei ben meiften

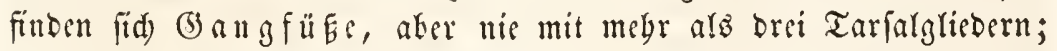
bei einigen fint die Borberbeine öl Mantefüfen, ober bie Simterbeine zu Sd)wimmfüвen umgeffaltet.

In anatomifder Şinfidst zeiduen fid) bie Sdjnaberferfe burd fol=

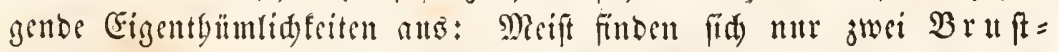
flloten, son Denen Der Gintere ber größere ift unb bie oft getrennten

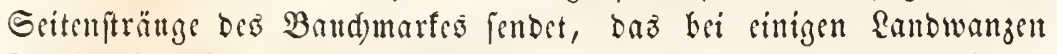
faft in sine sinjige Maffe veridmolzen ift. Der Sdylund ift meiftens eng, ber çgylusuagen bagegen fegr weit und vielfad) gewumben

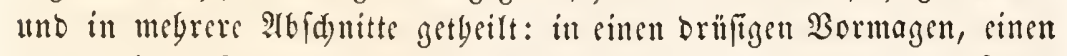
barmartigen Pittermagen, ber fid fकlingenartig juriatbiegt uno fogar

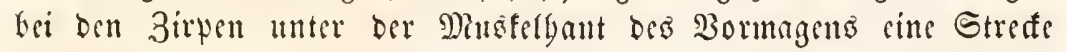
lang verlăuft, und sinen gewuntoenen Şintermagen, in ben zuweilent

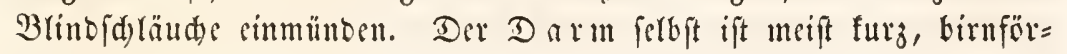
mig. Die Spcidgelor üfen, weldye Den Brattläufen feblen, find bei

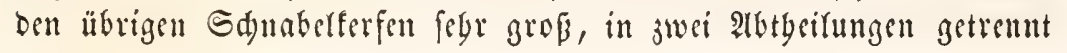




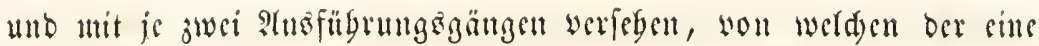
fogar bei sinigen ?trten in bis Baudjgëgle binabjteigt, um bann wic=

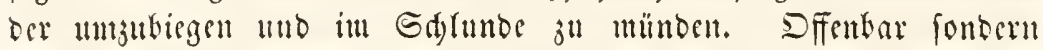

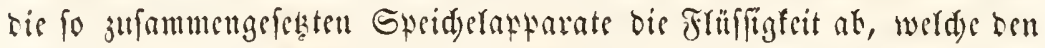
Stid) oer meiften $\mathfrak{B} a n u_{j}$ en für anbere Juleften unteroingt töotlid, für

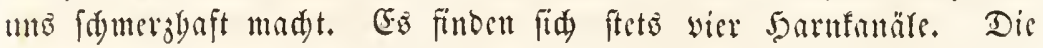

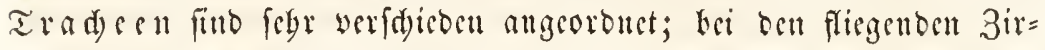
wen und sisangen aber bft mit grofen, brafigen Erweiternugen wer= feben.

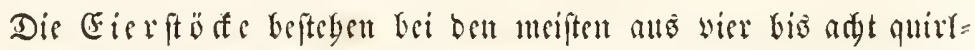

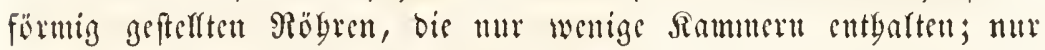
bic Battelübe und Birwen Gaben febre virle, anf werjweigten Cilcitern büfderförmig ftebente Eirögrcu. Dic Samentafde ift meift cinfad), rang, gewumben vocr birnförmig Gornig; sine Begattungstafde feblt rft; Sittorgane fitno wentig ausgebirtoet. Die männliden Folt

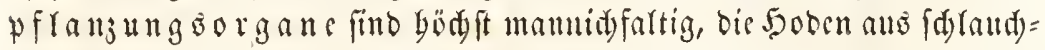

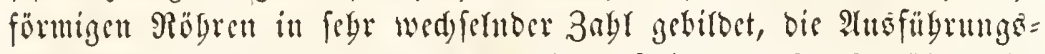
gänge meift lang, gewunden ando mit verfdiebenen Drüfentögren be= fert. Die Pattge ift einfad rögrenfürmig.

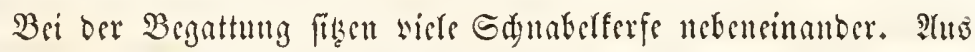
ben Giern foummen Rarwen, bic in Form, Gewobngsit, Rebenşart, Tabrung ben erwadjenen Igheren febr gleidgen, aber ftets flügetros uno meifit mit zartsm, fribenartigem fraum kebefft fint. Rad) mebr=

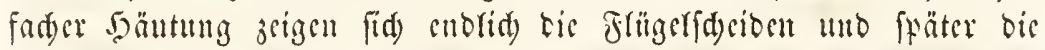
worlfänoing aušgechirosten frägel.

Stle Erfunbefferfe faugen Säfte, entweder won rebenben Snfeften ooer aud) wou Blättern. Die von Yyflanzenfäften retenden wobnen meift in 5aufen zufanmen und verurfaden ourd iogre Stidye frant=

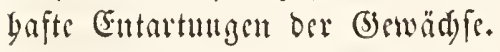

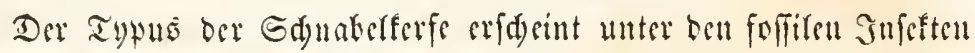
als siner ber frülyefent. Sm Sura fiuten fid grofie 2 Safferwanzen, cinige Ranbwangen und Singjirpen, arfo im Ganjen megr Fanificn

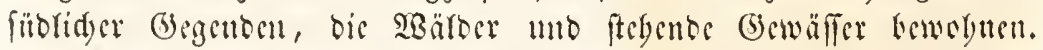

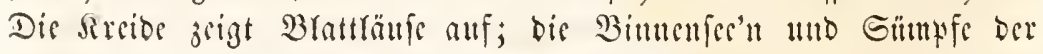
Tertiärzat Singzirpen, Salanmzinpen (Cercopis), uno zabrreidye Ranowanjen, bie benen ber jestigen Sqüpfung fegr nabe treten. 
2Bir thetlen bie Dromung ber Sdunberterfe in forgente Fa = milien:

Edbildäule (Coccida). Die meiften biefer Thiers wobnen in

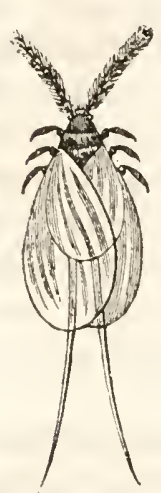

Jig. 679.

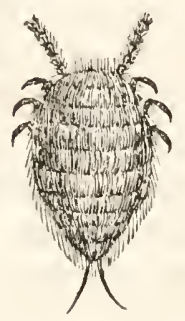

Coccus cacti, bie kifte Gudjentlle.

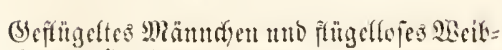
dgen; beíce ftatf wergräpert.

wärmeren 3onen, alle farafitifa) anf Bemädjan, bie fie fetten ver= laffen. Syre beftult, bejonters bie ber siscibdyen, ift fo abweidjent, sab man lange wou cinigen Itten bejweiferte, ob fie wirflid Thiere frien. Die Miännden find ftets geflïgelt, fdiranf, mit wagered)tem Sopfe, ramgen boriten= ober fdum= förmigen güblern, die meift belsant fint, und fegr fleinen ?tugen, bis aแร gebäuften einjernen Mebennugen

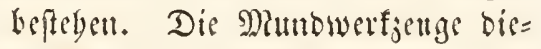
fer Thierden, bis im volfommenen 3utitande mu forbr furje 3eit reben unt feine Rabrum zu fid nebmen,

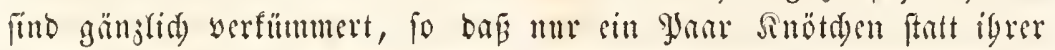
walrgenommen werben. Flügel fint gewölyntid nul jwet vorbanden, fegr felten findet man Syinterflüger, meift ftatt igrer nur Edywing= folfen ober verfümurerte Stummedn; fie find febr zant uno Gäutig.

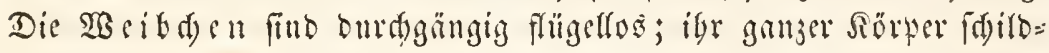

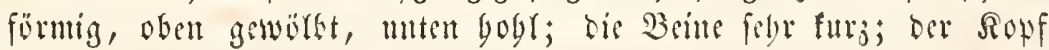

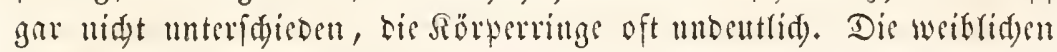

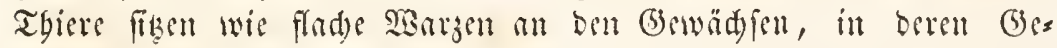
were igr mit fegr langen Borften werfegener Sdynaber permanent

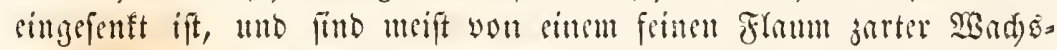
füben bebefft. Sie verlieren vft in biefen 3ujtande bie Beweglidfeit gänzlid und legen und ber Begattung bic (Eier unter fidd, fo bas

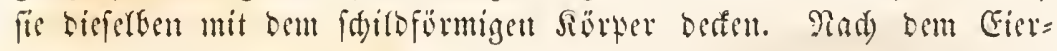

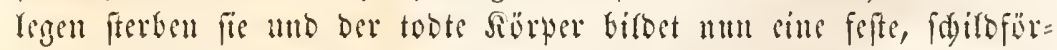

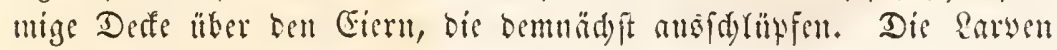

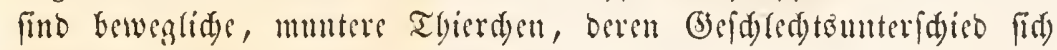

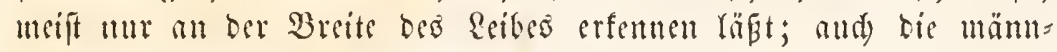

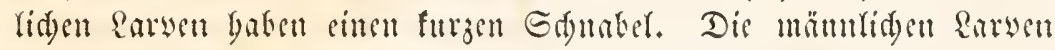

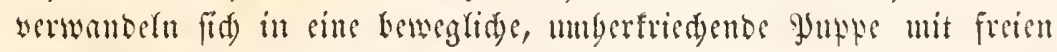

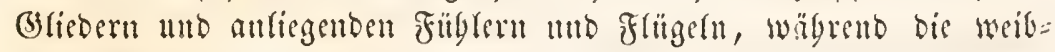
liden gupten fide mu burd) gröbere Breite yon ben serven mo 


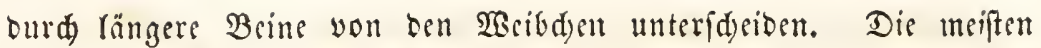

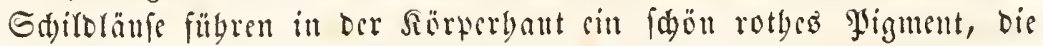
(5od)enille ober Siermestad. Man jildtet jur Giswiunung bicfes Jarbfuffes befonders in Mexifo sic Cactus =?aus (Coceus cacti), in= Dem man träd)tige $\mathfrak{B}$ cidacn in Eefonbere Reftden alff bie Brätter Der Yyfanzen fekt mit bie Rarwen, bevor fie fid feftgefingen baten, anf Diefen yflangen wertbeilt. Man faumelt Die todten Deännd)en nad) Der Begattung und töbtet sicjenigen träd)tigen $\mathfrak{B}$ cifd)en, Deren man nid)t jur Nadjud)t bebarf, auf crbisten B(sd)en, worauf man fie getrodnet

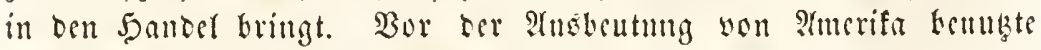
man ju gleidem 3weffe eine Edjiblausart, bie befonbers in Norb.

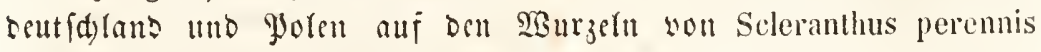
worfommt. Coccus; Aspidiotus; Porjhyrophora.

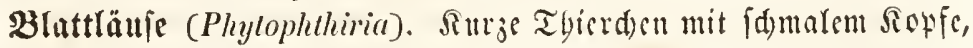

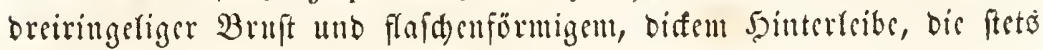
auf (5) emäd) len leben und Dort oft ourd) igre Etid)e (5allen uno äbulide Atuswüd) ve verurfaden. Die Fübler find faben= ober borften= förmig, länger als Der Siörper; Die ?tugen meift mittelgroß, rundlid) vorftelgeno, dic jübler jwifden ibnen singefert. Nebennugen feblen. Der Sduabel ift meift lang, Dïnn, sutfpringt an Der muteren Erite bes Soffes weit nad bitten bin mo wird unter Den Sowf zurïr= gefd)lagen getragen; Die Ed)nabelideite ift Drighlicorig; Flügel meift

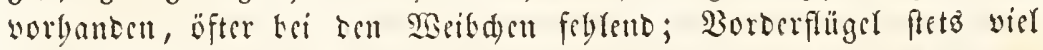
gröв̈r; Beine rang, Dünn; Tarfen jweiglicorig, mit zwei תlaucn werfeben.

Bei ben cigentliden Brattläufen (Aphidida) fteben auf beul Sinterlcite jwei gerabe Röb= rell, aแs benen ein füber 3 ufer= faft quillt, nad) Dem bis Imlrifat befonders febr tegierig futb. Geder Amcifenfted gat gewiffrmafien sine Domänc yon Bäumen, Eträud)

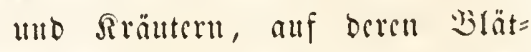
tern Into TEurjeln Brattlaus= colonicen fiben, die yon ocu Aneifen forglam getflegt, oft felbit won eimem Drte zum andern getra= 8ig. 681.

Beffügette Rofenbrattian (Aphis rosarum). gen werben. Man fiebt, wis bis Imeifen Dicies ibr Peltuich lieb= folen, fanft nit ben föblbörtern 


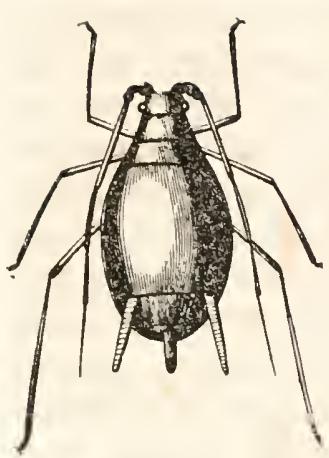

Jin 682 .

ftreideln uno floffen, fis fie ben நonghaft and oen Röbren raffen, welden bis Ameílen gierig sinfifluden. Dis Fortfflanjungiveife bisfer

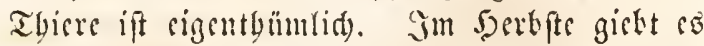
gefliigerte Mläunden mo $\mathfrak{B}$ cibd)en, bie fid tes= gatten, wouad) โas Däund)en ftirbt, bas 2Esibden feime Cier in Minten legt ober aud unter ber Cirbe an 2 Bnrzeln fortlebt. Sin Jrubjabre fried)en dis Sungen nus - flüger = lofe Meibden oocr vielutely 2 (mmen, berent Eierfiöte vielfammerige siröbren befizen 4 b furge Eilsiter obue Eamentaide, Beyattungs:= tajd) ober Rittorgane. Diefe Stmmen bringen

Elügeflofe sinne rerielten strt

obne Begattung burd intere Sinofpung Fiev bervor, bie nod im Eileiter aแรfdlüpfen, fo baj fie lebendige Sarven gebären, bis nad)

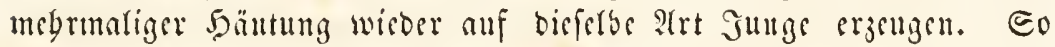
folgen fid oen ganzen Eommer biutourd) ad) bis jebn, unter günfti: gen llmitünoen felbit zwanzig uno mebr (benerationen ungefd)led)tiger, Durd Surspung fid fortfetender Ammen, bis julebt sine Eracugung von Männden und sierlegenden $\mathfrak{B} e$ eibden, die fid begatten, die Mribe

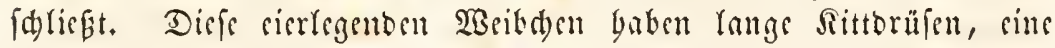

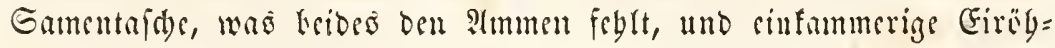
ren. Biele Blattläufe Lebingen Durd) igre Stides Rollungen uno

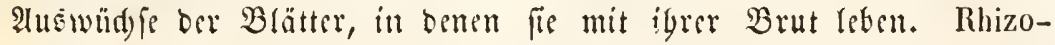
bius; Chermes; Aphis; Aleyrodes.

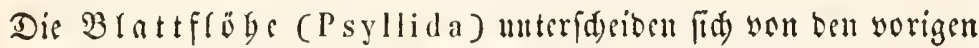

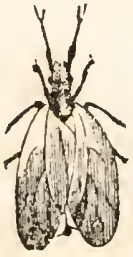

Fin 683.

Batattloh ver Binfen (Livia juncorum). burd) ciltell mebr rïfwärts singetenften Stad)e,

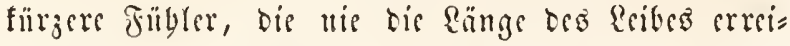
d)en uno all oer Sprize geipalten finb, unb verbifte, 3un Springen singeridytete Jiuterfdenfel. Beibe (3se = (d)ledter find fteto geflügelt. Sic leben cbenfallỏ auf Brättem, ftringen aber bei ber geringften $\mathfrak{B}_{c}=$

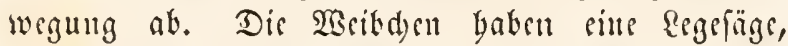

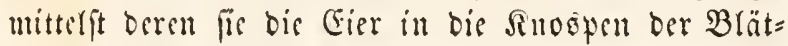
ter simfenfen. Livia; Psylla. 
Dis Faunilie ber Birpen (Cicadida) beftegt aแร bifteifigen Thie=

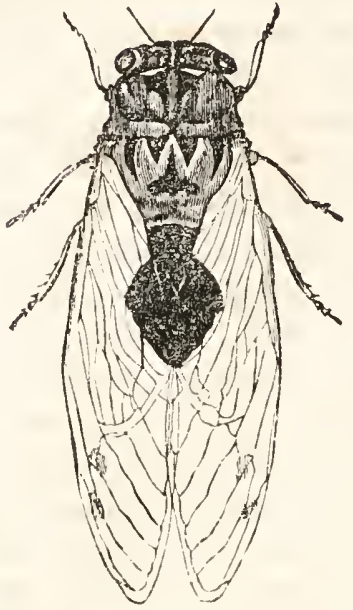

Fig. 681 . ren mit groferm querem sioffe, bis uur febr furge, forfenförmige fübler von brei

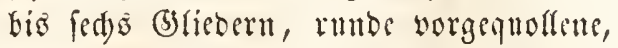

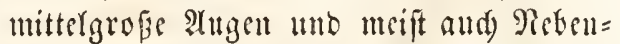
angen befisen, bie indeflen oft feglen, oder unr jwei, fegr felten brei fint. Der Sduabel ift furz, biff, febr mad) binten gejogen, fo defi er jwifisen ben $\mathfrak{B o r d e r}=$ fiifen ju entipringen id)eint. Der $\mathfrak{B o r b e r}$ rürfen bat oft aufallende Fortfäkse, Ber= rängerungen uno Dornen, ebenjo dic Etirn, welde zuweilen blafig vorgequol= Ien ift. Flügel find ftets in ber Bierjabl worbanten, meift glasell, bie worberen juweiren megr reberartig, bis binteren weidger, beibe mit Rebabern burdjogen.

Orup̃e Eingjirpe (Cicadia perla).

Dic Sinterbeine find meift Springbeine, Die Tarfen oreigliebrig, die Sirallen breit. Sie leben alle auf gyflan= zen, beren Saft fie faugen, pint rebbaft unb fpringen ober fliegen, wäbrend bie Rarven oft unbeweglid) fisen. Mant unterideibet folgente IInterfamilien:

Sdanmzirlen (Cercopida). Sörwer meift furz; Jübler Dres=

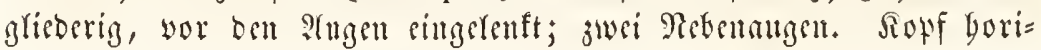

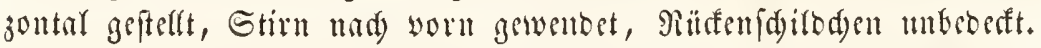
Die Sarven Yaffen igren flitfigen Rotb in Brafen ant osm after ber= wortreten unb bebeffen fid) fo mit einem Tröpfden Speider, bem T. $\mathfrak{g}$. ภutufufépeiduer. Telligonia; Cercopis; Aphrophora.

Budfergitpen (Membracida). Der Ropf febt fentectst, die

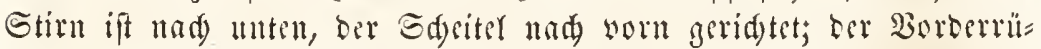

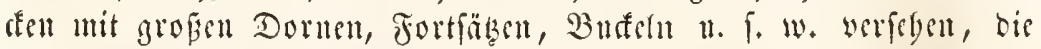
oft ben ganjen ecib bebecten mo woburel bie Tbiere sin abentener= rides 2Mreben erbarten. Borberftüger meift büutig, mit parallelen Prorn. Centrotus; Membracis; Darnis; Bocydium.

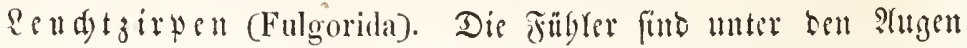
neten ben $\mathfrak{B a n g e n}$ singelenft und uteift unter siner Seifte, weldye bie Bangen won ber Gtirn trennt, werborgen. Der Ropf ift idarffantig, oft in eine Spitse oder Blafe vorgezogen, mit fdarfen Seiften bebeft; 


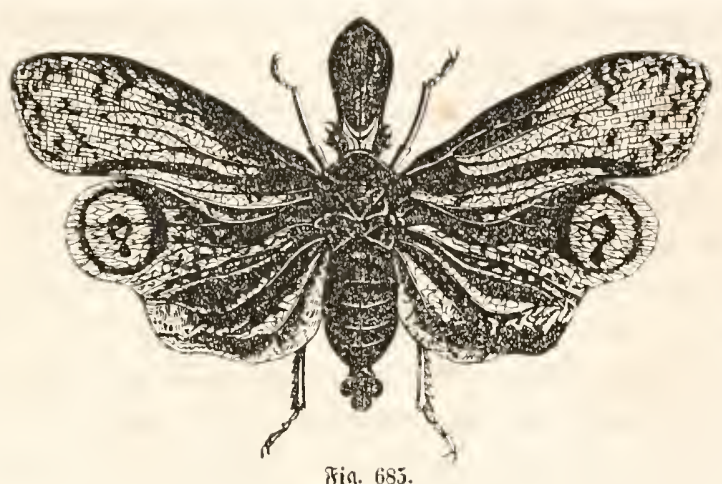

Der แนи

Flïgel meift gefürbt, jicmlid) glcidy. Mant glaubte son cinigen Arten, bem Raterneuträger nแร Sแrinam, Fulgora laternaria, insbefonbere, die boble Stirn lettdete, was aber unridatig ift. Tettigometra; Cixia; Pseudophana; Fulgora; Issus.

Singjitpen, eigentlide Cicaben, Cicadida. Die frübler fteben;

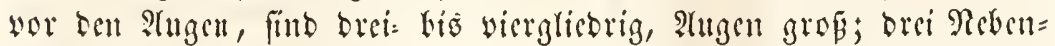

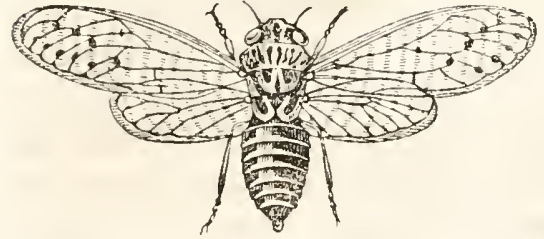

Fig. 656 .

tlmenjirfe (Cicada ulmi). nugen. Ropf breit, meift worne ein Sreis̄egunent bitbent. Sd)na= bet lamb, Flïgel ungleid), bie borberen ไänger. Die Rarven reten mestere Sabre, find plump und biff und graben fid) zum lleberwintern in bie Erbe. Dic secibden bobren ibre Fier in bie Pillbe ber Gerväđje mit cittem Regeftad)er. Die Mrännden baben an ber llnterfeite bes eriten bitnerleitseringels zwei tiefe, weite Etimmböglen, in beren Brmtoe

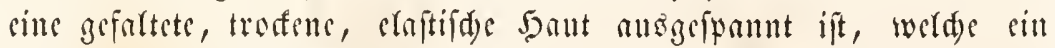

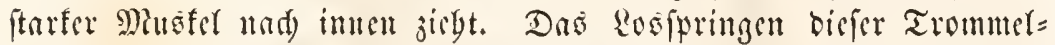
brut erjengt sinten fdarfen, fingenden, lanten Ton, ber wirflid nod)

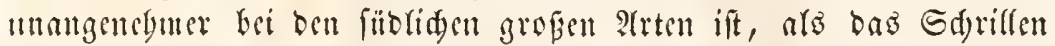
ber Syermden ober (bryllen unferer begenden, aber unbegrefflider

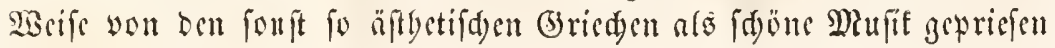
wurbe. Cicada.

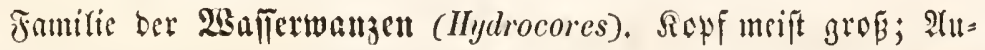
gen ftets beutlia, ftarf bervorragent. Fübler brei= ober viergliebrig, 
febr flein, unter ben stugen verfecte, meift in cimer Pimne liegent.

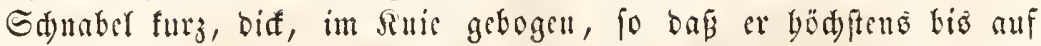
bie Mitte oer $\mathfrak{B r u f t}$ reidht. Flügel ungleid, bie oberen fergament= artig, Destent, bic unteren bünn, waflerbell mit wenigen Rängsonorn. Füfe febr verfdiden, bie worberen meift Raubfübe, bie binteren Sdymimmfüfe mit langen Borftenbaaren befest. Tarfen ein = lis brei= gliebrig, mit ober obue Srallen. Alle Arten leben in füfen (b) äflern unb bie meiften baben zu bem 3weffe ber 9tbmung au Siuterfeibe

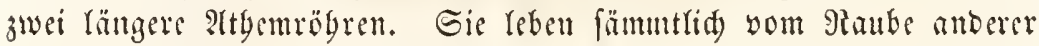
Snfetten, rie fie mit den Raubfügen ergreifen und mit bem ftarfen

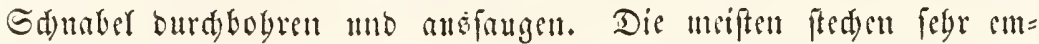
HFinblid. Man unteridycibet jwei llnterfamilien:

Ruberwauzen, Notonectida. Sopf febr breit, furj; Shnaber

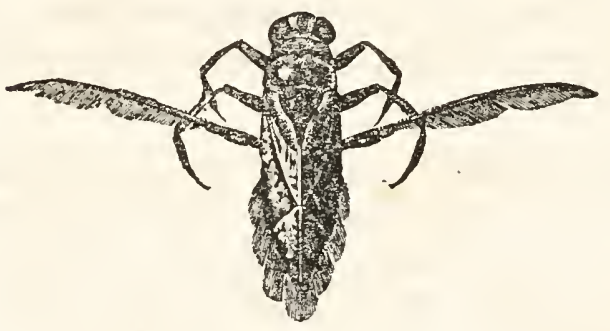

8ig. 687. Gemeine Ruberwanze (Notonecta glauca). bis anf bie Mitte ber Bruft reidyeno. Borber= füpe frallenartig gebo= gen, Jointerfü̈efegr lang, quer nad) Den Griten in Der Rube geridtet, platt= gebrült, mit langen Sdinimmborften an Sd)ientll unb Tatien, bie zweigliebrig fint. Band) flad, bebaart, Pä̈fen gewölth. Educlle gefdifte Sd)wimmer, Dic aber beim Sdwimmen ben Band) nad) oben, ben Räufen nad un= ten fegren, alfo verfegrt fowimmen. Corixa; Notonecta; Naucoris; Ploa.

Wafferfforpione, Nepida. Sopf meift frein, runblid); Sdyna

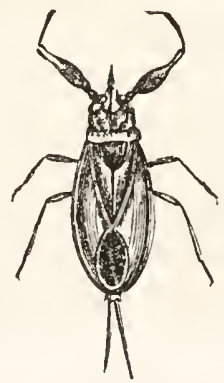

Fig. 688.

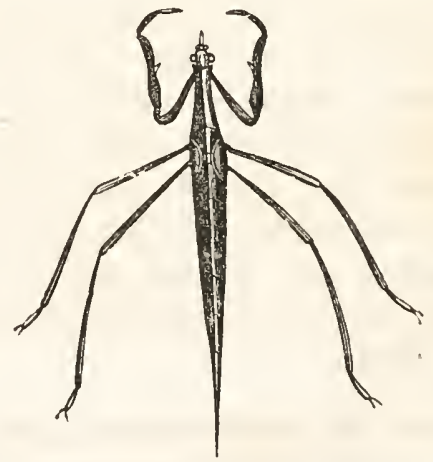

ซig. 689. Sinienwarze (Ranatra linearis). 


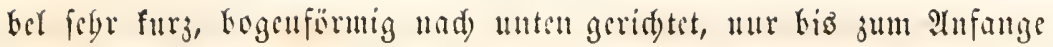
ber 2 ruft reid)end. Beine fabl, meift lang; Die Sinterbsine juweilen mit $30 r f t e$ befeist, abir nidyt breitgebrildt mo in Ruberform umge= wanbelt; Borberbeine fräftig, gebogen, jum Fangen cingeridtet, eint= germagen den Sdjeren der Sfortione äbnlid, wober ber Rame. Sointerleib mit langen 2tegemrögren. Siried)en meift langfan anf bem (5) runde Der Gewäfer, fommen aber Radto bervor, um fefbjt umber= jnfliegen. Nepa; Ranatra; Belostoma; Galgulus.

Familie Der Ranbwanzen (Geocores). Sürper meift breit, platt; Ropf fleiner als bei ben Rüdenfdwimmern. Fiabler froen = ober bor

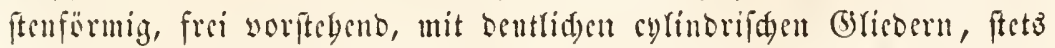
länger als ber Sotf. Der Rüfel entipringt an ber Spize Des Sopfes, wirb fnieförmig umgebogen und reidt böhites bis ans Fnoe ber Bruft. Sberftügel ftets won ben lluterflïgeln veridieden, feocrartig, ganj ooer nur jur bälfte börnig uno baun ganj oen Flägelocfen Der Räfer äbulidy. Nlntaflïger bäutig. Babbeine, in igrer Bildung fets gleid), oft mit fonberbaren Erweitermugen und Dornen verfeben. Die meiften baben cincu febr unangencbmen, efelbaften (3)rnd, Der lange baftet. Biele find mit fdünen Farben gejiert. Man bat viele Lluterfamilien unteridieben. Bai ben forgenden ift bie Ednabelfdeide oreiglicbrig und bis Jüfe baben feine baftapyen.

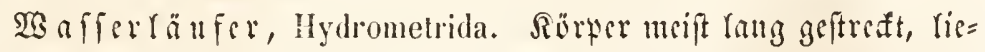
nearifa; Fübler lang; sierglisorig; Sdnabel bis auf bie Sorderbruft

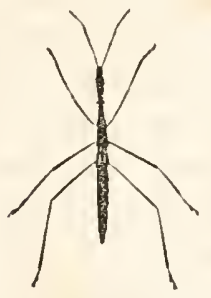

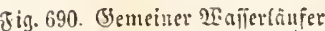
(ilydrometra slagnormul.) reid)ent, bidgt angebräft; Edaside oreigliedrig. Rebenaugen feblen. Flügel meift verfürgt oder felbft ganz feblend, felten wollftändig unb bamn Die Flïgeroecten ganj reorrartig obne bäntigen Anbang. Beine frbr lang, dün; bie Ginteren meift länger ars bie vorberet. Siralfen ill cinem

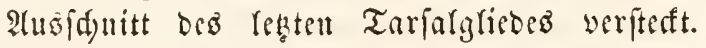
Der ganje Rörter if mit feinen, weid)en, fet=

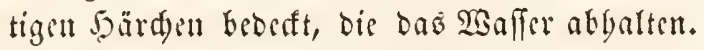
Die Thiere lanfen uno fpringen mit grofer Bebenbigfeit nuf oer Dber= fläd) bejonders ftebender berväfler mo näbren fid) won flcinen Sn=

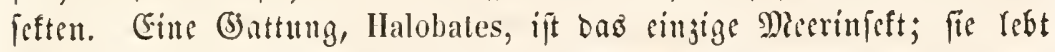
auf bober Gee in tropifden 3ouen. Hydrometra; Velia; Limnobates; Leptopus. 


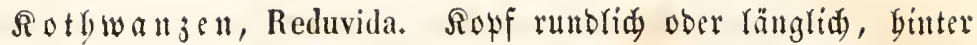

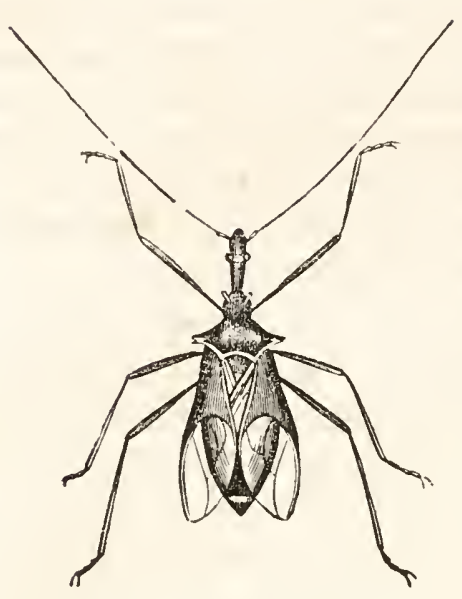

dig. 691. Sactertragente Futbmanje (Reduvius tuberculatus).

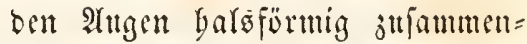
gefduitrt. Edyater furj, meift ab= ftebeno. Sübler lang, Dïnn; Plugen grof. Sritgeldecten wenig geabert. Beine meijt lang; Sdyenter oft wer= bifft, mit Stadyeln und Boriten be= febt. Sie nägren fid alle von anberen Sufeften, bie ibr, aud beul Mienfden fegr empfintolidyer Stidy augenbliaflid) töbtet; fino näd)tlid)e Tbiere, bie Tago Itnter Baumrinben, in Riket ber $\mathfrak{B}$ obnumgen Yauern und itt Der Dutt= ferbeit igrem Raube tad)geben. Rar= wetl meift bid)t bebaart, flaumig, mit Moeer uno Rebridyt bebeft. Reduvins; Gerris; Emesa; Nabis; Pygolampis; Cimbus.

$\mathfrak{B}$ eid)wange, Acanthida. Sopf tuld Reib flad, Gorizontar.

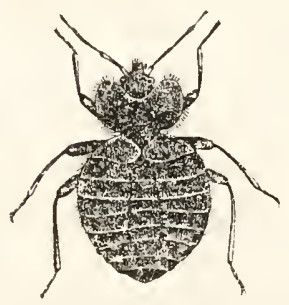

sig. 6.2. Stigen flein. Sdyabel furj, itl sitter Prinne unter ber Sieble verfteft. Fübler fnopf = ober fenlenförmig, furj, mur auf bic balbe Bruft reiderto. Flüger bünt, gentert, juweilen gänj= (id) febreno, Borberrilten, Jlügclocefen uno Sainterreib oft mit fonberbarell brajtgen unt bättigen Fortjäben verfeben. Berme jart, bünt, zuwsilen dic vorberen ju Raubfüben geftaltet Betrwanze (Acauthia lectularia.) unb verbift. Der ganje Sïrter weid. Seben mrift im Graje, ututer Bantmrinben, aber som Raube. Eine art, bie Bettwange (Acanthia leclularia), ift gänglid) flügerfos uno lebt nur

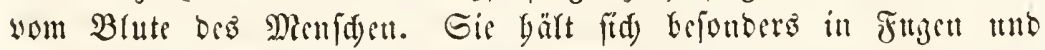
Riz̧en bes borjwerfes alt, erftart in ber Rälte unb fann in biejem 3uftanbe Jagre ofte Rabrung jubringen. Syrtis; Tingis; Aradus.

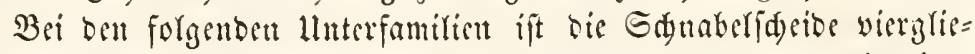
brig utto tteben ben Tarfartrallen zwei fleme Saftlapten angebradyt.

$\mathfrak{B}$ Yinbwa $z \mathfrak{z}$, Capsida. Siopf oreifeitig, Nttgen flein, Reben= angen ganj feblent. Fübler lang borftenförmig, bas jweite Grieb oft verbeft; Sörter meift ränglid, weid); Frïgeldeáen reberartig obne 2toern, mit jwei ungleiden 3effen; feglent juwetlen ganj. Betne bütm, farlen leid)t ab. Reben meift in Geferlfdaft im Grafe, an Banmptäm= 
men unb anf Sdyirmpflanzen. Capsus; Miris; Plytocoris; Pyrrhocoris; Halbicus.

Ranbwanjen, Coreida. Siörper meift länglidy; Ropf tlein, mit jwei beutfidyen voritebenden Mebenaugen. Fübler viergliebrig,

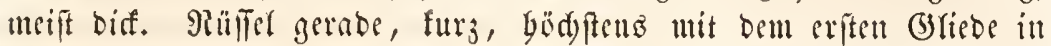

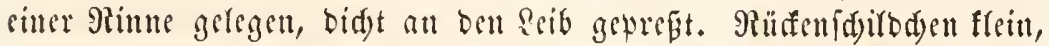
unbebeft; Flügerberfen reberartig. Sm Gebuifde, itm (3raje und auf Banmftämmen, leben vou Paube, fliegen zum rbeil gut. Coreus; Corizus; Anisoscelis ; Lygaeus; Pachymeris; Geocoris.

Sdilbwajen, Pentatomida. Rörper breit, owal, yart. Füb=

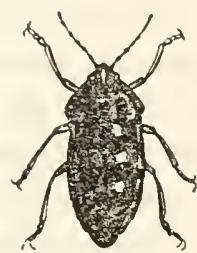

Jin. 693.

Blaue Eavilotwanze

selitellera

signata.)

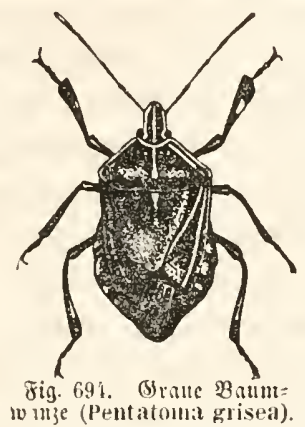
ler fünfglieberig. Dab Shild den Des Ritufens ift febr grofi, bebectt wenigftens ben Galben, oft ben gan= jen Jiuterleib, fo baf die Thiere won oben ber Siäfern febr äbulid feben. Sopffecil, Dreieffig; Jalo =

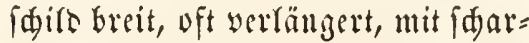
fen efen. Reben vereinzelt auf (b) w unze (Pentatonta grisea). Scutellera; Tetyra; Callidea; Cydnus; Cimex; Pentatoma; Acanthosoma; Aelia.

\section{Dic Orbun!y ber Gernoflügler (Orthoptera)}

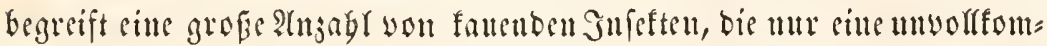
mene Serwanblung befitzen, unb beren Rarwen unb Suppen fid yon bem volffommenen Jufeft gautfäd)lid) nur burd) bie gröfere ober gerin=

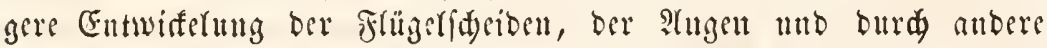

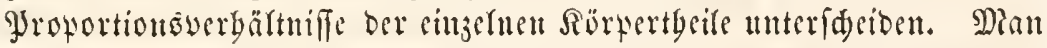
begränzte bio in bie nenete 3eit bie Drbnung gegenüber Derjenigen

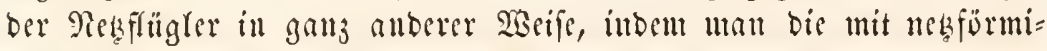
gen Flïgeln verfebenen Familien von ben Gerabflüglern abtrente unt ben Peuropteren jutbeilte, wenn gleid diefe sine rubenbe glatpe unt ganj anters geftaltete Diundotbeile befisen; erit jetzt, wo man ter

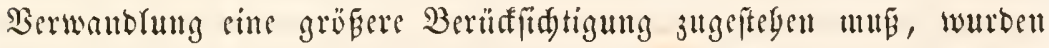
bie Netzflügler enger gefapt und bie ibnen früber jugetyeilten Gattun= gen obne Berwaudlung ju ben Berabflighern geftelt.

Man nuterfdecibet ftetõ bentlid die brei gropen Sï̈rperabtbei= lungen, Sopf, Bruft uno Baud) uno an ber Bruft meift mit Sidjerbeit 
die brei Ringe berfelben. Die Sörpertebefung ift weid, lederartig, oft mur febr zart, bei anbern aber, wenn audj bitun, fo bod) born= artig feft.

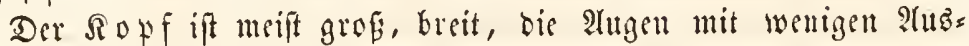

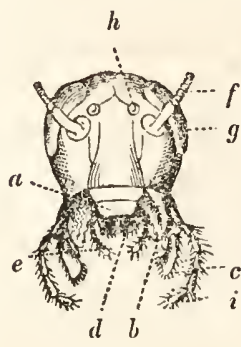

Jig. 695 .

Ropf einet Cdabe (Blatta) rou rotu gejebel.

a Sletlipbe, b Riun= baten. c Riunladen. d (S)e= fpaltene Unterlinpe. e sip= pentafter. f Die alsegrduitenenfüler. g ?lugen. h ?ie= benaugen. i Rimulatentaiter. nabmen ftarf berworteteno und mit siner gro= fen Fujabl Facetten werleben. Dis Fïbler fint fteto sorbanden und fait immer furent oder borftenförmig, oft won bebententer Sänge, bei andern fegr furz und anf cine fleine barborfte rebucirt. Sis fteben ftets jwifden ben Angen, Die bei mandyen familien ungebeuer grofi find, to bab the all einer bedeutenden Streffe des Sopfes einander beringren, wäbrend fie bei andern, vefonbers ben Sdureden, oft nur ziem= (id) flein fint uno vielen Sarven gänjlich feb= ren. Die Rebenaugen fodenen oft gänjlid ju feblen oder find fo flein, baj fie fid) umr mit Miilge entoefen raffen; went fie vorbanden, fteben fie im Dreief auf bem Sd)eiter.

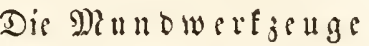

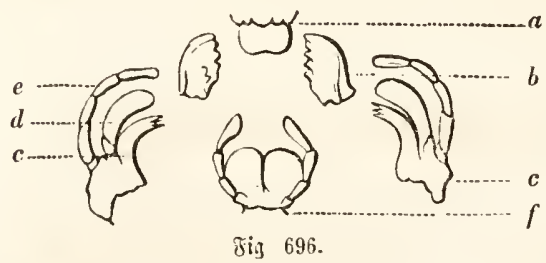

Rauwerfjeuge einer Ed)uarridgreffe (Acridium).

a Dterlipue. b Rimulaten. c Rimulade. d Şelm. e Shatpe Der Rimulate. f lluterlippe.

Der Gerabflighler fint ftets jum Sanen eingeridytet Imb nur bei wenigen Familien, berelt Biloer faum einige Stumben ju leben baben, ver= fümmert; - bei ben meiften ïbrigen febr ftarf unt an $3 u=$ fammenfezung feiller anbern Dronung naditebent. Die Dberlippe ift meift grof, breit; bie Simnbaten breit, immen gezäbuelt, bei ben fleifd)feeflenden Alrten ftarf bafig gefrümmt uno fpig; bei ben

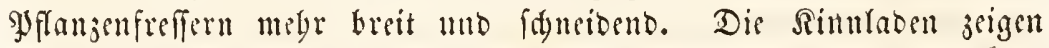
faft bei allen Familien eimen gejäbnelten Saautaft, fo wie beutlidge mebrglieberige garpen unt anferdem nod) sin mittleres Stn̈ä, weldes mamnigfad) wed) felnte $\mathfrak{B} e f d$ affenleit zeigt. Bei ben Beraoflüglern im engeren Gime (Ulonata) ift biefer Mittelaft blattartig gebogen, nad) worne ju breiter unb bilbet eine Gdmppe, bie woul beiben Geiten ber bie übrigen Miunbtbrile in äbulider $\mathfrak{B}$ eife beft, wie bie Ripten von oven uno unten ber, wepgarb man fie aud) ben belm (galea; galète) 
gennunt Gat. Bei ben l̈brigen, mit vier Rek̨flïgern werfebenen Fas milien ift refer Tyeil ber Siunlaben mur fabenförmig. Die lluter= lifte ift ftets aniegnlid entwifelt, breit unb in ber Mitte balo geferbt, bald burd) sitten tiefen Epalt oft bis anf ben (Brund getrennt; -

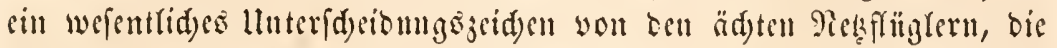

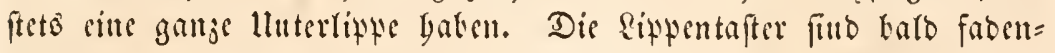
förmig, mebrgliebrig, bald breit, blattërmig unb baun in ägntidyer

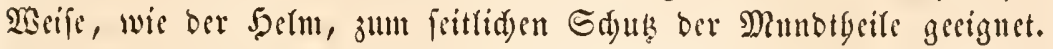

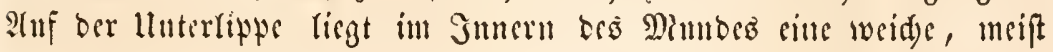
fuoffförmige 3unge.

Die Flïgel find tnd) verfdiebenen Rormen gebilbet. Die

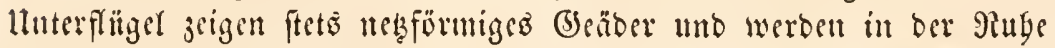
entweber ansigebreitet mo bann mifít fenfredt aufgefd)lagen, ober in

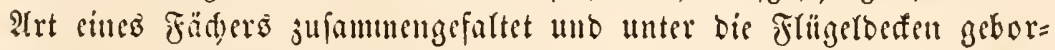
gen, in welderm Falle bann bie Sorberflüger mebr ober mittoer bäutig eridseinen und bie Rolle vou Flïgeldefen fpielen. 3uweilen feblen

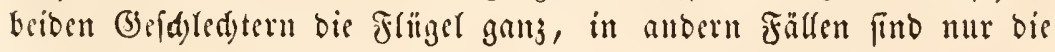
Sลeitd)en fliigello:

Reine Dronnng ber Juleften bïrfte fo visle Modificationen in Ban ber Fïfe aufmweifen baben, alz gerabe diefe; wir werben fie bei ben cinjeluen Jamilien alffübren. Der binterleib ift meift lang, bïnu; bei vielen mit einem Segefäbel ober cimer \&egeröbre, mit eigemen Zangenapparaten beim Männd)n, am binteren Ende verjeben.

Die anatomifde Etruftur ber Gerabflïgler gebt int Ganzen jiemlid) nabe an bie ser Säfer beran, went fie aud nid)t eine fold)e Mannigfaltigfeit ber Formen bietet. Das Rertenfy ftem ift ftets langgeîtreft, bie brei Bruftnoten, fed) bis fieben Baudjnoten bent= lida gefdicben und burd) bopelte Sängs faben mit sinanber verbunden. Die Brabflügler fint bie sinjigen Infetten, bei weld)en mit Sidger= beit eit (s) börorgan madygewiefen wurbe, weldes, merfwärbiger

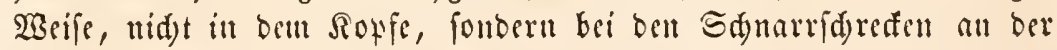

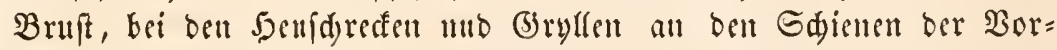
berbeine liegt. Bei erfteren befiubet fid binter einem Trommelfelle

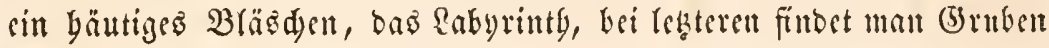




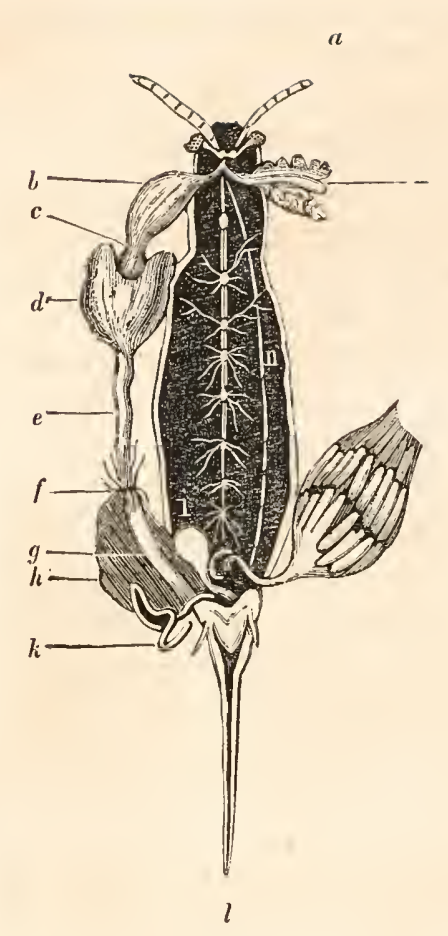

ชig. 697.

2!แatumic einer f̧euídrefe (Locuxia).

Die Derfe bes Rinfens it weggentm=

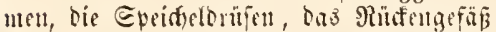
unt Det redste (Sirrito of Had) redyts, Darm= fanal uno ütrige Drgate nadi luts ge=

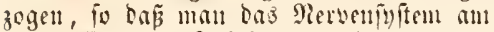
Slabe fieht. a Fühlfyörner. b firepr. c fiaumaget. d Miagen. e Sinterer Thacif

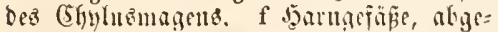
fdutten. g Dirform. h Eieritosfe i Samentaide. $\mathrm{k}$ Rittonife. 1 efigerifue.

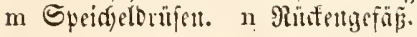

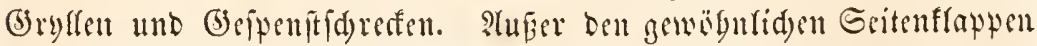

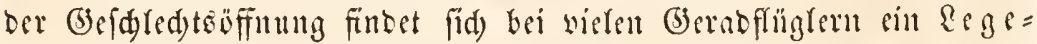
fäber oder eitte \&egefäge vor, die bald frei, bald im Sointerleibe werborgen ift. - Die 5 oden find aus Blindröbren jufammengefest, Die meift büfdelförmig zufammentreten; die Samenleiter find oft $u$ แr febr furz, zuweilen aber febr lang, fpiralig gewmuben und die Drii= fenapparate mandumal fegr bedentend entwiffelt. Der Senis ift yon

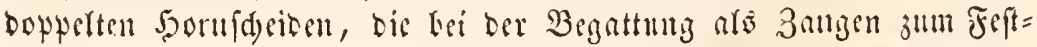
Tromutelfell mo Inbinter sille Tra= d) eenblafe liegt, läng welder Der [tezifiidse (s)bönerve (id) ausibrei= tet. Die Speiferöbre ift weit, fropfartig; Der Si aumagen, Der Darmuf folgt, im Gmeren mit $\mathfrak{g}^{e}=$ zäbuelten Formlatten berebt, Der

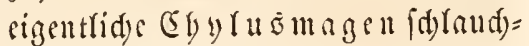
förmig; an oberen Crube Des Mra= gens finten fid) zwei ober megrere Blinbläce in bie Gpeidyelorị̈n singebettet. Der Darm ferbft ift fajt gernoe, bie Soarngefä brofer ?arabl norbandert. Dab Tradeenfyftem ift ungemein entwiffelt mut zwar it ber art, Dap ans jebem Etigna viele weite Stämme entipringen, bie unmittel= bar fid) an bie Digne verzweigen und ferge vicle negartize Serbin= Dungen eingeben, bie oft blafig auf= getrieben fint. Die crier fo ôfe fint ans vielen, zicmlid) laugen, biifdelartig ofer einzeilig in bie oft langen und gewandenent Cilciter eimmündenden Rögren jufammenge= ferzt; bie Ermentaide ift bimförmig ober aud in Gejtalt ziweier Brind fd)läud)e entwviffelt. Fine Begat= tungstafdye baben nur die Ribelfen, sin Sittorgan nur bie Soenfdrifen,

oder Sabblen, zutiden benent ein 


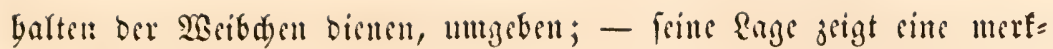

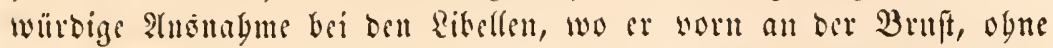
3ufammengang mit ben iibrigen (jofd)ledtstbeifen, angebradt ift.

Die ausgebilbeten Jufetten lefon alfe auf bel Eroe, in freicr Ruft; frittes in ober auf Dem SBaffer; and) gieft es frime Sdjmarober unter dicfer Srbunng. Die meiften leben won Ylfanjenblättern, Blu= menfäfen oder trofenen glflanjen und Tbierfoffen und mandse wers Den burd) igre 3 abl uno bifrägigfeit auberovbentlid) fdäblid. Nur wenige finto gäuler, bie fid won andern Snfeften nälyen, weld)e fie im Fruge ober Sprunge barden. Fine singige Familie lebt gefellig in beftimmten fojiafen Bejiebungen, affe anbern, wenn alld oft in ungebeuren Sdawärmen, vereingelt für fids.

Dis Rarben finden fid meift anf ocm Sande, wentige fantilien

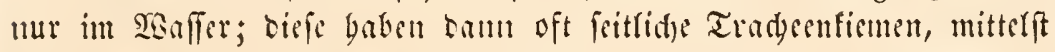
beren fie atbmen. Rauwerfiuge, Fïbe unt Reib biefer Sarven finto benen bes Bilbes febr äLnlid), mur feblen die Flüger burd)aus. Bei ber jueiten Säntung, nad) weld)er bie Thiere als freffenbe Jupte

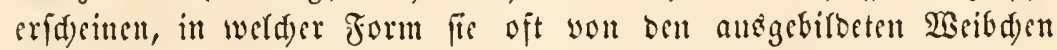
mux fdiver zu unterfdseiden fint, fommen bie Flüger in (jeftalt furjer

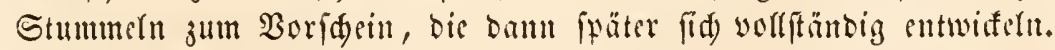
Die Rarven ïberwintern gewögnlid alo folde, wäbrello in Frübiabre

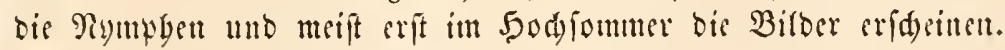

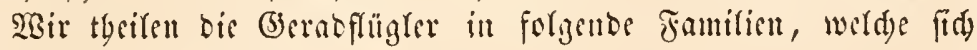

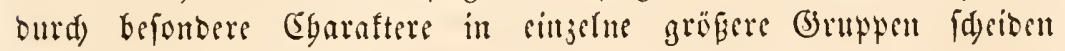
rallen.

Gine gröfere (3ruppe jeigt verfdicbene frifgel, inbem bas vor= bere Jaar leberartig, ju Flügeldeden, bas jweite Gautartig ift nut (iid) fäd)erartig faltet.

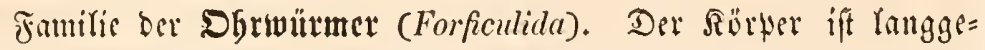

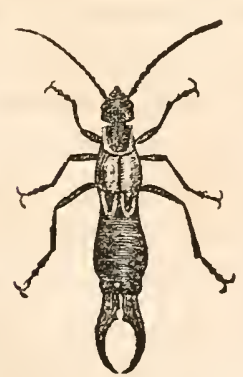

8ig. 693. Demeiner D6rwurm (Forficula auricutaria), Iauferio. ftreft, idumal, Der Sintreleib nur im Infange yon ben furjen Fingeloeden bebert. Der Ropf runtrid) ober Dresectig; Die Fübler jiemlid) lang fabenförmig, aแs 12 bis 40 Gliebern juam= mengeferst; bie Angen flein, freisund, bie Rebenaugen feblen. Der ddief nad) vorn ge= ridetete Miund jeigt eine balbrunds Dberlippe, breiectige, inten fdarfe, worn mit zwei Jafen= jäbnden befeste Riefer; (d)wad)e, jweigäbnige Sinnlaben mit idmalem Şelm unt fünfgliebe= 


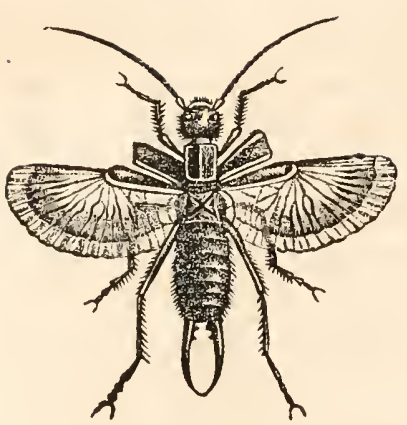

כig. 699.

Derfetbe mit aแşgebreiteten จินี้getn.

rigen Tajtern, beren erfte beibe Srieber febr furz füb unb sine bis zun Srrulloe gefpartene lluterlipte mit breiglieberigen Taftern. Die Flüger fint fo eigentyüm= rid) gebilbet, bar viele Raturforidger eine sigene Dronung (Dermoptera, Labidura) aus oer Familie madjtert. Die Flügel= befin fitt nur furj, reberartig; die llu= terfliiger befteben nus siltem fdumalen, leberartigen Stüd, etwa länger als bie Flügeloefen, an weldsem sill grofies, Galtreisfërmiges, von burd) fidtiger Şant gebildetes Strïf befeftigt ijt. Diefes bäu= tige Fringelftül legt fid) fäderartig zufaumen unb jwar fiofen bie Falten aut äußeren Enbe bes Reberftüfes jufammen; fo bas alfo diefe Faltung ganz ber bei ben llfonaten gewöbuliden gleid) ift. Der ge= fartete Fäd)er fuift fid aker nod) eimmal quer ill ber Mitte eill, wie

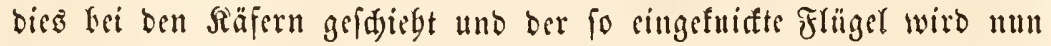
unter bas Reberftül bes lluterflügels gefd)oben, fo baf ber llnterflï=

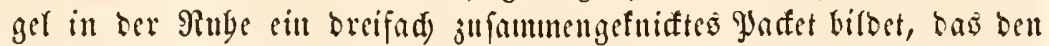
größten Theil bes Şinterleibes frei lägt unb gaus unter ber grlügel= beffe fteft. Die Beime fint (d)wad, bie Tarfen breigliebrig, bab Enoglieb mit zwei Siralfen, juweilen aud) mit einem fleinen Ballen verfeben. Der Şinterleib der Männd)en Gat teun gleidggropse, ber

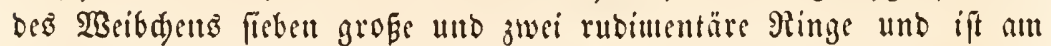
Enbe mit einer gebogenen Zange bewaffuet, bie beim Männd)en meift länger und gezübuelt ift.

Die Dgrwïmer fint febr unfdäblide Thiere, bie gern bunfle

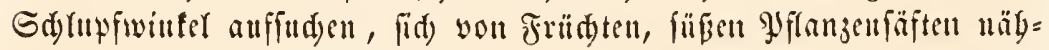

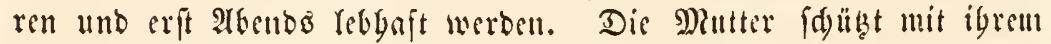

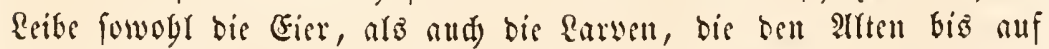
die feblenten Flüger febr ägulid) fegen. Forficula; Forficesila.

Die folgenden Familien Gaben reberartige Flïgerbecten, eittfad) fäd)erartig gefaltete lluterflügel unb cinen Jaelm an ber Siunlabe. (Ulonala).

Die Sthaben ober Safertacten (Blatlida) baben eitlen abge= platteten, runbliden ober liufenförmigen Siörper unb cinen feimen 


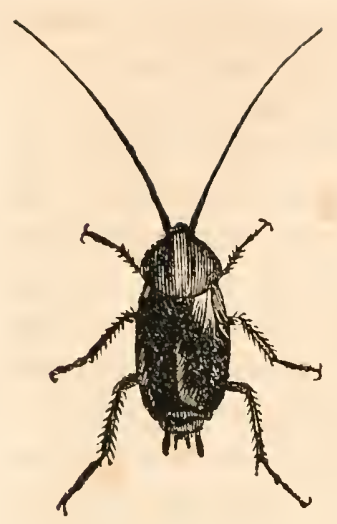

Jii] 700.

Deutifie Sd)abe CBlatla germanica).

bergfürmigen Sopf, ber fenfredut unter ber Borberbruft ftebt unb meift ganj won wirb. Fibler febr lang fabenförmig; Augen flein; Rebenangen zwei, faum bemerffar. Rie=

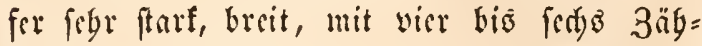
nen am Sunenranoc; Rimulaben bebaart, Sclm oval; Rabentafter fünfglicorig; Untertippe ganz geffarten, Sippentafter fünfglicorig, Bruft fdilloförmig, faft orcectig, Borberflïger felor breit, bïnn, mit bünuerem Innenranbe; lnter= flïger großz, orciedtig; Leibe uncift febr verfdice oen bei beiben (Beid)led)tern. Fine Gattung (Polyzostera) ift gallo. flïgeflos; bei anbern

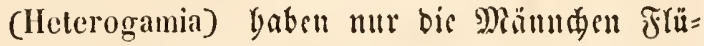
ger. Fü̈je - Edyreitfïfr - alle gleid); Tar= fan fünfglieberig, mit jwei Rrallen unb Fup̧ballen bajwifdsen. Itm Sinterleibe feitlid) geglieberte, ftad)clartige 2nbänge. - Lnangenegme,

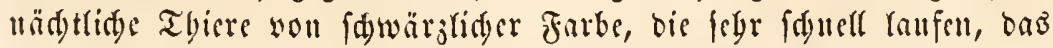

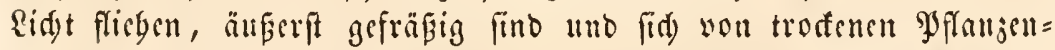
ftoffen, befonbers aber won allen ?irten trofener Rabrungḡborrätbe fïr Menfden eruäbren. Sie fuden bef̧baltb vorzugșweife Säufer und warme sunfle Sdylupfwinfer auf. - Einige Arten Yaben fid über bie ganje Crobe verbereitet. Dis Fier werben 110 d im \&eibe ber Mitter

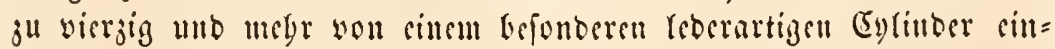
gefdyloffen uno in biefe Stifle gelegt. Blatta; Corydia; Blabera.

Familie ber Edyreffen (Saltatoria). Die Sdreffen Gaben cinen breieftigen ober rublidyen fiopf mit fenfred)t nad) unten gerid)tetem Miaule. Die Fïbler fillo meift lang faoenförmig, felten fur ober gar feulenförmig, bie 2ugen rund, vorftebent; Rebenaugen oft beut= lid in oer Dreizabl, juweilen febr verwifdt. Die Siauwerfjenge fint ftets febr mädtig; bic Dberlippe grofi; bie Riefer fdarf, breit, innen gejägnt; bic Rimnlaben meift gezägnelt, igre glalpen ftets fünfglicberig,

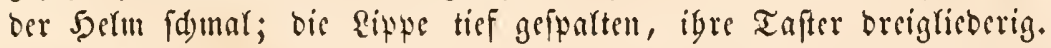

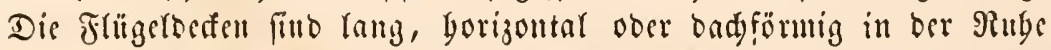
gelegt, uno bei ben veridicoenen lluterfamilien verfdieben geftaltet, ba fie bei sinigen are Toninftrument bienen. Dic Saenfel oer Sin= terfïßse finto verbift unb jum Springen thidstig; bei sinigen von un= gemeiner Ränge. Dlan unterfdeizet mebrere llnterfamilien. 
(5) ryllen (Gryllida). Die Fügler find febr lang, fcin, borften=

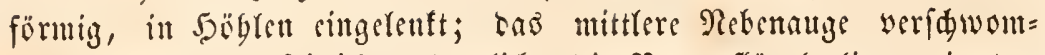
men, bie beiben jeitlidsen beutlid); bie Borberflüger liegen in ber Prube borigontal auf bent binterteib auf und find weit fürzer alo bie Flẗ̈gel, welde meifít breit aber ungefärbt find und riemenförmig ober in Spirafform aufgerollt anf bem Scibe liegen. Den Atmcifenbeimdsen

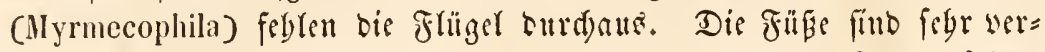

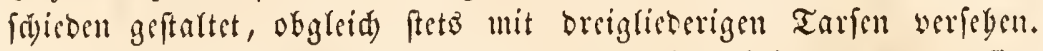
Bei ben Einen fint bie Borberfüpe gewögnlid, bei ben andern finto

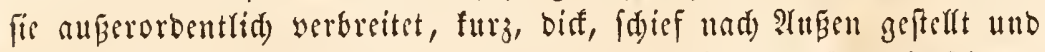

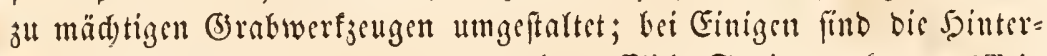

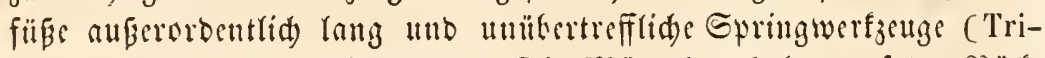
dactylus), bei anbern fdwäd)er. Die Miänuden baken auf ber Plü(t=

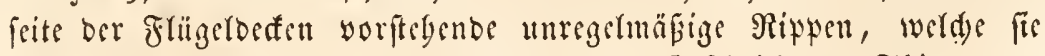
Geftig ancinanderreifen, woburd tas laute Gerfdrille ber Thiere ents

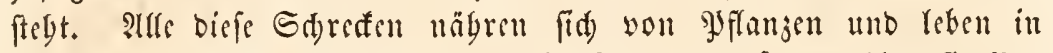

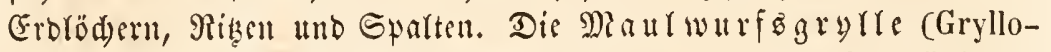

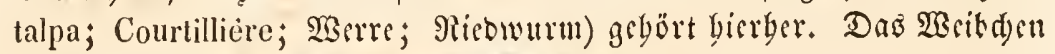

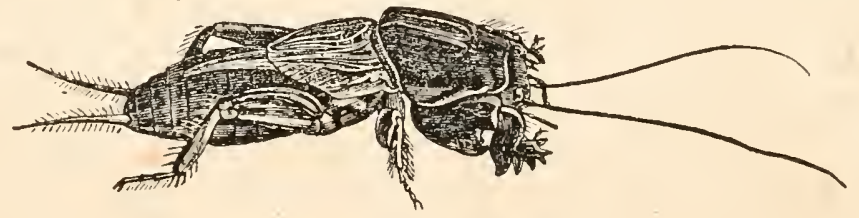

ชig. 701.

(5)emeine 2Berte (Gryllutalpa vulgaris).

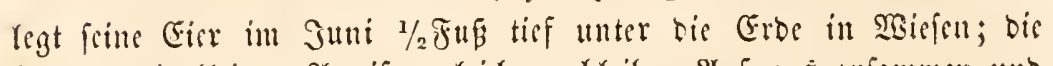

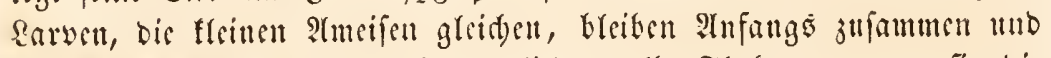
zeigen igre (begenwart burd) runblidse, gethe firefen ait, wo fie bis Braswurgech jerfreffen Gaben; fie üterwintern zerftrent und vollenden

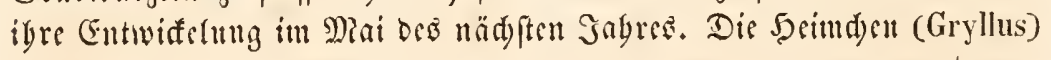

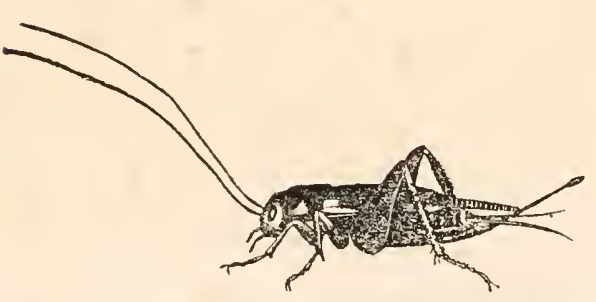

Jig. 702. Ins . Sam greimdien (Gryllus domesticus).

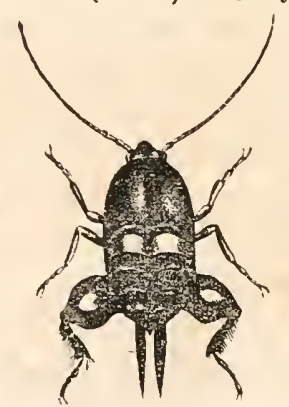

5ig. 703. Die Tureifenfifrerfe ifymecophila. 
im Felbe mot in biufern, bis P(meifubeimden (Myrmecophila) in ?meifenbaufen.

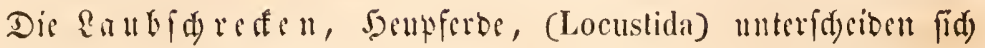

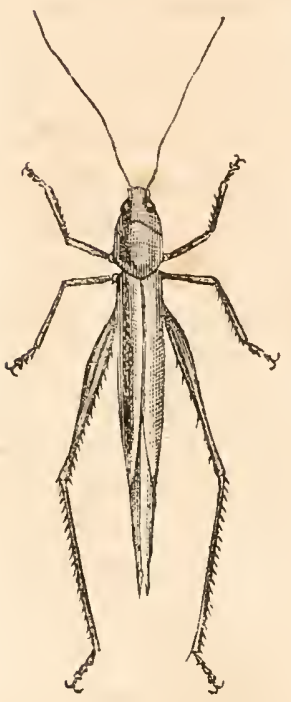

oig. 701 .

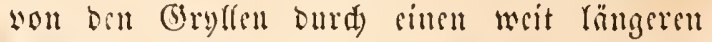
Siopte, Durd) ibre felgr feinen unb lan= gen Füblgirner, Durd) die rangen Flïget= becfen, welde nid)t borijontal, fonbern bad)= fïrmig in ber Rube liegen unb bic lluterflüget fait ftets gänjlid) beefen, fo wie ourd) bie viere glisberigen Tarjen, bie mit breiten, bergförmi= gen boppelten Jubballen verfeben find. Beide (b)efd)led)ter fint glcid) grob; bie Deännd)en baben in bem aufliegenten Theile ber rediten Jlügeloeffe eimen runbliden Durd) fid tigen Spie= gel, yon einem ringartigen erbabenen Rerwen umgeben unb im linten Flïgel, ber meift auf fem redten liegt, an ber entipredenten Stelle fart voripringente Rippen. Beibe Tyeile werben mit grofer Sdunelligfeit anfeimanber geristen und erjeugen fo bas Singen. Die 28 eibden baben einen langen, meift gefrumm=

Inร grüle Јॄeutferb (Locusta viridissima), ten Segefäber. In 2 säroern uno Gebrifden, nuf trodenen Siefen; fpringen weit beffer als Die vorigen; branden bis Flügel meift mur als Follfdirme; frefien Eant mo (bräfer, werben aber felber ourd) igre 3abl fdöblid. Locusta; Decticus; Gryllacris; Phyllopterus; Ephippiger.

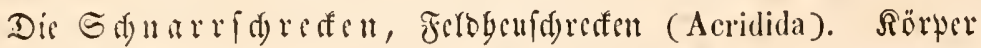

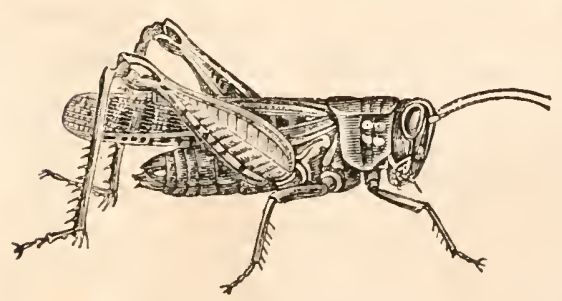
fürzer, giorängter; fübler furz, fiets fürjer als ber Siörper. Dis Sunftaugen find meift febr Dentlid); Dis Stirn Dresectig, oft zwifchen ben ?tugen frib worite= bent. Daz Gebörorgan, wel= d)es bei ben beiben vorigen linter= Familien in ben Sdjienen ber

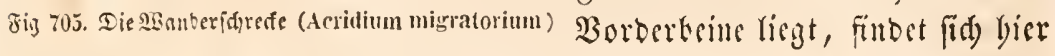




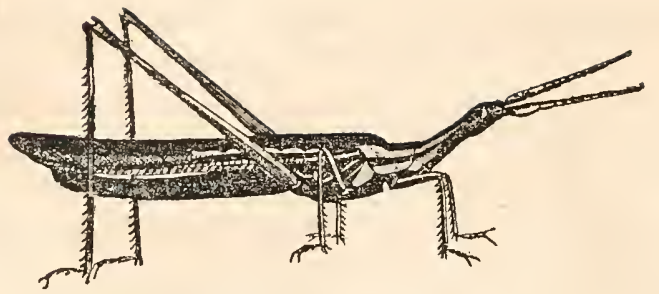

8io. 706. Tafenffirefe (Truxalis Masuta).

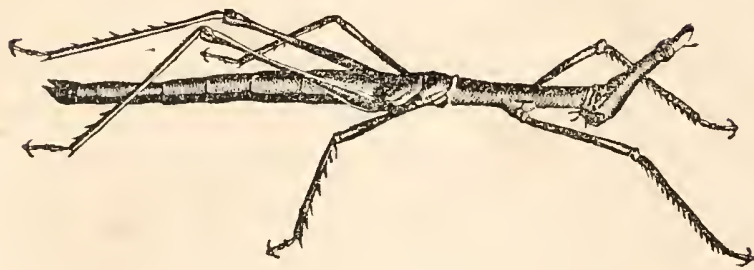

Jig. 708 Proscopia gigas.

atl erften $\mathfrak{B a n d}$ ringe Did)t litber Den Söffen. Die Regeideibe ber 2Bcibd)eno beftebt nidyt ans feitlidien, fonbern zwai oberen und jwei unteren Stüfen. Dis Tarfan futo breiglicbriz; bie Sprungbeine meift febr ftarf; die Flingel grob, mäctig, bäufig (d)ön gefärtht; Dic Stimme wirb ba= ourd) bervor ge= bradit, bais dic

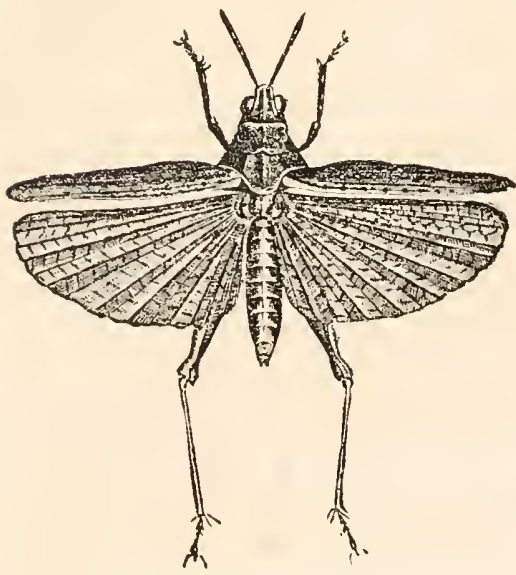

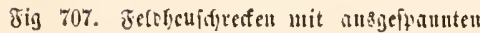

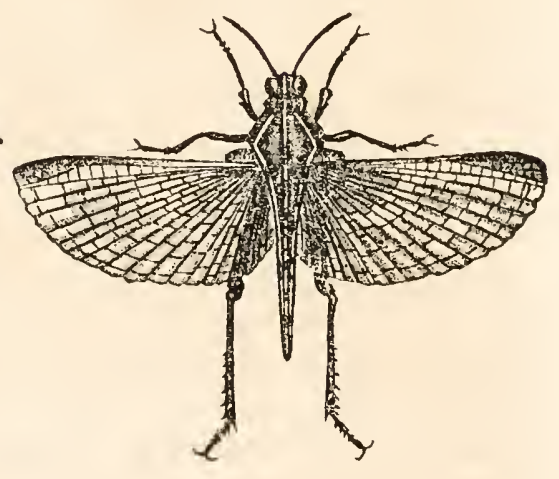

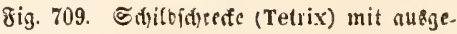
fpanten zlügefn. ztügetu.

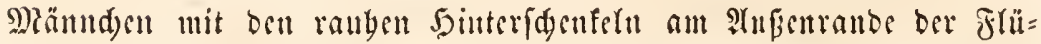
gelocten geigen. Die Thiere fliegen meift gern mb reidgt und ver= cinigen fid oft in Sd)wärmen. 3u ibnen gebört bic sanberbenfdede (Acridium migratorium) ber firblid)en (begenden, beren Seere wolfen= artig beranjeben unb burd) ibre unfäglide (befrägigfeit und jabrlofe Dlenge fo vielen Sdaben aurid)ten. Proscopia; Truxalis; Tetrix; Gomphocerus; Occipoda; Acridium. 


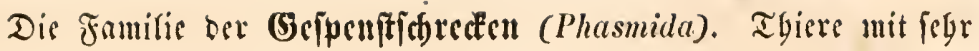

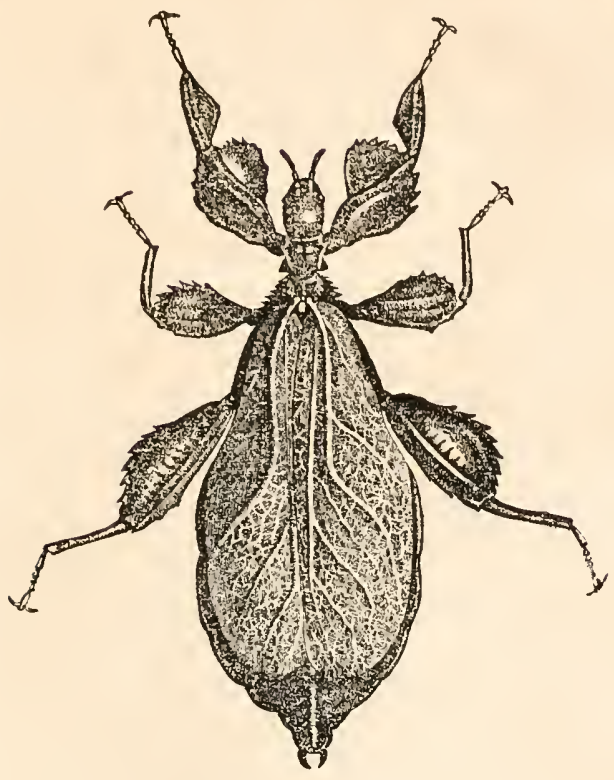

Jig. 710. Das trofene Bgatt (Phyllium siccifolium). langgeitreftem, ftabförs migem Reibe, vou jeltiam fparrigem ungelenfem Infeben, meift yon be: Dentender Grö̈e. Sopf cirnno, nad) worn ge= ridftet; Nugen flein aber ftarf vorjtebent, fugelig; Rebenaugen meipt un= Deutlid). Dberlipke grob, tief aแşgefduitten; Ris= fer flein, gezübuclt; Ilnterlipese viertbeiliy, bis auf ben Grund ge= fpalten; Ripentafter grofi, oreigliebrig; Niun= labentafter fünfglicbrig. Jiibler fabenförmig, ftetö fürjer als ber esib. Jlügel feblen oft gänj= lid); obere freft ftets felyr furz, fo bas bie Unterflügel nod immer sin oferes leternatiges Defferb baben. Bsine meift lang unb bünn, alle

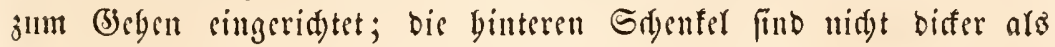
bie worberen, oft aber alle mit blattartigen Enpten und Reiften ser: ziert. Die flügellofen Rarven zeigen meift bieje 2tubänge unb Stad)eln weit ftärfer entroidelt. Tarfen fünfglieberig. Träge ̧njeften ber tropifden Giegenten, bis fids in befabr fteif maden unb nur yon gyflanzen Yeben. Bacillus, Bacteria (ganj ungefligelt); Cladoxerus (2Bribden ungeflingert); Haplopus; Phasma; Phyllium.

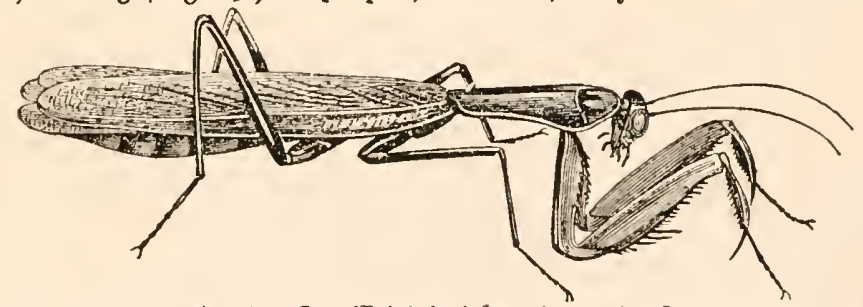

3ig 711. Das Meintahthnel (Mantis religiosa).

Fangheufdaredét (Mantida). Rörper langgeftreft; Ropf flein, fenfred)t geftellt; brei beutlide Rebennugen; Ptugen febr borftebend; 


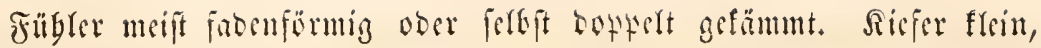
aber fegr ftarf unt vielfad) gejägnt. Llnterlippe vierlappig. Der

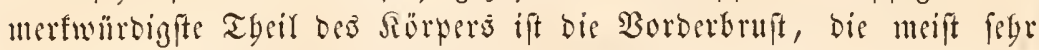
rang, bünn, badförmig ift und Gark anfgeridetet getragen wiro, indem an igrem vorberent Tyeife bie Breiffin

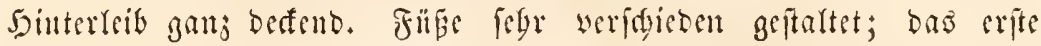

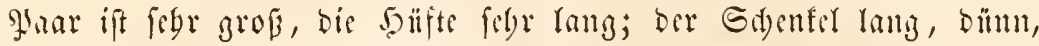

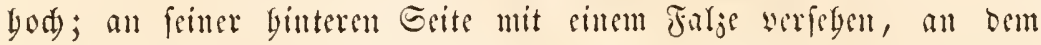

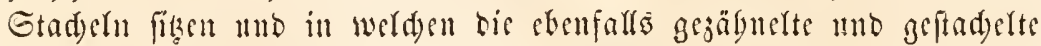
Edjene wie cine Tafdenueffertlinge singetlatpt werben fam. Die Finke werben beim Geben fiets ertyoben und cingefdalagen getragen, fo Daßj man glaubte, bie Snfetten gingen in Getender Etellung singer.

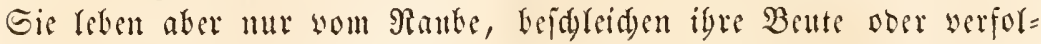

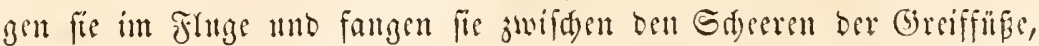

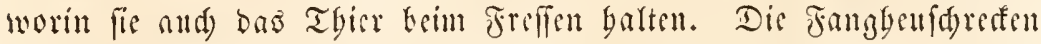

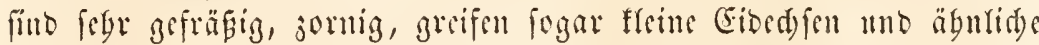

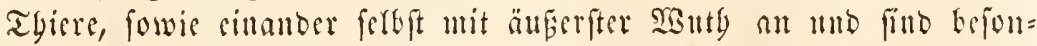

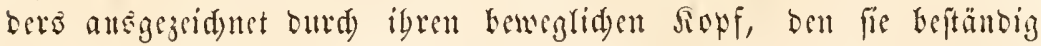

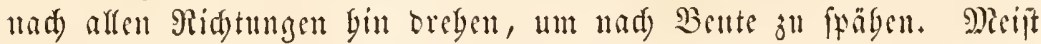

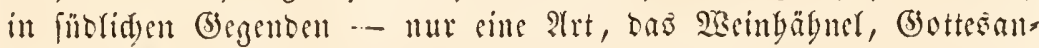
biterin (Hantis religiosa) gegt nörblid) in Deutfdaland bis jut Main= rinic. Mantis; Empusa; Blepharis; Harpax.

Bei ben forgenten familien fint Lie Borberflïger ben binterflï= gelnt in ibrem Baue gleid, wern and) oft in Form mo stuferen ferte

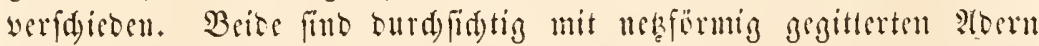
burd)zogen und bie llnterflüger werben nimate fäd)erfürmiz gefaltet.

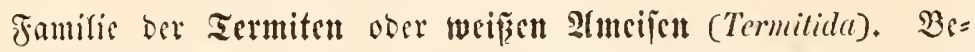

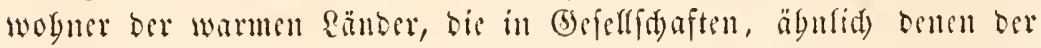

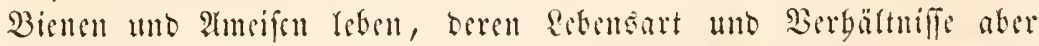

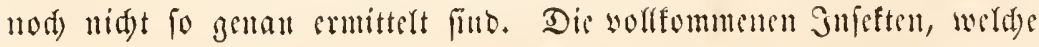
geflügelt finto, baten einen runten siopf mit worftegenten ?tugen, orei Rebenangen, furzen, rofenfranjartigen Füblern uno siamerfizmizen,

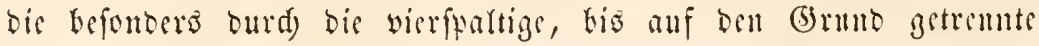

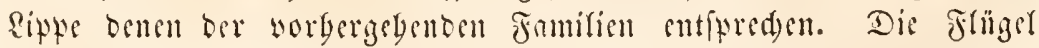

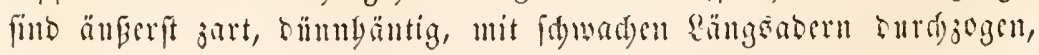


ชิ่. 712 .

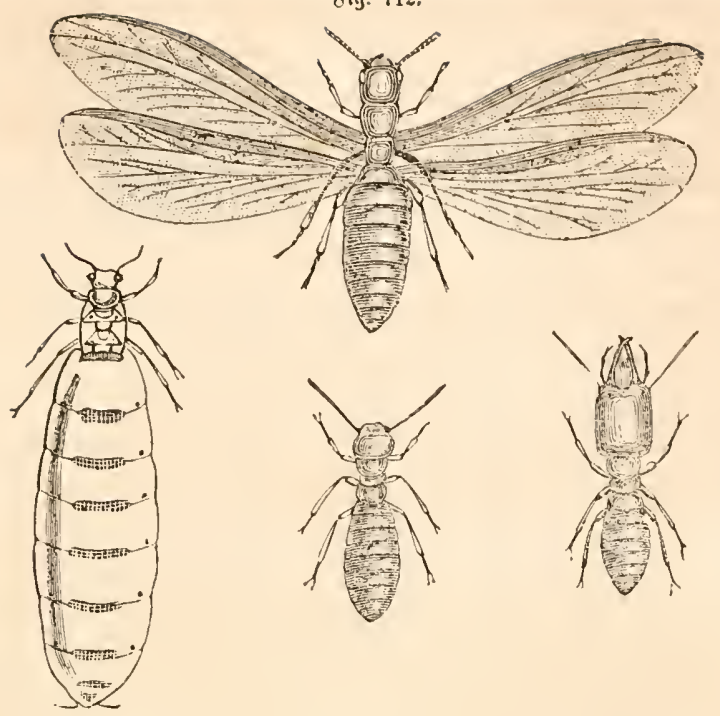

ชิ่. 713.

ชig. 714.

Jig 715.

כi. $712-715$. Termiten.

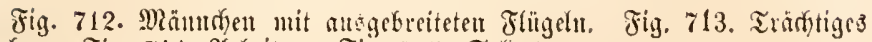

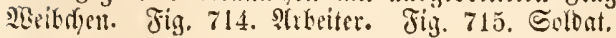

feben auf furjen Stunumeln unb fallen bei beiten (Beid)led)tern leidt ab. Die Tarjen füb siergliebrig. Die männliden Snbiviouen baben

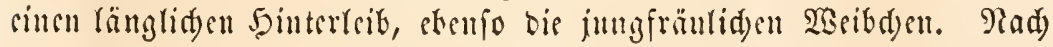

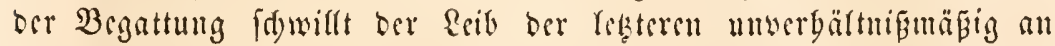

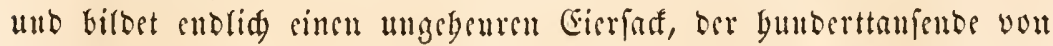

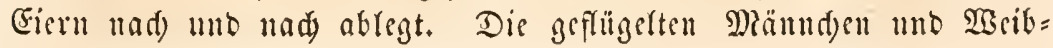
den vertaffen ju gewiffen 3riten it Edwärmen ben Stoff, unb be gatten fid) anfen; bie befrudyteten 2 seibd)en werben jurïrfebrad)t,

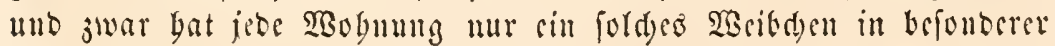

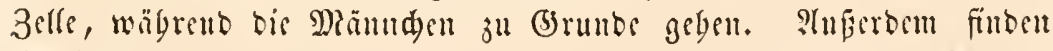

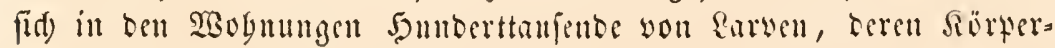

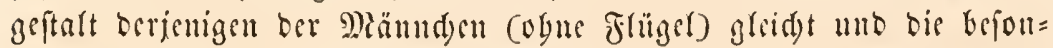

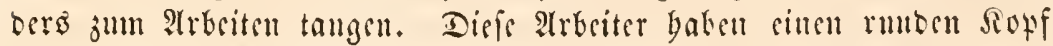
mit ocutrid)en 2lugen mo wenig soritebenton Siefern. Sie jeigen ie nad) ifrem atter, mebr ober meniger bentlid)e Flïgelfummeln. Fulo= (id) sine vierte ?rt you Snbiviomen, yon benen man mod) nidst red)t

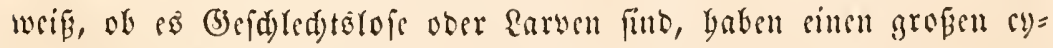
linbrifden Sopf obue atugen, mit fpilser Sdyanje uno langen, fdar = 
fen, ftatf gefrenjten 5afenfiefern. Sie fino weit weniger zaflreid, alo bie 2 trbciter, Deren Thätigfeit fie zu beauffidtigen fdachen. Sie vertbeibigen bejonbers bie şogunng, webgalb mau fie aud Solbaten

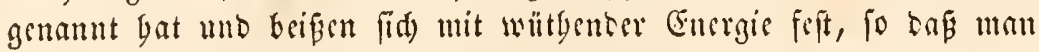

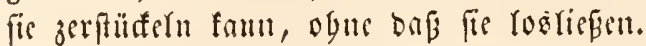

Die Termiten find weit fleiner alo unfere Imsifen, aber weit

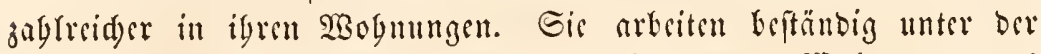

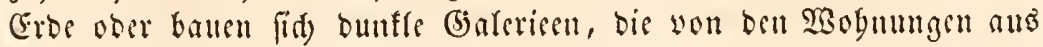
nad) Den Drten igrer Tgätigteit fübren. Gie nagen ?tlles an, befon=

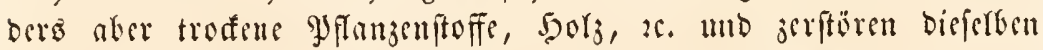
wou innen beraus, fo baj man erit beim 3ufammenbred)en ber volle

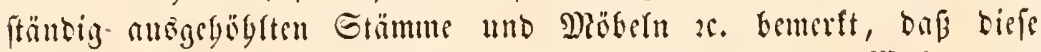

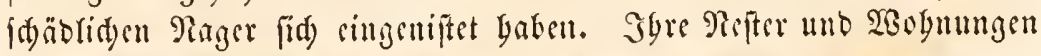

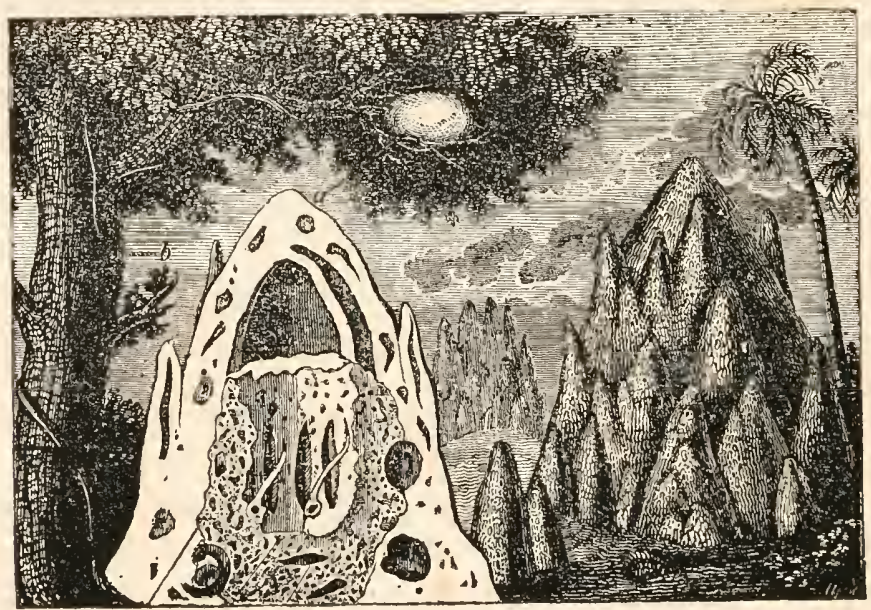

รig. 716.

SBofnungen von Termiten. Die fegelfömigen Stefter, von benen bas vorbere fenfredt Dutdiffnitten ift, gefiuren bem Termes bellicosus; - Dn 3

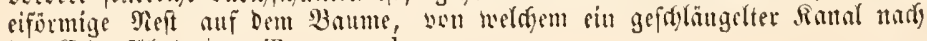
Der Erbe füfrt, tem 'Termes arborum an.

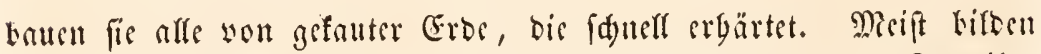

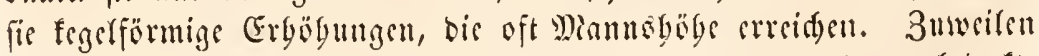
werben bie Refter aud) auf 3 ammäifen angelegt, wo bam betedte Gaferien 3ur Erbe fïgren. Sin Junern biefer ungebeuren Refter finbet man sine groge Galbrunde 3elle, bie wou bem befrudsteten

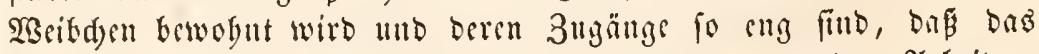
2 esibden fie nidat werlallen fann. Go wirb bort won ben Arbeitern 


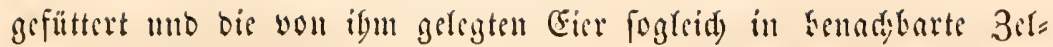
len gefdyaffi, wo fie won ben Prbsitern teforgt werben. Dis 3ellent fïr bic Eicr mito jungen Sarven befteben aus gefautem mab zna

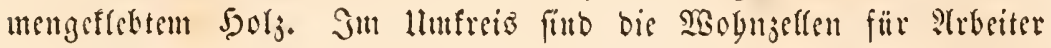

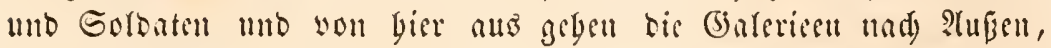

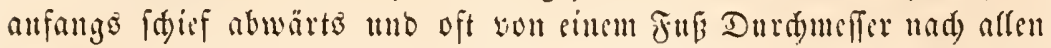
Sritu bit, bis fie in grober Entfermmig au ber Dberfläds wertbeift nแร่lanfen. Die Termiten fammeln sbenifowenig wie dis Stmeifen $\mathfrak{B o r}=$ rätbe sill. Termes.

Der vorigen Familie fteben fegr nabe de (Embionen (Embida), vereingelt lebente fïblidge Snjeften mit feftgaftenden Flïgeln, bis anf feinem Stummel fteben, augefdwollenen J̈̈̈en, breiglieberigen Tarfen tmb unr jweifpaltiger llnterlippe. Embia.

Dis Bücherläuje (Psocida) baben sinen breiten Sopf, worquel= lenbe Angen, borftenförmige, furje fithler unt im Dreief ftelsente Rebenangen. Die flïget fint entweber fegr grofi, bäutig, burd) fids)= tig, mit wenig tekartigen P(oern burd)jogen, ober feblen ganj. SJin= terleió furz; fïne büm, lang; Tarfa mu jweigliebriz. Dis Sian=

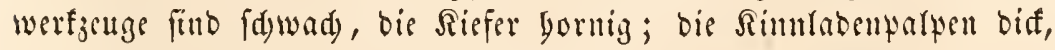
cy)linbrifd, fünfglicorig; bie sippentafter febr bünn. Sileiue, weidse, (d)uelfe Jnicten, bie an bunflen Drten Keben; - unter Rinben, in alten Büd)ern uno Sammlungen werben bejonberso bie Raryen bänfig gefunton. Psocus; Troctes; Thyrsophorus.

Die Familie ber Blajenfüre (Physopoda) Keftebt ans fleinen, bödftens sine Sinie langen Infeften, bie meift anf Błhmen, Blättern, Bammrinben leben, fduefl mo gemant umberlaufen und jiemtidy be= beno fpringen, inbem fie ben umgefdlagenen syinterleib int äbulid)r

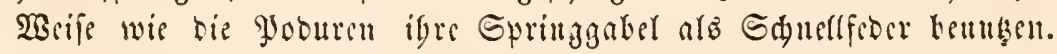
Der \&eib ift lang, idmal, flad); Der Jouf fenfred)t geftellt, oer Wiund nad) unten geridetet; Dis Fübler adjtglicberig, fabenförmig; binter ignen ftegen brei im Dreise geftellte Pebenangen; Die Plugen fint

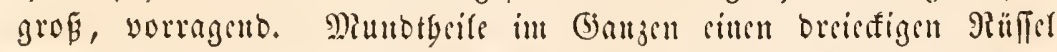
birbeno; Dberlipe orciscfig; Sicfer borftenförmig; Sinnlaben flsil, an bis grobe lluterlippe feftgewad)fen; sippen= mo saben = Tafter

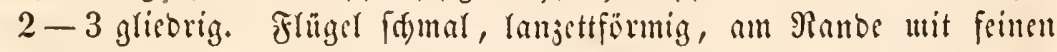
langen Saaren befekt; Borber= unb Şinterflëgel gallj gleid), burd)= fidtig, nur mit parallelen Rängänbern. Beine furz, bie Tarjen nur jweiglieberig mo bas lebgte Grieb mit einem rmben Sanguapf ver= 
felen; ogme Gpm. von Siruen. Sie nagen befonbers bie Dberbaut ber Yyflanzen uno Blumenblätter ab. Phloeothrips; Heliothrips; Melanothrips; Thrips.

Die Rarben ber folgenben Famitien Yeben im $\mathfrak{x a f f e r : ~}$

Die Florfliegen (Perlida) baben sinen grofien, breiten fiopf,

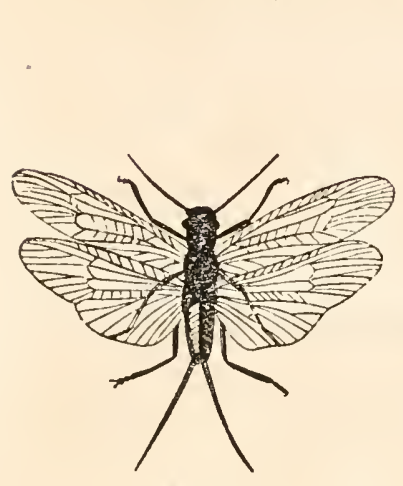

8ig. 717.

Bafie Jlurfliege (Perla patlida)

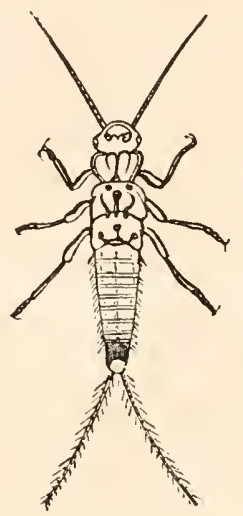

กiิ. 713.

vorftelyende Afugen, fange borfenförmige, weit yon sinander allf Der Stirn eingelentte Fübler; febr (d)wad)e Rauwerfaluge, bäutige fleine Riefer, Dogegen lange vorwagen= De ituete und äubere Sinnlabenpalpen und Rippentajter. Die Flüget werben in ber $\Re$ ube ge faltet und libereinander gelegt, fo baß bas $3 \mathrm{n}=$ sarve run Perla. feft febr f(d) fie baben mebr Rebaber als bei ben vorbergebenden Famition. Die Füpe fut lang, frin, bie Tarfen mu breigleorig, mit sinem Baffen jwifden Den Silanen verfeben. Der Shinterleib triggt jwei mebl voer minder lange Altbänge. Die vollfommenen Infeften leben von Blu= menfäften; die Rarven balten fid) bejonders gern it fliefenden (be= wäfern unter Strinen anf, baben grofie bafige Riefer und feitlidye baarförmige Trad)enfiemen an ben Seiten Des Şinterleiber, bie bei siner battung (Pteronarcys) fogar bei bem wollfommenen Sufette alb feitlide Fäben überbleiben. Perla; Nemura.

Bei ben (Eintagsfliegen (Ephemerida) find bie Sianverfaenge faft

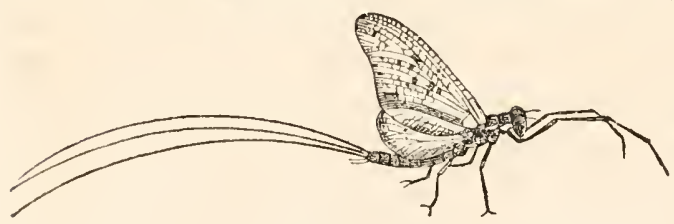

ชig. 719. gänjliç) verfümmert, fo Dá fie firum ju erfent= nen fitto - namentrid) frblen die Riefer gänz= (id). Die Thiere leben faum cinen Iag alb Emammerbanm's (Fintagsficge (Ephemera Swammerdammi). Bifber unb fieffen wäb)= 
renb biefer 3eit miemats, fonbern bänten fid) nod) eimmal nad) bem

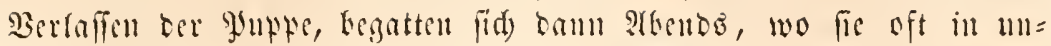

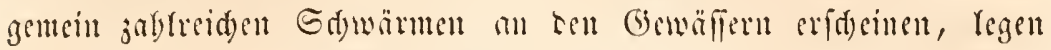

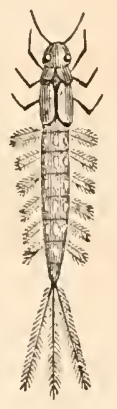

Jig. 720 .

Sarve ei er Ephemera ibre Eier nuto ferben an nädften Miorgen. Die Fübler fint ferr fur'j, orcigliesrig, borftig; bie Bor= Derflïgel, weit grüßjer alò bie Şinterflügel, werben in Der Anbe anfred)t getranger; Die BorberfüEe ferr lang, sün ; die Tarfen sierglépberig. Der febr weide Sinterleib trägt jwei sber brei feld lange Jaarbor= ften. Die Rarven leten jwei bis brei Jubre in

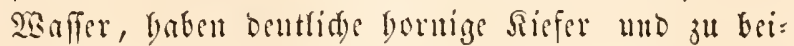

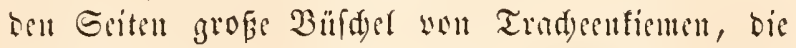
jugleid) alè Ruber bicuen. Die freflenben Pyuthen

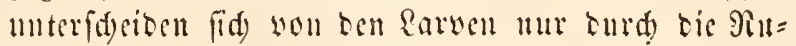
bimente ber Flïgel. Ephemera; Chloc.

Dis Teţte Familic bicfer Dronung ift bic ber 2 anflerjungfern (Libellulida), befantnt

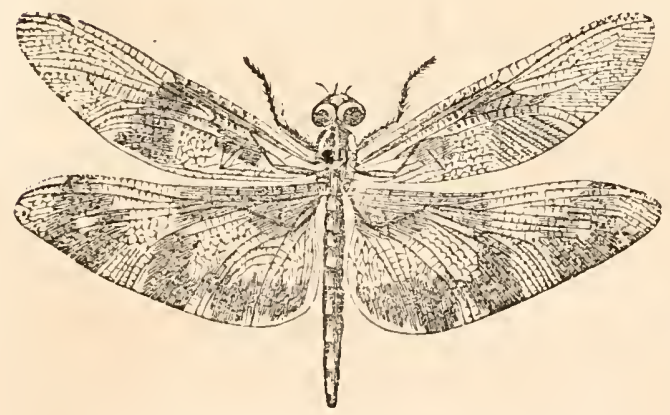

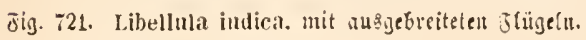
wegen igrer fdilanfen (be = ftalt uno ben meift id 0 : nen, burdy fid tigen Gdyit= rerfarben, werdae ibre Slïgel jierelt. Der Sopf ift grob, breit; bic ?tugen ungebener, meift

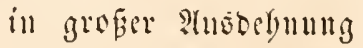
auf bem Ed):iter genäbert. Die Filblex find furg, boritenfürmig, fürjer alo rer Siopf, meift fie =

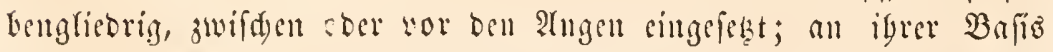

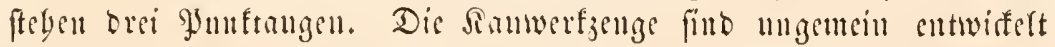
mud änferft fdarf gezäbnt, in llebereinftimutung mit ber ränberifden Rebensweife ber Thiere. Die Dberlipte ift grofï; bie Siefer bicf, furj, oben bafig, weiter Ginten gejäbuelt; die Simulaben innen baarig, an

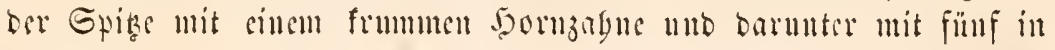




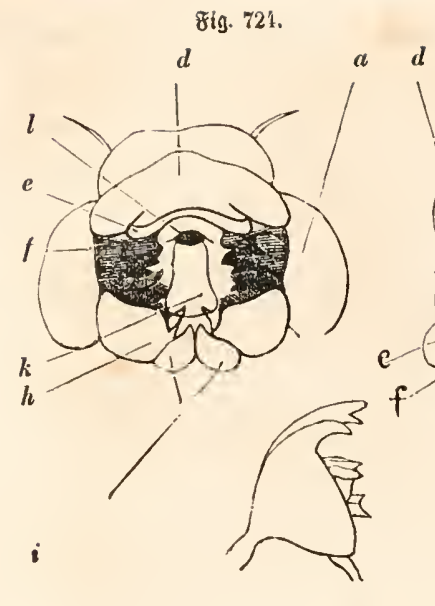

8ig. 725.
723.

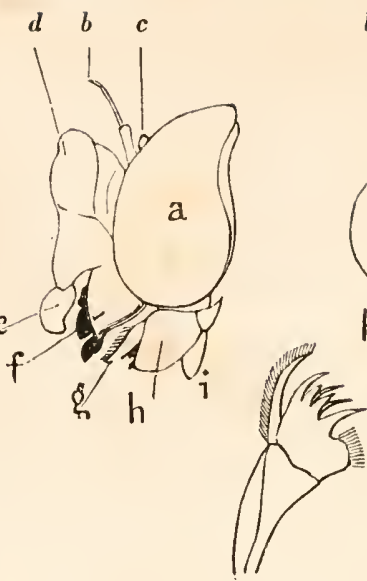

726.
722.

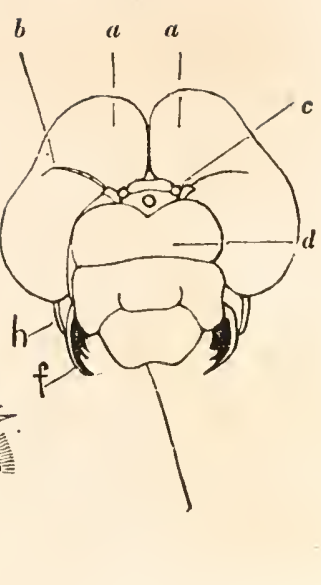

$e$

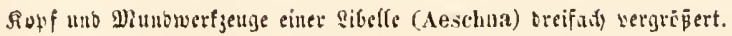

Fig. 722. Der Ropf won worte. Fig. 723. Bat Der Geite. Fig. 724. Syalb bon unten mit geäintetem Mlaule. Sig. 725. Der Riefer (mandibula) ifolirt.

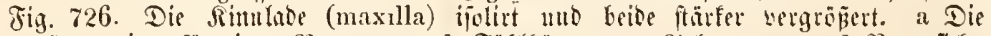

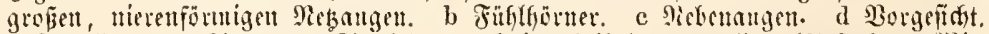
e Sberlippe. f Riefer. g Rimnlabs. h Seitentheile ber lluterlipue (Iater), i smit= tettheile ber gefpaltetten lluterlippe. $\mathrm{k} 3$ muje. 1 Edhluthoifunng.

jwei Plitgen geftellten langen Sornjägnen bewaffuet (oebgarb ranute man biefe Jamilie aud Odonata); Sinnlabentafter bif, borftig. Un= terlippe grof, fein gefparten; rie beiben Siptentafter in jwei bäutige Seitenflügel umgewantelt, weld)e bic Ramvertzeuge vou ber Geite bedfen. Mrittelfurut grofi, bod, fartig; Fläger Kang, burd) fid tig, fein gegit=

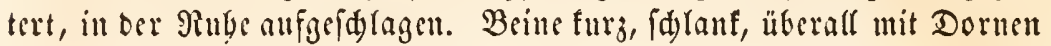

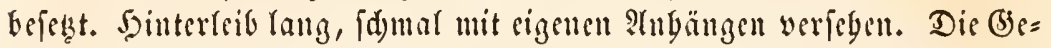
(d)led)tätgeile biefer Tbiere fino böd)ft cigentbümlid gebiroet. Die Rutbe bes $\mathfrak{M}$ ännd)ens, bie mit ciner offenen Enmenthafe in Berbintung ftebt, ift anßer aller Serbintung mit ben (jefd)led)tstbeilen am 2 nfang bes Seinterleibes unter ber Bruft gelegen, fo baß bie Miänuden, beren Gamenteiter am Enbe bess \&eibes, am After, münben, erft bie Samen= blafe füllen müffen, um fids begatten zu fünten. Gie faffen, fobarb 


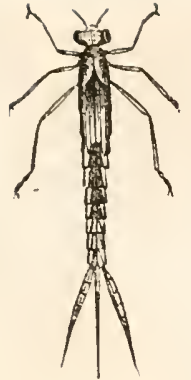

כin. 727.

Rarwe eitrer Mañ. jungfer (Agrion).

bics geideben ift, mit Der 3ange igres Syit=

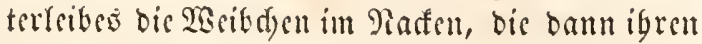

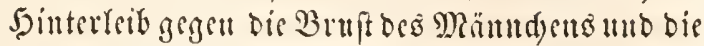
bort befublide Pintbe frümmen. Die Rarven

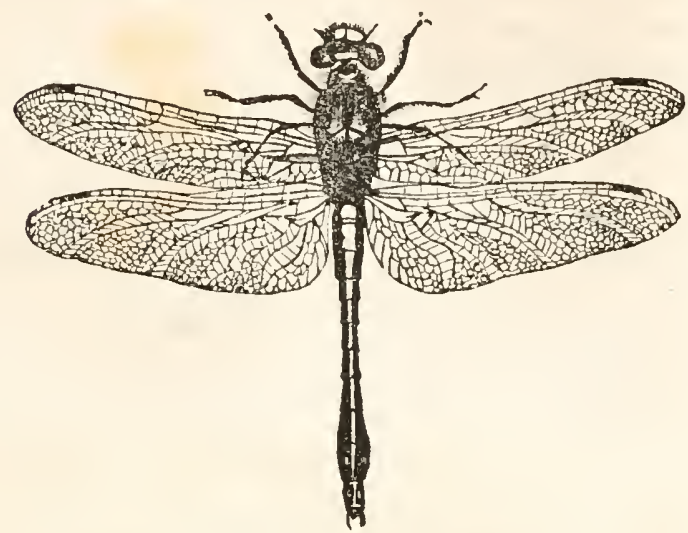

Jig. 728. Der 3ingenfineicer (Aeschna forcipata), ㄱ)

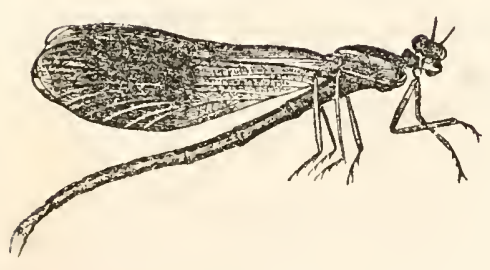

Jig. 729.

צBafierjungfer (Agrion virgo).

Yeben iul 2 Baffer unb zeiduen fid burd) sitt bisd sigentlünlide Bitsung ber lluterliphe aus, welde wie cine Magefe bas ganje (b) fidat won unten ber bebeft, aber wie sin Gtord, fundel auscinandergeflappt tmo vorigeidjoben werben fann, um als jangwerfagug zll bienen. Die vollfommenen Guleften fliegen meift

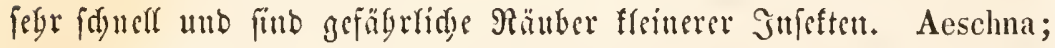
Gomphus; Libellula; Agrion; Heterophlebia (foffir im Jura); Lestes; Sterope (foffir).

In Den untergegangenen Gebufungen frielen bejonbers bie \&i= Gellen und Termiten eine Sauptrolle. Die erfteren beginnen fdon im Sias mb jeigen kefonbers it ben Golenbofer Sdyeferth, bie bem obe= ren Juta angebören, präd)tige, grofie Arten, bie meift bent Gattungen Aeschna unb Gomphus angebören. In ben Gümpfen ber Tertiärgett, befonbers it Deningen, gebören bis Ribellenlarwent ju ben gemeinfen Berfteinerungen. Die Termiten, biefe Bewobner tropifder $\mathfrak{B a ̈ l b e r , ~}$ beginnen int Jura, tnt finben fid) in ber Sercibe wis it ber Tertiär= 


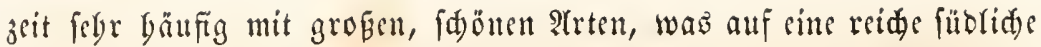

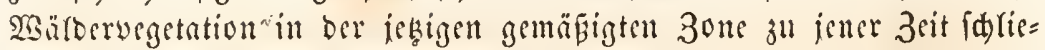

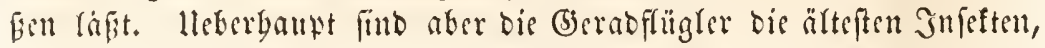

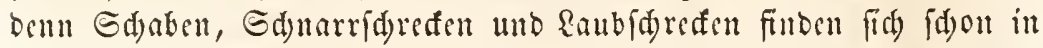
ber Sioblemperiode und von ba an ununterbrod)en in alfen formatio= nen mit megr fïblidyen arten.

\section{Luterklaffe ber Infiliten mit volltammener bermundumg.}

(Holometabola.)

Die Sronmug ber 3weiflïgler (Diptera) ift vielleidt bie

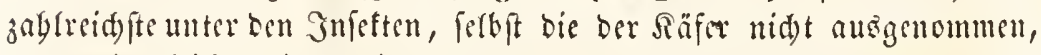
wenn fie gleid) weit weniger gefannt ift uno namentlid) bie 9 (rten bes

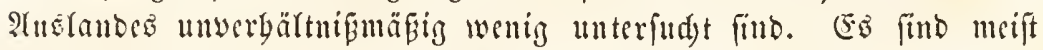
fleine, jarte Gufften, beren \$tufbewagrung ziemlidje Edjwierigfeiten,

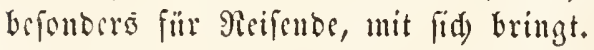

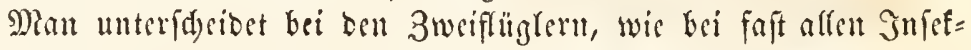

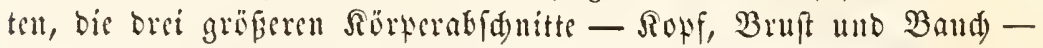

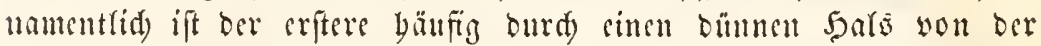
Bruft getrennt. Rut bei einigen parafitifden, ungeflïgerten Gattun= gen fdeint ber Sopf entweter nur fegr flein ober ferbft in ägnlider Sisife, wie bri ben Epinnen, mit ber $B$ ruft faft ju ciner Maffe ver=

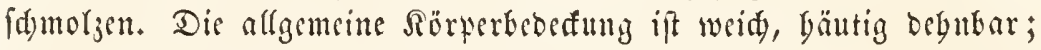
obgleid) man, namentlid) am Sainterteibe, nod) inmer bic sinjeluen

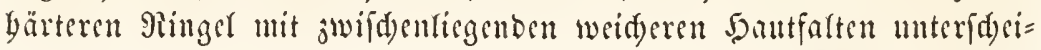

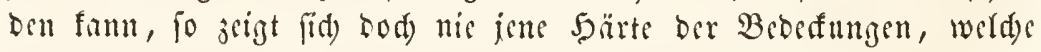
bei manden andern Dronumben, befonders ben Säfern, ju finden ift.

Die fübler find bei ben 3weiflüglern faft ftes vorn auf bem Sopje, an ber Stirn, jwifden ben stugen singelenft und mit igrer Bafiz cinander genägert. Sic jeigen jwei fegr verfdiebene Typen, wonad) man aud) bie gange Dronung in jwei lluterorbunngen,

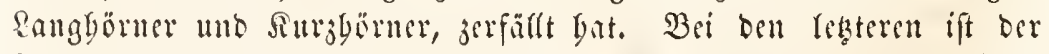

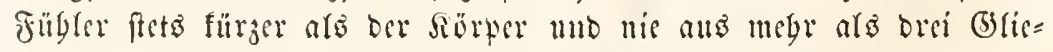

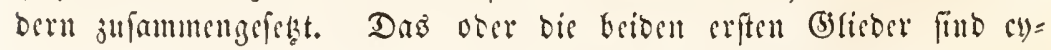

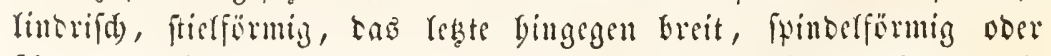
fdjwammartig unto sinzig mit jenen feinen Plied)gruben verfegen, bie 


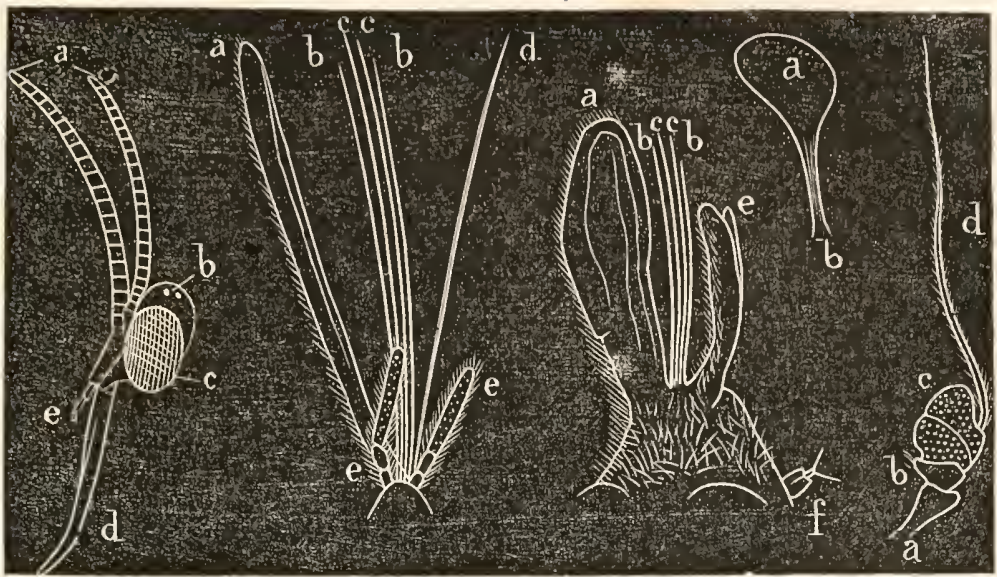

Jig. 731.

8is. 752.

Fig. 730. Sopf eines Ramghornz (Asindulum), yon ber Cerite gejefren.

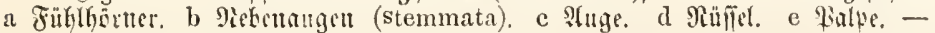
Fig. 731. Dif 9muntheile pinft @ifunfe (Culex pipiens) uno Fig. 732. Die=

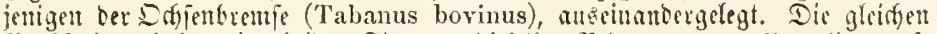
Budfitaken hafen in beiben Fignten biefibe Debentung. a untexlippe. b Riutbaffen (mandibulae). c Rimulaben (maxillae), d lluterlippe. e \$ialpe.

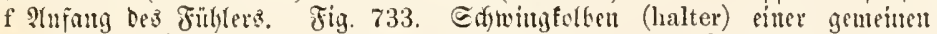
Etubenflege (musca). a Rolbiges Ente. b Eticl. Fig. 734. Jüllhoril ciltes

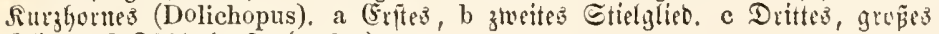
(stleo. d Füblertiorite (stylus).

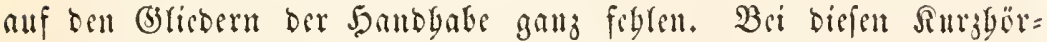
uern ftebt bann meift auf bem britten (Bliebe nod) eine furze, gerabe Borje (stylus), bie juweilen felbit Gelicbermug zeigt. Bei ben nie=

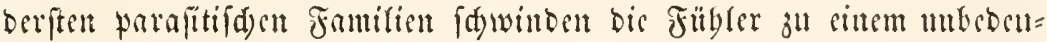
tenden gliebcrlofen Rnötden; bei Den Sanghörncrn bagsgen fuld fie

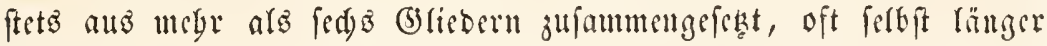
als ber Sörper und zcigen felgr mannigfaltige Geftulten, Febern, Je= Derbiifde, Gylillder, Solben, Faben.

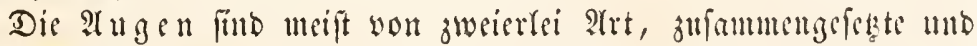
sinfad)e: erftere finto oft ungebencr grob, fritfid) gerüft und fd cinen mandymal faft ben ganjen fopf einjunebmen. Bcionders jeid)ucu fid

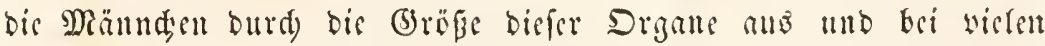
(5) attumben bildet bas 3mfammenfofien ber ?tugen auf ber Stirn für

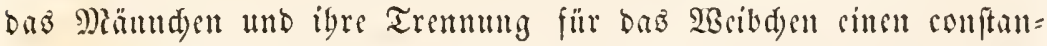

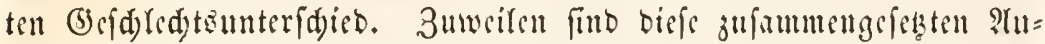
gen räumen ber eingelnen Facetten wurgeln; oft fint bie Facetten ber $38 \%$ 


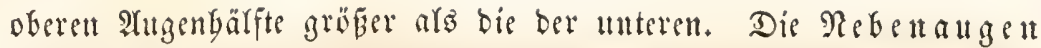

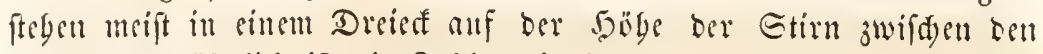
stugen; gewögulid) ift bie 3abl orei, felten finden fid nur jwei ober gar feilte.

Die $\mathfrak{M}$ un $b$ werf zeuge ber 3weiflügler find ftets zum Saugen eingeridstet, theilweife lerbft bei ben Rarwen und jwar ift es bejon= bers bie Rippe, weld)e jum $\Re$ ü flel (proboscis; trompe) umgewan= Delt ift. Der Rüfel ift meiftens fnieförmig in ber Mitte eingefniaft, bald fenfredst, balo borijontal unter ben Sopf geiteflt unb faun mei= feno zwifden bie Baffen zurüfigezogen werben. Seine untere Spize

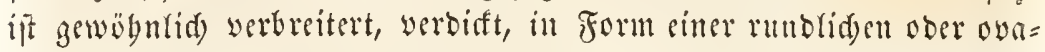

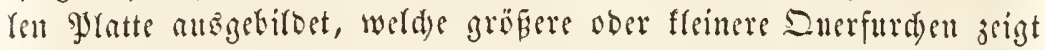
unb oft mit Sanaren befest ift. Die eigentlicke Mumoüfrumg befinbet (id) Hiber Diefer Hatte in Dem Sinie Des Rilffers an ben Enbe einer

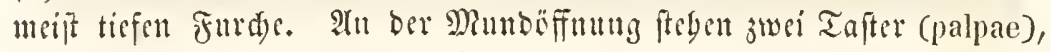
bie bei ben Siurjgërnern meift nur cin= bis zweigliebrig, bei ben saugbörnern vier = bis fünfglieberig, lang, mo oft in äbnlider : $B$ eife wie bie Fïblgorner, bufdyig fitt. Lnterfudt man beu Rüfel genaner, fo finbet man, ba bene Rügre mur eine Syülle bildet, in weldyer befondere fteife Soorn= boriten fteffen, Die offenbar ben Sinnbarfen und Simnlaben ber fauenden

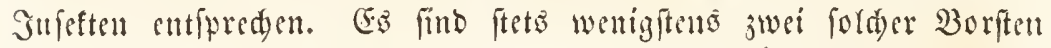
worbanden, bie meift mit ben glafpen in Berbinbung fteben unb offen= bar bie umgemanderten Simtlaben (maxillac) barfteflen. $\mathfrak{B}$ si einigen Familien fitm anferbem nod) zmei weitere Boriten vorbanben, weddse Den Sicfern (mandibulae) analog fint. Die fämmtliden in bem $\Re u ̈ f=$

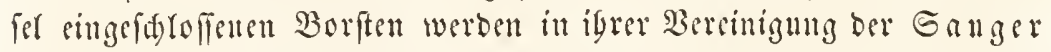
(haustellum, suçoir) geununt. A(ufer biefen $\mathfrak{B o r f t e n}$ fiutoet fid) nod)

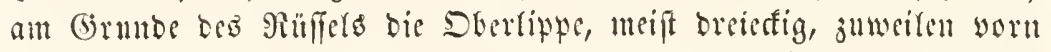

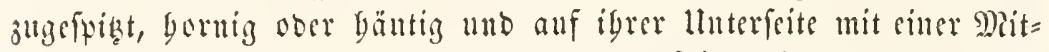

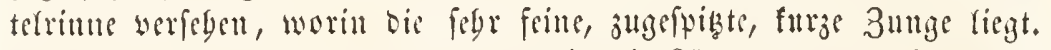
Sind biefe beiben Drgane bebentent in die Ränge gezogen, fo fderint

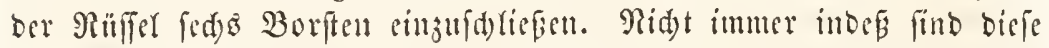
Minnoorgane wolffänbig - es finden fid) fogar mande Dipteren, wie 3. B. Henops, wo Dem ausgebilbeten Thiere jebe Spur won Mimb= werf

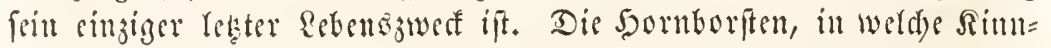

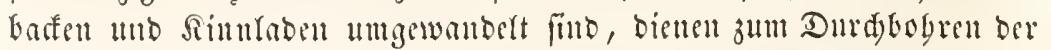

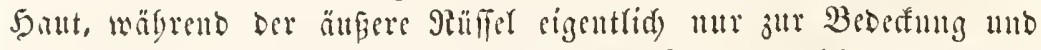
Jixirung Des Gaugers beftimnt ift. Die Säfte, welde nufgefogen 
werden, fteigen jwifhen ben Sornborften in bie Sable. Der Raum

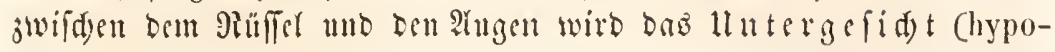
stoma) genannt; or ift meiftens burd) jwei worftebende mit fteifen Borften werfebene Bafen ausgefïlt, welde ber Rnebelbatt (mystax) beî́en.

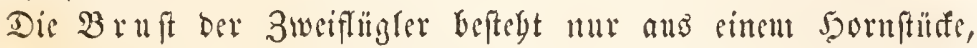
Deflen แripringlidge 3ufammenfeşung aแs orei Riugen burd) Duer= furden ober vertiefte Rinien mebr ober minber Dentlid) angegeben ift.

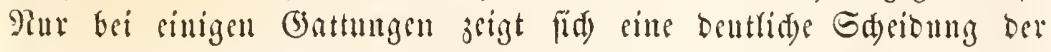
Borberbruft. Fit Der llnterfläd)e ber Bruft fiebt mat nie mebr als vier Euftëber - jwei worn in Der Räbe Des Ropfes, jwei ganj binten, unmittelfar bei Den Squingfördden.

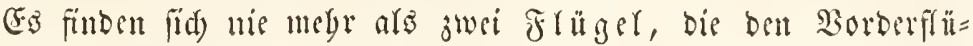
gelu ber vierfingeligen Jufeften entipedyen. Sie find ftets bäutig

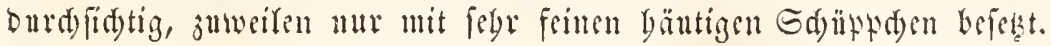

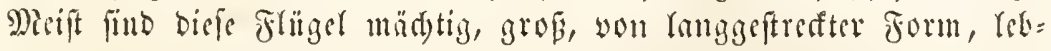
baft in Pegenbogenfarben fatlernb; bie Flugfraft ber Jufeften febr

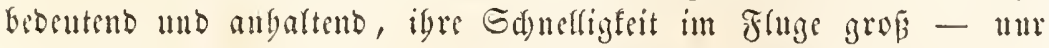

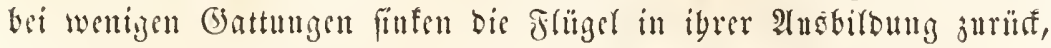

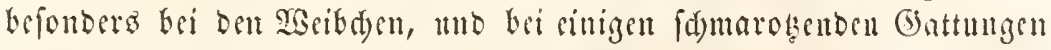

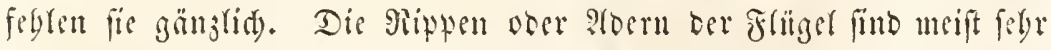

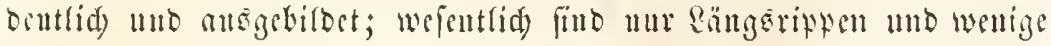
Querabern worbanden, io baj bie langgeftredten 3ellen meift und

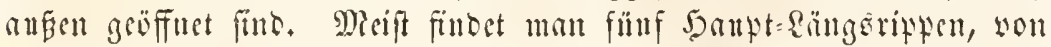
senen bie leiben erfen beut Borberrande Des Flügers febr nabe an= liegen.

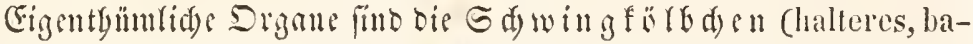
lanciers), jwei fleine beweglidge förperden, aus einem mebr voes minoer langen Stiel unb sinem runoen Rnöpfden beftebent, bie an bem Sointertbeile ber Bruft fteben, foft in beftändiger vibrirender $B_{e}=$ wegung find uno meift son jwei gyan bäntigen $\sigma_{\text {d) }}$ ppen (ailerons ober cuillerons) beteft fint. Dis form biefer Edmingforben gleidyt jiemlid) ben mit Retsen Eurd)flodstenen Rafetten, bie man beim Feberballfiel jum Edjlagen bes Balls getrandyt - ibr Ruken ift Dแเ ()กแร่ แแbefannt.

Die Fit be oer 3weiflingler find meift lang, bümn, aber fonft aus ben gewöbufiden Theilen jufammengefest. Der Tarfug bat immer fïnf Gsticber; bas Endglied trägt jwei, meift sinfade, juweifen ge= fparteme ober gejübnelte Rlauen, bie nur bei wenigen Gattungen ftart vortreten; meiftens befinden fid zwifden Den Slauen juei ober brei

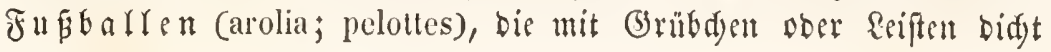




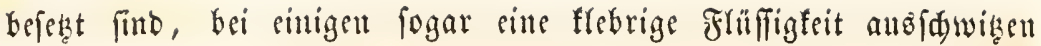
follell und ben Snfeften ałz Safitorgame bienen, womit fie fid an glatten Dberfläben, felbit in umgefegrter Stefung leid)t feftgalten fönneนt.

Dor binterleib ber 3weiflügler ift meift fdumal, länglid, zul= weilen aud breit und siförmig. Fre figt balo mit feiter ganzen Breite alt fer Bruft feft, bald ift er burd) simen Stiel mit igr verbunden. Gre jeigt meift $6-9$ fidjtbare Ringe unt enbet bei ben 2 Beibden oft

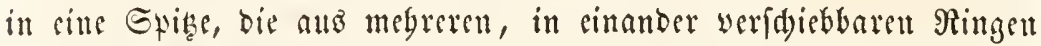
beftebt, welde wie eill Fernrolgr aub = unb singezggen werben fönnen.

In anatomifder Soinfidyt zeiducu fid bie 3weiflügler burd for=

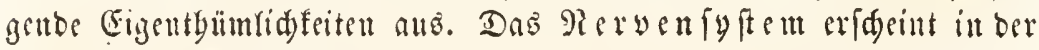

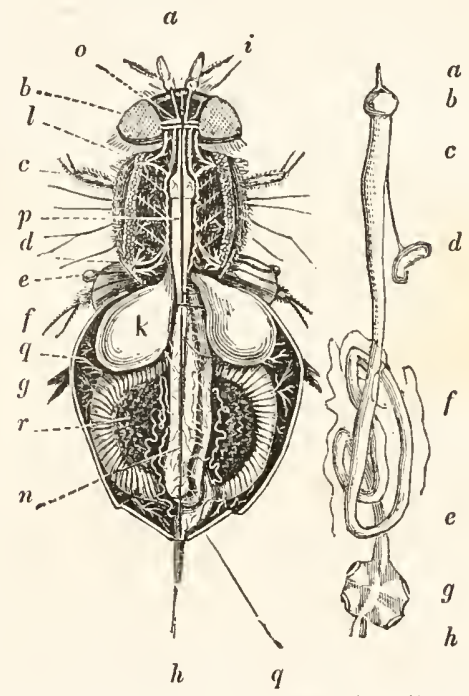

8is. 735 .
Jis. 737.

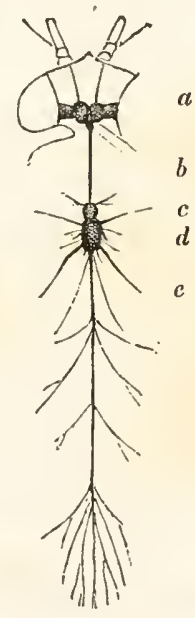

รig. 736 .

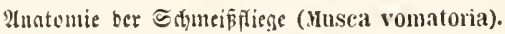

Fig. 735. Die Fliege ift vou Mïfen her geöfintet unb bie Deifen you

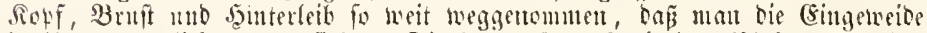

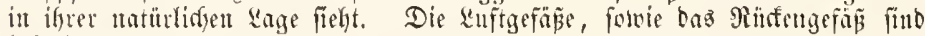
fefoutbers folwats gethaltert.

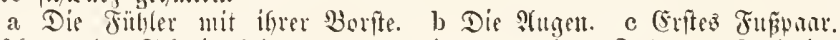

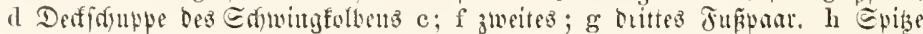

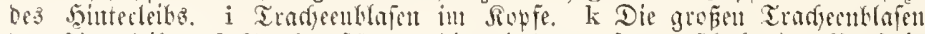

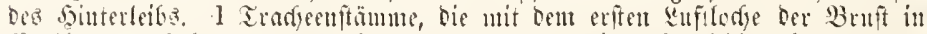

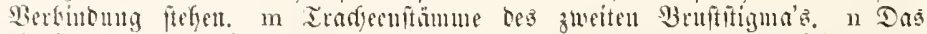

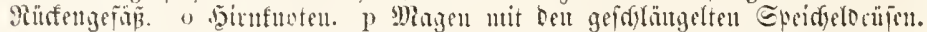
zu beiocn Eriten. q Dam mit Den Ballengefäien Daneben. r Eierftörfe.

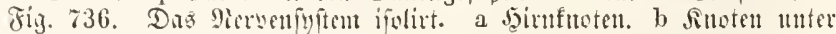

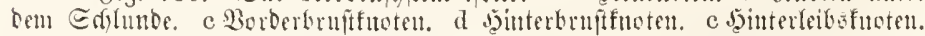

Fig. 737. Die Batonungsorgane ifolitt. a Edjluno. b froff. c Magen. d Eanguagen. c Darm, f Sallengefä̃ ber einte Seite, g Mapt= ratul. h iffer. 
Reger tแm fo geftrefter, je Yänger bie Reibesringe find, um fo fürzer unt gebräugter, je rumber ber binterteib fid) Darftellt. Dépgarb yaben bie Ranggürner wentgftenz fünf ober fed)z Baudfuoten; wäl)rent bsi ben eigentlid)en griegen mit bebeften Gdyingtorben, ben Musciben, Shapiparen, Deftriben gar feine, bei ben n̈brigen Sutrbbürnern is nad)

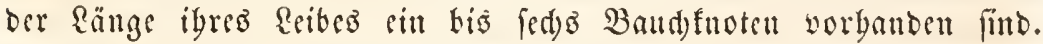

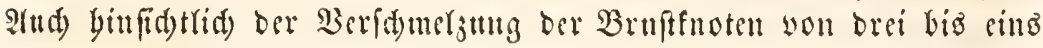

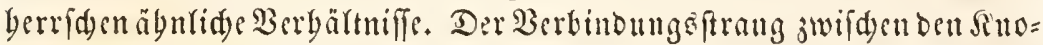

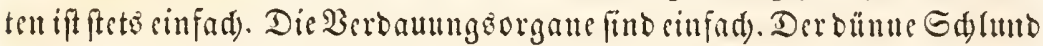
fübrt in einen furzen Rropf und sinen Yangen Magen, Dem zur Seite burd)

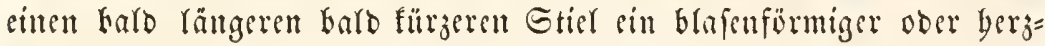

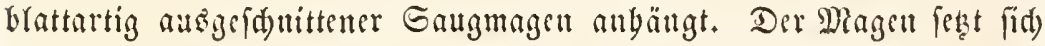

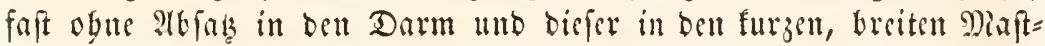
barm fort. Einfadye Speidel= mtto Eebergänge in Form dünner Rügr=

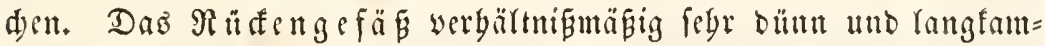

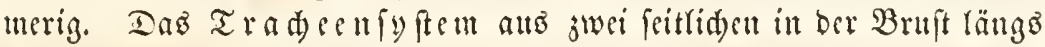

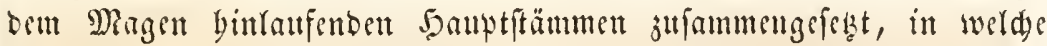

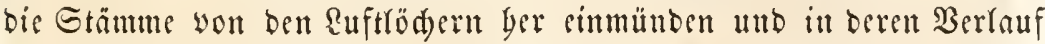
find befonbers zwei fleitere \&uftblafen in Siopf, zwei oft ungegener groper in Sinterteib ausjeidnen.

Die weiblidan Fortpflanjungoorgane beftegen aus gwei Eierftöffen, bie auz einer ltnjabr futrjer Rügrden gebirbet finto, Deren jebez brei biz vier Eier erjengt. Die Eiteiter find unr furz; ber Samentafden meift megrere, gewöbutlid orei vorbanben, won bödst maunigfartig wedffeluder Form, meift bornig bräunlid. Die Ederbe, obne Begattungstafde, meift oben erweitert ju cittem Eierbebälter, in weldem oft bie Eier fo Yange breiben, biš bie Rarven aus ber Eifdate gefrod)en fint, to baßj fold)e Fliegen rebentig gebärent erfdscinen. Bei ben gutuiparen, beren Cier unt Cireiter etenfalls abweichend ge= ftartet finto, werben fogar bie Rarven in biefem Beyälter burd bas Eefret sigener, kebentender Drüfen ernäbert uno erft nad) igrer $\mathfrak{B}$ er= fuptung innerbalb des $\mathfrak{B}$ egälterz won ber Miuter gevoren. - Die

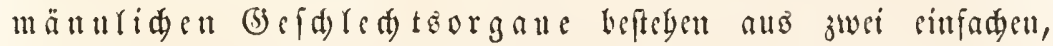
meift gelbliden ober bräunliden boben von birnfürmiger beftalt, furzen Samenteitern und einer meift furzen Rutbe, bie von zwsi bor=

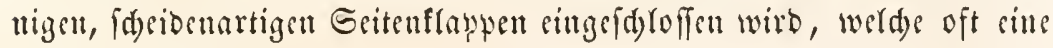
fouberbare beftalt baben.

Dir 3weiflügler Yeben alỏ volffommene Sulfeften meift mur futjas

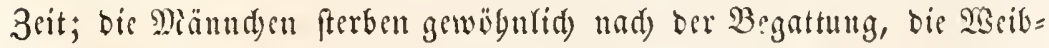
d)en nadbom fie für ibre Brut gejorgt baben. Sie finten fid meift

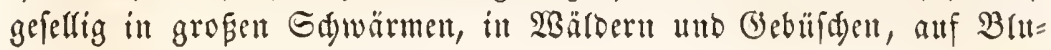


men uno Blättern, wo es etwas ju nafden und zu faugen gibt.

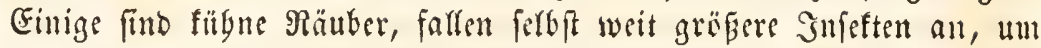
fie tob ju fiedjen und ausiufangen; anbere leben parafitify yon ben

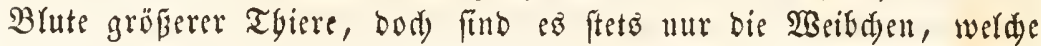
feden uno Blut faugen, niemals bie Deännd)en. Das̃ Tanjen und Sdwärmen Der Müfen und Sdynaten ift bas Borfpiel jum Begat=

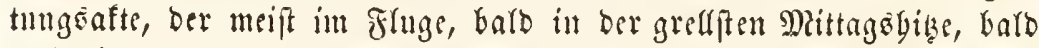
megr it ber Dämmernng vorgenomunen wirb. Die Cier, welde meift runblid obne aufallenbe Formgeftaltungen find, werben an bie Drte gelegt, wo bie Rarven leben; in Form jufammengeflebter fowimmen=

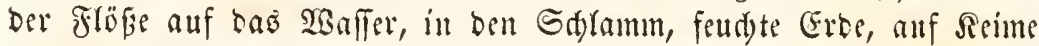
und Blätter ber gyflangen. Die Miaubfliegen legen ibre Fiet in bis Refter Der Bienen, beren Rarven won íler Radjommenfdaft getöbtet werben, swifden tie Blattläule, auf bie Saut gröferer Thiere, wo fie abgelest werben, un fib in Darm ju entwidedn M. F. w.

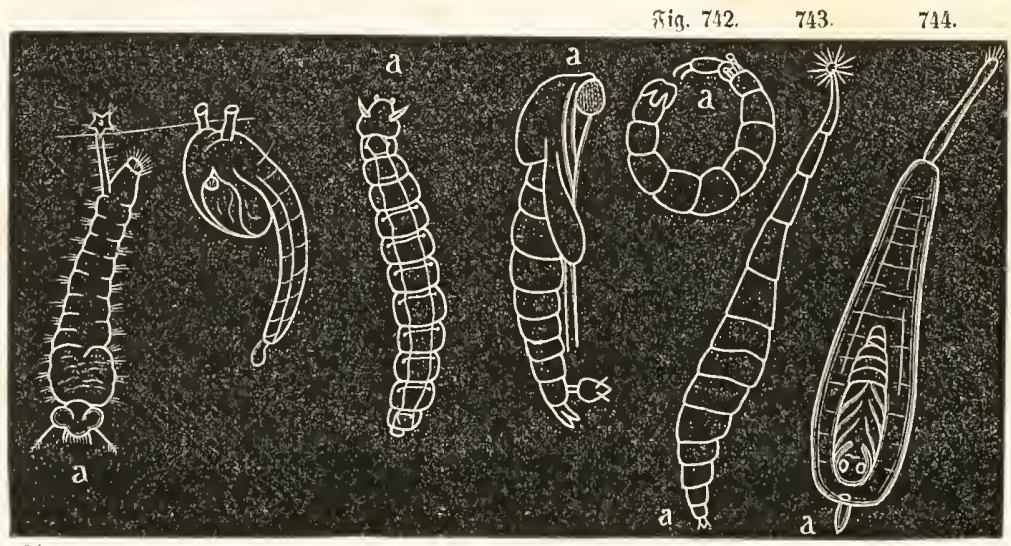

5ig. 73s.

$73 y$.

7.0.

$7+1$.

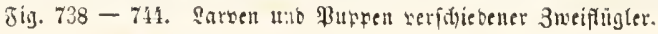

Fig. 738. Sarve, Fig. 739. Fuspe won Culcx in natürlidyer Eteflung im sisalfer. Die Earve zeigt bis lange, feitlid am Senterente angebradfte

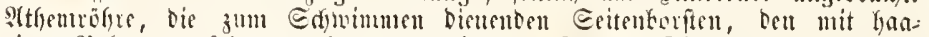

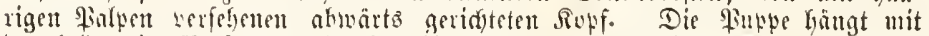

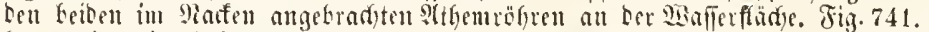
Earve ciner in Ed)wämmen lebenden Tipulite (Macrocera). Der Rop trägt

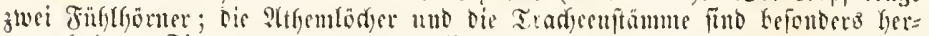

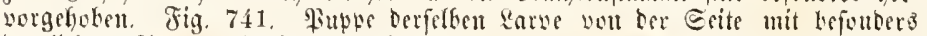

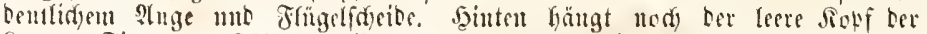

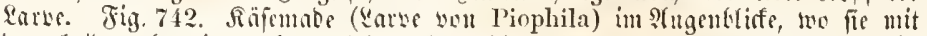

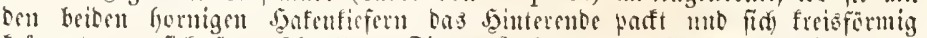
frummt, mu fidf fortjuidnellen. Fig. 743. Earse won Stratiomys, in natur=

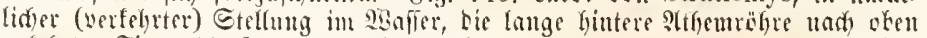
gefefyet. Fig. 744. Finpte beffelben sfjeres, num zu zeigen wie bie eigentfidge

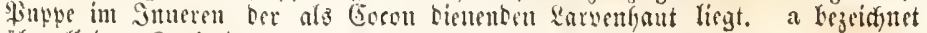
itherall baz Ropfente. 


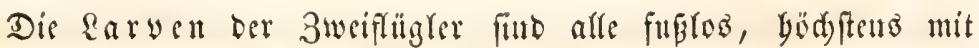

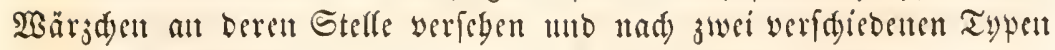
Beftaltet. Die Einen babell cinen weidsen yäntigen Ropf, Der mit furzen Saugorganent verfegent ift - biergin gebörent bie uteiften para= fitifden ober in faulenden Stoffen rebenden Rarven. Eintige it Erbe ober foldyen Materien Yebettbent Rarven Gaben inder fdon eillen bor= nigen Sopf, wounit aukerben alle in $\mathfrak{B}$ affer lebenten Rarwen verfe =

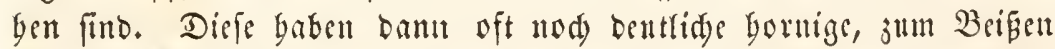

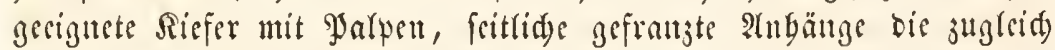

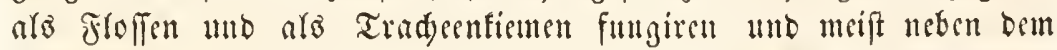
Sdwanje sine megr ober minder lange, mit cinem Boriftenferne wers fegene Âtbentrögre, Durd bie fie sie \&ult sinjichen. Cie bängen fid on biefent Endojwefe verfegrt in bas 2 affer, illoem fie ben Borften= ftern aut Der Dberfläde aubrereiten.

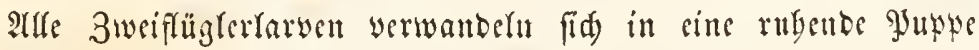
und jwar bient ben meiften bie eigene Rarvenbaut alö ăn

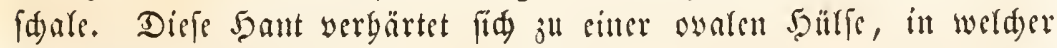

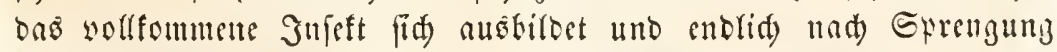
Der \$nitfe Gerworgcbt. Bei andern aber, namentlid bei ben im 2 affer rekenten Sdunfenfarwen, wirb bie Rarvenbant abgeftrcift, und cine

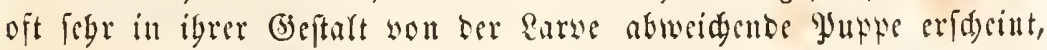

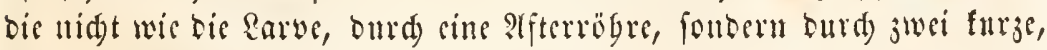
an ber Bruft angeteradte Peögren atgmet.

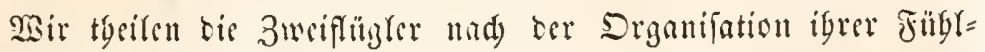

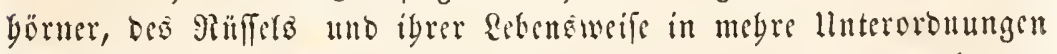
und Jamifion ab, beren wodftündige ?tufjäglung bei ber ungegentren

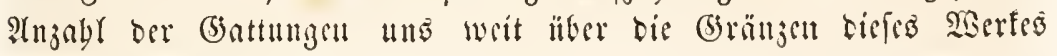

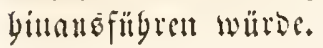

Die Utnterorbnung der buípienben Dipteren (Mphaniptera)

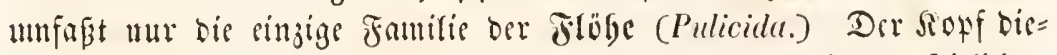
fer Thiere ift fegr flein, worgebengt unto nur mit sinfad)en feitliden

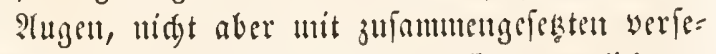

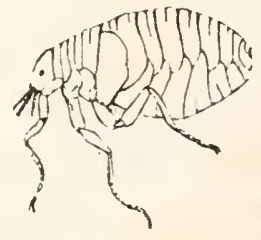

Fig. 745. Pulex intans. Der Mentitienfiug. ben. Dis Ringe oer Bruft fiulo beutlidy ge= trenut, aber in ibrer Gefitalt fegr wentig you

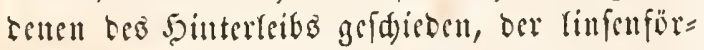
min, god) unt wou ber Geite frer jufanumen= georiät ift. Die Siörperbedsafungen find fort,

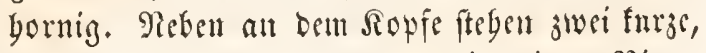
forbige Dreigliebrige fritgler, in cimer Rinne 


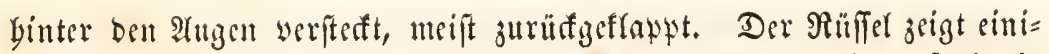

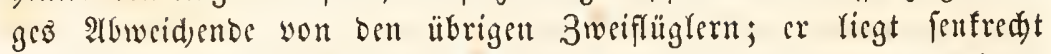
unter ber vorftebenden Siopfplatte uno beftegt aus siner zweiffappigen, geglieberten Sadeibe (Unterlippe) mit fünfgliebrigen $\mathfrak{Z} a$ ftern, aub einer

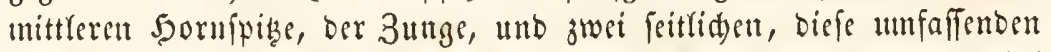

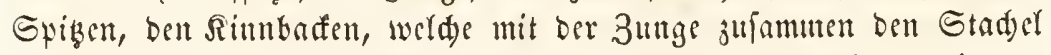
birben. 3ur Seite finden fid nod zwei geglieberte Jarpen, bie bent Sinntaben angebörent. Die Beine fint rang, die Sdenfel bif uito

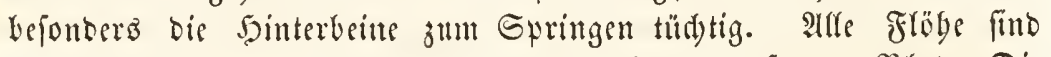
Sdmarober, aber nur bie 2 Beibden fteden und faugen Brut. Die

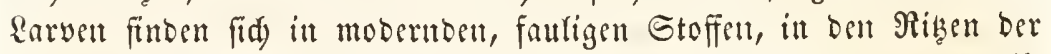

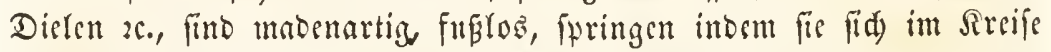
biegent unt baben sitten bornigen Sopf. Rad zwöf Tagen fpitmen fie fid sinen fleinen (socon aus Seibe, worans fie thad) etwa zwölf Tagen wicber als yolffommente Snfeften berworgeben.

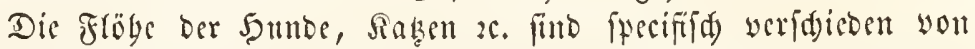

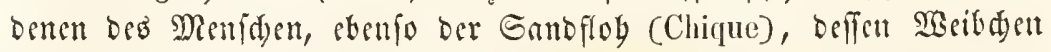

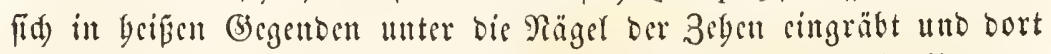
feine Brut abjeģt, bie worger ben Sinterteíb ungebener anftreibt.

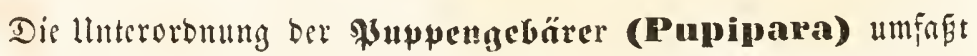

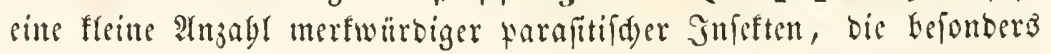

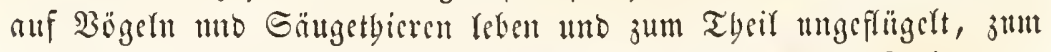

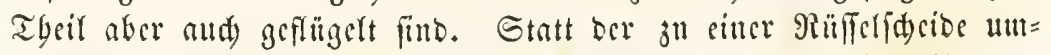
gewandeften llnterlippe baben biefe Jnfeften zwei feitlide Sornflappen,

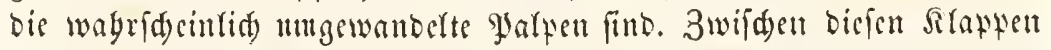
riegen anf cincm fleinen Borfprung zwei ftarfe fdutppige Sornborften, bic zum Sted)en biencu. Dic Fübler fint foldr veridgicden geftaltet,

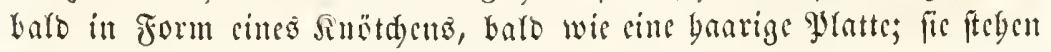

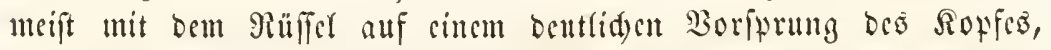

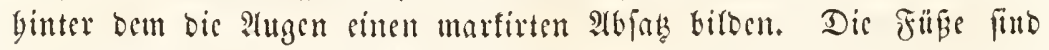
lang, ftarf, mit grofien sirallen an Entoe verfolyen, womit fid bic Thiere in ben baaren nutb Fecern igrer Tsogmunggeber foitlafen.

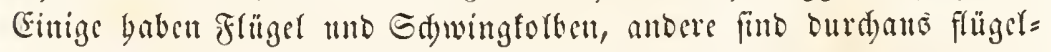

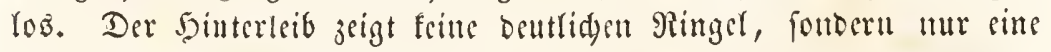
meide fely: Degneare Saut.

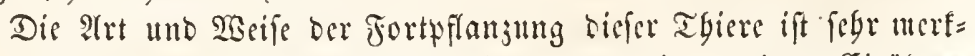
whirbig. Die Cicritüfe finto foly furr unt mit menigen Girögren verjegen; Die Fier ferbit formmen nad) Der Bejrudtentg in ben unte=

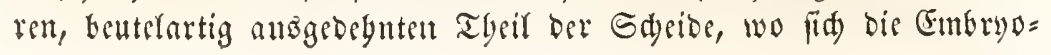


nen aแล่bitben unb aแสfd)lüpen. Die Mitter bebält bie Rarven in bempelben Safe, wo fie ourd) bas Sefret siner eigenen Drüfe ernägrt werben und fid entrid verpupten. Die guppen, wenn fie geboren

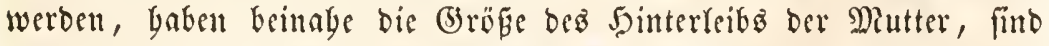
anfanģ weid แnb bläulid, erbärten bann unb fpringen enblid, brim

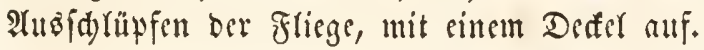

Sir unterfduciben zwei Familien. Die FledermauEläule (Nycteribida) fint vollfommen flügelloz. Ropf febr flein, vertifal gefteflt,

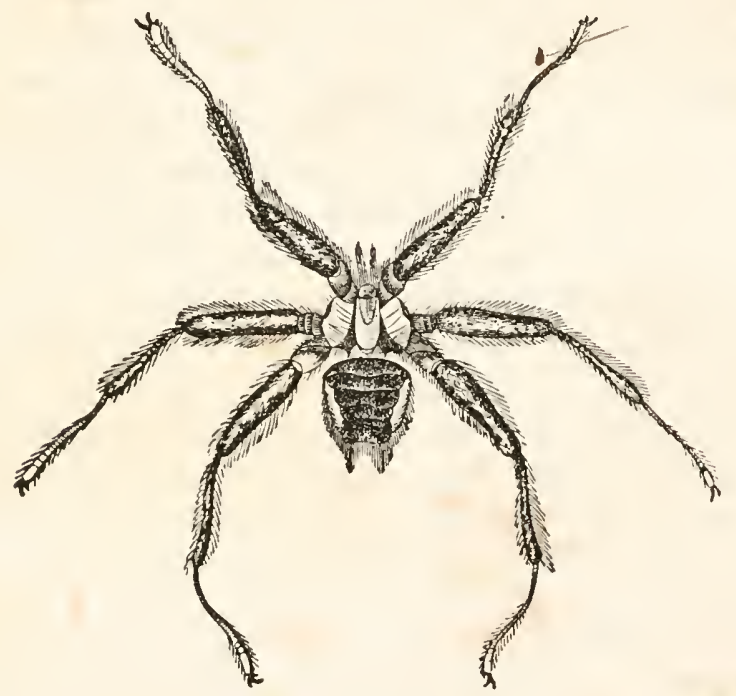

gig. 716. Nycteribia Westwoodi.

Bruft uno Baud) ju einer Maffe verfdmorzen; Fübler feblen ober fint nur in Form fleiner Rnötd)en worbanben. Die Beine felyr lang, baarig. Die Thiere gleid)en fleimen Spinnen, baben aber nut fedjo Beine und leben anf flebermäujen. Nyeteribia.

Die Şautläule (Ilippoboscida), Gaben einen breiten, ylatten Rör=

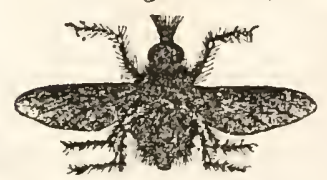
per, mittelmäßig groß̧en $\Omega o p f$, beutlid) getrenut yon ber Brnft, bie wieoer vou ungeringelten Sinterleibe abgelebt ijt; länglidje, zufammen=

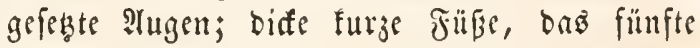

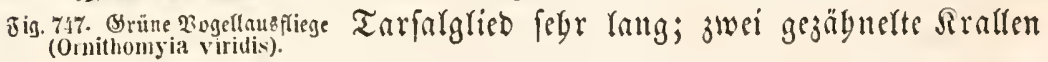




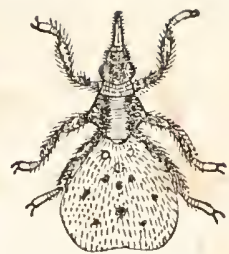

Fig. 748. 巨daifnus. (Melophagus oviuus).

am Enogliebe. Eimige (Hippoboscus) babent Flïgrl; anderen (Melophagus) feblen fie gänz= lid). Die (bieflïgelten fliegen fdiledt uno we= nig. Hippoboscus (auf Jerben); Ornithomyia; Olfersia; Ornithobia; Anapera; Stenopteryx (alle auf Bögeln); Leptotena (auf J̧irfden); Melophagus (auf Edafen).

Die britte lluterorbunn, bei $\mathfrak{B}$ citem bie jablreidjte an Fani= lien, Battungen uno Irten ift bie ber Surjhörncr (IBrachycera) ber eigentliden Fliegęu. Der siörer biejer Thiere ift meift breit, felten länglidy; ber siopf Galbfugelfürmig ober queroval, son ber Breite Der Bruft; oer Sointerleib breiter; Der

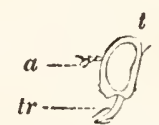

รig. 749. Supf eiller Solueb= fiege (Syrphus.)

a Fillflyorm. tr Ritifl. $\mathrm{t}$ @dyeitel.

Ritffel ift bald furz, biaf, fleifdig, in weldent Falle er meift ganj in eine Bertiçung am Bor= Derfopte jurürgejogen werben fant balo rang, vorftebend Dintu, leberartig. Das wefentlidjite Sennjeiden beftegt in ben Fiiflem, die göd)= ftento aus oref Griebern befteben, you welden jwei flein unb fticlartig, bas oritte bif, fnopfartig iff. Shuf biefem britten ftebt eine Grifer ober $\mathfrak{B o r f t e}$ (stylus). Die Fübler fümnen meift in eine Binne atm Sowfe eingelegt werben. Flïgel feblen nut in einigen Plusabmefällen, fonft fint fie ftets vorbanden.

Familie ber Daffelfliegen (Oestrida). Rörper bidt Gebaart.

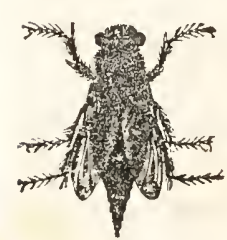

Tin. 750.

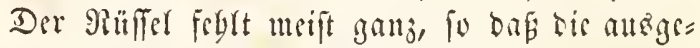
bibeten Tgiere feime Parrung ju fith nebmen

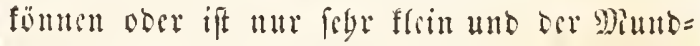

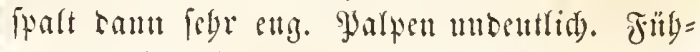
ler febr furs in einer ginne bes Sioffés gele= gen ; Drittes blics fuglid, bie biffe, fable Borjte

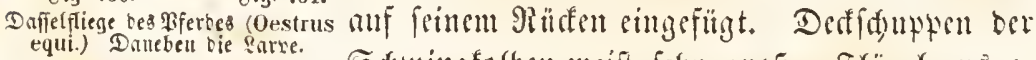

Gdivingfolben meift fegr grog. Flügel aแäge= breitet, in Der Rube som Reibe abjtebend.

Die aแรgebilteten Suleften leben nur febr furge 3eit, fliegen rafd mo fdusfl mit fdarfem, aber Yeifem Summen uno regen ibre (Fier an verfatebene Steflen auf bie Jaut grasfreflenber Sängetbiete. Die Rarven, welde aus biefen Giern berworgeben, fint ciförmig, igr Mano

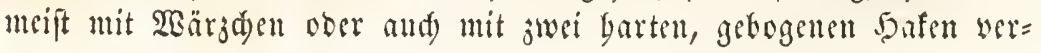




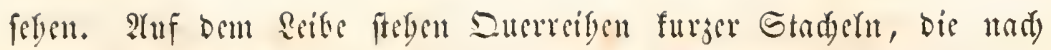

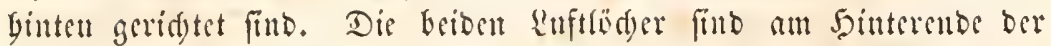
Rarwen angekradjt. Cintiger bicfer Rarwen bogren fid in bie Soutt Der Thiere uno cine Irt itl Gëbaunerifa aud) in bie ber Mienfden

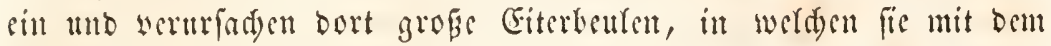
Berberende nad) inuen ftefen, wälgrend bas Sinterende gegent bie

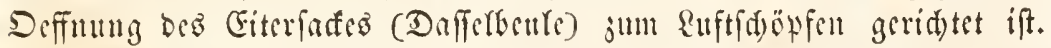
Diefe Dafferkenten werten oft in beifen Rändern fo zabtreid), bas bie Säute faft wertbloz werden. Llnter ben Ranbleuten yerfdet ber irrige

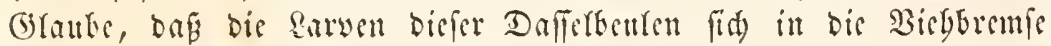

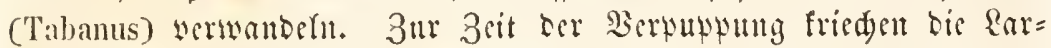

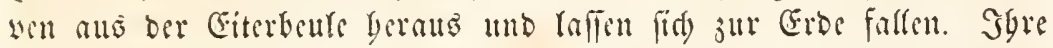

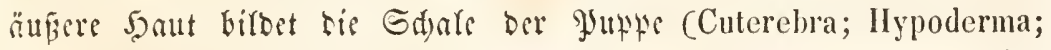

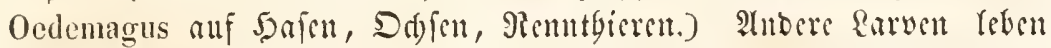
in ben Etimbiglen Der Gdafe und birfanaten - bie Mitter legt bic Eier an ben Eingan! ber Rajenböbren, von welden ans bic sar. vet bintauffriedent (Cephenemyia; Cephalemyia); nod) antoere entolid) regen igre Eier auf bie Gduutern ber Ysferbe, wo bie Taiere fie ab=

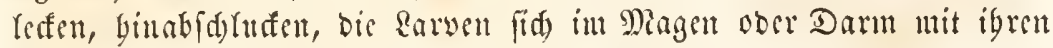

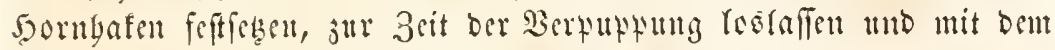

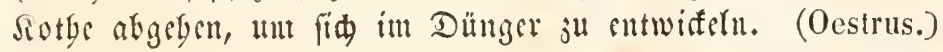

Heberaus jablreidy ift bie familie ber Fliegen (Inscida), welde etwa jweigututoert Gattungen jägrt, bie cine forde Menge von HeGer= gängen in ben eingernen CGarafteren jeigen, báp firds faum andors,

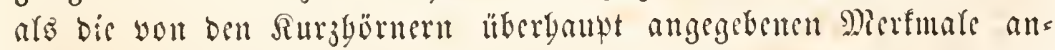

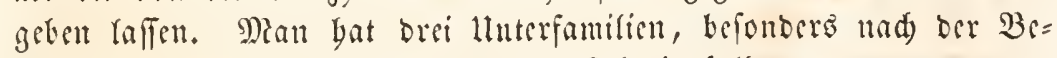
fdaffertyeit ber Deffidupern und ber Gifwingfolben angenomment.

Dungfriegen, Acalyptera. Deffidupen feglen ganj oder find

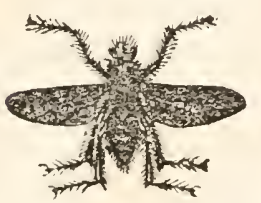

Jig. 752. Tungfliege (Scatophaga stercoratia) nur rubimentär. Die Gtim ift bei beiben (Se $=$ (d) led)tern breit, bic Füblerborfte Deutlid) atto eitlem ober juci Gliebern gevilbet. Der Sör= per ift ränglid, ber Rolf balbfugelig, bie grlï= get fow äd)er als bei ben lïbrigen Jliegen. Mlan finbet bis ausgebilocten Snfeften meift in folat= tigen Gebölzen, im Pafen unb auf 2Baffertflangen. Jyr Jlug ift lang= 


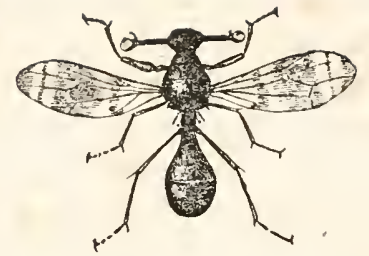

จig. 753. Briffentic.je (Dionsis ichueumoniles)

fam, fdwad. Die Rarven fitno wurmartig, mit bäntigem veränbertidaem Siopfe und reben theits in Mooer uno verwe= fertoen Gtoffen, tyeirs aud) in Iy flanzen, wo fie zumeilen (s)all=

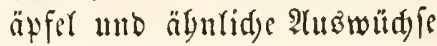
bervorbringen. Die Briflen= fliegen (Diopsis), Dungfliegen (Scatophaga), Die Fettfliegen (Piophila),

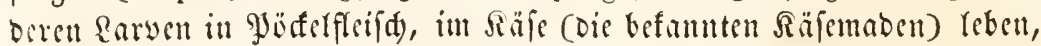
แno ourd) 3nfammenringelung igres Sörpers uno nadberiges Rog= fdunellen fpringen, gebören birber. Ortalis; Sepsis; Loxocera; Tetanocera; Dichanta; Borborus etc.

$\mathfrak{B}$ 〔umenfriegen Anthomycida. Deffidupten fleit, bie Sd)witl=

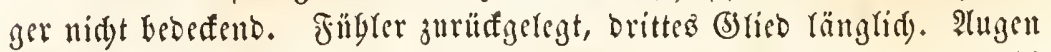

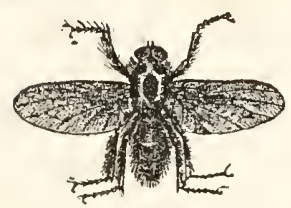

Tig. 754.

Betumenfliege (Anthomyia.) auf ber Stirn nabe gerifft, berügren fid) meift beim Männden. Siörper längtid, Jopf barb= ftigelid); Jing langlam. Die meiften reben in (bebiifden an beflen Tagen auf Blumen unb Zaffertflanjen - bie Männdyen birben grobe Sd)wäme in ber $\{$ ttft - bie Raryen baben meift jwei Ditubbafen und Yeben in aflen Irten yflumblider, bejunbers verwejenter Stoffe. Sinige Rarwen bogren fits

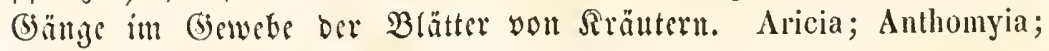
Tegomyia; Hydrophoria.

Die Freifdfriegen (Calyptera ober Creophila) baben meift cimen georungenen Siörerbat, runoliden Sinterleib, breite Bruft, queren Ropf uno grofie Deffiduppen, weldye bie Sdywingfolben gänjlid, überragen. Die friegen baben sinen rafden unb anbaltenten Fing, balten fid meift anf Brutmen oner anf verwefenten Stoffen tub in

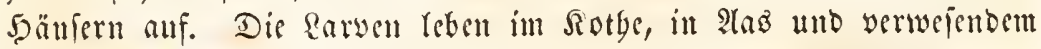
Jreifde (Sd)meiffliege, Sarcophaga) ober aud) farafitifd) in Raupen yon Grumetterlingen und in anberen Injeften, befonbers folden, welde

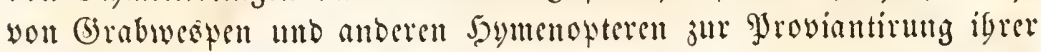
Brut bennlat werben. (Sduefffliege, Tachina). Jm Keģteren Falle regen bie Diutterfliegen bie Gier auf bie Rampen 2c. in bemierben $\mathfrak{A} u=$ genblife wo bie Miutter Grabwespe igre Beute in bas Sod ziegt,

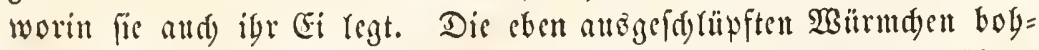
ren fid) ins Gntere ein, wo fie fid befonbers wom Getteörper näbren 


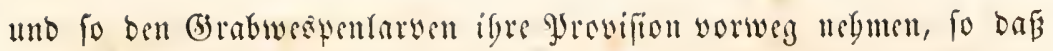

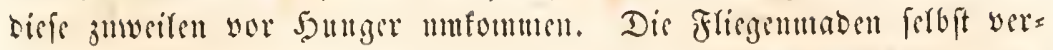

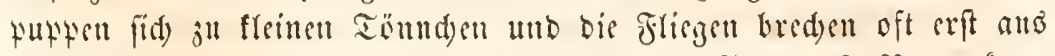

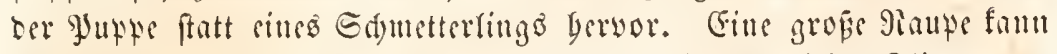

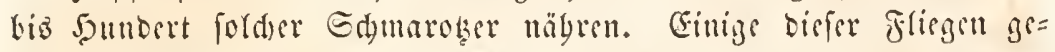
bären Yebentige Rarven. Dezia; Husca; Ocyptera; Gymnosoma; Thasia; Sarcophaga; Tachina; Stomoxys; Siphona.

Frmilie ber $\mathfrak{A}$ ugenfliegen (Conopida). Atte Friegen biefer $\mathfrak{F} a=$ milie baben lange, mäd)tige Flitgel, bie in ber 9ulye anf bem Sointer=

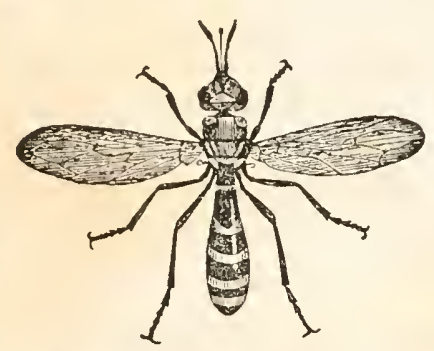

Jig. 755. Diaforffriege (Conons.) reib anfliegen mo Denfelben weit überragen. Der Siopf ift febr kreit, oft brafing anfgetrisben ober felbft fugetrund, Die 2Angen grofi ; ber Şin= terleib länglid), aแจ 6 bio 8 Rin= gen jufammengefebt. Die Sd)win= get find unbebst, bis Sduppen rubimentär ober feblen ganj. Maan bat mebreve Grutpen unterfdieben: Die Diff fopfriegen (Conopsida) mit vergeitreftem ftartem, gefnie=

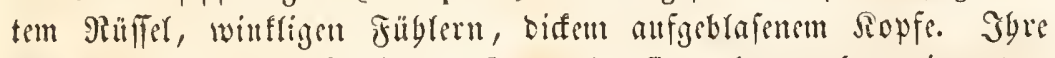
Rarwen reben parafitifity in ben 5 ummern, find aber nod wenig unter= fud)t uno bie aller ribrigen 2 (ugenfliegen gänglid) unbefannt. Conops; Myrpa; Zodion. - Dis (5) rofa angen (Tipunculida) mit fugerrumbem

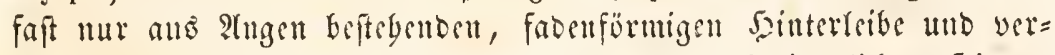
borgenem Rifffer; Die Scenopiden, mit flad)en, adtringelidem Sointer= reibe, in ber Plube einander ganj orfernben flügeln und warjenförmi= gem Enogliste ber Fühler; Scenopinus; bic Lonchopteriden, mit fuglidgem

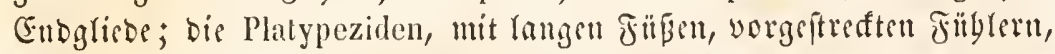
mit langer, fabler Enoborfte unb fribem Sointerlsibe. Platypeza; Callomyia.

Die Framilie Der Surzrüfifler (Brachystoma) begreift cine A(njabl von (Battungen, bei weld)en bie Rüfelfdeibe furjhäutig, mit biffem Pailfrlfopfe verfeben ift, welder beutlid) in jwei sippen gefpulten ift. Der Ganger bejtebt ans vier ftarfen Sornborfen, nidyt wie bei bent

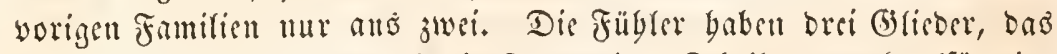

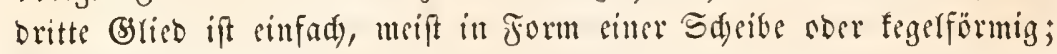
die Borfte ftegt anf friner oberen Fläd)e. Der Sointertrib aus fünf Pingen zufammengefert, fonifi) ober aud) abgeplattet. Fô fiub meis fteno grope farfe fliegen, yon welden siele von Jonig, einige aber 
aud yom Ratbe reben. Die Rarven find veridieben, balb mit wei= d)em, barb mit yornigem Ropf - sinige Keben in Mulum unb Mober, andere vom Raube. Man unterid)eibet sinige Ilnterfamilien.

Dolichopida. Grlänzende Fliegen mit metallifd) grütuen ober blauen Farben, Yangem beim Diännd) nat unten singeflapptem Şinterleibe,

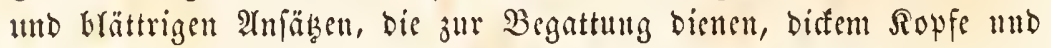

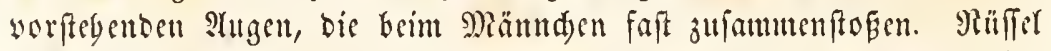
voritebent, Yarpen mit breitem bäutigent Endglicbe, bas bie Rüffers wurjel beft. Die Füßje find fegr lang, dünu; die brei Füglerglicber Deutlid), Yang, Die Borfte febr verlängert, meift cinfad). Rebbafte Flies gen auf Brumen uno Blättern im Somnenideine; faugen Soonig ober

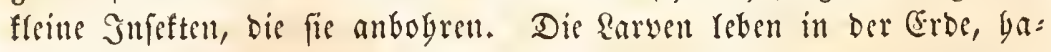

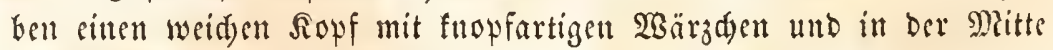

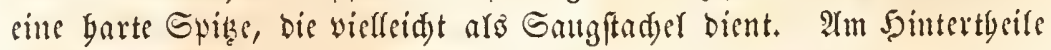
fitzen zivei frumme Safen. Dolichopus; Rhaphium; Corphyrops; Psilopus; Chrysotus; Sybistroma.

S d) webfriegen Syrphida. (3rofse, rebgafte, meift diffeibige Fliegen, oft mit fdönen, metallijon Farben geziert. Stirn vorjtebend;

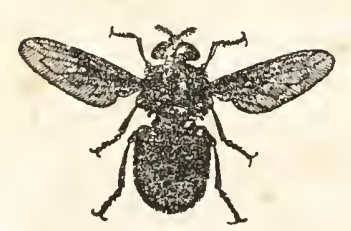

จิig. 756. รูummelfiege

(Volucella bombyleus.) Doerlipye breit, gewölbt, ausgerandet. Rilffer jurïfgejogen. Drei Junnttaugen. Seben auf Blumen; Die einjernen Gattungen erfdecinen, wem bieje brïgen. Man findet fie meift ein=

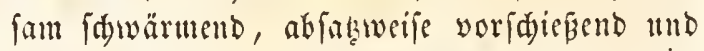
bann lange an bemielben grlaze fdweberib. Jgre Rarven, Dis einen weidyen bäutigen Rokf baben, reben theift in ber Erbe, im Mifte, in Murm ober in 3wie=

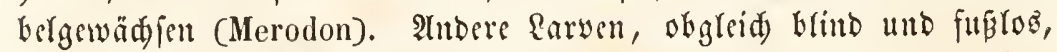
faugen bie Blattlänfe aus, nadbem dic Cier in beren Refter gelegt

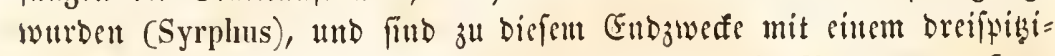
gen Stadel verfeben; andere (Volucella) Yeben in Reftern Der Sor=

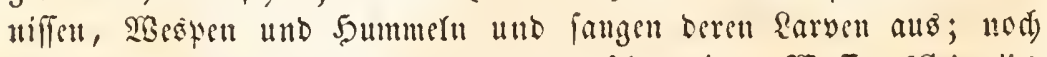
anbere enblity in flüfigem Sothe nub fdumubigem $\mathfrak{B a f f e r}$ (Cristalis) Ind find mit cinem rangen ferfpectivartigen 9 themroble am Sinter=

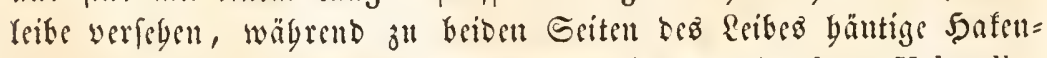
fortfä̉se fiø) finden, die zur Bewegung bienen. Syrphus; Volucella; Merodon; Psarus; Cristalis; Helophilus; Milesia; Cheilosia.

Die Stilettfliegen (Therevida) mit vorgeftredten Füblern, bie

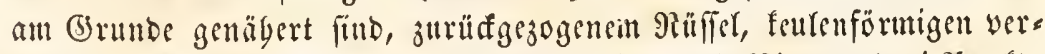
borgenen Jafpen, fegerförmigem Sinterfeibe aus 7 9ingen, orei Junft= 
augen, grauen ober 价wärsliden Farben. Sie Yeben in Sdjwärmen

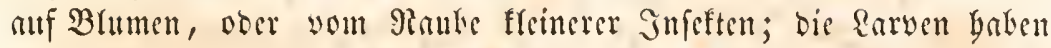
einen bornigen fleinen Sopf und rangen Reib mit 20 Pingeft und leken in Mintm. Thereva; Chiromyza.

Dic Sd) nepfenfliegen (Leptida). Müffer vorfetyent, Miüffer=

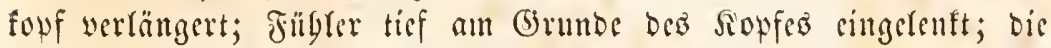

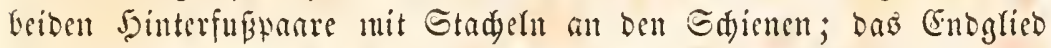
Des Tarfus mit brei Jubjuallen verfegen. Flüger abjtebend; Jinterleib

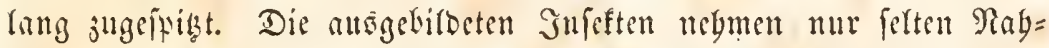
rung $j^{\text {th }}$ fid, bie aub Brumenjaft oder fleinen Juleften Geftebt; fie filzen meift rubgig in ber Sonne mit fenfredst aufgeridstetem Sinter= reife. Die Rarven leten in ber Grbe; sine im fübliden Gurepa worfoumende (battung (Vermileo) mad)t fid) im Sande cinen Tridster, in bem fie bineinfallende fleine Jurletten fängt. Syr Sö̈rper ift fegr lang, wurmartig; ber Ropf Lornig, Eegerfürnmig. Leptis; Vermileo; Atherix; Clinocera.

Die Fantilie ber Dormulaten (Notacantha) bat sinen fur

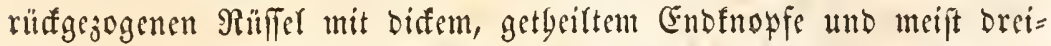
glieberigen Warpen, Deren Endglied oft fugelförmig ift. Die Fübler

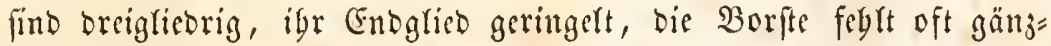

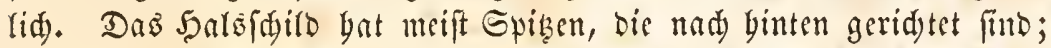
ber runblide Shinterteib beftegt aus fünf Deuttidjen Ringeln. Drei Jubsallen am Endogliebe ber Tarfen. Wian unterfdeibet befonders

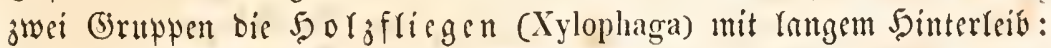
aนจ freben Ringeln, adjtringerigem Endglicbe ber Fübler, eingejogenem

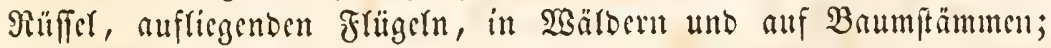
bie Gornfopfigen Rarven in Mufm - und bie $\mathfrak{2}$ affenfliegen

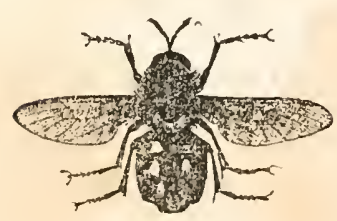

Jig. $75 \%$ (Stratiomyda) mit breitem siörper, breigliebe= rigen abfegenden Füblern, beren Endoglico fünfringefig und mit siner Borfte verfeben ift. Die Augen Gaben oben grübere Facetten, alz unten. Sis Gaben zuweilen rebgafte Distall= farben, fdwärmen auf Blumen; die garven

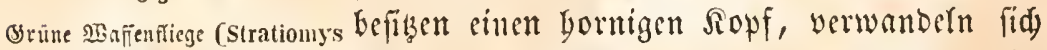
cameleo).

in igrer Rarvengaut und leben entweber im

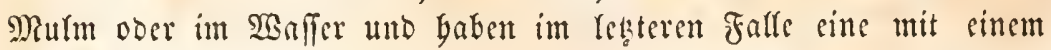
Borftenfranj ungebene 2 (tbeumröbre. Stratiomys; Oxycera; Platyra; Cyclogaster; Pachygaster; Sargus; Clitellaria; Nemotelus.

Bogt. Boologifdhe Briefe. I. 


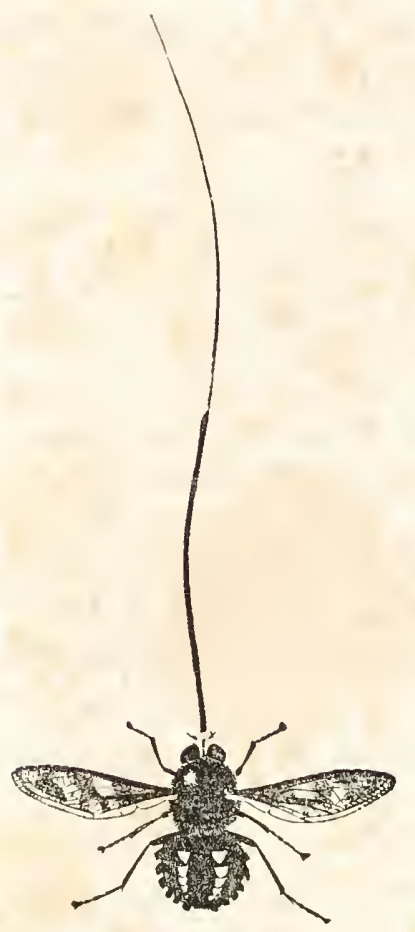

ซig. 758.
Dic Familie Der Rangrilliter (Tanystoma) begreift eine grop̧e $2(n j a g l$ meift fräftiger Fliegen, bie alle einen langen, oft bünnen, leberartigen, vors ftçenden Rüffer baben, beffen Sinopf und Enblippen meift wenig alţgeprägt find. Das britte Grlied ber Jithler ift sinfad, bie Borfte an feinem Ende ein= gefügt, Dod) ferlt fie juweilen. Der Ropf if balbfugclig, fo breit wie dis Bruft, nutr bei sinigen brattungen fegr flein; Der Sainterleib breit, folten länglida. CE find meift ftarfe friegen von räuberifden Sewognbeiten - ibre sarven fino nur menig befannt, aber bie beobaditeten Gatten alle einen bornigen Sopf mit Deutliden fauenoen Munowerf jengen und levten in Der Grbe.

\section{Man unterfdeibet viele Gruppen.}

Nemestrina longirostris.

Trauerfliegen (Anthracida). Sopf yorn rumb; Rüffer furo,

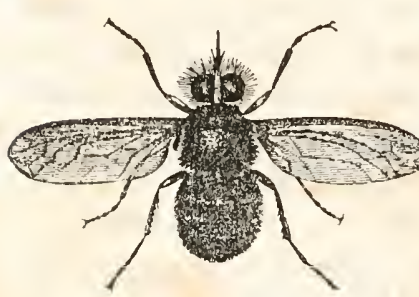

วิ่ง. 759.

Selber Trauerfaneber (Anthrax flavus). meif verborgen, nad vorn geridtet; (5nblippen des Snopfes beutlid; IJalpen singliebrig, an ber $\mathfrak{B} a f i s$ bes Rüffels. 2Hugen getrent. Bruft cben; Füßfe bünn, Jubballen rubiutentär. Flügel febr grof, feitlid) atsogebreitet. Meift (d)war' mit wcifen Sinien tutb Binden. Sie fawe= ben Iangfam itl (bebüld)en und auf Bru= men. Syre Sarven fitto unbefantut. Anthrax; Lomatia; Mulio.

Sd) webfliegen (Bombylida). Ropf flemer als bie Bruft. Rüffer Dünn, lang, mad) worn geridetet; Dberlippe febr lang. 


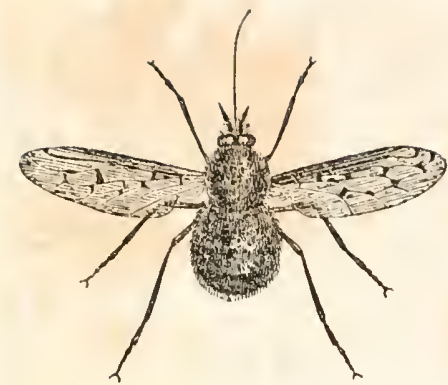

Jig. 760 .

Beflefter Sorrifineber (Bombylus pictus).
Jalpen eingliebrig, Fü̈ler rang, nabe ber cintuber; Borfte furj ober

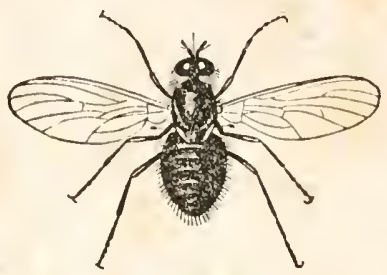

3is. 761.

Bahelfiege (Usia furcata).

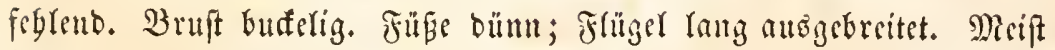
febr begante Fliegen, die äuperft founell mit ticfem Summen fort=

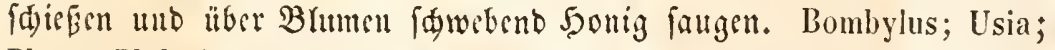
Ploas; Plthiria; Nemestrina; Xestomyza.

Mundyornfriegen (Acrocerida). Sopf fegr flein, unter ber Eufferigen 2 ruft verborgen, faft nur vou ben $\mathfrak{A}$ ugen gebirdot. Fübrer fegr fleit obeu auf ber Stirn; Borfte feblent. Der Rüffer unb bie

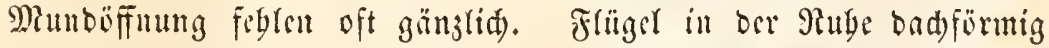

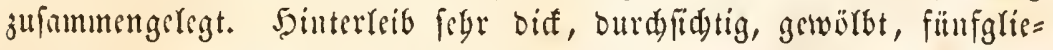
berig. Sis Keben auf Blumen, fliegen idjedyt. Panops; Henops; Acrocera.

Tangfliegen (Empida). Ropf flein, fugelig. Rüffer bünn, lang, gerabe uath unten geridtet. YJalpen jweiglicbrig. Fübler brei=

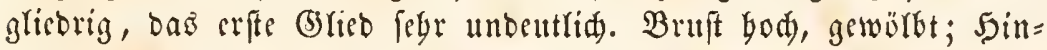

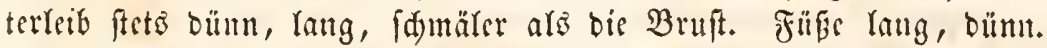

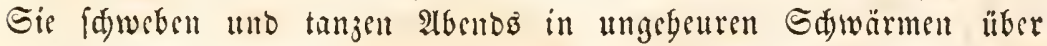

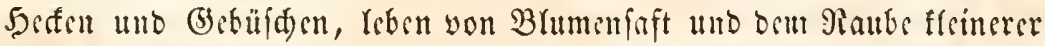
Jnfeften und meift getingt ben Mäundsen bie Begnttung nur, wäb=

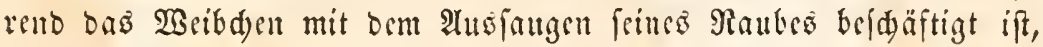
Dent cô int Fluge ober in Raufe fängt. Die Rarven füno untefaunt. Empis; Hilara; Rhamphomyia; Tachydromia; IIemerodromia; Drapetes.

$\mathfrak{B} \mathfrak{u} \mathfrak{f}$ rffiegen (Ilybotida). Siopf flein, gerabe vorgeftreft, fugerig. Brufp febr bod grwölbt, faft fugerig. Reib lang, geftrečt;

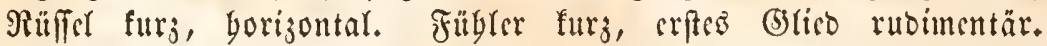

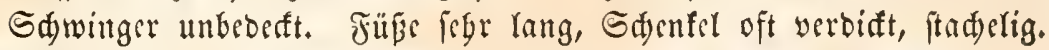
Fliegen fanell unt jagen anbere Grijeften. Ilybos; Oedalea; Ocydromia. 
Ranbfliegen (Asilida). Siopf grof̈, Stirn eingebrüat, AHgen

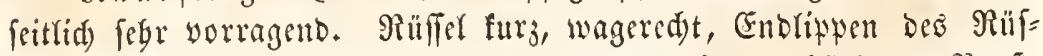
ferftopfes voripringend; Rippe furz; Fübler furz, abfebent; Borfte oft feblent. Das (sefidst febr Gaarig, Rnebelbart ftart. Sointertcib cy)linbrifd ober rumblid. Sdyinger unbebeft. Sdienen tuto Tar= fen frad)elig, Flügel grofi, ftarf. Sillbne Rüuber, bie an trodfenen, comnigen Drten ferbft weit grö̈ere Snjeften überfalfen, anjted)en und ansfangen. Dis Sarwen reben in Der crobe, Gaben cinen bornigen Ropf unb ftarfe, gefrümmte Rimubafen. Asilus; Dasypogon; Laphria; Dioctria; Rhopalogaster; Negapus.

Morofriegen (Mydasida), die Raubfliegen fïblider 3onen. Die gröpten unb ftäffiten Fliegen mit ftarfem, furzem アiüfel, ftarfem sinebelbart, eingebrïfter Stirn, sorftebenden 2 ugen, langen, fünfglie= berigen Füblbörmern, baburd) oen llebergang ju ben Rangbörmern mad)ent, obue Rebenaugen, mit febr ftarfen faddeligen Sinterbeinen.

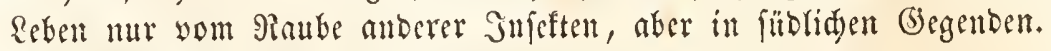
Mydas; Cephalocera.

Die Familic ber 2 remien (Tabanida) unterfdeibet fid von allen

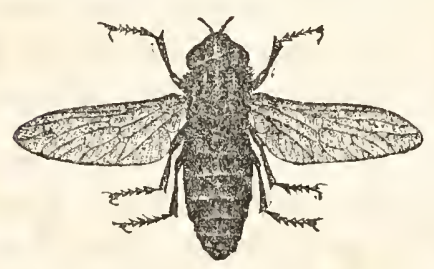

Fig. 762 .

Dajeubremie (Tabanus bovinus). übrigen $\Re$ urgyörnern burd) Dic Dr= ganifation ibres Rulfels, ber ganj Demientigen Der Shnafen analog gebaut ift. Der ganje fiörper ift Ereit, platt, ftarf; Der Sopf breit, jufaumengebrüdt; bie 2 ngen grof, meift grünlid) fdjiflerno; Der $\Re u ̈ f f e l$ vorjtebend, furz, biff; bie Mittel= fdienen mit jwei Spizen, bie Tarjen mit orei Fubballen verfeben. Das britte Jüblerglieb ift lang, cylindrifd, $4-8$ glieberig; frïgel frarf, badförmig. Gie fedsen febr empfindicl), faugen bas Blut ber Säugetbiere, fliegen auberorbentlid) fonell unb lang, obne ju ermü= ben unb baben cin reifes, (d)arfes Summen. Die Mämndy lanern in fomigen 2 arbwegen mo Sdyeifen auf bie 2 seibden, inbem fie eine 3eit lang faweben, oan plöblich an bas andere Ende bes 2 Eeges

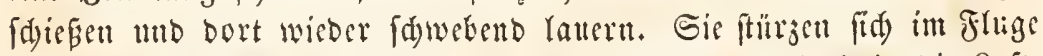
auf bic 2 seibden, parfen fie unb erbeben fid) Dann fyod) itl bie \&uft. Die Sarven reben in ber Erbe, Gaben einen bormigen, mit Gafigen Riefern bewaffueten Ropf. Die Yyupen fint Gaarig. Tabauus; Pangonia; Chrysops; Haematopota; Hexatoma; Silvius. 


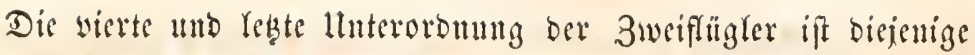
ber Enughörner (Nemocera). Der Siörper biefer Thiere iff büun, langgeftreft; ber Ropf flein, bie Bruft meift furb, aber bod)= getwörbt. Der Riliffer ift bard furr, balo rang. Die Yarpen Yang, wenigftens fünfglicberig, oft febcrbufdartig. Dic Fübler lang, bünn,

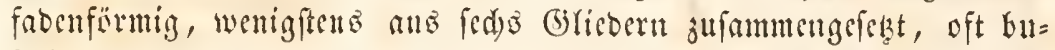

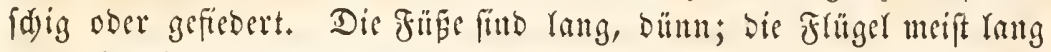
uno idumal.

ŞBir unterjasiben zwei fantilien:

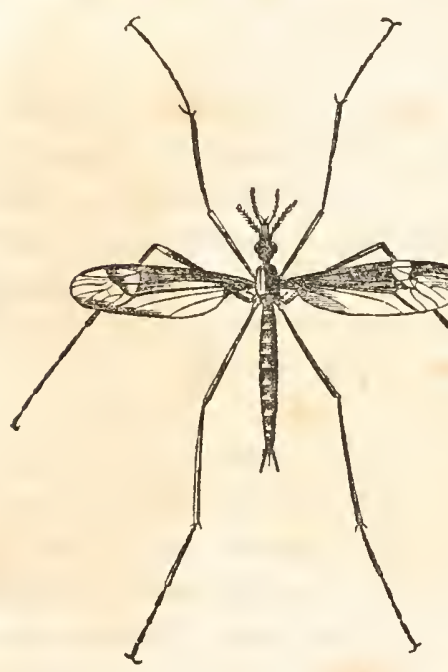

รig. 763.

Mlonoifynate (Tipula lunata).

Die Mürten (Tipulida) Gaben cinct $\mathfrak{f u r}_{j} \mathfrak{e n}$, biffen, vorftegenden Piitfier mit zwei beutliden Enolip= pen und nur zwei Jornborfen ( Rimbaten) im Smueren; bie $\mathfrak{T a}=$ fter yängen ober fint cingerogen unb gaben fünf Girieber. Cinige fted dent, bie meifen aber fitto vörlig webrlos. Sic tanzen meita গtbenos

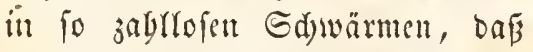

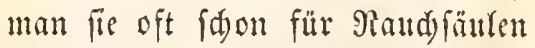
geyarten bat. Man bat megrere (3rupken unterfaicbert.

$\mathfrak{B} \mathfrak{l}$ u m e $\mathfrak{n}$ th ü $\mathfrak{f} \mathfrak{e} \mathfrak{n}$ (Bíbionida). Fübler worgeftrectet, waljenförmig an ber Splige jumeilen geftüpft.

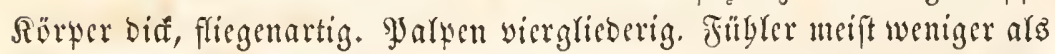

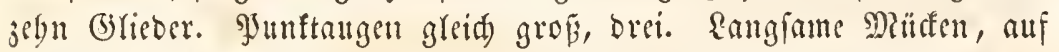
Bhrmen. Shre Rarven Yeben in ber Eroe ober im Mift umo lyabent

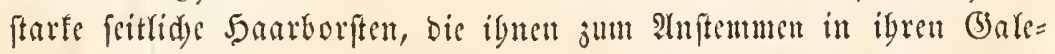
rieen bienen. Steden nidgt. Bibio; Dilophus; Apistes; Rhyphus; Icothopse.

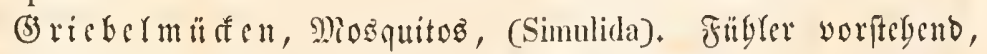
an ber Spire bünner, eiffglieberig. Tunftangen feglen. Siuffer yor=

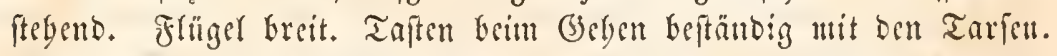

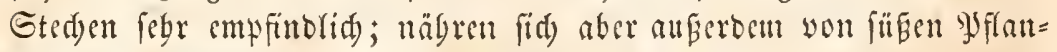
zenfäften. Sind bejonders in beísen Gegenden eine yुrage für Men=

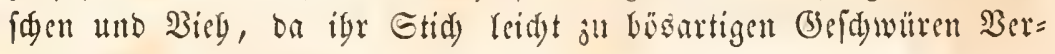
anlaflung gicbt. Simulia. 


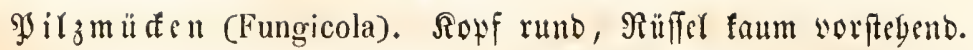
Fübler fabenförmigh, furz gebogen, meift 16 glieberig. Angen getrennt, rund ober Garbmondförmig. Drei im Dreieft gefteflte Sunftaugen, zuweilen bas mittlere rubimentär. Bruft gewörbt; Sinterteí lang,

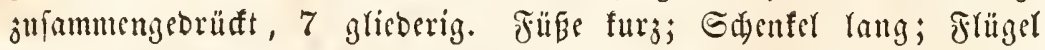

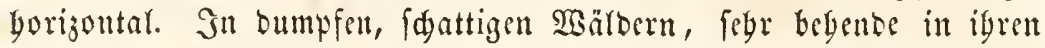
Bewegungen. Die Rarven in Sdwämmen, mit Gornigem Sopfe, Fügl=

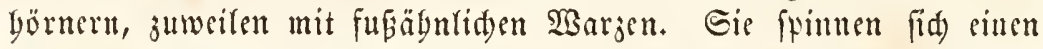
bünnen (Socon uno verwandefn fids im Sd)wamme ferbft. Bolitophilus; Mycetophilus; Dixa; Sciophila; Mycetobia; Sciara.

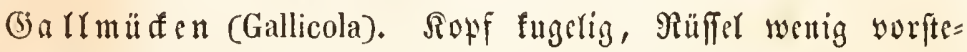

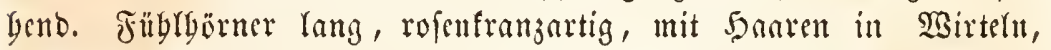
$12-24$ glieberig. Afugen nierenfürmig -- feine \$sunftaugen. Reib 8 ringetig, lang. Flüger plan ober badffërmig. Sie Yegen igre Eier

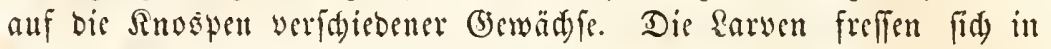
bie jungen Snospen ein, woburd) (Jallen getirbet werben, in benten fie wobnent und fid) sinpuppen. Lasioptera; Cecidomyia.

Erbmülen (Terricola). Sopf fugetig, vorn in sine furge

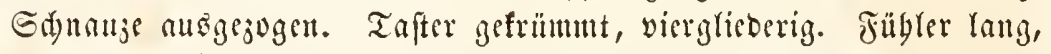

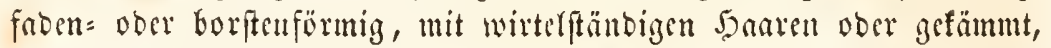
13-16glicberig. Sagen ganz oval. Seinte \$unftaugen. Bruft mit

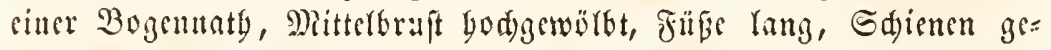

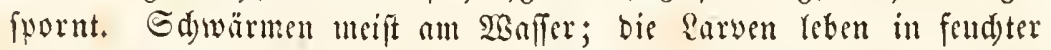
Erbe. Eine Battung, Chionea, ift flügeflos unb lebt im Norben auf bem Sdjtee. Tipula; Limnophila; Limnobia; Trichocera; Ctenophora; Erioptera; Ptychoptera.

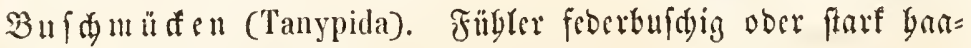

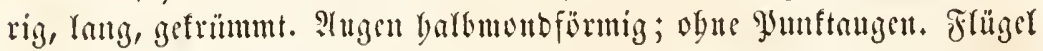

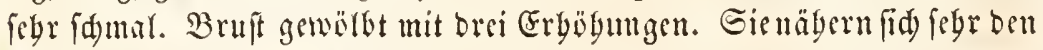
Sd) ufen in Form uno Birbung; aud) bie Rarven find ben Sdjnafentaryen

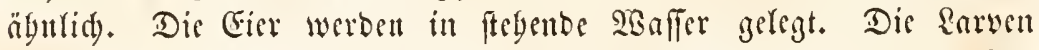
Yeben Darin, baben einen gornigen Sopf, bafige Sitefer unb uncift feito lide Sd)winmlappen. Einige bauten fid cigene Gä̈nge unter mobern= ben Brättern, wo fie in Gejelfid)aft leben. Chironomus; Choretra; Tanypus; Ceratopogon. 
Dis Familie ber S(bnufen (Culicida) bat sinen rangen, bünnen,

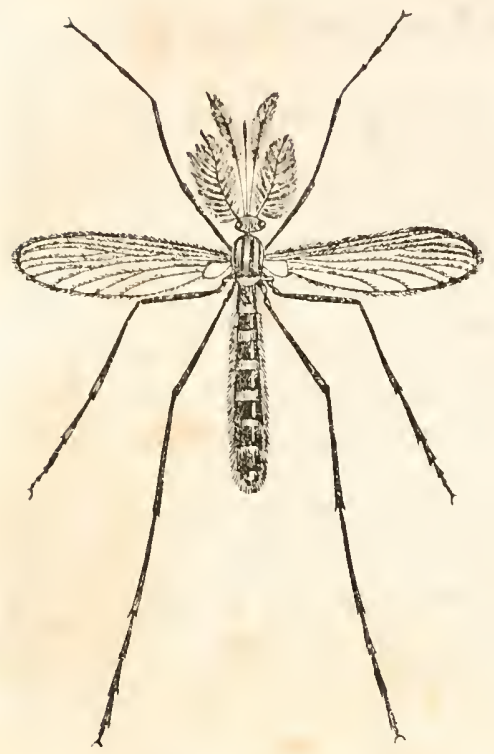

ซiij. 761.

Stedidunafe (Culex pipiens) rergríbert. gerioen Riulfer mit sier beutliden Borfen; fünfgliebrige Syalpen, bie meift länger fitto alz ber gilliles, 14 glieberige Fubler, lang, furdsig bei ben Mänuthen, boritig bei Den

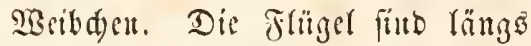

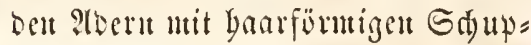

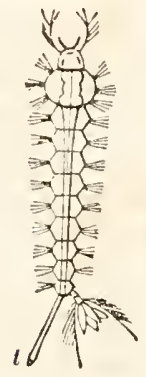

ซig. 765 Die :arre.

t Die Sthemrögte. pen befeet. शur Die 2Beibden fte= d)en. Die Rarven reben im $\mathfrak{\text { Bafler, }}$ baben eitren bor= nigen sopf mit jwei gefieberten Sinnbafen, bie cinen fteten Stru= bel unterbalten und eine lange Ittgemtröbre, bie (d) ief vom Reibes = ende abfegt und einen Borftenftern bat. Die Iywpe ift furz gebrun= gen und atbmet mit zwei an ber Bruft liegenden furgen Rögren. Culex; Anophales.

Unter Den folfilen 3weiflïglern treten zuerft bie Sangbörner auf unb bebalten aud in ben jüngiten formationen cin bebentendes nu=

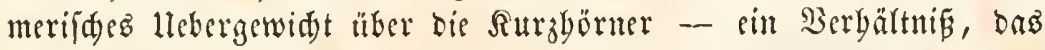
jetst gerabe umgetebrt ift, fids aber leidyt erflärt, wenn man bebenft,

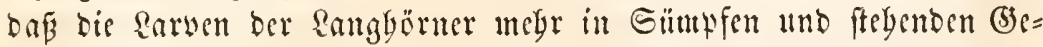

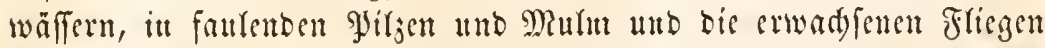
in $\mathfrak{x a ̈ l d e r n ~ m o ~ B a ̈ f ) e n ~ r e b e n , ~ w a ̈ b r e n d ~ b i e ~ R a r w e n ~ b e r ~ S u r j b o ̈ r n e r ~}$ in ber Erbe uno in Yyflanjen, bie Fliegen auf Bluten tmo Sräutern leben. Die Bibioniben find son benienigen Rurbbörnern, Deren Sar= ven in ber Groe ober im Mroder leben, nod bie zablrsidste Familie.

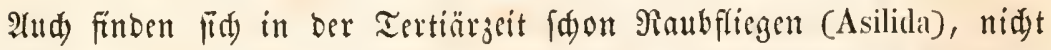
aber folde Surzbörmer, die bas Blut warmblittiger Thiere faugen. 


\section{Drsung ser Gdhnetterlinge (Lepidoptera).}

Die fdjummernden Farben, bic Bierlidfecit ber Form baben von

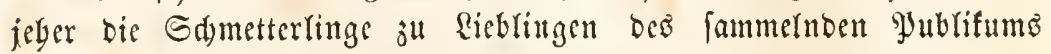
gemad)t, wägrend auf Der anderen Seite nirgends ber Difettantis= mus ber Sammler fdeled)tere Früdte getragen yat, als gerabe bei biefer Dromung.

Der Sopf ber Sdjmetterlinge ift meift fegr flein, uno in ben

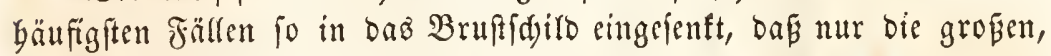
gewölbten $\mathfrak{A}$ trgen mit ben Taftern unt Füblern Gervorragen.

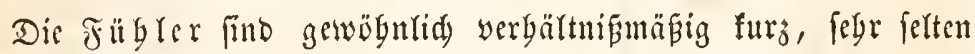

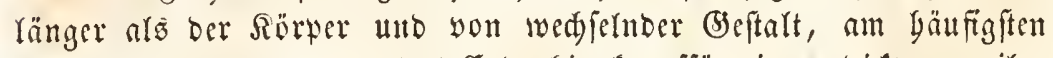
borftenförmiz voer gegen bas Ende bin fnopfförmig verbiat, zumeilen

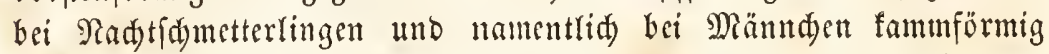
ober gefiebert; fie baben meift fegr sicle Bstieder, bie eng an einander riegente Ringe bitben.

Dic $\mathfrak{A} u g e n$ fint meift fegr grof, worftebend, rund ober byalb=

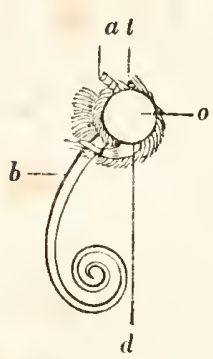

8ig. 766. Der fouf cinte Sithmetterlings non ber Seite gejeben.

t Der Rotr. a Dic $\mathcal{B a}=$ fits Des abucfontittenen Fith= lers. b Der fpiralig sutge= rollte Rüllft. d Die sippen= tajter ber limfeu Gritc. ODaB ange. rund, mit aukerordentfid) vieler Facetten ver= feben; bie Rebenaugen feblen meiftens ober fint fo unter ben Jaaren und Sduppen bes Sdyci=

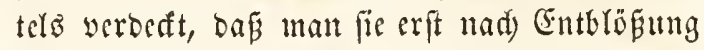
befferben auffinden fann. Dic Mundwett= zenge find cinjig jum Saugen cingeridetet uno bejteben bauptfäd)lid) aแo ben beiben atter= vrbentlid) vertängerten Siutultaben, welde bie Form einer Jalbeble Gaben, fo dá fie beim 3ulammentegen einent boglen Sanal, einent Pärfer birben, ber gewögntid) fpiralig singe= rollt, an ber llnterflăd)e bes Siopfes getragen wirb. Buwweilen erreidt biefer Piüffer sine un= gemeine Ränge, wie namentlid) bei Den 2 bento=

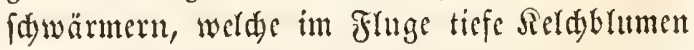
aแbुufaugen im Strnoce finto; nur in wenigen fällen feblt er ganz, und die volffommenen Sujeften leben Damn nur wenige Tage, einzig mit ber Fortpflanjung kefdaftigt. Die Sobrlippe ber Sdametterlinge wiro Dutd cine äurerft fleine breicfige ober rund lide Santfalte $\mathfrak{r e}=$

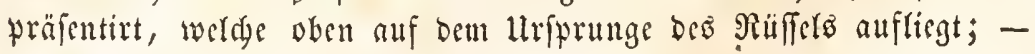




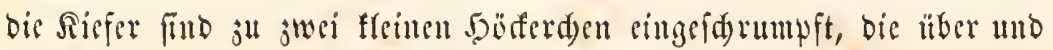
über bebaart fint. 3แ beiben Seiten Der röGrenförmigen Rimuladen fteben jwei äuferft fleine Rabentafter, bie gänjlid von ben groben begaarten Sippentaftern bedectit werben, welde meiftens oreigliebrig, felten nur sweigliebrig fint, und Den Pitiffel im aufgerollten 3uftande swifden fid negmen; - die Unterfippe ferbjt ift nur sin fegr furjer yäutiger Borfprung, an Dem Diefe großen sippentafter singes fügt fitio.

Die $\mathfrak{B} \mathfrak{r}$ ft, welde' faft immer belgart ift, läß̈t meift mur sine ringförmige Borberbruft wahrnegmen, Ginter welder Mittel = uno Shinterbruft zu sinem Stüfe verfdmolzen fint. 3u beiden Seiten Der

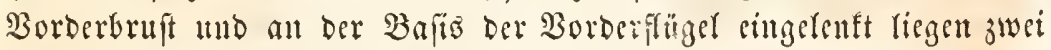
Gäutige Eappen Der Rürffeite auf, welde man die Flügelfduppen

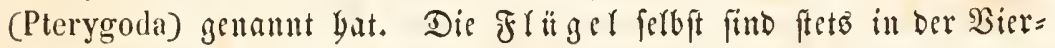

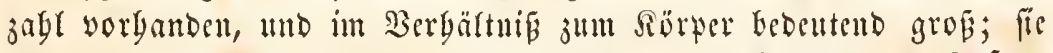

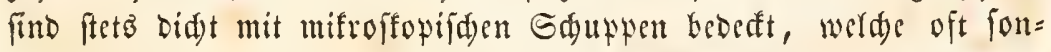

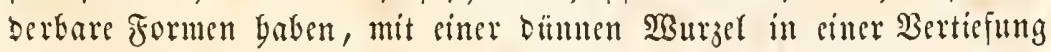
Der Frügelbaut fteffen, Dadjziegerförning übercinander Yiegen und öfters

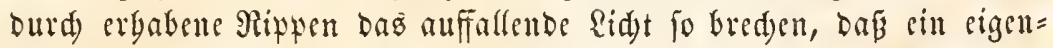

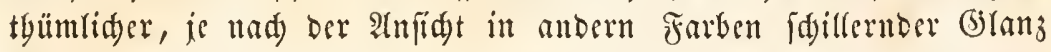

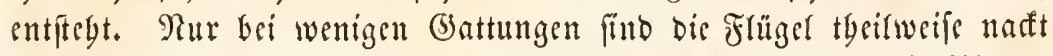
und Durdjifitig, bei anderen jun Theite gefpalten und bis Rippen

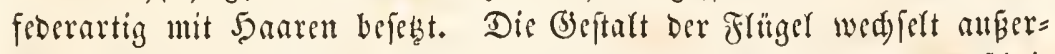
ordentrid, und liefert ebenjo fonftante Siennjeiden für bie ltnterjadsis bung Der eingefuen $\mathfrak{A r t e n}$, als bie Färbung und namentlid) Die Beid)= nung, welder zul Forge die Farben vertbeilt finto. Der lumrís ber Shinterflingel ift fegr verjdieden und befonders bei vielen Tagidmetter=

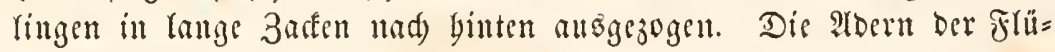
get find wenig jablreid) und birben nur eine geringe stujabl von

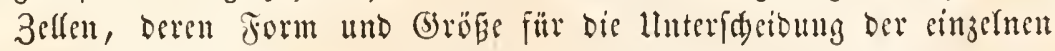

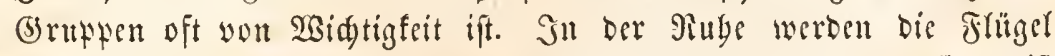
fegr verfidicden getragen. Die Tagjdmetterlinge fidragen fie meift fenfredt in bie Saöbe; bie Radtidmetteryinge legen fie Dadfürmig

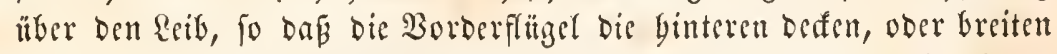

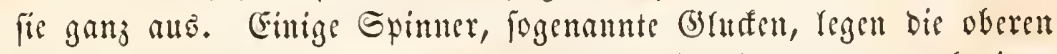

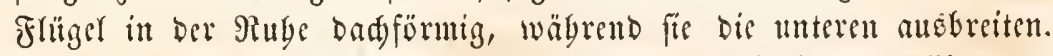
Bei mand)en Metten und Spinnern find Die Weibden yolffommen

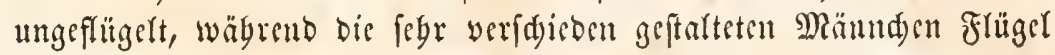




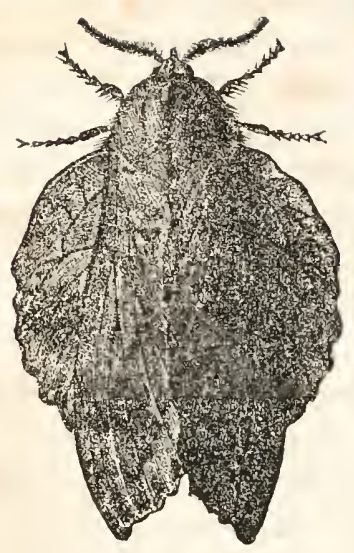

Jig. 767.

Die Eidfenglute (Bombyx quercifolia).

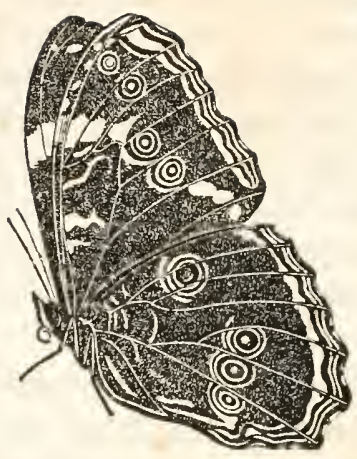

Tig. 768. Crim Tagidgmetterling, Morphe Helenor, fitzend mit zufammengejकीagenent

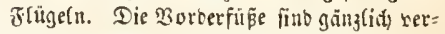
fümmert; man fieft nut bic beiben fọin: terfiñe.

befiten. Die Fü fe oer Sdymetterlinge fint wie bei ben üfrigen voff= fommenen Snjeften gebildet, bebaart ober befdupt, bie Tarfen fünf= gliebrig uno an ber Epite mit jwei Rlauen bewaffnet, swifden benen meift nod ziemlidy bebentento 5aaftappen fteben. Bei vielen Tag= idmetterlingen ift bas vorbere Juppaar flein, zum (5eben untauglid), ober ferbft gänjlict) werfümmert, fo bafi fie unr cine art bebaarter Slatten bilden, welde an ber Geite ber Bruft biunafgeidlagen wer= ben. Der Sinterleib ift ftets ränglid, warjenförmig, aus fieben

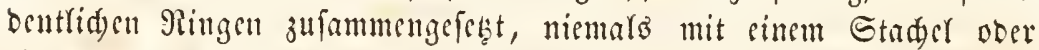

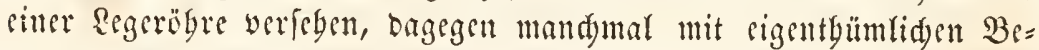
gattunģ่อน

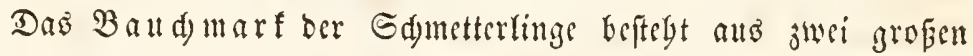

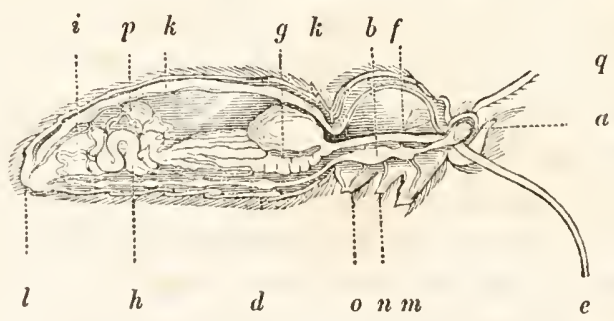

ซig. 769.

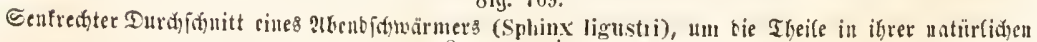
sage in zeigent.

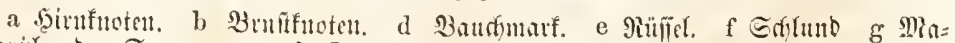

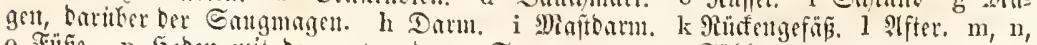

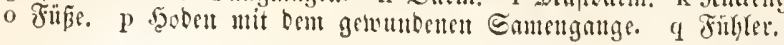




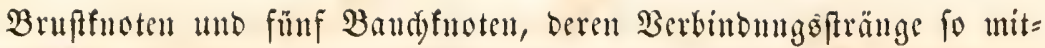

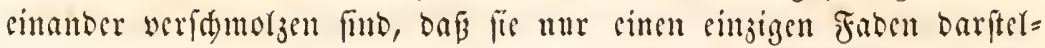

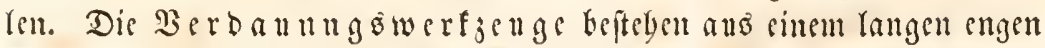
Sd) (umbe, in beffen unteres Ente sin runtidaer bünnwandiger Sang= magen mit sinem furjen Stiele lid cinfenft. Der Magen ift (d)land)= förmig, Der Darm büm, mebrfad) gewunben, der Diaftorm meift blafig aufgetrieben, jumeifen felbft ju cinem Shlinboarme erweitert,

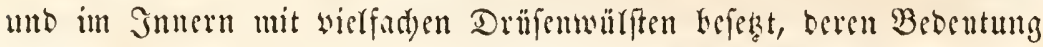
nod) nid)t befannt iff. Die Sarngefäpe fint frei mo meift fed) a an Der Zabl, bic Epcidjelgefä̈e oft fegr lang und juweilen felbft in bie

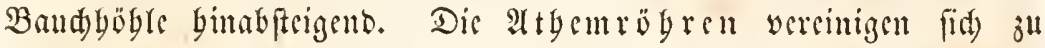

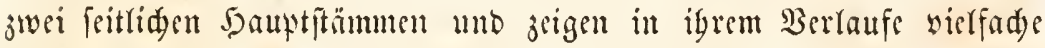
brafige Crrweiterungen, bie befonders bei ben Gdwärmern bebcutent entwiffert fint. Dic Gier fit ö a ber weibliden Sdmetterlinge fint

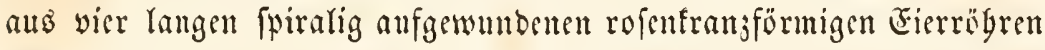
jufammengeferst, bie in sine furje Sdycibe münden, an weldyer cine grofe, birnförmige Samentajde und weiter unten eine jweibormige Rittorüfe cimmünoen. Die birnfürunige Begattungštajde, bie mit cinem Gejonderen Putbenfantal in Berbinoung ftegt, münbet ber Samentafde gegenüber burd) einen befonderen Ranal cbenfallo in bie Sdeibe sin.

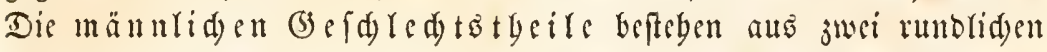
Sobenfd)länd)en, weldye meift veridgmoljen und in einer einjigen mitt=

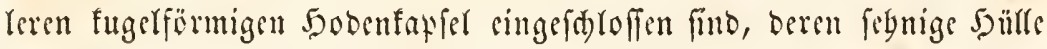
sime fajöne grinte ooer rotbe Farbe befigt. Afus biefer 5ooentapfer entfpringen jwei Samenteiter, weldye fid balo ju einem Yangen ge=

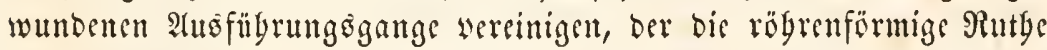
aแต่ทนีทอยร.

Die Eicr ber Sdjmetterlinge fint meift runblid, zismlid) feft und werben yon ber Miutter an fold)en Drten abgeragert, Daj bie

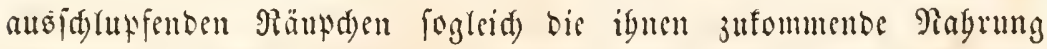

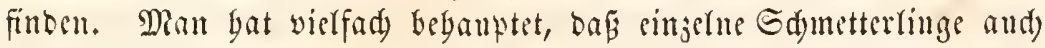

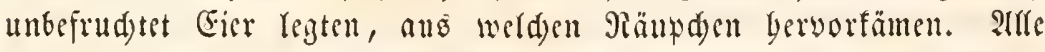

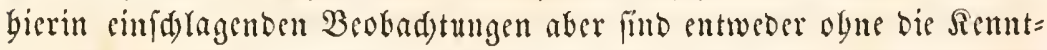
nis cigentgümlidjer Drganifationsverbältniffe, bie wir fpäter berübren werben, ober nur in unvolffäntoiger 2 seife gemad)t worben. Biele

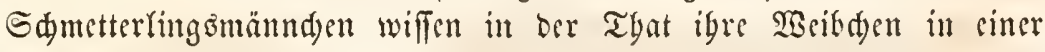
Entfernung von megreren Stmben ju finben, mo begatten fid mit

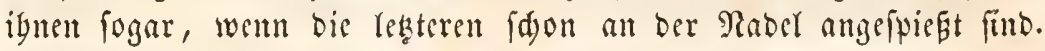
Die Eier ber Gdumetterlinge fönnen sine fegr grobe Sälte ertragen 
und in ber Tyat n̈berwintern bie meiften Gattungen als Fier ober

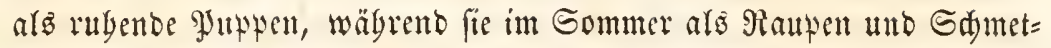
terlinge fid zeigen.

Die Rarven ber Sdjmetterlinge, bie allgemein unter bem Rament

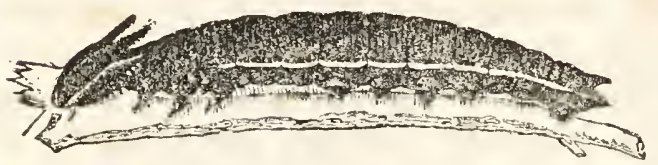

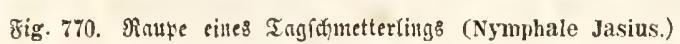

ber Raupen befanut finb, baben meift cine cylinbrifde, geftrectec (b) $=$ fitalt, uno zeigen fiteto alter bem bornigen Ropfe subulf Ringe mit

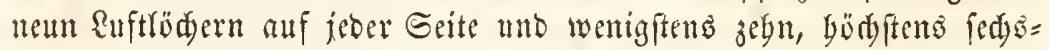
jegnt Fupparen. Der Sopf ber Raupen läpt weber Fübler, nod

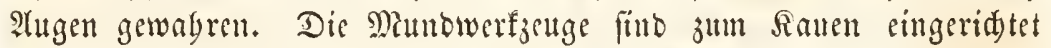
unb befteben aus jwei fräftigen, Gornigen Siefern, zwei Rinnlaben, mit fegr fleinen Rabentaftern, zwei fleinen Rippentaftern unb cinet

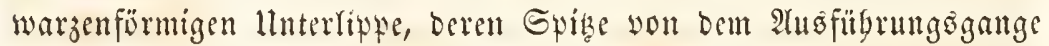
Der Spinnorüfen Durdbobrt ift. Die brei erfen Pinge bes Paupen= förpers tragen bie äd)ten ober bornigen fätae, welde mit flemen Sralfen befest fint, unb Den Fü̈en bes volffommnen Suleftes ent=

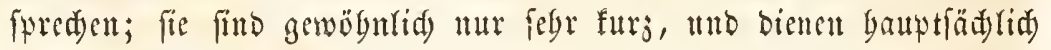
jum Unffammern ber 3weige, wäbrent die falfden Füpe ober Baud)= füre, bie an ben binteren förperringen fteben, wefentlid) jum (Geben bienen und meift bie Form von Gdröpffüpfen baben, bie nod obenein oft mit fleinen Safen bejebst fint. Der vierte, fünfte, zebute uno eilfte Ringet ber Rauten befizen niemals falfde Fübe. Bei ben eigentli= d)en Spannraupen fommen mu vier an bas bintere sörperende ge= ftelfte Paare falfder Fübe wor, weblalb fie beim fortichreiten ben Saum gleidjam ausmeffen, inbem fie fid erft mit ben Borberfüßsen anflammern uno bann Den Ginterleib nadjieben. Manden Epintern feblt bas bintere 9Jan ber Baudfübe ganj, ober ift ourd) jwei lange Faben erjest. Sinige Rauten yon Tagidmetterlingen befizen gans fonderbare Füblfäben im Racten, bie bervorgeftülpt werben fömmen.

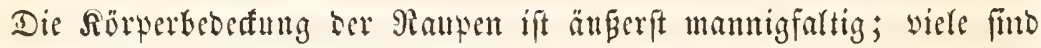
nadt, anbere über tnd liber mit rangen Saaren befest, welde leidut
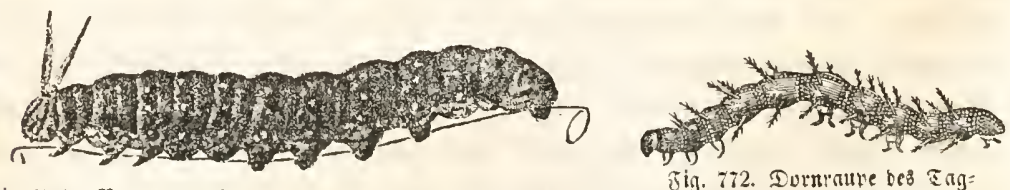

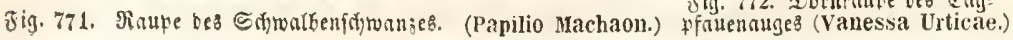




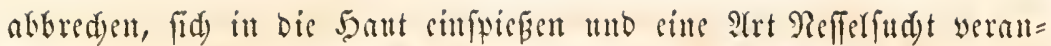
Yaffen fömen; nod) andere funb mit Dornen, börnern, ober biegfamen

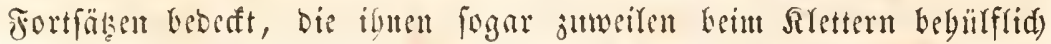

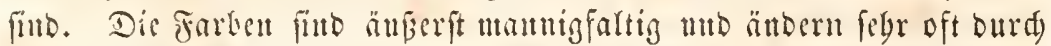

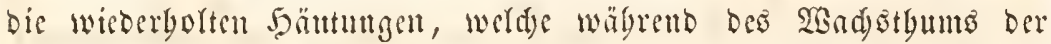
Ratule ftattinden. Die meiften Batuen verpttpen fids gegen ben

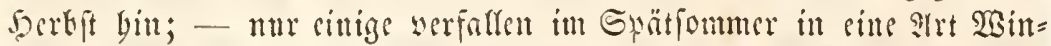
terfalaf, ans betm fie erit im frübling erwad)en. Sie näbren fid meift yon Brättern uno grüten Jyflanjentbeilen, wenige bobren in

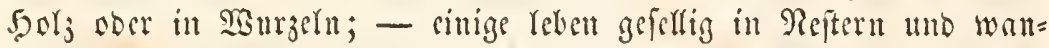
Dern in Colonuen son cinem Bamme zum anbern; bie meiften fint einfan unt obne weiteren befonderen Suftinft.

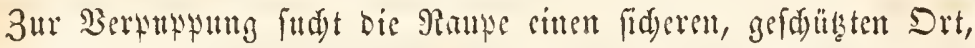
meift an ber llnterfeite Ser Bätter tmb 3 weige, in Epalten thlo Riber, unter bem Moofe ober in Der Eroe. Dis meiften fpintuen entweder eine förmlidye boulle von Scibe, zu weldem 3wefe fie ben Faben mibr ober minber regelutäßig fdlingen, ober fie bletben natt, tuib bäugen fid bann bald cinfady an bem Sdumanjente anf, bald

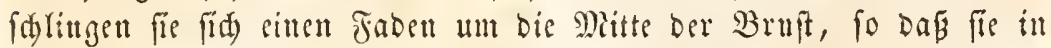
wagered)ter Stellung fid befindert. Die gs np pen find yornig, vorn Differ, binten geringelt mito jugefxizt, uno laffen

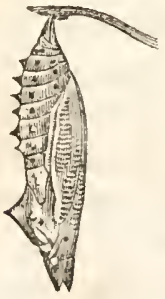
meift you angen die Flügel, bis Jübe und oft aud Den Biuffel erfenuen. Durd) mantigfal=

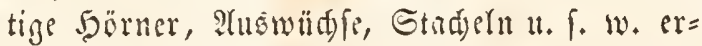
balten biefe Supten oft sin bödit bizarres 2 (n) febu. Die meiften Iagldmetterlinge, fo wis bie flrinen Radt thmetterlinge bleiben utur vier= zebn Tage, "bis sinen Monat in ber Juppe,

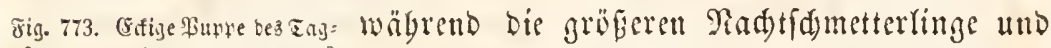

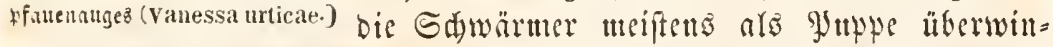
tern. Mande Jutren, weldye in ber Erbe ober im Juttern von Ge= wädfen in Gängen fid befittoen, die son ber SRupe gebohrt watroet, flettern gegen bas Ende ibres Juppenftandes mittelft eigener Stadjeln an oen Pingen itl bie Söbe bis an bie Dberfläde, fo bnf ber aus= friedenbe Gdmetterling beim Eprengen Der Juppenbant unmittelbar in Das Freie gelangt; - andere Yluppen zerftören felbit mittelit ibrer

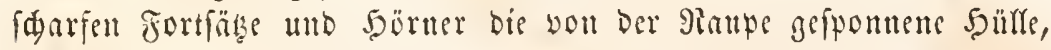
unb bei nod anderen erweidyt oer Sdumetterling bieferbe, uno burd)= bridt fie oant, bevor feine Flügel bart geworben fint. 
Sirir tyeifen bie Sdjmetterfinge in zwai ltnterorbnungen: $\mathfrak{T} a g=$ (d)metterlinge ober Reutengürner (Rhopalocera), uno Radtfdmetter= linge (IIeterocera), weldje fid) wicber in mannigfaltige familien unb unterfamilien idseiben.

\section{Die linteroronung Der Itaditiduntetterlinge (IIeterocera)} zerigt Föbler yon ber veridjicbenfen Befdnaffenbeit, meift zwar borften= fürmig, aber fonft bod yon allen formen bis zu berienigen cines vollfommenten Feberbufdes. Die Sdymetterlinge fdulagen niemals bie

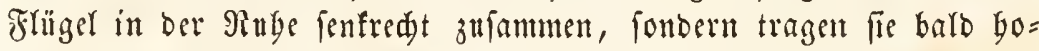

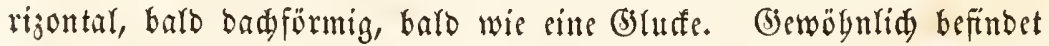

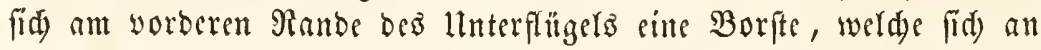
ben Sberflügel anlegt unb fo cin feites Bufammengalten ber Flüget

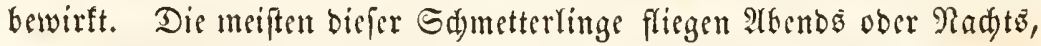

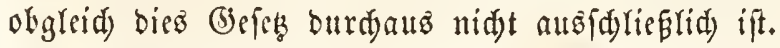

Die Familie ber Federmotten (Pterophorida), Gat Gorftenförmige,

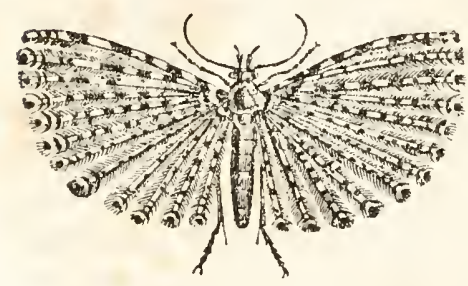

8ig. 774. Orueodes hexadactyla.

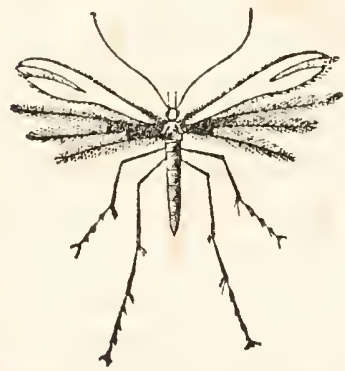

Fig. 775. Pterophorus pentadartylus. zicmlid) lange Fübler, zugépizste, wenig bebaarte Tafter, nierenför= mige, und) binten anże(d)ittene 2lugen, lange mit fpizen Sporen befezte Baite und einen langen, bünnen Şinterteib. Sie seidnen fid) vorjüglid burd eine Spaltung ber Frügel ans, indem bie Jinter= flügel ftets, bie Borberflügel mei= ftens in eingelne fingerartige Theile jerlegt fint, weld)e wie febern auf beiben Seiten mit Saaren befest fint, und fo bas Anfeben eines $\mathfrak{B o}=$ gelflügelö geben. Dic Paupen dic= fer niebliden Thierden fund tlein, natt, Gaben fedszebn färe, uno verwandeln fity in sime natte, mit

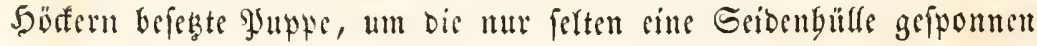
witb. Orneodes; Pterophorus. 
Die gamilic ber Motten (Tineida) beftegt aus meift febr fleinen

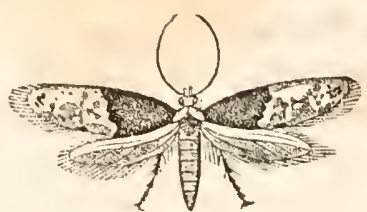

Edumetterlingen mit fabenförmigen Fïblern, bie juweilen länger alz ber Sïrper find, tho fdimalen ver= längerten Dlerflïgeln, weld)e zus

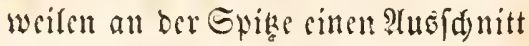

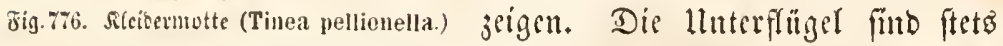
breit, ber \&änge nad) gefaltet, bie Tafter gewöbnlidg febr lang und

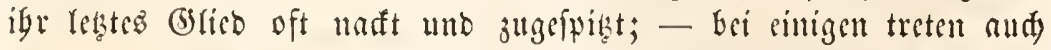
dic Riefertafter beutlid in bie Grid)cintung. Dic Räufden ber Mot=

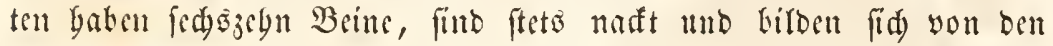
Stoffen, you welden fie leben, cine giöbre, bie entweber beweglid ift, fo baß fie biefelbe überall mit fid) berum(d)leppen fönnen, ober bie

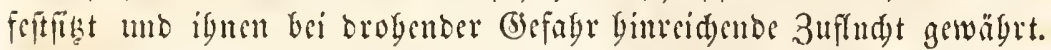
Biele biefer Raupen reben im Snnern won 3weigen und Rnogenen,

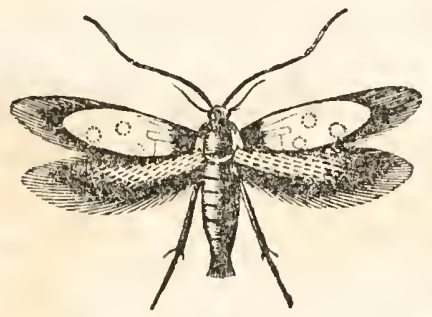

ig. 777. Setreibemutte (0ecophorus) in bem grünen (B) bebe ber Blät= ter, wo fie gewunbene (5)änge zwi= fden ben beiben Dberbautididyten graben; andere leben it troffenen Yflanzen= und Thierfitoffen, wo fie un oft, wic bie $\mathfrak{J e l}_{\mathfrak{j}}=$ uno Rlciber= motten unb bic (3) streib emotten, großjen Sdaben anriden. 3ur Berpup= pung falliçen fie igre Röbren mit Deffern von Geibe. Tinea; Yponomeuta; Adela; Aglossa.

Dic Familie ber Blattwictler (Tortricida) zeigt furze, faben=

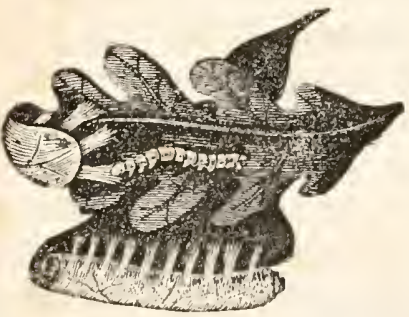

8ig 778. Pieit uno Rauke bes (Eifientwiffers (Tortrix viridissima.) förmige Fïbler, verlängerte, vorge= firedte Tafter, beren leşteż Gried bidst befdupt ift, badjörmige auf= liegende Flügel und cinen weit bife ren, fürizeren Seif, als Die Miotten, mit benen fie fonit in igrem $\mathfrak{B e r}=$ balten viefe Alebulichteit baben. Ibre Raupen baben fedsegebn Beine und verfertigen fid) baburd) cine (düzente Rögre, bag fie bic Blätter vom Ranbe ber anfrollen, unb mit Sci= benfäben förmlid) zu siter Röbre zu[ammentälen, innerbalb welder fie fid foüter werpuppen, wobei fie fid eincn Gocon von reiner Sribe fpinnen. Sie werben efento, wie die folgende Familic, ourd ifre Berberungen an (jewäd) fen zuveiten (däblid. Tortrix. 
Die Fantilie ber Büngler (Pyralida) beftegt aus mottenartigen

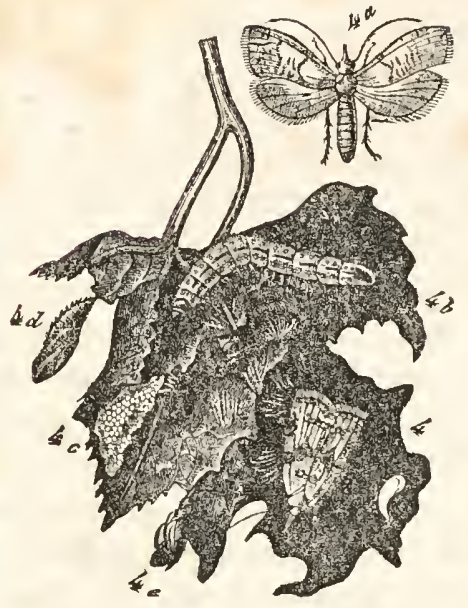

ชิ่ง. 779 :

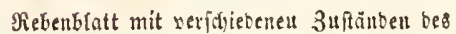

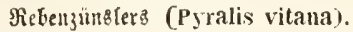

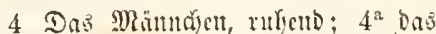

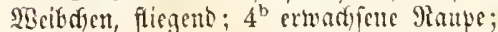

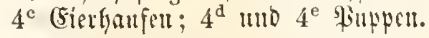
Sdymeiterlingen, Deren Fübler bei ben Mäınţen meift gefämmt ober gefiebert und beren Sitefertafter ftets febr beutlid) fint. Die Flïgel find lang, famal unb birben in ber

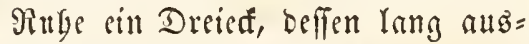
gezogene Epize ber Ropf ift; Die Beine find felyr lang, ftart ge= fportut; bie Raupen nur vierzebu= beillig, barrig uno fpinnen fid eigene Cocons meiftens auf ber Ilnterfeite Der Blätter; mande âten ridten an Dbftbäumen til $\mathfrak{B}$ einbergen grof̣e $\mathfrak{B e r w i f f t u n g e n ~ a n . ~ P y r a l i s ; ~}$ Botys; Pyrausta; Hermidia.

Die Familie der Sarträger (Psychida) beftegt uur aus cinigen fleinen Sdumetterlingen, Deren Männden gefiederte Füblet mo ftarf begrarte flügel beftizen und welde befonbers burd) ibre Rebeng= art im Raupenzuftante, fowie Durd) ifgre cigentlünlide fortpflan=

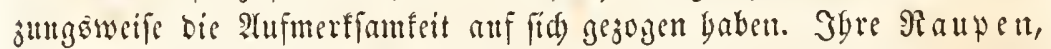

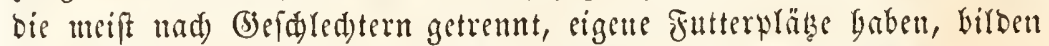

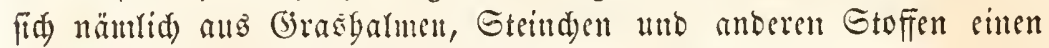
langen Gaf ober vielmebr eine waljenfürmige Rübre, bie je nad) ben (befdyedtern verideden ift, fo bafi man fan an ber form ber Gäafe bie männliden unb weibliden Ranpen unterfdeiben fant. Die Raupen, weld)e in Licfen Säfen fteffen, zeigen nur bas erite äd)te Jubpar volfommen entwifert, wägrend die anderen rubitmentär find.

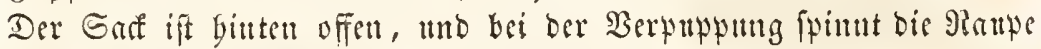
ign mit bem yorberen (slloe irgendwo an, orebt fid aber bann ber=

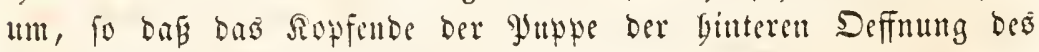

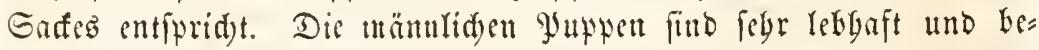
wegen fid in bem Gade bin unb her, die weiblidjen bagegen riegent

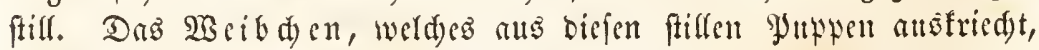
if faft vollemmen fuñlos, mabenförmig und zeigt feine Epur von Flügeln. Die siseibden ber einen (battung (Psyche) verlaffen ben Gaf niemals, foubern werben imterbalb defferten won bem Miänduen, 


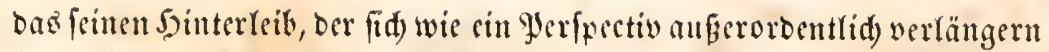
fann, in Den Gad bineinidiebt, innerbalb des Gafez befrud)tet, wäb= renb bie Sisedfeneiner anberen (Battung (Telaephoria) fid auben am Sade feftelaumern und Dort befrudyten laffen. Die befrudsteten 2 Beibden legen

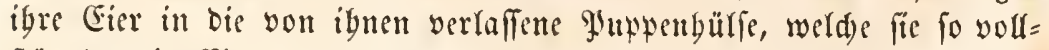

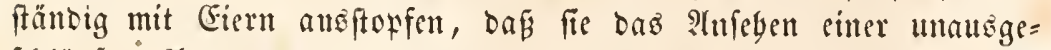

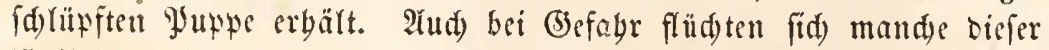
sceibden wieber in bie reere Juppenbülfe binein. Dis Migtenung

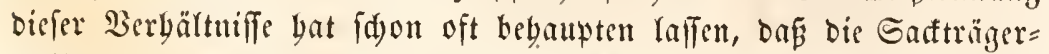
weibden aud) obue Befrudutung lebentääbige (Fier Yegten. Psyche; Telaephoria.

Familie Der Spanner (Geometrida). Die Sd)metterlinge diefer

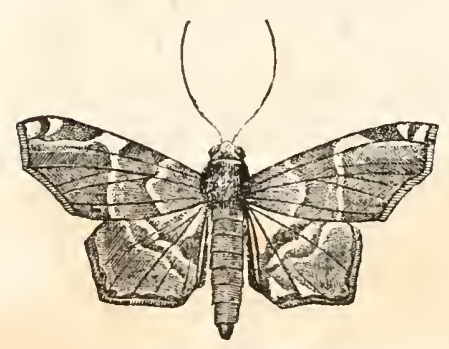

Fin 780. Herminia. Familic baben groß̈e, breite Flïger, weld)e ibnen viele Aebnlid)feit mit ben Tagidmetterlingen geben. Die Filb= ler find bei ben Männd)en gefämmut ober gefiebert, bie Tafter gewöbnlid furz, Der Rörper fd)lanf; Die Flïgel werben in Der Rube auggebreitet. Die Raupen find lang, Dünn, walzenför $=$ mig, nadt ober febr fparfam bebaart und gleiden meift bürren Baumzmeigen; fie Gaben gewöbntid nur zebn Yyar Beine und fpannen bef̧balb beim Sdreiten, ba ber ganze

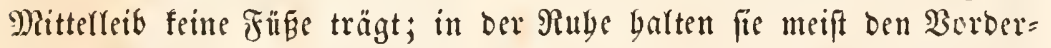
förper aufredt, inbem fie fid) unr mit ben falfden Füß̈en anflammern, und mandmal bebarren fie ftunbenlang unbereglid in biefer ermü= Denben Stellung. Die Puppen find naft uno meift nur mit wenigen Fäben angebeftet. Acaena; Herminia; Ennơmus; Fidonia; Zerene.

Die Familie ber (Eulen (Noctuida) umfapt Nad)tid)metterlinge

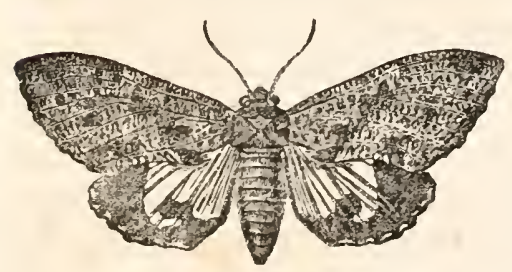

Fig. 781. Noctuella von meift Dunflen Farben, aber mit febr conftanten 3eidyuntgen, bie oft eine febr bebcutento (5iöfíge errei= den, ftets nur borftenförmige ober Göd)itens geterbte föbler befiben, und bereu sippentafter nur fur 3 find und mit einem fleinen, Dïnnen Bliebe entigen; Der Rüffer ift meijt 


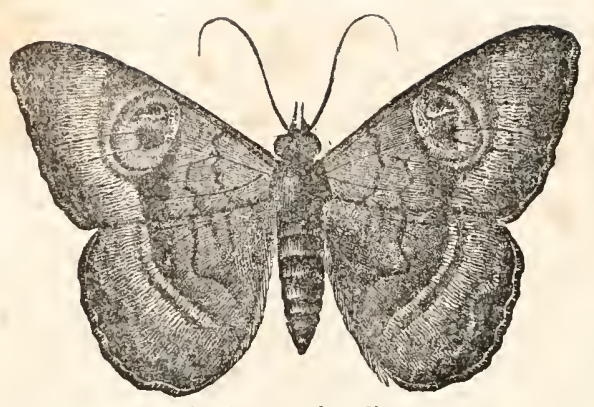

ซig. 782. Erebus limax

lang, ber Sinterleit fe= gelförmig, bünn bebaart, meift nur mit eng an= liegenden Sduppen be= fleibet. Die Raupen find lang, geftrect, oft $\mathfrak{a b g e p l a t t e t , ~ f u r ; ~} \mathfrak{b} e \mathfrak{b a a r t}$ und meift von Den Baum= rinben, andenen fie fizen, ¡dwer zu unteridueiben; fie baben gewöbnlid fedszebn Füpe und befonbers lange Rad fdieber; ibre Juppen find in einen laxen, foledt gearbeiteten (5ocon eins gefd)loffen. Noctua; Noctuella; Erebus; Triphaena; Catocala; Plusia; Cucullia.

Die Familie ber Şarpyen (Cerurida) beftebt aus Nad)tidmetter= lingen mittlerer (5röpe mit meift bid)t bebaartem, bidem Seibe, jottig baarigen Füßen, gefämmten Füblern, beren Fieberbärden oft febr lang find, unb breiten, auf ber Dberfeite bidt bebarten Flügeln, bie in Der Rube Dadjörmig jufammengelegt werben. Die Raupen find bödit eigentbümlid geftaltet; Der Ropf ift flein unb fann ganz in bie folgenben Ringel zurüfơgezogen werben; bie äđten Füßje find meiftens ziemlid lang, bie vier falfden Mittelfuppaare febr ftarf uno fräftig, bie Radjfieber feblen ganz und find burd zwei zangenartige Fäben

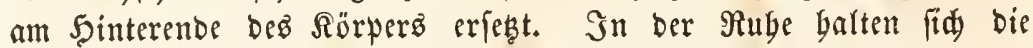
biffen und furzen $\Re a u p e n$ meift nur auf ben vier Mittelfuppaaren und beben Den Jinterletb fowobl, wie Den Borbertbeil bes Rörpers

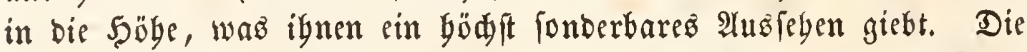
Suppe ift in einen Cocon eingeldloffen, ber mit abgenagten Solz= theilden burdyebt ift. Harpyia; Cerura.

Die Familie ber 5̧oljfpinner (Hepiolida) umfät einige große, biffleibige, bidtbefduppte Rad)tidmetterlinge mit gefägten ober ge=

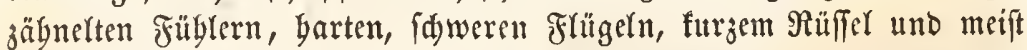
unideinbaren, ddmukigen Farben. Die langen, Yeberartig barten,

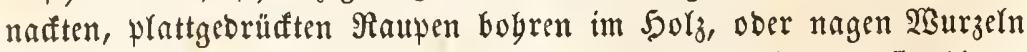
$a b$, und fönnen bierburd bebeutenden Sdaben altridten; fie bilben cin feftes, grobes (s) mebt find. Cossus; Hepiolus.

Die Familic Der Spinner (Bombycida) unfaß̈t eine grofe An = 


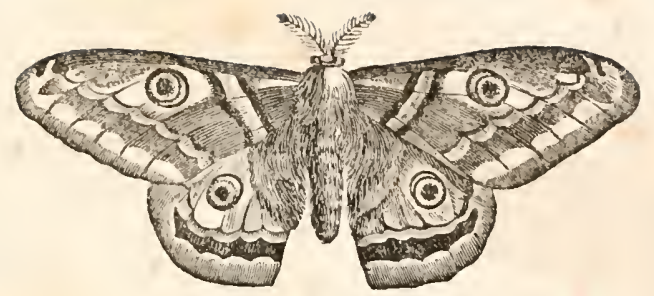

Jig. 783.

Sileines $\Re$ adtpfinuenauge (Saturnia carpini).

zabl yon Rad)tidmet= terliugen, Deren $\mathfrak{M a ̈ u n =}$ d)en ftetz fammförmige Fübler befitzen, die oft felyr augigezeidnet gefies Dert fint. Die Tafter find ftets furz, ber $\Re$ inffel febr furz und jumeilen gänżlid) verfđłwunben; Bruft und \&eib fino gewögnlidy bid)t bebaat unb jiemlid bif, bie Flïgel grob, abgerundet. Die Faupen baben afle 16 Beine, und zeigen binfidtlid ibrer Befleibung alle 3wifdenftufen von gänjlider Rađtbeit bis ju Der bidteften Bebarantig und Bemaffmung mit langen, fpizen Borften, bie bei ber Beriabrung abbreden. Aufe biefe Raupen

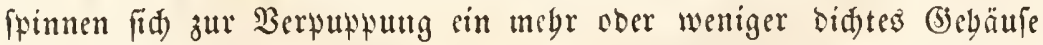
von reiner Seibe, bas bei mebreren 1 rten zu inbuftriellen 3 weffen

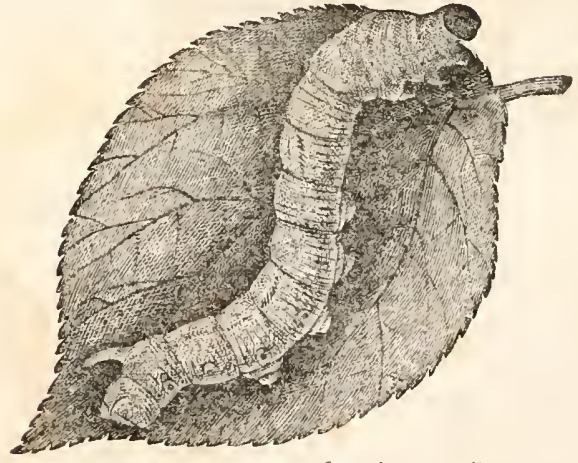

Jig. 784. Seitenraupe (Bombyx mori). benulzt wirb. Die Sei= Denraupe ift bie cinjige Art, welde in Guropa cultivirt wird. Go wärbe zu weit fübren, wolltit wir bier auf bie $\mathfrak{B e}=$ Dingungen Der Seiben= zïd)terei uäber eingeben, in welder man bie $\Re a u$ pen fo lange täbrt, bis fie fid volffommen eingeiponnen baben.

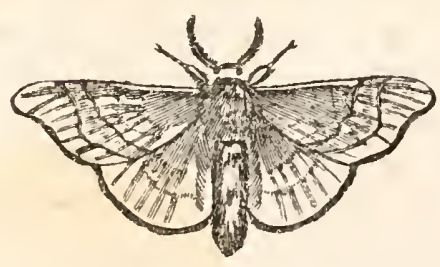

Jig. 785.

Seibenidimetterling (Bombyx mori).

Seber Cocon beftebt nur aus cinem einzigen Fabett, unb ba ber Sdmet= terling beim Ausfd)lïpfen Denfelben vielfad) Durdbridt und jerftört, fo Dá man ibn nidyt mebr abjpinnen fann, fo töbtet man dic loupen in Den Cocons Durd Jike, und läpt nur fo viele am \&eben, als zur Nadzudt nötbig fino. Bombyx; Saturnia; Sericaria; Euprepia; Orgyia ; Lithosia.

Die Framilie ber Abendfhwärmer (Sphingida), tmeift ziemlid) grofe Sdmetterlinge, mit langem, walzenfürmigem, binten zugefpize 


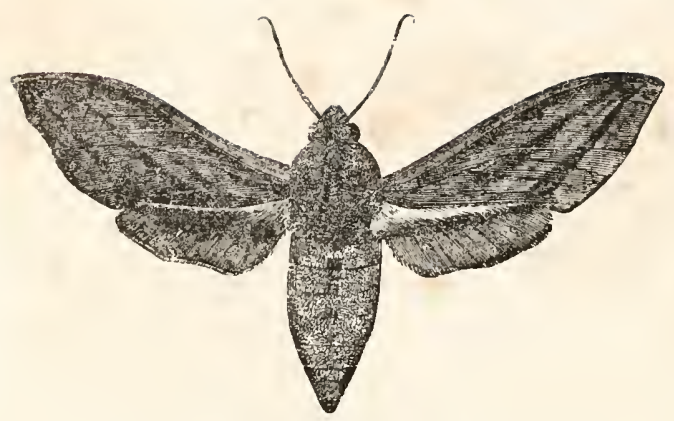

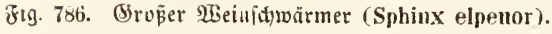

tem Seibe, ber mit eng anliegenden Sduppen bebefft ift, und furzen Füblern, die gegen bie Spiten bitt etwas verbifft fint und oft mit cinter bünnen, gewöbn= (id) bafenförmig umge= bogenen $\mathfrak{B o r j t e}$ abjditie= fen. Jumeilen find diefe Fübler auf Der Jrinen= feite gefägt oder mit abwedjelnden Saarbünbelgruppen befest. Der Riuffel ift gewöbnlid febr lang, oft viel länger, alỏ ber Rärper, nur

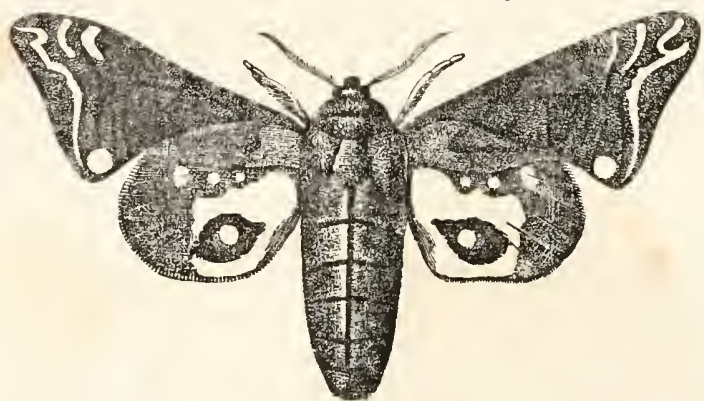

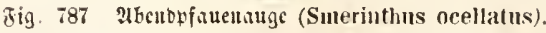

felten furg; bie flügel lang und fdumal, befonbers bie Borberflügel, und in Der Rube Dadfërntig übereinanber gelegt. Die Sdymetterlinge (d)wärmen meiftens mit lautem Summen nad) Sonnenuntergang, uno

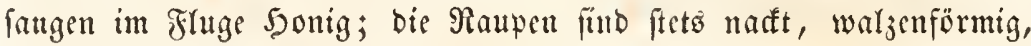

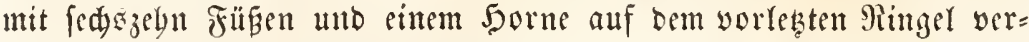
feben, Das nur felten burd eine Sylatte erfest ift; fie verplapen fid meift in ber crbe und crideinen im näd) ften Frübjabre als volftom= mene Tbiere. Acherontia; Sphinx; Smerinthus; Macroglossa.

Die Familie ber WBiboerbörnchen (Zygaenida) bejtebt aus meift

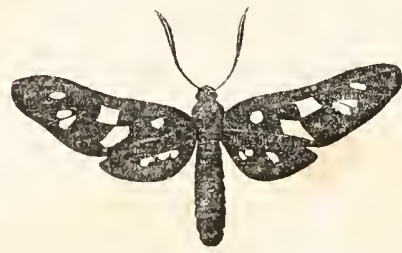

Jiy. Zor Zygaena syntomis. fleinen Sdmetterlingen mit Diffem, waljenförmigem Reibe uno id)malen, abgerundeten Flïgeln, bie nur febr fpariam mit Sduppen bebeft find, ia bei einigen faft fo glasbell unt Durdfiftrig erideinen, wie bie frlü= gel ber Sjautflügler. Die Fïbler fino meift jiemlid lang, gegen bas 


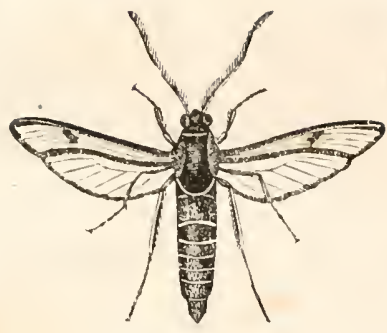

ซึig. 789. Sesia.

Ende bin verbift, an ber Epize bornförmig umgebogen; fie find ftarf befdupt, bei ben Männden oft gezäbnt, ober boppelt gefäınınt; Der Rïffel fein und Dïnn. Dic furjen, Fparfan bebaarten, fed)s = zebnfü̈rigen Ranpen fpinten fid in einen länglid)en Cocon ein, ber eine pergamentartige Confiftenz bat. Dic Edumetterlinge fliegen meift nur bei brennendom Sonnenfdeine. Zygaena; Sesia; Alycha.

Dic Unteroromung ber Sagid)utetterlinge ober Senlenbór: ner (Ropalocera) umfät nur folde Sdumetterlinge, welde singig bei Tage fliegen und in ber アiube bie Flügel aufredt zufan=

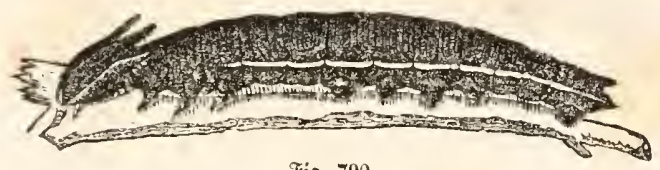

Fig. 790

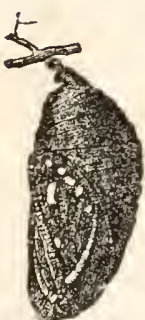

ชิig. 791.

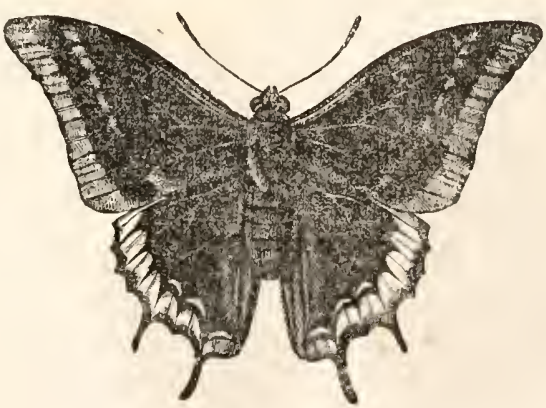

Fin 792

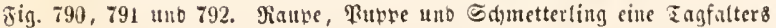

(Nymphatis Jasius).

menfd)lagen. Die Füblgörner befteben aus ciner Menge ringförmiger (3)ieber, bie gegen bas Ende bin in eine Reule anfdwellen, an welder meift nod) fid) eine ungcbogene bünne Spize befinbet; bie Unterflügel zeigen niemals eine Borfte zur Befeftigung an Die Dber= 
flïgel, wie dief́ bei ben vorberigen Familien Der Fall war. Die Raupen baben febr viele wedfernde Formen, oft febr fonberbare Auswüd)fe, unb billoen faft immer nafte \$uppen, bie nur felten in cin befpinnft eingefdloffen find. Wir unterfdeiden befonders nad Art Der 2 nbeftung Der Suppe Drei Familien.

Die Familie Der Diaflöpfe (Hesperida), fleine Sdymetterlinge

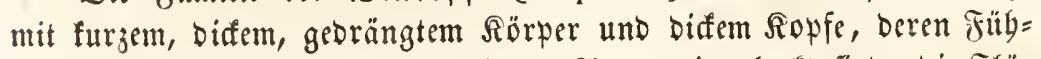
ler feitlid) weit von einander bei ben 2 ugen eingelenft find ; Die Flü: gel werben in ber Rube nur balb aufgeridtet, die Füße find alle yollfommen ausgebildet, uno die Syinteridienen mit zwei Seitenftadeln bewaffnet. Die Rautpen Gaben eimen biffen, queren Ropf, Dïnnet, waljenförmigen, nađten Sörper; Die \$uppen find waljenförmig, obne (5fen und ruben in eitrem Ssewebe, Das aus zufammengewidelten Brättern beftebt. Hesperia.

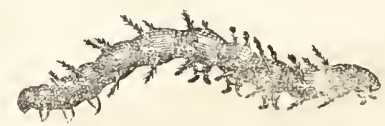

Jig. 793.

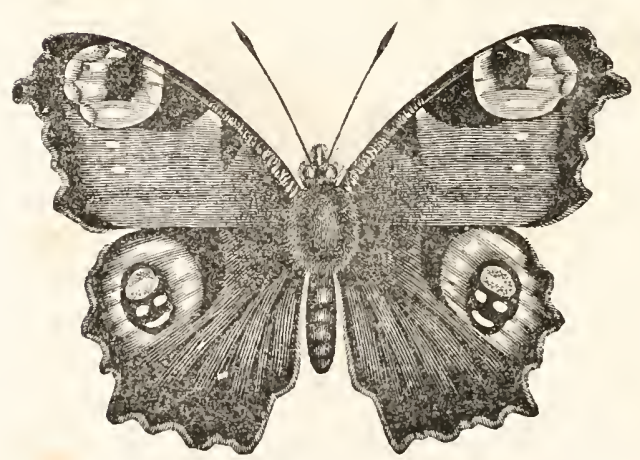

8is. 795.

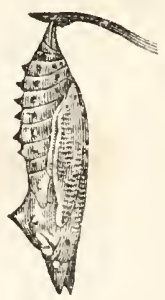

Jig 794

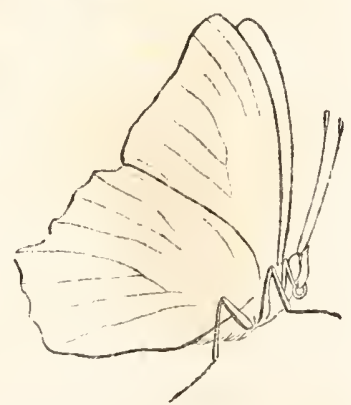

『is. 796.

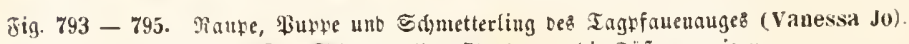

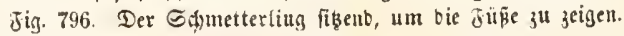

Familie Der Şängefalter (Suspensa), Bei Den Tagfaltern diefer atbtyeilung, wie ber folgenden, fteben bie fübler auf bem Ropfe febr nabe jufammen; Dagegen finto Die Borberfüße bei ben Männden im=

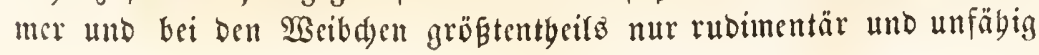




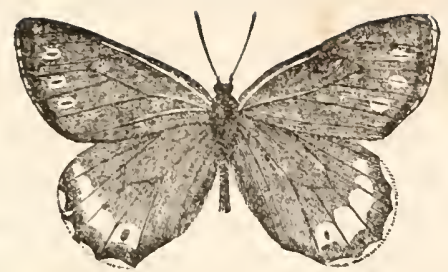

Fig 797. Satyrus Balder

zum Brben. Die meift bormigen, baarigen, ober mit eigentbümlidyen Fortiäzzen befęzten Paupen bängen fid bei ber Berpuppung fenfredtt an ber Sdwanjipize auf unb bil= ben eine nadte, meift eftige Puppe. Die (5)attungen fint febr zablreid). Vanessa; Satyrus; Pieris; Colias.

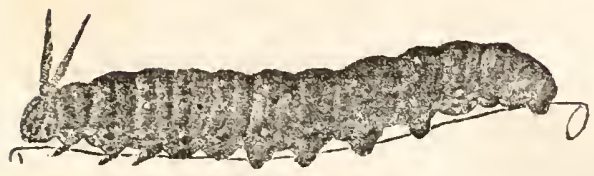

frig. 798.

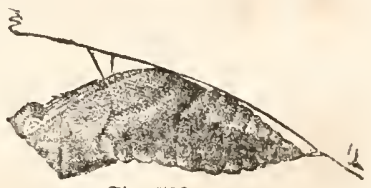

Fig. 799.

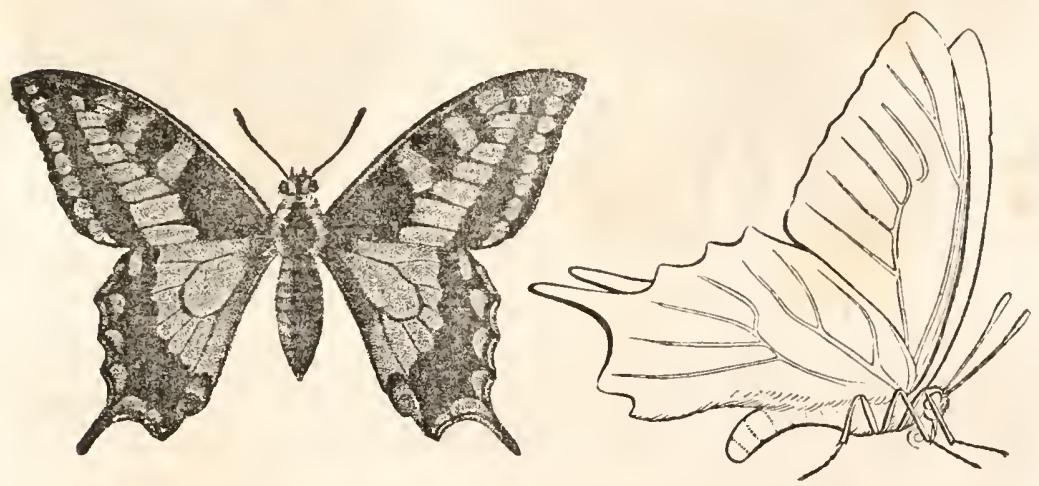

Tig 800 .

Jig. 801.

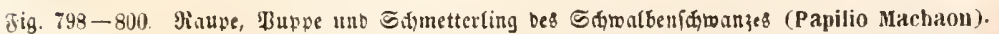

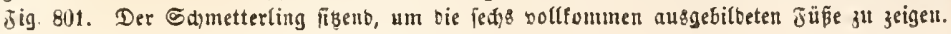

Die rekgte Familie ber Sd)metterlinge, diejenige ber (EDelfalter (Papilionida), unterfdeibet fid yon ber yorigen Familie im 3uftande Der yolffommenen Snjeften nur febr wenig, ba aud bei ibnen einige (5)attungen fï finben, bie nur vier ausgebilbete Füße befinen, wäb=

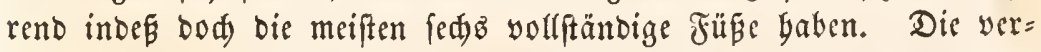

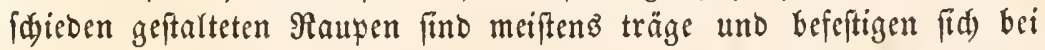
Der $\mathfrak{B e r p u p p u n g}$ in eigentbümlider $23 e i f e$, indem fie fid mit ber Sdywanzipize feftbängen, fid aber bann nod einen Faben über bie Bruft zieben, in bem die Suppe wie in einer Sdlinge yängt. Die grö̈ten uno idönften Tagfalter gebören biefer (5ruppe an, zu welder 


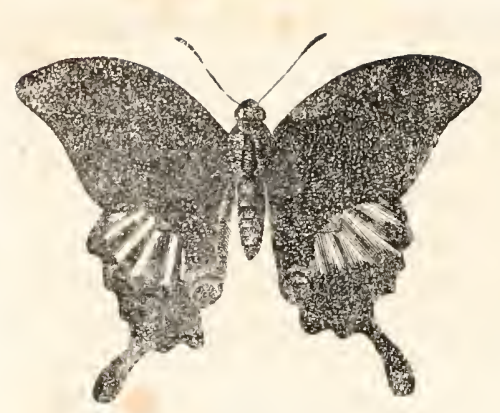

Jig. 802 Papilio Arjuna.

bejonders die berrlid gefärbten Fals ter ber fübliden 3onen gebören, welde burd die langen Sdwänze Der Sinterflügel fid aus a zeid)nen, fo wie bie vielfad) gefprentelten Sdectenfalter (Thais), beren Bidzad= zeidnung sine Cigentbümlidfeit ber Gattung ift. Finige Raupen biefer Familie zeidnen fid befonbers burd bie furge, plattgebrütte, fdilloför= mige Geftalt, unb bie Sdmetterlinge

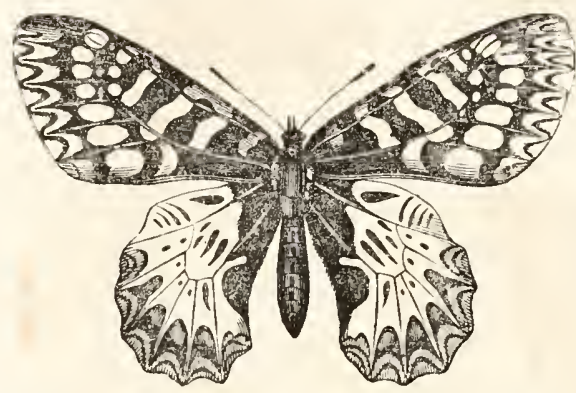

Jig. 803. Thais Hypsipyle.

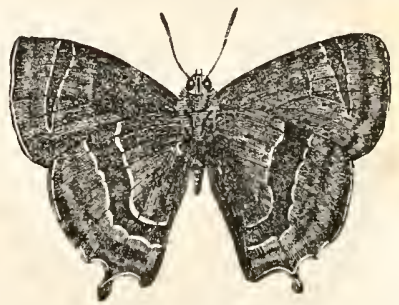

Fig. 804. Daล Birfentahnden (Polyoumatus betulae).

Durd) bie febr berfdieden gefärbten Flügel auz, ittbem die Dberflädbe meift eitfarbig, goldig ober blau, bie Unterfläde mit vierfad)ent fleinen Plugenflecten befect ift. Papilio; Polyommatus; Parmassius.

Foffile Sdutuetterlinge fdeinen erft mit ber Tertiärzeit aufgetre= ten $j^{\mathfrak{u}}$ feill; bie Spuren, bie nan in Sura bat funben wollen, gebö= ren wabrideinlid anberen Sronungett att.

\section{Sronung ser Etrepïpteren (Strepsiptera s. Rhipiptera).}

Diefe febr fleine Dronuth bejtebt nur aus einigen wenigen, auf verid)iebenen 2 segpengattungen fdumarokenden wittzigen Thierden, bie aber burd) bie mertwitrbig verfdiebene Bilbung ber beiben (Gefdred)=

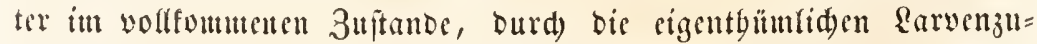
ftände utto Durd bie Diganifation ibres Sïrpers fid) von allet übri= gon Jufetten eutferten und cine eigente Dronung Drrftellent. 
Sange 3cit fannte man mur dic autżebildeten Männden, fleime

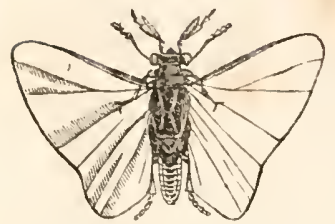

Fig. 805 Yiänndyen von Stylops Melittae. faum eime Sinic lunge, gefliggelte Thierd)en, bie man felten auf Dem Sjinterleibe von $\mathfrak{2}$ sespen flatternd antrifft. Der Siopf ift breit, furz, Die 2lugen febr grob, fugelfïrmig vorgequoller, gebäuft. Die Jübler find furz, gefpalten, fo Daź foeinbar vier Fübler vorbanden find ober aud bei ciner (3attung mit wenigen langen Rammblättern verfeben. Die Munowerf zeuge befteben aus zwei fäbel= förmig gefrümmten, bünnen Riefern, blattartigen Rinnlaben mit Drei= gliebrigen Taftern - bie indeß von bem Thierden gewí̈ nie gebraudt werben, da fie nur wenige Stunben leben und wäbrend biefer 3eit mit Der Begattung befdäftigt find. Die Füpe fino tur vierglieberig; bie flügel böd) jt cigentbümlid. Die Mittelbrult trägt zwei furze bäutige, fonderbar verbrebte, folbige Anbänge, welde einiger= maßen ben Sdwingtolben ber 3weiflügler gleiden, aber aud) als rubimentäre Flügeldeffen betrad)tet werben fönnen; an ber 5jinterbruft fteben jwei bäutige groß̈e, oreiectige flügel bie nur wenige fäd)erartige Jalten baben. Fis genügen biefe Flïgel aber trog ibrer (5iröpe nidht jum freien Fluge Der Thierd)en - fie flattern nur tanjend auf Dem Seibe Der $13 e s p e n$ und vielleidst and in ben Neftern berfelben umber, bis fie ein 2 beibden gejunden baben, mit Dem fie fid begatten. Зu Diefem Ende tragen fie an Dem jugefpizten Sjinterleibe einen bornigen Jafempenis, Der nad Der Seite ju eingefdlagen ift unb beutlid mit ben Gamenleitern in Berbinoung ftelt.

Die $\mathfrak{B} e \mathfrak{i b}$ en diefer Thierden, die Durd igre Drganifation Den $\operatorname{Räfern~am~nädjten~fteben,~bleiben~Das~ganje~Reben~bindurd)~in~}$ cinem larvenägnliden 3uftande fdmarobend im Siuterleibe ber 2 Bes = fen uno wurben bis in bie neuere 3eit ftetö für bie \&arven ber Strep= fipteren angefeben. Man nennt bie Wesesen, welde lold)e (bä̈te be= berbergen, furzmeg ftylopifirt. Bei ben fortpflanjungsfäbigen SEeibden ift ber Reib weid, geringelt, wurmartig, wei巨; Ropf uno 3rujt bagegen fint in ein plattes, linfenförmiges Sdilo jufammenver= id)molzen, das eine braune Farbe und bornige Beidaffenbeit bat. lluter bem Borberrande dicfes Sdjildes fiebt man bie fleine, galb= monbförmige Miunböffnung, die in einen weiten, geraben, blimb geen= Deten Darm fübrt, und neben welder jwei faịt unbeweglide bornige Stummeln Die Refte Der verfümmerten Sauwerfzeuge Darftellen. Mit 


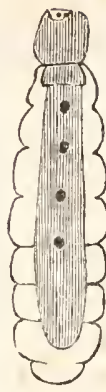

Jig 806

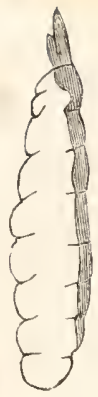

807.

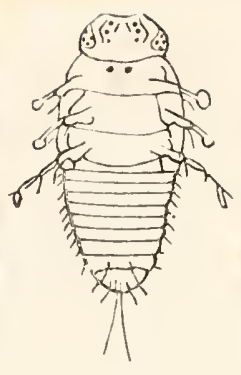

808.
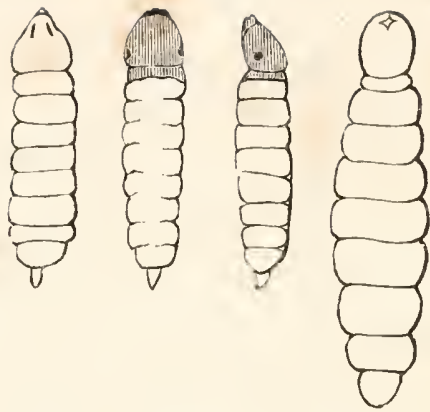

812 .

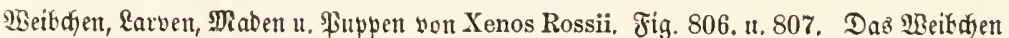
vou Der Baudfeite unb von Der Seite. Man fieft Deul bunfelu Brutfanal und bie

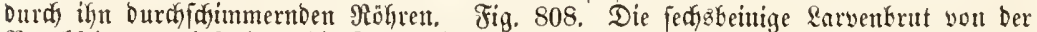

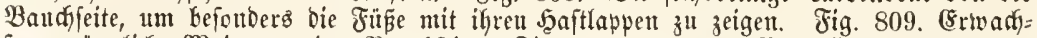
fene mäunlidye Mabe vou ber Baudjeite. Fig. 810. u. 811. Diänlide \$uppe, vom Baudy und von ber Seite her. Daz runde Etigma an Enbe bez Ropfídilldes und Der abjuringente vorbere Deffel zeigen fid beutlidy. Fig. 812. Neetblidfe Miabe, auzge= wady fent.

Diefem Ropfldilde fteaft Das $\mathfrak{B e i b d e n ~ z w i f d e n ~ b e n ~ S i n t e r l e i b s : ~}$

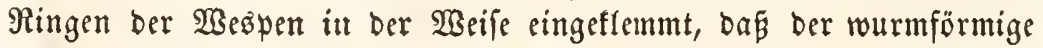
Eeib in bie Sinterleibşböble frei Gineinragt, ber Borberrand Des Ropfes aber nad auben idaut. Die Thiere dueinen ganj unbeweglid. Un= terfudt man ibren Bau genauer, fo finbet man in ber seibesböble auser Dem blinben Darme eine Menge von Eiern zerftreut zwifden bem Fettförper, und längs Der Baud) feite einen platten, breiten, binten gefdloffenen אanal, ber nad vorn in bas Sopfidilo übergebt und mit einer (đ)lizartigen breiten Deffnung, bie weit größer als bie Diund= öfrnung ift, unter biefer fid nad ausen öffnet. IUf biefem Ranal fteben brei bis̄ fünf etwas gebogene Röbren, bie einerfeits mit einer trompetenartig ausgemeiteten Münoung fid frei in bie Reibeşüble öffnen, anberfeits in Den Sanal, ben wir ben Brutfanal nenuen, münden. Dffenbar bient bie unter bem Munbe befindlide Shlizöff=

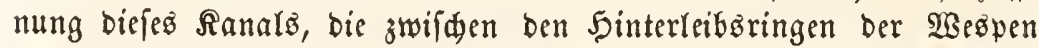
bervoritebt, als̉ Begattungsöffnung, burd welde bas Männd)en fein bafenförmiges Grlieb von außen einfübrt.

Die in ber Seibeşb̈ble Des $\mathfrak{B}$ eibdens frei befindliden cier ent= wideln fid in biefer Reibesböble unb es erzeugen fid barin Rarven, bie innerbalb Der Mutter ausfrieden, fo bá̈ oft Der ganze Seib Des Yseibdens mit ausgefrodenen Sarven erfülat ift. Diefe \&arven fino febr flein, febr lebendig, yon fdieferblauer Farbe, weśgalb man fie

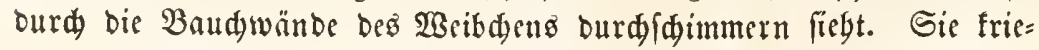


den fo lange itn Reibe ber Mutter umber, bio fie eine ber erwäbuten Rëbren bes Brutfanalez finben, Durd welde fie Dann in ben Brut= fanal tlettern, Den fie oft ftrobend erfüllen. Durd bie vorbere Deff= nung befferben frieden fie bann binaus auf ben Reib ber Wespen, auf bem fie munter einberlaufen. Die Rarven ber Strepfipteren baben in biefem 3uftande sinen megr ober minber fdlanfen, mit $B o r=$ ften befeţten, geringetten Rörper, einen barbrunben Ropf, zu beffen

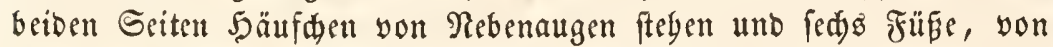
benen bie beiben erften गुaare mit runben ober länglidden Saaftlappen verfeben uno anbers als baz bintere yaar geftaltet fint. Sie laufen febr bebende unb einige fpringen aud ebenlo wie bie (5abelidwänje mit Şülfe zweier Borften, Die fie am Enbe bez Sinterleibs tragen unb unter ben Reib biegen unb losfđanellen fönnen. Dieje munteren Tbierden, bie man früber für Sdmarober ber für \&arven gebaltenen Strepfipteren=:Seibden anfab, bie aber in ber That nur ber erfte \&ar= yenzuftand felbft find, laffen fid yon Den $\mathfrak{B e g} p e n$ in ibre Refter tra= gen und bobren fid bort in bie fuklofen weidyen Rarven ber Sespen

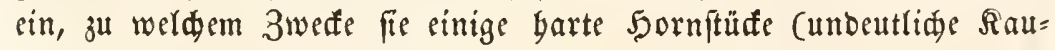
merfzeuge) am Ropfe baben.

Sn bem Reibe Der IBegpenlarven geben die fed) fipteren $=$ \&arben eine rüffdureitende Metamorpboje ein. Sie werfen thre Şaut ab, verlieren bie Fü̈pe unb verwanbeln fid in eine murm=

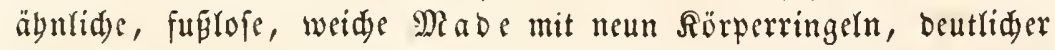
)) Xunböffnung, bie in einen blinben Darm fübrt, unb verfïmmerten

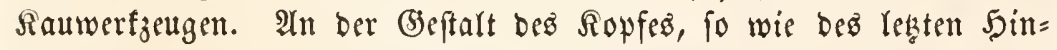

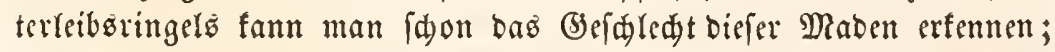
Der Ropf ber männliden Rarven ift fegelförmig gewölbt, Der ber weib= riden platt, fduppenförmig. Diele Maben bewegen fid febr träge

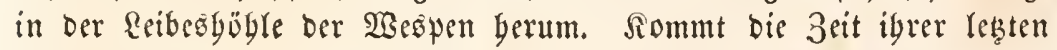
Serwanblung, fo bobren fie ben Ropf zwifden ben Eeibesringen ber SBespen Durd, bis fie Dort eingeflemmt fint. Bei ben weibliden Maben beftebt mun bie ganze Berwanblung barin, baj igr Siopffdilo bart uno braun wirb und bie Deffnung bes Brutfanalo erbält. Bei oen männliđen Maben erbärtet zwar aud ber Ropf, aber bie ganze Mabenbaut bient, wie bei vielen Fliegen, zugleid) als Yuppenbülle, uno in ibr bilbet fid bie männlide Juppe, an ber man faon bie

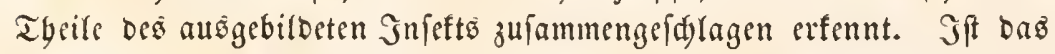

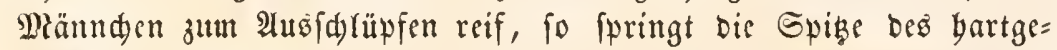
worbenen Ropfenoes Der Mabenbaut wie cin Defel $a b$, unb bas vollen=

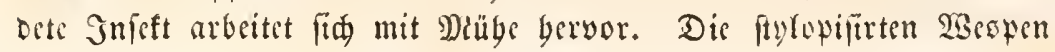




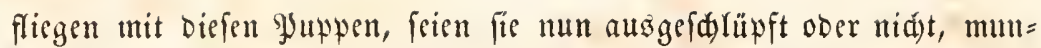
ter umber, obne llnwoblfein ju verratben. Man erfennt die Syupen leid)t, wenn man mit ber \&upe ben Sinterleib aufmerfiam unteriud)t uno Die Falzen Der Ringe betrad)tet. Füttert man Die ftylopifirten Raubwešpen (Ammophila; Melitta; Miscus; Polistes etc., die am bäuftgiten biefe Sdmaroger beberbergen), in Bebältern mit 3uder, fo gelingt es oft leid)t, bie fonft ungemein feltenen Tbierden ju erbal= ten. Man bat inebrere Battungen unteridieben, Deren Rebensweife aber febr übersinftimmt. Xenos; Stylops; Elenchus; Halictophagus.

\section{Orbung ser gtefifingler (Neuroptera).}

Diefe Dromung mieberbolt in Der Reibe Der Snieften mit voll= fommener Berwandlung Die Sronung Der Gerabflügler, Dis wir in

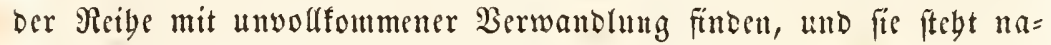
mentliá) Den (jerabflitglern mit gegitterten Flitgeln fo nabe, oas fie früber mit denfelben bereinigt wurde.

Die Restügler find meift weidse langleibige Snfeften von ge=

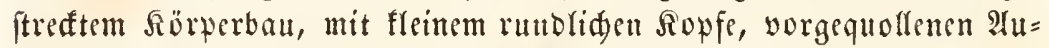
gen, beutlid) abgefebter Bruft und Sinterleib. Die Fïbler fimb ftets Deutlid, meift boritenfirmig, nur ferten gefnofft, folbig ober gefägt, meift länger als ber \&eib. Nebenaugen find bald vorbanden, bald

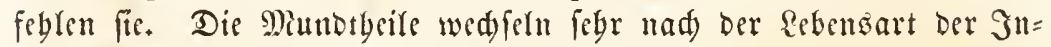
feften; bod find fie nie fo fräftig wie bei ben Gsrabfliglern, von Denen fid eill wefentlides llnterid)eidungsmerfmal Darin jeigt, Daf

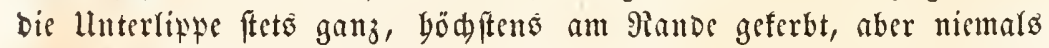
in zwei Şälften gefpalten ift. Die Riefer und Rimnlaben find bei manden Familien verfümmert, lesere juweilen mit einander in ber Mitte verwadjen; Die Siefer nie febr ftart und meift nur fducidend, niemals vielfad) gezäbnt. Syalpen fint ftets vorbanden, wenigitens in oer $3 a b l$ von vier; bei einer Familie finden fid) ferbit äusere und innere Rabentafter.

Dic Flügel find ftetso gleid) im Bau, nebförmig gegittert, grof́

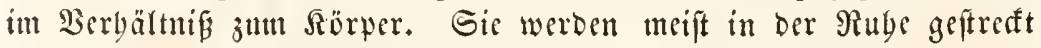
ober aufred)t getragen; nur weuige falten die llnterfligel, um fie $แ n=$ ter ben badförmigen Sberflügeln unterzubringen. Die Fithe find bünn, fein, oft mit Stadeln befest; die Tarien 4 bis 5 glicorig. Der bin= terleib lang, geftreft, bei eittigen mit jangenartigen atnbäıgen oDer beim 2 scibden mit eitter Segerübre verfeben. 


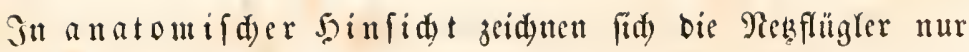
wenig won Den ïbrigen laugleibigen Jnfeften aus. Das Rerven= fy ftem ift langgeftreft, meift aus brei Bruftnoten und ad)t binter=

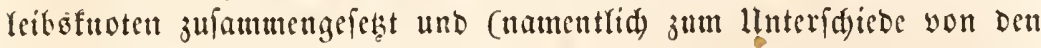
farfacen Reşflüglern, Die wir igrer utyolffommenen Berwandlung we= gen zu ben (berabflüglern fteflten), bie beiben Yetzten Baudf fnoten um= veridmorjen. Der Sdylund ift lang, nad) bintet blafig aufgetrieben, oft nod) unit cinem feitliden Saugmagen verieben; Der (Ebylușmagen quer geringelt; Der Darm gerabe und meift gleid) weit. Die Spei= derbritien fint ftarf entwiffelt, juweiten mebr bei ben Männd)en als wie bei ben $\mathfrak{B}_{\text {seibden }}$ (Panorpida). Das Iradeenfyftem ift einfad,

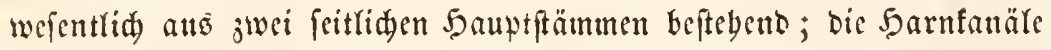
nur in geringer 3abl, aber febr lang und gewutuden, jum ltnteridaiede

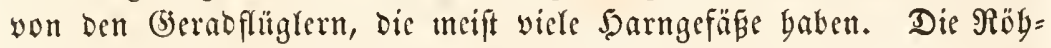

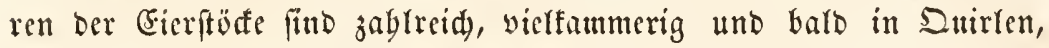
bald cinjarfig, bald au ber äuperen Seite Der weiten Gileiter ange= brad)t. Die Samentafde ift gemöbutid febr zufammengefest, indem

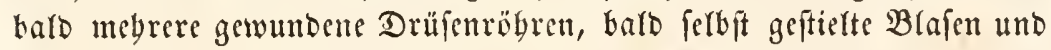
äbntidge $\mathfrak{A b}$ fonderungsorgane in fie cinmünden. Sittorüfen find eben=

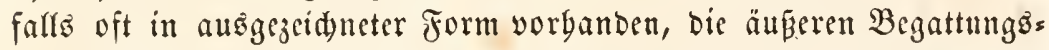
organe aber febre einfady. Bei den Mäunden find die Soden eiförs

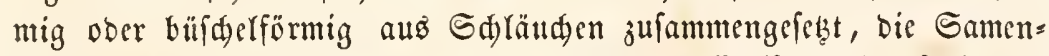

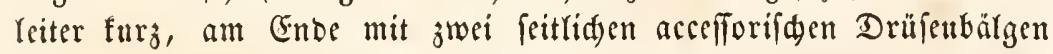
verifegen und bie Begattungsorgane aus jwei Jaar אTappen gebilbet,

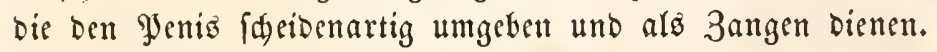

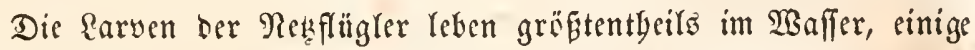

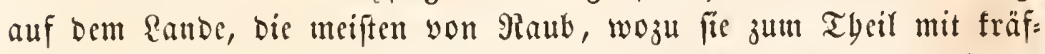
tigen $\mathfrak{B}$ eiß̄werf

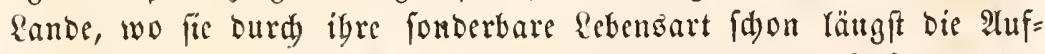
merfiamfeit auf fidi) gezogen baben. Dic vollfommenen $3 n f$ ften leben meift nur łurze Beit und fliegen befonders gerne an fonnigen Tagen

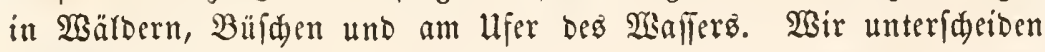
forgende Familien. 
Die Familie Der Sdumetterlingsfliegen (Phryganida), bat simen

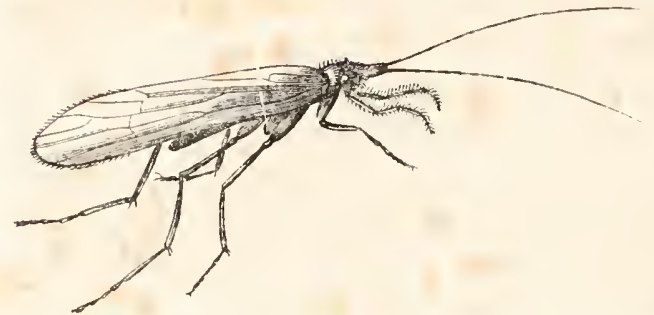

Jig. 813. (5eaberte 6 dmetterlingsfiege (Phryganea venata.)

fleinen, etwa gé gebeugten Sopf, lange borftenför: mige zäbler, mittelgroß̧e Augen und orei Reben= augen, yon benen jtwei zwifden ben $\mathfrak{A}$ utgen, eines jwifden ben güblern fitebt. Die Raumerfzeuge find fieto verfiummert; Die Riefer feblen ganz; die Rinnlaben find in ber Mitte verwadsen, tragen aber grobe, meift fünfgliebrige Tajter beim $\mathfrak{B}$ eibaen, wäbrend bas Männden oft nur orei ober vier S3rieber Daran bat. Die lln= terlippe ift fdmal geferbt, Die Rippentafter furz uno oreiglieorig. Die

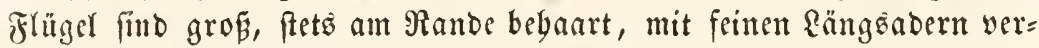
feben, bie feine nebartige Berjweigung zeigen; die binteren werben

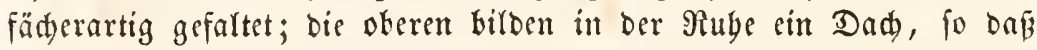
die Thiere manden fleineren Nadtidmetterlingen entfernt äbneln.

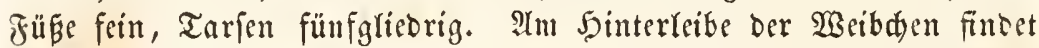
fid eine runblidse, jiemlid bebeutende, mit bornigen Rlappen umge= bene (5rube, worin fie Cierpatete bertmtragen. Die $\mathfrak{a} \mathfrak{a} \mathfrak{v}$ en leben
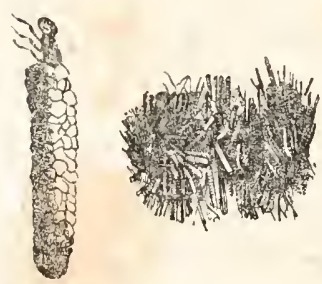

Jin. 814.

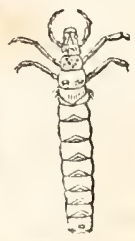

816

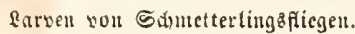

Fig. 814. Die sarve in ifrem (S)e=

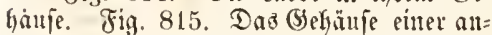
Dert Ifrt yon ber Seite. Fig. 816. Die farve aus bem Gefäule gentumuen. im Sarffer, baben einen weidyen runblidyen \&eib mit feitliden Safen am (Ende, ziemlid lange bebaate Fü̈e, einen bornigen fopf und bauen fị aนs Steind)en, Mu\{del=

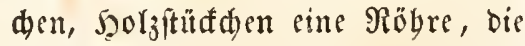
fie beftändig mit fï berumfdhleppen und worin fie fid ganj zurü $f_{j} i=$ ben fönnen. Zur $\mathfrak{B}$ erpuppung fpin= men fie auf beiden Seiten Der Röbre einen gegitterten Deffel und wan= beln fid in eine rubende Syupe um, bie aber wieber febr lebendig wird, wenn bie Fliege ausfrieden foll. Die Wuppen fprengen Dann Den Deffer, frieden an Safferpflanjen in

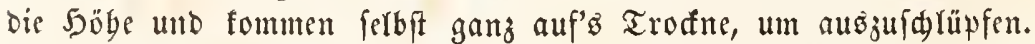
Phryganea; Limnephila; Mystacida; Trichostoma; Scricostoma; Hydropsyche.

Familie ber Sumpflibellen (Sialida), fleine Reşflügler mit flei= nem Ropf obne voripringenden Dund; borftenförmigen Foüblern, sent- 
liden Riefern, bie innen nod einen fdwaben Rebenzabn baben; fdar: fen Rinnlaben mit furjen viergliebrigen Taftern unb einfader, breiectig geferbter llnterlippe, bie nur febr furze Tafter trägt. Die Flügel find faft gleidh; bie Tarfen fünfglicorig. Sn 2imerifa giebt (5attungen (Corydalis); bier nur fleine Tbiere, beren \&arven im $\mathfrak{S a}$ aller leben, feitlide Büfdel von $\mathfrak{T} r a d e e n f i e m e n$ tragen unb aus Eiern bervorfommen, bie in braunen glattengaufen abgelegt werben. Sialis; Semblis; Corydalis; Chauliodes.

Familie ber (Erolibellen (Hemerobida), Ropf flein, breit, 2lugen

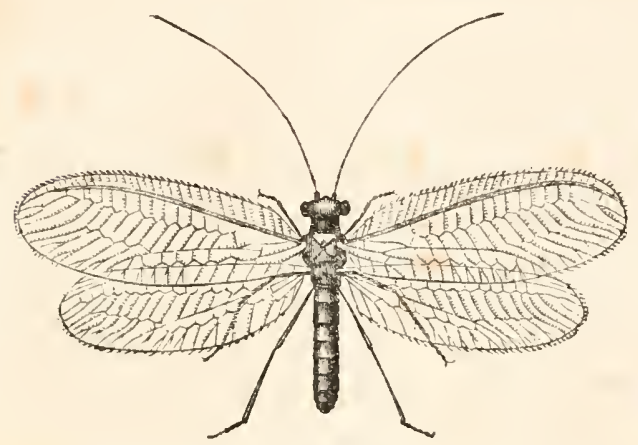

Jig. 817. Bemeine Grblibefle (Hemerobius perlat.) vorgequollen; Fübler febr lang, fabenförmig; Rebenaugen feblen. $\mathfrak{R u ̈ r}=$ per febr jart uno weid, Flügel fein gegittert, mit

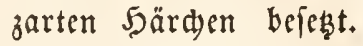
Siefer flein, fdneibend. Şüpe bünn; Rinnlaben= tafter ziemlid lang. Sie fliegen fdledt unb fdwer, verbreiten meift einen un= angenebmen Rotbgerud, Der lange an ben Fingern Gaftet. Shre Rarven Yeben auf Blättern, namentlid von Blattläufen, die fie mit ibren ftarfen bafenförmigen Sitefern Durdbobren. Yielleidt leben bie Rarven einer Gattung (Sisyra) in Sifwwafferfowämmen uno zeidnen fid burd eine fonberbare Birbung Der langen Riefer auв, bie äbnliథ, wie Die furzen Riefer Der Ameifenlöwen đuarfe Saugröbren find. Hemerobius; Sisyra.

Familie Der Almeifenlömen (Myrmeleontida). Die Bilber glei= den in Form unb Beftalt febr ben Bafferiungfern, unterfdeiden fid

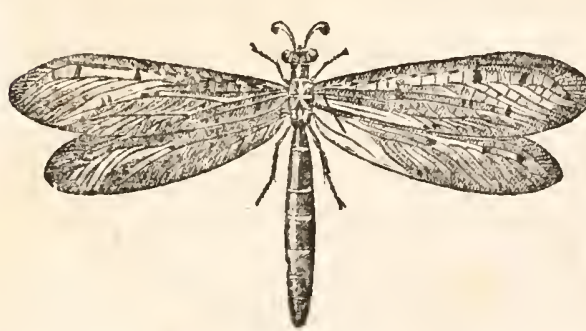

Fig. 818.

Fisuftirter 2tmeifentöroe (Myrmeleon punctatus.) aber auf Den erften $B$ lid Durd) die furzen feulenförmigen (Myrmeleon), ober langen getnopf= ten Fübler (Ascalaphus). Der Royf ift grof, quer, bie $2 t u=$ gen vorgequollen, bie Riffer einfad) bafig; bie Rinnlaben mit fleinen boppelten Taftern, Die cinfadye ganjanoige Sippe mit oreiglicorigen, grop̧en Tajtern verfeben, Deren jueiteg uno britteg (3)lied febr lang füb. Dic 
Flügel fint fein gegittert, Die Tarfen fünfgliebrig. Die platten furf= leibigen \&arven leben im Sande vom Raube; Die Des Ameifenlöwen,

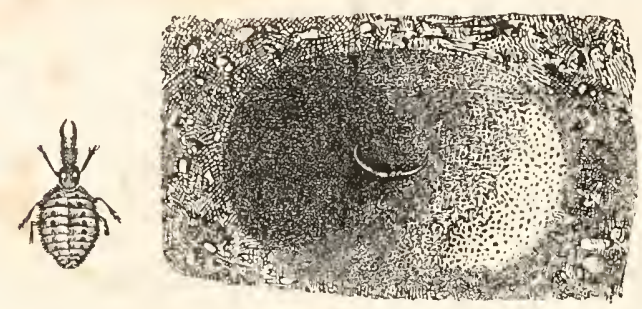

Fin 819 .

anrve bea Ameifentônen Die sarwe in ifrem Sanbtribter mit aufgeiperten siefern lauernt. Deren Ropf und Border= brufticbr flein find, wäb= rent bie beiben Sinter= ringe ber $\mathfrak{B r u f t}$ mit bem breiten Reibe verid)mol= zen find, legt fid an einem vor Regen gefdithten Srte, bejonders unter Daditraufen und Steis nen im Sande ein tegel= förmiges sod) an, in beffen (brunde fie mit aufgefperten Siefer= zangen lauert; fleine Jnfeften, welde binetufallen, werben augenblifflid) erfagit unb ibr Sturz nod) Daburd befdjleunigt, Dá ibnen Der Amei= fentöwe eine Rabung Gand von unten ber mit ben Siefern anwirft. Die Ricfer baben an Der Spize eine feine Deffung, bie fid in cinen Ranal fortietst, Der im Ropfe fid mit Dem Der andern Seite zum Sd)lunbe vereinigt; Dem Dpfer werben bie beiben Sineifangen in ben Reib gefdlagen unb bann baffelbe ausgefogen. Die Rarven geben rï̈t= wärtò. Myrmeleon; Ascalaphus.

Die Ednabelfliegen (Panorpida) baben einen fleinen fdunabel=

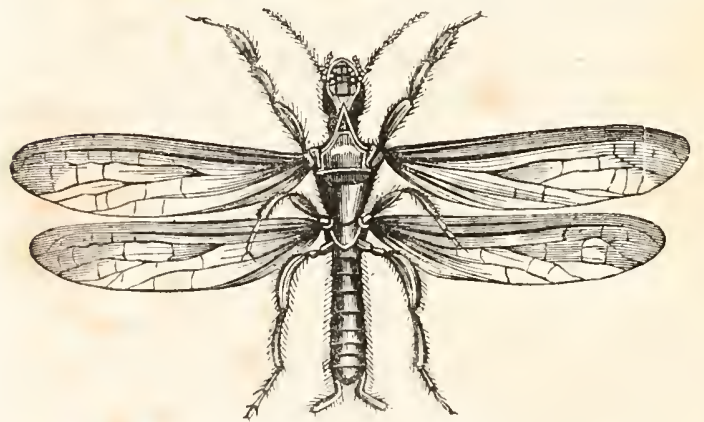

Jig 821. (Egmutifite Sdymbelfliege (Panorpa aegyptiaca.) förmig verlängerten Sopf, borftenförmige meift furze Filbler, bie zuweilen feberar = tig find, brei Reben= Augen, faneidende Rinnlaben und vier Tajter, von benen bie Rabentafter vier $=\mathfrak{b i z}$ fünfgliebrig, bie §ip= pentafter zmei = bis Dreiglicbrig find. Fäßpe und Flügel wed) feln febr in biefer Familie; erfitere baben zwar ftets fünf Tarjalglieber, finto aber bald felyr lang und ftad)lid, modurd die Thiere Den Gdunafen äbnlid feben; bald furz und baarig; bie Flügel find meift nur menig geabert und einan= 


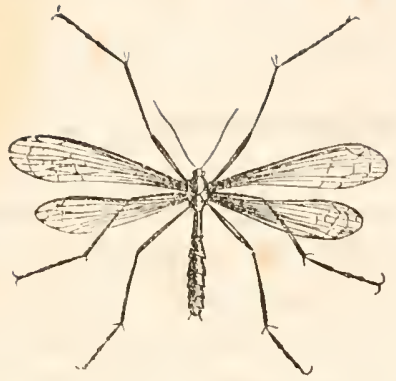

8in. 822. 5कmatenjungfer (Bittacus tipularides.)

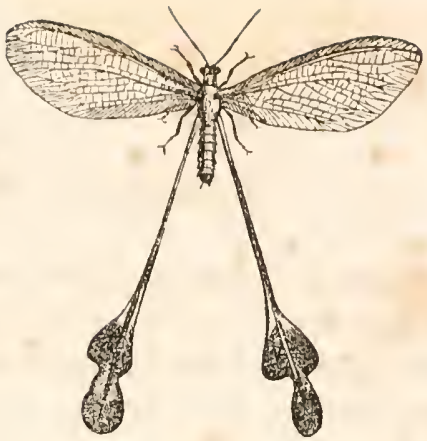

Jig 823. Batancirficge (Nemoptera.)

Der gleidy, juweilen aber febr ungleid, bie binteren lang ausgezogen; ia es giebt battungen, wo bie Sacibdyen ganj migeflügelt finto. Boreus; Panorpa; Bittacus; Nemoptera.

Jamilic Der Sameelfliegen (Raplidida), Ropf eiförmig, flein; vorn Ereiter, binten fdmäler; Atugen grofa, vorgequollen; Fübler furz, borftenförmig; Siefer ftarf, ffis, frumm gebogen, mit jwei fdarfen 3ägnen am Sutenrande unter ber Safenfpize; Rabentajter furs, vier=

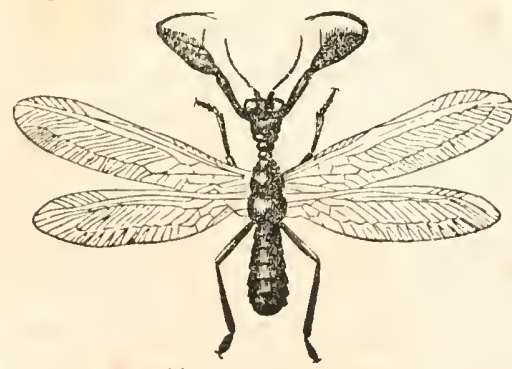

כig. 82 . Mantispa.

gliebrig. Borberbruft febr laug, f(d) mal, balsförmig aนร̉gejogen ; trägt

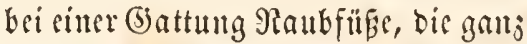

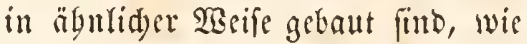
die ber Jangbenfdarefen und ber Gquillen; Flügel gleid), fein gegit= tert, fajt you gleider (joüze. Die Rarven find äuserfit bebend, reben an Baumrinden vom Rattbe und fpintuen fid eine Prt Cocon. Raphidia; Mantispa.

Follife Retzflïgler fitto im Banjen fegt ferten - man will Refite yon Jyryganiden in ben Bäbertbonen Fuglandz gefunden baben.

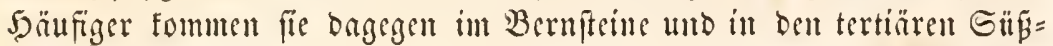
wafferablagernigen vor. 


\section{Sroung ber ฐäfer (Coleoptera).}

Diefe Dronung birbet unter Ion Snfeften mit sollfommener Metamorkgofe bie jablreidjte unb aun beften gefannte brupwe. Dic Mannigfaltigfeit ber Formen, welde biefe Thierc lieten, bie Sdyöngeit

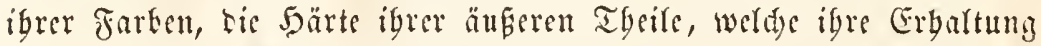
reidjt madjen, baben bicjer Dronung wrn jeher bie Borficbe ber Eammler uno Riebraber gefidyert. SBeit weniger, alo bie solfom=

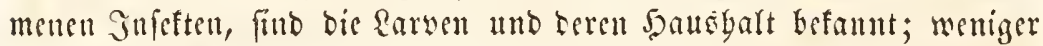
ferbft, als bei ben Sdimetterlingen, wo bas Sntereffe, unverfebrte Excmplare zu ergatten, zur 3udt ber Raupen und \$uppen auf= forberte.

Man unterfdeidet bei ben Riäfrn ftetż beutlid bic brei Jauptab= theifungen bes Rörpers, Ropf, Bruft und Sinterteib. Der meif

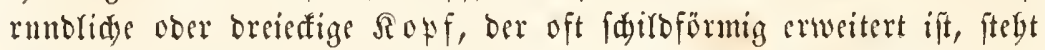

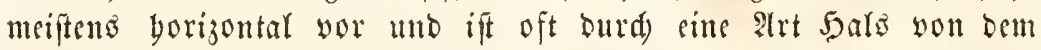
erften $\mathfrak{B r u f f r i n g e}$ getrennt, zuweilen aber ganz in benferben eingefügt

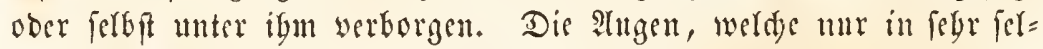
tenen Fälfen bei cinigen unter ber Eroe lebenden ITten (Claviger) feglen, find ftets zufammengefest und mit mebr ober minter grofen Facetten verfeben. Sie fegen auf ber Seite bes Siopfez, ragen oft wis freine Sarbfugern Gervor, find aber and oft nierenförmig unt

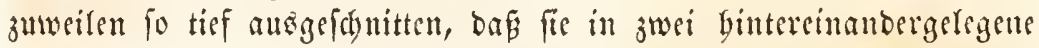
Theile getrennt fint. Bei manden battungen fpringt won oben ber

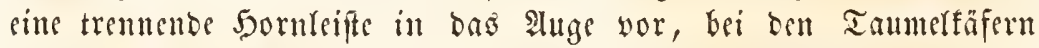
(Gyrinus) exiffiren gar zwei zufammengefegste, hibersinander liegente Atugen auf jeber Geite, von benen bie Gügeren nad) oben, bie nicberen nad) unten in Das Şaffer geridytet finb. Sein Räfer bat einfade

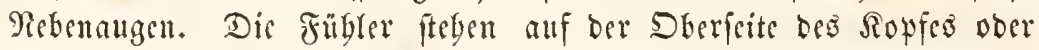
am Stinrande uno laten mrift 9 bis 11 Gslicber, beren formen

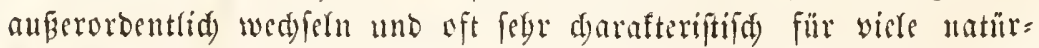
lide Pltetgeilungen fint.

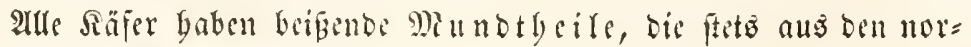




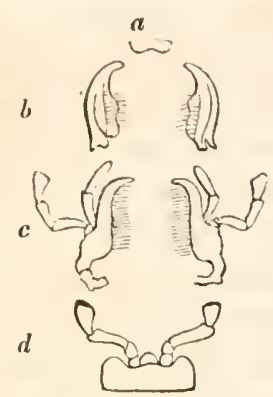

Jig. 825. Minubtheile cines \&auftåfer (Carabus)

auscinantergelegt, ater it iffret Matürlifien Eteflu!= gen zu cinnober helafient. a SHerlippe. b Riefer. c Rinn= labent. d lluterlipte.

malen fedgs Sampttbeilen, Der Dberlippe, den Riefern ober Mandibeln, Den Simuladen ober Marilfen, und ber IInterlipte juammengelebt fint. Die Dberlifpe ift meift ein fleines,

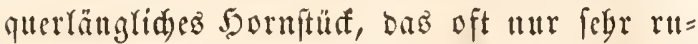
Diutentär ift, aber fonit wenige d)arafterififide Sennzeiden Lat. Die Riefer find faft immer gefrummte, fefte Sornbafen, bie oft weit yor Dem Ropfe woriteben uno bei ben Raubtäfern megr fäberförmig far arf und fpitz gejäbnt, bei Dell Syflanzenfreffern furj, oreserfig uno innen mit ftumpfen Fortfäben, Die oft in einander paffen, verfeben find. Bei cinigen, die fid you Sonig und Blumenitaub näbren, werben die Siefer felbit ganz ober nur aul Sunenrande bäutig. Sie befteben aus einem Stïfe, wäbrend bie Sinulaben ober lluterfiefer ftets zufammengefest fint und zwar aus sinem ques ren (b)lenfizüfe, ber 2Angel (cardo), auf welder cin ftelförmiges Stürf, Der Stiel (stipes) und auf Diefem das cigentlide Beifftüt ter Sinnlabe (mala) eingelenft ift. Diefes lektere if meift bafig ober

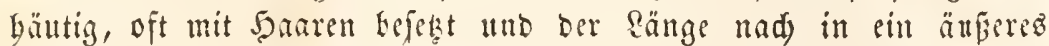
und inneres $\mathfrak{B}$ latt getbeilt. Stuf jeber Sinnlabe if wentigftens citt, bei ben fleifdfreffern aber jwei Labentafter (palpi maxillares) cinge= lenft, bie meift borftenförmig find und aus vier ober brei Gricbern befteben. Die querläuglid)e llnterítpe zeigt aufeen das Sinn (mentum), innen barauf liegend die 3unge und ftets jwei feittid)e, neben der 3 unge cingelenfte, $2-4$ glieberige Eippentafter (palpi labiales),

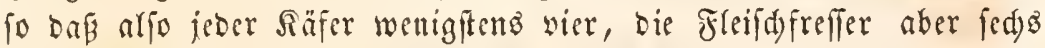
Tafter ill Ganjen befitsen.

Sinter bem Sopfe zrigt fid) bei allen Räfern ber Borberbruftring

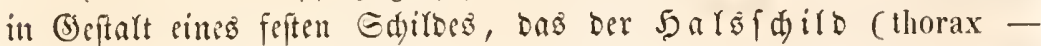
corselet) genant wiro uno Deflen Formen, Berjierungen uno 1 majang äunerft mannigfartig uno für Gattungen uno Arten febr bejeiduneno Find. San feiner lluterfäd)e, Der 3 or berbruft (Prosternum) ift Das erite Fubpanr eingelenft. Der jweite Bruftring, ber bie Flügeldeffen trägt, ift meift, to wie dic weiteren binteren Siinge, won bicfen bebect ober jeigt nur zwijd)en Den ?nfatsfellen ber Flïgelocfen cinen fleinen, mittleren, meift oreieftigen Raum, ben man bas Shiloden (Scu- 


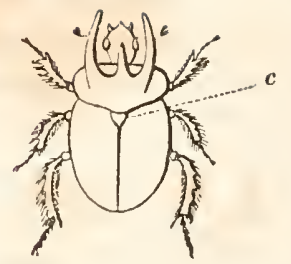

8is. 826.

Geotrupes stercoratius.

c Daz Sdyúlod)en żmi= fdyett Det Bafis bet Jliget= Dectett.

tellum) nennt. Der zweite Bruftritig trägt oben bie gornigent feften fol ï gel befen (Elytra), Die in ber Mitte mit bem Ratbrante jufam= menptogen, fo das fie cine getabe Rängglinie bilben. Sie bebeffell gewöbulid) ben ganjen Reib bis fll feimer binteren Gpike, fo baj ber Räfer, won oben gefelyen, nur brei ?(retbeilungen

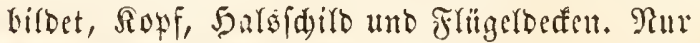
bei eintgen Räfern finb die Flingeldeden abge= ftukt, fo onj ein mebr ober minber bebentender Theil Der Sinterteifarringel frei liegt. Die

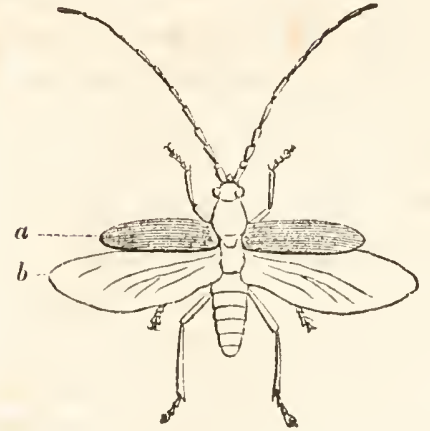

8ૅig. 827. Gin Siâfer in fliegender Etellung.

a Ftügcloefen. b llnterfilügel. Flügeldeden werben keim Fluge utr geboben, aber nidyt bewegt. Die Flïger, werde ber britte Bruft= ling trïgt, fin büutig, von \&ängḡ= abern Durdjogen tub werben, um Imter bie firigeren Flügelbeffen ge= forgen werbet jll fömen, in ber

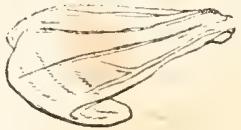

ซig. 828

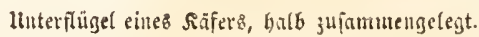

Ditte quer gefnift, eine Prt Ser Zu[ammenlegung, bie ben Säfern eigentgümlid ift. Pur felten ragen fie in oer Rutbe luber die bann verfürjten flïgeldeden berwor.

Betradytet man eiuen Sîfer vou unten, fo fiebt man aufier ben brei Bruftringen, welde bie Beille tragen, bie bornigen Siuge Des Sointerleibes, Deren Rormaljabl ueut ift, bie fid aber Durd $\mathfrak{B e r}=$

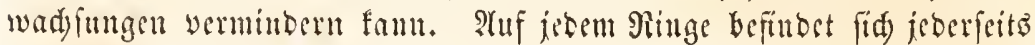

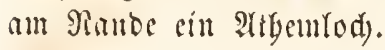

Die Beine find befonders widytig. Das Belenfittiof beftegt aus jwei, unteweglid) mit cinanter verbundenen Stücfin, sinem inneren,

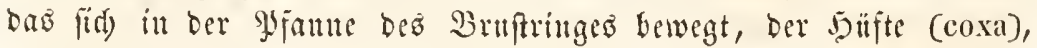
und cinem äuferen, beu Edenfelfnorren (trochanter). Beide Theife fino oft fegr darafterifitid) geftaltet. In bem sinoruen ift ber meift ftabförmigs Gdienfer (femur) und am Ende biefes die ebenfallo frab= förmige Erdicue (tibia) eingelenft. Der Fuß (larsus), ber Daв Enbe 
1) Ins Seines bilbet, beftert ans brei this fünf Gricbern,

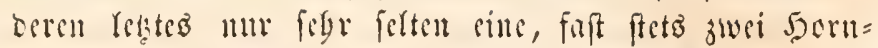

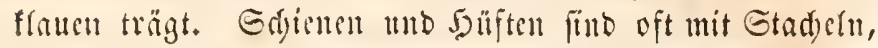
8ig. s29. Eic Tarjen oft mit 5anken beferet und bie 3abl ber Tar=

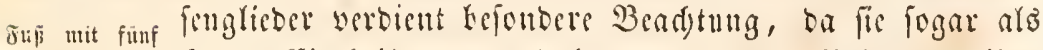

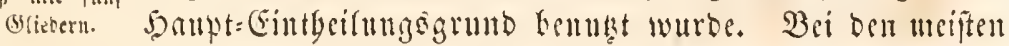

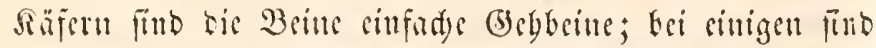
tie Borberbeine ju Srabfüben, bei anbern tie Shinterbeine zu Spring=

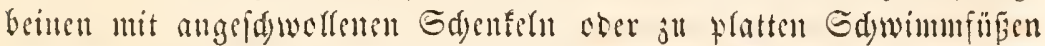
unigewandelt.

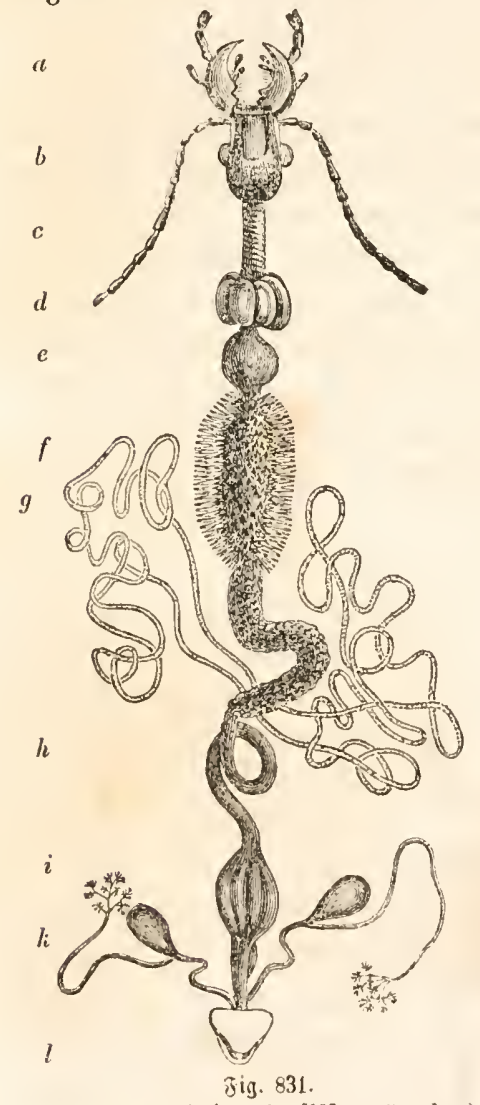

Ter Darmfaual eines : Euffäfers (Cirabus) iivlirt.

a Die אiefer und Taiter, vou oben ge= fefen. b Der Ropf mit ben Füftert uno Den halbfugeligen Slugent. c Der $\mathbb{E}$ (t)lunt. d Der gefaltete Rropf. e Der Rammagen.

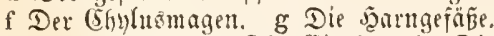
h Der Darm. i Die Eloafe. k Die Iffterorinet. 1 Der Iffter.

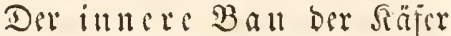
geigt eine grofe Diannigfaltigfeit ber Anorbunng. Dab Rervenfy= ftem Eeftebt entweber ans getrenuten

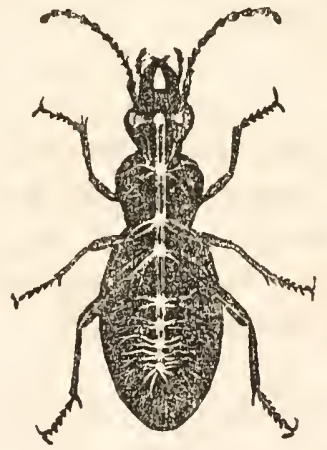

ซึ่ง. 830 .

Terrenigpen enes Carabus.

Sinoten, sic ftets surd) Dopyelts

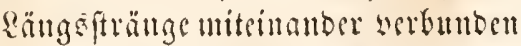
fint, beer แnt ans sincm birn= fuoten und orei bidst ancinander gereigten ?afduerfungen, won be=

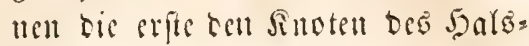
idjiroes, bie sweite bie beiben bill = teren Bruftucten, dis Dritte bis serfdymorgenen Sinterleitustuoten bariteflt, vou ter aแs alle Rerven Des Jjinterleibes ansftrablen. Der Gd)lund, ber jitulid) furj ift, gebt in einen meift furgen wno gefalteten sropf über, Ginter weldem bei ben 
Fleifdfreffern cin runber Rammagen folgt, ber ben übrigen Räfern feblt. Der Cgylusmagenifturz, anf feiner ganjen Fläd) ober nur bem yorbe= ren Theile mit zottigen Brinboärmen befect, Der Darm meift furr , bünn, binten ju einer Cloafe erweitert. Die Sarnfanäle find bintu, lang, nie mebr alo vier ober fed) ; meift fintoen fid am after nod) befonbere, zuvei=

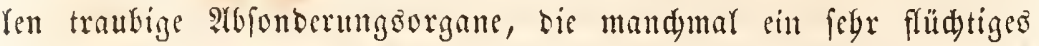

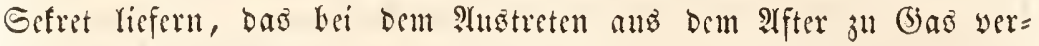
pufft. Die Ruftröleren find fteto febr entwiffelt, oft mit vielen \&uft= blafen befeşt uno fo angeoronet, baß fie fid unmittelbar yon ben \&uft= lödern ato an bie Drgane beräfteln, zugleid aber ftarfe, oft dop= felte Communicationoröbren unter fid zcigen. Die Cierftöfs fimb büiderförmig geftellte, meift orcifäderige Giröbren, beren 3abr yon 5

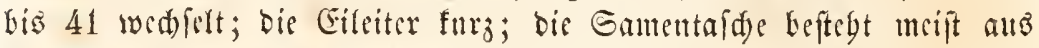
ciner feutenförmigen Siafer, bie cinen langen Gtiel und meift nod

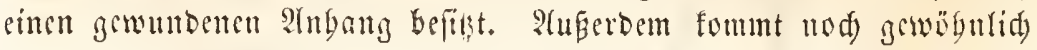
eime biffe, blinbe Begattungsitaide und einte Yange gewundene Edycide vor. Die Soden wartiren ungemein in fyrer Form; bie Gamenteiter find meift furs, und ftets find nod accefforifde Drüfan vorbanden. Die Begattungsorgame befteben ans suter breiten, platten, Durdbobr= ten Patge, welde in einter siaplel liegt mo mit biefer ourd vielfade Mlubfelu weit bervorgejdoben werben fant. Die Gier baben teine aนs่gezeityneten Formen.

Die Raryen ber säfer fino, wie fid bies bei ten fo mannig=
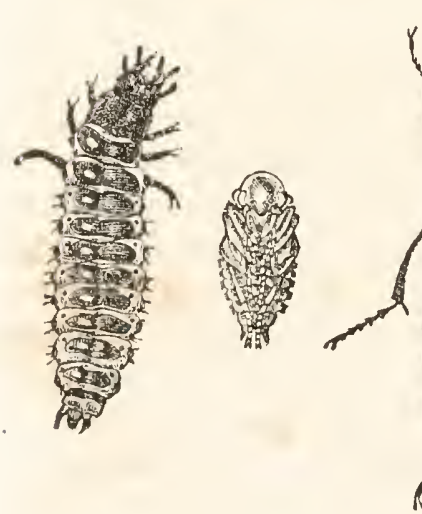

รin. 832.

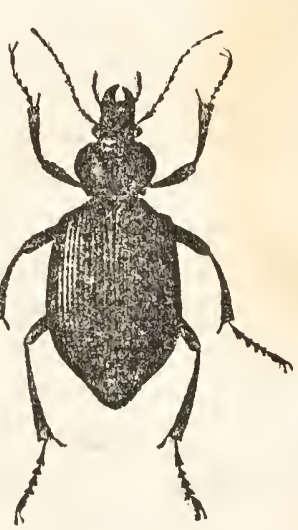

รig. 834. faltigen formen ber Dronung erwarten lick, cbenfalls zicmlid) wedi)= felno in Beftalt und ?turorung ifrer einjel= Hen Theile, bod) aber wirber lo eigentbümlid), bá miă)t (reid)t cint $\mathfrak{B e r}=$ weá) felutig mit Rarven attoerer Jufeftetiorbmun= gen Statt finden famn.

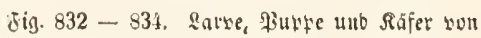
Calosoma sycophanta. 
รi.j. 8?6.

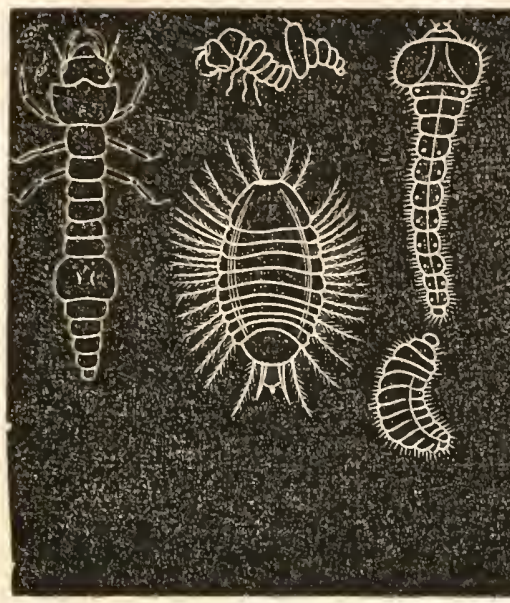

oi. 835

837.

839 .

840.

841.

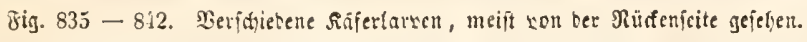

Fig. 835. Bou Cicindela campestris, befonbers ausgezeidnet burdf bie

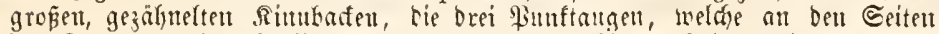

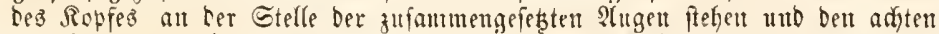

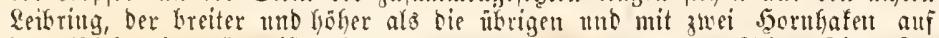
Dem Rüffelt bewalluet ift. Fig. 836. Diefelte Earve vou ber Seite. Jig. 837. Enrve yout Cassida equestris. Fig. 838. Bon Buprestis manca, fuñloz?.

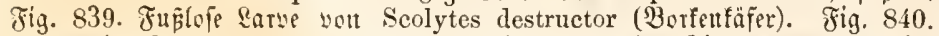

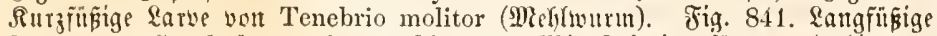
Earve von Staphylinus olens, Fig. 842. Mit Edymmfüizen unb hinteren

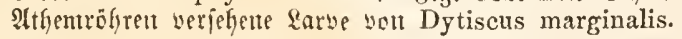

Der $\Omega$ örper biefer Thiere ift fteto geftreát, meift wurmförmig, sft beinabe bregrund; in ben meiften Fälfen aber von oben nad) un= ten abgeplattet. 3uweilen erfdeint er burd)gebendos weid; meift ift indeffen ber Sopf Gornig lind nur ber Sinterleib mit weider 5aut befleibet. Bei ben wenigften wirb aud) siefer mit feftem Sorne bedeft. Diefe feften Sarven fdweifen meiftens frei nady Raub unber. Der Ropf ift meift flad) georïft, flatt, rumblid, von Rinfeugeftalt und borizontal nad vorn ober nad, unten geridstet; bei einigen ffanjen= freffenden Rarven (B̧ätterbürner, Ruiffelfäfer, Borfenfäfer) ift er

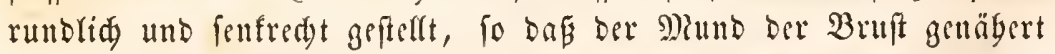
ift. - 3ufammengefeste $\mathfrak{A} u g e n$ fommen bei ben Rarven nie vor cbenjowenig cinfadye Stimaugen; oft, befonders bei ben 50 boobrern, feglen bie Augen gänjlid, wenn fie aber worbanden, fo fieben $1-6$ sinfad) $\mathfrak{A}$ ugen auf jeber Geite und zwar bann meift auf eitem ge=

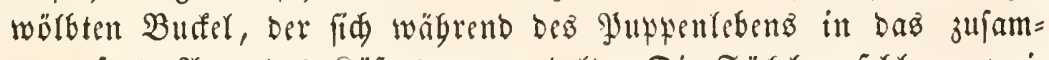
mengefeşte Auge Des Räfers ummandert. Die Fügler feglen juwei= 
ren, befonders bei 5oljbobrem - fie find ftets eittfad faben= ober fegelförmig, baben nie mebr arz vier Grleber uno fteben faft immer feitlid) am Sopfrande liter ben Riefern, felten auf ber Stirn= fläd)e.

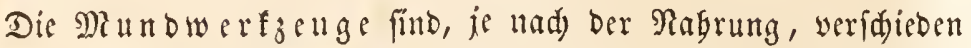
geftaltet. Dft bient als Derte ber ganjen Theile ein beweglides, an ber Stirn eingelenftes Ropfidyild, das inder eben fo oft feblt. Das= ferbe begeguet oft ber Dberlippe, bie mandjmal beutlid) abgefezt, $\mathfrak{b} e=$ weglid), juweileu mit ber Stirn vernadyfen ift ober ganj feblt, wo Daun ber Stirnand jugleid) ben Munbrand biloet und bie übrigen Fref́merfzenge ganz frei yor bem Sopfe fteben. Dief́ ift bei vielen, yom Paube Yebenben \&arven (Cicindelida, Carabida, Histerida, Lampyrida, Hydrophylida, Staphylinida) oer Fall unb baun ift bie Mund = offuung auferorbentlid) fein uno mur mit Mä̈be nadjuweifen. Die

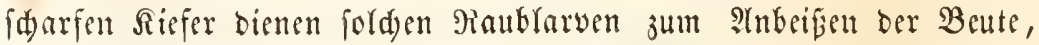
jum Durd)bogren ber baut und zun 3erfleifden ber Eingeweide, beren fliffige Beftandtbeife bann won ber feimen Mlunboffmung auf= gefaugt werben. Bei ben Bafferfäferlarven (Dytiscida) iff logar burduaus feine Dimbiffunng vorganden, fonbern beibe Siefer felbft you Rauälen burd)laufen, weldye fidy an Der Epize Der Riefer fpalt= förmig ïfuen uno Durd) bie ber Gaft oer Beute eingeiogen wirb. Siefer fitmo ftets vorbanden; - bei Den Räubern fäbel= oder fidel= förmig, fdarf uno fpis, meift üter ben sopf vorragent unb liber= einanbergreifetio; bei ben yffaujenfieflern furz, berb, orciectig, oft mit ftumpf gejäbuten sau= uno Edjueibefläden, bie gegeneinander paffen. Die Sinnlaben Gaben meift bieferben Theile, wie beim vollfoumes nen Räfer - sine Angel (cardo), bie jumeifen ftielförmig twirb und bam ben Saauttbeil bes (banjen ausmad)t - eine \&abe, die meift serwad) fen, zuweilen gejäbuelt, felten singelenft ift, unb cinen Tafter, Der fabenförutige Geftalt uno orei Glieber bat. Die Uluterlippe ift oft werwaden, ftetz fleill, igre Iafter jweiglieberig, bie 3unge meift nur rubimentär.

Bielen boljbobrenden Räferlaryen feblen bie Beine burdaus, bei anderen find fie nur burd borftentragende 2 sarjenvorfprünge ange= beutet. Saenn fie vorbanden find, fo ftelen fie an ben brei erftel, 


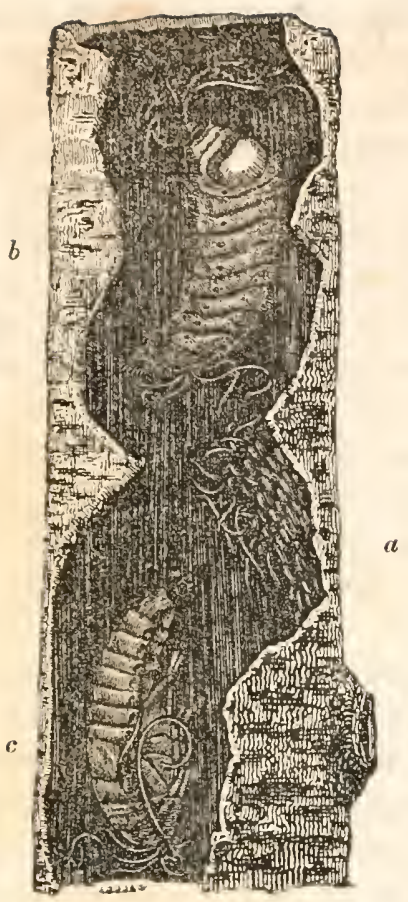

₹ig. 813.

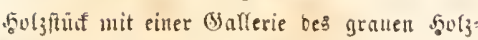
boffez (Lamia vomicosa).

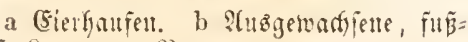
loje sarye. c Pitplie.
Dem Sopfe folgenden Rörperringeht an Der lluterfläd) unto befteben

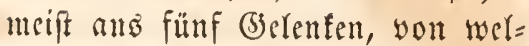

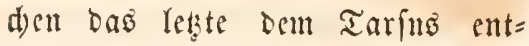
fpridut unt bei ben Earven ber Fiseifdfreffer mit zwei, bei ben Mai= wurmlaryen (Meloida) mit brei, bei allen l̈brigen mit nur einer Silaue bewaffuct ift. Die \&änge Der Beine ftebt meift mit ber Rebbaftigfeit uno Der Benteluft Der Rarwen im Ber= Gälniti. Der Reib beitebt binter Den Deinetragenden 9ingeln aus neun Pingeln, fo bafi alfo auber bem Sopfe in Ganjen jwölf Seg= mente vorbanten find, sine Reger, wovon inbej die sisafferfäferlaryen cine Auğnabue maden, Drren scib mur silf Gegmente jäblt. Fin Jjaar Irtbem(üd)er fteyt an oer Brupt, adyt Jyare an ben adi)t erften Sinter= leibofiegmenten. Der SPfter tritt meift röbrenfïrmig oder warjenför= mig bervor mo wird jum Rad)=

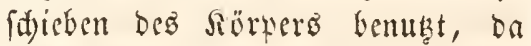

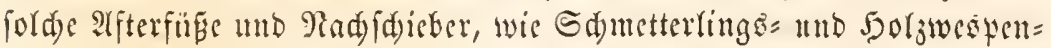
Raupen fie befizen, Den Räferlarwen gänjlidy abgeben.

Die raubenben Siafertarven reben meift in Erolöbern, im Mifite, unter Baumrinben, im Minlme, in (5)ängen mo Reftern ancerer Sn= feften, beren Raryen fie fejonoers beimfuden. Rur wenige Ḧbrrafden igre Bente im Sduाfe ober Eprunge, indem fie sorber baraf laurn (bies tynn befonbers die Enven oer Gand= und şafferfäfer), sic meiften freflen fublofe soer träge Thiere und namentlid Sarven, ju=

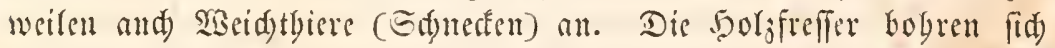
(b)änge, oft in bem bärteften Solje, meift aber in Den weideren Theilen, im Mrarke, beu Swrinte unb Bajte und unter ben Pimben. Biele freflen fanlende ober werwe ende Stoffe - einige werden uns

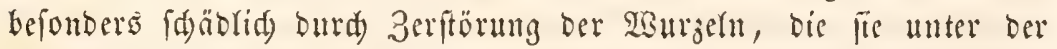
Eroe auffudien. 


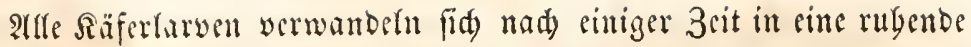
guppe. Die Rebentobuer mander Rarven fdeint megre Sagre ju Lautern; bie ber Diaifäer 3. $\mathfrak{B}$. wie man aus ben Flugiagren fdjlie=

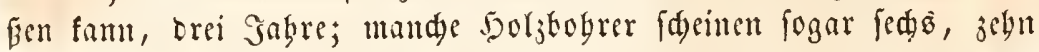
und megr Gagre afo Eurven zul reben. 3ur Berwandlung ziegen fid)

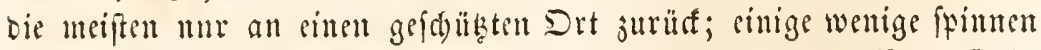
fid) aus grober Erib: einen (Socon; virle madgen fid) aus Grbe, $\mathfrak{b}_{0} l_{3}$,

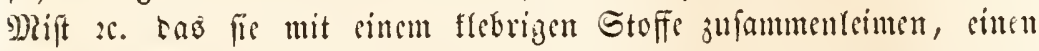
Gogfen Renmpen, der erbärtet uno in beffen Snterem bie ysupse liegt.

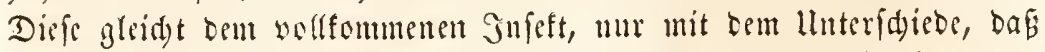
Der Rörper verfürjt und singebogen, bie Fübler unter bie Bruft ge=

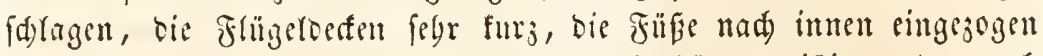
fint, wägrent jugleid oft nod befondere sthbänge exiftiren ober aud

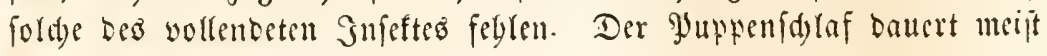
cinen $\mathfrak{B}$ inter Ginturd).

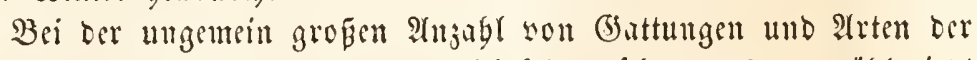
Sǟer, bie eincn georbneten Heberbliff fegr erfigwert (man zäblt jeķt stwa 30,000 befannte und befdricbene irten), war man vou 2 (nfang an bemulbt, Unterfdeidungşzeiden für größere Grupten ober lnter=

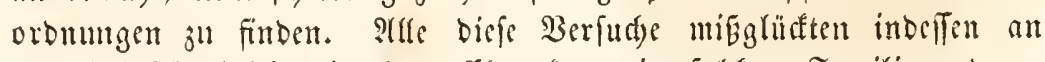
Der llubeptänoigteit eingelner Ggaraftere in folden Fautilien, Deren fonftige Berwandtfdaft nid)t ju räugnen war, uno an ben Mebergän=

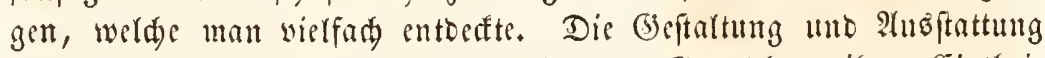

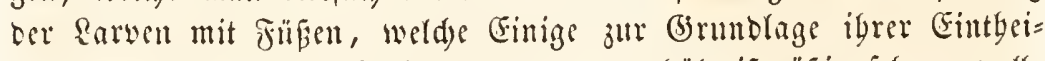

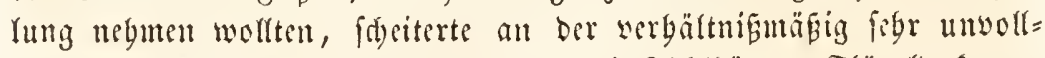

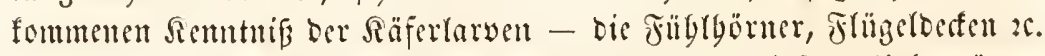

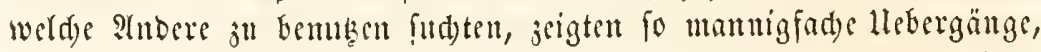

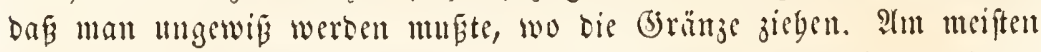
Yat fid nod bic (Eintlysifung von Eatreille stbalten, welder nad) ber 3abl ber Tarfenglieder an ben Fünen bie siafer in 4 atgtbeilungent bringt: Pentamera: Tarfen überafl mit fünf Ostiebern; Heteromera: Tarfen ber Borberbeine mit fünf, bie ber beiben Yaare ber binter= beine mit vier Brlicbern; Tetramera: Tarfen Ḧbetall mit vier Gticbern; Trimera: Tarfen überafl mit brei bjlicbern.

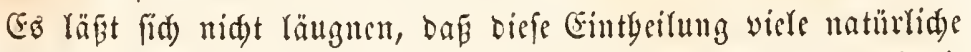
Groppen ridtig trennt, wie z. B. bie Seteromeren eine fegr wobl mit einanber yerbundene Reibe birben; auf ber anderen Seite aber würbe fic, bei farenger Durdfübrung, felbft eingelne Familien in fid) zer= fpalten und in verfdjiebene Unterorbmungen werfen, wägrent fie an= derwäts nabe verwande gamilien won cinander tremen wärbe. So 


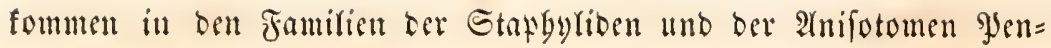
tamere, Seteromere, Tetramere unb Trimere Tarien vor; wäbreno bei vielen Rülfelfäfern ein fïnftes fleines Tarfalglicb verftect fid) finbet, unb äburidue Beifpiele mebr.

Berüffidstigt man bie ald für bie andern 2(btyeilungen bes

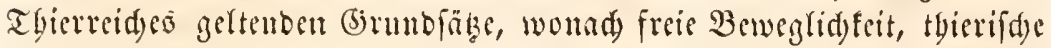
Rabrung, befonbers Pintb unb Benid)tung lebenter Tbiere ftets mit ciner böberen Drganifation verfunft finb, wäbreno Sylanjennabung, geringere Beweglidfeit, Entfernung won Ridgt unb \&uft cine geringere Etufe ber Drganifation bebingen; bebentt man fermer, baß cine gra= ouelle Entwiflung ber Typen fowobl in unferer lebenwelt, als in Den untergegangenen Gdüpfungen fid baritellt, cine Entwiatlung, Deren Reflex bie Claffification barftellen foll - jo wirb mat, bei genturer 2tuwenbung biefer Junte, aud) bei ben siäfern auf ver= fdiebene Reigen gefübrt, bie von getwiffen (jirnbtypen ausgebend fid) in äGnlider Weife fortentwictelt, wie bie Reiben, bie wir bei bent Sruftentbieren wabrnegmen. Sisir feben bie fiäfer in ben geologifden Epoden erif fiät, in beut Gura aufreten und jwar mit boljbobrent= ben, pflanzenfreflenben Familien, deven Sarven theils fuglos, theils

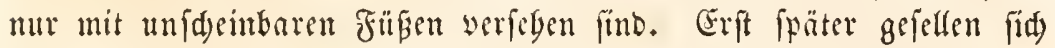

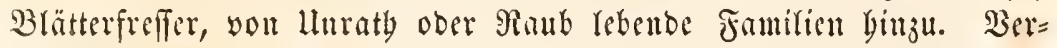
gleidgt man mit biefen llrfamilien ber $\mathfrak{R} a ̈ f e r$ bie jebigen Typen, fo

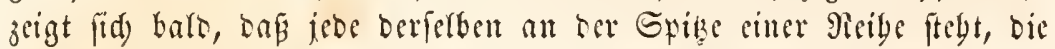
fid) größgerer freibeit in ber Bewegung als Rarve wie als volltom= menes̃ Thier, fo wie umfaffenderen Rabrungšbebürfniffen entgegen bilbet,

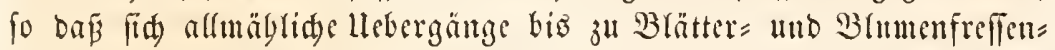
Den, ober felbit bis zu Freifdfreflenben (battungen finben, woburd) aud) eine (sgarafterifirung biefer Peigen jiemlid fdwer bält.

\section{Crife Reibe. Bierglieberige Solgbobrer.}

Familie ber Miltifelfäfer (Curculiomida). Die Siäfer biefer Fă

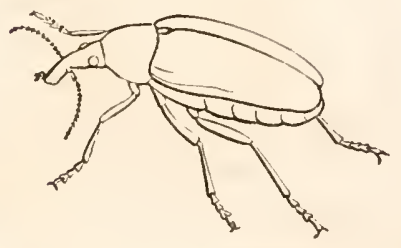

Fig. $81 \%$

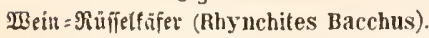
mitie baben meift silten elliptifden geib unb eituen mebr ober weniger riiffelförmig verlängerten sopf, an Deflen Geiten die Fibgler fiteben. Die Mundiffnung befinbet fid vorn an ber Spize des Rüffels; bie grefwerfaetige fint utr felye flein, die Tafter unbebsuteno, fegelförmig, 


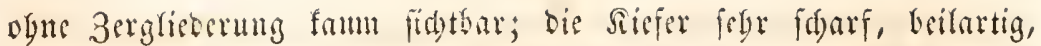
oft grjägnelt. Dic Fübler ftegen bei ben Gattungen mit beutlidyem, rangem Sdunber meift in ser Mitte beffelben vber etwas weiter nad) yorn unt fint entweder gefniet ober einfad fadenförmig. Bei ben gefuisten föhlern ift bas erfite (S) lied ungemein rang, ftabförmig, Dis andern Galieder furj, juweilen gefägt ober binfenfërnig, bas ober

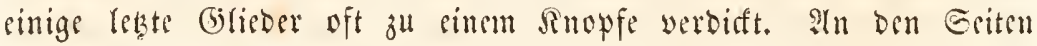

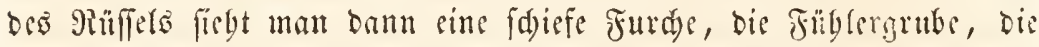

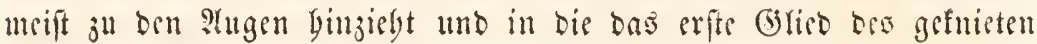

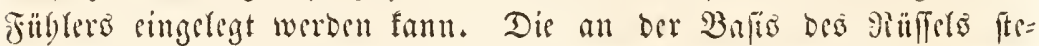
Genben S? ectig, binten breiter, bie flügeldeffin gerippt ober geförnt unt io bart,

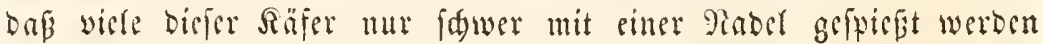
tümen. Die Tarjen find vierglisberig; - mur ferten findet fid sin

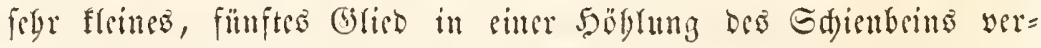
borgen. Das wortegate Tarfalglied meift berzförnig, jweigelappt; tab Yeşte mit Dopperter Nitaue.

Dir Earven tiefer Räfer baten weber gübe nod) 2 (ugen; fir

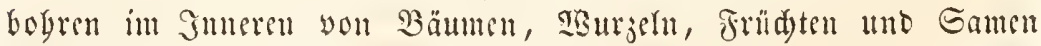

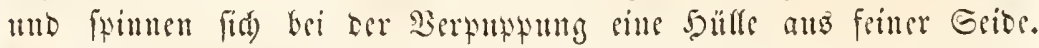
Die Sarven fowohs, wie bie Säfer ridgten grobe Serbernugen in Pffanjungen und Fruthotsorätyen an.

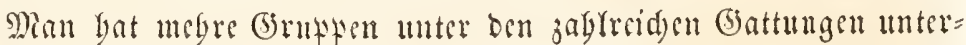
fdicben: Curculionida mit rangrme Pinffifer und gefniften Füblern. 3n

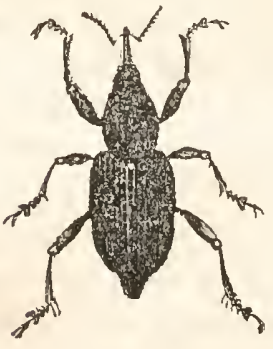

Fin. $8 i 5$

Der $\mathfrak{B}$ đInentäfer (Calandra palmarum).

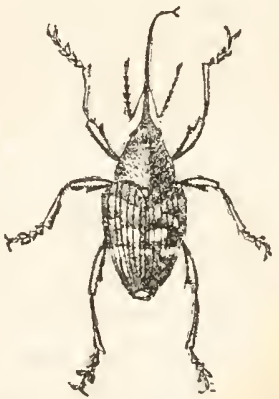

รig. 816 . iguen gegürt bie Oiats tung Calandra, won wel= ber sine $\mathfrak{A} r t$, C. granaria, ibre Girr in das reife (3streibe legt. Dis Sarve (oer fdjwarje Siorn=

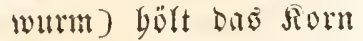
aus. Eime andere $\mathfrak{T}$ int gölt bic gralmitämme; iure brei 30 ll lange

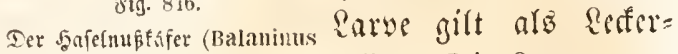
nuemm).

bificu. Dic Sarven an=

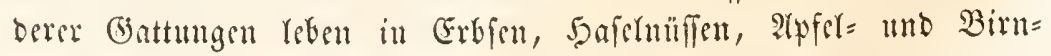
brhittlen is. Curculio; Cleonus; Lixus; Balaninus. 
Finer anderen (bruppe ferglt bie Füglergrube. Sie gat einen für=

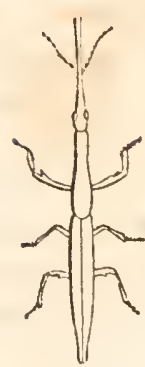

Jig. 817.

Brenthus. jeren Rüfer uno cinfade Fübler. Şierbin gebürt Der Rebenfed)er (Rhynchiles bacchus), Der $\Re$ äfer frifit

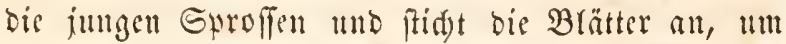
bie Fier bincinjulegen. Die Sarven faken die Blätter ab; - Der rotbe Siormwurm (Apion fru-

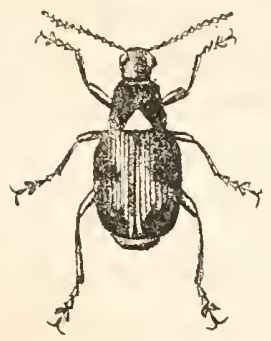

Jig. 818. mentarius); $A$ p. pomonae ber Styferwurm. Magdalis; Rhyuchiles. Bei ciner britten Grthpe ift Der Solf furz, frum fonabel= förmig, flad); bie গ̧alpen beut= riduer, die angen quer. Gie Yeben meift in angebogrtem Gamen Der Erbfenfafer (Bruchus pisi).

Erbientäfer (Bruchus pisi). Anthribus.

Gine sierte Grupte, Die Der Mycteriben, bat sinen furjen Rüler oder cinen nur oreiectigen Hlatten Soyf, fabcuförmige an Der Epilze etwas werdifte Fübler, an ben Borberfüfen fünf, an ben Shinterfüfen vier Tarfalglieder und fuglige Şüften Der Vorberbeine. Die fleiten

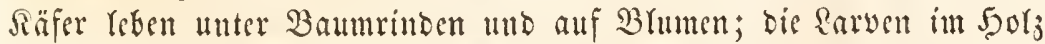
und perennirenoen Rräutern. Mycterus; Rhinosimus; Salpingus.

Jomitie ber Borfenteäfer (Bostrychida). Die Siäfer baben cinen

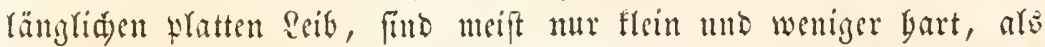

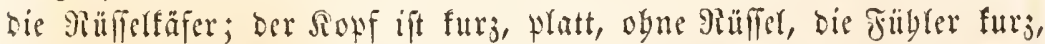
mit einem grofien, berben, meijt geringetten Fnofnopfe verfeben, ber

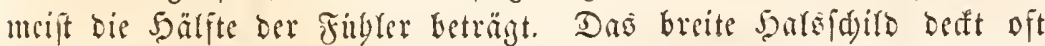
einen Theil bes Soyfes, ber barunter ju hängen fdecint. Die Fü̈в: Gaben ftets vier Tarjalglieber; bie binteren fteben weit yon ben übri= gen ab; bei sinigen finto bie Edienen gejäbnelt. Die Earven fint augenlos mb ibre Finfe fo fur; und unidseinbar, bafi fie mand)en Beobadytern entgingen. Säfer unb Rarven bicfer Fantili bogren in Yebenden Bäumen แnd jua vorjugšnsife an Baft unb Eplint, wo= Durd) Die Eaftrirulation gebinoert wirb unb bie Bäume verborren. Der Bud)orufferfäfer (Bostrychus typographus), ber eigentlüumliáe, werfd) (ungene, arabifd)en Budjfaben äbnlidye (5änge bobrt, bat befon=

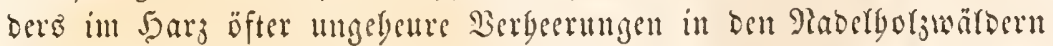
angeridetet. Man nent die Seranfbeit ber $\mathfrak{B a ̈ u m e , ~ d i e ~ e r ~ v e r u r i a d ) t , ~}$ Die 2 surmtrofnifs. Crinige, etwas abweidyende (5)attungen biefer Fa= milie wobuen in Edjwämmen. Mycetophagi; Lathridium.

Familis ofr Wlatteäer (Platysoma), Die Räfer find Yänglid), 
aber febr flad und Dïnn; Der Sopf runblid, ftets Deutlid, yom

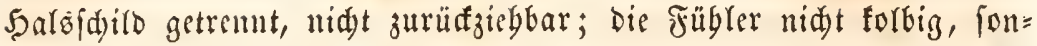
bern fabenförmig uno faum bei einigen Battungen an ber Spibe verbift; bie Fübe sinfad), ftete mit vier Tarfalgliebern werfeben, Deren feines erweitert ift.

Die Sarven baben feds furge, oreiglicberige Fitbe, einen flad)en Royf, aber feine Rugen unb bolrea, wie bie Räfer, in altem 5olge ober unter Rinben, zuweilen aud) in Gament. Die Rarve von Trogosita caraboides 3. B. benagt befonbere in ber Mrovence bie Getreibe= vorräthe Cucujus; Colydium.

3weite Reibe. Fünfgliederige $50 l$ gbobrer.

Sägebörner. (Serricornia.)

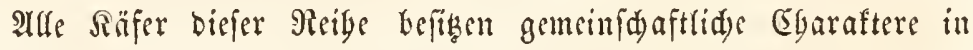

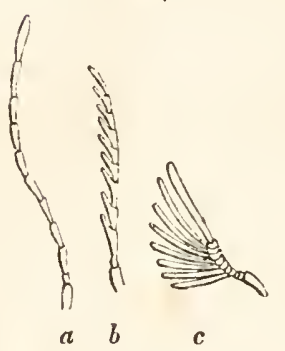
ibren Jüblbörnern und Filfert. Die erfteren werben nad) vorn zu bünner uno frub meift fammartig gezägnt ober förmlid) zu Rämmen ausgebildet; Die Füre find ftets fünfglieberig und bie oberen Tarjalglieber oft gelaptt und erweitert. Die Reibe erbetst fid bis ju Thieren, Deren Rarven won 2las und andern Sarven (d)maroben.

8ig. 849 .

उübier rou Sägebrinern:

a Rojenfranzartiger, $b \quad(5)=$

fägter, $c$ (Sistämmter Fühler.

Spibzbrüfe. (Sternoxia).

Die Familie Der Pradtfäfer (Buprestida) ift jwar in unfern

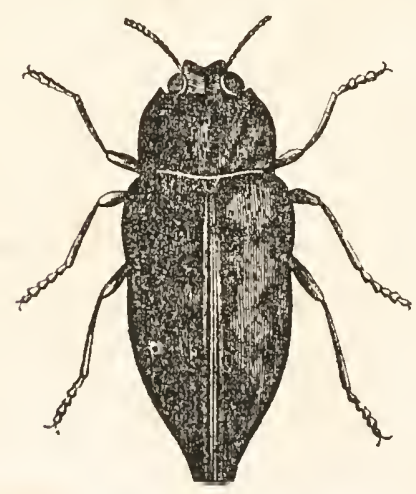

3ig. 850 .

Hroper \$radtthfer (Buprestis gigas). (bigenden nur Durd) wenige fleine Battungen, um fo bäufiger und

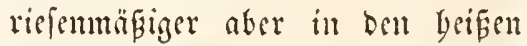
3onen reträpentirt. Die Räfr idiflern meift in ben rebbafteften Metallfarben, baben sine länglid)e (5)eptalt uth ausgejeidnet barte grii= gerbefen. Der Sopf ift meif́t bri= ter als rang, die Fübler furz, ftart gefägt, die einfaden gyafpen furj, ifr lestes (stied cylinorifa). Das 5arêf)ild breit, bie binteren Gefen gerabe; bie Borberbrult nad binten 


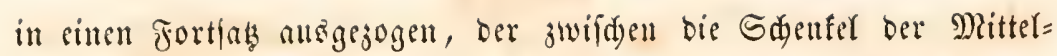
füber reidst, aber abgerlattet ift unto nidgt in sine Bertiefung past.

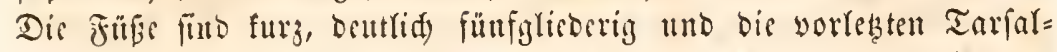

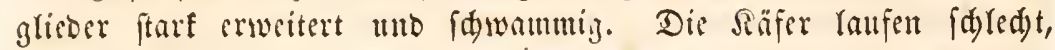

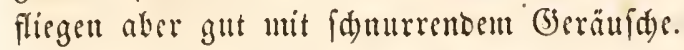

Dis Rarven find augenlos, wit ganj furjen warzenartigen Fünjden werjegen; Der Ropf ift fegr fleill, fleifdig; Der jweite Pringel aber

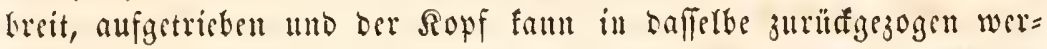
Den. Die Fübler fint feltr Elein; Rippentaffer feglen ganz. Die Riefer fint, wie bei ben meifen bol bobrenton sarven, furj, faft innen ftumpf gejägnt. Sie bogren befonders in trofenem Sorje umb reben

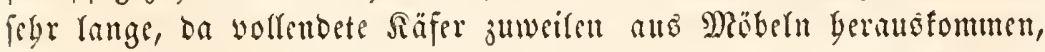
bis (d)on Jabre Gindurd im (bebraude waren. Buprestis; Melasis; Aphanisticus.

Dis Jamilie ber Sthnelfäfer (Elaterida) Lat mit ber yorigen

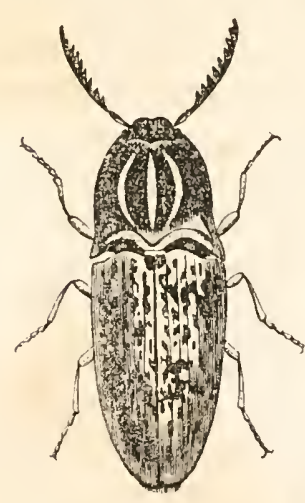

aig. 851 . die Form ber fübrgörmer, der Füpe, die Garten Frïgeroeffen, bie fonberbave Biroung Der Sorberbruft gemein; nur ifi ber fort= faz berferben uod) weiter nad) biuten aus= gezogen, von beiben Seiten jufammengebrït, fo bafi ar cine Doldgeftalt befint. Er papt in sille furdye ber Mittelfrult. Regt man bie Thiere alf ben $R$ iüten, fo fteifen fie ben Rörper, zieben föbler uno Jüpe an แHD ftopen bann mit Grualt die Epige der Sorderbruft gegen ben Rand bes Sodeb it Der Mrittelbrilft, fo baj ber Siöter mebre 30 ll bod it bie Ruft gefduleubert wirb. Dis

Edynelt ấer (Elater).

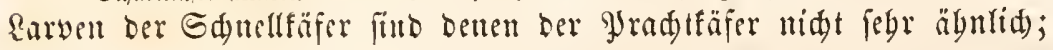
fie fint orabtförmig, bart, baben teine Dberlippe, Eagegen gang feit= (id) gelegene Rintrladen, eine febr lange faft unbetweglidge llnterlippe

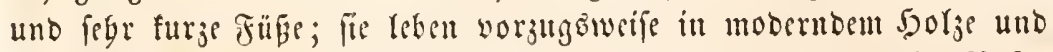
in rauzeln, wäbretid bie Räfer befontors auf Blumen, im Rafen unt im (5)treibe fid) unbertreiben. Finige Irten leudten; eine fiid=

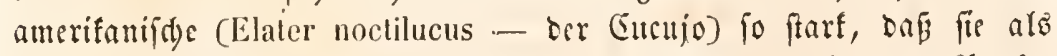
Scudyte bemulgt wird. Dis leud)tenden Theile find jwei runde Junte

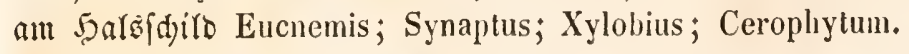

Die Familis oer Şorzbohrer (Xylotroga). Der Rörper Diefer Thiere ift länglid), ziemlid) weid); die Flitgelderten meift gefdlollen, 
bei cinigen Sattungen aber fraffent mo ferbft unvolffändig. Der runblidse Sopf bald frei, bard medr ober weniger unter bem 5alb= fdilde werfteft; die flïhler furz, weniger gefägt, als itt ber worigen Familic; Die Rimulaben ftarf, furz, gezälnt; Die cinfaden gyalpen meift am Ende verbift; Die Finfe ziemlid) lang, fdwad), ogue fdwam= mige Soblen, ourdgebends fünfgliebrig. - Dis Rarven baben alle

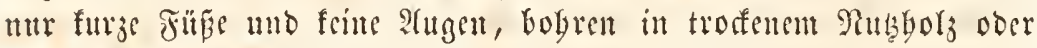
in trodenen Thierfötyern und futb wegen igres grofen Gdnecns be=

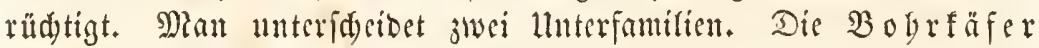
(Plinida) baben cinen fürzeren eiförmigen feften Sörper, gefd)loffene

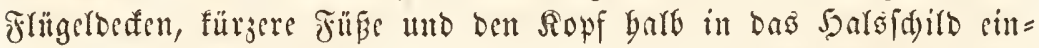
gejenft; fie reben bejonters in Sammlungen unb altem Solge. Der

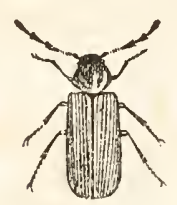

Fig. 852. Die Toptcu= Oig. 852. Die Tobtcil uhr (Anobium pertinax Bemügulidae Bobrfäfer (Plinus fur) greift meblt ber Rarue trofne Thierfüter unt Sarbarion an; bie Tobtenubl (Anobium pertinax) in altem Tubborje, loftt burd) 习Joden mit Den Siefern, feflt fid bei ser Beribrung toot uno lägt fid ferbft ourd) empfind= lide Miartern nid) jur $\mathfrak{B}$ ewegung werleiten. Ptilinus.

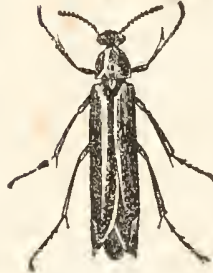

₹ig. 853.

Der Saifiguerftbohre: (Lymexylon nivale.)

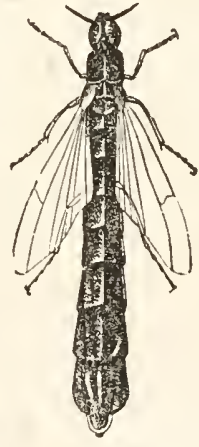

รin. 854.

Fomilie Der Weichffingler (Halacodermata). Der Siöryer ift meift lang geftreft, flad), weid), bie flügcloeffen reberartig bieglam, oft verfümmert ober mur beim Mäunden yorbanben; Det Fopf nad) $u n=$

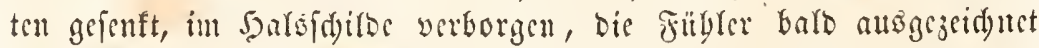
gefägt nub gefämmt, bald linicuförmig. Dic jicmlic) lanbfüfigen, mit

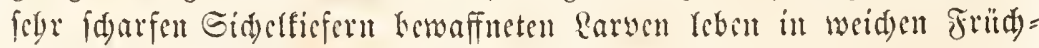
ten oder vom Raube, fut äliserft gefrägig und feben ben flügellofen

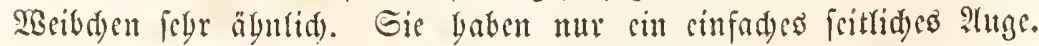
$\mathfrak{B}$ ir unterfdeciben vier lluterfamilien. 


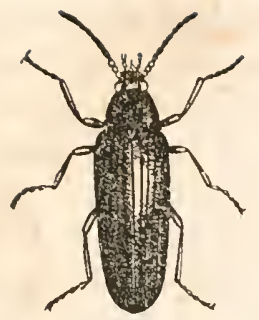

Jig. ¿55. Cebrio rufus.

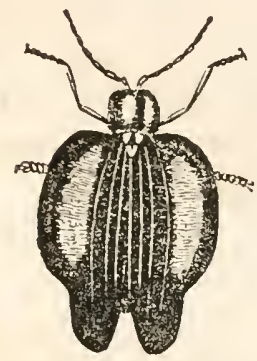

8ig. 856. Lycus.

Cebrionida. Sïrper mely ober minber geftreft, weids, bieglam; Sopf geburt; $\mathfrak{D b e r}=$ fimulaoen furj, cinfad); Salef daito quer, bin= tere Eafen zuweilen auszzjogen; Fübler lang, auşgejeidnet gefägt. Reben meift auf Sumpf= Iuto Safferpflangen; ibre sarven fint unbe= fannt. Cebrio; Sandalus; Scyrtes; Cyplion; Nycteus.

M a la chida. Rörper lang, fdmal; Solf

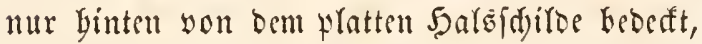
Das vierectig ober länger als breit ift; Dber= finulaben febrlang; Jüfe cinfad) obne Sd)เพämm= den; bie Şafen bes lekten Tarjalghedes inmen mit sintem 3äbndyen obar ciner baut nerfeben. Die Räfer finocu fid a tern; raufen finell uno fliegen gern; die Rar= wen in faftigen Frid)ten roer aud) wom Raube rebent. Dasytes in Sombeeren; Malachius; Melyris; Lycus.

La mpy rida. Rörper lang, đdmal; Ropf fait gans in bas platte

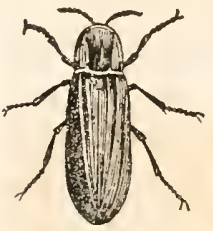

ชึig. 857 .

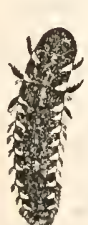

859 .

5aresfdild cingefenft; Doberfinnlaben fur', febr fpitz. Borlektes Tarfalghe crweitert, jwei= lappig, die Slauen sinjud). Die Siscibden fino oft ungefliigert. Die Saffer ftelfen fidy bei ber Berübrung todt; bie Raryen mägren fid yom Raub und find meift fdwärglid). Lampyris

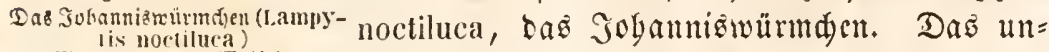
Disundent uno 2 seibrten.

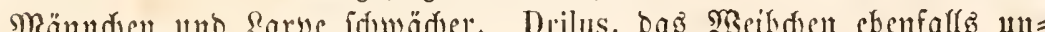

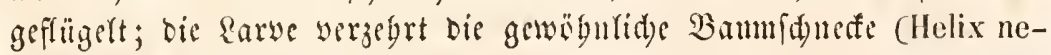
moralis) und puppt fid) in bem leergefreflenen (Bebäufe eint. Sie trägt ju Ecioen Geiten Borftentünocl. Telephorus; Omalisus.

Clerida. Sörper langgeftreft fomal, meit Gaarib; Sorf furz, 


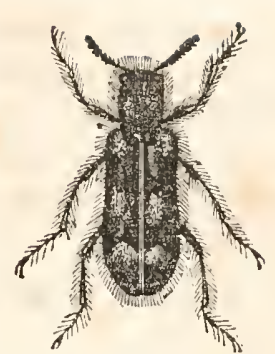

febr breit, oft breiter als bab oblonge Saalb= fdilo; fribler gerägt, oft gegen das Enoe fnopf= förmig verbift; bie 2lugen anşgerantet; Rimn= laben gezäbnt; Warpen tcurenfürmig; worleztes Tarfarglieb jueigelappt. Dic føünch, meift quer gebänbetten Säfer nuศ Brumen mo alten Bäumen; Die rofenrotgen, bebaarten Raven in

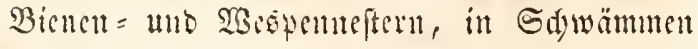
zig. 859. Clerus Alvearius. tulb in faulen 5olje, wo fie andere Raysen

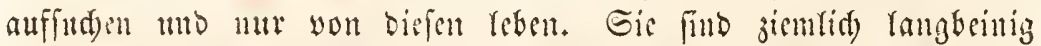
unb febr !ebbaft. Clerus apiarius, ber Bienenworf - bie Rarve rebt in Biencuftüfen und fript die Bienenlarven; Clerus alvearius - die

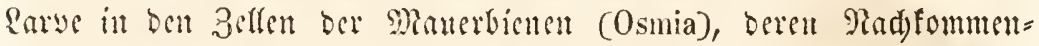
fdaft fie verjebrt. Necrobia - anf Gabavern. Tillus; Axina.

\section{Dritte sieibe.}

Familie ber $\mathfrak{B o d f a f a f e r ~ ( L o n g i c o m i a ) . ~ D i e ~ z u l ~ b i e f e r ~ F a m i l i e ~ g e = ~}$

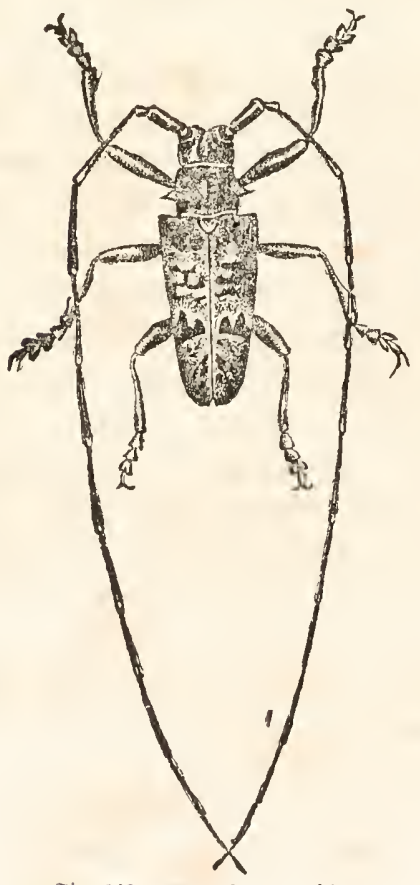

oig. 860 . Monochamat tridens. görigen, meift grofen unb fdünen

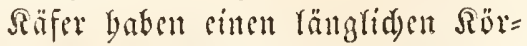
per, beffen Rürtenfeite meift flad), Die Baudfeite bagegen ftarf gewölbt ift. Der Sorf i ijt vorgeftedt, frei, meift fdumäler als bas flcime, vict= eftige Jalsidyito, bas oft mit Spizen umb Zarfen vergiert ift. 2(ugen läng= lid), nicrenförmig auģge (d)itten, in Dem $\mathfrak{A}(1 \mathfrak{s} / d)$ nitte ift meift oas Fübl= born cingelent. Fïbler fadenfü:= mig, meift wenigftents eben fo rang als ber Rörper, oft nod) bebeutenb ränger, febr feften fïrzer. Jumge

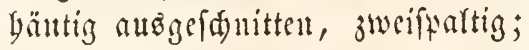

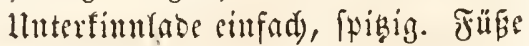
lang, beutlid) viergliebrig; bas Silanenglicb an ber $\mathfrak{B}$ แrzef mit cinem freinen Sinöyfden verieben, fo das bic Jü̈pe cigentlict) fünf (sticoer ba= ben; vorlebtes Tarjalghieb ftets, das 


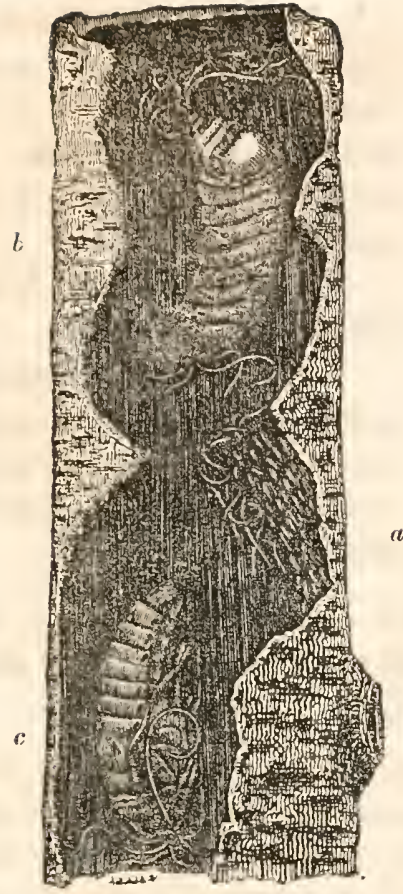

Jig. 861

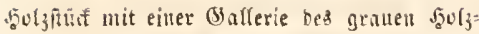
boctes (Lamia vomicosa).

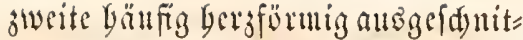
ten, fdyammig. Dic Säfer bar=

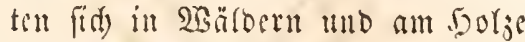
auf; die oft frbl grofen Rarwen bobren affe itl $50 l_{j}$, befonders im Stamme lebender $23 a ̈ m$, baben sinen fladyen runbliden Ropf obne Plugen und entweber gar frine ober mur feldr flcine, faum (5)e= lente jeigento Jü̈в. Shre Riefer find, wie bie aller antorn Sools= bubrer, furs, aber febr ftarê und (d) ucibend. Die meiften $\mathrm{Säfer}$ bic= fer Frmitie geben ourdy Miciben bes

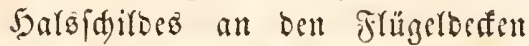
einen fnarrenden Ton wou fid .

Bei ber grofert Âtrangl ber (5)attungen bat man mebrere $\mathfrak{P ( b}=$ tyeilungen unteridieben.

Prionida. Füfler in einer

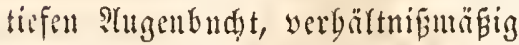
a (E) lupe Earve. c Pilppe.

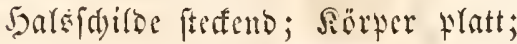

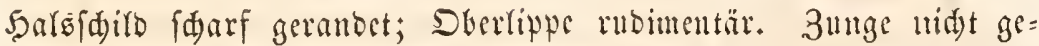
fwalten; Rinulaben meift ungemein grob und ftarf. Dreift febr grofe Räfer; cint ausländifdye ?trt (Hacrodontia cervicornis) erreid)t faft dic \&änge einer Sand. Prionus; Spondylis.

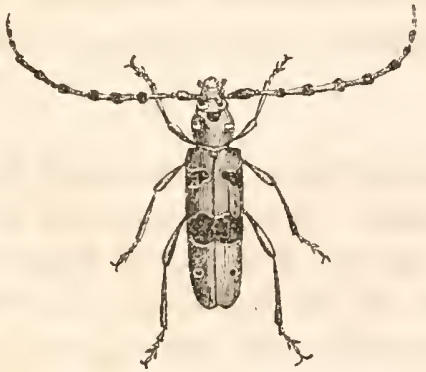

Cerambycida. Fübler febr rang; Sïrper gewölbt; Sarsidjilo obue forfen Rand; Sberlipes bentlid); Sintlaben fleiner; lluter= gefid)t vorfpringent aber flein; Mund đdräg uad) worn geridytet. Eigentlidge Joorbuate.

Cerambyx; Callidium; Calli-

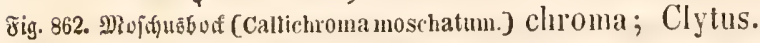




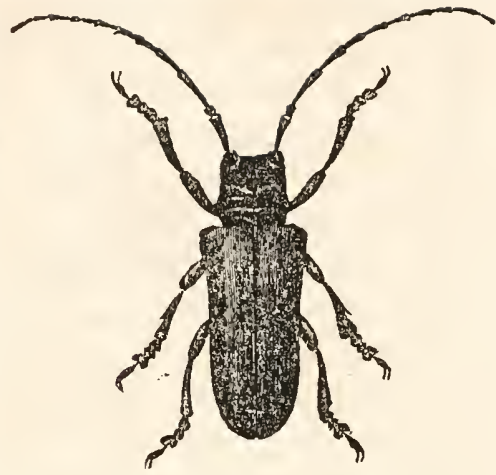

8ig. 863. Sramer 5ơ 3 bof (Lamia vomicosa.)

Bon iguen unterfdeioen (iid) Dis Ramioen nur Durd) eitlen fenfred)t geftellten Sopf mit grofem llutergefidst, fo oá oer Mund nad) unten geridgtet erfdeint.

Lamia; Saperda; Spondyltus.

Necydalida. Flitgel= beffen ungenitgend, entweber

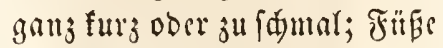
lang; Sdyenfer mo Edicn= beine feufonfïrmig angefdudlen. Necydalis; Molorchus.

Lepturida. Iluterfdeiben fid non allen worigen baburd, bak

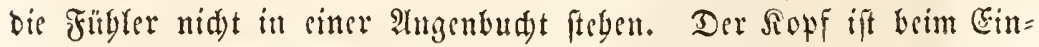
tritt ins Salsffdir ftarf jufammengefdnitht. Leptura; Rhagitm.

Familie Der Rilienßäfer (Criocerida). Rörper obal, felten fo lang

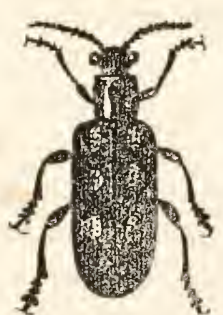

Jin. 864. Rutter Pilienfäfer

(Crioceris 12 punctats.) geftreft, wie bei ben vorigen, ftets länger alö Die Fithler; Ropf meift fajt fo breit als bas oblonge 5aloffdillo, bas ftets viel fdumäler als Die Flïgerdefen ift. Fithler fabenförmig; 3unge ausgefd)nitten; 乌̧afpen fletu. Füfe vierglies brig; worlectes Tarfalglico berzförmig. Beine zuweilen feulenförmig, fringen satn. Meift

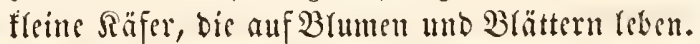
Dis Rarwen baben beutlides, aber furge Beitte und reben entweber in ben martigen Stengeln von Sagferpflanjen (Donacia), oder auf ben grïtuen Blättern verfdjicbener (b) wäd)fs. Jut reb̧tern Fafle maden fie fid) eine Deffe ans igrem eigenen Sotbe, ben fie über ben Rüafen binliber vorwärtşđicben. Donacia; Lema; (Crioceris); Auchenia; Orsodacne.

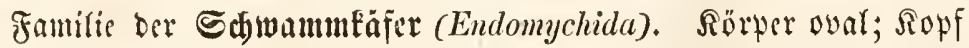
flein; Sarşfdilt itt Form sines Trapezes. Fübler länger als Sopf und Salsfdito jufammen genoumen, an ber Epize meift fnopfartig

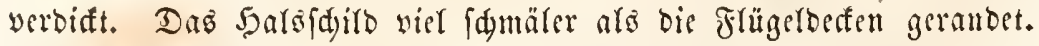

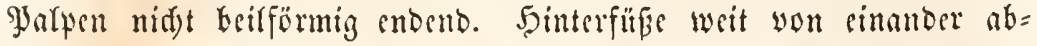
ferbent. IIn Den Tarfen nur orei Grleber; Das vorletzte meift lappig.

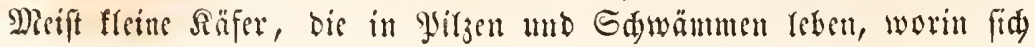


aud) Die furjbeinigen Rarwen finben. Endomychus; Lycoperdina; Eumorplius.

Familic ser Runbfäfer (Cyclica). Sörper mebr ober minber runo, freisförmig, yodgewölbt ober platt. Sopff ferr flein, meift gans

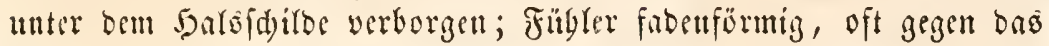
Enbe bin feulenartig verbift, furj. Fenere Sappen ber Simulaben tajterartig; 3uthe viereftig ober oval. Salsfdeflo an ber $\mathfrak{B a f i b}$ meift fo sreit als bie Flügelbefen; Füß̨e furs, überall mit vier Tarfalglies Dern, yon benen bie brei erfen fdwamtnig unb bas vortekte beraför= mig ift.

Die Sarven find mebr ober minber langbeinig, meift fdon von ägulich rumber Form, wis bas vollfommene Jnieft. Sie leben ent= weber im garendym ber Blätter ober auf benfelben, wo fie fid mei= fens Rägren ober Däd)e won ibrem eigenen Rotbe bilben. Man tyeilt fie ill mebrere Gruppen:

(FrDflöbe, Galerucida. Sïrper etwas länglid); Jübler jwifden Den Sugen nabe an ber Mitterlinie untuittelbar yor bem Munbe ein= gelenft; Lie Salpen enben mit jwe fegelförmigen, mit ben ungleid)= namigen Enoen aneinanbergefïgten Gjlieberm. Biele befizen verbidte

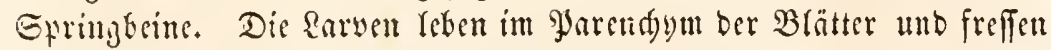
Diefes auz. Galeruca; Ilaltica, Erbflob.

(5) o do fäfer, Chrysomelida. Siörper fdildoförmig, faft rutto. Fäb= fer weit auscinander, neben ben Atugen eitlgelenft; Ropf bängent, balb in bas balsifdito eingefentt. Träge Thicre, bie meift ein fdar= fez Del hei ber Berübrung von fíd geben. Sarene langbanrig, frei oder in einer gefpontuenen Rögre, freffen Brätter. Chrysomela; Euinolpus; Cryptocephalus.

Squirb fäfer, Cassidida. Sopf flein, gänjlid unter bem freiten 5alsiddiloe vertorgen. Fübler genäbert, furz. Sörper fdilbförmig. Beine furg. Sebr träge Thiere, die faft ftetö rubig auf Blättern figen. Sarven runtrid, febr langlaarig; ridten ben Ifter nad) oben utto Eauen fid) ein Dad) von ibrem eigenen Fotbe, ben fie ftetö liber Den Rüđen nady yorn fdicten. Cassida.

Familie ber Blattlausfreffer (Coccinellida). Rörper runb, bod)= gewölbt, unten wlatt; Ropf flein, frei; Sïbler furz, fabenförmig ober gering feulenförmig; Borbertafter grofi, mit beifförmigem Enogliebe. 


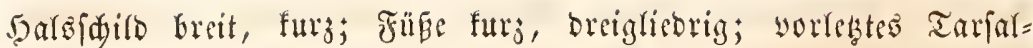
glieo tief gelappt. Beim Berübren lallen fie simen fdarfen gelben Saft aus ben Fugen ber Beine bervortreten. Rebenbige Räfer, bie gern fliegen und fid) wis bis langbeinigen, Yanglganigen, röbrigen Enrven, von Blattläufen näbren, bie fie in Menge vertilgen. Coccinella, MRrienfäfer. Coccidula; Scymnus.

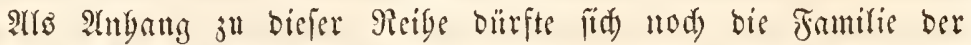
Saarflügler. (Trichopterygida) barifelíen; flente, winjige säferdyen

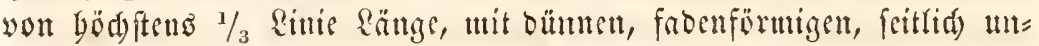
ter Der Stirn eingelenften Füblern, bie an ber Spize fnopfförmig werbifft fitto, utto oreigliebrigen Tarfen, won betten bie erften (s)fieber

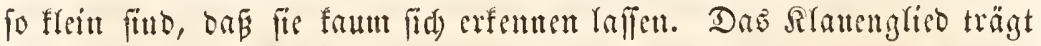
gwif̧en Den beiden Silauen einen geítielten Ballen. Die Beine find lang; einigen unter Baumrinden lebenten Irten feblen bie AHgen. İm merfwürbigften fint bie Flügrl gebaut; fie beftelsen ans sinem langen, boppelt gefniften, mittleren 5ornidafte, ber wie sine Feber auf beiben Geiten mit langen fumalen Borften beję̧t ift, mo mad

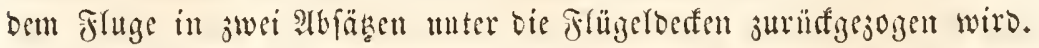
Sul Sietreide, anf Mif́t und unter Bammrinden. Ptilium; Trichopteryx; Ptenidium.

Sierte Reibe. Seteromeren.

Faft alle Räfer biefer Meibe baben an ben 3orbesfüben fïnt, an

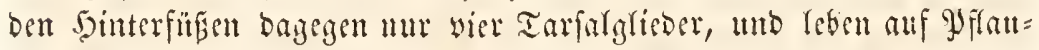
jen. Die Rarven fdumerousen ober freffen Yyflatjenftuffe.

Familic ber Blafenfäfer (Meloida). Rörper Yänglid); Def quere

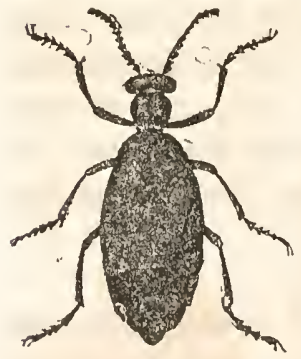

Jig. 86.5 .

Der Minimurm, Heloe moscarabeus.

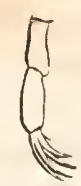

Jin. $866^{\circ}$

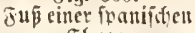
olicge.

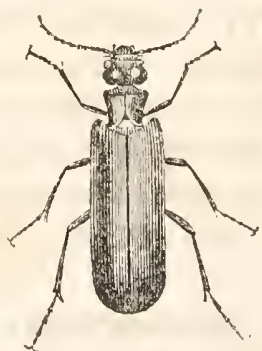

Fin. $86 \%$.

Exanifide stieze Lytta vesicatoria.

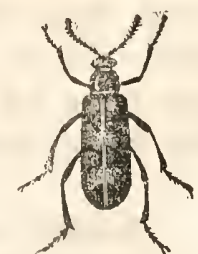

Tiq. 868. Mylabris vesicans. 


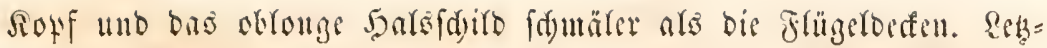
tere fegr weid), leberartig, biegfmu, bei eintigen (5attungen verfümmert,

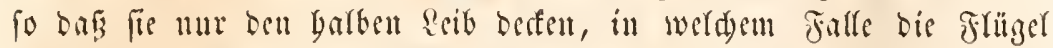
gänjlid) feblen. Jübler fabenfürmig ober gefägt. Die beiben Jiauen

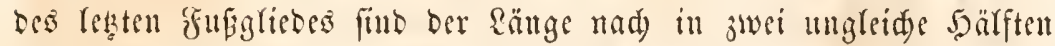

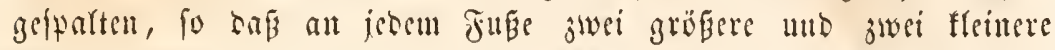
Silauen worbanden fdeinen. âte Sïfer biefer ganilie entyalten simen fdarfen Glajenjebenden, äzenden Stoff und werben aud an

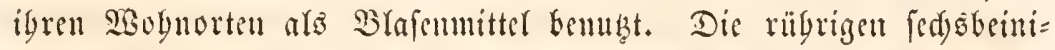
gen Sarwen baben mittellange Füpe mit brei Rlauten unt sinten baa= rigen Rörper - fie fduntoken auf Bienen unb Erobummeln, yon beren Earven fie fid wabrfdecinlid) Häbren.

Mcloe (Maiwurm), Lytta (Spanifde gliege), Mylabris (Cantharis Der IV(ten); Zonitis; Cerocoma.

Fanilie oer Spintelfäfer (Mordellida). Rörper fpindelförmig

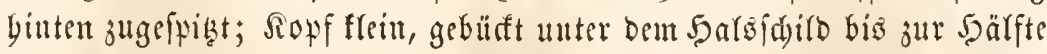

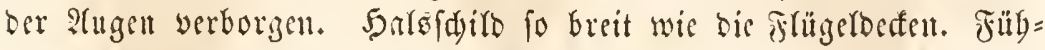
ler fabenförmig, faum gefägt. நinteridenfel uncift ctwas verbifft. Beine lang. Saufen büpfent mit grofer Sdyelligfeit und fellen fid) bei Berübrung toot. Die \&arven, welde feór furje fü̈̈e baben tmo Den Enruen ber 5oljwespen fegr äbulid feben, leben im Marfe vou Bäumen unb Siräutern; bie Siäfer auf grünen faftigen Blättern.

Mordella; Rhipiphorus; Scraptia; Anthicus.

Familie ber (Eardinalfäfer (Pyrochoida). Sürperform ber vori=

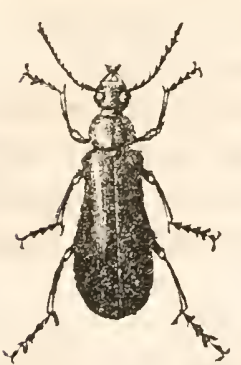

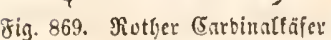
(Pyrochroa coccinella.) gen Jamilie, aber obue die bintere Gpibe. Sopf gerabe, wentig vorgeftreft, 5arbfdild ju= wcilen fømäler als bie Jjlügeldecten. Jübler fabenförmig ober gefämm!; beim Rännd)en oft ferbft webelartig. 23orbertafter febr verlängert mit verbiftem Enogliebe. Frïgerbedent oft be= Deutend uad) binten verbreitert. Füne lang;

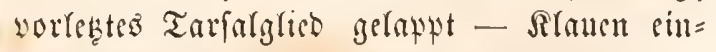
fad, ungejälont. Die Räfer auf gyflanjen; bie mittelbsinigen \&arven unter Baumrinden, iur Mulm abgeftorbener Stämme. Pyrochroa; IIelandrya; Serropalpa; Lagria; Dircaea.

Fantlie ber $\mathfrak{A e g e l f a ̈ h n t h e n ~ ( C i s t e l i d a ) . ~ S i ̈ r w e r ~ o v a l , ~ o f t ~ z i e m = ~}$ 


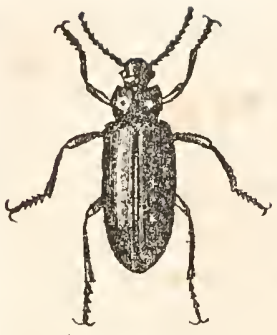

gig. 870. Hlelops.

(id) breit; Sarafoidilo meift fo breit alo dis Flügel. Dlund vorgefitedft, oft ferbit rüfrelar = tig verlängert, fo baßi fid die Ropfform Der= jenigen tor Brudbioen näbert. Fübler boriten= förmig, faum gefägt, juwcilen von Rörperläıge. Jübe febr lang, bünn, bie Sdenfel oft anjebn= (id) verbifft, fo Daf die auf Blumen rebenden Säfer gut fpringen. Dis . Borberbüften fteben bicht zufammen. - Die Earven Keben in Mulum und gleidfen febr Denen ber folgenden Familie. Cistela; Oedemera; Helops; Mycetocharis.

Familie ber Sobmarłfäfer (Melasomata). Siörper ränglid) ober

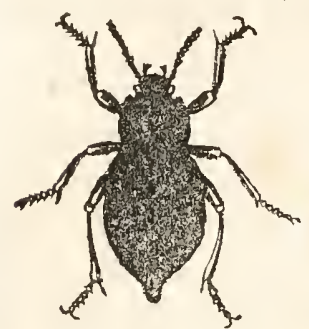

Tig. 871. Ter Tubtentäfer (Blaps mortisaga.)

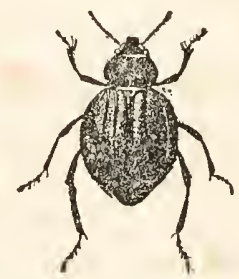

§ig. 872. Pimelia.

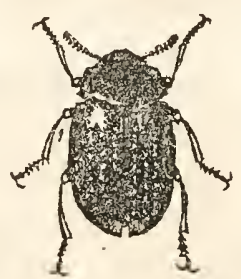

Jin. 873. Diaperis.

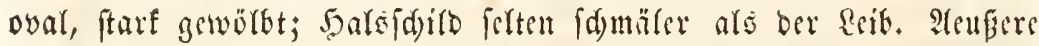
Defen meift jientid bart unb feft. Fübler furj, ferlfdnurartig un= ter Detl Soffrande eingefest. Dberficfer zweifpaltig; linterfiefer mit Gormiger Ritaue an ber Snnenfeite. Wielen Räfern feblen bie Jinter=

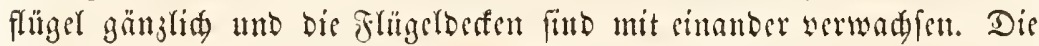

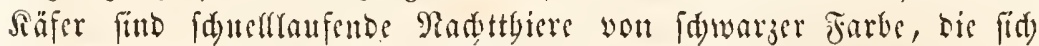
Tage über an Dunflen Drten aufgalten und Rad)tö umberfdweifen. Die mittelbeiniget, Drabtförmigen, mit abgeichtem Ropffallo verfelye= nen Rarven in Milm, Mebl, Brob. Tenebrio molitor (Mleblwurm); Blaps mortisaga (Tobtenfäfer); Opatrum; Ulona ; Crypticus; Diaperis; Pimelia.

Familie ber Süüuleäfor (Anisolomida). Sircine ovale ober rumb= lid)e Siäfer, in igrer Form oft Den Sd)irbfäfern äbntid). Fübler feu= lenförmig; Jüife furj uno fegr wed)felnd in Der Zabl ibrer Tarfal= glieber. Die Räfer leben auf Sdyämmen uno im Mulut uno fugetn fid bei ber Berügrung zufammen. Agathidium; Anisotoma; Tetratoma; Coleris; Agaricophagus. 
Fünte Reibe.

Fantilie ber Blattgörner (Lamellicornia). Die gröften befann= ten Siäfer gegüren biefer feghr zablreiden aus̆gezeidneten Familis an. Syr Rörper ift meift owal ober runtolid, bid, auf beiben Seiten ftart gewölft; Der Ropf flein, Der Stirnrand oft altögebreitet voer gorn=

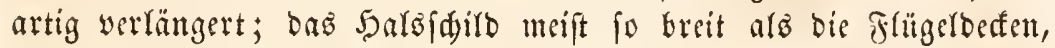
oft ebento wie Der Ropf mit fonderbaren Fortfäken, Spizen uno bär= nern gegiert. Die Fubler fiben in einer tiefen (j) rube unter ben Seiten Des Stirmrandes und fünnen meift ganj in bie=

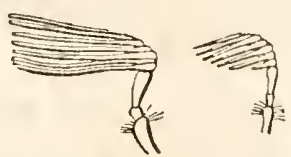

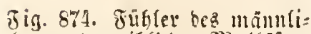
(b)en und neiblidyen $\mathfrak{D i a i f a f f e r s . ~}$

(Jelolontha vulgaris).

fer Grube geborgen werben; fie fint furz, geif= felfürmig; bie untern Glieber fnopfartig, die vorberen blatteörmig nebeneinander geftellt, to Dá bie fid) wie die Brätter eines $\mathfrak{B} u d e$ ö off nen unb fultȩ́en raffen mo eituen Saumm ober

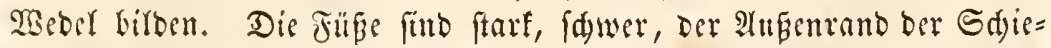
แen gezäbut; bie Tarfen ftets fümfgliebrig, die Enbfrallen ftarf. Beide (अeidededer unterfdeiben fid oft febr bebeutend im 2leuseren, inbem

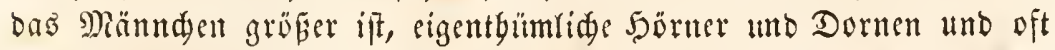
ungebeure Jiefer befigt, bie ben Tseibden abgeben.

Die Räfer reben yon Blättern, faulenden gyflanzenftoffen, S) iift unb andern Gxcrementen, baben einen fdurerfälligen Gang unb einen ungelenfen flug, bei bem fie laut fdnurren. Die Sarven find wal=

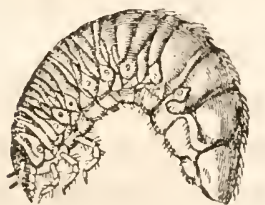

Jig. $875^{\circ}$ ?arre her Dififtafer: (Copris). zenförmig, weid), weiflid, mit facfërmigem $n=$ tergebogenem Enbtyeile, bartem gerbem bormi= gem Ropfe, der wie bei ben Raupen, wertifal ftegt, fedys Yaugen barten füben, aber obne Alt= gen. Der kefanute Engerling liefert bas befte Bito siner folden Rarbe. Sie leben megrere Gabre in fer Erbe von Mift, 2 Burzeln, \$flan= zenftrïnfen und verpuppent fid) bann in einem Durd) Sdleim jufam= mengeflebten Groballen.

Man unterid)eidet mebrere (bruppen in biefer zablreiden Familie.

Brumenfäfer, Cetonida, Sörper glatt, obne Zarfen, Bor= fprünge unb Sörnet, von oben flad, metallifa) glänjent; Ropf flein; 


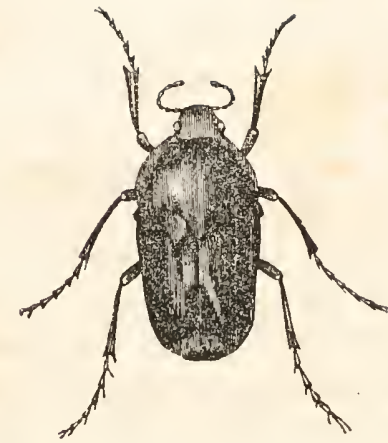

ชig. 876. (5) blotäfer. (Cetonia aurata.)

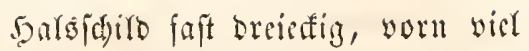
(d) mäler alo binten; Scitenitürfe ber Mitterformit wor Den Flïgerberfen won oben fidtbar; Fübler mit füderi= gen ober Dutenartig in cinander ge= f́teften Blättd)en; Rinnbacten unb Dberlipwe faft wöllig bäutig, bieg= fam; lluterfinnlabe pinfelattig; Soin= terende Des Rörwerg vou oben fidst= bar. Die গäfer auf Blumen, flie= gen germe; Dif Rarwen in Murm ober Stmeifentanfen, wo fie won ben Atmeifen gepflegt werben. Cetonia; Trichius; Goliathus.

Mif te äfer, Coprophagida. Sörper ftarf gewölbt, breit; Ropf unb Sargefdirlo meift mit Boriprïngen, Reiften uno börnern gejiert;

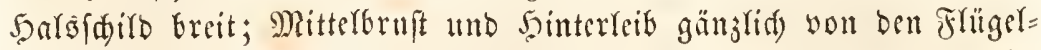
befen bebeft. Fïbler wie bei ben worigen; Rimubafen aufen bornig, iumen mit bäutigem Gaume. Säfer unb Sarven leben befonbers in

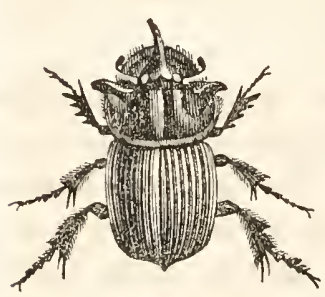

Fig. 877.

Mifftenfer (Copris imata.)

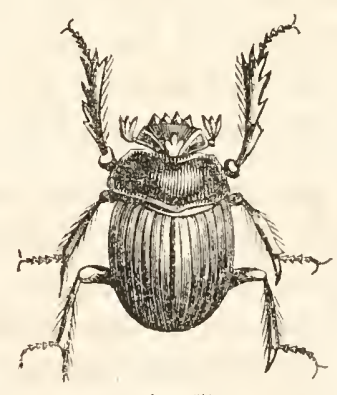

Tin $8 \% 8$.

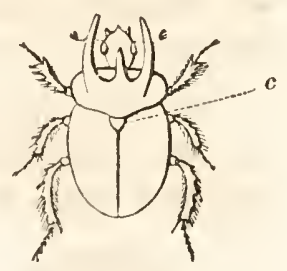

Tig. 8\%9. Sutffaben=

פiunienfäfer (Atenchus sacer.) täfer (Geotrupes strecorarius.) Sugflaben, unter welden fie tiefe, fenfred)te süder in bie Eroe bof = ren, fo wie in Miftganfen. Die Sacibden ballen alts feudytem Mifte eime Singer jufammen, in welde fie ein Gi regen und rollen bann bic Suget, rüfwuärtşgebend, fort, bio fie an geeigneter Etefle fie cingra= $\mathfrak{b} \mathfrak{c}$. Aphodius; Copris; Ateuchus sacel (ber beirige $\mathfrak{R}$ äfer ber alten Alegypter); Scarabacus (Geotrupes); Onthophagus.

Sornfäfer, Dynastida. Die gröften Räfer. Sopf und Sals=

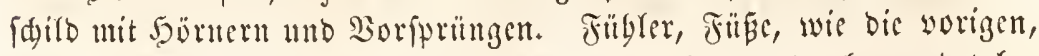
aber bie Simnbafen ganj bornig, Simnlaben furj unb abgermbet $\mathfrak{H}_{\mathrm{e}}=$ wimpert. Ilnterlipwe feglt meift; Borberrand bes meift ftadididen Ropfidiloes fewimpert. Earwen unb säfer in Mitm, Roge unb alten 


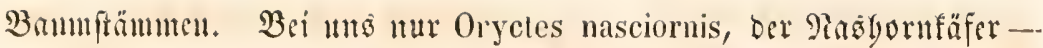
in fïbliden Gegenden viele Grathuigen: Dymastes (hercules), Atlas etc.

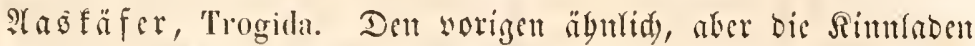
bornig uto bas Sioffidito unberwimert. Sopf unb Sarbldito obne

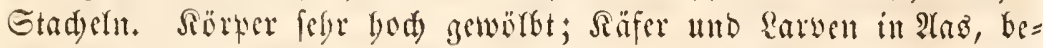
funders in fandigen Gezenten. Trox; Aegialia.

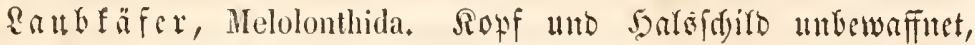
glatt. Sïrper gewölbt, eiförmig. Sinnbarten ftarf, bornig, biff, ge=

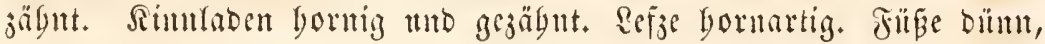
fd) wad. Dic Rafier leben von Blättern, zeigen fid) aber nur furze

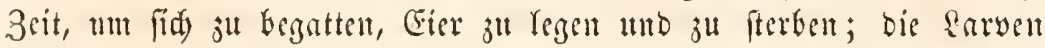

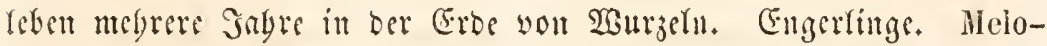
lontha (Mnifäfer); Amphimallum (Junifäfer); Anisoplia.

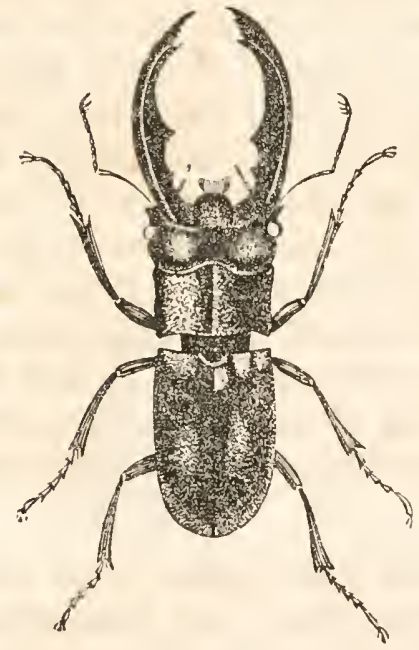

Fig. 880 .

Şirfdefäer, Lucanida. (5) rofic, ylatte, nach unten gewölote, ovale Räfer mit breitem Sal faldild, bas beutlid) vom ecibe abgefdreben ift; Fübler mit $3=$ bis 4 blättrigen subglicbern. Simbarfen febr grop, ftatf, beim Dlämuden oft geweib= artig vertängert; Ripwen, pinfelar= tig. Recfen befonders yjflatjenfäfte; Rarven in Malut und yoblen $\mathfrak{B a ̈ u =}$ men; fuppen fid) in Der (Froe in sillent Thonflope sit. Lucanus cervus (Jirfd) (d)röter); Platicerus ; Sinodendron.

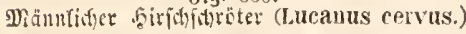

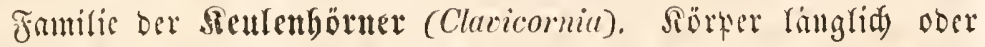
ciförmig; Sintertbeil oft nid)t ganj yon ben abgeitulaten Flïgeloefen bebeft. Sopf meift weit fleiner alo bas Salsid)ilo, bas Ginten mift Die Breite Der Flügeloefen bat. Die Fublgürner ferben nidyt, wie bei ber yorigen Fantilie, in einer brube, fondern frei am Rande bes̃ Sopfes jeigen einen unften aแb einfad)en Gsfiebern beftebenden Sticl und am Ente eine fnopfartige ober feutenfürmige Injdwellung, bie meijt aus $4-5$ cingelnen Gjfedern bes

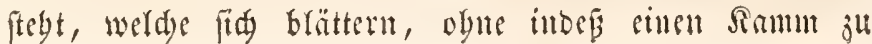




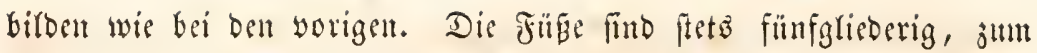
Raufen geidjift, bie Tarialglicber ganz.

Die Säfer nagen faulende yflanzen uno Tbtrriftoffe, fliegen gut unt raufen fegr fdinell. Einige liben im sisafer, baben aber feine

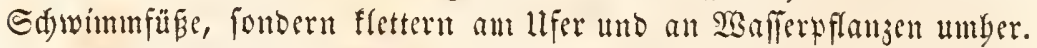
Die Rarven baben einen cylinbrifden wuruff̈rmigen, aber geraben

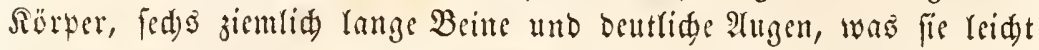
von ser vorigen famtilie unterfateibet. Sie leben in Mulm, befon= bers aber in tgierifden Stoffen, trofenen wie fautenden, fint fegr munter und agil uno oft ftarf belgart.

SBir theilen bie zablreidge famifie in megrere llnterfamilien:

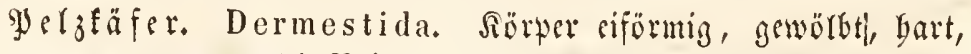

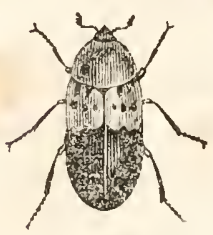

हีं ig. 882. de $\mathfrak{B}$ eine fömen augezogen werben, aber nidt volftändig, indem die Tarfarglieber frei blei=

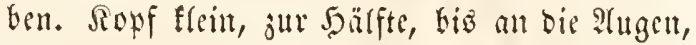
in bas Jalêf)ils singelentt; Fübler furj, Ent: feule unr oreigleberig, aber bas Enoglied oft fegr grof uno lang; Dberfinnlaben biff, fur gejäbut. Die Räfer leben befondere in $\mathfrak{y e l}_{j}=$ Epcffifer (Dermestes lardarius) awerf und troffenen Thieritoffen, in Mufeen uno joologifaen Sammlungen, jumsilen auf Blumen; Dis baarigen Rarben, an benfelben Drten, rid)ten groge Dermilftungen an, ba fie meift im Berborgemen arbeiten. Sie vertupen fid in ber cigenen Rarventant,

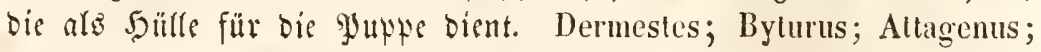
Anthrenus.

Bon biefer Fantilie fdeibet fith als fleine (3rmppe Durd) voll= fommen juridficblore Beine, breite Ilnterfdenfel uno Bermadjutug Der orei vorberen Esiberringe, die Gruppe der gुillenfäfer, B yrrhida, beren Rarven, Retensart 2c. ganj analog ber vorigen ifi. Die Siäfer, bic meift an lanbigen Drten Yeben, fugeln fid zulanmen und fteffen fid) toot. Byrrhus.

Ca to pida. Rörter längliq, mäpig gewölot; Sopf flein, unter

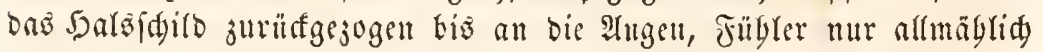
verbiat, nid)t fuopfförmig geendet; Salefditlo nad bem Tobe nad) vorn geneigt; Beine bünn, lang. Die Räfer Kaufen fegr fdnell, ftellen fid) beim $\mathfrak{B} e r u ̈ b r e n$ tobt. Choleva; Scydmaenus; Scaphidium; Colon; Catops; Agyrtes. 
Stubfäfer. Histerida. Söruer breit, flad, tad) bem Tobe

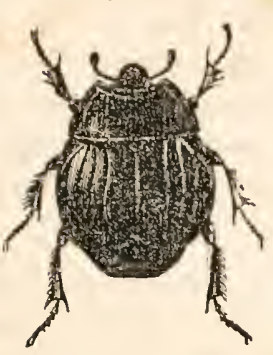

Jig. 883.

Anåtăfor (Hister cataverinus). wenig gefrïmmt, mgemein bat. Sopf flein,

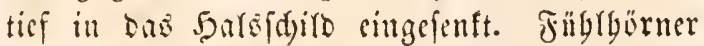
elfglicocrig, mit feftem Sinoyfi, ftarf gefrümont; Sinnlaben ftarf, gejäbnt; bic Sointerbüften ftarf \{eitlid) geitellt; Sorberbüften ber Mlitterlinie genäbert. Sütie ftarf bebornt, famerfällig.

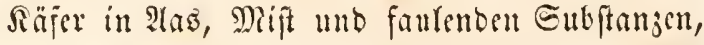
bie furjü̈ß̈igen nadten augenlofen \&arven eben= Dufelbft. Hister; Saprinus; Platysoma.

Reftëfer. Nitidulida. Sïrper flad, mit fdarfen Ränbern;

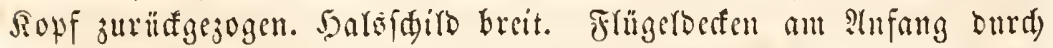
cin breiefiges Sdjilbden getrentut. Fübler gerabe, gefnopft, jwi id)en

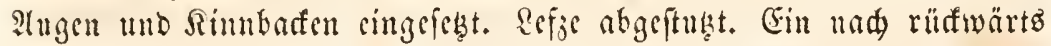

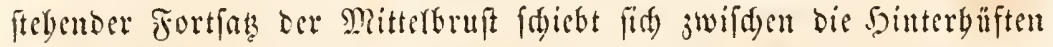

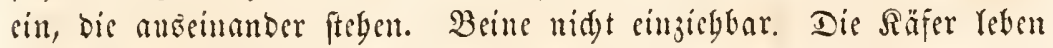

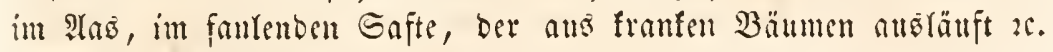
Nitidula; Peltis.

Stinffäfer. Silphida. Sïrper flad), 仯arfranbig, meif $\mathfrak{b} e=$

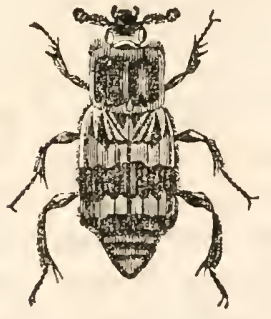

fig. 881. Gart; Flügeroeffen gewögnrid) binten abgeftukt, fo baf mebrere Ringe bes Sinterleibes fid tbar fint. Füblgörner feulenförmig liber ben Rinn= bafen eingefert. Gdjilbden swifden ben grü= gerbecten großj. Refje ausgefdnitten. Fortians ber Dittelbrujt nad) Ginten nur febr flein. Souften cillanoer genäbert. (jejtalt nad) bem Tobe febr gebürt. Dis fidnell unb gut lau= fenten und fliegenden Säfer ftinten fegr, geben beim Ergresfen frinfenden, flüfigen Sotb von Tobtengritiber (Nerrophonusves pillo).

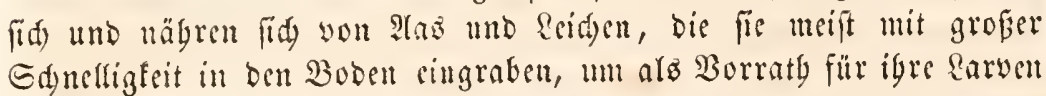

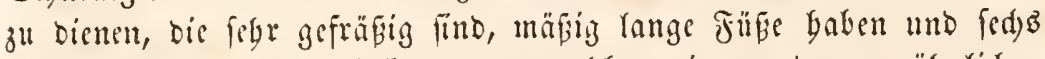
Iugen auf jeoer Geite befizen, von welden wer an ber gewöbnlidyen Etelle binter ber Sintenfung bes Füblers uno jwei unter bem fïbler nad) unten zerüaft fteben. Necrophorus; Silpha.

Jantilie ber 2 meifenfäfer (Clavigerida). Sebr fleite Räferden mit fdumalem Sopfe, obne Yugen, furzen Füblgörnern, bie nur aus fed)s Griedern befteben und beren letztes Gbleb befondero grofi, lang 
unb cylimbrifd ift. YJarpen flein, einfad, au ber Spize mit bopper=

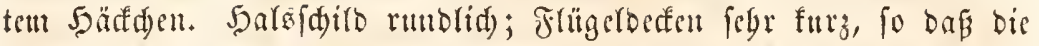

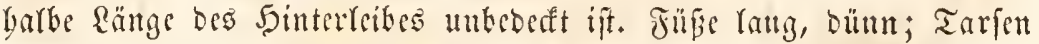
nux breiglieberig und bas Enbglicb tut mit einer Sitlle verfeben. Die Siäferwen liben utr in Itmeifenbanfen unb werben yon biefen,

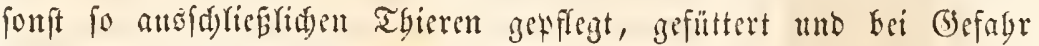
ferbit fortgeid)lewpt. Claviger.

Familie ber Taffäfer (Pselaphida), Sërwer int Ganjen birn= förmig; Siopf länglid), frei, Augen frarf vorragent; fübler lang, meift bartig, an Enbe gefnopft ober feurenförmin, elfglieberig. Yarpen

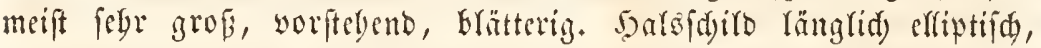
Band) runblid), you ben quergeftukten Frügelbeffen mur balb bebedit. Fübe lang, fdwar); Taren nur breiglieberig, Fnoglico mit jwei STauen. Silcine Säferd)en träger Natur, bie meift Tags über ftill im

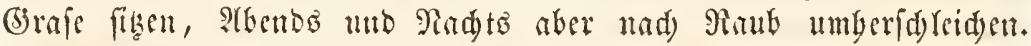
Pselaphus; Bryaxis; Bythinus; Tyrus.

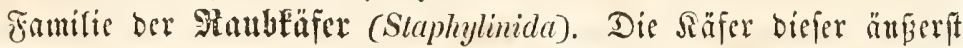

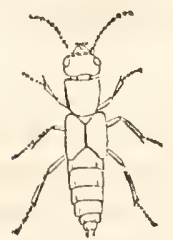

Jig. 83.5.

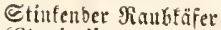
(Staphylinus olens). zableciden Familie baben eitlen langen, meift fpinder= ober wurmfönmigen Sörper und fteto fegr rubimen= tî̉re, meift quer gef̈ulgte glügeldeden, bie ben gornigen, feften Siuterleib nur theilweife beffen, aber die frï= gel, bie zuweilen feblen, ganz umidlefenen. Die Fïbler find jebn ober uteift elfgleberig, entj, fabenförmig ober fdwad) gerägt, nut ferten gefnowt; bie Riefer bebeutend grofi, bactig, fpits, meift ungezangnt; bic

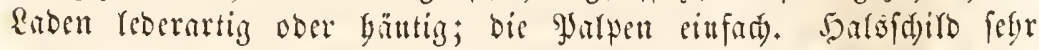

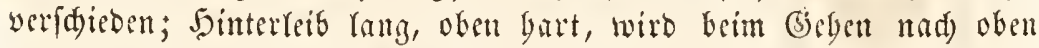
gefrüumt und zeigt am J̧interenbe jwei blafenförmige $\mathfrak{B a r j e n , ~ b i e ~}$ wilffürlid) Gerborgeftedt werben. Die Jüpe fint lang, friftig, balo mit Dornen bewaffet, bald webrlog und bie 3abl ibrer Taralglies Der auferorbentlid) wechiclub, fo bafi man affe Ratreffe'fden llnter= orbmungen, Ylentameren, Seteromeren, Tetrameren und Irimeren in biefer Familie bertreten findet. Die Rarwen feben ben wofffommenen

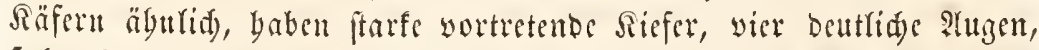
fed) lange Fübe mit einfad)en Slauen mo sinen platten bornigen Siörwer. Säfer mo Raryen find äuberft rebrafte fübne Ränber, bie bejoubers andere Jujeften jagen und biejen im shift, unter Baum= rimben 2 . nadyfteflen. Die meiften baben einen unangenebuen (Bernd). Staphylinus; Quedius; Oxyporus; Omalius; Tachinus; Tachyporus; Lomechusa; Stenus; Bledius; Oxytelus. 


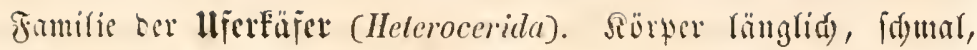

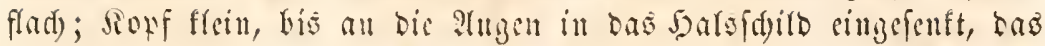

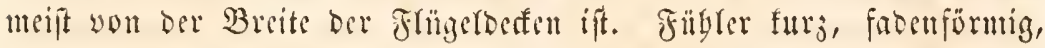

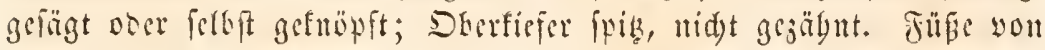

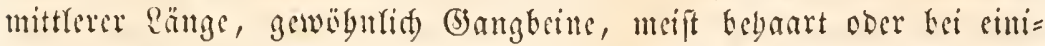
gen mit Etadectn befent. Die Tarjen buben bei cinigent wier, bei an=

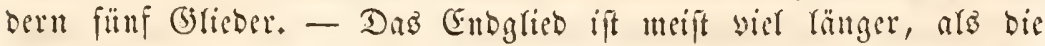
yorberen uno mit zwei ftarfen grofien Sirauen bewaffinet. Dis fdyell=

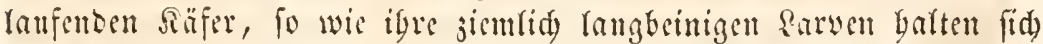

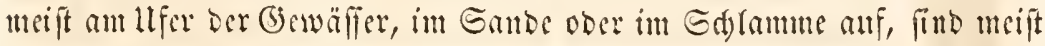

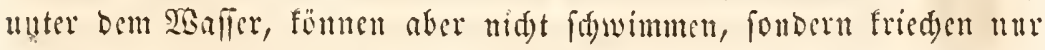
am B̧obemund an 2 Safferpflanjen muber. Hetcrocerus; Parnus; Elmis; Georyssus.

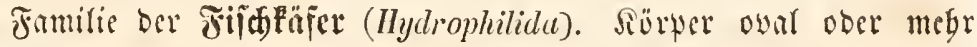

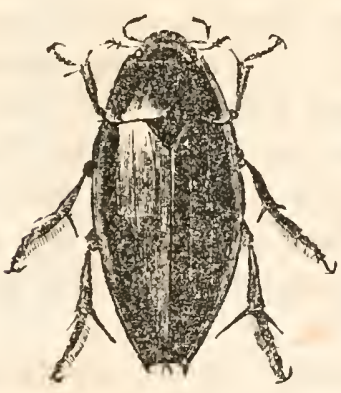

Biin. 836.

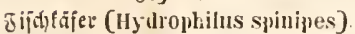

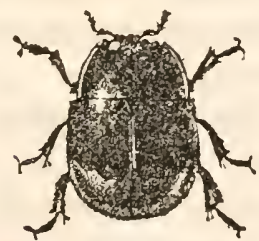

Jig. 887.

Sphatidium scarabeoides.

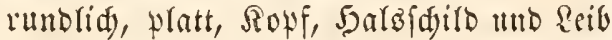
eng ancinamber geidglofien, meift grob. Fübler fur ${ }_{3}$, feulenförmig, omddblättert, mit langem Stierglicbe, sintigermagen benen Der Brätterbörtuer äbutlidy. Bordertafter meift fo lang ober felfolt länger als bie Füblgörner, zmrïfféfd)lagen. Beine ver= fdieben geftaltet, frets aber mit fünf $\mathfrak{z}$ ar: fargliebern. Bei bert auf bem Ranbe, be= fonders im Mifte lebenden Gattungen (Sphacridium; Cyclonotum) finto alle Sunfe (3angfüвe und die Sdienen mit Dornen bewaffinet; bei ben in $\mathfrak{B a}$ afer fdimment = ben bagegen (Hydrophilus; Hydrochus; Laccobius) fint bie beiben garave ber Şin= terfüpe lang alıg gejogen, flatt und burd

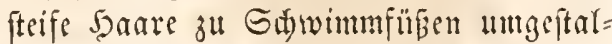
tet, wälgrend bie Borberfüpe Gangteine

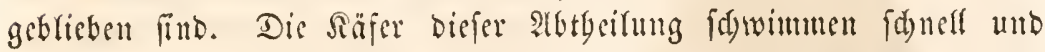
gut, fliegen fabuerfällig mit Bicjumfe am Itbend und fommen oft an bie Dberflädse, wo fie \&uft unter bie Frä̈gelderfent nchmen, ju weldsem

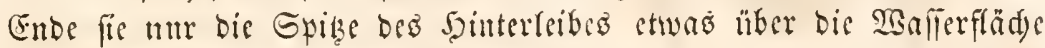

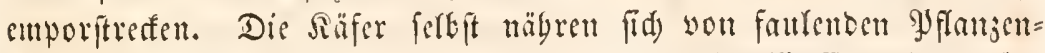
ftoffen; Die Sarven bagegen, welde chenfalts im sisaffer Yeben, find 
arge Räuber, Die mit bem platten twurmförmigen uad) binten juge=

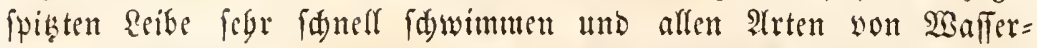
tbieren, ferbit jungen Fifien, sifrig nadftellet. Sgre ftarfen Siefer find fürzer atz die Syarpen; die dïmen Füge yon mittlerer \&änge. Die Rarven werpuppen fids in ber Grbe unb bilden eite ovale gluppe, an beren Sinterente man nod) bie beiben Ittgemtübren fiebt, Durd)

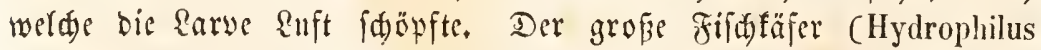
piceus) ift ber grïgte $\mathfrak{B a f f e r f a ̈ f e r ~} n$ mferer Gegenden.

Jamilie ber Taumelfäfer (Gyrinida). Räfer flein, eiförmig, platt,

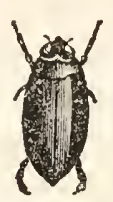
wie alle Săferfäfer. Sopf flein, big an bie $\mathfrak{A}$ ugen in

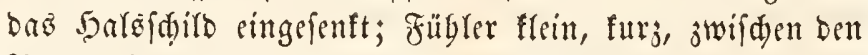

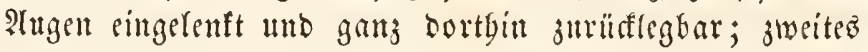
(3) fico berferben mit sinem tottenförmigen Fortfabe verfebst, in weldem bas wurffïrmige, geringelte Fube Des Füblers รig. 883. Eaumeffafer fteft; bie Plugen borijontal balbirt, fo bafi jeberfeits jwei

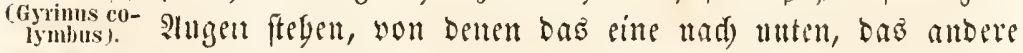
nad) oben gerid)tet ift; Sorterfübe gewöbntidge (5) angfübe, Dünn, lang; Sinterfübe febr furz, Gafenartig getrümunt, flatt; Tarjuz im Banjen oreiectig, exftes Grleo febr gros, bie übrigen fegr fleit, mit fteifen

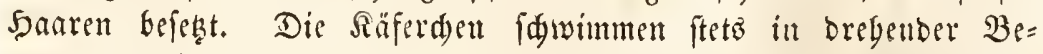
wegmitg allf fer Dberflädye ftebenoer (Jiewäfer. Sarven im Saffer, lang, flad); atbmen burd) feitlide Siemenbuifdael unb yaben, wie alfe folgenben, ben eigentlidgen fleifdyfreffern angebärige Siäferlarwen, zwei Jiauen an ben gïßrn. Gyrinus; Orcetochilus.

Finnilie Der Rafjerfäfer (Hydrocantharida). Sïrwer abgewlattet,

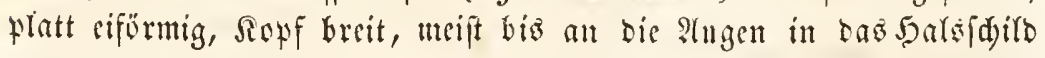

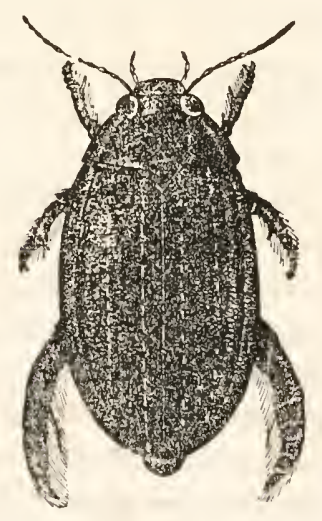

Jig. 889. Dytiscus latus. siltgefentt. Fübler borjtenfürmig,

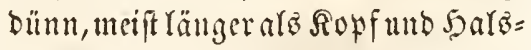
fdilo zulammengenommen. Silnn= raben bünn, (d)arf, imen gewimpert, aufen mit jwei glaten bejest, wou benen die än Berett vierglieberig, die interen zmeiglieberig find, fo oas mit ben Simmladen = Taffert im (5)anjen fedta gralpen vorbanben fint. Borberfüpe Gangbeine; bei den Mänud)en find die drei erften Tarfarglieber in sine breite Gang= id)eibe erweitert, womit fie fid felyr feft aubeften tïnnen. Şinterfïbe 
lang, prattgebrüft, mit Gdywmmborften befest. Die Siafer Yeben alfe

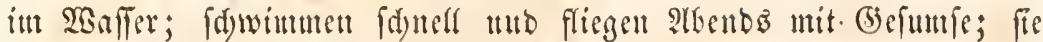
find febr rätberifd) und fallen alle :Trten fdwäd)erer 2 Baffertbiere ath. Die Rarven find rang, fomal, fratt, mit beutrid) abgefergtem, rutteett Sopfe. Die ungemein grofen Safenfiefer, die weit bervorfeben, find an ber Gpike Durdjbobrt tho Sanäle fübren aแts ibnen in bie Speiferöbre. Der Mutb feglt biefen Rarven gattz; fie fd)lagen bie Safen in bet Reib rebenber Tbiere und fangen bie Säfte ourd) bie Siefer eith. Sie baben lange, gewimperte Sdywinmfübe, zwei furze

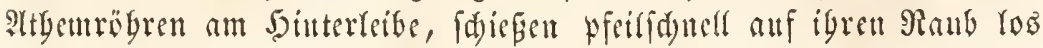
unb gelten ferfit in Fifdeted en für verberblidy. Dytiscus; Colymbetes; Pelobius; Noterus; Hyphydrus; Haliplus; Iydroporus.

Familie Der Raufeäfer (Carabida). Sïrper Yänglid), theift ftarf

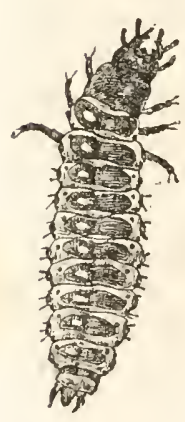

8ig. 890 .

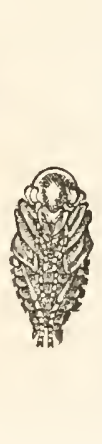

รig. 891.

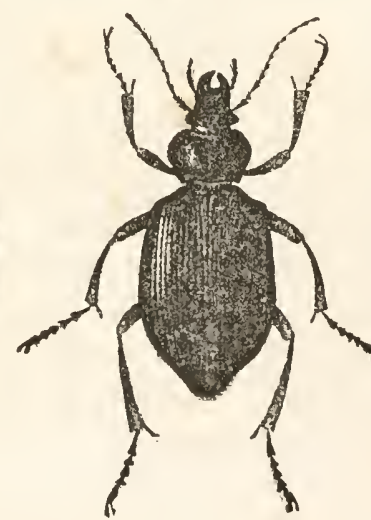

8ig. 892.

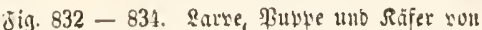
Calosoma sycophanta.

gewölot, bart. Siopf fleit, fdmal, meift weit

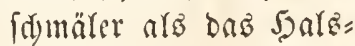
fdild. Ittgen worite Yento. Fübler von mitt= Yerer Ränge, borften= oder fabenförmig. Rittubarfen (d)arf, ganjrandig, ftart gefrümmt, meift jiemlid) woritebent. Sintulabent ganj bafig mit boppel= ten Tajtern, wie in ber worigen Familic. Finfe lang, bünn, ftetỏ mit fünt Tarfalgriebern, bie meift bei ben Meännd)en verbreitert finto. Flügeldeden, den Şinter= reib meift ganz bebecfend. Die Säfer biefer jablreidjiten muter allen Säferfantlien find alle gute \&ätfer, bie meiften aud) vortrefflide frlie= ger. Sie fdweifen, die Cinen mebr bei $\mathfrak{x a g}$, bie 2(nbern mebr mäd)t=

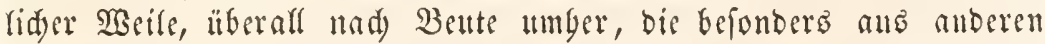
Sufeften beftebt. Die uneiften baben einen unattgettebmen (Bertd);

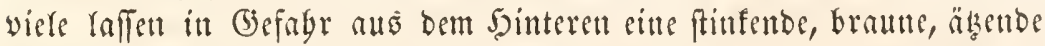
Friifigfeit. Die Rarven futb meift etwas abgeplattet, loortig, mit ftarfem, oben fladem Sopfe, fed)s langen Beinen und fed) é einfad)en Tugen anf jeber Seite, die auf eimer gewölbten Beule fieben; fie baben ebenfalls ftart vorfpringende, fid)elförmige, fpike నicfer unb leben wom 
Raube, meift it verftedten 2 ufentbaltoorten. Crinige, wie bie Carlo= foma= Rarven, fagen felbft igre ans Raupen beftebende Beute auf $B a ̈ n=$ men. Man Gat, um die ungemein grofie Anjabl ber Gattungen über= \{dauen zu fönnen, mebrete llutergrmppen aufgejtellt.

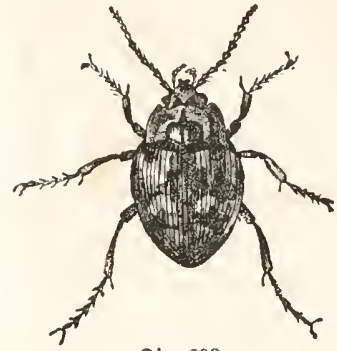

Fig. 893.

0mophron marginatum.

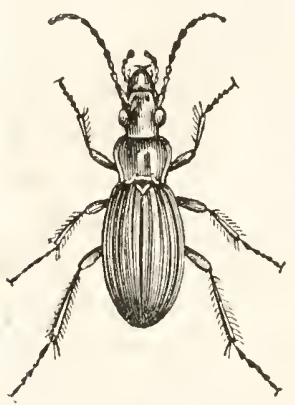

ชig. 894.

(B) blbener \&auffäfar (Carabus auratus).

Subulip alpa. Enoglied Det Jaauptpar= pen fpis, bünn, furz, bas worbergebente lang, to bas bie Sarpen prriemenfürmig fint. Bor= berfüве anşgefdnitten. Sebet meift am 11 fer ber Gervafffer. Bembidium; Omophron; Tachypus.

Carabida. Borberfdienen mit zivei Dor= nen, ofue 2Hêfdnitt. Refze sweilappig ober gefurdt. Sërter gebrungen; Atugen vorftebent; Siefer ftarf; Jrügeloeden ganj. Эुalpen ziem= (id) grof; Fnoglied ftumpf, gröfer uno breiter als das vorbergebende. Sprizen einen febr äkenben Saft aus bem âfter gegen igre $\mathfrak{B e r}=$ forger; ftellen felbit anderen Jnfeften sifrig nad). Die Rarven einiger (Calosoma) in Rat = penteftert. Carabus; Calosoma; Cychrus; Nebria ; Procrustes.

Sämmtlid) folgende Gruppen zeigen am Junenrande ber Bor beridjenen einen tiefen cinidutt.

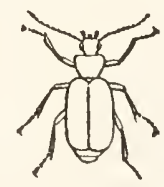

Tig. 895. Lebia.

Brachinida. Flügeloefen geftutht, fo dak die Spikge bes Şinterleibes you oben fidyt= bar ift. Tarfen ber Männden faum verbrei= tert. Der Bombarbierfäfer, bet bei bet Ber= forguny frinem Feinbe sinen äkenten, blauen Dunft mit börbarem Sinalle aus bem iffet flitgegenfuft, gebört bierber. (Brachinus crepitans). Attjerbem Lepia; Dromius; Cymindis; Odacantha.

L i c in ida. Flügelbefen tarf abgerundet; Sargefdild

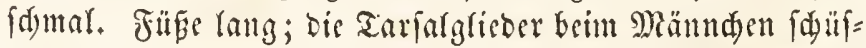

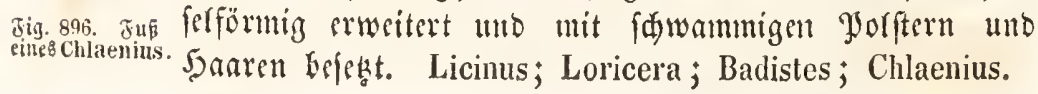

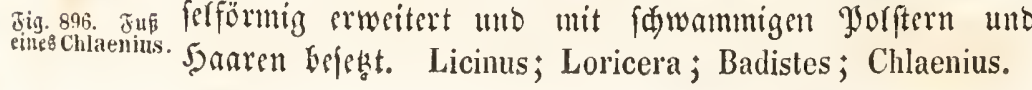




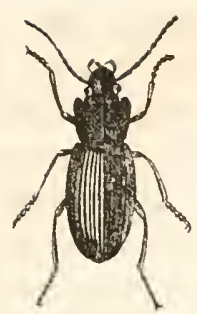

ฐig. 897. Hlarpale.

Il a r palida. Flügeldeffen fpitzig; Sor= berfdjienen eingefdyitten, aber obne 3ägne.

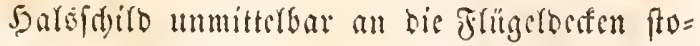
5ent. Die Tarfarglieter futo balo medr, bald weniger erweitert unb unten mit Bürften yer= felen. Harpale; Mormolyce; Feronia; Amara; Pterosticlus; Cephalotes; Treclus.

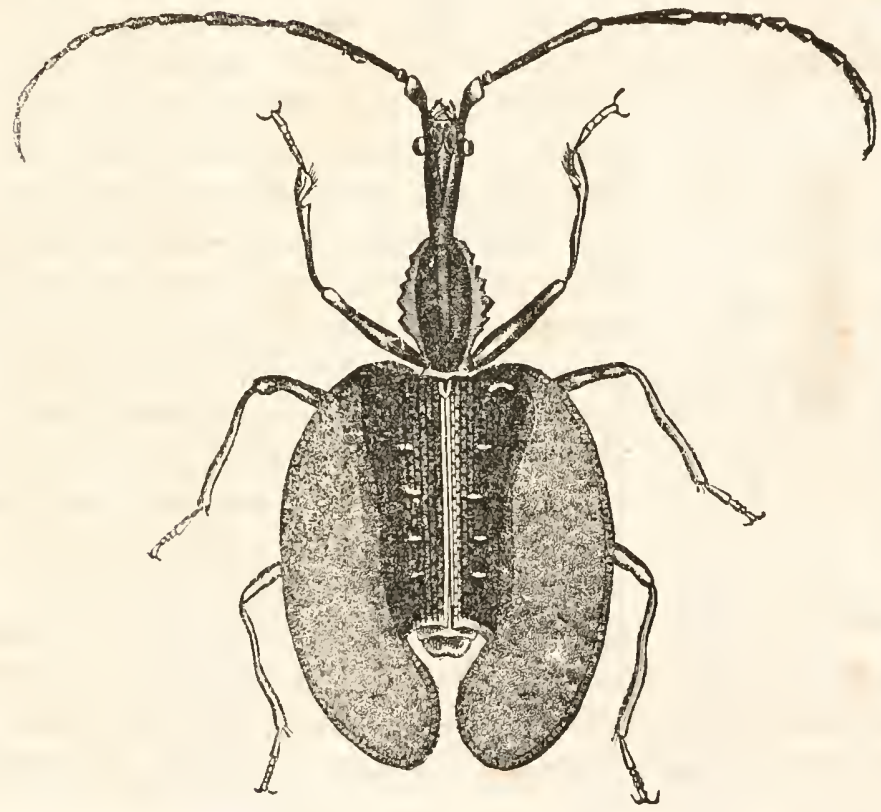

Ji⿰. 898. Mormolyce phyllodes.

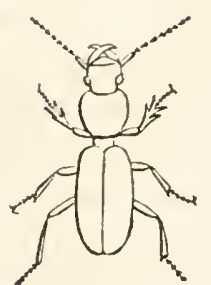

รig. 899. Scarites.

Scaritida, Borberfaienen febr ftarl att = gefđnitten, in eincn ftarfen Dorn aแegebeno,

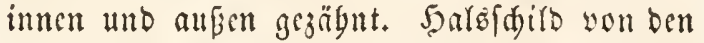
Flügelbefen abgefelst; Frügelderfen abgerumbet. Tarfalglieber oes Mämnd)ens nid)t erwittert. Scarites; Clivina; Dyschirius.

Familie ber Sandeäfer (Cicindelida). Rörper länglid). Sopf breiter ałs bas biume, meift verrängerte 5albfd)itb. Fübler faben= 


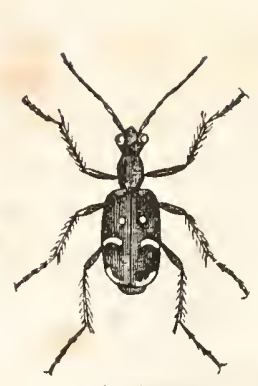

Fig. $90 \%$

förmig, won mittlerer \&änge, yor ben $\mathfrak{a}$ ugen eingerentt. Diefe fegr grof́, vorjtebend. Riefer woriftegend, grof, jtarf, fegr idara, innen meift megrfad) gesälnt. Rinnlaben ge= bogen, an ber Spitze mit einem be=

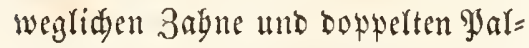
pen. Sippentafter ftarf bebanrt. Beine Yang, fietô fünfglieberig, ogne Cieindela campestris. Sinntabe e einer Eicintele. Zägne DDer Einfldntte an Den

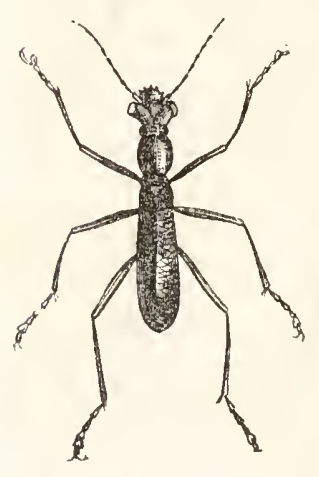

3ig. 902.

Tricondylus apterus. Edjenen und ogne Erweiterung ber Tarfal= glieber. Ulnermiblide $\Re$ äuber, bie meift auf trofenem, fantigem Boben jagen unt vicl flie= gen. Die Rarwen Yeben in Rödern im Sande, Yaben einen biffen, Greiten $\mathfrak{S}$ off mit vorftelyent= ben Itugen auf jeber Seite, fidelfürmig getoo= gene, 价arfe Riefer, fed)z lange Beinte mit zwei Srallen unt zeidnent fid baburd) ats, bas

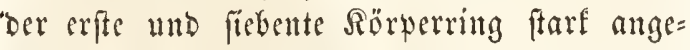

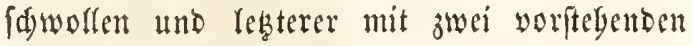
5ornlyafen verfegen ift, was fie beim $\mathfrak{A}$ tuf = unt

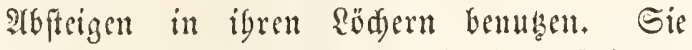

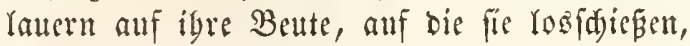

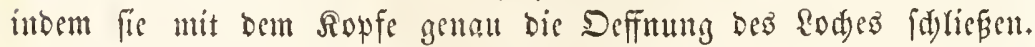

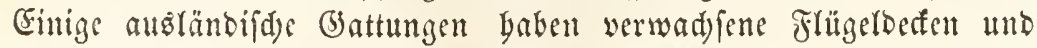
ermangern ber Jłtügel. Cicindela; Collyris; Manticora; Tricondylus.

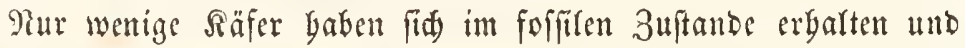
aud) Diefe meif nur in fatwer erfenntaren Brudjtülen. Sie treten zuerit in Sura all und jwar nur mit boljbogrenden Battungen, bie

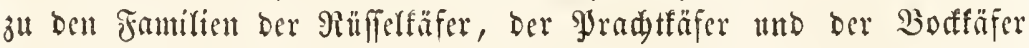

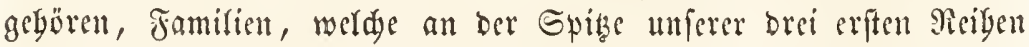
fteyen. Die \$radjtfäfer bominiren in allen tertiären (Epod)en weit über bie Sdynellfäfer, bie ignen am nädfiten feelen unt in ber $\mathfrak{T} e r=$ tiärzeit find fie fogar bie zaglreidje Familie unter ben $\Re a ̈ f e r n$ über= Gaupt. Sn Der Sireibe treten ju ben erwälynten Familien bes Jura Dic Fifd)fäfer (5y)bropgitioen), bie aud in ber Tertiärzet weit über bic anderen SBafferfäfer, bie 5ybrocantlaren, Domintren, wäbrend in

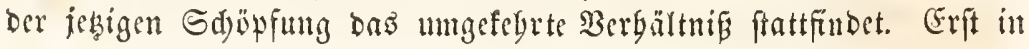
Der Tertiärzeit treten Brättergörner (Lamellicornia), Reulengürner 
(Clavicornia) und Rauffäfer (Carabida) auf, to bap alfo erft in ber unz junädjf légenden łeriode bie wabren Fleifdfreffer unter ben

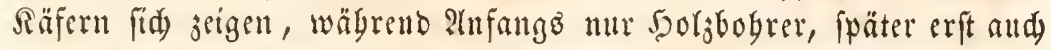
Brätterfereffer fịd zeigen.

\section{Dronutig ber santfiügler (Iymenoptera).}

Die Snfeften, welde biejer Srbnung angegören, Yaffen alfe beuts

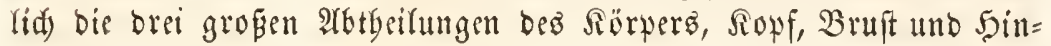
terleib, und meift ferbit in ber ârt getrennt wagrnegmen, ba biefe Stüre burd Gtiele miteinander verbunben find. Der Sopf ift meift viel breiter, als lang, unt fo geftellt, da bie Ditubwerfzeuge fent= red)t nad unten fadaun; bie Frübler find von mittlerer Ränge, wogl niemals länger, als ber Rörper, meift boriftenförmig ober gefniet, feften feulenfërmig unb nutr bei wenigen Garttungen gefäntunt ober ge=

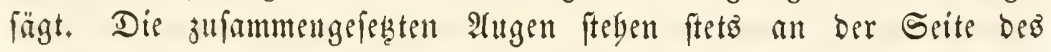

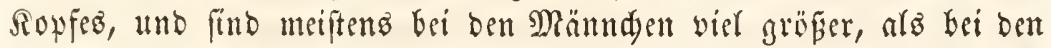

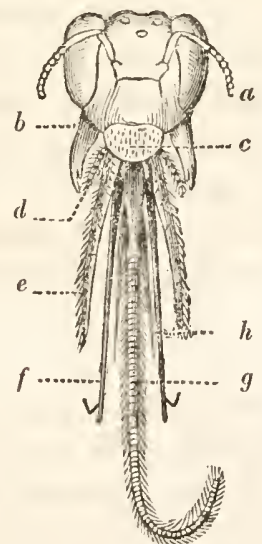

8ig. 903

Ropf einer sielte (Aththophora) son worn scieben,

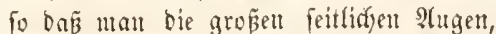
Die orei ReFenangen, bie Fübler und Mlunt= werfyenge in ifyer naturlidyen sage fiebt. a Fingler. b Riefer. e Sberlippe. d Die fur: jen Rimulabentaftet. e Die berfängerten $Q a=$ bett. f Die fritliffen verlängerten sappen Der lluterlippe. $g$ Der mittlete Sappen (3unge) zum Rüpel numgeitaltet. $\mathrm{h}$ Die fefor bertăngerten Eippentaper.

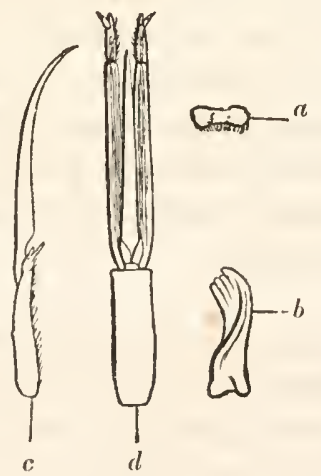

Tin. 904.

Die Minomerfieuge ciner Jonigbiene (Apis) aแzeinanbergelegt.

a Die Stertippe. b Der gefrummte แn gezähnelte Ricfer. c Dielange, Dintute, fübelförmige Rimnlace mit tem fleinent Tafter in Gelente. d Die unterlippe mit ben feitligou Rappen uno ber mittle= rent 3nuge. 


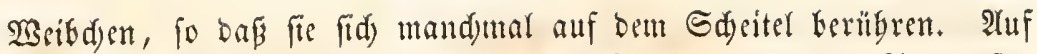

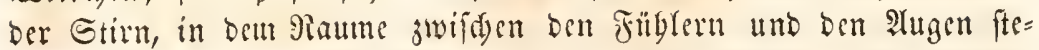
Gen brei fleine fuglige Rebenangen, weld)e nur äußerft ferten bei un= geflügeten parafitifasen Gattungen feglen. Die $\mathfrak{R u}$ ub werf bejtelgen bei allen bautflüglern aus siner ziemlidy fleinen Sbertippe

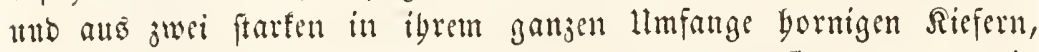

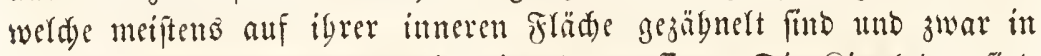

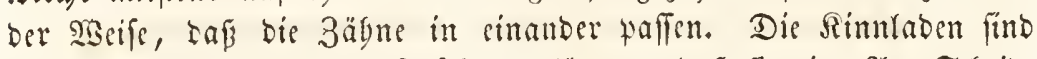

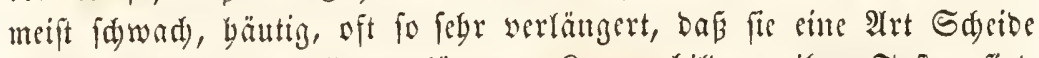

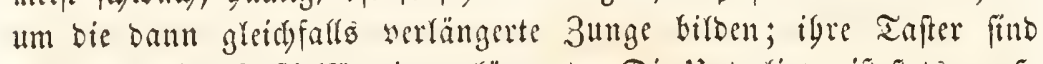

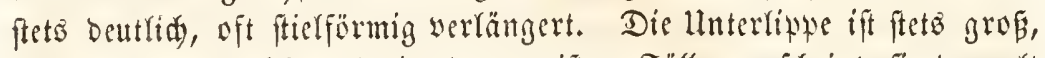
igre Tafter bentfid ulto in ben meiften fällen erfdseint fie boppelt gefpaltent und igr mittlerer Theil, bie 3unge, megr ober minder ver=

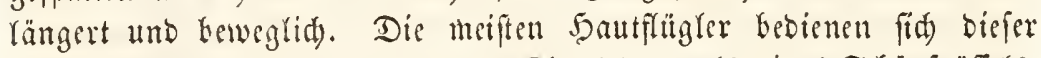

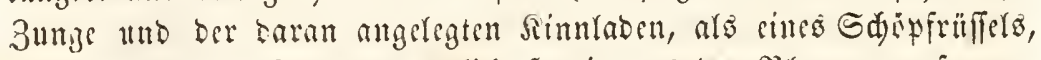

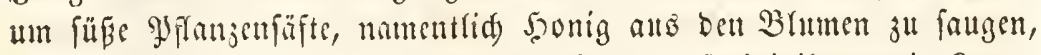

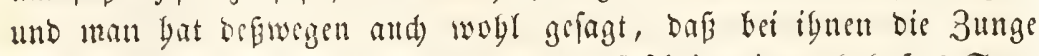

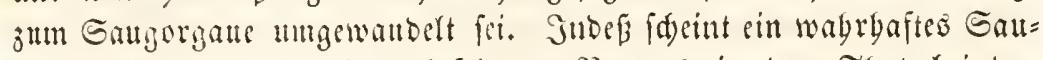
gen burdi Serîtelfen eines luffteeren Saumes in ber That bei ben

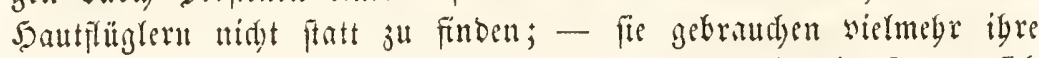

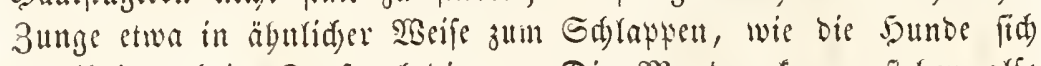
Der igrigen beim Sanfen bebienen. Die Munbwerf jeuge fteben alfo

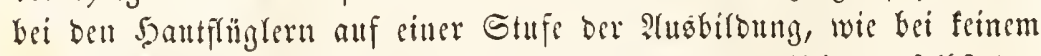
anderen Snfafte, itboem ignen eittes Theiles das Berfecinern ferbft ber bärteften Eubftanjen Durd igre mäd)tigen Siefer müglidy gemad) wirb,

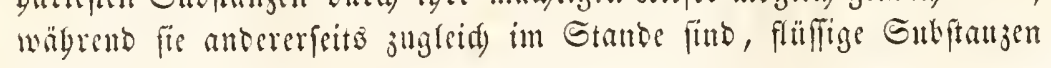
aufjuntelmen.

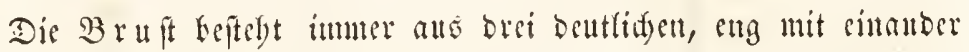

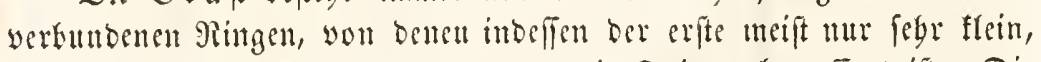

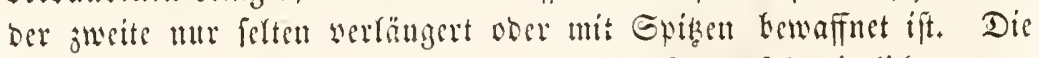

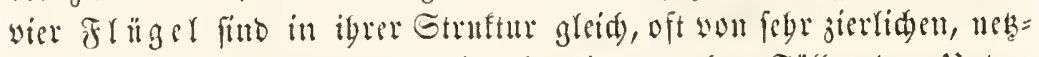
fürmigen 2 (bern burdjoggen, bie aber in mand)en Fällen ben llnter= flïgefn gäuzlid, uno ben Sovererflügeln bis auf einige Nutimente

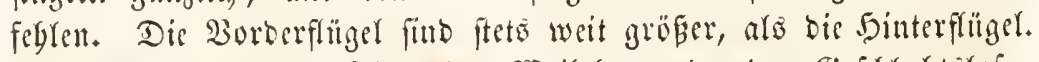

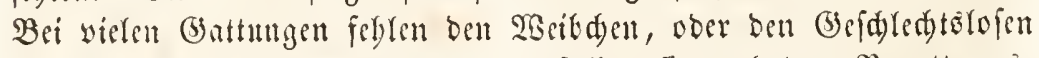

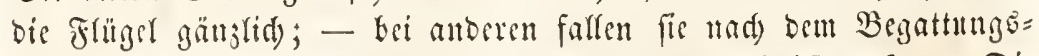
gefduäfte ab, ober werben fogar woul ben Thieren ferbft entfernt. Die

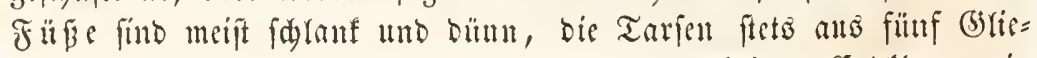

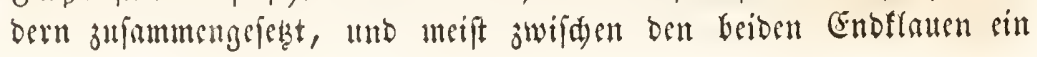


fleiner mittleter Jubballen wabrnebmbar. Der binterleib ift ge=

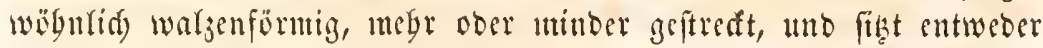
mit feiner ganjen Fläd)e, ober nut mit sinem bïnneren Gtiele, ber juweilen fegr verlängert ift, an beur binteren Ende oer Bruft; bei manden (Battungen ift logar biefe cinlettungèftelle weit obeu auf ben

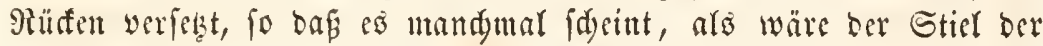
Mitterforuft eingerflanst.

Die $\mathfrak{B}$ eibden fämmtlider Jantflügler find an bem binteren Fube bes Reibes mit eitlem eigentbümliden Apparate verieben, welder je nad) bejonderen Mlobififationen feiner Struftur baro als Eegefäze (terebra), bald als Stader (aculeus) bejeidnet wirb, illoeffen ftetỏ

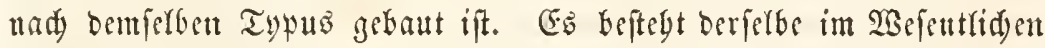
aus sinem mittleren, bei ben Regerägen meift geraben anto jientid ge= räumigen, bei ben Stadeln fäbelförmig getrïmmten Salbfanale, ber utit bein Ento bes Gifeiters in Berbintung ftebt, uno in beffen Pinne

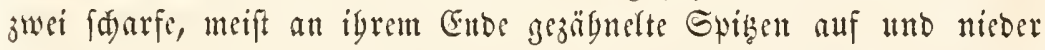
bewegt werben fönnen. Mit diefem Stilett fteben werfdeiedene Sorn= fitiffe itt Berbiutsung, weld) fattelartig bas (5nbe bez Maftbarms und

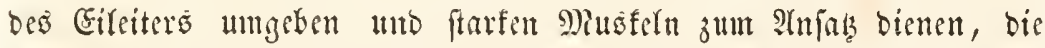

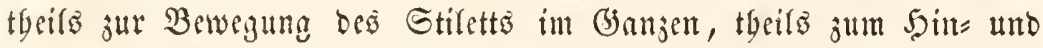
Serjieben ber intern Boriten beftimmt fino. Sei ben eigentliden

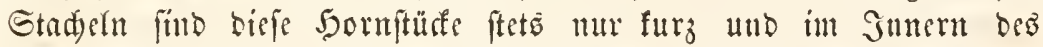
Seibes verborgen; - bei ben Segerübren aber fenden fie meiftent Fort= fäłs: nad) Ginten, die sime jweiflappige Gdeibe un bas Gtilett biroen.

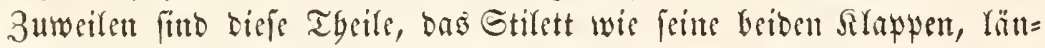
ger als oer Sïrper, oft aber fönnen fie gänzlid zuritfgejogen wer= Den und treten nur banu beryor, wett bas Thier verwutben, ober begufs oes ?(blegens feiner (Fiet ein Sod) bohren will. Die cigentlid

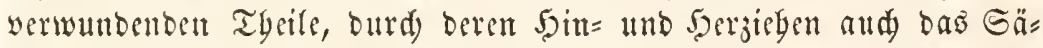
get oder Bobren bewerfitefligt wirb, fint bie beiben interen Stadel: borften, wäbreno bie Salbrintte bes Gtifettō, fo wie bie äuberen Silap= pen, unr ju firation bes ganzen spparates bient.

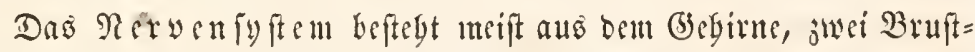
fnoten uno fünf bis feds Baudnfnoten, beren beibe relzteren oft mit= cinander veridumolzen fitto. Der Berbau fegr eitfad); - ber lange Gdylutb jeigt meiftens eine binnmandige Crweiterung, bie fid zuweilen zu cinem förmlidyen Eangmagen $a \mathfrak{b}=$ ddnürt, ber mittelft sines furjen Stieles in ben Sdjlund einmünoet; 
Magen und Darm fitto bei benjenigen Sautflüglern, welde lange leben, yielfad) gervunden, bei ben anderen faft gerabe; die Sarngefäpe find febr zablreid) und meiftens vielfad) gewunden, die Speiderorüfen meift ziem= (id) veräfeft, traubenfürmig und oft gänzlid in bem sopfe verborgen. Die Ruftröluen vereiniget fï) in zwei feitfiden Sauptitämmen, aนt wrlden bis Aejte an bie Sïrperorgane ausgeben, zeidnen fid aber burd vielfade blafige $\mathfrak{A n f d w e l l u n g e n ~ a u s , ~ b i e ~ b e f o n d e r s ~ o f t ~ i n ~}$ bem Sinterleibe eine ungemeine Gröge erreiden. Die Zabl ber (Fier röbren wedyfelt yout eitter einzigen bis zu bunbert tno megr auf einer Geite, und ftets find biefe Eierröbren mebrfammerig, fo baf mande 2 Beibden sine ungemeine Fruditbarfeit entwideln fönnen. Die

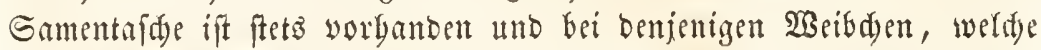

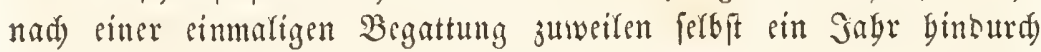
befrudtete Gier legen, ziemlid großj. Die Gamentbierden erbalten fing lange 3eit in Der Gamentaid) unveränbert ant Reben. Durd Dieje Eimridtung wiro ber Fortbeftand uno bie Ernenerung ber jägr= liden Gefellidaften, welde bei vielen 5autfüglern vorfommen, eittjig

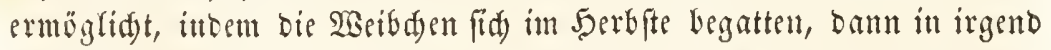
eituem Sdlupfwinfel hberwintern, uno bennod burd bie in igrer $S_{a}=$ mentafde aufgefpeiderte Samemma fe fägig find, im Beginn bes früb= jabres befrndtete Gier und bamit ben Brund einer neuen Gefellidaft

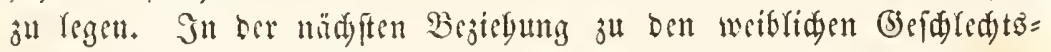

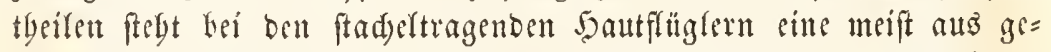
wuttocnen Ed) (äud)en bejtegende Drüle, weld)e waflerfrete Itmetfenfäure abjondert, bie fid in einer eigenen (b) iftbrafe fammelt, unb burd)

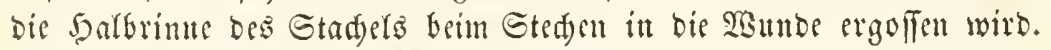

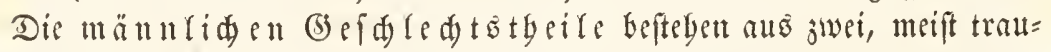

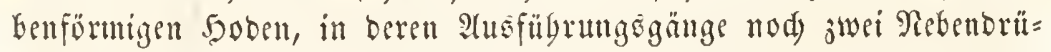

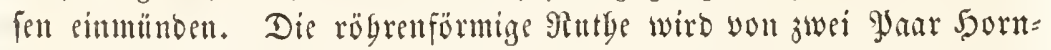
flappen, bie ten Sdyeiden Der Regerügre analog find, cingeldloffen. (biftoritfe und Stadel feblen aflen mäunlidyen Sautflüglern Durdaus.

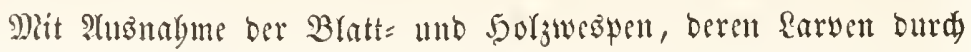

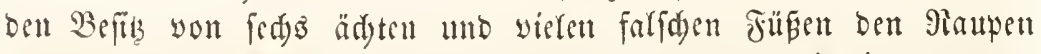
abnfid) feben, baben alfe Sautfügler fublofe Rarwen mit einem wurm= fürmigen Rörper unt bornigem ober felbft weidem Sopfe, an Deffen Ende meijt jwei ftarfe, gefrümmte siefer und furge Riunlaben mit Tajtern berworifelgen. Die Sarwen puppen fid alle nad) furzer 3ait igres Rebens eitn und fpimnen fid) zul biefem Enbe eine gewöbntid un= regelmäsige Soülle yon Geidenfaden, Da fie alle fublos fimb, fo for= 
gen bie Mütter für bas Emporfommen ber bifflofen 2 bürmden ent= weber burd Berwoviantirung igres Reftes, wonad) fie bas (Fi feinem worgefdriebenen Entwifelungägnuge überlaffen, ober fie füttern aud bie Sarven täglid) mit Rabrung, bie fte fïr bie Rad)fommenfdaft fammeln. Gerwöbulid werben bie garben ber in Geferfidaft lebenden Sautfligler gefittert, wägrent bie Cinfanen igre Sarven ein für alle Dar mit Mabrung verieben. Der eingetragene gyroviant beftebt theilo aแts Sonig unb Blumentaub, theilb aus Yebenben, burd) einen Stid) gelïbuten Infeftett. WBir werben weiter unten bie mertwitroigen Er: (d)einungen näber in bas शtuge faffen, welde bei biefer Sorge für die Jungen beobadytet murben.

Die Gefellidyaften, Deren wir fo eben erwäbnten, befteben wefent= Yid) nur ju bem 3werfe ber gemeinfd)aftliden Alufergiebung ber Jun= gen. Jgre Cintidungen, bie man oft mit ben fiatliden Cinrid)= tungen ber Meniden vergliden bat, futt verfdjicbener art. Die jäbrliden beferridaften werben in unerem sitma von ben eigentlidyen 2 seopen unb ben Summeln gefildet unb jebes: mal im Beginne bes Frübiabres neu von einem einjigen im Serbfte

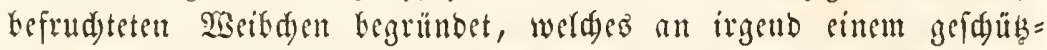
ten Drte äferwintert bat. Dieje Gejellidaften bejteben ftetz nur aแz Männd)en und Weibden, bie aber merfwärbiger Weife jwei Maçen bitben, inbem inan fteto fleinere und gröpere Jnbivibuen beiber Gejdledter barin vereinigt fübet. Die Eleinen 2 Beibden follen nad ber Bebauptung einiger Beobadter nur folde Eier regen, aแอ benen Mlännd)en bervorfommen, utto nur bie grof̧en खseibden follen fäbig fein, zu l̈berwintern unb newe folonien

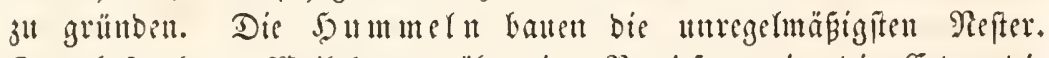
Dả befrudtete Saseibden gräbt eine Sertiefung in bie Crob, bie breit uno wenig tief ift, unb überwölbt biefe 50 blung nit einer Moos=

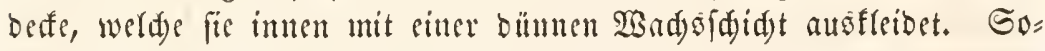

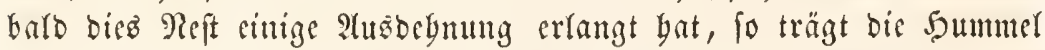
5onig unb Blumentrub ein, ben fie ju einem Teige verarbeitet unb ju unregefmäßigen Sugetn ballt; - in biefe Mafle legt fie bie Gier, unb wägrend bie bald ausgefdlüpfen Rarven innen freffen, fïgt bas 2Beibden von ausen ftets neue Maffen von Futter Ginju, fo baj ber

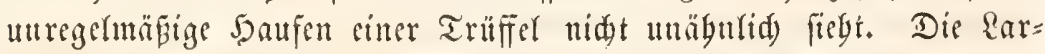
ven verpuppen fid nun, inbert fie fid 3 ellen fpimen, weld)e cinem Fitigergute uidt unäbulid) feben; aus ben SJuppen fommen fleine 2Beibden Gervor, welde ibrer Mutter fogleid in ben Mrbeiten Gelfen, 
intem fie bie muterber berangewadfenten Rarwen füttern, und bie übri= gen Yeergewordenen Fingerbutjeflen mit Sronig füllen. STus ben ge=

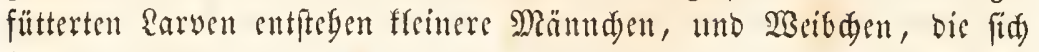
begatten und son betten nad)yer bie 23 eibden ebenfallo bei ben $\mathfrak{A} r=$ beiten belfen; erfit gegen das Enbe bes̀ Sonmers werben biejeninen Eier gelegt, ans benen bie Männduen uno $\mathfrak{B}$ sibdyen ber grofén Raçe

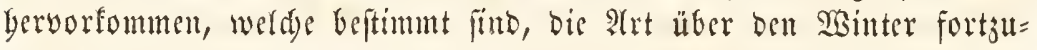

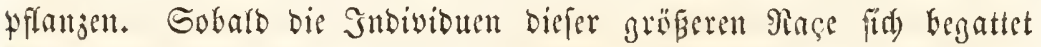

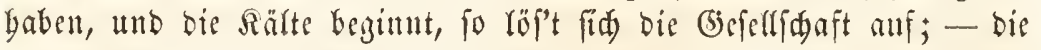

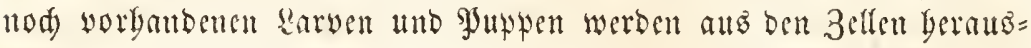
geriffen und ungebradt; bie Snbivibuen ber fteineren Piaçe fo mie

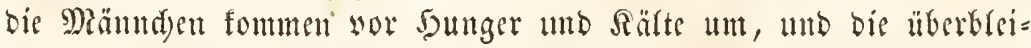

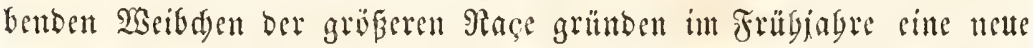

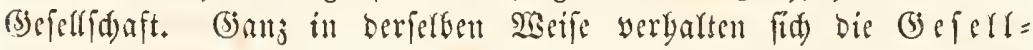

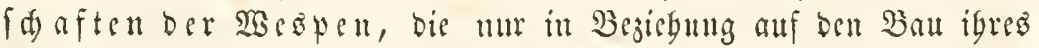
Reftes sinen böberent Sintittrieb zeigen. Die Refter bejtegen aus Zel=

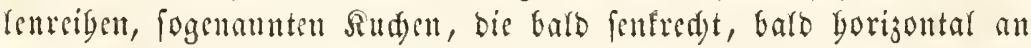

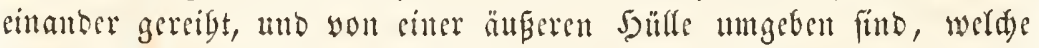

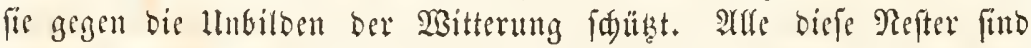

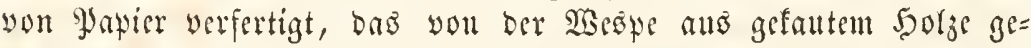

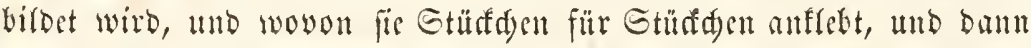

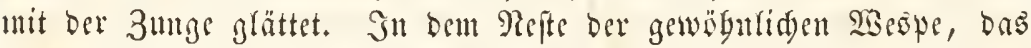
in siner gerüuntigen 5oügle unter ber Erbe augetegt wiro, wägreno bis Sorniffe bas ilyre in boghe Bäune, andere ?trten cs ganj frei an

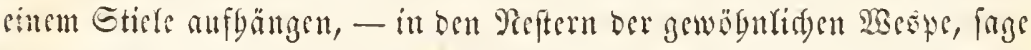
id), fintben fid sier bis zeln borizontale Ruden, aus ciner cinzigen

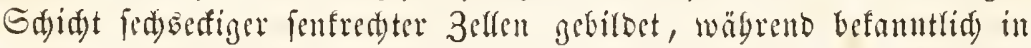

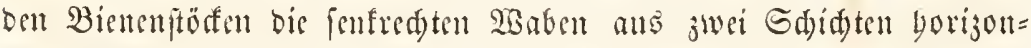

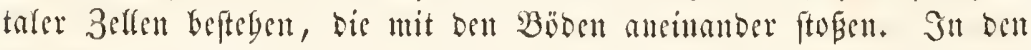

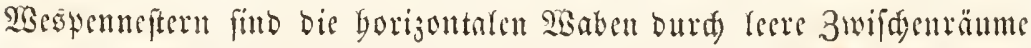
getrennt, weldse ben sisespen geftatten, überall umberjugelen, und bie

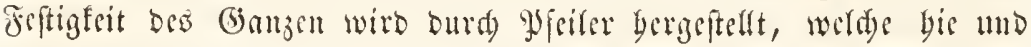
oa bie cinzeluen 2 gaben mit cinander verbinden.

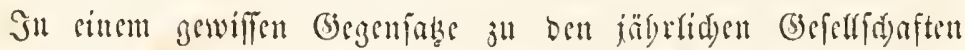

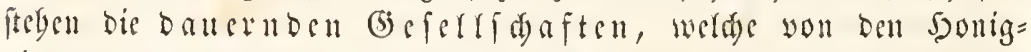
bienen unto ben sigentlid)en Atmeifen getifoet werben. Die siognun= gen, werke son biefen Thieren erridytet werben, bienen nidit mur jut

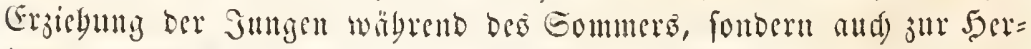

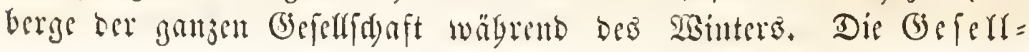




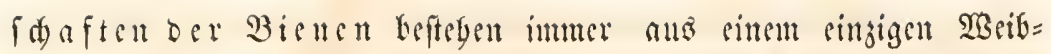

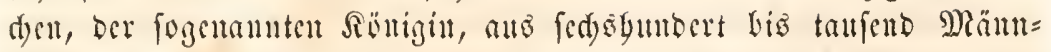
d) ten 2 Seifden, ben ?trbeiterinnen, weldye bie Sorge für bie Sungen und

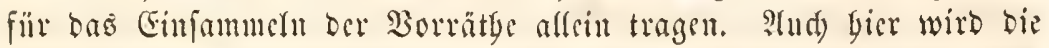

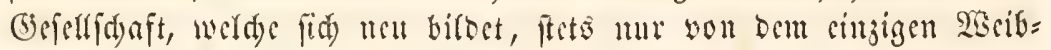

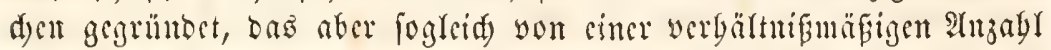

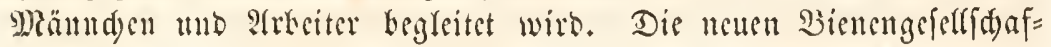

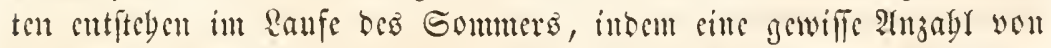
3iăntden uno Arbeiteru, mit cincm 2 seifdyen an Ecr Spize, Den

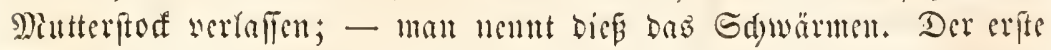
Sdiwarm, welden einte Gefellidaft liefert, wirb won ben uriprintgli=

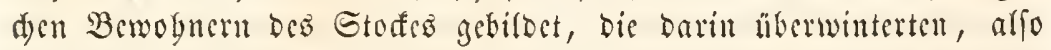

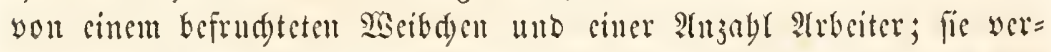
Iaffen ben Stod, um ibrer Radfommenfidaft gylas ju madya, mo fliegent, in biffem banfent der Röntigin folgent, fo range umber, bis biefe fid irgentwo nicberlä̈t. Die wilden Biencen wäblen ju ibrer

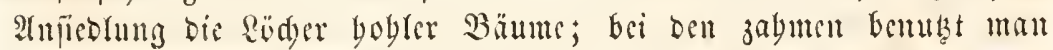
bic Rieberlafung ber Siönigin, um fie in cinen menen Stod zu faffen.

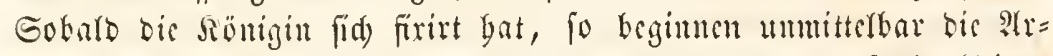

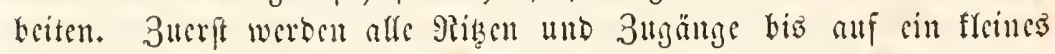
Fluglod) mit cinem $\mathfrak{E}$ lebrigen Etopfwadjic (propolis) zugetlebt, uno bann bie 2 saben begonnen, bic aus bopelten Sdjichten fed)šfeitiger

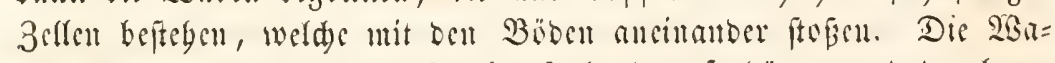

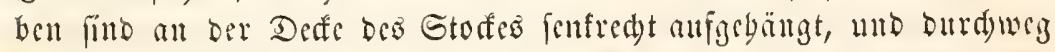

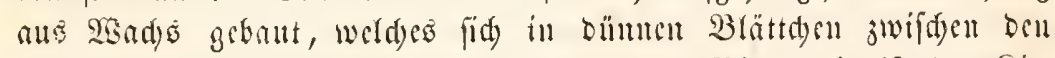

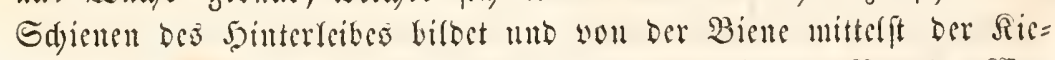

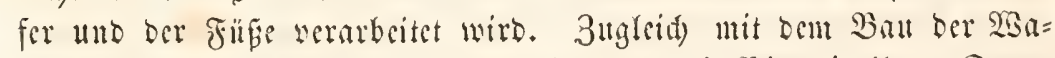

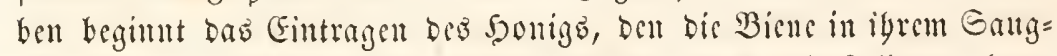
magen uady Saufe bringt, uno burdy Erbred)en in bic 3effen enteert,

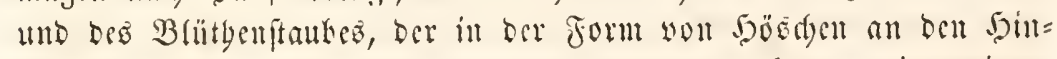
terbeincu getragen wird, und inuergalb bes Stofes jul siller cigen= tgümliden Maffe, bent fogenannten Bicnenbrobe, verarbeitet wirb, unb bejonters zur Rabrung oer Rarvent bicut. Sobalo dic sisabut

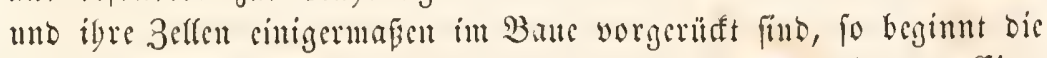

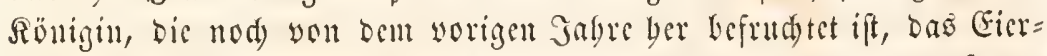
regen. In jebe 3elle wird eint Ei an ben $3 o d e n$ gebeftet; - allfange

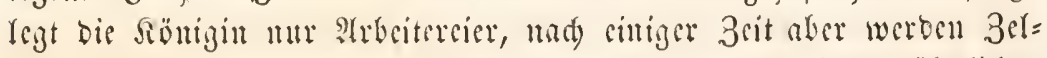

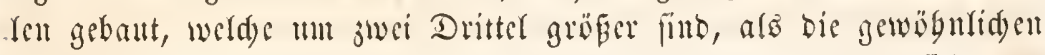

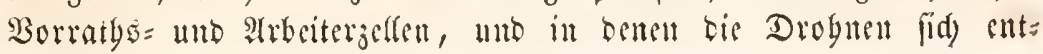


wifern. Nad) Dent Drobnenzellent erft bauen bie $\mathfrak{A r b e i t e r}$ sinige we=

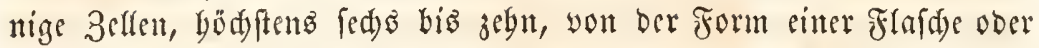
ciner langgeftreften Birne, bie ingenbwo an bie $\mathfrak{B a b e n}$ angstebt werben, fenfredst mit ber Deffnung nad) unten fdanen, und zur (Er=

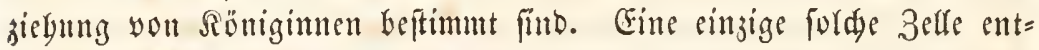

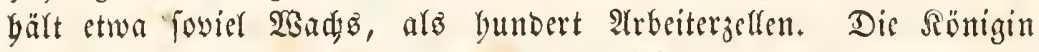

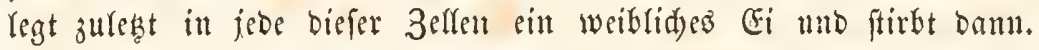
Die (Fier entwidestu fid) mit verfdjedener Sdnelligkeit. Die ganze

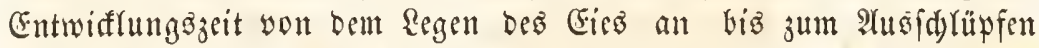

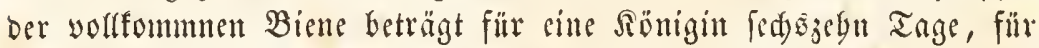
cine Arbsiterin zwanjig Tage, für eine Drobne vier und zwanzig Tage. Şägrent ber Rarvenzeit werben bie fuflojen weiden 2 sürm=

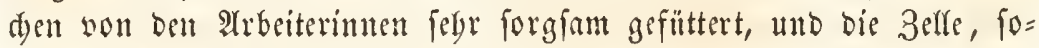

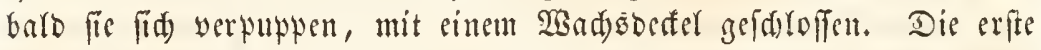
Der augftredenden Rönigimnen töbtet fogleid) nad) igrer Gaburt bie nod) in Der Belle eingefdroffenen weiblid)en gुapyen und breibt fortan

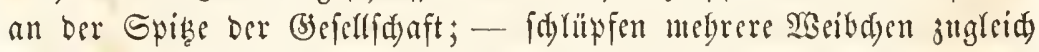
aแts, fo fümpfen fir fo range unter sinander, bis sine tiberbleibt; if aber unglüttlider 2 seife bie alte Rönigin fo lange am Reben geblie=

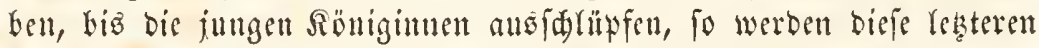

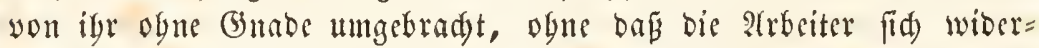

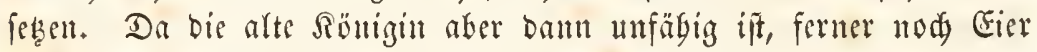
zu Yegen, fo zerftreut fid) bie Geferlfdaft entweber bsi igrem Tobe, ober aber bie Itrbeiter bilben fid) Daburd) sine neue Sönigin, dáp fie

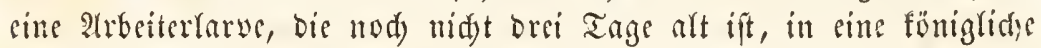
Befle bringen uno mit föniglidem Futter nägren; - in Disfem Fafle

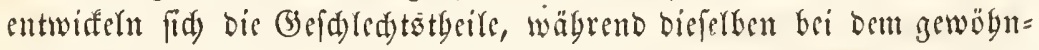

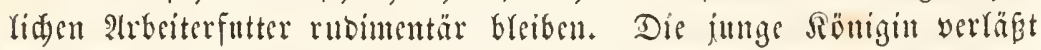
bald nad) igrer Gefurt in Beglcitung Der Drobnen ben Stof, be=

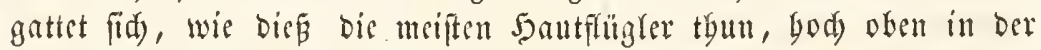
\&uft, fegrt baun in ben Stoff zurüaf uno regt nunt Eier in Derferfen

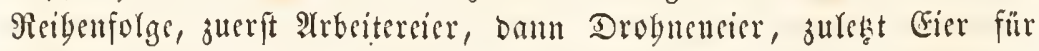

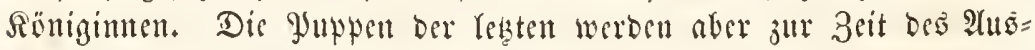

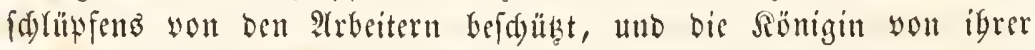

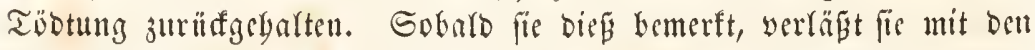

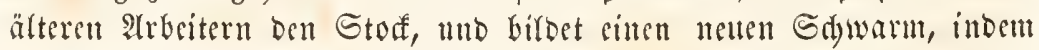

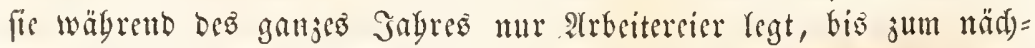

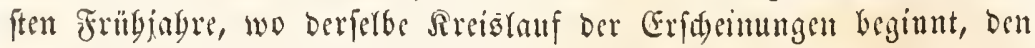

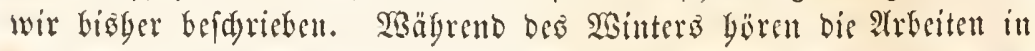


Den Bienenftören auf; - vorber aber, im Monate $\mathfrak{A} u g u f$, werden fämmtlide Drobuen, bie Der (Befellfdaft angebören, won ben 2lrbeitern umgebradyt.

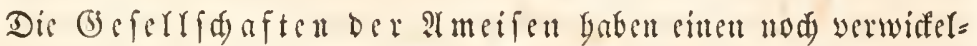
teren 5aughalt, als bie ber Bienen. Die meiften diefer Thiere bauen

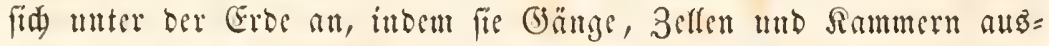

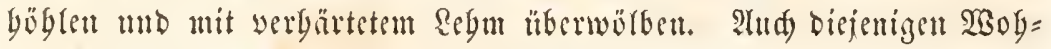

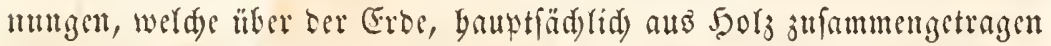
fint, befitzen simen unterirbifden Theil, in welden fith bie Ameifen bei brobender Gefagr ober im SBinter zurüfiegen. Prefe Gefellfdaf= ten befteben aus geflitgelten 2 seibden, fleitteren Miännden uno nod fleiteren ungeflügeiten Trteitern; meijtens แnterfdeibet man bei bie=

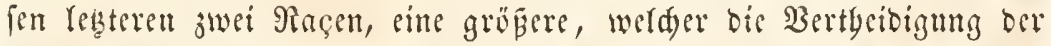

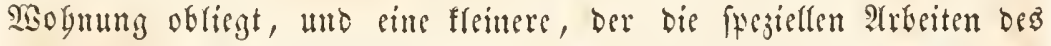

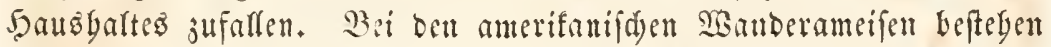
bie zablreidas Truppen, bie in langen Colomen maridjiren, mur ans Eleitteren Irbeitern; Die Inbivibuen Der größ̈eren Pạçe marfdiren ganj in äburitger siseife wie Dffiziere zur Seite ber Colonmen, mb man fiebt fie bänfig auf l̈berragende 3weige ober Brötter flettern, und von biefem erböbten Stanbpunte aus Den 3 แtg Der Trupen anf= merffam beobadjten.

Die Ameifen fammeln Durd) mus feine Borrätbe ein, fondern fallen

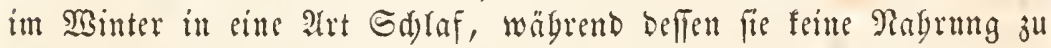
fid nebmen. Säbrent ber Sommersizeit näbren die Irbeiter nid)t

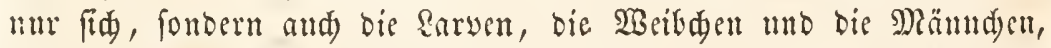
welde alle untbätig fint, mit allen mögliá)en organifdyen Etoffen, be=

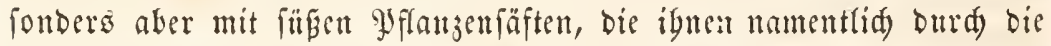
Brattläufe veridafft werben. WBir baben fdou bei biefen Thicren

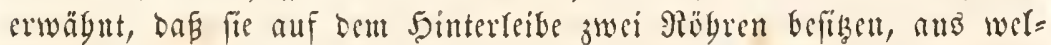
d)en yon 3eit ju 3eit cin füfer 5ontigfaft quillt, weldyen bie Imeifen febr begierig auflefen. Die Blattläufe werben von ben 2 tmeifen mit ber gröften Gorgfalt bebanbelt, yon abgeftorbenen 3weigen und Guroffen auf frifde, lebente Brätter verfest, und mit ben föblgör= mern fo range geliebfofet, bis fit Sonigiaft von fid geben. Die mei= ften Irten yon Ameifen bauen vou ifrem Nefte aus bebeffte 2 Bege, wabre Sunfffragen, แadb bet $\mathfrak{B}$ ämmen unb Sträแdern, auf Denen fid bie Colonien ibres Meffuiches befinden; andere bringen ferbft foldge Blattläufe, weldye an sisurgelfitüfeu baufen, in igre Refter, wo 


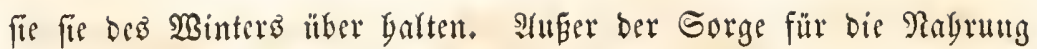

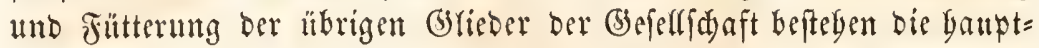

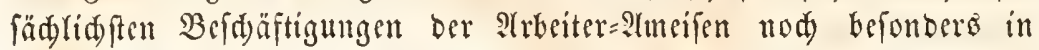

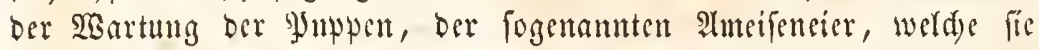
beftänbig zwifd)en ibren Ricforn mulerid)leppen, um fie barb an bie Sonne, barb tiefer Ginab in bie (s)änge zu tragen, fowie in Der Sorge für Das 5aน regetmäpig gefdrlofien werben.

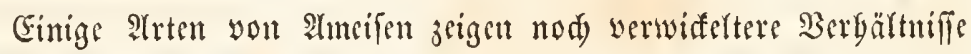

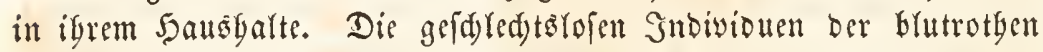
umb ber röthlidgen 2 (meife, welde in unferen Gegenten yorfoumen,

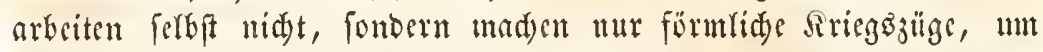

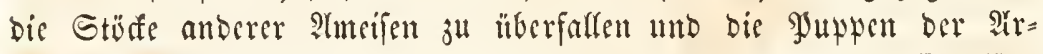
beiter baranz za rauben. Maiftens ift igre Iaftif bie, báp fie Hröbz= lid) cinen benadjbarten 2 tureifenbaufen überfalten, und wenn feine

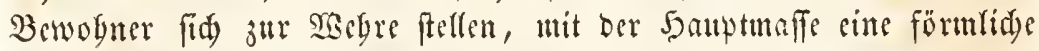

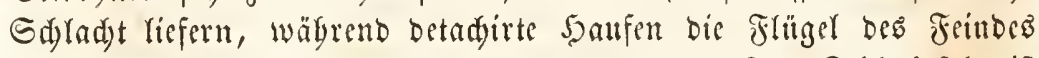

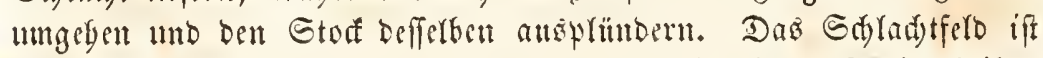
nad) cincm fordsen Siampfe mit seiden bebert, beibe Theile beisen fid mit ber größsten Errbitternng berum; Die \$erwumbeten uno SampF= unfäbigen werben von igren Frennden aus dem (betünutel an fidere

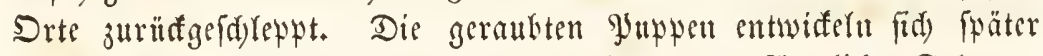

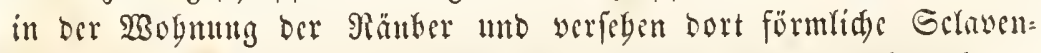

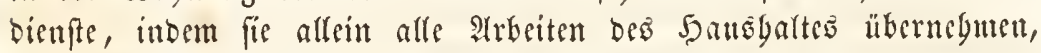
igre untgätigen $\Re a ̈ u b e r$ füttern unb beren Rarven bejorgen. So ent=

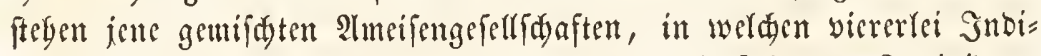
vibuen exiftiren: Männden, 2 eibd)en und friegfügrende Jnbivibuen

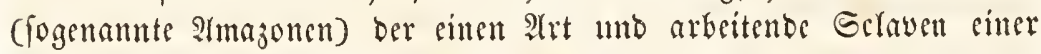
anderen ?trt.

Die Bjoündung neurr ameifengefellfdaften gefdiegt in forgender

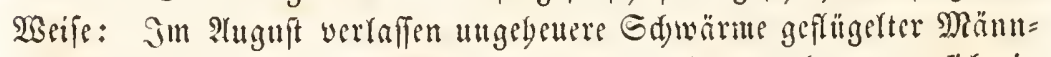
den uno 2 Beibden an Radymittage bie Stöffe unto Vegatten fid in Der \&uft. Die Miänudjen fterben faft ummittelbar nad) Ser Begattung; bie meiften $\mathfrak{B}$ Beibden werben yon ben 9 rebeitern eingefangen und it

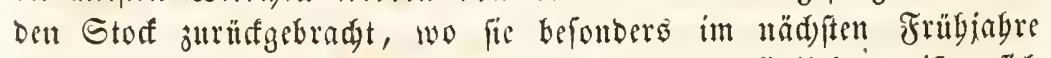

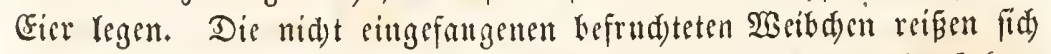
zuerft felbet bie frïger ans, welde fegr lofe auf Stummeln fteben,

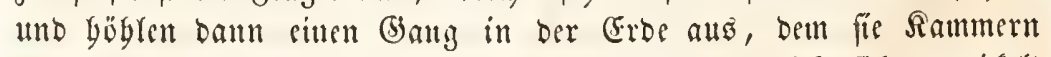
beifüben, in welde fie Irtbeitereier Yegen. Sobarb diefe fid) entwifelt 
Gaben, Gerfen fie igrer Miutter bei igren ?trbetten, b̈berwintern mit

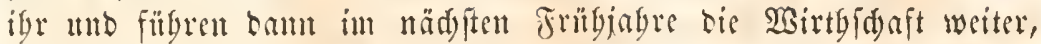
wäbrento bas 2 seibden ganj in ägnlidger Tseife, wie bei ben Bienen,

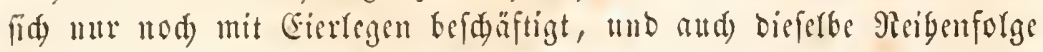
beibegart, intem es erit Strbeitercier, bann mämtlidg und weiblide Eier Yegt. -

Spuren verfteinterter Sautflighter finden fid juerft im oberen Jura, bam aber in grofer Dienge in ben Güpuafferfdidgter ber Tertiärgebilbe. Die Atmeifen fpielen in biefen Edjidten sine wefent= lidje siolle - man findet oft Sdjieferwlatten in Deningen, bie förm=

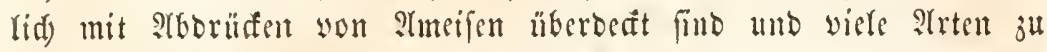

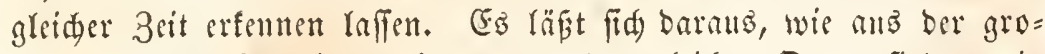
Eent 3agl wour Termiten, bie unan an Den gleiden Drtent fintoet, ein

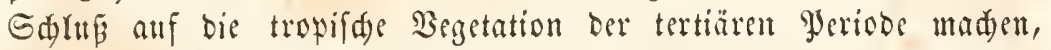

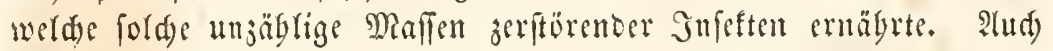

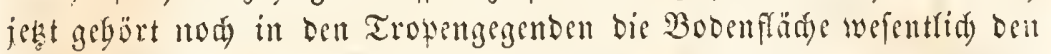

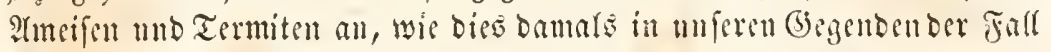

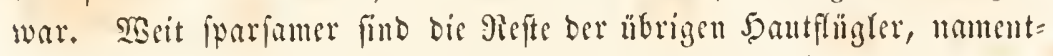
lid) Der Sonigfammler, was mit ber geringen Entweifefmng frautar=

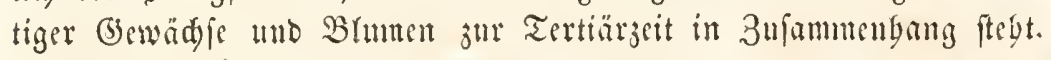

TBir erfennen in ber Drounung ber beatflügler vier Micigen, oc=

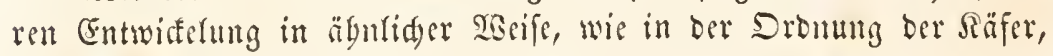

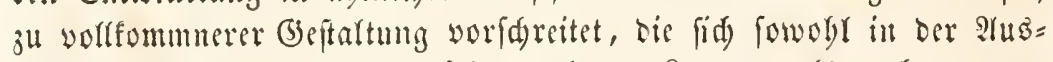
Gilbung beš vollfommmen Grifftes unt Der Rarven, als aud) nament=

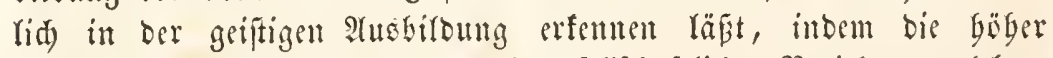
fregenten Typen biefer Dronm in geferfferaftlident Beziegungen leben, uno in ber Gorge für ibre giadjfommenfdaft, fowie für bie Ergaltung

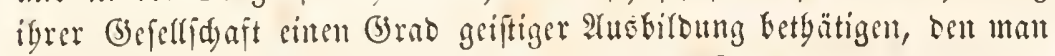
bet alfen andern Thieren vergebens futhen birfte.

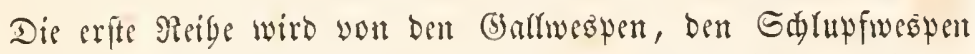

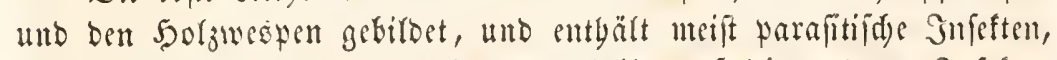

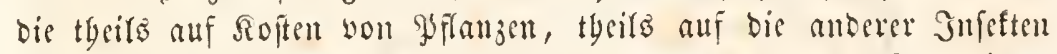

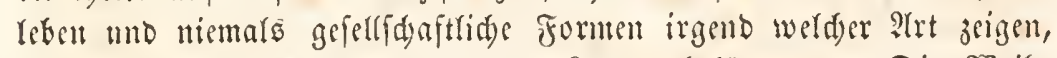

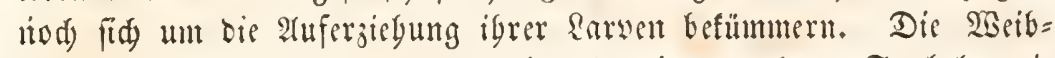
den Gaben ftetş cine Regeröbre, nieunats einen wabren Etadel, wie

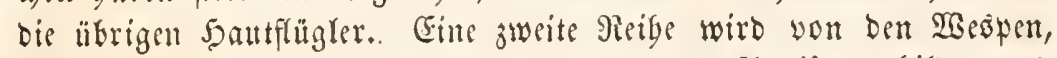
eine britte von ben Bienen, sine vierte von Den Ameifen gebildoet, und 


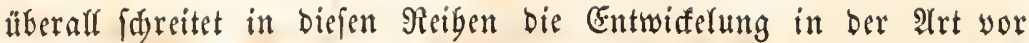
fid), Daß̧ bei Den Riebergefteflten Die Earven zwar von Der Mutter mit Jroviant yerfeben, bann aber fid felbft itberfaflen werben, wäls=

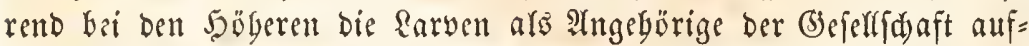
erjogen und wäbrend ber Syeriobe ifrer llnbebülflidfeit entweber von Den Miütern felbit, ober von ben verfümmerten $\mathfrak{B}$ eibden ernäbert und gepflegt werbett.

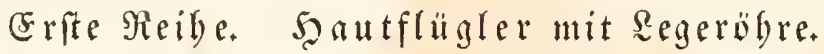

Die Familic Det (Sallwezpen (Cyniphida) beftegt aus einer 2 n=

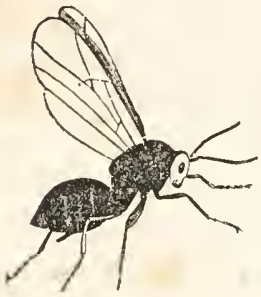

ซig. 904.

Mespe Der Fantbergalle (Cynips gallae tinctoriae). jabl meift febr fleiner, träger Gnfeften, bie

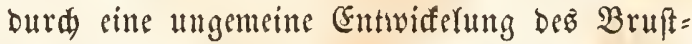
ftüres buferig erideinen. Der Sopf ift flein, quer geftelft, bie Bruft breit, god, eiförmig, Der Sjinterleib gewöbnlid) runb und burd cinen furzen Stiel mit bem Bruftetüfe verbunben. Meift ift ber Reib an feinem binteren Enbe zlt= fammengebrüft, und endet bort in swei Rlap= pen, welde die auferorbentlid) bünne und feine Regeröbre einjilięen. Die Fübler find gerabe, mitten auf oer Gtirn eingelentt, aus breizebn bis fünfzebn Griebern zufammengelest, fürjer bei den Sacibden; Die Sberfippe febr flein; die Riefer furj, biff, am Ranbe gezägnelt; bie Rimnlaben am Ende mit einem grofen, bäntigen Sappen verfeben; Siefertajter furz, fünf= glieberig, Sippentafter rubimentär. Die glügel find febr zart unb burdjfidtig und zeigen nur febr wenige, unbebsutende Tlorm, Dis fogar bei cinigen (battungen gänjlid) feblen.

Die Galfwespen Yegen igre Eier unter Die Dberlyaut Der gyflanjen, in bas 3eflengewebe berfelben, inbem fie mit ibrer Regeröbre, bie aus einer cinfaden 5alblastbe und zwei barin verborgenen gezäbnelten Borften beftebt, ein 8od itt bie äupere Jälle fägen, in weldes fie bann igr (Fi einjdieben. Die Berwundung erjengt bei ben bewäd)= fen sine boble, meift barte Gefdumulft, in beren Snmeren bann bie fuplofen Sarven leben und fid yon sem Marte bes Gallapfelo näly= ren. - 3uweifen verpuppen fid die \&arven im Jumern Der Gafläpfel felfft; Andere bobren fid) Gervor, und verpuppen fid in ber Frbe. Jn ben meiften Garläpfern rebt nut eime Sarve; ez giebt inbeffen 


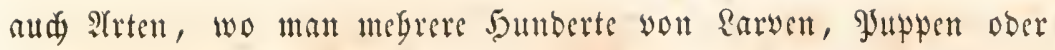

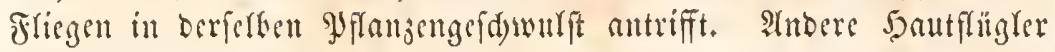
mit Yonger Segerögre bringen oft ibre Cirer in biefe Gaalläpfer Ginein,

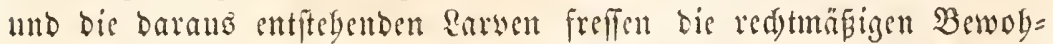
ner berferten auf und entwifeslu fid) auf Soften berferten. Dic Garle äpfer Der Eidsen, weId)e wou ciner befonderen Irt (Cynips gallae linctoriac) beryorgebradjt werben, bienen igres groferen Geshaltes an (jerbefäute wegen befonbers jur berftellutg fdjwarger Farbe. Figites; Eucoila: Cynips; Allotria; Ibalia.

TSir fünnen bie folgentoen Familien unter bem gemeinfamen $\mathfrak{R} a=$

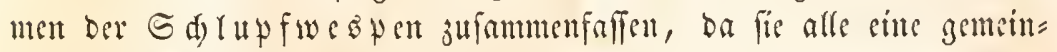
fame Eebengart und ägntide Snduftrie befitsen. Die 2 Beibden regen nämlin igre Eier entwesor in bie Refter ober unter bie Saat anderer

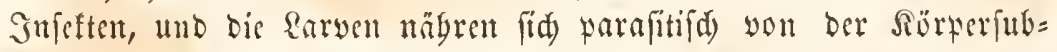
ftanls ber Thiere felbft, weld)e fie bewognen. Bejonders Gäufig fint

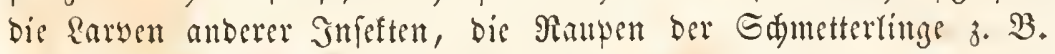

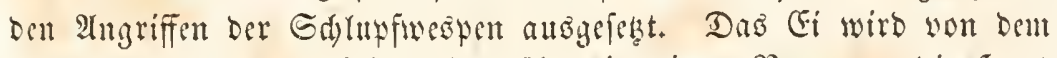

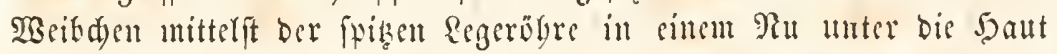
Der giaupe gefdgoten, und die ausfriedsente fublofe sarve nälyt fid

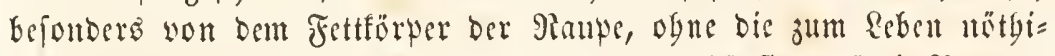

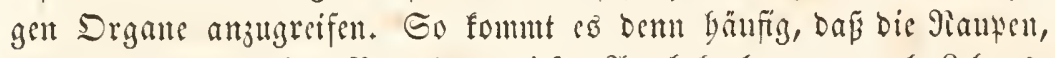

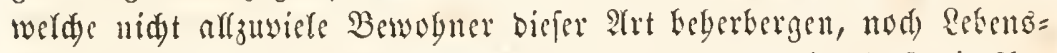

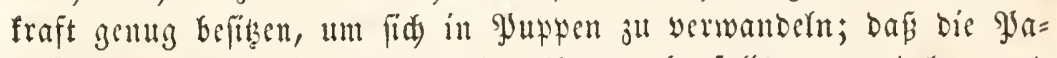
rafiten fid baun im Snureen ber \$suppe cbenfalls verwandern, unt

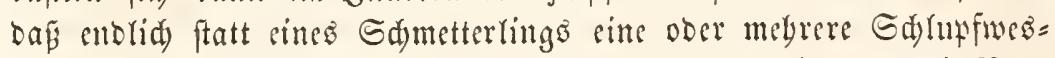

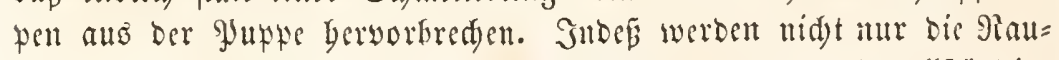

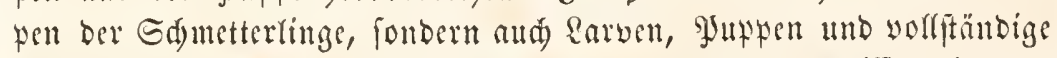

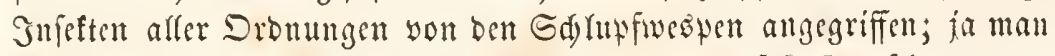

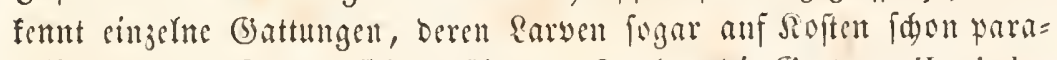
fitifich Yebenber Rarven fï ernäbren. So Yegt bie Gattung Hemiteles

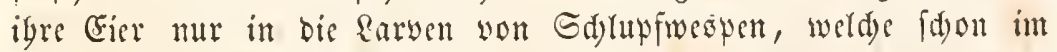

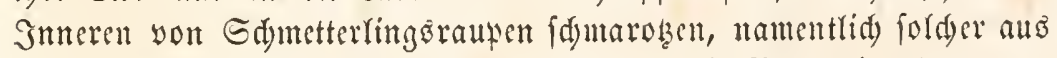
ber Familie ber Braconiben; und wälrent die Braconibenlarve ben Jeetfürper der Raupe versegrt, wiro igr eigener Fettförper wieder

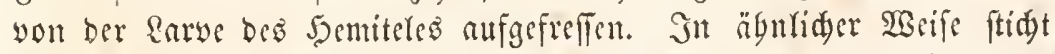

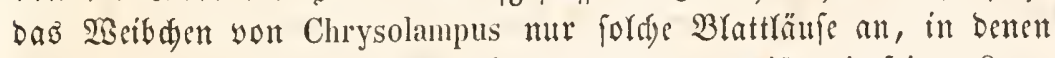

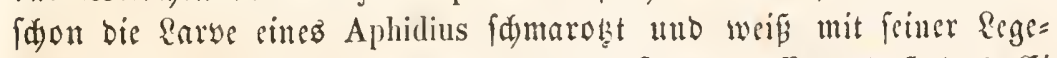
röbre ben Sdmarober in ber Błattlaus fo zu treffen, dar bas Gi im Smeren feines Sörpers abgelagert wirb. Alle bie fdmmaroksenden

\$ogt, Boologifde Briefe. I. 
Rarven biefer Sd)lupfwes̄pen find wurmfürmig, weid), weißlid), Durd)=

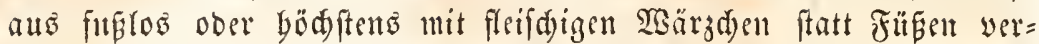
feben; fie bilden nafte Supten im Gnneren ber Thiere, auf Deren

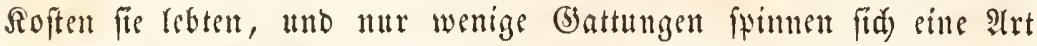

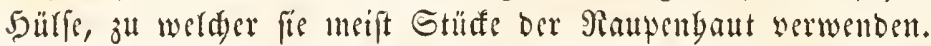

Familie Der Epringmespen (Chalcidida). Meift febr fleine Sd) luffwešpen, mit fomatem, querem siopfe und furzen Füblern von

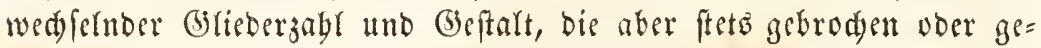
fnift, am Eirte feutenförmig gefägt oder gefiedert finto und Deren eritez, fticlartig verfängertes (Stico in ciner Duerfurde ber Stirn geforgen werben fant. Die Miundorgane find benen ber vorigen

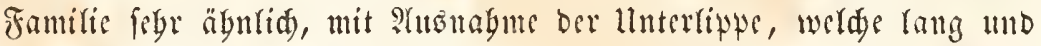
foumal ift unt mit cinem breiten runden Rappen endigt; - bie Bruft ift meift bod grwölbt und buterlig, ber Jinterteit rund und mit sinem furzen Stiele an Der Bruft befeftigt. Die Flitgel Gabelt meift gar feine Rerven, oder mur citen furzen Rantonerven, Der quer in bie

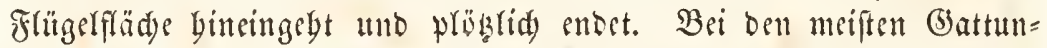
gen fint bie Sinterfdenfer fegr versiaft unt oft mit Spizen und Dor= nen verfeben; cinige $\mathfrak{Z}$ eibden find yolffommen flïgellow; iste Rege= röbre ift meiftens zientidy lang, gerabe und wird bee den meiften in Dem Balidje verborgen, bei antberen aber fäbelartig über bie Rüften=

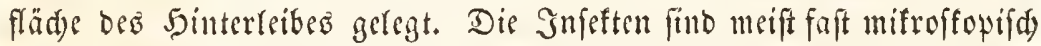
aber mit rebgaft glänzenden Metallfarben geziert, und entwiafectn fid oft zu Şunderten und Taufenden, felbit it Den Eieru anderer Jnfeften. Chalcis; Perilampus; Torymus; Pteromalus; Encyrtus; Platygaster; Leucopsis; Eurytoma; Callimome; Spalangia.

Dic Familie Der Edfwanzweapen (Proctotrupida) befregt ebent=

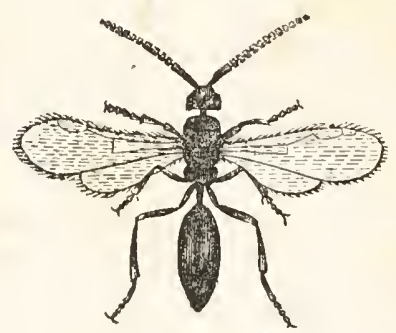

ชig. 906. Bethylus. falle jum grö́ten Theil aus fegr fleinen, faft uifroftopifden Snfeften, welde Durd) Den MRangel ber Flü= gelnervell und bie bälfig verbidten Beitte, fo wis bura bie Struftur Der Mitutbeife ber vorigen Fantlie nabe fteben, fiet aber von ibuen Durd) bie gerabell, niemalo gefnid" ten Fübler, ben Mangel ciner Furde vorn an Dem Royfe und bie meift 


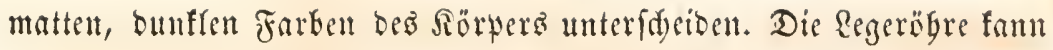
mtr bei wertigen jurn̈afgejogen werben, wägrend fie bei ben meiften Gattutyen fret Gerworftegt; bie Rarben Teben Gefonbers in Giern yon antersu Suffeten, fowis in ben Rarven son 3 weiflüglen. Diapria; Sparasion; Platygaster; Proctotrupes; Dryinus; Labeo ; Betlyylus; Negaspilus; Ceraphron.

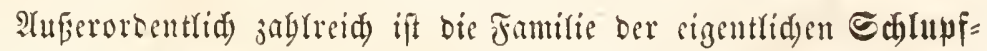
wespen (Ichnenmonida), bie meift einen rangen, fdunaten Rörper,

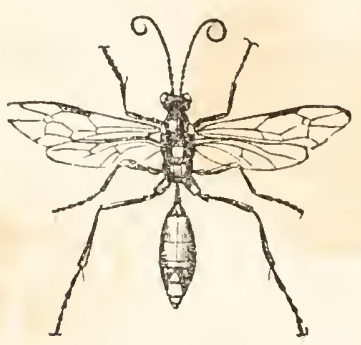

Jig. 907.

Ichiteumon. fleimen, queren Ropf, ovale $\mathfrak{B r u f t}$ und langen Sitterleib Gaben, ber bald felyr bünn gefticlt ift, barb aud) mit feiner gan= zen Breite auffikt. Die Füblyöner find meift febr lang, borftenförmig, felten ge= zäluelt ober fentenfürmig und bei bem lebenden Snefte faft beftändig in rebyaft sibrirender Bewergut raffen fid mur fdwerig unteridesiben, bie Riefer fint bif und jweizägnig, bie llnterlippe febr flein, igre Tafter vierglieberig, wäbrend die Rabentafter fünf (s)licber baben, yon benent

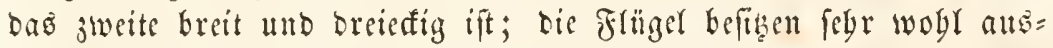
gebilbete Reţabern, und bie Füre find meift febr lang, bütn, aber niemals jum Epringen tauglid. Die Regerögre wed) felt nuperortent=

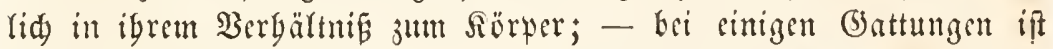
fie faum fidtbar, bei anderen, welde tefonbers ibre Gier in bie gar= ven gefrlliger bautflïgler regen und biergh die Reftyüllen berferben Durdbbohren müfịen, ungemeint lang, ja felbjt läuger, ałs ber ganje Sïrwer. Sie beftegt frets aus zwei bornigen Sdjeiben uno cinem mittle= ren Stilett, weldye felbit wieber aus einer salbrime unb jwei gejäbnel=

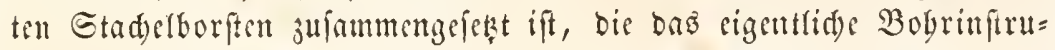
ment bilben. Man yat in biefer l̈berats zablreiden Familie, welde uur in Dentfdland megrere taufend Irrten zäglt, einige lluterfamilien unteridieben, inbem bie eigentliden Sdurumontion (Iclmeumon; Tryphon; Bassus; Metopius; Ophion; Pimpla; Acaenites; Cryptus ) einen fünfringeligen 5interleib und an ben Dberflügeln jwei rütfau= ferto Rerven befitzen, wälrent die Braconiden (Bracon; Vipio; Aphidius; Microdus; Agathis; Ichneutes; Microgaster) bei gleidyer $311=$ fammenfęung bes Sinterleibes nur einen jurüflaufenden Rerven in Den Dberflügeln befizen, und bie Aryfioen (Alysia; Sigalphus; 
Chelonus; Rogas; Helcon) an bem Jinterteibe güdfitens brei beutlidse

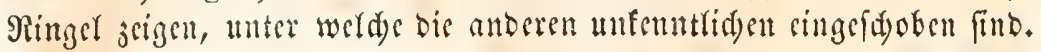

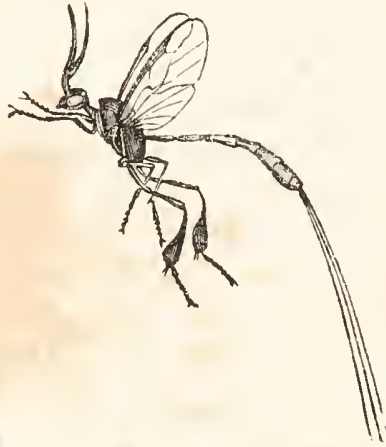

sig. 908.

Foemus jaculator.

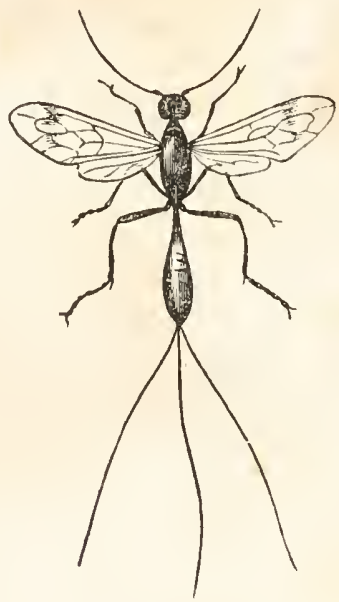

ซig. 909.

Aulacus.

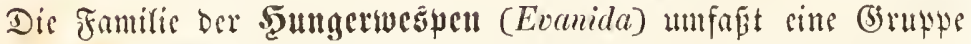

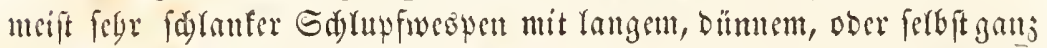
verfümmertem Sointerteibe, beffen Stter oben auf ber Sinterfruft meift umunitterbar binter bem Mittelbruftidittoe eingelenft ift. Die Fitgler

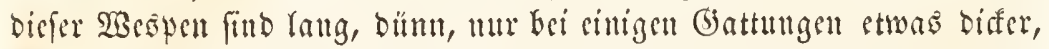
und im Infange ctwas gefnict. Die Rabentafter find fedseglicberiz; bie Sippentafter sierglisberig; Dic Dberflïgel meift volfonmen geabert unt mit gefdyloffenen Beffen verfegen. Die Regerögre ift fegr lang, fo

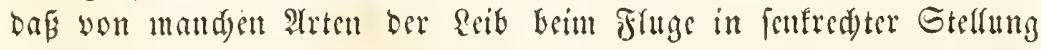
getragen werben mur. Evania; Focnus; Brachygaster; Pelecinus; Stephanus; Megalyra; Aulacus.

Die Familie bir Goldwegpen (Chrysida) beftegt atz ftrjen,

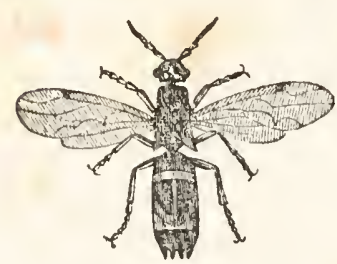

Jig. 910 .

Oolowe se (Chrysis).

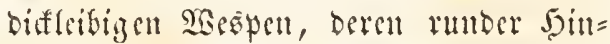
terceib meifit afgenlattet unt auf ber uth=

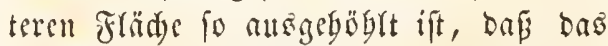
Snlett ign, wie sin Sdild unter bis Bruft

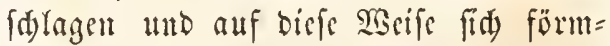
(iid) zulamumenfugetu faun. Der fo gebil=

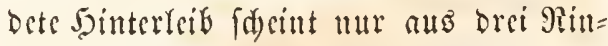
geft julaumengefest, ba bie übrigen Gin= teren Ringel nad) inten singejdoben fint. Die Jübler ber Gord = 


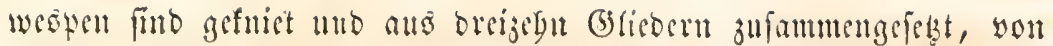
benen bas erfte febr lang ift unb ben Gtiel ber Geifigel bildet. Die

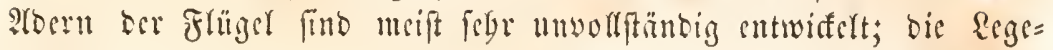
rögre if nur furj, aber bif umb ftarf, fo baf bis Thiere cmpfindid bamit fted)en fünnen; - ba fie aber nidst in Serbindung mit einem

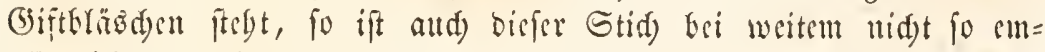
yrittolid ober bösartig, als berienige ber eigentliden ftadeltragen= ben 5autfügler, ju weldan bie Golowesten ben llebergang biloen. Die Rarwen fer Golowespen, foweit man fie bis jetzt beobadytet bat,

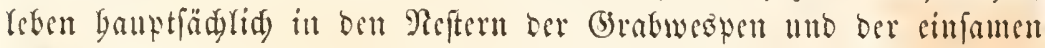
Bienen, beren Rarben fie alffieffen. Die (Solbwesten fdidsiden fidd)

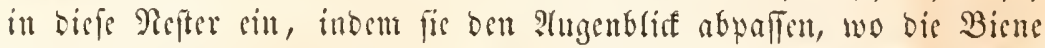
ober Grabwespe fid entfernt, tme grovifion ju bolen; bic Gold = wespe legt bann ibre Gire an Gtellen, wo fie von ber bemtegrenton

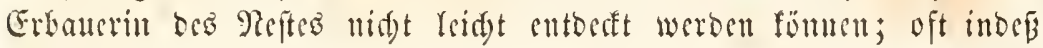

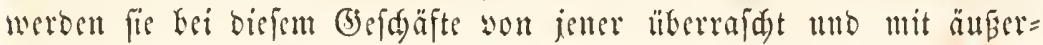
fter sisuth angegriffen, wo ignen baun bie Fäbigfsit, fid zufammen ju fugelu, sin vortefflid)es Bertyeidigungônittel bietet. Chrysis; Hedychrum; Parnopes; Stilbum; Pyria.

Die 5 oljwesten, weldye wir bier folgen laflen, obgleid) fie, genauer genommen, wobl sine Reibe fïr fid bifoen birtften, ba $0=$ wobl bie Bifoung bes vollfommenen Infettes, aro uamentlid bicjenigen oer Larven, febr bebeutend son ben Typen ber Ḧbrigen 5aupt=

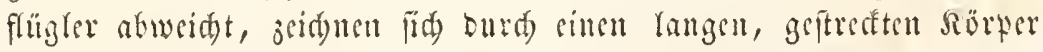

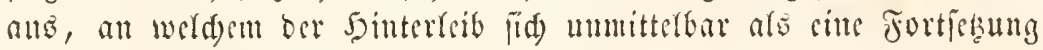
Der Bruft barjeflt uno nismals sinen Stiel zeigt. Die Sarwen biefer

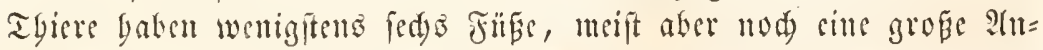
jabl you farfden Bandffinsen, woourd) fie Gdjmetterlingsraupen fo ägnlidy werten, oap einige ältere Beobadter fie wirflid) bafür an=

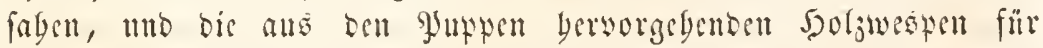

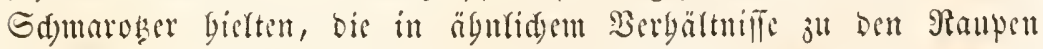
ftütoen, wie bie Sd)lupfwespen. 28ir unterideiben jwei Jamilien.

Die sigentlid) Şoljwes̄pen (Urocerida) baben einen beimabe runben Soff, ber meift oer $\mathfrak{B}$ ruft unmittelfar aufingt, tho sinen $c y=$ linorifden Sïrper, an beffen binterem Eubs bie febr ftarts, fägeför = mige eegerögre bervorfebt. Dis Fibler finto febr lang, forfenfürmig, aแs vielen flemen Gliebern jufammengefat und oft in ber Form vou Biboergörnern gefrümmt. Die Munbwerfaenge befteben aus juei 


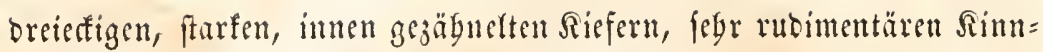
raben mit furzen zweiglicberigen 2 afern und einer fdjmalen llnter= lippe, bie längere, vierglicberige after trägt. Die Flügel fint ftart= jellig, bie vorberen weit größer als bie Ginteren, unt bie Regerögre

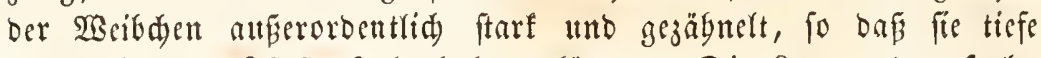

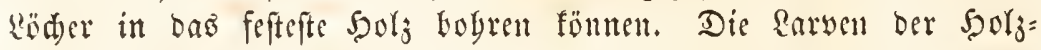
weÊpen find cylinorifd, geftreft, mit Gartem, Gornigem Sopfe uno fed) fleinen geglieberten Füber werferyen, fo bafi fie faft ganj bas

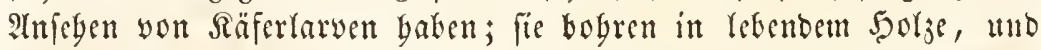
werwandert firt) nad) einigen Jagren, nadidem fie fid einen lofen Seibencocon gefpomen Gaben. Sirex; Xiphydria.

Dic Fatnifie ber Blattwespen (Tenthredinida) ift ber vorigen

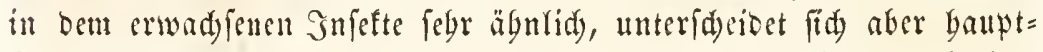

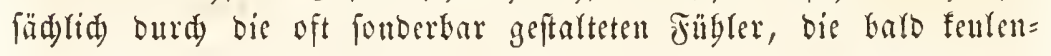
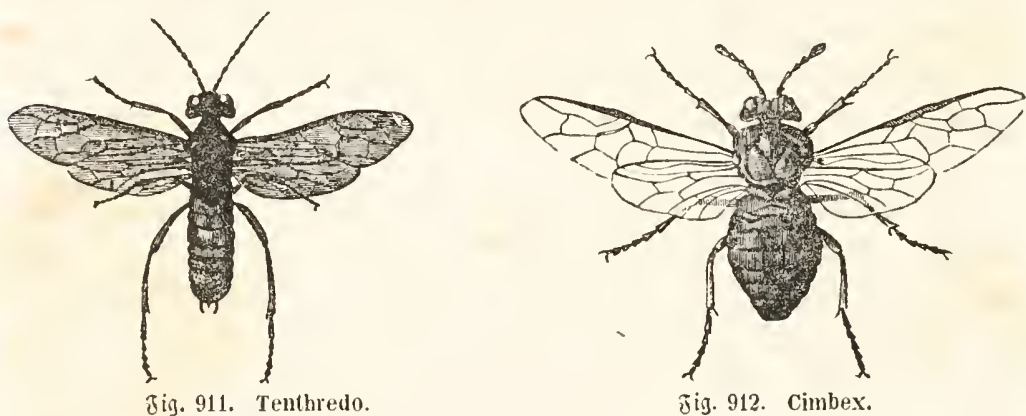

כi่. 912. Cimbex.

förmig, barb aušgezeidunet fammartig geftaltet fint, fermer burd bis

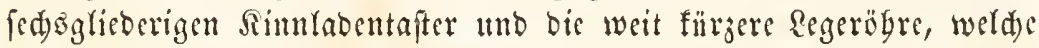
intoés ebenfo ftarf und fägeartig gejägnelt ift, als biejenige ber vori= gen Jamilie. Die meiffen Blattwesepen fägen bie Blätter ober lafti= gen Stenget mit biefer Regeröbre an, worauf lid bieje meift cinrollen tmb fo ber jungen sarve Sdut gewäbren; bie Rarven felfeft baben

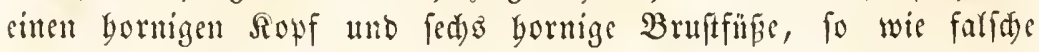

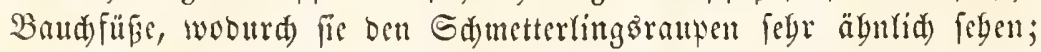
fie unterideciben fid aber von biefen gerabe burd) bie 3abl ber ?: Ifter=

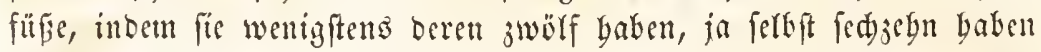
fönnen, wägrend bie Sdmetterfingsraupen nur ad) und Gödifens

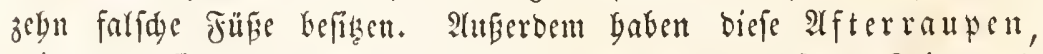
wis man fie genannt yat, zwei cinfade 2 (ugen auf ber Stirn uno zwei felgr fleine fegelförmige Fübler, bie ebenfalls ben ädten $\Re$ aupen 


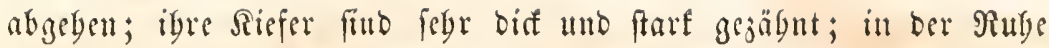
rollen fie fids meift fpirafförmig anf mo fprizen, fobald man fie berïlgrt, sinen nuangenely risdenden Saft ans feinen, feitliden Deff= unugen, die unter ben \&uftëdern liegen. Alle biefe Rarven find

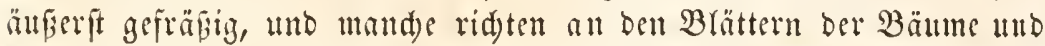
Srätter grofie פerbermugen an. Die meifen fpinnen fid in ber Erbe, oder unter abgefallenen Brättern ein, und mand)e bleiben feğr range 3eit als Earven in igren Gefpinnfen. Tenthredo; Lophyrus; Lyda; Xyela; Cephus; Cimbex; Hylotoma; Schizocera; Dolerus; Selandria.

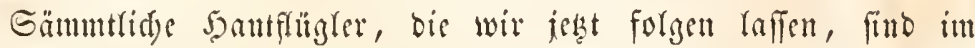

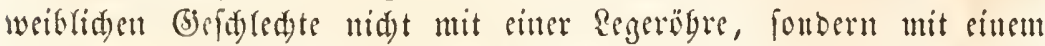
(3) ift ftad) el bewaffuet, ber mit einer eigenen Drifje und siner $\mathfrak{B l a}$ fe in Berbinbung ftegt, weldye im Memente Des Stides bas Gift in bie

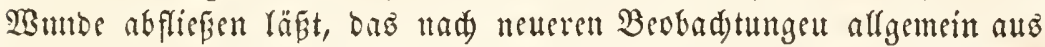
waflerfereser ?tmeifenjäure befteben fort. Der Stad)et ift übrigens genau aแb benferben Theilen jufanmengeist, wic bie Regerögre, unb nament=

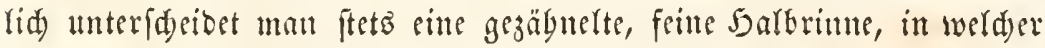
juse bünne, sbenfallz gejägnelte Stadierborften sorgefdoben werben

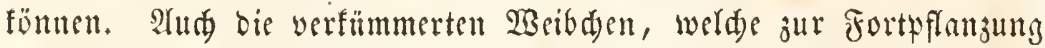
untanglide find, Gaben biefen Stadjel, ber ben Mzännden gattj allge=

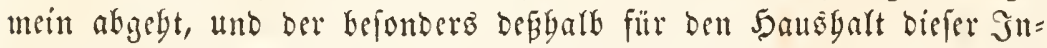

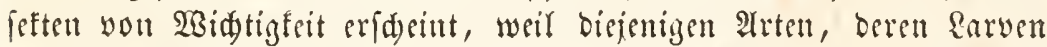

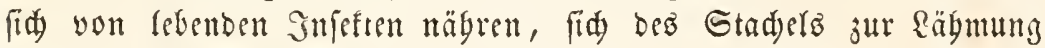
igrer Bente bebienen.

\section{Reibe oer wespen.}

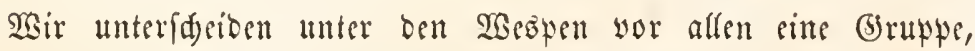
Deren Eebensart viele gemeinfame Gigentgümlidifeiten bat, weß̧balb

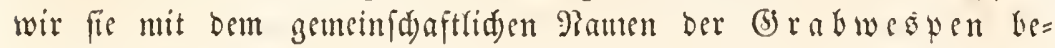
zeid)nen. Atle biefe Thiere leben sinfam, niemals in Sefellfdaft;

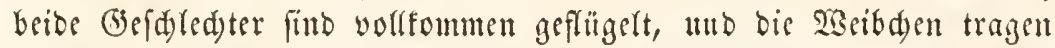
Sorge, Den an einem geidüßzten Drte rebenden Rarven bie bis ju igrer Cimpupwung nötgige Rabrung beijugeben, weld)e immer aus lebenten Infeften beftegt. Die meiften bisjer Tbiere bogren ju biejen

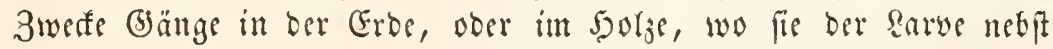
ibrem Mroviante sin Rejt bereiten; andere mauern jerbjt mit Sano 
unb Miortel förmlide Zellen auf, in welden bie Rarwe verborgen tift. Der Jुrovinut, welden Diefe Thicre ibren Rarven beigeben, beftebt aนs Iebenten Infeften und Rarven alfer Dronungen, fowie aud) aus Spinnen, weldye itl Dem Refte aufgeidjidtet und allmäblid yon ber fid entwiafelnoen Saegenlarve verzebrt werben. Cine jede Grab= wespe verproviantirt ibr Reft mur mit ciner beftumenten Art von

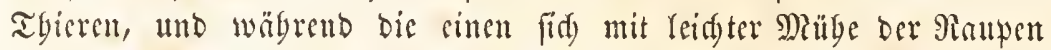
ober Rarven bemäbtigen, dis ignen feinen WBiberitand entgegen fescen fönnen, fo foftet es ben anderen oft einen barten Rampf, bevor fie cine Biene, eine Spinne ober gar eine Rïd)endabe über=

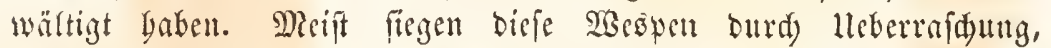

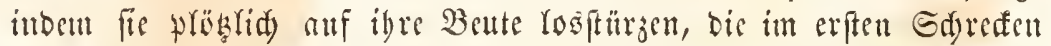

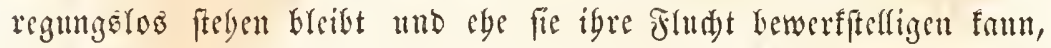
yon ben farfen Siefern ber sisespe an bem Ropfe gewadt wird. Sn Demferben Angenbrife biegt bie Grabwerspe ibren fdy ranten bin= terleib unter ben Baud Der Beute unb bogrt Den Stadel an irgend eincr weiden Gtefle ein. Die Berwullong bat unmittelbar cine eigentbümlid)e Räbmung Des Getroffenen jur Folge; Das geftodacne Thier faun meiftens nod) feine Beiue fdwad) berwegen, ift aber fonft in sittem 3uftande, wie went es in tiefen Sd) bef verfunfen wäre, fo

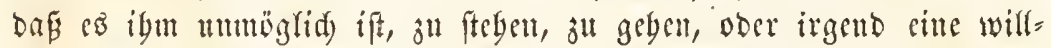
fübryide Bewegung anşufügren. Sn Diefer geräbuten, wiflenlofen 3 ftande bleiben bie getroffenen Thiere nidyt nur Tage, fonbern Sodden und Monate Iang am Reben und erbalten fid frifd und weid, ogne sinjutrodten, fo dap die sarve, welde fie vergebren forf, Dis gebörige Rabrung aus ignen jieben fann, wäbrend fie bod un=

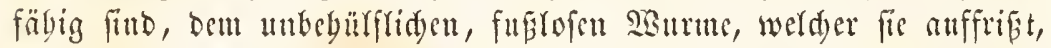

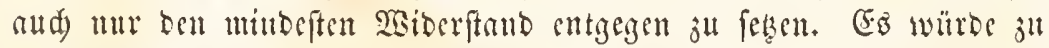
weit fügren, wollten wir auf bie Ginjefnbeiten eingeban, welde in grofer Menge befannt find, und Die, matïrtid je und ber Irt ber

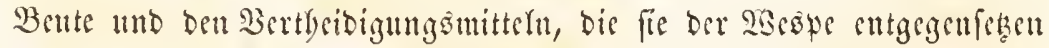
fïnnen, anferordentlid wed)feln, wäbrento fie in oen allgemeinen 马ïgen, wie wir fie eben mitgetbeilt baben, ülereinftumen. 
Dic Familie Der (Sartemwespen (Scolida), bic yauptfädlid) in

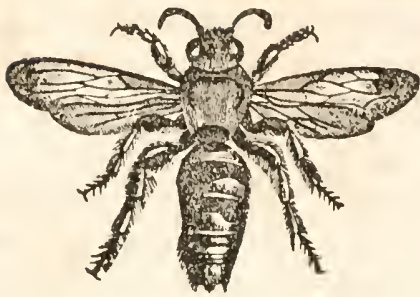

Jig. 913- (Sartenwespe (Scolia hortormm,) wärmeren Gegenten febr verbreitet ift, bildet getwiflermafien ben $l$ leber= gang von ben Gd)lupfipespen ju ben eigentliden (jrabivespen burd) Die Irt und 2 Beife, wie fie für igre Rarwen forgen. Die sinjige Art nämlid), beren Soutgabalt bis jetst beobadtet wurbe, fuddt bic Rarwe

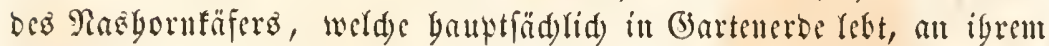

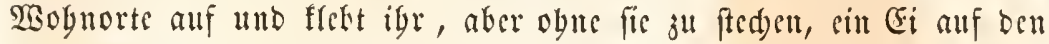
Rücfu, aus bem fäter bie Sarve bervorgebt, weld)e ben Engerling Des Rašborntäfers auffipt, ber fo grop ift, baß er zwei Rarven ber Gartenwege genilgende Ragrung bieten fönte. Dic vollfommen Infeften find gropi, ftart bebarrt, namentlid an ben furzen biffen Beinen, unb baben furze, an ber Spilze verbifte Jügler, bic bejon= Ders beim 2 seibten febr furj finb. Der Gtiel Des ciförmigen Sain= terleibes erfdyeint fo fur leib ummittelbar an ber Bruft angefügt fdeint. Scolia.

Die Sandwespen (Sphegida) find fd)lanfe Thiere mit lang=

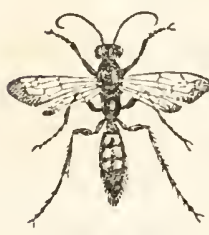

厄ig. 914. Pompilus. gefticlteut ciförmigem Sjinterleibe und febr langen Sinterfüsen, bie meifens an ben Sdiencu geftadelt fitto und febr gefdift jum ?luswerfen des Ganbes benust werben. Die Fübler find lang, bünn, fabent obcr borftenförmig, bic Borberbruft flein und ring= förmig; die langen fdarfen, innen gezäbuten Siefer fteben bei einigen Gattungen nod) weit über ben Ropf Gervor. Sie verproviantiren igre Rarwen bejonbero mit Gpimt = raupen, mit Spinnen ober แtit 5cufdreften unb Edaben, beren fie (id) oft erft nad) bartem Sampfe bemeiftern. Sphex; Ammophila; Pompilus; Pelopaeus; Dolichurus; Chlorion; Calicurgus; Anoplius; Pepsis.

Die Shnubelwespen (Bembecida) unterfd)eiben fid you ben vori= gen Gauptfäd)lid) Durdy ben febr furjen Stiel Des bjinterfeibes, fo wis Durd) Den Bau ber Munbwerfjeuge, intem bie Siefer (d)mat, büแu und fait unbejägnelt, bie Dberlippe furj, Dagegen Die Sinnlaben febr lang unb fabenförmig, unt bic Unterlippe ebenfalls auserorbentlid) yerlängert unt an ibrer Epibe gefpartent ift. Die Borberbruft ift nur 
fegr flein und bildet einen bünnen Ring Ginter Dem Ropffitele. Die Sdynabetwešpen find alle jebr lebgafte, fidnelfflegende Thiere, bie igre Röder in Sanbe graben, und bie Rarven mit lebenden Fliegen ver= proviantiren. Bembex; Monedula; Stizus.

Dic Silberwespen (Crabronida) baben cinen meifí augefpitzten

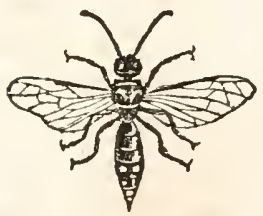

8ig. 915. Sapyga. Sinterleib, Der mit eitem diffen furgen Stiele an Der Bruft bängt. Der Ropf ift breit; Die Borberbruft tur fegr flein und ringfürmig; bie Mlunbiverfjeuge gebrängt, \&aden uno lln= terlippe im Segenfał z" Der vorigen Familie nut febr furj und mit einem rumbliden Rap= wen geendet. Shre Sarven werben bejonders

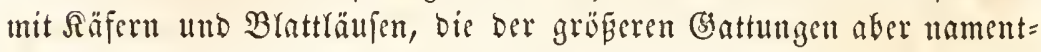
(id) aud) mit Şonigbienen verproviantirt, benen fie sifrig nad)feflen. Crabro ; Cerceris ; Sapyga ; Larra; Astata; Lyrops; Nysson; Oxytelus; Pemphredon; Trypoxylon.

Die Familie Der eigentliden 2 segpen (Vespida) unterideioet fid

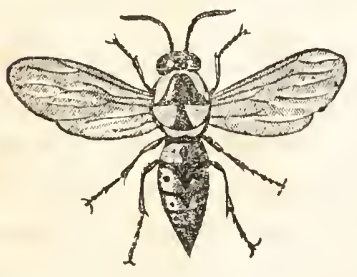

Fin 916 . you ben vorbergebenden Familien, die alle cinfam für fid leben, Durd) ibre biefellig= feit in Tobuung und Reftbau. Ga font =

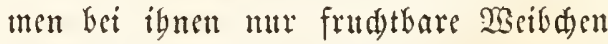
uno Männd) feine fogenannten (bs $=$ (d)led)tàlojen yor, wie bei den Bienen und Atueifen, während fie fonjt binfidst=

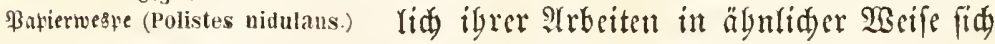
vereinigen, wie die eben genamten Familien. Die meijten näbren ibre Stmgen und füttern die Sarven gemeinfdaftlid) mit Sonig alt; es finben fid) inbes aud) Darin llebergänge ju ben (jrabwespen, baß einige (Battungen (Odynerus; Masaris; Synagra) bie gemeinfdaftlid) gebauten Refter mit Yefenden Snjeften verprosiantiren. Der Ropf Der SBešpen ift meift breit; Die Fübler furj, nad) Dem (Ende bin etwa verdifft; bie Siefer furg, aber febr fräftig, fajt ebenjo breit alo lang, fdief abgeitułt, uno mit vier 3ägnen verfeben; bie Zunge furs, bei= nabe berjfürmig; bie Augen ausgefdnitten; bie Sdjenen ber Sinter= beine geftadelt, bie Tarjen aber obne irgend welde Erwetteruttg. Die Dberfitiger werben ber \&änge nad in ber Mathe gefaltet, ein Egarat=

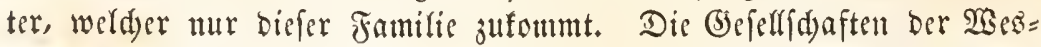
pen gebören, wie dicjenigen ber Soummeln, ju Den Sommergeferfedaf= 


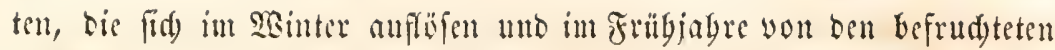
2Beibdyen, weldye die Rärte in irgend cinem Sdylupfwinfel luberftanden

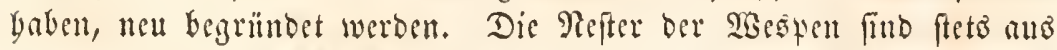

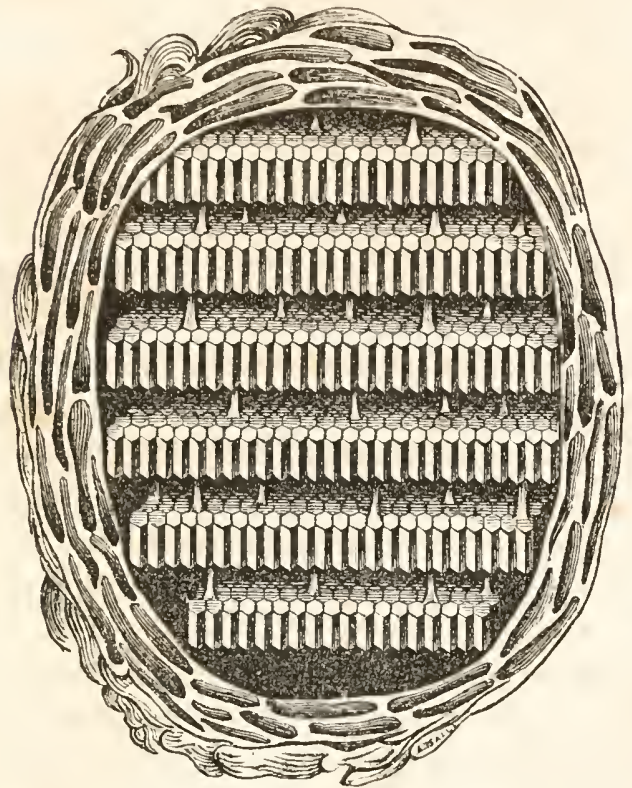

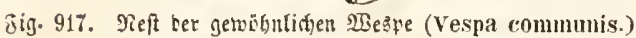
jerfautem Solje verfer tigt, ong fie mittelft if $=$ rer frarfen Sinnbafen jerifyittern turd ourda ithen flebrigen Speider fll eitter Art mebr oder minder feinen lyapieres jufammenteimen. Das Meft feloft wirb in bobs= Ien $\mathfrak{B a ̈ u m e n , ~ a n ~ g e f d ) ~ i ̈ : ~}=$ tell Drten angebrad)t, ober aud) eillfady in ber siseife an Yyflanjentent= ger anfgebängt, $D a \tilde{\beta}$

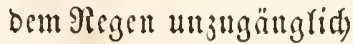

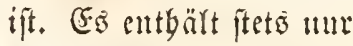
wenigen Sorraty von Jonig, ba bic \&arven unmittelbar mit bem ge=

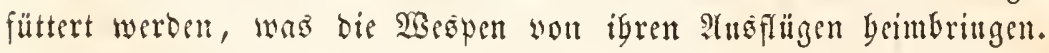

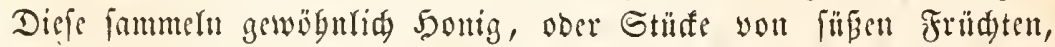
$3^{r e i f e n}$ aber and) gern folde Jneften an, die Joning fammeln, wie namentlid) Bienen und Fliegen; in ber Roth begnïgen fie fid inter aud) mit anteren Injeften unt jonftigen Galbfaulen Etoffen, bejonoers Fleifd, weldes fie igren Rarven jutragen. Dieje baben im (3)egenfaze ju Den Bienenlaryen ftarte Riefer, welde Denen ber vollfommnen $\Im_{n}=$ feften ägnlid) finto, unb mit welden fie an ben $\mathfrak{B a ̈ n b e n ~ i g r e r ~ 3 e l l e n ~}$ fragen, fobald fie 5unger empfinden. Vespa; Polistes; Eumenes; Odynerus; Synagra; Masaris. 
Reibe ber Bienen. (Apida).

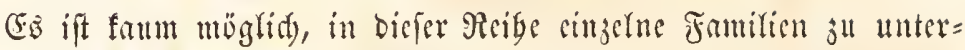
fdeiden, ba alle cGaraftere, welde man dafür Gat anffetlen wolfen, fo allmäblig in cinander übergelyen, baj fid nirgends fdarfe brem linien jeigen. Die Bienen jeigen sinen gemeinfamen Gbaratter in ber

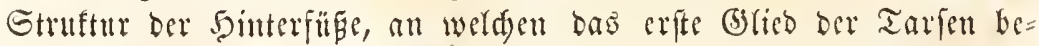
beuteno verbreitert ift, und cine barb länglid)

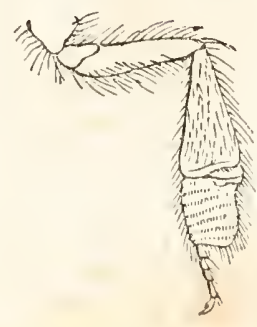

Fig. 918. viereffige, bald mebr oreiedige glatte barftellt, bie oft nod mit baaren ober Bürfen verfeben ift, and zum Sintragen bes Blumenftaubes bient. Die Sauwerfienge oer Bienen fino febr yeridjicben won benen ber Saespen; bic Dher= lippe ift frein, fotroförmig, bie Siefer melor ober mintor bafenförmig, immen farar unb entweber glatt, ober unt mit cinem 3alye wer=

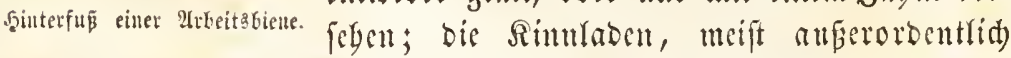

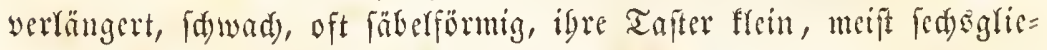
orig; die Rippe gewögnlid ungemein lang, fabenförmig, am Grmbe mit swei Gdupten unb mit rangen Taftern verfeben; fie bitbet sinen Gqüpraiffer, womit ber Soung alfgefangt wirb. Die flitger fint meift ungleidy, bic yorberen weit größer, alo bie binteren, ber \&eib an vielen Stellen bebart, was jur Sammlung bes Błmmentanbes bemigt wird, Der bei ben cinen an den Sinterfü̈en (Apis; Bombus; Anthophora; Centris; Xylocopa), bei anberen an bem Bande (Osmia; Megachilus; Anthocopa; Anthidimi), bei anteren an oer Bruft (Panurgus; Andrena; Haliclus; Ancyla; Colletes) gefammelt, geballt mo fo und) Sanje getragen wird. Bei affen cinfan rebenden Bienen fin=

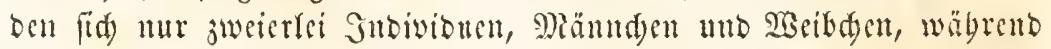
bei ben gefelligen werfümmerte Sacibden, Gefd)led)tolofe ober atrbetter - yorfommen, welden bauptä̈blidy die Cinfammlung Der Sorrätbe uno Die Gorge für bie Jungen obliegt.

Die Rebensart ber veridjebenen Bienen zeigt felor wedjelnoe Berbältmiffe. Es giebt cine Gruppe (Psithyrus; Phileremus; Melecta; Nomada), Deren Sarven auf Rafyrmig you sonig uno Brumentaub angewiefen find, vhne bafi die Mïtter im Strnbe wären, biejen ju fammeln und cinjutragen. Die ju bicicr Grappe gebörigen Gattun= 


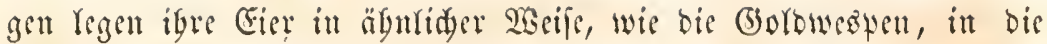
Pefter ber übrigen Bienen, befonbers ber sinfam rebenten, und bie barans entfebenten sarwen, bie fich weit fduefler entwiffeln, als ber red)tmäfige Betwobner, jebren bie für Denferben beftinmte Jabrung auf utto weiben ign baburd) bem Sungertode. Sn cimer anteren (Gruple (Eulaema; Anthophora; Macrocera; Meliturga), bauen bie Sacibden eigentlide Refter, bie aus einem Santen von Zeflen befteben,

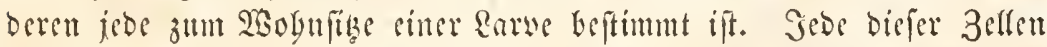

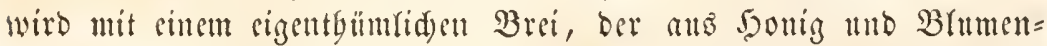
ftab jufammengefnetet ift unb ber Rarve bis ju ibrer Entwidelung binreidentse Rabrung bietet, angefüllt. Die 3rlfe wirb bann, nadjocm sin Ci bineingelegt ift, geid)loflen, uto die Rarve ibrer weiteren Ent= wisfelung ïfertaffet. Die meiften biefer Refter werben in ber Eroe ober in Mhanem angelegt (Colletes; Audrena; Megachilus; Panurgus; Ilalictus) unb bie 3ellen ans simem erbärteten Ieige gebant, ben bie Bienen juerfit mit igren Sitnbaten ourdyarbeiten und bann mit ben Beinen unb Dem Miunbe formen. ATbere Gattungen, bie man $\mathfrak{M}$ a $\mathfrak{e} \mathfrak{l}=$ bienen genannt bat (Chalicodoma; Osmia; Heriades; Chelostoma), bemben j" igren Meftern oen Mlörtel Der Miauern, utt fertigen aแber= orbentlid) barte flumpenartige (bsbämle an, welde ctwa wie Gdywal=

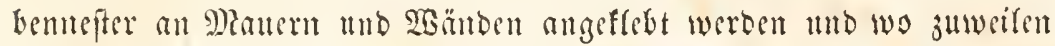
bie 3elfen mit zierfid) jugef werdell. Megachila.

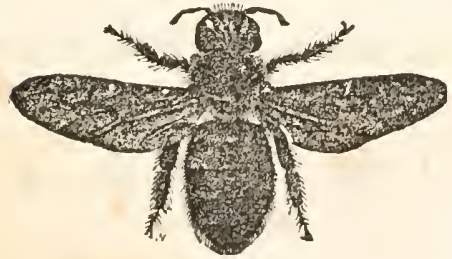

8ig. 919.

Şulartiene (Xylocopa)

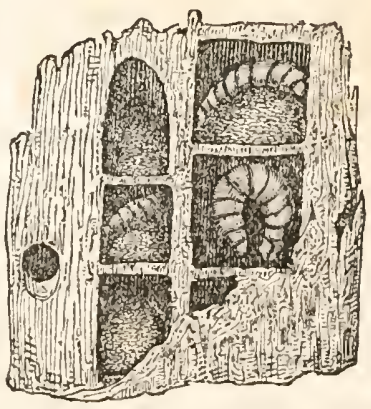

Jig. 920 .

Dat Teit einer 5yot3biente.

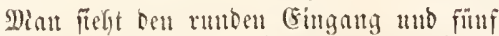
Bellen mit Frovinnt mo mehr soer minter entwifelten Earven gefïllt.

Rod) 2lubere (Centris; Xylocopa) Gobren in altem Soolje cincu

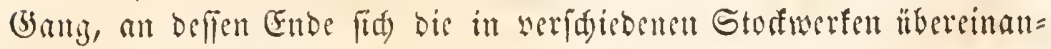
ber regenden Zellen befinden. 
Die gejerrig rebenden Bienen (Apis; Melipona; Bombus) find bie cinzigen, welde cin wabres Rörbden an bem erffen Tarjal=

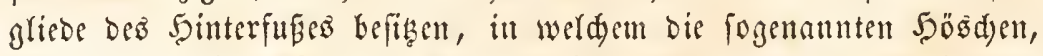
D. b. Die in einen Rlumpen geballte Rabung von Blumentanta nadh baule getragen werden. Sgre (jefellidaften finto balo jäbrig, wie

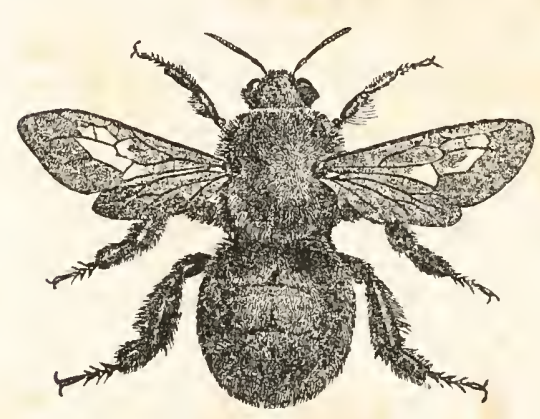

Fig. 921.

ร̧นmnie( (Bombus)

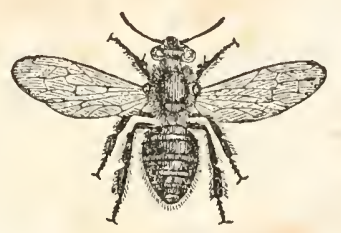

ริig. 922. Itrbeitşienc.

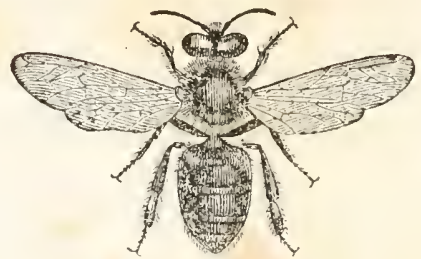

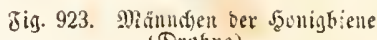
(Diufne).

Diejenigen Der Jummeln, bald Dauernd, wie die Der Şonigbienen, und

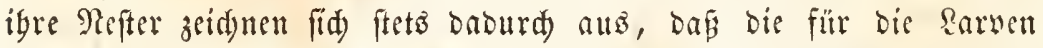
beftimmten 3elfen nur aนs cittem cigentbümliden SGbonderungéftoffe, Dem $\mathfrak{B a d}$ ie, gebildet werben. Diefes $\mathfrak{B}$ ach s wirb it bütnen Brättden

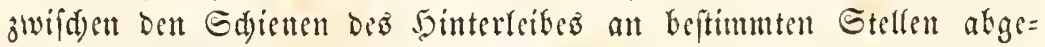
lagert, Dort Gervorgejogen und mittelft des Epeidels erweidit und verarbeitet.

Bei beiben arten von Gefellidaften fommen ftetò oreierlet Эndi= vibuen: Männden, gröpere frudtbare $\mathfrak{S}$ sibd)en, und fleinere un= frudtbare $\mathfrak{B}$ etbden, ober Arbeiter vor; eB berridat aber ber luter= (d) ied, onf in ben Sommergefelf fdaften die 2Beibden ebenjo thätig arbeiten, als die 9rbeiter felbit, wäbrend bei ben ausbaucrnden (5) fellfdaften ber Sonigbienen nur cin eittjiges setbden in jeder (5se=

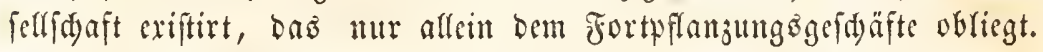

Reibe der Itmeifen.

In Der Familie der Sammaroferameifen (Mutillida) fommen nur stwei Arten von Stloiviouen vor, geflïgelte Mäund)en uno ungeflü= gelte $\mathfrak{S e i b d e n , ~ d i e ~ m i t ~ c i n e m ~ f t a r t e n ~ S t a d ) e l ~ b e w a f f n e t ~ f i m b ~ u n d ~ f e b r ~}$ 
empfintlid fed)en. Dis Füblgöner find meif furj, borftenförmig,

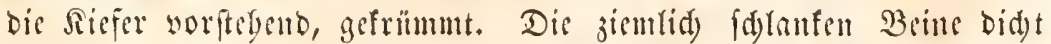

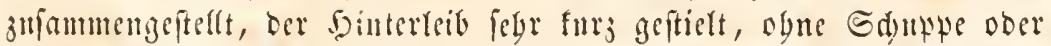
Sinoten an biefem Stiele. Die meiften Gattungen reben in beifen Rändern; Die in biefigen Gegenden worfommenten in ben Reftern Der Sommeln. Shr weiterer Şausgalt ift Durdaus unbefannt. Mutilla; Dorylus ; Labydus; Myrmosa.

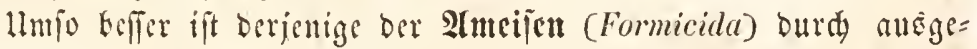

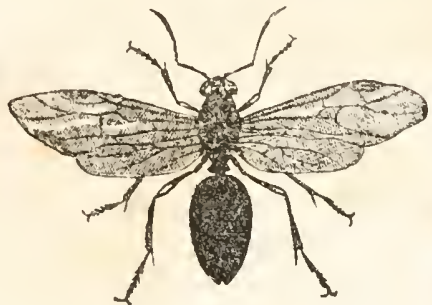

Fig. 924

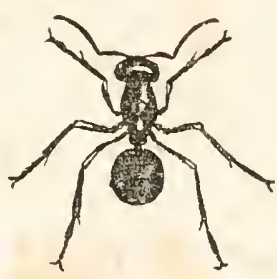

รig. 925.

Deiblidye rothe Itmeife.

seid)nete Beokad)ter aufgeflärt. Die Ameifen Yeben in ftändigen (5) =

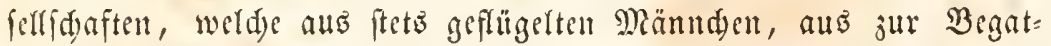
tungsjeit geflïgelten TBeibden und aus ftets ungeflïgelten Arbeitern jufammengefest fint. Der Sopf biefer Thiere ift oreiefig, ourd sinen Sticl you Der Bruft gefdieden, mit fdarfen, mafiven, auf ber immeren Flädue gezägnelten Riefern verfeben; die Alugen find flein, meift rund; die Fübler geifelförming gefnift, ons erifte Gried lang und gerade, bas Cride aus vielen fleinen Griedern Jufammengefest. Die Bruft erid)eint lang, zufammengebrüft; Der Şinterleib beftielt, und juar ift Diefer Stiel entweder ans siner Sduppe, oder aus einem balo cint= faden, bald boppelten Sinoten gebildet. Biele Ameifen befiţen einen Stader, andern aber gebt Derfelbe ab, und fie befizen bafür bie gä Gigfeit, bie in Der Giftblaje entbaltene Flinfigfeit, wafferfreie Ameifen=

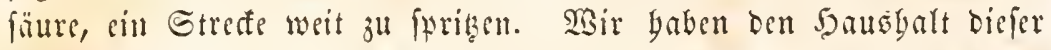

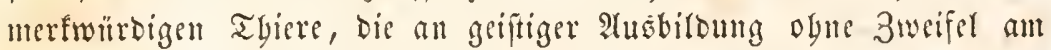
bödjen unter alfen Jnfeften fteben, fdon früber näber betradytet. Formica; Ponera; Hyrmica; Atta. 


\section{Berbefferungen im erften $\mathfrak{B a n d e . ~}$}

Seite 16 3eite 14 won oben - fatt 1798 - liez 1789 .

" " " 19 won tutten - fi. Gelgarptete - l. Gelyanptetert.

" 25 " 13 v. ob. - if. Geidfledfter - I. Battumgen.

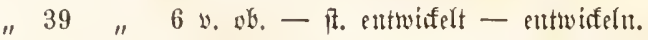

" 42 " 14 v. ob. - ft. und genatere $-\mathfrak{l}$. z̆ genaturer.

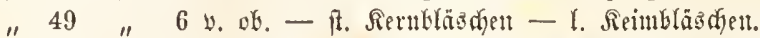

" 59 " 14 v. 15 v. of. - ft. Das ägntlidge - l. ein ăhnlidjes.

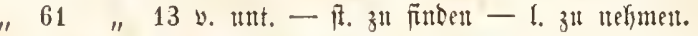

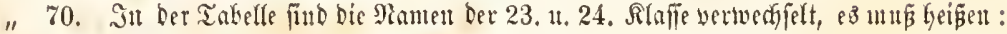

23. Meptiliert. Reptilia.

24. \&urche. Amphibia.

" 77 3eile 5 v. unt. - po. vorkanben - l. vorhanben zu fein.

" 101 " 20 v. ob. - fis. int weldde - I. int weldjes.

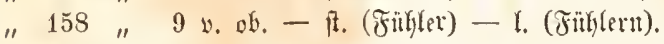

" 159 in Der Figurenerflarung - ft. Die untere Fignt - l. Die obere Figur.

" 232 3eile 13 v. o. - F. weldger - I. weldyent.

" 236 " 17 \%. o. - ff. Daz - I. Dás.

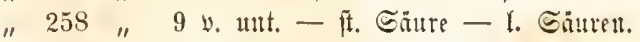

" 260 " 20 v. of. - ft. in - l. im.

" 281 " 19 b. unt. - R. 鸩e - I. iffer.

" 286 " 13 v. vb. - fit. Theite - I. Theile.

" 302 " 15 v. of. - it. gelegen - r. liegent.

" 304 " 13 ע. ob. - fit. eigekngen - l. cingebogent.

" 402 " 10 w. unt. - fi. Arachnita - l. Arachnida.

" 438 " 5 v. uttt. - ft. Kepers - l. Eejegt.

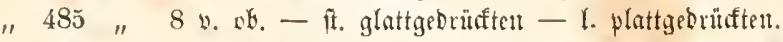

" 543 " 9 Der Figurenerflärung - ft. Tenebris - l. Tenebrio.

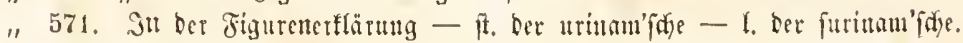




\section{Su) fem}

Des erfent Bantes.

\section{Cinleitung}

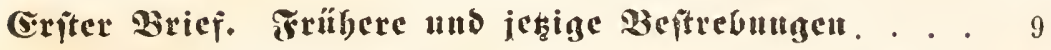

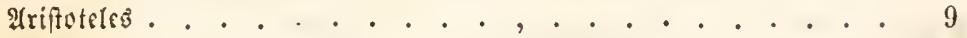

§imnè . . . . . . . . . . . . . . 10

Cuvier . . . . . . . . . . . . . . . . . 13

Jepige Riqtung. . . . . . . . . . . . . . 15

3wciter Brief. Das Enften . . . . . . . . . . . . . 19

Irt . . . . . . . . . . . . . 20

(5atttng . . . . . . . . . . . . . 24

Familie, Dromung . . . . . . . . . . . . . . . . 27

ßlafle, Srcis, Sgrovinj . . . . . . . . . . . . 28

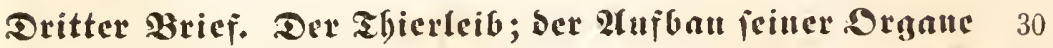

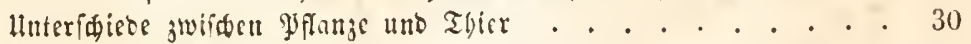

Entwidefung ber Drgane. Snrtode. . . . . . . . . . . . 36

Berbauungöorgane . . . . . . . . . . . . . . . . . . 38

Sirelglauf . . . . . . . . . . . . . 41

2ttmmng . . . . . . . . . . . . . . . . 41

Animate Junftionen. $\mathfrak{B}$ etwegung . . . . . . . . . . . . . 43

Sinnesorgane . . . . . . . . . . . . . . . . . . 44

Rerveniyfem. Geifige Fäbigteiten . . . . . . . . . . . 40

Fortpflanjung ............... . . . . 47

3ellen . . . . . . . . . . . . . . . 48

Jafern . . . . . . . . . . . . . 50

3icrter Brief. Die Fortpflambug unb bie baxaif ge= gründete Cintbeilung. . . . . . . . . . . 51

lırgeugung. . . . . . . . . . . . . . . . . 51

Beidledtalofe Beugung . . . . . . . . . . . . . . 54

Igeilung. Snožpung. . . . . . . . . . . . 55

ઉefdeledtlide 3eugung . . . . . . . . . . . . . . . . 56

Camte . . . . . . . . . . . . . . . . 57

Befru币tung . . . . . . . . . . . . . 58 


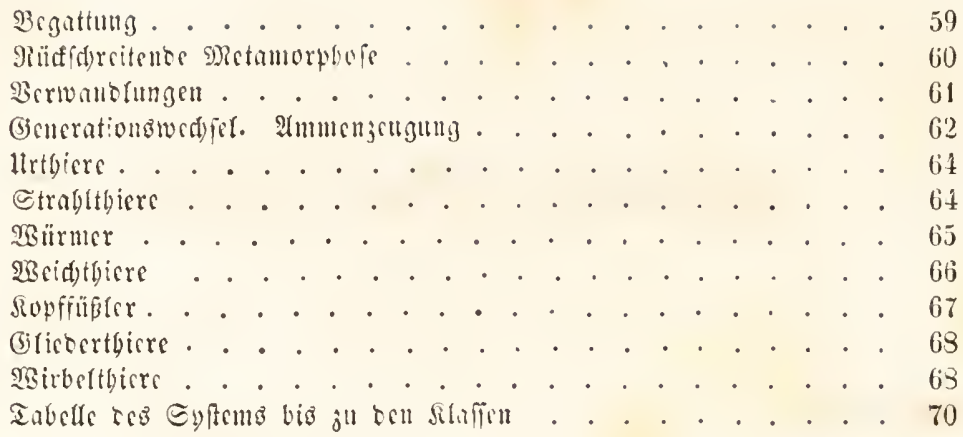

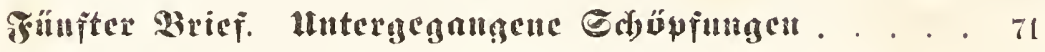

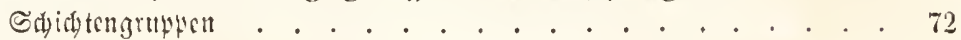

Itntergrgangenc 9 trten. . . . . . . . . . . . . . . 74

Entwiffétung ber Igpen . . . . . . . . . . . 75

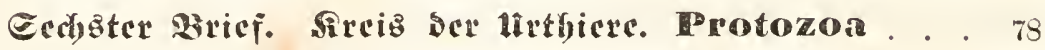

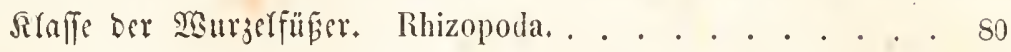

Eillfribige. Honosamatia . . . . . . . . . . 81

\$sechiettgierdjen. Proteida . . , . . . . . . . . 81

Sapiettficrdjeu. Arcellida . . . . . . . . . . . . . 82

Bielfammerige. Pol lytbalamia . . . . . . . . . . . . 83

Einjriler. Sticlostegida . . . . . . . . . . 81

Doppelzeiler. Enallostegida. . . . . . . . . 81

Edjueffmzeifr. Ilelicostegillat .

Spiralgeilrr. Entomostegida . . . . . . . . . 84

Arrbgeiter. Agathistegida . . . . . . . . . . . 84

Sinforfteine. Nunnulita . . . . . . . . . . 84

Rlaffe Det Infuforien. Infusoria . . . . . . . . 85

Minolofe. Astoma . . . . . . . . . . . . . 93

Hentorringe. Astasida. . . . . . . . . . . . . . . . 93

Gepanjerte Iscuberlinge. Dinobryida. . . . . . . . . 93

Sirangthirrdfon. Peridinida . . . . . . . . . . . . 94

Grastfierdyen. Opalinida . . . . . . . . . . . . . . . 94

Rnn fǘrenoc. Stomatoda . . . . . . . . . . 94

Monaber. Monadida . . . . . . . . . . . 94

(s)ofentbierd)en. Vorticellida . . . . . . . . . . 95

(Sepanjerte. Oplirydina . . . . . . . . . . . . 95

Sanartgicrdan. Trichodida . . . . . . . . . . . . 98

Walzentgierd)en. Enchelina. . . . . . . . . . 98

5orbtgicrocm. Trachelina . . . . . . . . . 98

Menfcutgierden. Nassulina . . . . . . . . 98 
Borftentficrden. Setifera . . . . . . . . . . . 99

Scodycttgirutgrn. Oxytriclina . . . . . . . . . . . 99

Radgentgierdgen. Euplota . . . . . . . . . . . . 99

\section{Eicbenter Buci. Stecis ber Etrabltbicte. Dadiala}

Sraffe ber gुofyten. Polypi

Scdôt

Baumforallen. Madreporida

Bederforaflen. Cyathoplyyllida

Drobtoraften. Turbinolida

Eomentorallen. Astreida

Schmammforaflen. Flingida .

Plugrnéorallen. Oculinila

Stanbenforaflen. Autipathida

fillffirablige. lentactinia.

Groblitten. Zoanthida

Sranentonen. Actinida

Srcheffern. Elwardsida

Af tffrabligr. Octactinia .

Srgelforallen. Tubiprorida

gitigforallen. Aleyonidia.

Rinbonforallen. Gorgonida

Grefocrn. Pennatulida

Derridirme. Luceruarida

Rlaffe der Duallentolypen. Hydromedusae . . . . . . . 126

Eiistuaflerpolypen. Ilydrida . . . . . . . . . . 128

Röhrenpolypen. Tubularida . . . . . . . . . . . 12?

Gitofenpolypen. Campanularida . . . . . . . . . . 129

Sdirmqualf

gyiljanallen. Medusida . . . . . . . . . . 135

Serquallen. Oceanida. . . . . . . . . . . . . . 136

Sd)eifenquallen. Aequorida. . . . . . . . . . . . 136

Saarquallet. Berenicila. . . . . . . . . . 137

$\mathbb{3}$ urjelquallr. Rlizostomida . . . . . . . . . . . 137

Rüfrlquallen. Geryonida . . . . . . . . . . . 137

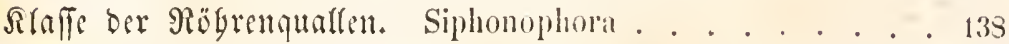

Geeblajen. Pliysalida. . . . . . . . . . . . 138

Snorpelquaflcu. Velellida . . . . . . . . . . . . . 139

Doppelauafler. Diphyida . . . . . . . . . . . . 140

Silafle or Gtaderbäuter. Echinodemala . . . . . 142

Spelilich. Crinoidea . . . . . . . . . . . 15?

Srcäpfrl. Cystocrinida . . . . . . . . . . . 151 
Seite.

Sertilien. Encrinida . . . . . . . . . . . 155

Actinocrinida . . . . . . . . . . . . . 155

Pentacrinida . . . . . . . . . . . . 156

Encrinida . . . . . . . . . . . 156

Saarferne. Comatulida . . . . . . . . . . 156

Sefterne. Stellerida . . . . . . . . . . . 158

Sonnenfterue. Euryalida . . . . . . . . . . . 159

Sぬlanzenferne. Ophiurida . . . . . . . . . . . 159

Serfterne. Asterida . . . . . . . . . . . 160

Speigel. Echinida. . . . . . . . . . . . . 160

Seeigel. Cidarida . . . . . . . . . . . . . . 165

Sdilbigel. Clypeastroida . . . . . . . . . . 166

Rufigel. Cassidulida . . . . . . . . . . . . 167

Scerjigel. Spatangida. . . . . . . . . . . . . 167

Seewa $\mathfrak{f}_{\mathfrak{c}}$ n. Holothurida . . . . . . . . . . . 168

Saftwalien. Synaptida . . . . . . . . . . . 168

Seewalgen. Ilolothurida . . . . . . . . . . 168

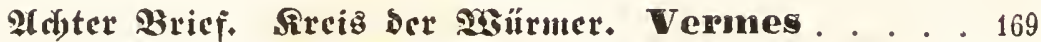

Rlaffe ber Runbwürmer. Nematelmia ........ 175

(5) regarinen. Gregarinea . . . . . . . . . . . 178

Siaker. Acanthocephala . . . . . . . . . . 180

Sa iten würmer. Gordiacei. . . . . . . . . . 181

Fabenivürmer. Nematoidea . . . . . . . . . . 181

Spufwiirmtr. Ascarida . . . . . . . . . . . . 184

gुfablwärıner. Strongylida . . . . . . . . . . . 181

Aalmürmd)єn. Anguillulida . . . . . . . . . . . 184

Rlaffe ber gुlattwärmer. Platyelmia . . . . . . . 185

$\mathfrak{B} a n d$ würuler. Cestoidea . . . . . . . . . . . . . . . . 190

Melfinwürmer. Caryophyllida . . . . . . . . . . . 195

Sicmenwürmer. Lignlida . . . . . . . . . . . . . 195

Bancwürmer. Taenida . . . . . . . . . . . . . 195

Bhafrmwïrmer. Cystica . . . . . . . . . . . . . 196

Saugiürmer. Trematoda. . . . . . . . . . . . 197

Doppellögcr. Distomida . . . . . . . . . . . . 203

Dreiloder. Tristomida . . . . . . . . . . . 203

Birlüٌre. Polystomida . . . . . . . . . . . 203

Soblentwü ruler. Planarida . . . . . . . . . . . . 205

Sdwanjwürmer. Rhabdocoela. . . . . . . . . . 206

Eoblenwürmer. Dendrocoela . . . . . . . . . . . . 207

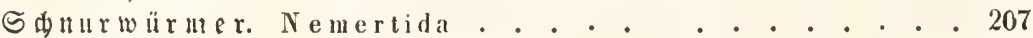

Rilffelloje. Microstomida . . . . . . . . . . . 209

Sduurwürmer. Nemertida . . . . . . . . . . . 209 
Eeite.

RTaffe ber Räbertbierc. Rotatoria . . . . . . . . 210

golpuenartige. Sessilia . . . . . . . . . . 214

BLumentbierdicn. Floseularida . . . . . . . . . . 215

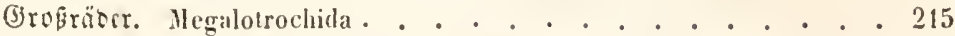

Squilumenoe. Natintia. . . . . . . . . . . . 215

Sisträbertficre. Polytrocha. . . . . . . . . 216

Doppelräbertbiere. Zygotrocha . . . . . . . . . . . 216

Slaffe ber Ringelwürmer. Annelida . . . . . . . . 217

ङुger. II irudinea . . . . . . . . . . . . . . . 224

MBeidergel. Malacobdellida . . . . . . . . . . . 227

Rüjtrgel. Clepsinida . . . . . . . . . . . . 227

Blutegel. llirudinida . . . . . . . . . . . . . . 227

Sterntürmer. Gephyrea

Erowürmer. Scoleina. . . . . . . . . . . . 229

Regentoürmer. Lumbricida . . . . . . . . . . . 229

Bafferidtängrl. Naidida. . . . . . . . . . . 230

Rö́rentuli rmer. Tubicola . . . . . . . . . . . . . 230

Afufternivürmer. Hermellida . . . . . . . . . 236

Mecrpinfel. Sabellida . . . . . . . . . . . . . . 236

Brrünvürmer. Chloraemida . . . . . . . . . . . 236

Sqlangenwïrmer. Errantia. . . . . . . . . . 237

giers. Arenicolida . . . . . . . . . . . 239

Eecraupen. Aphroditida . . . . . . . . . . . 239

Eduppenlofe. Amphinomida . . . . . . . . . . . . . . 240

Peripatida . . . . . . . . . . . . . . . 240

গRantenmürmer. Nereida . . . . . . . . . . . 240

§iєfertoürmer. Eunicida . . . . . . . . . . . 240

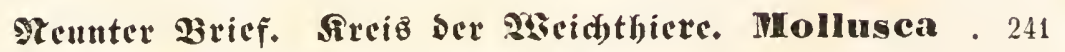

Itnterfecis ber Miollafoiber. Molluscoida . . . . . . 246

Slaffe der Moostgicre. Bryozoa . . . . . . . . 247

Sictósirbler. Stelmatopoda . . . . . . . . . . 252

Taufenbtvirbler. Milleporida . . . . . . . . 252

Robrenvirbler. Tubuliporida . . . . . . . . . . 252

Sruftenwirbler. Escharida . . . . . . . . . . 252

Armivirbler. Lophopoda. . . . . . . . . . . 253

Febrbuidnirbler. Plumatellida . . . . . . . . 253

Slaffe ber Rippenquallen. Ctenophora . . . . . . . 255

Gurfenqualfrn. Beroida . . . . . . . . . . 256

Banbqualfen Callianirida . . . . . . . . . . 256 
Slafle ber Mantertbirre. Tunicala . . . . . . . . 253

Spefdetiben. Ascidiae . . . . . . . . . . . . 262

Bufammengsferte. Compositac. . . . . . . . . . . 265

(3) ferllige. Sociales. . . . . . . . . . . 266

Einfacje. Simplices . . . . . . . . . . . . . 267

Jeuerzapfen. Pyrosomida . . . . . . . . . . . 267

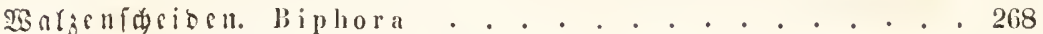

Salpen. Salpae. . . . . . . . . . . . . 268

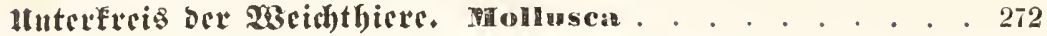

Sifaffe ofr Mufdertbiere. Acephala . . . . . . . . 274

Itntertlaffe ber ?trmfinfter. Brachiopoda. . . . . . . . . . . 283

Silbiften. Rudista . . . . . . . . . . . . . 288

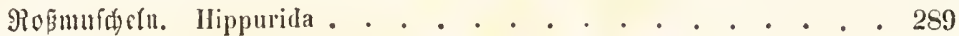

3iegenmufdefn. Caprinida . . . . . . . . . . . 289

Regelmäpige. Regularia . . . . . . . . . . . . . . . 290

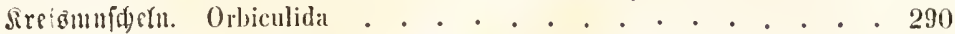

Sodmuideln. Tcrebratnlida . . . . . . . . . . . 290

3ungemmufdern. Lingulida . . . . . . . . . . . 291

Itutertaffe Łer Blattifimer. Lamellibranchia . . . . . . . . . . 291

Seitenmulfern. Pleuroconcha . . . . . . . . . 302

Ifuftern. Ostreida . . . . . . . . . . . . 303

Sammmuffeftr. Pectinida . . . . . . . . . . 30"

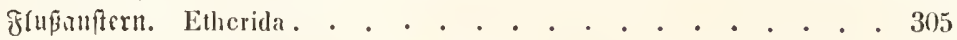

Ed)malnutdefn. Malleida . . . . . . . . . . . 305

(bicnmuldern. Chamida . . . . . . . . . . 305

(jerabuluffell. Orthoconcha . . . . . . . . 306

Werlenmufdern. Aviculida . . . . . . . . . 307

Mirsmufdern. Nytilida . . . . . . . . . . 308

Flnßmuidjeln. Najadis . . . . . . . . . . . 308

Drricfmuideln. Trigonida . . . . . . . . . . . 309

Ird)emunufdern. Arcacida . . . . . . . . . . . . . 309

5oerzmufdetn. Cardida . . . . . . . . . . . 310

Erbiemmidern. Cyclasida . . . . . . . . . . . 311

Irogmuffén. Mactrida............. . 311

§luffunifdefn. P'ylorila . . . . . . . . . . 311

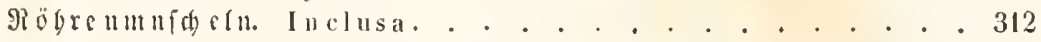

Sobrmuidelu. Teredida. . . . . . . . . . . 313

Eiøbufdern. Aspergillida. . . . . . . . . . . 314

Shaffe ocr Edyuden. Cephalophora . . . . . . . 315

Itnterflañe ser jloñenfuser. Pteropoda . . . . . . . . . . . 329

Sirgfallidenden. Hyalida. . . . . . . . . . 330

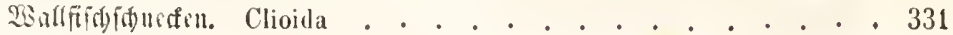


Mttantioen. Allantida. . . . . . . . . . . . 332

Sielidueden. Firolida. . . . . . . . . . . . . 333

Yreilfduecfell. Sagittida . . . . . . . . . . . 333

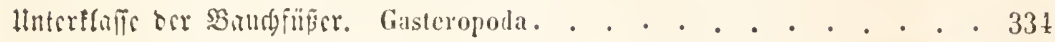

Sifmenfiguedf $u$. Branchiata . . . . . . . . . 33j

Rilidenfiemer. Opisthobranchial . . . . . . . . . . . . 337

Bifafuiducten. Bullida. . . . . . . . . . . 338

Sechárir. Aplysida. . . . . . . . . . . . . . . . 339

Fibenflueden. Eolida . . . . . . . . . . . 339

Eternibnedfr. Dorida . . . . . . . . . . . . 310

Segelfinnefen. Tritonida. . . . . . . . . . . . 341

Blättáerlfducfen Phyllidida . . . . . . . . . . . . 341

Geitenfiemer. Pleurobranchida. . . . . . . . . . . 341

Salöfiemer. Prosobranchia . . . . . . . . . . . . . 342

Edülifrffueffr. Patellida . . . . . . . . . . . . . 342

3nguidneder. Dentalida. . . . . . . . . . . . . 343

ZBurmidurten. Vermetida . . . . . . . . . . . . 344

פeübeniducfen. Capulida . . . . . . . . . . . . . 345

Rapfidgudfen. Sigaretida . . . . . . . . . . . 346

Emmpijtuefen. Paludinida . . . . . . . . . . . . 346

Rabclidfucfen. Cerithida . . . . . . . . . . . . 346

Flügelígnedelt. Strombida . . . . . . . . . . . 347

Eijinneffen. Orulida . . . . . . . . . . . . . 347

Jeezelfignedin. Conida. . . . . . . . . . . . 349

Jaltenfdurd̆rn. Volutida. . . . . . . . . . . . . 349

Iburmidnefen. Plenrotonida . . . . . . . . . . . 349

Epintrlidueden. Fusida. . . . . . . . . . . . . 350

Jelfinidueffen. Muricida . . . . . . . . . . . . . 350

Sortmigneden. Cassida . . . . . . . . . . . . . 350

Iritonaförner. Buccinida . . . . . . . . . . $3 j 1$

Rontifuerion. Neritida . . . . . . . . . . . 351

Sireifelidenedten. Trochida . . . . . . . . . . . . 352

Sirvgren. Haliolida . . . . . . . . . . . . 352

Quallenbocte. Santhinidis. . . . . . . . . . . . 353

\&ungenid) neffen. Phlnonata . . . . . . . . . . . . 353

SBarjenícheden. Onchidida . . . . . . . . . . . 355

Griblornfdumeten. Lymmacida . . . . . . . . . . . 356

Slgriduefen. Auriculida . . . . . . . . . . . . . 356

Sduirfelfoltedin. Helicida . . . . . . . . . . . . 357

\$Bghitheffit. Limacida . . . . . . . . . . . . 357

Fauftidnefter. Ampullarida . . . . . . . . . . . . 358

Ibüriftlecfent. Cyclostomida. . . . . . . . . . . . 353

アäferfinnefen. Chitonida . . . . . . . . . . . . 359 


\section{3ehnter Bricf. Sreis ber Sopriiizler. Cephalopoda 361}

Bierfiemer. Tetrabranchiata . . . . . . . . . 383

Jertboote. Nautilida . . . . . . . . . . 385

Immonagörner. Anmonitida . . . . . . . . . . . 386

3weilif mer. Dibranchiata . . . . . . . . . . 387

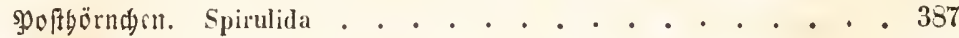

Iintenfifie. Sepida . . . . . . . . . . . . 338

Domnrtkite. Belemnitida. . . . . . . . . . . . . . 339

Adtfü̈̈rer. Octopodida . . . . . . . . . . . . . . . 390

Eilfter 3rief. Sicis ber Glieberthicre. Articulata . 392

RTaffe ter Rruftentbiere. Crustacea . . . . . . . . 403

Itnterflaffe ber Şautterbfe. Eintomostraca . . . . . . . . . 423

Ranfenfüßer. Cirrlipedia . . . . . . . . . . . . 423

Entrmmufdetı. Lepadida . . . . . . . . . . . . 427

Mecreidgeln. Balanida . . . . . . . . . . . . . . . 428

Sdmaroberéceble Parasita. . . . . . . . 428

Sörnerläuf. Penellida . . . . . . . . . . . 431

Etơffichläuf. Chondracanthida . . . . . . . . 432

Barichläuґє. Achtherida . . . . . . . . . . . . . . . 432

etörläuґe. Dichelestida . . . . . . . . . . . . . 433

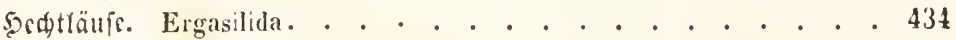

Saififialäure. Pandarida. . . . . . . . . 434

Flunterfüufe. Caligida . . . . . . . . . . . 434

Simpfentäufe. Argulida . . . . . . . . . . . . . 435

Sternläufৎ. Nyzostomida . . . . . . . . . . . 436

Srebaftö́c. Copepoda. . . . . . . . . . 436

Mecrflogs. Pontida. . . . . . . . . . . . 438

Eycroper. Cyclopida . . . . . . . . . . 438

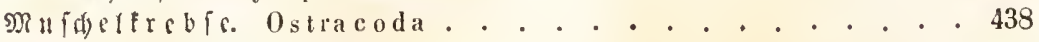

Eqdalenflübe. Cyprida. . . . . . . . . . . 439

Biliderltrebfe. Daphnida . . . . . . . . . . . 440

Blattfüßer. Phyllo poda. . . . . . . . . 441

Slattreble. Apusida . . . . . . . . . . . 443

Siemenfüfe. Branchipida. . . . . . . . . . 443

gुalä

Battida . . . . . . . . . . . . 446

Calymenida . . . . . . . . . . . . . 447

Asaphida . . . . . . . . . . . . . . 447

Ogygida. . . . . . . . . . . . . . . 447

Odontopleurida . . . . . . . . . . . . 448

Olenida . . . . . . . . . . . . . . 448

Campylopleurida. . . . . . . . . . . . 448 
fladtreble. Phyllosomida. . . . . . . . . . . . . 454

Scuíd,refentrobfe. Squillida. . . . . . . . . . . 455

Geififfecbfe. Mysida . . . . . . . . . . . . 455

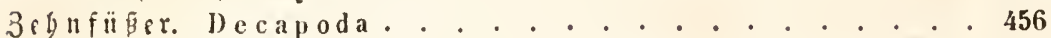

Jirebie ober Rangidwänjer. Macrura . . . . . . . . . 456

Barnerlen. Carida. . . . . . . . . . . . . . . . 459

Şummcr. Astacida . . . . . . . . . . . . . . . 459

(3) rutuentrebie. Thalasinida . . . . . . . . . . 460

\&anguftrn. Palinurida . . . . . . . . . . . . . 461

\$albjdwängrt. Anomura . . . . . . . . . . . . . . 461

Fernbarbinctrobir. Pagurida . . . . . . . . . . . . 463

Sanbtroble. Ilippida . . . . . . . . . . . . . . 464

Porjellanereble. Porcellanida . . . . . . . . . . . 464

Rüfenfïßет. Notopoda . . . . . . . . . . . . 465

Srabben. Brachiura . . . . . . . . . . . . . . 465

Spinumfrabben. Oxyrhincha . . . . . . . . . . . 469

Sunbtrabber. Oxystomata . . . . . . . . . . . . 470

Bogenfrabern. Cyclonietoba . . . . . . . . . . 470

Santrinbben. Catometoba . . . . . . . . . . 471

llnterflajן orr Sikaugen. Edriophthalma . . . . . . . . . . 472

Keblfüpr. Laemodipoda. . . . . . . . . . . . 473

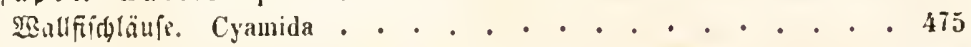

Gefipenftérebir. Caprellida . . . . . . . . . . . . 475

floblrcbif. A mplipola . . . . . . . . . . . . . 475

Quallenflöbe. Ilyperida . . . . . . . . . . . 476

Elobtrebfe. Gammarida . . . . . . . . . . . 477

Iffeln. Isopoda. . . . . . . . . . . . . . . 477

EnuBuffirn. Bopyrida. . . . . . . . . . . . . . 479

Jif́nalifln. Cymothoida . . . . . . . . . . . . 479

Singstaincln. Sphaeromida . . . . . . . . . . . 480

Sdudtalleln. Idotheida . . . . . . . . . . . . 480

Bafferaffétr. Asellida . . . . . . . . . . . 480

\&anbalfér. Oniscida. . . . . . . . . . . . . 481

Rlaffe ber Taufenbfüb̈er. Myriapoda......... . 482

Doppelfüß̈r. Diplopoda . . . . . . . . . . . . 484

Einfüßrer. Chilopoda . . . . . . . . . . . . 485

Rlaffe ber Iradaniocrt. Arachnida . . . . . . . . 486

Spinnenartige . . . . . . . . . . . . . . . . 494 
\{rebgfpinucu. Pyenogouida . . . . . . . . . . . 495

Bärtbifrdit. Tardigrada . . . . . . . . . . . . . 496

Milbcn. Acarina . . . . . . . . . . . . . . . . . 497

3ungcumürmcr. Linguatulida . . . . . . . . . . . . 499

Balgutilben. Simonida . . . . . . . . . . . . 500

Siräbmilbcn. Acarida . . . . . . . . . . . . . 501

3rfen. Ixodida . . . . . . . . . . . . . 501

Säfcrlüıf̊. Gamasida . . . . . . . . . . . . 502

2Baffermitern. Ilydactmida . . . . . . . . . . . 502

yflanjenmilben. Oribathida . . . . . . . . . . . 503

Eromiteru. Bdellida . . . . . . . . . . . . 504

\&anfuilben. Trombidida. . . . . . . . . . . 50t

20 fbrfpinncu. Opilionida . . . . . . . . . . . 505

Spinnen. Araneida. . . . . . . . . . . . . 506

Spinten. Araneida . . . . . . . . . . . . . . . . 508

Bogrlfpinnen. Mygalida . . . . . . . . . . . . 509

Sporpionfpiuncu. Solpugida . . . . . . . . . . . 510

Srrbiartige Spinumtbicre. . . . . . . . . . . . . . 511

Bü

Sforpiour. Scorpionida. . . . . . . . . . . . 512

(S) eifelfforpions. Phrynida . . . . . . . . . . . 513

Slaffe der Juleften. Insecla . . . . . . . . . . 515

Ilnterflafic shue Berwanblung. Ametabola . . . . . . . . . . . 559

\&älıfৎ. Pcoliculida . . . . . . . . . . . . . 561

Bogellä̆f. Nimida . . . . . . . . . . . . 561

Sabclipringer. Podurida . . . . . . . . . . 562

3uffergäffe. 1.cpismida. . . . . . . . . . . . . 563

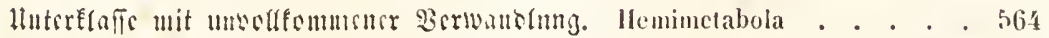

Sshnabcffeff. Ilemiptera . . . . . . . . . . . . 56t

Sd)iftünfc. Coccila . . . . . . . . . . . . . . 567

Silattläuc. Phytophthiriat. . . . . . . . . . . 5688

Blattläıl. Aphidida . . . . . . . . . 563

SRlattfläge. Psyllida. . . . . . . . . . 569

3irpen. Cicadida . . . . . . . . . . . . . 570

Gdammzirpen. Cercobida. . . . . . . . 570

Buffijirpru. Hembracida. . . . . . . . 570

Qfudtjirpit. Fulgorida . . . . . . . . . 570

Eimgjirpen. Cicadida . . . . . . . . . 571

2Bafferwanzen. Hydrocores . . . . . . . . . . . 571

Minocrwanzst. Notonectida . . . . . . . . 572

2Eafreforpions. Nepida. . . . . . . . 572 
Erite.

Santwanjen. Geocores. . . . . . . . . . . . . . . 573

Sisalferfänfir. Ilydrometrida . . . . . . . 573

Sotgmanzen. Reduvida. . . . . . . . 574

MBcictwanzen. Acinthida . . . . . . . . . 574

Bfimbivangen. Capsida. . . . . . . . . 574

Rantwanzen. Coreida. . . . . . . . . 575

Sditbwanzert. Pentatomida . . . . . . . . 575

(3)erabfiabler. Orthoptera . . . . . . . . . 575

Sorwiürucr. Forficulida. . . . . . . . . 579

Edjabrir. Blattda . . . . . . . . . . . 580

Sdfreffil. Saltatoria . . . . . . . . . . . 531

Gryllen. Gryllida . . . . . . . . 582

Sanbidfrefill. Locustida . . . . . . . . 583

Sduarrfderden. Acridida . . . . . . . . 583

Gripenfifdeccfeu. Phasmida . . . . . . . . . . 585

Sangidreffen. Mantida. . . . . . . . . 585

Termitrı. Termitida . . . . . . . . . . 556

Embiten. Embida . . . . . . . . . . . . 589

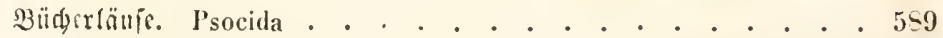

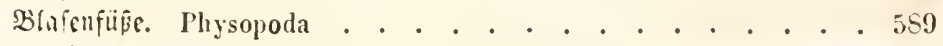

Fforfliegen. Perlida. . . . . . . . . . . . 590

Eintagglicgen. Ephemerida . . . . . . . . . 590

\$safleriungfern. Libellulida . . . . . . . . . . 591

Ituterkfaffe ber Snfiften mit bodfoumener Berwandung. Itolometabola . 594 3 werflïgler. l)iptera . . . . . . . . . . 59t

Sü̈penter 3weifligler. Aphaniptera. . . . . . . . . 601

fjröge. P'ulicida . . . . . . . . . . . . 601

gुmpengebärer. Pupipara . . . . . . . . . . . . 602

Efecrmanthün. Nicteribida . . . . . . . 603

5 5uttäufs. Ilippoboscida . . . . . . . . . . . . 603

Surjgüncr. Brachycera. . . . . . . . . . . 60"

Daffefflicgan. Oestrida . . . . . . . . . . 60t

gfiegri. Muscida . . . . . . . . . . . 605

Iungflirgon. Acalyptera . . . . . . . . . . . $\quad 605$

Bfuncuflirgen. Anthomycidil . . . . . . . . 606

grcifaflicgon. Calyptera . . . . . . . . 606

?ugenflieg'n. Conopida. . . . . . . . . . . 607

Surgrififter Brachistoma . . . . . . . . . . . 607

Enwebflezen. Syrphida . . . . . . . . 608

Etilettfliegen. Theredta . . . . . . . . 608

Squncpfonfliegen. Leptida . . . . . . . . 609

Dorurïđen. Notacantha . . . . . . . . . 609

\$ulgfliegrn. Xylophaga . . . . . . . . 609

$3 a$ affufliegrn. Strationyda . . . . . . . 609 
Seite.

Eangrüilf(er. Tanystoma . . . . . . . . . . . . 610

Trauerfliegen. Anthracida . . . . . . . . . 610

Sduebfliegetl. Bombylida . . . . . . . 610

Munobornflieget. Acrocerida . . . . . . . . . 611

Ianjfliegen. Empida . . . . . . . . . 611

Bufelfliegen. Ilybotida . . . . . . . . . 611

Ranbfliegen. Asilida . . . . . . . . . 612

Moroflirgen. Mydasida. . . . . . . . 612

Bremisn. Tabanida . . . . . . . . . . . . 612

Eangbörner. Nemocera . . . . . . . . . . . . 613

Müđen. Tipulida . . . . . . . . . . . . . 613

Stmmenmiitútu. Bibionida. . . . . . . . . . 613

Giriebelmiifen. Simulida . . . . . . . . . 613

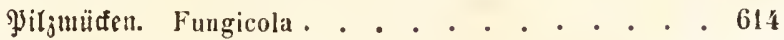

(ballmiiłen. Gallicola . . . . . . . . 614

Eromüđen. Terricola . . . . . . . . . 614

Bufdrmüđfn. Tanypida . . . . . . . . . . . 6:4

Squafen. Culicida . . . . . . . . . . . . 615

Sqmetterlinge. Lépidoptera . . . . . . . . . 616

Radfidutterlinge. Heterocera . . . . . . . . . . . 622

Frbermotten. Pterophorida . . . . . . . . . 622

Motten. Tineida. . . . . . . . . . . . 623

Blattwidfler. Tortricida . . . . . . . . . . . . 623

Bünder. Pyralida . . . . . . . . . . . 624

Safträgrr. Psychida . . . . . . . . . . . 624

Spanner. Geometrida. . . . . . . . . . 625

Eulen. Noctuida. . . . . . . . . . . . 625

5arpyen. Cerurida.............. . 626

\$oljipinner. Hepiolida. . . . . . . . . . . 626

Epinner. Bombycida . . . . . . . . . . . 626

Akenbíwärnter. Sphingida . . . . . . . . . 627

Wibocrbürndien. Zygaenida. . . . . . . . . . . 623

Sentenförner. Rhopalocera . . . . . . . . . . 629

Diftöpfe llesperida . . . . . . . . . . . 630

5ängrfalter. Suspensa. . . . . . . . . . . 630

Ebelfalter. Papilionida . . . . . . . . . 631

Strepfipteren. Rhipiptera . . . . . . . . . . . 632

Ręflügler. Neuroptera . . . . . . . . . . 636

Sdmettertingeffiegen. Phryganida. . . . . . . . . 638

Sumpfibellen. Sialida. . . . . . . . . . . 638

Erblibellen. Hemerobida . . . . . . . . 639 
Seite.

Mmcifenlöwen. Myrmeleontida . . . . . . . . . . . 639

Sdnabelfiegen Panorpida . . . . . . . . . . . 640

Sameelfliegen. Rhaphidida . . . . . . . . . . . 611

Säfer. Coleoptera . . . . . . . . . . . . . . . 642

Erfte Reige. Bierglieberige 5olgbourer . . . . . . . . . . 651

Rüffeftäfer. Curculionida . . . . . . . . . . . . 651

Borfenfäfer. Bostrychida . . . . . . . . . . . . 653

Ylattfäfer. Platystoma . . . . . . . . . . . . 653

Jwwrite Reibe. Fïnfglicterige Şolgbogrer. Serricornia . . . . . . 654

J̧radtfäfer. Bubrestida . . . . . . . . . . . . 654

Sqnelleäfer. Elaterida . . . . . . . . . . . 655

\$oljbobrer. Xylotroga. . . . . . . . . . . . 655

Bobrfäfer. Ptilina . . . . . . . . . 656

Werftbogrer. I,ymexylida . . . . . . . . . 656

Wriфflügler. Malacodermata . . . . . . . . . . 656

Cebrionida . . . . . . . . . . . . 657

Malachida . . . . . . . . . . . . 657

Lampyrida . . . . . . . . . . . . 657

Clerida . . . . . . . . . . . 657

Dritte Rrige . . . . . . . . . . . . . . . . . 658

Bodfäfrr: Longicornia . . . . . . . . . . . . 658

Prionida . . . . . . . . . . . . . . 659

Cerambycida . . . . . . . . . . . 659

Lamida . . . . . . . . . . . . 660

Necydalida . . . . . . . . . . . 660

Lepturida . . . . . . . . . . . . 660

Silientäfer. Criocerida . . . . . . . . . . . 660

S๙roammfäfer. Endomychida . . . . . . . . . . 660

Runbfafer. Cyclica . . . . . . . . . . . . 661

Eroflöbe. Galerncida . . . . . . . . 661

Solofafer. Chrysomelida . . . . . . . 661

Stbilbtäfer. Cassidida . . . . . . . . . 661

Blattlaug̊freffer. Coccinellida. . . . . . . . . . . 661

Saarflïgler. Trichopterygida . . . . . . . . . . . 662

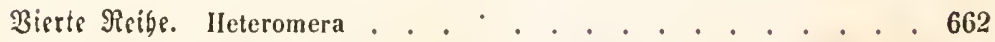

Blafentäfer. Meloida . . . . . . . . . . . . 662

Spindelfäfrr. Mordellida . . . . . . . . . . . . 663

Sartinalfäfer. Pyrochroida . . . . . . . . . . 663 
๔ite.

Seģefläbudfer. Cistelida . . . . . . . . . . . . . 663

Sdbruajtäier. Melasomata . . . . . . . . . . . . 664

Snätelfäfer. Anisotomida . . . . . . . . . . . 664

füufte Reige. . . . . . . . . . . . . . . . 665

Blattfürner. Iamellicornia . . . . . . . . . . . 665

Bluncutäfer. Celonida . . . . . . . . . 665

Miffłąfer. Coprophagida . . . . . . . . . . 666

Seorntäler. Dynastida . . . . . . . . . 666

Alaftifer. Trochida . . . . . . . . . . . 667

\&anbëäer. Melolonthida . . . . . . . . 667

Siridgeäfer. Lucanida . . . . . . . . . . . . 1667

Sentenbörner. Clavicornia . . . . . . . . . . . 667

Yjeljfäfer. Dermestida . . . . . . . . . 663

Byrrhida . . . . . . . . . . . . . 668

Catopida . . . . . . . . . . . . . 668

Stuk̨täfer. Histerida . . . . . . . . . . . 669

Mrftëffer. Nitilulida . . . . . . . . . . 669

Stinffäfer. Silphida . . . . . . . . . . . 669

2uncifenkäfer. Clavigerida . . . . . . . . . . . . . 669

Tafffäfer. Pselaphida . . . . . . . . . . . . . 670

Maubfäfer. Staphylinida . . . . . . . . . . . . 670

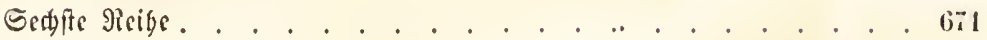

llferfäfer. Ileterocerila . . . . . . . . . . . . 6で!

Silchfäfir. Hydrophilida . . . . . . . . . . . . . 67т

Tammelfäfer. Gyrinida . . . . . . . . . . . . 672

Şaffertäfer. Ilydrocantharida . . . . . . . . . . 672

Eaufeäfer. Carabida . . . . . . . . . . . . . . 673

Subulpalpa . . . . . . . . . . . . 674

Carabida . . . . . . . . . . . . . . 674

Brachinida . . . . . . . . . . . 674

Licinida . . . . . . . . . . . . . . . 674

IIarpalida . . . . . . . . . . . . . . 675

Scaritida . . . . . . . . . . . . . . 675

Sanbläfer. Cicindelida, . . . . . . . . . . . 675

Sautflügler. Ilymenoptera. . . . . . . . . . . 677

Erfte Mcilge. Mit Segeröbre. . . . . . . . . . . . . . 688

Galfwe zpen. Cyniphida. . . . . . . . . . . . . 648

Springweâprn. Chalcidida . . . . . . . . . . . . . . 690 
๔d)

Eshtmpiocipen. Jchncumonida . . . . . . . . . . . . 691

Sungrrusafen. Evanida . . . . . . . . . . . . 692

Golamroupu C'hrysida . . . . . . . . . . . . . 692

Soljucopen. Urocerida. . . . . . . . . . . . . . 693

Bhttwréfen. Tenthedinida . . . . . . . . . . . 69'

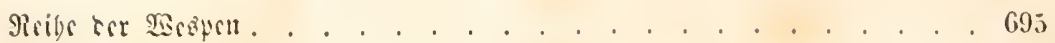

Gartenturêfen. Scolida. . . . . . . . . . . . . . 697

Sanowraprit. Sphegida. . . . . . . . . . . . . . . . 697

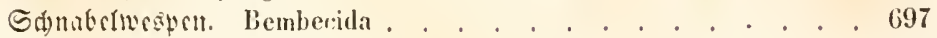

Silbrtwespen. Crabronida, . . . . . . . . . . . 698

Bş̧⿻上丨. Vespida . . . . . . . . . . . . . . 698

Srife orr Bienen. Apida. . . . . . . . . . . . . 700

Mesigs ber ?tmeifa . . . . . . . . . . . . . 702

Eqmarobramrifrn. Mutillida . . . . . . . . . . 702

?tmrifen. Formicida . . . . . . . . . . . . . . . 703 






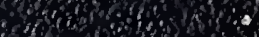

,

3.

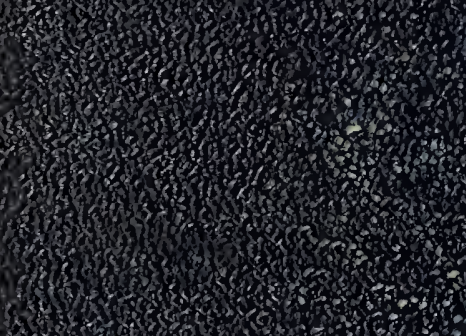

S.7.

3.

-

H.

H.t.

,

3.

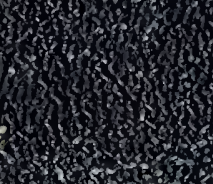

(3)

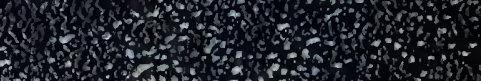

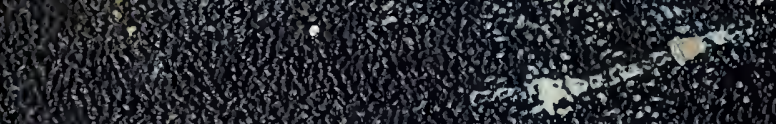

W

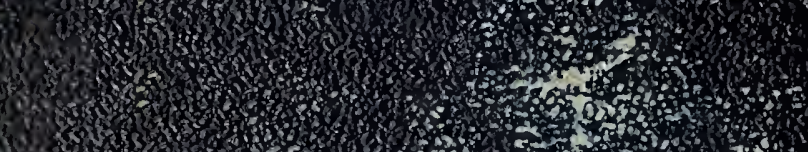

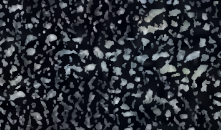

H.

P

ㄱ. - -

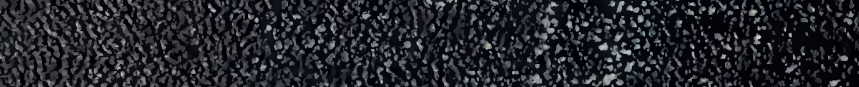

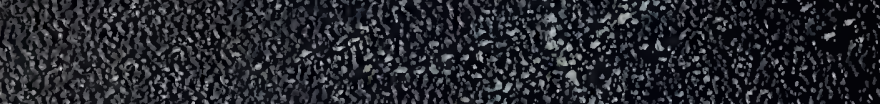

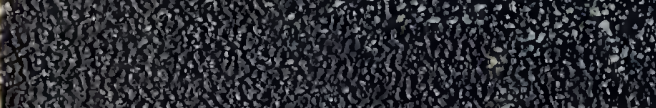

13.

1.t.

13.t.

H.t.

1. 